
(1) (1)

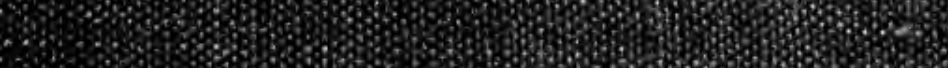

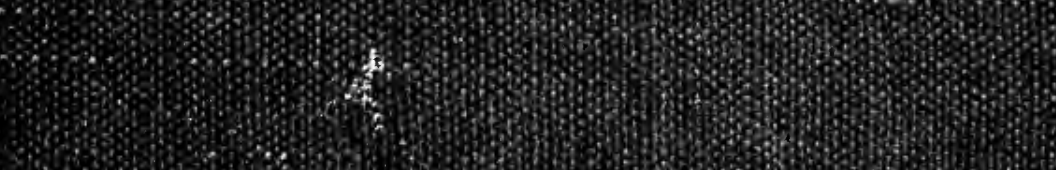

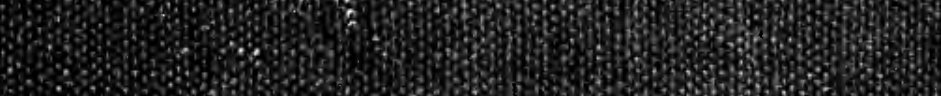

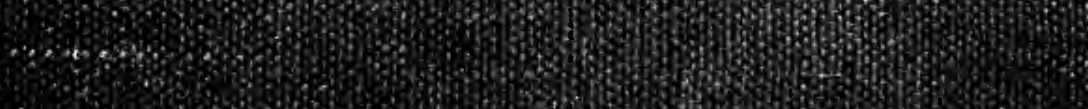

Ho $x$ (s)

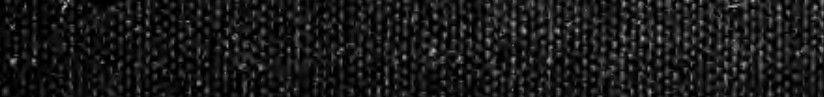
3. 30 . 2. W

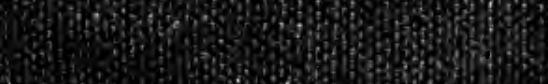

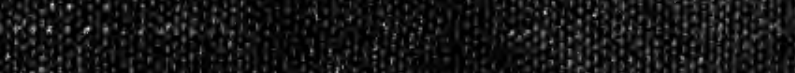
1.

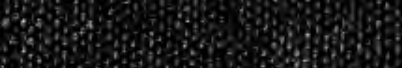
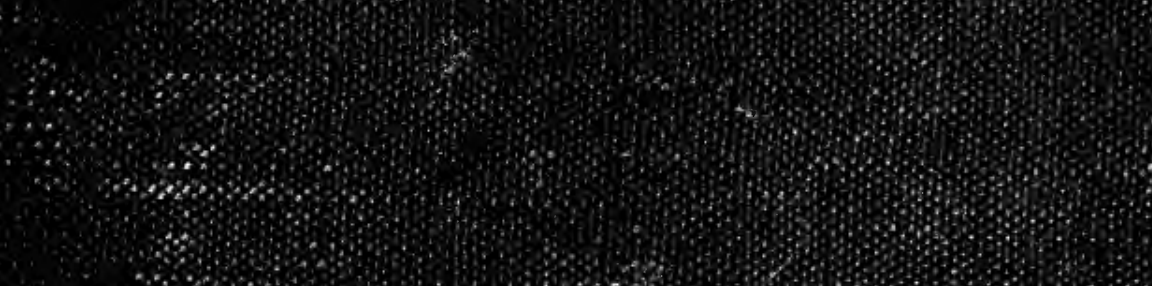

$\therefore \%$
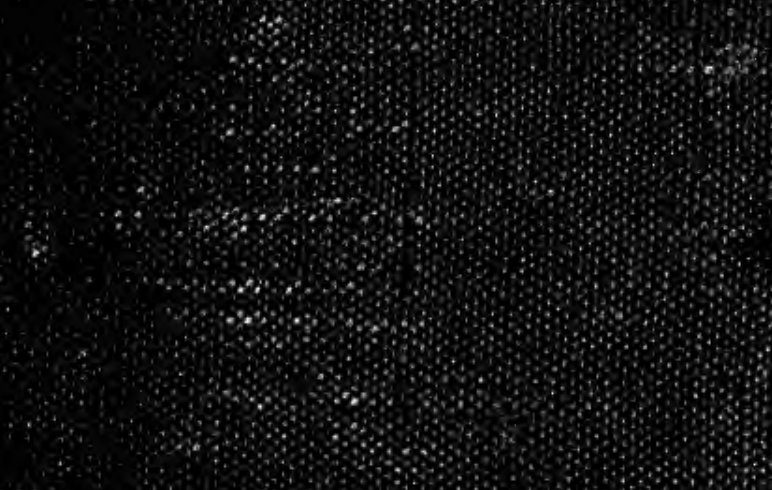



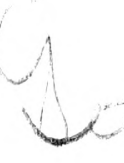





\title{
CASES AND OPINIONS
}

$(1 \mathrm{~N}$

\section{INTERNATIONAL LAW}

WITH

\section{NOTES AND A SYLLABUS.}

\section{BY}

\author{
FREeman SNOW, Pir.D., LL.B.
}

INSTRUCTOR IN INTERNATIONAL LAW IN HARVARD UNIVERSITY

B OSTON :

THE BOSTON BOOK COMPANY.

$189 \%$. 
Copigright. 1893.

by Frengax srow

PRFGWOK RY

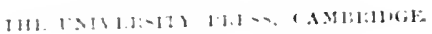




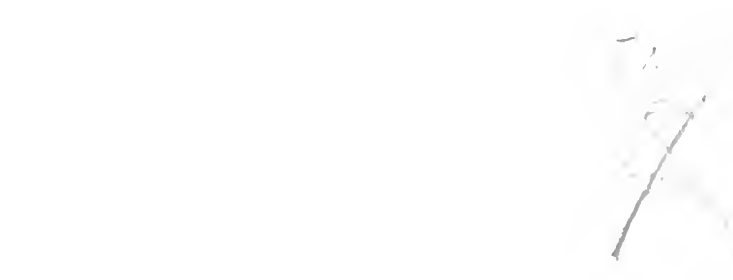

PREFACE.

TuE design of this work was formed some years since, while teaching the subject of International Law in the Unitod States Naval Acadeny, and the greater part of the compilation was made during a subsequent residence of three years in France, Germany, and England; but other duties have, till the present time, prevented its completion.

The object has been primarily to provide a convenient collection of materials relating to International Law, for the use of students. To avoid the method of instruction by lectures alone, and the even less satisfactory method of recitation from text-books, it is believed, that the "case system," introduced into the Harvard Law School a score of years ago, by Professor Langdell, offer's a happy substitute. Indeed, having employed that system for the last half dozen years, in classes in International Law, in Harvard University, I am thoroughly convinced that it is well adapted to that subject; the only drawback has been the difficulty of finding the necessary materials in a convenient form.

By this method, the student is called upon to take an active part in the exercises of the lecture room ; he is to report briefly the facts and judgment in a given case, and then is to explain the principles and their application, and must maintain his position against the criticisms of the instructor, and the other members of the class. The student should thus acquire a firmer grasp of the subject than he can get from the study of text-books alone; he is, moreover, mole inter- 
p-tal in hi- work. as. I leelieve. experience has show whereser the sirtem has treen intrulnced. These cases

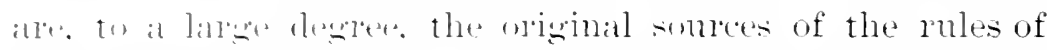
International law : and they fumish the opportmity of Indonning fimilial with the joleats of the eminent menjuntwe and state-men-who have controlled the develoment wi thi-law. Mamy of the ates. in addition to decinge the

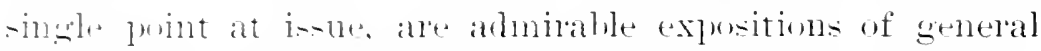

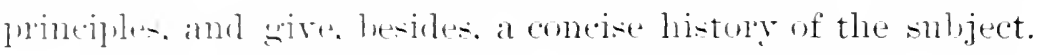

It is not propment. howerer. to discard text-books. It is interet the justly (velehiated anthors of treatises on Internathomal Law who hare andyzed and systematized the suh ject.

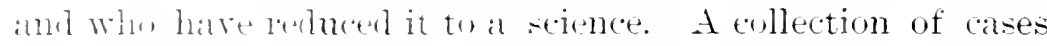
and ninions. mudenter: must necesanily leare many gaps.

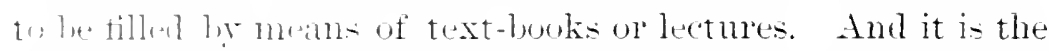

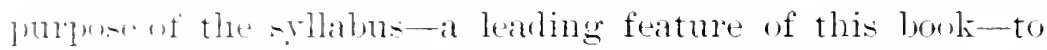
make arailatild the opinions of a mmber of the most eminent witers. of diffrent comntries by gromping references to their wolk-miler elediti heads. It will then be made possible to

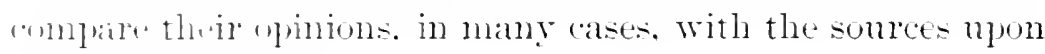
which they all reely.

It is theswht. further. that a collection of leading cases and minisms may fore to he a convenience for those whe are atllent upm to deat with the practical questions of Internaltinnal Law riz. Law?ers. Legriskators, and Diplomatists. With this and in riew. it has been the almost invariable

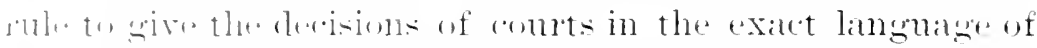

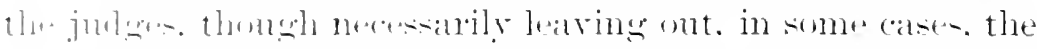

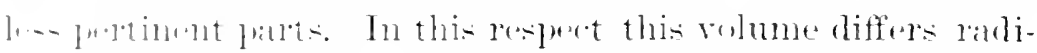

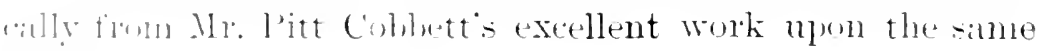
$-11,1, \ldots+1$

FREEMAX STOW.

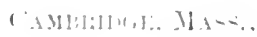

- $111,1-1,1-9: ?$. 


\section{TABLE OF CONTENTS.}

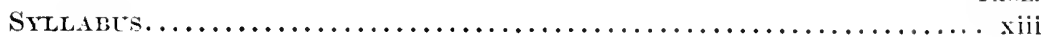

\section{INTRODUCTION.}

$\S 1$. International Law is a Part of the Municipal Law of States.............

\section{PART I.}

International Relations in Time of Peare.

\section{CHAPTER I.}

STATES-TELRTORIAL RIGHTS.

\$2. Definition and Character of Sovereign States.................

\$. Aequisition of Territory ................................ ;

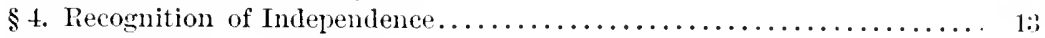

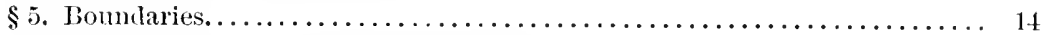

$\$ 6$. The Effect of a Change of Sovereignty........................ 1s

(a) Upon Public Riglits and Obligations.................... is

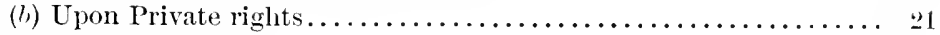

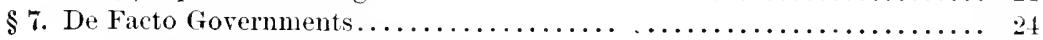

(a) Recognition of Belligerency........................

(b) Succession to the Rights of Belligerent Communities.......... 24

$\S 8$. Territorial Waters of a State.................................

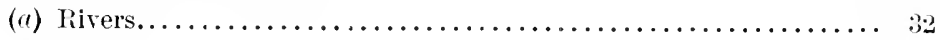

(b) Straits....................................... 41

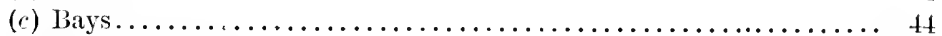

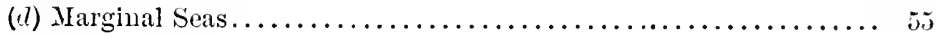

\section{CHAPTER II.}

TERFITORIAL JURISDICTION.

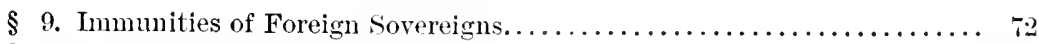

$\$ 10$. Immunities of Diplomatic Agents.........................

(a) Criminal Jurisliction..........................,

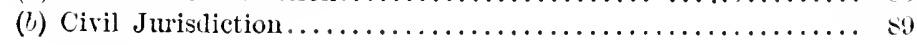




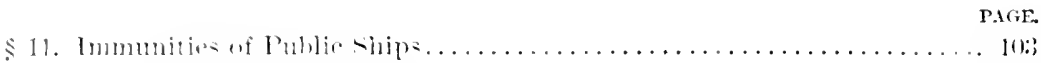

(1) -lij

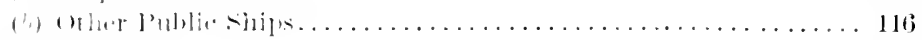

1.. Yurant

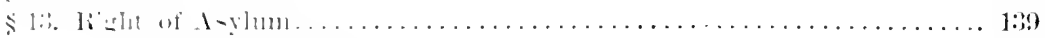

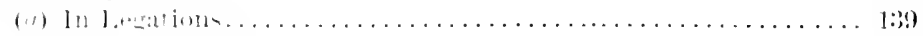

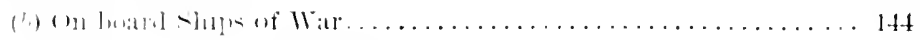

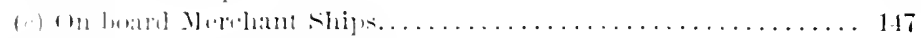

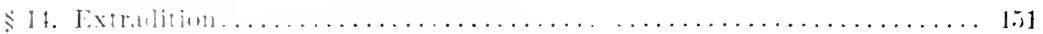

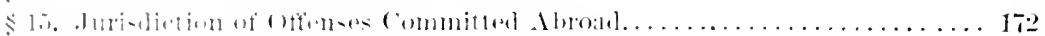

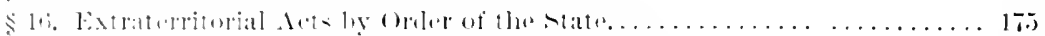

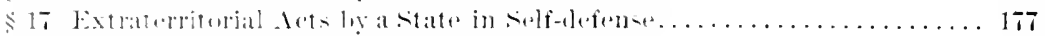

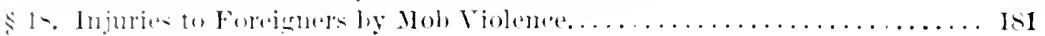

\section{('IIAPTEI IH.}

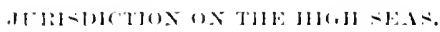

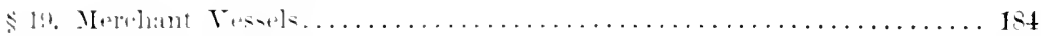

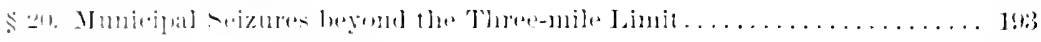

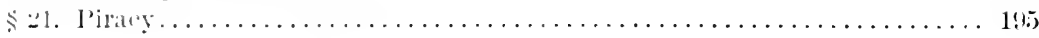

\section{('IIAPTER IT.}

X.ATION.AT.ITY.

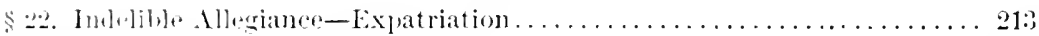

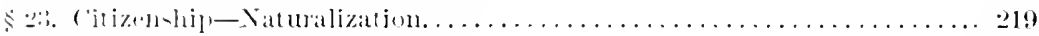

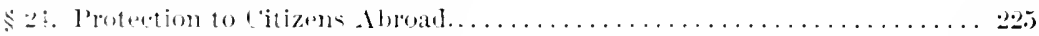

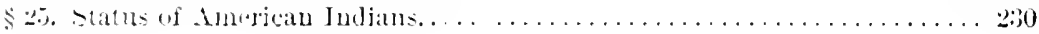

I'. II'T' II.

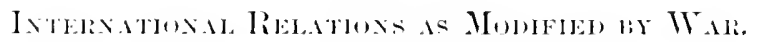

('IINTERI.

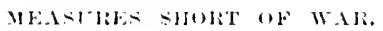

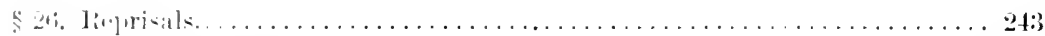

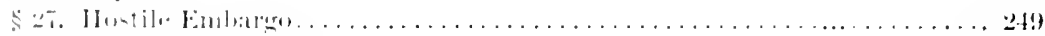

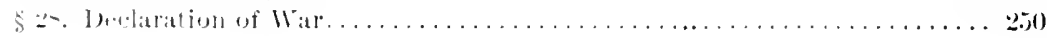

('IIAPTER II.

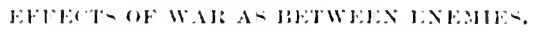

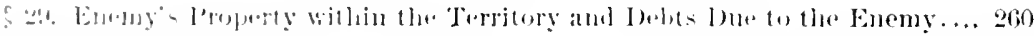

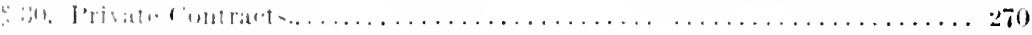

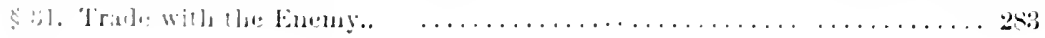




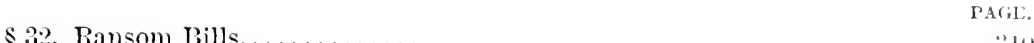

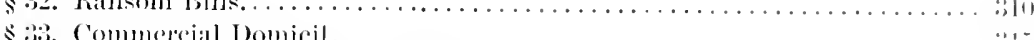

s.

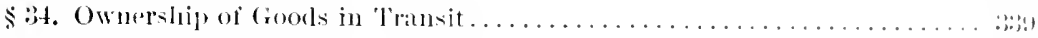

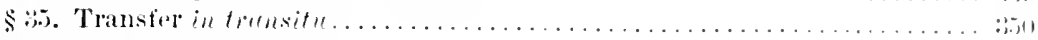

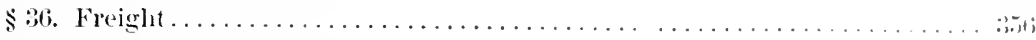

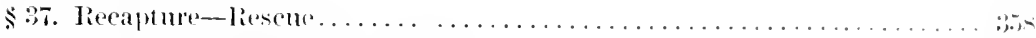

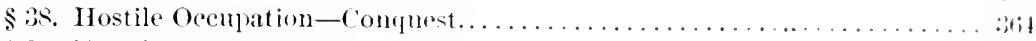

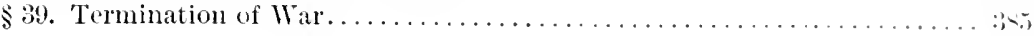

\section{CIIAPTER III.}

\section{RELATIONS BETWEEN IBLLIGEIEXTS ANI) NETTHAL}

$\$$ 40. Belligerent Capture in Teutral Waters . . . . . . . . . . . . . . .

$\$$ 41. Equipment of Vessels of War in Nentral Territory............... $4(12$

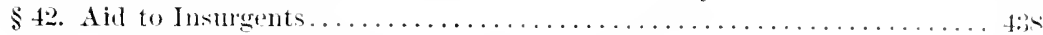

(a) Luans of Money.........................

(b) Ships, Munitions, and other simpllies.............. 44 ;

$\$$ 49. Sale of Munitions of War hy a Nentral State. . . . . . . . . . . . . . 4.i!

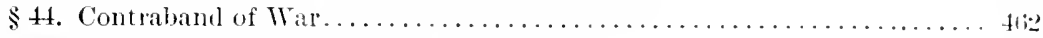

$\$ 4$. Dispatches and Persons as Contrabant . . . . . . . . . . . . . . 47

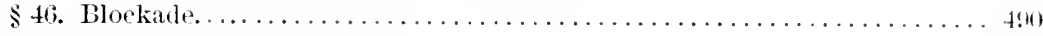

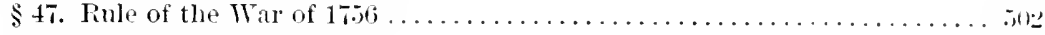

$\$$ 48. Contimons Voyages . . . . . . . . . . . . . .

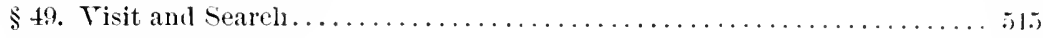

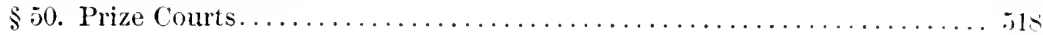

\section{APPENDIX}
A. The Behring Sea Arbitration. . . . . . . . . . . .
B. The Declaration of Paris . . . . . . . . . . . . . . .

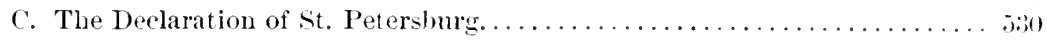

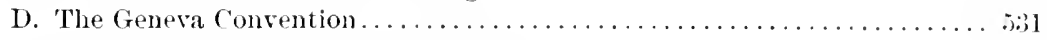

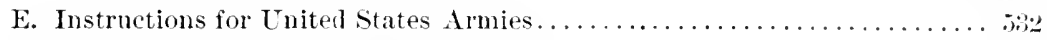

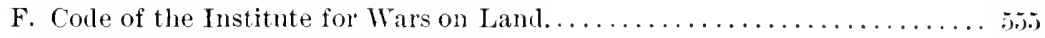

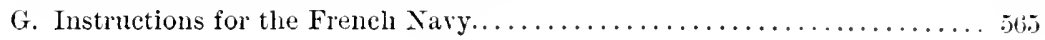





\section{TABLE OF CASES.}

\begin{tabular}{|c|c|}
\hline & P.16 \\
\hline berdeen, Op. of ............ 14s & Cellamare's Case... \\
\hline Adams, J. Q. to Nonroe........... I:3 & C'harles I., Proclammation of . . . . . 4t; \\
\hline certsen $v$. Slip Aurora ........ 1:32 & Sharming Nancy, 'l'lue.......... 31: \\
\hline labama, The............... 4\% & Chavasse, E.t porte........... tio \\
\hline libert's Case................. 218 & hin King, Ed prorle............ 2l! \\
\hline bassallor of Peter the Great.... 89 & $r .1$ IIubbart.... \\
\hline al de Rues, La............ 400 & $r$ Or. of $\ldots .$. \\
\hline Co.v. Canter..........372 & cen, The .......... \\
\hline , J., Case of .......... 1s. & Constitution, The............ 114 \\
\hline$l^{\prime} \ldots \ldots \ldots \ldots \ldots \ldots \ldots$ & Blackburı. . . . . . . . :310 \\
\hline n, The.............. 8ist & $\ldots \ldots \ldots \ldots 1:)(i$ \\
\hline harina, The......... :34; & arrison .... \\
\hline he................. & ing, Att.-(ten. Op. o \\
\hline , The................ 40 40 & Cutting's Case......... \\
\hline a, The........ $8 ;: ; 0$ & \\
\hline$\ldots \ldots \ldots \ldots 30 s$ & P. of. . \\
\hline (1). . . . . & De Haber $x$. Queen of Port \\
\hline (i) & $\ldots \ldots 4$ \\
\hline$n \ldots \ldots 261$ & 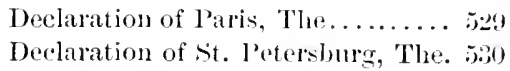 \\
\hline$\ldots \ldots \ldots 97$ & y $\ldots \ldots \ldots \ldots \ldots \ldots$ \\
\hline$\ldots \ldots 150$ & ase................ \\
\hline$\ldots \ldots 22$ & $0-\Lambda \mathrm{m}$ \\
\hline$\ldots \ldots \ldots 2+9$ & $\ldots \ldots \ldots \ldots$ \\
\hline$\ldots \ldots \ldots 521$ & Don Pacifico, Cas \\
\hline$\ldots \ldots \ldots 189$ & Dubois' Case ....... \\
\hline$\ldots \ldots \ldots .330$ & \\
\hline$\ldots \ldots \ldots 402$ & \\
\hline he... 4:3 & $2: 30$ \\
\hline$\ldots 267$ & tehell... \\
\hline$\ldots 120$ & muel, The.... \\
\hline$\ldots 26 ; \%$ & len's Case........... \\
\hline own, J., Case of ........... 14t & y St. Pierre, The........... 341 \\
\hline & ige $x$. Il Fadilon.... \\
\hline 17 & \\
\hline$\ldots+40 ;$ & Page. . \\
\hline$\ldots 16 ; 3$ & $\ldots+28$ \\
\hline$\ldots .161$ & alistment Let, Brit \\
\hline
\end{tabular}




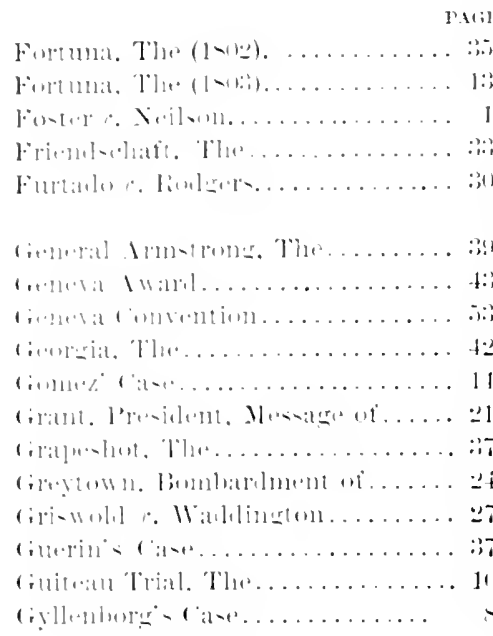

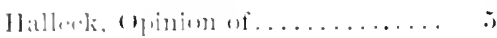

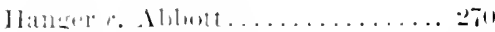

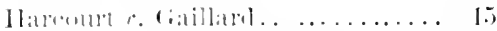

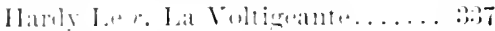

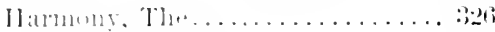

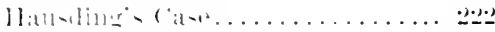

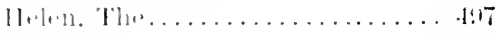

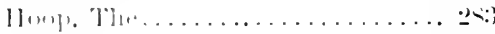

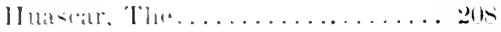

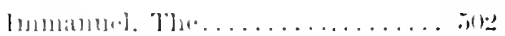

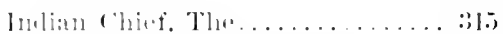

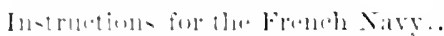

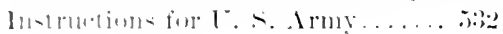

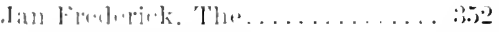

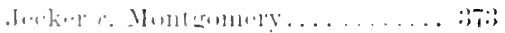

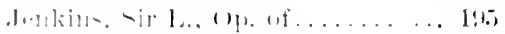

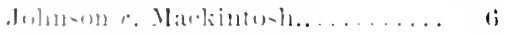

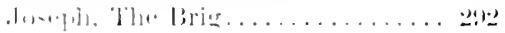

K.+11, (1). 10...............

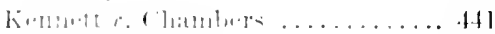

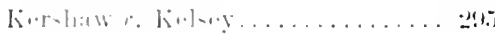

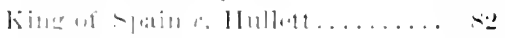

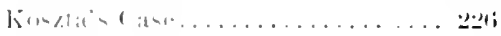

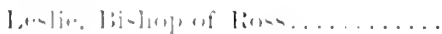

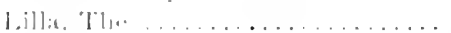

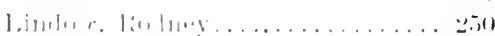

I.611. 1,.
F.1GE.

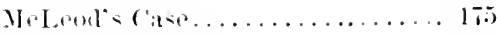

Mallinu, Thle. . . . . . .

Magdalina stean Navigation ('o. r.

Yatrin . . . . . . . . . . . . 10?

Matrellan l'irate. [hate. . . . . . . 20.5

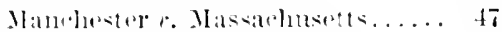

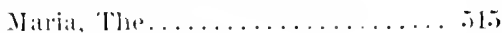

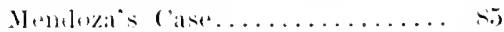

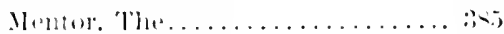

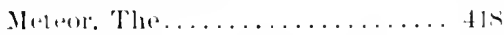

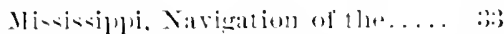

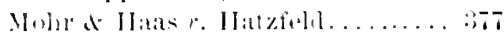

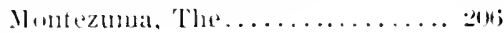

Sinn $T 1_{1}+\ldots \ldots \ldots \ldots \ldots \ldots \ldots .4: 4$

Nathille. The.............

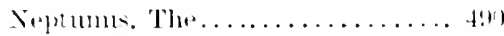

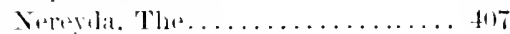

Vemtitited, The............. 47

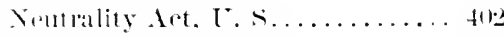

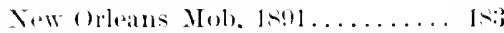

New (trleans Riot. K.) l. . . . . . 1-1

Xivton. The, and The sally...... 1:1

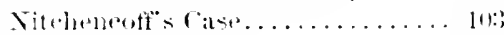

Nymph, The............... Biti

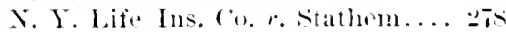

Oecupation of Xiales..........

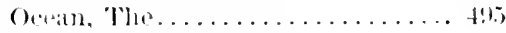

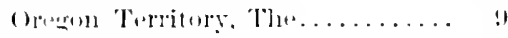

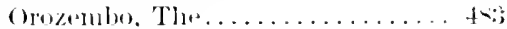

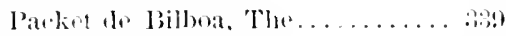

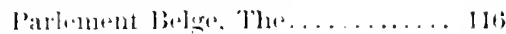

latrixent, Tlu..............

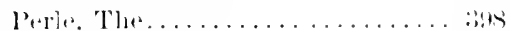

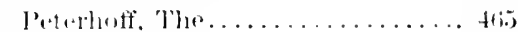

lhiliper. llatch.............8.

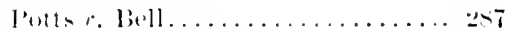

l'rin Frelerik, The.......... 1l;

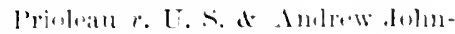

sısı................. ד

Prize ('ases, The (1) . . . . . . . . 2.54

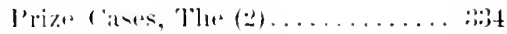

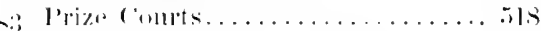

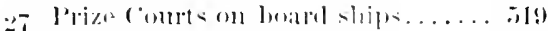

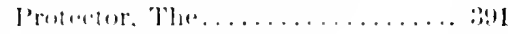

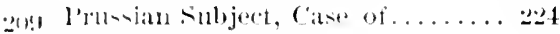




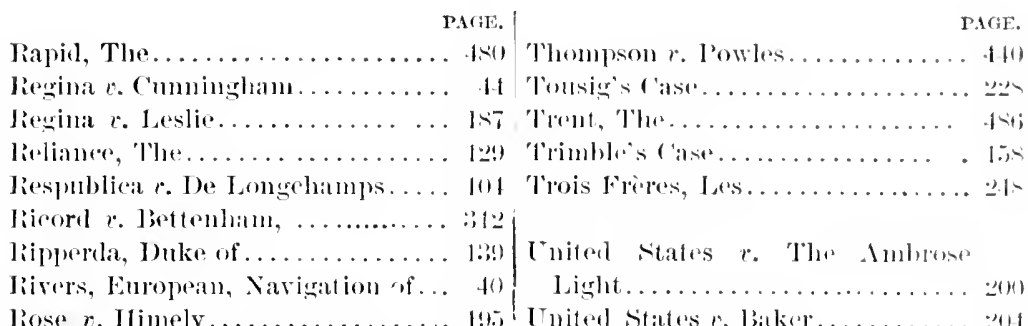

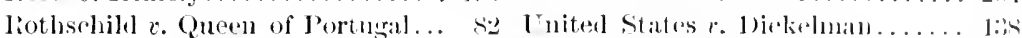

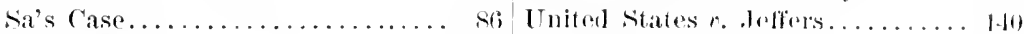

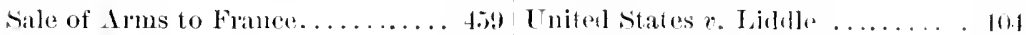

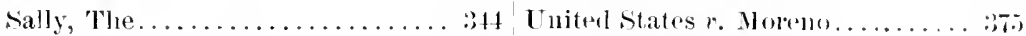

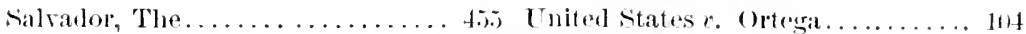

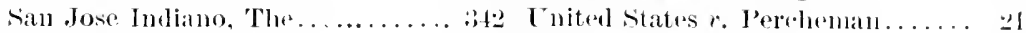

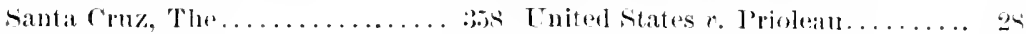

Santa Lueia.............. 12 United States $x$ (Qniney........ 412

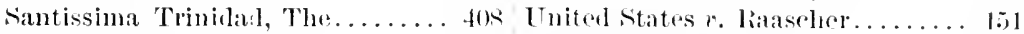

Seotia, The.............. I Tniter States $r$ lime..........

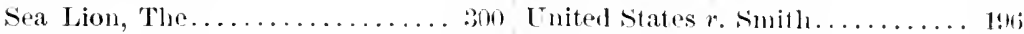

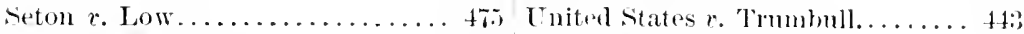

Shenantoah, The........... 4:) United States $v$. Wagner......

Silesian Loan, The.............24:3

Sotello's Case.............. 147 Vavassenr $r$ Krnpl..........

Somd Dnes, The........... 41 Venus, The.............. 81s

Stephen Hart, The............ sog) Villasseque's Case............

St. Albans Raid, The......... 162 Virwinius, The............ 17!

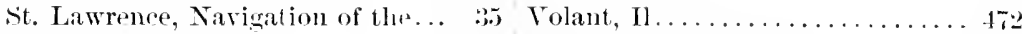

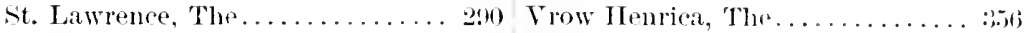

St. Marks, Seizure of .......... 17. Vrow Margaretha, The. . . . . . . 3.50

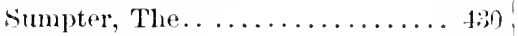

swimeherd, The............. 3. Wagner's Case............. 2..5

Ware $v$. IIylton................ (n)

Tacony, The............. $4: 1$ Wheaton's Case...........

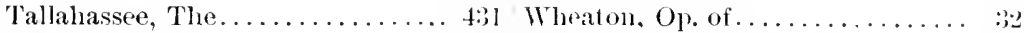

Taylor $x$ Best............ gr Wildenhus' Case........... 120;

Tempest, The............ 12. Willendson $x$. The Försiket..... 19.2

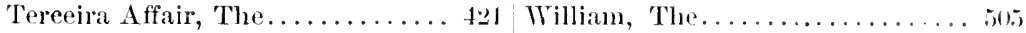

Tentonia, The............ 950) Willian Bagalay, The......... 26:3;

Texan Bonds.............. 1s Williams, I., Case of...........21;

Thetis, The.............. 889 Wolff $x$. Oxholm...........26 



\section{SYLLABUS.}

[Explanation of References.-The references in this Syllabus to the standard modern authors, are to the following editions of their works:-

Bluntschli, 2d Freneh Ed., translated by M. C. Lardy $(1<-t)$; Calvo, 5th Ed. (1858); Creasey, "First Platform of International Law," (1876); IIall, :3 Ed. (1890); Halleck, Ed. by Sir s. Baker (1878); IIeffter, th French Ed. by F. II. Geffeken, translated by J. Bergson (1883); Phillimore, 3d Ed. (1879- ); Walker, T. A. "The Science of International Law" (1893); Wheaton, Ed. by Lawrence (1863), and by Dana (1866), referred to by title Wheaton (L) and (D) ; Woolsey, Erl. by T. S. Woolsey (1890); Wharton's " Digest of International Law" will be referred to as "Wharton's Digest."

This collection of Cases and Opinions will be cited as Cases and Op.]

\section{INTRODUCTION.}

1. Definitions of International Law, or the Law of Nations. (Halleck, I., 41; Wheaton (L), 26, (D), 23 ; Hall, 1 ; Woolsey, 2 ; Creasey, 1 ; Calvo, I., 139.)

2. Origin of the terms " Law of Nations," and "International Law." Compare with the terms "Jus Gentium," ".Jus Nuturels"." "Droit des gens," "Droit international," . Tölkerrecht." (Wheaton (L), 1t-21 and notes, (D), $4-6,16-21$ and note $?$ : Woolsey, 10 ; Creasey, 17-21.)

3. Is International Law a branch of true Law? Objections by Austin and his followers to the term "law" as used in "international law," on the ground that there is no superior power to enforce it: it has no "sanction." In accordance with this view see, (Austin's Jurisprudence, abridged Ed.. pP. i- 14, is? 63, 74, 85; Stephen's History of the Criminal Law. IT.

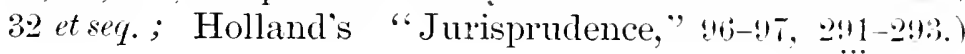


1 Mpmal to this riew (Fir Henry Maine: "International

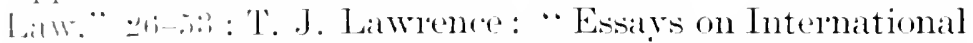
litw". 1 : Hall. 1t-17: Bluntsolnli, 2-10: Moolsey, 206-2!) ;

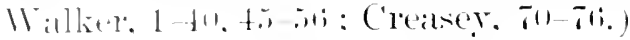

t. The Sources and Nature of International Law. CIheaton, (hillter 1. : Hallerk. I., chapter II. : Hall, 1-1t : Blunt-

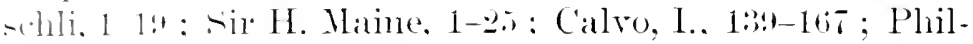
limure. 1.. (hajpter III.)

$\therefore$ Historical sketch of International Law. (Halleck, chaptel l.. IValker, it-112: Calvo. I., 1-1:37. For extended wolls. sere Mard's Law of Nations: Wheaton's History nt the Law of Nations: Laturent : L'Histoire de l'Humanite. (r.t)

†. International Law is a part of the law of States. (Cases and

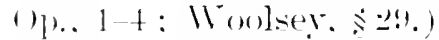

-. The leading writers on International Law. (Calvo, I., 27-9:,

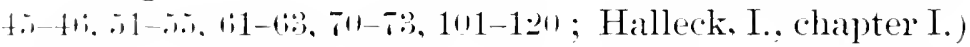

- Private International Law, or the Conflict of Laws. (Hall, $5 t$;

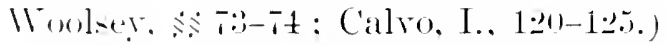

\section{PART I.}

INTERAATTOXAL LAW IX TIME OF PEACE.

1. SUNEREIGX STTATES-DE FACTO STATES.

(a) Sosereigne strates.

؛. Sovereign States are the Subjects or Persons of International Law. Inall. 1 - 1:1: Bluntschli, Arts. 17-27: Phillimore,

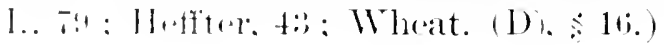

11. Definition and Nature of Sovereign States. (Whoaton (L),

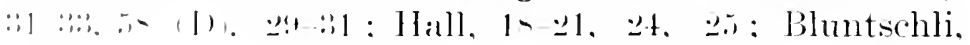
Art- 1-

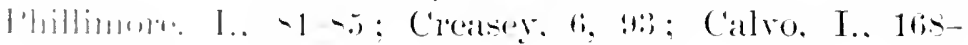
1.11: II+1191.1. (5.) 
11. Distinction between Internal Sovereignty and Extcrnal Sov-

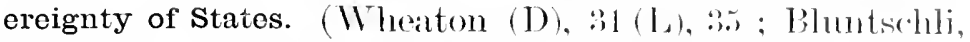

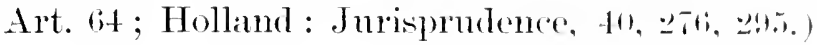

12. Internal changes in a State do not affect its standing in International Law. (Hall, 22.2, 2:3; Wheaton (1), :?.: (1)). 3:-84 ; Bluntschli, Arts. :4-10; Creasey, !9-109: 11oolsey, 38, 89; Phillimore, I., 202-212.)

13. The fundamental Rights and Duties of States. (Hall, 45-47; Halleck, I., so-s. ; Wheaton (L), 11.), (D), s!), !).)

14. Classification of States: "Centralized States," "Pcrsonal Union," "Real Union," (Bunderstaat), "Confederate Union," (Staatenbund), Protected State, Neutralized State. (Hall, 2531 ; Bluntschli, Arts. 70-76; Wheaton (D), 41) 41 , 7:, 78, 82, and note 82 (L), 71-76; Halleck, I., (i2-6t; ; Phillimore, I., 94-101; Calvo, I., 173-17!) (Creasey, 19.5-142.)

15. The Equality of States. (Wheaton (L), 5s, (D), 5. ; Halleck, I., 09-12: ; Heffter, 65-70; Woolsey, ș st; Bluntschli, Art. 81; 'T. J. Lawrence, Essays, No. 5.)

16. Date of the commencement of States. (Hall, si-90: Wheaton (L), ti-tr; (D), 41 ; Bluntschli, Art. 29 ; Halleck, I., $7 t$ and note 1.)

17. Effects of the recognition of a new State by the parent State, and by third states. (Hall, 85-93; Bluntschli, Art. :30; Wheaton (D), 32 ; Halleck, I., T2 and note 1.)

15. When is the recognition by third States of a new State claining independence, proper? (Cases and Op., 13; Hall, !1 -9:3: Bluntschli, Arts. 31-85 ; Halleck, I., 72-7t; Wheaton (L), $46-47$; (D), $41-46$ and note 16 ; Creasey, 67-601; Phillimore, II.)

19. Methods of Recognition-The Congo State. (Hall, RS, note $193, \& 26 . *)$

20. The effect of a change of Sovereignty upon public rights and obligations. (Case of the Texan Bonds. Cases and ()po.. 18, and 20, n.; Opinion of Kent, Hb., 21; Hall, 11.2-11:?; 


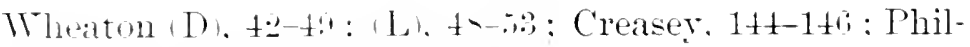

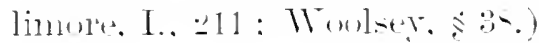

21. Effect of change of Sovereignty upon prirate rights. (C'ire of [. S. r. Perehemann. Citses and Op.. 21 : Opinion of Bayiard, Il. . …?

$$
\text { (b) Ite Facto Sitres. }
$$

$2:$ What are de facto States, or Belligerent Communities? Hall. :1-:::3: Hallecti. 1.. (i-.)

$2:$ Recognition of Belligerency. Oplinion of Dana. Cases and

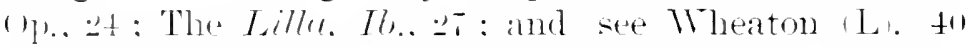
note. 1). note 1.i : Hall. :3-5: : Wharton's Digest. I..

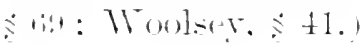

‥ Hare Belligerent Communities any legal right to recognition by Sorereign States? (Hall. 33-35: Bluntschli. Art. $\therefore 12.11$.

2. Forms of recognition. (Hall, $8 \overline{-}-39$ : Wheaton (D), 3i. n.)

24. Recognition of the Confederate States, 1861. (Hall. :4-4: : Woolser, : 1all: Bluntschli. in R. D. J.. II. trie : Wheaton (D), : :-. note.

ㄱ. Succession to the rights of Belligerent Communities., $\mathrm{L} . \mathrm{S}$.

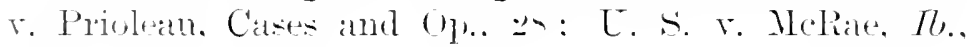
$\therefore 2.12$.

‥ When a Belligerent Community becomes independent, what are its relations to the contract rights and duties of the parent State, as to (1) Treaty obligations, (2) Property, (3) Debts. Hall. "1-10.' Bluntschli. Arts.. ti, t-.

2:1. Right of the United States to the British American Fisheries.

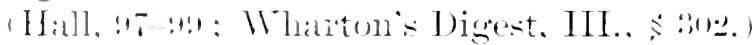

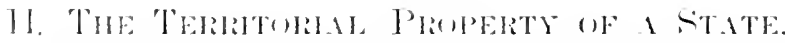

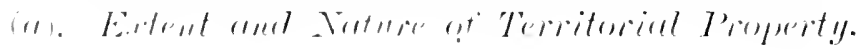

$\therefore$. In what does the territorial property of a State consist?

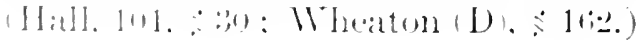


31. What is the nature of the proprictary title of a Stato in (1) the land owned by indrviduals, (2) public lands, (3) navy yards, arsenals, ete., (4) lakes and rivers, (5) the marginal sea. (Hallerk. I., 1:2-1:31 : Pluntschli, Arts. 20iti-

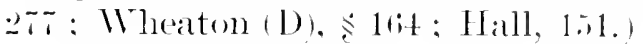

32. Eminent Domain; "Absolute" and "Paramount" rights in the soil ; "Property" and "Domain." (Halleck. I., 1’y-1;, : Wheaton (D), s 16:?.)

\section{(b). Acquisition of Territory.}

39. Modes of acquiring territory. (Hall, : :1: Hallerk. I.. 1:31: Wheaton (D). $(161$.

34. Title to territory based on discovery. (Case of Jolnusonv. M(Intosh. Cases and Op.. i.)

35. Title to territory, based on prior discovery of the coast, of mouths of rivers, upon occupation, exploration, and contiguity. (1) The Oregon Territory. Cases and ()p.. !! : (:) Delagoa Bay, 16.. 11; (:) Texas, Hall, 111-11:,.)

36. Inchoate title acquired by discovery. Occupation, to give title, requires (1) intention to occupy, (2) continuous occupation, (3) to be a State act, or one adopted by the State. (Hall, 106-10\%: Bluntschli. Arts. உた--27!: Phillimore, I., 3.9: Walker. 150, 160.)

37. Abandonment of territory once occupied. (Santa Lucia. ('ases and Op., 12: Hall, 11ऽ.)

35. To what extent inland does the discovery of the coast give rights? The discovery of the mouth of a river? (Cases and Op., 12, note: Hall, 10s-110, and 10, note:- : Tralker, 161.)

39. Tendency to change the law of occupation-Berlin Conference, 1885. (Hall, $3: .^{*}$ )

40. Does prescription give a valid title to territory by the rules of International Law? (Hall, 121-1:2, $34 ;$ : Philli- 


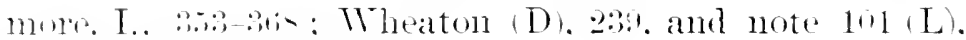

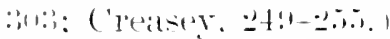

11. Acquisition of territory by aceretion. (Cases: The dima.

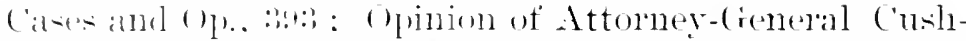

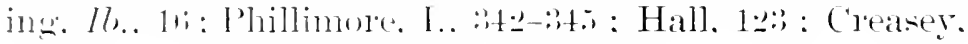

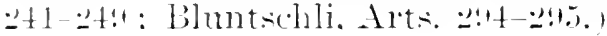

4.2. Acquisition of territory by conquest or cession. (Philli-

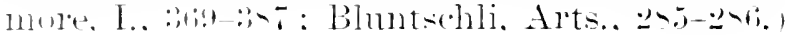

(1) Doplesition of Rights in Foreign Territory.

4:. Serritudes in International Law. (Phillimore. I., 3-5-39.2:

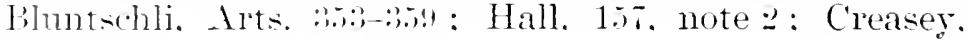
$20.1-2.1 !$.

4. The navigation of rivers. (Cases: 1. Opinion of Theaton. (ats and (1).. :2: : :. Navigation of the Mississippi. Il.. :3: : S. Varigation of the St. Lawrence, 16.. 35: t. Eurojeiln livels. Il.. f': Hall, 1:21-18:9 and notes: Bluntschli. Alts.:311-:15: Woolser. 7!- : : : Halleck, I, 147-15\%.)

4.) Protectorates over semi-eivilized peoples. (Hall. 127. $\therefore \because \div$

\section{(d) Bontataries.}

4i. The Political Department of the Government, in the United States, determines what are the boundaries under treaties. I Futer r. Veilson. ('ases and Op., 1t: in re CooperThe sarward (ase. 14:3 L. S. Rep., tiz.)

t. River boundaries are how determined? (Opinion of Atroney-(ieneral ('ushing. Cases and Op.. 11; : Bluntselli.

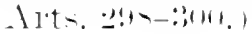

4. How are boundaries usually determined in the ease of lakes

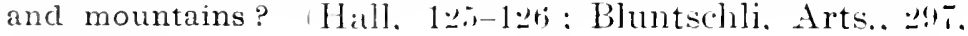
$\because, 111-: 31:, 1$

$$
\text { (r). Tirriturial Wieters of a State. }
$$

:'. The history of attempts to appropriate the seas, or por- 
tions of them; the contest between maro elausum and maro liberum. (Hall, l:3:-1.il, stu) Mheatullis llistruly of the Law of Nations. liz liz: ('alvo. l., til tibi:

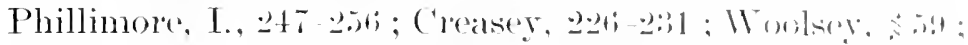
Cauchy (Ed., Istie), II., !2 12t ; Wheaton (I)), Moto No. 113 ; Walker, 16:3-171.)

50. The origin of the rule limiting the territorial right of a State in the sea to a marine league from the shore. 'Terrae dominium

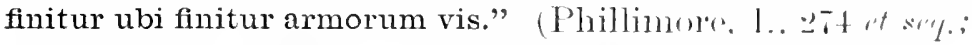
Hall, 1.51-1.58; Wheaton (D), \$ 1-!) and note No. 11.5; Creasey, 233-240 : Walker, 171-175: The Case of The Queen v. Kern, Cases and Op., 5. ; Wolser, di- 7r: Halleck, I., 13-14; Calvo, I., tri-tso; Mharton's Dig.. s.2.)

51. Bays, Gulfs, and Straits, which are more than six miles wide. (1. The sound Dues, Cases and Op.. 41 : :2. The Bosplnorus and the Dardanelles, $I b ., 4: 3: 8$. Regina r. C'mmningham. Ib., 4t ; 4. Cable Co. v. Telegraph C'o., Il., t. : ; Man.

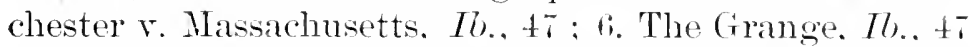
n., see also : Hall. 15:-1.50; Bluntschli. Art. :319: Perels.

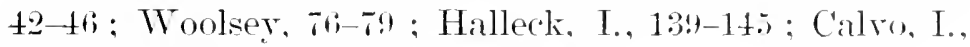

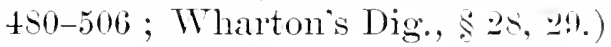

52. Interoceanic Canals-Suez Canal neutralized. (Calvo, I... . 516 ; Boyd's Wheaton, 30.5 b. \& c. ; T. J. Lawence, Essays, 37.$)$

\section{TERRITORIAL JURISDICTION.}

(a) Doctrine of Exterritoriality-Eaception to the Rule of Exclusice Territorial Jurisdiction.

3. Sovereigns are exempt in their persons and property from the jurisdietion of foreign courts of law. (1. Tavasseur $\mathrm{r} . \mathrm{Kr} u 1)$. Cases and Op., 72 : 2. De Haber r. Queen of Portugal. Ib., 76; 3 Priolean v. U. S. and Andrew Johnson. I7.. : : : 4. U. S. v. Wagner, $T b$. . 7 ; 5. other cases, $T 7$. . 4.), note. And see: Hall, 162-167 ; Phillimore. II., 139-1.5.): Blumtschli, Alts. 129-134.)

54. Diplomatic Agents-Immunities from Criminal Jurisdiction 
1. Bishop of Ross. Cases aml Op.. - : : 2. Mendozal. Tri..

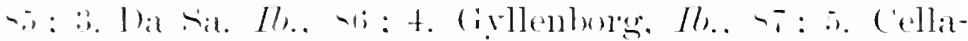

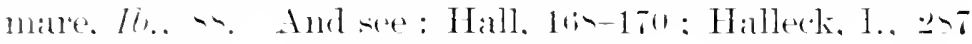

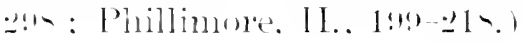

$\therefore$ Diplomatic Agents-Immunities from Civil Jurisdiction. (1. Am-

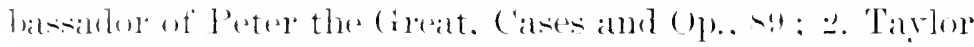

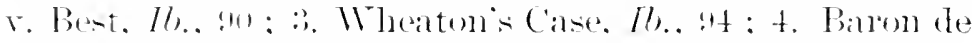

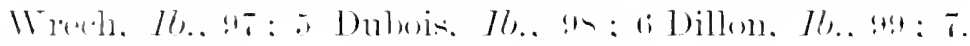

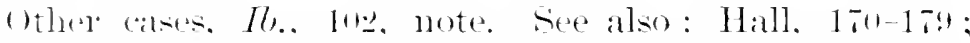

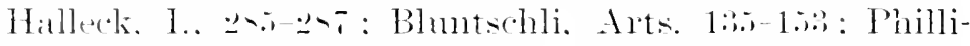

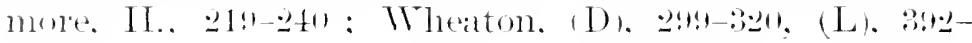
$+11 i .1$

iti. Armed Forces and Ships of War in foreign territory are not subject to the localjurisdiction. 1. Exchanger. AlcFadilom.

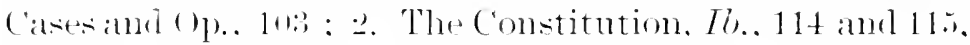

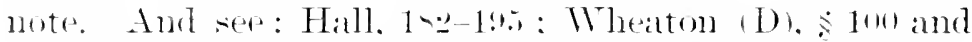

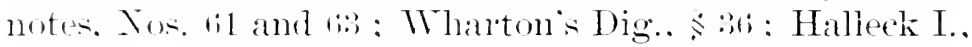

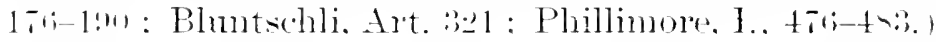

$\therefore$ Public ships other than ships of war are not subject to civil process in foreign ports. I'The l'erlement Belye. C'ases and () l). 116 and 120, note: Hall, ș.,

$\therefore$ Merchant ressels are not, as a general rule, exempt from the local jurisdiction, in foreign ports. (1. The Nellowe allet the

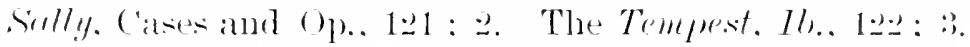

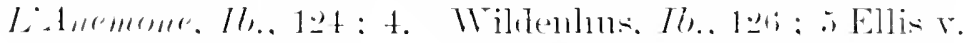

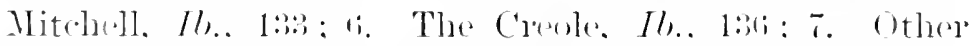

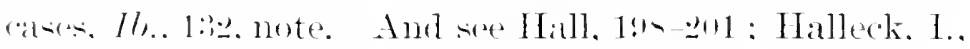

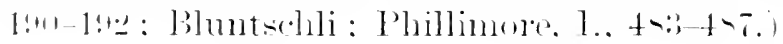

i!t. Reasuns for the fiction of Exterritoriality-The reasons usually

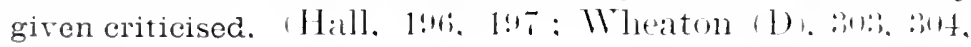
linte.

$$
\text { (b) Rigght of Asylum. }
$$

(i). Legations do not, as a rule, grant asylum to political refugees nor to fugitives from justice-Exception, in the case of Spanish

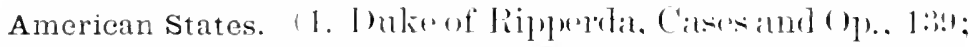

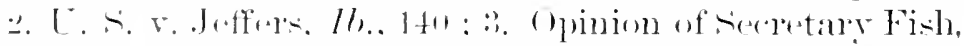

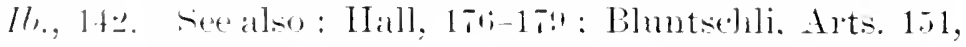
$\because 111.2111 .1$ 
61. Whether ships of war may grant asylum to political refugees, opinions differ. It is the common praetice in Spanish American waters.-(John Brown Cases and ()p., 1 th and Ho, motr.)

6.:. Ierchant ships, having no immumities from foreign jurisdiction, by International Law, cannot properly grant asylum to politieal

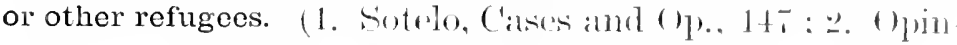

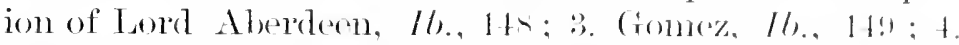
Batrumdia, Th., 1.in, note; J. B. Noore, in the P'olitical science (cuarterly for ls:t:)

(c) Other Questions of Territorinl Jurisuliction.

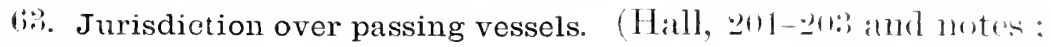
The (neen v. Keyn.)

i.t. Are aliens exempt from military duty? (Hall, 2014 ok; ; Blunt-

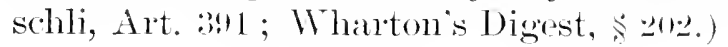

65. Are offenses committed by foreigners, beyond the limits of a State, subject to the Jurisdiction of its Courts? (Cas of ('it ting. Cases and Op., 172 and 17t, note: Hall. 2016;-20!s and notes; Wharton's Philoseplry of Crim. Law, :in!) el sey. : Fiore, in R. D. I., XI., 310-31!.)

6if. Criminal Jurisdiction of the State Courts in the United States.

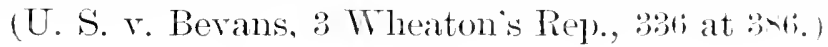

67. Extradition of fugitives from Justice-1. It is not a duty under International Law, in the absence of treaty-2. In the United States it is exelusively a Federal question-3. A person extradited is to be tried for that offense only for which he was extradited. (1. U.S. v. Rauscher, Cases and Op.. 1.il and 1.;. note ; 2. Arguelles, Moore, on Extradition, I., :i:, Finar. on extradition, 1:-1t; $:$ Ex parte Holmes. Noore 1. is 58 ; Spear, 20: Winslow, Moore, 1., 196, ⒈.)

6. As to the surrender, under extradition treaties, by a State of its own eitizens. (Case of Trimble, ('ases and () 1). 1.i amo 160, note: Moore, on Extradition, 1., 1.i.)-1!:?.)

69. States do not, as a rule, surrender persons charged with political or military offenses--What is a political offonse? (1. Cazo, Cases and Op., 161; 2. St. Allums Raill, /l.. 16i2: 


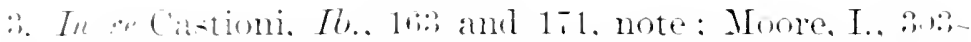
: $2:-1$

71). Leading works on Extradition. (Billot: Traite de lextra-

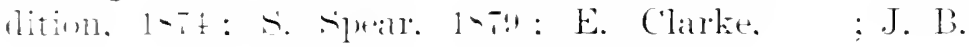
Hente. 1-!1 : 1)e citienlitz: 1. Lammaseh.)

71. Extraterritorial acts of persons by order of their Government.

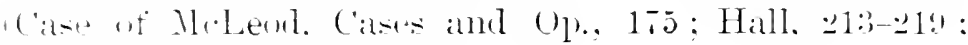

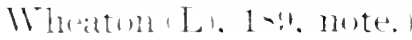

-.. The Extraterritorial acts by a state in self-defense. 1. The

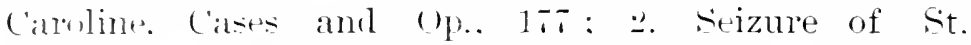
Marks. Ml.. 17: 3. The Tirginius, Mr.. 17!. See Hall. $\because 1 i j-\ddot{-1}+1$

$7:$ Responsibility for injury to foreigners by civil commotions and mob violence. The New (olleans Riot. 1-i, ('ases and (1).. 1-1: Xew orleans Mob, 14!1. Ml.. 1-3, note : James Brrce. in the Xew Review for Mar. 1-41: Calro. th Ed.. III..

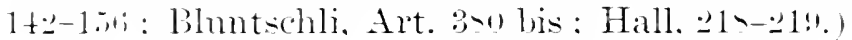

IV. JLRISDICTION ON THE HIGH SEAS.

it. Is the jurisdiction of a State over its citizens and property on the high seas exclusive? (Hall. $24:-{ }^{\prime}+4$; Wheaton 1 D). $\therefore 111,11 \%$.

$\therefore$ Theory of the territoriality of merchant vessels. (Hall, 24+ $2: 1$ : Blunt

7i. Impressment of Seamen. (Wheaton (D), $\leqslant 11$ - 10 -1 and note ii.

$\because$ Jurisdiction over merchant ressels on the high seas. (1. The

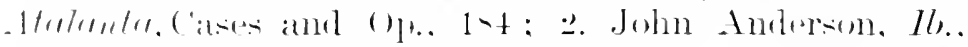
$1-\therefore: \therefore$ Regina r. Leslie. Ib.. 1-T: t. The Belyeuland. l! . . 1 - !! . 1

- Mumleipal Seizures beyond the Three-mile Limit. (C'ase of

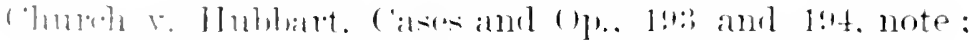
Alommont uf E. J. Pluelps hefore the Behring sea Tri 


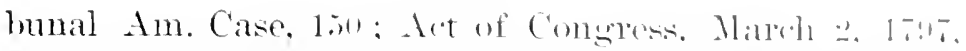

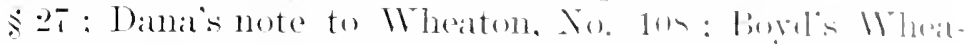

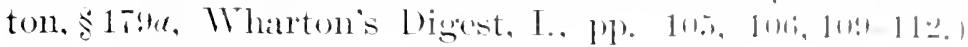

79. Piraey-Definition and character of Piracy jure gentium. (1. (1)inion of sir L. Jenkins. (atses and (1). 1:5: :

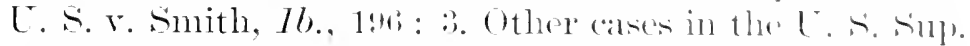
Cont are, U. S. r. Palmer,: Wh., 610: L. s. v. Klintok, 5 Wh., 152: C.s. r. Pirates. M., 1-s: L.s. v. Hohnes. Ib., +12. See also: latwrences note to Wheatom. Xo. 7!) : Hall, 252-261 ; Phillimore, I., tye et sey.; Bluntschli. Arts. $: 343-352$.

80. May Rebels and Insurgents be regarded as Pirates? Piracy by

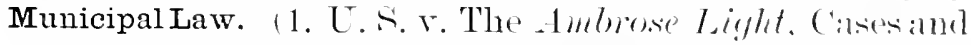
Op.. 200 and $24 t$, note: 2 . The Magellan l'irates, $/ 6$.

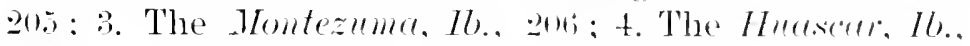
20s. See also: C.s. r. Baker, in Blatch., di, and ITharton's Dig., III., thit: The Chesapeale, M., I., F: : The Carthagenian Insurgents, Il). III., thit, and Hall, entil. And see: Hall, $261-264$; Calvo, $11+6-11+5$; Woolsey. $\$ 1.5$; Wheaton (D), 19ri, note.)

81. The Slave Trade is not Piracy jure gentium. (Case of Le Louis, Cases and Op., 20!!: The -tutelope. 10 Wheaton. 66. See also: Wheaton (D), $12.5-13 \%$, and notes s.5-s:1; Woolsey, $\$ 1+6$.)

\section{T. INTERVENTION.}

8. Character of Intervention-Conditions of. (Hall, ㄴ>1-24:; : Bluntschli, Art. tit: Wheaton (D), 68: Wharton:s Dig.. I., 55 ; Phillimore, I., 5.30-6:35; Heffter, 116-111: Creaser, $2-8-296$.

83. Intervention, on the ground of self-preservation. for the protection of (1) institutions, (2) good order, (3) the extermal safety of the intervening State. (Hall, 2a:-2): Pomeroy, 245; Creasey, $297-30)$.

8t. Interrention against illegal or immoral acts-Caso of Greece, 1826 ; Bulgaria, 1876. (Hall, ․osi.) 
- $\therefore$. Intervention under a treaty of guarantee-by invitation of one of the parties in a civil war-under collective authority

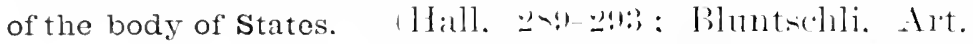

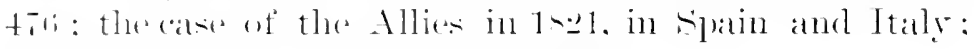

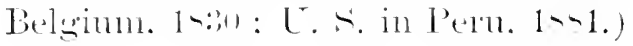

\section{Talionalily.}

-li In what does Nationality consist? The Doctrine of Indelible Allegiance.-Expatriation. 1. Oprinion of Cothlmm. ('ases

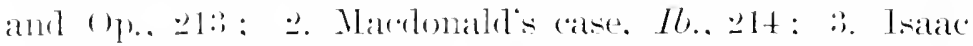

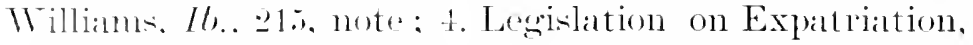

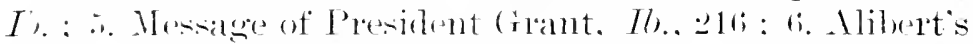

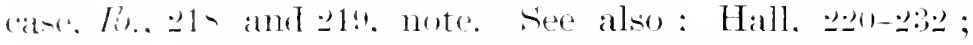
Wheaton (L), -!) ot ser. : Creasey, 3.5 ; Halleck. I., if el ser.: Walker. 2014-21s: Heffter, 1:36-138; Wharton: Digest. \$1 171: (alvo, II.. 2t.)

-7. Citizenship-Naturalization. (C'ases: Ed jurte Chin King,

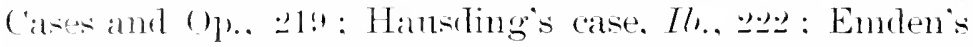

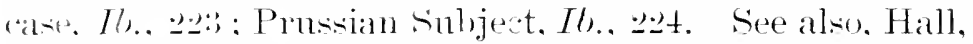

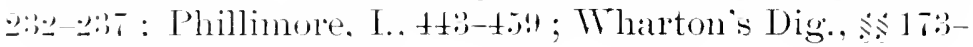
lit: Halleck. I.. :isti.)

- If a naturalized citizen returns to his native land, what are his rights? (Case of 1 agner. Cases and (Y).. 2.25;

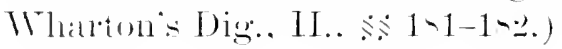

- N Nationality of children born abroad; of illegitimate children; of married women. (Hall, ․ㅡ.)

(11). What is the effect of domicil, and a declaration of intention to beeome a eitizen, upon the nationality of a foreigner? - Is he entitled to the protection of his adopted State when

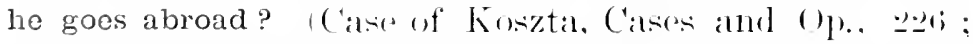

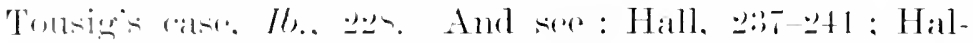

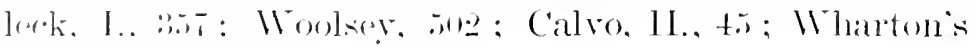
l)in... I . . : :is

(1) Persons destitute of nationality-Meimalhlosen.--Hall, 2+1; linutwhli. Art. :iris.!

1.'. Status of the Chinese in the United States.-Treaty of 1880 , 
and Acts of Congress of May 6, 1882, July 5, 1884, and tho Geary Act of 1892.-Under the fourteenth Amendment to the Constitution, Chinese ehildren born in the United Statos are eitizens thereof.-It was so held in the case of Look Tin Sing, 35 Fed. Rep., 354, and in the case of Chin Sing.

93. Status of Indians in the United States. Indian tribus

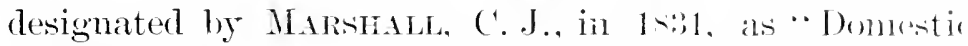
Dependent Nations" "the Cherokee Nation v. Georental, is Peters' Rep., 1.) Since 1atl no formal treaties have leorn made with sribes, and they have becon suljectesl to the authority of Congress. But in 1sit, the Supromo Cont held that an Indian born in a tribe, thomgh having left it. was not a citizen, and the fomrteenth amendment did not apply to him. By the legislation of 1sis, howeres. Indians even in tribes have been generally subjected to the jurisdiction of the Ferleral Courts ; and it would sorm that they should now be citizens by birth under the fomrteenth amendment. (1. Elk v. Wilkins, Case; and (1).. 230; 2. U. S. v. Kagama, Ib., 2:3:; ant see the case of Crow Dog, 109 U. S. Rep., 5.jt; Wharton's Dig., II., 592$.

\section{International Agents of a State.}

94. Persons designated by the Constitution of a State to manage its Foreign Affairs-Department of Foreign Affairs-Stato Departmont, in the United States. (Hall, 2.14, 2!5.)

95. Diplomatic Agents. (1. Ambassadors, Legates, Nuncios. 2. Enroys and Ministers Plenipotentiany. D. Ministers resident. 4. Chargés àAftaires. The first three classes are accredited to the Sorereign, the fourth to the Minister of Foreign Affairs.)

96. Rights of Diplomatic Agents-Refusal to receive a Ministermust be persona grata-Credentials; Letters of Credenee, Letters Patent; Fuil powers ; Instructions ; Passport. (Hall, 296i-301; Bluntschli, Arts. 1.i!-1!0); Whetaton (L), ㄹ:

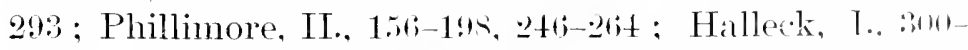
304: Calvo, III. \$ 12812 et ser.: Woolsey, 126-1:35: Heffter, 479-45t, t91-49!1, 507-51t; Wharton 's Dig., I. $8.82-83$. 
1\%. Termilation of Mission-Recall, and Dismissal. (Hall, 301-

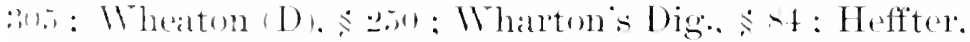

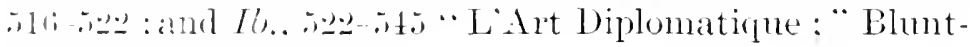

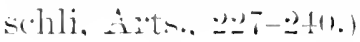

"'. Ambassacors' Rights in friendly States, on their way to or return from their posts. (Jall, s: !!-101: l'hillinole. IT.,

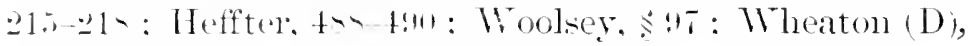
$\therefore \therefore+1+2+1$.

!!!. Consuls: Origin of office-Functions-Appointment-Dismissal -Privileges-Consuls Diplomatically accredited-“Lettre de provision"-Exequatur. (Sehuyler"s "American Diplo-

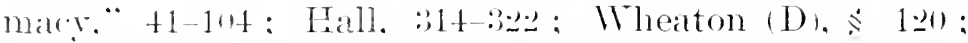

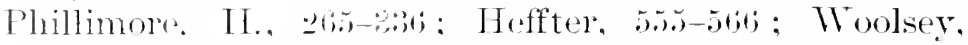
1.2-15: Calvo, III.. 1960-1390; Halleck, I., 310-3:30 ; Wharton: 1)iget. $\leqslant 113-124$.

1ii). Judicial Functions of Consuls in semi-civilized lands.

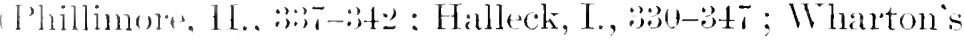
1)is... $\leqslant 1 \%$

\section{Treaties.}

111. What Treaties are not subjects of International Law ? (Hall, :i2:; and note: Blunts(-hli, Art. $4+3$.

11.2. Kinds of Treaties-Conditions necessary to the validity of Treaties-Authority of persons contracting-Freedom of Consent-Intimidation-Fraud, etc. (Hall, :3:2:)-3:27; Heffter,

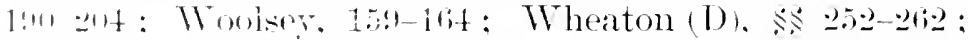
Ifallork. T.. 2:it 20:7 : Bluntechli. Arts. 412-424, 4t2 : Phil-

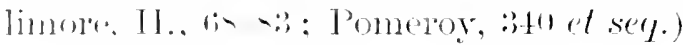

11:\%. Forms-Tacit and express ratification-Refusal to ratify-Com-

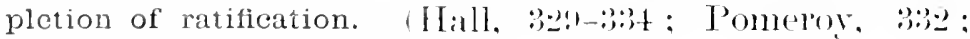

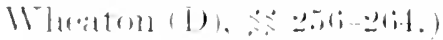

111. Interpretation of Treaties. Convention of 1818 between England and the United States (Fisheries), the Clayton-Bulwer

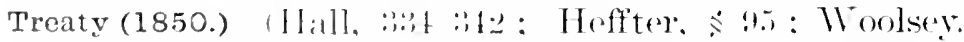

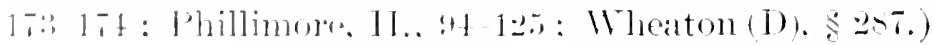


105. Confliet between different Treaties, or between different Parts

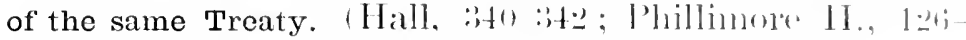

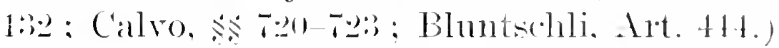

104i. Treaties of Guarantec. (Hall, :it.) :it.): Bluntschli, Arts.

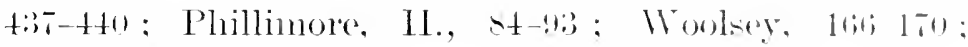
Heffter, s: $: 1$.

107. Legislation necessary to carry treaties into effect-Is the House of Representatives in the United States under obligation to pass aets neeessary to carry treaties into effect? The Jay Treaty, 1794, The Alaska Treaty, 1867. (Wheaton (D)),

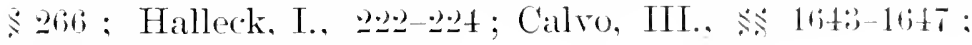
Wharton's Dig.. $\leqslant$ 131

111. A Treaty dates from the time of Signing, not from that of Ratification.

1119. The obligation of Treaties-Difference between a void and a voidable Treaty-Test of voidability. (Hall, :3, i, :3i!t: Creaser, 40-4t; Phillimore, II., 7t; M. Bermand, “Lectures on Diplomacy," 16is ; Heffter, 4s: Bluntschli, Arts. 415, 456-461 ; Pomeroy, 347 ; Mame: "Ancient Law,"

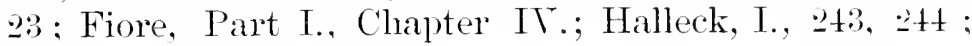
Wharton's Dig., 13ia.)

11). Most favored Nation Clause in Commercial Treaties. (Tharton's Dig., s 1:3t.)

111. Renewal of Treaties. (Hall, 11\%.)

IX. Anicable Settlearext of Displtes AND ATteapts To Mitigate the Evils of War.

112. Arbitration-Mediation. (Hall, 361-36i; ; Bluntschli, Arts. tos-49s; Calro, 1706 et ser.; Rouard de Carl. "LiAli-

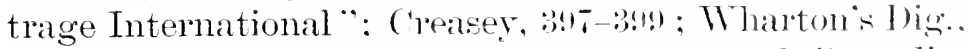
\$16; Sheldon Amos: " Political and Legal Liemedies

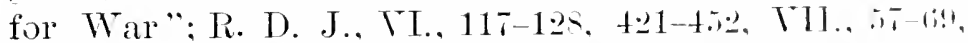
$27 \%,+18,423-426,70$, YIII., 167. X., 66i1 ; Halleck, I., 413-41s ; Phillimore, III., 1-17.)

118. International acts and movements with a view to mitigate the 
evils of war. , The ". Jenlalation of Palis." Appendix B :

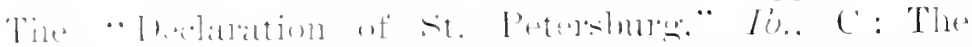

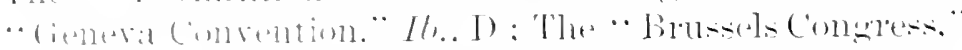

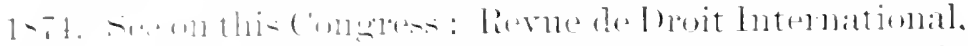

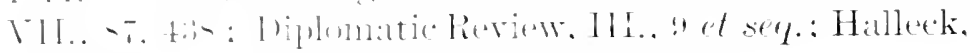

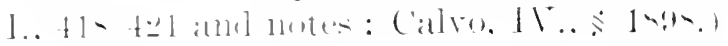

111. Acts of Individunls and Societies: Founding of the "Institute of Intermational Law," 1871, and the "Association for the Reform and Codification of International Law," at about

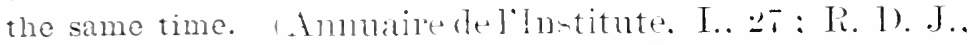

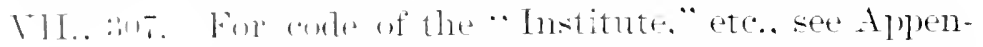

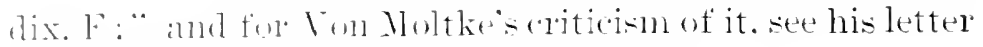

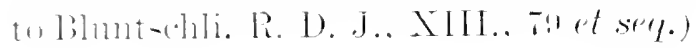

\section{PART II.}

IXTERIXIUAAL RELATUNA AS MODIFIED BY TI. R.

1. MEASTEA SIORT (OF MAR-I)EFINTTON OF WAR-DECLARATTOS OF 11 AR.

11\%. Reprisals-Retorsion-Pacifie Blockade. (1. Silesian Loan.

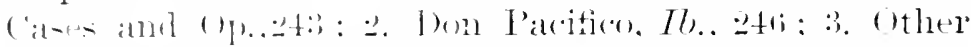

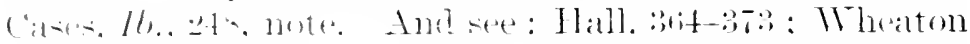
1).

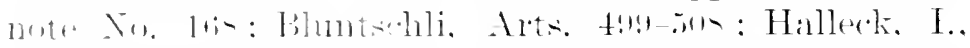

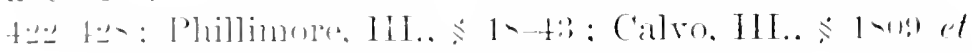

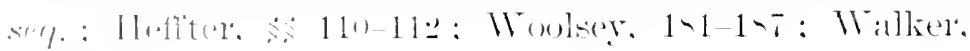
lin lin. 1

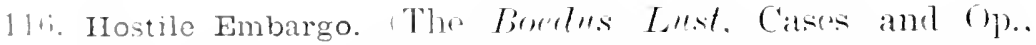

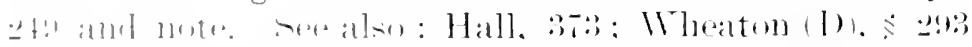

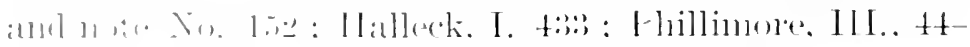

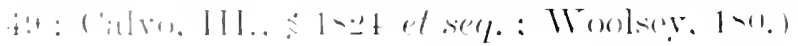

117. Declaration of War-War without a Deelaration-Civil WarDate of the beginning of a War. 1. The Toutomire. Cases and

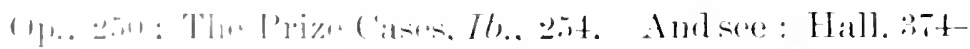

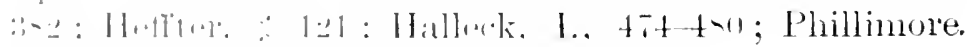

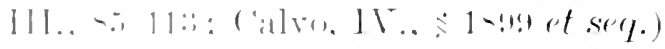


11S. Definition of War-Its Object-Causes of War-Kinds of War.

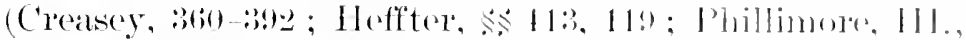

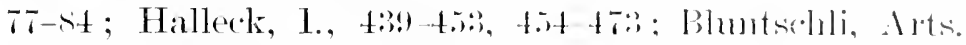

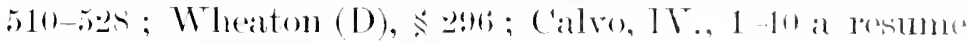
of opinions of writers : Woolser. 211.)

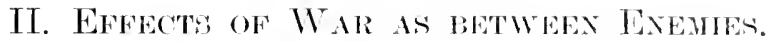

\section{(a) Lan's and Usages of Tlar-Comeluet of ITostilities.}

119. Who are enemies in a war? One theory is that all eitizens or subjects of one belligerent state are the enemies of all the eitizens or subjects of the other. Another theory is that war is a eontest between states, and that private individuals of the belligerent states are not enemies at all. The first is the old view, and is still supported by the better authority. (Creasey, :7i :3it: Calvo, 208.52136 ; Halleck, II., 52 58; Bluntschli, Arts. 52!-580; Woolsey, 550; Walker, 278.)

120. All peaceful relations between the bolligerent States and their eitizens cease on the breaking out of war. But modern usage permits alien enomies to remain in the territory unmolested unless their prosonee becomes dangerous to the state. (Mall,

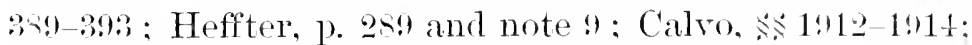
Phillimore, III., 12s-130; Halleck, I., 48:-4...)

121. Who are Non-Combatants? (Hall, 39t-390; Wools's , 2112.1; Halleck, II., 2-3.)

122. Who are lawful Combatants ?-Conditions-Authority-Organization-Dress. (Hall, 894;, 51!-525 and notes ; Halleck, Il.,

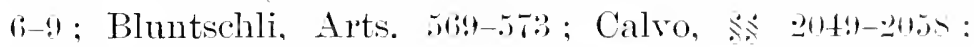
Walker, 24!); Woolsey, 214-215.)

123. Maritime War.-Privateers-Letters of Marque and ReprisalVolunteer IJavy. (Hall, 5.5-5)! ; Wheaton (D), s:sis and note No. 173; Wharton's Digest, $358-35$; Calro. $\$ 20 \%$ et seq. ; Halleck, II.. 9-20 ; Woolsey, 201-20s: Heftter. $\$ 2 t$; Declaration of Paris, Appendix B.)

1:4. Prisoners of War.-Whomay be taken prisoners?-TreatmentParole-Exehange-Ransom. (Hall, t18-41:); Halleck. II.. 3 n., Tt-89) Davis, 239-237: Creaser, 452-4.2: Calvo. s. 2133-2157; Blintschli, Arts. 599-626.) 
12.. Care of the sick and wounded-Genera Conrention-Rea-Cross

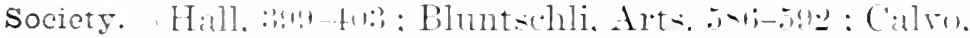

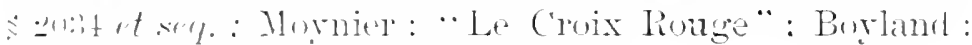

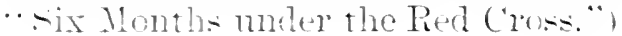

1:1i. Instruments of War-Means of Destruction. (Hall. . .

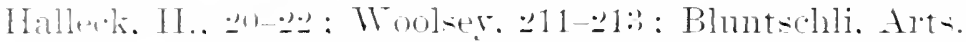

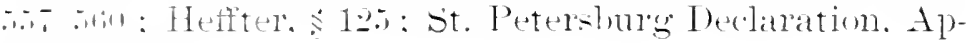
luncix I).

12-. Derastation.-Is it erer lawful? Hall, in:-i:; : Halleck. I1.. 11 ; -11:!.,

1.-. Bombardment of towns-Fortified-Open. (Hall. i:s: Daris.

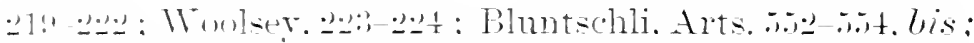
(alvo: $2010-204$. All the important cases will be formetinc (alro.)

1:"'. Deceit-Spies-Balloons. (Hall. 59., 589 : Halleck. II.. 22$\therefore$ : Calro. $\because+1-211$.

(1) Etivet of II ar "jom Property. and Commercial Relations urith the Enemy.

1:11. When war breaks out between two states, the movable or personal property of citizens of either, found in the territory of the other, on land, was by the old and strict rule of war confiscable. Debts due to citizens of the enemy State followed the same rule. But in modern practice this rule has become nearly obsolete.

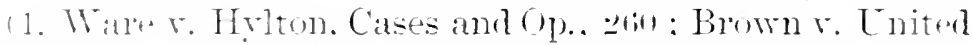

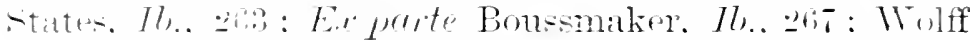

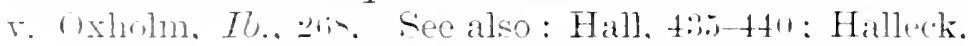

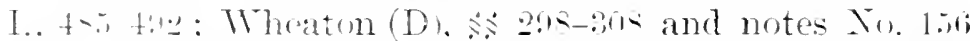

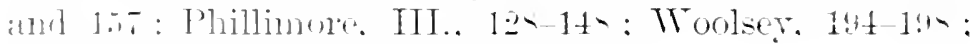

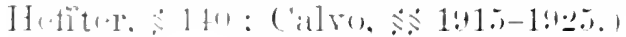

1:i. Property of the enemy found afloat in ports, on the breaking out of war was gencrally confiscable as prize until a very recent time. But here too. later practice would seem to harediscarded the harsher rule. Compare with Embargo-case of Boedus Lust.

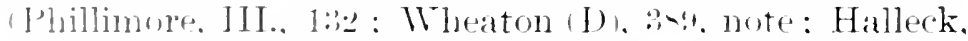
1.. $4: 1-1: 2.2$ : The Johanue Emilie, Cases and Op. 270, n.) 
132. Debts of a State due to the Enemy and the interest thereon are

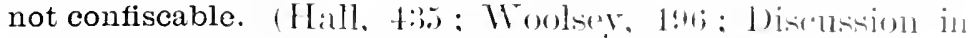
the case of the Silesian Loan : Phillimone, III., I 々.)

139. Immovable property-lands and houses-of the cnomy within the limits of the other belligerents are never con-

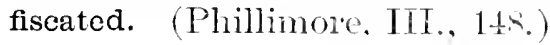

131. Property of the enemy fcund on the sea or in the ports of the enemy, is confiscable as prize of war-Modified by the Declaration of Pars. (Appendix B. Hall. 4:3, 14 , and $4+2$, s $1+6$.)

135. Contracts between enemies made before the war. -1 . Executed Contracts.-2. Executory Contracts.-Statutes of Limitation.-Interest on Debts.-How affected by war? (1. Hanger r. Abbott, Cases and Op., 2070: 2. Ciriswold v. Waddington, Ib., 2rt; 3. N. Y. Life Ins. C'o. ․ Stathem, Ib., 27s. See also : Gamba v. Le Mesurier. $t$ East., 407; Halleck, I., ts1; Walkel, 276: Hall, :3- : Kent, I., 6s.)

136. Effect of war upon treaties between the belligerent States previously existing. (Wheaton (L), $160-47 \%$ (D), :,i.) and note ; Hall, 35-3-7: Phillimore, III., 7:2-911 : Bluntschli. Art. 535; Case of the Society for the Propagation of the Gospel v. New Haven, Wheaton's Rep., 494; Heffter, (12:)

\section{(c) Trade with the Enemy.}

137. Trade or Intercourse with the enemy is wholly interdieted; and is in all cases illegal, unless under a license of the State. (1. The Hoop, Cases and Op., 2s3; ‥ Potts r. Bell. Ib., 257. See also : Hall, 387-355; Kent, I., 6rj-ti9: Halleck, II., 15t-15s; Heffter, 123 ; Phillimore, III.. 111;-1.21 ; Calvo, \$\$ 1926-1929; Woolsey, 255; Wheaton (D), ㄴ: 349317, and note No. 15s.)

135. Licenses to trade.-They must, as a rule, be granted by the Supreme Authority of the State, and must be granted or assented to by both beliigerents. (Hall. 5.9-isti: Halleck, II., 36t-379; Woolsey, 256. Case of the Sea Lion, 
(atses and ()p. 3in. gives the practice of the United

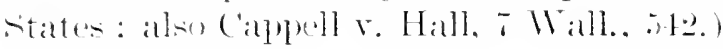

15:. After the outbreak of war, a eitizen may not go or send to the enemy's country to bring away his property. (The

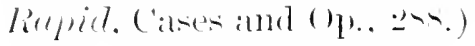

14'. Citizens who are residing in the enemy's ecuntry, on the outbreak of war should be granted a reasonable time to return with their property to their own country. (1.

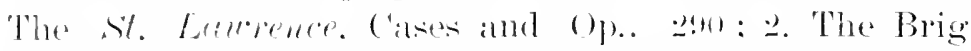

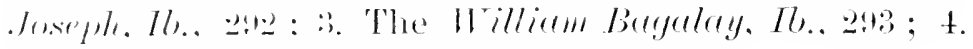

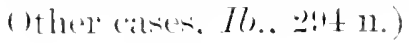

141. Contracts entered into with enemies during war by eitizens residing in the enemy's country. (Kershaw r.

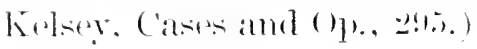

1.2. Bills of exchange drawn by a citizen, while a prisoner in the enemy's country, upon a person in his own country, and sold to an enemy-Is this a trading with the enemy? Intrine r. Morshead. Cases and Op.. 30 : and Kent, I., ii: Halleck, I., th1 : Wheaton (D), \$:31\%.)

14:. Agerits-Right to employ agents in the enemy's countryappcinted (1) before the war-(2) During the war. (Lnited states r. (irossmayer. Cases and $\mathrm{Op}_{\mathrm{p}} .20 \mathrm{~s}$; Filor's case, (1) IIll. 4.i.)

1H. Insturance on ships of the enemy. (Furtade r. Rodgers.

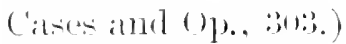

14. Ransom Contracts-Ransom Bill-Safe Conduct-Exception to the rule in respect to trade with the enemy. (1. Cormu

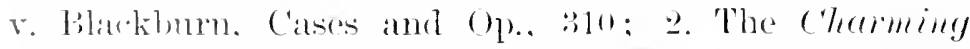

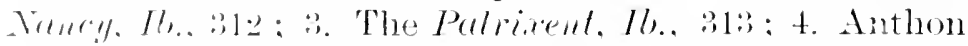

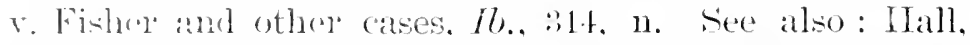
trit-til : Italleck. II., 3.9-361 ; Wheaton (1)), $\$ 41$, and note No. 1:4: Phillimore, IIL., 6tt-6t5: Woolsey, 2t5-

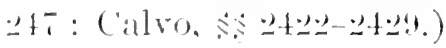

14t. Pacifie intercourse of Belligerents-Commoreia belli: Flags 
of Truce-Truces-Passports-Armistices-Cartels-Capitulations-Licenso to Trade-Ransoms. (Hall. ifl inti : llal-

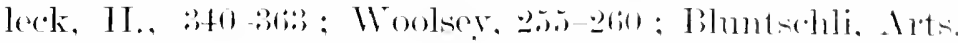

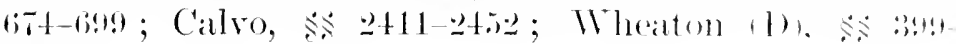
tos.)

(a) Commereial Domicil-Satiomal Cuaracter of Peoperty.

147. The National Character of property, in time of war, depends upon the domicil of the owner-French Rule. (1. 'I'he

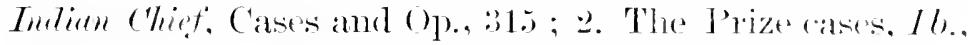

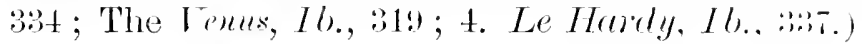

148. What constitutes Domicil-How determined-Animus manendi-Time. (The Hammu, Cases and (1)., :326. And

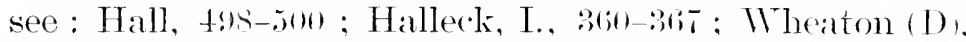

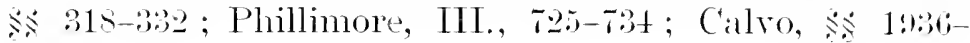
$19+5$.

149. House of Trade - It takes the National Character of the country in which it is established-Exception: House of trade in a neutral state, and the partners, or some of them, reside in an enemy country. (Hall, inl; Wheatom (1)). (39t.)

150. The Product of the Enemy's Soil takes the National Character of the country where it is situated. (Bentzen r. Borlt. Cases and Op., 830 ; Hall, 5(1.2; Wheaton (D). $5:$ :3t;389.)

(e) Ownership of Goods in transitu, on the Oceam. in time

$$
\text { of } T^{\mathrm{T}} \mathrm{ar} \text {. }
$$

151. In time of war, or in contemplation of war, Goods shippeci on contract are at the risk of the Consignee during transit-The French rule permits the shipper to take the risk by agreement. (1. The Packet de Bithor, Cases and () p.. :3:3:1: :2.

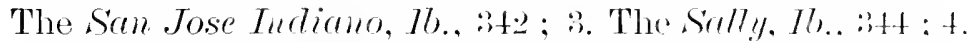

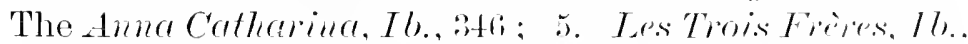

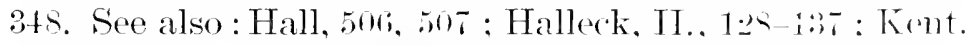

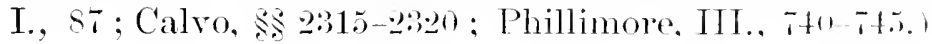

152. Transfer in transitu-Stoppage in transitu-Aceording to the 3 
rule of the English and American Prize Courts, property, in hostile at the tme of shipment, eamnot change its character cluning transit by sale to a neutral. I. 'Phe lin/l M/1'-

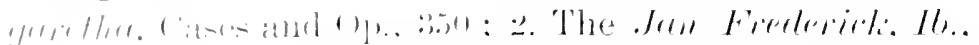

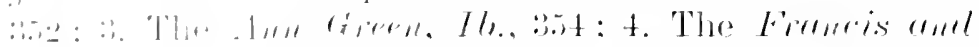

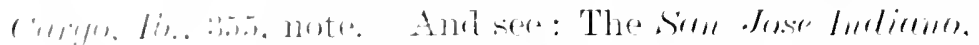

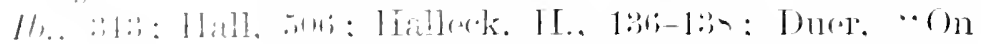

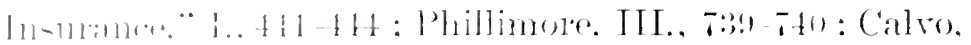
$\therefore$ and. 2u- dissents from the English and Ameritan r.i....

1.i). National character of merchant ships, and their transfer during war from a Belligeront to a Neutral. (Hall. 5ilt-

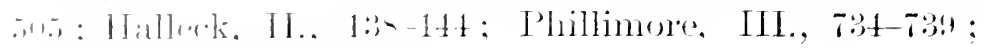
(

1.it. Proof's of the National Character of merchant ships. (Calvo,

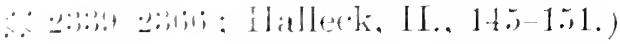

la., Fishing Boats geicerally exempt from seizure. (Hallex lk,

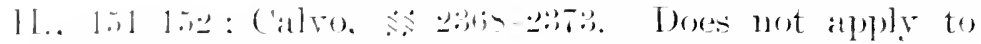

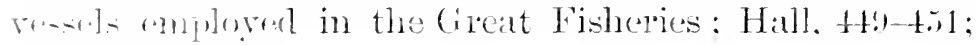
$110,1+1, y, 8,2)$

1.24. Freight in the case of eaptured vessels. (1. The Tirm,

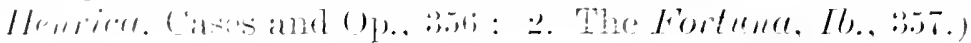

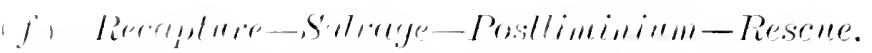

1.7. Recapture-Salvage-When does title to recapturel property vest in the Captor? 1. The Sirnle C'rus. ('ases and ()p)..

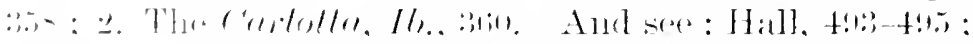

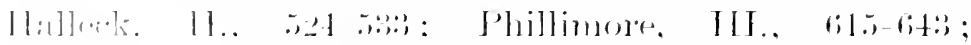

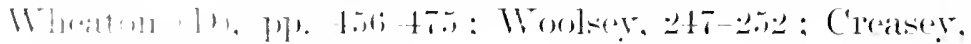

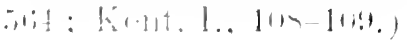

1.i- Rosme by Noutrals. I'The Emily S\% I'irere. Cases and

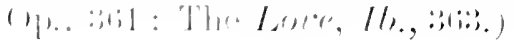

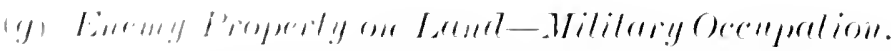

1.it. Public Property of the Enemy-Lands, Buildings, Arehives, Works of Art-Movable or personal Property. (Mohr ald 
Haas v. Hatzfeld, Cases and Op., 87. Serealso: 1lall.

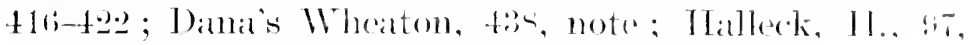

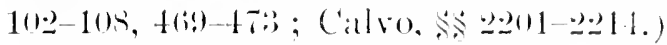

160. Private property, Real and Personal, as a rule, not confiscable, at least not by way of Booty, though personal proporty may be taken by way of Contributions and Requisitions-Comparison in respect to the difforent rule appliced to enemy's property at sea and on land. (Whrieton (1)).

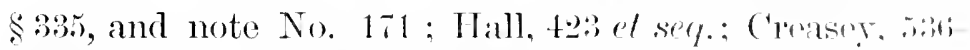
5.56; Heffter, \& 1:3: : Bluntschli, Art. bis: T. J. law-

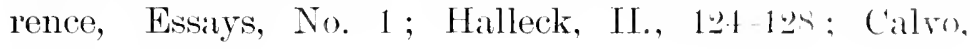
$\S 299+$ et seq.)

161. Requisitions and Contributions in land wars-Will they be resorted to in maritime wars? (Hall, tor-4:3); Hallerk,

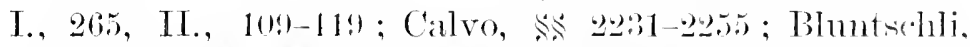

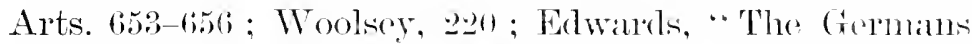
in France" ; Sherman's "Memoirs," II., 17., 1-1-1〉t. $207,227$.

162. The Bombardment of Towns. (Hall, 534, 535.)

163. Military Occupation-The general character of the Pight and Jurisdiction of an Invader over the territory oceupied by his armies-Old Theories-Modern View. (Hall, tie

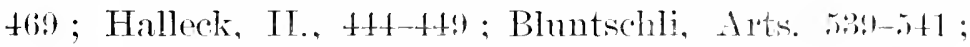

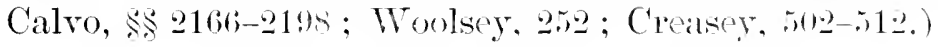

164. Relation of the territory occupied to the Government of the Invader-To that of the State invaded. (1. Lnited States r. Rice, Cases and Op., 31it; 2. Fleming v. Page, Il.. 34is: 3. Cross v. Harrison, 16., 871: 4. Jecker v. Montenemery. $I b ., 373$; 5. Case of Guerin, $I b ., 875 ;$ 4. Case of Villatsseque, Ib., 380. See also: Halleck, II., 4t9-4til; Hall. 497.)

165. De facto and Constructive Occupation.-(Hall, thi-t-.): Halleck, II., 4t6-4t!) ; (reasey, su:?; Walke'l. :4tt :itri.)

166. Rights of the Oceupier over the Persons of the territory occupied-"War Rebel." (Hall, Hi?-titi; Halleck, Il., thit 468 ; Creasey, 516 ; Calvo, $\$ 2166$ et se..) 
11i. Rights of the invader over Incorporeal Things, as Debts, ete.

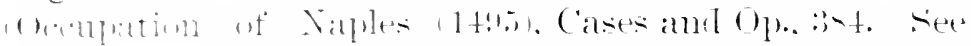

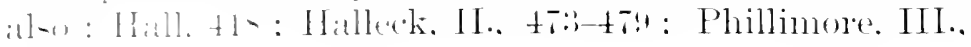
$-: \div-411$.

\section{he Triminution of Har-Compuest-Cession.}

lii-. What malks the date of the end of a War?.-Treaties of Peace-Proclamations in Civil Wars. 11. The Thertis. C'ases

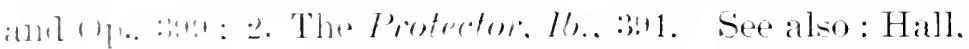

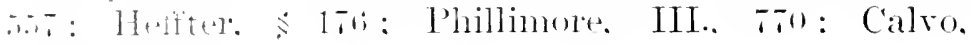

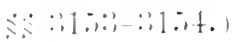

11:4. Elfect of Treaties of Peace in settling general rights and obligations of the parties-Effect upon acts done before the war-Upon acts done during the war-Upon acts done subsequently to the treaty of peace. Hall. Sis-itis: Thillinnore. 1II. T-1 - - t : Heffter.

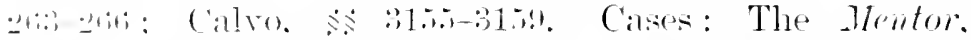

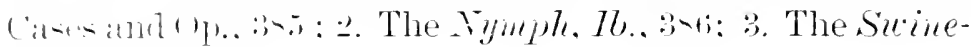

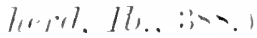

17.. Postliminium-Uti possidetis-How do they apply to terri-

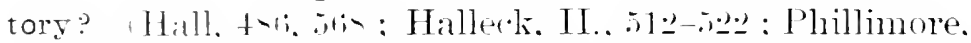

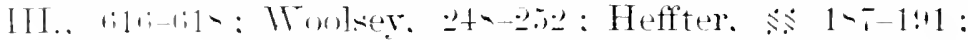

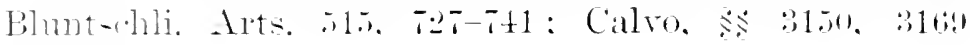

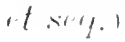

17. Conquest-Cession (The Elector of Hesse Cilscel. C'ases

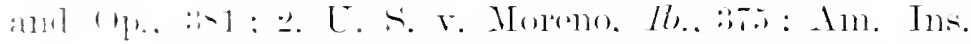

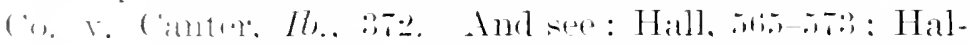

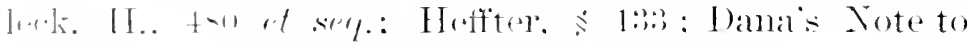

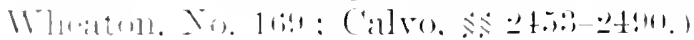

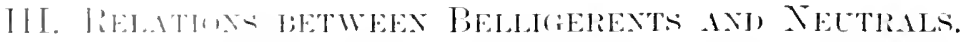

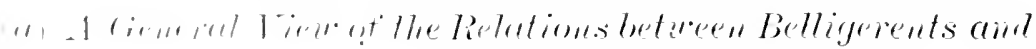
verticels.

17.2. Ifistorical Sketch of the Subject. Hall. . Nitint : Halleck,

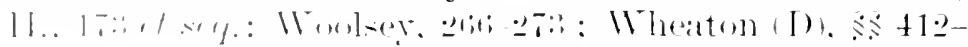

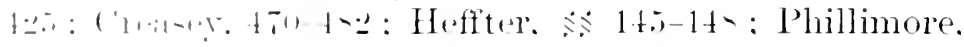

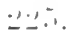


(b) Nential Dnties.

173. Neutrals are not to permit their Territory to be used for hostile purposes by either belligerent-Transit of troopsFitting out hostile expeditions-Capture of vessels in neutral

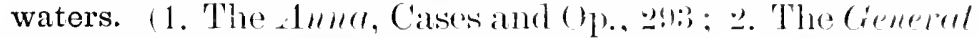

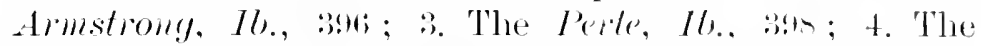
Amm, Ib., 400 ; Other cases, Ib.. fol, note. See also: Hall, 4!5-612 : Halleck, II., 17::-1>1 ; Phillimole, III.,

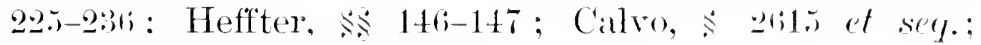
Bluntschli, Art. $7+$ t! et secy.)

174. Equipment of vessels of war in noutral territory. (1. U.S.

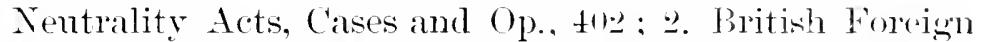

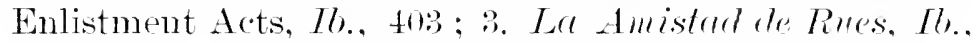

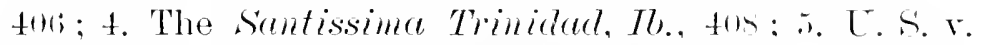

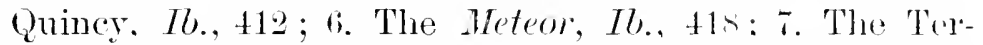
ceira Affair, $I b ., 421$; s. The Alabama, 425; 9. The Florida, Ib., 42s: 10. The Shemandoall, Jl., 4.09: 11. The Georgia, Il.. 42!); 12. The Smmpter, etc., Ib., tron; 1:. The Genera Award, Ib., 481. See also: Hall, (il.26.91); Halleck. II., 1st-195; Dana's Note to Wheaton, No. 215 ; Walker, $458-50.2$; Phillimore, III., 236 et ser.)

175. Loans of Money to Belligerents. (Hall, 5!)-5!19 : Bluntschli, Art. 695 ; Halleck, II., 19.; Phillimore, III., 24..)

176. Sale of Munitions of War by a Neutral State. (Sale of Arms to France, Cases and Op., 4.9! : Hall, 5!!..)

177. Aid to Insurgents-Loans-Munitions of War. (1. De II iitz r. Hendricks, Cases and Op., 48s: ?. Thompson v. Powles, Ib., 4t0: 3. Kennett v. Chambers, 1l., $441: 4$. U. S. v. Trumbull, Ib., 449; 5. The Saliador, Il., tis. And see: Phillimore, TII., 247-2501).

(c) Contraband of $1 T^{2} a r$.

17s. General Law of Contraband. (Hall, itt ; Halleck, II., 2tt: Woolsey, 218 : Phillimore, III., 38s: Wheaton (D), stiti et ser.)

179. It was formerly the custom to declare by proclamation at the 
beginning of a war what articles would be consictered

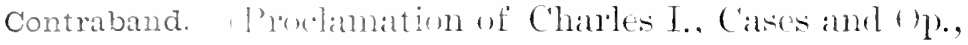
$41 i-1,+1$

14!. Classification of Contraband-Res ancipitis usus - Occa-

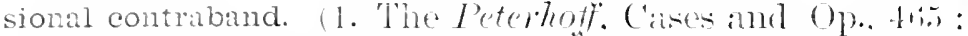

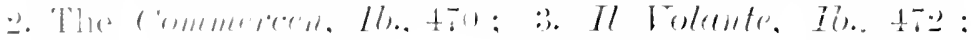

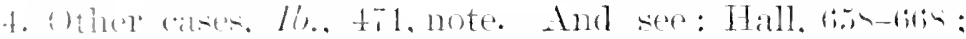

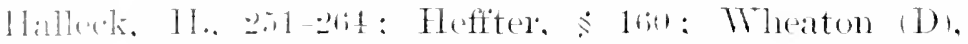
sto

1-1. Penalty for carrying contraband - Time when penalty attaches-Rule of English and American Courts-French Pulc. 1. The Vulfolitet, ('ises and Op.e tit : 2. Seton

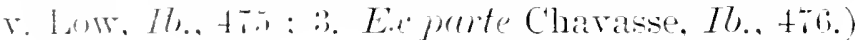

1‥- Dispatches and Persons as Contraband. (1. The Atrilanta,

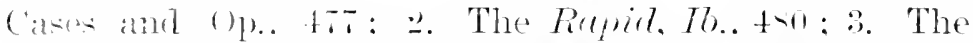

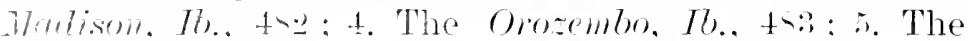

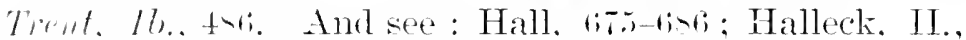
2.2t, note: Moolsey. 395-3:39: Heffter, $\$ 161$ a.)

\section{(1) Blocliate.}

14:). The purpose of Rlockade-What is an effective BlockadeNotification-De facto Blcckade. 11. The Veptumles, Cares

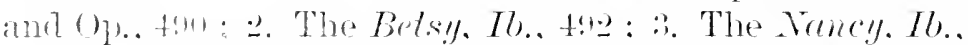

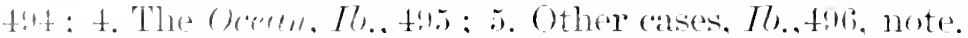

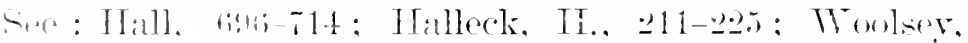
: 1.

1-4. Penalty for Breach of Elockade-Whon does the penalty attach?-Fiench Rule. (The Helen. Cases anel Op.. t!it.

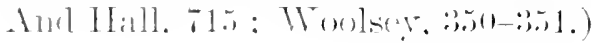

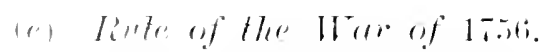

$1-\therefore$. Treutrals may not engage in a trade during war, from which they were cxclucied in timo of peace. 11. 'The Immenturl.

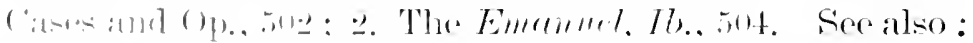

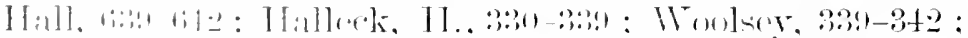

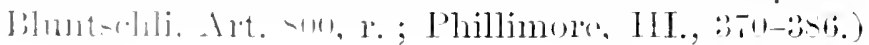




\section{(f) Continuous Toyayes.}

186. Colonial Trade, and Coasting Trade-Extension in 1793.

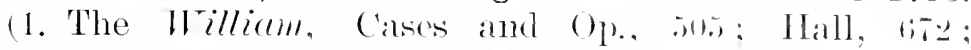
Woolsey, 8.:5: Phillimore, Ill., :3.s.)

15. Applied to the Carriage of Contraband, and the breach of blockade by American Courts. (The Sheple'n Herl, Cirses and Op., 5og. See also: Hali, 65:3: Walkel, 51t, i15, 5.5.5 Phillimore, III., :31-403. Fxtract from the Ber-

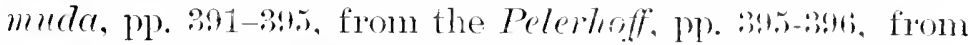
Hobbs v. Hemning, pp. 395-403; Bluntschli, Art. s.8. r. 5 ; Calvo, $2502-2766$.

\section{(g) The Right of Search and Capture.}

188. The Right of Visit and Search is a belligerent right, to which Neutrals are subject-And resistance in any manner to this right entails condemnation. (The Holia, Cines and Op., 515. And see: Hall, 725-731 : Halleck. IT., 267. 268, 283-296; Phillimore, III., 522, 54t, 5., : Woolsey, 358, 361 ; Calvo, $2939-3909$, as to whole subject of Tisit and Search; Wheaton (D), 52.5-5.25; Heffter, s? $16 \tau-1 \%$. $)$

159. Formalities of the Exercise of the Right of SearchGrounds of Capture-False Documents-Spoliation of Papers. (Hall, 732-it1 ; Halleck, II., 2!7-29!; Phillimore, III., 596.)

190. The Right of Visit and Search in time of peace-Impressment of Seamen-Slave Trade-Protection of Seais-Piracy. (Halleck, II., 26-282; Phillimore, III., 5.5-5.9. Ant see the case of Le Lomis, Cases and Op., $\geq 1$ c, and p. 518 , note ; Woolsey, 365-386; The Behring Sea Arbitration, Cases and Op., 5.21.)

191. The Right to capture Enemy's goods in Neutral vessels, and Neutral goods in Enemy's vessels-" Free ships, free goods"-Declaration of Paris. (Hall, 65i-695, $117-7 .+3$.

$$
\text { (7) Prize Courls. }
$$

192. The Constitution of Prize Courts in different Countries. 


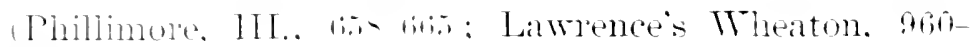
$\because+i+1$.

1!: The Principles and Practice of Prize Courts. (Phillimore.

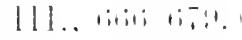

1:4. Decisions of Prize Courts-They are courts of the captors' country. Dewions of P'rize Counts, Calses and Up., iI . .

1!. Prize Courts on board ships-Practice of Captain Semmes, of the Alabama. (C'alses and (U)., 51:1) 


\section{CASES AND OPINIONS}

0.5

\section{INTERNATIONAL LAW.}

\section{INTRODUCTION.}

Section 1.-International Law is a palit of the Munichal Law OF STATES.

\section{OPINION OF BL.ACLSTONE.}

(Blackstone's Commenturies, Bosk, IV. Chap. IV.)

Trie law of nations is a system of rules, deducible by natural reason, and established by universal consent among the civilized inhabitants of the world ; in order to decide all disputes, to regulate all ceremonies and civilities, and to insure the observance of justice and good faith, in that intercourse which must frecruently occur between two or more independent states, and the individuals belonging to each.

This general law is founded upon this prineiple, that different nations ought in time of peace to do one another all the good they can, and in time of war as little harm as possible, without prejudice to their own real interests. And, as none of these stintes will allow a superiority in the other, therefore neither can dictate or prescribe the rules of this law to the rest; but such rules must necessarily result from those principles of natural justice, in which all the learned of every nation agree; or they depend upon mutual compacts or treaties between the respective communities: in the construction of which there is also no judge to resort to, but the law of nature and reason, being the only one in which all the con- 
theting protes are equally conversant, and to which they are thllitlly siltijet.

In allium states this law, wherever it contradicts or is not provilent for hy the munieipal law of the comentry, is enforeed by the mat pumen: but since in bingland no royal p)wer can introdnce a

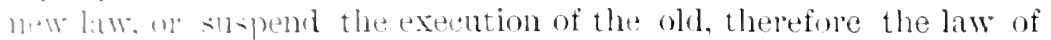
narims (wherever any question arises which is properly the olject wi in furiations is here alopted in its full extent by the common

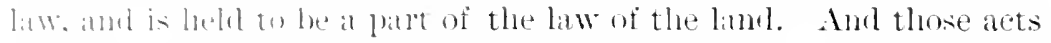
wif paliament, which have from time to time been matle to enforce this mivaril law. on tufulitate the exention of its decisions, are

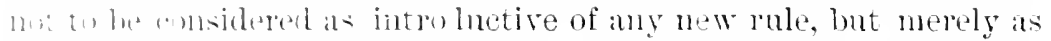
hathatory of the old fumbumental constitutions of the kingdom; whthmt whis it must cease to he a part of the eivilized workd. 'Phus in mer'antike questions, such as bills of exchange and the like; in

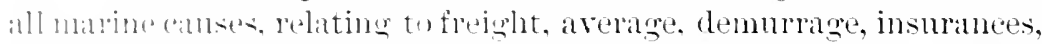
huttomry and others of a similar nature; the law merehant, which is a luancle of the law of nations, is legularly and constantly adhered t1. So ton in all disputes relating to prizes, to shipwrecks, to hostires. and ransom hills. there is no other rute of decision but this

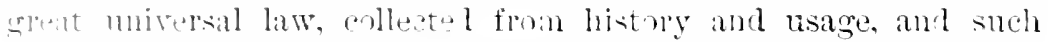
writer's of all nations and langhreges as ale generally approved and allumenl of.

Bnt, thongh in eivil transactions and questions of property between thr subjecti of different states, the law of nations has much scope and extrut. as abouted ly the law of England; yet the present

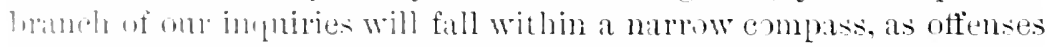
arrinet the lat of mations can ralely be the objest of the eriminal

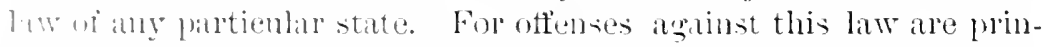
Piphlly inciclent to whole states or nations; in which case recourse

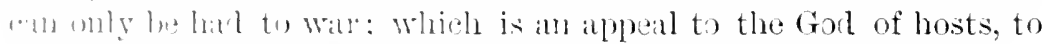
pmish smoh infaetions of public taith as are committed by one imformblent pople arimst another: neither state having any -mpring jurisulietion to resort to npon earth for justice. But where thr indiviluals of any state violate this general law, it is then the interest as well ats duty of the sovermment, moler which they live. as animblvert 11 mon them with a beeming severity, that the

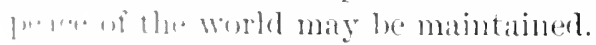

Fir in vilu womld nations in their collective capaeity observe

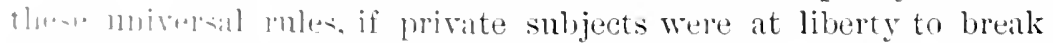
then at their mon cliceretion, and involve the two states in a war. It in the lefole incomblent npon the nation injured, first to demand anti-fortinn and justice to be done on the otfender, by the state to 
whieh he belongs; and, if that be refused or neglected, the sorerrign then avows limself an accomplice or abettor of his subject's crible, and draws npon his community the ealamities of foreign war.

\title{
TIIE SCO'TIS.
}

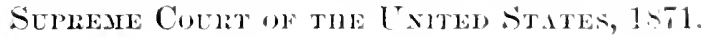

$(1+$ Hullare, 170.$)$

Discussion of General Principles.

Judgment by Stroxri, J. :-

* * * Undoubtedly, no single nation ean elnange the law of the sea. That law is of miversal obligation, and no statute of one $1 \mathrm{l}^{\circ}$ two nations can create obligations for the world. Like all the law of nations, it rests upon the common consent of civilized conmmunities. It is of foree, not because it was prescribed by any superior power, but because it has been generally accepted as a loule of (o) 1luct. Whatever may lave been its origin, whether in the rsigges of navigation or in the ordinances of maritime states, or in botl, it has become the law of the sea only by the coneurrent sanction of those nations who may be said to eonstitute the eommereial world. Inany of the usages which prevail, and which have the force of law, doubtless originated in the positive prescriptions of some simgle state, which were at first of limited effect, but which when generally acepted became of universal obligation. The Rhorlian law is supposed to have been the first system of marine rules. It was a code for Rhodians only, lut it soon beeame of general anthority because aecepted and assented to as a wise and desilable system by other maritime nations. The same may be sairl of the Amalphitan Table, of the ordinances of the Ilansentic Leagne, and of parts of the marine ordinances of Lomis XIV. They all became the law of the sea, not on aceount of their origin, but by reasom of their aceeptance as sueh. And it is evident that mosess grentril assent is efficacions to give sanction to international law, there never ean be that growth and development of maritime rutes whieh the eonstant changes in the instruments and necessities of navigation require. Changes in nautical rules have taken place. How have they been accomplisher, if not by the eoneurrent assent, expressed or understood, of maritime nations?

When, therefore, we find such rules of navigation as are nentioned in the British orders in council of Jannary $9 t h, 1863$, and in 
com act of Conderes of l-it. alecepted as obligatory mles by more

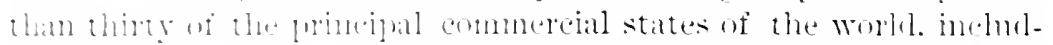

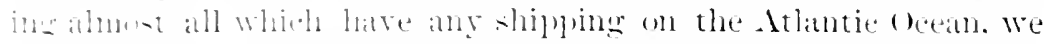

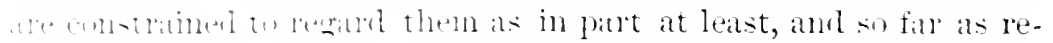

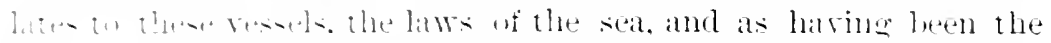
I w at aly tinn when the collisime of which the libellants com-

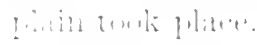

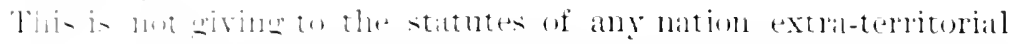

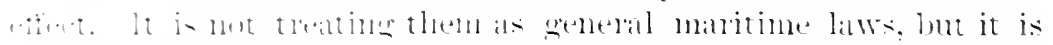

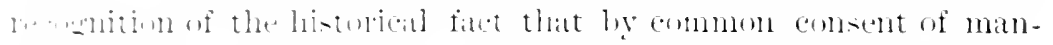

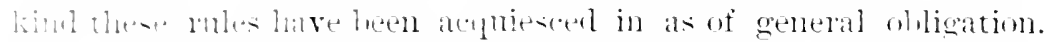

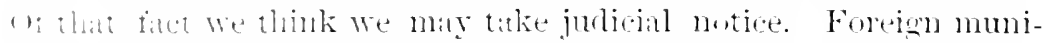
indill las mo-t. indeed, be proved as facts, but it is not so with the

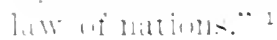

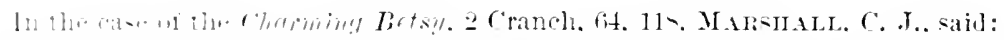

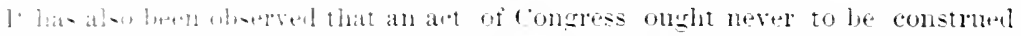

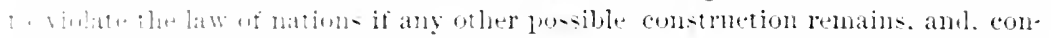

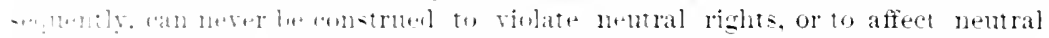

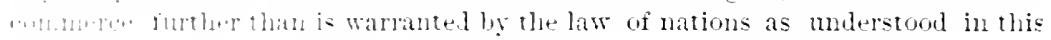

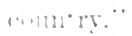

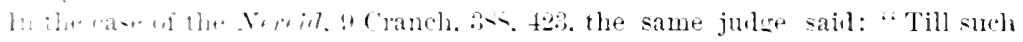

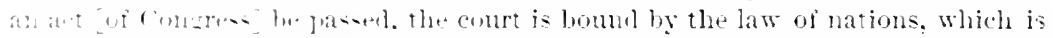

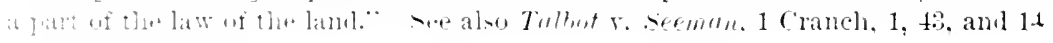
$11: 11: 1, \cdots, 17,1 \cdots$

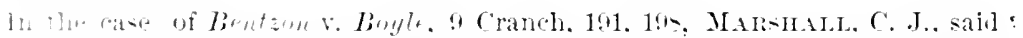

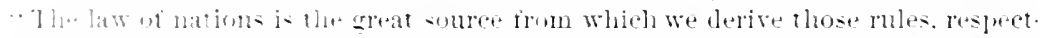

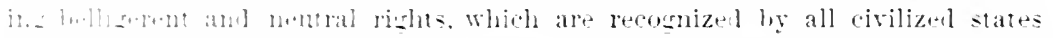

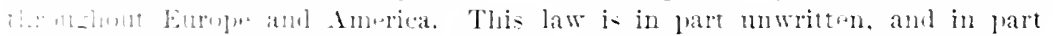

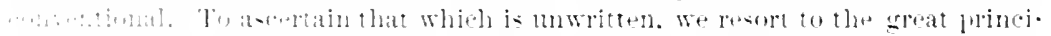

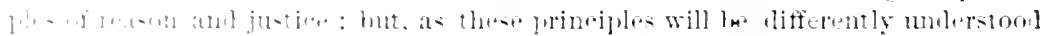

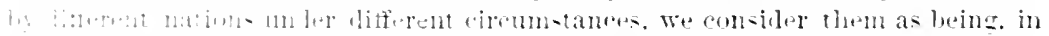

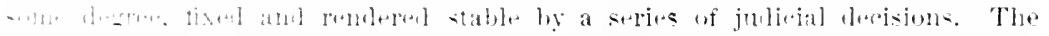

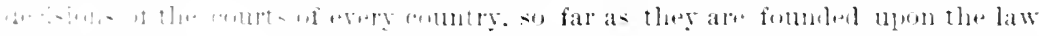

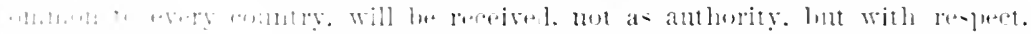

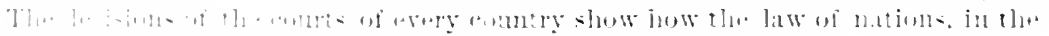

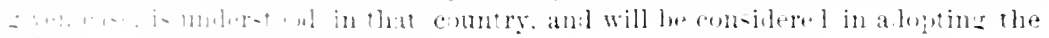

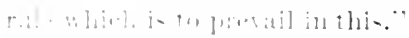

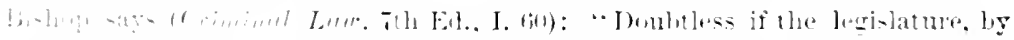

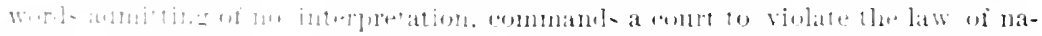

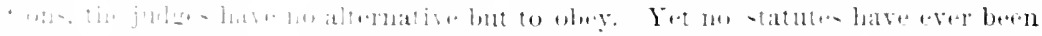

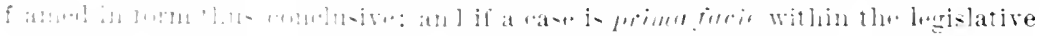

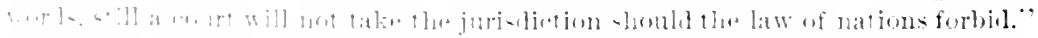

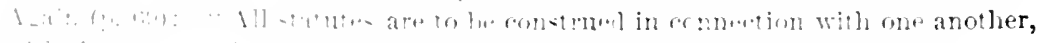

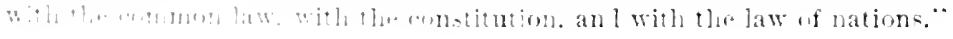




\section{PART I.}

INTERNATIONAL RELATIONS IN TIME OF PEACE。

\section{CIIAPTER I.}

STATES-TERRITORIL RIGITS.

Section 2.-Definition ani Cillideter of Sovereigx Staten.

\section{HALLECK'S INTERNATIONAL LAW, I. 58.}

"A State is a body politic, or society of men united together for mutual advantage and safety. Such a society has affidirs and interest. peculiar to itself, and is capable of deliberation and resolution; it is therefore regarded as a kind of moral person, possessing a will and in understanding, and susceptible of rights and obligations. From the nature and design of such a society, it is necessary that there should be established in it a mblic cuthority, to order and direct what is to be done by each individual in relation to the end and object of the association. This political authority, whether vested in a single individual or in a number of individuals, is properly the sovereignty of the State.

"This term, however, in internitional law, is usmally employed tn express the external rather than the internal character of a natimn, with respect to its ability or capreity to govern itself, independently of foreign powers. A sovereign state may, therefore. he defined to be any nation or people organized into a boty politic and exercising the rights of self-government." 


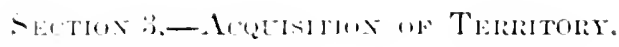

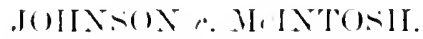

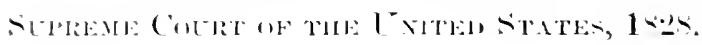

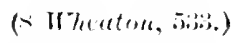

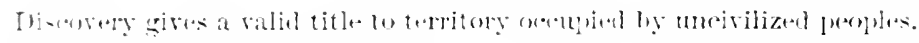

The righe of the Xorth Ameriean Indians a the lands which they possessed

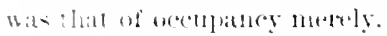

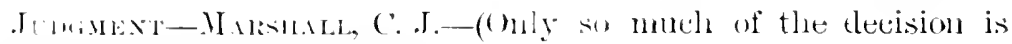

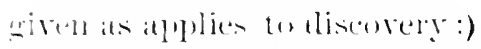

"The plantitt - in this anse dain the lanel, in their deelaration

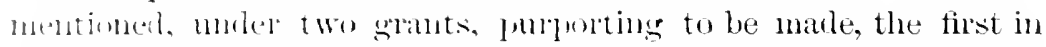
$17 .:$ and the last in 175,5 , by the ehiefs of certain Indian tribes, cometituting the Illinois and the P'ankeshaw nations ; and the puestime is, whether this title ean be recognized in the courts of the [lititel sitates.

.. The facts ats stated in the case atgued, show the anthority of the ehiptis who executed this conveyance so far as it could le griven by their own people: and likewise show, that the particular tribes for Whom these chictsacted wete in rightful posiession of the lant they sul. The impuiry, therefore, is, in a steat meatsure, confined to tho forrel of Indians to grive, and of private individuals to receive, a title which ein be sustained in the cromts of this comntry.

. An the linhts of society, to prestribe those mules hy which prop. nty maty be anplired and preserved is not, and eamot be, drawn inu plustion: as the title to lands. especially, is and most be

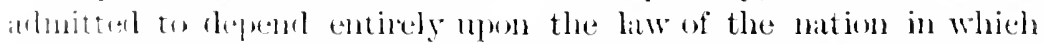
they lin. it will be lecessary, in pmstumg this inguiry, to examine,

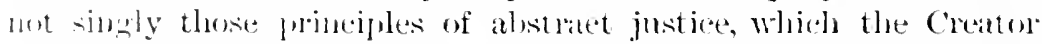
of all things has implessed on the mind of Ilis ereature man, and Whill ant almitul to regulate, in a great degree, the rights of "ivilized nathoss, whose perfect integendence is ateknowledged: but

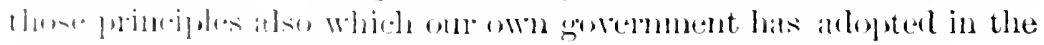

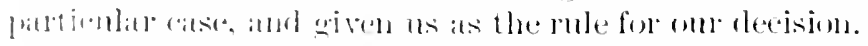

. 11 the discevery of this inmense comtinent the lations of

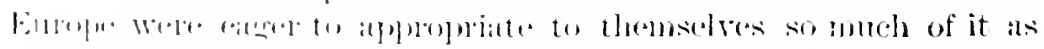

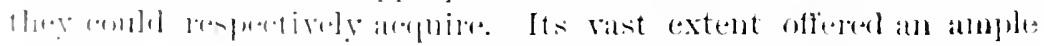

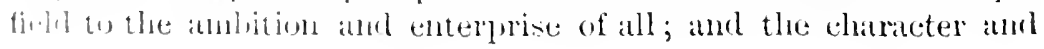


religion of its inlabitants afforeleal an apology for considering then

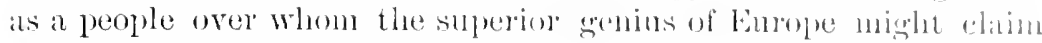

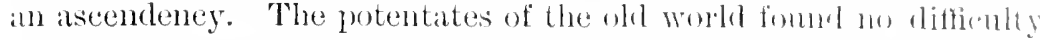
in convineing themselves that they mate ample enmpensantom to the inhabitants of the new, hy bestowing on them rivilization and Christianity, in exehange for molinited inclependence. lint, as they were all in pursuit of nearly the same object, it Wals necessaly, in oreler to avoid eonflicting settlements, and conserplent was with each other', to establish a principle which all shonla ackmowledge as the law by which the rights of accuisition, whieh they anl asserted, should be regulated as between themselves. This prineiple was, that diseovery gave title to the govemment by whose suljects, of hy whose authority, it was makle, against all other kuropeall governments, which title might be emsmmmated hy possession.

"The exclusion of all other Europeans necessatily gave to the mation making the discovery the sole right of acpuiring the sorit from the natives, and establishing settlements npon it. It wats at right with which no Europeans eonde interfere.

"It was a right which all asserted for themselves, and to the assertion of which, by others, all assented.

"Those relations which were to exist between the diseoverer annl the natives were to be regulater by themselves. The rights thu: acquired being exclusire, no other power could interpose between them.

"On the establishment of these relations, the rights of the origrinal inhabitants were, in no instance, entirely disregarded, but were necessarily, to a considerable extent, imprared. They were admitted to be the rightful ocempants of the soil, with a legal as well as just clinm to retain possession of it, and to use it aceording to their own discretion; but their rights to complete sovereignty, as inclerendent nations, were necessarily diminished and their power to dispose of the soil at their own will, to whomsoever they pleased, was denied by the original fundimental prineiple, that diseovery arat exclusive title to those who made it.

"While the different nations of Emope respected the right of the natives, as occupants, they asserted the ndtimate dominion to be in themselves; and clatined and exereised, as at ennserutence of this nttimate dominion, a power to grant the soil, while yet in possession of the natives. These grants lave been understom by all to convey a title to the grantees, subject only to the Indian right of ocenpallicy.

"The history of Ameriea, from its diseovery to the present day, proves, we think, the universal recognition of these principles. 


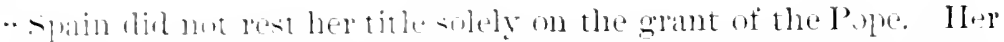

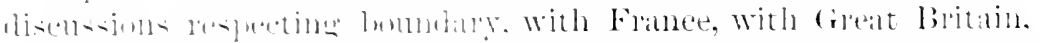

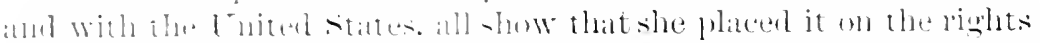

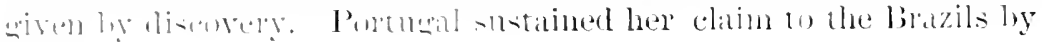
the -ithet tit te.

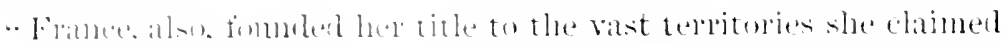

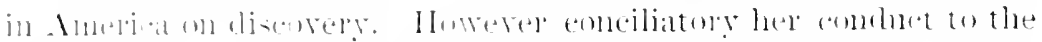

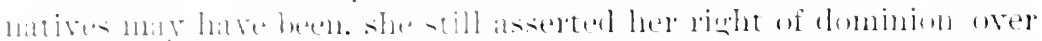

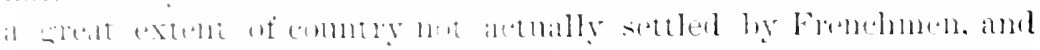

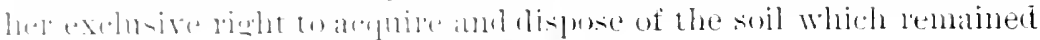

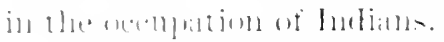

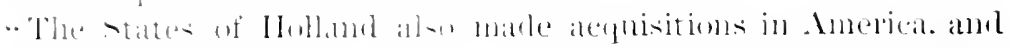
-mstainer their right on the common prineiple adopted lig all Einulue.

. Xu one of the purers of burne gave its full assent to this

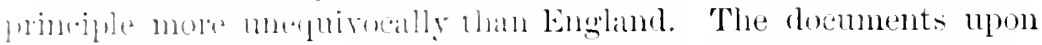

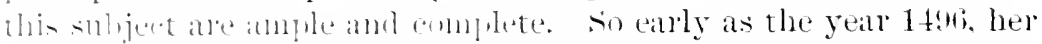

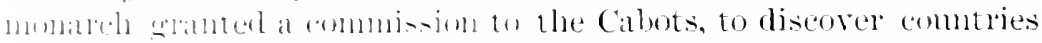

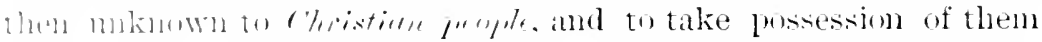
in the Hand at the kine of Eneland. Two years afterwards, Cabot

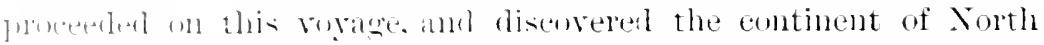
America, alomen which he sajlel as far south as Virginia. To this Aisconery the binglish trace their title.

- In this first eftont male by the English government to acquire

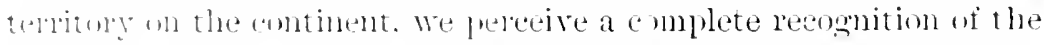
mindple which has heen mentimed. The right of discovery given hy this onmulision is monfined to comntries then manown to all Chri-tian pophle: and of thes commtries Cabot was empurered to lake por.

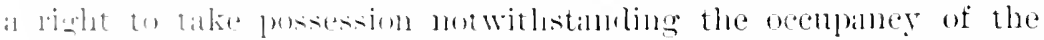
native. who wolu heatleds, and. at the sime time, admitting any

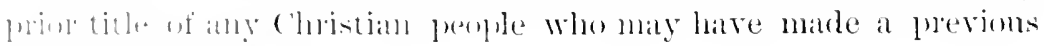

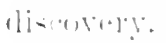

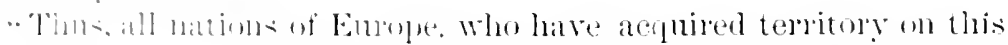

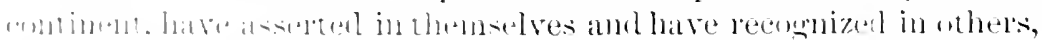

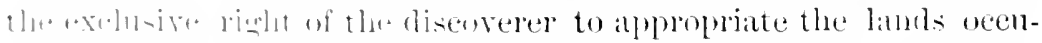
birel lug ilı Indialls.

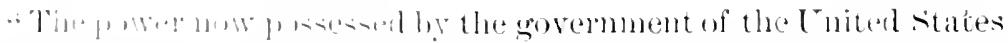

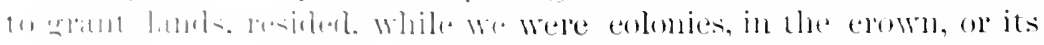
aritilin.

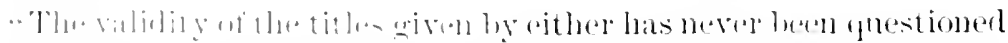

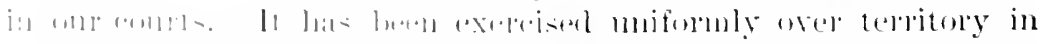

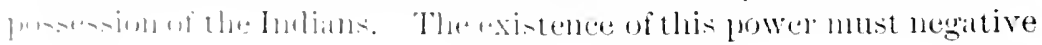


the existence of any lisht which maty ennflict with, and onntwe is An absolute title to lands cammot exist, at the same time, in lifferent persoms, or in different governments.

"An absolute, mont be an exelusive title, on" at leatst a tith which

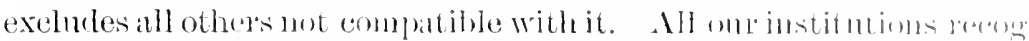
nize the absohte title of the erown, subject only to the lubian right of ocempaney, and recognize the absolnte title of the cowro to extinguish that right. This is incompatible with an absolute and complete title in the Inclians."

\section{TIIE OREGON TERRITORY.}

(Wheaton's International Law, 3,l. Ed. 1.220.)

Tre claim of the Lnited states to the territory between the liok

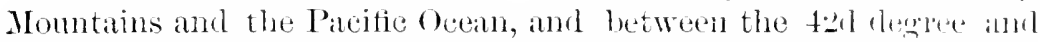
$5+$ th degree and to minutes of north latitude, is resterl by them upon the following grounds:-

1. The first discovery of the month of the river colmubia by Captain Gray, of Boston, in 1792: the first diseovery of the sinnees of that river, and the exploration of its conrse to the sea by caitalins Lervis and Clark, in 1\$15-6; and the establishment of the first posts and settlements in the territory in question ly citizens of the Cnited states.

2. The virtual reeognition by the British govermment of the title of the Cnited states in the restitution of the suttlenent of Astoria or Fort feorge, at the mouth of the Columbia River, which had been captured by the British during the late war between the two countries, and which was restored in virtue of the 1 st article of the treaty of Ghent, 1814, stipulating that "all territory, places, and possessions whatever, taken by either party from the other during the war," ete. "shall be restored withont delay." This restitution was male without any reservation or exception whatsorerer, communicated at the time to the Ameriean government.

3. The acquistion by the United states of all the titl's ut spain, which titles were derived from the discovery of the cuatsts of the region in question, by spanish subjects, before they harl been seen by the people of any other civilizer nation. lis the sol article of the treaty of 1819 , between the Enited states amb Spain, the boundary line between the two comtrixs, west of thr Mississippi, wats established from the mouth of the river saline, to 
centain guints on the lied liver and the Arkansis, and rmming

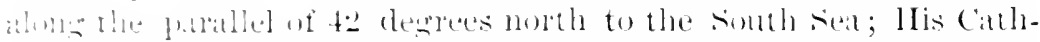
whe Majesty cenling to the Enited states . all his rights, chims,

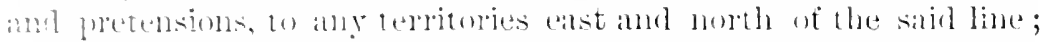

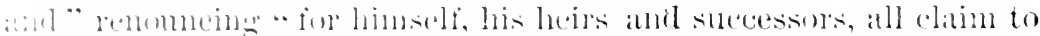

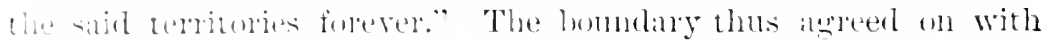

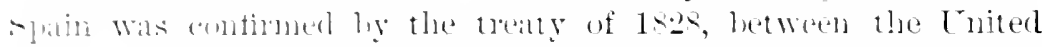
states and Ifexier, which had, in the meantime, become inderen-

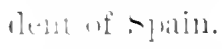

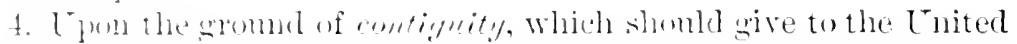

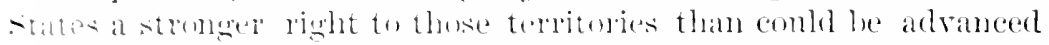

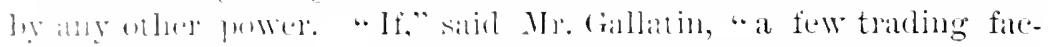

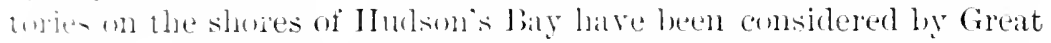

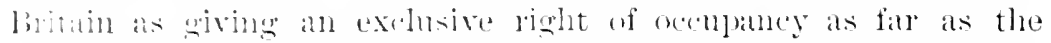
linky Momatins; if low infant settements on the more southem

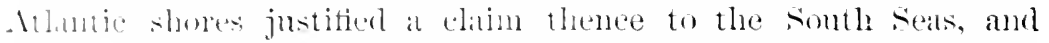

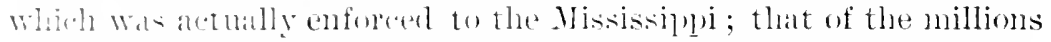

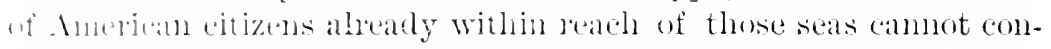
sintently be rejected. It will not be denied that the extent of conlimmon combly to which an actual settlement gives a pror right, mun-telend, in a consirlerable degree, on the magnitude and pop)nlankm of that settlenent, and on the facility with which the vacant aljacent lind misy, within a short time, be occupled, settled, and crltivated hy suel pelulation, compared with the probahility of its

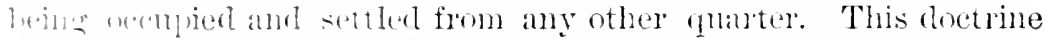
wat aluithel to its fullest extent by Great biritan, as appeated by all he: alaters, extencling from the Atlantic to the l'arcific, given to

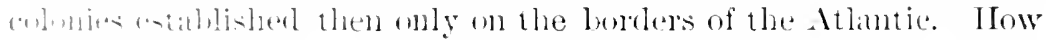

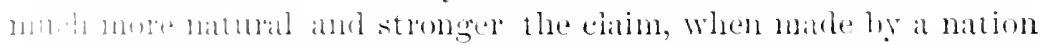
when frondation extended to the centual pruts of the continent, and whon loninions were by all acknowledged to extend to the lincky Mrinualis."

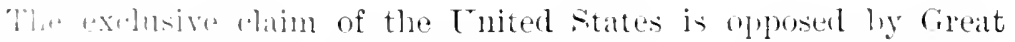

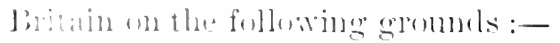

1. That the Colmbia was mot diseovered hy (iray, who had only

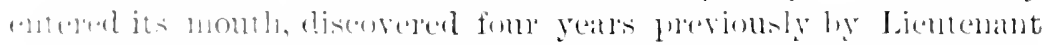
Juan withe lintish naty and that the exploration of the interior

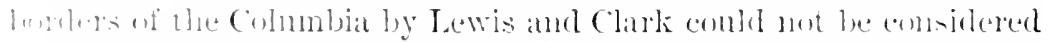

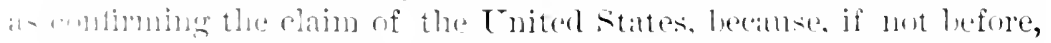

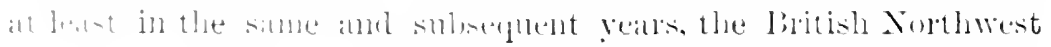

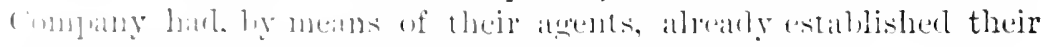

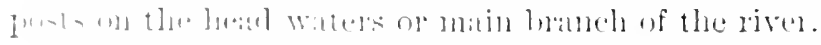

¿. That the restitution of Astoriat, in 1yls, was aceompanied by 
express reservations of the cham of Geant britain to that torritons.

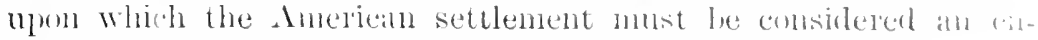
erratchuncut.

3. That the titles to the territory in question, derived by the

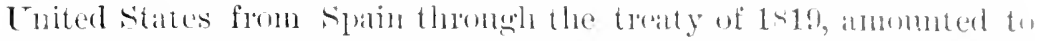
nothing more than the rights seculerl to Span equally with Great Britain by the Nootkat Somm Convention of 17s0: 11amely, to settlo on any part of those comntrics, to navigate and fish in theip waters, and to trade witl the natives.

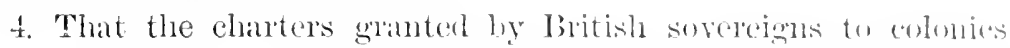
on the Atlantie coasts were nothing mole than cessions to the

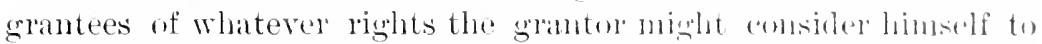
prosess, and eomld not be considered as hinding the subjoros of any other nation, or as part of the law of nations, until they had been confirmed by treaties.

DELAGOA BAY, 19:?.

(Itall's Internotional Lar., Br. Eil., 119.)

"A somewhat recent controversy to which title by ocenpation has given rise tumed mainly unon the efifect of a temporary cessa tion of the athority of the oexupying state. From 12.2:) to 1-5, when the matter was settled by allitration, a dispute existed between England and Portugal as to some territory at I deligua bay, which was elamerl by the former under a cession by native chief: in the first-mentioned year, and by the latter on the gromuls, amongst others, of continuoms oecupation. It was adnitted that. Portuguese territory reacled to the northern hank of the Rio dro Espirito santo, or English River, which flows into a bay, and that a port and village harl long been establisherl there. The plestion Was whether the soveleignty of Portugal extended sonth of the river, or whether the lands on that side had remained in the pussession of their original owners. England relied upon the facts that the natives professerl to be independent in 1803, that they anderl as such, and that the commandant of the fort repurliated the prssession of anthority over them. In the memorials which were sulmittert on behalf of Portngal, amidst much which hath no slextial referemets to the territory in disponte, there was enomgh to show that gust. had been maintained within it from time to time, and that anthority hat probably heen exercised intermittently over the natives. Tha area of the territory being snall, and all of it being within eatsy 
reach of a fores in possession of the Portuguese settlentent. there

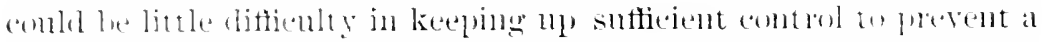

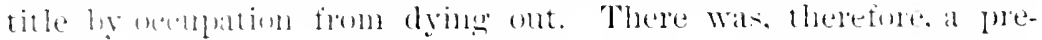

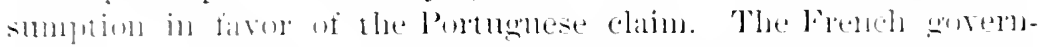
ment. Whide ared as abitgatore towk the view that the intermp-

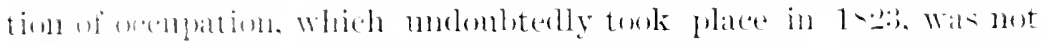

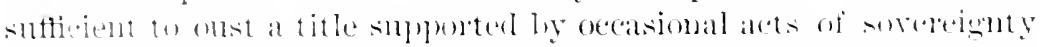

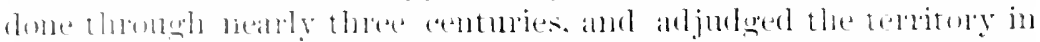

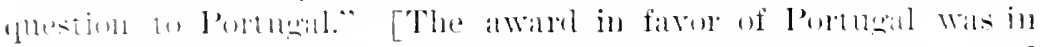

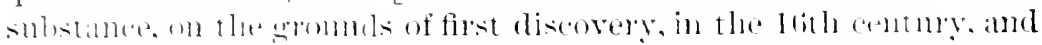
of eontinned vecupation and control of the territury in dispute.]

\section{S.INTA ILCIA.}

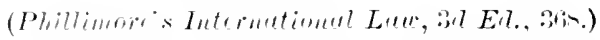

. Theye was a dispute of long standing between France and Eneland resperting sinta Lucia, one of the lntilles Islands. After he lang of dix-la-chapelle (174), the matter was referred to the

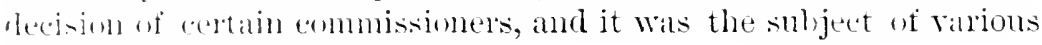
state Palues in 1751 and 1754.

". The fremoh newotiator's maintaned, that though the English had extahlished themselves in 1639, they had been driven ont ol

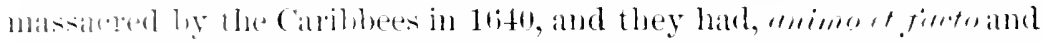

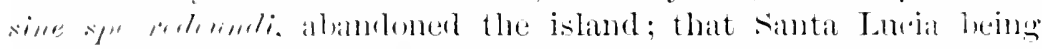

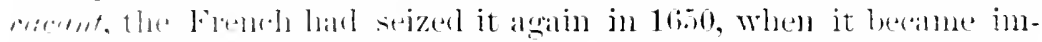
morlindry, and withme the necessity of any prescriptive airl, their

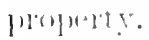

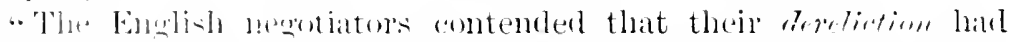

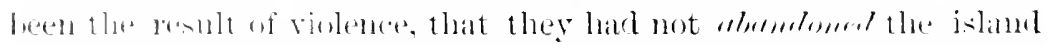

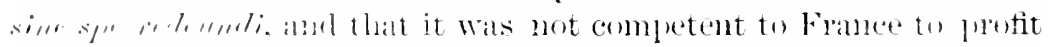

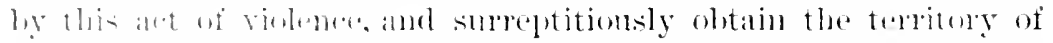

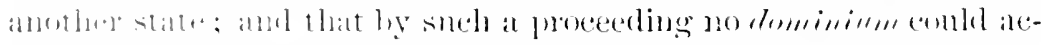

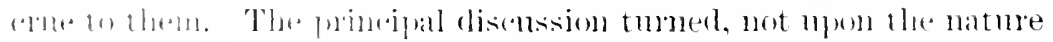

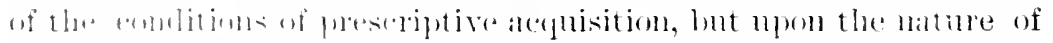
the anditions of wolmotary leleliction, by which the rights of pop-

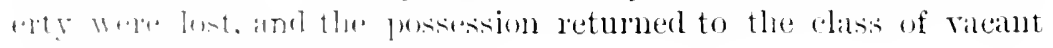

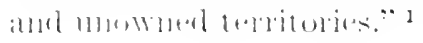

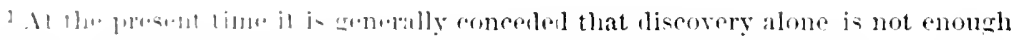

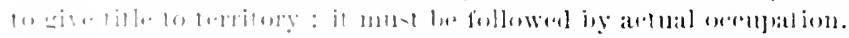

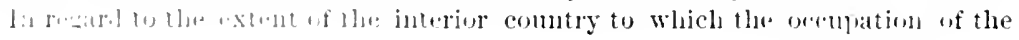




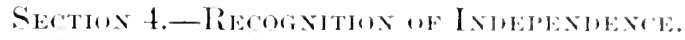

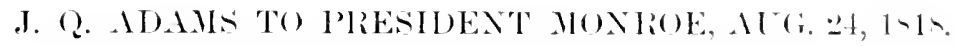

(1 Hhatenis Digest, 121.)

"There is a stage in such (revolutionary) entests wher the party struggling for independence has, as I enceire, a right to demand its acknowledgment by neutral parties, and when the acknowledgment may be granted without departure from theobligitions of neutrality. It is the stage when the independence is established as matter of fact, so as to leave the chance of the upunite party to recover their dominion utterly desperate. The neutral nation must, of comse, judge for itself when this period has arrived ; and as the belligerent nation has the same right to judge for itself, it is very likely to judge differently from the neutral and to make it a cause or pretext for war, as Great Britain dir expressly against France in our Revolution, and snibstantially against IIolland.

"If war thus results, in point of fact, from the measure of recognizing a contested independence, the moral right or wrong of the war depends npon the justice and sincerity and murlence with which the recognizing nation took the step. I am satisfied that the cause of the sonth Americans, so fatr as it consists in the asiertion of independence against spain, is just. But the justice of a canse, however it may mlist individual feelings in its favor, in not suficient to justify thind parties in siding with it. The fact and the right eombined can alone authorize a neutral to acknowledge anew anci disputed sovereignty."

sca-coast gives title, the extravagant claim was lut forwarl in some of the earlier charters, granting lands in North America, that snch right extendet from the Atlantic to the Pacific Ocean. A more reasonable rule was laid down by the Inited states commissioners, appointed to settle the bommlary of Lonisiana, namely, "that when any European nation takes possession of any extent of seacoast, that possession is understoot as extending into the interior comntry, to the somres of the rivers emptying themselves within that coast, to all their lianches, ant the country they cover, and to give it a right in exclusion of all oflure nations to the same."

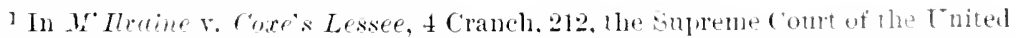
States say : " That 1 he sereral states which composel this l'uion. sol thr at least as regardet their municipal regulations, became entitlel, from the time when they 


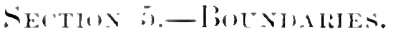

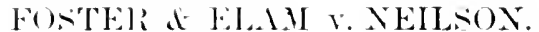

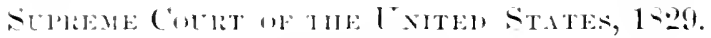

$$
(\because 1+1+1,2, \cdots)
$$

This was the ate of lands in the lispuled teritory bet ween the rivers Iberville and linglite sranted to the platintits by the spanish governor. The defendant

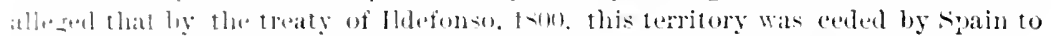

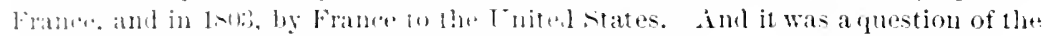
interperation of the treaty of ression.

The cours relused 10 an into the merits of the treaty, but considered it self benum

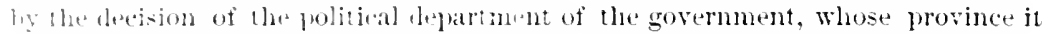
was in deal with foreign relations.

Extrat from the judgment, Mirsimal, C. J.:-

.. - In a eontroversy between two nations concerning national lomulary, it is searcely possible that the courts of either should lefine to abide by the measures adopted hy its own government.

. There being no eommon tribmal to decide between them, each deternines for itself on its own rights, and if they eamot adjust their chifferences peateably, the right remains with the stromgent. The jurliciary is mot that repartment of the woresmentent to which the assertion of its interests against foreign powels is enofided ; and its duty ammomly is to decide mom individual rights, aceosding io those grinciples which the politieal departments of the nation have ptahlisherl. It the combe of the nation hats heen a plain one, its molt: would hesitate to promomee it erroneous.

Wentaren themselves independent, to all the rights and powers of sovereign states,

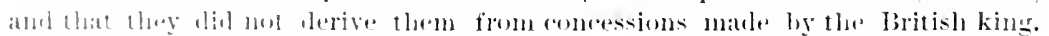

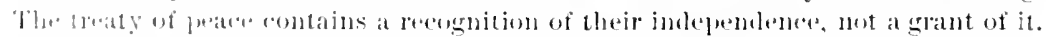

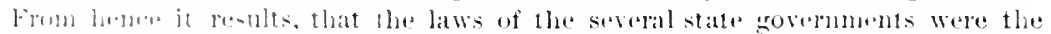

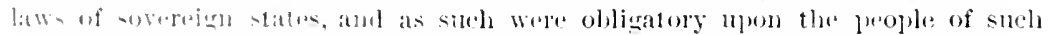

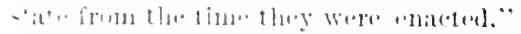

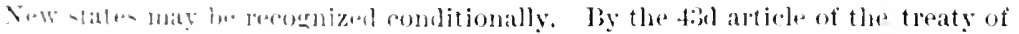

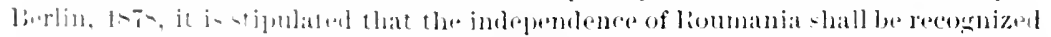

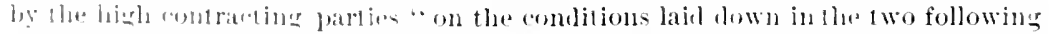

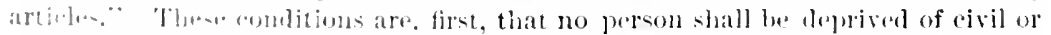

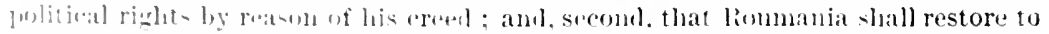

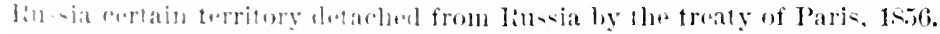

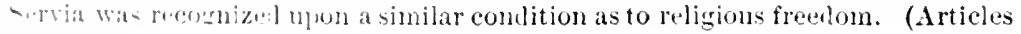

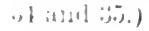


"We think then, luowever indivilual jurlues might constule the treaty of st. Ildefouso, it is the provinee of the conlt to (antinlu its decisions to the will of the legishature, if that will hats hen chenty expressed. *

"After these acts of sovereign power over the territury in clispute, asserting the American construction of the treaty by which the govermment claims it, to maintain the opposite eonstrutem in its own courts would eertainly be an anomaly in the history and pritetice of nations. If those departments which are entrusterl with the foreign intercourse of the nation, which assert and mantain its interests against foreign powers, have mequivocally asserted its right of dominion over a comutry of which it is in possession, amm which it claims moler a treaty ; if the legrislature has acted on the construction thus asserted, it is not in its own courts that this construction is to be denied. A question like this respecting the boumdanies of nations, is, as has been truly said, more a political than a legal question; and in its discussion the courts of every country must respect the pronounced will of the legislature." 1

\section{IIARCOLRT $v$ GAILLARD.}

\section{Suprene Colrt of tile Linten Sitates.}

(12 Wheuton, 5223.)

This was the case of a British grant of land within the limits of the old thirteen colonies, made during the Rerolutionary war. in Iiti.

Held that such grant was invalin, on the ground that the title to lanils hat already passed to the United States.

Extract from the opinion of the court :-

"But this is not the material fact in the case; it is this, that this limit was claimed and asserted by both of those states in the Declaniltion of Independence, and the right to it wats established by the most solemn of all international acts, the treaty of peate. It has never been admitted by the Lnited states, that they acquired anything by way of cession from Great Britain by that treaty. It his been viewed only as a recognition of pre-existing rights, and on that principle the soil and sovereignty, within their acknowledged linits, were as much theirs at the decharation of independence as at this:

1 To the same effect, see In re Cooper, 14: Lnited States Reports, 4i2. 
homr. liy reference to the treaty, it will he fomd that it amomnts lo a simple reconition of the independente and the limits of the Enital states. Without any language purponting a resion or relin-

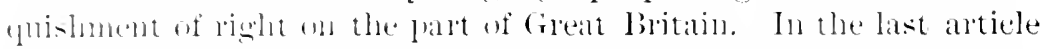

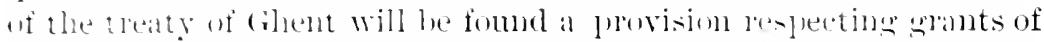

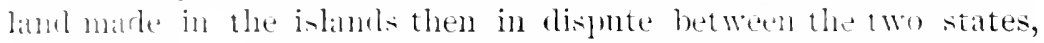
which athorls an illustation of this doetrine liy that article, a stipulation is made in faror of grants before line war. Int none for thone which were male during the wal. Amb such is munestionahly the law of nations. War is a smit prosecuted hy the sword; and where alue question to be decicled is one of orignal cham to territory. slants of soil made forfornte bello by the party that fails (an only derive valielity from treaty stjpulations."

OPINION OF TIEE ATTORNET-GENERAL OF TIIE UNITED STATES, 18.56 .

(8 Op. Att.-(ien. 17.5.)

When a river forms the boundary between two states.

Sin.--Tonr note of this date, communicating a clanse in the drat of the lroposed report of the commissioners for determining the lummlay between the Mexican Republic and the Lnited States, luesents the following question of public law:

". I portion of the benulary is formed by the Rio bravo, which is subject to chande its course in two ways first, hy gralual aceretion of one uf its balnki. followed, in many cases. by conlesponding degratation of the opmosite bank; and, secondly, by the more violent atein of the water. leaving its actual bed and foreing for itself a new unte in another direction. In case of any such changes in the bed of the river, dees the bomdary line shift with them, or does that line remain constant where the main comse of the river ran as reprecinted hy the mats accompanying the report of the commissioners:

"The respmate thisinguiry depends, in palt, on the terms of the trealty betweon the two rejublics prescribing the bmandary line, the luaterial part of which, in so fal as regards the preant question, is to effert, lbat the lins "beginning in the conlt of Mexico, three

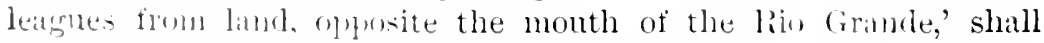
maceer thence "np the miclde of that river' to a certin point. The treaty further provides that commissioners appointed by the 
two govemments shall survey and mats ont mom the land tine

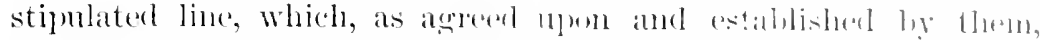

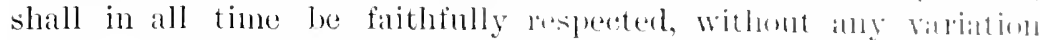

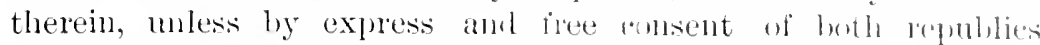
(Treaty of Iecentier $30,1859,10$ stat. at I alloge, 1\% 11:3:2.)

"If the question here were of artain other parts of the hommary which are to rum on parallels of latiture or by straisht line form juint to point, in that case the monuments placed by the eomminsioners, ol the line as otherwise fixed hy dencriptive words referring to natural objects, or hy the drawings and mals of the eommisisionels. Womld, it is plain, he conelusive, in all time, by force of the stipmations of the treaty. It would be the line asteer mpon and estahlished, even although it should afterwarls pove that, by reatson of erore of astronomical olservations or of caloulation, it varied form the parallel of latitude where that was the line, or in the other part dir not malie exactly a straight line. So, if, in another portion of the lommaly, which calls for the rivers Gila and colorado, there were controversy concenning the identity of either as mon the northeastern homblary of the Cnited States, as there one was in regard to the true sit. Croix, then, also, by force of the treaty, the determination of that point, by the commissioners, wonld be conclusive in all time. But the present question is a different one, and depends in part for its solution upon other considerations.

"In this case the boundary is wot an astronomical ol geographical line, but a natural olject, defined ly the treaty. Ancl there is no equirocation here between two distinct natural objects, each of them answering to the descriptive langnage of a stipulation. It is the Rio Bravo, with a course as definite, and almost as destitute of tributaries and embranchments, in its main course, as the Nile. That is a fact which eamnot be modified by sureys or reports.

"However, the established principles of public law come in luere to settle the question in all its relations.

"The respective territories of the Enited States and of the Mexican Republic are arcifinious; that is to say, territories separated not by a mathematical line, but by natural objects of indeterminate natural extension which of themselves serve to keep oft' the public enemy. Such are mountains and rivers. (Barbeyrac's Gotins, liv. ii., chap. 3, § 10 and note; Coceii (rotius Illustratus, ibid.)

"When a river is the dividing limit of arcifinious territories, the natural changes to which itself is liable, or which its action maly produce on the face of the country, give rise to various questions. according to the physical events which occur, and the previns relation of the river to the respective territories. The most simple 
of all the nripinal onditions of the inpuiry is where the river alper-

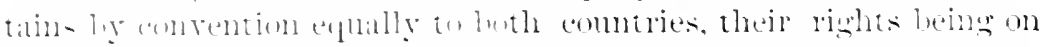

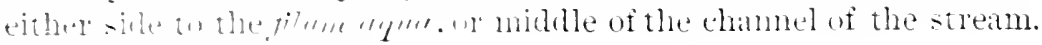
That is the present filet.

.. Wish suh enulitins, whitever ehanges happen to either bank

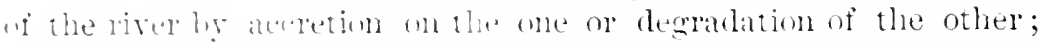
that is by the gratul and an it were insensible accession or absiration of mere purticles. the rivel ats it russ comtinues to be the

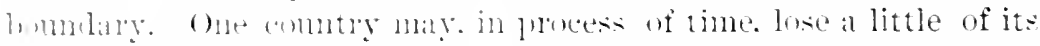

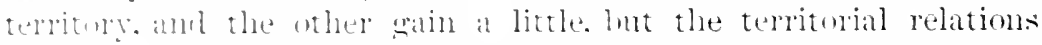

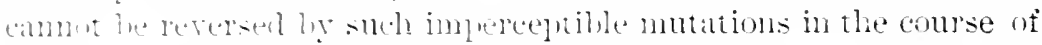
the river. The general aspect of things remalins melanged. And the convendence of allowing the river to retain its previons function,

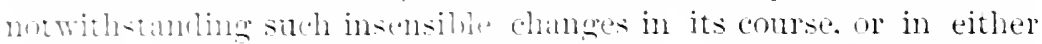

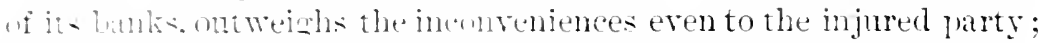

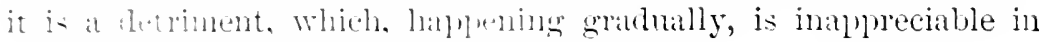

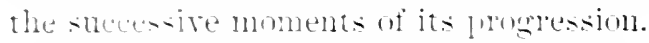

. lint. on the othe" hand. if. deserting its original bed, the river forces for itself a new chamel in another direetion, then the nation, thromen whose territorg the river thus breaks its way, sutfers ine jury ly the los of arritory gronter than the benefit of retaining the natural viver boumlay, and that homblary remains in the midale of the deserterl river bul. For, in truth, just as a stone pillar constitutes a bumbary not lecause it is a stone, but becamse of the blace in which it stamls. so a river is mate the limit of nations, not lecanse it is rmming water bearing a certain geographical name, but leemase it is water flowing in a given channel and within given banks, which are the real international boundary."

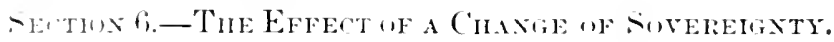

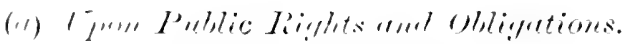

TEXIX IBONIS:

(1 Whortuil s Digest. 201-23.)

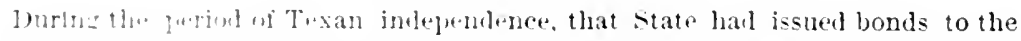
wxtent w maty milliom of dollars, secured by the reventes of the State: and

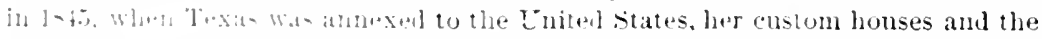

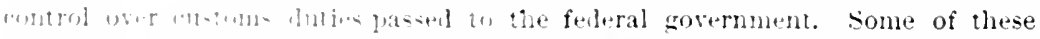

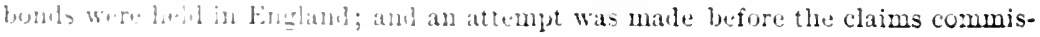




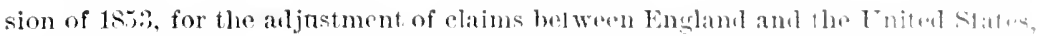
to hold the federal government resensible for the payment of liue 'Texan bond.

In his opinion, Mrr. Ulham, commissioner said :-

"The matter of the indehterlness of 'Texass was a distinet subject of agreement by the terms of the union. Aceording to those terms the vacant and manpropriated lands within the limits of 'Texils we.... to be retained by her, "and applied to the payment of the delsts amm liabilities of the Republie of Texas, and the residne of the lanut; after discharging these debts and liabilities, wats to lot disposed of ats the State might direct, but in no event were the rlehts and liabilities to become a charge npon the Govermment of the Uniterl States.' (C.S. Statutes at Large, vol. 5, 1. 798.)

"The lands of Texas were thus specifically set apart for the payment of the debts of Texas, by agreement of the two fovernments, in addition to any separate pledge Texas had previously mide of this class of property, for the payment of her rebts.

"The United States subsequently, by act of Congress, on the !th of Septemler, 1850 , on eondition of the cession of large tracts of these linds, agreed to pay Texas $\$ 10,000,000$, but stipulater " that $\$ 5,000,000$ of the amount should be retained in the Uniter States treasury until creditors, holding bonds, for which duties on imports were specifically pledged, should file releases of all clains against the United States.' [U. S. Statutes at Large, vol. 9, ch. 4., 1. 4ti.]

"It thus appears that the United States has acted, from the ontset, in concert with Texas, in causing express provision to be marle for the payment of these debts.

"A difficulty early arose in carrying the law, above cited, into effect, for the reason that the pledge of payment of the debts of Texas was made generally upon her revenues, and was not specifie 'on imposts' eo nomine, and for the further reason that doubts arose whether any portion of the delots could be paid under this contract, unless the whole could be discharged."

(Report of the commission of claims under the convention of 15:53.)

Mr. Dana says of this case :-

"It certainly would not be satisfactory to say that the Inited States discharges its obligation to the creditors of Texas, to whom her customs were pledged, by paying only the amount of the customs received.

"The United States determines what those duties shall be, in reference to the interest and policy of the whole Repullie. The condition of Texas is changed by her annexation. The new sovernment has a large control over the material resources of the inlrabit. 
ants, in the way of internal revenues, excise or clirect taxation, in its

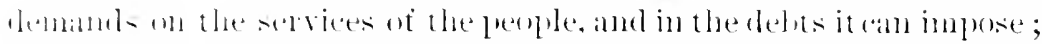

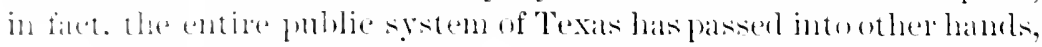
and un - nled stalte tet lhing any lomger exists as that to which the

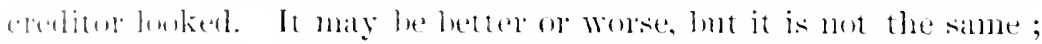
and, if the enties baid ly the l nited states and collected in Texin

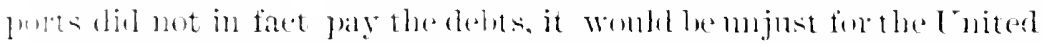
stater to limit the grament of the creditor to thens. 'The truth is, ly the ammexation the Enited states chamsed the mature of the

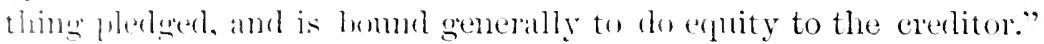

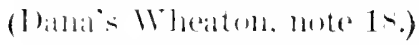

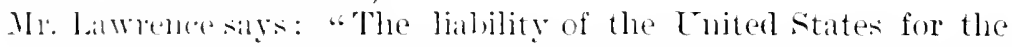

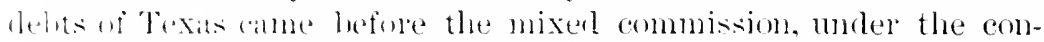
rention with England of 1 s:3, in the case of a Blitish subject who

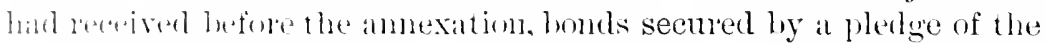
bith and revenno of 'lexas. It was disposed of on the gromed that mer having heen make a sulject for international interposition agtinst the Lnited states, it did not fall within the soope of the eonromtion: but it seemed to he arinitted that the liability of the Cuited - taltes. if any, alose, not form the merger, but from the transfer, moler the Constitution of the Enited states, to the Federal Government of the duties on imports. It was said ly the American Commis-joner, in anmomeing his opiniom, that it was an inalemate riew of the case to lexard this ammexation as an entine arlogt iom of one nation aml its leremes by another. - Texals is still a sorereign state, with all the rights and alpareities of government. except that her internatimal redations are controlled ly the United states, and she

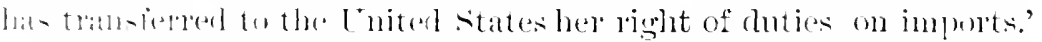

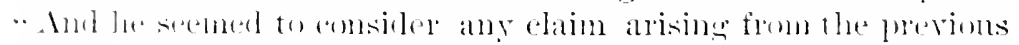

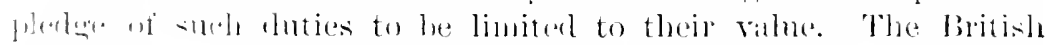

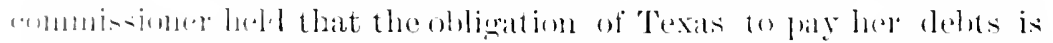

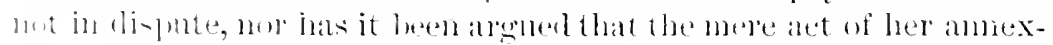
athell to the Chiterl states has transfored her liabilities to the

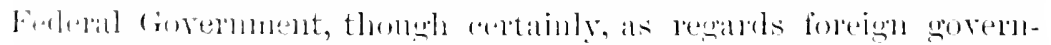

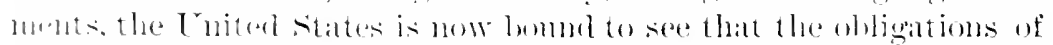

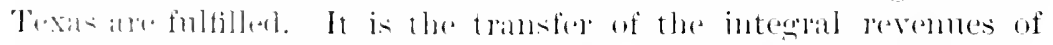

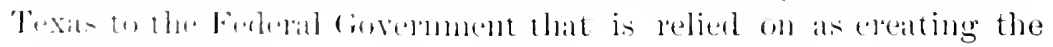
$110 \%$ liathility ${ }^{\cdots}$

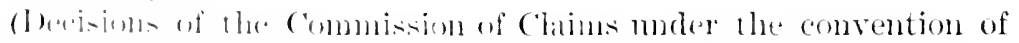

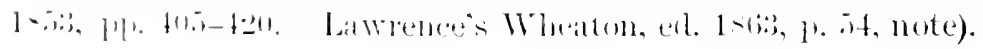

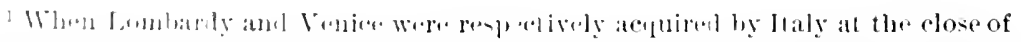

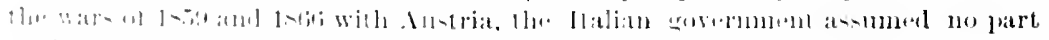

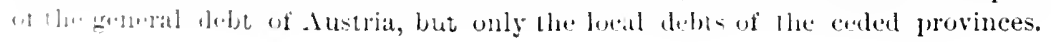




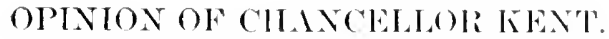

\author{
(hent's Commenturies, I. 2.5.)
}

"It is well to be understom, at a poriol when alterations in the constitutions of govermments, and revolutions in states, alle fomiliar, that it is a clear position of the law of nations, that treaties alde mon

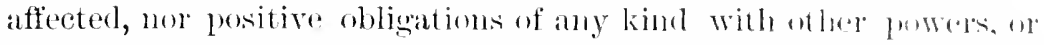
with creditors, weakenerl, by any such mutations. I state neither loses any of its rights, nor is rliseharged from any of its duties, ly a change in the form of its eivil govermment. The borly politic is still the same, though it may have a different organ of commmonination. So, if a state should be divider in respect to territory, its rights and obligations are not impaired ; and if they have not heen apportioned by special agreement, those lights are to be enjoyed, and those obligations fulfilled, by all the parts in common."

\section{(b) Tjon Private Riglits.}

\section{THE UNITED STATES $\mathrm{Y}$ T'ERCIIEMAN.}

\section{Supreane Court of the Uxiten States, 14:3:3.}

$$
\text { (7 Peters, 51, sti.) }
$$

Jnan Pereheman elamed two thousand acres of land lying in the territory of Florida, by virtue of a grant of the Spanish governor of that province mathe in inlis. After Florida was eeded to the United states by the treaty of 1s!a, this claim was rejected by the United States comminsioners appointed to settle chaims to teritory in Florida; and the question then came before the court for decision.

IIeld that title to private property in the soil is not affected by a cession of territory.

Marsmall, C. J., delivered the opinion of the eourt, an extract from which is as follows:-

So, in the ease of the cession of Alsace and Lorraine to Germany in Li1. no part of the French national debt was assmmet by Germiny on their aceonut. (B)untschli: Droit International, Article th.)

On the other hand, on the seizure of hehleswig-IIolstein by Prusia. in Irifi. 1hw

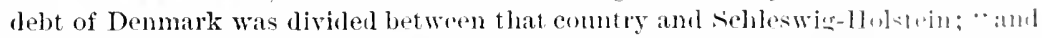
in the same year, Italy, by conrention with France, took upon it we - w much of the Papal delt as was proportionate to the revenues of the l'alpal perinees which it had appropriated." (Wall's International Law, :3l ed., 102, not?.) 
"It may not he nuworthy of remati that it is very mosual even

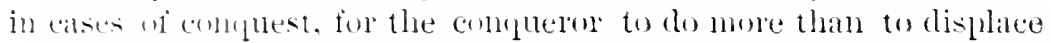
the soreletgh and assmme dominion over tire country. The modern

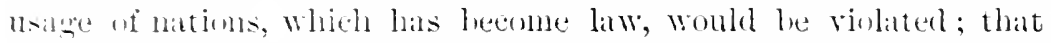
semse of justice and of right which is acknowledged and felt hy the whole civilized world would le: ontraged, if private property should le gesterally contiscated, and private rights ammled. The penple change their allegiance; their relation to their ancient sovereign is dissulverl ; but their relations to each other, and their rights of propenty, rentin malisimbed. If this be the modern dule even in cases of ementest, wher com dombt its application to the eatse of an amicable wrion of territory: Had Florida changerl its sovereign by an at containing me tipulation sespeeting the proferty of individuals, the riglit of property in all those who hecame subjects or citizens of the new grormmont womld have been matfected by the change. It woukl haveremainer the same as moler the ancient sovereign. ***

". A cession of territory is never molerstool to be a cession of the lonerty helonging to its inhabitants. The king cedes that only which betonged to him. Lands he had previously granted were not his torede. Neither party could so understand the cession. Teither fraty could consider itschf as attempting a wrong to individuals, condemed by the practice of the whole civilized world. The cession of a territory hy its name from one sovereign to another, conveying the compound idea of surrendering at the same time the lands and the feople who inhabit them, would be necessarily understond tin phos the surereignty only, and not to interfere with private prolerty."

\title{
OINIUNOF IAIYARD, SECRETART OF STATE.
}

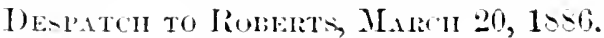

$$
\text { (1 Wherturis Ligest, 16.) }
$$

In the territory conquered by Chili frum Peru in the war of $1580-1592$, citizens w the Cnitul stalm lath arognired certain rights from the Parurian government

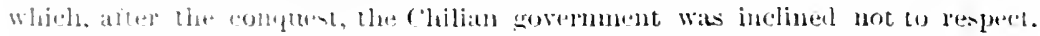

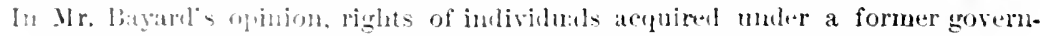

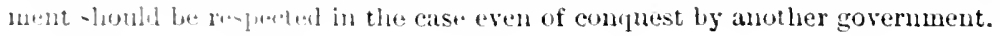

"Th" dexisin now marle rests on an allered rule of interna-

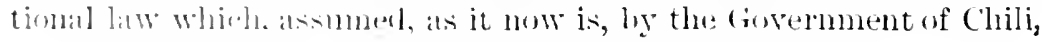

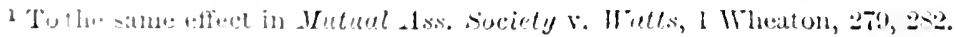


beemes a proper matter of disonsion between ombehms and that Govemment. It is asserted by the fovermment ot chili four, in international delations, and the maintenance of internationat hutiss, the action of the judicialy in Chili $\mathrm{i}$, to be treated, when atsinmul

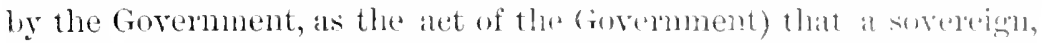
when ocemping a conplered territury, has, by intenanional law,

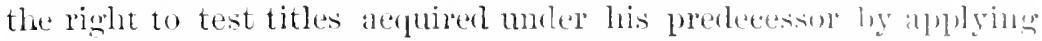
to them his own municipal law, and not the municipal law of his predecessor moler which they rested.

"The Govermment of the Eniterl States, therefore, holks that titles derived from a duly constituted prior foreign (iorrmment to which it has sticceeded are 'comseerated by the law of mations' even as against titles claimed under its own subseruent laws. The rights of a lesilent-neutral-having become fixed and resterl hy the law of the comutry-cammot he clenied or injurionsly affecterl hy a dange in the sovereignty or publie control of that country ly transfer to another Govermment. Ilis remedies may be affected by the change of sovereignty, but his rights at the time of the change must be measured and determined hy the law under which he acquined them. *** The Govermment of the Lnited States is therefore prepared to insist on the continned valinlity of such titles, as held hy citizens of the Lnited states, when attacked by foreign Govermuents succeerling that by whith they [were] granted. Title to land and landed improvements, is, by the lim of nations, a contimous right, not subject to be divested by any retroactive legislation of new Govermments taking the place of that by which such title wats lawfully granted. Of conrse it is not intended here to cheny the prerogative of a conqueror to confiscate for political offenses, or to withdraw franchises which by the law of nations can be withlrawn hy Govermments for the time being. Such prerogatives have been conceded by the United States as well as hy other nembers of the fannily of nations by which international haw is constituted. What, however, is here denied, is the right of any Government to doelare titles lawfully granted by its predecessor to be vacated hecamse they could not have been lawfully granted if its own law hakl, at the time in question, prevailed.

"This pretension strikes at that principle of historial munioinal continuity of Govermments which is at the basto of interialiunal law." 


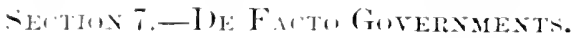

(11) Retrengition "ft Belligeremey. OMINIONOF DINA.

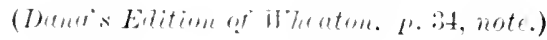

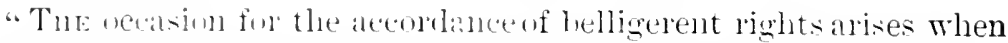
a ciril confliet exists within a forejen state. The reason which refluires and which can alome justify this step hy the govermment of inother conntry is, that its own rights and interests ane so far attereted as to lequire a definition of its own relations to the parties. IVlece a falent government is seeking to sublue an insmection by municipal foree. and the insulowents claim a political nationality and letligerent dights which the parent govemment does not concede, a Jeemention by a foreign state of full helligerent rights. if not justificel ly becesity. is a gratuitous demonstration of moral support to the letellion, and of censure mpon the parent govermment. But the situation of a foregen state with reference to the comtest and the (ombition of attail's between the contending parties, may be such as to justify this alet. It is importint, therefore, to determine what state of atriars, and what relations of the foreign state, justify the le(c)suition.

"It is cortain that the state of things between the parent state and insurgents most amount in fitet to a erop, in the semse of intermational haw, that is, powers and rights of wal must lue in actmal

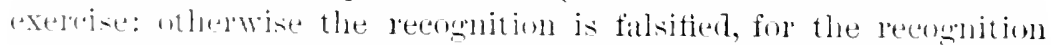
is af a fatet. The tests to deternube the question are varions, and fir mole decisire where there is maritime wal and commeredal

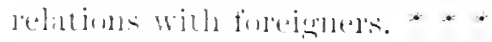

- Is to the relation of the forrign state to the contest, if it is

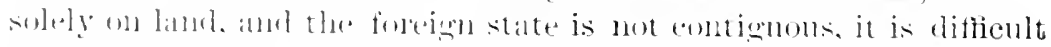

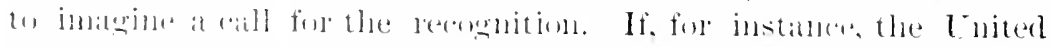

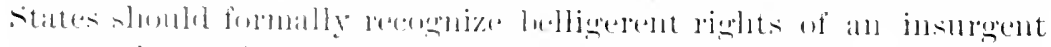

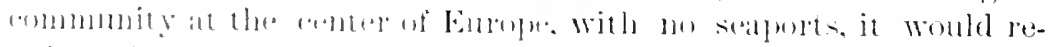

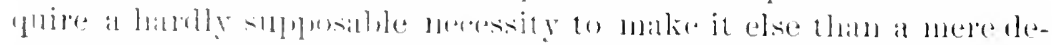

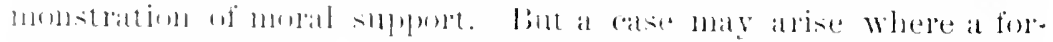

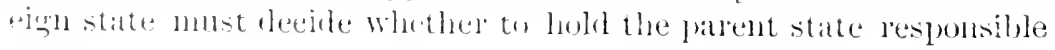


for acts done by the insugents or to deal with the insinements as at

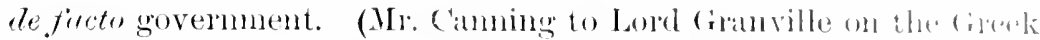

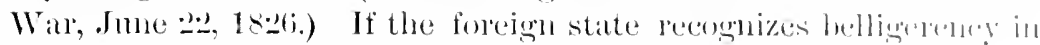
the insurgents, it releases the parent state from respmsibilit for whatever may be done by the insmegents, of not done by the fratent state, where the insurgent power extemds. (Ml. Alams to Ml' Seward, June 11, 18(j1, I)ip. ('in. 16i).) ln a contest wholly num land, a contiguons stale maly be obliged to make the deroinom whether or not to regard it as war ; but, in pratetiec this luas mot been done ly a genelal and prospeetive declaration, but ly andual treatment of cases as they arise. Where the insmrgents and the parent state are maritime, and the foreign nation has extensivo commercial relations and trade at the ports of both, and the foredgin nation ancl either or both of the contending parties have ans alderable naval force, and the domestie contest must extend itself orel the sea, then the relations of the foreign state to this contest ane far different. In such a state of things, the hability to pritical complications, and the questions of right and duty to be decilerl at onder, usually away from home, by private eitizens or naval officers. seent to require an anthoritative and general decision as to the stotus of the three parties involverl. If the contest is a walr, all foreign citizens and officers, whether executive or julicial, are to follow one line of conduct. If it is lot a warl, they ale to follow a tolally different line. If it is a war, the commissioned ermiser's of both silles may stop, search and capture the foreign merchant-vessel ; anrl that vessel must make no resistance, and must submit to arljulication by a prize court. If it is not a war, the ennisers of neither lialy can stop or search the foreign merchant-vessel; and that vesiel maty resist all attempts in that direction, and the ships of war of the foreign state nay attaek and capture any eruiser persisting in the attempt. If it is war, foreign nations must await the adjulication of prize tribunals. If it is not war, no such tribunal can be openerl. If it is a war, the parent state may institute a blockade jum :/ntimn of the insurgent ports, which foreigners must respect: hut, if it is not a war, foreign nations having large commercial intercouse with the conntry, will not respect a elosing of insmrent polts by latper decrees only. If it is a wall, the insurgent crmiser's ane to be treilted by foreign eitizeiss and officials, at sca and in port, as law ful hellinereents. If it is not a wall, those eruisers are firates, and mat be treated as such. If it is a wal, the pules amb liskis resproling carrying contraband, or despatches, or military persons conte inte play. If it is not a war, they do not. Within foreign jurisilietion, if it is a war, acts of the insurgents in the way of prepratition and 
opuipments for hostility, may he lueaches of nentrality laws: while, if it is mot a wall they do mot come into that caltegory, but into the

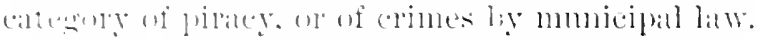

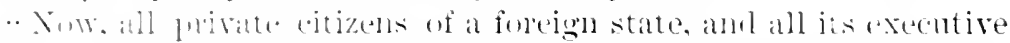

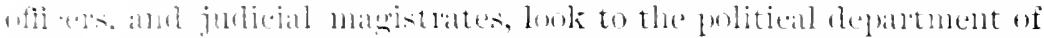

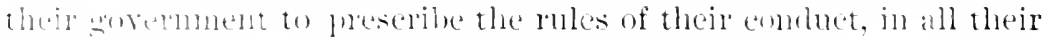

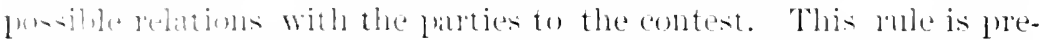

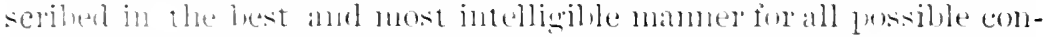
tingenefer hy the simple declaration that the contest is, or is uot, to

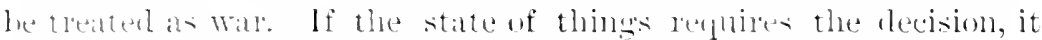

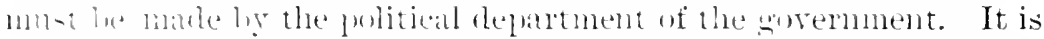
not fit that cases shomld be lefito he deciderl as they may arise, by

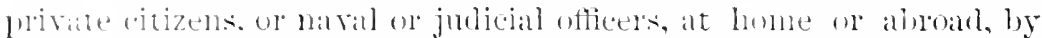
steil w lamel. It is. therefore, the custom of nations for lhe political

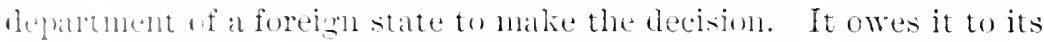
own citiztns, to the contending parties, and to the peace of the world, to matir that decision seasonally. If it issues a fomal declaration w helligeren rights prematmely, ol in a contest with which it has

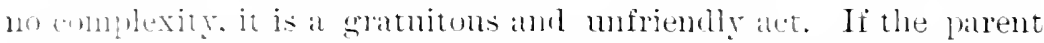
gorrmment complans of it, the complaint must he mpon one of these frromnds. Torlecide whether the recognition wats mealled for and [Hesnatture. repuires something more than a consirleration of proximilie fact and the overt and formal acts, of the rontending parties. The foreign state is bomd and entitlel to consider the preculing history of the parties; the magnitule aml completeness of the pulitive and military organization and preprations on each sith: ahe probihle extent of the confliet by sea and hand : the proballes cxtent and ripulity of its development; and, above all, the

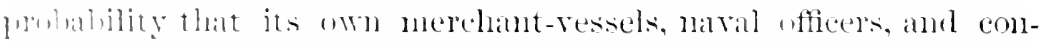

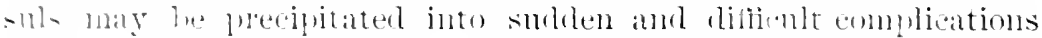

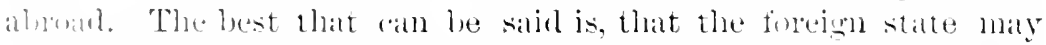

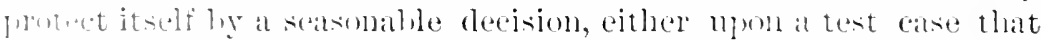
arias, or hy a general pospertive decision; while, on the other

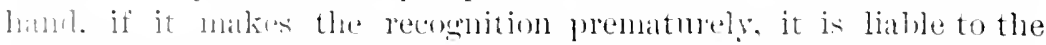

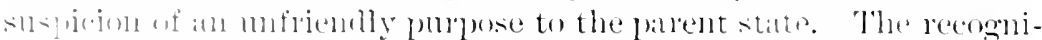

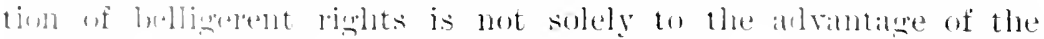

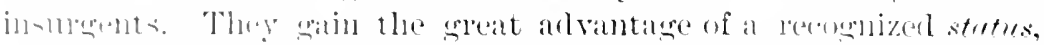

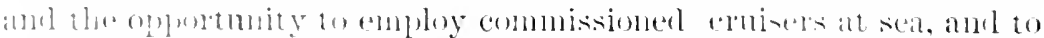

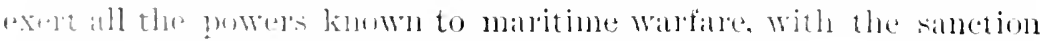

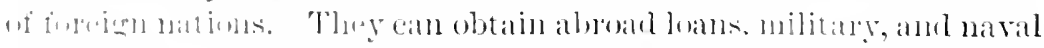

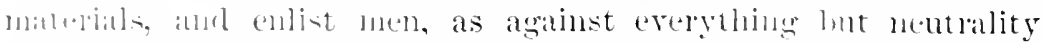

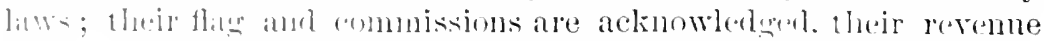

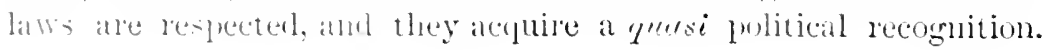


On the other hand, the parent govermment is relioved from lempln-

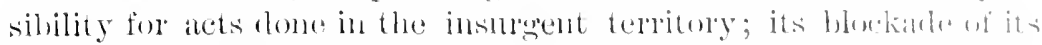

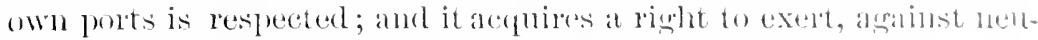
tral commeree, all the powers of a party to a mallitile war."

TIIE I.II.T.L.

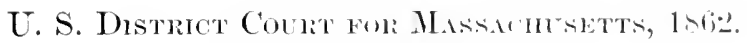

(2simegues Derisions, 176.)

The Lilla was condemned by a Prize court of the Confederate States, and subse-

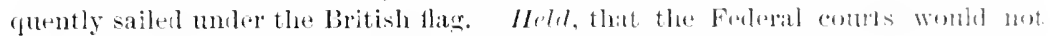
acknowledge the validity of the decisions of the prize courts of the Confenteriaty, although they had recognized the helligerence of that govermment.

This was a Maine brign called the betsy Ames, captured by a comferlerate privateer commanded by II. S. Lihl,y, earrierl into ('harkes-

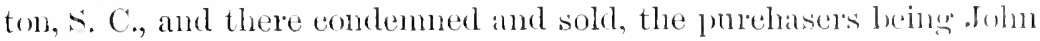
Fraser of Co. of that eity. Iner name was chamged to the Mary Wright, and, loaded with cotton, moler the command of Libly, she ran the blockade, arrived at Liverpool on the 2.1 of 1 luil, 1:tio, and disposed of her cargo. April 2 th she was registered as a british vessel, called the Lilla, and in the name of lR. (x. B., as sole omber. A fortnight later she sailed for Nassan, N. I', moner the enmmand of A., aceording to her paper's, but really still muler commanul of Libhy. There is evidenee going to show that it was arrangerl that Fraser \& Co. should have a steamer of theirs follow to Nissiut, there take on the Lilla's caroo and proeed to Charleston.

Parts of the cargo were falsely acommented in the name of R. G. B. for the purpose of deeeiving the Lnited states ernisers.

The ressel was seized by the United Ntates gumboat Quaker ("ity, brought in, and claimed by her original owners.

Sprdore, T., deeided that R. (x. B. lost whatever he possessed in the cargo by reason of his falsely documenting other gouk as his own to deceive belligerent cruiser's and that the vessel shombl he

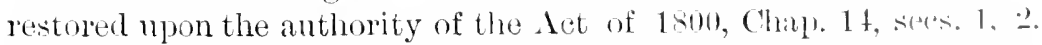
C. S. Stats. at Large, 16, which provides that when a merehant rester belonging to any person under the protection of the Unitul sitates, shall have been taken by a publite enemy, and shall he reatptmet liy a public armed vessel of the Uniter states, such vesisel mot latrinin

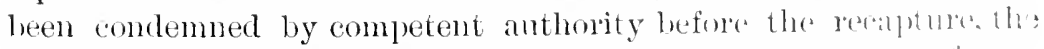
same shall be restored to the former owners ulom palyment of one 
eighth part of the true value, for and in lien of sulvage. The court also sills:-

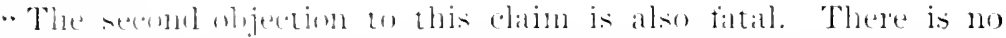

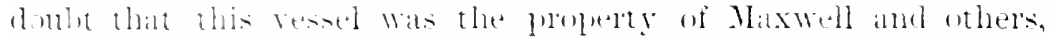

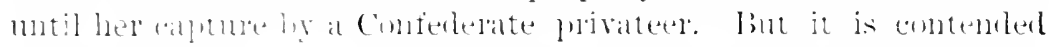

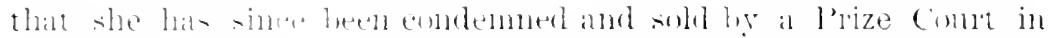

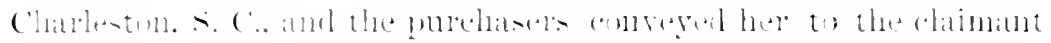

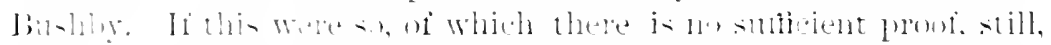

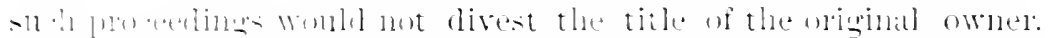

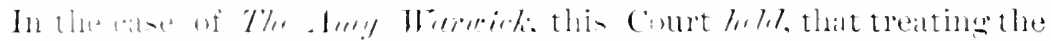

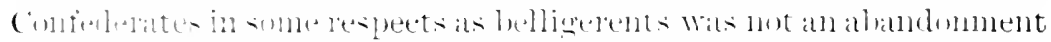

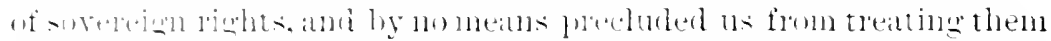

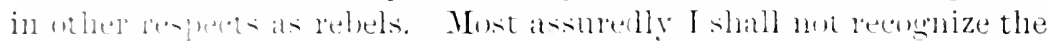

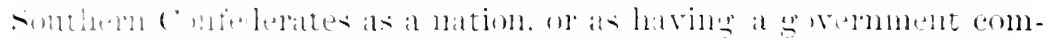

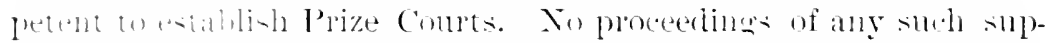

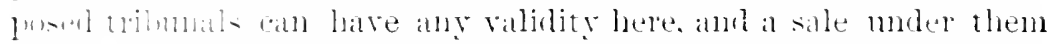

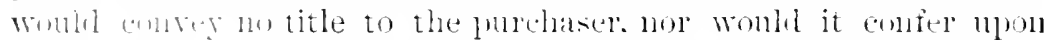

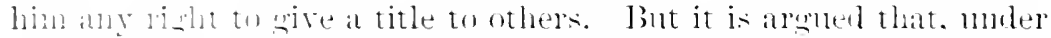

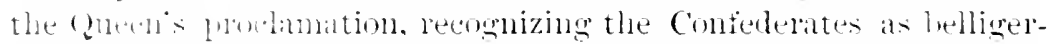
ents. a birish emont womld hold a sale to be valid. What the decis-

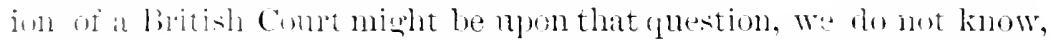
it never having hen there litigated. But such a decision. if made,

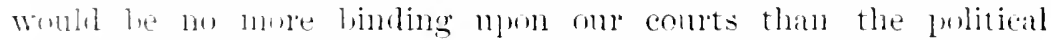
viens af the british government would be upon the lresident or the Cinlugess."

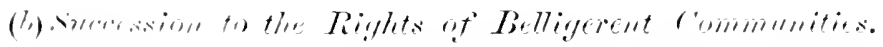

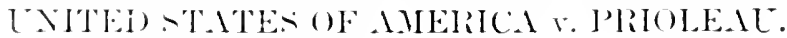

Cinsinetis, 1-ifi.

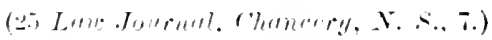

I fun thas -

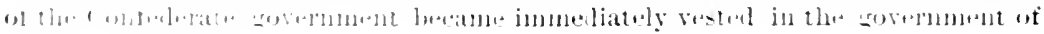

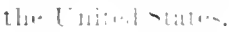

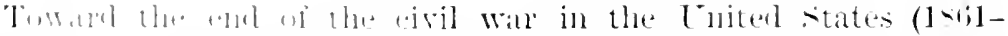

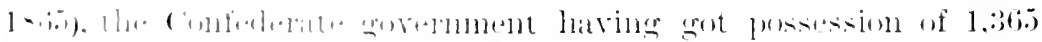

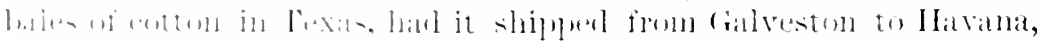

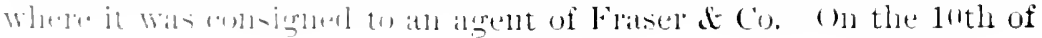




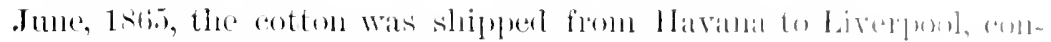

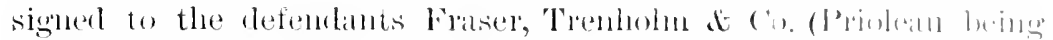

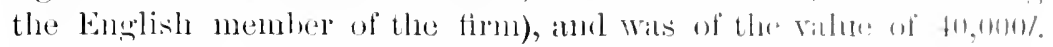

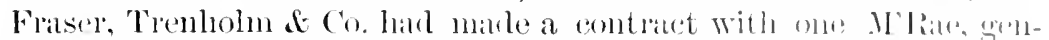

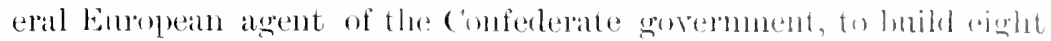

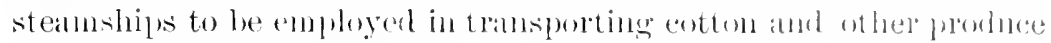

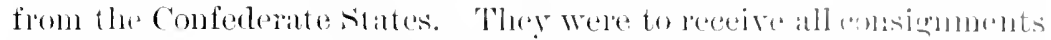

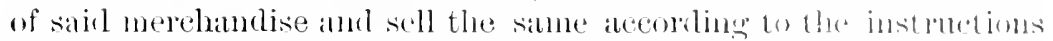
they should reeeive for that purpose. The compraty were to adrance the expenses of transportation, and were then to lecomp themselves out of the proceeds of the comsigmments. They hat allearly expended $20,000 \mathrm{for}$ saling expenses, to say mothing of the cost of the ships.

When this eonsigmment of entom arrived in Liverpool, the cinfedelate government had heen dissolved, and the Conferlente titates had submitted to the authority of the Cnited States government; and the litter goveriment filer a bill praying to hat the enten delivered up to them, and for an injunction and peedrel.

Julfment.- Woov, V. C.: "There are one or two prints which, I think, are tolerably elear in this ease. The first point is with refrence to the right of the $I^{r}$ niter states of Ameriea, at this moment, to the cotton, subject to the agreement. I treat it first in that way. It has scarcely been disputed on the present aroment, and oould hardly be disputed at any further stage of the inguiry, that the right is elear and ristinet, because the cotton in question is the admitted result of funds mised by a de focto government, exercising authority in what were called the Confederate states of Amelicar; that is to say, several of those states which, in union, formerly comstituter the Enited states, and whieh now, in fact, constitute them; and that re forcte govermment, exereising its powers over a comsidererable number of states (more than one would be quite enongh), raises money-be it ly voluntary contribution, or be it hy taxation, is not of much importance. The defendant Priolean, in eross-examination, admits that they exereised considerable power of taxition ; and with those means, and chaming to exereise that anthority, they obtained from several of the states of Ameriea fomm hy which they purchased this cotton for the use of the de fireng gorermunent. That being so, and that de facto govermment being displiteded I apprehend it is quite clear that the Cnited States of Anerioa (that is to say, the govermment which has been snceesstul in displiacing the de fircto govermment, and whose authority was nsmper or displacerl, or whatever term you may choose to aply to it). Hle allthority being restored, stand, in reference to this cotton, in the posi- 
tion of those who have adpined, on behalf of the citizens of the

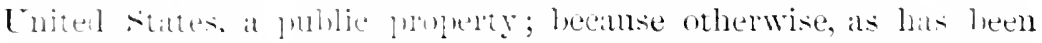

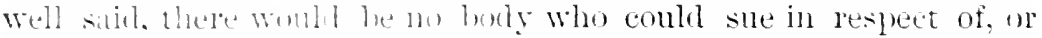

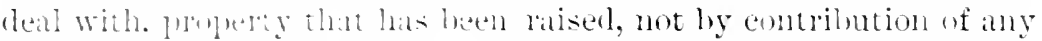

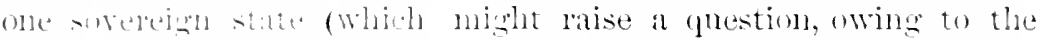

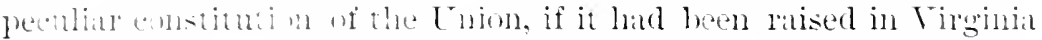

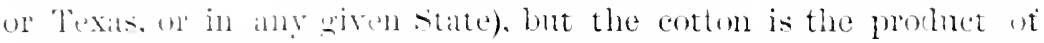

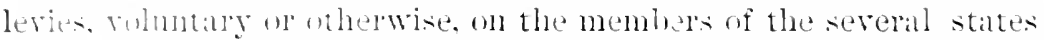
which hare mited themelves into the Confecterate states of Anerical, and which are now maler the control of the present platintitrs, ant are lelpesented, for all furposes, ly the present plaintitis. That heing so, the right of the present plaintifis to this cotton, subjer to this arreement is. I thinls, tear, hecanse the agreenent is

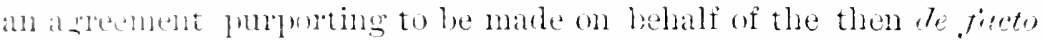
exining chmernment, and not of any other persons. That calse of

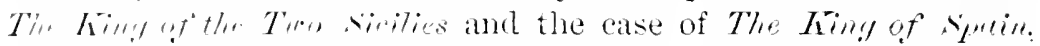
and nher calses of the sime kind, which it is not necessary to gu thrmah. show that whenever a govemment mo forcto has cistained the pusesidon of property, ats a govermment, and for the pmposes of the whernment to firefo, the government which displaces it succetels to all the rights of the former govermment, and, among other things succeds to the property they have so acpuired.

" Xim I eome to the seeond head of the question, and I confess at this moment. as at present adrised. I do not feel much houbt on the sulject, namely, the question whether or not. taling this property, they must or must not talke it subject to the agreement. It appears

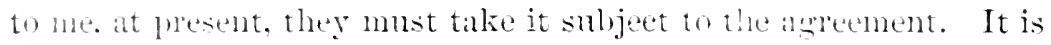
an andernent entered into by a de forfo government, treating with leswhs who have a perfect right todeal with them. I almedend if they ham leten American suljects they might do so. One of them. Printeru. is not an American subject; he is at naturalized libitish sulgiert he womlel have a perfect right to deal with a de firefo

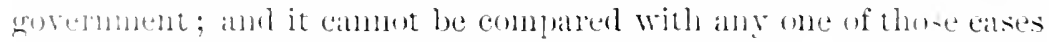

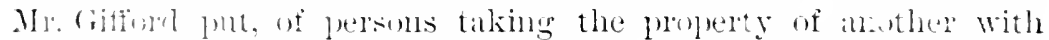

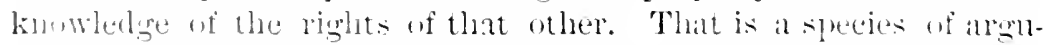
ment that eanued he alphlied to international catses of this descriptim. and for a vely gand reason; if so, there womld he no pusilsility

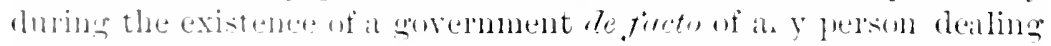
with that corvernment in any part of the worlel. The conts of

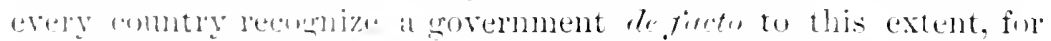

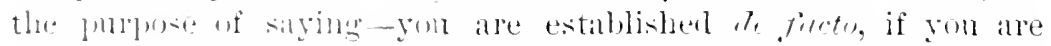

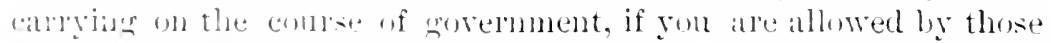
whon gou attiect to gasern to levy taxes on them, and they pay 


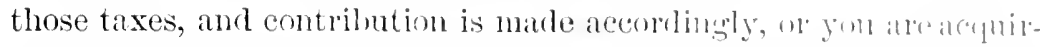
ing proprety, and are at war, having the rights of hellimerents, nut being treated as mere rebels by persoms whe sily they and the

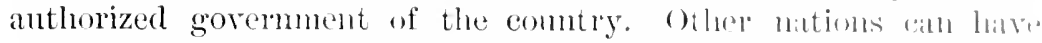

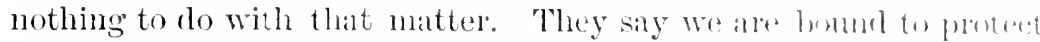
our subjects who treat with the existing governunent ame we must give to those suljects, in omr country, every right which the worranment de fecto can give to them, and must not allow tho surerexling government to assert any right as against the contrats whilh have been entered into ly the govermment de ficeto; lnit, as cxpresserl by Lord Cranworth in the case referred to, they must sucererl in every respect to the property as they find it, and subject to all the (ommlitions and liabilities to which it is subjeet and by which they al'e bound. Otherwise, I do not see any answer to Mr. James's illustration, and I do mot see why there should not have been a lill filert to have the Alabmm delivered up; * * * because on the theory of the present plaintiffs, it was their property just as much as their cotton is now. If the case had been this (and it is the only ease I can consider as making any difference, but that difference wonld be fatal to the plaintiff's case in another point of view) : if they har been a set of marauders, a set of robbers (as was said to be the case in the kingdom of Naples, truly or untruly), devastating the comntry, and acquiring property in that way, and ther affecting to deal with your subjects in England, it would not be the United states, hut the individuals who had been robbed and suffered, who could cone as plaintiffs. The L'nited States could only come to claim this lecanse it has been raised by public contribution; and although the Cniter States, who are now the government de fucto and de jure, clitim it as public property, yet it would not be public property unless it was raised, as I have said, by exercising the rights of govermment, and not by means of mere robbery and violence.

"I confess, therefore, I have so little doubt, that this agreement is one that would be binding on the plaintiffs, that I eamnot at against these gentlemen without securing to them the reasomable benefit of this agreement; and I camnot put them moler any terms which would exclude them from the reasonable benefit of what they are entitled to, and must be held entitled to, as I think, at the hearling of the cause."

[The Vice Chancellor then proceeds to decree that the entton was now the property of the United States Government, but that they must take it subject to the obligations entered into respeeting it by the de facto Confederate Govermment.

The defendant Prioleau was appointed receiver, with power to sull 
the enton. lut he was regutred to give security for its value ultra the $20.0101 \%$. the ammmt of the refendant's lien. $\left.{ }^{1}\right]$

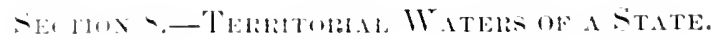

(1) liileris.

OPINION OF WIEATON.

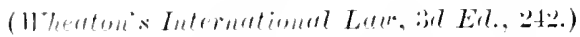

"The temitory of the state includes the lakes, seas, and rivers, entimely indued withn its linits. The rivers which flow through the teritory also form a part of the domain from their somes to there munhs on as far as they flow within the territory, including the bag-on estmates formerl by their junction with the sea. * * *

"Thing of which the use is inexhaustible, snch as the sea and ruming water, cammot he so appropriated as to exelucle others from nsing these elements in any mamer which does not occision a loss

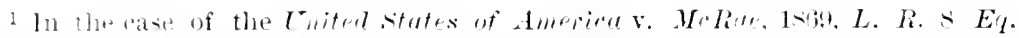

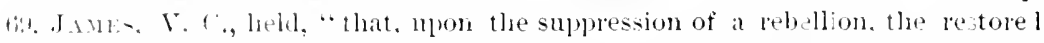

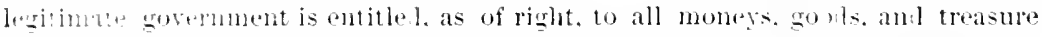
which we smblic property of the government at the time of the outbreak. such

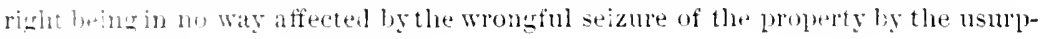

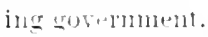

"but with mepect to property which has been volumtarily contributed to, or

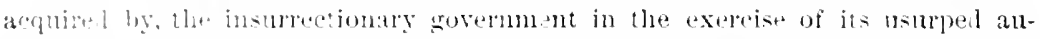

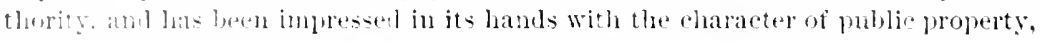

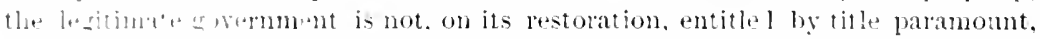

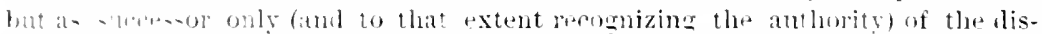

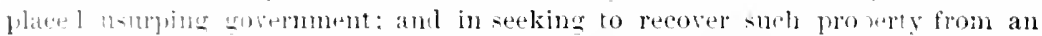

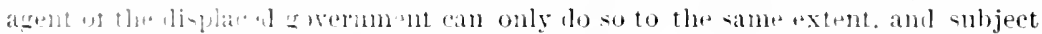

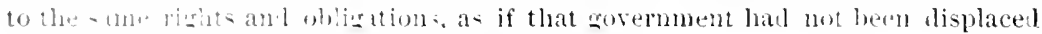

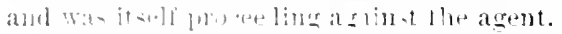

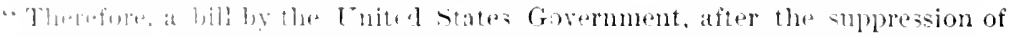

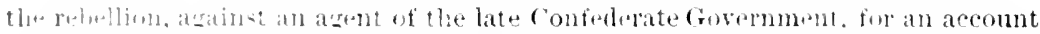

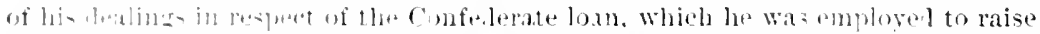

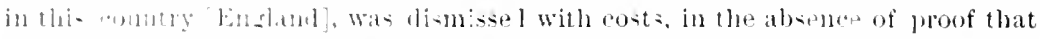

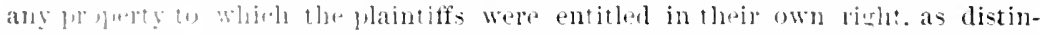

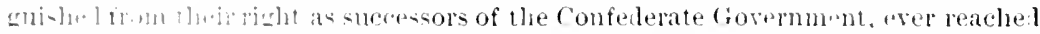

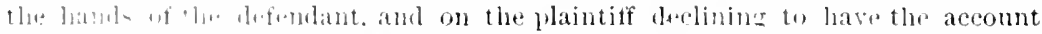

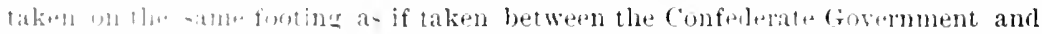

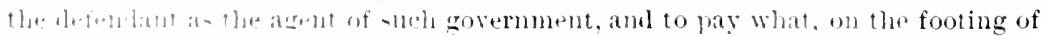

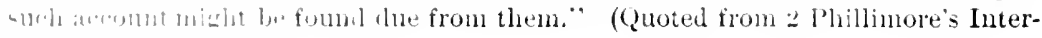
national I,aw, l.5t.) 


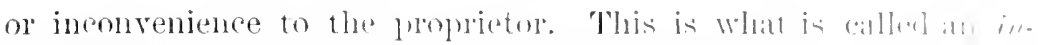

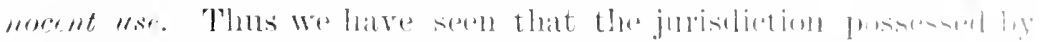

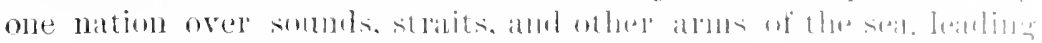

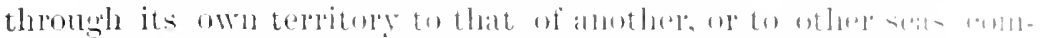

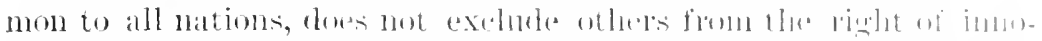

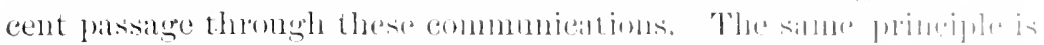

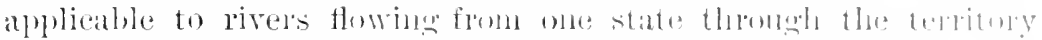
of :unother into the seal, or into the territory of a thipl state. 'Tlut

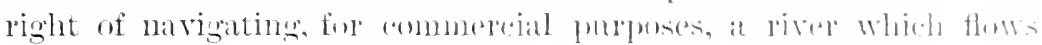

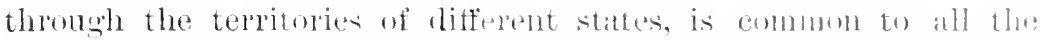
mations inhabiting the different pats of its banks; hut this lingt at innocent passage being what the text writels call all impolfort right,

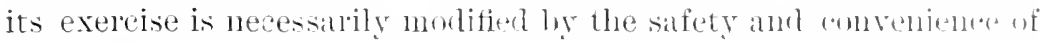
the state affected ly it, amb can ouly be effectually secured ly mutual convention regulating the mode of its exereise."

\section{TIIE N.IVIG.JTION OF TILE MISTISTPPI.}

(Whecetonis International Lar, :3, Erl, 247.)

"By the treaty of peace enneluded at Paris, in 176\%, hetwen France, spain, anl Great Britain, the plovince of Camada Wals couldel to Great Britain by France, and that of Florida to the sime furer by spain, and the boundary between the French and britisl fussessions in North Anterica was asecertained hy a line drawn therengh the midale of the river Mississipui from its sompere to the Iherrille, and from thence through the latter river and the lakes of Manderis and Pontehartrain to the sea. The right of navigating the Miscissippi was at the same time seenred to the subjects of treat britinin from its somrce to the sea, and the passages in and ont of its momth, without being stopler, or visiter, or suljected to the payments af any duty whatsoever. The provinee of Lomisiana was soon afterwards ceded by France to spain; and by the treaty of Paris. 17-:, Florida was retrocerder to spain by Great britain. The independenes of the United States was acknowlerged, and the right of narigute ing the Mississippi was seenred to the citizens of the Lnited status and the subjects of Great Britain by the separate treaty betwon these powers. But spain having become thus possessed of both hatuks of the Mississippi at its mouth, and a eonsiderable distance alms its month, elaimed its exclusive navigation below the print when the southern boundary of the Enited states struck the rirel. This claim was resisted, and the right to participate in the nivigation of 3 
the river form its somper to the seal was insisted on hy the Fuited

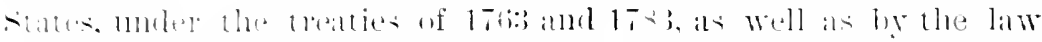

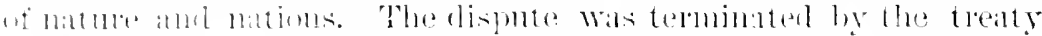

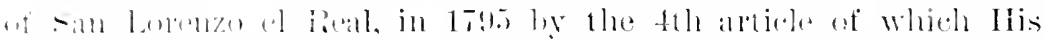

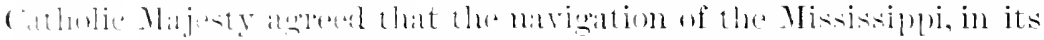

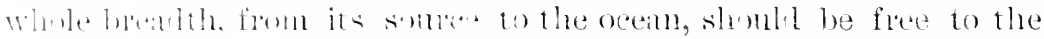

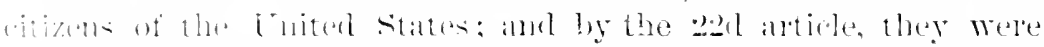

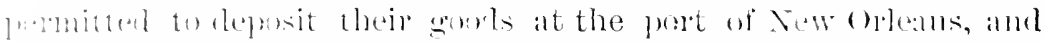

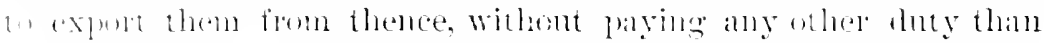

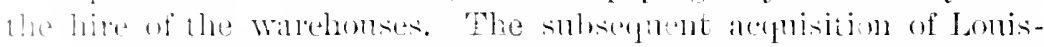

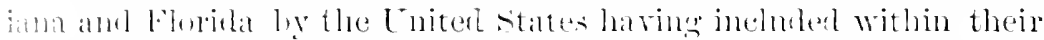

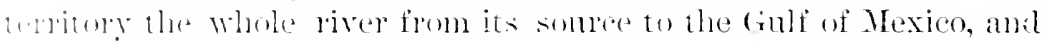
the stipulation in the treaty of $17-3)$, semplug to british subjects a

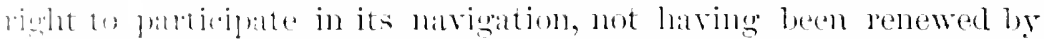
the tealty of (ihent. in $1-14$, the right of navigating the Mississiple i- mow rested exhlusively in the Enited states.

." The right of the Cuited states to participate with span in the natrigutom of the river Mississipln, was rested by the Amerian

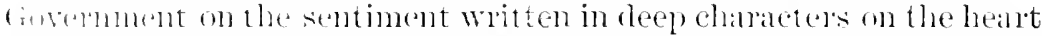
uf man, that the reean is free to all men, and its rivels to all its inhalitants. This natural right wat fomud to be muversally ateknowl-

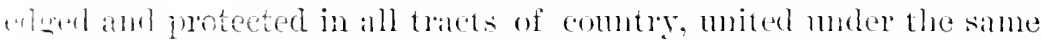
Inditial sonety. hy laying the navigable rivers open to all their inhahitants. When these rivers enter the jimits of amother soriety, if the right of the unper inhahitants to descend the stroam was in mly cate ofstrueder, it was an alet of foree ly a stonger sociefy

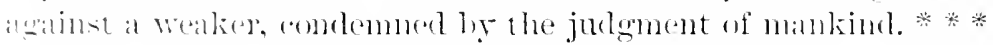

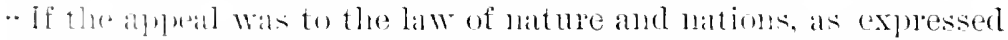

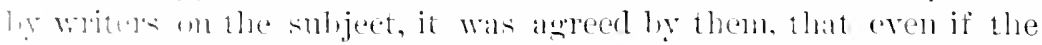

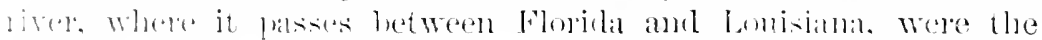

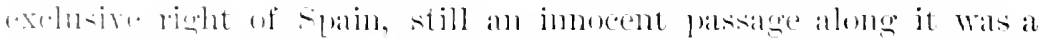

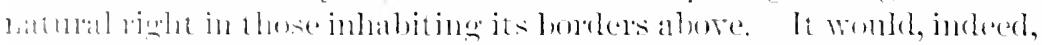

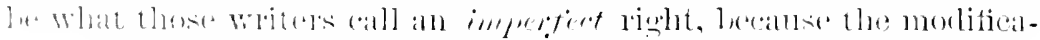

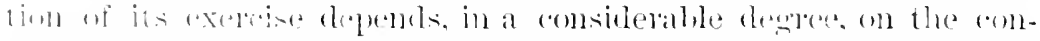

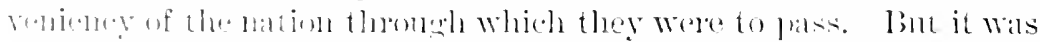

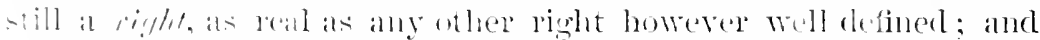

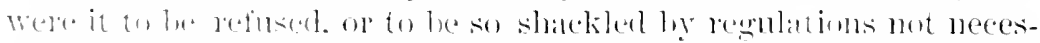

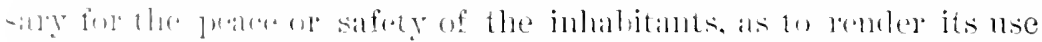

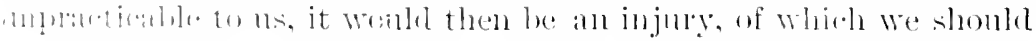

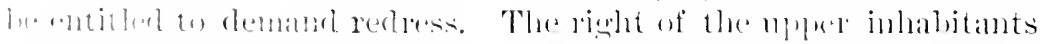

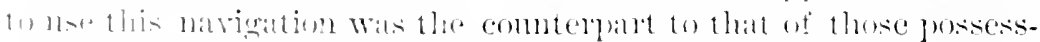

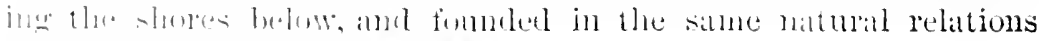
with the sil and water. $\%$ * * 


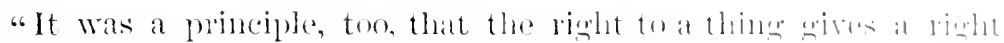

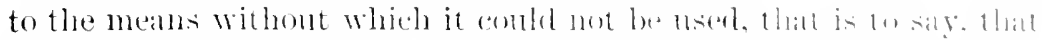

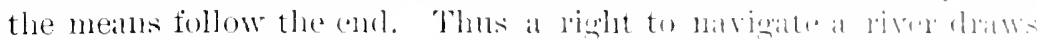

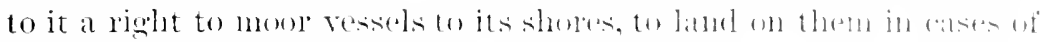

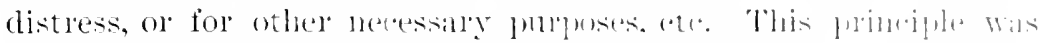

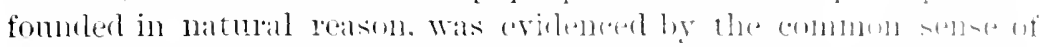

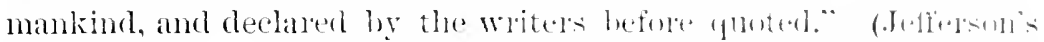

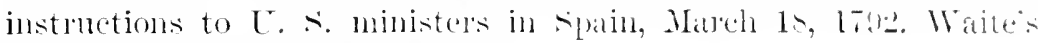
state Palpers, vol. x. 1'1. 1:3.j-1 140.)

\title{
THE NATIGATION OF TIIE $>$ T. I.IVRLNCL.
}

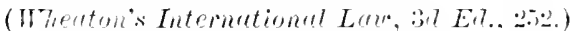

"The relative position of the Cnited states and Guent Britain in respeet to the navigation of the great northern bakes and the river st. Lawrence, appears to be similar to that of the Fuited states and spain, previonsly to the eession of Lonisiana and Florida, in respect to the Mississippi; the Cuited states being in possesion of the sonthern shores of the lakes and the river st. Lawence to the print where their northern boundary line strikes the river, and rideat Britain, of the northern shores of the bakes and the river in its whole extent to the sea, as well as of the southern banks of the river from the latitude $\frac{1}{4} 5^{\circ}$ north to its month.

"The elaim of the people of the Lnited states, of a right to marigate the st. Lawrenee to and from the sea. Was, in $1 \times-2$; the sulject of discussion between the American and British Governutems.

"On the part of the Inited states Gorermment, this right is rested on the same grounds of natural right and obvious necesily which had formerly been urged in respect to the river Mississippr. The dispute between different Enropean powers respecting the narigation of the Scheldt, in 178t, was also referred to in the corresundence on this subject, and the case of that river was distinglushed from that of the St. Lawrence by its peruliar circumstances. Amones others, it is known to have been alleged by the Dutch. thit the whole conse of the two branches of this river which pasterl within the dominions of IIolland was entirely artificial: that it amed it: existenee to the skill and labor of Dutchmen; that its lanks hald been erected and maintained by them at a great exprese. Hesues. probably, the motive for that stipnlation in the treat y of Wentphalia, that the lower Scheldt, with the canals of Sas and win, and other 
momthe of the sor arjoining them, shoult be kept closed on the side belomging to Iholland.

" lint the atat of the sit. Iawrence was totally different. and the principles on which its free maveration was maintainel lis the

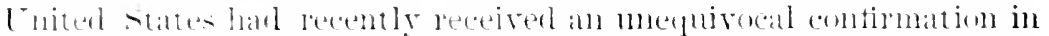

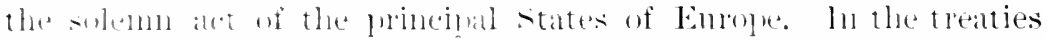

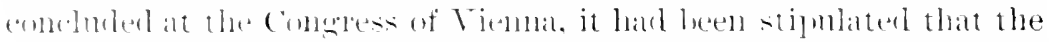

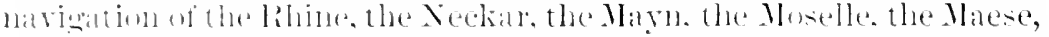
ambl the scheblt. slombl he free to all nations. These stipulations. to

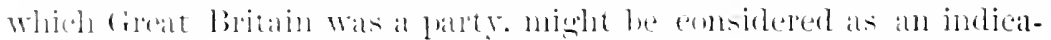

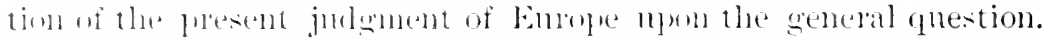

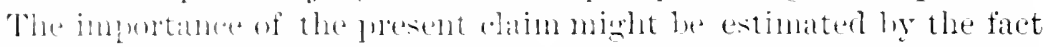
that the inhahitants of at least right states of the American Enon,

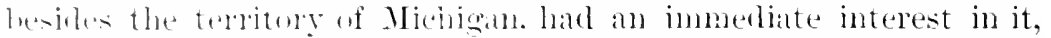
hesiles the pondertive interests of othel parts comnected with this Jivel and the intand seas through which it eommunieates with the ocean. The risht of this great and growing polubation to the use of this. its omly matural ontlet to the ocean. Was supported by the sane principles and anthorities which had been ureed by Mr. Jetferson in the negotiation with spain respecting the navigation of the river Misisistrie.

"The mesent elaim was also fortified by the consideration that this mavigatom was. lefore the war of the American lievolution. the ammon lunerty of all the British subjects inbaliting this eontinent, having been acynired from France by the mited exertions of the mother comtry and the colonies in the war of 17 an. The ram of the Luited states to the flee navigation of the st. Lawrence Was of the salne nat me with that of Great Jritain to the navigation of the Misisiplei, as recognized by the ath altiche of the treaty of Paris, liti:s, when the north and lower shores of that river were

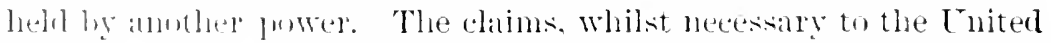
status. Was nol injurious to Great Britain, nor could it violate any of hel just lights.

"() the but of the British Govermment, the claim was consiclered as involvine the gluetion whether a fertect right to the free navigat-

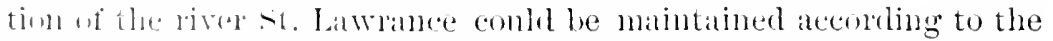
principles and pritelice of the law of nations."

.. The libely of passage to be enjoged hy one nation through the dominims of another was treaterl by the most eninent writers on fullie liw at a plalitierl, oceasional exception to the paramount rights of lun wery. Thry made no distinction between the right of biastge hy a liver, Howing from the possessions of one nation

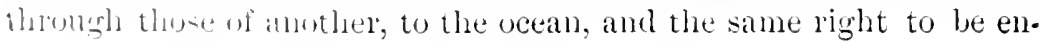




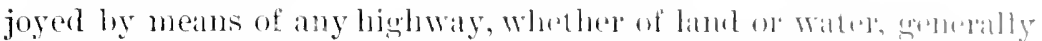

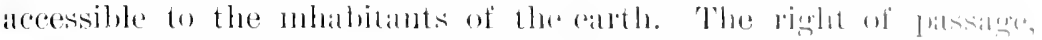

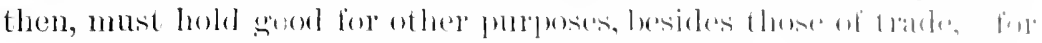

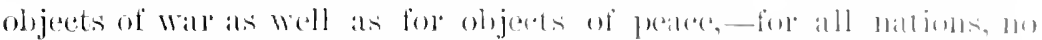

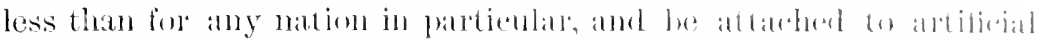

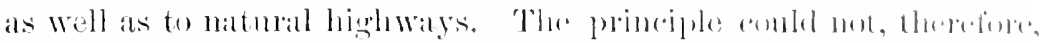

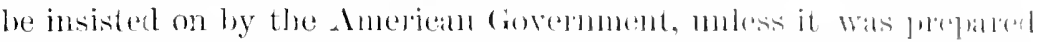

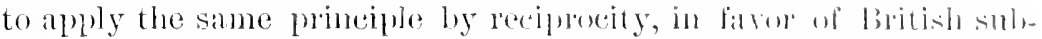
jects, to the navigation of the Misissiphi and the IJulson! andess

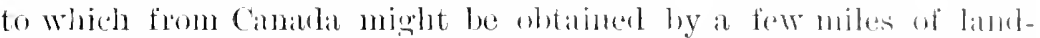

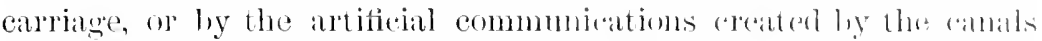
of New York and Ohio. Hence the meossity whinh has bern foll by the writers on public law, of controlling the oferation of a prineiple so extensive and dangerous, by restricting the riglat of lansit to purposes of innocent utility, to be exelusirely detemined by the locil sovereign.

"Hence the right in question is temed by them an impurtion right. But there was nothing in these writers, or in the sijpulations of the treaties of Viemna, respeeting the navisation of the surate livers of ciemany, to combenames the Ameriean dercine of an absolnte, natural right. These stipulations were the losult of mutual consent, fommed on consideration of mutual interest growing ont of the relative situation of the difïerent states concerned in this navigation.

"The same observation would apply to the varions conventimal regulations, which harl been, at different periods, anplien to the navigation of the river Mississippi.

"As to any smposed right derived from the simultameons acpuisition of the st. Lawrence by the British and American people, it could not be allowed to have surviver the treaty of 17.2 .3 , hy whide the independence of the Enited situtes was acknowledgerl, and a falltition of the British dominions in North Ameriea was malle betwern the new govermment and that of the mother comntry.

"To this argument it was replierl, on the part of the Tunted States, that, if the st. Lawrence wore regurded als a stomit momberting navigable seas, as it ought properly to he, the we womb he las controversy. The principle on which the right to narigate straits depends, is, that they are accessorial to those seas which they mitu. and the right of navigating which is not exchusive, hut anmmm to all nations; the right to navigate the sass drawing after it that of passing the straits. The Enited states and cirat liritain have hetween them the exchsive right of navigatiog the lalis. Tha s. Lawrence connects them with the ocean. "The riglit to nilvigute 


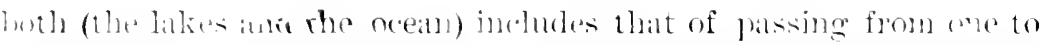

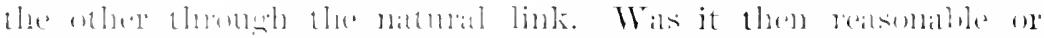

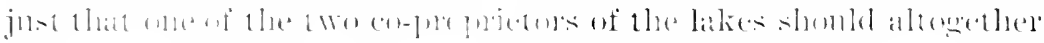

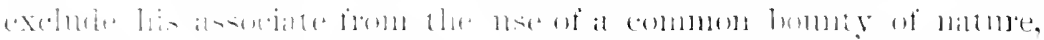

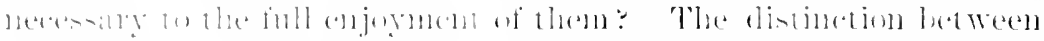

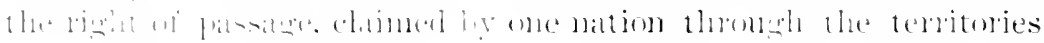

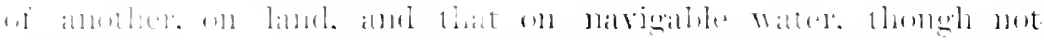

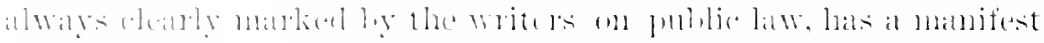

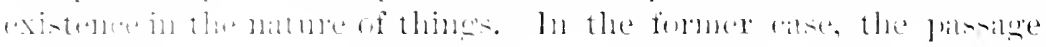

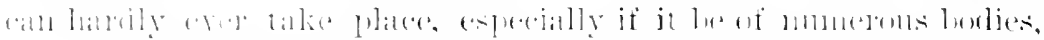

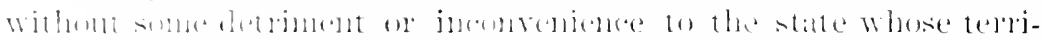

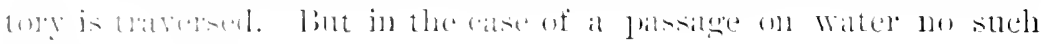

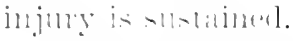

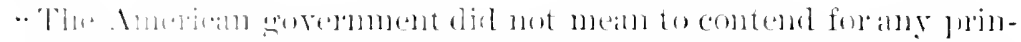

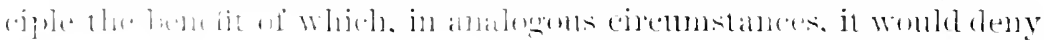

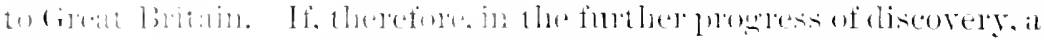
(a)

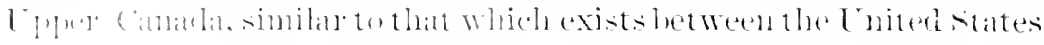

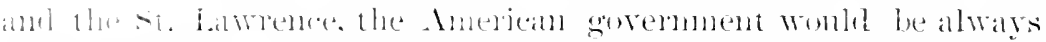

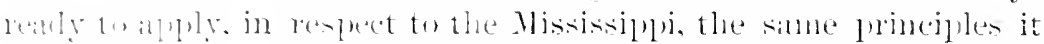

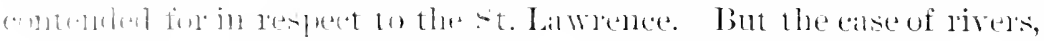

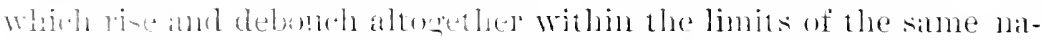

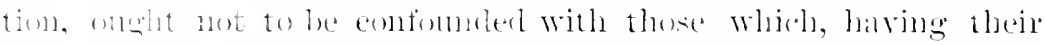

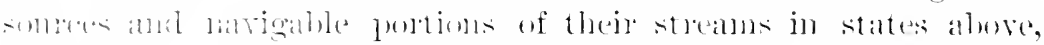

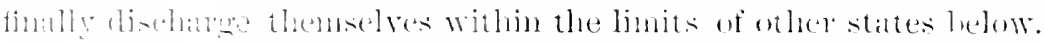

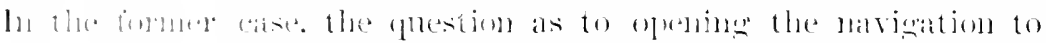

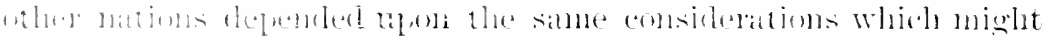

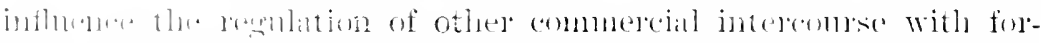

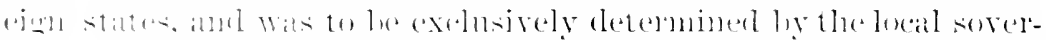

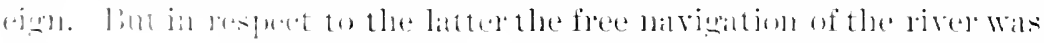

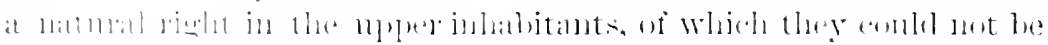

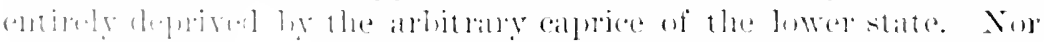

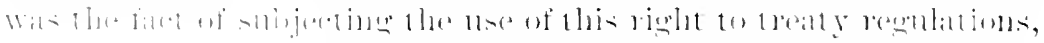

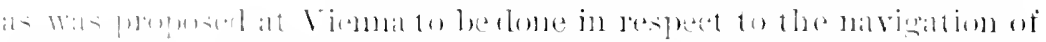

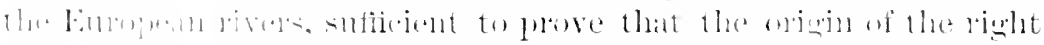

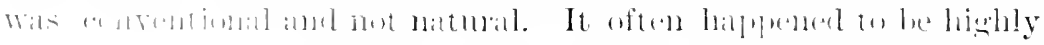

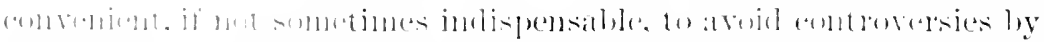

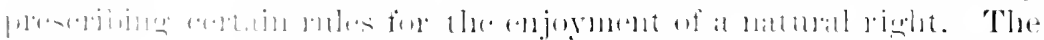

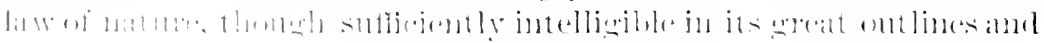

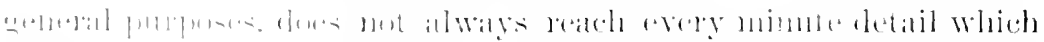

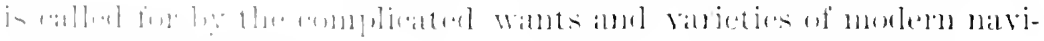

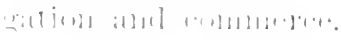

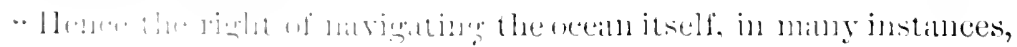




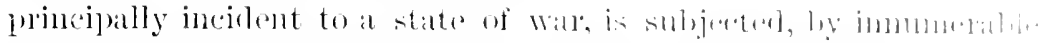

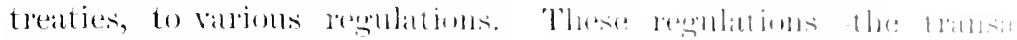

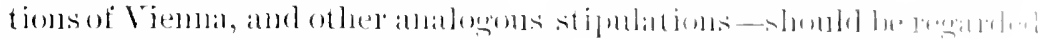

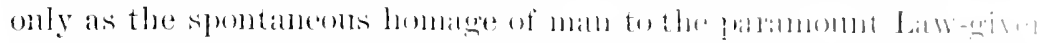

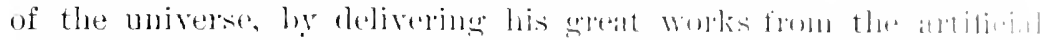

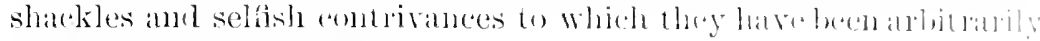
and unjustly subjeredel."

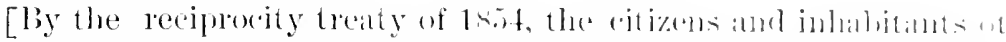

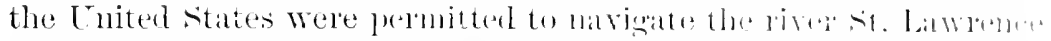

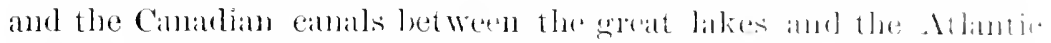
Oedan; and british subjects were slanterl the right to navigate lake. Michigan. This treaty was alsogated in 18lib.

The treaty of Waslington of May s, 1st1, porilles as follows:

\section{ARTICLE XYTI.}

"The navigation of the river st. Lawrence, axcending and de-

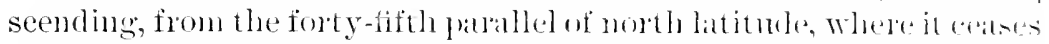
to form the bommlary between the two comtries, from, to, and indo the sea, shall forerer remain free and apen for the pulpessos at commerce to the citizens of the Tuited states, sulject to any law and regulations of Great Britain, of of the Dominion of Camalat, non ineonsistent with such privilege of freo navigation.

"The navigation of the rivers Vukon, Poncupine, anci stikine, ascending and desceutling, from, to, and into the sea, sluall formest. remain free and open for the purposes of commerce to the smbjexts af IHer Britamie Majesty and to the eitizens of the Trujted tiates, subject to any laws and regulations of ejther conntry whin its own territory, not inconsistent with such privilege of navigation."

\section{ARTICLE XXVII.}

"The Govermment of IIer Britamic Majesty engages 10 mpe unom the Govemment of the Dominion of cambla to secuue to the citizdes of the United States the use of the Wellam, st. Lawrence, amb other. canals in the Dominion on terms of equality with the inhahitame of

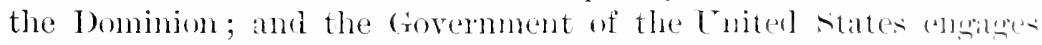

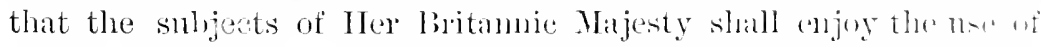
the st. Clair Flats caual on terass of expality with the inhahitants

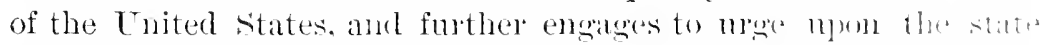

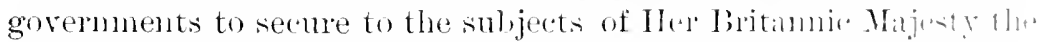

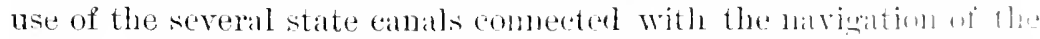
lakes or rivers traversed hy, or contignoms to the lumming lin..

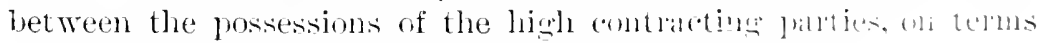
of equality with the inhabitints of the Lnited siatrs." 


\section{MRTIClE XXVII.}

"The mavidation of Lalie Michigan shall also, for the term of

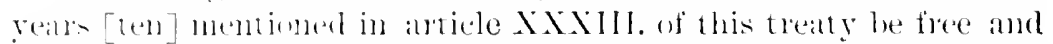
(1)

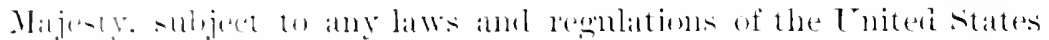
11. uf the stales burlening theren not intensistent with such privi-

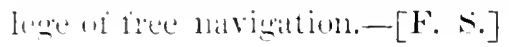

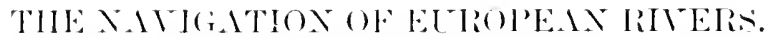

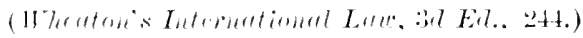

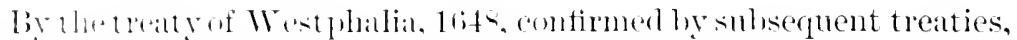
- Alu navigation of the river seledelt was closed to the belgie

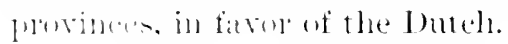

The forcible opening of this navigation hy the French on the

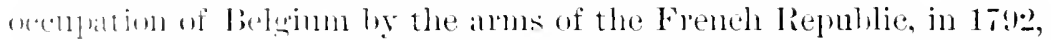
in vindtion of these treaties, was one of the principal ostensible

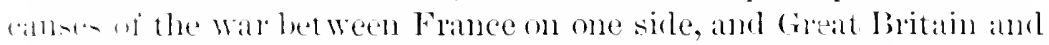
Hoiland on the other. By the traties of Viemat, the belgie porinces

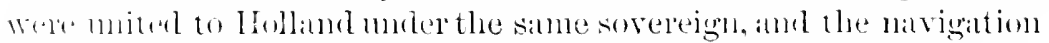
wi the shelelt was placed on the same footing of frecolom with that uf the lihine and other great European rivers. And by the treaty

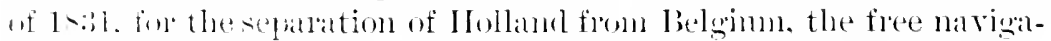

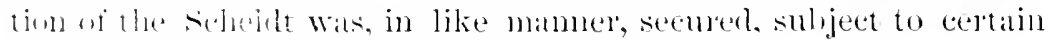
dutits.

- liy the treaty of Fiemma, $1 \times 15$, the commerebal navigation of

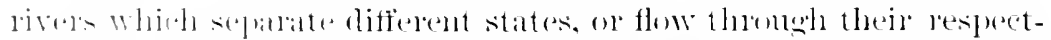

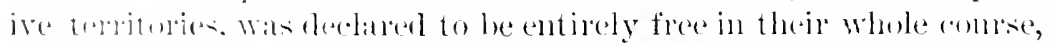

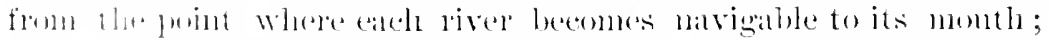

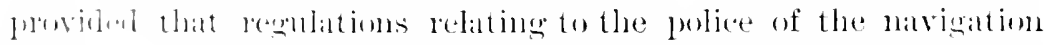

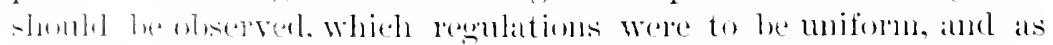

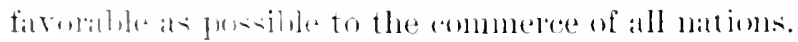

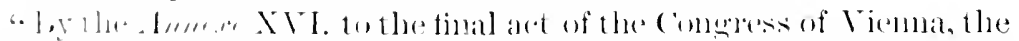

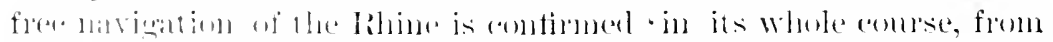

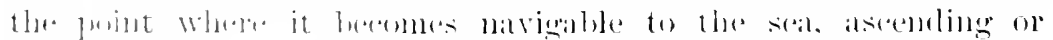

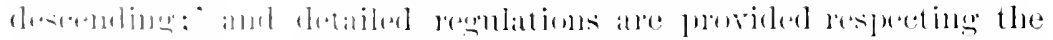

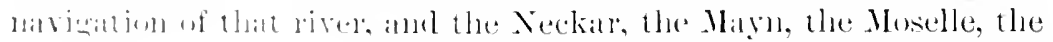

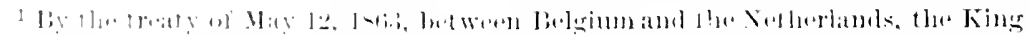

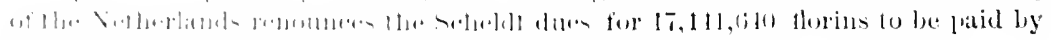

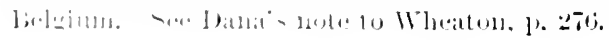


Meuse, and the Scheldt, which alle declaned in like manner to ha fints

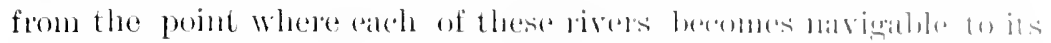

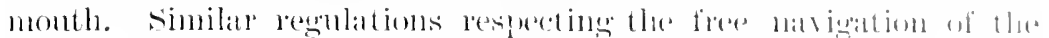

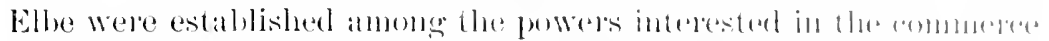

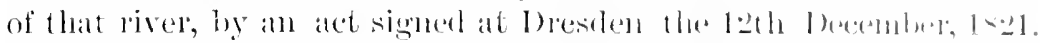

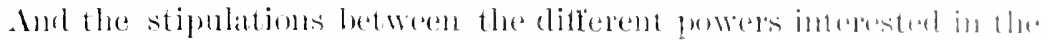

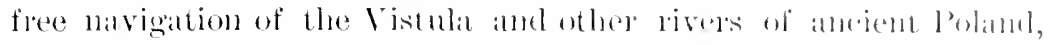

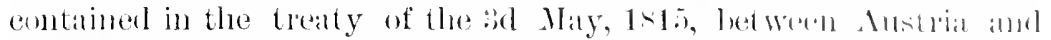

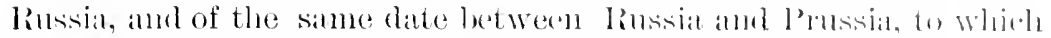
last Austria subsequently aceeled, are comfimml by the timal and of the Comgress of Viema. The same treaty also axtomels the (nemeral principles atoptet hy the congress relating to the mavigution of

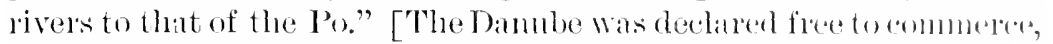
under certain restrietions, hy the treaty of Paris, in 1s.ji. see

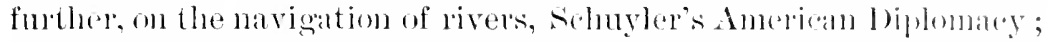

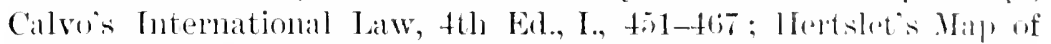
Emope hy Treaty ; Englehand, in the lierue de Droit, International, vol. XI., pp. $363-381$. F. s. $]^{1}$

\section{(b) Struits.}

\section{TIIE SOUNI DUES.}

\section{(Wherton's Interational Lar, :3 Erl., 2:?1.)}

"The supremacy asserted by the king of Demmalk ovel the Sommd and the two Belts which form the ontlet of the baltic sia into the ocean, is rested by the Danish pulshic jurists mom immemonial fure seription, sanetioned by a long sncession of treaties with other powers. Aceording to these writers, the Dinish chim of soledeingty has been exereised from the carliest times beneficially for the flortection of commerce against pirates and otluer enemies hy moms of guard-ships, and against the perils of the sea by the establishment of lights and land-marks. The banes continued for sevelal rentumbs master's of the coasts on both sicles of the somm, the flurime of sicanianot having been cerled to swerden mutil the treat y of lineskibl. in 1658, confirmed by that of 16100, in which it was stipmlated that smellut

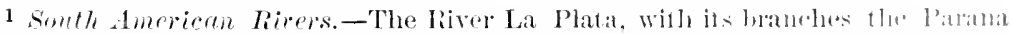

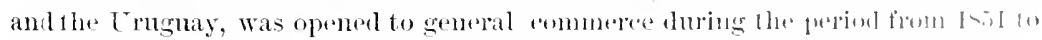

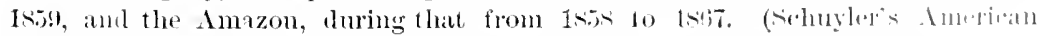
Diplomacy, :319--344.)

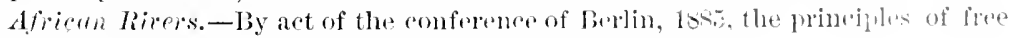
navigation were extended to the Congo and the Xigers. 


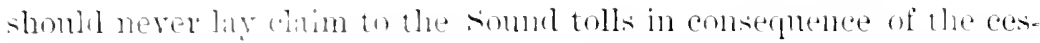

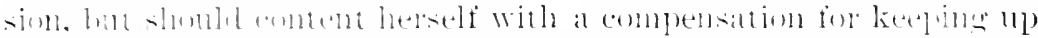

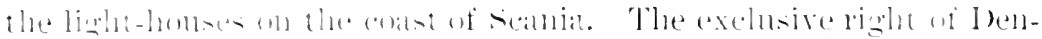

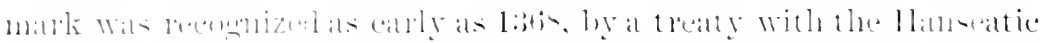

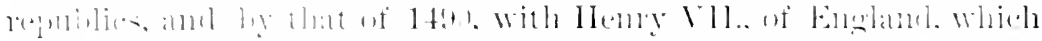

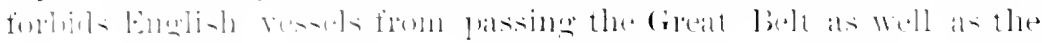

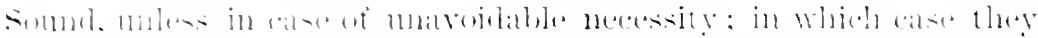

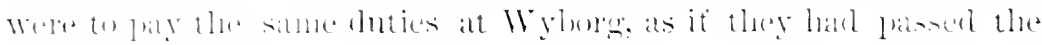

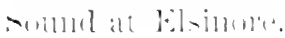

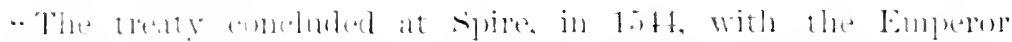

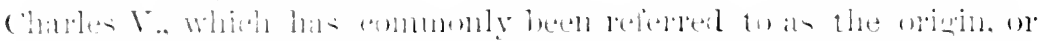

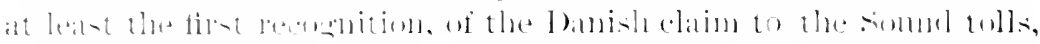

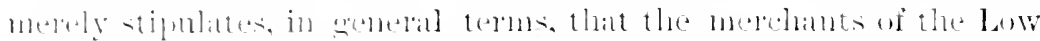

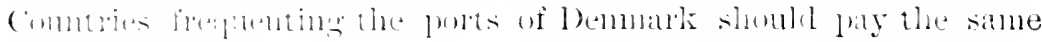

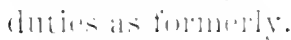

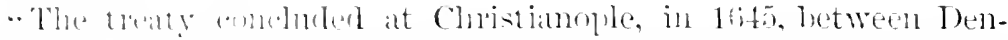

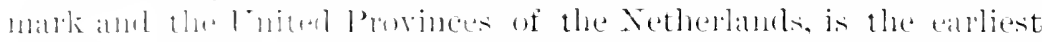

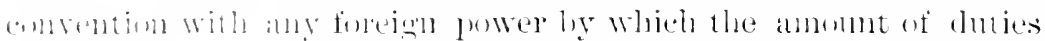

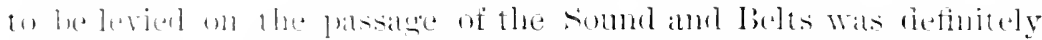

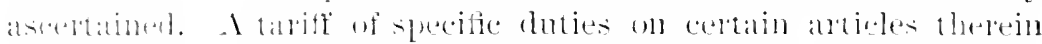

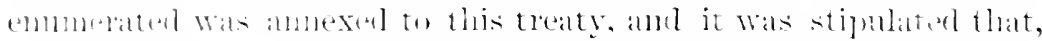
-

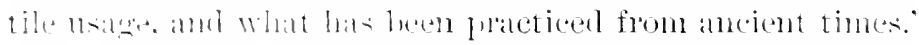

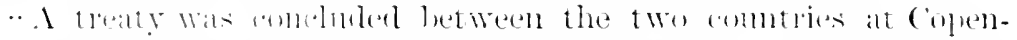

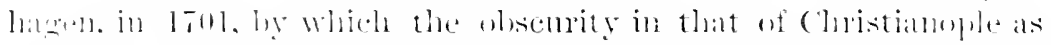

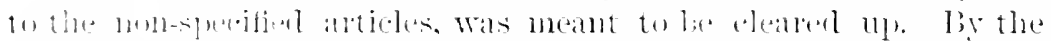

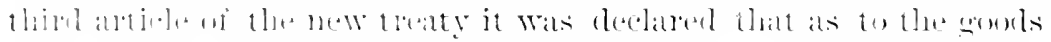

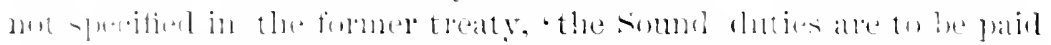

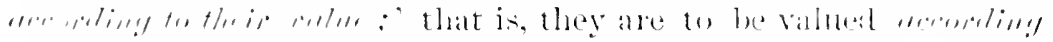

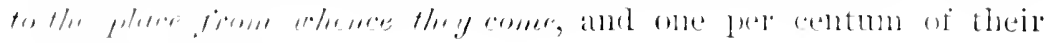
vallete to lin pritil.

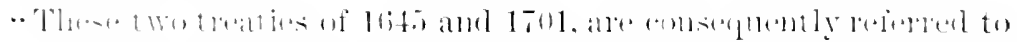

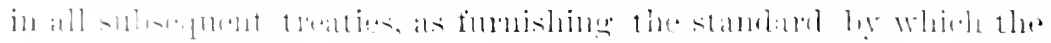

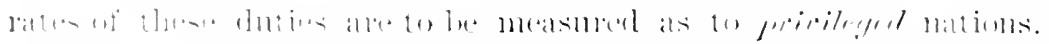

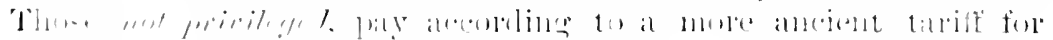

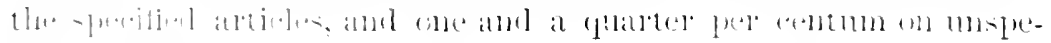

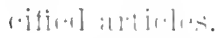

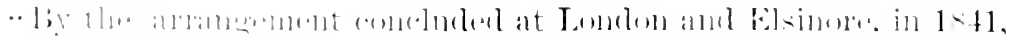

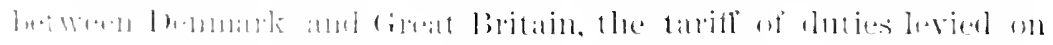

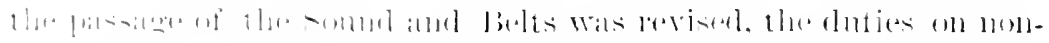

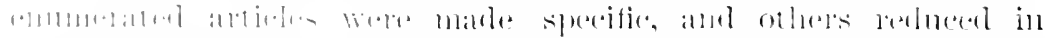

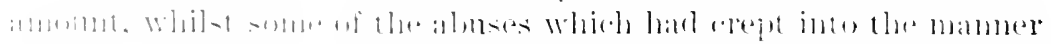

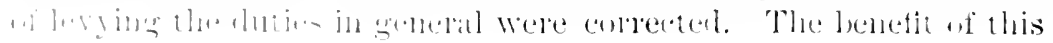




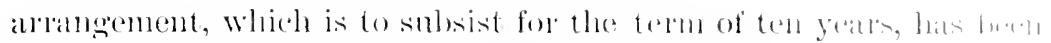
extended do all other nations privileged by treatly."

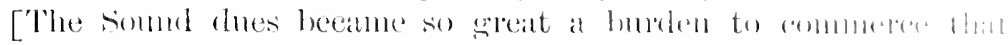

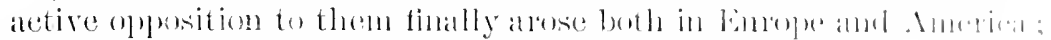

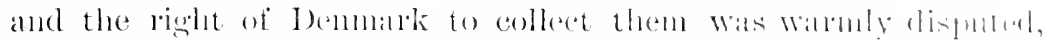

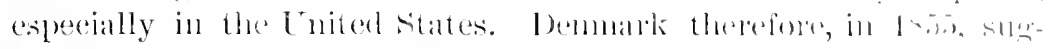

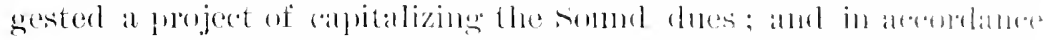

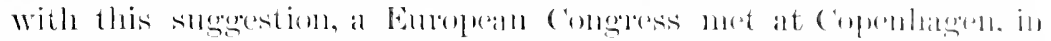

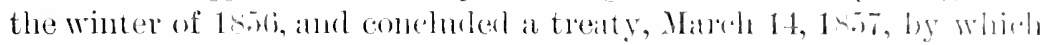
these dues were forever atolished, in onsidelation of a present

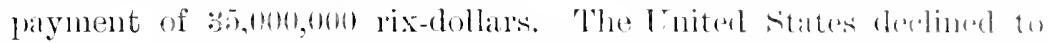
become a party to the treaty, hecanse, as P'resident l'idere sabl, "Demmark does not ofter to sulnmit to the convention lhe gurstion of her right to levy the somul dnes." And further that the purposition eontemplated a political result - " the balatmee of pewar among the governments of Europe." The Lnited states, howerer,

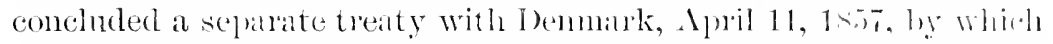
717,809 rix-dollats were paid to bemmalk, in ensidelation of hre agreement to keep up lights, buoys, and pilot astablishments. thus avoiding the recognition of the right of lemmalk to collect the durs.

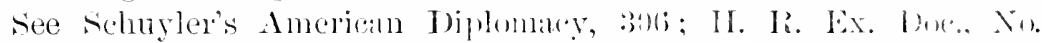

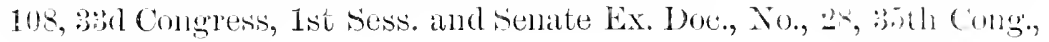
1st Sess.-F. S.]

\section{THE BOSPIORES AND TIE DARDANELLES.}

(IIherton's International Lan, :3l Erl., 2:30.)

"So long as the shores of the Black sea were explusively lwssessed by Turkey, that sea might with propriety he consirlemel a mere rensom: and there seems no reason to question the rishn at the Ottoman Porte to exclude other mations firme narigatine the passage which comneets it with the Mecliteromean, both shores of this passage being at the same time pontions of the "lobkish terlitory; but since the territorial actuisitions male hy linsial, and alle commercial establishments formed by here on the shomes at that Enxine, both that empire and the other matrime powers hatre luscome entitled to participate in the commeres of the blatek rab, am consequently to the free navigation of the Inodandles and lla.

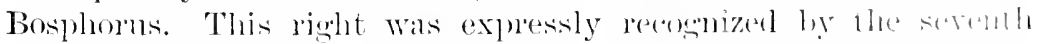

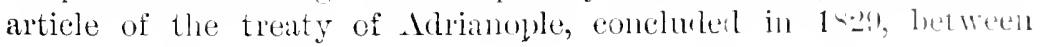


linsia and the Porte, hoth as to linsian vesiels and those of other

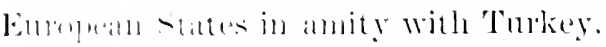

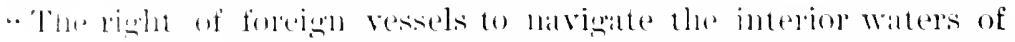

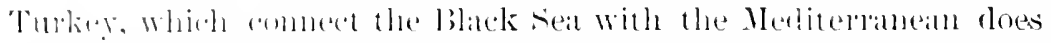

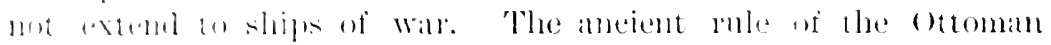

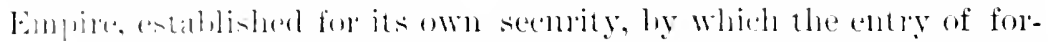

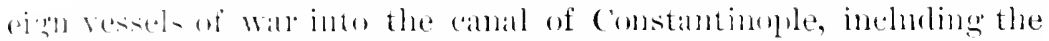

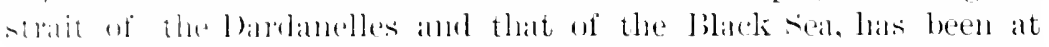

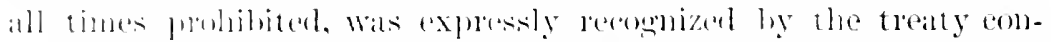

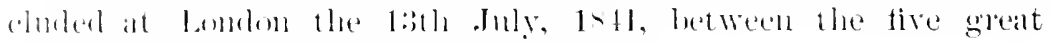

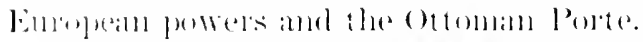

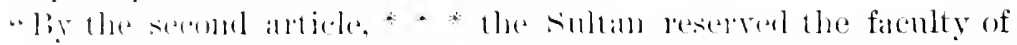

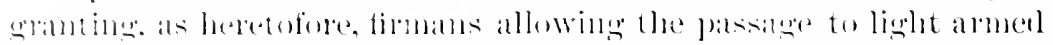

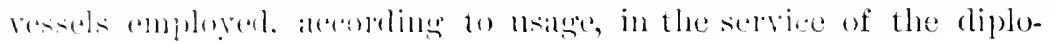

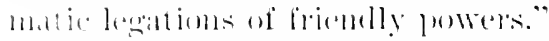

[* lig the treaty of l'anis in 1siti, as molified hy the treaty Lon-

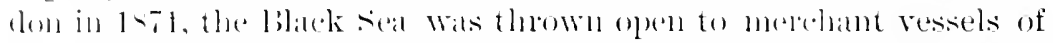

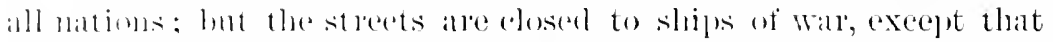
lhe sultan has the firrulty of opening them in time of preace to the

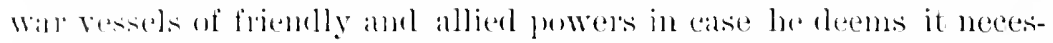
sily for carrying ont the stipulations of the traty of lanis. The

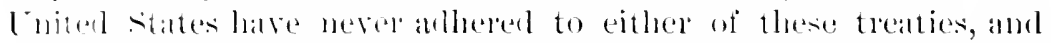
latre always mandatued that their right to semb ships of wall into

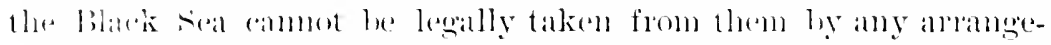

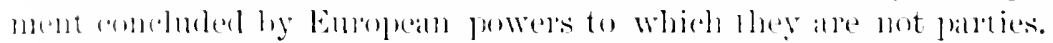

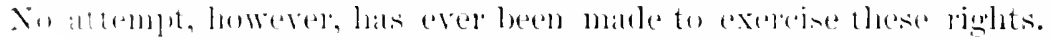

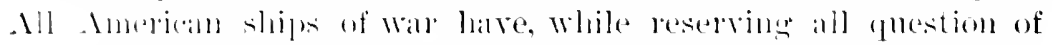

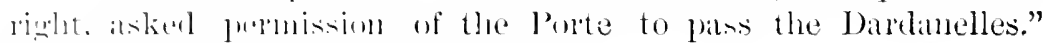
colmyleg's American Ibiplomacy, :317.]

\section{(c) $\operatorname{lin}+1, \mathrm{~s}$.}

\section{RIEGIXI VEXNINGIIAI.}

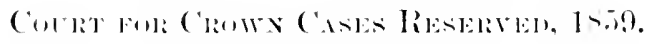

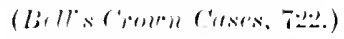

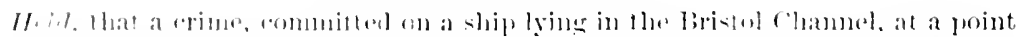

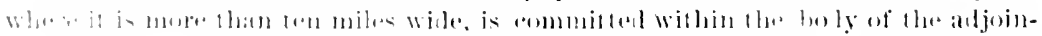

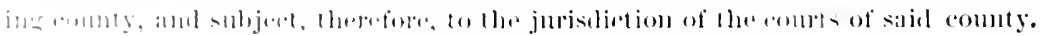

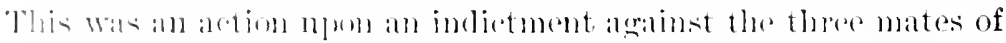

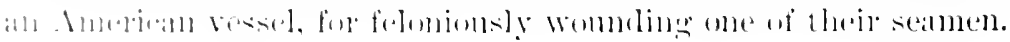




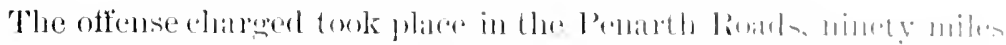

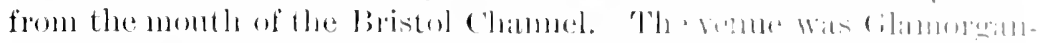

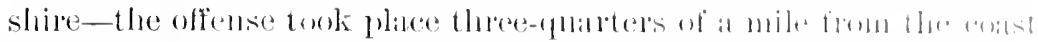

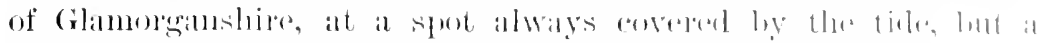

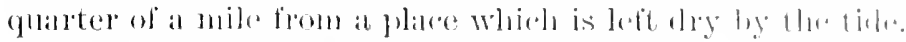

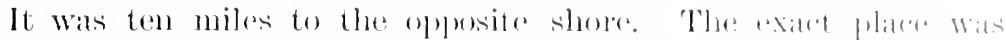

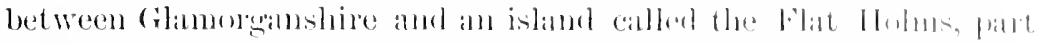
of the comnty of cilamorganshire, and two miles insirle that i-lande

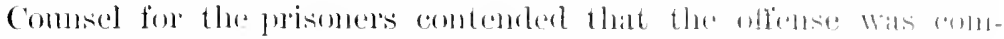
mitted on the high seas-the crome that it was in the rommy an Glamorgin.

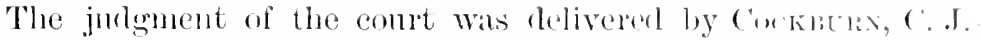
"In this case we an" of opinion that the enturetion is right. The only question with which it becomes necessilly for us lo deal is whether the part of the sea on which the vesisel was at the time when the offense was committed, forms part of the comnty of dilamolgan ; and we are of ophinion that it does. The sea in fluestion is part of the Bristol chamnel, both shores of which form part of England ane Wales, of the comnty of somerset on the one sille and the comity of Gianorgan on the other. We ane of opiniom that, lowkins at the loeal situation of this sea, it most be taken to belong to the counties respectively by the shones of which it is lommoled ; and the faet of the IIolms, between which and the shome of the eomuty of Glamorgan the place in question is simater, hatring alwals lean treated as part of the parish of Carriff and as part of the combly of Glamergan, is a strong illustration of the principle on which we proceed, namely, that the whole of this inland sea between the commties of somerset and (ibamorgan is to be considered as within the comties, by the shores of which its several parts are respeetively bounder. We are, therefore, of opinion that the place in question is within the body of the county of Glaninorgan."

TIIE DIRECT UNITED) STATEA CABLE COMPANT v. TIIE ANGLO-AMERICAN TELEGRAPII COMHANY.

\author{
Plist Counen, 1867. \\ (Law Reports, : A't. C'ases, :394.)
}

Held, that Conception Bay, in Newfoumlland, which is somethine orep filteen miles wide, and forty to fifty miles long, is a British bay, and a late of the territorial waters of Newfoundland.

This suit was one in which the Respondent Company had uhtaned 


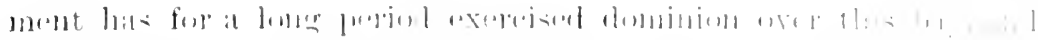

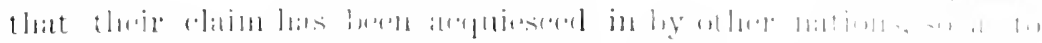

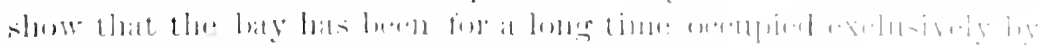

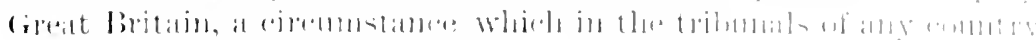

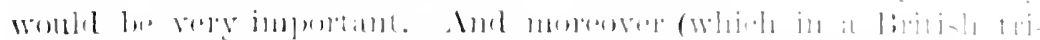

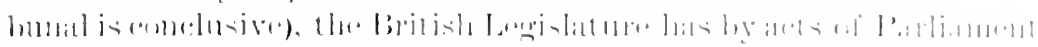

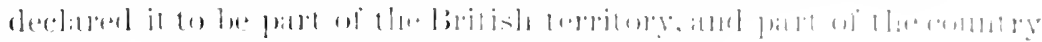

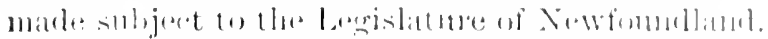

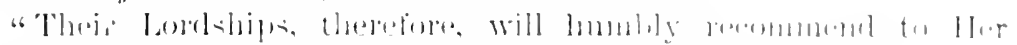

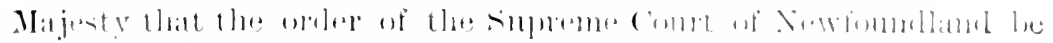

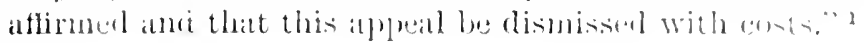

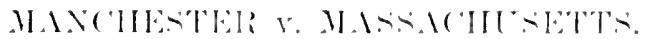

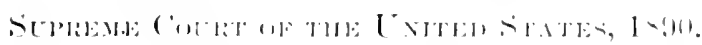

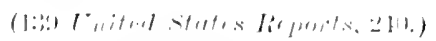

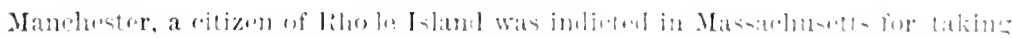

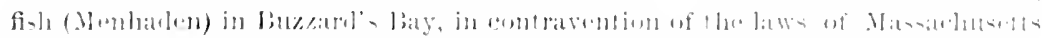

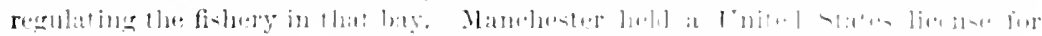

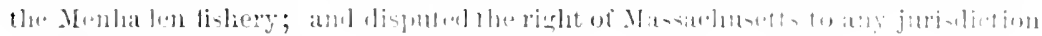
over ande tishoriss.

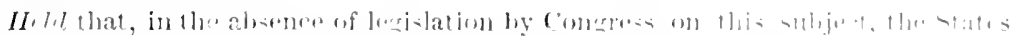

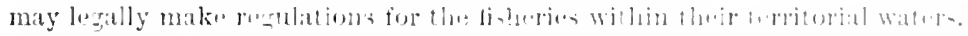

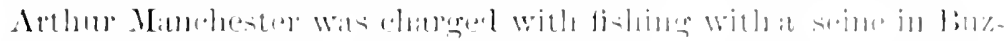

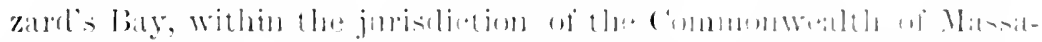

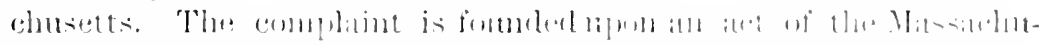

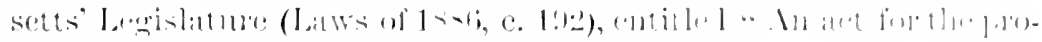

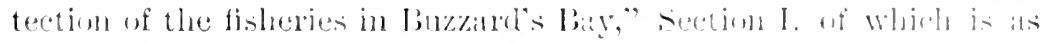
follows:-

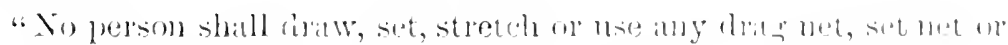

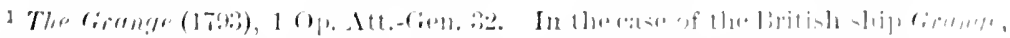

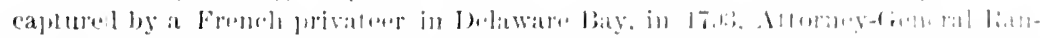

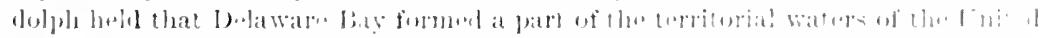

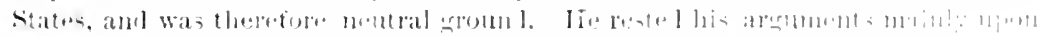

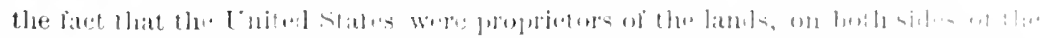

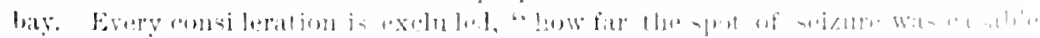

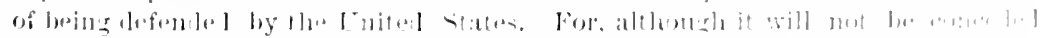

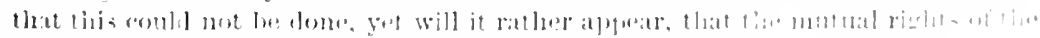

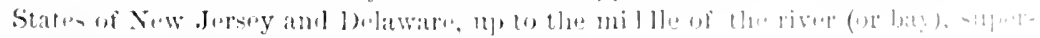
serle 11 we neresity of sum an invetiation."

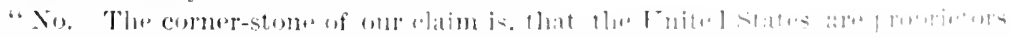

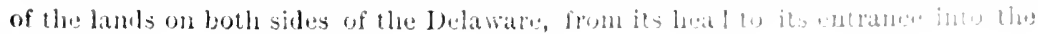
sua." 
gill net, purse or sweep seine of any kind for taking fish anywhere in the waters of benzad bar withe the juristiction of this commonwalth, nor in any hallor, core or bight of sald baly except as hereinatitu providerl."

linzand s bity at its montly, is more than one amd lese than two marime leagnes in width-at the point where the acts complained of tomk plikes. it is mole tham two leagnes in width, and the nearest

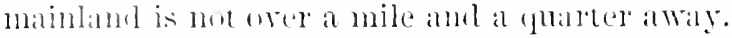

The defendant requested the (ourt of Massaldusets for a number of luling, the first and thind of which are (1) The act complained of was on the high seas, and without the jurisdiction of Massachusetts. (:) The defentant cammot be beld muless the act complained of wats dme :mel commited within the body of a comty, as molerstond at eommon lims.

These instructions weere refused, and the court told the jury that if they fonnd that the platee where the acts were dome was within a marine leange of the shore, it was within the jurisdiction of the Commonwealth.

The decision being against the defendant, he appealed to the supreme Compt of the trited states.

Mr. Instice Buxcnforo, after stating the case, delivered the opinion of the court :

". The principal contentions in this court on the part of the defendant are that, although Massachusetts, if an independent nation, could hatre enated a statute like the one in question, which her own conts would have enforeed, and which other nutions would have reconizul, yet when she became one of the Inited States, she sme remdered to the general government her right of control orer the fisheries of the vecan, and tramsferred to it her rights over the waters adjacent to the coast and a part of the oeean; that, as by the Constitution, article:;, section :, the julicial power of the L'nited states is marle to extend to all cases of admiralty and maritime jurisdiction, it is ansistent only with that view that the rights in respect of fisheries should be regarded as national rights, and he enforced only in national compts: that the proprietary right of Massachusetts is confined to the body of the comnty: that the offense committed by the defendant was committed ontside of that territory, in a locality where legislatire control did not rest mpon title in the soil and waters, but apon rights of sorereignty insepandily comnected with national charater, and which were intrusted exchurely to enforcement in armiralty courts, that the Commonwealth has no jurisdiction upon the ocean within three miles of the shore; that it conld not, by the statute in question, oust the Cnited states of jurisdiction; that fish- 
ing upon the high seas is in its natme an integrall patrt of mathonal

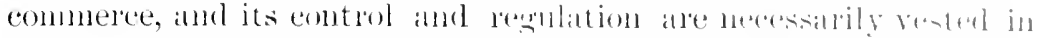
Congress and not in the individual states ; that comgless lats mant-

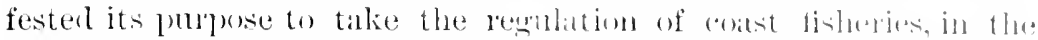

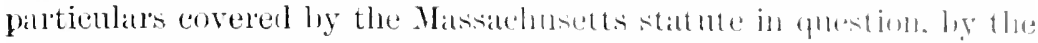

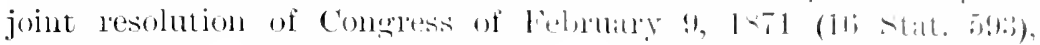

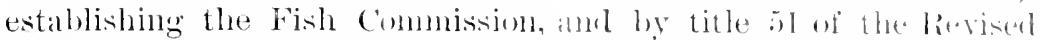
Statutes, entitled 'liegulation of frisheries' and hy the alet of Fub-

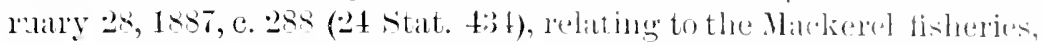
and by atets relating to bountics, privileses, and andeaments, and ly granting the license muler which the defendint's steanel wats fislsing ; and that, in riew of the act of Compress authorizing sulh linduse, 110 statite of a state conld defeat the right of the defendiut to fish in the high seas under it.

"By the Public Statutes of Massachusetts, part 1, title 1, (. 1, see. tions 1 and 2 , it is enaeted as follows: reetion 1. "The territorial linits of this Commonwealth extend one marine leagne from its seashore at low-water mark. When an inlet or arm of the sea does mot exceed two marine leagues in width between its headlands, a straight line fromone beadland to the other is equivalent to the shore line.' Scection 2. "The sovereignty and juristiction of the Commonwealth cxtend to all places within the bomndies thereof, suliject to the rights of concurent jurislietion grinted over platees cerled to the Cnited states.' The same Public statutes part 1, title 1, e. 2.2. seetion 1, contain the following provision: "The boundaries of comnties bordering on the sea shall extend to the line of the commonwealth, as defincd in section one of chapter one.' Section 11 of the same chapter is as follows: "The jurishiction of comnties separated by waters within the jurisdiction of the Commonwealth shatl be concurrent upon and over such Wuters.' By section 20 of chapter 196 of the acts of Massichusetts of $1 \times 2$, it is provided as follows: 'Section 2. The harbor and land commissioners shall locate and define the courses of the boundary lines between adjacent cities and towns bordering upon the sea, and uyon arms of the sea from highwater mank outward to the line of the Commonwealth, as defined in. said section one [section one of chinter one of the Genclall statutes]. so that the same shall conform ats nearly as maty be to the comrse of the boundary lines between said adjacent tities and tomms on the land; and they shall file a report of their doings with suitalle plans and exhibits, showing the boundary lines of any town by then locatted and defined, in the registry of deets in which deeds of reill chtilte situated in such town are required to be recorded, and also in the office of the secretary of the Commonwealth.' 
"The report of the sunerior Court states that the point where the

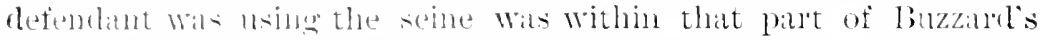

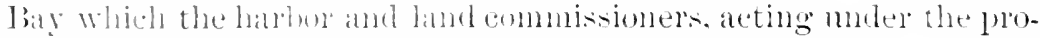
viskms of the alet of $1-1$, hall, so far as they were calable of doing

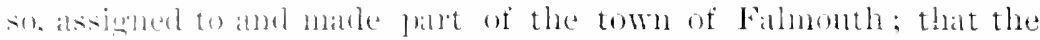
distance between the leadlanels at the mouth of Bnzzarls Bay was mole than the and less than two marine leagnes; that the distancoserosesail bay, at the point where the atets of the defendant were llone, is more than two marine leagnes, and the olposite points atre in different comties; and that the place where the defendint

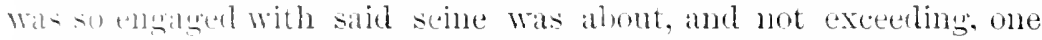
mile and a llarter from a point on the silore midwaly fom the north line of " the tom of Falmonth ' to the somth line' of that town.

" linzzarles bay lies wholly within the territory of Massachusetts, laning bimstable comnty on the one side of it, and the counties of linstul and Plymonth on the other. The defendant offered evidence that le was fishing for menhaden only, with a puse seine; that - the luttom of the sea wis not encroached upon or clisturled; that it Wis impossible to discern oljects across from one headland to the other at the month of Buzzard's Bay;' and that the steamer Was duly emolled and licensed at the port of Newport, Rihoule Ishan, moler dhe latrs of the Enited states, for carrying on the menhaden tisherg.

" lig section 1 of chapter $19 \%$ of the laws of Massachusetts of 1891 , it wats ellated as follows: section 1. "The bommaries of cities and towns borlering unon the sea shall extend to the line of the commonwealth ats the same is defined in seetion one of chatpter one of the (itheral statutes.' Section 1 of chapter 1 of the General statutes (e) tains the provisions leefore recited as now contained in the

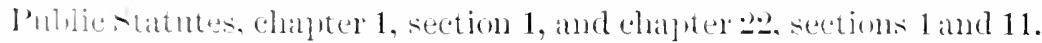

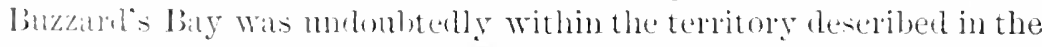
dharter of the Colong of New Plymonth and the l'rovince darter. lig the definitive treaty of peace of september $3,17-3$, between the l'nited Ftates and (rreat Britain (S Stat. -1), IJis Britannie Majesty arekowledged the Inited states of which Massathusetts Bay Was we, to he free, sovereign and independent states, and ledared that he treated with them as such, and, for himself, his heirs and sneetsons, relinguisher all claims to the government, proprietary and ceritorial linhts of the same and every part thereof. Therefore, if

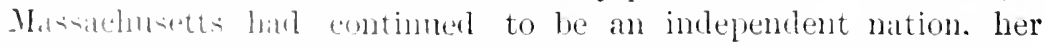
bemmlanies on the sea. as defined by hel statutes, wond muntestionaldy he alshomledent hy all foreign nations, and her right to control the fi-heries within those boundaries would be conceded. The 


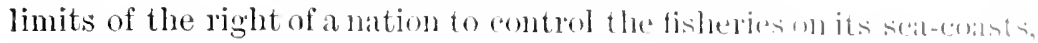
and in the bays and arms of the seat within its teritury, hate merel

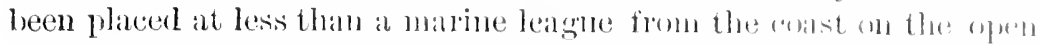
sea ; and bays wholly within the territoly of at mation, the headhands

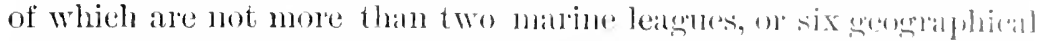
miles, apart, have always been resareded as a pate of the torritury af

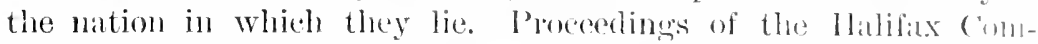
mission of 1875 , nuter the treaty of Washington of May s, 1 his. Executive Document No. 89, 45th Congress, 2d sesion, Mo. Ricps., P). 120, 121, 160 .

"On this branch of the subject the case of The ?"ue" r. K. y", " lix. D. 63, is eited for the plaintiff in error; but there the question wats not as to the extent of the dominion of Great linitain orer the ajn sea adjacent to the coast, but only as to the oxtent of the existing jurisclietion of the Court of Adminalty in England over oflenses eommitted on the open sea; and the decision had nothing todo with the right of control over fisheries in the open sea or in bays or arms of the sea.

"In all the cases cited in the opinions relivered in The ?luen v. Keyn, wherever the question of the right of fishery is referrerl to, it is conceded that the control of fisheries, to the extent of at least it marine leagne from the shore, belongs to the nation on whose coust the fisheries are prosecuted.

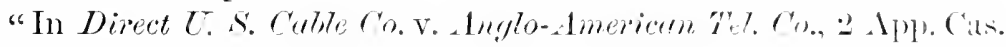
394 , it became necessary for the Privy Council to determine whether a point in Coneeption Bay, Newfomdland, mole than three miles from the shore, was a part of the territory of Newfonmand, amd within the jurisclietion of its legislatme. The average wiolth of the bay was about fifteen miles, and the distance between its heallands was rather more than twenty miles; but it was hell that Concention Bay was a part of the territory of Newfomolland, beamse the British govermment had exercised exchsive dominion over it, with the acquieseence of other nations, and it hat heen dectared by act of Parliament 'to be part of the british territory, amb part of the country made subject to the legislature of $\mathrm{X} \mathrm{e}^{4} \mathrm{~W}$ foundland.'

"VVe think it must be regarded as established that, as between nations, the minimum limit of the territorial juriseliction of a nat im over tide-waters is a marine league from its enast ; that batys wholly within its territory not exceeding two marine leagues in width at the month are within this limit; and that includer in this territorial jurisdiction is the right of control over fisheries, whether the fish be migratory, free-swimming fish, or free-moving fish, or tish attalcherl to 
an embelded in the wil. The open sea within this limit is of course.

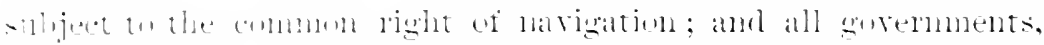

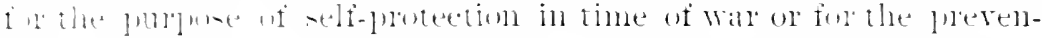

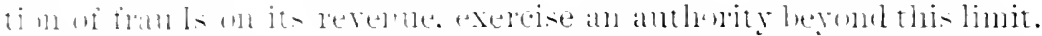

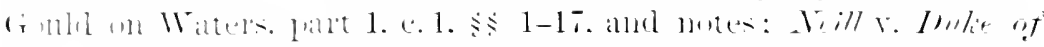

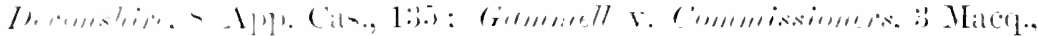

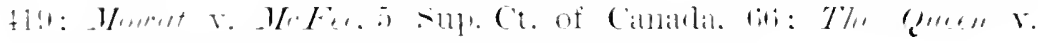

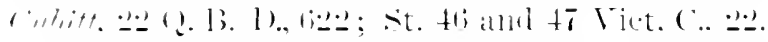

"It is funther insinted hy the plantifi in elore that control of the

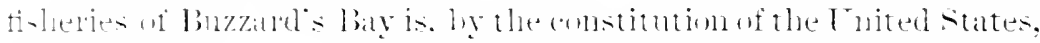

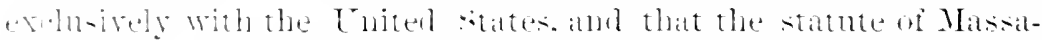

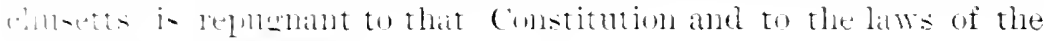
linited stilter. - *

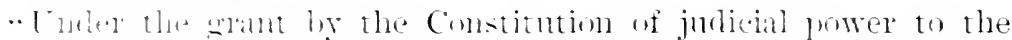

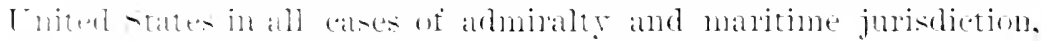

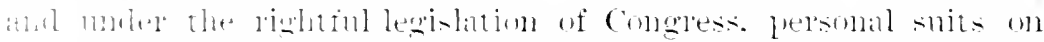

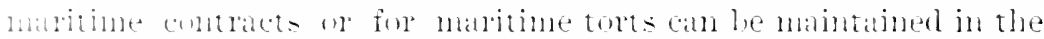

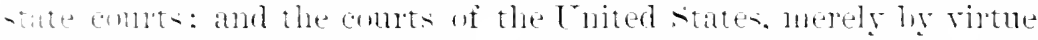

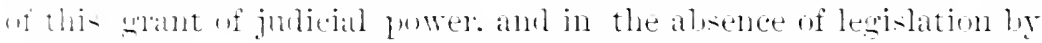
(impless. hate nu criminal jurisdietion whatever. The crininal

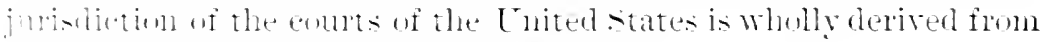
the siatuter withe. Enited staltes. **

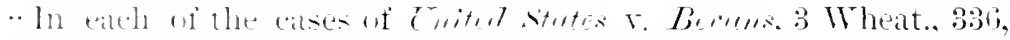

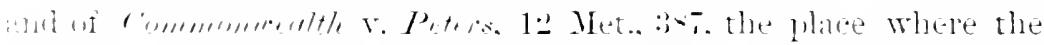

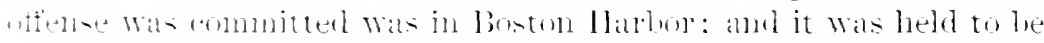

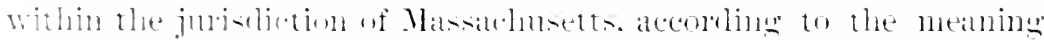

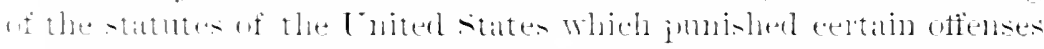

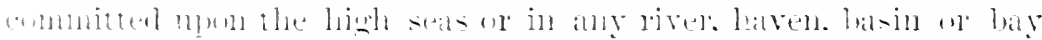

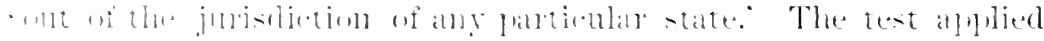

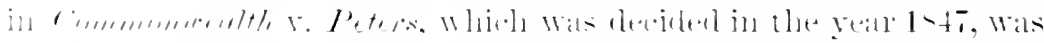

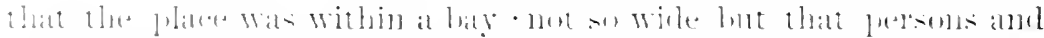

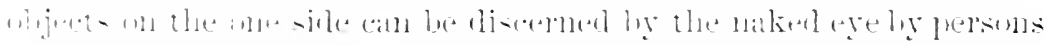

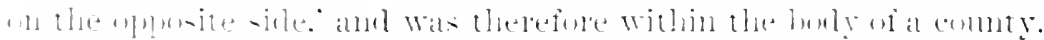

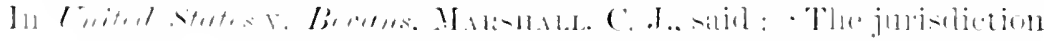

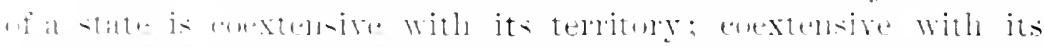
1.

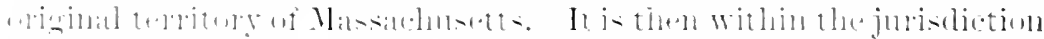

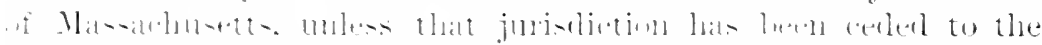

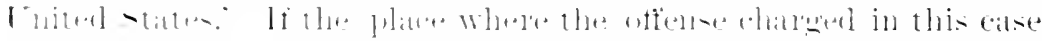

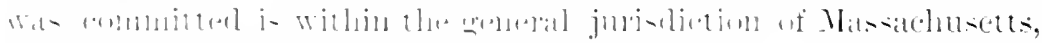

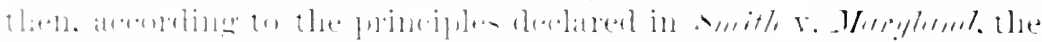

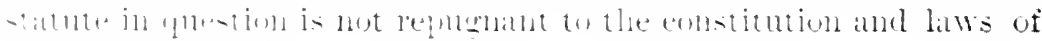
1.1.: [niter] statter. 


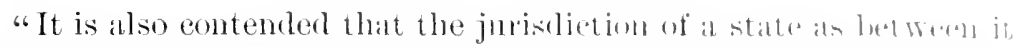

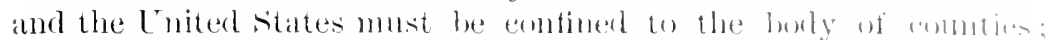
that eomuties most be defined ateending to the enstomatry lingli-h

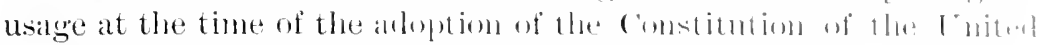

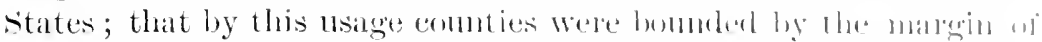

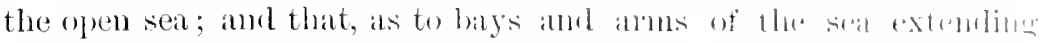

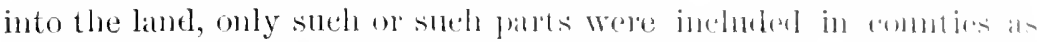

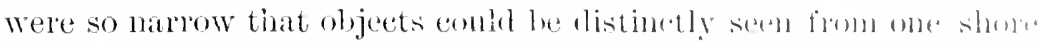
to the other by the maked eye. But thege is mo indiontion that the.

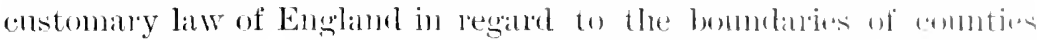
was adopted by the constitution of the luited firtes as a measume to retermine the territorial jurisclietion of the statrs.

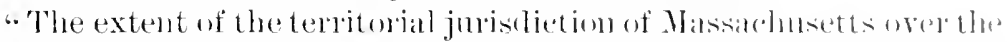
sea afjacent to its coalst is that of an inderendent nation ; and, exarent so far as any right of comtrol over this teritory has been granterl to the Cnited States, this comtrol remains with the state. In F mitol

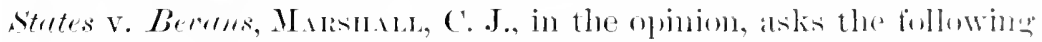
questions: " Can the cession of all cases of admiralty and matime" jurisdiction be emstrued into a cession of the waters on whill those cases may arise? As the powers of the respective foremmonts now stand, if two citizens of Massachusetts step into shallow wated where the tide flows, and fight a duel, ane they not willin the junishirtion, and punishable by the laws of Massatehusetts?' The stat ntes of the Enited states define and pmish but few offenses on the high seas, and, unless other offenses when committed in the sea near thes coast can be punished by the states, there is a large immmity fom punishment for acts which onght to be pmmishalole as rominal. Within what are generally reeognized as the territorial limits of states by the law of nations, a state can define its bommlanies on thes sea and the bommaries of its comties ; amb by this lest the commonwealth of Massachusetts can inelude Buzzand's Bay within the linits of its counties.

"The statutes of Massachusetts, in regarel to bays at lealst, malke definite boundaries which, before the passage of the statutes, wares somewhat intlefinite; and lihode Island and some other states have

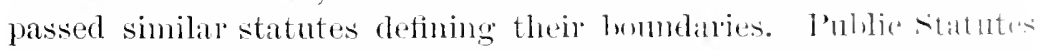

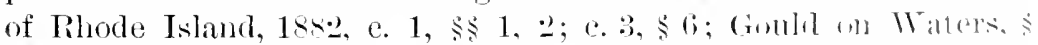
16 and note. The waters of Buzzard's bay are, of comme, navinathe

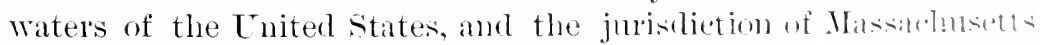

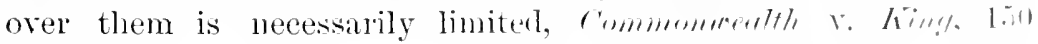
Mass., 2.21; but there is no oceasion to comsider the pumer of the

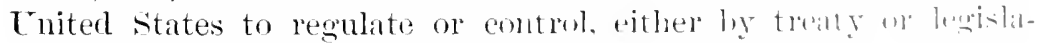
tion, the fisheries in these waters, becalse there alo w existing 
treatien on atch of Congress which relate to the monhaden fisheries in ill ll at bity.

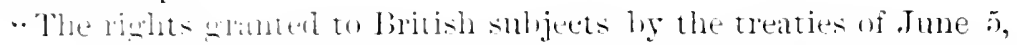

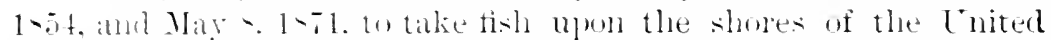

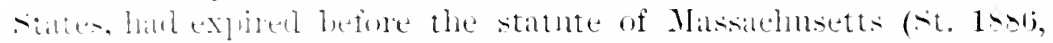

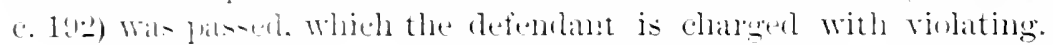
The Fish cimminion was instituted for the potection and preseration of the foum fishes of the const of the Luited states.'

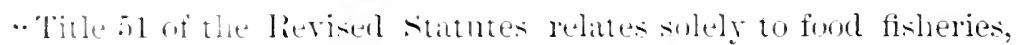

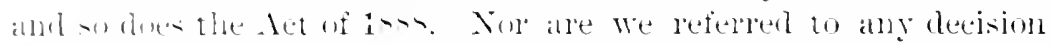

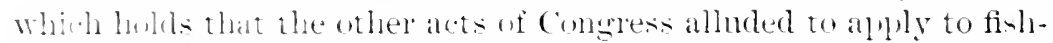

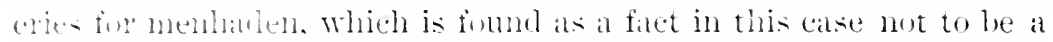
foum ti-h. and to he only valuahle for the purpose of bat and of manditet tue into fish oil.

." The statute of Matsilchusets which the defendant is charged with vishating is, in terms. contined to watters, "within the jurisdiction of this commonwealth: "and it was evidently pitsed for the preservation of the fi-ls, and makes no discrimination in favol of citizens of Masiatehatts and atginst citizens of other states. If there be a libely of fisling tor mimming fish in the navigable waters of the

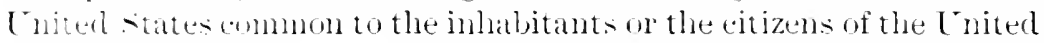
states mun which we expless no opinim, the statute may well be com-jolemer as an inpratial and reasonable resnlation of this liberty; and the sulject is one which a state may well be premitted to regulate within is territory, in the absence of any dembation by the fuited states. The presvation of fish, eren athongh they are not nserla ing for human bejugs. but as fool for other fish which are s) M-enl. is for the enmmon benetit: and we are of opinion that the statnte is not repugnant to the comstitution and the laws of the Linited -tilte..

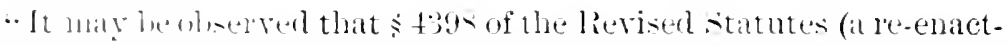

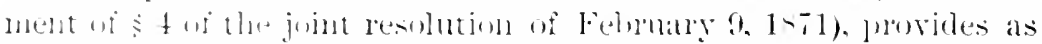

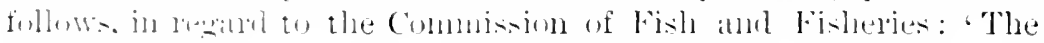

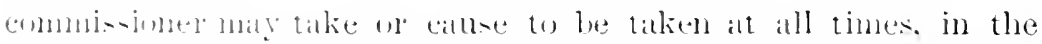

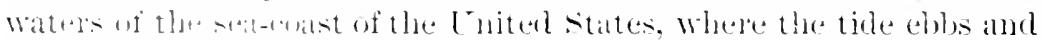

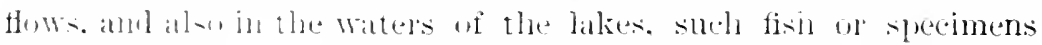
therent an may in his judenent, from time to time, be necelful or

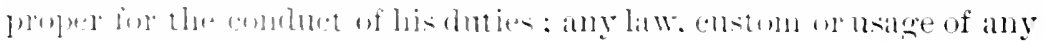

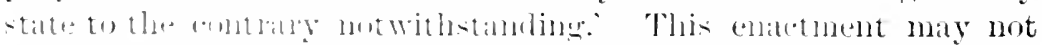
imperperely lo (4)

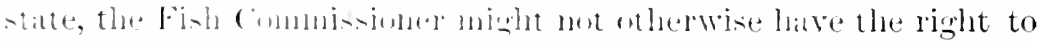

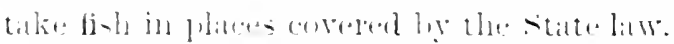

"lihe pertinent observation may be manle that, ats Congress does 
not assert, by legislation, a right to (ontuol pilots in thr hays,

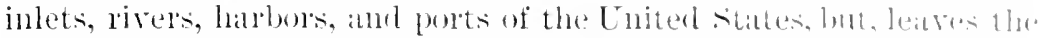

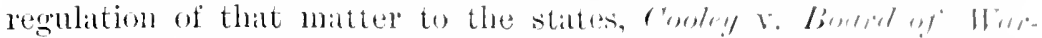

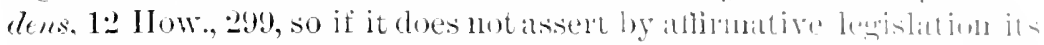

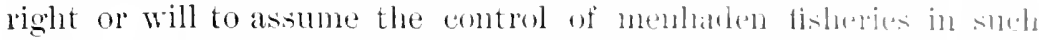
bays, the right to control such fisheries must remain with the riate which contains such hays.

"We do not eonsider the question whether or not Congresis wombl have the right to control the menhaden fisheries whiel the stathte of Missachusetts assumes to control ; but we nean to sily only that as the right of control exists in the state in the absence of the affirmative action of Compress taking such control, the fatet that (4) gress has never assumed the control of such tisheries is pristive eridence that the right to control them still remains in the siate."

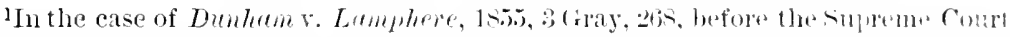

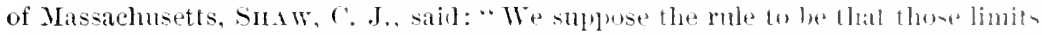
extenu a marine league, of Inpe geographical miles irom the shore : and in ancertaining the line of shore this limit lows not follow ach narow inlet or arm of the sea, but when the inlet is so narrow that persons and objects, an be discernol across it by the naket eye. the line of territorial juristiction streteides across from one headland to the other of such inlet."

\section{(d) Warginal Seas.}

\section{THE QLEEN $r$. KEIN.}

\section{Colrt of Crow Cases lieserved, 1876.}

\section{(L. R., 2 Exchequer Dirision, 63.)}

History of the development of the rule fixing the limit of territorial waters at three miles.

A foreigner, sailingalong the English coast, within this three-mile zone. cemmits an offense against an English subject. IIcll, that he was not subjen to the jurisdietion of the Admiralty, nor its suceessor the Central Criminal comt, in the absence of an act of Parliament expressly conferring snch jurisdiction.

The prisoner was indicted at the Central Criminal comet for the manslanghter of .Jessie Dorcas Toung on the high seas, and within the jurisdiction of the Admiralty of Eugland. The deecardel wats at passenger on board the struthclyte, a british steamer bomml from Iondon to Bombay. This vessel, when one and ninde-tuthe of at mile from Dover pier-head, and within two and a half miles fimm Jover beach, was run down and sunk by the Feomenen, a fielman 
stemer. In the collision, the deceased woman was drowned, and the prisomer, the entutin of the Formeonie, is comvieted of man-

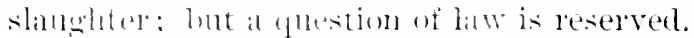

An objection was taken on the gant of the prisoner that, inatimuch

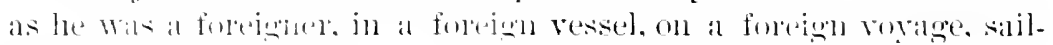
ing 11 mon the high seats, he wat not subject to the jurislietion of any coment in this comberty.

The cromn contends that inammele als, at the time of the collision, loth ressels were within the distance of thee miles from the English shore, the offense was temmitted within the realun of Englamb amb is triable by the Euslish eomt.

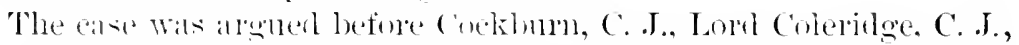
Kelly, (: B., sir li. Bhillinente. limmwell, Johrek, and Amplslett,

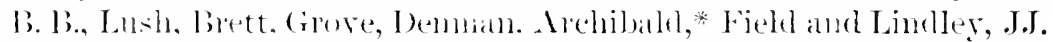

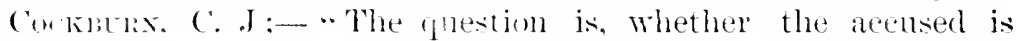
amenable to nur bu, and whether there was jurisdiction to try him?

"The legality of the comvictin is contested, on the ground that the alecused is a foreigner'; that the Frowoming the ship he commanded, was a foreign vessel, sililing from a foreign pont, lonnd on a foreign royage; that the allened offense was committed on the high seas. Ender these cincmotances, it is contended that the acenset, thomgh he may be anemable to the law of his own comntry, is not capable of being tried and pmished hy the law of England.

"The fatets on which this defense is based are not calpable of being disputerl but a twofold answer is given on the part of the posecution:-1st. That, althongh the oecurence on which the challoge is fombled took platere on the high seas in this sense that th:

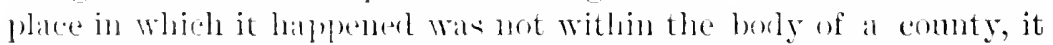
oecurreel within three miles of the English coast; that hy the law of nations, the seal, for a spare of three miles from the const, is part of the toritory of the comotry to which the coast belongs ; that,

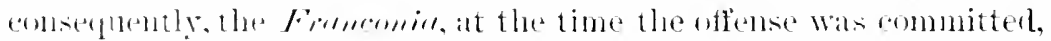
was in English waters, and those on bourl were therefore subject to Euglish lilw.

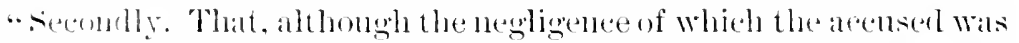

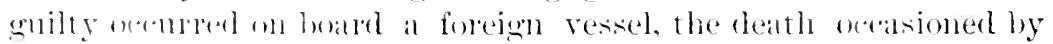

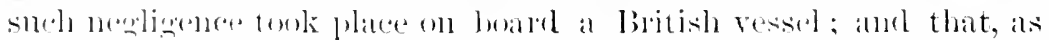
a british ressel is, in point of law to be onsirlerent britisle territory, the oflense. hatring berall eonsmmmated by the death of the deceased in a Iritish ship, mmet be eonsidered as baving been committed on British territury.

-According to the general law, a foreigner who is not residArchibal.t. J.. died after the agum ant and before the judgment was deliverel. 
ing permanently or tempurarily in british territury, al an buat a

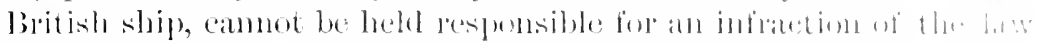
of this comitry.

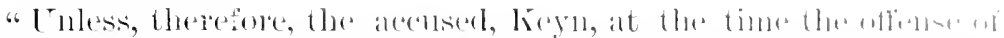

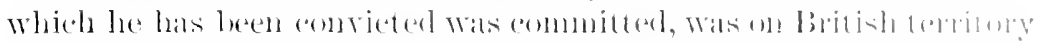

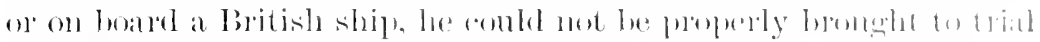

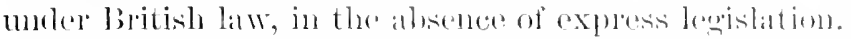

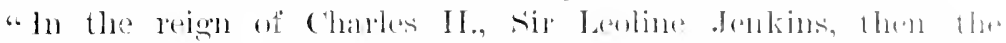

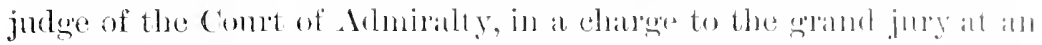

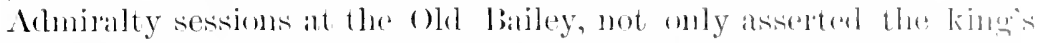
sorereignty within the fom seas, and that it was his right and

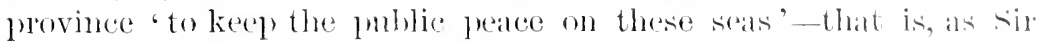
Looline expmunds it, "to preserve his subjects and allies in theil. possessioms and properties 11 mon these seas, and in all freedom and

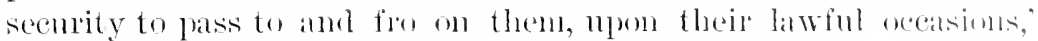
hut extended this anthority and juristiction of the King. "To pureserve the public peace and to maintain the fieedom and saturity of navigation all the world over ; so that not the ntmest lommol of the Atlantic Ocean, nor any comer of the Merliterrandan, man any part of the sonth or other seas, lint that if the peace of cion and the King be violated njon any of his suljeets, on upen his allies or their subjects, and the oftender be afterwarks hemsht 110 or laid hold of in any of lis Majesty's ports, such breach of the peatere is to be inquired of and tried in virtue of a emmonision of nger and terminer as this is, in such comnty, liberty, or place as Ilis Majusty shall please to direct-so long an alm hath God by the laws grivin to his vicegerent the King.', * * *

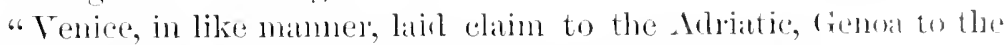
Ligurian Sea, Demmark to a portion of the Nonth sea.

"The Portuguese dainer to bar the ocean lonte to Inslia amb the Indian seas to the rest of the world, while spain made the like assertion with reference to the West.

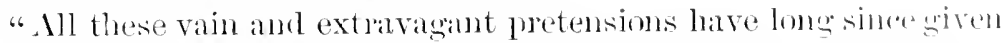
way to the influence of deasom and common sense.

"If, imleet, the sovereignty thms asserted had a real existence,

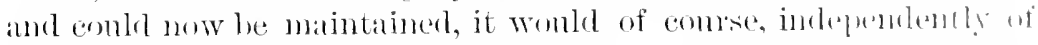

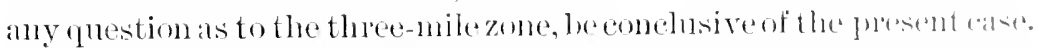
bint the elaim to such sovereignty, at all times mufommled, has lomen since been abandoned. No ome would now dream of asseretinge that

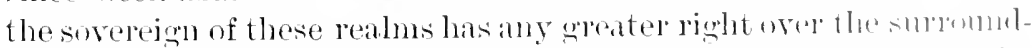
ing seas than the sovereigns on the opposite shores: of that it is the

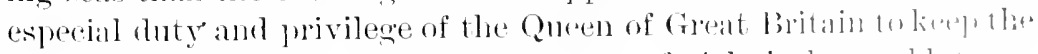
peace in these seas; or that the Comet of dolnibally comble try at 
foreinner for an ofînse committed in a foreign ressel in all parts of the Chammel.

. Xin miter of our das. except Mr. Chitty in his treatise on the forlugative. Has anserted the ancient doctrine. Blackstone, in his Chalpter on the prerogative in the Commentaries. while he asserts that the manow sats ale part of the realn, puts it only on the ground that the jurialiction of the Admialty extends ore? these seas.

- lle is silent as to any jurisliction orer foreluners within then. The concensus of jurists, which his been so much insister on as ambority is perfectly mamimus as to the nom-existence of any such jun-diction. Indeed, it is because this cham of soreleignty is adnitted to be mutenable that it has been found necessing to resort to the theory of the three-mile zone.

.. It is in rain, therefore. that the ancient assertion of sovereignty orel the narrow seas is involied to grive combenance to the rule now somble to be established, of jurisdiction orer the three-mile zone.

"If this rule is to prevail, it must be on altogether" difierent grounds. To invelite ats its fomudation or in its suppert. all assertion of sorereignty which, for all pratetical purposes, is, and al waly has been. idle am momemed. and the invalidity of which renders it necessary to lare recourse to the new aretrine, involves an inconsistenty, on which it womld be superfluoms to dwell. I must confess myself mable to commehend how, when the ancient dnctine as to sovereignty over the narrow seas is alduced, its operation can be contined to the three-nule zone. If the argmont is good for anything, it must aplly to the whole of the surombling seas. Int the comsel fol the Comn evidently shrank from applying it to this extent. surb a pretomion wombl not be admitted or endmred by foreign nations. That it is ont of this extragant assertion of sovereisuty that the doctrine of the three-mile juristiction. asserted on the latet of the Crown, and which, the older cham being necessialy abimbluterl, we are now called upon to comsider, has sprung up, I leallily arlusit.

. With the relebated work of Crotius, mhlished in 1609, began

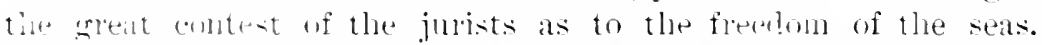

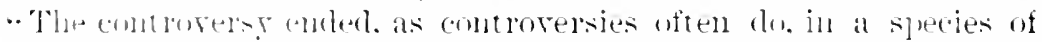

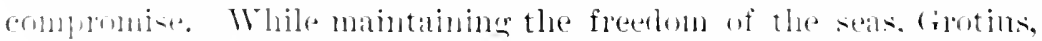

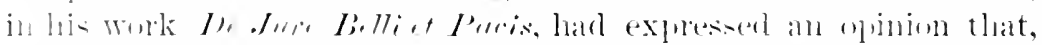

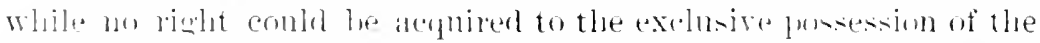

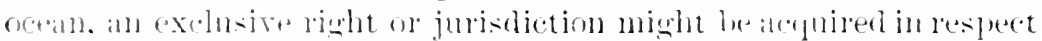
of partienlar portions of the sea adjoining the terriong of individual states.* * 
"Other writers adopted a sinibur prineiple, hut with rery varying

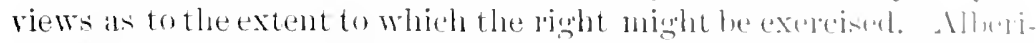

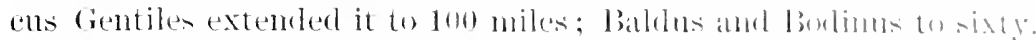

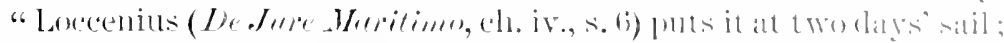

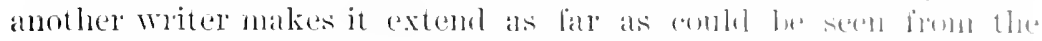

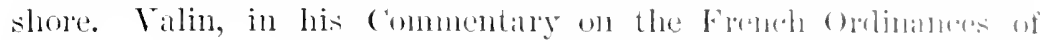

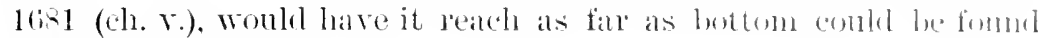
with the leat line. $* * *$

"Differing altogether from these writers ats to the "xtent of maritine sovereignty, Bynkershoek, an adroxate, like (irntiss, for

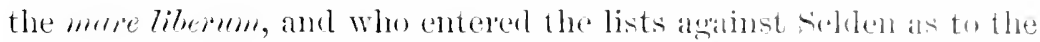
dominion of England in the so-caller Eumlish seat, in his tratise the

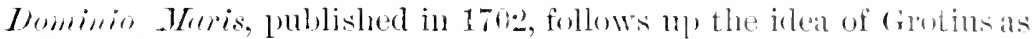
to a limited dominion of the sea from the shore.

"After combeting the doetrine of a more rlomsum as regards the sea at large, and enmmerating these ineonsistent opinions, whin he seems little disposed to respect, liynkershoek contintes: "Iline videas priscos juris magistros, qui dominium in mane forsimm ansi sunt agnoscere, in regundis ejus findons admolum vaguri incertos.' 'Quare ommino videtur rectius, he adds, after clisposing of the foregoing opinions, "Eo potestatem terre extmoli, funusque tormenta exploduntur; eatenus quippe, cum imprrare, tum possidere videmur. Loquor antem de his temporibus; quibus illis maehinis utimur; alioquin generaliter decentum esset, potestaiem terre finiri, ubi finitur armorum vis; etenim haec, ut diximus gossessionem thetur.'

"We have here, for the first time, so far as I am aware, a suresestion as to a territorial dominion orer the sea, extending as fin as cammon-shot womld reach-a rlistance whoh snceeding writers tixed at a marine league, or three miles. Prior to this, no one luad sugersted such a limit.

"The jurisdiction, assumed in the Admiralty commisions, or exercised by the Court of King's Bench in the time of the Erlwards. was fomuled on the King's alleged sovereignty over the whold of the narrow seas; it had no reference whatever to any notion of a tan intorial sea. To English lawyers the idea of this linited jurishliotion was utterly mknown.

"With Selden and Hale, they stood wy stontly for the Wing"s undivided dominion over the four seas. No English antlor matics any distinction, as regards the dominion of the cromm, lextren the narrow seas as a whole and any portion of them als anl joment to the shore. The doctrine was equilly unknown to the seoted lawyers. *** 
- Even to on times the doetrine of the three-mile zone has

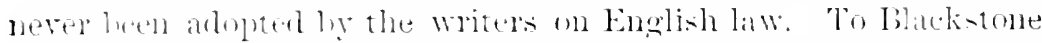
who, in his confuntentaries, treats of the sea with reference the the

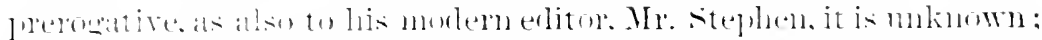

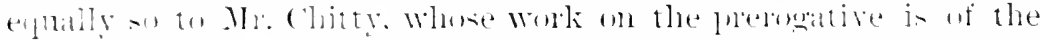

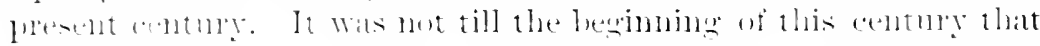

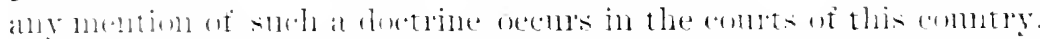

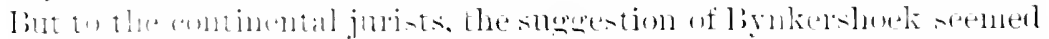

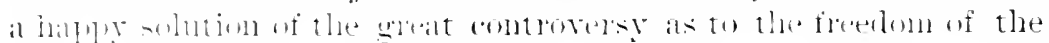

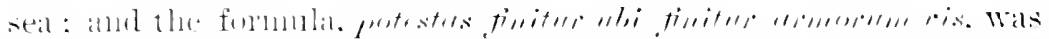

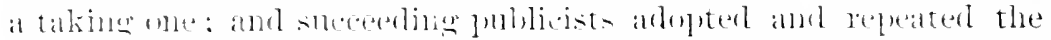

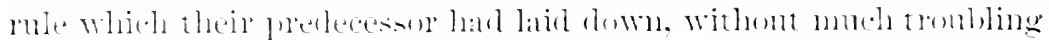

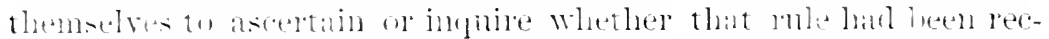

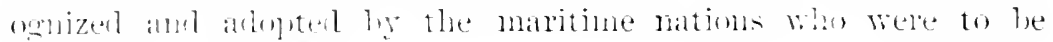
attereted ly il.

* But to what, after all, do these ancient anthrities anomnt? ()f what arailatethey towarls establishing that the soll in the theemile zome is but wi dhe territorial rlomain of the Croms: These

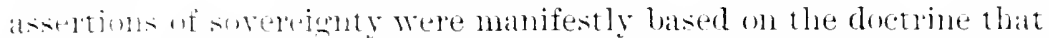

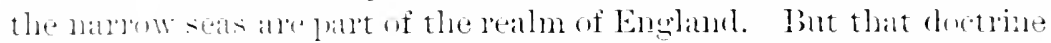
is num exploder. Whan at this day womld venture to affirm that the

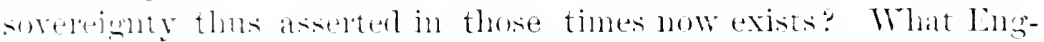
lish lawyed jo thene who womld uot shrink from maintaining-what

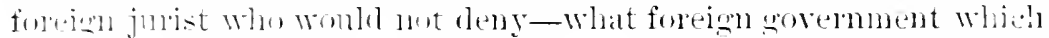
would wot repel sluch a pretension: I listened carefully ta see

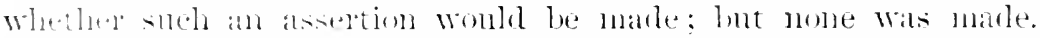

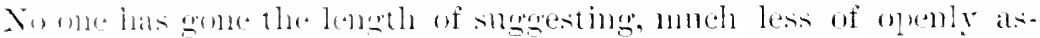
selting that the jurisitetion still exists. It seens to me, that when

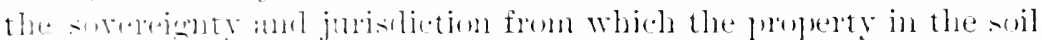

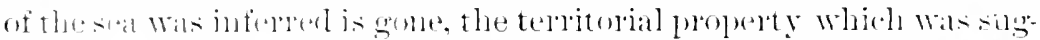

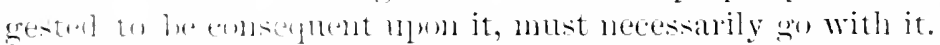

. It thus anderatiun, as it seems to me that the littoral seal

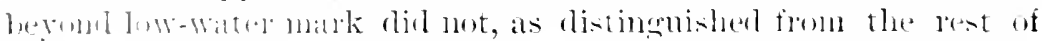

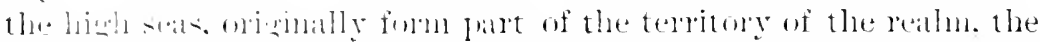

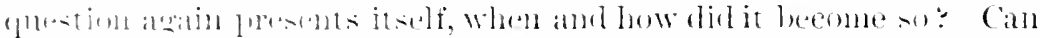

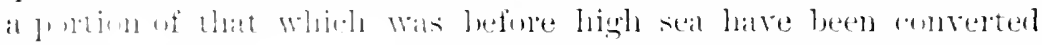

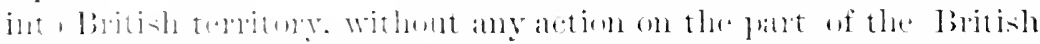

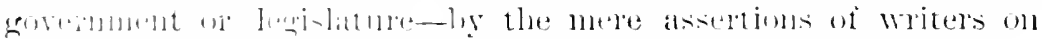

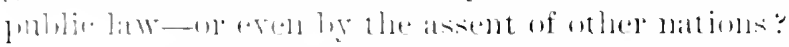

" And whan in shlpent of this pusition, or of the theory of the

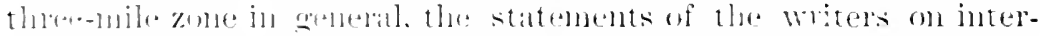

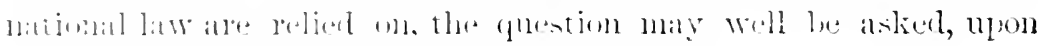
What anthority are these statements foumrled: 
"When and in what manner have the mations, who ars to ln ai-

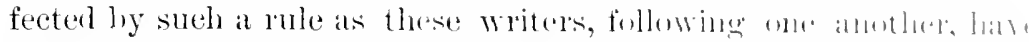

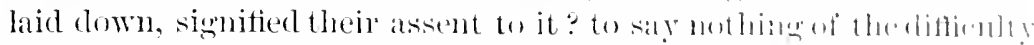
which might be fonnd in salying to which of these couflieting mingions such atssent had been griven.

"For, even if entire manimity harl existel in lespect of the ind-

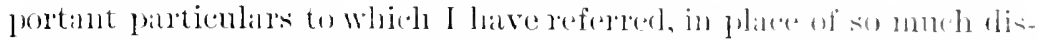
crepancy of opinion, the question womld still remalin, lun fall the law as stated ly the publicists had received the assont of the oivilized nations of the world.

"For writers on international law, howerer" vahulhe their laturs may be in elucirlating and ascertaining the principles and rules of law, eannot make the law. To be binding, the law must have lecedvert the assent of the nations who are to be bound by it. This asicul may he express, as by treaty or the acknowledged comomrence of governments, or may be implied from established usige,-an instance of which is to be found in the fact that merchant vessels on the high seas are lield to be subject only to the law of the nation muler whose flag they sail, while in the ports of a foreign state they are sulject to the loeal law as well as to that of their own commly. In the absence of proof of assent, as deriver from one or other of these sourees, no unanimity on the part of theoretical writers womld warrant the juclicial application of the law on the sole anthority of their views or statements. Nor, in my opinion, would the clearest proof of unanimous assent on the part of other nations be sufficient to authorize the tribunals of this conntry to apply, without an let of Parliament, what would practically amount to a new law. In so doing we should be unjustifiably usurping the province of the legislature. The assent of nations is doubtless suficient to grive the power of parliamentary legisiation in a matter ofluewise within the sphere of international law, but it would be powerless to confer without such legislation a jurisdiction beyond and muknown to the law, such as that now insisted on, a jurisdietion over foreigners in foreign ships on a portion of the high seas.

"When I am told that all other nations have assented to such an absolute dominion on the part of the littoral state, wer thin portion of the sea, as that their ships may be exchderl fiom it. and that, without any open legislation, or notice to them or their subjeets, the latter may be held liable to the local law, I ask firs what proof there is of such assent as here asserted; and, seconclly, to what extent has such assent been earried : a question w: infinite in-

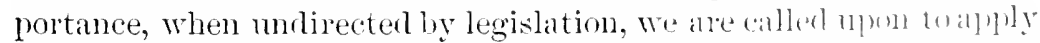
the law on the strength of such assent. It is said that we ale to 
tatie the statement of the publicists as conclusive proof of the assent in fuestim, and mucl has been said to inpless on us the reslect which is due to their anthority, and that they are to be looked npon as witnesies of the fatets to which they speak, witnetoes whose statements of the fommlation on which those statements lest. We are searecly at liherty to question. I demur altogether to this losition. I entertina a profomm respect for the opinim of jurists when dealing with the maters of fuldicill principle and opinion, hut we ane here dealing with a question not of opinion lunt of fact, and I must asidet my entire liberty to examine the evidence and ser upon what fomblation these statements are batsed.

. The prestion is mot one of theoretical opinion, but of fact, and, fortmately, lhe witers upon whose statements we are called upon to ace have ationded ns the means of testing those statements by reference to facts. They refer us to two things, and to these alonetreaties and nsage.

- Let us lonk a little more closely into both.

.- rirst. then, let us see how the matter stinds, as regards treaties. It may he asserted, withont fear of contradiction, that the rule that the sea smrombling the coast is to he treated as a part of the arljacent teritory. so that the state shall have exelusive dominion over it, and that the law of the latter shall he generally applicable to those pasing over it in the ships of other nations, has never heen mate the suliject matter of any treaty, or, as matter of acknowledged right, has formed the basis of any treaty, or has ever been the subject of diplomatic disension. It has heen entirely the creation of the writers on international law. It is true that the writers who have heen cited, comstantly refer to treaties in support of the doctrine they assert. Bat when the treaties they refer to are looked at. they will he fomel to relate to two subjects only-theobservance of the lights and obligations of neutrality, and the exelusive right of ti-lings. In fixing the linits to which these rights shomld exteml, nations have so far followed the writers on international law as to alopt the three miles range as a convenient distance. Thele are sorolal treaties by whieh nations have engared. in the event of either of them leing at war with a third, to treat the sea within theee miles of each other's coatsts as neutral territory. within which no warlike operations shombl be calried on; instances of which will be fomm in the varions treatises on international law. Thus for instance, in the treaties of commerce, letween Great Britain and France, of reptember, 17-6; between France and Russia of Jamuary, 17-T; between Great Britain and the Enited states, of October, 179t, eateh contracting party engages, if at was with any 
other nation, not to earry on hostilities within cammen slun of the coast of the other contracting jaty ; or, if the other shomll he at war, not to allow its vessels to he captured within the likw distitner. There are many other treaties of the like temor, al lint of whith is

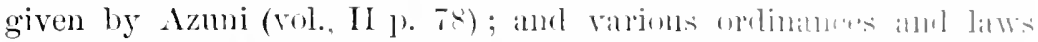

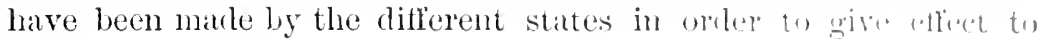
them.

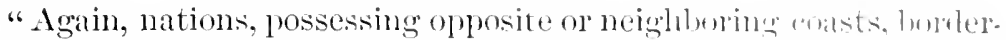
ing on a common sea, have sometimes fommel it expelient to agree that the subjects of each shall exereise an exclusire light of lishing to a given distance from their own shores, and here also latve aecepted the three miles as a convenient distance. smoh, for instance, are the treaties made between this eomitry and thr fonited States, in relation to the fishery off the coast of Newfommlame, am those between this comntry and France, in relation to the fishery an their respective shores; and local laws have been passel to grive effect to these engagements.

"But in all these treaties this distance is adopted, not as matter" of existing right established by the general law of natioms. hat as matter of mutual concession and convention. Instead of uplululing the doctrine contended for, the fact of these treaties having been entered into has rather the opposite tendency ; for it is ubrims that, if the territorial right of a nation horlering on the sea to this nortion of the adjacent waters had been established by the common assent of nations, these treaty arrangements would have been wholly superfluous.

"Each nation would have been bound, independently of treaty engagement, to respect the neutrality of the other in these waters as much as in its inland waters. The foreigner invading the rights of the loeal fisherman would have been amenalle, eonsistently with international law, to local legislation prohibiting such inflingement. without any stipulation to that effect by treaty. For what object, then, have treaties been resorted to? Manifestly in onder to obviate all questions as to concurrent or eonflicting rights arising uncler the law of nations.

"Possibly, after these preeedents and all that has been written on this subject, it may not be too much to say that, independently of treaty, the three-mile belt of sea might at this day be talien ato belonging for these purposes, to the local state.

"But it is scarcely logical to infer, from such treaties alone. that, because nations have agreed to treat the littoral sea as belonging to the country it adjoins, for eertain specified objects, they hat therefore assented to forego all other rights previously enjoyed in common. 
and have sulmitted themselves, even to the extent of the right of mavigation on a pontion of the ligh seas, and the liability of their smijets iheren to the criminal law, to the will of the local sorereign, and the juriseliction of the local state. Equally illowieal is it, as it seems to me. from the adoption of the three-mile distance in these

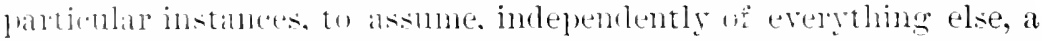

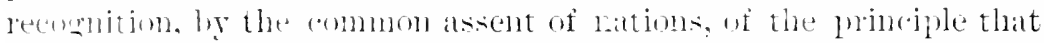
the suljects of one state pasing in slijps within three miles of the con-t uf anchlaer, shall be in all respects subject to the law of the latters. It may be that the maritine nations of the world are prefared to acouiesce in the appopriation of the littoral sea : hut I cannot think that these treaties help us much towads arriving at the conchuson that this appropriation has actually taken place. At all crents. tle question remains, whether julicially we can infer that the nations who have heen parties to these treaties and, still further, those who have not. have thereby assented to the application of the arminal lat of other nations to their subjects on the waters in yne-tim. and on the strength of such inference so apply the criminal kaw of this combtry.

." l'be mocertainty in which we are left, so far as judicial inowledge jic concerned. as to the extent of such assent, likewise presents, I think a very serious obstacle to our assuming the jurisdiction we are ciller npon to exercise, independently of the. to my mind, still more srims difficulty, that we should he assmuing it without legis. lutive warlaust.

"som mull for treaties. Then how stinds the matter as to usage, to which reference is so frequently mate by the publicists in support of their dectine:

"When the natter is looked into, the only usage found to exist is stroh as is comnected with navigation, or with revenue, local fitheries, of neutrility, and it is to these alone that the usage relied on is confiuerl. Tsage as to the application of the general law of the local state to foreigners on the littoral sea, there is actually none. Xin mation has arlogated to itself the right of excluding foreign vests f fom the use of its external littoral waters for the purpose of narigation, ol has assmmed the power of making foreigners in foreign sliph basing througl these waters subject to its lilw, otherwise than in revect of the matters to which l have just refered. Nor have the tribunals of any mation hele foreigners in these waters amenable wemelally to the local criminal law in respect of offenses. It is for the fint tine in the annals of jurispludence that a court of juntice is mom callor mum to apply the criminal law of the country to such a care as the present. 


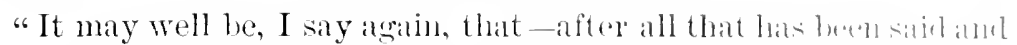

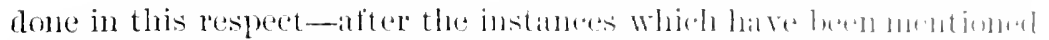

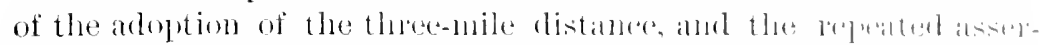
tion of this doetrine hy the writers on publie law a lation whinh shombl now deal with this frotion of the seal as its owns se ats to

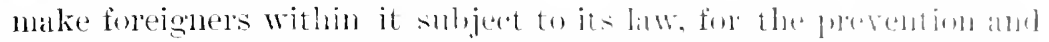

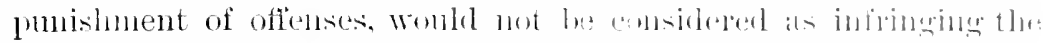
rights of other nations. Bat I alphelemel that als lhe ability so to deal with these waters wombl losmlt, not from any ariginal of

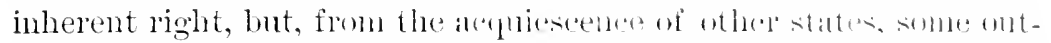

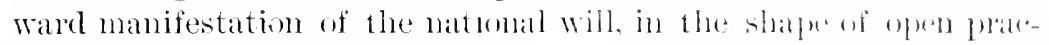

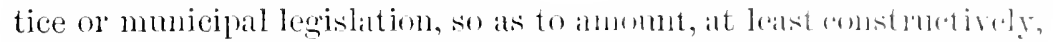

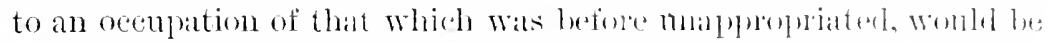
necessilly to render the foreigner, not previomsly amenthle to ond general law, subject to its control.

"That such legishation, whether consistent with the seneral latw of nations or not, would he bincling on the tribunalis of this anmery -learing the question of its comsistency with international lalw to be determined between the govermments of the resuentive nations-m can of course admit of no dombt. The question is whether surh legislation would not, at all events, he necessuly to justify om courts in applying the law of this comntry to forejomeses moler entirely novel circumstanees in whieh it has nevel hedu alphied before. $* * *$ *

"It is mnecessary to the defense, and equally so to the decision of the ease, to determine whether Palliament has the right to treat the three-mile zone as part of the realm consistontly with international law.

"That is a matter on which it is for Parliament itself to decile. It is enongh for us that it has, so far as to be binding mon $11 \mathrm{~s}$, the power to do so. The question is whether, acting jurlicially, we an treat the power of Parliament to legislate as making up for the absence of actual legislation.

"I am clearly of opinion that we cannot, and that it is only in the instance in which foreigners on the sea have been mate specitically liable to our law by statntory enactment that that law can he aldulied to them.***

"Mitherto, legislation, so fill as relates to foreimes's in forcign ships in this part of the sea, has been confined to the milnteninde of nentral rights and obligations, the flerention of beilehes of the revenue and fishery laws, and, moler paticular cirmmstances, to cases of collision.

"In the two first the legislation is altugether irrespective of the 5 
three-mile ristance. heins fommed on a totally different principle, mancly, the riglut of a state to take all necessary measures for the protection of its teritory and rights, and the prevention of any breath of its revenue laws.

*It is apparent that. with the exception of the penalties inposed for violation of neutral duties or breaches of the revenue or tishery laws, there has been no assertion of legislative authority in

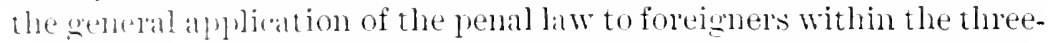
mile zone. The draislature has omitted to adopt the alleged sovereignty orer the lithoral sea, to the extent of making our penal law apulicable generally to foreigners passing through it for the purpose of narigation. Can a court of justice talie upon itself, in such a matter, to do what the legislature has not thought fit to rlo-that is, make the whole body of onr penal law applicable to foreign vessels within three miles of our const?

. It is fulther aplument from these instances of specific legislation that. When ascertaining its power to legislate with reference to the foreigner within the three-nile zone, Parliament has deemed it necessary, wherever it was thought right to subject him to our law, expresily to enact that he should be so. We must talie this, I think, as an exposition of the opinion of Parliament that specific legislation is here necessary, and consequently, that without it the foreigner in a foreign ressel will not come within the general ha of this country in respect of matters arising on the sea.

"Letwislation, in relation to foreign ships coming into British ports and waters, rests on a totally different principle. als was well explained by Dr. Inshington, in the case of The Ammonlis.

...'The Parliament of Great liritain it is true. says Dr. Lushington, 'hats not, atecorling to the prineiples of pullite law, any anthority to legislate for forcign vestels on the high seas. or for foreigness ont of the limits of blitish jurisliction; though, if l'arlianent thought fit so to do, this eond, in its instance jurisdiction at least, would be

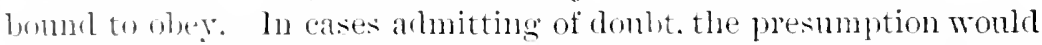
lue that Parlianent intender to legislate without violating any rule of international law, and the construction has been accolveliugly.

.. Within, howerer, British juristiction, namely, within British territory, and at sea within three miles from the coast, and within all British rivers intin fonces, and over foreigners in British ships, I apprehend that the British larliament has an undoubted right to legrislate. I am further of opinion that Parliament luas a perfect right 
to say to foreign ships that they shall not, withomt omplying wit! British law, enter into british ports, and that if they do chlol they

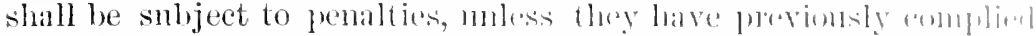

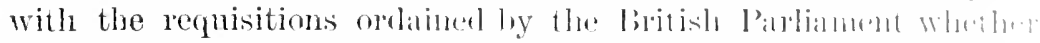

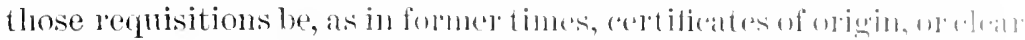

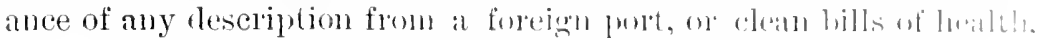
or the taking on board a pilot at any plate in on out of lirisish juric. diction before entering british waters.

" "Whether the Palliament has so legislated is now the plustion to be considered.'

"In the result, looking to the fact that all pretension (o) solereignty or jurisdiction over foreign ships in the narrow seals hat long since been wholly alandomed-to the nncertainty whichattardus to the doctrine of the pullicists as to the degree of soverejenty alul jurisdiction which may be exereiset on the so-called territorial salto the fact that the right of absolute sovereignfy therein, and uf penal jurisdiction orer the subjects of other states, has nerer leepll expressly asserted or conceded among independent nations, or. in practice, exercised, and acquieseed in, except for violation of nemarality or brench of reveme or fishery laws, which, as las loem pointul ont, stand on a different footing as well as to the fact that, meither" in legislating with reference to shipping, nor in respect of the arininal law, has Parliament thought proper to assme territurial sorreeignty over the three-mile zone, so as to enact that all offrusis committed upon it, by foreigners in foreign ships, shomld be within the criminal law of this comtry, hut, on the comtrary, whererere it was thought right to make the foregone amenable to om litw. hats dome so by express and specific legislation. I camot think that. in the absence of all precelent, and of any judicial decision or anthority applicable to the present purpose, we should be justifien in holding an offense, committed under such ciremustances, to be punshalle by the law of England, especially as in so holding we must derelate the whole body of our penal law to be applieable to the foreigner parsing our shores in a foreign vessel on his way to a foreign port.

" Maving arrived at this conchusion, it becomes necosiary to comsider the second point taken on the part of the Crown, namely. that though the negligence of which the aceused was guilty ocenrmel on board a foreign ship, yet, the death having taken plice on lubirt a British ship, the offense was committed within the juristiction of a Britisl court of justice. ***

"The question is-and this appears to me to have luen lust sight of in the argument-not whether the death of the decearat. which no doubt took place in a British ship, was the act of the de 


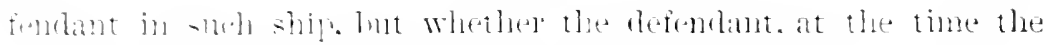

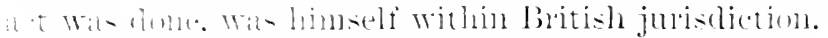

.. lint in mint wi fiect. the defomelunt was. at the time of the oc-

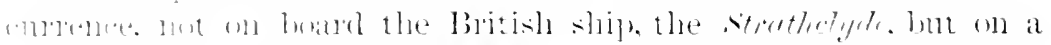

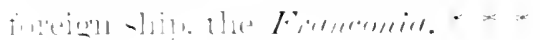

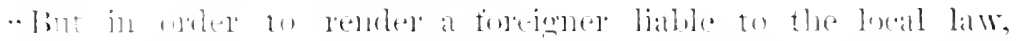

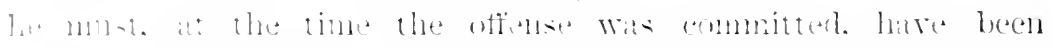

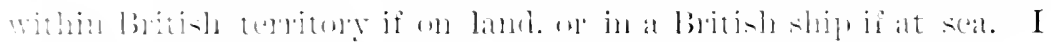

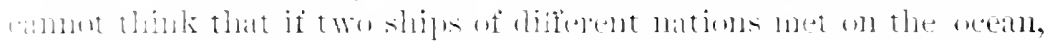

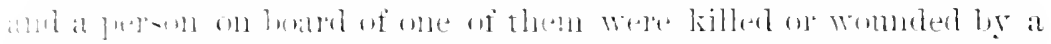

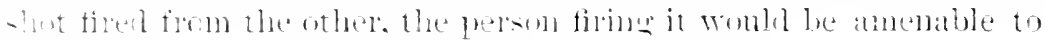
the lis of the shin in which the shot texk etrect."

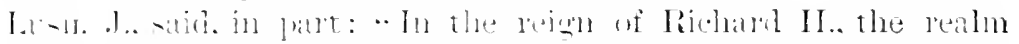

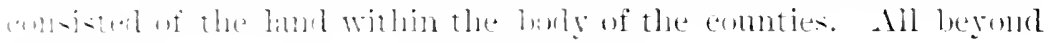

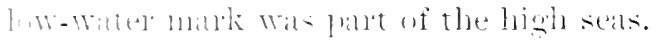

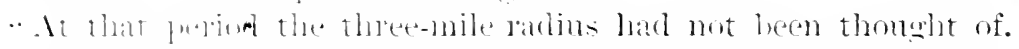

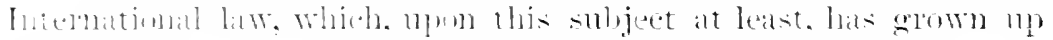

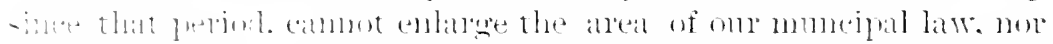

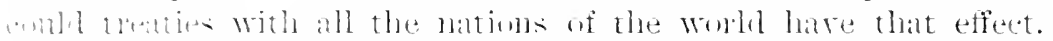

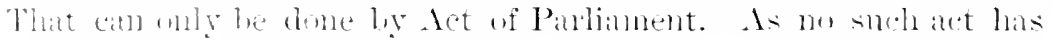
leen parsen. it follows that what was ont of the realum then isout of

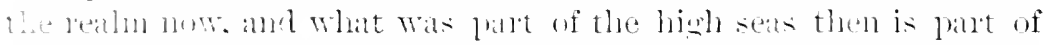

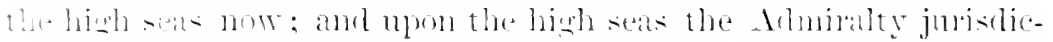

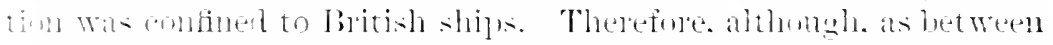

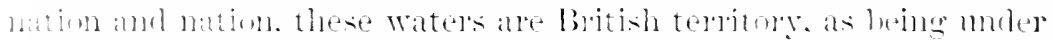

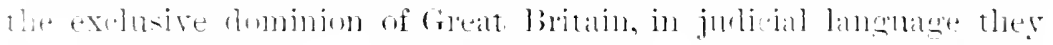

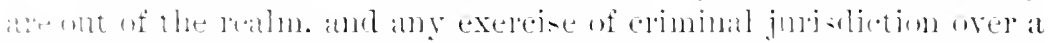

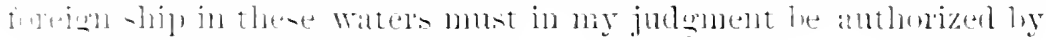

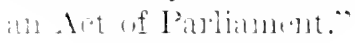

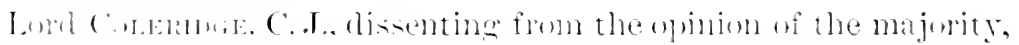

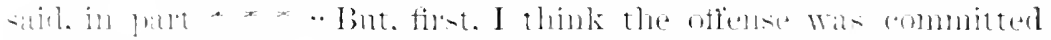

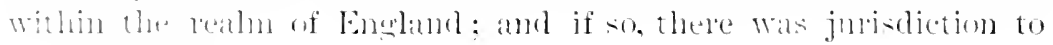
tirit.

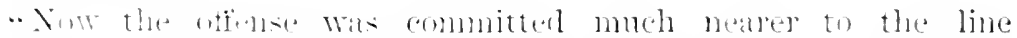

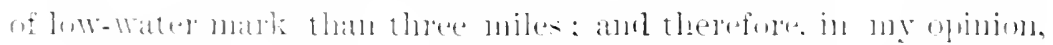

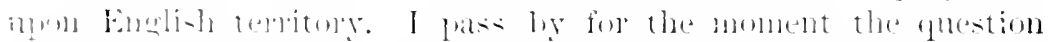

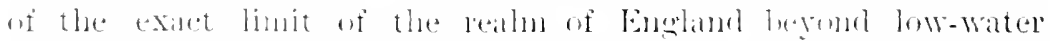

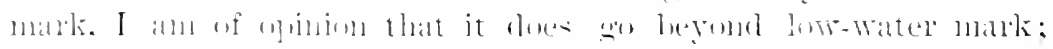

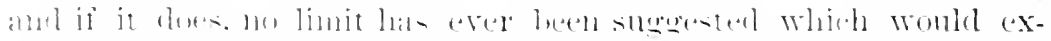

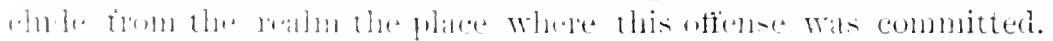

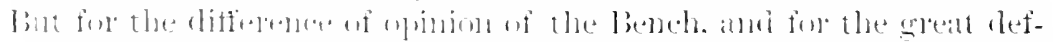

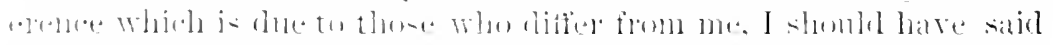

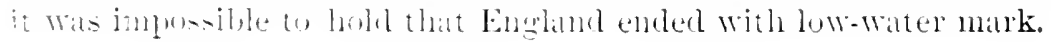




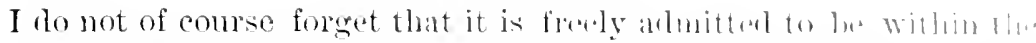

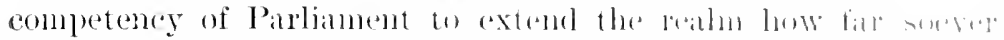

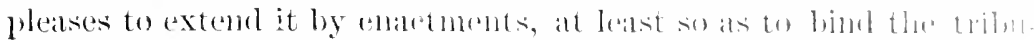

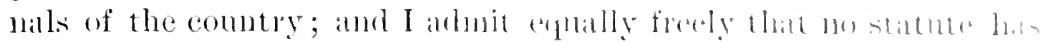
in plain terms, or by etetinte limits, serextemeled it.

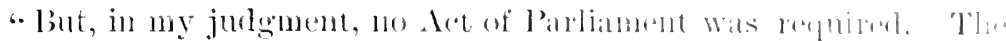
proposition contender for', as l molemstaml, is that fol ants atre of

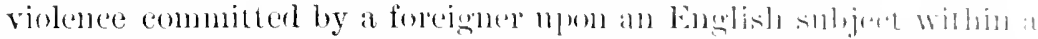

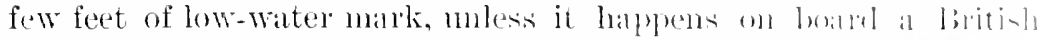
ship, the foreigner eamot be trierl, and is rlispmulshallle, * *

"liy a consensus of writers, withont one singlu anthority u the contraly, some portion of the coast-water's of a commly is comsitered for some purposes to belong to the combly the andsts af which they wash. ***

"Jluis is established as solidly, as, l:y the rely matme of the" ase, any proposition of international law can he. strielly speaking, intermational law is an inexact expression and it is ant 10 mislead if its inexactness is not kept in mind. Lam implies a langives, and a tribunal eapable of enforeing it and coereine its transgressors.

"But there is no common law-giver to sovereign states am mo tribunal has the power to bind them by decrees or coerce lnem if they transgress. The law of mations is that collection of nsans whald civilized states have agreed to olserve in their dealing with ome another. What these usiges are, whether a particular ond has a has not been agreed to, must be matter of evidence. Treation and acts of state are but evidence of the agreenent of mations, and do nut

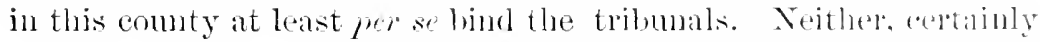
does a consensus of jurists; hut it is evidence of the arementent ui nations on international points; and on such points, when they anise, the English courts give effect, as part of English law, to silch anderement. ****

"We find a number of men of elncation, of many ritrentut nations, most of them minterested in maintaining any pitrtionlal. thesis as to the matter now in fuestion, argeeing aremerally for nearly three centuries in the proposition that the territory of a matritime country extends heyond low-water mark.

"I ean hardy myself eonceive stronger evidence to sluw thit, at far as it depends on the agreement of nations, the territory of mint time countries does so extend.

"If the matter were to be determined for the first tims. I

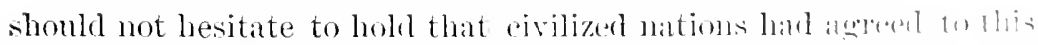
prolongation of the territory of mantime states, upm the and hority 
wi the witers who have been rited in this alronment as laying down

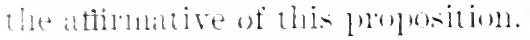

- Furthernore, it has been shown that English julges have

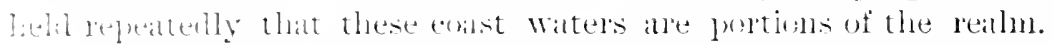

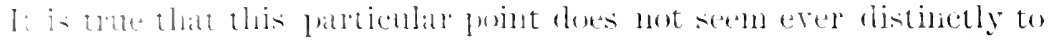

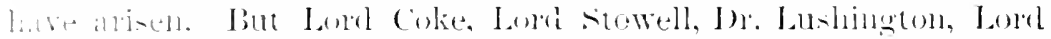

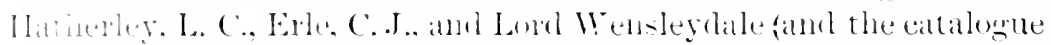
might be latgely extencleal) have all, not hastily. hat in writing,

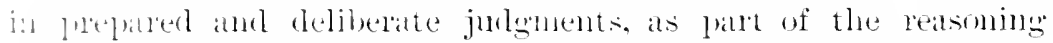

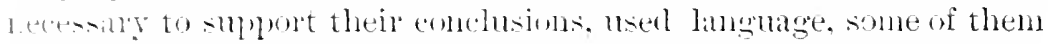
soleatedy, which I am mable to eorstrue. cxcent as asserting, on the pant of these eminent gersons, that the realun of Englind, the terlitory of England, the punelty of the state and Crown of Engbaml wrer the water and the land beneath it, extemels at least so far byend the line of low water on the English enat. as to inelude the llite Where this offense was committed. *** The English and - buelinan lext witers, and two at least of the most ennent Anerican jinloge. Matrshall and story, have ludel the same thing.

. Further-at least in one remalnable instance-the British I'anlianent has declated amb enacted this to be the law. In the pres-

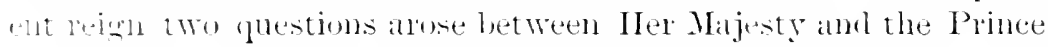
wi Wales ats to the property in minerals below high-water mark aromml the const of Commall. The first question wats ats to the popperty in minerals between high and low-water mak anomm the wain of that comnty : and ats to the ponelty in minelals below lowwater mark won ly an extension of workings begun above lowWatcer mitrk.

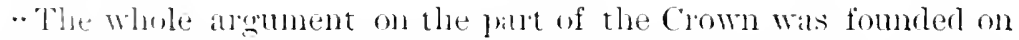

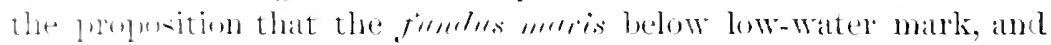

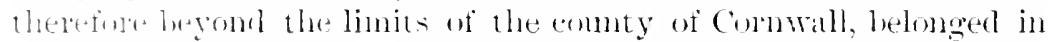

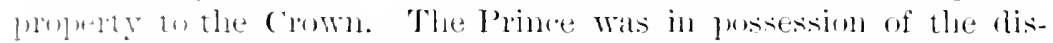

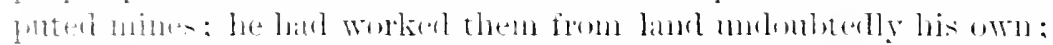

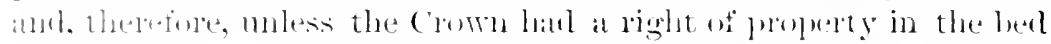

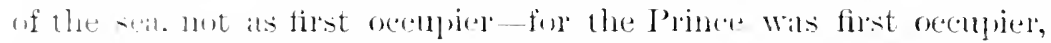

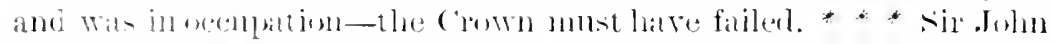

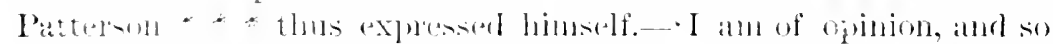
derille. that the right to the mindals below low-watted mak remains

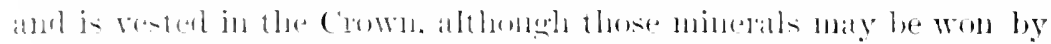

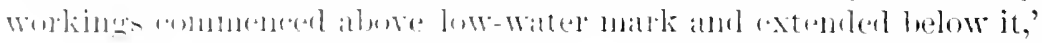

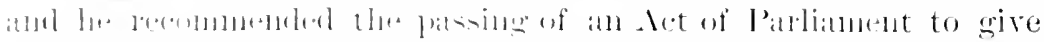

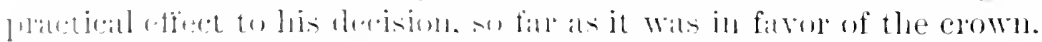

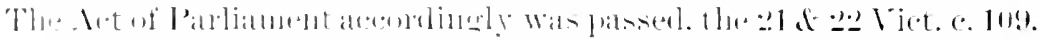
. 11 e hate therefore, it secuss. lhe express and refinite anthority of 
Parliament for the proposition that the realum does not and with bus-

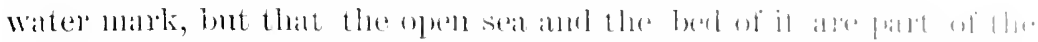

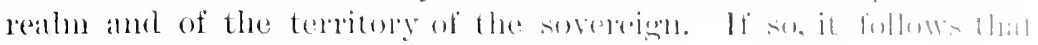

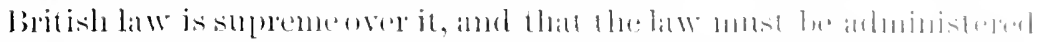

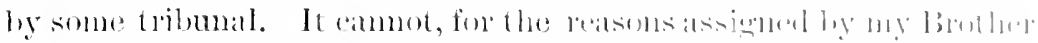

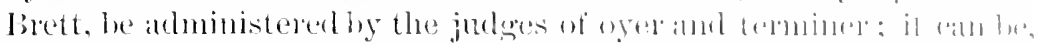
and always combl be hy the Aelminalty, and if hy the Arminally, then by the Central criminal comt."

The comt quashed the conviotion.

The majolity of the Comet wats composed of ('ondimm. C. I.

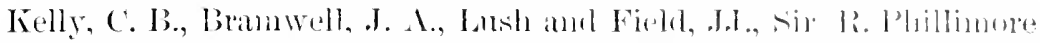

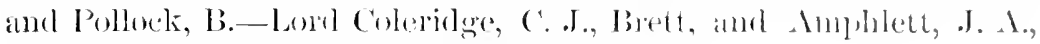
Grove, Demman and Lindley, .J.I., dissenting.

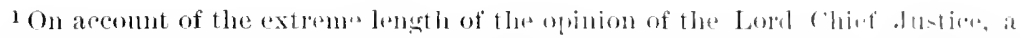

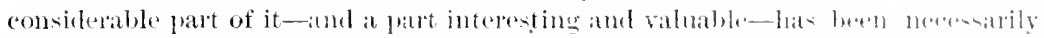

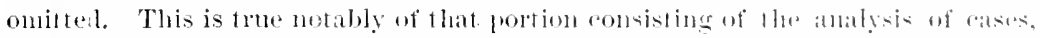
and of the abstract of the opinions of text writers. It is rengerfed, loo, that the opinions of the other julges eamuth be given.

For criticisms of the jutgunent in this rase, sa stephen's Hintory of the criminal

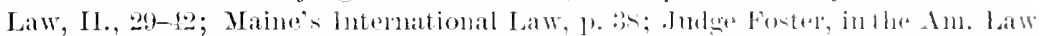

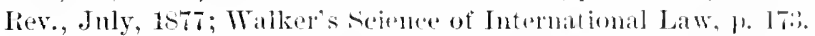

In consegnence of the decision in this case, an act was passed in lhe session of

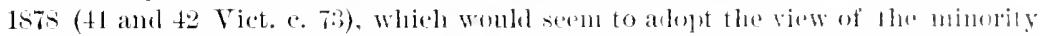

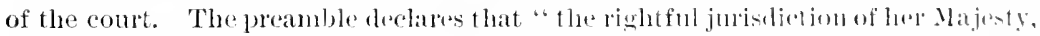

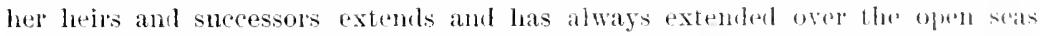

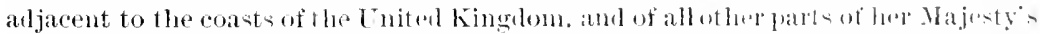

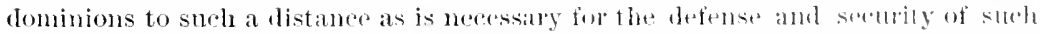
dominions," and that "it is expedient that all offenses eommitted in the ogen sal within a certain distance of the coasts of the I'nited Kinglom and of all ot her luats of her Majesty's dominions, by whomsoevel committed, shomb be deill with accoreling to law."

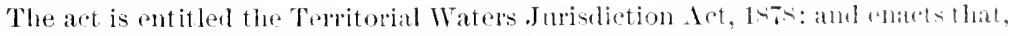
"An offense conmittel by a preson, whother he is or is not a subjert af luer Majesty, on the open sea within the territorial waters of lere Majouty"s dominions,

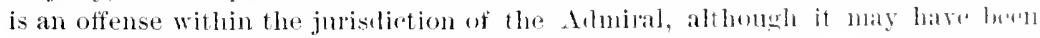
committed on board or by lueans of a foreign ship, and the person whe conmintent such offense may be arrested, tried and punished acoordingly.

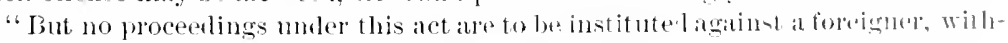
out the comsent and certificate of a seceretary of state, or in the arase of a colomy. the certificate of the Governor.

"The Territoriai watrys of her Majesty"s dominions, in reference to the sill,

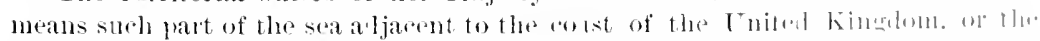
coast of some other part of her Majesty s dominions, a is dremed hy intermatimal

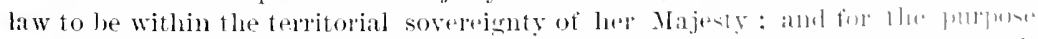

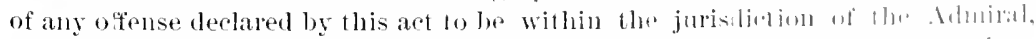

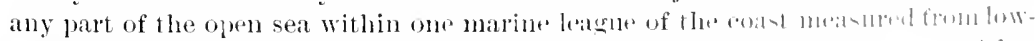

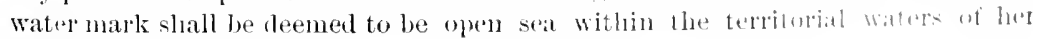
Majesty's dominions." 


\section{CHAPTER II.}

TERIITORIAL , JRISDICTION.

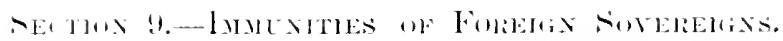

\section{VAVASELR v. KRTPI.}

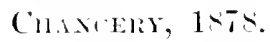

$$
\text { (L. R., (Hentery Dix., s.s.) }
$$

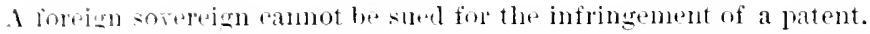

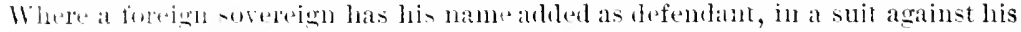

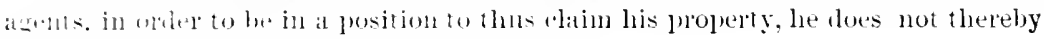
subject himelf to the juristiction of the court.

Josiah Varisiseur, the platutifi in this case, had brought an action

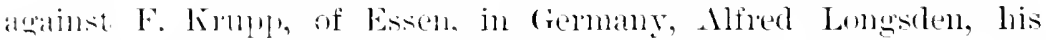
anent in England, and Ihrens \& Co., deseribed as agents for the Gorement of Japan, claming an injunction and damages for the intringement of the planinte"s patent for making shels and other funjertiks. The shells in question had been made at Esisen, in

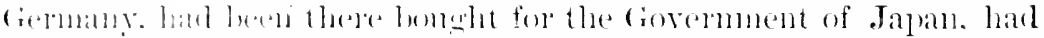

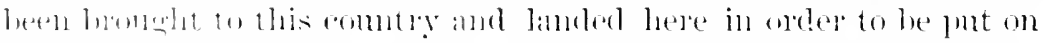

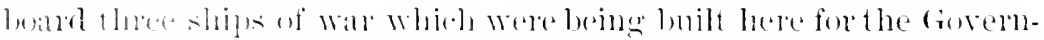

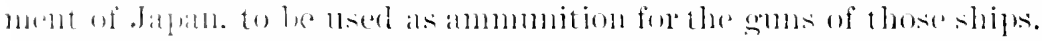

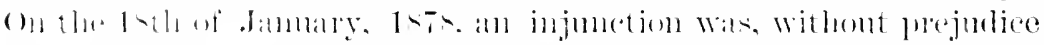

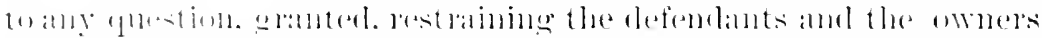

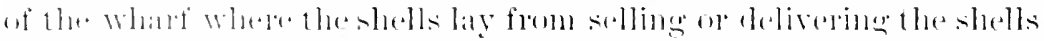

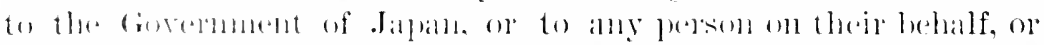

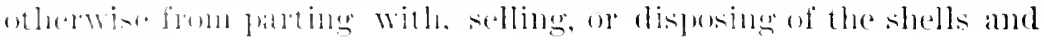
lnojectilis.

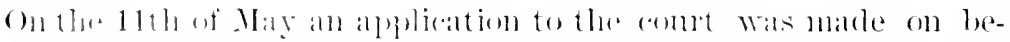

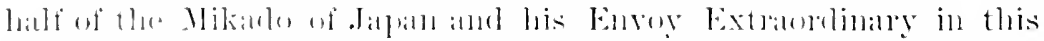

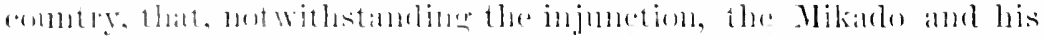

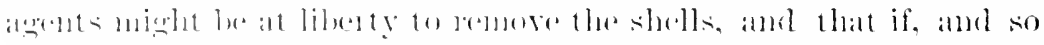

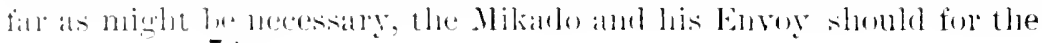


purpose of making and heing headed mon such applikation lu mblut as defemblantio in the suit.

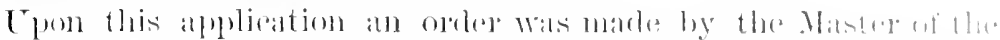

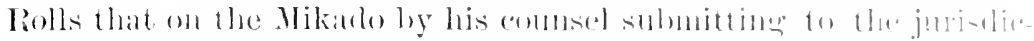

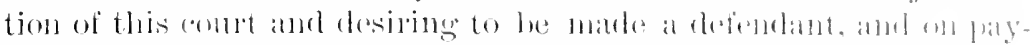

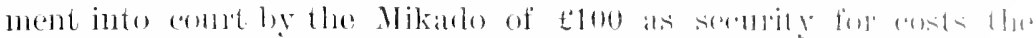

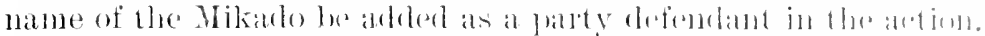

Sotice of motion was theng given on the pate of the Vikathe that the injunction might le disisolverl, and that the Mikalle might les at liberty to take possession, and remore. ont of the juristiotion of the comrt, the shells in question, the property of his Imperial Majesty.

James, L. .J., Bnett, L. .J., and Cotrox, L. .J., concured, eath delivering an opilion.

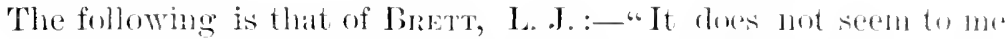
that in this case there is any fact whateres in dispute.

"These shells were manle ly Krolpl at Essen. That Was mo infringement of the plaintiff's gatent. In Germany they wejesolut to the Mikalo and paid for loy the agents of the Mikanto. Noment

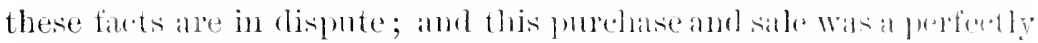

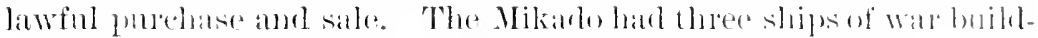
mg in this fomonty, and he drsired that these shells shombl be somt

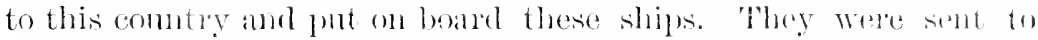

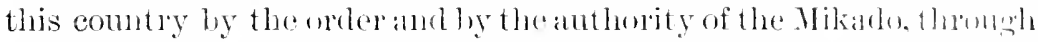
Ahrens \& Co. They were homght into this comutry, and they were deposited on a wharf. The plaintiff then funding these shells in this comtry, and finding, as he alleges, that they were mald anombling to the process of his patent, asserts that the lomging them inte this comntry hy Ahrens \& (o. is an infingement of his latent hy then ; and therenpom he brings an ation aganst Ahrens d ( Co. for the in. fringenent. In that action he chims an injunction andinst Mhroms \& Co., and it may he that he elams an order from the comet wo destroy those shells hecanse he says they anc an infringement of his fatcht.

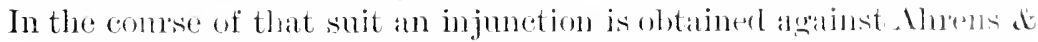
Co., and against others, which injunction in terms forbigls them form delivering these shells, which with other things and in their possession, to the ships of the Mikado, and in fact forligls them thom sending the shells to .Japan. To this artion the Mikadle wate me

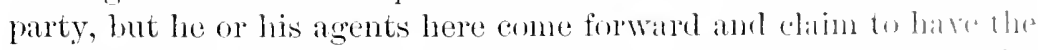
delivery and possession of these shells. The drfombants in the action are not unwilling to gire the shells to the Mikaln, bat they

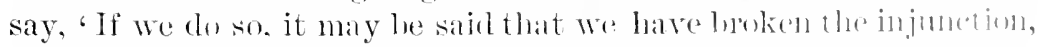
and we may therefore be liable to eertain penalties.' It serems tome 
begomd di-pute that this was the purpose for which the Mikado

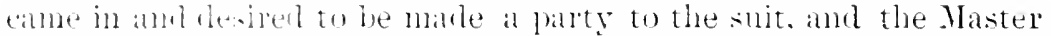

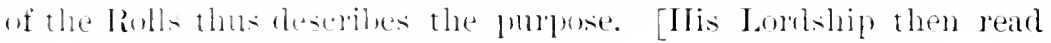

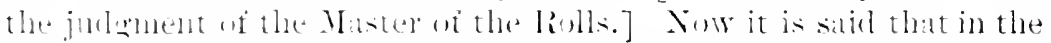

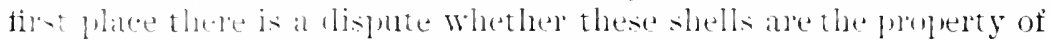

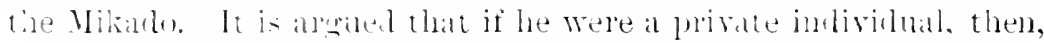

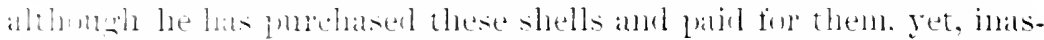
murhas there has been an infingenent of the patent. the property

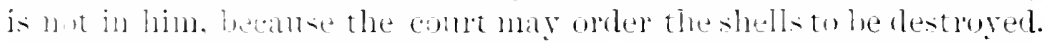

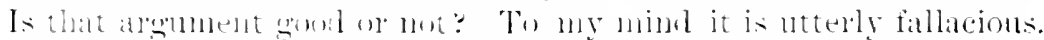

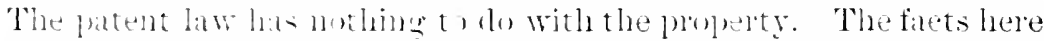
ane molisputer that Krul'l malde them with his own materials in

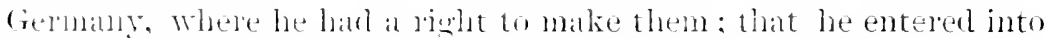
a contratet to sell - peejtic shells to the Mikarlo: that that contract was lobromed, and that the shells were paid for, and that they were delivered in Gemany to the Hikindos agent. Well, muless the ghtent law prevents the property from passing nowory ean doubt that the property passed to the Mikado. Therefore the clispute is not 11 un facts. hut unom a false themr of law, that the patent law

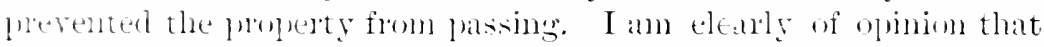
the patent law did not prevent the property frobl pasings. The

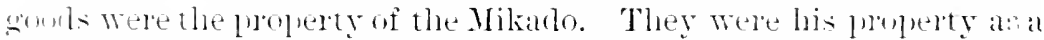
soreden: they were the property of his comntry ; am therefore he is in the positom of a foreign soremeign having pronerty here.

. Whether the falet of Ahrens of Co. hringing these gonds into

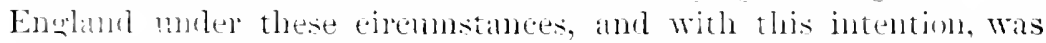
an influsement ef the patent. I deeline to eonsiler. I shall assmme for this flup pose that it was an infingenent, and that we have in this

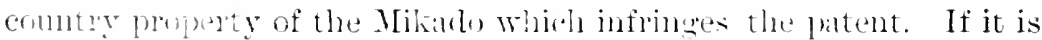

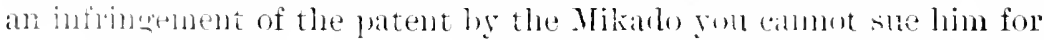

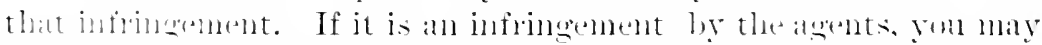

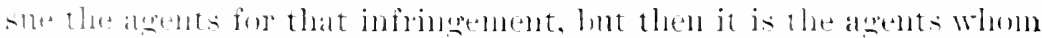

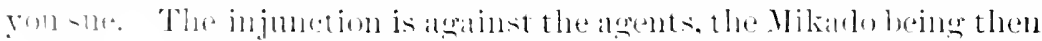

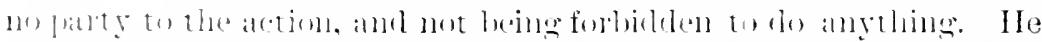

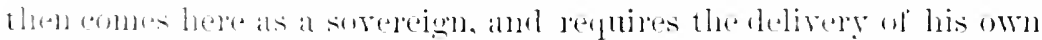

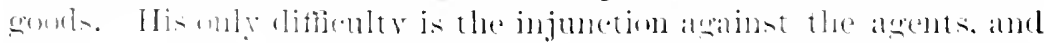

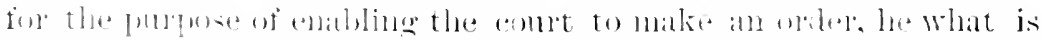

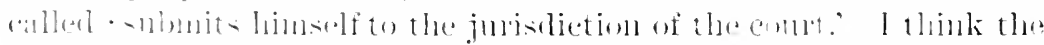

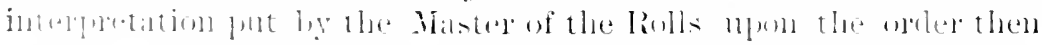

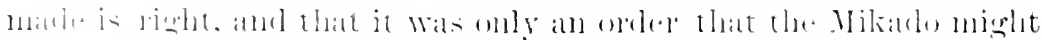

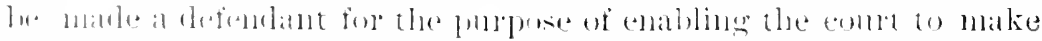

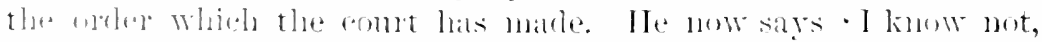
and I care not, whether my agonts have infringed your patent law. 
I lave property in the eombly, which property is my mon I

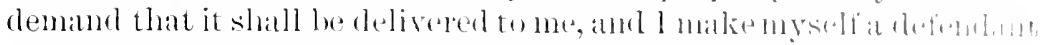

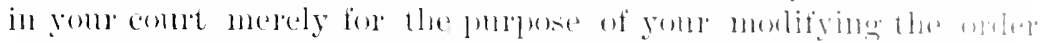

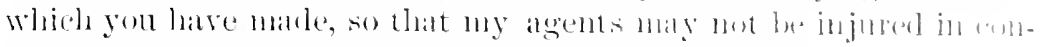

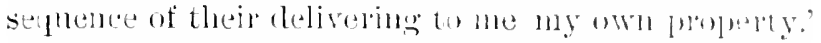

" And the only order that the Master of the liobls lats matlo is that

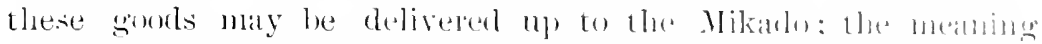
of which is that the mere fact of the Mikalde taling then shellis

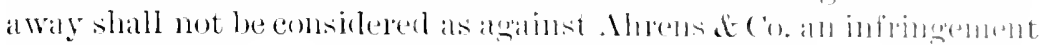
of the injunetion. 'That is the whole efiedet of thisorefer. The Miliallo has a gerfect light to have these gombs

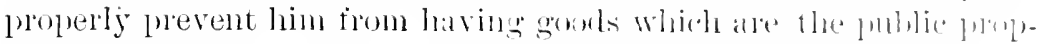

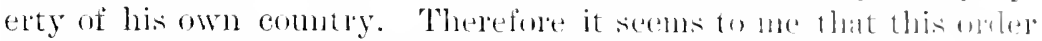

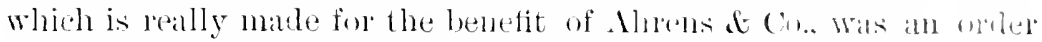
rightly male, and that this appeal cammot be sllstainerl."

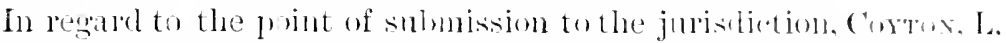

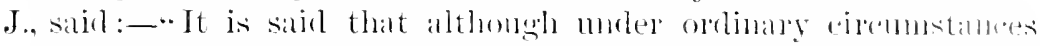
thele is no jurisliction as agatiot a forejen soveleigh, yot thalt in this farticular case there is juriscliction in comsepurene wi the

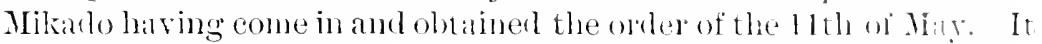
is salit that a soveleign sumg submits himself to the eomet an and ordinary plantiat, and that the Mikando, in consepulence of having obtained this order and ated nym it, puts lomself in the puition of an ordinary plaintiff. In the tist place, there is this fallacy : the Mikarls is not now in any way suing in the orlinaly sense of the worl, mor has he come to the comt to establish as aciain an adverse colam his title to the property, which is really what is meant hy a foreign sovereign coming here to sue toestallish his rights. Ite is simply coming, and sayme. The oribe of the conte mosithly in-

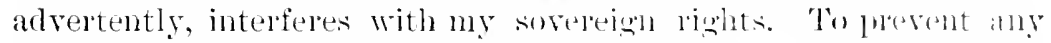
question as to the defendants' committing al loweh of the injum ion by allowing me to remove the property, make an order that they les at liberty, notwithstanding the injunction, to hand them osere to me!

"so that, in my opinion, the very fommlation for the sumerestion fails.

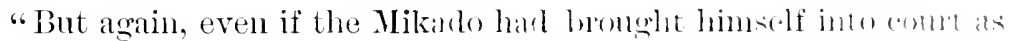

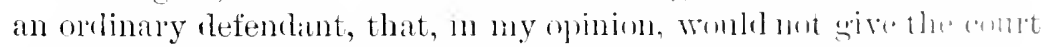

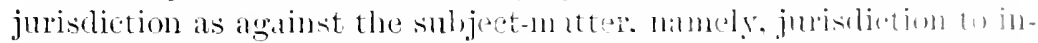

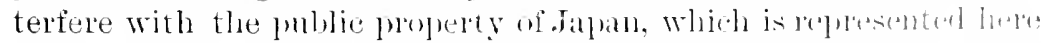

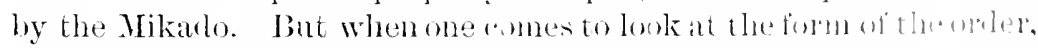
the Mikado does not hy it come in as an orelinaty refemlant. lis it he simply says I wish to bring hefore the court the farts: lhat then are my property, that the defendants were not comstumbing low 


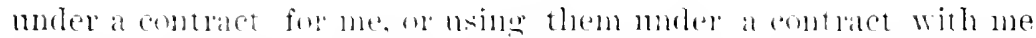
I wish to shmo that they are my poperty. I wish to alyly fol

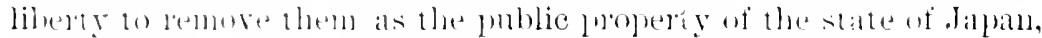

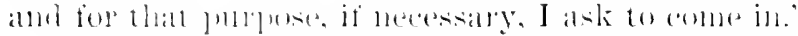

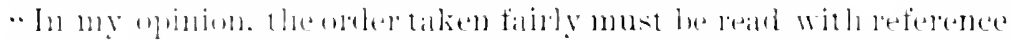

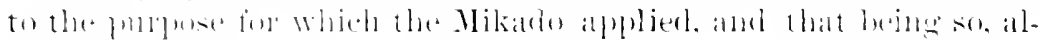

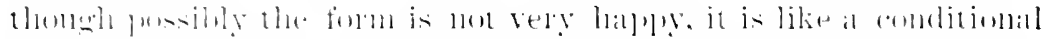

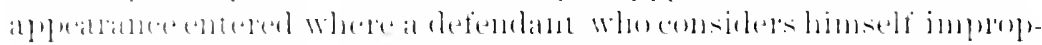

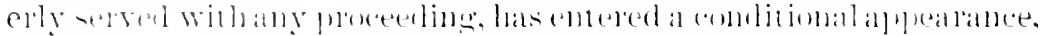

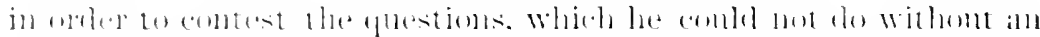

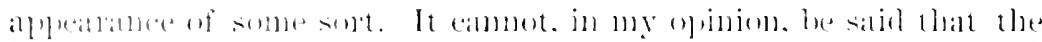

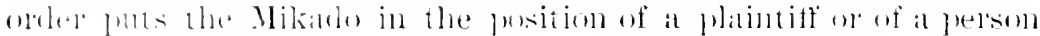

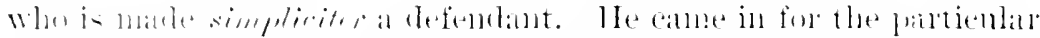

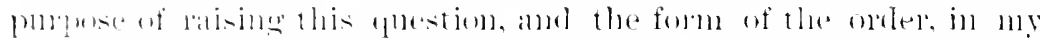

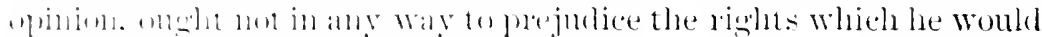

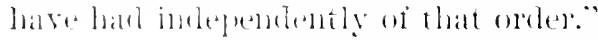

Jne- L. J. :-...'This appeal is dismissed with costs."

\section{J)E HABER Y. QLEEN OF PORTLYAL.}

Queves bixn, 15.)1.

$$
\text { (17 (2)ernis Burlh. 19) }
$$

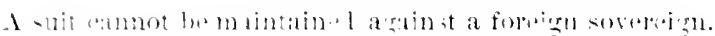

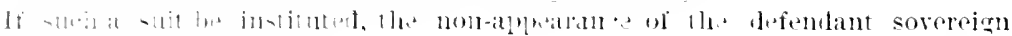

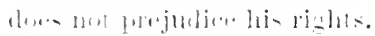

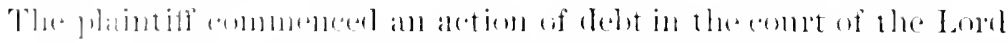

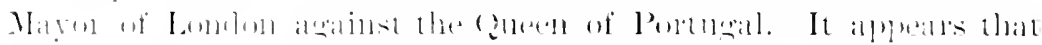

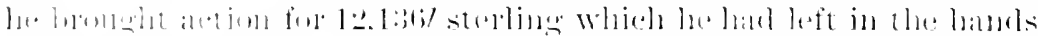

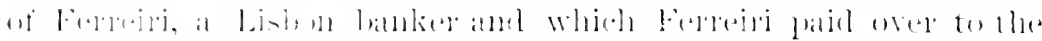

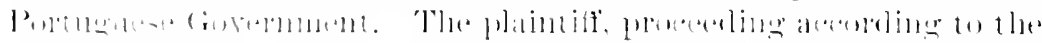

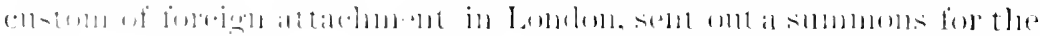

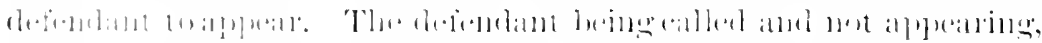

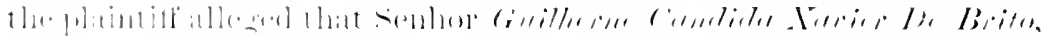

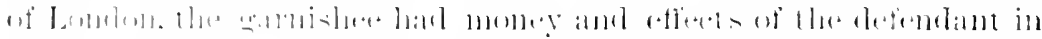

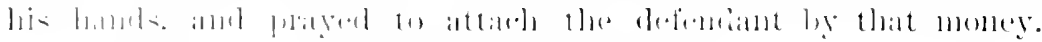

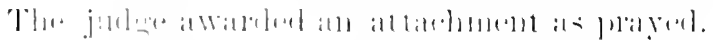

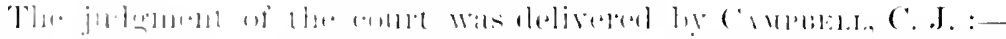

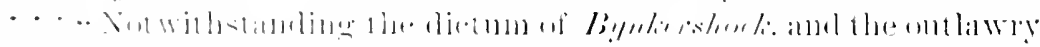

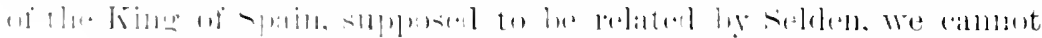

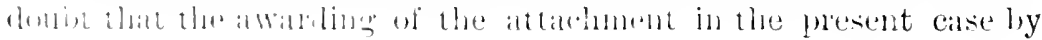




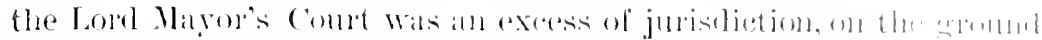

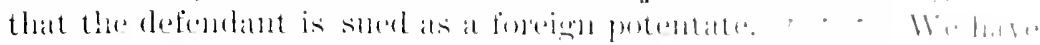

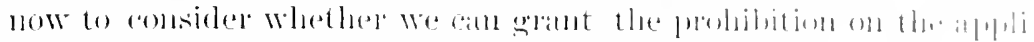

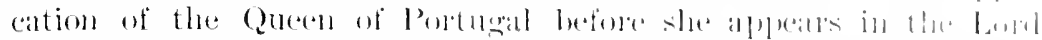

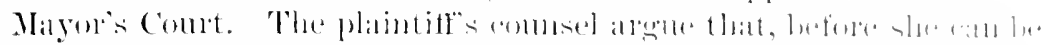

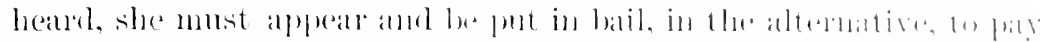

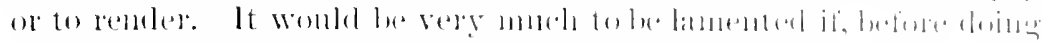

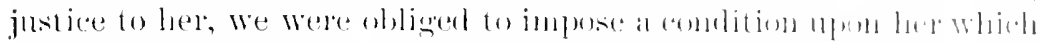

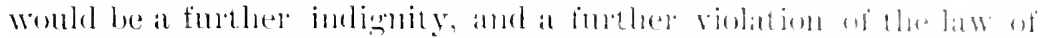

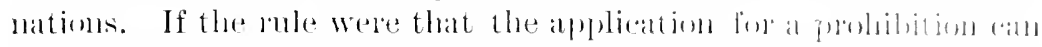
only be by the defendant after aphearance, we shembl have hald lit he scomple in making this an exerption to the role. Bat we find it labl down in boolss of the highest anthority that, where the andet to

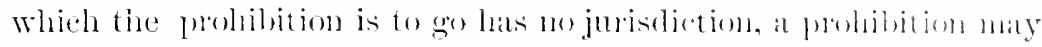

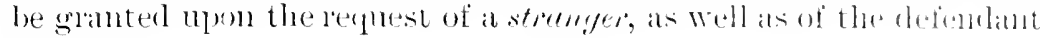
himselt.

"Therefore this court, vester with the power of porenting all inferion courts from exceeding their jurisdiction to the prejulice of

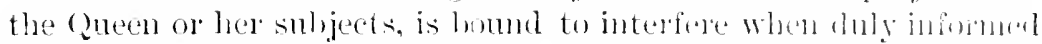

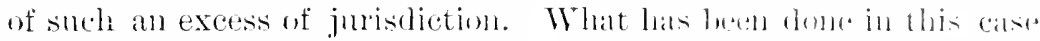

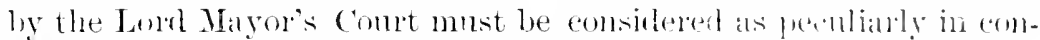
tempt of the crown, it being an insult to an ind "armulent surereign, giving that sovereign just cause of complant to the british fousernment, and having a tendency to bring about a mismoles-amding between onr gracions sovereign and her ally the Queen of l'metant.

"Therefore, mpon the information and complaint of the gumen of Portugal, either as the party griever, or as a stornefre, we think we are bomnd to correct the excess of juristiction bumeln to om notice, and to prohibit tas Lom Mayor's Court fon procecoing further in this snit.

"Rule absolute for a prohibition."

\section{PRIOLEAC v. UXITED STITES ANT ANIIREW .JOINAON. \\ Ix Eigrti, 1860 .}

$$
\text { (L. R., } 2 \text { Equity, (j.)! ) }
$$

Where the United States are plantifis in a suit, and the defomlinte bring a cros-bill for discovery, and add the name of the Plexilent of the l'nitut taten at

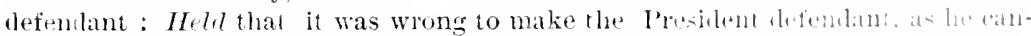

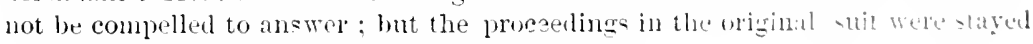
until the answer of the United states was put in. 


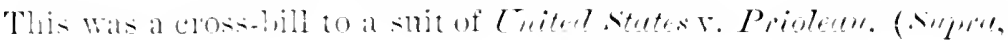
s.

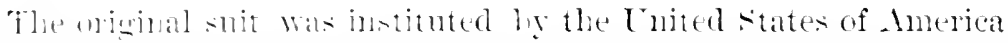

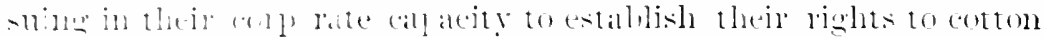

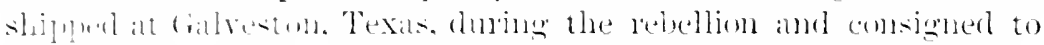

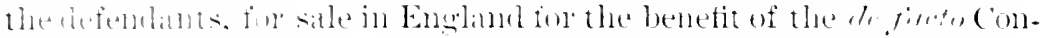

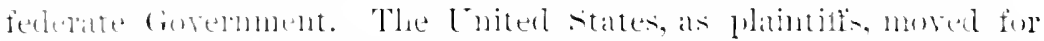

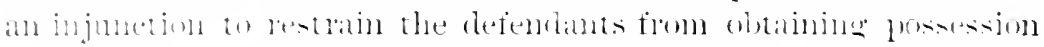

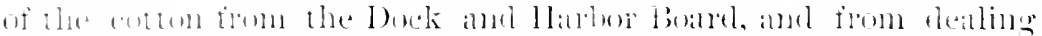

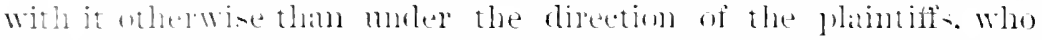

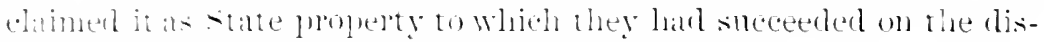

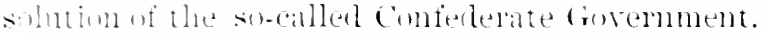

The Vice-chancellor mathe an wrel appointing Mr. Probean

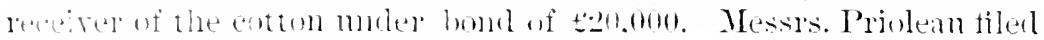

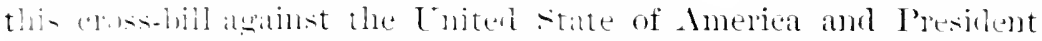

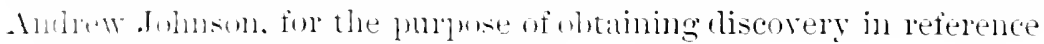
to ihe mattels in question in the snit.

Xismorer having been gut in hy President Johnson. the plaint-

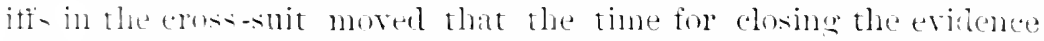

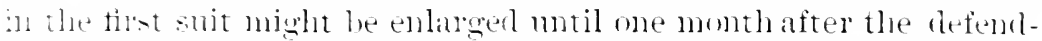
ant wo the eross-bill han put in their answer. and that, failing such atn-wer, the rectivership of Priolean might be discharged and his reconnizances racated.

Extracts from the opinion of the rice-Chancellor are as foll॥1:-

"The quetion in this are is one in some regree norel, but the

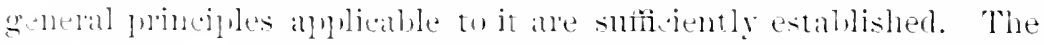

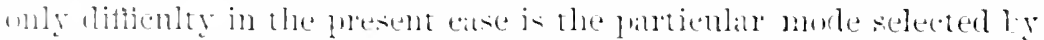
the phatutitis in the coss-sut for am aring at the ohject they have jis view. A bill being tiled hy the Enited states of America, moler

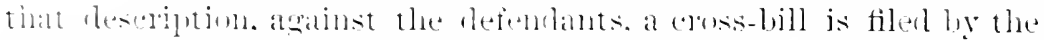

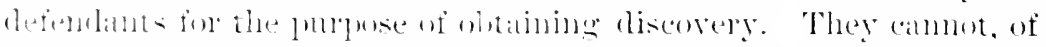

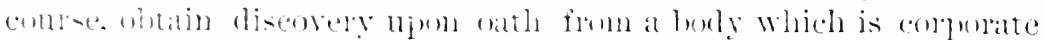

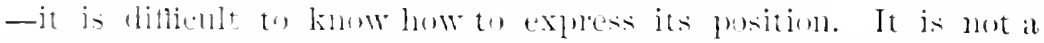

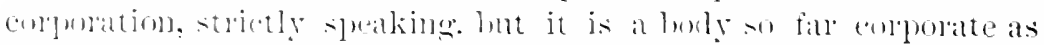

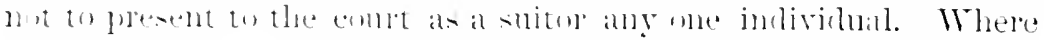

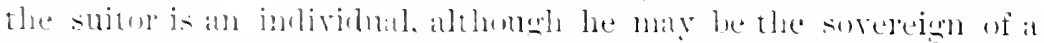

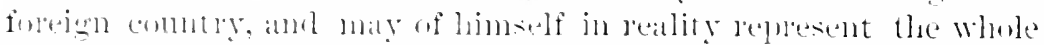

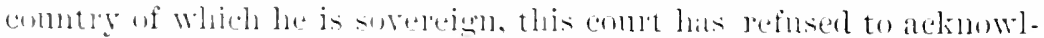
etere him when ha cones here als a smitor in any other capasity than a- a plivate indivinual. It hats heen eletermined by the highest an-

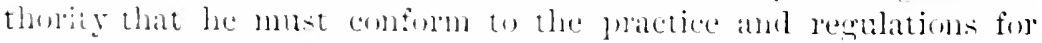
adminisuation of justice of the tribunals to which he resorts for 


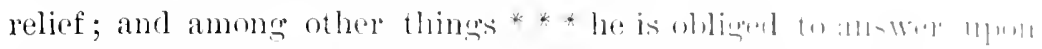

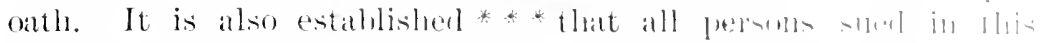

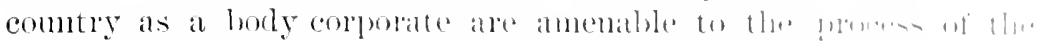

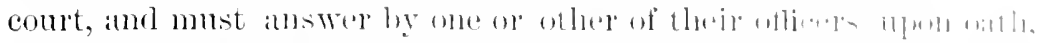

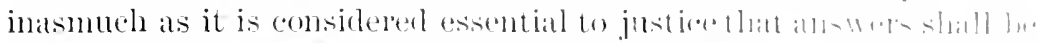

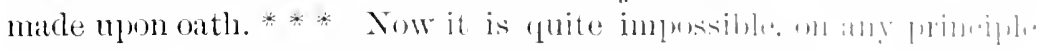

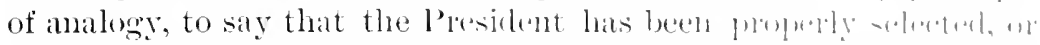

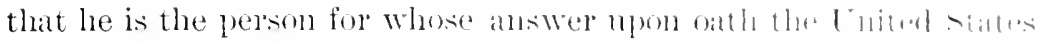
must wait before they proeerl in their origmal suit. * Xom the selection of the President of the Enited states is (1) and and to this objection, that the comt camot take julloial notion-mol do I smppose it is a matter of fact-that the Eniter states forromment have

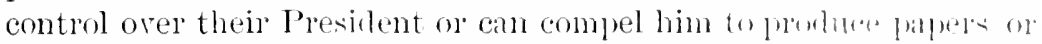

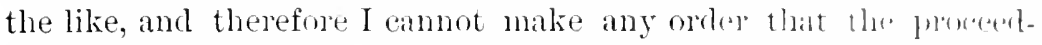
ings in the original suit be stayed until the Presirlent hat jut in his answer. ***

"I can do no more than make an order staying proceslins nut il the answer of the Cnited states is put in."

\section{UNITED STATES OF AIERICA $\checkmark$ M.MTIER.}

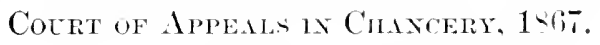

$$
\text { (L. R., 2 Chencery Appeals, s’o.) }
$$

A Republic may sue in its onn name; and it need not have or create an oflicer to maintain a suit on its behalf.

The bill in this suit was filed by "The Unitell states of Imerica" against agents of the Confederacy, doing business at Liverpmol.

The bill alleges that the defendants had large guantitien of cott m consigned to them-that in 1865 the rebellion was suppresised and that all the property leld by the govermment of the soralled comfederate states, inchuling all moneys, goods and ships in the purer of the defendants, had vested in the plantiff.s. The bill priyed for an account, and for an order of payment of the money in the lamis of the defendants, and a delivery of the goods and entum in their. hands. The defendants demurred generally, objecting that the hill should put forward the President of the United states al sinne stilte officer, upon whom process might be served, and who mig'nt answer a cross-bill.

The demurrer was allowed and now the plaintifl's alpeil.

The opinion of Lord Cainss, L. J., is as follows :-

"It is admitted that, upon the statements in the lill. it must 
be taken that the pronerty clainter in the suit belongs to the

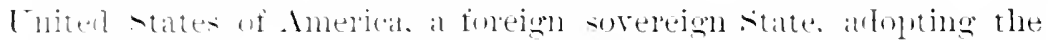

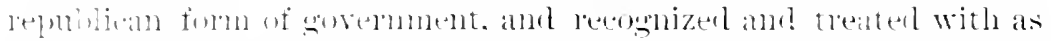

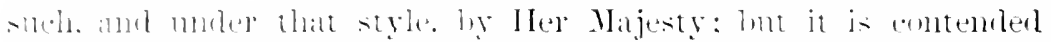

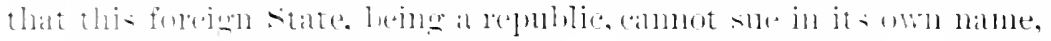

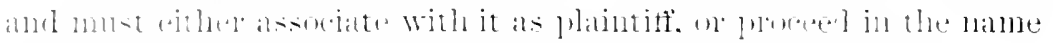

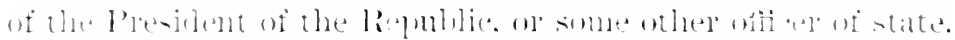

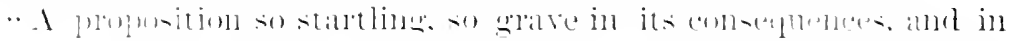

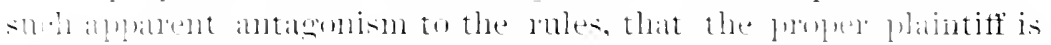

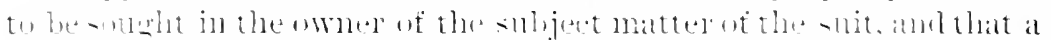

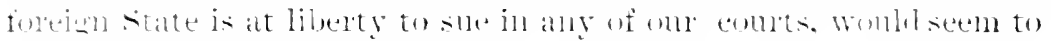

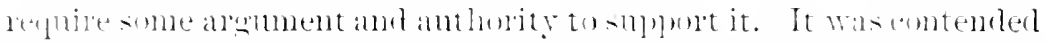

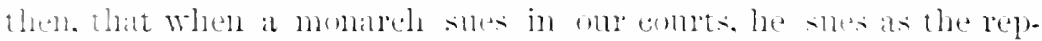
linentative of the state of which he is the serereign: that the monerty elaimed is lonkent upun as the property uf the people or state and that he is pelunited to sue not als for his am property, but a the head of the executive asermment of the state to which the moperty belongs: and it wats eontembed. in like manner, that

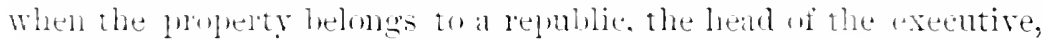
or in other worls the Plesident. onght to sue for it.

." This al'gument, in my opinion, is fommel on a fallacy. The

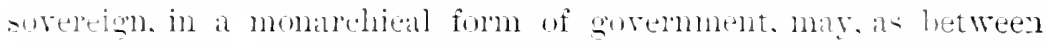
him-eli and his shijects, be a trustee for the latter. more or less limited in his powers orer the property which he setes to recover.

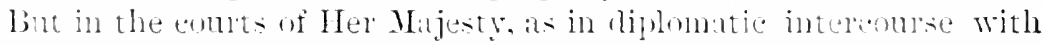

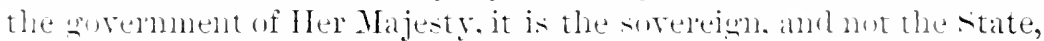
(1) the subjets of the sorereign, that is recognized. From him, and as repuesenting him individually and not his state on kinglom, is an

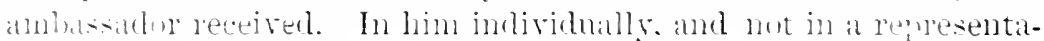

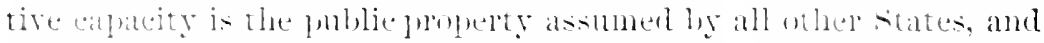
by the compts of othel states. to be vested. In a republic, on the

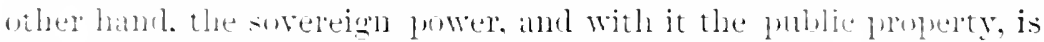
letel to remain and to resile in the state itselt, and not in any

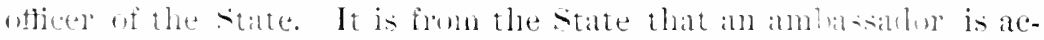

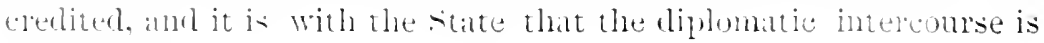
ewrembeterl.

"It was then contended that the republic of the Guiterl states as

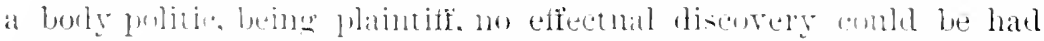

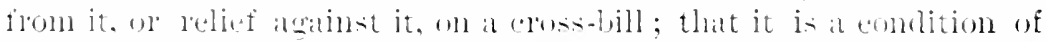

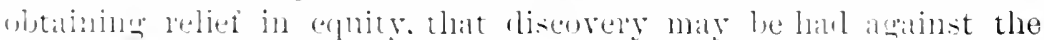

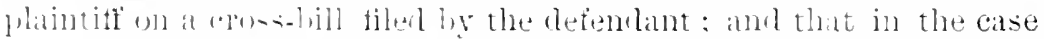
of a corpulation. this right is preserved by the rube that its officers may be male endefendants for discovery. 
"It is to be observed, howerel, with regald to the calse wi an an"

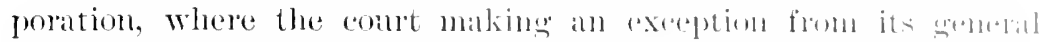

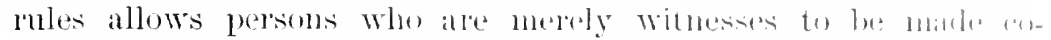

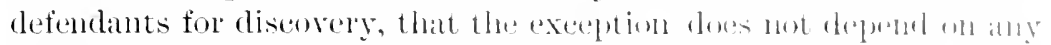

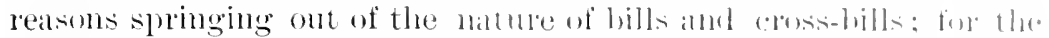

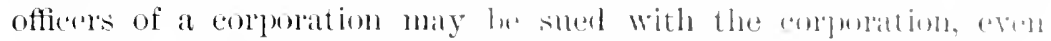
where no litigation has been enmmenced by the endentition; mor

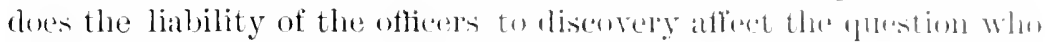

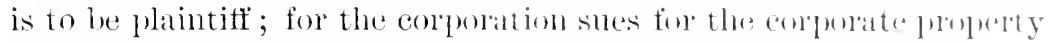
without joining any officer of the eorporation as a es-phantint.

"The rule of the comt as to comporatims, if it proves anythins, would seem to show that in a eloss-bill aganst the l mited sitates, there would be a right to join some officer of the Lnited siates for the purpose of discovery.

"The Vice-Chancellor appear's to have thomght that the l'wesilent of the Enited States was not an oftieer who conld thus be joinerl as a defendant, and I do not desine to expess an opinion diftering in that respect from the opinion of his Inomor. But if the reference to suits against corporations does mot establish a right to make some officer of the Enited states a co-rlefentamt to a cross lill, it is, ats I think, altogether irrelevant. It is, lowever, in my opiuson, an error to suppose that the right of a plaintiff to sue depends in any way on the effectiveness of the discovery which on a crosis-bill an be exacted from him. From an infunt, a lunatic, a representative, trustee, or executor, wholly ignorant of the ocemrences which are the subjects of the suit, no practical discovery can be obtained, and yet they can maintain a suit.

"I apprehend that the only rule is, that the person, state, or cor" poration which has the interest must be the plaintifi, and the eonlt will do the best the law admits of to secmre to the defendant surh defensive discovery and relief as he may be entitled to. The comt can in all cases suspend relief on the original bill until justice is in this respect done to the defenclant.

"The case of the Columbirn crovermment r. Rothechil, 1 Sim., !1, however, was said to be, and the Vice-Chancellor aplean's to hatre considered that it was, a binding authority against a suit in this form. I cannot so view that case. The bill was filed in the name of the State of Colmmbia, and if this bill hath heen filed in the mame of the Government of the United states, the case womld har bere allatia-

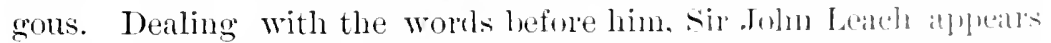
to have held, and to have most properly ledel, that an mulimmm and undefined body, such as the govermment of a sitate comlil not sue by that quasi-corporate name, and the explessions in his 
jurgment seem to me to intinate no more than that if the persons so deseribed comld whe at all they must come forward as individuals,

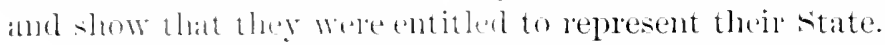

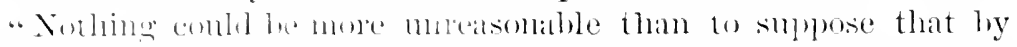

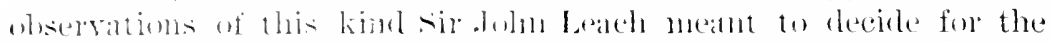

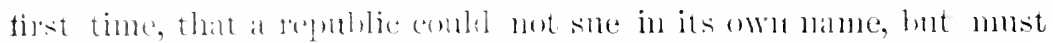

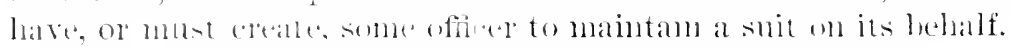

. I think ihe demmere in this case motst be werruled."

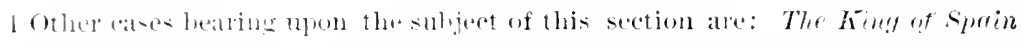

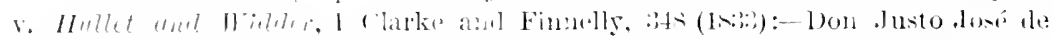

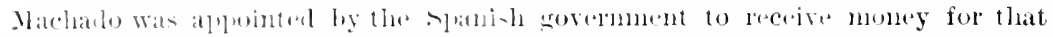

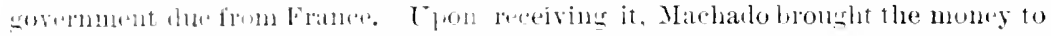

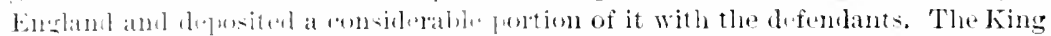

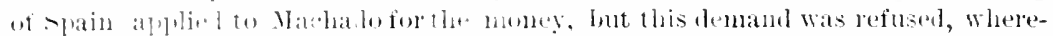

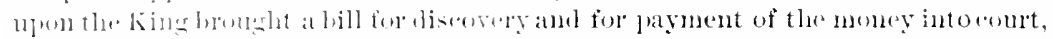

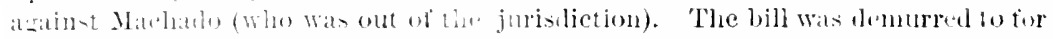

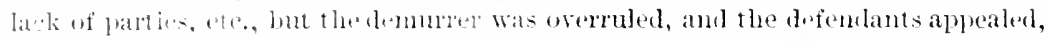

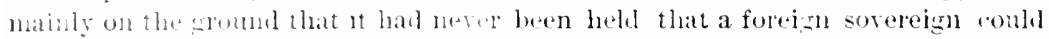

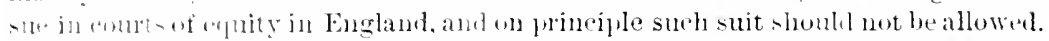

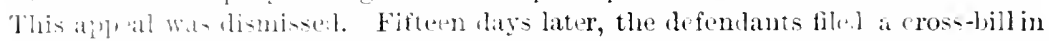

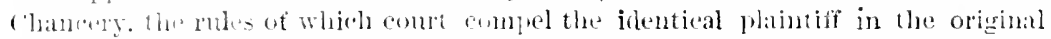

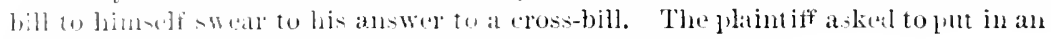
an were either liy lis atent, or withont abth or signature.

'Jhe Houne of Lords refused to devinte from the practice of the court.

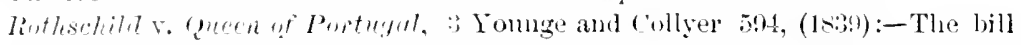

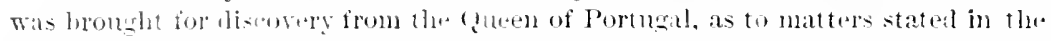
bill, and for a commiscion to txamine winesses in l'ortugal, and for an injunc-

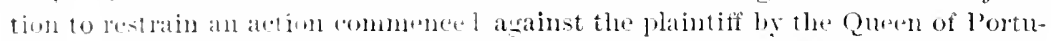

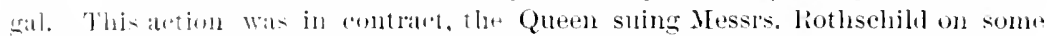

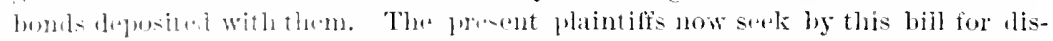

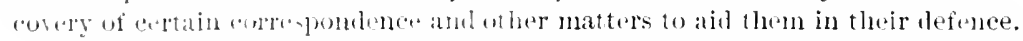

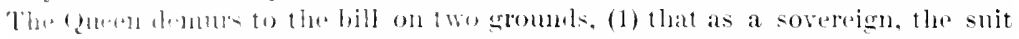
Was sot maintainable araint her-(z) that the plaint iff's had made no case for dis(c)

Tha fir-t point only is mosillered.

The conde overpulen the demurrer, and, in the course of its decision, Baron

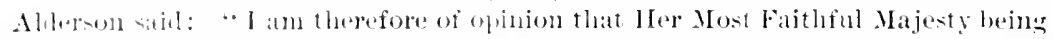
a stlitur volumarily in a comrt of Fuslish law, luecomes sulpject as to all matters connected with that sut, to the jurisliction ol the Court of Equity." 


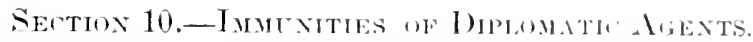

(1) Crimiunl furisoliction.

\author{
CASE OF LESLIE, BISIIOP OF ROSE, $15 \mathrm{~T}$

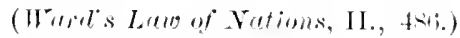

Is the ambassador of a deposed sovereign entitled to the immmites acroritel to; diplomatic agents:

In the year 1507, Lestie, Bishop of Ross came to the comt if Engkmd, in behalf of Miry Queen of scots; who, althomgh she Wils detained prisoner in England, wats allowed to semel him to pleate hesfore the commissioners appointerl to examine into her canse. Nothing was determined by the commission: but leslie continned at court, and exercised the oftice of ambassarlor of Matry for the space of one year, when, being coneerned in raising a rebellon atwinst thes English Government, he was committed to the custorly of the bishol of Jondon. From this he was soom liberaterl, and returning to his function of ambassador, eontinned to preserve it neall wo rears longer. At that time, being detected in the attempt to ratise at serious conspiraey in favor of Mary, against Elizabeth. he wals ance mole committed ; and the following questions encerning him were pmo pounded to David Levis, Talentine Dale, William Drury, William Aubrey, and IIenry .Jones, learned ciril lawyers: 1. Whether an ambassador, procuring an insurection in the Princes comntry towards whom he is ambassador, is to enjoy the privilene of an ambassador?

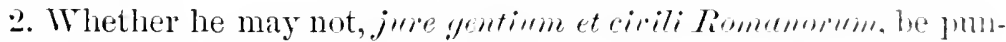
ished as an enemy, traitor, or tomspinator against that l'rinces, untwithstanding he be an ambassarlor?

To these two questions they answered: "Touching these two questions, we are of opinion, that an ambassarlor proeming an in. surrection or rebellion in the Printe's eomery towals whom he is

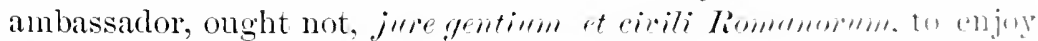
the privileges otherwise dne to an ambassador: but that he mal. notwithstanding, be punished for the same.

3. Whether, if the Prince be deposed by the common anthrity of the realm, and another elected and invested of that chom, the solic. 
itor or here of his canses, and for his aid (although the other Prince

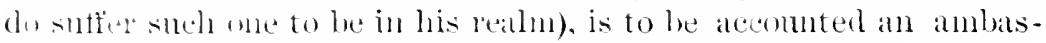
satur. or to enjug the privilege of an atmbatsialor"

Tothis ther answered: " Weduthink that the solicitor of a Prince lawfully depured, and another heing invested in his platee, cambot

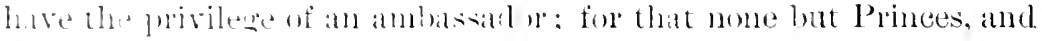

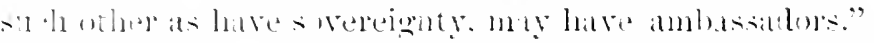

4. Whether a l'rince, coming into another re:tlu, and remaining

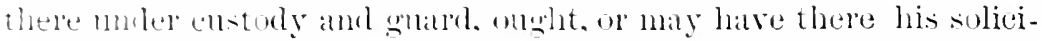
tom of hi-catlses, and if he have, whether he is to beaceomted an

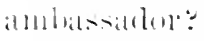

The hlis they answered: "We do think that a Plince coming into

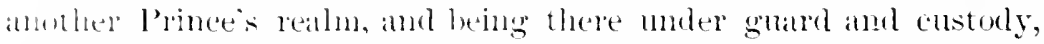
and remating still a Prince, may lavea solicitor there; but whether le is lo be alcomuted an ambassaldor, that dependeth on the nature of his rommuliminn."

i. Whether. if such a solicitor beso appointed by a Prince so flying, or comme into another Princes realm-if the Prince in whose reahn the Princeso in guard, and his solicitor is, shall denomee, or cause tw he denomced. to such a solicitor or to such a Prince mader custorby. that his sild solicitor-shall hereafter be taken for no ambatssillor-whether then such solicitor or agent can justly cham the gurilene of ambassitlor?

To blis they answered: "We do think that the Prince to whom any pernon is rent in messatge of ambatsiador, may for callses forbid him to enter into his lands, or when he hath received hin, command him to depart: yot so hong as he doth remain in the realm, and not exceed lle bummls of an ambassimlor, he may claim his privilege ats ambats-aller, or solicitor, aceording to the quality of his commission."

6. Whether, if an anbasidur be conferlerate, or aicler, or comforter"

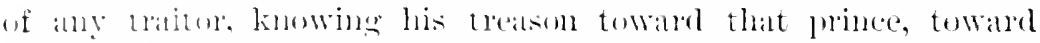
whoms and in whose realm he pretendeth to be ambasider, is mot

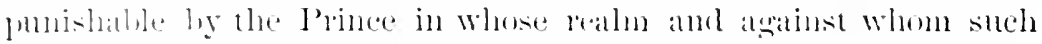

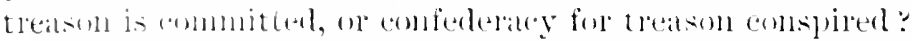

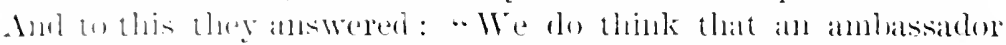

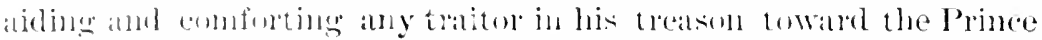

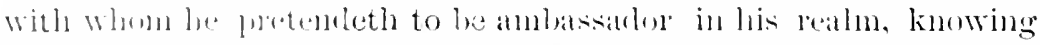

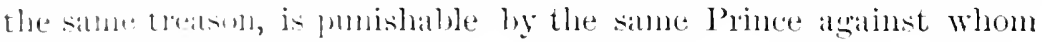
slleh treation is anmmitterl."

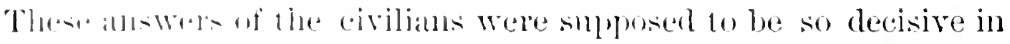
firrout the intentions of the comet. thatt the Bishop was sent for fomm lis confinement in the Isle of Fly, and after bejus shamply rebulied, was told le should 10 longer be considered ats an ambats- 


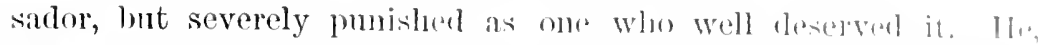

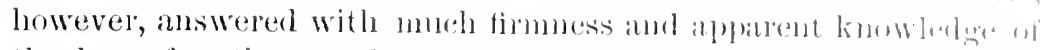

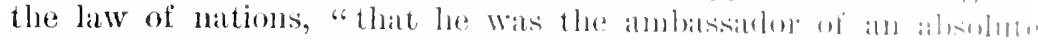

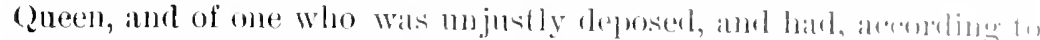

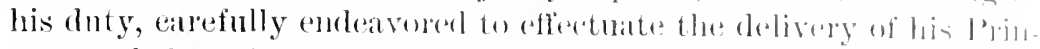

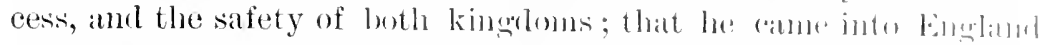

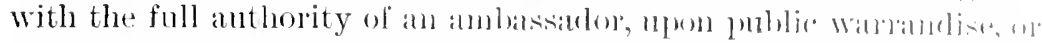

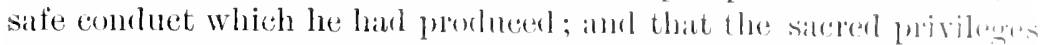
of ambatsadors were by no means to be violated."

Burleigh, in return, observed "that no privilege or pullic warrandise could proteet ambissalors that oflend against the pmbli, majesty of a Prince, but they are liable to menel actions lon the salure otherwise lewd ambassadors might attempt the life of Princes withont any pmishment." 'The bishop persisted in his positions,

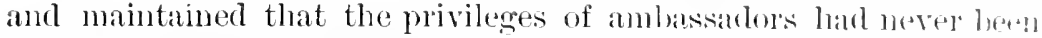
violated vir juris sed vir fireti, not by regular form of trial. lut by violence; his boldness, or the true view which he seems to have taken of this nice subject, appears so far to have weighed with the Ministers of Elizabeth, that they dicl not dare to plut him to death. with the Duke of Norfolk and other consplinators, but after duaining lim for some time in prison, banished him the country in 15\%:;.

MENDOZI'S CASE, 1584.

(Ward's Law of Nations, II., 522.)

An ambassador cannot be punished, but may be sent out of the country.

In the year, 1584, Mentoza, the spanish ambassador in Englind, laving eonspired to introrluee foreign troops, and detlorome tles Queen, it was a matter of diffienlty how he should be pmisluel. Ind the council thought the opinions of Lewis Dale and the othere civilians good law, they probably would have ated npon them ; for here was a case precisely similar to that on which they lanl heen consulted. 'They however took the opinions of the celehriater $117 x^{2} l^{2}-$ icus Gentilis, then in England, and of Ifottoman in Franee, who luth asserted that an ambassalor, though a conspirator, conle wot he lut to death, but should be referred to his principal for punishment: or: (according to IIottoman) sent away by force out of the country. In consequence of this, Mendoza was simply ordered to deprirt the realm, and a commissioner sent to spain to prefer a eomplatint against him. (Camden, 296.) 


\title{
(CASE OF DA S. 1G,
}

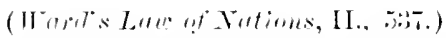

The brolher of an ambassator and a member of his suite, was executed, for semtition and murder.

- In 16ir:; I on Pantaleon sia, hother to the Portugnese ambassador

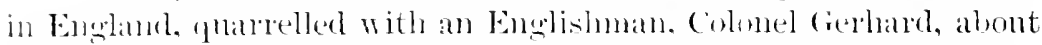
sme matter in the new exchange ; a senitle emsned, in which Gerlatd was serelely womded. The pramel was renewed the next day, at the sime place: hut this time sa came with fifty followers, all armed to the teeth, with the deliberate intention of destroying his alversary. The result was, that many English were womnded, and me jerson (a Mr. (i)eenway), aceidentally present, killed; that the (inamls were called in, and fired upon ly the Portugnese, several of whom they took to prison; the rest, with sa, took refuge in the hotel of the Portugnese ambassador. The ambassator wis afterwards required to deliver ne others, of the delinguents, which re. puest lue complied with, and his hother was anong them. IJe

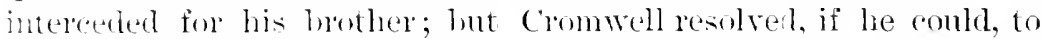
tly him ly the law of the land. He, therefore, comsulted the most minuest of the pofessors of the civil haw to settle hor such a har-

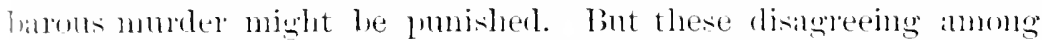
themselyes, he left the deesion of the atfair to a comt of delegates, ansisting of the Clief .Justice and two other jurges thee noble.

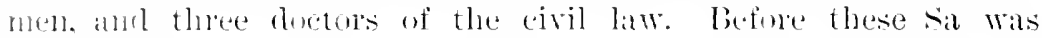
(examinierl.

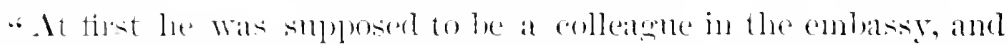

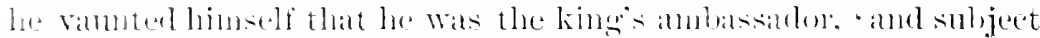
wo the jurisdietion of 110 one else: Ile was malle lowerer, to pro-

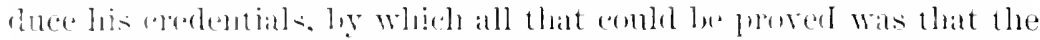

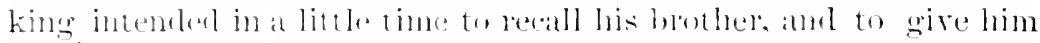

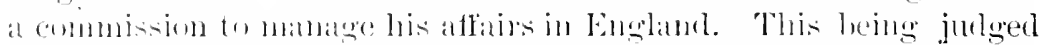

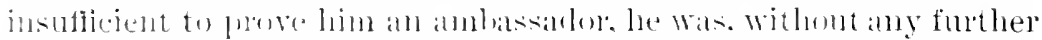

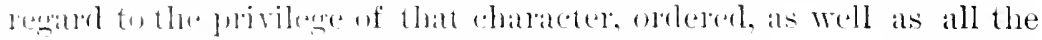

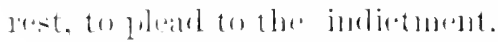

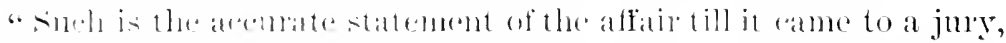

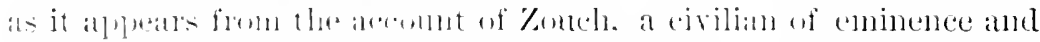

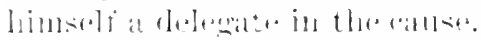

"It is evirlent. from this aceont of the matter, and one of more 


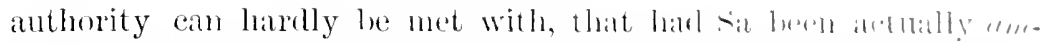

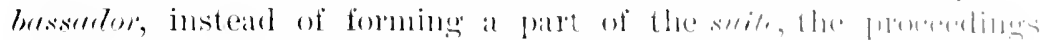

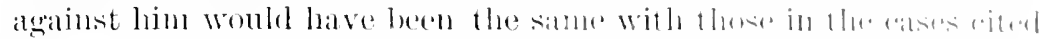

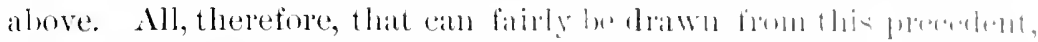

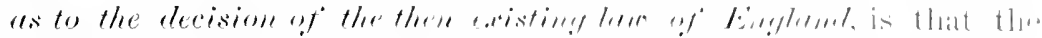

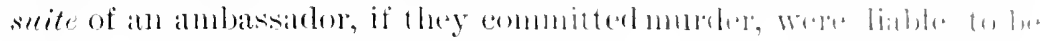

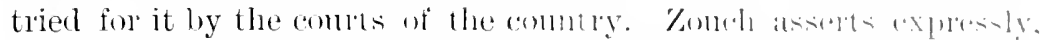

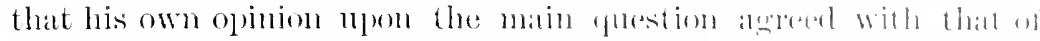
Gootins and the best authors, as to the exemption of ambissadols

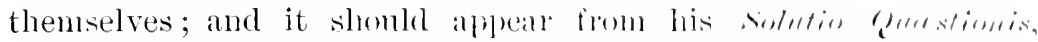
that if sa could have prover that he was an atetual ambatsider, his plea before the delegates wonld have been allowerl."

\section{GTLLENIBORG' CASE, 171\%.}

\section{(Itordx Law of Vulions, II., its.)}

It was held in this case, that if an ambassater conspires to orembow the grovermment to which he is accredited, he may he arrested: and that his praper's may be seized.

On the 29th of January, 1717, the wovernment of England laving certain information of a eonspirary to invade the combly and dethrone the King, contrived by Gyllenborg, the ambassinlar of swerlen, at that time at peace with Great Britan; they ordered the arrest of that minister, which was aceorelingly effected. Gencral Walle and Colomel Blakeney to whom the dhange was entrusted, fomm him making up dispatches, which they told him they hat molers to soize; and they even insisted upon searehing his cabinet. Which, "1pon the refusal of his lady to deliver the keys, they actually holie open. Gyllenborg complained of these proceedings, as a direct hreach of the law of nations, and some of the foreign ministels at the court of London expressed themselves to the same eflect; npm which the secretaries of state, Methuen and stanbope, wrote rircular letters to them, to assign reasons for the arrest, which satisfied them all except Montleone, the Spanish ambasiarlor, who in his answer observed, that he was sorry an other wny conld be fallen upen for presserving the peace of the kingtom, than that of the arlest of at public minister, and the seizure of his papers, which are the repositories of his secrets, two facts which seemed sensily to wrmm the law of nations. The observation, however, answers itsell: since

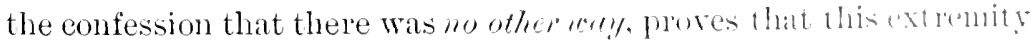
was the simple consequence of those mirersal laws, which erer will 
and must overcome all other; I mean legitimate necessity, and self. defence.

\title{
PIINCE CELLAMLRE'S CASE, 1T19.
}

\author{
(Whitents romses rithores. I., 149.)
}

For conspiring against 1 he $^{2}$ state an ambassator was arrested and conducted acros the fromter into his own comnly.

Prince cellamare the ambassador of spain at Paris, was the instrument of Alberonis hostile intrigues aganst the regent.

Ie was in close correspondence with many of the malcontent French molility, lut his chief confindints were the Duke and Duchess of Inine, who hat never forgiven the Inke's removal from the posts of authority asigned to him by the will of Louis XIV.

1 blot was oreminged (though it seems douhtful how far the design was serimsly entertainerly for carrying off the regent into Fiain, and placing Philip $V$. at the head of the French Government. Asistance was expected from Brittany, which was just then in agitation in comsequence of an attempt against the ancient privileges of the province: and a fleet was actually dispatched from spain to support the insurection. The confelerates, however, were hetrayed to Dnbois; an agent of Cellamare was seized at Poitiers on his way to Itarlid : and dispatches of which he was the bearer fully compromised all the principal parties to the scheme.

A detachment of troops was sent to guard the hotel of the ambassarlor. while the Minister of War. Le Blanc, and the Minister of Foreign Ifrairs, Dnbuis, mate an examination of his papers.

Cellomare aldrated to the other ambassadors resident in Paris, lont reatrding such a consuracy as depriving him of all privileges, they refused to interfore.

On the other hand, to justify these extreme measmes, the regent publisherl a circular letter to the foreign ministers setting forth the firctio of the comsunacy, and the imminent dinger to the state.

fome lays later. letters of cellamare were made public, which prover conchnsively his lart in the emspiracy.

Cellamane was then confined in the chatean De Iblois, with orders to detain him there till the French ambassador at Madrid should arrive in liance.

On the llews of the arrival of the Fench ambassador at Bayonne,

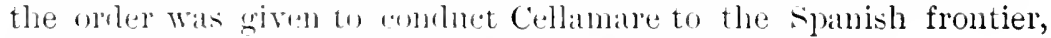
ant this order was carried out on the bth of March, 1719. 
(li) Crivil .roristliction.

\title{
TIE AMBASSAIOUR OF PETER THE GRLAT, GM.
}

\author{
(Blackstone's Commentarios, Bowl. I., CHap. VII.)
}

Neither an ambassador nol any of his suite can bre proserented bor any lim or contract in the courts of the country in which they residte.

"In respect to civil suits, all the foreign jurists anpee, that meither. an ambassador, nor any of his train or comites, can be prosecuted for any debt or contract in the conrts of that kingrom wherein las is sent to reside. Yet vir Edward Coke maintains, that, if an an!bassador make a contract which is good jore femtimm, he shall answer for it here. But the truth is, so few eases, if any, had arisen, wherein the privilege was either claimed or disputed, evon with regard to civil suits that our law-books are, in seneral, quite silent upon it previous to the reign of Queen Ame; when an ambasialor from Peter the Great, Czar of Museovy, was actually arresterl and taken out of his coach in London, for a deht of tifty pounds which he had there contracted. Instead of applying to be dischanerl upon his privilege, he gave bail to the aetion, and the next dia complained to the Queen. The persons who were concerned in the arrest wree examined before the privy council, of which the Lord Chief Justice Holt was at the same time swom a member, and seventeen were contmitted to prison: most of them were prosecuter by information in the Court of Queen's Bench at the suit of the attorney-general, am at their trial before the Lord Chief Justice were convicted of the facts by the jury, reserving the question of law, how fill those facts were criminal, to be afterwards argued before the judges; which question was never determined. In the meantime the Czar resenterl this affront very highly, and remanded that the sheriff of Middlesex and all others concemed in the arrest shonld be pmished with instant death. But the Queen, to the amazement of that despotic comrt, directed her secretary to inform nim 'that she could inflict nu pmuishment upon any, the meanest of hei subjects, mless warranterl ly the law of the land; and therefore was persuaded that he womld not insist upon impossibilities.' To satisfy, however, the clanmos of the foreign ministers, who made it a common cause, as will an to appease the wrath of Peter, a bill was brought into parliament. ankl afterwards passed into a law, to prevent and punish smch ontrateous insolence for the future. And with a copy of this act, eleyilutly 
engroside and illmminated, accompanied by a letter from the Queen, an ambarsitur extrandinary was commissioned to appear at Moscow. Who declaterl that though her majesty comld wot inflict such a pmishment ats was lepuired. becanse of the defeet in that partieular of the former established eomstitutions of hel kingriom, yet, with the mamimoms comsent of the porlinment, she himl eamsed a new alet to le passerl, to serve ats a law for the futme." This hmmil-

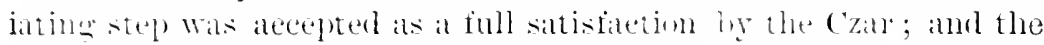
offenders, at his request, were dischalged from all ialther prosecution.

." This statute recites the arrest which had betn makle in contempt of the protection grimted hy her majesty. contraty to the law of nations, and in prejudiee of the rights and privileges, which ambassadors and otler public ministers lave at all times been thereby posscised of and ought to he kejt sacred and inviolable:' wherefore it enats that for the future all process whereby the person of any ambassirlor, or of his domestic or domestic servant may be arrested, or his was distrained or seized, shall he utterly null and void; and the lerwhs frosecuting, soliciting, or executing slteh process shall be leemed violiters of the law of nations, and distmbers of the public lepuse: and shall suffer such penalties and eorloral punishment as the birl chancellor and the two chief justices, or any two of them, shall think fit. But it is expressly provided, thit no trader within the rescription of the bankrupt laws, who shall be in the service of any ambasidur, shall be lubileged or protected hy this act; nor shall ang we be flumslued for arresting an ambasador servant, unlesis his mame be registered with the seeretary of state, and by him trin-mitted to the sheriffs of I.ondon and Midnlesex. Exeeptions that ane suretly eonformable to the rights of ambassadors as observed in the most eivilized eomtries. And, in eonsequence of this statute, thus leclitring and enforcing the law of nations. these privileges are now held to be part of the law of the land, and are constantly allowed in the cuurts of common law."

\section{T.IYLOR v. BENT. \\ Conmer Plesis. 1554. \\ (14 C'munerm Burth, 4-i.)}

A publie minister who whage in tratte in the sontry w wheh he is accred-

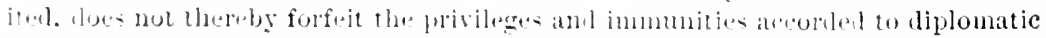

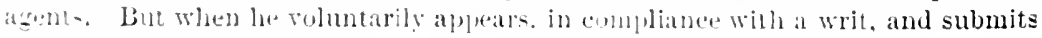
himself to the jurisdiction. the conr will nut interfere for his relief. 


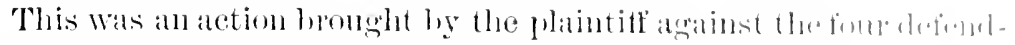

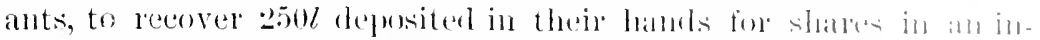

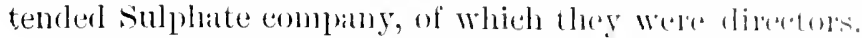

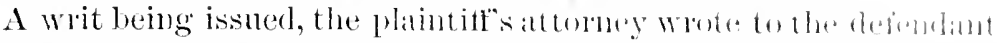
Dromet, asking the name of his solicitor to whom ha shomle semel the

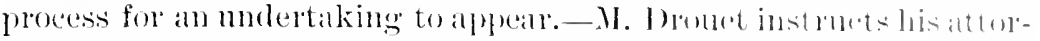

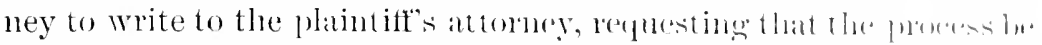
sent to him. The eanse came to an isstle, motice of trial wat wirm, appearance daly entered and J)rouet obtaincel a rule for a sperial jury.

Two days later Irouet took ont a smmmons on the of hel parties to the suit to show why all procedings shombl not he stalyed, on. why his mane should not be struck ont of the proceedings on the ormul that he was protected from such a suit hy reason of his heing a puldie minister, first seeretary of the Belgian legation at the conle of it. James.

The defendant Drouet ol,tained a rule misi.

Jenris, C. J. :- "This ease was very elabualtely argued yestermay, and the importance of the subject indueed the cont to take time to losk into the various authorities which vere referred to. I an of opinion that the rule should be discharged. There is no dombth that the defendant Drouet fills the chatacter of a public minister to whir.h the privilege contended for is applicalble: and I think it is ronally clear, that, if the privilege does attach, it is not, in the ase of an ambassador or public minister, forfeited by the party's engaging in trarle, as it wonld, by vintue of the proviso in the 7 Anne, c. $1.2, \mathrm{~s} . \overline{\mathrm{s}}$, in the case of an ambassador's servant. If an ambissarlor or pullic minister, during his residence in this country, violates the chatroter in which he is acerediterl to om comt, by engaging in commereial transactions, that may raise a question between the govemment of this comntry and that of the comntry by which he is sent; but he loves not thereby lose the general privilege which the law of natioms has conferred upon persons filling that high charater, - the powiso in the statute of Anne limiting the privilege in cases of traling applying only to the servants of the embassy.

"For this, Barbuit's Case, Cas. Temp. Talbut, 2s1, is an anthority.

"Admitting, then, that M. Dronct is a person entitled to the privileges and immmnities which the law of England acomets to annbassadors from foreign friendly conts, and that he does und fortuit them by engaging in commercial ventures, - the poestion is whethele

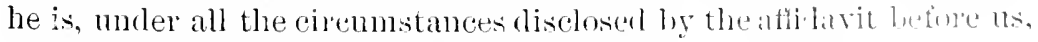
entitled to the privilege which he claims.

"Although it is admitted that no process can lua aribible agrainst 
the person or the goorls of a foreign ambassarlor or minister, no case has beth eiter to show that an application in the present form, to stay all purecelings, is avalable in the comts of this country. On

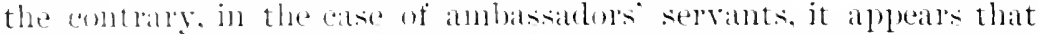

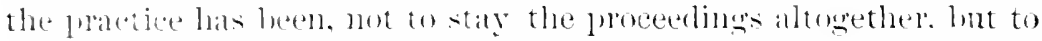

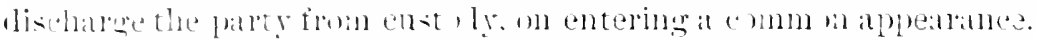

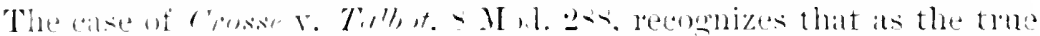
grinciple. The motion on the palt of the defendint there was to set

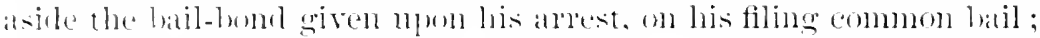

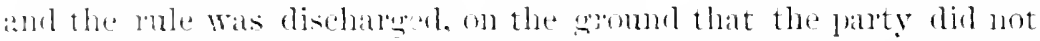
ming himself strictly within the privilege allowet to the servant of an anhassulu': the contet holding that, to entitle him to the privilege, he onght to he a tomestir servint, and really to exercise the duties of the whe and that his heing a mere nominal servant is not enomoh.

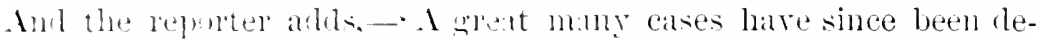
temined npon the same principle: hut it was in these cases held, that the inlea of a domestir servant was not confined to his living in a fonein minister's lonke, porided he was a real servant, an!l antmally gerformed the service. The course, therefore, seens t) have been in these cases, not to more to stay all proceedings. but to meve to set aside or cancel the bat-homd, upon the defendant s filing; common hail. No case has been eited of a motion to stay the proceedings. where the persomal liberty of the applicant has not heen intufered witl. Further, I am aware of 11 , ase in which. where

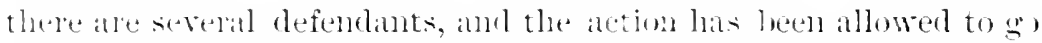
on to the verere of trial, the procectings have heen staged upon the applieation of one of the defendants.

"sucha contre wombl he obviomsly mjust to the other defendints,

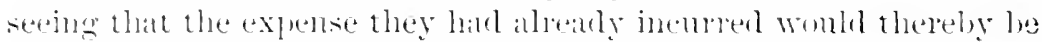

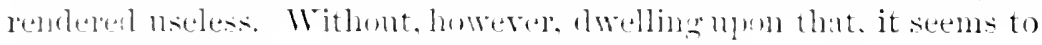
me that this motion most fail, upon the merits.

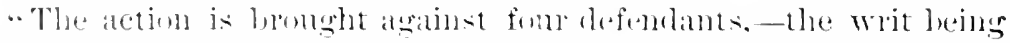

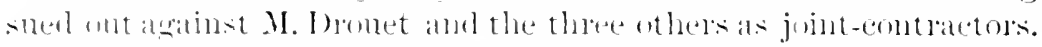

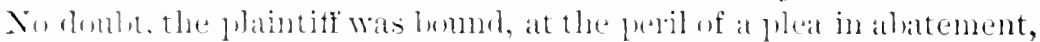

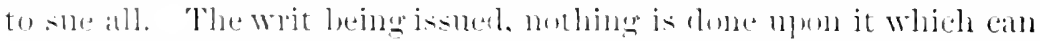
at all interele with the exereise ly 11 . Inomet of his rliplomatio

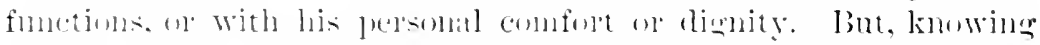
that a wit hats isolled. ol haviner reason to helieve that it is about

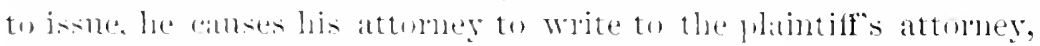

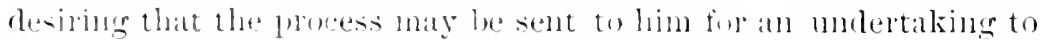

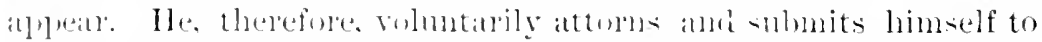

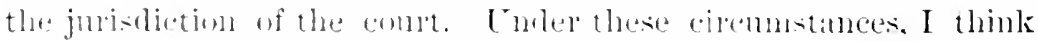
lec camnot be permitted mow to complabin thate the suit has leen im- 
properly instituted andinst him. On the contribly l think, that. hy

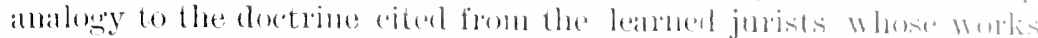

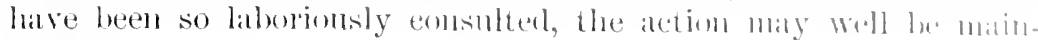
tailinel.

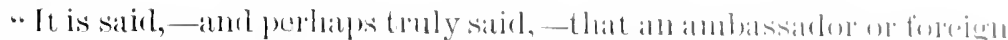

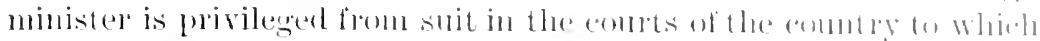

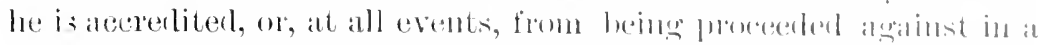

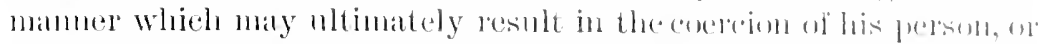

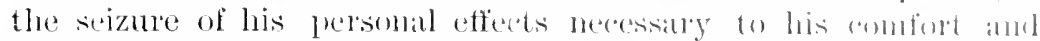

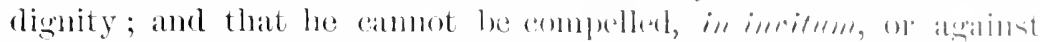
his will, to engage in any litigation in the entuts of the amontry to which he is sent. IBnt all the foreign jurists hold, that if the shit ean be fomoled without al tacking the persomal liberty of the and als. sador, or interfering with his elienity or persomal andort, it maly proceed. Valdous passages have been cited to show, that, in commbrim, where the Civil law prevals, and where jubstietion and be fommlenl by a proceeding in rem in the first instance, where there an homses or lands, which are immovalile, that may le taken to fomml tho jurisclietion, the suit maty procete Movalule gomels, tom, which are meomnected with the personal comfort and dignity of the ambassulor, may be taken for the sume purpose.

"And when we consider the effect of the procerling, and what may be done hy the party sued, there seens to he no substantial distinction hetween the two moles: beanse, althom it is trute, that, in

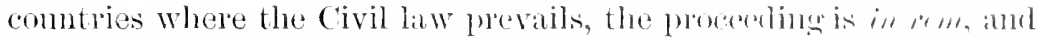
the means of litisation between the parties incirlentally establishod withont any molestation or interterence with the person of the do.

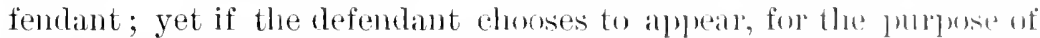
proteeting his goods and investigating the matter in thispute. he may convert that which was originally a proeerling in rem into a por ceeting in persomem. And such is eommonly the eomrse in the scotch eourts. If, therefore, as in I Iollame, and in somentlen commeries,

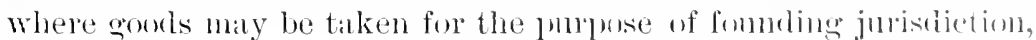
the defendant may eome in and convert the proverling in rem intu

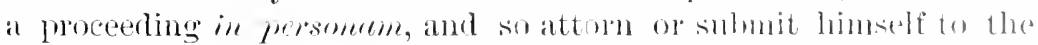
jarisdiction, it seems to me that there is no distinction leetwon that

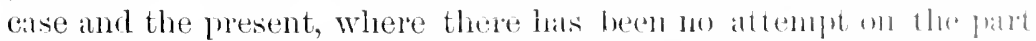
of the plaintiff to disturl, the comfort or intertere with the pustomal liberty of the foregign minister ; he where there has herell 1 he moro

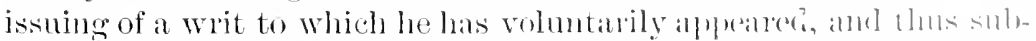

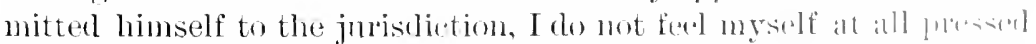
by the argument urged hy Mr. Willes, that the privilume in thestion,

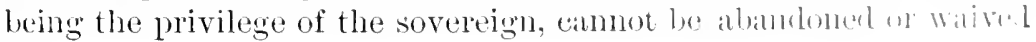


by the andhassalon; for, when the anthoritjes upon which that argument is onmht to be sustained, come to be eximnined, they do not shew that the ambasidos may not submit himself to the juristiction for the funduse of having the matter in difference investjested and

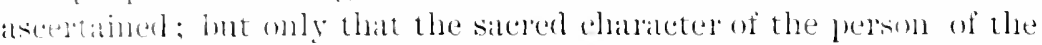

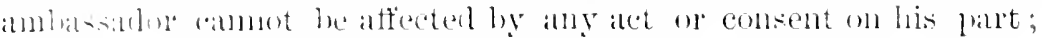

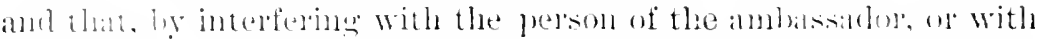

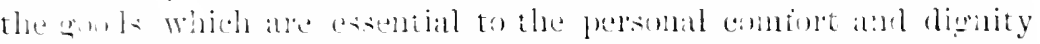

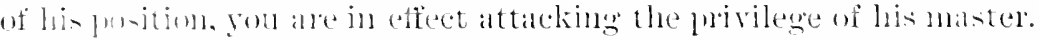

That, hemerer, is not the case here; for anything that allpears,

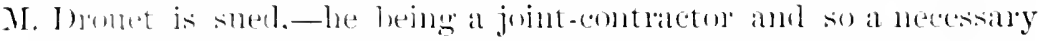

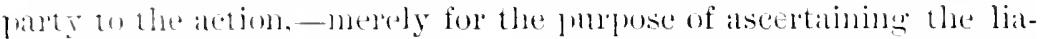
libity of the ofles defendants. If he had not thomeht fit ro attom

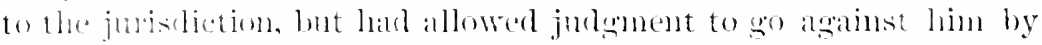
defanli, ane anstat that anything would have been douse mous the

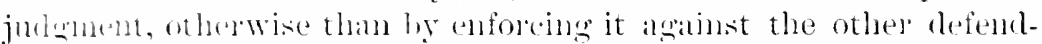
ant-. If any a. so. of fi fir. were issued agaiust him upon the julgment. the statme of Ame would have applied, and the compt might

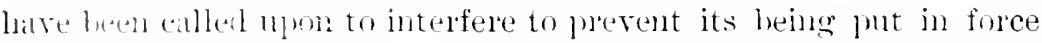
agimat him. It seems to me that M. Mronet here has courted the jurisdirtin, and that we onght not to interfere."

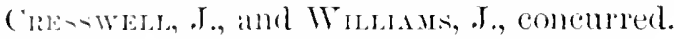

Peresm, for the platintiti, asked for costs.

Pe, C'urium.-. We saly nothing abont costs.

Rule dischargee.

\title{
WIIEATONSCASE.
}

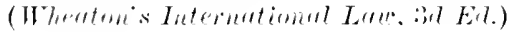

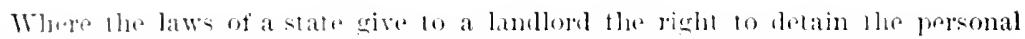

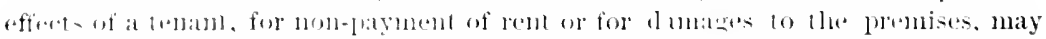

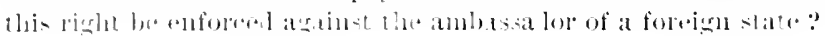

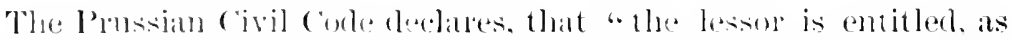

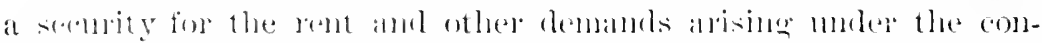

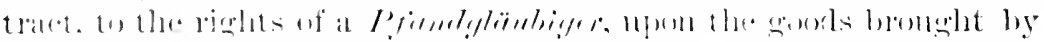

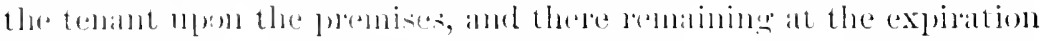
of the leatse."

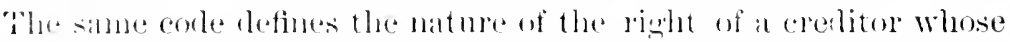

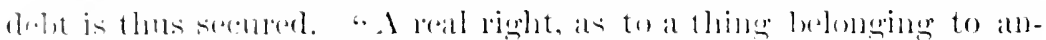
othed, assigned to any letson ats security for a debt, and in virtue of 
which he may demand to be satistied ont of the sulstmme uf Hh.

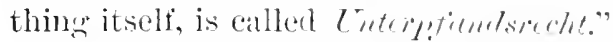

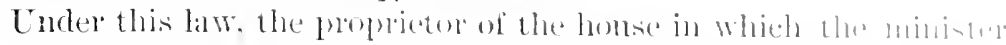

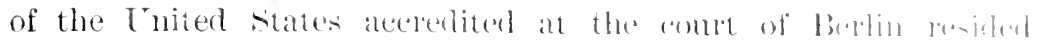

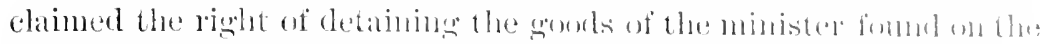

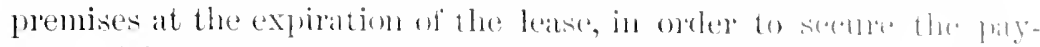

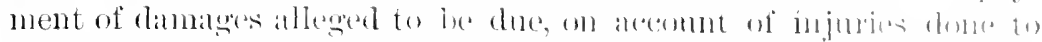

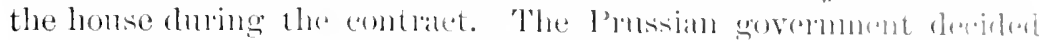

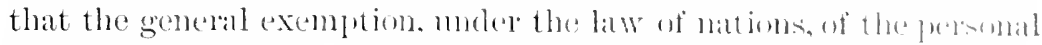

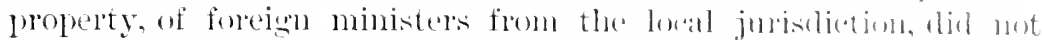
extend to this case, where, it was contombel, the right of denemtion

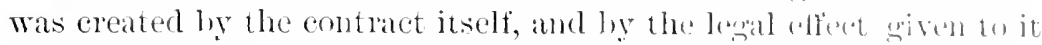
by the local law. In thes seranting to the propletere the rishts of at

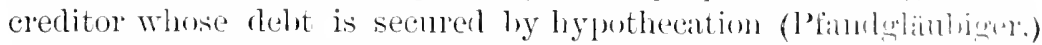
not only in respect to the rent, but as to all other demamls arime under the contrat, the Prussian Civil conle confers upm him al i, ll riglet as to all the effects of the temant, which may be formel an the premises at the expiration of the lease, by means of which be may retain them, as a seeurity for all his chims derivel fom the contract.

It Wals stated, by the Ameriean minister, that this decision pilaced

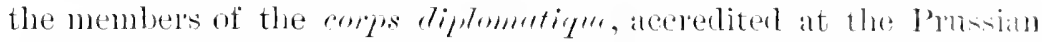
conrt, on the sime footing with the smbjects of the eomntry at to the right which the Prussian Corle confer's upon the lessol of asitraining the gooks of the tenant, to enforce the performande of the contract. The only reason allexed to justify such an exeption to the general principle of exemption was, that the right in foluelion

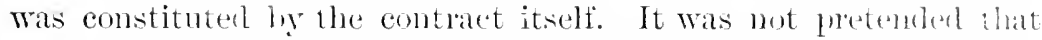
such an exception had been laid down hy any writer of anthenity on the law of nations; and this consideration alone presented a stomen objection against its raidity, it being notorions that all the exiphtions to the principle were earefully emmmerated by the nust esteemed pullic jurists. Not only is such an exeeption not anfirment

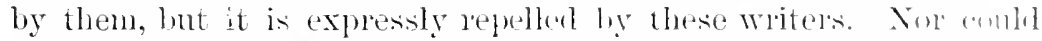
it be pretended that the practice of a single govermment, in at simeles case, was snmeient to create an exception to a principh which all nations regarlent as sacred and inviohible.

Douhtless, by the Prussian Corle, and that of most other nations, the contract of hiring gives to the proprietor the right of seizing. an detaining the ands of the tenant, for the non-paymont of rem. of damages incurren by injuries dome to the premises. But the flumtion here was, not what are the rights eonferred by the muni ilul laws of the conntry upon the proprietor, in respect to the terlatit 
who is a sulject of that combly; but what are those rights in re-

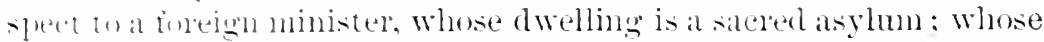
fersm and property ale entilely exempt from the lotal jurisdiction; and whe (am only be compelled to perform his entrats ly an apjoal to hi- own govelnment. Hele the eontrat of hiring consti-

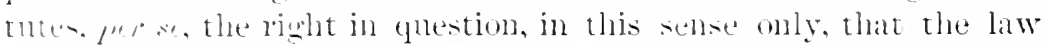

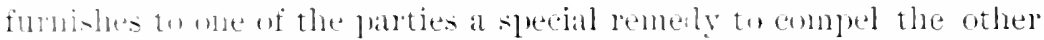
(1) Jufurn its stipulations. Insteal of eompelling the lesson to resont to it fersomal aetion against the tenant, it gives him a lien upon the ands fomme on the premises. This lien maty be enforeed agibint the sulijeet of the comntry. becanse their goods are subjeet to jis daws and its dibmals of justice; but it emmot be enforeed aginins foreign ministers resident in the comntry, because they are sulpicet neither to the ane nor to the other.

Th deprive a minister' of his privilege in this case would be to deprive him of that indegendence and secmity which are indispensably mecessary to enable him to fultill the duties he owes to his own wovermment. If a single article of funiture mal be seized, it may all be seized, and the minister, with his fanily, thus be deprived of the means of sulsistence. If thesanctity of his dwelling may be riolater for this purpose, it may be violated for any other. If his frivate poperty may be taken mon this pretext, the property of his grovement, and even the arehives of the legation, may be taken upun lhe same pretext.

In leply to these aroments it was mede on hehalf of the Prussian gorermunent, that if, in the present eatse any Prussian anthority

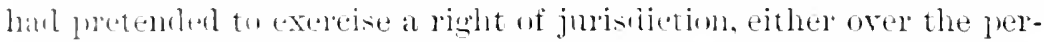
soln of the ministel ar his property, the solution of the question would dombtesingertain to the law of nations, and it must be determines atreording to the precepts of that lats. but the only question in the present case eould be, what are the begil rights

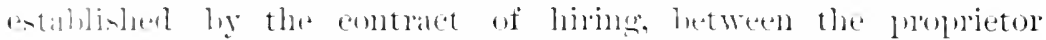
anel the temant. To deternine this question, there combl be no otlere me than the eivil law of the comntry where the contract was malu, and where it was to be executerl, that is. in the present (at-r. the civil come of I'mosiat.

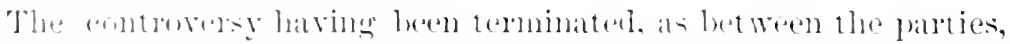

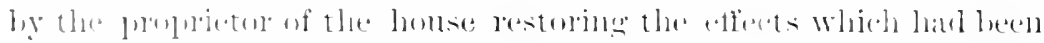

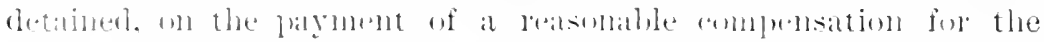

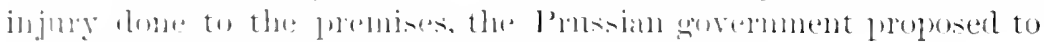
the Ameriean grosernoment the following question:

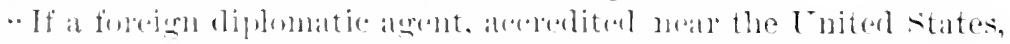
enters, of his own aleeorl, and in the frestribul forms, into a con- 


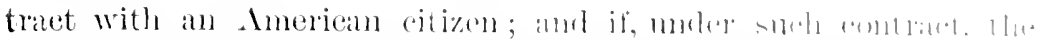

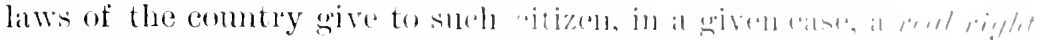

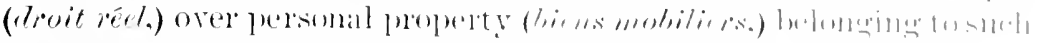

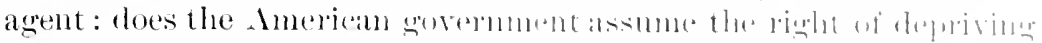
the American citizen of his renl right, at the simblhe instatuen of the diplomatic agent relying upm his extrit-terituriality "

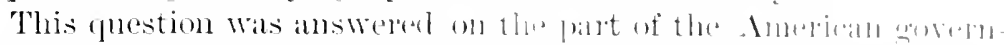

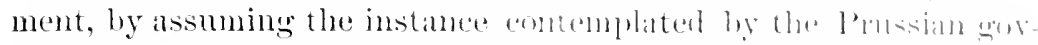

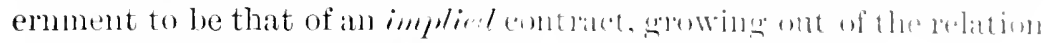
of landlord and tenant, hy which the former had seomed to him

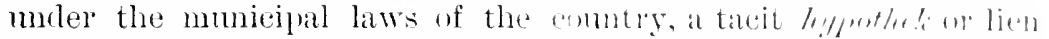

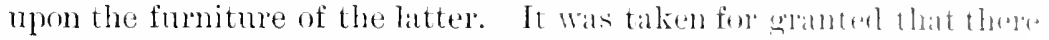
was no express hypothecation, still less any grime in flel./, which

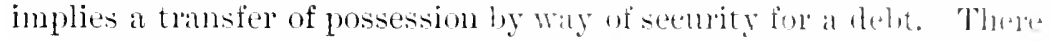
comld be uo dombt that, in this last case, the pamee has a enmpletr.

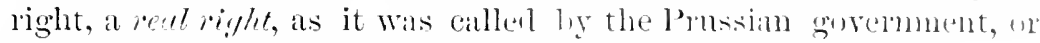
jus ine, ret in the least affected hy riplomatic immonities.

With these distinctions and qualifioations, the Amerion gosmon. ment had no doubt that the view taken by its minister (Wheatom) of this question of privilege was entirely correct. The serise of that govermment had been clearly expmesied in the act of Concress, 1790 , which inchdes the very case of distress for rent, anong oflue legal remedies denied to the creditors of a foreign minister.

The Prussian govermment adheren to its view of the cas, ant the question, therefore remained unsettled, as between the two gorernments.

\section{CASE OF B.IROX IIE WIECII, $17 \% 2$.}

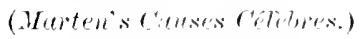

Is it an infringement of a minister"s diplomatic privileges to withhold his pass. ports, until his debts are paill?

In 17\%:, the Baron de Wrech, Minister Plenipotentiary of the Landgrave of IIesse-Cassel at the comet of Paris, Was recalled from his embassy. He was about to quit Paris withont paying the delus which he had contracted there. IIis creditors, especially a Mandais de Bezons, besought the Minister of Foreign Affatirs not to grant

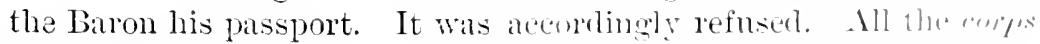
diplomatique at Paris remonstrated against this act ats at bulation of International Law.

The French Minister, le Duc al diguillon, replied in an chathenate 
memoir drawn un ly. I'fetfel. mon the Rights of Ambassaldors; refeuderl. mun the anthority of rrotius and bynkershoke the right of using that slecies of constraint against an anblusarlon which olid not interiere with the exerejo of his functions. Ile further appealed to the batcice of nther states. as waranting thestep which had been taken, and ejuecially to that of Hesse-Cassel itself, which had impris-

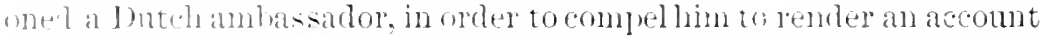
of a chardialde institution of which he had been the anministrator. It Was anduited that this attack on the person of an anbassador was indefensille. but it was arded that Holland had not denied the jurisdiction of Hesse-Cassel in the matter.

The Landgrave was compelled to make an arrangement with the creditors of the Baron de Wrech, before that minister could obtain lis passport.

CASE OF DEBOIS, 1856.

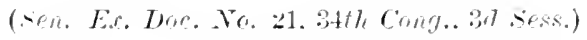

A foreicn minister cannot be compellel to appear before a court as a witness.

A case of homicide having occurred at Washington, in 1-iti. in the presence of the Duteh minister, whose testimony was deemed altogether material for the trial. " and inasmuch as he was exempt from the ordinary process to compel the attendance of witnesses," an aphlication was made by the district attorney, through the secretaly of state, to Mr. Jubnis to aphear and testify. The minister latving refused, 1,y the manimoms arlvice of his enlleagues, in a note of the 11 th of Mily, 1s.iti, to the secletiry of state, to alpedr as a Witness, Mr. Matrey, secretary of state, instructerl, May 15, 1856, Mr. lelnument, minister of the Inited states at the Inarue, to bing the matter to the attention of the Netherlands tiovernment.

Mr. Matrey sags that " it is not dombted that loth hy the usage of mations and the laws of the Cniter states. Mr. Dubnis has the legal right to rlecline to give his testimony; lut he is at perfect liberty to exereise the priviluse to the extent reduested, and hy dring so he does not smliject himself to the jurisdiction of the comntry. The circumstalloes of this case are such as to appeal strongly to the universial serse of justice.

"In the event of M. Van I Iall's surgesting that M. Dubois might give his deposition ont of connt in the ease, you will not omit to state that by our constitution, in all criminal prosecutions, the 


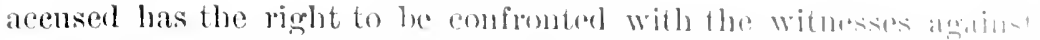

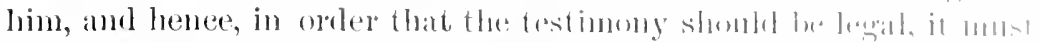

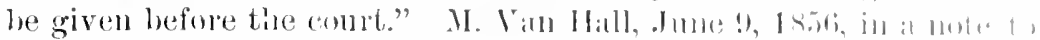

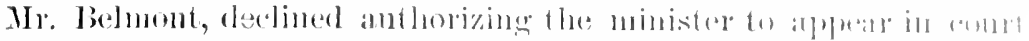

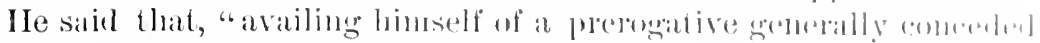

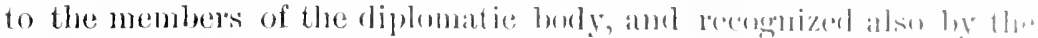

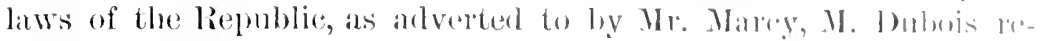

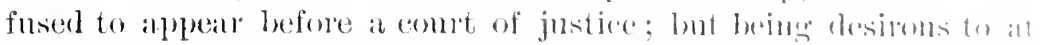

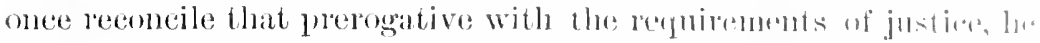

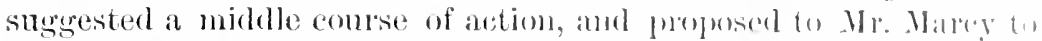
give his dechation muler anth, shomld he be anthorized to that effect by the Government of the Netherlands. After taking the King's orders on the sulject, I did not hesitate to give such anthority to M. Dubois, approvines at the same time, aml formally, the? line of conduct which he pursued on that oeeasion." M. Mnbuis addressed a note to Mr. Marcy, on the olst of .mme, stating llat he was anthorized to make his declaration morler oath at the I)epartment of state, adding, "it is molerstonl that, on sich an oreasion, no mention is to be made of a cross-examination, to which I andel not suljeet myself." The declaration was not taken, as the distriet attorney stated that it would not be admitter as evidences.

\section{DILLON'S (ASE, 1854.}

\section{(1 Itluarton's Digrest, 606.5.)}

The elanse in the Constitution of the United States whith gives a persmancuse]

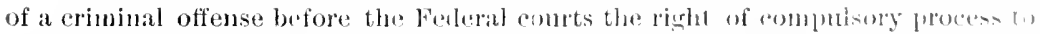
procure the presence of witnesses in his favor, and to be confronterl by the wit. nesses against him, prevails over a treaty which exmpts the consuls of a formen State from appearing before the courts as wituesses.

In 1854 Mr. Dillon, then comsul of France at San Franciseo, Wits brought into the United States l)istrict Cont, then sitting, (n) an

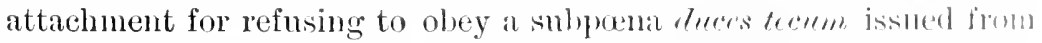
that court to compel his attendanee at a criminal trial then ant there pending. Mr. Dillon protested andinst the plocess on two grounds: (1) Immmity from such plocess by intermational latu: (2) immunity under the French-Ameriean treaty. The seend puint

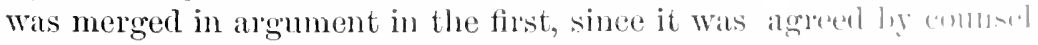
that the treaty privilege could not stand in the way uf a larty"

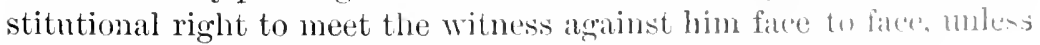
that privilege was in accordanee with pullic international law.

On this question the court (IIvfrus, J.,) spolie as follums: 
- It the atemsed. he vinte of the comstitutional povision in this:

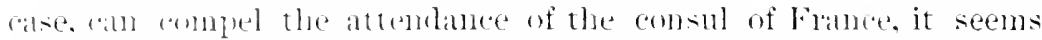

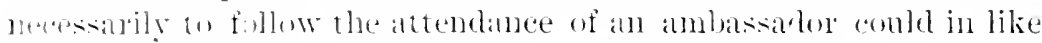

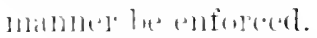

." The immmity atromeder to and persomal inviolability of ambassa-

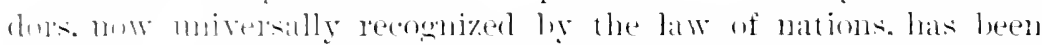

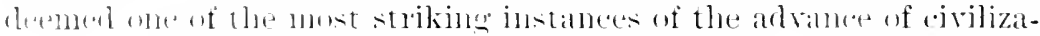

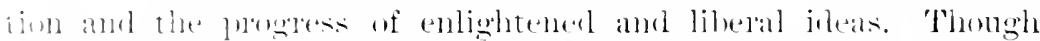

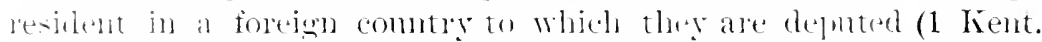
cim. fis), thril gersons hare. ly the comsent of all mations, been

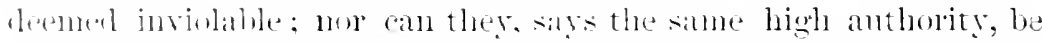

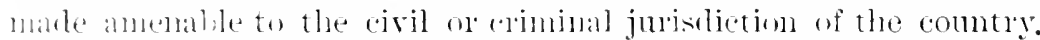

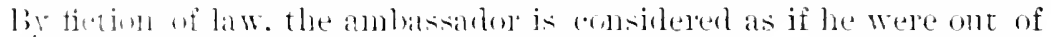

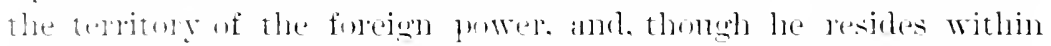

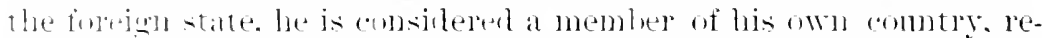
tainime his oldeinal domicile, and the Govelmment he represents hats

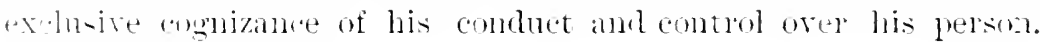
(1 kent: (om.. tii.)

- Ines them, the Constitution of the Cuiter states, ly the provi-

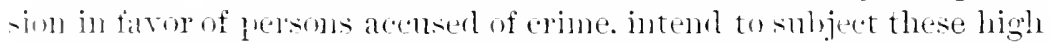
fimetimnates to the process of the emmts, and does it anthorize and

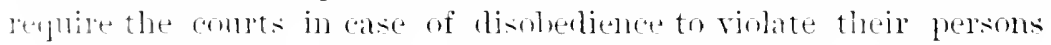

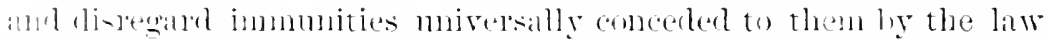

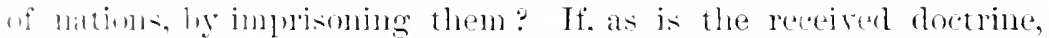
tise ambasidur cammot, eren in the atse of a high crime commiated ly limsulf, he proceeded against, it is olwioms that for a lesser

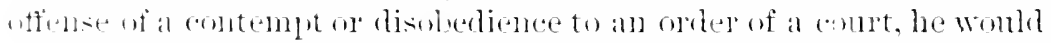

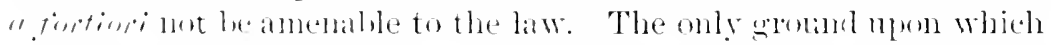
the light of a connt to compel the attendance of an anmasardon hy

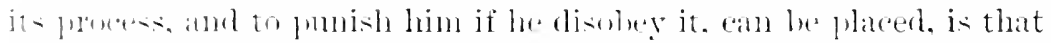
the cinnstution is in this case in conflict with ame paramoment to

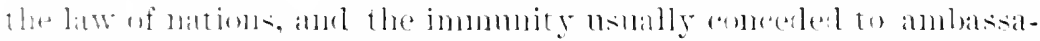

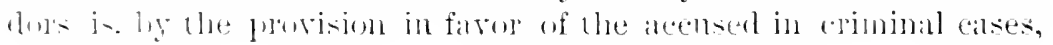
takine awals.

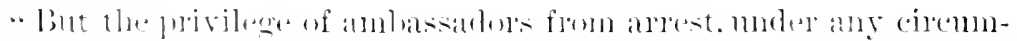

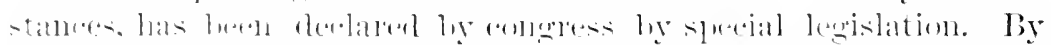

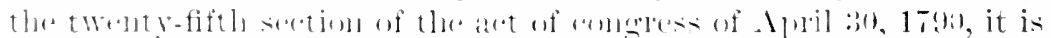

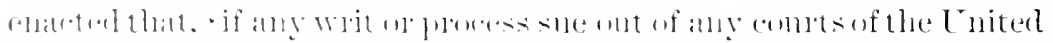

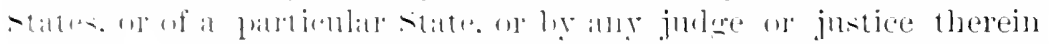

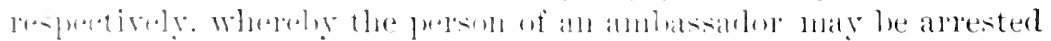

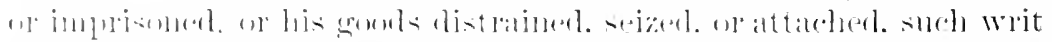

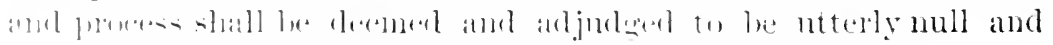

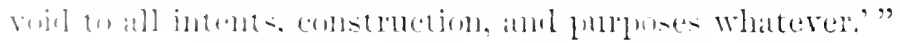




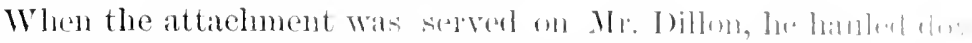

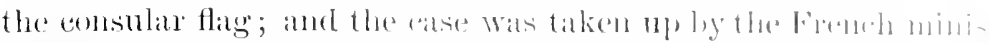

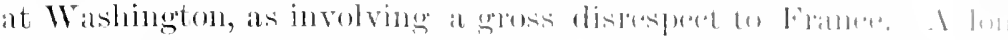

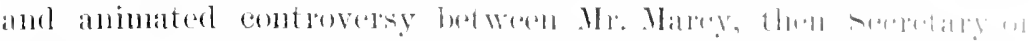

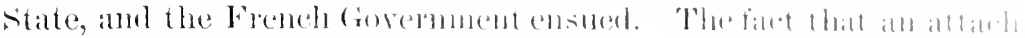

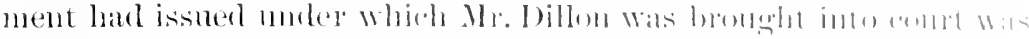

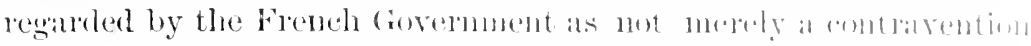

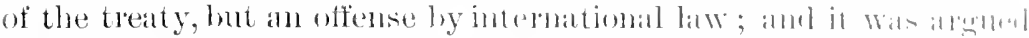

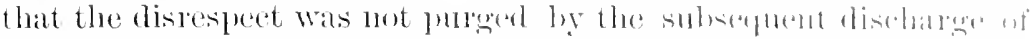

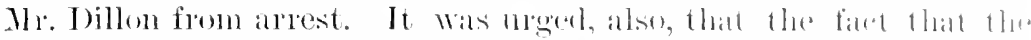

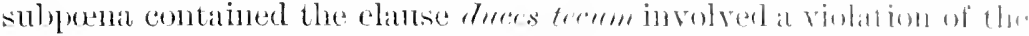

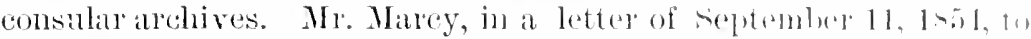

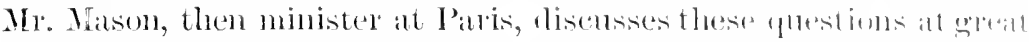
length. Te maintains that the povision in the Ferlenal (amstitution

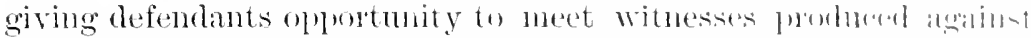

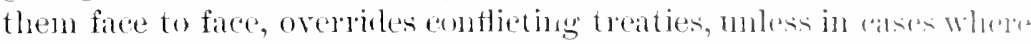

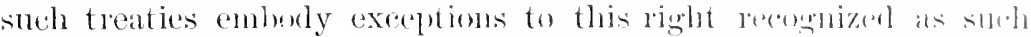

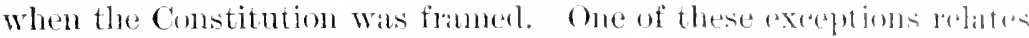

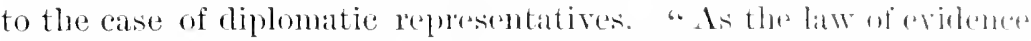
stool when the Constitution went into effect," ways Mr. Mitr"y. "allnhassadors and ministers eould not he served with ampulsoly plocess to appear as witnesses, and the dause in the comstitntion re-

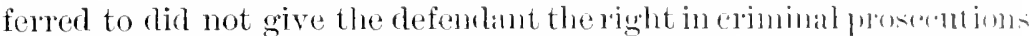

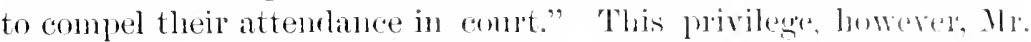
Marey maintained, did not extend to consuls, and consuls, therefore. conk only procure the privilege when given to them hy trang whinh. in criminal cases, was subject to the linitations of the comstitutim of the Cnited States. Mr. Marcy, however, finding that the French Goverument continned to regarel the at tarhment, with the sulperhit deces tecum, as an attack on its homor, oflered, in a lottor to. Mr. Mil-

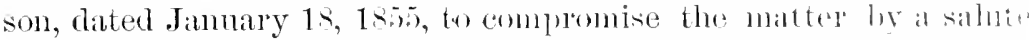
to the French flag upon a French man-of-war, stoplung at sin Franeiseo. Conut de Sartejes, the French minister at Washington. asker

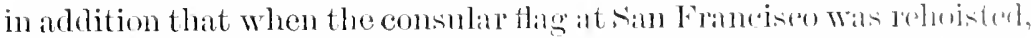
it shonld receive a salute. This was dedined hy Mr. Minreg.

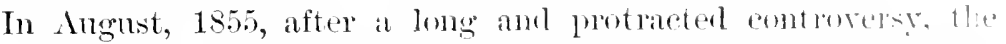
French Government agreed to accegit ats a sufficient saltistimetion an

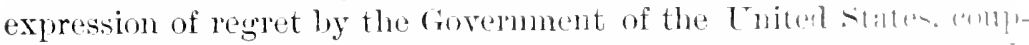
led with the provision that "when a French national ship w spmatron sluall appear in the harbor of sin Francisen the ['uitul sallas authorities there, military or naral, will salnte the mattional that

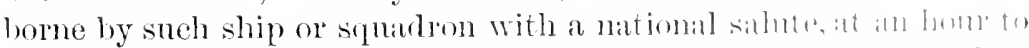

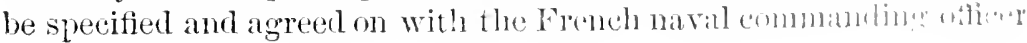




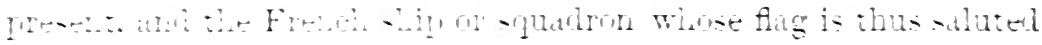

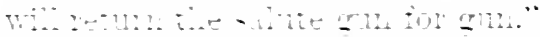

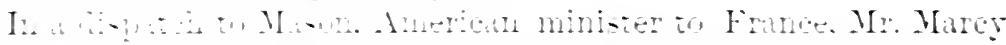

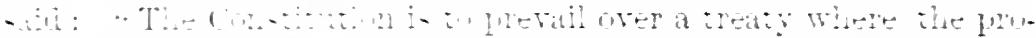

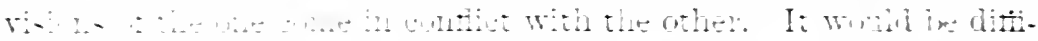

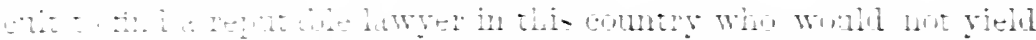

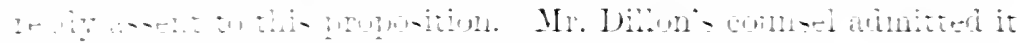

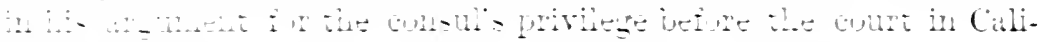
i $2 \cdot$.

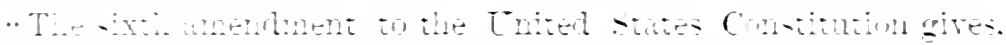

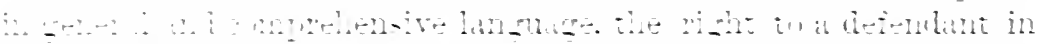

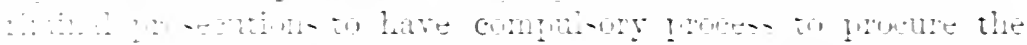

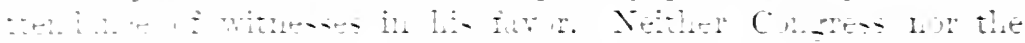

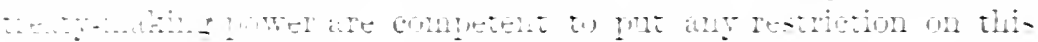

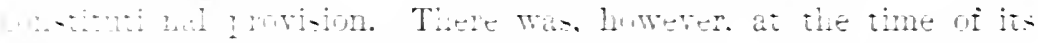

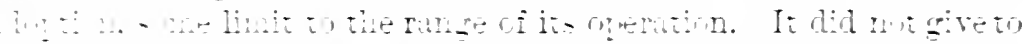

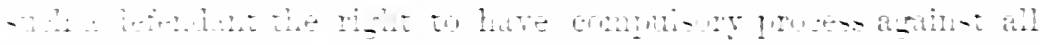

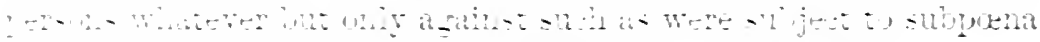
a

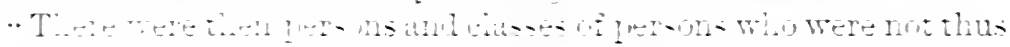

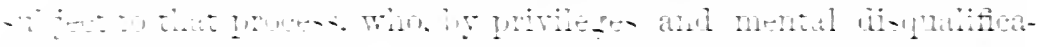

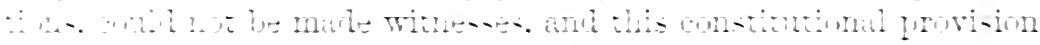

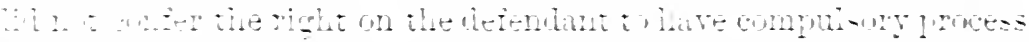

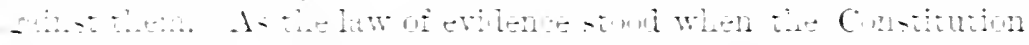

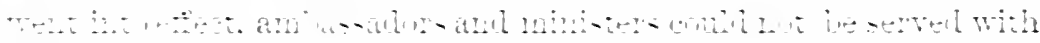

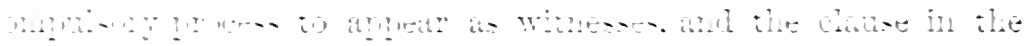

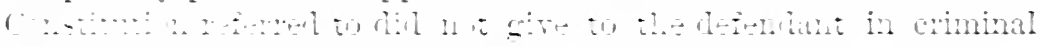

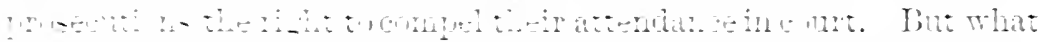

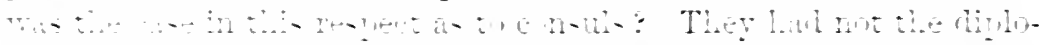

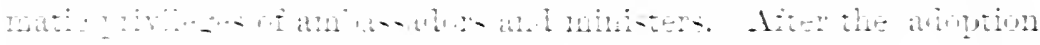

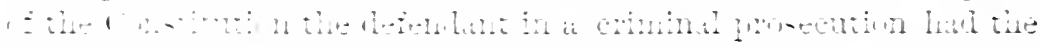

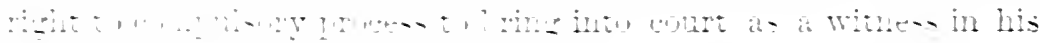

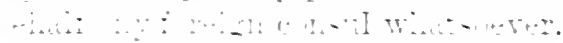

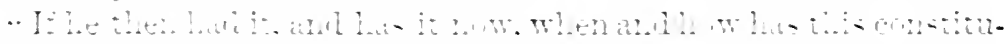

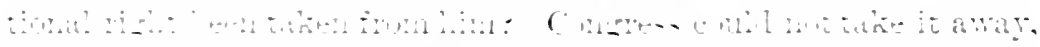

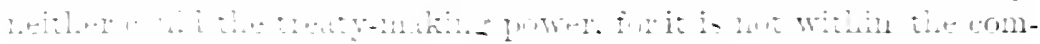

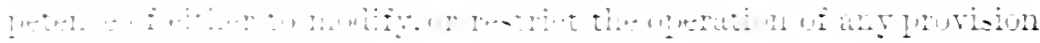

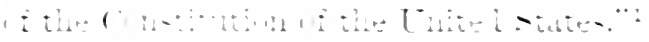

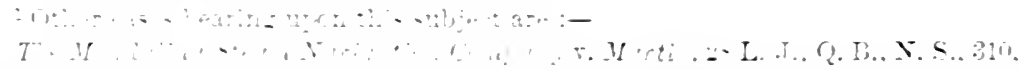

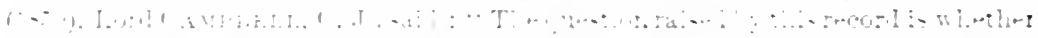

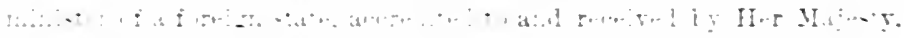

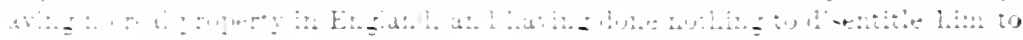


CHAP. II.] THE SCHUUXER " EXCHANGE" e. MliAll!M.

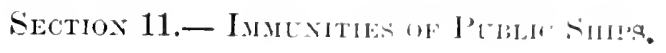

(11) $x \%$ ij, $" f^{\circ} 11 \% 1 \%$

THE SCHOONER "EXCHAN(IE" v. HFAJI)(

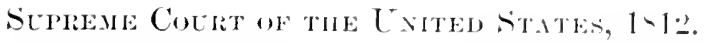

(itruell, 11i.)

It is a principle of public law, that national ships of war, entering the port of a

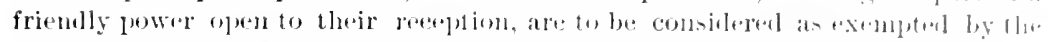
eonsent of that power from its jurisuliction.

Appeal from the sentence of the circuit cont of the I Hited sitates for the district of Penusylvania.

The schooner Exchange, ownet hy .John M'Fathom and Willian

the privileges generally belonging to surh public minister, may be sure, againet

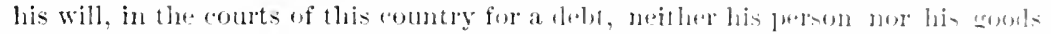
being toueled by the suit, while he remains suele public ministel." Mrld, thal h. could not be so sued.

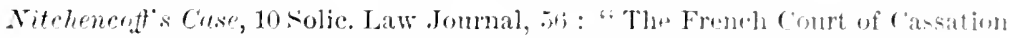
has quashed the appeal of Nitrhencoff, the liusian sentenferl to indrimonuent for life for a murltrous attack upon X. de bahkl, in the huthe of the Riskian Alubassarlor in Paris. It will be reunembered that this case gate rise le a diplonatio.

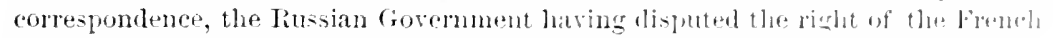
courts to try the murderer, and claimed a right to hate him erven up for trial in

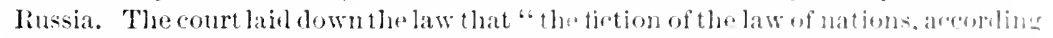
to which the honse of an anbassalor is ropuled to be a continution of the territory

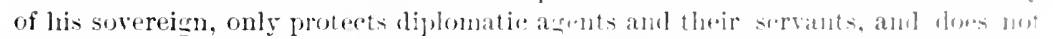

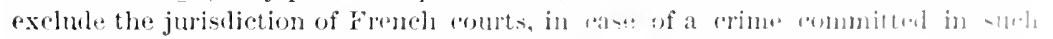

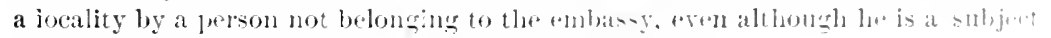
of the nation from which the ambassalor is aremelitull."

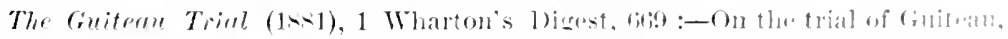

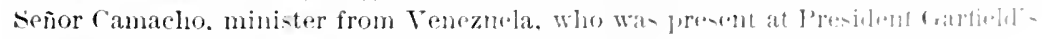
assassination, ras called as a witness for the proseroltion.

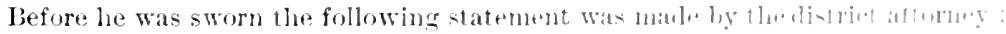

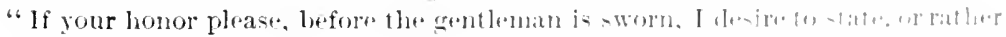

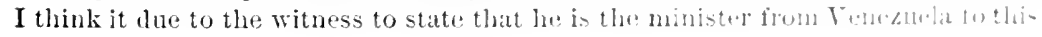




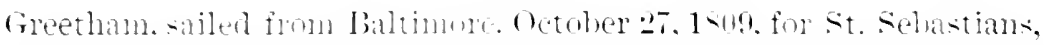

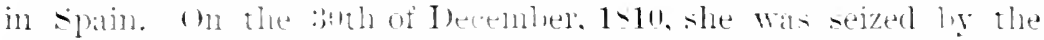
order w Xilfulem lonaldate : and was then armed and enmmis-

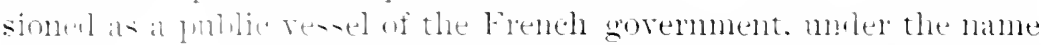

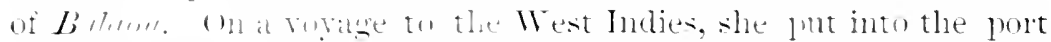

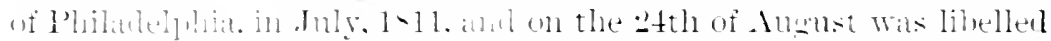

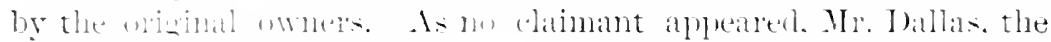

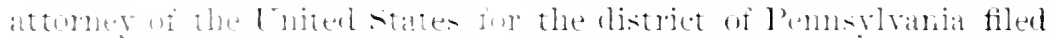

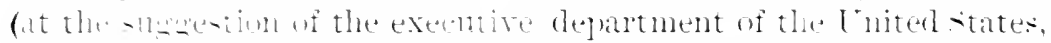

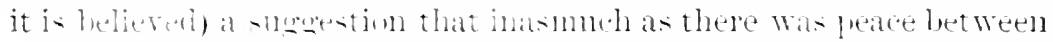

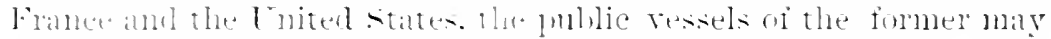
enter inde the forts and harbus of the latter and depart at will withont serizne ol detention in any way.

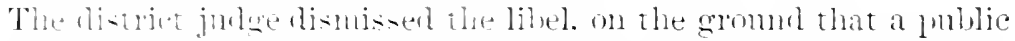

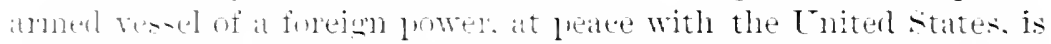

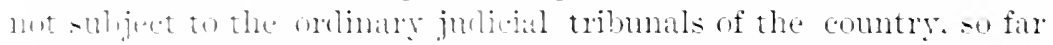
as rewals the gatestion of title. by which the foreign sorereign daims tolinkl ber.

The libellants aplealed to the circuit compt. where the sentence

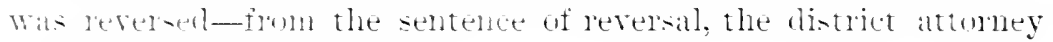
aldeallell th this comrt.

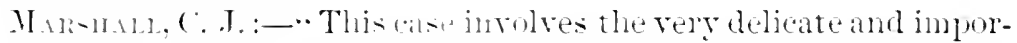
tant infury. whether an Anerion eitizen can assert. in an American amut. a title to an armed national ressel, found within the waters wi the fuiterl states.

"The question has been consirlered with an eamest soliciturle,

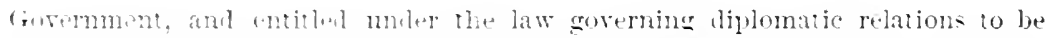

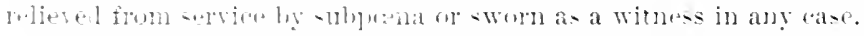

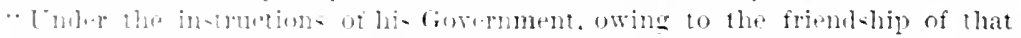

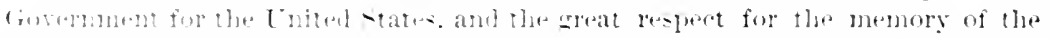

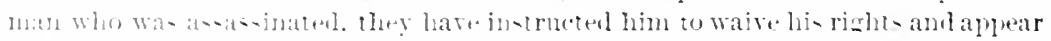

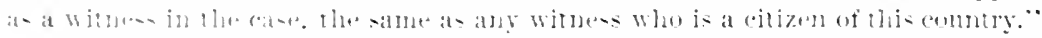

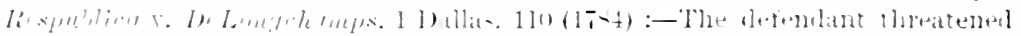

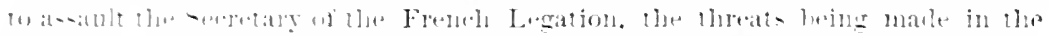

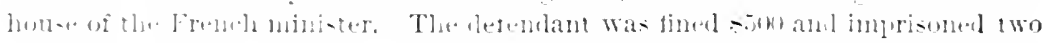
vinar.

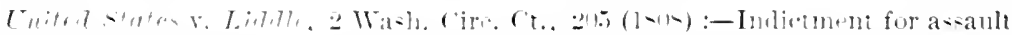

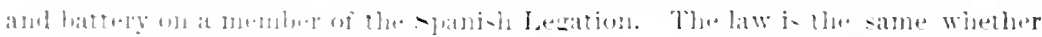

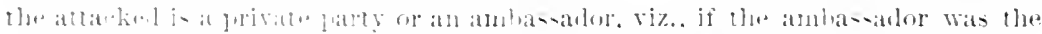

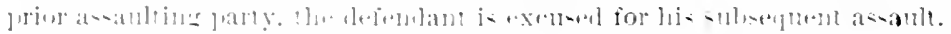

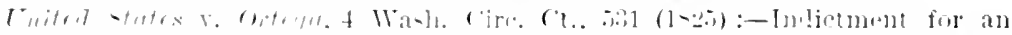

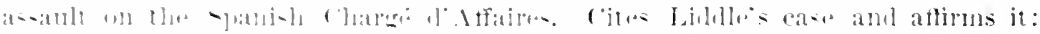

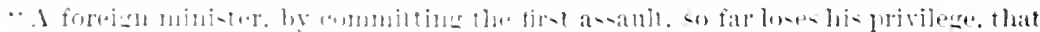

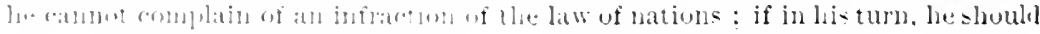

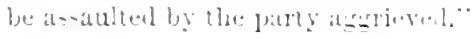


that the decision may conform to those frimeijules of Hationd an muneipal law by which it oment to he rexulatem.

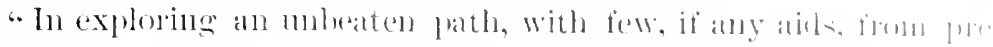

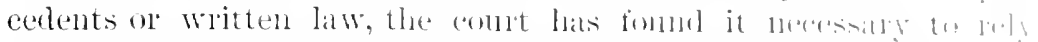

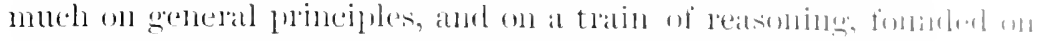
cases in some degree analogoms to this.

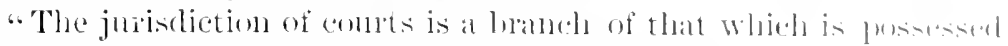
by the nation as an independent sorerejess power.

"The junisliction of the nation within its own tordenty is nuopssarily exchuse and alsolute. It is suseeptible of no limitation mot

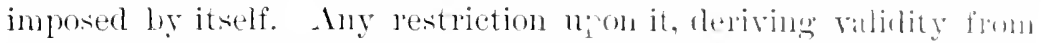

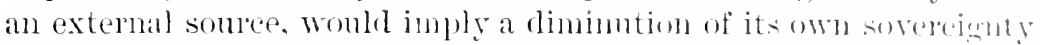
to the extent of the restriction, and an investment of that sorerrignty to the same extent in that power which could impose such gestrintions.

"All exceptions, therefore, to the full and complete power af at nation within its own teritories, must be traced mp to the comsont of the nation itself. They can flow thom no other legitinnate sombere.

"This consent may he either expess or implied. In the latter" calse, it is less deterninate, exposed mone to the mucelatintios of construction; hut, if understond, not lesis ohligatory.

"The world being composed of distinct sorededonties, possessing equal rights and equal independence, whose mutual benctit is promoted by intercourse with each other, and by an interchange of those rood offices which hmmanity alictates and its wants redpile,

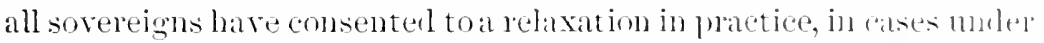
certain peculiar circumstances, of that absolute and enuplete jurisdiction within their respective territories which sorereignty conters.

"This consent may, in some instances, be tested hy commun usage, and by common opinion, growing out of that usace.

"A nation would justly be considered as violating its faith, although that faith might not be expressly plighterl, which shoull sudrenly and withont previous notice, exercise its territorial fumers in a manner not consonant to the usages and received obligations of the civilizerl world.

"This full and absolute territorial juldsdiction beins alike tie alttribute of erely sovereign, and heing incapable of conferring watrit

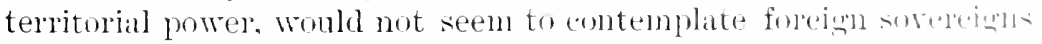
nor their sovereign rights as its objects. One sorrereign heiner in 110 respect amenable to another, and being bound by ollingations of the highest character not to degrade the dignity of his nat iom. ly phit ins himself or its sovereign rights within the juristietion of annther, 
eall be sulposed to enter a foreign territory only under an express license of in the contidence that the immunities belonging to his indepremlent soredeign station, will be extenderl to him.

- This perfect equality and absolute independence of sovereigns, and this common intelest inpelling them to matnal intereomse, and an intephance of geon offices with each other, have griven rise to a clikn uf catse in which every sovereign is unterstood to wave the exereise of a bat of that eomplete exchuse territorial juriseliction, which his been stated to be the attribute of erery nation.

* lst. One of these is admitied to le the exemption of the person of the soredeign from andest or detention within a foreign territory.

. If he enters that territory with the knowledge and license of its soreleign. that license, aluhugh containing no stipulation exempting his person from arrest, is universally understood to imply such sipulation.

.. Why has the whole eivilized world eoncured in this construction: The answer camot be mistaken. A forejensosereign is not molersumel as intending to suljeet hinself to a jurisdiction incomlamihle with his dignity and the dignity of his nations and it is to aroid this subjextion that the license has been obatinet. The charalctel to whom it is given. and the object for which it is gromted, equally leduire that is should be eomstrued to impart full security to the bel'soll who hats obtained it. This secmity, however, need not be axpessed ; it is implied from the cincumstances of the case. shonl one soreleign enter the territory of another, without the consent of that other, experset or impliet, it womld present a question which does not alpear to he perfectly setterl, a decision of which is not necessury to any condusion to which the compt may

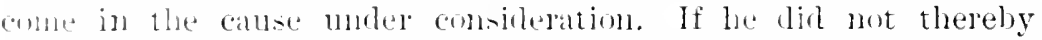

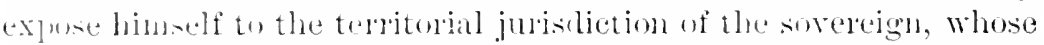
flomingms he harl entered, it womld seem to be becintse all sovereigns indpliedly engage nut to arail themselves of a power orer their

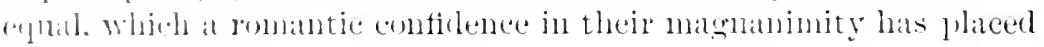
in thoil hasuls.

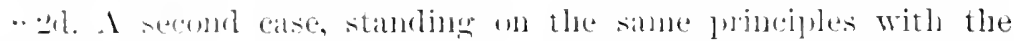
fir-t. is the immunity which all civilizerl nations allow to foreign ministers.

"Whitever maly be the principle on which this immunity is

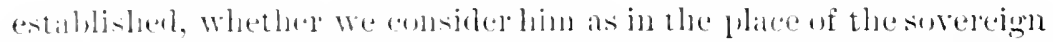

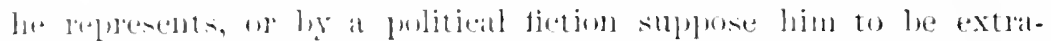
toreitorial, and therefore, in point of law, not within the jurjerliction of the sorereign at whose combt he resiles: still the immmity itself is granterl hy the goreming power of the nation to which the 
minister is deputed, his fiction of extrat-territoriality andu mon im.

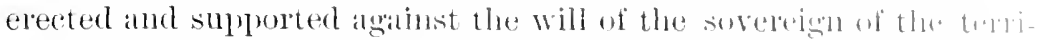
tory. Ile is smpposed to assent to it.

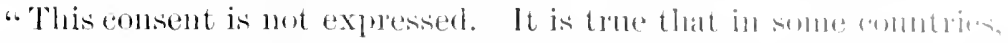

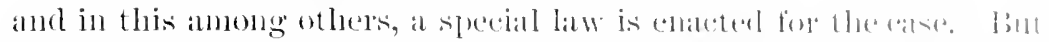

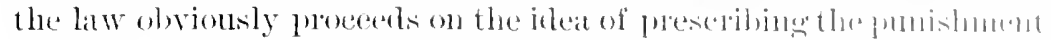
of an act previonsly molaw ful, mot of granting to a forcign ministop a privilege which he would not otherwise posises.

"The assent of the sovereign to the very impertant and extensive exemptions from territorial juristiction which ane anlmittent to attald to foreign ministers, is implied from the consiblerations that, withunt such exemption, every sovereign womlel hazam his own dignity by emploging a public minister aloroat. Ilis minister womld owe temporary and local allegiance to a foreign prince, and womkl be bas competent to the objects of his mission. I soreleign commiting the interests of his nation with a foreign power, to the ande of a person whom he hats selected for that pmrpose, calmot inteme to subject his minister in any degree to that power ; and therefore a consent to receive him, implies a eomsent that he shall pussoss those privileges which his principal intended he shomh retain, mivilemes which are essential to the dignity of his sovereign, and to the duties loe is bound to perform.

"In what cases a minister, by infacting the laws of the conntry in which he resides, may subject himself to other fmuishment than will be inflicted by his own sovereign, is an induiry foreign to the

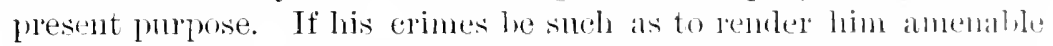
to the local jurisdietion, it must be beamse they forfeit the privileges anmexed to his character ; and the minister, hy violating the eonditions moler which he was received as the representative of a foreign sovereign, has surrendered the immunities granted on those conditions: or, according to the true meaning of the original assicut, has ceased to be entitled to them.

":3d. I thind case in which a sovereign is molerstond to corle al portion of his territorial jurisdiction is, where he allows the troms of a foreign prince to pass throngh his anminions.

"In such case, withont any express declaration waiving jurislic:tion over the army to which this right of passige has lexell wammol, the sovereign who should attempt to axereise it womb certainly lus

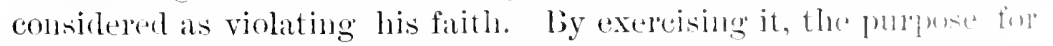
which the free passage was granted would be defeaterl, and a luntion of the military force of a foreign independent nation womkl lu diverterl from those national objects and duties to which it wils applieable, and rould be wilhdratw from the controt of the sorer- 
eign whos fow and whose safety might greatly depend on letaining the exclusire commatme and dispesition of this fores. The grant

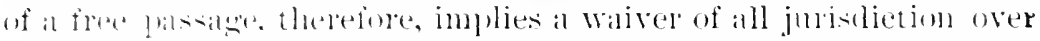

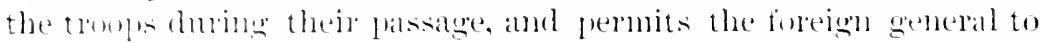
nse that discipline, and to inflict those punishoments which the gerelument of his army may repuire.

- lint if, withomt silch expess pelmit, an atroly shombl be led

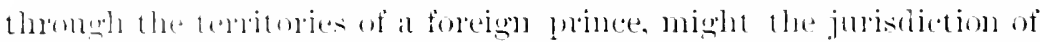
the teritong be right fully exereised orer the individnals composing this alme:

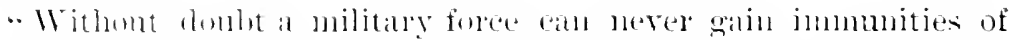
any oflede description than those which wall gives ly enteding a

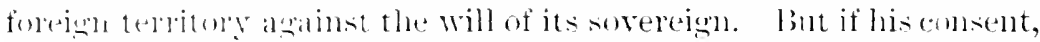

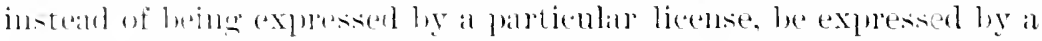

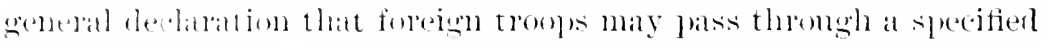
trace of combury a clistinction letween such general permit and a particular license is not frereeived. It wombl seen reasomable that wely inmmity which womld be confermed by a special license, womk be. in like manner conferred ly such gemeral permit. We latre seen that a linemse to pass thromgh a territory implies immmnities not expersierl, and it is material to inquire why the lieense itseli may mot he presmmerl?

"It is obvions that the passige of an army thromgh a foreign territory will pubshly be at all times inconvenient and injurions, and womld often he imminently dangerous to the sovereign thromgh whose dominion it pasied. Finels a practice would break down some of the most recisive distinctions between peace and watr, and would leduce a Hation to the neesesity of resisting by wal an act not alsolutely hosile in its chaldater, or of exposing itself to the stratagems and flanks of a power whose integrity might be dombted, and who might

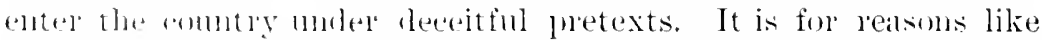
these that the anelat linense to forejenters to enter the dominions of a frimbly power, is nerel molerstom to extend to a military

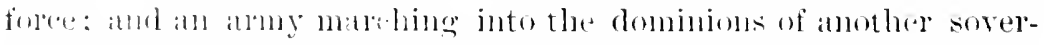

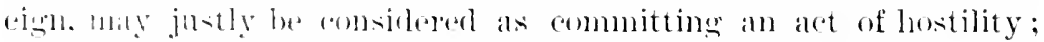

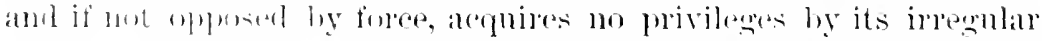

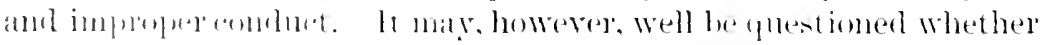

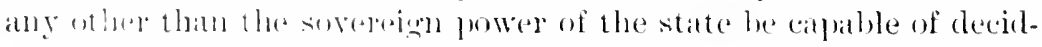

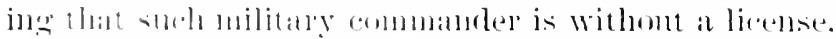

- lint the mo which is applicalble to armies, does not appear to be

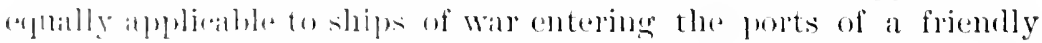

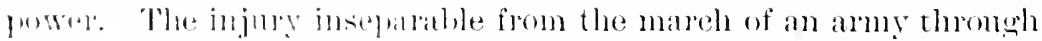
an inlatited comntry and the danger's often, indeen generally, at 


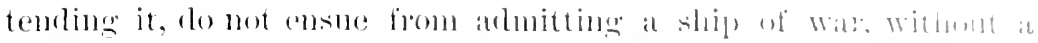

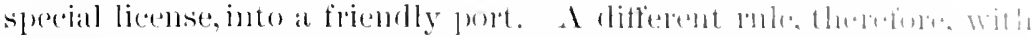

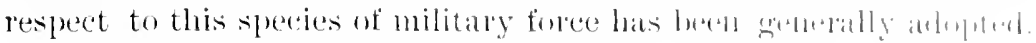

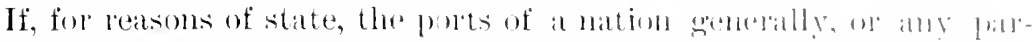

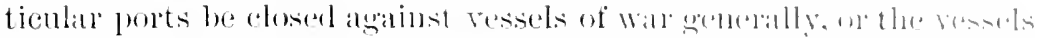

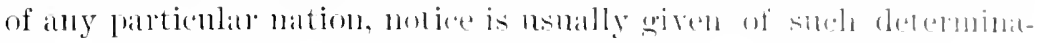

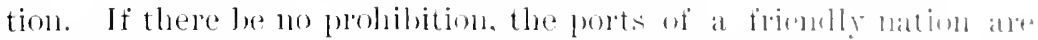
considered as open to the problie ships of all pumers with when it is at peace, and they are supposed to enter soll purts and to leemain in them while allowed to remain, moler the protection of the gorermment of the place.

"In almost every instance, the treaties betwesu civilized nations contain a stipulation to this effect in farol of vessus divou in hy stress of weather or other urgent necesity. In shell astes the

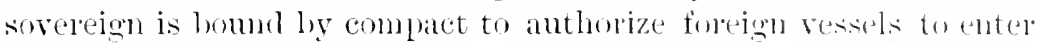
his punts. The treaty bids lim to allow vessels in distresis to find refuge and asylum in his ports, and this is a license which he is not at liberty to retract. If wonld he difin alt to asion a leasm forl withholding from a license thus granted, any immonity fom local juristiction which would be implied in a spectal license.

"If there be no treaty applicable to the case, and the sorereinn, fom motives deemed adequate by himself, permits his ports to d"2main open to the public ships of foreign friendly pwers, the conclusion seems irresistible, that they enter log his asicent. Anul if they enter by his assent necessarily jmplief, no just reason is gerceived by the cont for elistinguishing their case fom that of vestets which enter by express assent. In all the cases of exemption which have been reviewerl, much has been implierl but the obligation of what was implierl has been found equal to the oflingation of that which was expressed. Are there reasons for denying the apllicaltion of this principle to ships of was?

"In this part of the subject a difficulty is to be ancomutered, the serionsness of which is acknowledged, but which the com will not attempt to evade.

"These treaties whieh provide for the aduission and sate depanture of public vessels entering a port from stress of weather. or uther urgent cause, provirle in like manner for the private resicts uf the nation; and where public resiels entel' a pol't muler the general license which is implied merely from the absence of a luohilitim, they are, it may be urged, in the same condicim with mathont

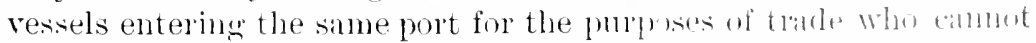
thereby claim any exemption from the juriscliction of the combly. It may be contended, certainly with much plansilility if not cor- 
reetuess, that the same rule, and same principle are appliealle to publie and private ships a and since it is ahoitted that private ships,

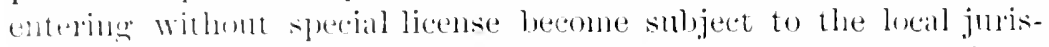
dictions it is domanded on what anthority an exception is made in firror of ships of wall.

- It is hy no meins conceded, that a private ressel really arailing herself of an asymm porvided ly treaty, and not attempting to

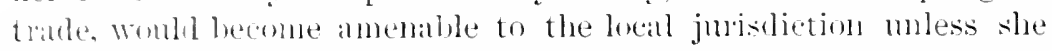
enmmitten some alet forfeiting the protection she elaims under comfart. ()n the entrary, motives maty be assignted for stipulating and acomelinger immmoities to ressels in cases of distress, which womb nut he demameled for, or allowed to those which enter voluntarily, and for ordinary purposes. On this part of the sulject, however, the enult does not mean to indicate any opinion. The case itself maty pusibly oecur, and ought not to be prejudiced.

$\therefore$ Withont decinding how fill such stipulations in favor of distressed rescols, as are usmal in treaties, may exempt private ships from the juriadiction of the place, it may safely be asserted that the whole reasoning mon which such exemption has been implied in other cases, applies with full force to the exemption of ships of war in this.

". It is impossible to conceive, says Vattel, "that a prince who sends an ambissuror or any other lininister can have any intention of subjecting him to the anthority of a foreign power, and this consinderattion fumisimes an additional aroment, whieh completely establishes the independency of a public minister. If it cmmot he reasomably presmmet that his sovereign means to subject him to the anthority rif the prince to winm he is sent, the latter. in receiving the minister, consents to admit him on the forting of independency ; and thus there exists hetween the two princes a tateit eonvention, which gives a luew force to the nattral obligution.'

" Equally imposible is it to conceive, whatever may be the construction ats to private ships, that a prince who stipulates a passage

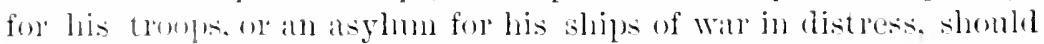
mean to sulject his amy or his nary to the jurislietion of a foreigu sovereigh. And if this camnot le presimmed, the sovereign of the port must be comsibered as having conceded the privilege to the extent in which it most have been molerstom to he asked.

"To the court, it aplears, that whele, without treaty, the ports of a nation are open to the private and pmblic ships of a friendly bower, whose subjects have also liberty without special license, to enter the comntry for husiness or amusement. a clear distinction is to be diam between the rights aceorded to private individuals or 


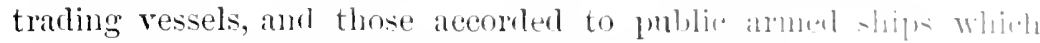
constitute a part of the militing foree of the nation.

"The preceding reasoning, has maintained the prom nitions that

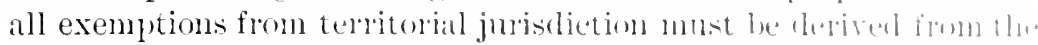
consent of the soreleign of the territory; that this (o) - mat maly he implied or expressed; and that, when implierl, its ext+nt monst he

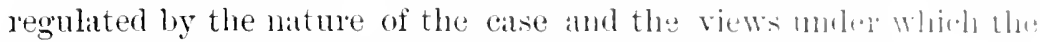
parties repuiring and conceding it most be smplosed to atet.

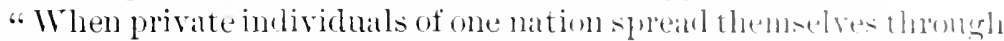
another as business or caprice may direet, mingling indiscrimimately with the inhabitants of that other, or when merellint rests enter for the purposes of trade, it would be obvionsly inconvenient and dangerous to society, and would sulject the laws to comtinnal infraction, and the government to degratation, if such individnals on merchants did not owe temporary and local allegiance, and were not amenable to the jurisdiction of the country. Nor can the foreign sovereign have any motive for wishing such exemption. IIis sul,jeets thus passing into foreign comtries, are not employed hy hin, nor are they engaged in national pursuits. Consegnently there are powerful motives for not exempting persons of this description from the jurisdiction of the country in which they are found, and no one motive for requiring it. The implied license, therefore, under which they enter, can never be construed to grant such exemption. But in all respects different is the situation of a pubric armer ship. She constitutes a part of the military force of her nation ; acts under the immediate and direet command of the sovereign; is employed by him in national objects. He has many and powerful motives for preventing those objects from being defeated by the interference of a foreign state. Such interference cannot take place without affecting his power and his dignity. The implied license, therefore, under which such vessel enters a friendly port, may reasonably he comstruterl, and, it seems to the court, ought to be construed, as continining an exemption from the jurisdiction of the sovereign, within whuse territory she claims the rites of hospitality.

" Cpon these principles, by the manimous consent of nations, at foreigner is amenable to the laws of the place; but certainly in practice, nations have not yet asserted their juristiction orer the public armed ships of a foreign sovereign, entering a port olen for their reception.

" Bynkershoek, a jurist of great reputation, has indeed maintained that the property of a foreign sovereign is not distingurhable ly any legal exemption from the property of an ordinary individual, and has quoted several cases in which courts have exercised juristiction 
wrer anses in which a foreign sorereign was made a party defendanst.

"Withont inclicating any opinion on this ynestion, it may safely be athimed, that there is a manifest distinetion hetween the private property of the person who haplens to be at prince, and that military force which smplorts the sovereign power, and maintains the dignity and the indepentence of a nation. A prince, hy atequiring frivate preperty in a foreign country, may posibly he ensidered ats mbifecting that property to the teritorial juristiction: he may be

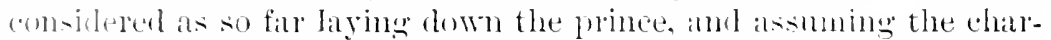
acter af a private individual; but this he cammot be presumed to do with respect to any portion of that armed force, which npholds his cromm. and the nation he is intrusted to govern.

. The only applicable case eited by Bynkershoek, is that of the Sumish ships of war, seized in Flushing for a debt due from the King of spain. In that case the states generally interposed; and there is reason to believe, from the mannel in which the transaction is stated, that, either by the interference of gorernment, or the decision of the comt, the ressels were released. This case of the sumish ressels is, it is believed, the only ease fumished by the history of the world, of an attempt made by an individual to assert a claim agatinst a foreign prince, by seizing the armet vessels of the nation. That this proceeding was at once arrested by the government, in a nation which appears to have asserted the power of proceeting in the same mamner against the private property of the luince. womld seem to furnish no feeble argument in support of the miversality of the opinion in farol of the exemption elaimed for ships of war. The distinction mate in our own laws between public and private ships wombl alpear to proceed from the same opinion.

"It seens, then, to the conrt, to be a prineiple of publie law, that national shiss of war, entering the port of a friendly power open for their reception, are to be considered as exempted by the consent of that power from its jurisdiction.

"Withon doult, the sorereign of the place is capalle of destroying this implication. Ite may elinim and exercise jurisdietion, either by employing force, or by smbjecting such vessels to the ordinary tribmath. lint, mutil sueh power be exelted in a mamer not to he misunderstond. the sovereign tamot be ensirlered ats having imprated to the ordinary tribunals a jurisdiction, which it would be a breach of faith to exereise. Those general statutory provisions, therefore, which are descriptive of the ordinary juristiction of the judiuinl tribmals, which give an individual whose property has been wrested from him, a right to clain that property in the eourts of 


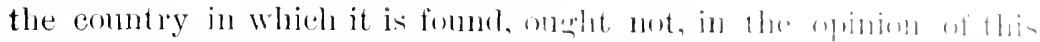

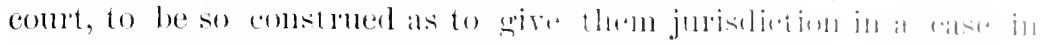

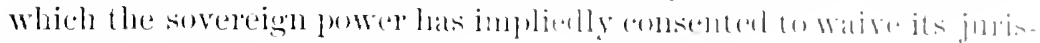
diction.

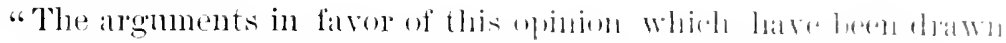

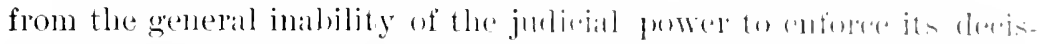

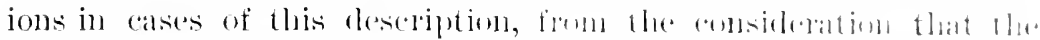

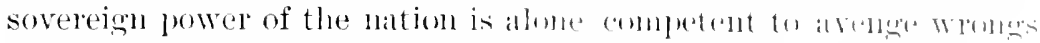

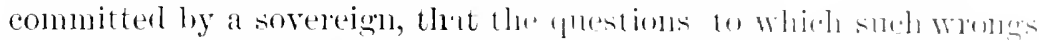
give birth are lather gutestions of policy llatu of law, that they alde

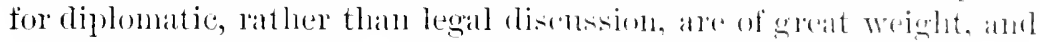

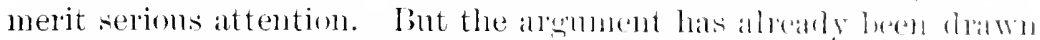
to a length which forbicts a particular exannination of the puints.

"The grinciples which have been stated will now lwaphlied to the" case at ball.

"In the present state of the evidence and poncenlings, the F.' chenege must be comsigtered as a vessel which wats the property of the libellants, whose elaim is repelled by the falct, that she is 110 w a national armed ressel, commissioned hy, and in the service of the Emperor of France. The evidence of this faet is not controverterl. But it is contended that it constitutes no mar to an inguiry into tlas validity of the title, hy which the emperon holds this vesicel. Every person, it is alleged, who is entitlert to property bromght willin the jurisdiction of our courts, has a right to assert his tithe in those courts, mless there be some law taking his case ont of the general rule. It is therefore said to be the right, and if it he the right, it is the duty of the comrt, to inquire whether this title has been extinguished by an act, the validity of which is recognized by national or municipal law.

"If the preceding reasoning be correct, the Eachrume. being" a public armed ship, in the service of a foreign sovereign, with whom the government of the Lnited States is at peace, and labring entereri an American port open for her reception, on the terms on which ships of war are generally permitter to enter the ports of a fricndly purer, must be considered as having come into the Amerian territory, under an implied promise, that while necessanily within it. and le. meaning herselt in a friendly manner, she should be exemlt form the jurisdiction of the country." 


\title{
TIIE "CONSTITLTION."
}

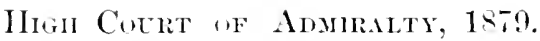

(to Leru, Jomeruel, P. D. d. A., 1:3.)

I ship of war of a foreion state cannot be proceded against in a suit for salvage.

The fitets are sufficiently stated in the opinion.

sir lenbert Inm monese:-" In this calse an application was made to the contr to allow a warrant to issue of a peculiar character-il warrant which was to be served upon a ship of war belonging to an independent state at amity with IIer Majesty. The court direeted the calce to stand over, and suggested that it would be proper that notice shonl he given to his Excellency, the American Minister in Londom, and to Lord silisbury, als secretary for Foreign Affiars. The court has reason to congratulate itself that it took that step, for the result lass been that it has had the arlvantige of hearing the opinion of comnet on behalf of the Lnited states and of the learned gentleman representing the Crown. It appears from telegrans which have palsed in the ease that a claim has been marle by the owner of the tug for 1,imo, but that the Anerican Comsul at Portsmouth has forwarted simply a cheque for : $n$ nol, in recognition of the services which the tug has rendered. The owner of che tug was dissatisfied with that anmont; and conseguently made an application to this comrt for an order to issue a warrant to arrest the constitution and lier (a)rigo.

"The question, therefore, which is raised under these proceedings is whether I have any juristietion to permit the arrest of a foreign ship w war ledonging to an indegendent state in anity with our sovereign, and I harrly think that it can be deniert that if I were to exercise the jurisilietion which is eraverl in the present case, I shombl be thing that for which there exists no direct precerlent. (1) the contrary, J have nowhubt als to this general proposition-that ships of war betonging to another nation with whom we are at peace are exempt from the cival jurisdiction of the courts of this country; and I have listened in vain for any peeuliar circumstances which wonl take this calse out of that general proposition. It hals happened to me nore than ance to have lecen requested by foreign states to sit as arbitrator, and to make awarls in differences which had arisen between them and British suljects. IIad such an application 


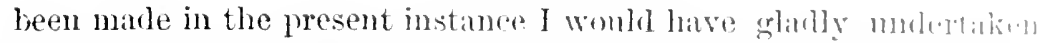
the duty sought to lee imposed 11 on me; hut that is mot the stallow matters I have now to consicher. All that I hare now to deromoine

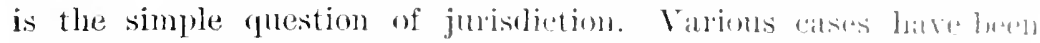

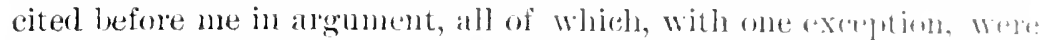

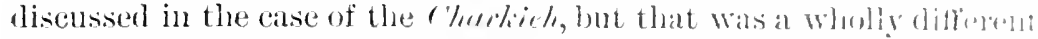

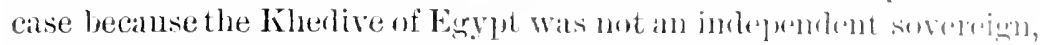
and the charlich herself formed one of a flect of molehintment. I may in the lengthy judgment which I delivered in that cann-, halve let drop some expression which may have griven rise to am implusion that a foreign ship of war is liable to arrest, hut, in that catse this question, as it is here raised, had not to be decided. Now that it comes before me in this plain and simple form, I feel no dombt that it would be improper for me to aceede to the regnest of the ommer of the steam-tug, nor do I think, as I have sad above, that the Constitution is liable to the process of this cout. In rearird to the question of the liability of the cargo, I must say I see mo distinction between the issue of a warrant in the ease of the ship and in the case of this cargo; it is on board a foreign vessel of war. and is under the charge of a foreign government for pmhle purpuse.

So that, having no authority to issue either of the warmants frayed for, and as no preeedent exists for such a course, I must dismiss this motion with costs."

${ }^{1} \mathrm{Mr}$. Cobbett (Cases on International Law, 8., says: "Before the decisicn in the case of the Constitution, some lonbt sems to have existed as to whethey salvate proceedings might not be instituted in the Engli-h court of Almiralty agaimat a public ressel. In the case of the Churlith, iir R. Phillinore har sail, "Il is by no means clear that a ship of war to which salvage services have been rendered, may

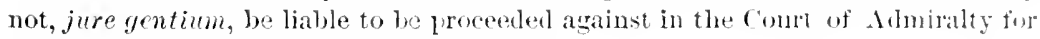
the remuneration the for such services."

"In a much earlier case, of the Prins Freteril (2 Dorls., 451). a Dutch man-1)" war, whilst on a voyage from Batavia to the Texol, was partially disabled ly stres of weather off the Scilly Isles, and was bronglit into Ifomt's liay with the assistance of the master and crew of a Iritish brigr. belonging to the port of Penzante. The Prins Frederile was at the time employed in bringing home a cargo of spine belonging to the Dutch Government, and for this purpose some of her gnme hat been removed. The salvors instituted salvage proceedings against the rewil. wat the ground that sle had for the time being, at least, lost the character and privilewes of a publie vessel, and also on the further gromin that such procemlings lueing in rem, and not against the King of the Xetherlands personally, were minder any cireumstances admissible. Aceording to Lord Campbell, who puoted this case in $1-51$ (17 Q. B., 212), Lord Stowell took a strong view against the asserterl juriviliotion. To aroid diffieuly, Lord Stowell caused a representation to lie male (t) the $[\text { but. }]_{1}$ government, who consented to his disposing of the matter as arbitrator. Aring under this authority, Lorl Stowell awarded the sum of stontand costs to the salrors."

Mr. Dana, in his note, No. 6:, says: "It n:ay be eonsirlered as establislicul law, 


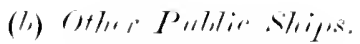

\author{
THE - PALLEMENT BELGE."

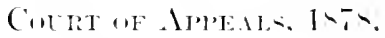

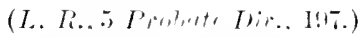

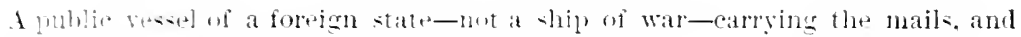

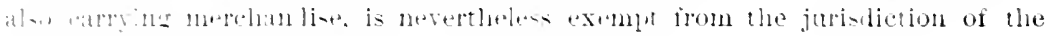

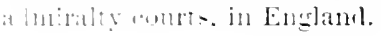

This was an anpeal on hehalf of the Crown from a recision of sir li. I. Inillimure.

The jurlownent of the court (James, Bagorallay, and Brett. L. I.J.)

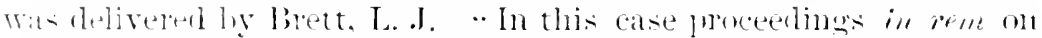

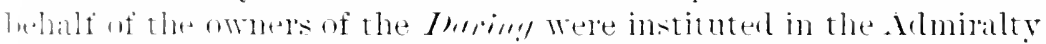
I bringm. in acomdince with the forms preseribed hy the Jndicature

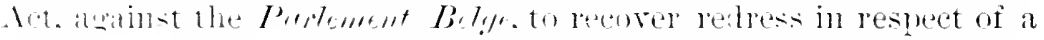
mplisins. A wit was served in the nstal and prescriber mamel on

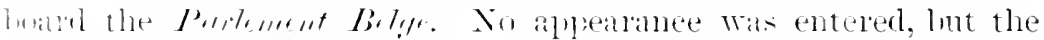
Alomerefinemal. in answer to a motim to direct llat judgment with ast: shombl be entered for the plaintiffs. and that a warant

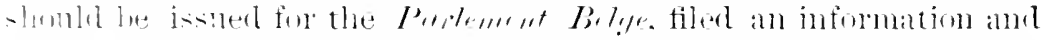

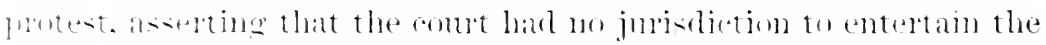

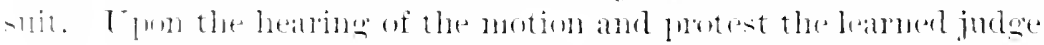
wi the domimalty bivision oremmlerl the protest and allowed the

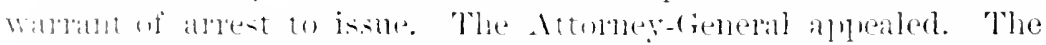

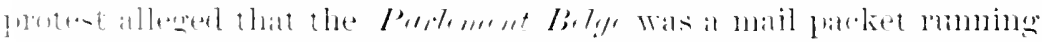

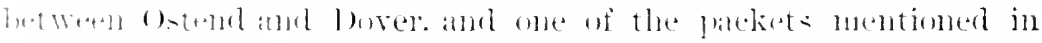

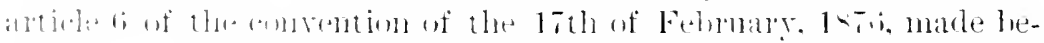

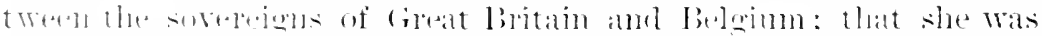

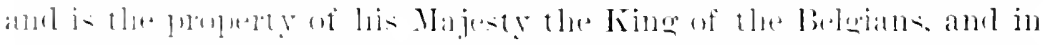

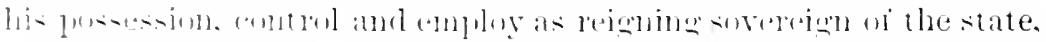

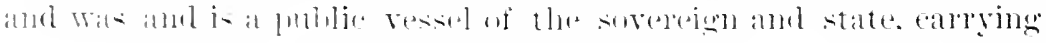

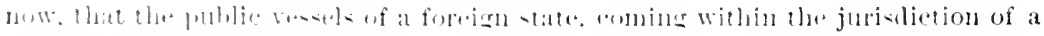

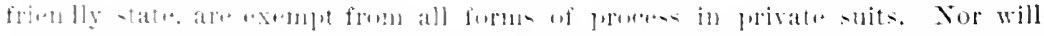

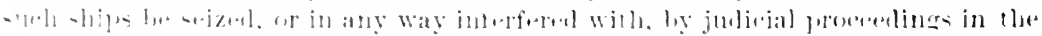

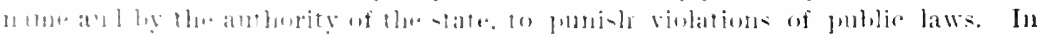

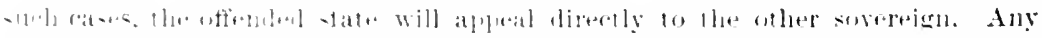

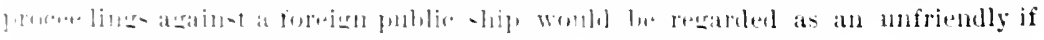

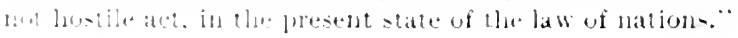




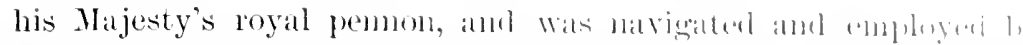

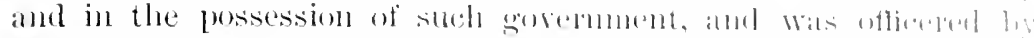

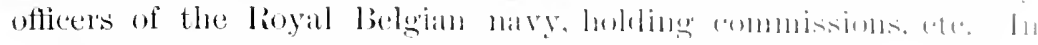

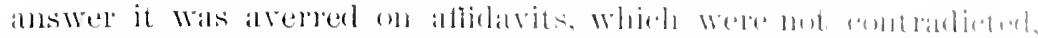

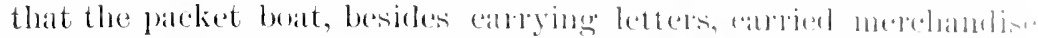
and passengers and their hugendere tor libe. *

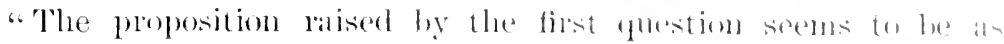

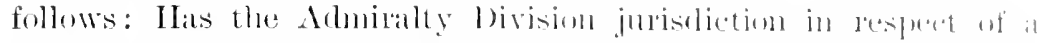

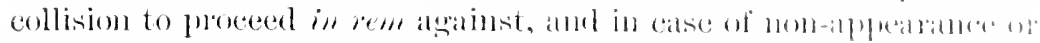
omission to find bail, to seize and sell, al ship fmesent in lhis

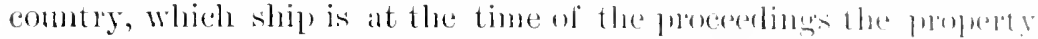
of a foreign sovereign, is in his possession, antol, and romploy ats sovereign by meams of his commissioned officers, amblis a fmbli. vessel of his state, in the semse of its hejng userl for pmomses treated

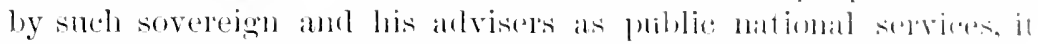

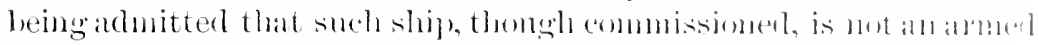
ship of wall or employed as a part of the military forece of his comilly? $*$ **

"It is admitted that neithe thesovereign of Great britain 110 " any friendly sovereign call be arlversely fersombly impleatiol in any court of this eometry. It is admitted that no ammel ship of wal of the sovereign of Great Britain, or of a forejgn sovereigh can be seized by any process whatever, exercised for any lurpose ly amy amm of

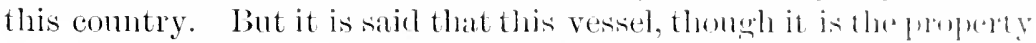

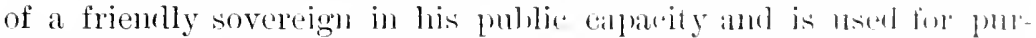
poses treated by him as public national services, ean he seized and sold moder the proeess of the Admiralty Comt of this anmery, hecanse it will, if so seized and sold, be so treated, mo in a sult brought against the sovereign personally, hut in a suit in in agahet the vessel itself. This contention raises two questions; first. sllyposing that an action in $20 m$ is an action acainst the ponperty anly. meaning thereby that it is not a lecal proceeding at all anainst the owner of the property, yet can the property in phestion he subjext to the juristiction of the court?

"Secondly, is it true to say that an action in $2 m$ is only am soluly a legal procedure against the property, ol is it uot rather a promenture indirectly, if not directy, implemling the owner of the pornoly t, answer to the julgment of the combt to the extent of his intrest in the property? ***

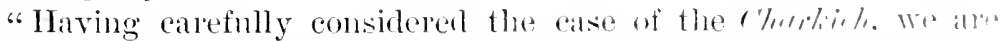
of opinion that the proposition derlueed fom the ealliel asise in an earlier part of this judgment is the anrect exprestion of the law w nations, viz., that as a conseguence of the absolute inderenclument 
"very sovereign anthority and of the internitional comity which induces erery sorereigh state to respect the inflependente of every other soledefin state, each and every one declines to exeloise by means of any of its compts, any of its territorial jurisdietion over the

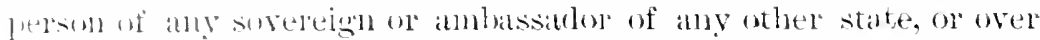
the pullic pongerty of any state which is elestined to its prublio

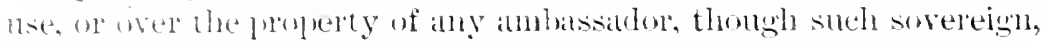

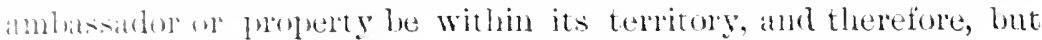

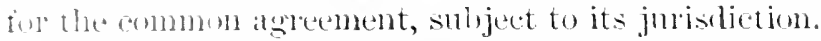

." l'his plopustion would determine the first yuestion in the present case in firron of the protest, even if an action in rem were held to be

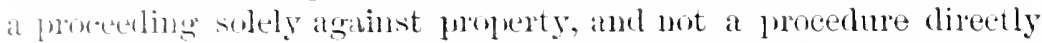
11. indirectly impleading the owner of the property to answer to the jurlement of the comt. Bnt we emmot allow it to be sulposed that

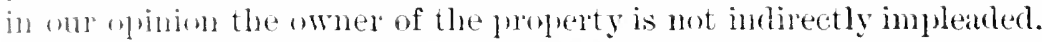

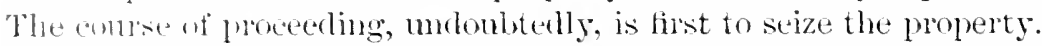
It is mulumhtelly, not necessity. in order to enable the comrt to pro"eterl further, that the ommer should be persomally served with any process. In the majority of eases, bromght mreter the cognizance uf an Adminalty Comt, no such persmat service comld be effected. Amother comse was therefore taken from the earliest times. The seizure of the property was made hy means of a formality which was an public as cond be devised. That formality of necessity gave notice of the suit to the agents of the ewner of the property, and so, in substance, to him. Besides which, hy the regular comse of the adminalty, the owner was cited or had motice to appear to show anse why his property should not be liahle to answer to the complatimst. The omer has at right to alpear and show cause, a right which cannot be denied. It is mot neessiry, it is true, that the noticen citation slrould be persomally served. But muless it were consillated that, either by means of the publicity of the mamer of arresting the fonderty, or by means of the publicity of the notice or

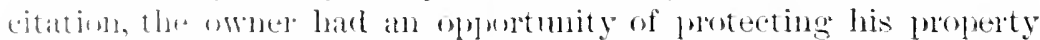

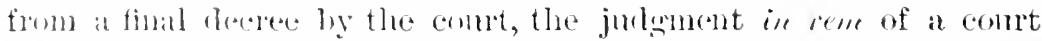
womld lx manifesty eontray to natural justice. In a cham mate in lesperet of at collision the purperty is mot treated as the dohnquent

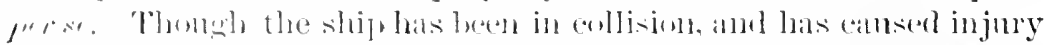

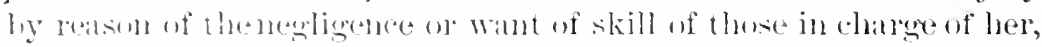

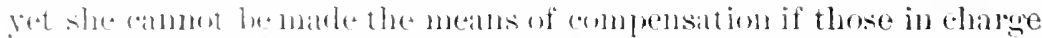
of her were mot the servatus of her then owner, as if she was in

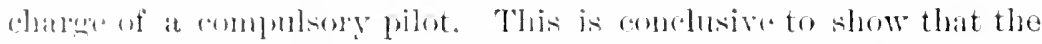
liability to compensate must he fixed not merely on the property, lut also on the owner throngh the property. 
"If so, the owner is at least imliredly impleallok to answere to, that is to say, to be affected lyy, the jurlement of the "orllt. It is an

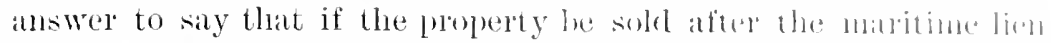

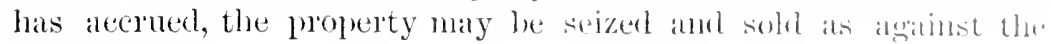
new owner.

"This is a severe law, probaluly arising form the dithenlty of otherwise enforeing any remedy in filvor of an injuleal snitur. lint thr

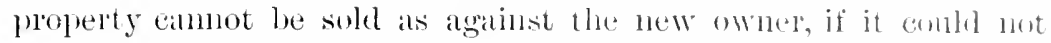
have been sold as against the owner at the time when the allexwl lien acerued. This doctrine of the compts of Almiralty sures only to the extent, that the imocent purchaser takes the punerty subject to the inchoate matrime lien which attacher to it as anginst him who was the owner at the time the lien attacher. Thle new owner has the same public notice of the suit and the salne opporttunity and right of appearance as the former owner womld hatre hath. ITe is impleaded in the same way as the former ownor woml have been. Either is affecter in his interests by the judgment of a cont which is bound to give him the means of knowing that it is ahomt to proceed to affeet those interests, and that it is lomul to luear him if he objects. 'That is, in on' opinion, an implealing.

"The ease of The Bold Bucclengl does not decile to the eontrary of this. It decifles that an action in rem is a different action form one in personam and has a different result. Bnt it does not decide that a court which seizes and sells a man's property dews mot assume to make that man sulject to its jurisdiction. To implear an independent sovereign in such a way is to call upon him to sacrifite either his property or his independence. To place him in that position is a breach of the principle upon which his immunity flom jurisdietion rests. We think that he camnot be so indirectly impleaderl any more than he could be directly impleaded. The case is, npon this consideration of it, monght within the general lule that a sovereign authority camnot be personally implearlerl in any cont.

"But it is said that the immunity is lost ly reason of the ship having been used for trading punoses. As to this, it must lus maintained eithel that the ship has heen so used as to have luen employed substantially as a mere trading ship and not sulstant billy for national purposes, or that a use of her in part for traling pur. poses takes away the immmity, aithongh she is in postesion of the sovereign authority by the hamds of commissioned ofticers, ambl is substantially in use for national purposes. Both these porpustions raise the question of how the ship must be consiflered lo hare been employed.

"As to the first, the ship has been hy the sovereign of Iielginn, 
by the msllal moans, dechued to be in his possession as sorereign, amb to he a puldir vesicel of the state. It seems rery dithicult to sily thit any anm an infuire ly contentions testimomy whethel

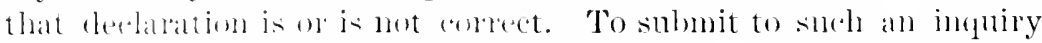

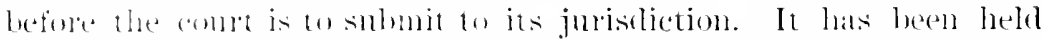
that if the ship he dectated he the sovereigh anthority hy the wsuld mealls 10 he a ship of war. that dechation cannot be inquired into.

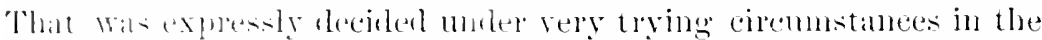

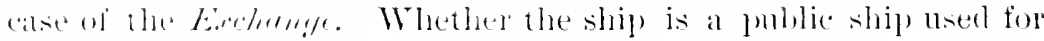
mational fmoloses seems to eome within the same rule. liat if

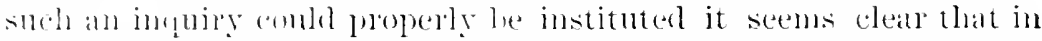

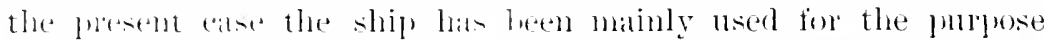
of almying the mals, and only subserviently to that main object for the punpuses of trade. The (atrying of passengers and merchandise las been sulurelinated to the duty of calrying the mails. The ship is men, in fact bomght within the first proposition. As to the second. it has heen frequenty stated that an independent sovereign anmot he fersomally sued, althmoln he has carried on a private trading adrenture. It hats been held that an ambassidor camnot be

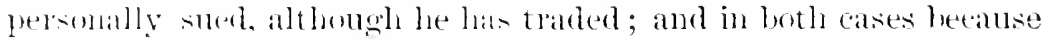
slu a snit womld he inconsistent with the independence and equality of the stalte which he repuesents. If the remedy sombht hy an alction

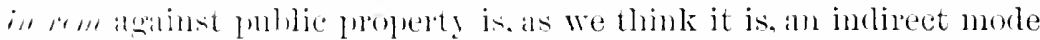
of axeroising the anthority of the enurt against the owner of the lowely then the attempt to exercise such an anthority is an at tempt incomsistent with the indeigendence and equality of the state

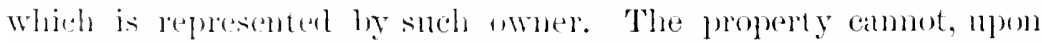

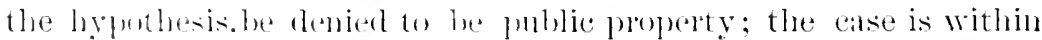
the terma of the rule; it is within the spirit of the rule; therefore,

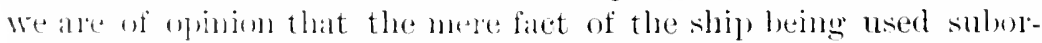
dimately and partially for trabling purposes does not take anay the

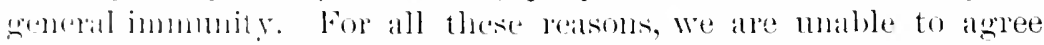
with the learmet jublge, and have come to the comelusion that the jurlgment nuln be leversed."

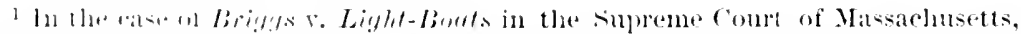

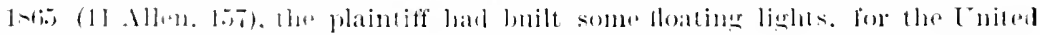

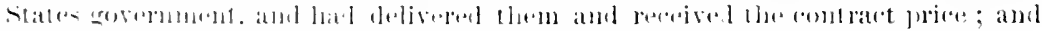

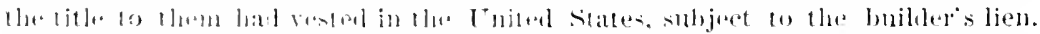

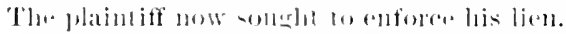

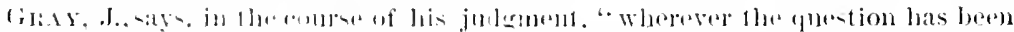

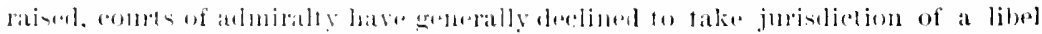

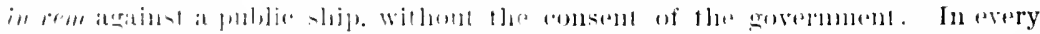

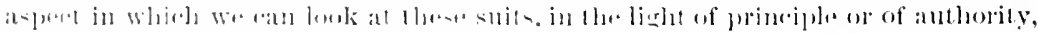

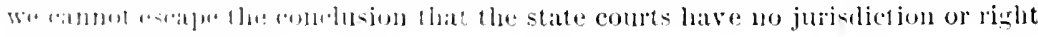
(1) enti:ltaint thent.." 


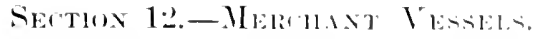 \\ THE "NEWTON," ANI THE "

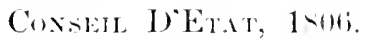

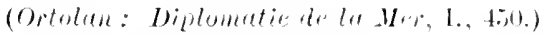

This is one of the earliest cases tending to establish what is sommtimes callew thr

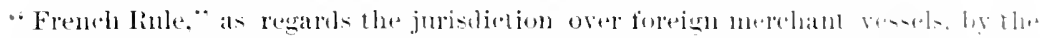

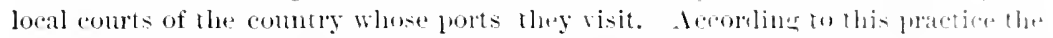

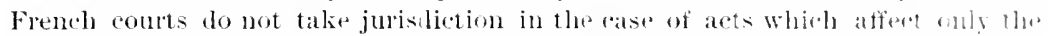
foreign vessel and its crew; tmess the acts are such as disturb the beate ol the port.

In 1806, while the Strom, an American merchant slitu. Was in the port of Antwerly, a quarel took place letween two sallom in at boat belonging to the ship. About the sante tine. when the solly, also an American merehant ship, was in the port of Marseblles. the mate dangeromsly womber one of the crew on the ship. 'The American consul claimed exelusire jurisdietion in each case. This chan was upheld by the Comseil d'Etat, in the following judgment :

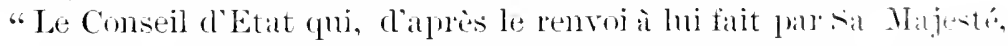

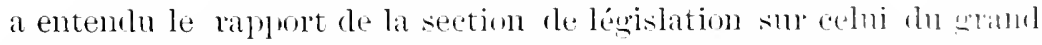
juge, ministre de la justice, tendant à regler les linites de la juriflitetion que les comsuls res Etats- Lnis d' Amérique, anx ports de Marseille et d'Anvers, réclament par rapport aux délits commis is lumb des valsseux de leur nation étant clans les ports et les raules de France ;

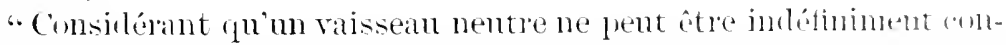

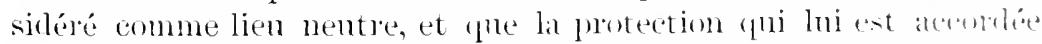

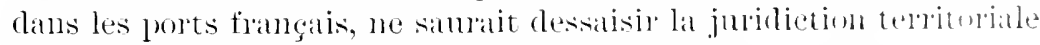
pour tout ce qui touche aux intéreds de l'Etalt:

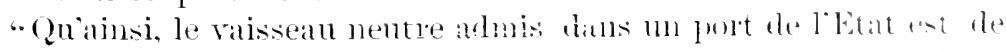
plein droit soumis aux lojs de police qui régissent le lien wit il est reçu;

"Qne les gens de son épuinage sont émlement justiobibles dr. tri-

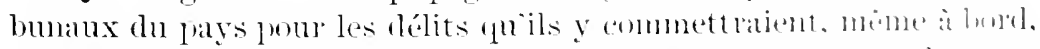

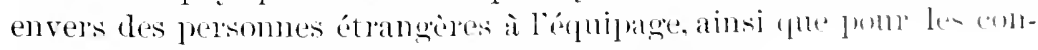
ventions civiles qüls pommaient faire avee alles:

- Mais que si jusque la la juridiction territoriale est lons de linute, 


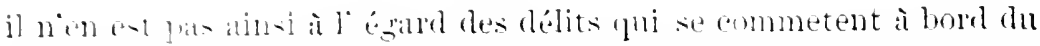

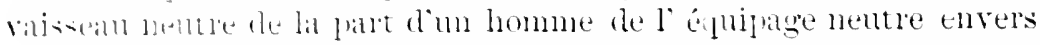

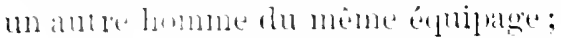

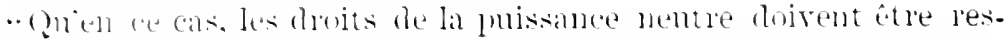

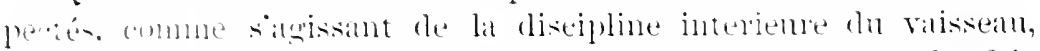

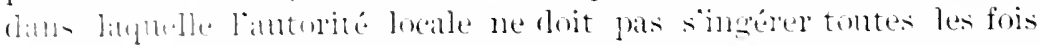

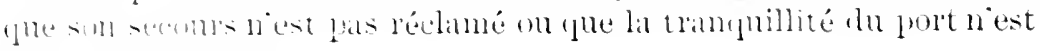

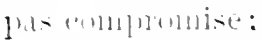

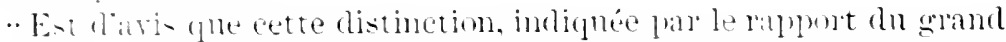

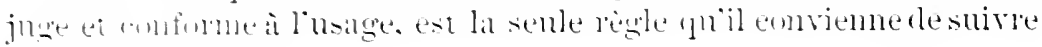

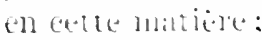

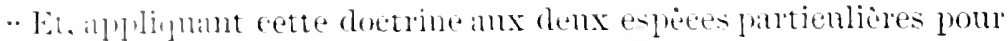

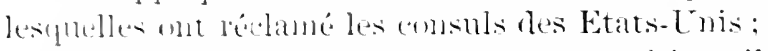

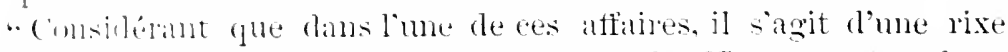

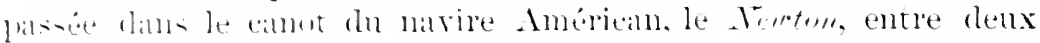

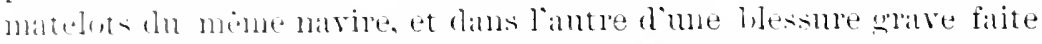
linde congtaine en second du movile la solly ì un de ses matelots

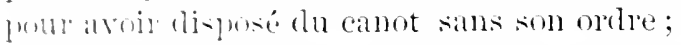

. Est davis qüil y a lieu d'ateeneillir la rédanation et d"interdire anx tribunax ildanģais la commisance des deux attaires précitées."

\title{
THE " TEMPEST."
}

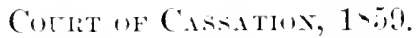

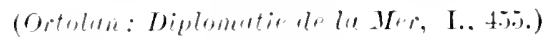

The Froncly couts take juristiction in the case of a murtere committed on board

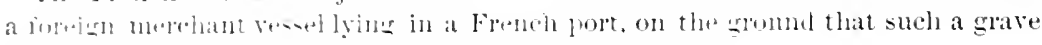

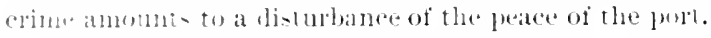

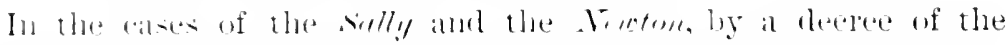

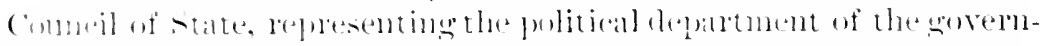

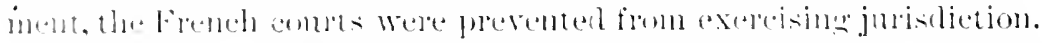

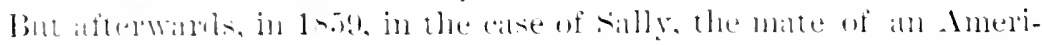

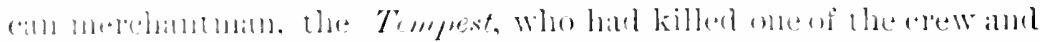

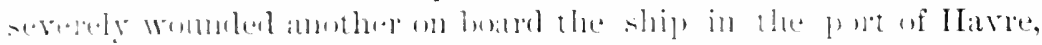

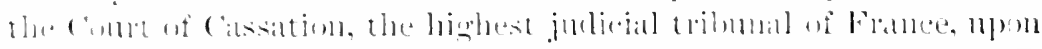

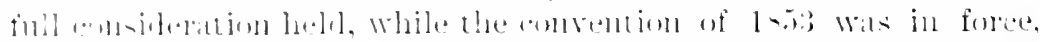

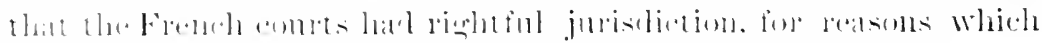

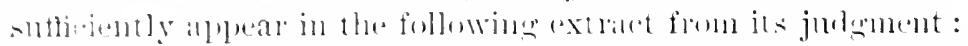

. comsiclerine that it is a principle of the lal of mat ions that erery

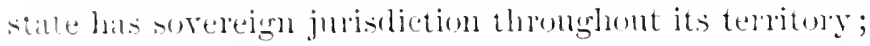


"Considering that hy the terms of article B of the Ciml. Nilpul. M

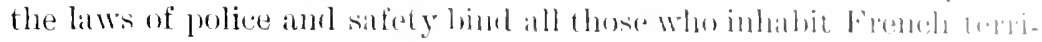

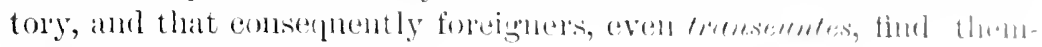
selves subject to those liaws;

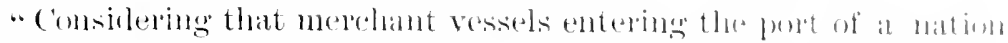

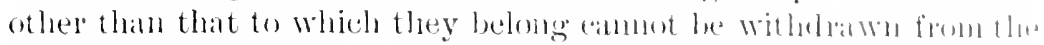
territorial juristietion, in any tase in which the interest of 1 la stalle

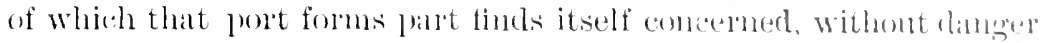
to gon oreter and to the rlignity of the governument;

"Considering that every state is interesterl in the remesciom of erimes and offenses that may be committer in the forts of its trom-

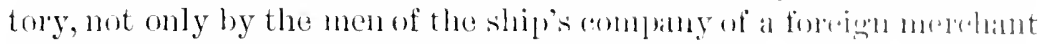
vessel towadel men not folming part of that complany, hut reven ly men of the ship's eompany amomg themselves, whemeref the act is of a nat une to compromise the tranguillity of the pont, an the intervention of the local authority is invokerl, or the alet eomstitntes a crime ly

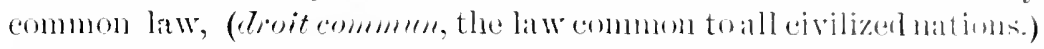
the gravity of which does not permit any nation to latve it mupmished, withont impugning its rights of juriselictional and territurial sovereignty, becanse that eline is in itself the most manifest an woll as the most flagrant violation of the laws which it is the duty of every nation to canse to be respected in all pruts of its territory."

[irticle VIII. of the Treaty of 1s.5:s, referred to, stipmlates that, "the respeotive Consuls-Creneral, Comsuls, Vice-Comsuls, or Comsmlan Agents, shall have exclusive charge of the intemal order of the mer. chant-vessels of their nation, and shall alone talke connizandes of difterences which may arise, either at sea on in port, between the eaptain, officers and erew, withont exception, particularly in leforence to the arljustment of wages and the execution of contracts. The local authorities shall not, on any pretext, interfere in these differ. ences, hut shall lend foreible aid to the comsuls, when tiney may ask it, to arrest and imprison all persoms compusing the erew whom they may deem it neeessary to confine. Those persons shall he arrextur at the sole request of the Consuls, adrlessed in writing to the local anthority, and supported by an official extract from the resister of the ship or the list of the crew, and shall be held, during the wholio time of their stay in the port, at the disposal of the comsuls. Their release shall be granted at the mere pequest of the coms!nls malle in writing. The expenses of the arpost and detention of thuse lersuns slatl be paid by the Consuls."] 


\author{
"L:INEMONE."

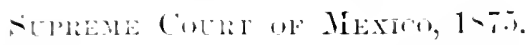

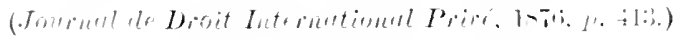

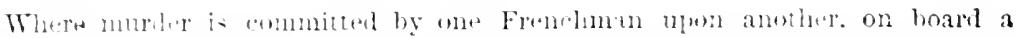

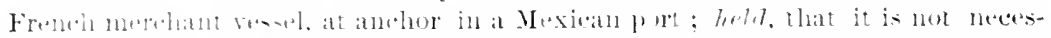

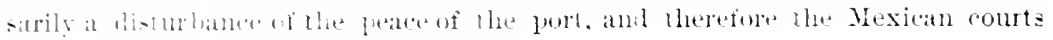
will not an whm, jurisilietion of the case.

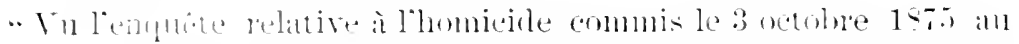

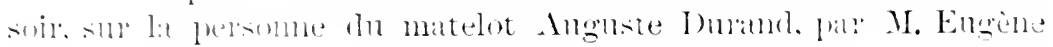

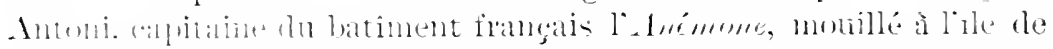

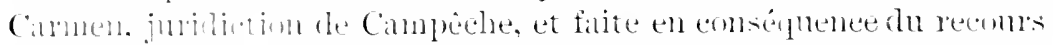

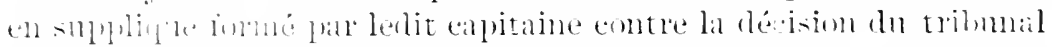

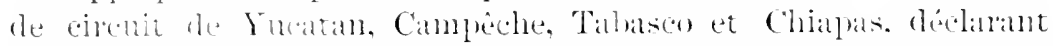

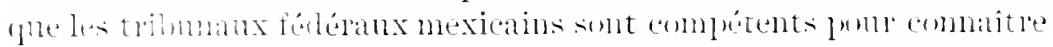

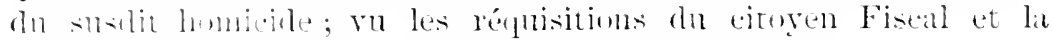

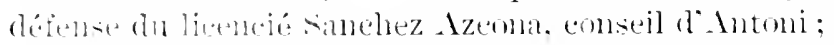

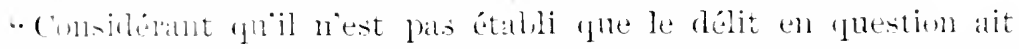

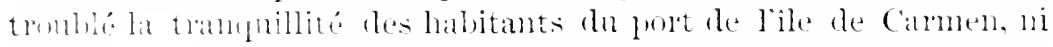

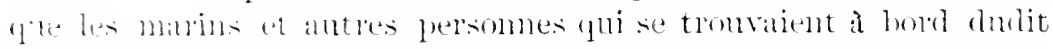
hatment aient dentandé protection anx antorités mexicantes. ni

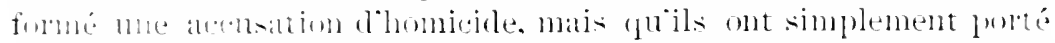

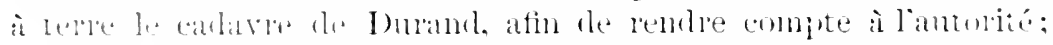

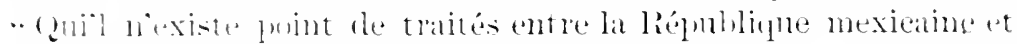

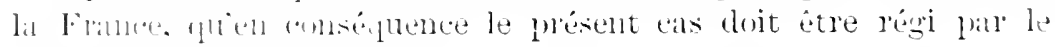
druit the ricipuriti:

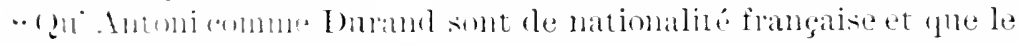

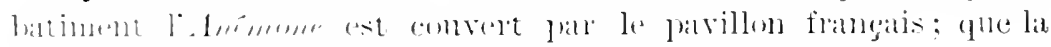

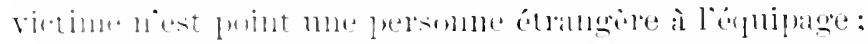

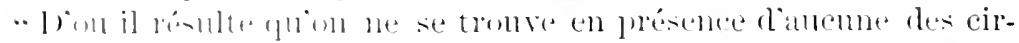

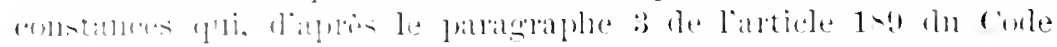

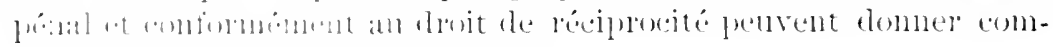

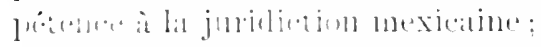

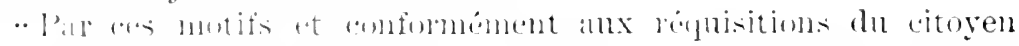

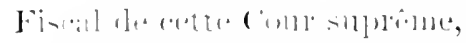

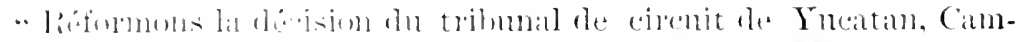

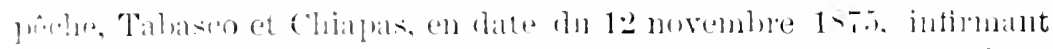
colle du tribunal he district de Cinnpiche, du 26 octobre précédent, 


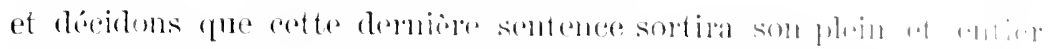

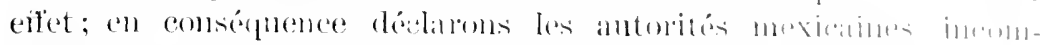

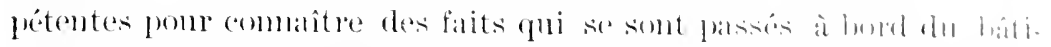

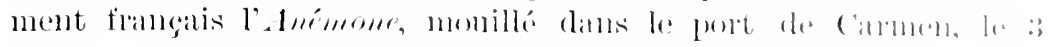

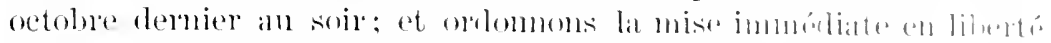

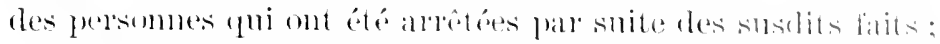

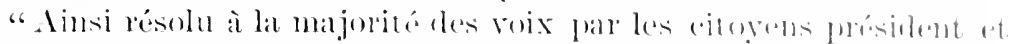

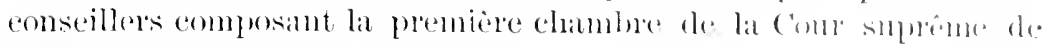
justice des Etats- Lnis meximains.

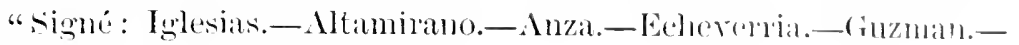
Aguiliur, seerétaire!"

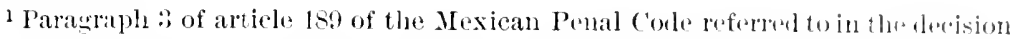
is as follows :

"Sont ronsidérés comme exéculís sur le territoire de la liépulilique: 1s...2. . . .

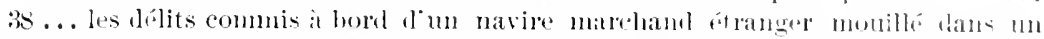

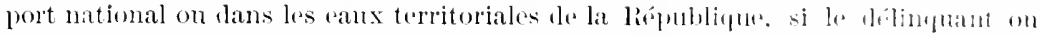

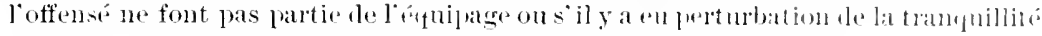
du port. Dans le cas contraire, on suiva le droit de réciprocite."

The Circuit Court harl assumed juristiction of the case on entumle very similar

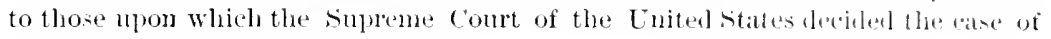
Wildeuhus:

"Le tribumal de circuit fondait son infiruation sur les motify suivants:

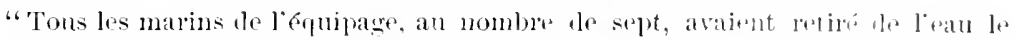

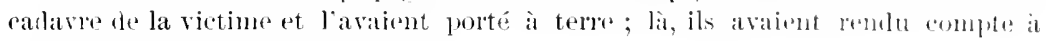
l'antorití el fait leurs declarations.

"Lorstu"un crimr ou delit de droit commm commis a bord d'un navire marchand étranger a troublé la tranquillite dn port, les antorités du pals sont rompertentes pour en comaitre.

"Ces autorités sont égalenent compétentes lorsine les intéresciés onl réclamé lemr protection.

"L"homicide est un délit public qui, nême commis sur des particulier's, manare la sécurité de tous.

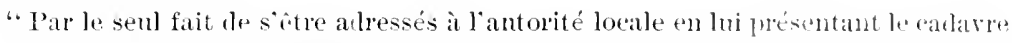

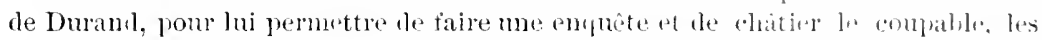
marins ont demanclé aille et protection à l'autorité du port et se sont soumin it a juriliction."

In comparing this case with that of the Tempest, the comsel fer the llefence aind: "Ce n'est pas comme pour le erime commis an Iavre en 1 s.j9 a horel lu vavire américain le Tempest ; lì, les autorités françaises durent intervenir (tant l"émotion était granle!) pour protéger le coupable contre les marins lu port ot lis lablikants de la ville "qui hni eussent inévitablement fait application de la loi de Lyncis." 


\title{
CAE OF WIIDENIILS.
}

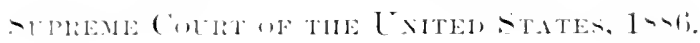

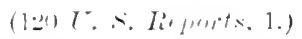

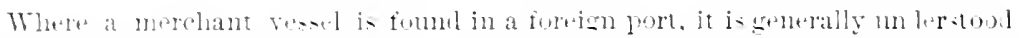

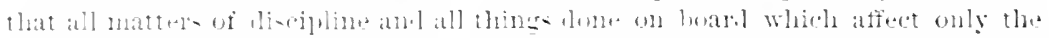

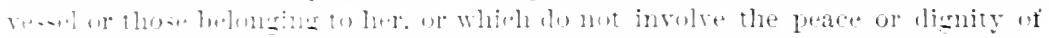

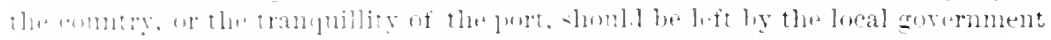

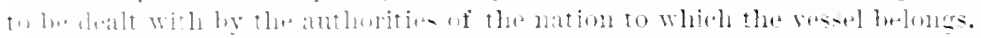

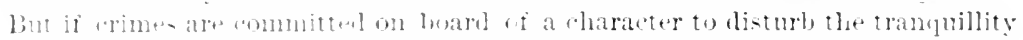
wi the lont the enent of the country should take jurisdiction. And murder is 11.11 to 1 w such al erime.

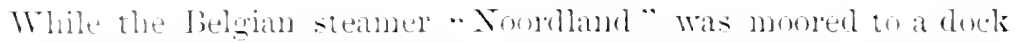
in Jusey Cing. Xew Jersey, an athily arose between decks in whing oweph Wildenhus killed oue Fijens. Wildenhus was at-

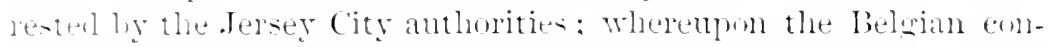
sul applied to the L. S. circuit comt for Xew Jersey, for luis releatse

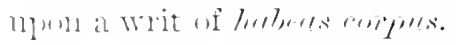

The comet refused to deliver the prismor, and to reverse that reci-ion. - An alpleal is taken to this comrt.

Whate. C. . helivered the orinion of the court. from which the folluming ale (ximats.

" The enurts of the Tnited states have jowel to issue writs of

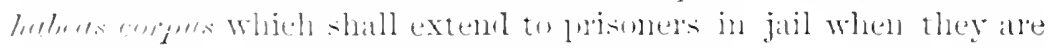
in - enstuly in vindetion of the Constitution or a law or tratty of the Enited states. and the plestion we hare to comsider is, whether

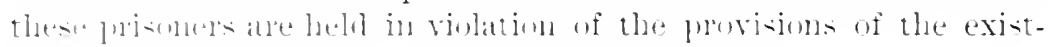

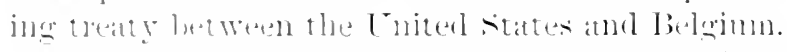

-. It is jant of the law of civilized nations that when a merehant

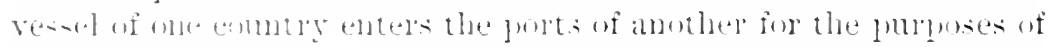

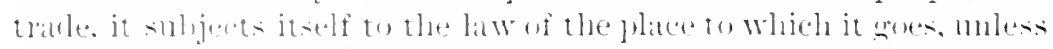

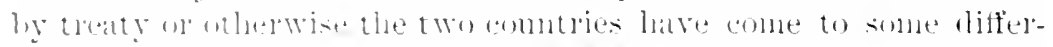

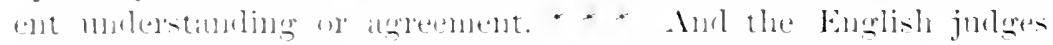

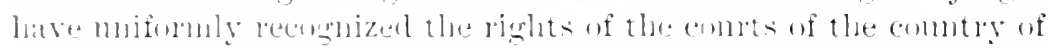

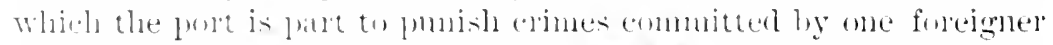

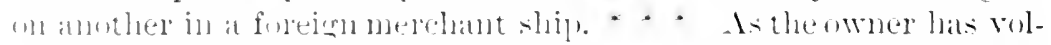

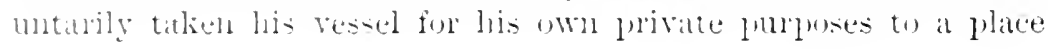


within the dominion of a govermment other than his amm, and from which he seeks protedion during his stay, he owes that worrolument such allegiance for the time being as is date for the punteretion to which he becomes entitlerl.

"From experience, however, it was fommd long" and that it wombl be beneficial to commeree if the local government wald alstibu from interfering with the intermal discipline of the ship, and the general regulation of the rights and rluties of the oflicers and arew towards the vessel or among themselros. And s:s ly anmity it came to be generally molerstoon among civilizol nations llat all matters of discipline and all things done on loard which affected only the vessel or those belonging to her, and alid not involve the peace or dignity of the eomntry, or the tranguillit y of the port, shomlel be left by the local govermment to be dealt with ly the antmrities of the nation to which the ressel belonged as the laws of that nation or the interest of its commerce should require. But if erimes are committed on board of a character to disturl the peate and tranquillity of the comntry to which the ressel has been bromble the offenders have nerer lyy comity or usage been (ntitled to any aximption from the operation of the local laws for their pmishmitnt, if the local tribunals see fit to assert their authority.

"Such being the general public law on this subject, treaties and conventions have been entered into ly nations having eommerobal intercourse, the purpose of which was to settle and definc the riohts and duties of the contracting parties with respect to anch other in these particulars, and thus prevent the inconvenicnce that might arise from attempts to exereise eonflieting jurisdictions.

"It *** appears that at first provision was made only for giving consuls police authority over the interior of the ship and juriseliction in civil matters arising out of disputes or differences on board, that is to say, between those belonging to the resicel. Curler this police anthority the duties of the consuls were evidently confined to the maintenance of orcler and discipline on hoard. This gare them no power to punish for crimes against the peace of the comntry. In fact, they were expressly prohibited from interfering with the local police in matters of that kind. The cases of the sally and the Veroton are illustrative of this position. That of the sully related to the discipline of the ship and that of the Ferton to the mante. nimce of order on board. In neither case was the distmrbance of at character to affect the peace or the dignity of the comtry.

"In the next conventions, consuls were simply made jurlges and arbitrators to settle and adjust differences between those on lwakl. This clearly related to such differences between those belonging to 
the ressel an ate caphble of adjustment and settlement ly judicial

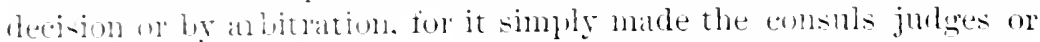
arbithatols in such mattels. That would of itself exclurle all idea of fmmin-hment for erines andinst the state which atfected the peace

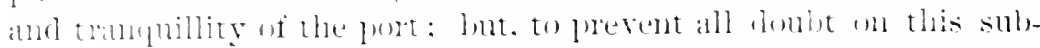

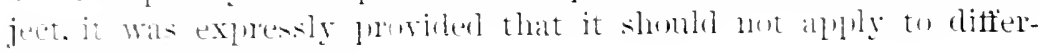
encese withat chatriaterle

- Next canne a form of convention which in terms ante the omsuls

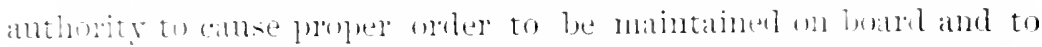

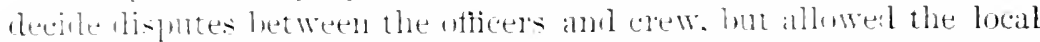
anthuties to intertere if the disolders taking plate on bayd were

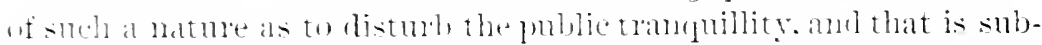
-tantially all there is in the convention with belginm which we have now to eonsidel. This treaty is the law which now goserns the concluet of the [nited states and Belerim towards each other in this maticular. Ealch nation has munted to the other such local julvedictinn within its own dominion as may le necessary to maintain orfer on hord a merchant ressel. but has reserved to itself the right to interitere if the disorder on bond is of a natme to disturb the jublic tranquillity.

.. The thaty is part of the supreme law of the Canted states, and hat the same force and effect in Xew Jersey that it is entitled to elsewhere. If it gives the consul of Belorim exchsire jurislietion wel the atfense which it is alleged has heen committed, within the territong of Xew . Tersey. We see no reason why he may not enforce

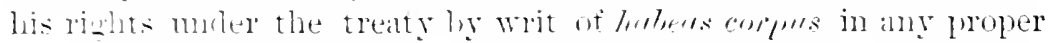
come wi the [nited states. This heine the ease, the only important que-tim left for om aleternination is whether the thing which has

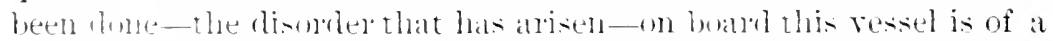

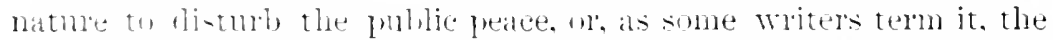

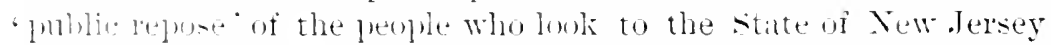
for thein lontextion. If the thing done-the disonder, as it is called in the treaty-is of a character to atfeet those on shore or in the port when it hecones known. the face that only those on the ship saw it when it was done is a matter of no monnent. Those whos are not on

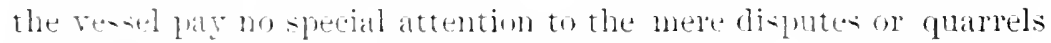

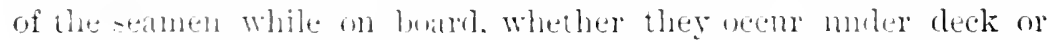
abore. Neither do they as a rule care for anything donte on board which lebater only to the liscipline of the shipe or to the preservation of orrer and anthority. Xot so, however, with crintes which from their ararity awaken a molice integest as sonn as they hecome known, and e-pecially those of a dhancter which every ejvilized nation considers it-elf bound to proride a serere punishment for when com- 
mitted within its own juristiction. In smeh casts impluify is antain

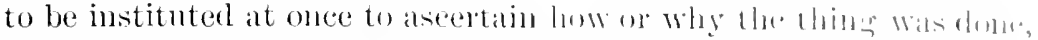

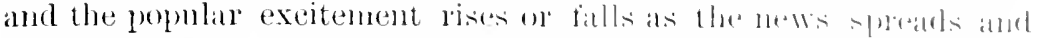
the facts become known. It is mot alome the pullicily af llse ar.t, 10

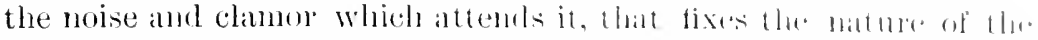

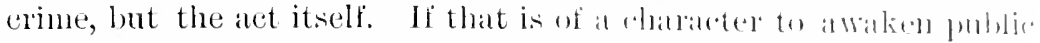

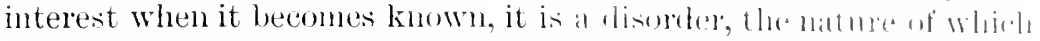

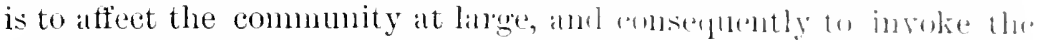

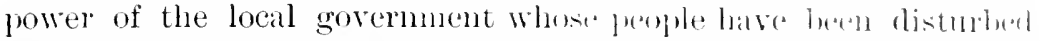
by what was done. The very nature of sleh an ate is torlisturb the. quiet of a peaceful commmnity, and to create, in the langlatere of the

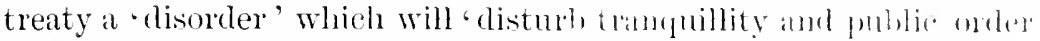
on shore or in port.' The principle which governs the whelle matter is this: Disorders which distmb only the peace of the shij on those on board are to be dealt with exchusively ly the sorereignty of the home of the ship, but those which distml, the public peace may be suppressed, and, if need he, the offemer's punished hy the poner anthorities of the local jurisdiction. It maly not be easy al all times to determine to which of the two juristiotions a particnlal act of olisorder belongs. Huch will undoubtedly depend on the attending eircumstances of the particular case, hut all must concele that felonions homicide is a subject for the local jurislietion, and that if the proper authorities are proceeding with the case in a regular way, the consul has no right to interfere to prevent it. That, according to the petition for the habeas corpus, is this case."

\section{THE “RELI $\backslash$ NCE."}

\section{U. S. Circuit Colrt for Sin. Dist. of N. T., 1st?.}

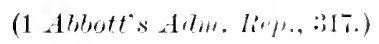

The Reliance, a British ressel, rescued gomb from the wreck of another liritish vessel; and afterwards arrived in the port of Xew York, and inslituted proceenlings for salvage. Jurisdiction was refused.

This was a libel in rem filed by the owner, master and crew of the bark Reliance against One Hundred dind Ninety-four shawls siltred

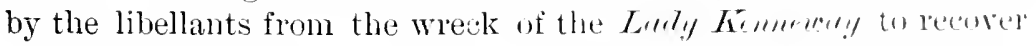
salvage compensation.

The Reliance was a British vessel which left Liverpoul lumed to New York. Near the coast of Englamd, she fell in with the Larl! henneway and boarded her, finding no pelson on loarr.

The Lady Kennevay was a British East Indimman, owned in 9 
London, on her way to London from Bombaly. The master of the Reliduce ordered several cases containing shawls to be taken from her, and then abandoned lier. The Rolirnce pursued her way to New York. where she arrived December $1,1 \times 47$.

A libel Was filed against the ehief part of the articles brought from the Laly Femmory. The British consul, by leave of the court, intervened in behalf of the mknown British owners, praying the comrt to orler restitution for their benefit of the property attached, atter allowing the libellants a reasonable salvage, if, in the judgment of the court, "they proved a case of derelict, and their conseyuent right to salvage."

The individual claimants, as well as the consul, set up defenses anainst the awarl of salvage, charging waste, damage, and destruction of the apparel and stores of the ressel.

It is insisted that the court should decline jurisdiction in the case, becanse the Lorly Kennerroy was an English vessel, then on a homeward royge, with her caroro for an English market, and the Relience at the time. Was an English vessel, with a British crew on board, who had signed British articles and that aecordingly both vessels and libellants wele bound to return to terminate the royage at a british port.

Betts, .J._- "*** As a general principle, the citizens or subjects of the sime nation liave no right to involie a foreign tribunal to adjudicate between them, as to matters of tort or contract soleiy affecting themselves. It rests in the discretion of the court, whose antlority is invokel, to determine whether it will take cognizance of suth mattel's or mot. ***

"As maritime combts proceed npon a common rule of right and compensation in salvage rases, the question of jurisliction in that elass of actions will sellom be raised or regarled before them.

"The conlts will take corrnizance of those cases as matters of course, if either party is territurially within the jurisdiction of the court; and the property beins bronght within their jurisdiction, althomgh the salvors and claimants may be citizens ol subjects of different nations, the compt will mulesitatingly dispose of the subject, if satistied that the whole right is before it,-salvage being esientially a question of the jus gentimm.

"I find no anthority of weight which imposes on the conts of our comutry the necessity of determining eontroversies between foreigners resirlent abroar, either in common-law actions, transitory in their nature. or maritime proceedings when the remedy is in rem.

"If the roctrine were peremptory, imparting to suitors the right to such airl, and imposing on courts the obligation to afford it, 


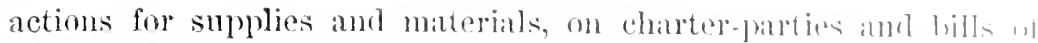

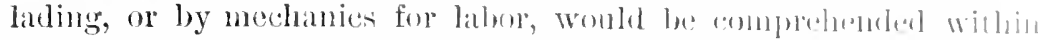
the elass, equally with suits for Wages on lontomly lumls or for salvage eompensation.

"I am satisfied the law is not so. In my jurlemment it wamll b." lamentable if courts were compolled to dofer the lowiness af the citizens of the eomntry to bestow their time in litimation lestweren parties owing no allegiance to its latws, and eont libuling in un waly to its support. Should it transpire, in the procress of the litigntion, that the law of the domieile of the partics must be aseertamed in order to adjudge rightly on their chams, or that witmesses must lwe examined there to fix the facts in eontroversy, the comit might low compelled to suspend its movement and wait mutil these calrhinal particulars could be supplied from abroat. Every tribmual expe. riences the inconvenience and montisfactoriness of so settling (onntroversies between those even who ean have no other means of ledress, and will recognize the valne of the prineiple which enahles them, in regard to foreigners, to remit their enntroversies to their home tribmals, where the law is known, and the falcts an be mone surely determined. This cont has, in repeated instaness, acter upon this acceptation of the law; and believing it to be the somm and safe rule, I shall adhere to it in all cases authorizing that rxercise of discretion.

"The question to be considered is, whether, in this ease, the rights of parties would be best promoted hy retainimg the case and disposing of the subject here, or by remitting it to the home eourts af the salvors and claimants.

"The answer adrances many grave imputations andinst the eonduct of the master and seamen on board the wrok and after the property came into their possession, and these charges are not witlout color of proof to support them. Their ease does not, aceoluingly, come before the court with the most persuasive claims to its interposition and favor. When salvage services are emincutly melitorious, and the only inquiry to he marle is the late of award to lue allotted, Admiralty Courts would be solicitous to give erery luaticable despatch to suits by the salvors, and relieve them loth form delay and expense in obtaining their just reward. It ronles sanerely occur that any court would withhold its aid from snch suitors. It is quite different when the foreign owner of the property aharess his fellow-subject with embezzlement amr spoliation, aml other. wanton misconduct in respect to it, and prays the privilege to coultest his claim to compensation before the anthorities of their common country. *** 
"The termination of the voyage of the Refirme was in England, where it is to be prestmed she would arrive within a short period attel leaving this port, amb it is most fitting that the guestion of the

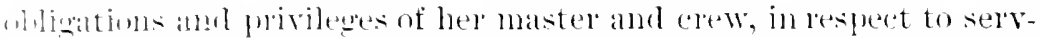
ine rentered a british resiel, a wreck or in distress on the English mats. shombl be determined in the comts of that matim.

. As the libellants maty not recham the ponesty attached in their

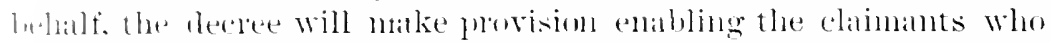
have interened in their own right, and the British Comsul in behalf of moknown owners, to tike the gronds unt of eourt and ship them to their port of destination."

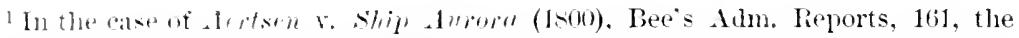
- wit wa brought bor seamenls wages and to obtain a discharge on accome of the

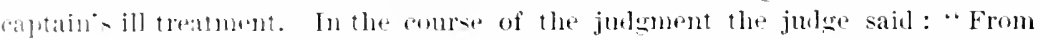

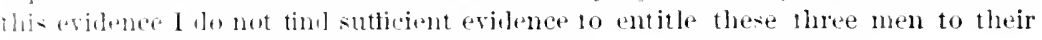
Alechatren (from the completion of the royage).

*(1) Because no mulawful weapom was used.

" (2) sutficient prormation tor the eaptain's arts.

". This is the ease of a wentral vessel, the "rew of which are bound by their arti-

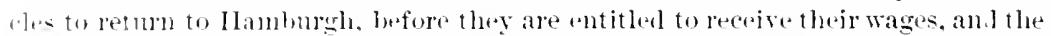

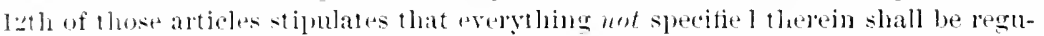
lated acomoling to the marine law of llamburgh for regulating the conduct of

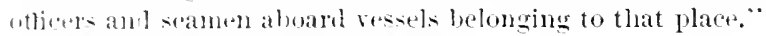

The suit was lisminath with costs.

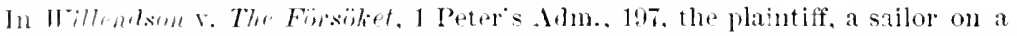
I banish thi], eitul his calptain on a claim for wages. The juclge, in the conrse of hi- opinion, says that his generai mule has been not to take cognizance of disputes betwen masters and crews of foreign ships.

"I haw." sail he, "** * in peculiar cases * * *ompelled the payment of wates ** anistel in recovering deserters * * (an:l in) renducing to obedience

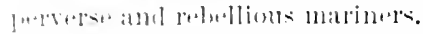

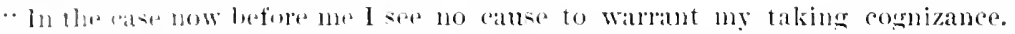
It is the luty at the matere to return the seaman 10 his own commery. This he

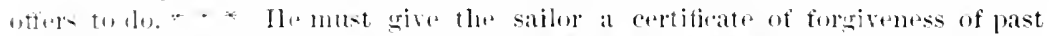

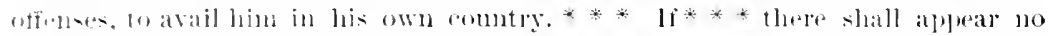

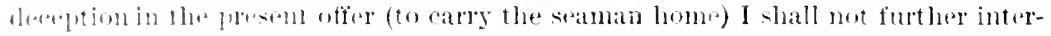
tom. but dismin lle suit."

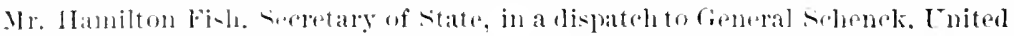

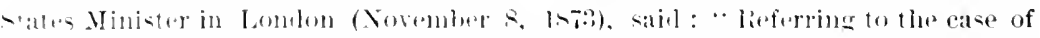

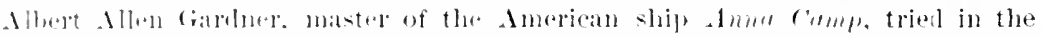

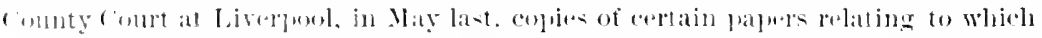

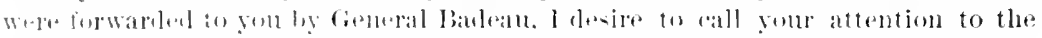

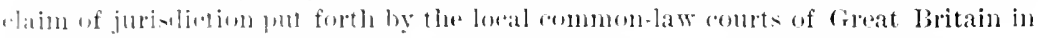

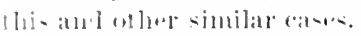

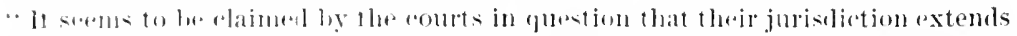

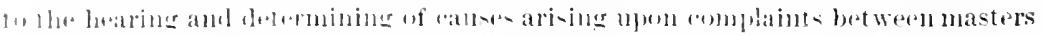

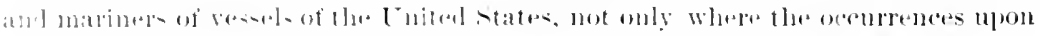
whin the complaint nuty be fommlent took place within british ports or waters, 


\title{
ELLAS v. MITCHELL.
}

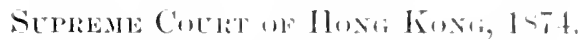

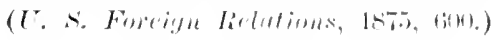

This was the case of a controversy botween a saman and the makter of ant

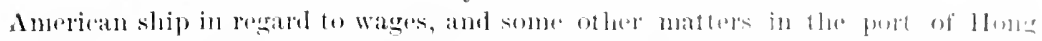

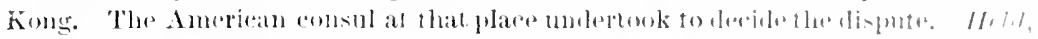

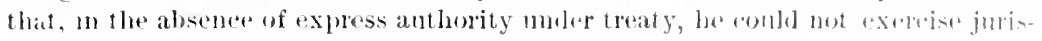
diction in such matters.

Judgment, Sisats, C. .J.:--

"Ont deeision in this apleal having beon for some time come to, we handed to the registran onr eonehuled julgment and hy am dimetion he save it ont on the Tth of November last. 'That dexeision was in the following terms: "We have folly consinlered all the fiarts in this ease and the very able argments which, on the bat of the appellant, Mr. Kingsmill submitted to ns. The respmelust dirl not appear. We are of opinion that the applellant has firiled to shom that the decision in the summary branch of this emot is women. It is our duty, thelefore, to dismiss this appeal.' 'The respondrut hat incurred no costs; we sily mothing as to eosts. Sume questions as to the duties and jurislietion of consuls have arisen in this calse to which we shomld wish to advert, but as these questioms arise ont of this case, rather than lead mp to on deeision, we pmpose at a morn convenient opportunity to refer to them. It sems to ns that a some what exaggerated notion as to the duties and juristiction of comsuls in this colony is prevalent.

"The gromols and reasons for the decision in this rase were vory carefully consideled and eonferred on between us. We were andurent in the conclusion that the appeal must be dismisised. In order that the parties might not be kept longer in suspense, we dirested the decision which I have just read to be given out hy the rewistrial an th+*

bnt also when the offense which is mate the gromul of artion wats commitum on board the ressel on the high seas.

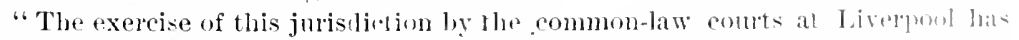
alrealy been the canse of much annoyance and in some instundes serions indentvenience 10 masters and owners of Ameriman ressuls, and if persinted in mily affect injurionsly the interests of American shipping."

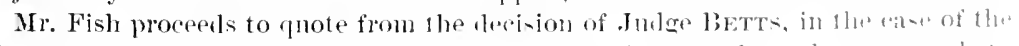

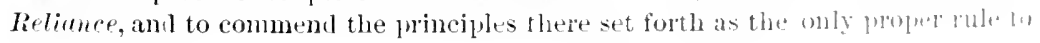
be followed. 
Fth day of Xovemler, as I have already said. There seems to have leen a salve misilpurehension that this case came hefore Mr. Justice sumblen ats an aldeal from the decision of the consul of the United stilter.

. It wis mut so. From the first it was treated by the learned judge

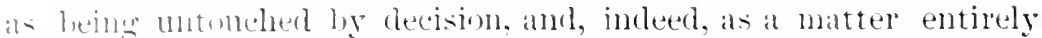
Hew aims the comsul of the Enited states. True it is that a disciandes of the phintitf from the ship, and an accomnt taken in the fresane of the comsul of wages armed, were jodnced and relied on his the detemelant. the mater of the ship, as an answer to the plaintit"s chim: lont it was held in the smmmary branch of this comt, num the evilence before it, that in nu, wy was the comsul acting $00^{\circ}$ incerenine juliedally, either as to the rlischarge, or as to the aceount. Yo ditin for mbitul dismissal had heen raised before the eonsul. It minht have heen properly rased hefore the poper judicial tribmal uf anl within the Inited states; hut no evilence was adduced to slow that that authority was vested by the law of the Cuited states in the ansull here. Even if it had been so vested by any such law of the Lnim, it required the force of a treaty, and an act of Parliament. or lnal orlinance, to enalle the consul to excreise any extra-teritorial julliakl fower within British territory. Although some instructions wo the consuls were produced to the cont, no act of Congress mas funhued, nor was there any evidence that there was any such act, ir common-law power in a consul. According to chancellor Kent's Commentatris. rol. I., p. so, et ser., consuls are commercial agents. * * In some places they have been invested with judicial powers crer nisputes hetween their own merchants in foreign ports ; lunt in the commereial treaties mate hy Great Britain there is rarely any stipulation for clothing them with julicial anthority, except in treatien with the bathery powers. And in Enghand it hats been held that a amonl is not strietly a julicial officer, and they have there no

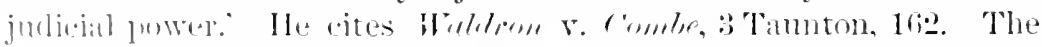

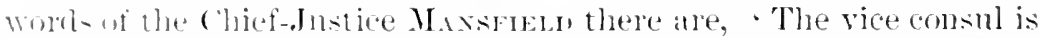

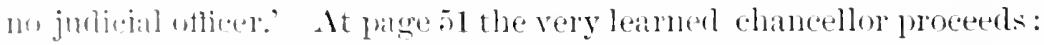

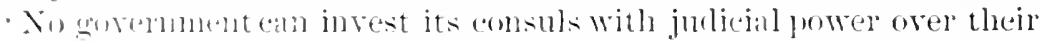

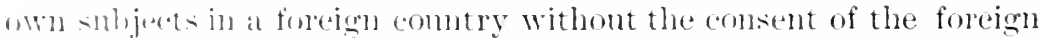

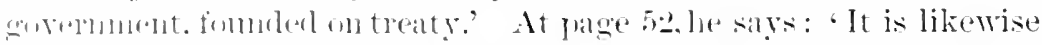
mate theil duty (i. . of oomsus), whele the laws of the comntry permit. to alministre on the lersonal estates of American citizens dying

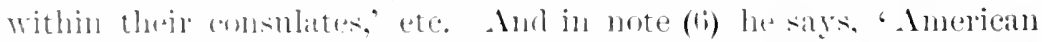

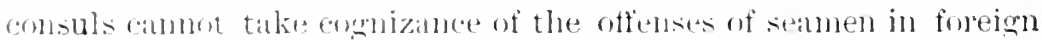

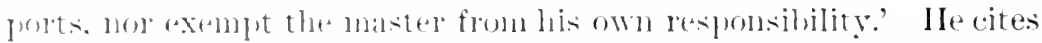

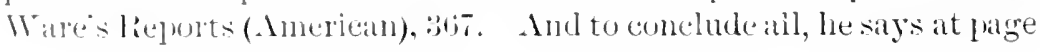


5:3: "The consular convention between Flance and this anduntry (i, ,

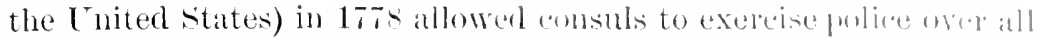
vessels of their lespective mations within the interion of the rasids, and to exercise a species of eivil juristiction hy determinime dismotes

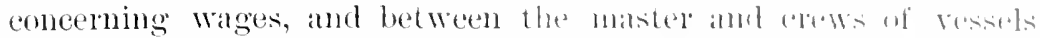

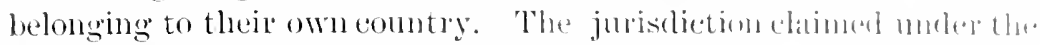

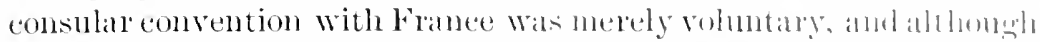
exehsive of any coereive anthority, and we (i. . the luiterl states) have no treaty at present which eoncedes even such omsular func. tions.' We quote the gth edition of Kent's Commontandes (1-5). We have before us the valuable work of Jurge bombiel, the lawdictionary, the the edition of $18-2$, and in it we find mothing to vary all that Chancellor Kent asserts. P'arsoms' Law of shiphlum, pul. lished in 1869, is to the same effeet. One quotation fom l'ansons, vol. II., p. 56 .

"He there says, 'a discharge (i. e. of a seaman.) when male in a foreign port, is required to be marle betore the consul; lut the par ment of wages already due is not.' Imb this to such an extent that the learned author adds. "and the comsul has no light to chasege a tommission for witnessing the settlement, in other works, he has nothine to do with the settlement of the wases due ; fortion he has mo allthority in reference to damages for breach of contract, or otherwise, between the master and the seaman. Now, if the consul has mostuch anthority, the anthority must be somewhere, and it cammot he andtended, upon any grounds of which weare aware, that this count has not the fullest anthority over all such ulisputes. It is quite clear that the legislature of this comutry can, hy statute or orlinamce, wive extraterritorial powers to consuls, hut as all sueh powers ane in derogition of the roval prerogative all such laws must be construed strictly. It appens to us that ordinanee No. 4 , of 1850 , has no bearing on the question before us. It relates to cases of desertion from ships, and to nothing else. Ordinance No. of of 1 ri: is prohibitory. It says that no British seaman shall be dischargerl elsewhere than at the harbmmaster's office, and that every seaman discharger from a forrign ship, represented by a consul here, shall, within twonty-fom homs of being discharged at the oftier of his consul, ol vior-emsul, ploduce at the harbor-master's ofice a curtificate of his dischilrese.' Now, this is not an enahling statute, and it gives mo momele to any consul which he had not before. All it does is to assmme that every discharge of a foreign seaman will have hede wivest alt the oftice of the consulate of his comntry. But for loustation the discharge of a seaman is a matter between matster and seiman only. 
Notleaty has heen poduced, no act of l'arlianent or ordinanos other

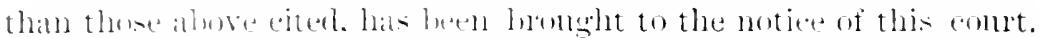

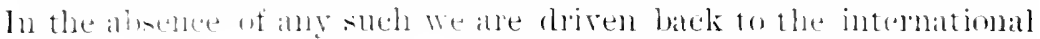

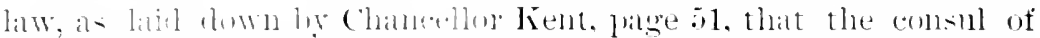

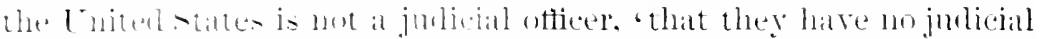

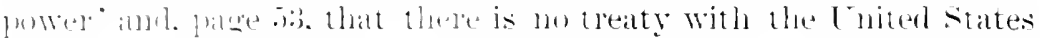

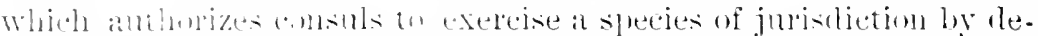

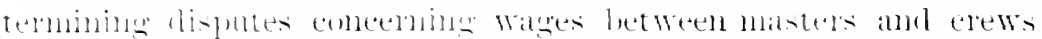

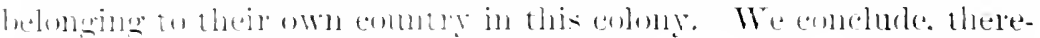

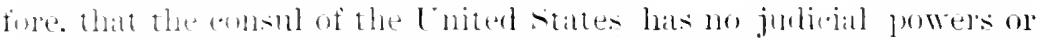

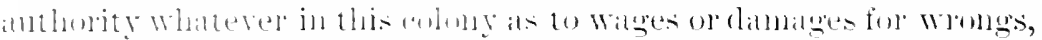
betwere fuited states mal-tels and seamen, which the judicial

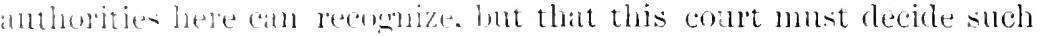

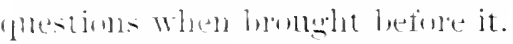

. What we hatesild as to the consul of the Lnited states applies

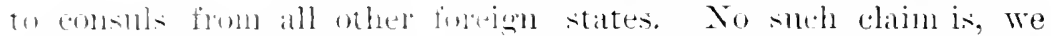
believeset nl, in any other part of the british domninions. In China,

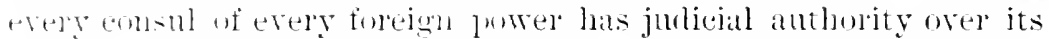

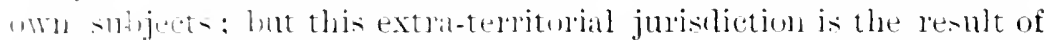
express tratly and is confelred on them by the chactments of the

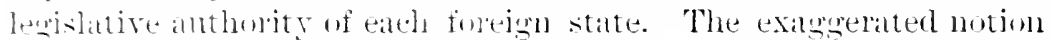
as to comsular anthority here has probably arisen fom the powers ancerled to them in china lut which are not concerled hese.

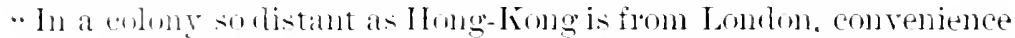

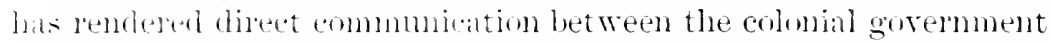
and consmb hele on many sul,jets properly diphomatice convenient for all parties. This has poblably tenderl to induce an overestimate

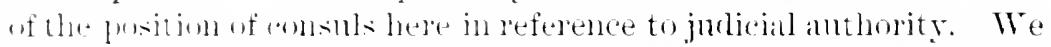
feel eneat resper for the comsuls in this colong, both officially and fersmally, hat we must see that the anthority of this comet is not

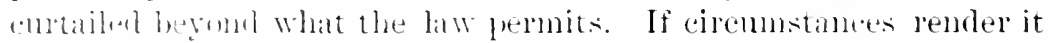

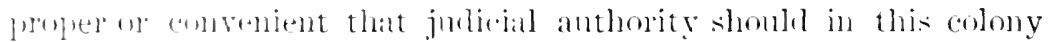
ret in ans-inls. it must be olutainced by treaty and legislation. This whet has no prowel to concede it."

\section{TIIE" "( REEOLE." $1+41$.}

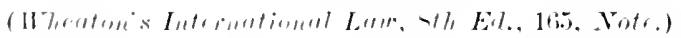

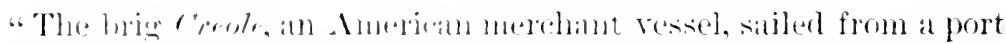

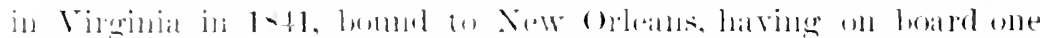

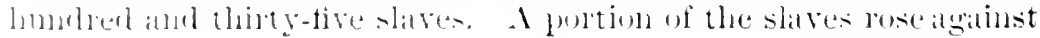


the offieers and got complete possession of the veside killime and

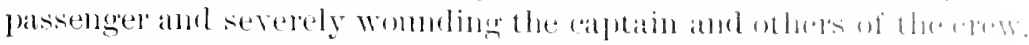
in the strugere. The

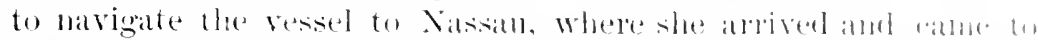

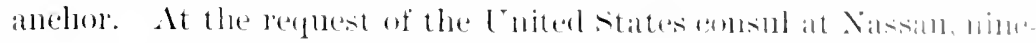
teen of the slares. Who wero identified as having talien lat in 1 l. aets of violence. Were arrested by the loeal alltholitir.s, and lald to arat the decision of the British foremoment. As to the lost af the slaves, there was a question whether they got on shore and milum

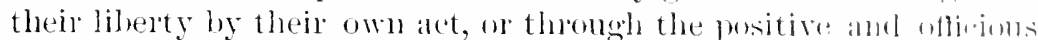
interference of the colomial anthorities, while the vessel was mollol. the control of the consul and master. Mr. Melster, serebtary of state, addressed a letter to loor Ashbmetom on this subject. Mis position is, that e if a resisel of the Enited states, pulsuing law ful voyages from port to port along their own shore, are driven by stress of weather, or carried hy mbaful foree, into Jritish ports. Whe govermment of the Enited states camnot comsent that tha lonal authorities in those ports shall take ald vantage of such mistortunes, and enter them for the purpose of interfering with the anditim of persons or things on boand, as established ly their own laws. li slaves, the property of citizens of the [nited states, escalpe intor British territories, it is not expected that they will be lestorend. In that case, the territorial juristiction of England will hatre heame exclusive over them, and must decide their comblitom. lint saves on board of American vessels lying in British waters ale mot within

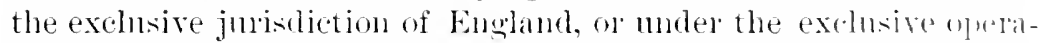
tion of Englisin law; and this fomds the hroal distind bum betwen the cases. ** In the opinion of the govermment of the I nited states, snch resiels, so driven and so retained by neresity in a friendly port, omoht to be regarded as still fulsuing their orremal royage, and tumed colt of their direct course by disistor an by wongful violence; that they onght to receive all assistande necessary to enable them to resume that direct comse, et $\cdot * * *$,

"The Cnited states Government remanded the lestoration of th..

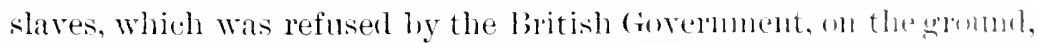
that, being in fact at liberty within the British dominions. he? ("ondel not he seized there when charger with no crime aganst british law. and while there was no treaty of extrarlition. This also wath then sulmitted, as a private claim for gecmiary indemmity to the (amm-

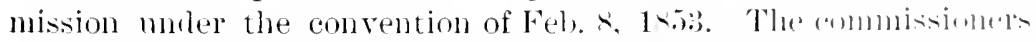
being unable to agree, it was hy the terms of the comvention. lofirled to an umpire, Mr. Joshna Jates, of Lomion.

"In deeiding the case, Mr. Bates stated two propositions of law :- 
“1. Thith as the shres were perfectly quiet, and on board an American ship nuler the command of the captain, the authorities shomald have seen that the captain was protected in his rights over ilinill.

...2. That. - the municipal law of England camnot anthorize a magistrate an vinkte the law of nations, by invaling with an armed force the risid of a friendly nation that has committed no offense, and

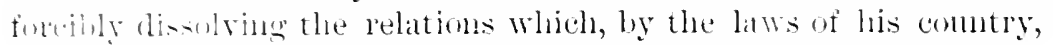
the master is inmind to preserve and enforce on board." 1

i Mr. l)ana eriticies the decision of Mr. Bates in this cane. "It may be con-

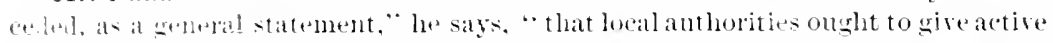
atd on a manter in delemding and enforcing, against the inmates of his ressel, the risht with which his own nation has intrusted hom, if these rights are of a character trenerally recougnized among all nations, and not prohibited by the law of the flawe. [3ut it naty well almit of doubt, whether the local authorities must give at"ite atil to the mater atgainst persons on board his ressel who are doing no nore than patertully and quietly dissolving, or refusing to recognize a relation which Exist only by tube of the law of the nation to which the resel belongs, if the latw

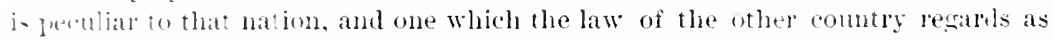
again-t commont right and public morals. The local authorities might not interfere

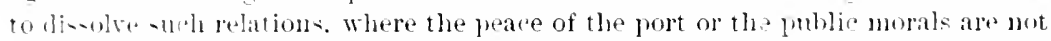
fut in peril : but they might, it wonld seem, decline to lemi fores to compel their

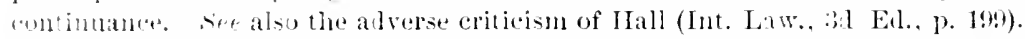

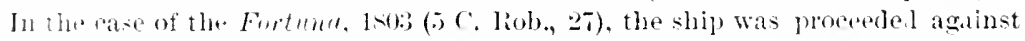
for at violation of the blockade of the lleser. The master of the captured ressel

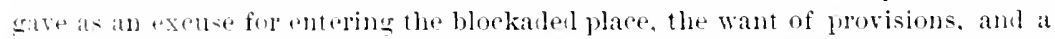
strong we-trly winl. Sir W. Sent hell that "want of provisione" was not such an "impretive and wrer-puling eompulsion" as to exense a breach of blockade. bat on the other erouml, after further proof, the sessel was restored.

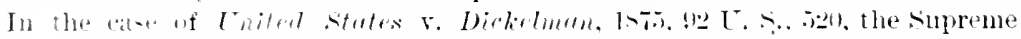
court "mulationlly atfimed the rule that merchant ressels are subject to the local juricliction when in foreting jorts.

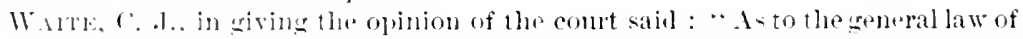

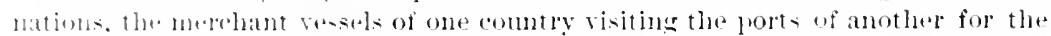

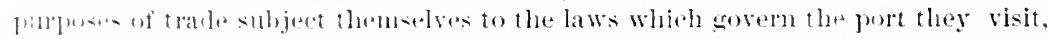
of lone at lle'y remain; and this as well in war as in peace, unless it is otherwist morited by treaty:" 
Section 13.- Rimint ar AsYluir.

(') Ill Ligretions.

\title{
DUKE OF RIPPERIA'S ('ASE, 1726.
}

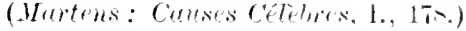

Right of asylum in the British lesation in Matrid denited by the govermment of sprain.

Baron Ripperda had been a colonel in the service of the siatesGeneral of the Enited lrovinces, and hath been sent by them as minister plenipotentiary to the court of Madrid. After two yeans of residence at this eomt, he had so captivated the mind of l'hilip $\checkmark$., that that monareh took him into his service, mate him minister of finance and of foreign affilirs, and confered upon him the title of Duke. Aceused by the Imperial Ambatsatelon at Marbid of sererety faroring the interests of IIolland and England, he was tinally defrived of his offices, though granted a pension hy the King. Fearing. as he said. the emmity of the populatee, be took refuge in the lontel of the English Ambassador, Lord stanhope. The Spanish governunent would seem at first to inare acpulesced in this andugenent, hut learning that the Duke had important state palpers in his possesion. it denanded his delivery. Not meeting with a compliance to this de. mand, the question was referred to the comeil of Castile, whether, without violating the law of nations, the Inuke of lingerda combl be forcibly taken from the house of the English Ambassador. The Council replied in the athimative: "To at otherwise would be to employ a system which had been adopted to fateilitate the intercourse of sovereigns, for the destruction and ruin of their anthority. To extend the privileges accorded to the hotels of ambisisalor:s in faror of merely ordinary offerses to persoms intruster with the finances, the powers, and the serets of a state, when they liareb-

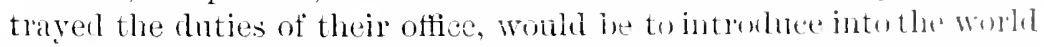
a pinciple most injurious to all nations. If this maxim we we to become the rule, sovereigns would be obliged to see maintained at their own cumts those persons most actively engiged in malchinattions for thejr ruin."

Lord Stanhope's house had already been under strict smroillandes:

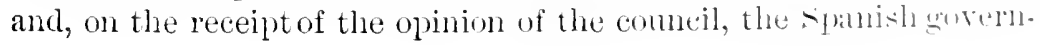




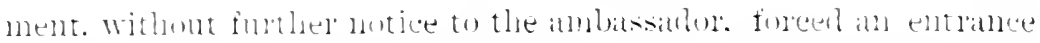

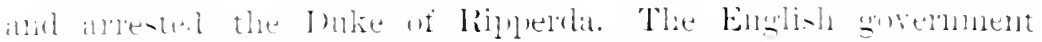

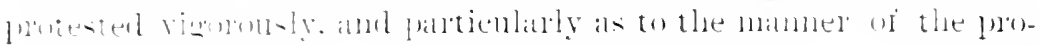

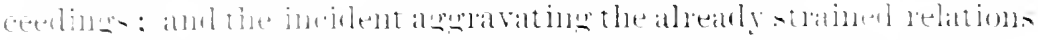

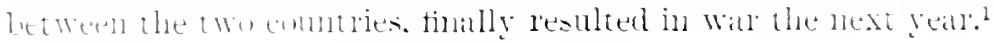

\title{
IXITEI STITES , IEFFElit.
}

\author{
L. - (

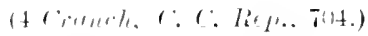

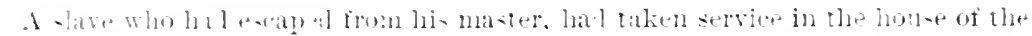

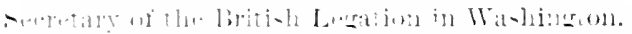

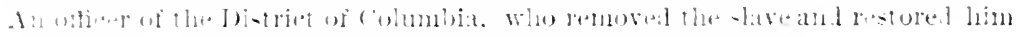

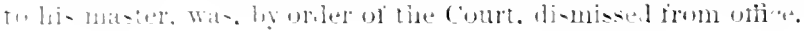

Francis - Key. Itturney of the Cnited riates for the I)intrict of

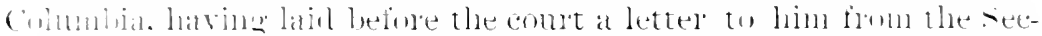

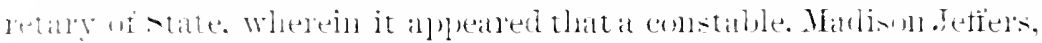

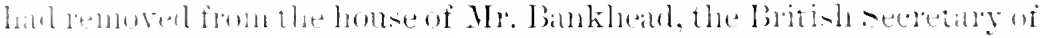

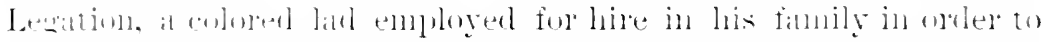

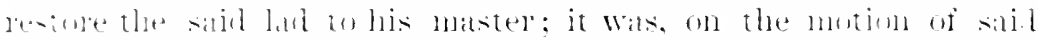

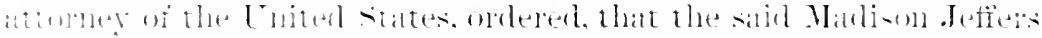

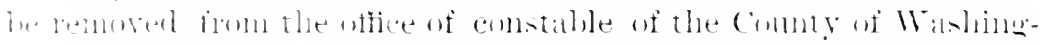

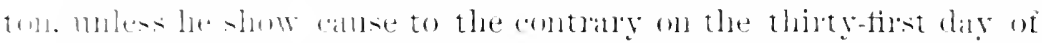

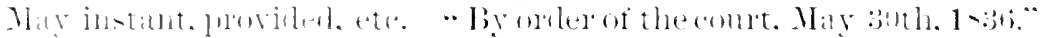

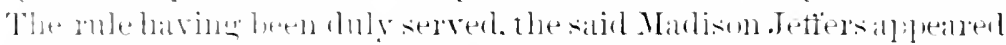

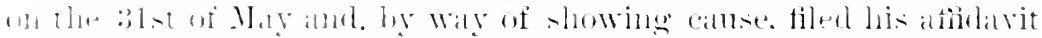

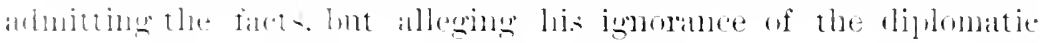

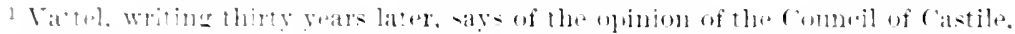

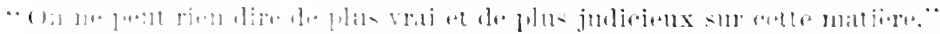

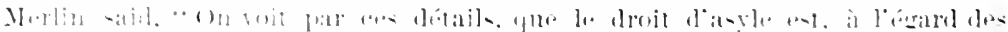
J

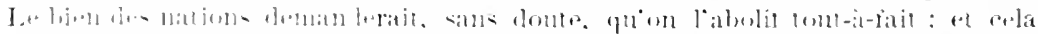

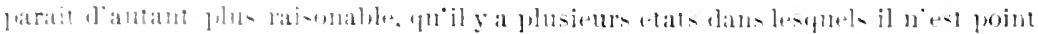
(1):!1!13."

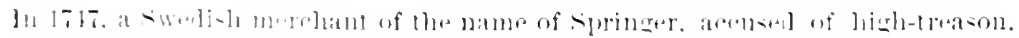

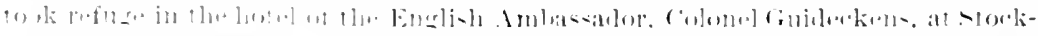

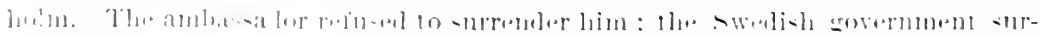

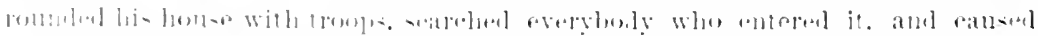

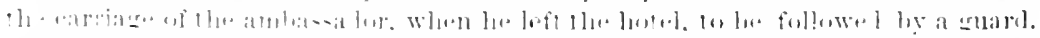

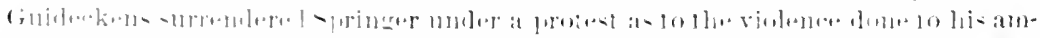

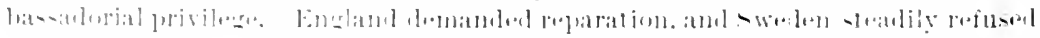
to give it, and the amba-ators from the two court were mutually withlawn. 


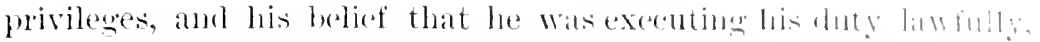

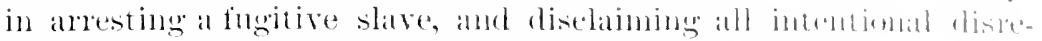
speet to Mr. Bamklead.

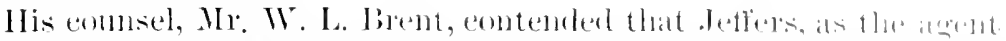
of the owner of the slave, had a light to take him ally whele: and

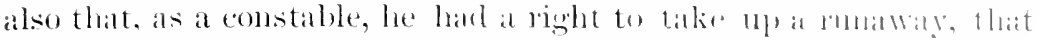

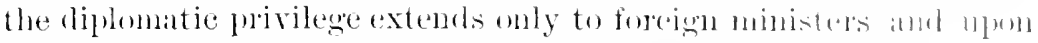

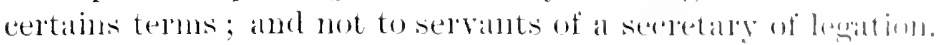

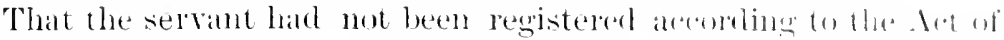

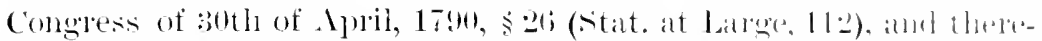

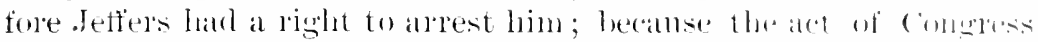
for punishing the violation of privilege does not extend to thore who may aldest a servant not registered. By not regintering his servallt,

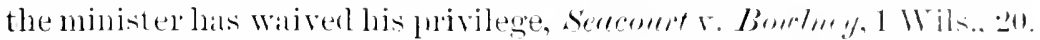

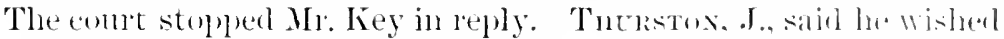
no further time or argument. Ile was of opinion that defiers shombl be dismissed form office.

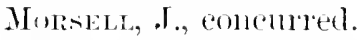

Consos, C. J., wonld have taken time to tomsirler; hut salid that his present opinion eoineided with that of the connt.

Wherempon the comt passerl the following ordel:

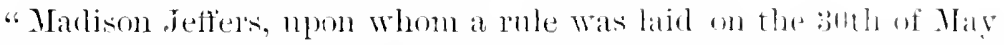
last, to show canse why he should not be removed fom the oliter of constable for the comity of Washington, upon the gromeds therein stated, appeared and filed his aflidavit, and the sime was leall and heard, and he was further heard by his comsel wherempun

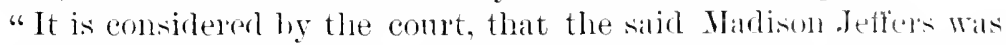
guilty of a viobation of the privileges of Itis Britamic Maljesty"s Enyoy Extrandinary am Minister Plenipotentiars. as stated, in his letter to the secretary of state referred to in the said rule; and the said Madison .Jeffers, having shom no sufticient canse to the comtray, it is therempon considered by the cont, this 7 th day of .Jnne, 1836, that the said Madisom .Jetters be, and he is herely, removed from his said office of constable for the county aforesalia." 


\title{
OPIXIOX OF MR, FISII, SECRETARY OF S'LATE.
}

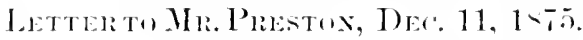

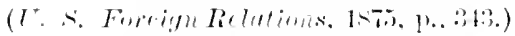

1 criticism of the praetien of glanting a-ylum to pritical refucees, by foreign leations, in the spanish American states.

$\therefore$ The right to grant asylum to fugitives is one of the still open ynestions of pullic law. 'The practice, lowerer, has been to tolerate the exereise of that right, not only in American comntries of spanish origin, hut in flain itself, as well as in IIayti. This practice, howerer. lias never aldlesced itself tothe full faror of this Government. In withholding approval of it, we have been actuated by respect for emsisteney.

"- It is not probable that the practice would ever be attempted in this combry, or, if attempterl, conld be tolerated, and the discomntenance which the Cniterl states extends to the practice is upon the principle of doing to others as we would they should do unto us, so that when we acknowledge thesovereignty of a foreign state by conchling treaties with and hy acerediting diplomatic officers to its Government, we implielly, at least, acknowledge it as a political equal, and we claim to extend to all the political prerogatives and immmities which we may claim for ourselves.

" We sincerely desire that it may be miversally recognized that foregu legations shall nowhere he marte a harhor for persons either charger with crimes or who may fear that such a charge may be made.

" l'ominent amomg the reasons for objection on our part in giving asylum in a legation. expecially in the foremuents to the south of us, in that smoh a practice obromsly temls to the encouraement of offenses for which asylmu may he desired.

"There is camse to beliove that the instability of the foremments in comntres where the practice has leen tolerated may in a great degree le imputed to such toleration. For this reason, if for none other, the foremment of the Enited States, which is one of law and orler and of constitutional olservance, desires to extend no encouragement to a practice which it believes to be calculated to promote and encourage revolntionary morements and ambitious plottings.

"Instances, too, have occurred where asylum having been granted 
with impunity, has heen grossly abused to the defeat of justien, lut

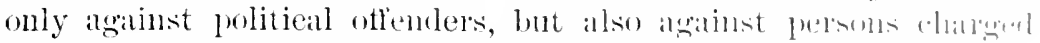
with infamons crimes. Suel abnsess ale plainly ineomplathl. witl the stability and the welfare of (iovermments, and af socinty itself.

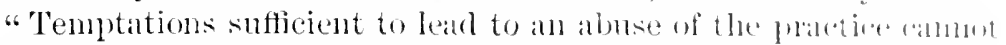
fail to abound in most persons who ma exereise it. Sild tromplattions are incident to human nature, and in comntries where politioal revolutions are of frequent occurence one must he gifted with 111 common self-denial to be wholly free from their influences.

"It is believer, however, to be somm poliry not t" expose a minister in a foreign comtry to the embarrissments attemiant upon the practice. Still, this fovernment is not, by itself, and indopendently of all others, disposed to alsolutely prohibit its diplomatic representatives abroad from granting asymu in erery ease in which application therefor may be made.

" We do not, however, withhold from them our views of the practice, and will expect that, if they do exercise the premgative, it will be done under their own responsibility to their own Governument. We would prefer, therefore, not formally to assent to the probositions contained in the memorandum above referred to withont aseer. taining the viers of the other Govermments concerned in rearar to then.

"Some, at least, of those propositions appear to be far emougls; but as the circumstances of cases in which asylum may he granted greatly vary, it would, in the opinion of the undersigned, be preferable, until an understanding and an approach to accord of views as to the future practice in this regard can be had by the other powers, that every such ease should be treated according to its merits, rather than that we should be fettered in advance by rules which may be found not to be practically applicable or useful." "

1 The printed personal instructions of the government of the Lnitel states to its diplomatic agents of date of 185., eontains the following clanse :-

"In some countries, where frequent insurreclions oceur and consequenty instability of govermment exists, the praclice of exterritorial asylum has beconit su firmly established, that it is often invoked by msuceessful insurgents, and is ruactically reeognized by the loeal govemment to the extent even of respecting the premises of a consulate in which such fugitives may take refuge. This (iovernment does not sanetion the usage, and enjoins upon its representatives in such countries the avoidanee of all pretexts for its exereise. While indisposed to direct its agents to deny temporary shelter to any person whose life may be threatened by mob violence, it deems it proper to instruet its representatives that it will not countenance them in any attempt to knowingly harbor offenders against the lat : from the pursuit of the legitimate agents of justice." 


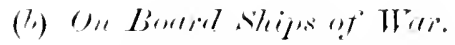

\section{(ADE OF OUIN BROUI.}

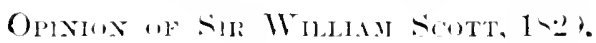

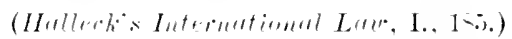

In the opinion of sir Willian sion, the right of asylum as regards political refigeres den not properly belone to ships of war.

In 1-20, Juhn Brown, a british subject, commaneled a vessel engaiger in the revolt against the spanish Colonies. Ile wats taken prismer by the sumiarls. hut escatped fom prison, and took refuge on hand 11. .I. $\therefore$ "Tyne," lying in the port of Lima. Nir William sontt, heing regnested he the Adminalty, gave his opinion on the quention, as follows:-...ir,-I have to acknowledge the receipt of yom letter dated the ".5th nlt., enchosing copies of a letter, and it: enclosures from Captain Faleon, of II. M. . . Tyne' and of the case and opinion of the Kings Adrocate, relative to Mr. John loumm, a native of Ireland, who. heing a prisonel, in the hambli of the spaniands. effected his escape and came on boand the 'Tyne, at Callas, and las since arrived on burl the same within the realm of England (latring claimed the protection of the Hacs), and acpuainting me that their Lordships conceiving that they had no atuthority to detain him, and beinw smported in

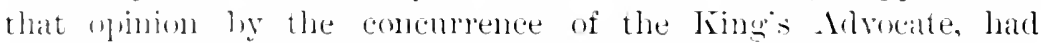
allower hin to depart without restraint. Epon this statement I have no olstration to make, not heing desired hy their Jordships to dmake any; but if my opmiom load been sequired, it would lave condeded with what hats heen advised and dome. A more extensive and impontant question is poposed to me, viz.: Whether any butish snlyect comping on bond ally of II. M.s ships of war, in a foreign port and form the judicatme of the state within whose territory such prot may he sitnated. is entithed to the protection of the British flag, and to be deemed as within the Kincrlom of Great Bribin and Ireland:" Cpon this question proposerl generally I feel us lesitation in eleclaring that I know of no such right of protection helonging to the british flage and that I think snch a pretension is mufommlerl in point of principle, is injurions to the rights of other countries, and is inconsistent with thuse of our own. The 


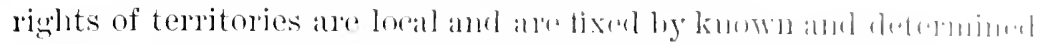

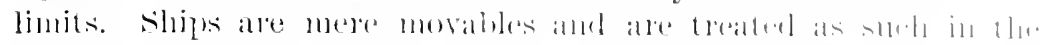

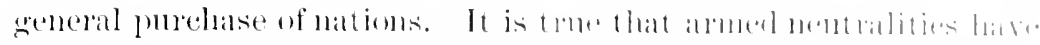

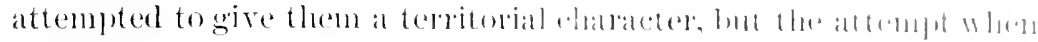

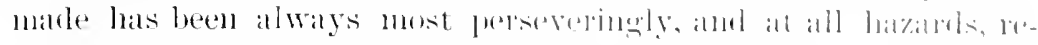

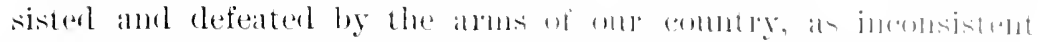

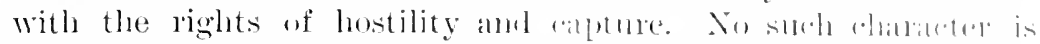

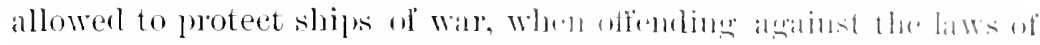
nentrality upon the high seas, whene no lowal anthority whalterel. exists; still less ean it be elaimen whele there is a visible anm

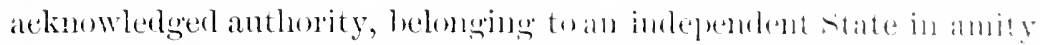
with the nation of which the ships of wan belong. Sill a lead to mothing but to the confusion and hostility whith wail mpm conflicting rights. The eomment amsenfence of matmons las for certain reasons, and to a certain extent. establisherl in firvol of foreign ships of war, that they themselves shall not he lablile to the civil process of the comotry in whose ports they ant lying, thoment even the immonity has heon oceasiomally questioned. lint that incividnals, merely belomging to the sime combtry with the slif st of war, are exempt from the civil and reminal poeses of the comatry in its ordinary administration of justin by getting on board stuph ship, and chiming what is alled the protection of the flits. is a pretension which, however heard of in partice occasionally, hats no existence whaterer in principle. If the British flag anverts a man-of-war into a Britisle territory, the flag of other nat ims must be allowed to possess the sime property in lleir marine: for there is no prineiple whatever that can be alpondiated exchusely to the British flag.

"It therefore must be allowed recipumally that a Flanjurd geotting on board a Spanish ship of wall lying in I'ortsmouth harbor shall be proteeted from British justice. I leliere the andunistration of that justice woukl retum a very spexty aud alerisive negative to any such pretension on behalf of smanimeds charged with buing amenable to British law.

"But the inconvenient effoets of comsirlering such a ship) a slanish territory woukl go much further-to the extent of lototeding a

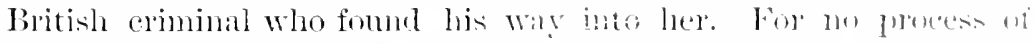
British justice ean be executed on a british subjeet in a Fondign territory. When I give this as my decided perstatsion munt thin subject generally, I do not mean to say that in the infinitu pus. bility of events eases may not arise in which suele a lmotertim might be indulged.

"But such cases are justified only by their orn peeulian and ex10 
traordinary circumstances. which extend no further than to those immerliate eases themselver. and furnish no rule of general pratctiet in such as are omolinary. Ilow far the case uf Mr. Brown comes within such a leseription I an mot enalled to state confidently by any exat knowledge of the facts, and particularly of the nature and validity of that authority under which the atcts charged upon him by the spmiands are said to have leeen committed. It would be imponer in me to detine what the spitish Govermment had

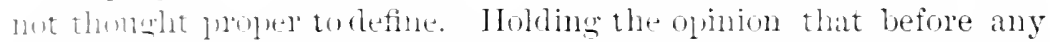
Let of l'alianent or proclanation istued, it was unlawful for it british sulject to alceelt a hostile commission from any persons .ither in witl or rebellion awainst a State in amity with the Crown uf crent britain. I am led to think that the Franiards would not lat fe leen ehareahle with illegal violence if they had thought [under to cmploy force in taking this person ont of the ressel (british), and I ard that it was certainly rery molecirable to furnish occatoms for the lawfol nse of force in the intercourse of friendly nations. Talking the anthority under which Brown acted to be chats invald (which I do not mean to assert), I think it might posibly allean that Captain Falon's combuct was more to be commender for its hmmanity and spirit than for its strict legality. - William roott, Cirafton itreet, 2-th November, 1-2:?."

Ionthe receint of thic opinion a coly thereof was forwandent to the Foreign office,

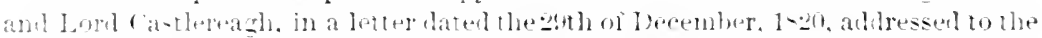

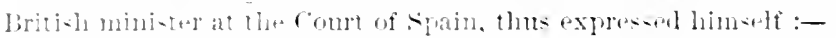

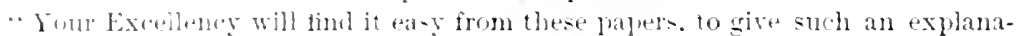
1ion of the circum-tane which athonted the liberation in Encland of this indi-

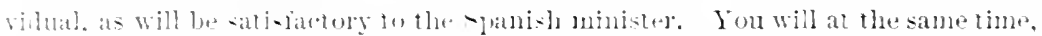

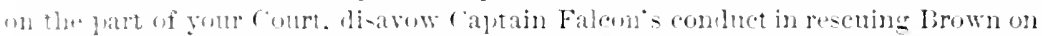

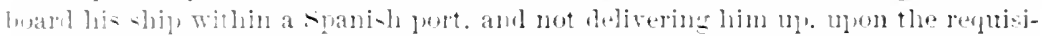

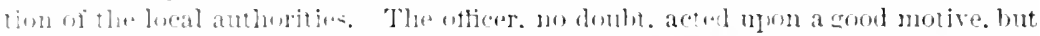

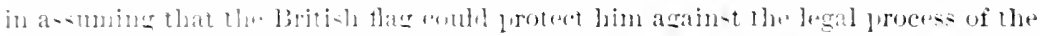

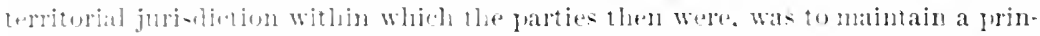

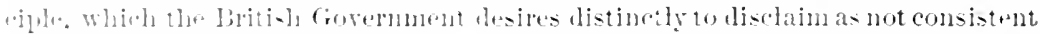

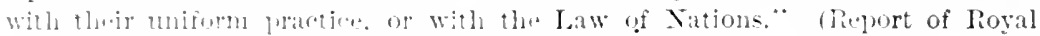

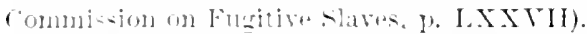

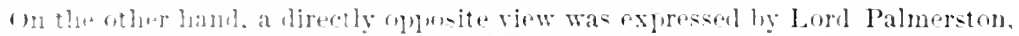

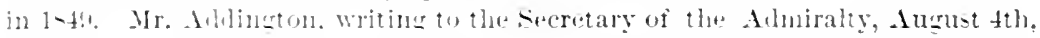
iaid :-

"Tiscount Pahmerston dipects ne to repuest that you will actptaint the Board of Almiralty that his Jordh ip is of the opindon that it would not be right to receive

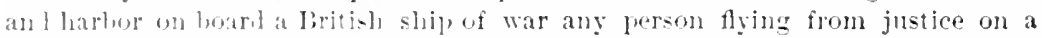
criminal "haren, or whe was acealing from the sentener of a erent of law. But a Briti-h mantef-war hal alway and croryhere been consideren a safe place of r.jug fol l person of what wer country or party who had songht shelter under the Lritioh flag from jersectution on accuint of their political conluct or opinions: 


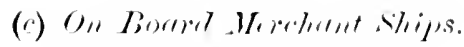

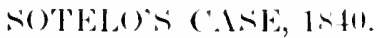

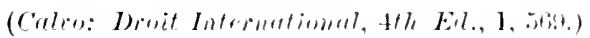

The right of granting asylum to political refugrees does not belone to mele hatut ressels, in the ports of such refugess' (onutry.

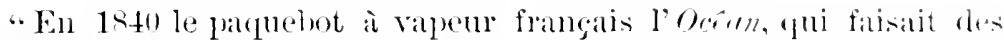

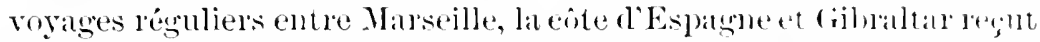
à son hord, al monilage de firao (Valence), M. Sotclo, ex-ministre espagnol, poursuivi ponr anse politigne. Ayant lemis en mel salls

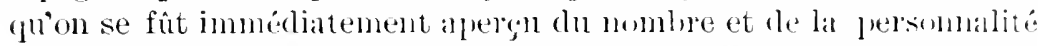
des passagers quil avait embanqués, le navire se remolit à Mlinante; mais là, an moment même de la visite de donane et de police. M. sotelo fut recomm, saisi, emmené ì terre, puis emprisonnc. Ite

and this protection has been equilly offered. Whether the refugere was cueating from the arbitrary acts of a momarehical government, or from the law less violedun of a revolutionary committer. $* * *$

"Although the commander of a ship of war should not seek out or invite pulitical refugees, yet he ought not to turn away or gire ul any who may reath his

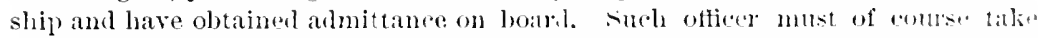
care that such refugees shall not earry on from on board his ship any politiral correspondence with their partisans on shore, and he ought to avill hims lif of the earliest opportunity to send them to some place of safety plewhere." (liep. of Royal Comm. on Fug. Slaves, p. 1.i.).

For a full disenssion of the purstion of the exterritoriality of ships of war, sut the separate reports of Lord Chief Jnstice Cockbum, and Mr. liollwry in the "liphort of the Royal Commission on Fugitive slaves"" 18.6. Mr. Linthery takes strong ground against the right of asylum on such ships.

Sin James Fitzjames Stephen, another member of the commission, takes similar gromud. (Stephen's History of the (riminal Law, II., ī).

As to American practice, Attomey-(irneral Bradford held, in 17!4, that a "writ of lecteres corpus may be awarded to bring up an Amerian subjeet unlawtinly detained on board a forejgn ship of war, the commander being amenaly lo th the usual juristiction of the state where he happens to be, and not entitled to clitm the extraterritoriality which is annexed to a foreign minister and his demisil." (Whart on's Digest, I.. 13:.)

But in 185.), Attorney-fieneral Cushing-a high authority-helu, that a " priwoner

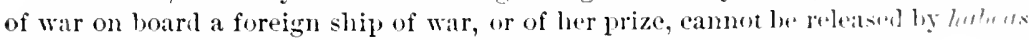
corpus issung from courts of the Lnited States or of a particular state." Aml again, in 1856, "ships of war enjoy the full rights of extratcrituriality in forejen ports anl territorial waters." (Wharton's Digest, I., lis.) lt would werne to follow, therefore, that right of asylum could be granted on American shij w war. In south American ports it has frequently been done. 


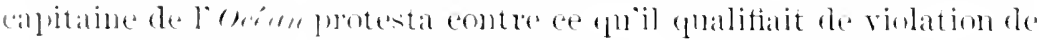

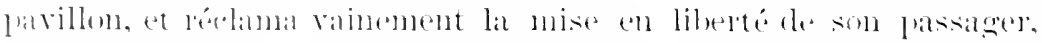

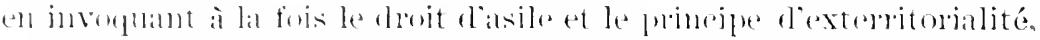

“ses commmoniations diphomatiques échangées an sujet de cette

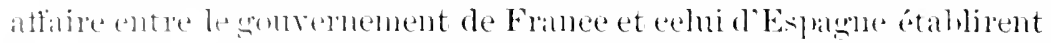
ile la manjere la phe péremptoive que la combunte des antorités

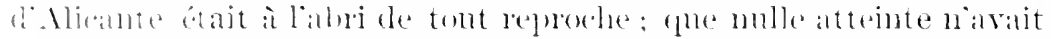

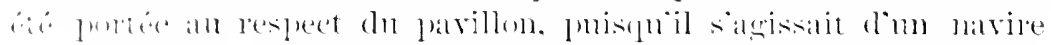

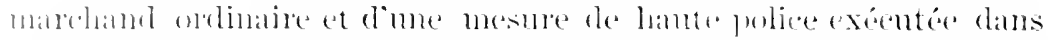

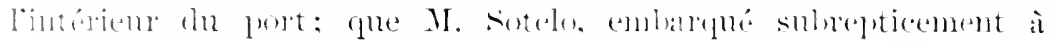

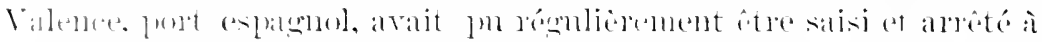

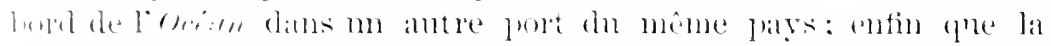

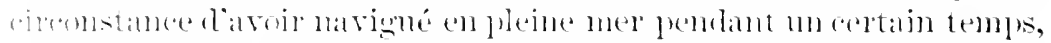

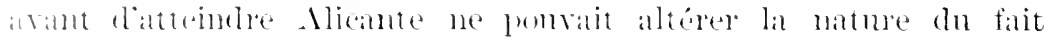

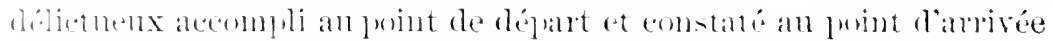
sms lempire des mêmes luis de la même législation teritoriale."

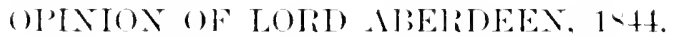

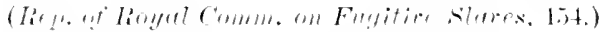

Mroblant ressels gersess mo right of asylum.

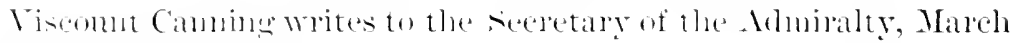

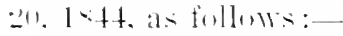

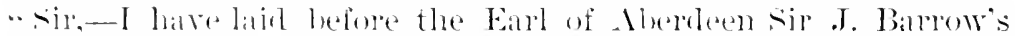

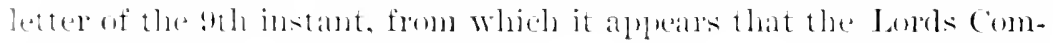

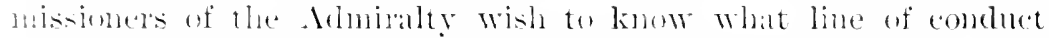

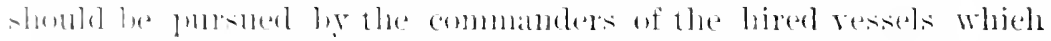

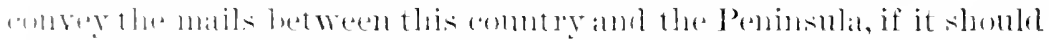

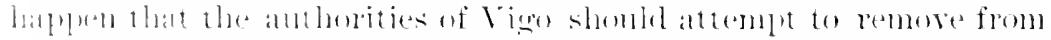

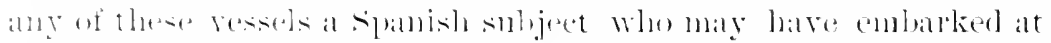

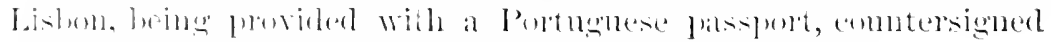

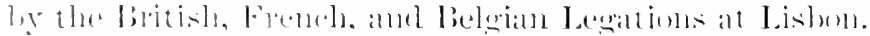

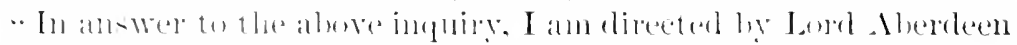

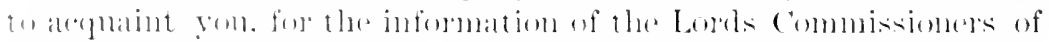

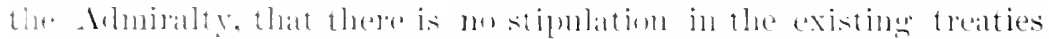

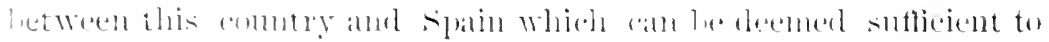

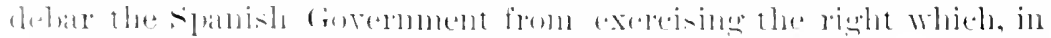

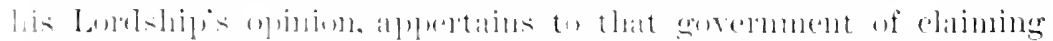
it

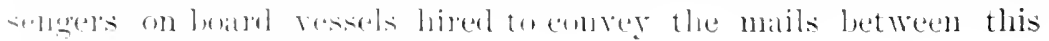
amotry and the l'eninsula." 


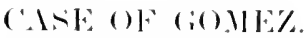

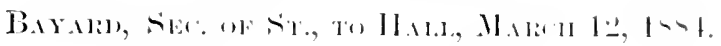

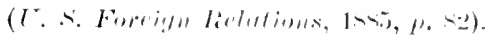

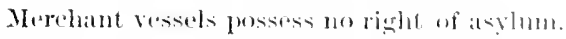

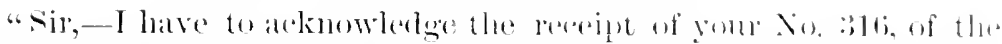

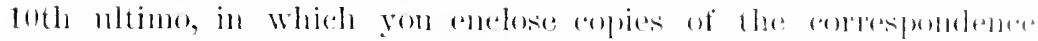

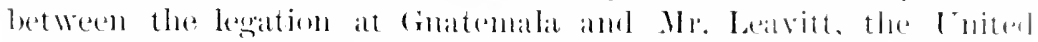

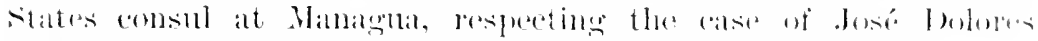

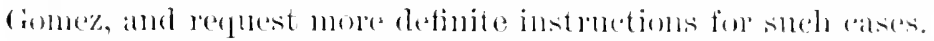

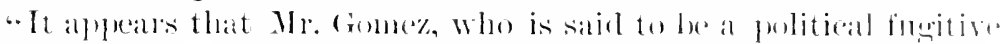

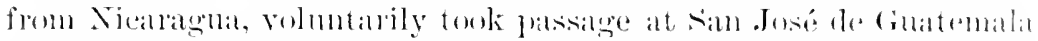

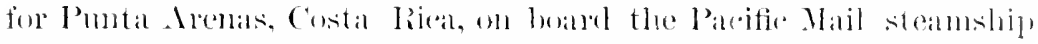

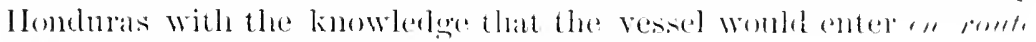

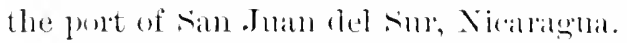

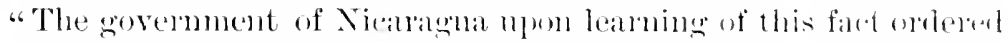

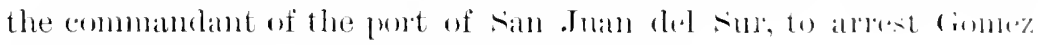
lyon the arrival of the IIomhurati at that pont.

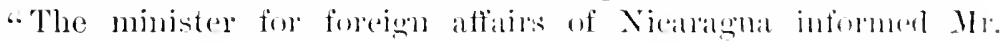
Leavitt, Enited states romsul at Managua, of the atetion of the wolemment hy a telogram, as follows:

"Government has ordered the commander of port sam . Juan del

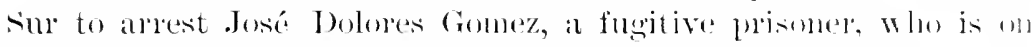

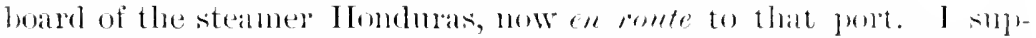
pose the eaptain will not interfere with the action of llaw anm-

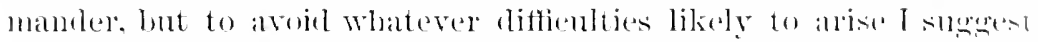
yout to send a telegraphic messige to the eaptain of the Homburat at Sim Juan del sur, stating that the orele hats been issued ly lhe govermment and recommenting him to support the eommameles as there is no gromel on the pant of the eaptain to hinder the exeention of the govermment order.'

"It appeal's that, before Mr. Icatvit hall an olpmetmity to all upon this refuest, you tolegrajuled him as follows:

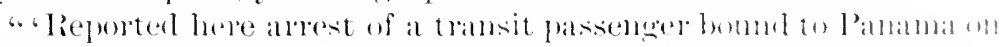

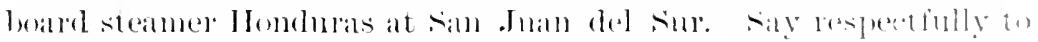

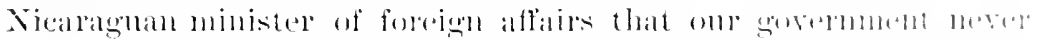

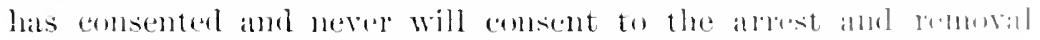

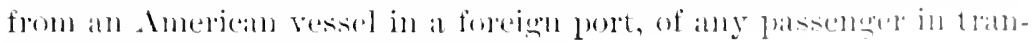
sit, much less if offense is political.' 


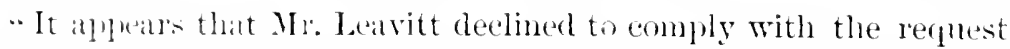
of the minister of foreggn affairs, and followed your instructions by submitling a coly in witing to the minister.

-From the brief outline given hy the consul of the subsequent luneerlines, it appears that the govermment antherities at san

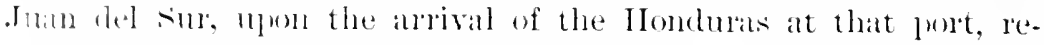
fllested the captain to deliver n] Mr. cionez. This he declined to

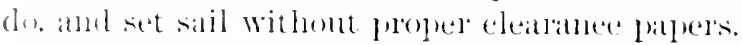

"The (onsul reports that for these offenses the captatin has been therl by the Nitaraguan government ame found guilty, and althomgh

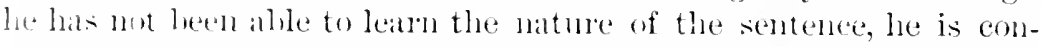
vineerl. from the posent attitule of the govermment, that the sentence will lu exeented in case of the return of the calptain or the ristel within the jurisdiction of the Government of Nicaragua.

*. As the nature and character of the procedings against the captain of the Inomburas are not known to this J)ejaltment, a full and detailed bedont shombl be male as early as praticable. It is clear

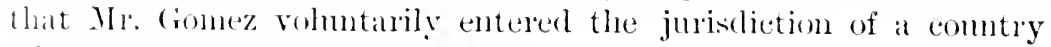
whose latw lue baul riolatel. * * *

"It maty be safely affirmed that when a merchant ressel of one "mutry visits the ports of another for the purposes of trade, it owes

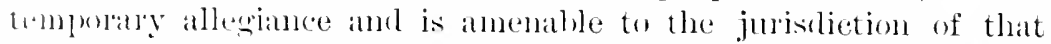
comnty, and is suljeet to the laws which govern the port it visits $\therefore$ lom as it remains, monless it is otherwise provided ly treaty.

"Any exemption or innmunty from local jurisaliction must be deliver from the consent of that comery. So such exemption is matre in the treaty of commerce and navigation comeluded between this commtry and Nicanagua on the 21st day of .June, 1867." 1

'In the similar ase of Barmulia, lsom, the government of the Tnited states

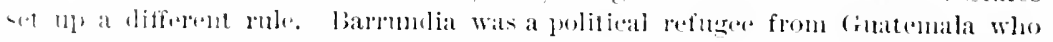

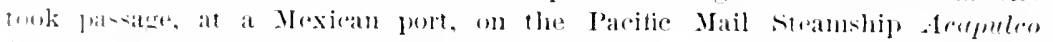

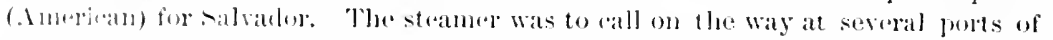
Gilltemata: and on leamine of the morements of barmulia, the geremment of

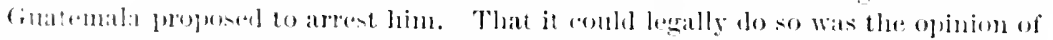

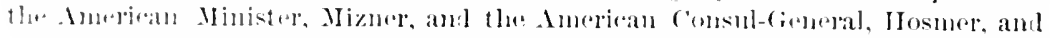

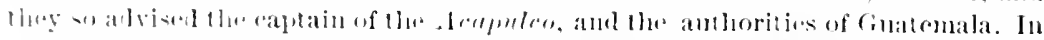

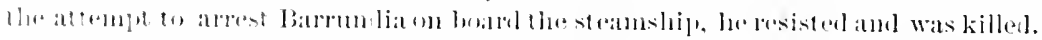

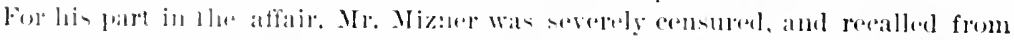

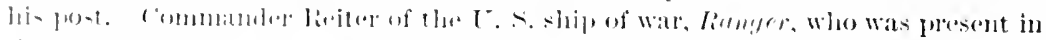

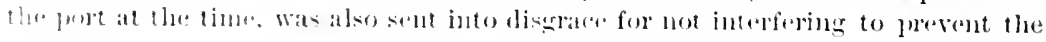
itrmes.

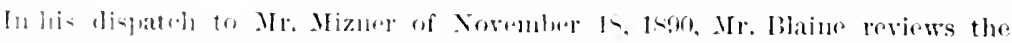

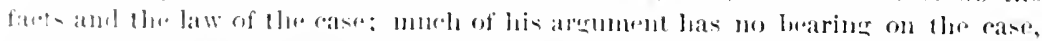

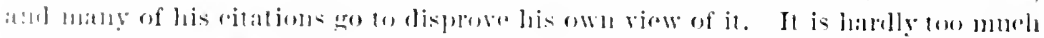
16 - ily that there in no foumlation in International law for the position of the 


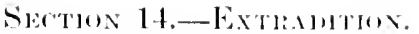

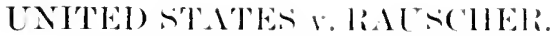

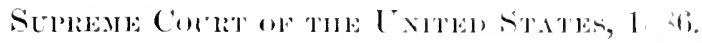

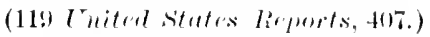

There in no rule of international law reguiring states to deliver up fugitives from justire from other states.

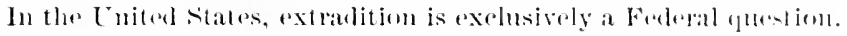

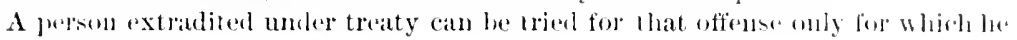
was extriulited.

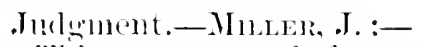

"This case comes before ns on a certificate of arvision of ophinim between the jurlges holding the (irenit comt of the Luiterl states for the southern Instrict of New York arising after verelict of gruilty and before jurlgment, on a motion in arrest of jurlguncut.

"The prisoner, Willian Ranseher, was indicted ly a grand jury,

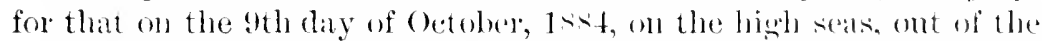
jurisclietion of any particular state of the Inited states, and within the admiralty and maritine juristlet ion thereof, he, lle sald Willian Rauscher, being then and there secoml mate of the ship .J. F. (hal]-

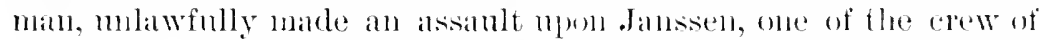
the ressel of which he was an officer, and unlaw fully inflicted npon said .tanssen crtel and mustal pmishment. This indictment was formel muler $\$ 58+7$ of the Revised statutes of the Lniterl states. * * *

"The prisoner having been extradited upen a charge of murder on

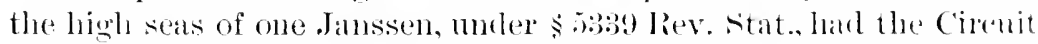
Court of the Sonthern Distriet of New York jurisilietion to put hin

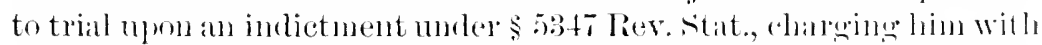
ermel and monsual punishment of the same mant he being one of the crew of an Ameriean vessel of which the defendant was an wfticer, and such punishnent consisting of the identieal atets proved in the extritdition procecelings?

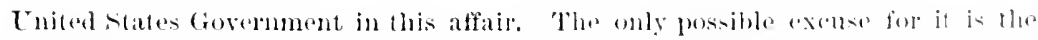

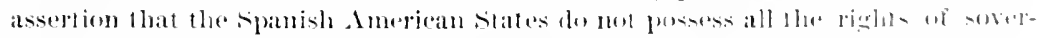

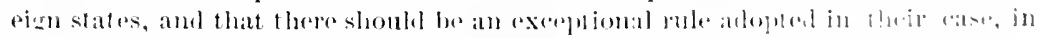

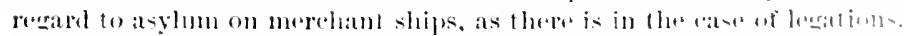

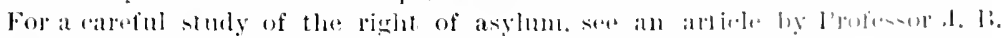

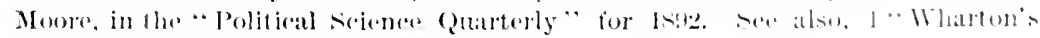
Digest of International Lilw;" $\$ 104$. 
"The treaty with Great britain, under which the flefendant wassu-

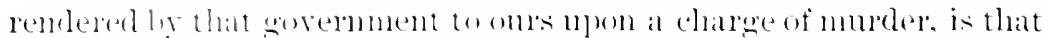

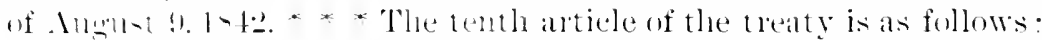
-It is angled that the Inited states and her liritamic Majesty shall,

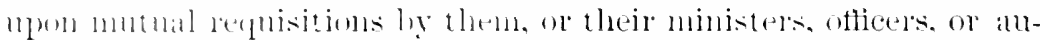

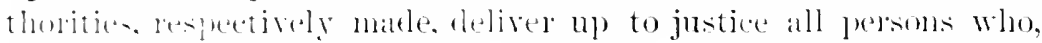
being dored with the crime of murder, or assanlt with intent to

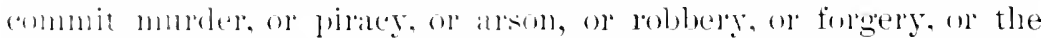

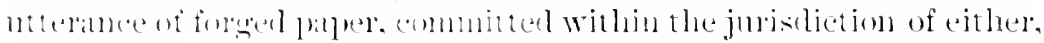

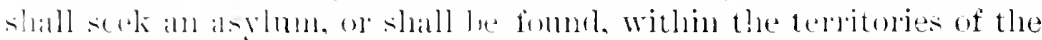

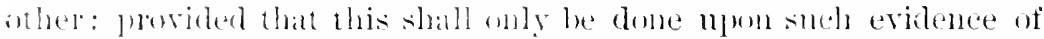

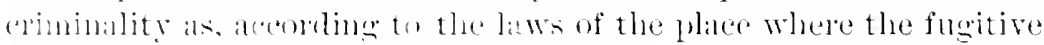
or person so chanden shall be fomm, womli justify his alprehension and commitment for trial, if the erme or ofiense hat thele heen committel: and the respertive julleses and other magistrates of the two

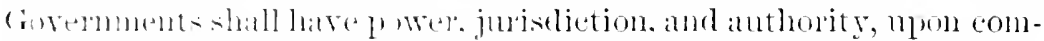

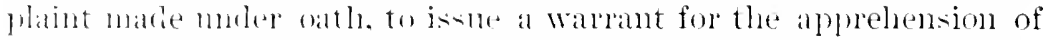

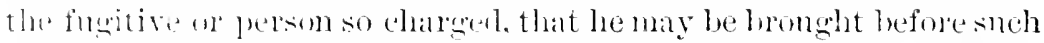

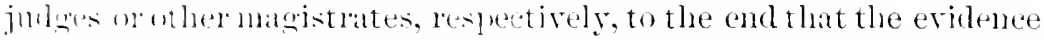
of eriminality may he heard and consintered : and if, on such hearing, the evilume be deemed sufhejent to snstain the charge, it shall he the duty af the eximnining jurlue or magistrate to certify the same to the fonere a xerutive anthority. that a warant may issue for the smremler of such foreitive.

"Xot only has the general suligect of the extrarlition of persons,

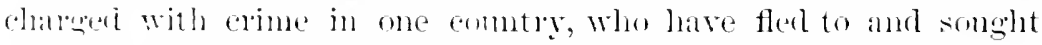

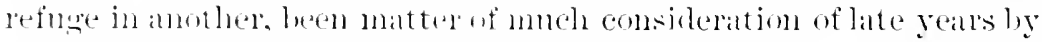
the exemtive byartments and statesmen of the govermments of the civilized portion of the world. ly varous pulplidists and writers on international law, and ly secedalists on that subject. as well as by the

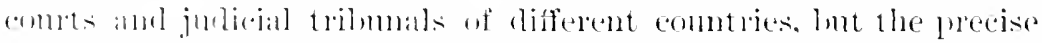

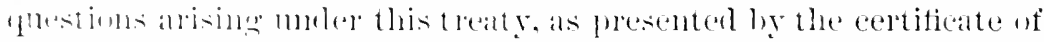

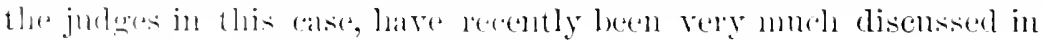
this combly and in cireat Britain.

"It is wn? y in motern times that the mations of the carth have im-

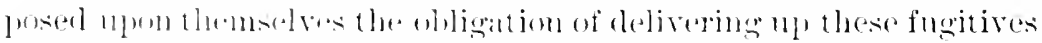

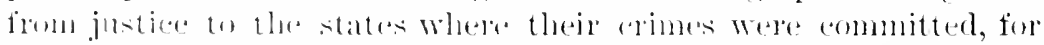

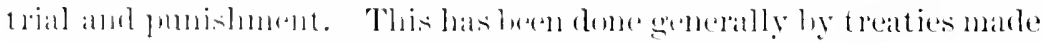

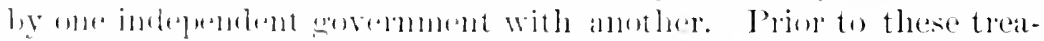

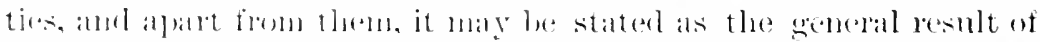
the writers 11 men international law, that there was no well-elefined

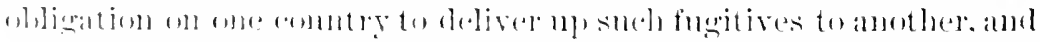
thome such delivery was often mate, it was nom the principle of 


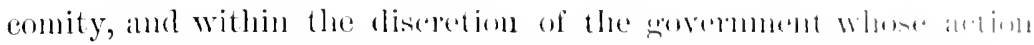

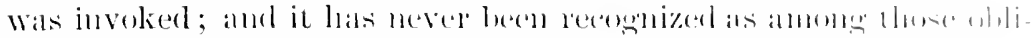

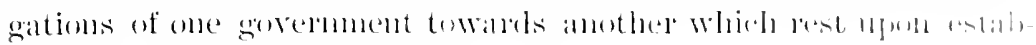
lished principles of inlemational law.

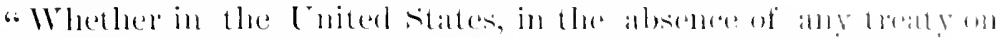

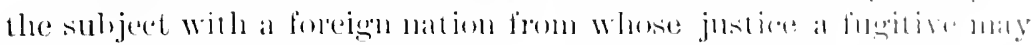

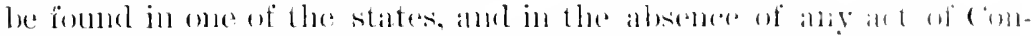

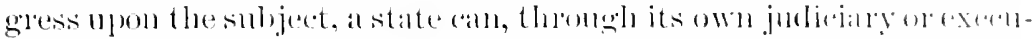

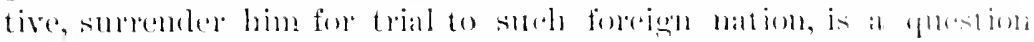

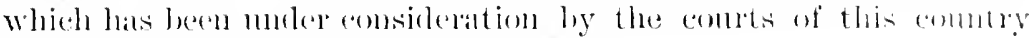
withont any very eonolusive result. *** *

"There can be little dombt of the sommluess of tha oprinion of

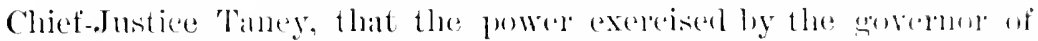

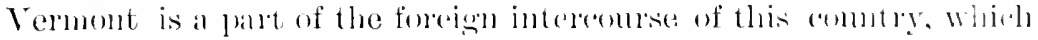

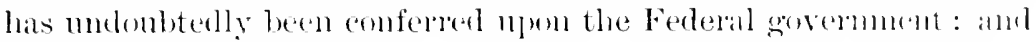
that it is clearly inchuled in the toraty making power and the

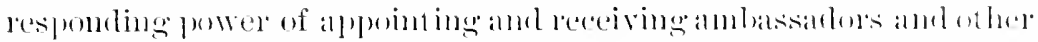

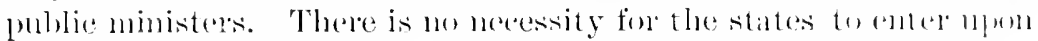
the relations with foreign nations which alde neressalily implied in

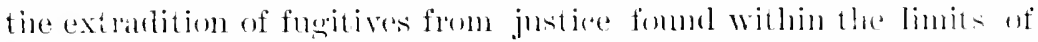
the state, as there is mone why they shombl, in theipown mame, make

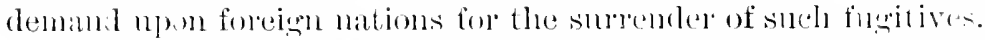

". At this time of day, and after the repeated examinations which

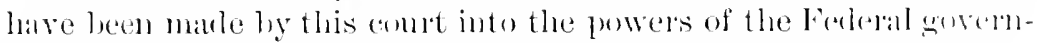
ment to deal with all such international questioms exchusively, it "an hatrly be admitted that, even in the alsence of treatide ar ands of Congress on the sulject, the extralition of a fugitive flom ju-tive call beeome the sulpect of negotiation between at state of this luim allu a foreign gorermment.

"Fortmately, this question, with others which might anise in the absenere of treaties or alets of compess on the subjert, is mom of very little importance, sinee, with nearly all the nathons af the

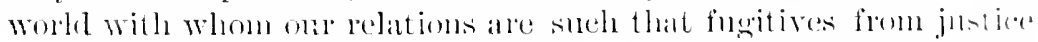
maly be fomm within their elomingons of within oms, we hate lataties which sovern the rights and amolnet of the parties in smeh cases. These treaties are also supplemented by alots of concress, and beth alle in their matme exi bisine.

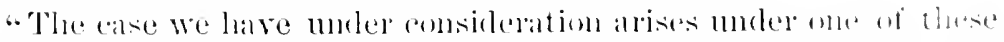

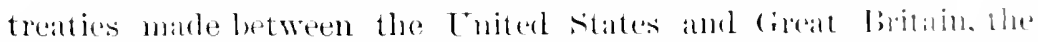

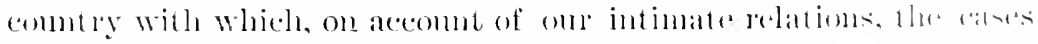

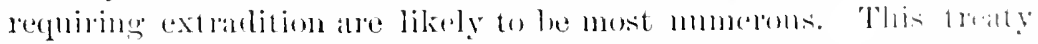

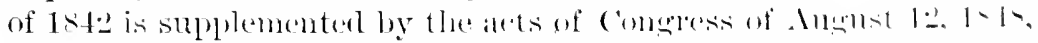

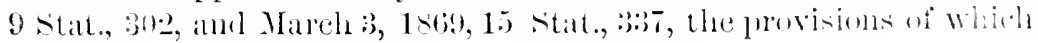




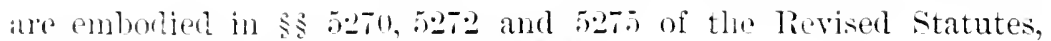
mmer 'Title I.XVI.. Extralition.* * *

. The treaty of $154: 2$ leing, therefore, the smpreme law of the land, whiclu the eomts are bomal to take judicial notice of amel to enforce

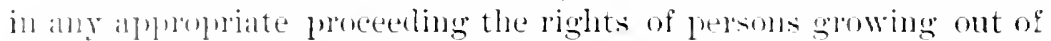
that anty. We proceerl to inguire, in the first plice, so fan as pertinent to the puestion certified hy the circuit juriges, into the true construction of the treaty. We have alrearly setu that, according to the doctrine of publicists and writers on international law, the

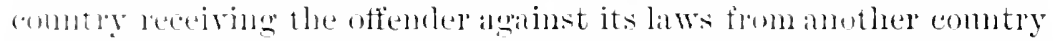
had mo right to proceed aginst him for any otlere offense than that for which he hat been delivered wl). This is a principle which commenois itseli as an appopriate adjunct to the discretionary exereise of the purer of rendition because it can hardly be supposed that a govermutent which was under notreaty obligation nor any absolute olligation of pmblic duty to seize a jerson who had found an asylum within its bosom and tum him over to another eomtry for trial, would be willing to do this, muless a case was made of some speeific nffense of a character which justified the govermment in depriving the party of his asylum. It is unreasonable that the comtry of the asylum shomld be expected to deliver up such prerson to be dealt with hy the demanding govermment without any limitation, implied or otherwise, mon jts posecution of the palty. In exercising its discletion, it might be very willing to deliver up offenders against such laws as were essential to the protection of life, liberty and person. While it womld not he willing to do this on aceount of minor misitemeanors or of a certain class of political offenses in which it womld have 10 interest or sympathy. Acoorlingly, it has been the fulicy of all govermuents to grant an asylum to persons who have fled from theis homes on aceome of political distmbances and who might be there anemalle to laws framed with regarel to sueh sub-

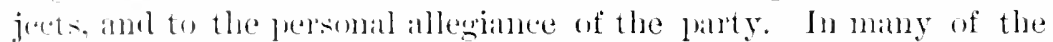
treaties of extrarlition lestreen the civilized mations of the world, there is an axpess exchusion of offentels andinst sucle laws, and in mone of them is this class of offenses mentioned as being the fommolation of extralition proceedings. Indeed, the enmmeration of offenses in most of these treaties, aml espeedally in the theaty mow moler eon-

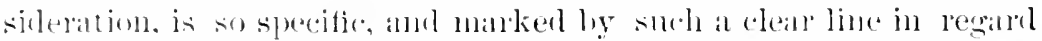
to the magnitme and importance of those oflenses, that it is impossible to erive any other interputation to it than that of the exchusion of the rient of extralition for any others.

.. It is therefore, very relear that this treaty did not intonel to depart in this respect from the recognized publie law which hat prevaled 
in the absence of treaties, and that it was not intenderl that fhis treaty should be used for any other fmrjose than to secme the trial of the person extradited for one of the offenses ermunemater in thes treaty. This is not only apparent from the enemelal principhe that the speeific enmmeration of eertain matters and thing implies the exchusion of all others, lout the entire face of the treaty, includiug the processes by which it is to be carrier into effect, enfirms this view of the subjeet. It is unreasonable to suppose that any lemand for rendition framed mpon a general representation to the soremment of the asylum (if we may use such an (xp)ression) that the party for whom the demand was made was guilty of some viobation of the laws of the eomntry which demancerl hin, withont slerifying

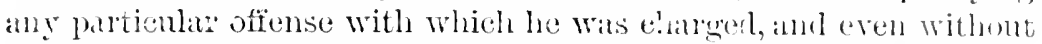
speeifying an offense mentioned in the treaty, wonk receive any serions attention; and yet sheh is the efrect of the construction that the party is properly liable to trial for any other ofiense than that for which he was demanded, and which is described in the treaty. There wonk, muler that view of the subject, seem to be no neerl of a reseription of a specific off̈ense in making the demand. Dial. so far from this being admissible the treaty not only furoviles that the farty shall be charged with one of the erimes montioned, to wit, murler, assanlt with intent to commit murler, pinacy, arsom, rob-

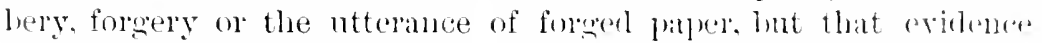
shall be produeed to the judge or magistrate of the combly of which such demand is made, of the commission of such an offense, and that this evidence shall be such as acorrding to the law of that country would justify the apprehension and ommoniment for trial of the person so charged. If the procedings moler which the party is arresterd in a comntry where he is peaceally and quietly living, and to the protection of whose laws he is entitled, are to have no influence in limiting the proseention in the country where the oflunse is charged to lave been eommitted, there is very little use for this partienlarity in elanging a specifie oftense, requiring that offonse to he one nentioned in the treaty, as well as sufficient evirlenn of the party's guilt to put him upon trial for it. Nor can it he sitil that, in the excreise of such a delieate power muler a trenty so well guarled in every particular, its provisums are obligatory alome on the State which makes the sumenter of the fugitive, and that that fugitive patses into the hands of the rombly which chatrises him with the othense, free from all the positive requilements and just imnlications of the treaty muler which the transfer of his persm talkes place. A moment before he is moler the protection of a corrmo ment which las afforded him an asylum from which he ean only be 
taken moler a very limiter form of furcelne, and a moment after le is fomm in the lusession of another sovereignty by virtue of that foreterling. hut divested of all the rights which he had the monntht hefore. and at all the rights wheh the law governing that

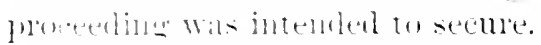

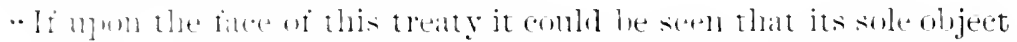

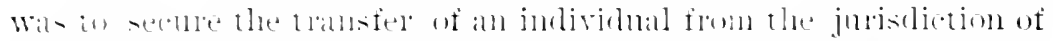

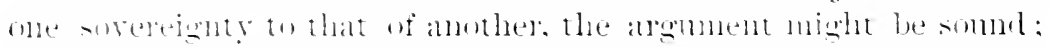
lut as this right wi transtere the right on demann it. the obligation

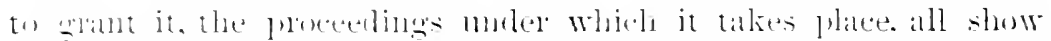

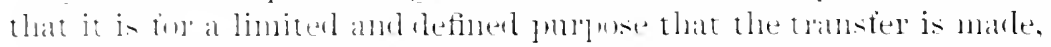

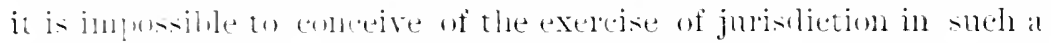

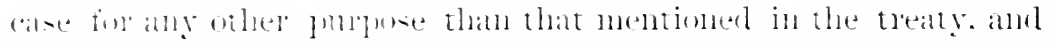

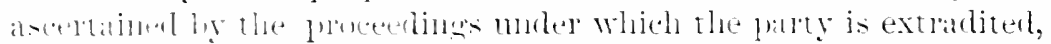
withent an indelication of fraud upen the rights of the party extradited and w that fath to the combly whele permitted his extraditim. Xo sneh riew of solemn puble treaties between the great matims of the earth can be smstained by at tribumal called mpon to

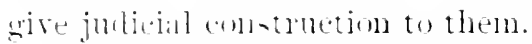

.. Tlle onpuste riew has been attempted to be maintaned ju this

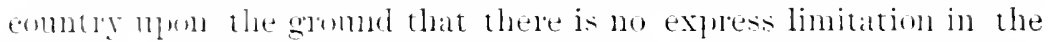
treaty uf the right of the comntry in wheh the ofiense was commitred to try the person for the crime alone for which he was ex-

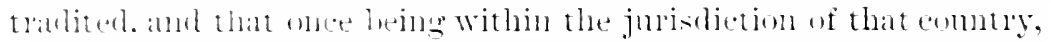
114) mattel hy what entrivance or fratud or by what pretene of

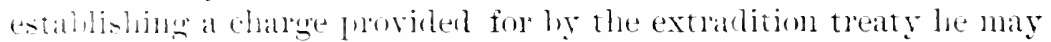

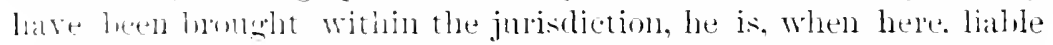

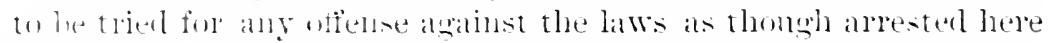

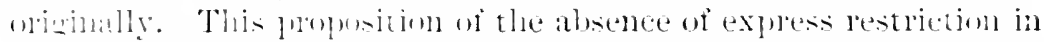
the dratig of the righte try him for other otfemses than that for which ho was extmalited, is net hy the manifest seope and object of

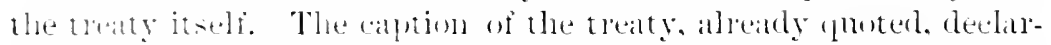
ing that its fmome is to settle the mmolaty line between the wo

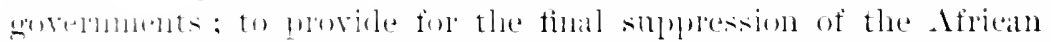

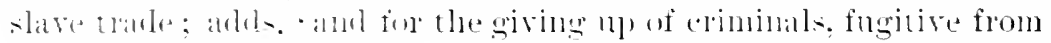

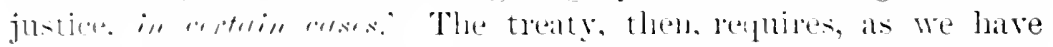

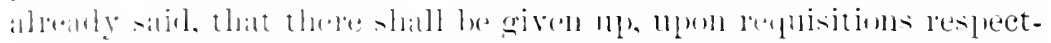

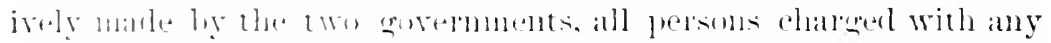

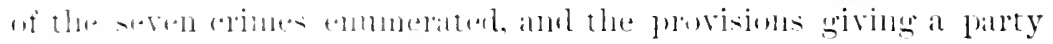

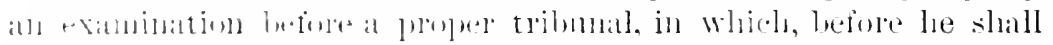

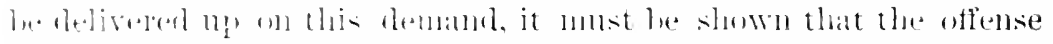

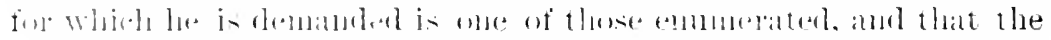
funt is sufticient to satisfy the comt ol magistate luefore whom 


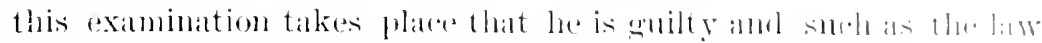

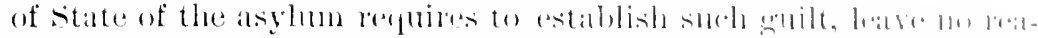

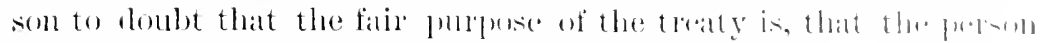

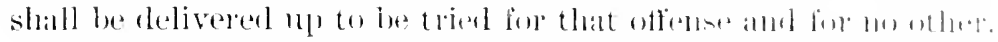

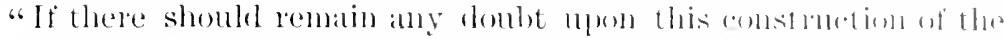

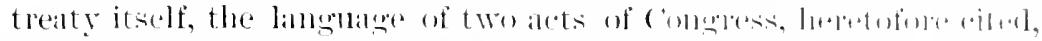

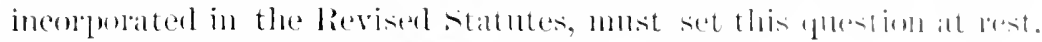

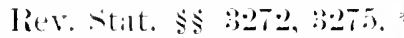

"The obvious meaning of these two statutes, which have ledelenese to all treaties of extralition male hy the Enited Stalles, is thitt the.

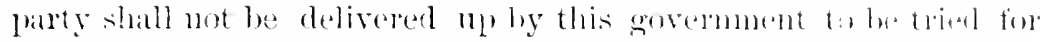

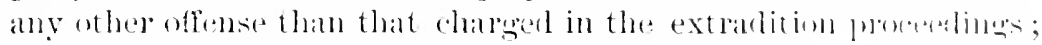

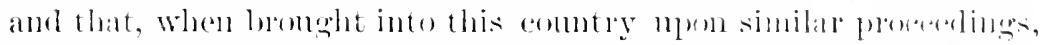

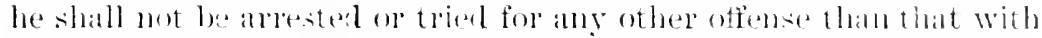

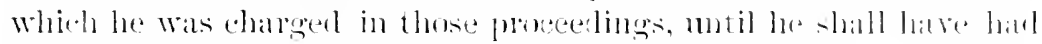

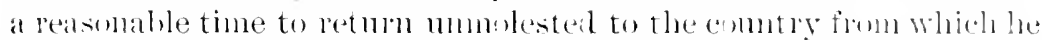

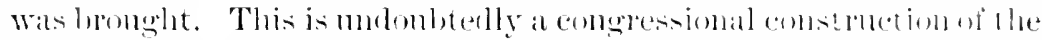

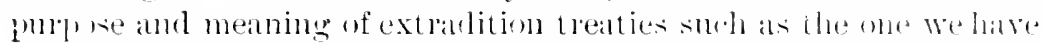

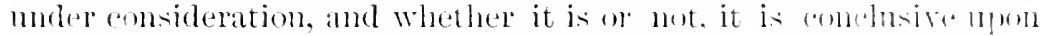

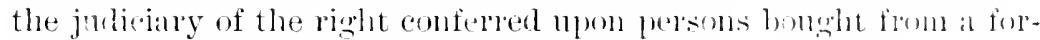
eign eomntry into this moler such proceedings.

"That right, as we molerstamb it, is that he shall bo trial omly for

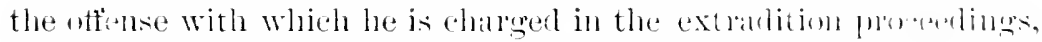

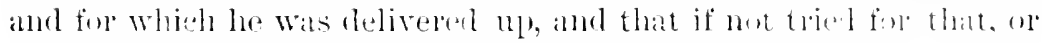
after trial and acpuittal, he shall have a reasonahle timm to leave the comatry before he is arresterl upsm the charge of any wher crime committed previons to his extradition. * * *

" l pon a review of these decisions of the Forteral and siate comts,

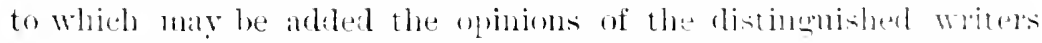

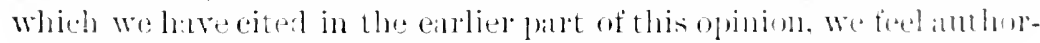

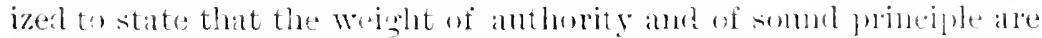

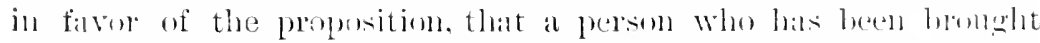

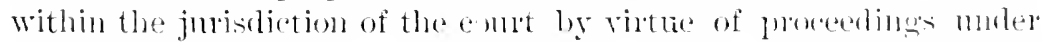
an extralition traty, can only be tried for ane of the otforstes deseribet in that treaty, and for theoffense with whels he is ehatger in

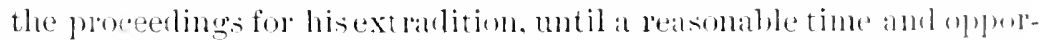
tunity have been given him. after his releatse or trial nuen stech

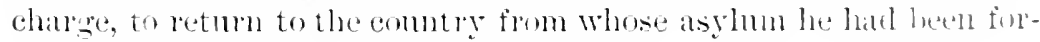
cilly tiken murer thuse procerbings."

W.1', C. J., dissenter from the opinion of the comrt.1

1 The lecision in Rauscher's case put an eml to a controvery hetween the Inited

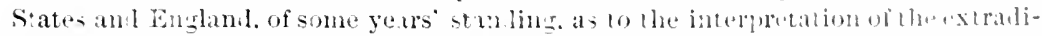

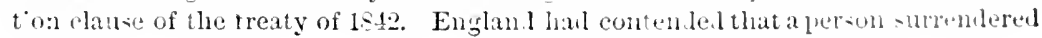


TRIMBLE'S CASE, 1884.

(Morre one Eictiration, I., 10if.)

The guestion as resands lhe power and duty of a state to surrender its own ritizens muln treaties of extratition.

The question of the power of the govermment of the Lniter States to smremble its citizens under the treaty with Mexico of 1s61, was discossed in 1s-4, in the case of Alexander Trimble, an Anerican citizen, whose extradition was demanded on charges of robbery and minnerer.

The first article of the treaty stipulates that the contracting parties shall, on requisition "deliver up to justice persons, who, etc." lint in the sixth article, it is further declared that "neither of the contricting ganties shall be bound to deliver up its own citizens under the stipulations of this treaty."

The govermment of the Enited States declined to order the surlembler of the prisoner, on the gromd that, as the treaty negatived any obligation to do so, the President was not invested with legal alluthrity to act.

Mr. Frelinghuysen said, "It appears that, hy the opjinions of several Attorneys-fieneral, by the detisions of our courts, and by the rulings of the bepartment of state, the President has not, independent of

unler the treaty, conld be trie l for no offense axcept the specific one for which extrabition was acrople. The govermment of the Lnited statrs hal insisted, on the other haml, that a pelvon onde extralited cond be indicted and tried for offenses other than that charge, in the demand for extralition. (Fee the cases of lawrence and Win-low. Yoore's Extradition, I., 196-219; Wharon's Inigest, II.,

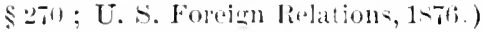

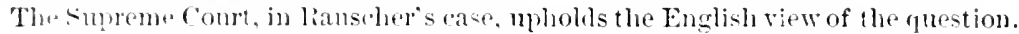

Provious io this anthoritative fecjom, juclicial opinion had heen divided. In

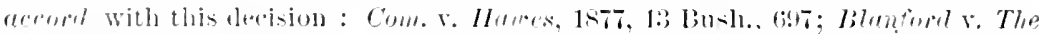

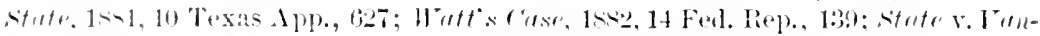

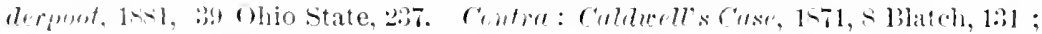

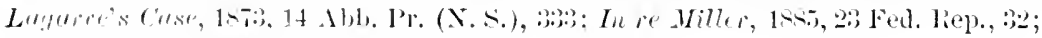

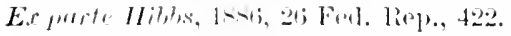

The lecisions of the Fromeh eomr of Casation are in aecord with that of the

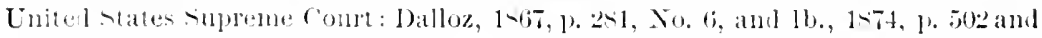
notes.

In Ratuchers case, the supreme cont expressed the opinion that, in the absence of treaty, there was moler intermational law no risht of extralition.

And further that in the Lnited States extralition is a matter exclusively in the

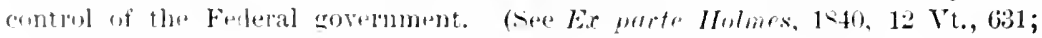

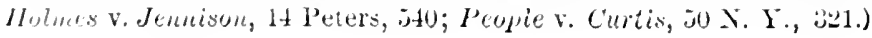


treaty provision, the power of extruliting an American citiz"rt: and the only question to be considered is whether the treaty with Maxin., eonfers that power.

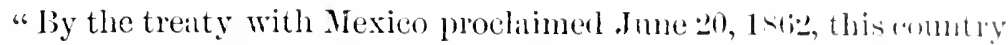
places itself under obligations to Mexico to surrombler to justices persons aceused of enumerated erines committed within the juristlietion of Mexico who shall be found within the territory of the l nited States; and further provides that that obligation shall not extend to the surrender of Ameriean citizens. 'The treaty confer's mpun the President no affimative power to surdender an American cirizen. The treaty between the United States and Mexien cleates an ohligattion on the part of the respective govermments, and does no more, and where the obligation ceases the power falls. It is trute that treaties are the laws of the land, but a statute and a treaty alu sul, ject to different modes of construction. If a statute ly the first section should say, The President of the United States shall surrender to any friendly power any person who has committed a crime against the laws of that power, but shall not be bound so to surrender American citizens, it might he argued, perhaps correctly, that the President had a discretion whether lue would or womld not smprender an American citizen. But a treaty is a contract, and must be so construed. It confers upon the Presiclent only the power to perform that contract. I molerstand the treaty with Mexico as reading thus: The President shall be bound to smrender any jerson guilty of erime, unless such person is a citizen of the Lniter states.

"Such being the construction of the treaty, and beliering that the time to prevent a violation of the law of extradition was before the eitizens left the jurisdiction of the Lnited States, I telerrapher the Governor of Texas that an Ameriean eitizen eonld not legally be held under the treaty for extradition.

"It would be a great evil that those gnilty of high erime, whether" American citizens or not, should go mumnished; but even that result could not justify an usurpation of power.

"On further refleetion, in view of the fact that fourteen of oum" treaties with other nations contin provisions identical with that contained in our treaty with Mexico, and impressed also with the fatct that the safety and peace of society on the frontier wonld be greatly injured if criminals, because citizens of this country, conld here fiud an asylum and go unpunished, I coneluded that the question was one of too much importance to be settled by the dietum of any individual. but should receive judicial determination, and to this end I telegriplued the officers to hold the accused until they received other dirertim. The aceused had, however, after my first telegram, been disohatrged 
"I now pupose to juform the offieers in Texats, who, subject to the smprovison of the l'resilent, areathorized to determine whether

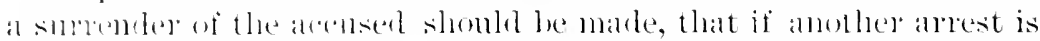

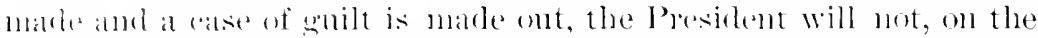

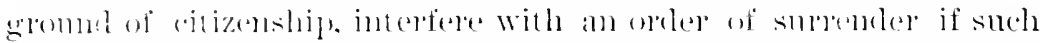
be mate. hut lequires that the acensed he informed that if he or they

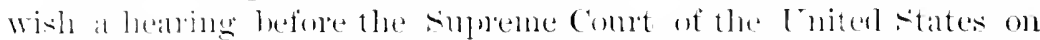

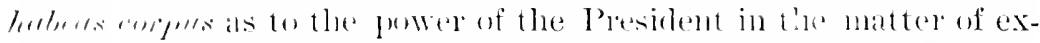

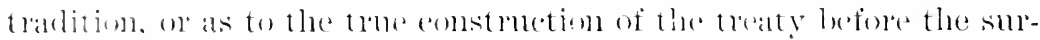

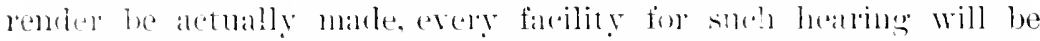

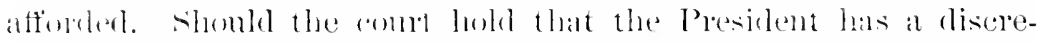

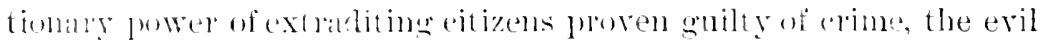

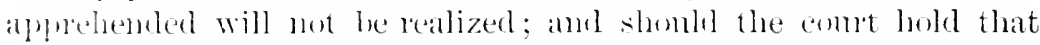
the President has the power toextradite only when lonud hy deaty to doso, (omgless can them, if it should be its pleasme, ly statute comter the discretionary power."

${ }^{1}$ In a sinilar ease. in 189:3, not yet reporte l, it in moratool that the Foleral

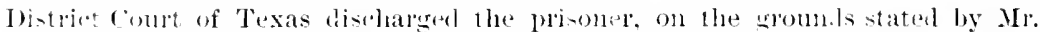

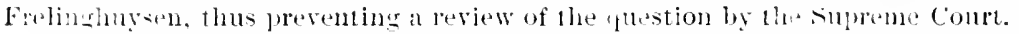

"The semption of citizens from extralition has been maintaine 1 on varions sromin. The only one which neel serionsly be notied is that by tha laws of

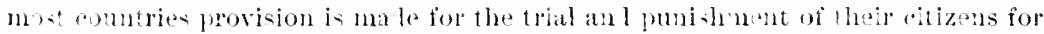

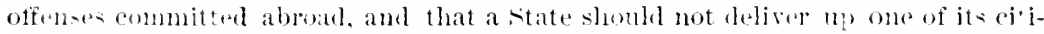

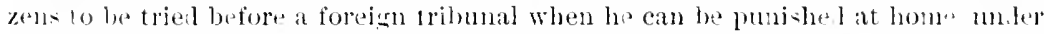
it own laws. By Englata and the Cnited states alone are offenses, eren when "rmmittel by lheir citizens or subjects, trenel as entirely local." (Moore's Extra liti, m, I., l.;.)

In netoriating "xtrulition treaties these two states have therefore been willing 10 sipulate for the ren lition of their own subjects or citizens. In leed, the Cuited

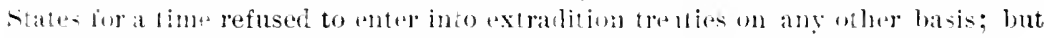

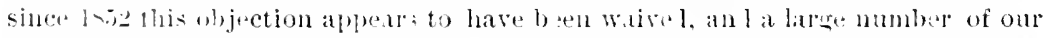
treatios of extralition, as that with irexico, exempts each jarty from the obiga-

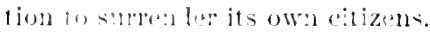

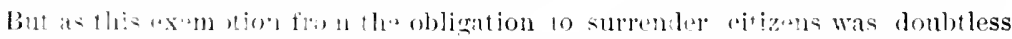

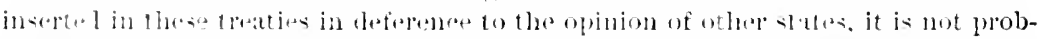
able thet it was inten le $l$ as an absolute prohibition upon the presilent of the

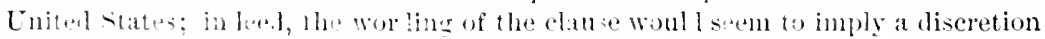

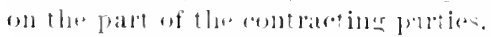

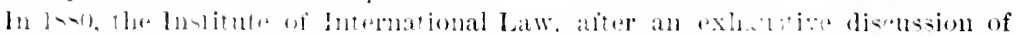

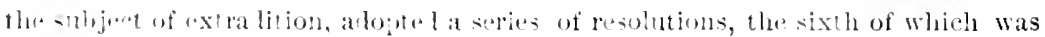
an follows:-

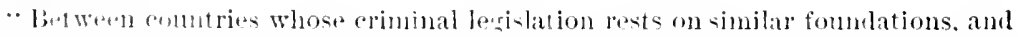
Which have eonfidence in each of her"s ju licial instutuons, the extration of their own oitizens would be a means of securint the good andministration of eriminal justive. because it onshe to be desimble that the atuthorities of the forme delicti

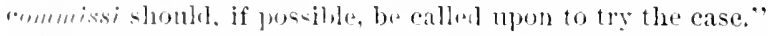

Sen this subject: Moore's Extradition, 1., 15\%; Dana's Wheaton, pp. 189-191, noles. 
C.ISE OF ( $.1 \%(), 1 \times 5$.

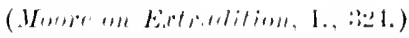

What eomstitutes a pelitial offense:"

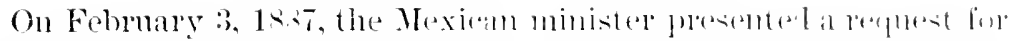

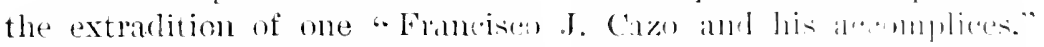

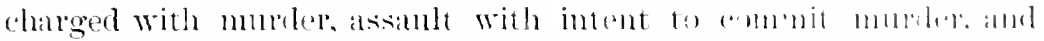

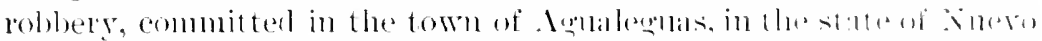

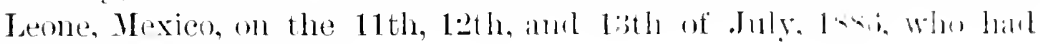
taken refuge in Texas.

The evidence disclosed that thoe or fom days poviomsty to the 11th of July, it was reported that calzo wals cominge to attack the town. Just before miduight on the luth of July, a mmoline of jer-

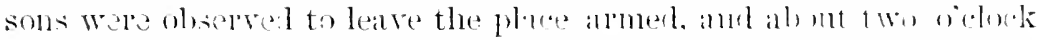
on the morning of the 11 th an attack was malde hy a part of thirtyor

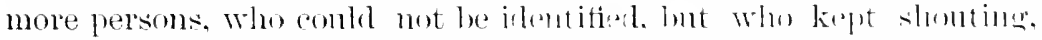

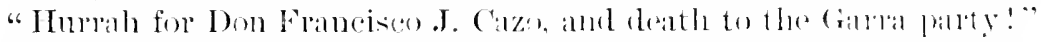

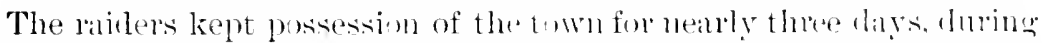
which time they had arm lenconnters with the inhabitants, seized hors sand other property, and enmmitted other ants af violende. When they departed. Cazo left a proclamation with a ritizen of the town with disecons to publish it. In reply to the appluation for extradition, Mr. Bayard, then secretary of state, on Folmary 7 , 187., wrote as follows:

"After" a caldefol examination of the papers enclosed in pour note. I am mable to avoir the conclusion that the acts of cato and his associates, who were about thirty or forty in mumber. were clearly

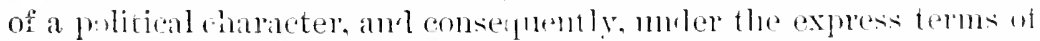
article rI. of the treaty above m un i nel ale not a poper basis for

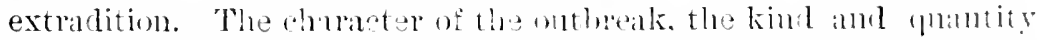
of the property taken, and the mome of attack all had to that conclusion.

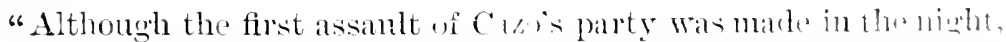
there was no effert to conceal the persomal identity of the lathles. and such property as was seized was taken manifestly fom the lubpose of militaly equipment, for which it wis andapter. The oristemen offered of the falet that Cazo led the attack is the testim my a waral

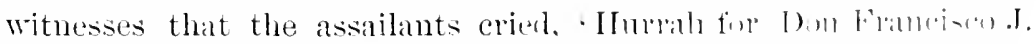
Cazo!" and at least one witness testities to the anlditional and atconn. 11 
panying exclamation wi, Death to the Gallat party!' Another witnesistales that Cilzo lefi al proclamation in the hands of a resident of Analenars. with a view to its publication. Indeed, all the eircimm-iances puint to the conelusiun that the athitid was an arowed partisinl puliticitl contliet."

TIIE ST. IIIINS R.IID, 1964.

(Minite on Eirtorititim, I. I2:2.)

What constitutes a political offense?

(1) Oetober 19.1 19it, one Bemnett II. Young and thirteen or four-

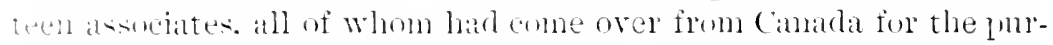
lowe latided the town of st. Alhalus, in the state of Vermont; pillitger the hank; set fire to several haldings: took and held a number of eitizens as prisoners: and committed other acts of violence. While in presession of the bank they seizer a man named breck, who had entered on private business and ly threats of violence compelled him to give up a sum of money which he had in his possession. They were finally driven away ly the citizens of the town, one of whom

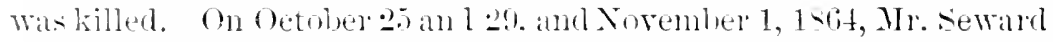
male requisitions for their sureuder on eharges of murder, assault with interit to commit murler. and robbery. They were all ardested

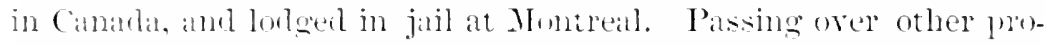
ecolings. which will he noticed in their proper place, they were bromght before Justice Compol. of the city of Montreal, by whom

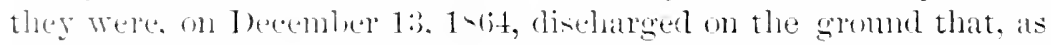
thele Wats no warlunt from the Goremor-general to anthorize their andest, as lepuired by the Imperial axtralition act then in foree, there

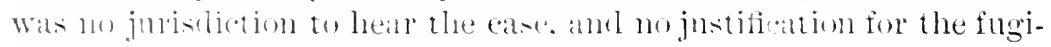
tives further detention. Inmediately mon their discharge, a war-

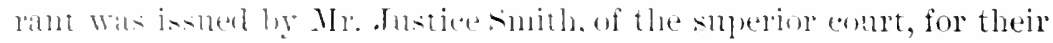
le-anlent. An this warlant only tiveof the fugitives were taken, and

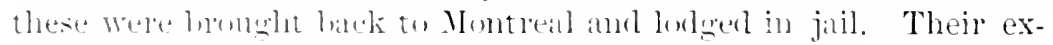

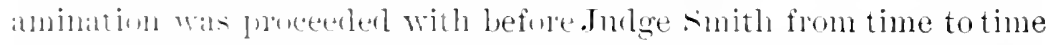

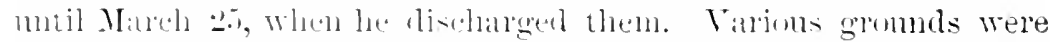

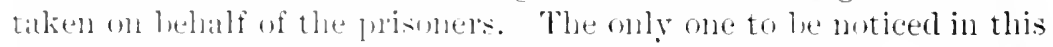
plate is the elatim made that the aros witl which they were charged were belligerent, and therefore not within the extradition treaty. It was shown that bomengeld a commissiom as a first lieutenant in the army wi the Confederate states, under an appointment by resident 
Davis, dated June 16, 1864, and sirned hy Jas. A. Seldon as sereluetity of Wal. It was contended that in the attale on st. Mhands he Wats

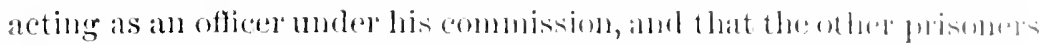

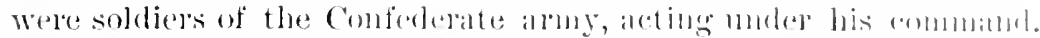

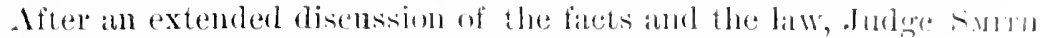
states his conclusions in the following langllate: -

"I am thelefore constrained to hohl thal the altark on st. Mlhing Was a hostile expedition, authorized both exporesly and impliodly ly

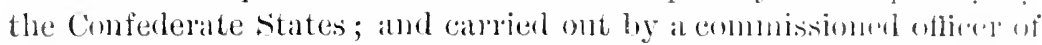
their army in command of a party of their solnless. Mmel, threfente, that no act committed in the comse of or as incident to, that at talli cim be made the gromul of extratition moler the Ashburtom treaty. And that if there had been any breach of neutrality in its inception, upon which point I state no opinion, it does not affect this appliation, which must rest entirely upon the acts of the prisoners within the territories of the state demanding their extradition, and upon their own status and authority ats belligerents." 1

\section{Re CASTIONI.}

QCEEN'S JEETH, 1890.

\section{(L. R. Quren's Bench Itir., 149.)}

What constitutes a political offense?

On an application for a writ of lorbers cormus, the motion was made on behalf of Angelo Castioni, for an order misi calling npon the solieitor to the Treasury, Franklin Lushington, Esq., a metropolitan police magistrate, and the consul-general of Switzerland, as representative of the swiss Republic, to show cause why a wit of holuen rompres shonld not issue to lming up the borly of Castioni in onder that he might be discharged from custorly.

The prisoner Castioni hat heen arrested in England on the requisition of the Swiss Government, and brought hefore the masistlitu at the police comt at bow street, and hy him committed to prison for the purpose of extradition, on a charge of willful murles, allegrol to have been committed in switzerland.

The facts, which were contained in depositions sent fom șwizerland, in the depositions taken before the magistrate at bow stren.

In the ease of Burley, 1s64, who was charged with similar houtile acts again-1

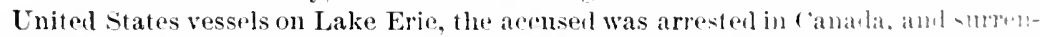
dered up to the United States. But on his trial, in Ohio, the conm heth thith his ants were belligerent and not eommitted unimo furandi. (Moore"s Extralitivil, I., 3...) 
and in afindaris mael on the hearing of the motion were shortly as follow: -

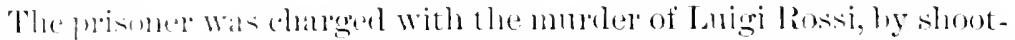
ing him with a revolver on september 11, 1s9o, in the town of bel-

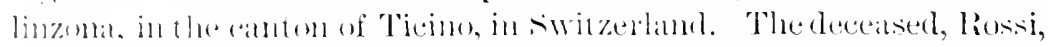

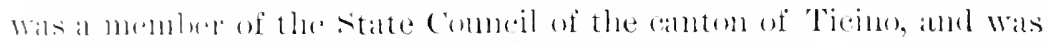

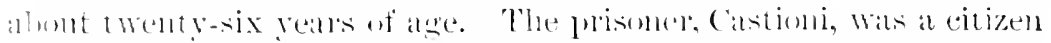

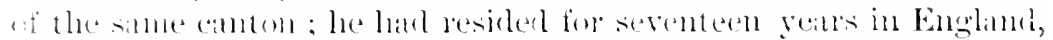

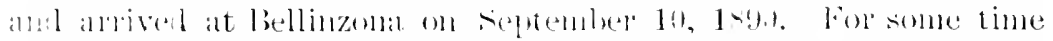

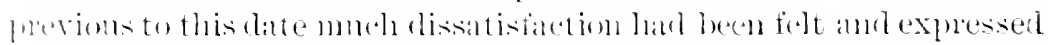

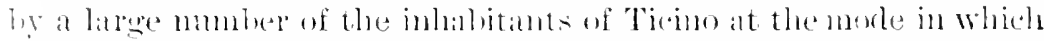

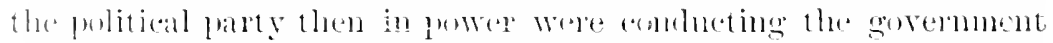

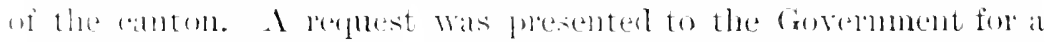
levision of the anstitution of the cantom, muler ant. lis of the constitmion. which provides that " The comstitution of the canton may he

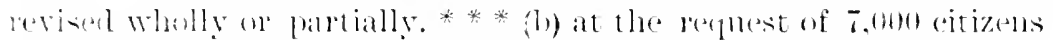

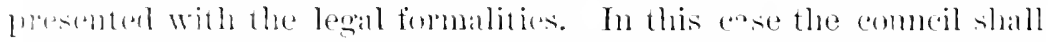
whing ane month sulmit to the people the question whether or not they wish to revise the comstitution," and a lat of May 9, 15T, prescribes the comse to be arknoted for the execontion of letter (h) of alt. 1 is.

The covermment laving declined to take a popular vote on the frestion of the revision of the anstitution, on septembr 11, 1<9, a mmber of the eitizens of bellinzma, ammo whom was Castioni,

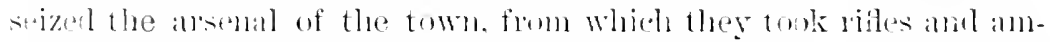

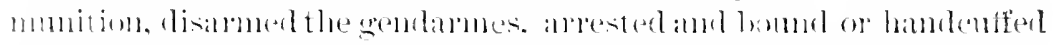

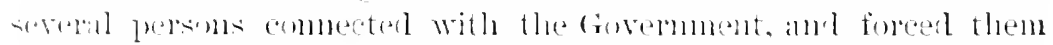
to manh in frent of the amed crowel to the mmicipal palace. Armisim an the patace was demanded in the name of the perple, and

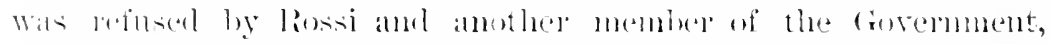
who ware in the pabere. The arowl then buke open the onter gate

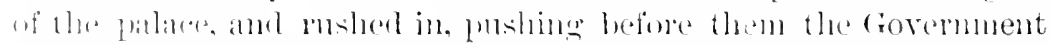

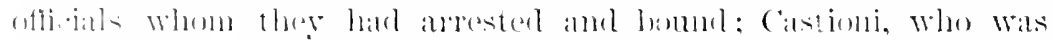

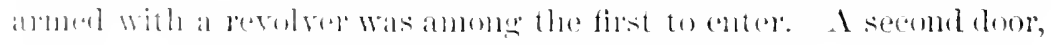

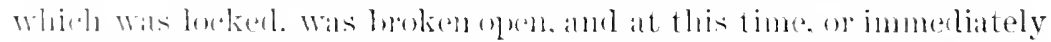

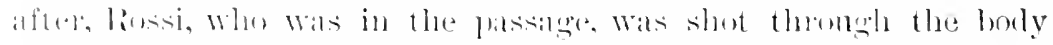

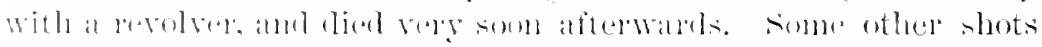

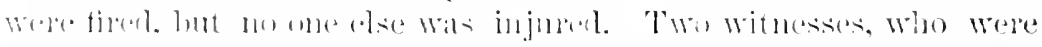

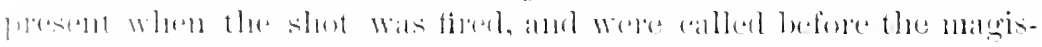

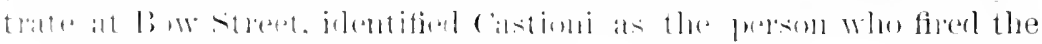

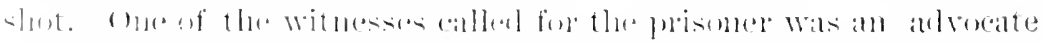

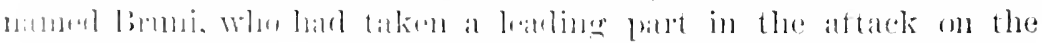

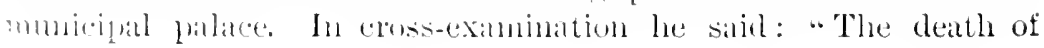


Rossi was a misfortune, and not necessily for the rising." Thlowe

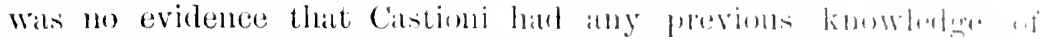

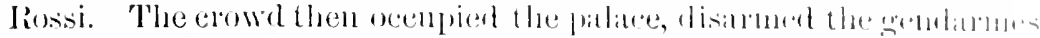

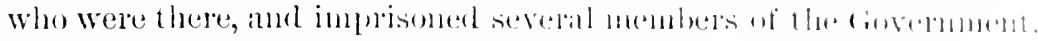
A provisional foremment was alpminterl, of wheh limmi wat at member, and assmmed the Govermment of the comtom, whirh it lin.

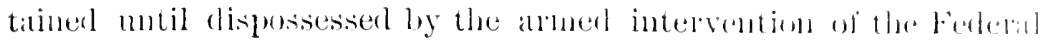
Govermment of the liepublie.

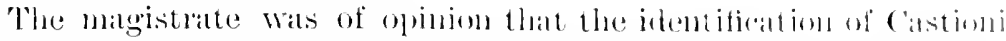

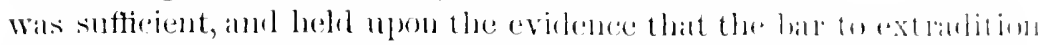

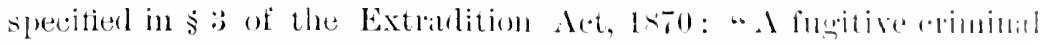

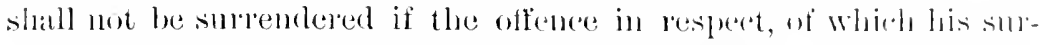

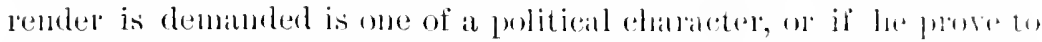
the satisfiution of the police magistrate, of the combt befole whom

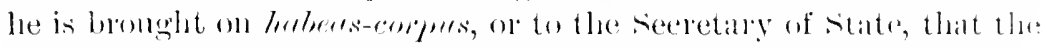

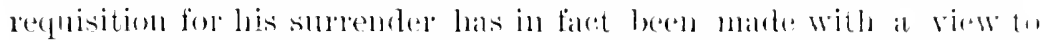

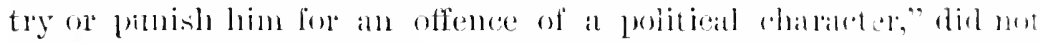
exist, amb committed Castioni to prison. by the extmatition treaty"

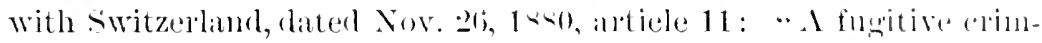
inal shall not he smmendered if the offonce in lesperet of which his

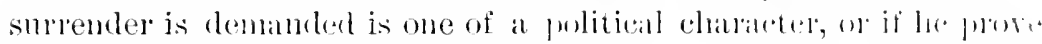

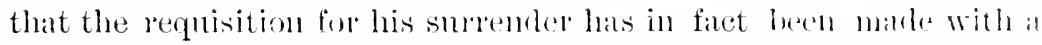
view to try and pmish him for an oftence of a political character."

Sir Charles liussell, for the prisoner; the Attorney-fenclal, for the Ciowll.

Dexas, .J.:- Looking at the extreme importines of this case, I shoud have been disposed, if I had felt any serions domb as to the course we onght to purstle, to have taken time, not so mull to tomsider what onr judgment shonhl he as to hake calle to put it in tha

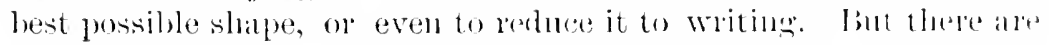
many considerations which apply to eases of this solt. ()he is. that here is a man in enstody who has bedn in custody for a comsiderable. time, and 110 greater delay than is reisomably necessilly whellt to be

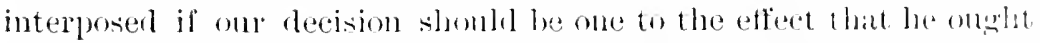

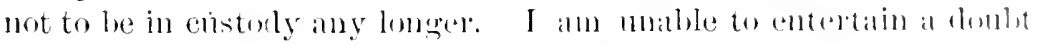
that this is a case in which we onght to moder that the prisonser be discharged.

"There has been no legal decision as yet mon the meaning uf

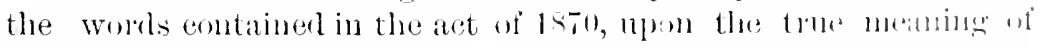

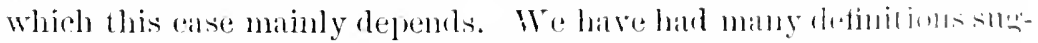

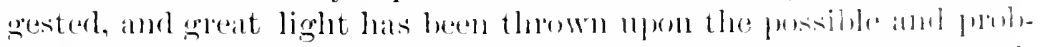

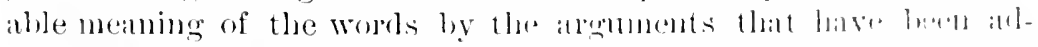

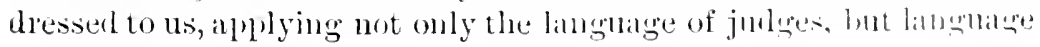


nsed in text-lwok s, language used by great political anthorities, and in one case ly a most learned philosopher. I think it has been useful insmll a case as this that we shomld hear a disension as to the pos-

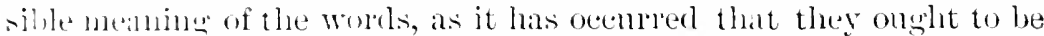
comstratel to prople such as those whose opinions have been cited, and esecially I may aply that observation to the case of my re?y leamed lirother whose assistance we halre on this occasion in Aceding the present cilse. I do not think it is necessary or de-irable that we should attempt to put into language, in the shape of an exhmitive definition, exactly the whole state of things, or every sate of thing which bring a particnlar case within the description

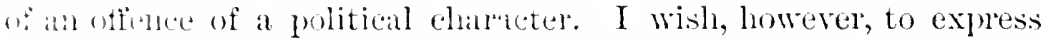
an (n)inion as to one matter mon which I entertain a very strong winion. That jis, that if the description given by Mr. John Stmat IIIl, - dny wifence committed in the comse of or furthering of civil wir, insurrection, or political commotion, were to be eonstrued in the solse thit it really means any act which takes place in the comres af a political rising withont reference to the object and intention of it, and other circumstance; comnected with it, I should say that it was a wong definition and one which conlel not be legally applied to the words in the Act of Parliament. Sir Charles Russell -lleresterl that 'in the course of was to be dead with the words following, 'or'in furtherance of, and that 'in furtherance of' is equivalent to 'in the course of.' I camnot quite think that this was the intention of the speaker, or is the natural meaning of the expression; hut I enimely concur with the observation of the Solicitor-General that in the other sense of the words, if they are not to be construed as merely equigalent expressims, it would be a wrong definition. I think that in orter to bring the case within the words of the Aet and to "xilurle extralition for such an act as murler, which is one of the exhalition offences, it must at least be shown that the act is lone in fimtherance of, lone with the intention of assistance, as a sort of 1 bert act in the course of acting in a political matter, a politi al rising. al a dispute between two parties in the state as to which is to latre the gorernment in its lands, before it ean be brought within the meaning of the worts used in the act.

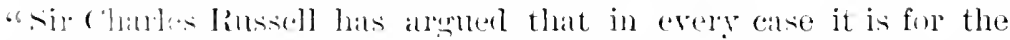

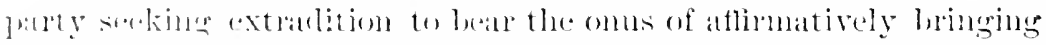
it willin the meaning of those wombs. On the other Inanl, it has

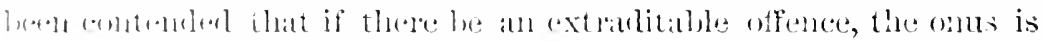

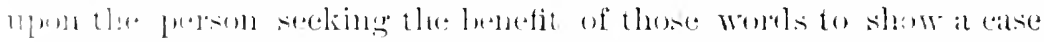

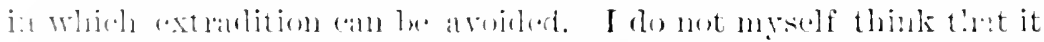

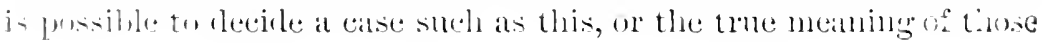


worls, by applying any such test as on whom is the onus. I la lun

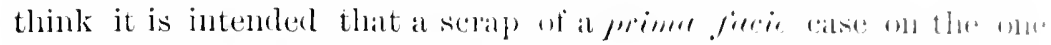

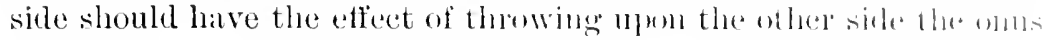
of proving or disploving his position. I hok at the worke of the act themselves and I think that they are anainst any such natrom technical mode of dealing with the alse. The Worts of s.:

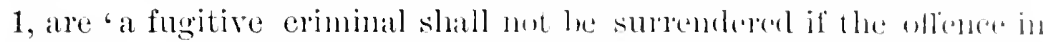
respeet of which his surender is alemantent is onte of a political eharater.' The section itself herins: "The following restrietions slatl be olserved with lespect to the suremeler of funitive "liminals." There is nothing said as to upon whom is the omes probereli, or that it shall be mate to appear by one side or the other in sllch a eatse. It is a restrietion upon the surenter of a fugitive criminal, and however it appears, if it does alpuat, that the act was, in the jumgment of the eourt, an offence which would otherwise le an offonce according to the laws of this comutry, but an offence of at jolitical character, then wholly ir'espective ut any doctrine of onms on the one side or the other, that is within the juriscliction, and he cammot be surrendered. It was at first contended, in oplosition to the alplulicaltion for a hebeus corpus, that if the magristrate upon this question once made up his mind, the court har no jurisdiction to deal with it. It appeans to me that this proposition camnot be maintained on the very fice of the act itself, which reynires by s. 11 that the magistrate shall inform the prisoner that he mat alply for a holbers corpuss, and if he is entitled to apply for a hellens corpus, I think it follows that this cont must have power to go into the whole matter, and in some cases, certainly if there be fresh evilence, or perhaps mpon the same evidence, might take a different view of the matter from that taken hy the magistrate.

"It seems to me that it is a question of mixerl law and filctmainly indeed of fact-as to whether the facts are sneh as to briner the case within the restrietion of $s .3$, and to show that it was an offence of a political character. I do not think it is disputed, or that now it can be looked mpon as in controversy, that there was at this time existing in Ticino a state of things wholl would cerlainly show that there was more than a mere smatl rising of a few perple a gainst the law of the state. I think it is charly malle out by 1 he fatets of

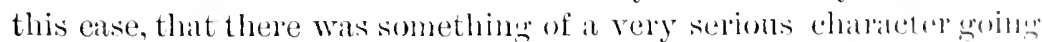
on-anounting, I should go so fall ats to sily, in thalt small community, to a state of war. There was an aromed bexly of nom who had seized arms from the arsenal of the sitate: they wore lushine into the municipal comeil elamber in which the gerermment of the State useal to assemble; they demanded admission; anlunission wa! 
refused: some firing took place: the onter gate was broken down; and I think it ako anpeats perfectly platin from the evidence in the mase that Catstoni wats a gerson who bald been taking part in that mowement at a munele earlies stige. He was an aletive party in the morennent he hath taken plart in the binding of one nember of the gonernment. Some time before he arrived with his pistol in his hiand at the seat of gorsernment, he had gone with mult itudes of men, armed with arms from the arsenal, in order 60 attak the seat of anemonent. and I think it must be taken that it is quite clear that from the reply tirst, he was an atetive party one of the rehellious

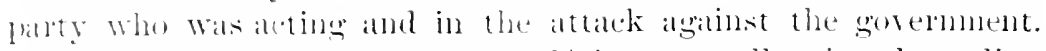
Xow, that being so, it resolves itself into a small point, depending on the avilence which wats taken before the matgistrate, and anything that we can collect from the evillence that we have before us and irom the whole circumstances of the ease.

- Before dealing with the evidence, I will say one thing about the messige which was onjected to and which wats rean after a slight discusinn, npon the mulerstanling that we were not going to use that dencment as evidence of any particular fact, but that it would be only used ats an important dodment showing that the government if the comnty had themsetres looked upon this as a serions pultieal rising, and a serious state of violence by a very large body of the prople atginst the government. I mean so to use it, and I have never thom of ust ofing it in any other way. I think that was the understanding now which we allowed it to be read, and I feel that 1 an not justified in using it for any other purpuse. Then it is reducerl to the question of whether. upon the depositions sent over, and upon the denositions before the magistate and mon the fresh farcts, if there he any, which are hrought hefore us on the affidarits, we think that this was an alet done, not only in the collse of at political rising, but as part of a peliticall rising. IIere I must sily at mee that I assent entirely to the observation that we cammot decide that ane-tion merely by ansidering whether the ate done at the monent at which it was done wats a wise aret in the semse of being and alet whieh the man who dis it wonld latre been wise in doing with

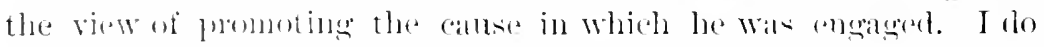
not think it womld be at all conns-lent with the real meaning of the worls of the stallue if we were to attempt so to limit it. I meam, I do lont think it would be right to limit it in the wily sugerested by

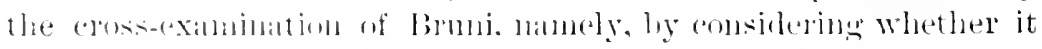

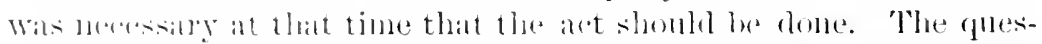

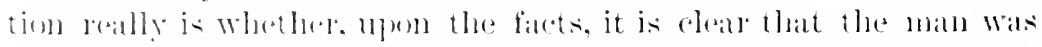
allting at one of a 11 muber of persons engaged in alets of violence of 


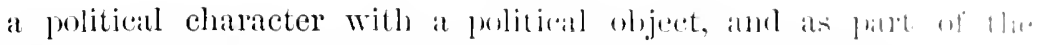
political moventent and rising in which he was taking latt. Xous.

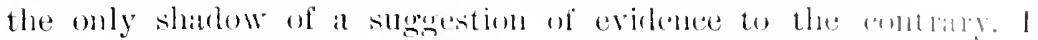

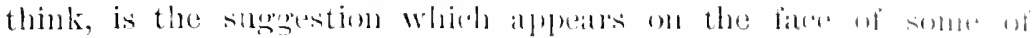

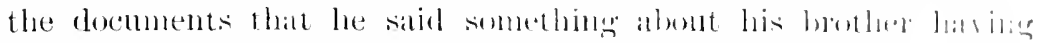

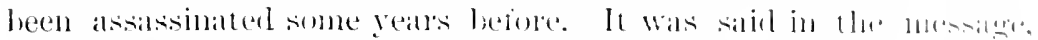

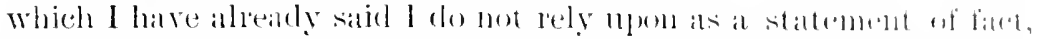
that he did at the time he fired use the expersione My hathers death cries for rengeance!' 'That is in the dormment, and is a statement of falet which I to not rely 11 men, and l do not think that I an justitied in relying upon it, thomgh if I commonted on that, I

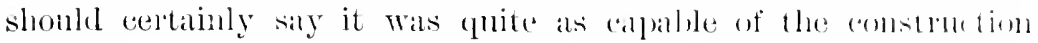
put mpon it by sir Charles linssell, that he was mot intengling to murder liossi, of whom he knew nothing, anel of whose anmention

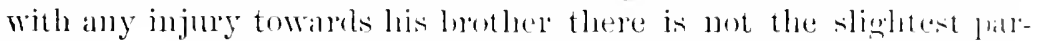
ticle of evidence, as that it moms anything of the kind sleseresterl. Then it amounts to a very litter, and it comes to clisension as to the facts of the case, and as to what was taking place at the exale 1 moment at which the shot was fired. I have arefully followed the discusiom ats to the facts of the case, and if it were mencerly I could go through them all one by one, and point ont, I think. ihat, looking at the way in which that evilence was given, and all the. evidence itself, there is nothing in my judement to disphise the view which I take of the case, that at the monent at which calminni fired the shot, the lensonable piesumption is, not that it is a maltel of absolute certaint y (we canot he absolntely certain about anyluing as to men's motives) but the reasomable assumption is that he at the moment knowing nothing abont lossi, having mo spite al illwill against Rosit, as far as we know, fired that shot: lhalt ho. fired it thinking it would alvance, and that it was an act which wats in furtherance of, and done intending it to be in furtherane of the very olject which the rising had taken place in weler to promute, and to get ris of the Govemment, who, he might, mutil he hat al,solutely got into the plate, have supposed were resisting the entrance of the people to that place. That, I think, is the fair and ratsonalue prestamption to draw from the facts of the rase. I dh mot

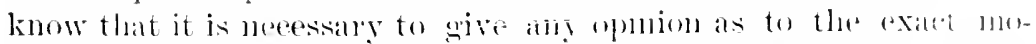
ment when the shot was firel ; there is some conflict alwoll it. Therre

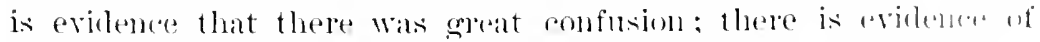
shots fured after the shot which Castioni fired ; and all I rall rily ithat lowking at it as a question of folet, I have come to the ande-llsion that at the time at which that shot was fired he areferl in the finl-

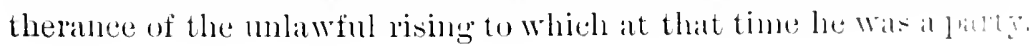


and an active party - a lerson who hat been doing active wolk from a roly meh earliel period, and in which he was still atively engagel. That being so, l think the writ onght to issme, and that we shmlil be acting contrary to the spirit of this enaletment, and to the fair meaning of it, if we were to allow him to be detained in custacly lengers".

II whis-.J., salil, among other things, "Now what is the meaning of erime of a political chatacter? I have thought over this matter rey much indeed. and I bave thought whether any definition can be wiven of the political charactel of the erime-I mean to say, in langhage which is satisfactory. I have fomml none at all, and l can ima pine for myself mone so sitisfatetory, aurl to my mind so complete, as that which I find in a work which I have now before me, and the language of which for the purpose of ny present judgment I entirely alopt, and that is the expression of my bother stephen in his IIstong of the Criminal Law of England in vol. ii., pp. 70, 71. I will not do more than refer to the interpretations, other than those with which he agrees. which have heen griven mon this expression, "gulitical chanacter"; but I adopt his rlefintion absolutely. "The third meaning which may be given to the words, and which I take to be the true meaning, is somewhat more complicated than either of these I have deroribed. An act often falls moler several different refinitions. For instance, if a ciril wall were to take place, it would be high treason by levying wall arainst the gueen. Every ats in which a man was shot in action would be murder. When"ver a lonse was bunt for militaly puposes arson would be commiture. To take cattle, ete. ly renuisition would be roblery. Ac-

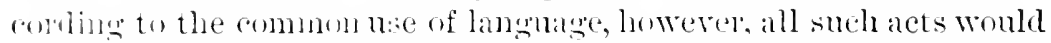
he pritical offences, berallse they would be incidents in carrying on a civil war. I think, therefore, that the expession in the Extratitim A.t ought (muless some better interperetation of it can be slleresterl) to be interemeter to mean that fugitive criminals are

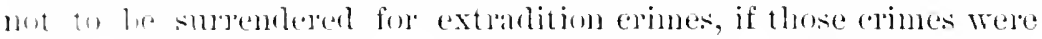
inusilental to and formen a part of political distmbances. I do mot

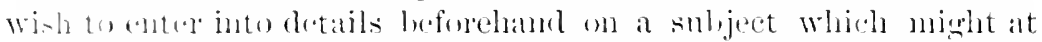

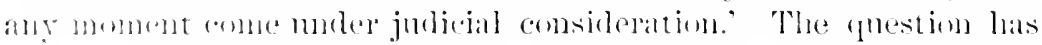

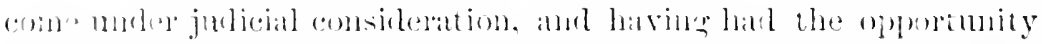

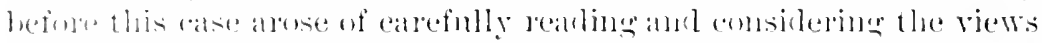

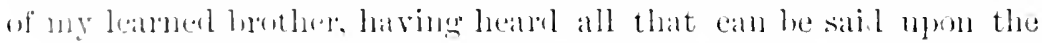
smljot, I arbot lis language as the detintion that I think is the mo-t jerfoet to be fommel or alpable of being given as to what is the matning of the phrase which is made use of in the Extradition $1(\cdot) * *$ 


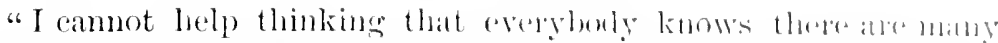

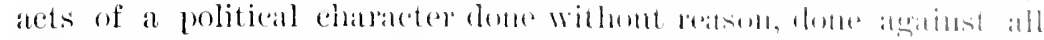

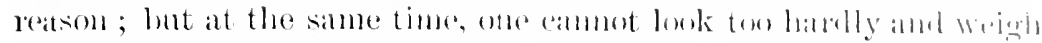

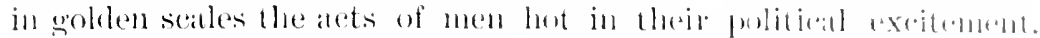

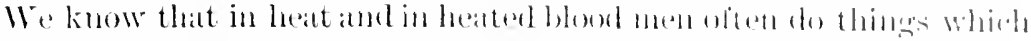

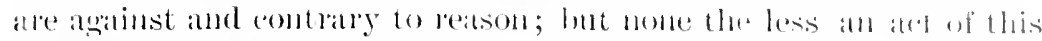

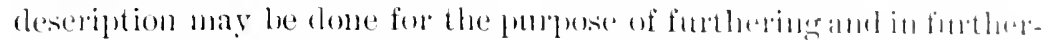

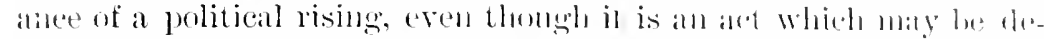

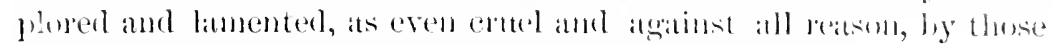
who ran ealmly reflect thon it after the battle is arer.

"For the reatsons I have expresicel, I am of opinion that this rule onght to be made absolute, and that the prisonter ought to be lits. chilsoul." 1

1 Politiral offenses:-"Most condes extend their definitions of treason in arts

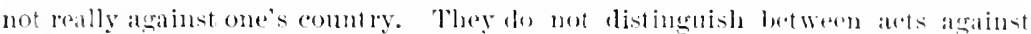

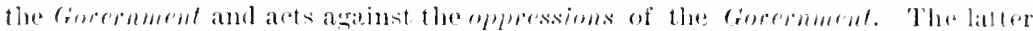

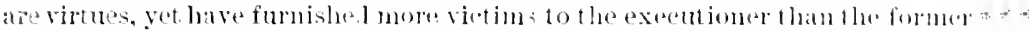

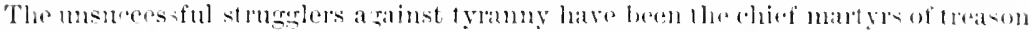

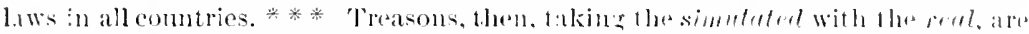
sufliciontly punished by exile." (Jefferson to Carmichated and Short, 17!re. I Am. st. Pap. For. Ricl., 2.s.)

In reecent years there has been mu"h disenssion as to the mature of the rrime

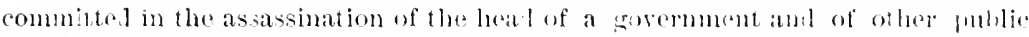

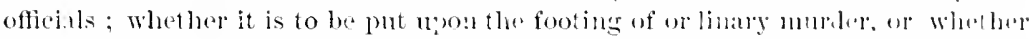

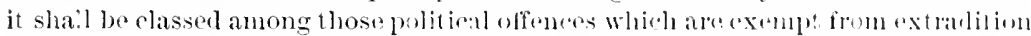

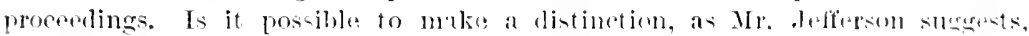

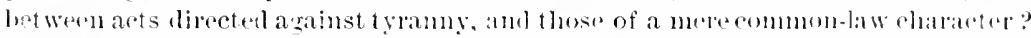
soun such distinetion has probalny influenet statesm in their dealing with the

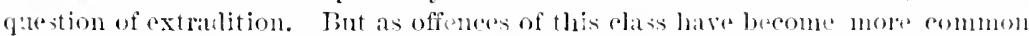

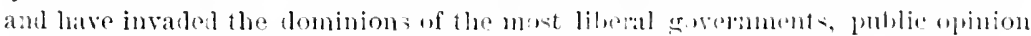

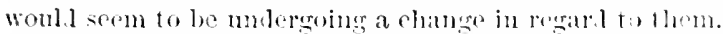

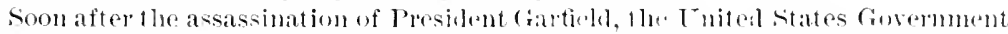

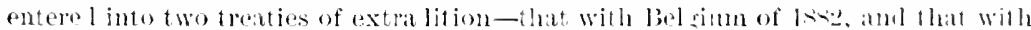

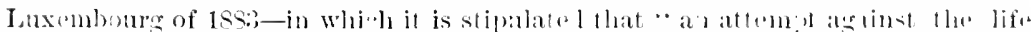
of the bead of a foreign government or atedinst that of any monher of his family,

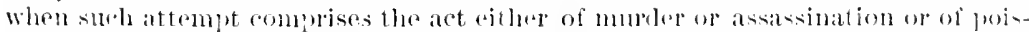

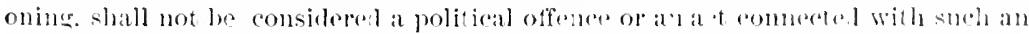

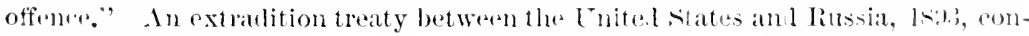
tains a similar clanse.

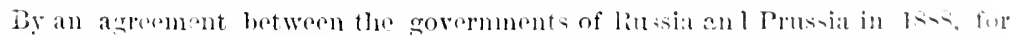

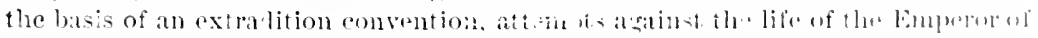

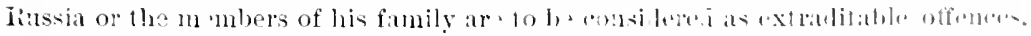

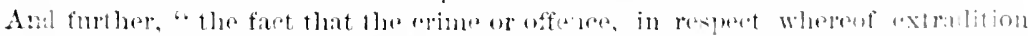
is demanle l, has been committe for a politial object. shall in no case be a reaton

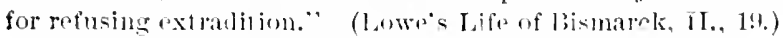

On this subject, see Moore's Extratitioa, I., B.j-ixti. 


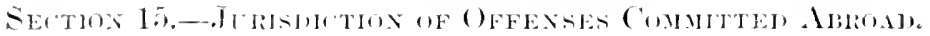

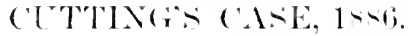

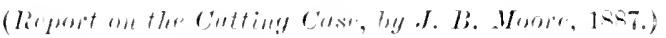

May the courts of a state lake jurielietion in the case of oftenses against its citizens, commitled by forigners in foreign comntries?

1. K. ('nt inge, a ritizen of the Enited States, Was anested in Paso

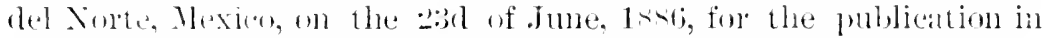
'lexits of a libel andinst a Mexiean eitizen. Cutting had been for some time a resident of I'aso del Nonte, engaged in enliting a news-

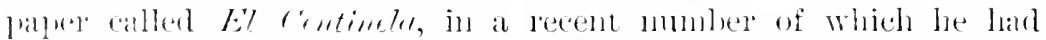

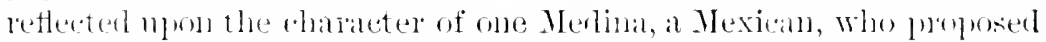
to start a rival newspalper in the sane town. For this publication Cutting was. at the instance of Merdina arrested, bumght lufore a

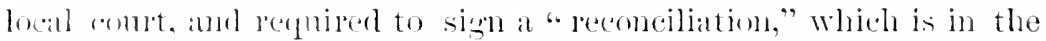
nature of a complendise or settlement betwern the panties, in consideration of whith the party who feels limself atserieved abandons penal pronereslings. Cutting then bat the following notice insedted in the El Prese Mrerlel, in Texats :

"To Enigelio Melina, of El Paso del Norte:

- El Jaso, Texals, Jume 1rith, 1reri.

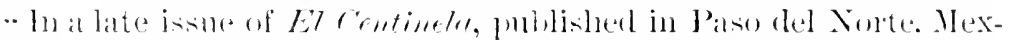

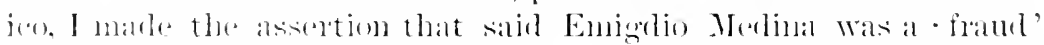

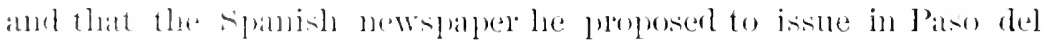

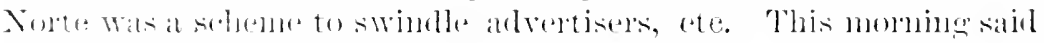

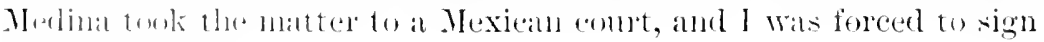
almoneiliation.

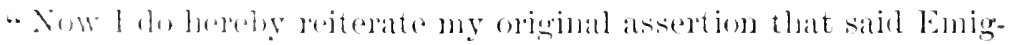

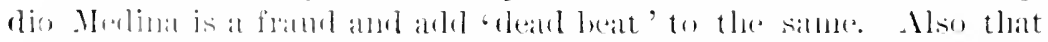

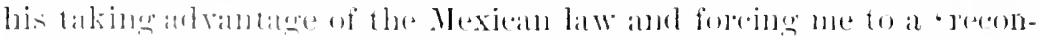

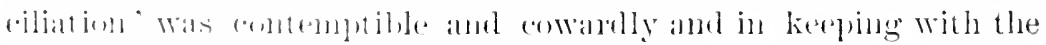

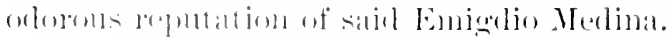

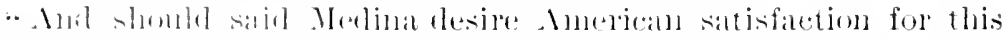
rejtraltion, I will he pleaserl to grant him all be may desire, at any tinte, in ally manner.

".. K. C"T"Tixin" 


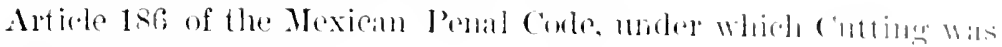
arrestod, is als follows :

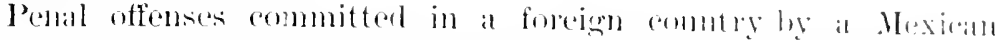

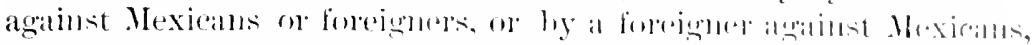

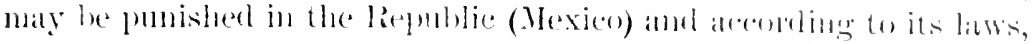
subjext to the following eomlitioms:

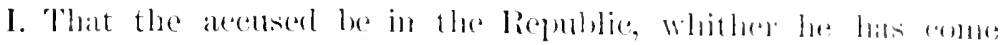

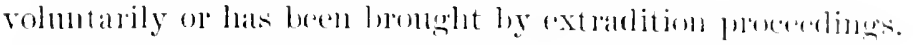

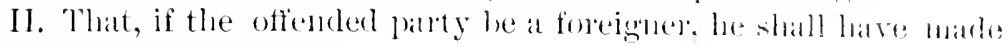
proper legal eommlaint.

III. That the acened shall not hatre lesen defintively tried in the comotry where the offense wats eommitted, ald if trient, that he

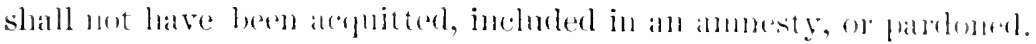

IV. That the heach of haw of whinh he is alerested shall hatre hes

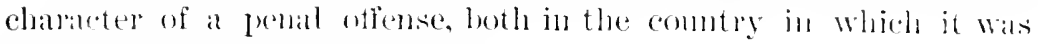
commitud and in the licpmblic.

V. That by the laws of the Remmblic the offense shall be sulajert

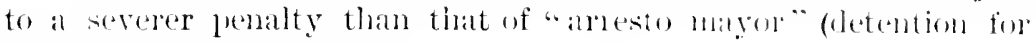
from tme to eleven months).

Notwithstanling the demand of the Cuited states (July lath) for the "instant release" of cotting, "now unlawfully imprisoned at

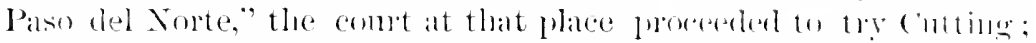

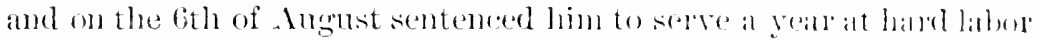

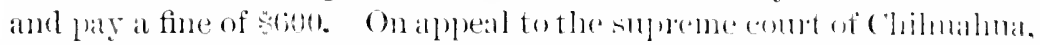
that comt on the 2lst of Angust, fully alphored the definion of the lower cont ; hat the prisoner wats released on the gromut that the

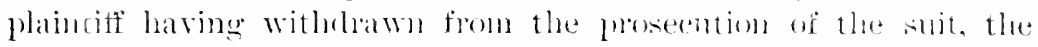

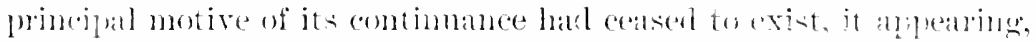

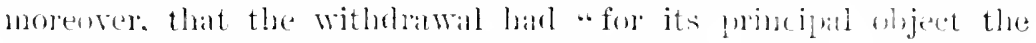
quieting of the al:nm conserpuent npom his complatint."

The govermuent of the Luited states then demanded an imblemnity. for the inprisomment of Conting; and further, repolested of ilexion the abolishment or modifieation of the offensive aldiele al her coule. Mr. Bilvad, Secutaly of State, wote: "Tlis gowemment is still eompellerl to deny. What it denied on the 1 hh of July, 1-4h, and what the Mexican gowermment has since exerutively and jumlicially

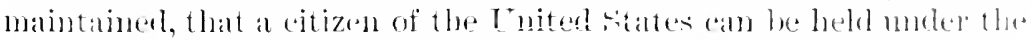
pules of International haw to answer in Texico for an offense onnmitter in the Cuited states, simply becallse the object of that offende halpleneel to he a eitizen of Itexico. The govelnment of Yexico hats endeavorer to smstain this pretension on two gromels: First that such a cham is justifier by the rules of International Law and the positive legislation of various comtries; and. serembly. on the ground 
that such a claim heing marle in the legislation of Mexico, the question is one solely for the deeision of the Mexican tribmanls." Again, "there is no principle hetter settled than that the penal laws of a comntry have no extrateritorial force. Each may, it is true, provide for the punislment of its own citizens for acts committed by them nusile of its territory: lut this makes the penal law a personal statute, and while it may give rise to inconvenience and injustice in many cases, it is a matter in which no other govermment has the right to interfere. To say, however, that the penal laws of a commtry can bind foreigners and regulate their condnct, either in their own or any other foreign country, is to assert a jurisliction orer such comtries, and to impair their independence. Fuch is the comcensus of opinion of the learling authorities on Intermational Law at the present day."

1. Inisliction of extrateritorial offenses.-The position of the government of the Inited states in the rutting case, that the Mexican law giving to its courts the jurisliction of extraterritorial offenses, is contrary to custom and int ernational law, and that the principles insolved in it are practically obsolete in practice. would seem not to be borne ont by facts. Aside from the guestion whether the commonlaw doetrine of territorial jurisdiction is the more expedient practical rule, it nay at least be said that it is liy no means so universally prevalent as to warrant the ascertion that it has become a rule of international law. Fot only are there many cotes which go quite as far in the direction of extraterritorial juristliction as that of Mexico. but there is probably not a state which adheres strictly to the territorial thery. In the first place, practicaliy, all states punish their own eitizens for offenses of one kind or another committed in foreign comtries. Eren Encland punishes not only for treasonable acts, but also for bigamy, murler, and manslanghter committed al,roal ly her subjects. The latrs of the Inited states, too, provide for the punshment of certain oftenses committed abroul by their citizens. (Revised

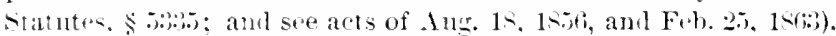

secondly, In regald to foreigners, there is a large number of eodes which take jurinlini on of offenses arainst the state committed by them in foreign states: and a lesor number which go further, ant extent their juriseliction to offenses against intivinal: of this number, are Austria, Inngary, Italy, Norway, sweden, linsia. Creseres, and Lrazil, as well as Mlexieo.

A rain. there are many cases in the state conts of the [nited states, where acts. (fon by letsons withou the state but which take effect within the state, are hell to low bon by persons enotruetirely within the state. and juristietion is assumed. Thus, if a man in one state fines a grum orer the boundary line and kills a man in

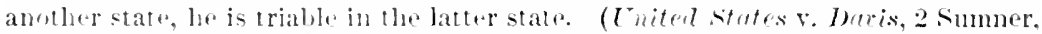

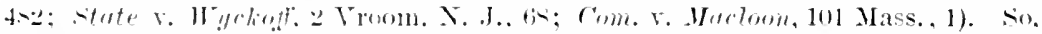
the anthor of a libu, weted ly him in one country, and published by others in another country. is triable in the latter contry. (Com. r. Blending, :) Pieliering

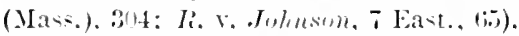

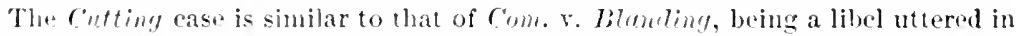
Texas, but beine circulated and havine its effect in $\mathrm{Xfexieo}$ : is the offense different in principle from that of wounding a man in one state by firing across the boundary from anoller state? 


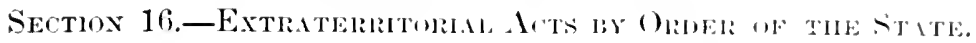

\author{
MCLEOD'S CASE, 1897. \\ (IItleck's Internutionul Larn, I., 4209.)
}

An individual is not to be helu personally responsible for acts done by him in a foreign State by orker of his government.

"During the disturbances in Cpper cimada, in the winter of 1837 , a steamboat called the 'Caroline, belonging to an American owner, had been actively engager in conveying arms and stores from the American sicle of the river to the Camalian rebels. Who were in possession of Navy Island, and had been boarded in the night time by a party of Canarlian Royalists, while she was lying within the jurisoliction of the territory of New York, set on fire, and sent down the stream, when she was precipitated over the falls of Niagara and dashed to pieces. An American eitizen, nanted Durfee, was killed in the affray, and several others womuled.

"In the month of Jamuly. 1st1, a British subjest domiciler in Canada, named Alexander MeLeod, was smdlenly arrested while engaged in some business, within the territory of the state of $\mathrm{Xew}$ York, and thrown into prison by the anthorities, on the charere of having been concerned in the destruction of the 'Caroline' and the alleged murder of Durfee.

"MeLeod was, in the month of May, removed by luberes roppess from Lockport to New York, in the eustody of the sheriff of Niagara Comnty. Previonsly to this, the following note, lated March 1:2, 1s41, Was sent hy Mr. Fox to Mr. Webster, the new Anerican Secretary of State :-

"IIer Majesty's Government have hau muclel consideration the sulject of the arrest and imprisonment of Alexander MeLeom, on at pretended charge of arson and murler; and I an directed to make known to the Government of the Lnited States, that the bitish Government entirely approved of the conse pursued by him. I an

Among jurists there is a wide difference of opinion in regard to the merits of the two systems-the "territorial" and the "personal" theories of juri-ilintion. (T. E. Holland : Jurisprudence, 2l El., p. 31s; F. Wharton: Philosoplly of Criminal Law, p. 309, et seq.; L. Bar : Pricate Intermational Late, Tran-lation by C. R. Gillespie, p. 620 et seq.; Wharton's Conflict of Law, $\$ 1$ 10; "Ca+" if 1. K. Cutting, by the Minister of Foreign Relations of the Republic of Mexico," Isso.) 
instructed to demand fommally. and in the name of the British

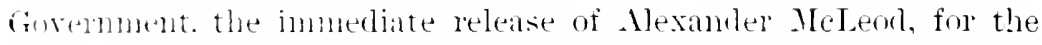
reatom that the transildion was of a public charater, plamed and

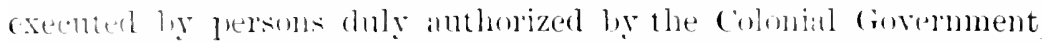
to balie such measules as might be necessaly for putecting the

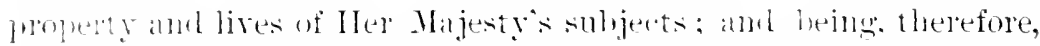
an and of jullio duty, they cammot be held responsible to the laws and trimmals of any foreten comutry.

"Ml. Waster, in his comespondence with Mr. Fox, the British minister, silk that "The Goremment of the Cuited states enter-

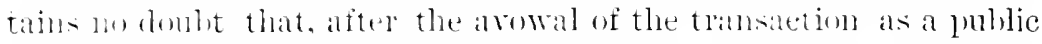
transirdion. anthorized and mulertaken by the british amborities, maviduals concelned in it omght not, by the principles of public law am the reneral nsige of civilized states, to he holden personally peimusible in the oribury tribmats of law for their particination in it. And the Plesident plesumes that it ean handly he necessary to sil that the Anerican people. not distrustful of their ability to ledres mblie wrongs by pullic means, cammot desire the pmishment nit individuals when the act eomplained of is declared to have bern an act of government itself. ***

.. The inmletment aganst MeLeod is pending in a State court, lut his rights, whatered they may be, are no less safe, it is to be presmmerl. than if he were loblen to answer in one of the comrts of this govemment. IJe demands impmity from personal responsibility, by riltue of the law of hations, and that law, in cirilized states, is to he resuecterl in all compts.'

"The supreme Comrt of the state of New York (25 Wrend. R.,

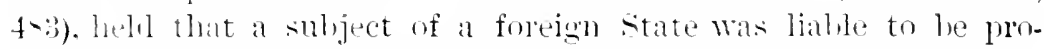
ceerled against individnally, and tried on an indictment in the criminal courts for arson and murler notwithstanding the acts for which the indicturent was made had been subeduently arowed by

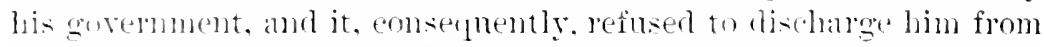
custonly. The opinion of the comt was deliveren ly Mr. Instice Cowen. and is of great length. So far as the question of national law is anderued, the opinion lests mpon the pioposition. that till

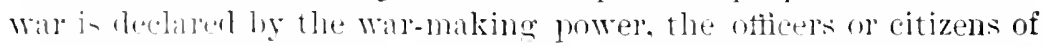
a foreign wormment. who enter our teritory are as eompletely ohnoxims to bmislment hy nu law as if they har been born and alwar readed in this combly : that while two mations are at peace with each other, the acts of hostility hy indiviluals must be regarded as private and not public acts and that the enuts will hold the parties indivinully responsille, notwithstanding the avowal of such acts i,g their government." 
[Meleod was therefore put upon his trial, but the failume rof thu

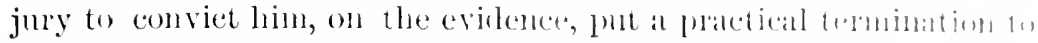

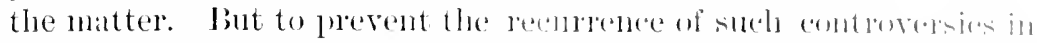
the future, by which the aletion of one of the states might jenpardize

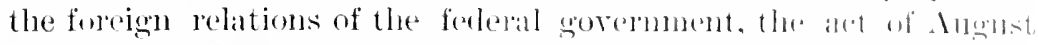

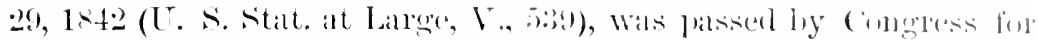

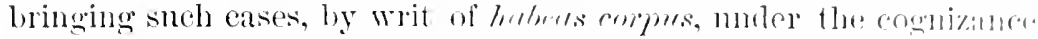
of the courts of the Linited shates at the inception of the procededings.-F. S.]

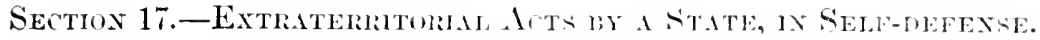

\section{TIIE "CAR()IINE," $18: \%$.}

$$
\text { (IIharton's Ditgest, } 550 \text { r.) }
$$

A riolation of foreign territory may les justified on the aroma of the neresity of self-defense.

In 1837 an insurrectionary movement was made in Clper Canada, having in riew a reform in the coremment of that purevince. A proclanation latd been issmed flom Nary lskmul, in the Niaganat River, signed by William Lyon Mackenzic, chaimman fwo tem. of the provisional govermment, alling upon the reformers to muke that island thein place of rendezroms, and to ald otherwise in revolutionizing the province. It stater that the command of the forces

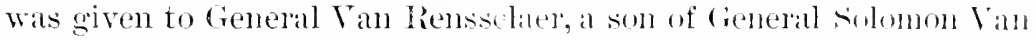
Rensselater, of Alluany. The sympithy manifested ly some ritizens of the Cnited states with the Cimalian insurgents, induced the governors of New York and Termont to issue proclamations, wanning the citizens of these states to refrain from any mulatul alds within the territory of the Eniter states. Notwithstanding these prockmations, the insurgents were joined by citizens of the l'nited States; whence also they receiver amms and munitions of wall. The steamboat Camolim owned hy an American citizen, was sald to be engaged in transunting recmits amb sapplies to the remolezrous on Nary Island; and it was further pesemmed that this loat would be the means of transferring the experlition to the Candian shure. Ender these circumstances, the British offlece in commmon determined to destroy the Caroline. I force was acondingly derpatuled for that purpose on the night of the 2ath of Jecemler. 1-.3. . Xit finding her at Navy Island, the party proceeded to her mowrings at 
Schlosser on the American shore, attacked the crew, one of whom wits killed, took the lont into the stream and left it to he carried over Niangra Falls. A proelamation was promptly issued (Jammary 5 , 14:-4), by President Van Buren, enjoining on all citizens obedience to the laws and warning them that the violation of omr neutrality wonld subjert the offenders to funishment. General Seott was forthwith ordered to the Camadian frontier to assume the military command there; and requisitions were male upon the Governors of Sew York and Vemont for such militia force as General seott misht regnire for the defense of the frontier.

On the other hand. the act was male a sul,ject of eomplaint by the American government, on the cround of a violation of territory; but it was justified by Great Britain on the ground of the neeessity of selt-preservation.

'The question remained msettled till 1842, when Mr. Webster, in conespondence witl Lord Aslumenton, eontended, that for such an intringement of territorial rights. the British govermment must show - a necessity of self-defense, instant, overwhelming, and leaving no dhoice of means and no moment for deliberation: " and it should further appear that the Candian anthorities, in acting moler this exigence. "did nothing umreasonable ol" excessive, since the act, justified by the necessity of self-defens. mmst be limited by that necessity and kept clearly within it." Lom Ashlmmton admitted the correctuess of Mr. Webster"s doctrine. and asserted that the destruction of the comoline came fully within its limits: and, though the alet was justifible, an apology for the violation of territory should lave been marle at the time. This was aecepter by the Lnited states as satisfartoly, and the sulpect was allowed to drop. (Parliamentary Papers. 1s4:, lxi. $46-51$ : Wharton's Digest of International Law, I., s50 c; Benton's Thirty Years in the senate, II., 289 , $45 \overline{5}$.

\section{SEIZTRE OF ṠIIXT MARR'S.}

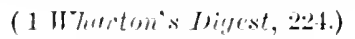

Neresity justifies an invasion of foreign territory so as to subdue an expected a.sialant,

In 195, muldr orders of Mr. Monroe, measures were taken for the restruction of a fort helr ly ontlaws of all kinds on the Appalachicolit River, thrn within the spmish territory, from which parties harl gone fortlo to pillage within the United States. The governor of Pensacolia had been called upon to suppress the evil and punish 
the marauders, but harl refuserl ; and on his refusil, llu. - ilumi-? teritory was entered, and the fort attacked and lostrogel on the glound of necessity.

General Jackson put his seizme and ocenpation of the fout alt faint

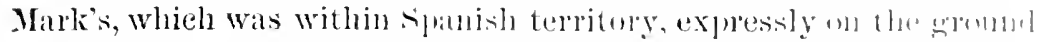

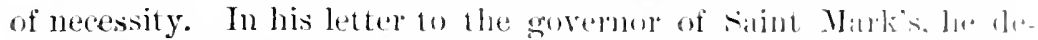

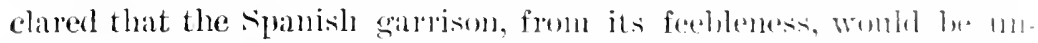
able to resist the attackis of Indians who intended to malke it a hata. for their operations against the Lnited states.

"To prevent the recurrente of so soss a violation of mentrality, and to exelucle our savage enemies from so stromer a lublel as silint Mark's, I deem it expelient to marrison that fortress with Mnlerian troops until the close of the present wall. This measure is just ifiahle: on the immutable prineiples of solf-defense, and eamot lut lestisfactory, under existing cirenmstances, to his Catholic Maljesty the Fing of spain. Ender existing treaties letween the two sormenments, the Fing of spain is bund to preserve in peace with the citizens of the L'nited states, not only his own suljects. lut all Indian tribes residing within his territory. When called num to fulfill that part of the treaty in relation to a savare tribe who hav" long depredated with impmity on the Anerien fromtier, incompre. teney is alleged, with an acknowledgment that the same tribe latro acted in open hostility to the laws, and invaded the rights of his Catholic Majesty. Is a mutual enemy, therefore, it is experoterl that every facility will be afforded by the agents of the King of Finin (1) chastise these lawless and inhmman sarages. In this light is the possession of Saint Marli's by the American forces to be viewerl." I

\section{TIIE "VIRGINILS," 1ST:3.}

\section{(C. S. Foreign Rolutions, 1sit; Perl. Popers, 1sit, rol. 7i.)}

Seizure, on the high seas, of a ressel carrying a foreign flag, on the gromm of self-tlefense.

The rirginius was registered in the Lnited States and corrried the American flag; but, as it eventually appearerl, she wat really thes property of certain Culnan insurgents, and was employed in aid of the rebellion in Cuba. On the 9th of July, 187:), she arrived at lineston, Jamaiea, and on the 2:3d of Oetober she cleared ostensilily for

1 The seizure of Amelia Island, in 1817 , by authority of the government of th."

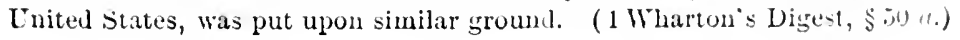




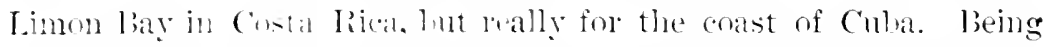

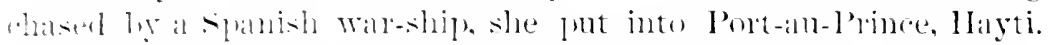

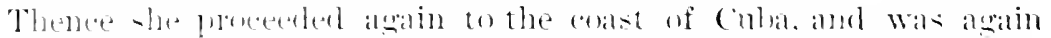

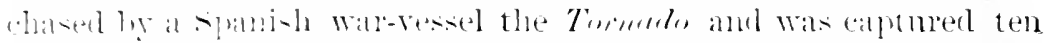

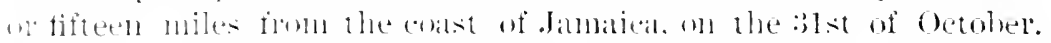

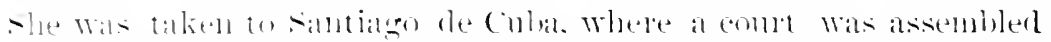

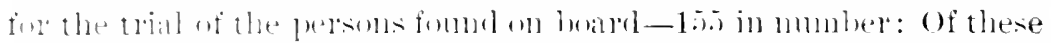

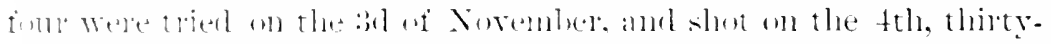

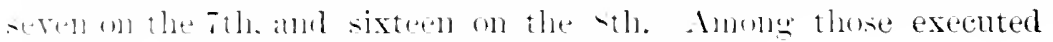

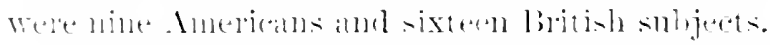

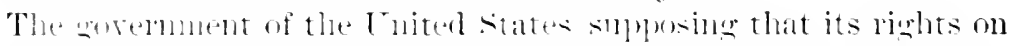

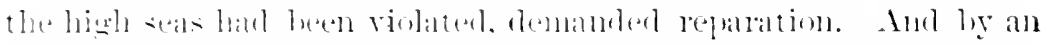

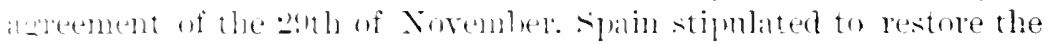

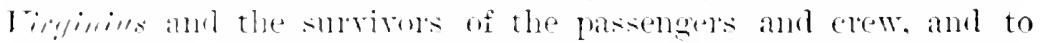

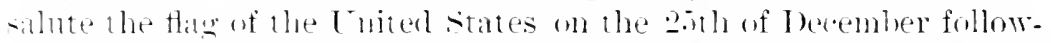

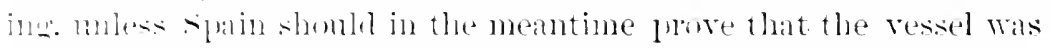
mi entitled to rary said flag. The matter was sumbitted to the

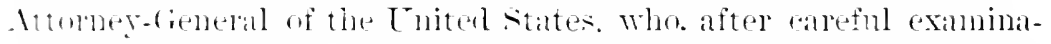
tion, reponted an the 12th of December, that the registry of the riefinies was framblulent. and that she had therefore no right to

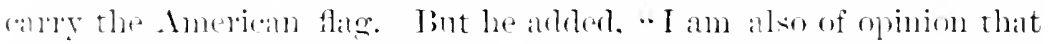

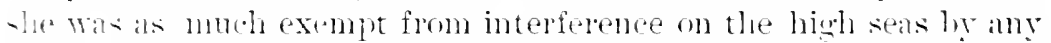

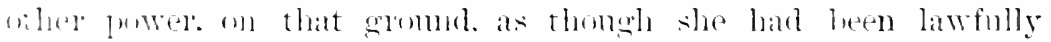

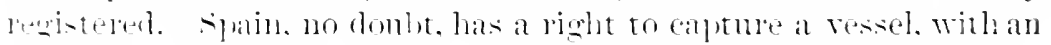

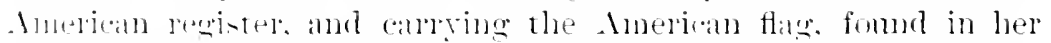

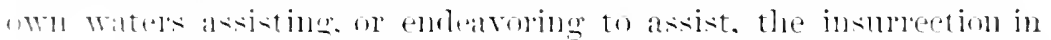

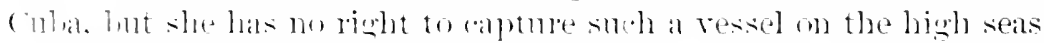

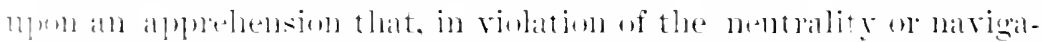
tind laws of the [nited states, she was on bele wat to assist satid

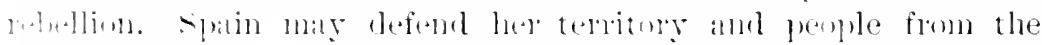

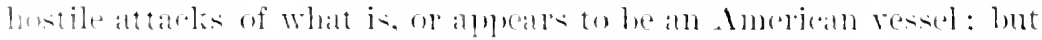

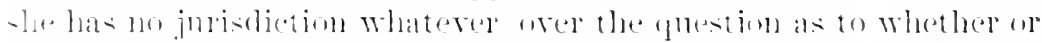

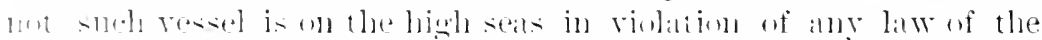

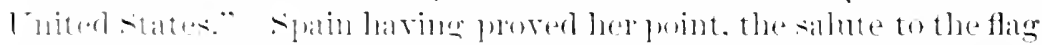

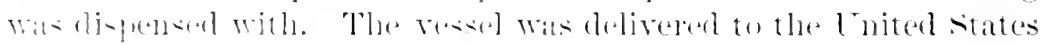

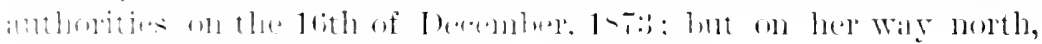

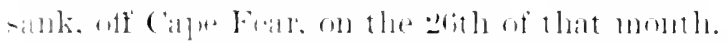

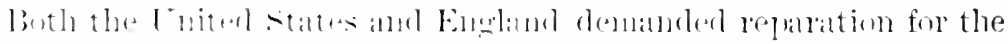

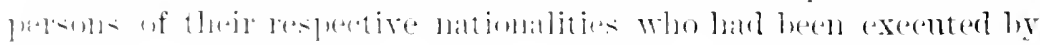

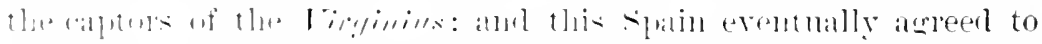

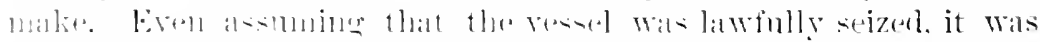

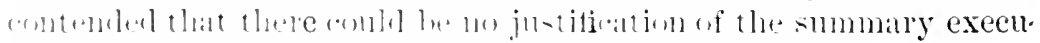

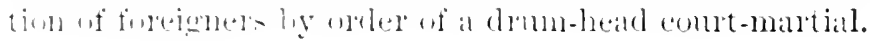


The position of the Attorney-(ieneral, that sprain hand no riglit to

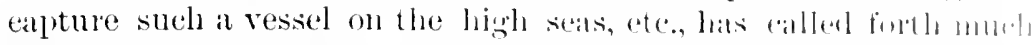
adverse eriticism. both Woolsey and lotuat justitiol the calpume at

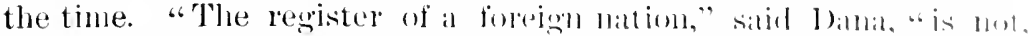

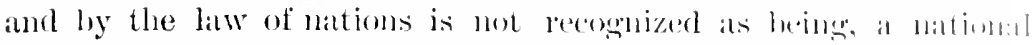

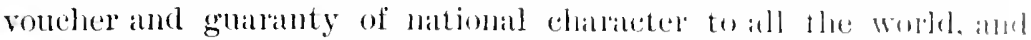
nations having cause to arrest a vessel, would en hehind surb a

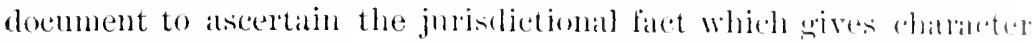
to the doemment, and not the doemment to the fart." II Was the

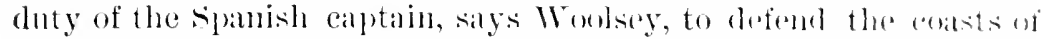

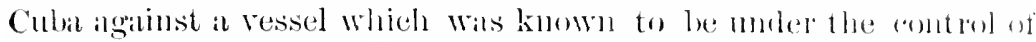

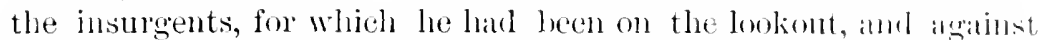
which the only effectual security was apture on the high stats. (Woolsey's International Law, bith Ed., ple. B(ix, 3(it).

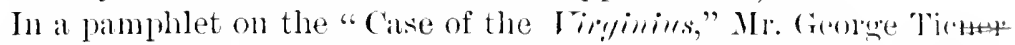
Curtis took similar gromul. "We rest the seizure of this vesure" he says, "on the great right of self-lefense, which, springing fmon the law of nature, is as thoroughly incorporated into the law of nations as any right can be."

\section{Section 18.-Ixjury to Forelaners by Mon Vuolexce.}

\section{NEIV ORLEANS RIOT, 1851.}

(2 Hharton's Digest, 600.)

A State is not responsible for injuries to aliens, through civil commotions or mob violence which it is miable to control.

On the receipt of intelligence from IIavana, in 1<51, of the sumbmary execution in Cuba of a number of American ritizens, who hat aceompanied Lopez on his filibustering experlition to that islame riots immeriately took place in New Orlams and Key West, directed against the spanish residents of those eities. The simish comsulate in New Orleans was attacked; and murh injury was dome to gejsons and property. For these injuries, the spanish gromerment demander reparation from the government of the I Inited stalles. Th these demands, Mr. Webster, Secretary of State, replicrl, Noremble 13, 1851, as follows:-

"The assembling of mols happens in all comtries: pumlan rin-

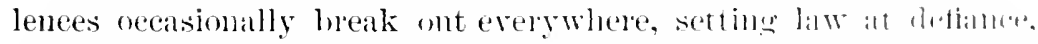
trampling on the rights of citizens and private men, and smletimes 
on those of pmilic officers, ami the agents of foreign govermments, topecially ontitled to potection. In these eases public faith and na-

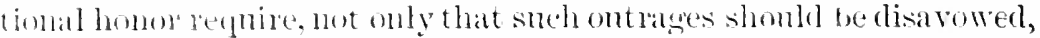
lint also that the perpetrators of them shombl be junished wherever it is gusible to hring them to justice; and, furthel, that full sat isfaction shonle he mate in rases in which a duty to that effect rests with the government, acomding to the seneral principles of law, public taith, and the obligation of treaties. Mr. Calderon thinks that the enormity of this act of popmlar violence is heightened by its insult wh the flity of spain. The soremment of the Luited states would arnestly depecate any indignity offered in this comtry in time of leare to the flarg of a nation so ancient, so respectable, so renommed als rilull

"It anpears, howerer, that in point of fact no flar was actually flyiug of pullicly exhibited when the outrage took place ; but this rin make no difference in regud to the real nature of the offense or its emomity. The persons composing the mob knew that they were ottering insult and injury to an officer of IIer Catholie Majesty, residing in the Cnited states moler the sanction of laws and treaties; and therefore their conduet admits of no justification. Nevertheless, Ir. Cableron and his govermment are aware that recent intelligence latl then been received from IIarama, not a little calculated to excite lopular fecling in a great city, and to lead to popular excesses. If his he no justification, as it certatuly is none, it may still be taken into view, and reginded as showing that the ontrige, however flaslant, was eommitted in the heat of bloml. and not in jursuance of any profleternined plan or pmpose of injury or insult. * * *

"While this sovermment has manifested a willingness and determination to lerform every dnty which one friendly nation has a right to expeet from another, in casesof this kind, it smploses that the rights

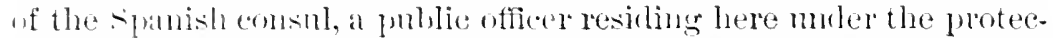
tion of the Inited states sovermment, are quite different from those of the sirnish subjects who latse cone into the enmtry to mingle with onl own eitizens, and hele to pmstue their private business and

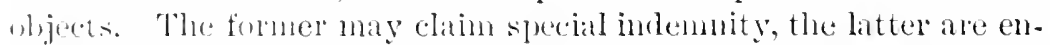

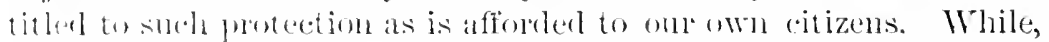

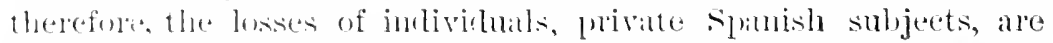
creatly to he renetterl, yet it is mulerstenel that many Anerican

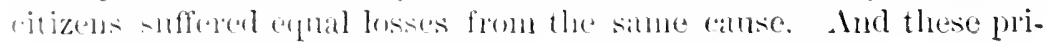
valte indiviluals, smbjects of IIer Catholit Majesty, coming rolum-

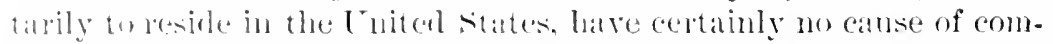

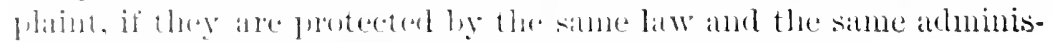
tration of law, as native born citizens of this country. 
"They lave in fact some allantages over the eitizens of the statt" in which they halyen to be, inasmoth as they are enabled, mud they

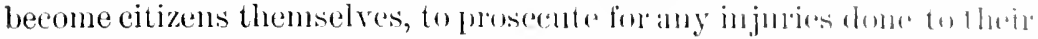
persons or preperty in the combs of the Luited states, or the statu courts, at their election.

"The President is of opinion, as aldearly stated, that, for obvinus reasons, the ease of the eomsul is different, and that the wowermunt of the United States should provide for Mr. Laborle a just indermnity ; and a recommentation to that effect will be laid before (ongress, at an early period of its alphoathing session. 'Jlis is all whirh it is in his power to do. The case matye a new one, hut the l'besident being of opinion that Mr. Laborde onght to be indemmitied, has not thought it necessiary to searrell for precelents."

It would appear, by the resolution of Congress, Mareh 8,1 , i::, that Congress did not limit the indemnity to the losies incmured lig the consul. The resolution is as follows:-

"Resolved, etc., That the Presilent of the Tnited States he, and is herehy, requested to ause an inrestigation to be marle of any losises that may have been sustained ly the comsul of spain and ot her persons residing at New Orleans or at Key West in the year eighteen hundred and fifty-one, and who at that time were sibjects of the Qneen of spain, by the violence of individnals arising out of intelligence then recently received at these places of the execution of certain persons at IIavana, in Cuba, by the spanish anthorities of that istand, and that such losses so ascertained to persons at that time subjects as aforesaid, on the eertificate of the seeretary of state that the same are proven to the satisfaction of the President, together with the reasomable costs of the investigation, shall be paid to those entitled ont of any money in the Treasmry not otherwise alpropriated." I

${ }^{1}$ The New Orleans Mob, 1891.-The prestions growing out of this New Orleans affair, in 1s21, present some peeuliar features; and foreibly illust rate certain the feets, as regards the conduct of foreign relations, in the federal system of the Inited States.

The Chief of Police of New Orleans had been assassinated in a most dastarilly manner: and strong suspicions of complieity in lle murder rested on the members of an Italian society called the "Matiat." $\Lambda$ number of Italians wer" tinally arrested and put upon their trial, bia in ibe ent were acpuitled by the jury. brelieving that the jury had been tampered with, and that there was, in this case, at signal failure of justice, a public indignat ion meeting was helel, whiels was attuded by the better elass of eitizens; intlammatoly addlesses wele male, and mastres

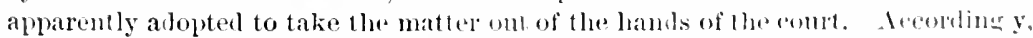
a mob assembled the next morning, and, as it would atprar, wilhout any probes from slate or eity governments, broke "ren the jail where the atensel were silt incarcerated, and shot or hanged a number of the suspected Itallans. Among his 


\title{
CHAPTER III.
}

\author{
JURISDICTION ON TIE IIIGII SEAS
}

\author{
SEATH 19. - JERTHANT VESSELS.
}

THE “ ATALANTA," 1856.

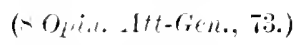

Ierchant ships on the high seas ane shiogect to the jurisdiction of the comtry of their flas.

In 1-iti, a case arose in reference to seamen, stuposed not to be citizens of the Enited states, who. having committed a mutiny at

number were several who were not naturalized, and were, therefore, still citizens of ltaly.

The President, by the siecretary of state. expressed regret for the occurrence and declared his purpese to lay the matter before Congress at its next session, and to reommend that an imlemnity be whont to the families of the mudered men.

The Italian govermment was not sit i-fie.l with this position of the Enited states, but demanded further that the leaters of the mob be eriminally prosecuted and junishen accordines to law.

With this drmand the govmment of the Enited states could not comply. how"rer willine it mierht he to do so. It j- well known that the federal conts have no common-law jurialiction in criminal matters: it was impossible, therefore, to

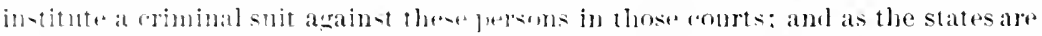

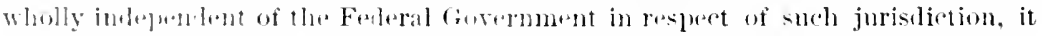

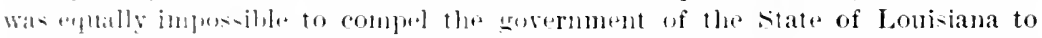

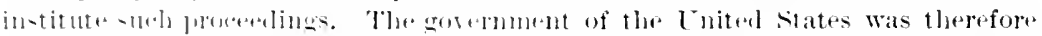

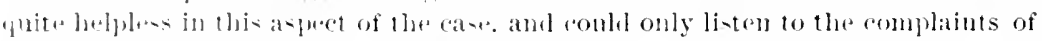
laty, and try to explatin to her statemen the intricacies of the Cnited states (⿻)1stitution.

It is muloubtedly whlin the completwere of fongress to confer upon the ferleral

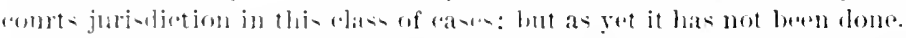

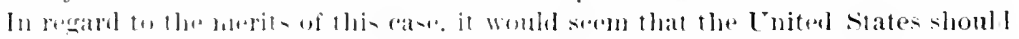

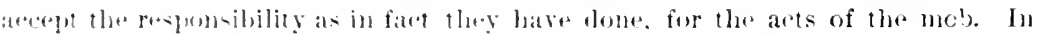

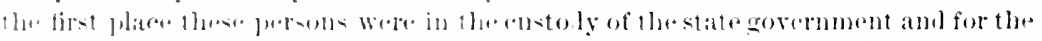

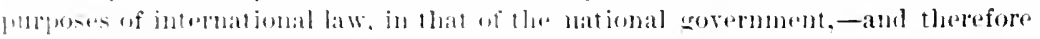

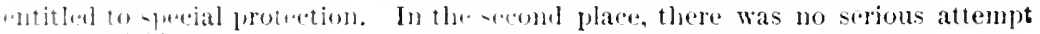
$1-4$ 


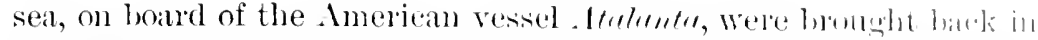
the vessel to Marseilles, Where, on the applieation of thr ansill al the Cnited States, they were receiverl and implosoned hy the linat atuthorities on shore.

six of them were afterwards on his applieation taken from grisum

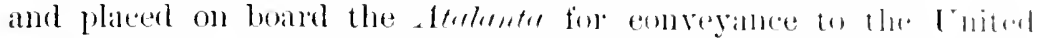
states moler charge of erime. Then, with motioe to the ansul, hut in spite of his remonstrances, the focal anthoritios went an lwanl of

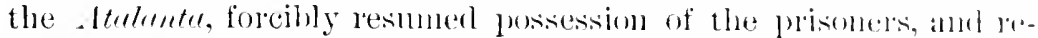
placed them in confinement on shore. Mr. Masom, in a note of the 27th of Jume, 18 si, says :

"It is the first instance, in which a vessel wearing th" flan of the Enited states, lying in a French port, or a French ship lying in a port of the Enited States has, sinee the date of the trally, han visited hy police officer's withont the anthority of the consul." (.MS.

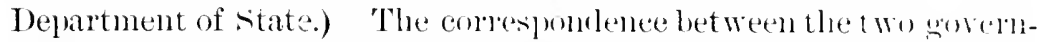
ments having been subnitted to the Attorney-(ieneral of the loniter states, he concurred in opinion with the Amerian Minister, "that the local authority of Marseilles exceeterl its lawful pwer in -mbstance, ats well as in form, and that there combl be no conthire on the part of France with other powers on accomet of the nationality of the prisoners, for they were always in the eonstructive, if not in the actual, custody of the United states."

\section{CASE OF .JOIIN ANDERSON.}

Erarts, Ser. of State, To Welon, Jely 11, 18.9.

( $11 \%$ hafouis Digrest, 12:\%, 125.)

An offense committed on an American merrhant vessel on the high -ear is exchnsively within the jurisdietion of the courts of the Cnited states, whaterer be the nationality of the accuse.l.

"I enclose herewith a copy of a dispatch recently receired from

on the part of the proper authorities to quentl the riot; and it is germenally mulerstood that a government is liable internationally for injuries tone to " alien residents by a mob which by due diligence it could have suppressiel."

The Italian government eventmally withlew the domand for the punishment of the actors in the atfair. and accepted a monry indemnity instrat.

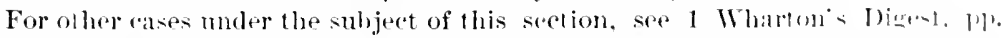

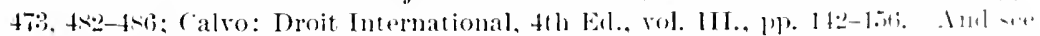

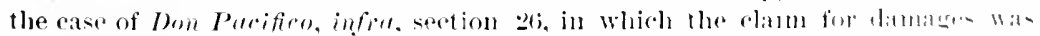

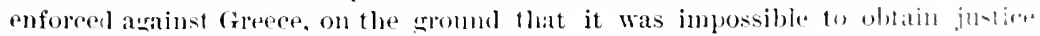
thuough the ordinary channels-the courts. 
A. C. Litchfielt, Ery. wnsul-general of the Lnited States at Cal"mltil, in relation to the catse of one John Anderson, an ordinary sea-

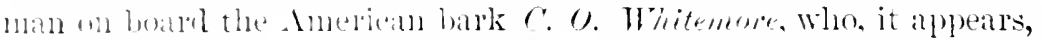

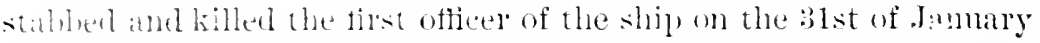
lakt. While that vesiel wats on her way from Xew Tolk to Callenttil, sixten ditys from here port of deprinture, and on the high seats in

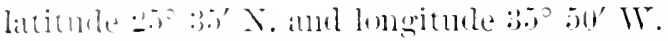

" l'n will perceive that the consul-general involed the aid of the

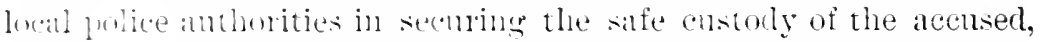
whe wats a prisoner of the Fuited states, mutil he could complete

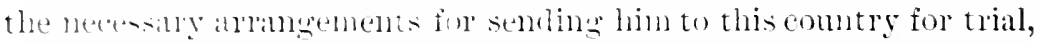
angind whose municipal laws only he wals atecused of having offended, and that while thus in the temporary custody of the local police, the colonial anthorities took judicial cognizance of the matter, chaming, moler the advice of the advocate-genteral of the colony, that. muter a colonial statute, which confer's upon the courts of the colong juristietion of crimes eommitted by a British subject on the Ingh seats, even though such crimes be committerl on the slip of a foneign nation, and that inasmuch as the acensed, although appearing on the shipis antictes moler the name of John Anderson, subject of sweden, had declared that his reali name was Alfred IInssey, amd that he was a native of Liverpol and therefore a British sub. ject, the case came within the juristiction of those courts.

"The matter is now believed to have reached that point in the jurlicial proceedings where effective measures for asserting the jurisdietional rights of the L'nited states would be unavalialle in this farticular ane. And whilst I entertain no doult that the accused will recrive as fair a trial in the high conrt of Calcntta, where it is

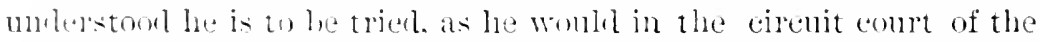
Fniter stater, in whith tribmal he would be arraigned were he sent here for trial, I deem it proper. at the same time to instruet you to loring the "guestion to the attention of IIer Matjesty"s Government, in

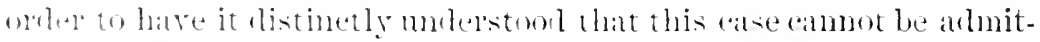

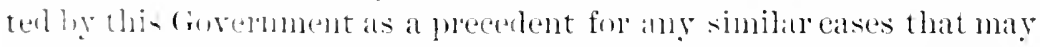
mite in the futme. So principle of publie liw is better understom

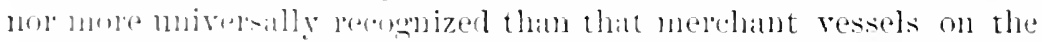
hish a a are male the jurialietion of the nation to which they be.

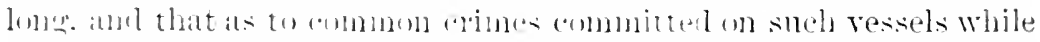

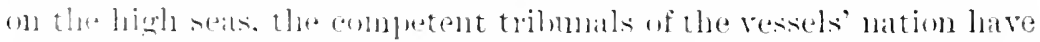

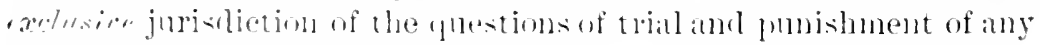
person thus aecusen of the commision of a crime arganst its muni-

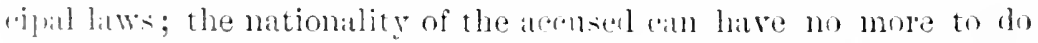
with the question of jurisdiction than it would had he committed 
the same crine within the geographical territorial linits of the late

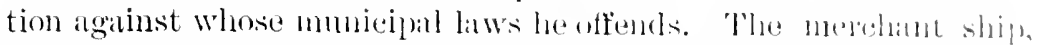
while on the high seas, is, as the ship of wall everywlele, a part of the territory of the nation to which she belongs.

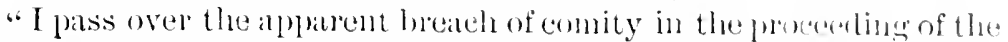
colonial officials als being rather the lesult of inalvertence and jossible miseoneeption on the pant of the Gorementent law officen of the colony, than any design to question the sovereignty of the Enited States in this or eases of a similar nature."

"I have to acknowledge the receipt of your dispateh No. 17, of the 16th ultimo, inclosing a eny of the correspondence between your legation and the foreign office in relation to the calse of . John Nurterson, who was tried in Calentta for a crime allegred to have been com-

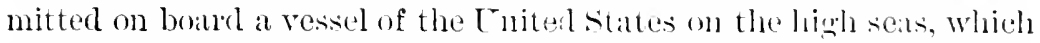
correspondence contains an exprexsion of the regret of Her Majesty"s Govermment that the antion of the anthorities at Callonta in the carse in question, should have been governed by a view of the law which, in the opinion of IIer Majesty's Government, camnot be smpported.

"In reply I have to instruct yon to eonvey to the proper quarter" an expression of this Depratment's appleciation of the candor and goodwill with which IJer Majesty's Government have emsilemed this matter, and I say, moreover, that it has afforded this rovermuent great satisfaction to learn that the action of the anthoritius of Cal. cutta in the case of Anderson is to be attribnted to a misennception, and not to any design to question the jurisdietion of the Inited States in that or any similan case." (Mr. Hay to Mr. Low ell, July T, $1880)$.

\title{
IREGINA v. LESLEY.
}

\section{Colmt for Crow Cases liesenven, 1860.}

\author{
(Bell's (rowen Creses, 2.20)
}

The master of a British ship may detain ('hilian outlaws on boan his ship, against their will, while in Chilian waters, by aterenn'm with the ('hilian government; but he cannot lawfully transport them on the high seas muler such agresment.

The prosecntor and others were Chilians who were binished by their government from Chili to Enghand. The swermment af Chili hired the defendant to take the banished men to England in his ben sel, then lying in the territorial waters of Chili. This flan wats at?ried out and now the defendant is prosecuted for folse impurismment. 
Juhgment, hy lins: ( . .J.:- - In this case the guestion is whether a combietion for false imprisomment ean be sustained mpon the follow-

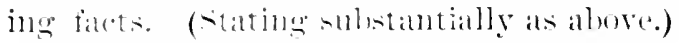

"Then, wan the tomvietion be sustained for that which was done within the (hilian waters: We answer no.

. We asmme that in chili the ate of the corormment toward its suljeets wats lawtul: and although an Einglish ship in some re-peets carries with her the laws of her conentry in the teritorial waters of a foreign statle yet in other lespeets she is subjeet to the latws of that state ats to alets donte to the smbjects thereot.

- We atsinme that the gerermmellt combl justify all that it ajel within itsown territorg, and we think it follows that the defendant ean justify all that lue rid there as agent for the goremment amb meler it - anth hority.

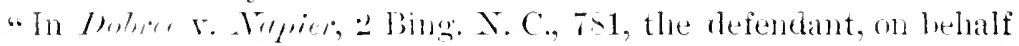

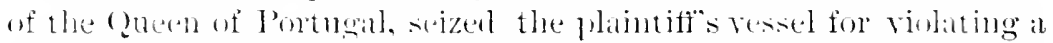

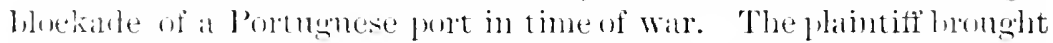
trespass: and jumgnent was for the defendant, betanse the Gueen of l'ortugal, in her own territory, had a right to seize the resiel and to embloy whom she would to make the seizme; and therefore tha defendint, thom an Englishnian seizing an English vessel. could justify the act moler the emplorment of the Queen.

. We think that the alcts of the refendant in Chili became law ful on the same principle, and that there is therefore no gromel for the comriction.

"The further question remans, Can the eonviction be sustaned for that which was done out of the Chilian teritory: and we think it (iill.

"It is ciear that an English ship on the high seat, ont of any foreinn trutury, is subjoct to the laws of Endand ; and persons, whether

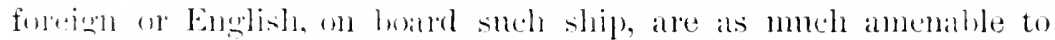
Englioh law as they wombl he on English soil.

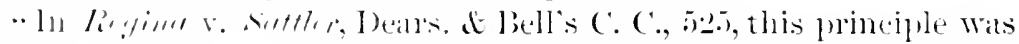

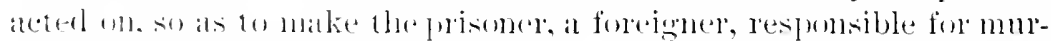

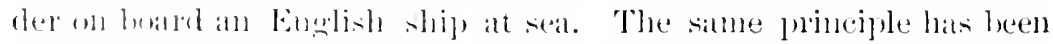

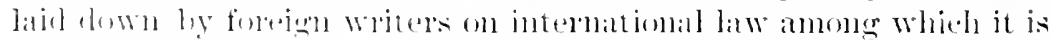

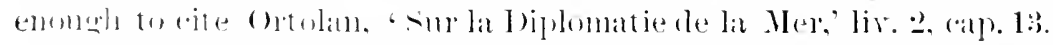

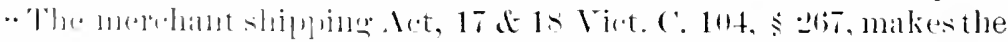

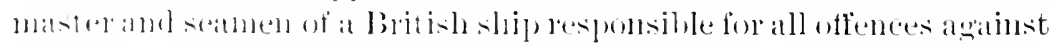

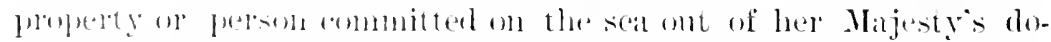
mingons as if they hal been eommitter within the juristiction of the

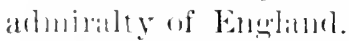

"such being the latw, if the act of the defendant amomned to a 


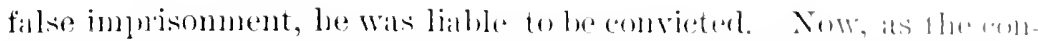

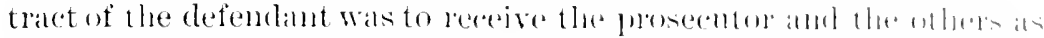
prisoners on boarel his ship and to take them, withont their antent

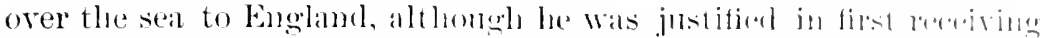

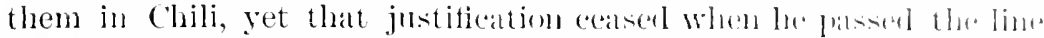

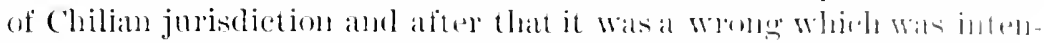

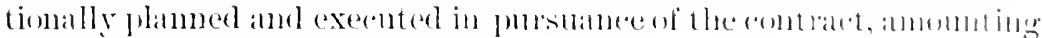
in law to a false imprisomment.

"It may be that transportation to England is law ful he the law uf Chili, and that a Chilian ship might so lawfolly tamspont ('hilian suljects: but for an English ship, the laws of ('bili, ant of the state, are powerless, and the lawfulness of the acts must be tried hy buglish litw:

"For these reasons, to the extent above mentioned, the conviction is athimed."

\section{TIIE " BELGEXLAND."}

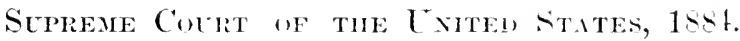

(11t Creited stutes Reports, 35is.)

In a case arising out of the collision of two foredinn ships, which alterwarls arrive

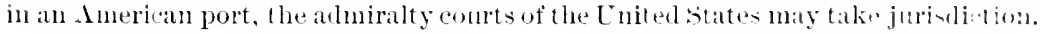

This case grew out of a collision in mid-ocean between the Nolwe-

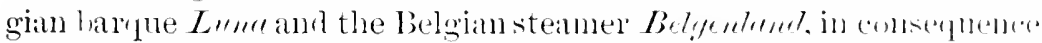
of which the Lume wats rou down and sunk. Partof the crew of the Lnm, including the captain, were rescued hy the steanes amb

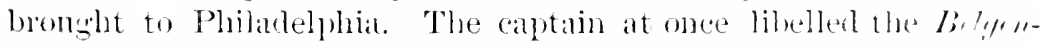
loner. The District Cont decided in farer of the libellant, giving at verelict for $850.04: 4$.

The circuit court confirmed the verdict, and the lihellere nom appeals to the C. S. sinpreme compt. Only so much of the catse is given as refers to juristliction.

Mr. Justice Bronfey delivered the ofinion of the cont, from which the following extracts are taken:

“* * We shall content oirselves with inquiriug what rule is followed by Courts of Admiralty in dealing with mallime canses arising between foreigners and others on the high seas.

"This question is not a new one in there compts. Sir William Seott hat oceasion to pass 10 om it in 1799. An American ship was taken by the French on a voyage from Philatelphlia to I.molom. and afterwards rescued by her crew, carried to Englant, and litelled for 
salvage; and the court entertained jurisdiction. The ercw, however, thongly engaterel in the Anerican ship, were British born subjects, and weight was erven to this ciremonstance in the disposition of the case. The juclere, howerer, mate the tollowing remanks: but, it is askerl. if they were Ameriean seamen, womld this compt hold plea of thein demands? It maly be time enough to answer this question whenerer the fact occurs. In the meantine. I will saly withont scluple that I can see no inconrenience that womld arise if a British comrt of justice was to hold plea in such a case; or conversely. if American comts were to hohl pleas of this natme respecting the merits of IBritish seamen on such occasions. For salvage is a questim of jus : gutim, and materially difierent from the question of a matiner"s contract, which is a ereature of the particular institutions of the country, to be applied aud comstrued and explained by its own fatrienlar lules. There misht be gond reason, therefore, for this

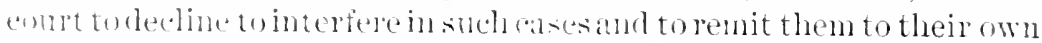
domestic formm : hut this is a general claim, upon the general gromul

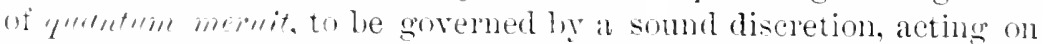
grenterll frinciples; and I can see no reason why one eountry should i)e afraid to trist to the equity of the courts of another on suld at guestion uf such a nature, so to be determined.' The Tro Fricme, 1 Ch. Rol,. 2,- 1,27 .

"The haw las becme settled rery much in accord with these views. That was a case of salvage; but the same principles would scem to alphy to the case of destroying or injuring a ship, as to that of salvig it. IBoth, when acted on the high seas between persons of different mationalities. come within the domain of the seneral law of

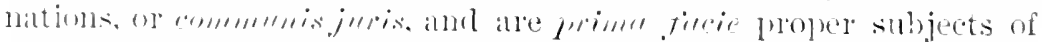
infuiry in any cent of admiralty which first obtains jurisdiction of the resender offerming shipat the solicitation in justice of the meriturions, or injurerl, parties.

." The sime question of jurisdiction arose in another salvage case which cande hefore this cont in 1-0.t, Mesone v. The Bloirecen, Cranch, :2tu.

"'llhere a Fronch thip, was savel by a British ship, and brought into a prot of the Enited states; and the question of jurisuliction

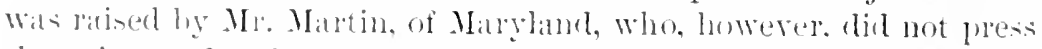
the print. and reforem to the obserbations of sir William seott in

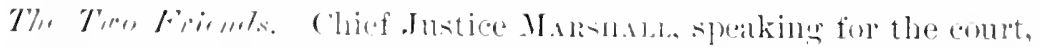

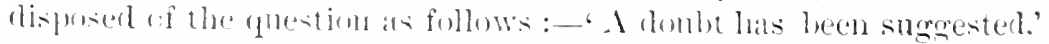
sald lee "resperting the jurisdietion of the ennt, and upon leference to the anthritjes, the joint roes not alplear to bave been ever settled. These doulsts seem rather fomded on the idea that upon 
principles of general policy, this cont onglit not to take comnizinuen of a case entirely between foreigners, than from any lositire incatpacity to do so. On weighing the considerations drawn fron pullix

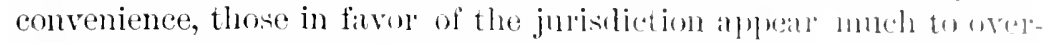
balance those agranst it, and it is the opinion of this contet, that, whatever doubts maty exist in a case where the juristiction mat be objected to, there onght to be none where the partics assent to it.' ***

"In the absence*** of treaty stipulations, however, the case of for"eign seamen is molonhtedly a special one, when they sue for Warges under a contract which is generally strict in its character, and framed according to the laws of the comtry to which the ship behongs; framed also with a view to secure, in atcordance with those hws. the rights and interests of the ship-owners as well as those of matstel" and erew, as well when the ship is abroad as when she is at home. Nor is this special character of the case entirely alsent when for'eign seamen sue the master of their ship for ill-treatment. On general principles of eomity, Anniralty comets of other comutries will not interfere between the parties in such cases mless there is special reason for doing so, and will require the foreign eomsul to be notified, and, though not absolutely hound by, will alwalys pay due respect to, his wishes as to taking juriscliction.

"But, although the courts will use a diseretion about assming jurisdiction of controversies between foreigners in cases arising beyond the territorial juristiction of the countsy to which the connts belong, yet where such controversies are commmnis juris, that is, where they arise uncler the eommon law of nations, special gromuls should appear to induce the eourt to deny its aid to a foreign suitor when it has jurisdietion of the ship or party charged. The existence of jurisclietion in all such cases is beyome dispute; the only question will be, whether it is expeclient to cxercise it. * * *

"In another case, Justice STory examined the subject rely fully, and came to the conchusion that, wherever there is a matime lien on the ship, an Admiralty Court can take jurisclietion on the principle of the civil law, that in proceelings in rem the proper formm is the locus rei sitr. He added: "With reference, therefore, to what may be deemed the public law of Europe, a proeeding in rom may well be maintained in our conts where the property of a foreigner is within our jurisdiction. Nor am I able to pereeive how the exercise of such judicial authority elashes with any principles of publie policy.'

"That, as we have seen, was a case of bottomry, and . Justice FTor ${ }^{\prime}$ in answer to the objection that the contract miglit hilve been entered 
into in reference to the foreign law, after showing that such law minht be proven here, sald: "In respect to maritine contracts, there is still less reason io recline the jurisdiction, for in almost all civilized comntries these are in general substantially governed by the siture lules.'

"Instice story"s decision in this ase was referred to by Dr.

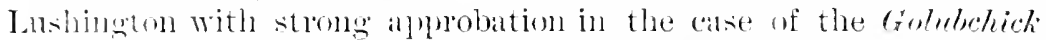

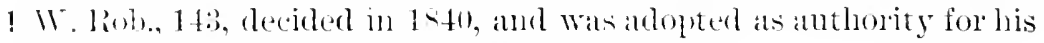
taking jurisliction in that case. ***

"A Danish ship was smok by a Blemen ship, and on the latter being libelled, the respondents entered a protest anainst the jurisdic-

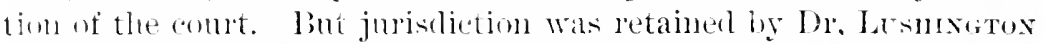
who amomgst other things, remarked: "An alien friend is entitled to sue (in om conts) on the sume footing as a British-born subject, and if the foreigner in this case harl been resident liere, and the anse of action harl orighinated infor mpus romitutus, no objection and have been taken. Reference being male to the observations of Lord stowell in cases of seamen's wages, the judge said: "All questions of collision are questions commmmis juris; but in case of mariners wages, whoever engages voluntarily to serve on board a foreign ship, necessarily undertakes to be bund hy the law of the comntry to which sueh ship belongs, and the legality of his claim must he tried by sueh law. One of the most important distinetions, therefore, respecting ases where both parties are foreigners is, whether the case be commmis juris or not. *** If these parties must witic mith the ressel that has dome the injury returned to its own comntry, their remedy might be altogether lost, for she might never lethin, and, if she disl, there is no part of the world to which they minht not be sent for their redress.'

"In the subsequent ease of the Griefsuml, 1 swabey, 430, decidter by the sume jutge in 18.59, which arose ont of a eollision between a British barque and a Persian ship in the Dardinelles, Dr.

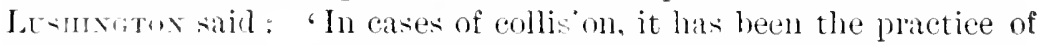
this romntry, anrl, so far as I know, of the Enopean states and of the Enited states of Anerica, to allow a party alleging grievance ly a collision to procest in iem against the ship wherever found, and this practice, it is manifest, is most conducive to justice, because in very many cases a renely in porsmmm would be implacticable.'

"The subject has frequently been before on own Adninalty Conts of original jurialietion, and there has been but one opinion expresserl, namely, that they have juriclietion in such eases, and that they will exercise it muless special circumstances exist to show that justice would be better subserved by declining it. *** 


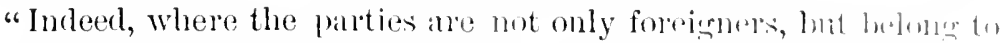

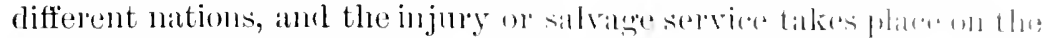

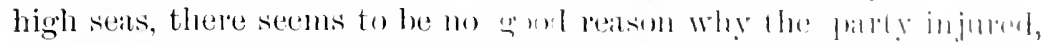

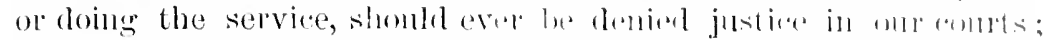

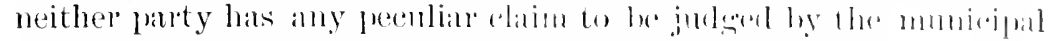

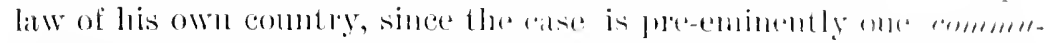

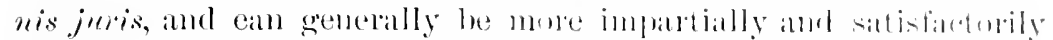

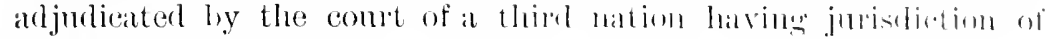

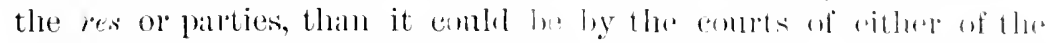

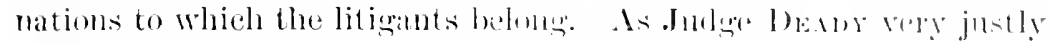

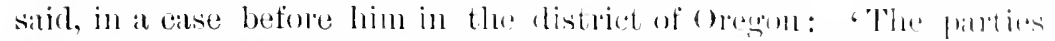
eamot be remitted to a home formm, for, beims smbjods of ditlerent governments, there is no such tribmull. The formm which is combmon to them both by the jus gentiom is any conte of almilalty within the reach of whose process they may hoth be fomel. lie inhecol r. Groene, :3 sawyer, 2:30, 2:3i.

"As to the law which shond be applied in cases betwen parties, or ships, of different nationalties, alising on the hish sasts nut within the juristiction of any lation, there cata he no doubl hat it must be the general maritime law, as understom and arministered in the courts of the country in which the litigation is prosecuted."

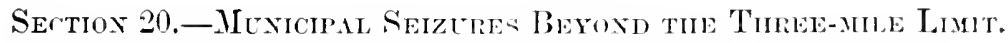

\title{
CIILTCII r. HLBIBART.
}

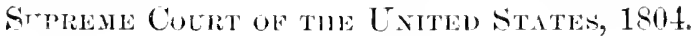

\author{
$(\because C+m \cdot h, 1-7$.
}

Holl. that a state moy seize forian morhant vessels beyond a morine learue from the eart, in order to enforee its narigation and resente latis.

While the Amerien vessel dermen wats between form and fire leagues from the brazilian coast she was seized by the gorermment of Brazil for attempting to early on illieit trade with its citizens.

Upon the controversy as to whether the govermmont of lirizil had

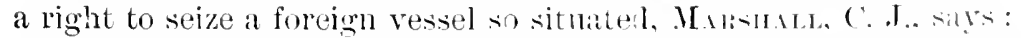

“*** As a general principle, the nation which prolulits commercial intereourse with its enlonies nust be supposel to ardopte measures to make that prohibition eff'eetual. 'They must, therefore, 
he supposed to seize vesiels enming into their harbors or hovering on their coasts in a conclition to rade. ***

"To reason from the extent of protection a nation will afford to foreignes's to the extent of the means it may use for its own security does not seem to be perfectly eorlect. It is opposed by principles which alle muversally acknowledged. The anthority of a nation within itsomn teritory is absolute and extusive. The seizure of a resed within the range of its eamuon by a foreign foree is an invatsim of that territory and is a hostile atet, which it is its duty to repel. But its lower tosecure itself from injury mat certanly be exercised heyome the limits of its territory. L Pon this prineiple the right of a bellinement to search a nentral ressel on the high seas for contraband of wall, is miversally admitted, beemse the belligerent has a ripht to prevent the injury done to himself by the assistance intemled for his enemy ; so, ton, a nation has a light to probibit any commeree with its colonies. Any attempt to violate the laws male to proteet this right, is an injury to itself which it may prevent, anc? it has a light to use the means necessiry for its prevention. These means do not appear to be limited within any certain maked boundaries, which remain the same at all times and in all situations. * * *

"In difïerent seas and on different eoists, a wider or more eontrated range, in which to exercise the vigiance of the government of the comntry, will be assented to. Thus in the channel *** the seizure of vessels on suspicion of attempting an illicit trarle must necessarily he restricted to very narrow limits, but on the anst of south Anerion, selolom frepuented by ressels but for the purpose of illieit trake the vigilance of the government may be extended somewlat further. *** *

"The right of the sibunialds was supposed to be exereised un-

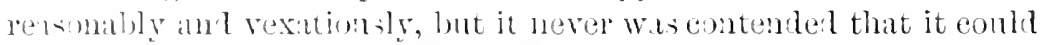
only be axeloised within the range of the eamon from their batteries. Inrlad, the right wiven to onr own revenue cutters, to visit rescols foml leapues form om const, is a declaration that in the

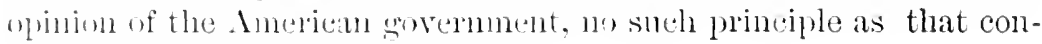
teruterl fort hats at leal existence." I

1 Mr. Dana. in speaking of this decision (I)ana's Wheaton, p. 259, note), say's as

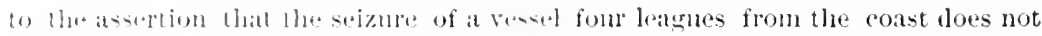

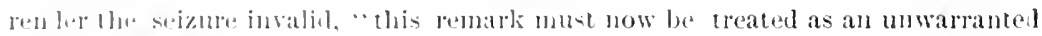
mini-sion. * * Il may be sail that th" principle is sotled, that municipal seiz-

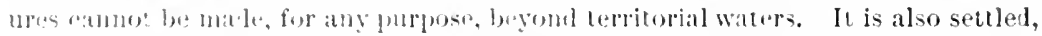
that the limit of these waters is, in the abanen of trealy, the marine leagne or the

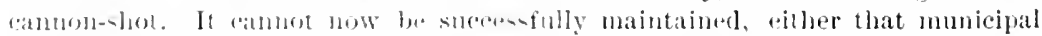
vicite ant wareh nay low male beyont the territorial waters for special purposes, or that there are different bounds of that territory for difforent objects. *** In 
SECTION 21.-P'PinCY.

\section{OPINION OF SIR LEOLINE JENKINS.}

Chinge to the Jotry, 1668.

(Life of Sir Leoline Jentins, I., S6.)

Definition and character of Piracy.

"There are some sorts of felonies and offences, which camnot be committed anywhere else but upon the sea, within the jurisdiction of the Adniralty. These I shall insist npon a little nore prirticularly, and the chiefest in this kind is piracy.

"You are therefore to inquire of all Pirates and sea-rovers; they are in the eye of the law hostes humeni generis, enemies not of one nation or of one sort of people only, but of all mankind. They are outlawed, as I may say, by the laws of all mations, that is, out of the proteetion of all princes and of all laws whatsoever. Everybory is commissioned, and is to be armed against them, as against rehels and traitors, to subdue and to root them ont.

"That which is ealled robbing upon the highway, the same heing done upon the water is ealled piracy. Now robbery, as 'tis dis-

the earlier cases, the courts were not strict as to stamlards of distance, where no foreign powers intervenel in the canses. In later times, it is safe to inter that judicial as well as political tribnuals will insist on a line of marine territorial jurisdiction for the exercise of force on foreign vessels in time of peace for all purjoses alike."

There still stands upon the Statute Book of the United States a law passed in 1790 anthorizing their revenue officers to stop and visit foreign ressels four leagues from the coast. The British "Hovering Act," passed in 1734, and which doulthers suggested the American Act, contained a similar provision. But this, says Mr. Boyl (Boyd's Wheaton, p. 241), has long since been repealerl. "The ju'sent customs' legislation makes a distinction as regarls the extent of jurisliction claimenl for revenue purposes, between ships belonging to British subjects and shipe belonging to foreigners." There is no longer any anthority under English laws 10 risit a foreign vessel beyond the three-mile linit. (See Customs Consoliclations Act, 1870 , Sec. 134.)

See further on this subject, the case of Rose v. Himply, 180s, 4 Cranch, 241 , in which the Supreme Conrt of the United states held that a seizme, muler matoms' regulations, of a foreign vessel beyond the territorial waters of a state was not valid. See also, the case of Hulson v. Guestier, 1810, 6 Cranch. 281. 
tinguished from thieving or lincepus. implies not only the actual taking away of my gools. while I am. as we saty in peace, but also

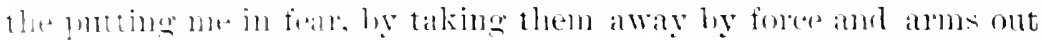
al my hamls. ol in my sight and presence; when this is dome upon the seat, whlumt a lawtul eommision of wat or reptisils, it is downlimlit pinter.

-. And sild was the wenerosity of om ancient English, such the athumperter of om laws ardinst pirates and searorers, that if any

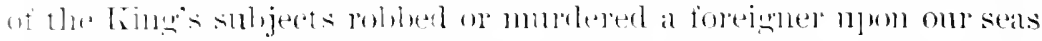

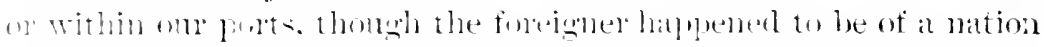
in hutility atalinst the King. yet it he hald the King's passingt. or the lond Amimal's, the offender was publisherl, not as a felon only, bit this aime was male hish treason, in that great Prince IIemy

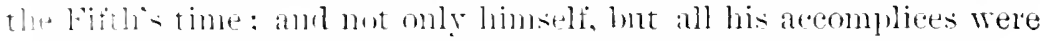
to sutfer as traitors against the erown and dignity of the King."

\section{LXITED STATES r. SIITII.}

\section{Scprene: Cutrt uf the L'Niten States, 1820.}

(.) Hocutou, 150.)

The Contitution of the Lnited states confers unon rongress the power to "define

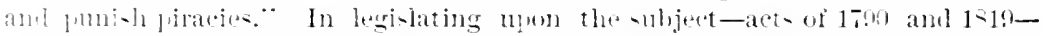

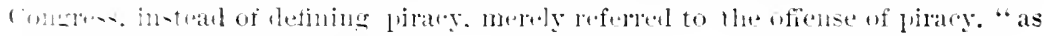
Heti:nen lig the law of nations.".

II. M. That thi- lefintion was sufficient to meet the rectuirements of the Constitutins.

This Wak an indictment for piracy against the prisoner Thomas

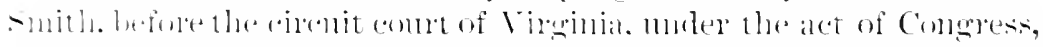
ut $1 l_{1}$ :

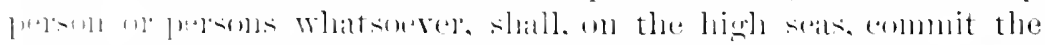

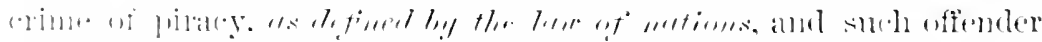

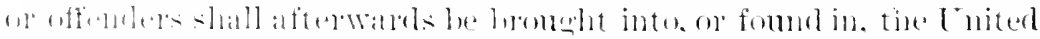

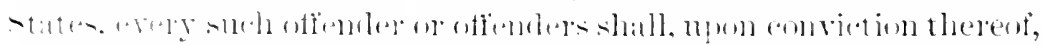

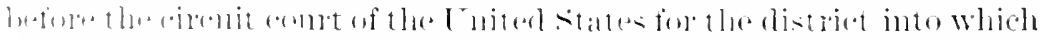

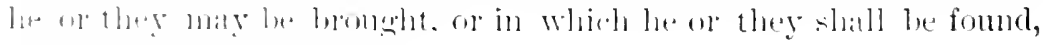

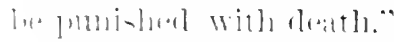

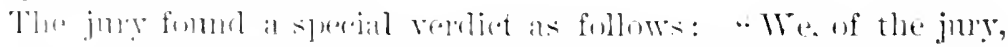

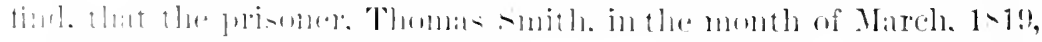

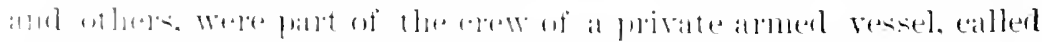

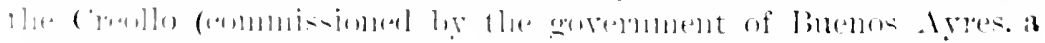

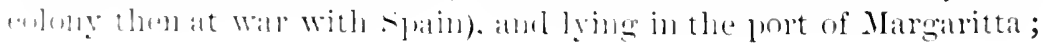




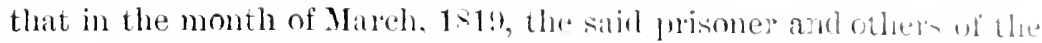
crew mutinierl, confinerl their ofticers, letit the vessel, and in the silit port of Marganita, seized by violentee a vessed ealled the Indesistible, it private anmed vessel, lying in that punt, commissimed hy the gas-

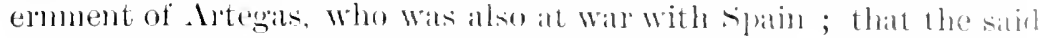
prisoner and others, having so positessed themselves of the sitil vesiol, the Irresistihle, appointed their ottiers, proceded to sea on an aruise, without any doemments or commision whateren ; and while on that cruise, in the month of April, 1s19, on the high seas, committed the

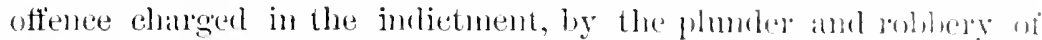
the spanish ressel therem mentioned. It the phumberme rohbery atoresaid be piracy moles the act of the comgress of the loiteil States, entitled, "An act to protect the commerre of the Eniterl states, and punish the crime of piracy, then we fiml the said [uisones. guilty; if the plunder and robbery, above staterl, be mot piracy under the said act of Comgress, then we find him, not gnilty."

The circuit cont divided on the question, whether this le pirary as defined by the law of nations, so as to le pumishable muled the act of Congress, of the 3 a of March, 1519, and thereupon the question was certified to this comt for its recision.

Mr. Justice STon, delivered the opinion of the cont :- " 'l'le' act of Congress upon which this indictment is fommled provides, that if any person or persons whatsoever, shall, mpon the high seats, commit the crime of piracy, as defined by the law of nations, and such offemmey or offenders shall be bronght into, or found in the Cnitel states, every such offender or offenclers shall, upon conviction theren, ete. be punished with death.

"The first point made at the bar is, whether this enactment be a constitutional exercise of the authority delegated to Compress upm the subject of piracies. The Comstitution declares, that compless shall have power 'to define and punish piracies and felmies, comm. mitted on the high seas, and offences against the law of mations.' The argument which has been nrged in belalf of the prisenter is, that Congress is bound to define, in terms, the offence of piracy, and is not at liberty to leave it to be ascertained by judicial interpretaltion. If the argument be well fommed, it seems amitter hy the comsel that it equally applies to the sth seetion of the ace of comgress of 1790 , ch. 9, which dechares, that robbery and mmmer com. mitted on the high seas shall be deemed pinacy; and yed. nutwithstanding a series of eontested ad julleations on this sertion, no drult has hitherto been breathed of its conformity to the comstitution.

"In our julgment, the construction contenderl for prowerls 11 mon too narrow a view of the language of the Constitution. The pumer 


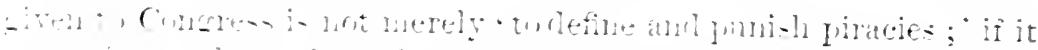

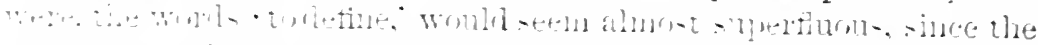

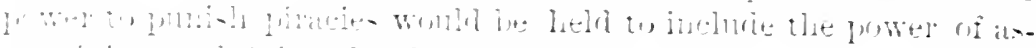

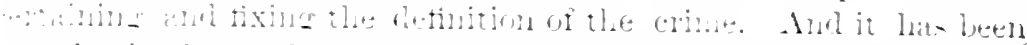

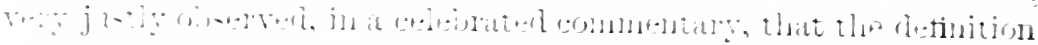

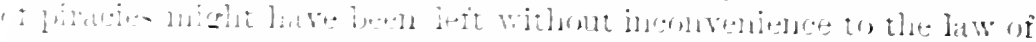

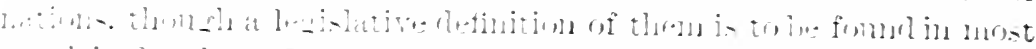

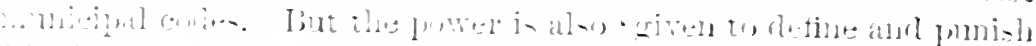

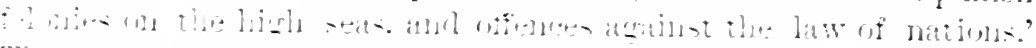

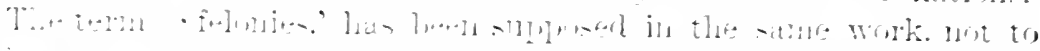

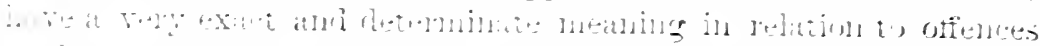

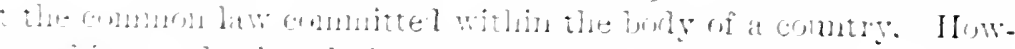

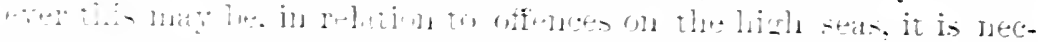

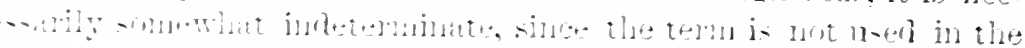

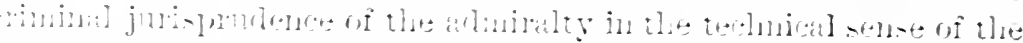

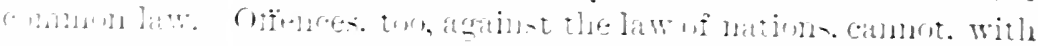

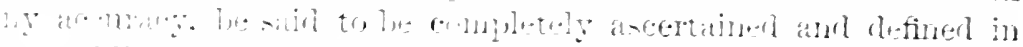

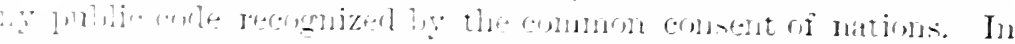

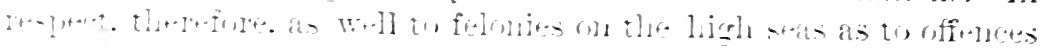

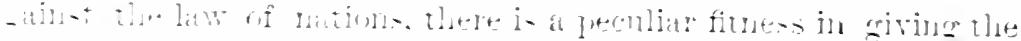

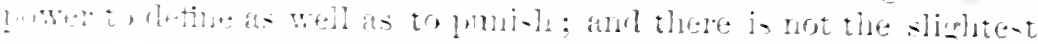

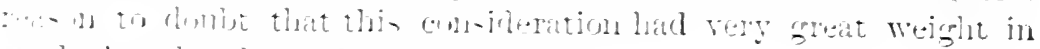

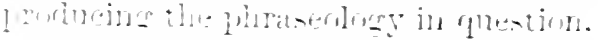

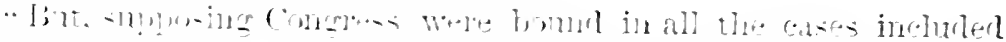

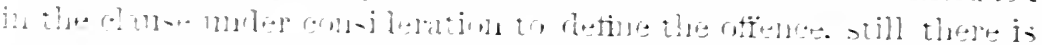

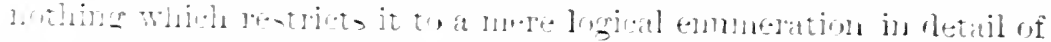

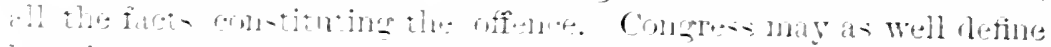

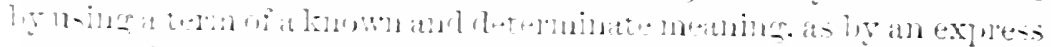

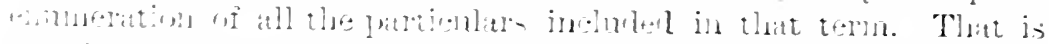

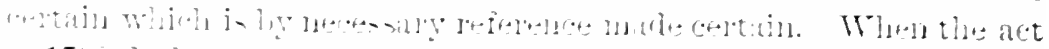

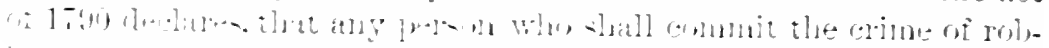

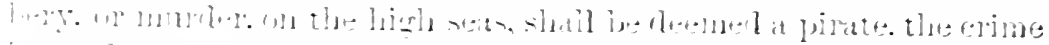

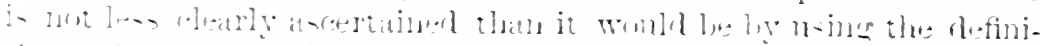

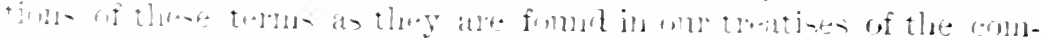

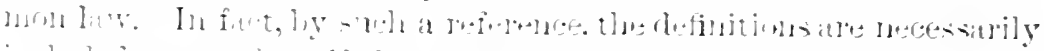

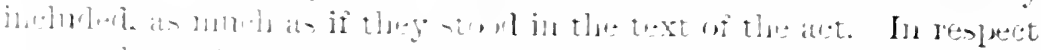

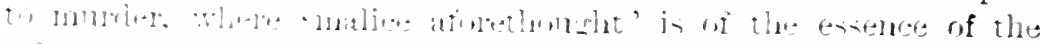

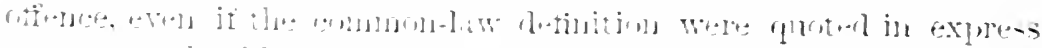

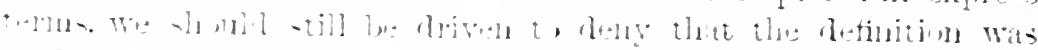

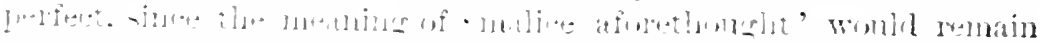

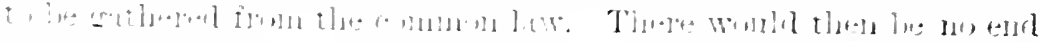

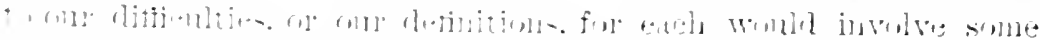

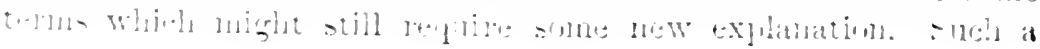


construction of the Constitution is, thelefore, wholly indricilllu. To define piracies, in the semse of the Comatitution, is morely un emmmerate the crimes which shall amstitute pilatey ; and this maly

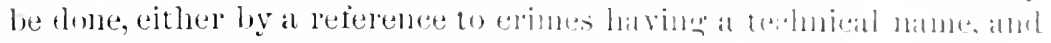

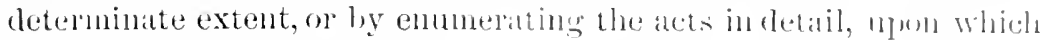
the punishment is inflicter.

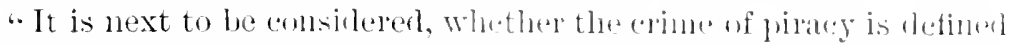
by the law of nations with reastmable certainty. What the law of lations on this subject is, maly beaterentinet by ensulting the works

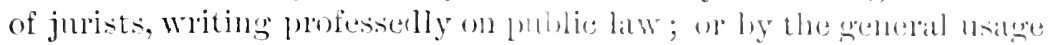

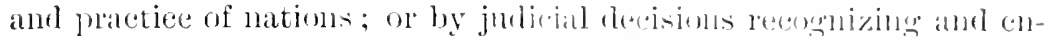
forcing that law. There is seatrely a writes on the law of matems, who does not allude to piracy as a crime of a setted and determinate nature; and whatever may he the direlsity of drefinitions in otlel. respects all witers eoncur, in holling that robluery, on forcible depredations upon the sea, mormo, fommli, is piracy. The silue doetrine is held by all the great writer on maritime law, in terms that admit of no reasomable doubt.

"The common law, too, recognizes and punishes piratey ats an ofience. not aganst its own municipal come lut as an offence aldinst the law of nations (which is part of the common law), as an ofiences arinint the miversal law of society, a pirate being deened an enceny of the human race. Indeed, until the statute of 2xth of Itemy VIII, ch. 15, piracy was pmished in Englam only in the andminlly ats a civil law offence; ancl that statute, in changing the juristiction, hats been mivelsally arlmitted not to have changed the naturt of the offenes. sir Charles Hedges, in his charge at the arhiralty sesisions, in the case of Reav. Donsom, 5 state Trials, declarerl in emphatir terms that "piracy is only a sea term for robbery, piralcy being a roblumy committed within the jurisiliction of the athminaly. sir Iconline Jenkins, too, on a like occasion, derlater that a robluely, when committel mpon the sea, is what we call piracy;' and he eitel the eivillaw writers, in proof.

"Anrl it is manifest from the languare of sir Milliam Blackstome, 4 Bl. Comm., 7:3, in his comments on piracy, that he comsirlererl the common law definition as distinguishable in no esiontial respect from that of the law of nations. So that, whether we alvert to writers on the common law, or the maritime law, or the law of nations, we shall fund that they universally treat of pirateg ats

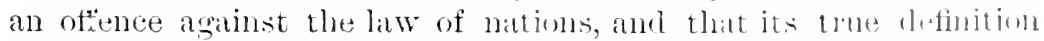

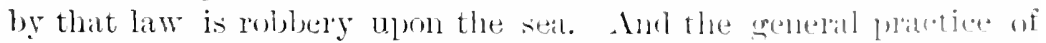

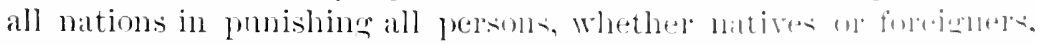
who have committed this offenee against any gersoms what andere, 


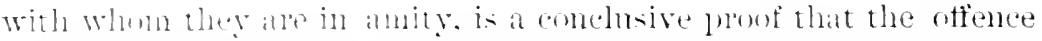

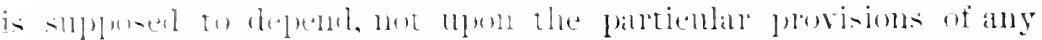

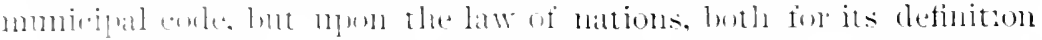

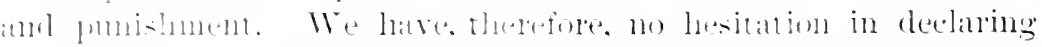

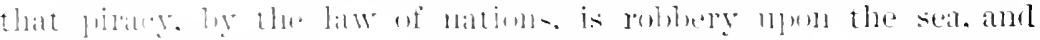

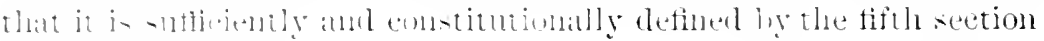

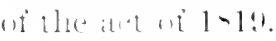

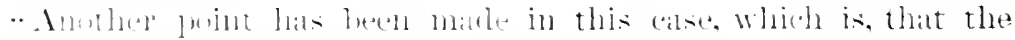

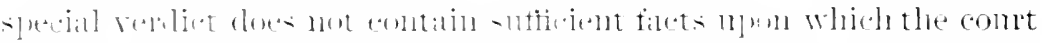

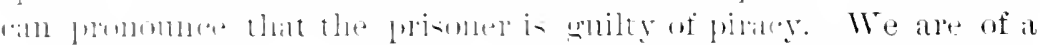

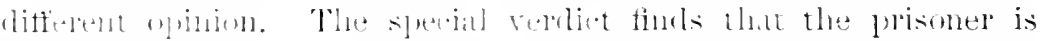

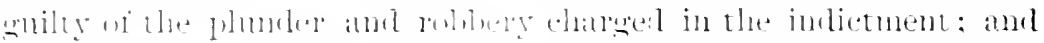

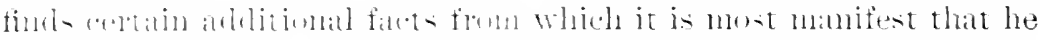

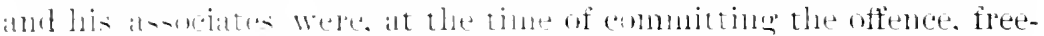

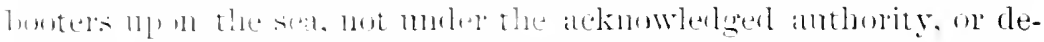

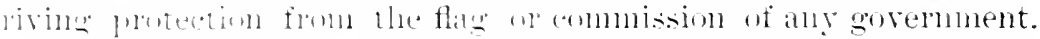

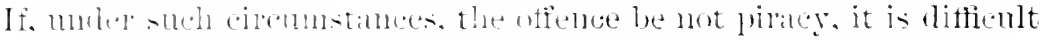

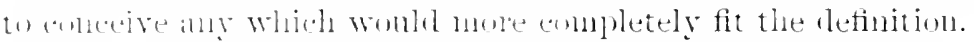

- It is to be eretified to the circuit Comt, that mom the facts

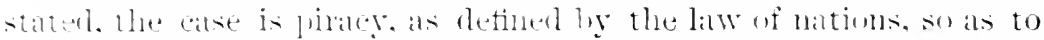

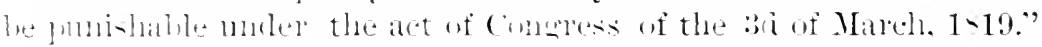

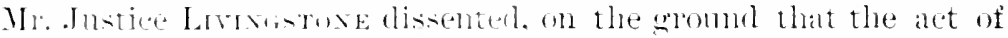
Conerese did not contain such a definition of piraley ats the Constitution reppluites.

IXITED -T.ATE

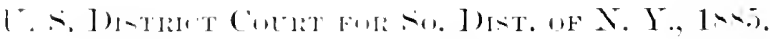

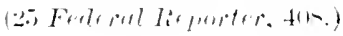

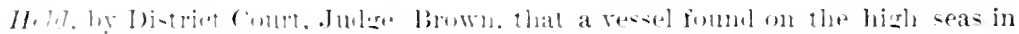

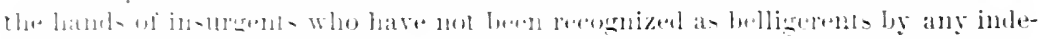

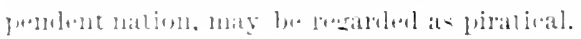

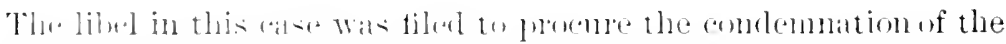

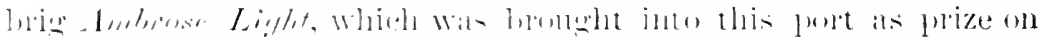

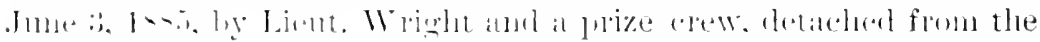

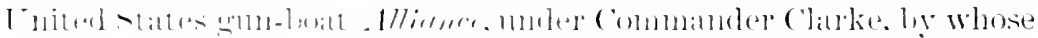

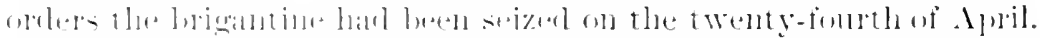

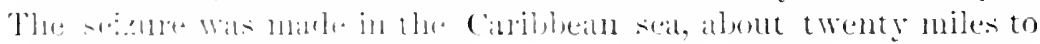

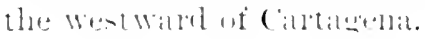




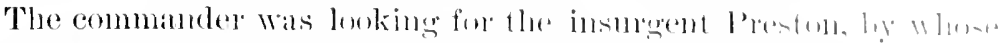

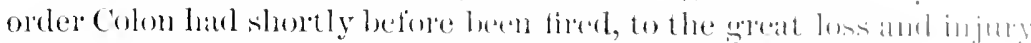
of omr citizens.

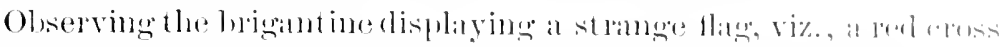

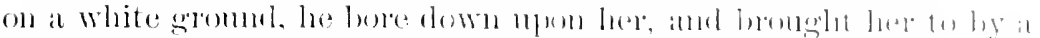

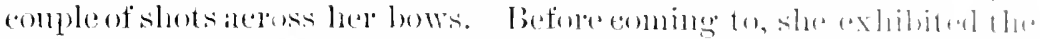

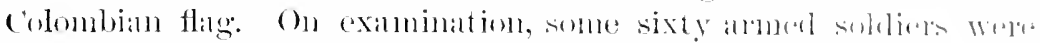

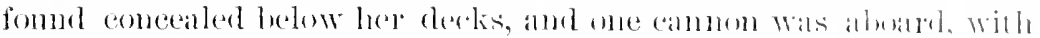

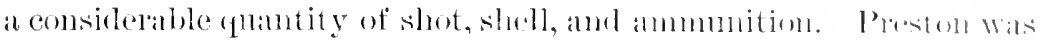

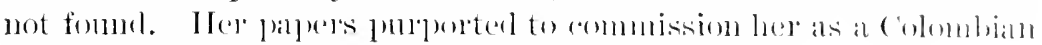
man-of-wan, and reatel as follows: (Tramslations.)

"I, Pedroa Lata, governor" of the province of barlampuilia, in tho state of Bolivial, in the Lnited states of Colsmbia, with fall pwores conferred ly the eitizen pesiclent of the state, I givo to whom il may

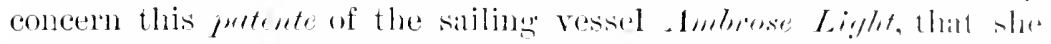
may navigate as a Colomblin vessel-of-wat in the waters tomeloing the coast of this repulilie, in the Atlantic orean.

"Therefore, the general commandints and calptains of the vescels of war of the friendly mations of Colombia ale reduested lo wive this vessel all the comsioleration that by right ledomes to the resseds of the class of the Lembose Light of all civilizerl nations. In dhe faith of whidh we have given these presents, and signed with lublo with the secretary of my uffice, in the city of Barlanguilla, on the cionteenth daly of the month of April, 18xis.

$$
\text { (signerl) }
$$

"Perlunal lillá

The Seeretary [Nis.s. "li. A. Del Valle.

(Indorsed:) "office of the Military,

$$
\text { " barmanumilla, April 1s, 1845. }
$$

"Registered and noted in folio and book, respectively.

"The General in Chief, N. Jumeno Collante.

\section{"Arjutant and secretary, 1. Solanom."}

Believing this eommission to be irlegular, and to show mo bawful anthority to cruise as a man-of-war on the high seas, commandel Clarke reported her moler seizme, in acordance with the mat regulations, to Arminal . Towett, commanding the Nonll Mtantic syluabon, then cruising in the Central Anerican waters, and the adminal directed the vesisel to be takento New York for anlunliation as prize. The vessel was at first smprosed to belome to citizens of

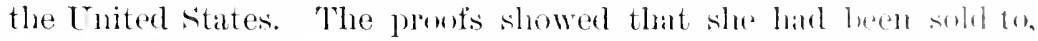
and hegally belonged to, colente, one of the chiof military louldus of the insurgents at balrampuillat. Nome of her officess on crew were

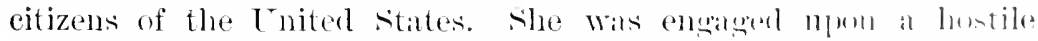
expedition against Cartagena, and designed to assist in lhe hochinle 
and - inge of that gurt by the rebels against the established government of the Luiterl states of Colombia. She had left sabinilla on

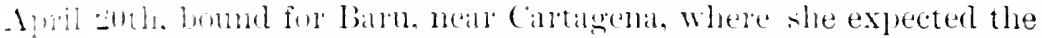

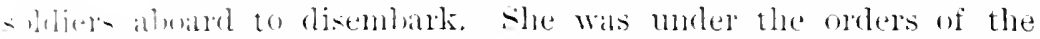

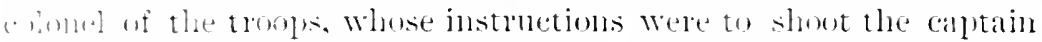
if discredient to his orders. Further instructions were to fight any Colombian resiel not showing the white flig with a red cross.

Salanillat. and a few othel anjicent sea-ports, and the province of

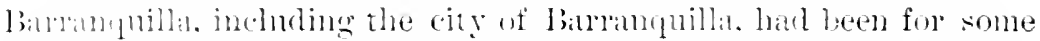

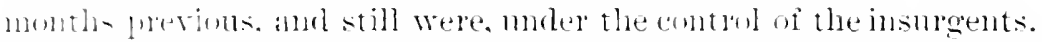
The land ald not show that any other deperbations or hostilities were intomert hy the vesid than such as might be incident to the stumble between the insursents and the government of Colombia, and wh the so-called buckate and siege of Cartagena.

1-re-pects any lecognition of the insurents ly foreign powers, it dirl ant alleats in evilence that me to the time of the seizure of the

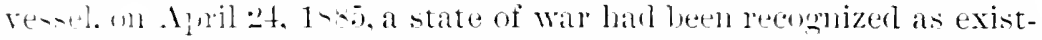
ing.or that llue insurgents had ever leeen reconglized as a re fiecto sorelnment, or as having belligerent rights. eithe ly the colombian woremment. or ly om own government, or by any other nation. The chinumts intorluced in evilence a diplomatic sote from om

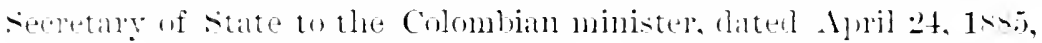
whirl. it was contender, amomed to a recognition hy implication of a statte of war. The govermment claimed the forfeiture of the ship

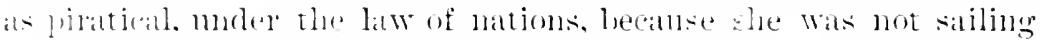

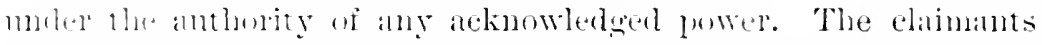

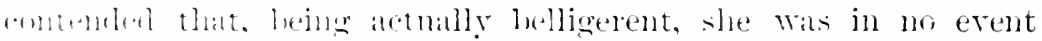
firatianl hy the law of mations; but if so, that the subserguent re-

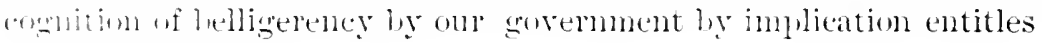

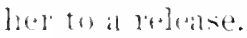

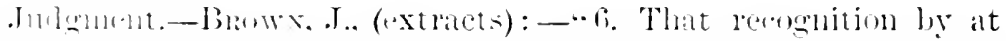

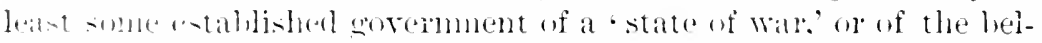

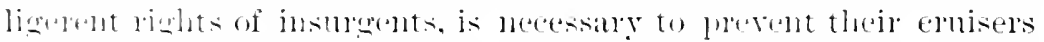

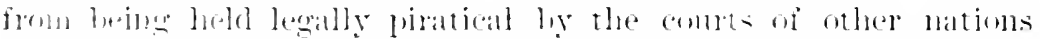

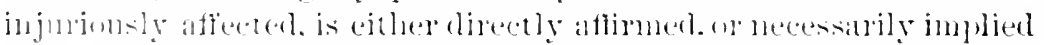

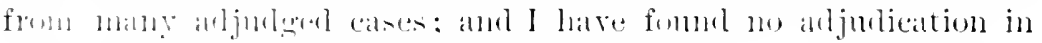

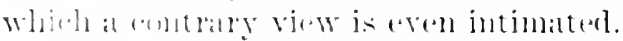

. This eneat weinh of alltherity drawn fom every somece that

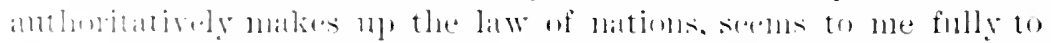

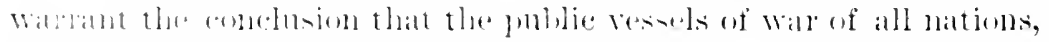

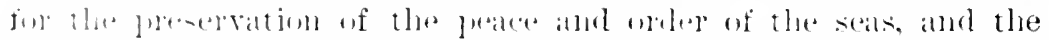

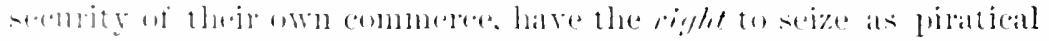
all vesocts carrying on, or threatening to cally on, mulawful private 


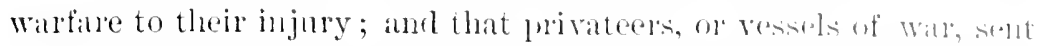

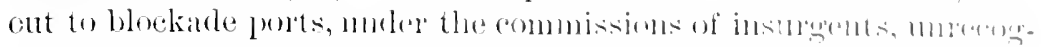

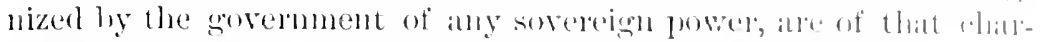

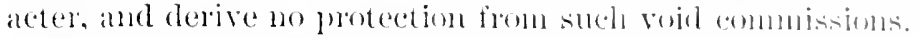

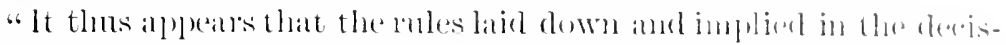

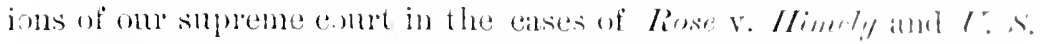

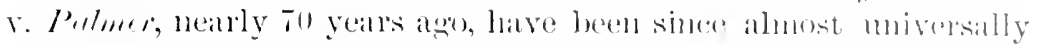
followed. The practical respomsibility of detomining whether insurgent ressels of war shall be treated as lawhol beiligepents, ol at

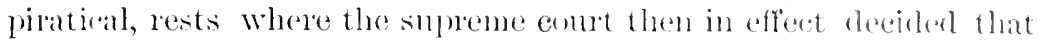
it onght to rest, viz., with the political and exemt ive depoumbents of the government. These departments have it in their powar, at any moment, throngh the granting or withlobling of recomition of helligerency, and thromgh the extent of such recognition as they may

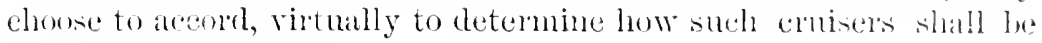
treated ly the eomets.

"Even after jurlgment and sentence the prisoners may, bike smith and his associates, convicted hefore Mr. Justice colder, be tratted, and exchanged, as prisoners of war. Anct it is with those deprartments, exclusively, that the discertion onght to rest forketernine when and how its technical rights andinst rebel cruisers shall be onfolreed. Its nar.l regalations will bo fiamed accorelingly ; and any seromed malle muler such regulations may be enforeed, or at any moment remitted, at the pleasme of those departments.

"Where insurgents conduct an anmerl strife for political amband and aroid any infringement or menare of the rights of foreign natimman the high seas, the motern paretice is, in the absence of treaty stipmlations on other special ties, to tilke no notice of the comtest. (1) of the earliest applications of this rale that I have mot is in the answer of the states-general to Sir Joseph Tork's denum in 177 for the surenrler of I'aul Jones' prizes as piratically calptured, in whirlo theid Mightinesses say that " they had for a century past strictly observerl the maxim that they will in no respeet presmme to julge of the lewality or illegality of the atetions of those who, up m the open seat, have taken any vessels that do not helong to this comntry. (1) this puint Prot. Lawrence, in his recent I Iand-book of Int. Law (Iomklon, 1-Wh), silys:

". When a community, not being a state in the "Ye of interlattinnal law, resorts to hostilities, it may, in respect of walr, he enchmen with the rights and subjected to the obligations of a state if ot lege pumers

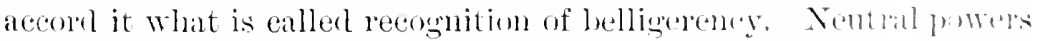
should not do this *** muless it atfeet by the strugerle the interent:

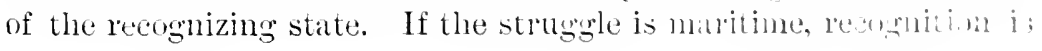


almost a necessity. The controversy of 1stil illustrates the whole yutestiull.

". The platedier is stated by Iall as follows: "When, howerer, giratial atets latre a political object, and are direetel solely andinst

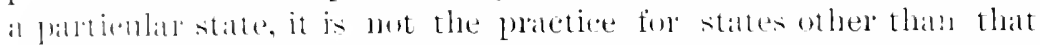

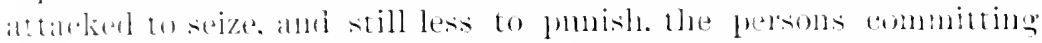
them. It womld be otherwise, so fill als seizure is ancerned, with le

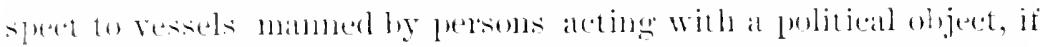

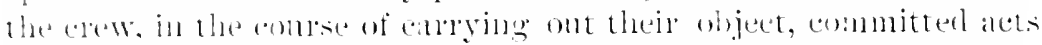

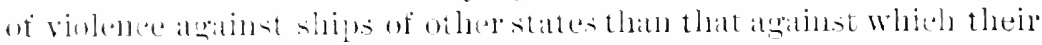
pulitiall operattion was aimed and the mole in which the clew were dealt with wombl pobbably depend on the cincumstances of the catse.' Int. Ialw, ș s. 1. 2.1:;.

. Whether a foreign nation slabll exereise its rights only when its

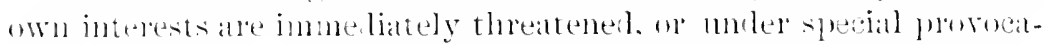

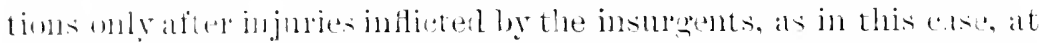
colon, is a dustion purely for the exedutivedepartment. lin when

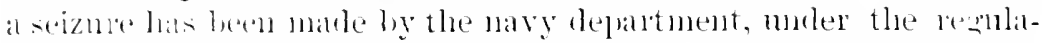
tions, an 1 the case is prosecuted before the count by the government

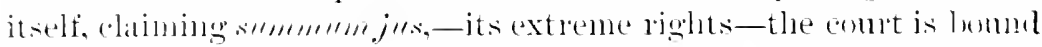
to alply to the case the striet technical rules of international law.

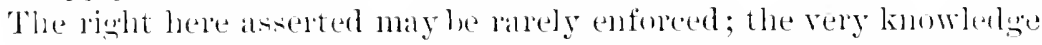
that the lisht exists temds, effectually, in most cases, to pleverit ally violation of $\mathrm{it}$ on at least any actual interference by insurgents with the riglis of other nations. But if the right itself were deniel. the commeree of all nations would be at the merey of every petty am test carried on ly irresponsible insmrgents and marauders muler the nathe of wats.

"In the absence of any recognition of these insurgents as belliger-

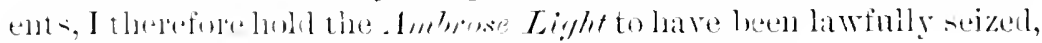

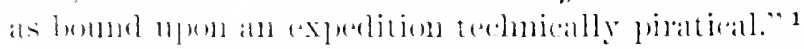

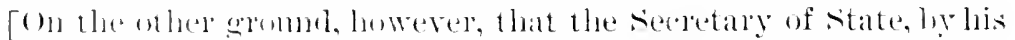
mol. (1) the (olombian Minister, April $2-t, 1-5$, had recognized by implicallion a state of watl, the resicel was released.]

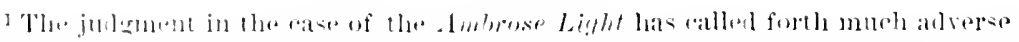

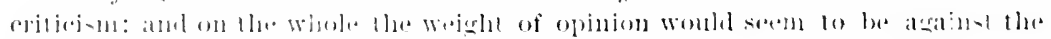

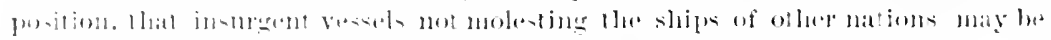

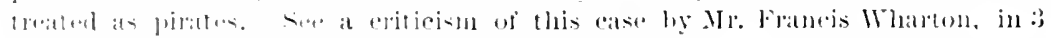

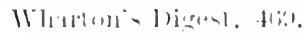

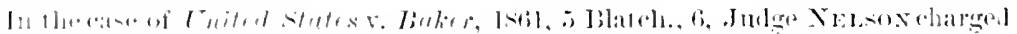

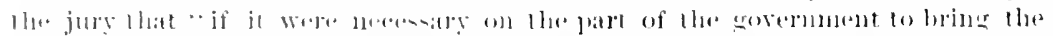

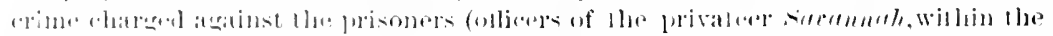

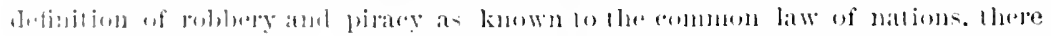

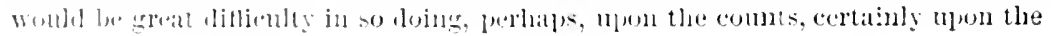




\title{
TIIE MAGELLAN PIRATES.
}

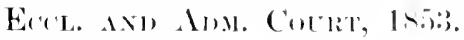

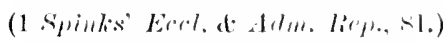

Insurgents may become, by deprelations against third powers. pirates as well ats insurgents.

\section{Lesimgtos, J. (extract):-}

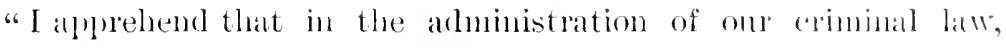
generaly speaking, all persons are held to be pirates who alde fomml

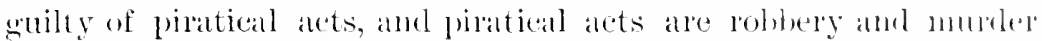
upon the high seas. I lo not believe that, even where human life wais at stake, our courts of common law erer thomble it necessary to extend their juguiry forther, if it was elearly poved andinst the accuser that they hat committed roblery and momler mpon the high seas. In that ease they were adjurged to be pirates, and sullored accorringly. *** It wats never, so far as I alu able to find, deemed necessary to inquire whether the parties so comvieted hald intanderl to yoh or to murder on the high seas judiscriminately. Thomeng the mmuicinal law of different comntries may and does differ in matuy respects as to its definition of piracy, yet I applehend that all mations agree in this, that acts such as those which l have mentioned, when committed on the high seas, are piratical acts, and contrary to the

evidence. For that shows, if anything, an intent to depedate npon the ressus

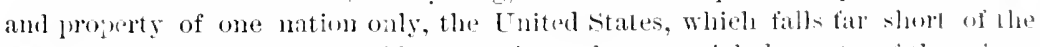

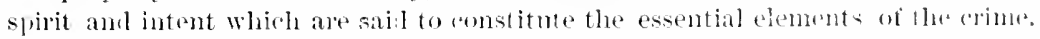

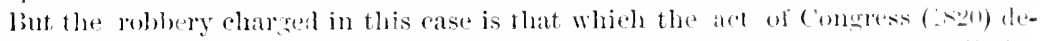
scribes as a crime, and may be denominaterl a statnte. offence at contratlindinguisherl from that known to lhe law of nations. The act leclares the peran a pirate, punishable by death, who commits the erime of robbery mon lhe high seat, agitinst any ship or ressel, ete." The juy did not agree in this cal- lint in

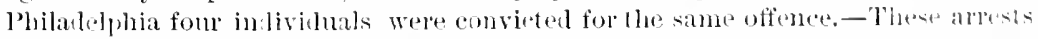
led to relaliatory action on the part of the Confederate states. Ant on the :31 t

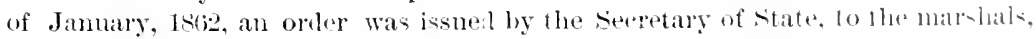
directing the transfer of all prisoners chargeil with piraeg, incluling llsose who had bese convietel at Philadelphia, to a military prison for the proment it was materstood, of exchanging them as prisoners of war. (Lantrences Whoton.

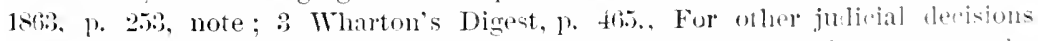
toneling the status of the rebels in the civil war in the [nited states, see llue

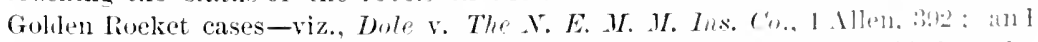
same in U. S. Circuit Court for Massachusets: in which it was ledel that the rebels in that war were not pirates juie gentium. 
law of nations. * * * I thiuk it does not follow that, beause persons who are letels and insulgents may commit against the ruling powels of theil own comntry acts of violence, they may not be, as well as insmlents and rebels, pirates also; pinates for other acts committer tomalds other pelsons. It does not follow that rebels and insmlerents mar not eommit piratical acts asmanst the subjeets of other states, esperially if such acts were in no llegree with the insurpection or rebellion. Even an independent state may. in my opinion, le grilty of piratical acts. What wele the barbary tribes of olelen times : what are many of the African tribes at this moment? It is, I helieve, notorions that tribes now inhabiting the Ifrican coast of the Ilediteranean will send out their boats and eatch any ships becalmed upon their coasts?

". lre they not pirates hecanse, perhaps, their sole livelihood may not lepend mon piratical acts: I am aware that it has been said that a state eamot be priratical, but I am not disposed to assent to such dictem as a universal proposition."

\section{TIE “ MIONTEZL ILA," 157 T.}

(rotro: Dinit International, 4th Er., I., 591.)

Ship belonging to insurgents, and confining their hostile acts to the parent surermment, are not to be treated as pirates by foreign powers.

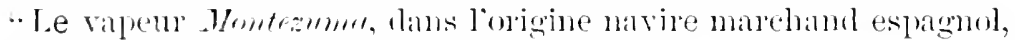
gasse an service de lonsmlection cubane, se tromvait dans un cas analogne ì celui dul lontcine.

"An commenoment do 15T, ce navire itant parvem dams les

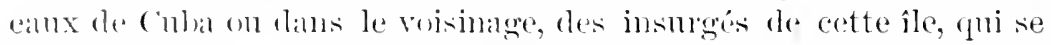

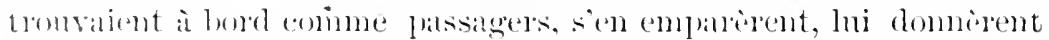

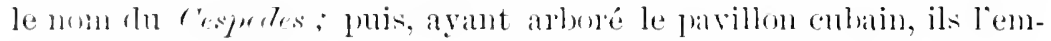
ployerent à attanner les navires mareluands de l'Esuagne dans le Rin de lia Plitta.

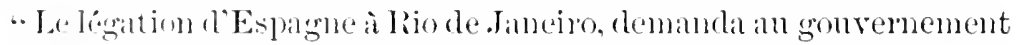

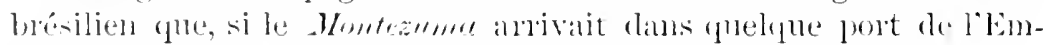
pire, il fut traite comme pirate et sommis à tonte lat rigneme des lois. En léponse ì cette demanrle, le haron de cotejipe, ministre des affiares étrangeres du bróil, adressa, le 1:2 jamrier, la dépeche

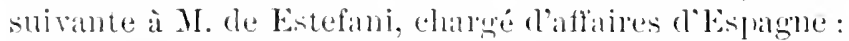

.. - Le gouvernentent de sit Majesté Catholinne pent soumettre le Homtezume à toute lar rigueur de ses lois eomme pirate. Persome 
ne lui déniera ce droit; mais le gomvernement impérial. yni ut

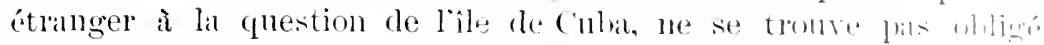

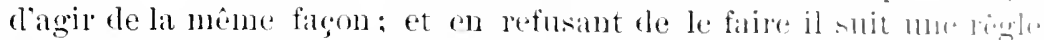

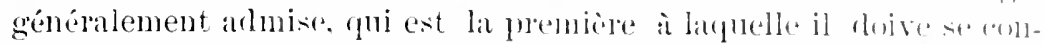

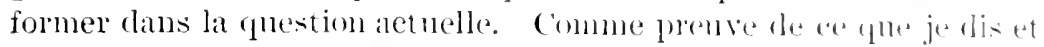

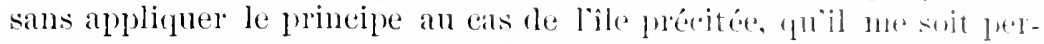
mis de signaler que tout gonvernement qui liost pats intéresé lams

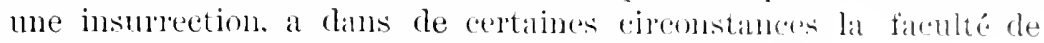
recomnatre anx insurgés le caractire de belligéants.

"Il nest pas rloutenx que l'île de cuba soit en état re léledlion et que les individus qui se sont empares du .Montanmon, solont des insurgés de eette íle. Cette circonstance à laquelle M. de Estefini lui-mème fait allusion dans sa premiere note suffit pom domuen an fait de ces individus la signification politinne qui lemr méonmant dans sa seeonde. IBien plus M. de Estefani dit que les insurewo destimaient le vapeur ì attaquer les navires marehands fle l'E-plogle dans le Rio de la I'lata; d'oì il resulte, le eas étant hicn "xaminé, que ces insurgés paraissent être des agents politiques agissant dans des fins politiques.

"Les pirates, ì proprement parler, sont ceux qui conrent les meres pour leur propre compte, soms antopisation computente, dius lo hut de s'emparer de foree des navires yulils rencontrent, cu commotlant des déprédations contre tontes les mations indistinotement. Cette définition ne pent certainement sappliquer ì cenx qui ont pris le Irontezuma. A cela sopposent les arguments mêmes nis ou avant par la législation de Sa Majesté Catholique. Les hostilités qu’elle dénonce et prévoit ne sont pas dirigées eontre tontes less nations, mais miquement contre l'Espagne; elles nont las pom but de commettre des déprédations, mais d'aider la cause d'une colonie en insurrection.

"C"est pour ces considérations, qui me paraissent conduantes, que le gouvernement impérial ne se eroit pas autorisé ì oremmer la saisie du vapeur ; et en admettant qu'il s'y déterminât, les tribmuax, envisageant le eas sous un autre aspect, ne se jugeraient las compétents, parce que ledit acte aurait été accompli sur m navire espagnol par des indiridus qui se trouraient à bord ou dans des eaux qui neétaient pas brésiliennes.

"On ne samrait invoquer le traité d'extradition entre le lirésil et l'Espagne. Le ehargé d'affiares ne demande pas qu'on livre lex gens qui ont pris le Montezmm, mais qu'on les punise an Ibril. Le traité n'éclaircit done pas la question et ne fotrnit point d"anguments contre la décision du gouvernement espagnol.

“M. de Estefani ne se juge pas compétent pour appréeier linna- 
Josice qui fremt exister entre le cas do Monteanume et celui diantres

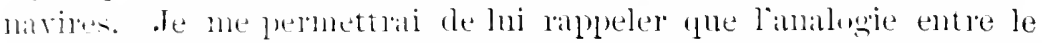

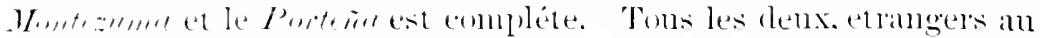

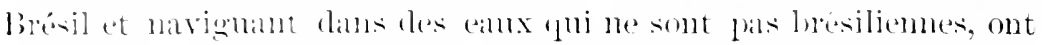

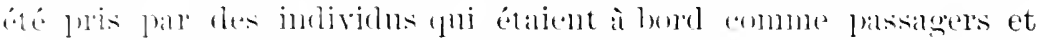

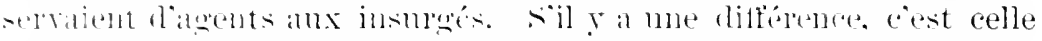

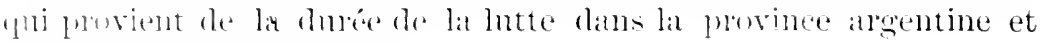
dans lit colomie esplagnole.

-. Le sombernement impélial respecte les principes acceptés par

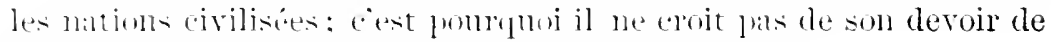
consentél' à la demande de la légation d'Espagne."

\section{THE "HL.1SC.MR," $14 T$.}

(:) Itherfouis Iligest. l. 4t.)

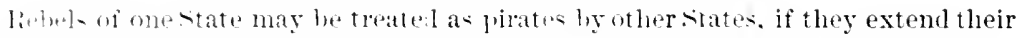

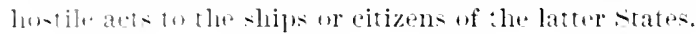

. The arew of the Peruvian monitor. the Mmosen, anchored at

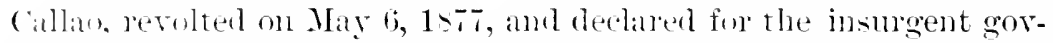
ermment of P'ierola. The ITwesme proceeded to sea withont opposi-

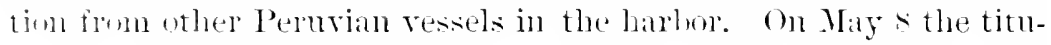
lar genternuent of Peru issued a declee calling the crew of the Hunser, " rebels, and anthorizing lee capture (and stating further that the Permian wovemment wombl not he responsible for the acts

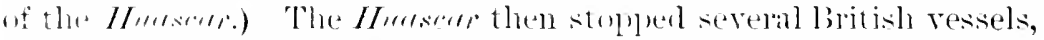
taking ont wi one of then two ofhios: who were going to Peru to

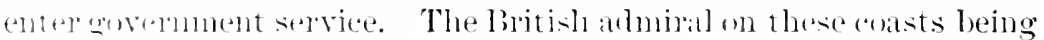
atrised of these proceedings, and also of the soizule of certain

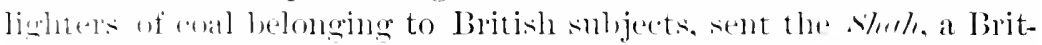

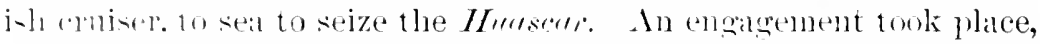

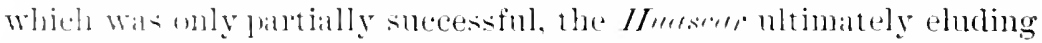

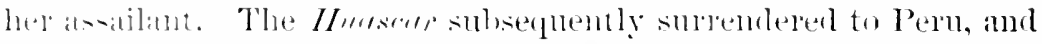

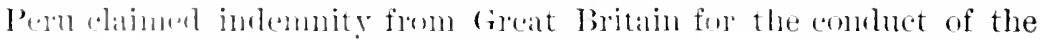

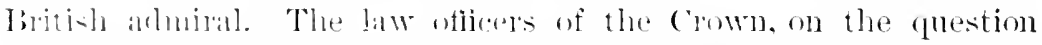

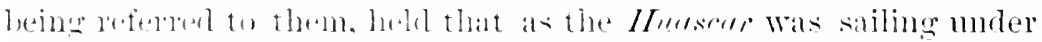

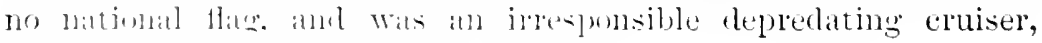
approsed the comduet of the anduiral." 


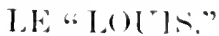

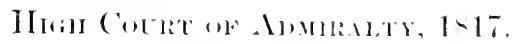

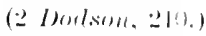

The slave tratle is not piracy by the law of nat ions

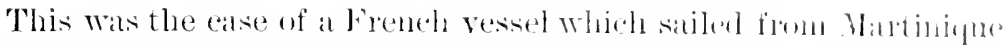

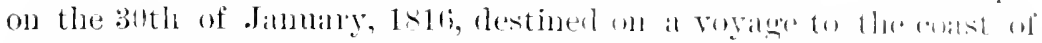

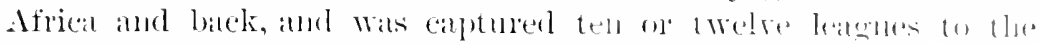

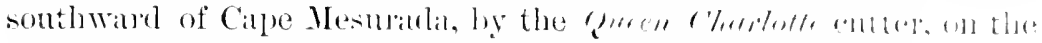

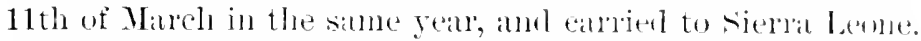

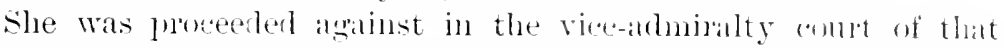
colony, and the information pleated,-1st, that the soizons were duly and legally commissioned to mate calptures and solzones. 2̌l, That the seizure was within the juristiction of the comt. :il, That the ressel belonged to French subjects a others, and was ditterl ont, mamned and navigated for the purpose of earying on the Ifricant slave-trade, after that trade haul been abulished hy the internal bitus of France, and by the treaty hetween firtat Britain and Fane. Hth, That the vessel harl bargained for twelre slaves at Mrsilralat, and was prevented by the capture alone from taking them on hand. 5th, That the brig being engiged in the slave-trale, contrany a the laws of France, and the law of nations. Was liatlele to amolemintion, and could deriveno protection from the Funch or any wher Hian. lith, That the crew of the brig resisted the gateen Charlotte. and piratically lilled eight of her erew, and wommed twelve others. Tth, Thitt the ressel being engaged in this illegal trathio resisted the king's duly commissioned eruisers, and did not allow of seareh mnt orerpowered by mumbers. And sth, That hy reason of the cinemmstances stated, the ressel vas ont of the protection of any law, amb hiable to condemmation. The ship was condenned to IIis Majesty in the rice-atmiralty const at sierra Leone, and from this decision an appeal was made to this comrt.

Sir William Scott delivered the judgment, extracts from which are as follows:- " Cpon the first quetion, whether the linit of search exists in time of peace, I have to observe that two principlus of public law are generally recognized as fundanental. (He is the perfect equality and entire independence of all distinct siates.

"Relative magnitude creates no distinction of pight, relanire inn. becility, whether permanent or casual, gives 110 additivnal right to the 
more powerful neightor: and any arrantage seized upon that ground is mere nsurpation. This is the sreat fommlation of pullie law, which it mainly concerus the peate of mankind, both in their pub-

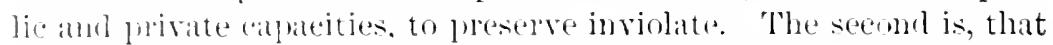
all mations hejug equal, all have an equal right to the iminterupted nse of the mappropriated parts of the ocean for their navigation. In plates where no local aththority exists, where the subjects of all states meet mpon a forting of entire equality and imbendence, no me state. or any of its suljects, has a right to assmme or exercise anthority orel the subjects of another. I can find no authority that sires the right of intermution to the narigation of states in amity unom the high seas. excepting that which the rights of war give to both belligerents against neutlials. This light, incommodions as its exercise may oceasionally be to those who are suljected to it, hats been fully established in the legal practice of nations, having for its fonmdation the necessities of self-defence, in preventing the enemy from heing supplied with the instrmments of war, and from having lis means of amoyance augmented by the advantages of maritime eommorce. Against the property of his enemy each belligerent has the extreme rights of war. Agrinst that of nentrals, the friends of both, each has the right of visitation and search, and of pursuing an inguiry whether they are emploged in the service of his enemy, the right being subject, in almost all cases of an inpuiry wrongfully pursued, to a compensition in costs and damages. * * *

"The right of risitation being in this present case exercised in time of peace, the question a rises. how is it be legalized? And looking to what I lave describer as the known existing law of nations, evidenced by all authority and all practice, it must be mpon the gromml that the captured resiel is to be tirken logally as a pirate. or else some new gromul is to be assined on which this right whieh hats been distinctly admitter nut to exist generally in time of peace an he supjorted. Wherevel it has existed it has existed upon the gromud of repelling injury, and as a measure of self-defence. No flactice that exists in the world earres it farther.

. It is perfectly clear, that this ressel cammot be deemed a pirate from any want of a national chamater legally obtained. She is the monerty, mot of stat-rovers, hut of French acknowledged romieiled suljects. She luas a French pass, French register, and all proper documents, and is an ackunwedger portion of the mercintile maline of that comntry. If, therefore, the charater of a pirate can be impresserl npon lier, it must be only on the gromd of her occupatim as a slave-traler; no other act of piracy being imputed. The question then cones to this:-can the occupation of this French 
vessel be legally deemed a piracy, inforring as it must do, if i! lu, all the pains and penalties of pirasy" I most remenulus, that in discussing the question, I must amsible it, not alembling lo ills

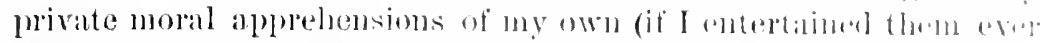

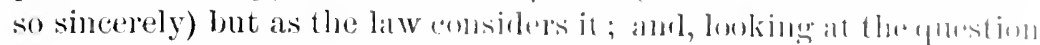

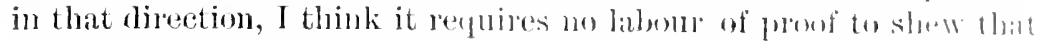

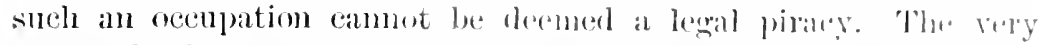
statute lately passed which malies it a tams]ortable oflemen in any

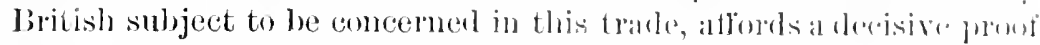
that it was not liable to be comsidererl as a piracy, amel a rapital offence, as it would be in forcigners as well as liritish subje.ts. if it was a piraey at all. In truth it vants some of the distinguishing feitures of that offence. It is not the act of flechooters, momites of the human race, remomeing evory combly, and latroning erery comtry in its coasts and vessels indiscriminately, and thelely cout ing an miversal terror and alarm; hut of persoms entining theil. transactions (reprehensible as they may be) to particnlar (omulies, without exciting the slightest apprelension in others. It is not thes act of persons insulting and assanlting enasts and vessels agniast the will of the govemments and the comrse of their laws, but uf lustsms resorting thither to carry on a traffic (as it is there most mutortunately deemed, not only recognized hut invited by the institutims of those barlarous commmities. Jut it is mmecessary to pursur this topic further. It has not been contender in arommont, that the common ease of dealing in slaves ennld be deemed a pirary in law. In all the fervor of opinion which the agitation of all questions relating to this practice has excited in the minds of many int dlligent persons in this comntry, no at tempt has ever been thought of, al last with any visible effect, to submit, any such question to the jurlesment of the law by such a prosecution of any form instituted in any court; and no lawyer, I presmue, cond be fomd hardy emomeh to maintain, that one indietment for piracy conld be supported by the mere evidence of a trading in slaves. Be the malignity of the practice what it may, it is not that of pirary in legal comsinterat ion.* * *

"If I felt it necessary to press the emsideration further, it womld be by stating the gigantie mischief which such a claim is likely on produce. It is no secret, particularly in this place, that the right of search in time of war, though mupestionable, is not smbminterl to withont complaints, lond and bitter, in spite of all the molificatims that can be applied to it. If this right of war is importerl into pratre? by convention it will be for the prudence of states to regulate hy thit convention the exereise of the right with all the softenings of which it is capable. 
." Treaties, howerer, it must he remembered, are perishable things. and their obligations are dissilated by the first hostility. The (wrenants. lonverer solemn, for the abolition of the trarle, or for the exercise of modes of prevention, enexist only with the relations if anity anomg the confederate states. At the same time it may le holned, that on long as the treaties do exist, and their obligations an sincerely and reciprocally respected. the exercise of a right, Which fro tomfoconverts a state of peace inte a state of wall, may be -1) condurterl as not to excite just irritation. But if it be assumed by foree and left at large to operate reteinenally mon the ships of every state (for it must be a right of all against all), without any other limits as to time, place, or mole of incuiry than such as the mondenere of garticnlar states, or their individnal suljeets, may immise. I leave the tragedy contained in this case to illustrate the effects that are likely to arise in the very first stages of the process, without arding to the accomt what must he consirlered as a most awful part of it. the perpetual irritation and the miversal hostility which are likely to ensue." (For other cases npon the subject of the shave trade see The Amerlie 1 Acton's Adm. Rep., 240 ; The Fortu-

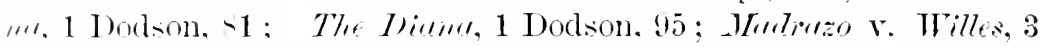
birnivell \& Alderson, 35:3; The Aictelope, 10 Wheaton, 66. See, ako. Danats Wheaton, pp. 20:3-213.) 
CIIAPTER IV.

NATIONAI, I T Y .

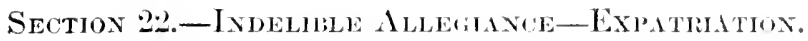

\section{OPINION OF COCKBURN.}

\section{(Cocklnem's Nationality, 6-14.)}

"Nationality by birth or origin depends, aceording to the law of some nations, on the place of birth; accorking to that of uthers on the nationality of the parents. In many countries both eloments exist, one or other, however, predominating. 'Thus, ly the law of England, the status of a subject depends generally on the plare of birth: nevertheless, the descendants, of a natmal-born subject, for two generations, though born ont of the dominions of the crown. are, to all intents and purposes, suljeets. In like mamri, by the litw of France, though, generally speaking, it is necessary to le born of French parents to be a Frenchman, an exception is mate in fivour of the chile of a foreigner, if born in France, subjeret only to the condition of the French nationality, being claimed within a presscribed period.

"By the common law of England, every person born within the" dominions of the Crown, no matter whether of English or af fortisn parents, and, in the latter case, whether the parents were nettled, an merely temporarily sojomming in the country, was an English sul. ject; save only the children of foreign andiassarlors (who wore excepted because their fathers earried their own nationality with them), or a ehild born to a foreigner during the hostile oxempation of any part of the territories of England. So effect alphalls to hare been given to descent as a somree of nationality.

"The law of the United States of America agrees with om wm. The law of England as to the effect of the place of hirth in the mat ter of nationality beeame the law of America as part wi the law of the mother country, which the original settlers carried with then. **** 
" liy lhe law of France, anterion to the revolution, a child bonn

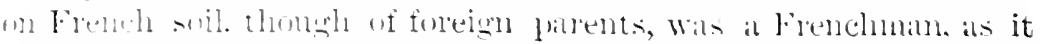

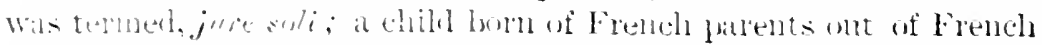

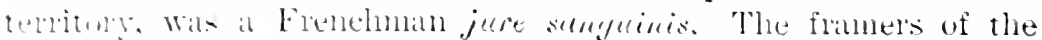

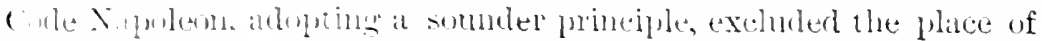

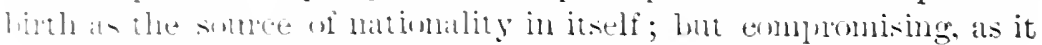
wele. with the wh rule, they allowed the plater of hinth to have ef-

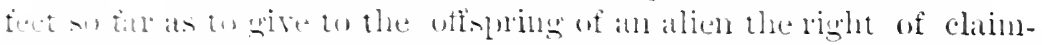

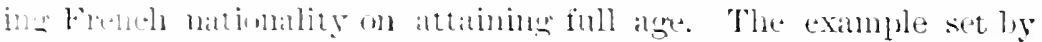

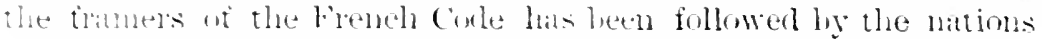

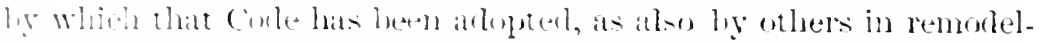

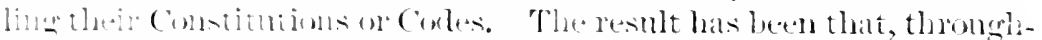
whi the Fumpun states aenerally. descent, and not the place of

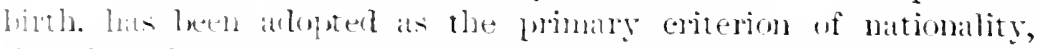
tholngh with a leservation in some. of a right to persons born with. in the tendeny to daim nattomality within a tixed period. Thus, While in some of hese eomeries nationality is derived from parentwee alwite, in whers the right lecomnes eomplicated hy reatson that in adbitan to garentage. birth within the dominions of the particuLitr combly comfers eitizenship on the offspring of aiven patents13 sonte alsolutely-thongh suljeet to the right of the individual encenderl to reject it at majomity-in others on the light being claimed on certain specified conditions."

\section{MACDONALD: CASE, 1TH.}

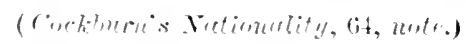

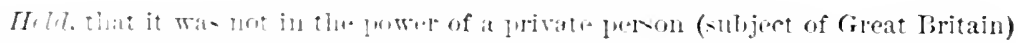

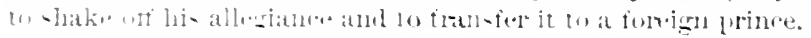

"In thr (atse of . Eneats Materfonalel, who wats tried for high trea-

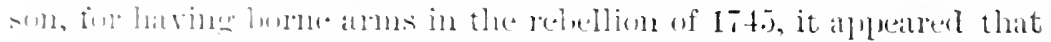

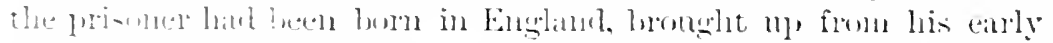

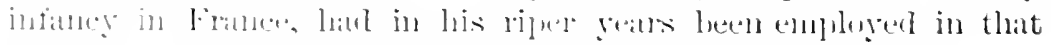

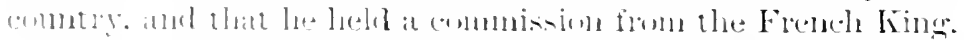

- After a fitint altrompt to make ont that the [orismer lual heen

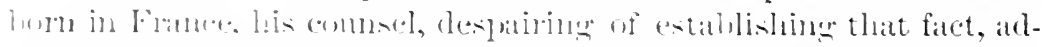

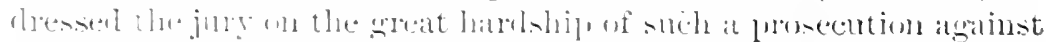

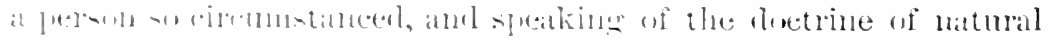

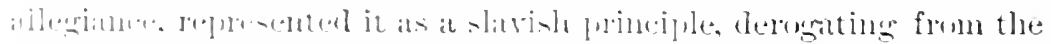

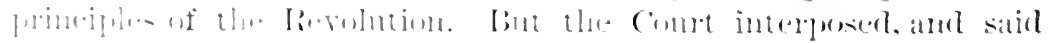

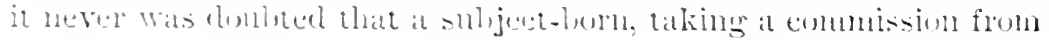


a foreign Prince and eommitting light trason, may he punishert ats a subject for such treason, notwithstamling his foreigh commission; that it was not in the gower of any private person to shalke otf his allegriance and to tramsfer it to a foreign frince mor was it in the power of any foreign prince, hy natmalizing or employing a subjext

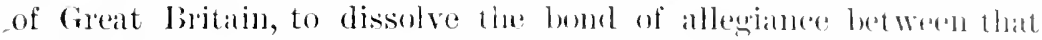

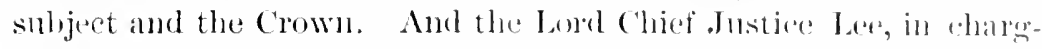
ing the jury, told them that, the overt auts laid in the indictment having been jowved aganst the prisoner, and armitted by lim, the only fact to be tried ly them, was whether he was a subject of Great Britain ; as in that case he must be fomnd wnilty.

"The prisoner was aceordingly found guilty, but reeejverl at pardon on condition of banishnent." 1

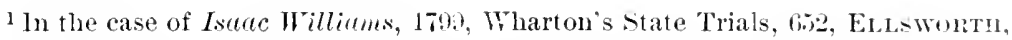
C. J., said:-

"The common law of this country l'mains the same as it was befole the ferolution. The present question is to be deeided by two great principles; on. is, that all the members of a eivil community are bound to ach of her by eompact. The other is, that one of the parties to this eompart cannot dissolve it by his own act. The compaet between our community anl its members is, that the community will proteet its members; and on the part of the members, that they will at all times be obedient to the laws of the emumunity and faitliful in its defence. This compact distinguishes our goverment from those which are founded in violence and frand. It necessarily results, that the nembers camot lissolve this compact, without the eonsent or defauit of the community. There has been here no consent-no default. Default is not pretended. Express consent is not claimed; but it has been argued, that the eonsent of the community is implied by its poliey-its conditions, and its aets. $*_{*}^{*}$ Consent has been argued from the acts of our govemment, permitting the naturalization of foreinners." But in the opinion of the Chief Justice no such inference coukl be drawn from this fact. When foreigners became naturalize 1 in the Lnitw States, the question of their right to lenonince their native allegiance was one between them and their native country, with which we were not eoncerne?.

Proclemetion of the Prince Regent. July 24, 1814, Coekburn's Nationality. 7:-

"A proclamation by the Prince Rorent, of the 20th July, especially directed against America, after prolibiting all natuml-born subjects of II M Majesty from serving in the ships and armies of the Tinte: states, and eharging all such per'sons at once to quit such servire, proceetis as follows:

"And whereas it has been further represented to us that diver's of our nat malborn subjects as aforesaid have been induced to areept Letter's of Xalluralization or Certificates of Citizenship from the saitl Tnited states of Ameriea, vainly snplosing that by such Letters or Certifirates they are discharged from that fluty an 1 allegiance which, as our natur.l-horn subjects, thery owe to ns: Xow we to herehy warn all snel our natural-born subjects, that no stelh Jetters of Xaturalization or Certifieates of Citizenship do, or ean, in any manner diseliarge our natural-born subjects of the allegiance, or in any dergree alter the duny which theg owe to 11 s. their natural sovereign. ****

"Moreover, that all such, our subjects, as aforesaid, who have voluatarily en 


\title{
ME-SIGE OF PRESIIOENT GRANT, 14-73.
}

\author{
(2) 11 hrutoton: Digest, :312).
}

. 1 invite the andest attention of comeress to the existing laws of the londed states reprecting expatriation and the election of nationality ly incliviluals.

- Matny ditizens of the Enited states reside permanently abroad

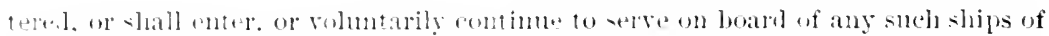
War. or in the lan l foreen of the sain] ['nited states of Americal, at emmity with us, arta and will be entilty of hish triaton."

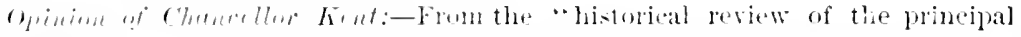
dispanom in the Futhal coum on this interesting subject in Anerican juris-

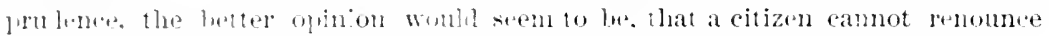

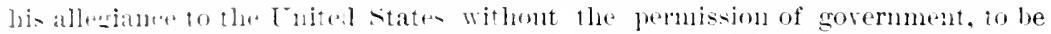
andared ly law: and that. as therw is no existine lecriblative regulation on the che the rilu of the English common law renains unaltered." (2 Kent's Comnetriarie... p(i).)

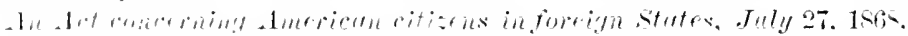

"Whereas the richt of expat riation is a natural and inherent right of all people.

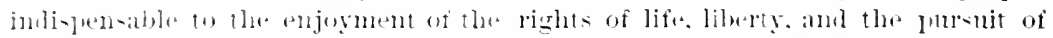

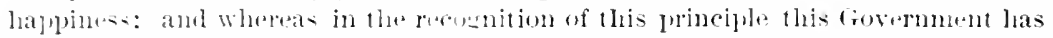
froply reedivel omigrants from all nations, and invested them with the rights of citizenshij: and whelteis it is chinuel that such Amerioan citizens, with their

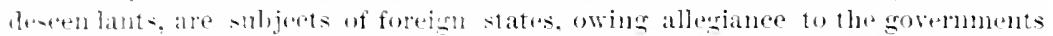

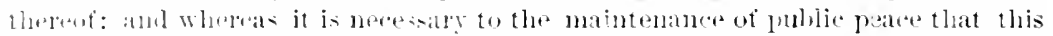

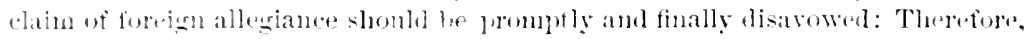

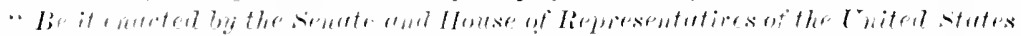

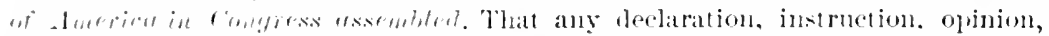

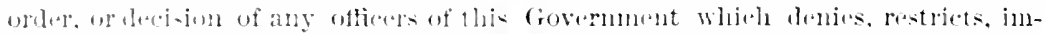

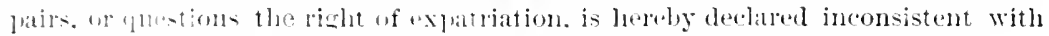

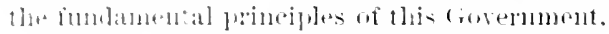

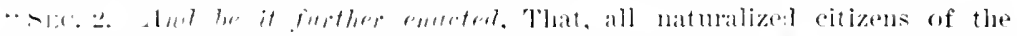

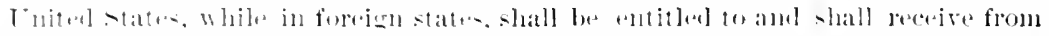

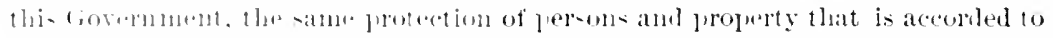

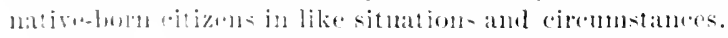

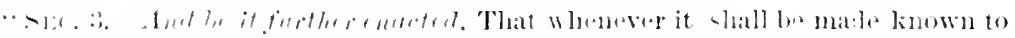

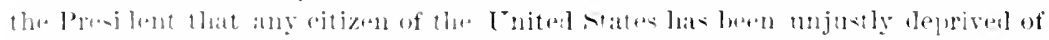

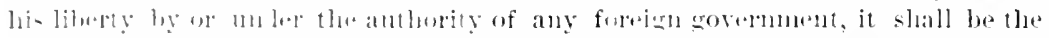

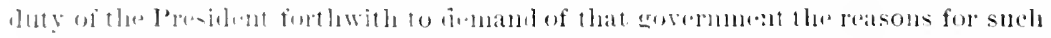

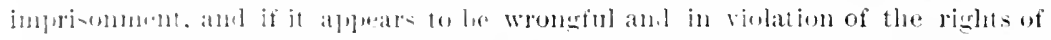

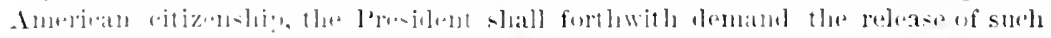

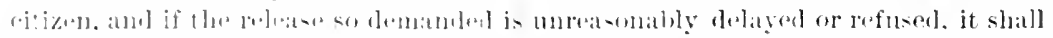

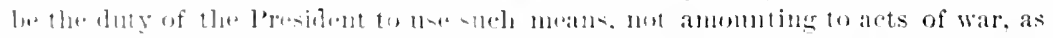

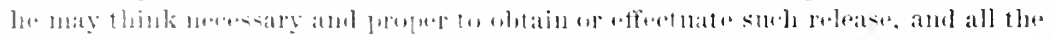

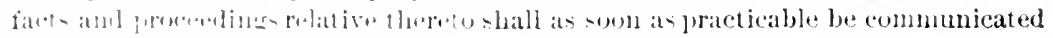

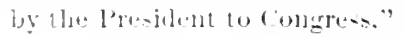




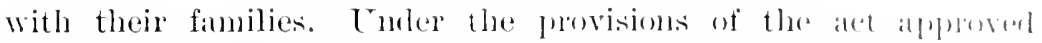

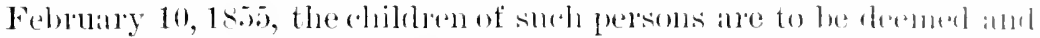
taken to be eitizens of the Luited states, hut the rights of ritizenship ale not to deseend to persoms whose fathers mever resided in the Thited sitates.

"It thus latplens that persons who have nevel resiched wiblin the

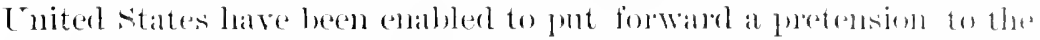

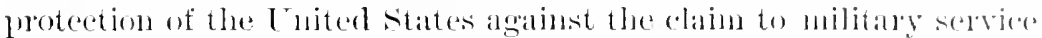

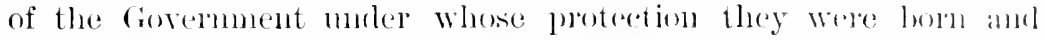
have been learoll. In some cases cron maturalized citizens of the Enited states have retmued to the land of their birth, with intent to remain there, and their children, the issme of a manriagenontrated there after return, and who have never been in the Enited stalles, have laid chain to om protection, when the lapse of many yeans hald imposed upon them the duty of military serviee to the only Goremment which had ever known them personilly.

" L'util the year 1868 it was left embarrassed hy conflicting" opinions of eomets and of jurists to detemnine low far the losetrine of perpetual allegiance deriverl from om former colonial relations with Great Britan was apjliable to Aneriom ritzens. Compers then wisely swept these douhts away by enacting that 'any derelantion, instruction, olinion, oneler, or decision of any offices of this coremment which renies, destricts, imprais's, or questions the rigle of expatriation, is inconsistent with the fundanental principles of this Govermment.' But Compess dirl not indicate in that statute. mor has it since done so, what acts ase reemed to work expritriaton. For ny own guidance in determining such questions, I required (under the provisions of the Constitution) the opinion in writing of the principal officer in each of the Executive Departments upon certain questions relating to this subject. The result satisfies me that further legislation has become necessiny. I therefore comment the

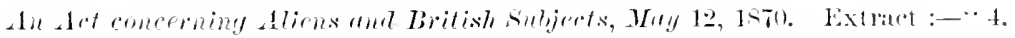

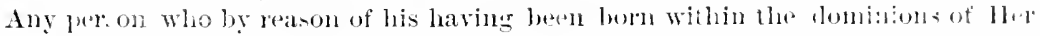
Iraje ty is a natural-born subject, but who also at the time of his birith became, molep the law of any foreign state, a snbjert of sueh state, and is will wheh sulfject, may, if of full age and not muler any disability, make a declatalion of alionity in manner aforesail, and from and after the making of such declaration shali wates to be a Jritish subject. D. From and after the passing of this art an allen sindl not be entitled to be trie:l hy a jury de mertietate linglese, but shall lue triable in the same manner as if he were a natural-horn snloject. $*$ B. Any liritish suljuet who has at any tine before, or may at any time after the passing "f this ant. when in any foreign state and not unler any disalsility, volmntaly become natualizad in sucle state, sha'l, from anl after the time of his so having berome nat mralizal in such foreign state, be deeme: to have ceased to be a 13ritish subject and be regarded as an alien;" ete. 
smiject to the cureful consideration of Congress, and I transmit herewith appes of the several opinoms of the principal officers of the

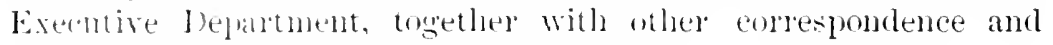
lertinent information on the sanne subject.

.. The Cnited states, who led the way in the overthow of the fembal doctrine of per' letmal allegince, are among the last to indicate low their own eitizens nay eleet another nationality. The papers sulmitted lerewith indieate what is necessary to place us on a par with oher leading nations in liherality of legislation on this internatimal fuestion. We have ahealy in on treaties assented to the grinciples whiel womld need to he embodied in laws intended to acemplish such results. We have agreed that citizens of the Conited states maty cease to he citizens, and may voluntinily render allesiance to other powers. We have agreed that residence in a foreign land, withont intent to retum, shall of itself work expatriation. We lave anded in some instances upon the length of time necessary for such continued residence to work a presumption of such intent."

\section{ALIBERT'S CASE, 1852.}

(Iienoit on Naturalization, Tinited states, p. 133.)

A citizen of France loses his French nationality by being naturalized in a foreign state.

Alitert was a native of Digne, Basses Alpes. IIe went to the Cuited states in 183x, at the age of 18, and, after going through the minal fomalities, was natmalized in $18+1 ;$. In 18.22 he retmoned to France and was arrested while on a visit to Jigne as an "insommis" of 1 -:39. and plearled his matmalization as exempting him from seresiee. The l'nited rtates consul at Marsolles applied to the general commanding the district, who informed him that dliberts claim was fonment in light, if his matmalization was really lated in 1sta, ats his matmalizatton womld incaparitate him from servina in the Freneh arme, ancl the date of it womle prove that mome than three years had

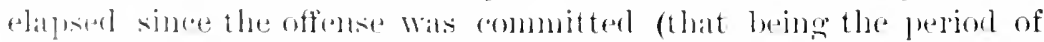

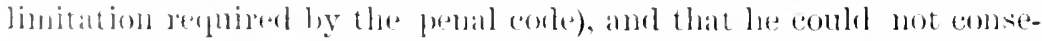

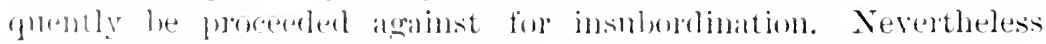
Alihert was brought hefore a "oonseil dr gotlere" at Marseilles, and exmelemment to a montlis imprisomment.

Plute camse wats then bronght by alpeal before a smperior military 


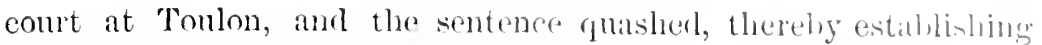
Alibert's immunity from conseription.'

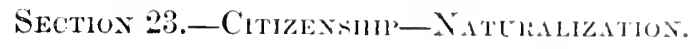

Ee Parte CIIIN IIING.

Ee P'urte CIIAN SIN IIEE.

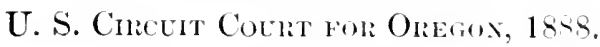

(3.) Federal Repoiter, 8.54.)

Children born in the United states of Chinese parents are citizens of the Inited states.

Aplelication for writ of haberes enpres.

DE.WY, J._"The writ of hubers conp"s in these cases was allowerl and issued on Jume 25,1858 , and they were heard together on the sanle day.

"The petition of Chin King states that she was born in sim Francisco, Cal., on October 10, 1stix; while that of cham sim Itee states that she was born in Portland, Or., on Marele 15, 15-5; and they each state that they are restrainer of their liberty by Willian Robert Lairl, the master of the British bark 'Kitty' betanse the collector' of enstoms for this port refuses to allow them to land from sabl bark on the grome that the petitioners are Chinese, and have no retum certificate, as required by the act of Congress on that subject; but

1 In the case of Michael Zuiter, 1s69, hefore the cont of first instance of Wissembours, the question was whether he was exempt fom military sorvice. Aml this depended upon whether he was a citizen of France, for, by the ol $_{\text {anticle }}$ of the law of March $21,15 \cdot 2$, as the court say, "nul ne peut etre atmis dalls les troupes françaises s'il n'est francais."

Zeiter contended that he had been naturalized in thr [roited slates, and hat therehy lost his French nationality. The cond assented to this riew of the law but demanded furlher proof of his natmalization in America. When he hite frocurel satisfactory proofs, lhe coutt decred as follows:

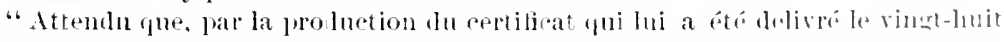

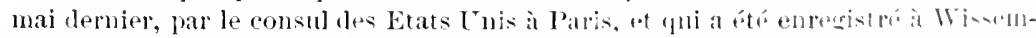

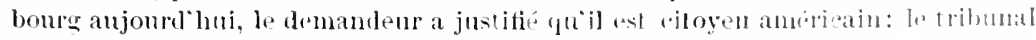

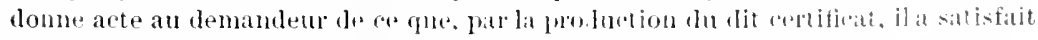

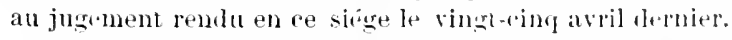

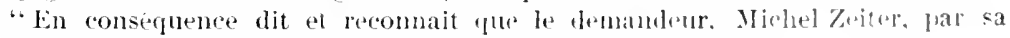
naturilisation en pays étranger, a perdu la qualité de français.", 
they arer that they are native-born citizens of the Lnited states and therefore not includer within the terms of said atct.

. The return of the master to each wit states that the " Kitty'

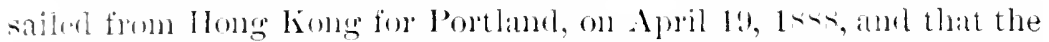

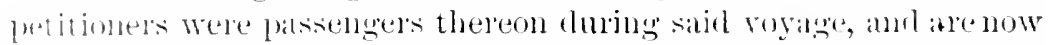
in ensonly on boad the same, for the reasons stated in the petitions.

.. (1) application the Lnited States district athorley Was allowed to intervene on behalf of the L'nited states, and allege that he had

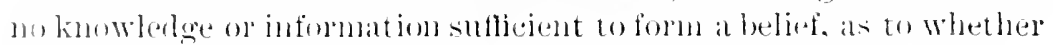
ilue petitioners were hom in the Inited states, as allegerl, on not.

.. (In the hearing it appeared that Chung Yip Gen is a Chinese medehant, who has lived and dome business in this city for the patst

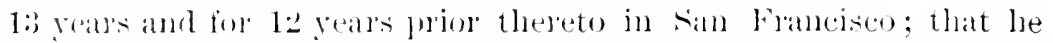

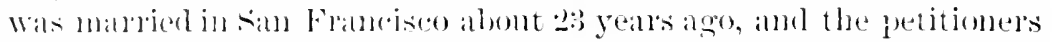
are his danghters, the older one having been born in sim franciseo,

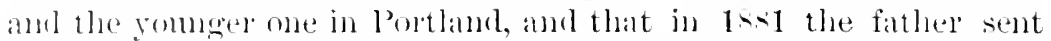
them and their mother to China, from whence they were to return when they lileatised.

- by the ammon law, a child boun within the allegiance-the jurisliction-of the Lnited states, is born a subject or citizen thereof, without reference to the political stretes or eondition of its latrents.

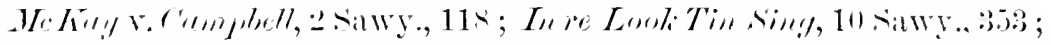

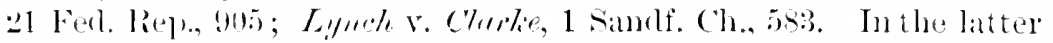
ase it was hold that Julia Lyneh, who was hom in New Jork in 1-l!1, of alien parents during a temporary sojomm by them in that

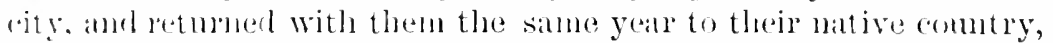
Where she resided mutil ler death, was an Amedican eitizen.

- The vice-elancellol, after an exhamstive examination of the law,

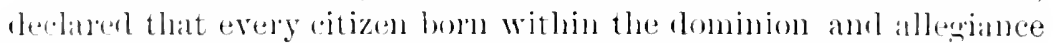
of the fonted states wats a eitizen thereof, withont reference to the sitnations of his panents.

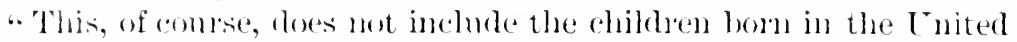

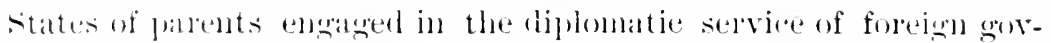
exmments, whose sesidence, in contemplation of public law, is a part of their own (*omitry.

"The rule of the common law on this subject has been incorporateil jute the fomdamental law of the lamel.

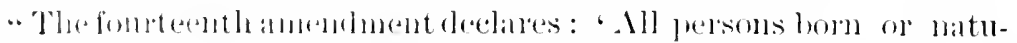
ralizerl in the fonted states, and subject to the jurisdirtion thereof, ase ritions of the Lnited States, and of the state wherein they resira.

"In L" re Look T"in Sing. 10 Sawy., 353; 21 Ferl. Rep., rm., it was hekd that a person bom within the Lnited states, of Chinese parents, 


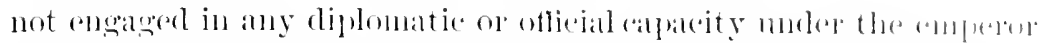

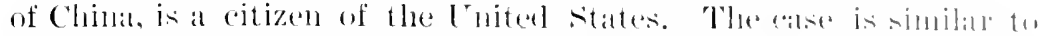

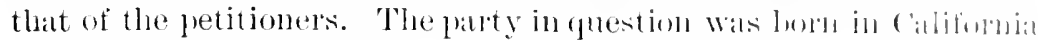

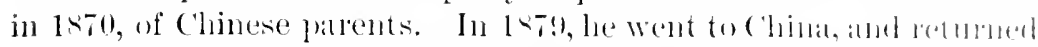

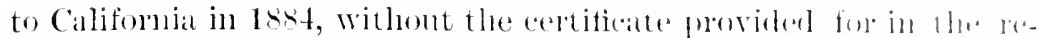

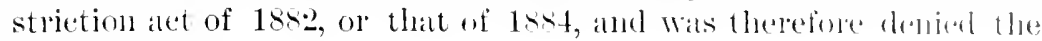
right to lande.

"Mr. Justice Febr, in clelivering the ophinion of the cont. in which

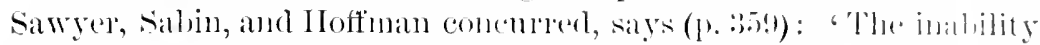
of persons to become ritizens muder those laws (uf natmalizallion) in no respect impairs the effeet of their birtle, of of the birth w llein: children, npon the sfotus of either, as citiznns of the Lriterl states.'

"The only point marle by the district attorney asainst the petitioners on the question of their citizenship) is that they loft this country without, as he claims, any definite or fixed purpose to return.

"But I think the evidence does not warant so strong at statement. For anght that appears they intended to return; and the finct that they have returned gives strength to the inference. The most that ean he said is, there was no time fixed for their retum. And that is the case with hmodreds of minor American aitizens, who so alload vearly for nurture and erlucation. But it seems that the aidzonship of the petitioners womld not be affected by the fict, if ther hat never eome hack, moness it also appears that they had in some formal and affirmative way renounced the sime.

"Howerer, in my julgment, a father eamot deprive his minor" child of the states of American citizenship, impressed upon it by the circumstances of its birth under the Constitution and within the jurisdiction of the United States.

"This stutus, once acquired, can only be lost or changerel by the act of the party when arrived at majority, and the comsent of the govermment.

"By section 2 of article 4 of the Constitution it is provicled: "The citizens of each state shall be entitled to all privileges and immunities of citizens in the several states.'

"It has always been held that the privileges and immmuities there referred to are fondamental; and that a citizen of one state may at least, under this provision, pass through or resinte in any other state of the union for the ordinary pursuits or purpuses of lite.

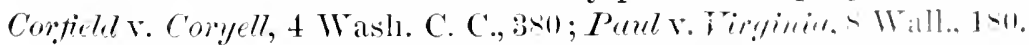

"The action of the collector ju these cases has the effect, and is so intender, to deny these eitizens of the Lnited states the right of fiee locomotion within the same,-the right to come into, fasis throngh, 
or reside in this state, and is therefore contrary to and in violation of the eonstitutional povision gnaranteeng suth right to erery eitizen.

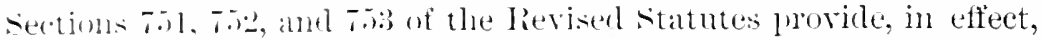
that the compts of the Enited States and the jurbes thereof shall

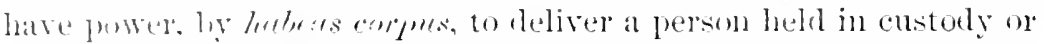
restratinet of jis liberty in violation of the Constitution or of a law ar treats of the Inited states.

- The gretitimers. as we have seen, are restrained of their liberty in viokation of the Constitution, and therefore this eourt has jurisdiction to discharge them on hembers anyms.

"The petitioners are discharged from enstody."

\section{IIALSIDING CALE.}

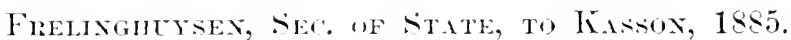

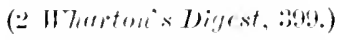

Children born in the Lniled states of alien parents, and never dwelling in the Lnitel states are not citizens thereof.

The "ase of Ludwig Hausding, appears to have been decided atecoreling to the law and the facts. It is stated that having been born in the Cuited states of a saxon subjeet, he was removed to his fatler"s native land, where he has ever since remained, althongh his fatles las subsepnently hecome a citizen of the Enited states. You lefuserl a bassport on the ground that the applicant was born of Saxon sulijects, temporarily in the Inited States, and was never 'chrolling in the Inited States, either at the time of or since his parrutis naturalization, and that he was not, therefore, naturalized liy fores of tlee statute, section :-17-2, Revised statutes.

"It dox not alpear from your statement whether Wilhelm IIansdine, the father, had deelared his intention to become an American citizen befone the binth of Ludwig. While this, if it were established, would lend an appoarance of hardship to an atrerse decision upon his elaim to be deemed a citizen, yet, even in this case, as the statutes stand. your alecision would conform to the letter of the law,

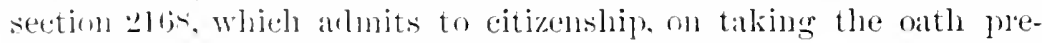
seriber hy law, the widow and elibluen of an alien who has declared his intention hut ries hefore eompleting his naturalization.

"I Iy provirling for special exemption exolumes the idea of any other exemption, as for instance in the case of the non-completion of 
the father's natmalization before the permanedit lemoval of the minor son from the jurisdiction of the I nited itates.

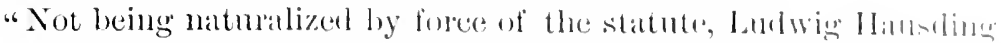

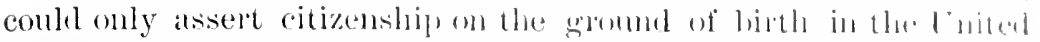

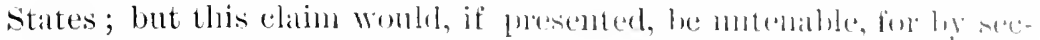
tion 1992, Revised statutes, it is made a combition of reitimoliph by

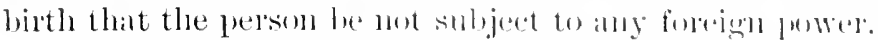

"This last considelation serves only to answer the "quale" which you amex to your statement of the Hamsinge case.

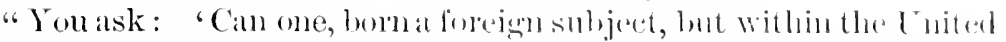
States, make the option after his majority, am while still living" abroad, to adopt the citizenship of his birthplater: It seems mot, and that he must change his allegiance ly endigration ambl leand process of natmalization.' Sections 19192 and 1:19:3 of the lievisen Statutes clearly show the extent of existing logislation; that the fact of birth, moler circmustances inplying alien sulijection, establishes of itself no right of eitizenship); anel that the ritizenslip of at ferism so born is to le aequired in some legitimate manner thromgh the operation of statute. So statute contemplates the alconisition of the declared character of an Ameriean citizen hy a person not at the time within the jurisdiction of the tribunal of recorel which confer's tlat character."

\section{EMIDEN' CASE.}

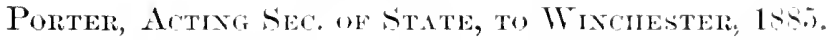

(2 ITrotoris Digest, 410.)

Clililren born abroad of citizens of the Luited States and rontinning to reside abroat, are not eitizens thereof unless they elect to become sneh on connine of atede

Robert Enden was born in Fitzerland, in $186 \%$, and at the time of his application in 1885 for a pissport, haul never been in the fuited States. Ifis father, a Swiss by origin, Wals natmalized in New lork in $1 \times 54$, but soon afterwarls retmrned to switzerland, where le contimuel afterwards to reside.

" Endoubtedly, by the law of nations, an infant child pilltilies: of his father's nationality and domieile. But there are two difficulties in the way of applying this rule to the present calse. In the first place a parent's nationality cannot, especially when proluced by naturalization, be presumed to be adhered to after a lesidence in the country of origin for so long a period as in the present case. 
"In the second plice the rule as to thildren only applies to minors, since when the child hecomes of age he is required to elect between the commtry of his residence and the comntry of his alleged technical allewinnce. Of this election two incidents are to be observed: when more malle it is final : and it requires no formal act. but may be inferred from the conduct of the party from whom the election is repritied.

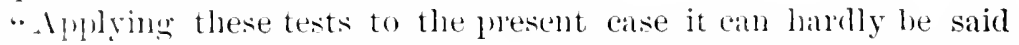
that llr. loblert Emolen's elaim to be a eitizen of the Lnited states is. as a matter of international law, made ont. The buden of proof is always on the applicant for the pasipolt, and here there is no evilence to prove either his father's non-abindomnent of his Cnited states citizenship, or his own election of such citizenship, save the applications of father and son for passports."

\section{A PRLSSIAN SEBIECT.}

\section{OpINiON OF THE ATt.-GENERIL, 1875.}

(2) Hhartoris Digest, t12.)

Ender the treaty between the Lnited States and the North German Conferleration of INtis, a Prussian by bith, natmalized in the Cnite: states, is presumed to hare renounced his American eitizenship, if he retums to Prossia, and resides there lwo sears.

"A Prusian subject by birth emigrated to the Cnited States in $184<$, became naturalized in 1854 , and shortly afterwands returned to Germany with his family, in which was a som borm in the Luited States, and becane domiciled at Wiesbaden, where, together with his fanily, he has since continuously resided. The son having reached the age of twenty years, has been ealled upm by the German foremment for military duty. The father inroked the intervention of the Lnited states legation at Berlin, Imt declined in behalf of the som to give any assmance of intention on the part of the latter to retmm to the Fnited states within a reasonable time and asimme his duties as a eitizen.

". Irticle IV. of the natmalization treaty hetween the Tnited States and Xomth Germany of lotix, reads as follows: 'If a Ceman naturalizer in Anerical renews his residence in Nolth Germany withont intent to return to Anerical, he shall be held to bave renomeed his naturalization in the Cuited sitates. *** The intent not to return nniy be lueld to exist when the person naturalized in the one country resides more than two years in the other country.' 
"It was held (1) that muler the above antide, the father mun l

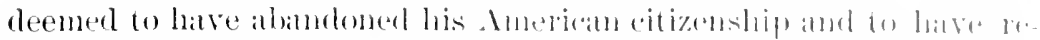

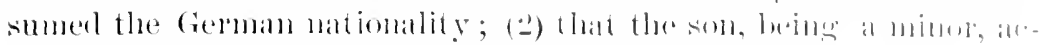

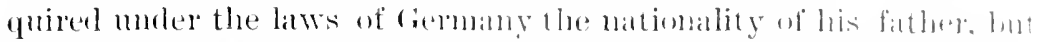
did not thereby lose his Americam nationality; (:i) that mom attatil-

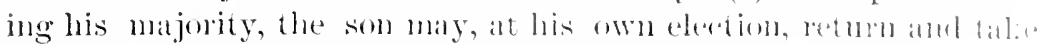
the nationality of his birth or lematin in fermany and letain his are quired nationality; (t) yet that during his minolity amb while domi. eiled with his father in (iemany, he camnot rightfully clain exemption from military cluty there."

Section 24.-Proterton to Critzexs Amondl.

\section{WATERISCASE.}

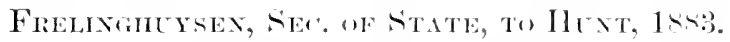

( 2 Wharton's Diguest. :39:2.)

What are the rights of a foreign minor who emigrates to the l'nitel states, and becomes mat uralized there, and then returns to his native land : Maty he be forced to serve in the army of his original state?

"From the responses previonsly made to your inquiries in Mr. Wagner's behalf, it alpreas that the brunt of the charge against him was that he, a minor, quitted laussian juriseliction in advaneas attaining the age when he might have been ealled upon for militay service. Ile was born at Lodz, 185, and in $187+$ heame hable wh

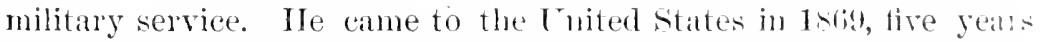
before the liability cond rest npon him. When the techmian offense, styled evasion of military duty, which is the sole drangente against him, hegan to exist as a tangible aceusation. lieinhardt Wagner had already, by residenee in the Enited states for more than three years preceding his majority, acquired mnder on statules the preliminary rights of eitizenship. Vo nation shomblassert an absolute elaim over one of its subjects under eircmmsimces lilis these, and it is thought improbahle that Russial will persist in sheh a claim, even if made. There woull be no limit to such at preturion. for the taking of a male infunt out of linsia miglet le rewalled with equal propriety as an 'evasion' of eventual military serrice.

"It is tantamount to asserting a right to pumish any male lius. 15 
sian who, having quitted linssian territory and become a citizen of another state, may afterwarel retmin to liussiat

"This daim is different flom that put forth by some govermments for the completion of military duty fully acerning while the subject is within theje jurisoliction, and actually lett mofulfilled. It is, for eximple, clatmed that a subject who leaves the comtly when ealled npm to serve in the army, and becomes a citizen or subject of another state, may, if he retmms to the former juristiction while yet of ane for military anty, be compelled to serve ont his term. This rule appears lursh to us, and get it goes no further, as a matter of fact, than a contention that an obligation of service aceruing and mpaicl while the subject is a resident of the comntry, continues, and is to be extinguished in kind by performance of the alleged defaulted service.

" Bnt, harsh as it is, it is wholly different from the inflietion of vindictive pmishment, as, for instance, exile for the constructive evasion of an inchoate obligation. To exact the fulfilment of an existing obligation is one thing; to inflict corporil pmishment for not reeognizing a future contingent obligation is another."

\section{KOSZTAS CASE.}

\section{(Corlemmis . Wrtionulity, 11s.)}

Status of a foreigner who has "leclared his intention" to become a citizen of the Inited states and who has a domicil in the country, when he is temporarily out of their juristiction.

Kosztil was a IIngarian, and one of the refugees of $184 s_{-9}$. IIe went to Twkey, where he was arrested and imprisoned at Kutahieh, lut releaserl on conclition of learing the country. IIe went to the Enited states and made the nsmal declination of an intention to become naturalizod. In 1858 he returned to Turkey, and went to singrma on commercial business, and there obtained from the Enited states' Consul a traveling pass, stating that he was entitled to American protection. On the ?21st of June, 185\%, he was seized by some persons in the pay of the Anstrian Consulate and taken out inter the latrbor in a brat: he wiss then thrown into the sea, and Wals piekerl up by a buat from the Anstrian man-of-war "IItussar." The Enited states Consul went on board to remonstrate, but the Ciptain of the "IIussar" persisted in retaining Koszta. Thereupon the 'niteil States' Chargé d'affaires at Constantinople requested 
the Captain of the Tnited States' ship of was "St. Iomis" to (lemalul Loszta's release, and, if necessary, to have recontse to fores.

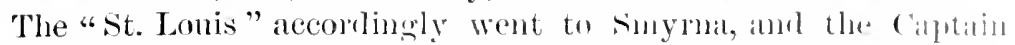
in pursuance of his instructions, staterl to the commandere of the. "Ilussar" that uniess Koszta was at once delivered lo him he shmoln take him by force of arms.

As a conflict between the two ships of war wonld have lnes attended with great danger to the shipping in the prot and to the town, the French Consul offered his mediation, and Kosztal was thes given over to his cale to be kept until the decision of the respectiva governments was ascertainerl.

On the 29th of August, 185\%, the Austrian Chargé d'Afrijes at Washington presented a formal remonstrance to the Cuited states Government, protesting against the elaim of the Enited States to afford protection to Koszta, and calling on them to disirow the conduct of their agents and to grant reparation for the insult offered to the Austrian flag.

Mr. Marcy replied on the 26tin of September, 15.5\%, contenrling, first, for the general right of every citizen or sulject, "having fithfully performed the past and present duties resulting from his relation to the Sovereign Power, to release himself at any time from the obligation of allegiance, freely quit the land of his hirth and arloption, seek throngl all comntries a home, or select anywhere that which offers him the fairest prospect of happiness for himself and his posterity;" secondly, that Koszta was not an Austrian subject, as by al "decree of the Emperor of Austria of the 24th of March, 1 : :32, Austrian subjects leaving the dominions of the Emperor withont permission of the magistrate and a release of Austrian citizenship, and with an intention never to return, become ' unlawful emigrants,' and lose all their civil and political rights at home." Thirdly, Mr. Marey put forward the somewhat startling proposition that althongh Koszta had not yet been naturalized and lecome a citizen of the [nited States, yet having become domiciled in the latter comntry. he wis entitled to be treated in all respects as a citizen of the Cuited states. In support of this proposition Mr. Marcy writes as follows:-

"It is an error to assume that a nation can properly extend it: protection only to native-borm nr naturalized citizens. This is 1 mt the doctrine of international law, nor is the practice of nations cilcumseribed within such narrow limits. This law does not. as has been before remarked, complicate questions of this natme ly respect for municipal codes. In relation to this subject it has clear and distinct rules of its own. It gives the nat ional character of the comntry, not only to native-born and naturalized eitizens, but to all resirlents 
in it who ase theye whith, or exen withont, an intention to become

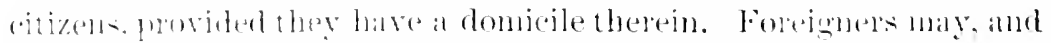

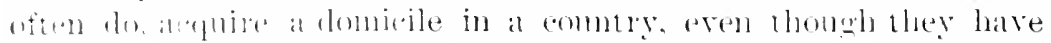
entered it whth the arowerl intention not to become nallualized

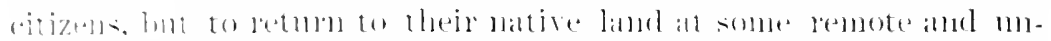

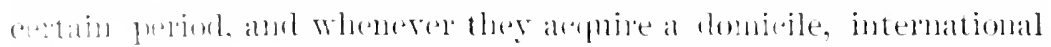
Jow at ane impresios mpon them the national character of the

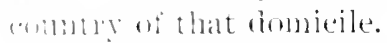

- ll is a maxim of intermational law halt domicile confers a mational

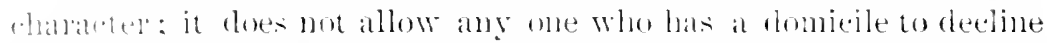

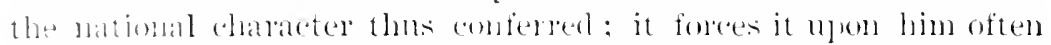
fery muld aganst his will, and to his wealt detiment. Intemational

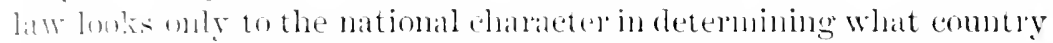

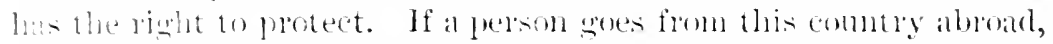
with the nationality of the Enited states, hlis law enjoms mon ot her mations to respeet him, in regand to potections as an American atizes. It concodes io every comntry the right to protect any and all who may be elothed with its nationality."

\title{
TOLXIG:C C.ISE, 1S.)4.
}

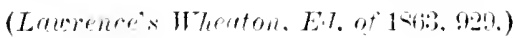

A foreigner who has "derlares lis intention " to beome a citizen of the Cuited

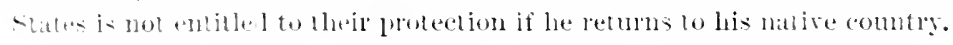

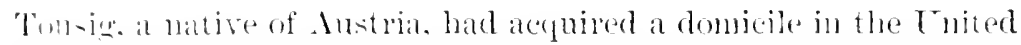

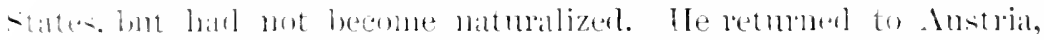

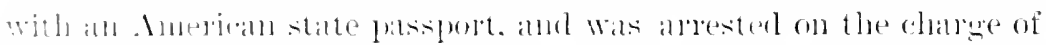

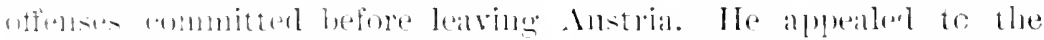

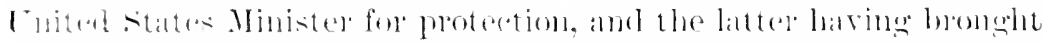

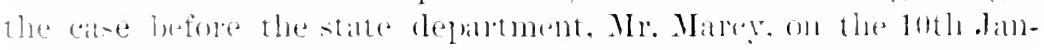

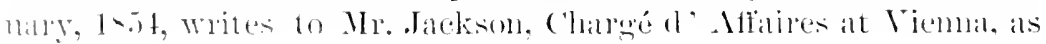
follom: :

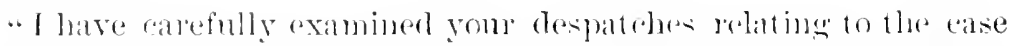

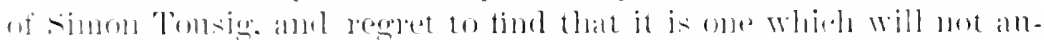

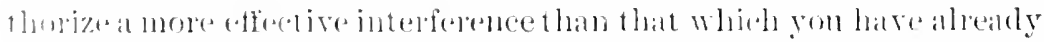

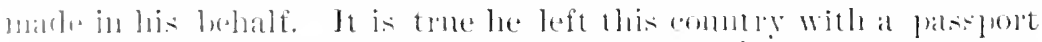

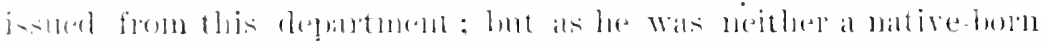

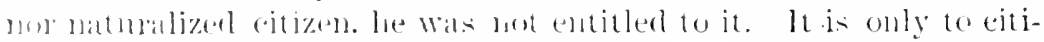

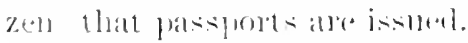

$\therefore$ Astmming all that could posibly helenge to Tousig"s calse, - that 
he had a domicile hele and was athally ioihed with the mathonality of the Enited states, - there is a feature in it which distingurisher is from that of Koszta. Tousig voluntarily leturned to Mustria, and placed himself within the reach of her municipal latws. Ilo wem hy his free act moler their juristietion, and thelety suljected himadi

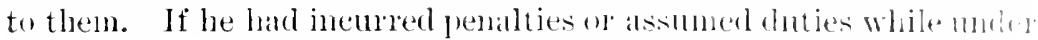
these laws, he might have expecterl they would he raforced andinst him, and should have known that the new political relation les haul

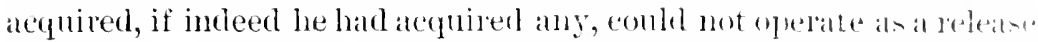
from these penalties. Ilaving been once suljoet to the municipat laws of Austria, and while moler her jurisdietion violated these laws. his withdrawal from that juristietion and aequiring a different national character wonld not exempt him foom their oferation whenever he again chose to place himself under them. Every mation, whenever its laws are violater by any one owing obedience to thrm, whether he be a citizen or a stranger, has a right to inflict the penalities incurred upen the transgresisor, if found within its jurishotion. The case is not altered by the character of the laws, muless they are in derogation of the well-established international code. No nation has a right to supervise the mmicipal code of anothro mation, or claim that its citizens or subjects shall be exempterl form the operation of such code, if they have roluntallily placed themselves under it.

"The eluaracter of the municipal laws of one comntry does unt furnish a just ground for other states to interfere with the exention of these laws, even upon their own eitizens, when they have gone into that comtry and suljected themselves to its juliseliction. If this country can rightfully elaim no such exemption for its native-lon's or naturalized eitizens, surely it camnot claim it for those who have at most but inchoate rights of citizens.

"The principle does not at all interfere with the riglst of any" state to protect its citizens, or those entitled to its protection, when abroad, from wrongs and injuries,-from arbitray ats of opplession or deprivation of property, as contrabistingusher from fremalties and punishments incured by the infaction of the laws of the combery within whose jurisdiction the sufferers have placed lhemselves. I do not discover any principle in virtue of which this sovernurent can claim, as a matter of right, the release of 'Tousig.

"He has roluntarily placed himself within the jurisliction of tl.,

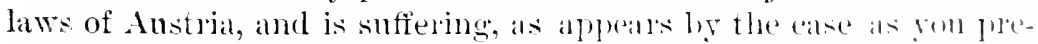
sent it, for the acts he had done in violation of those laws while lue was an Austrian subject." 


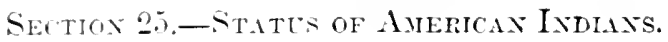

\section{ELK ソ. WILKINS.}

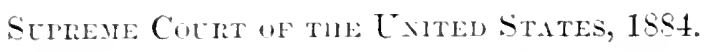

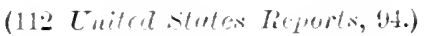

This was an aetion bought ly an Indian in the Circuit Court of the Initerl states for the I)istrict of Nebraskat, against the registrat witue of the warks of the city of Omaha, for refusing to register him as a grutitied voter therein.

Ir. Jistice (indr delisered the opinion of the court, extracts from whic? ale as follows:

... The question then, is, whether an Indian, hom a member of raferf ule Indian tribes within the Luited states, is, merely by reason of his him hithin the Cnited States, and of his afterwads volumtaly sprating hinself from his tribe and taking up his residenteanomg White rizens, a citizen of the Cnited States, within the meaning of the first section of the Fourteenth Imemlunent to the Comstitution.

" Cunter the comstitution of the Cuited siates, as originally establishen, "Indians not taxed, were exchded from the persons aceording to whos mumbers representatives and direct taxes were apportioned anomp the serend states and Conders had and exercised the power to resulate connueree with the Indian tribes, and the members there-

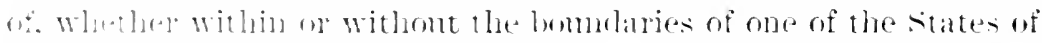

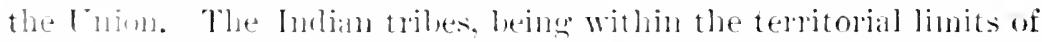

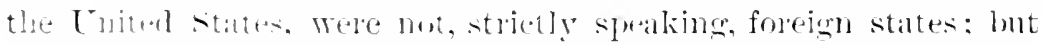

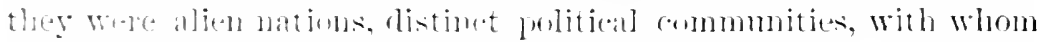

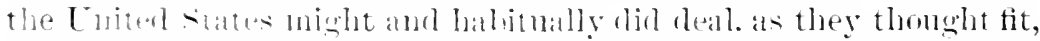

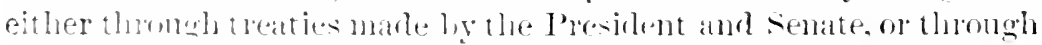

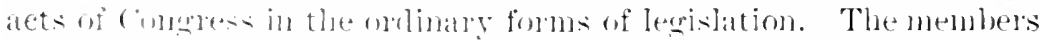

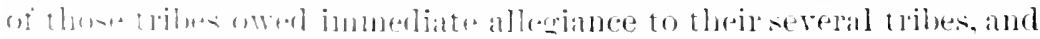

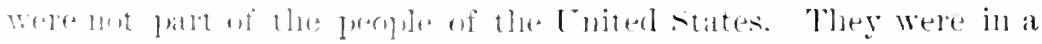

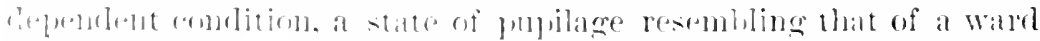

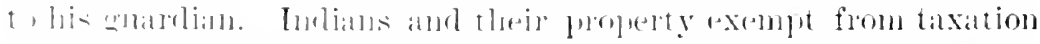

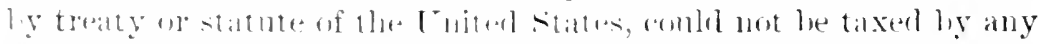

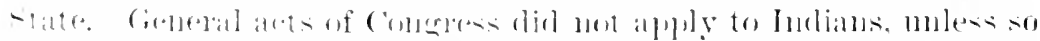

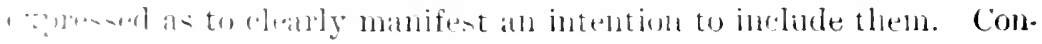




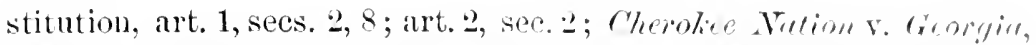
5 Pet. 1 ; Worcester v. Georgir, (i Pet.,515; . . Grom Ibog's C'use, 111.4 I. ค. 556 .****

"The alien and dependent comrition of the members of the molian tribes could not be put off at their own will, without the action of assem of the United States. They rele never dexund eitizns of the Enited States, except moler explicit provisioms of terat ol statute to that effect, either decharing a certain trilse, or such membles of it as chose to remain behind on the removal of the tribe west watrol, to be eitizens, or authorizing individuals of paticnlar tribes to lescome citizens on application to a comt of the Lniter states for naturalization and satisfactory proof of litness for civilized lite. ***

-. Chief Justice Taxer, in the pasatge cited for the plaintiff from

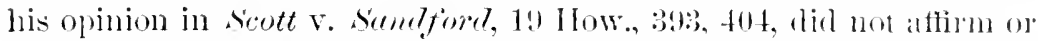
imply that either the Indian tribes, of individual members of those triber, had the right, beyond other foreigners, to become citizens of their own will, without being naturalized by the Luited states. Ilis words were: 'They' (the Indian tribe-) - may withont dombt, like the subjects of any foreign government, be naturalized hy the anthority of Congress, and become citizens of a sitate, and of the Luited states; and if an individual should leave his nation ol tribe, and take up his abode among the white population, he would he entitled to all the rights and privileges which would belong to an emigrant from any other foreign people.' But an emigrant from any foreign state cannot become a citizen of the Lnited states withont a formal renmciation of his old allegiance, and an anceptance by the I nited states of that remunciation through such form of naturalization as may be required by law.

"The distinction between citizenship by birth and citizenship by maturalization is elearly marlied in the provisions of the Constitution, by which 'no person, except a natural born citizen or' a citizen of the Enited states at the time of the adoption of this Constitution, shall be eligible to the office of President:' and 'the Congress shall hatre power to establish an uniform rule of naturalization.' Constitution, art. 2 , sec. 1 ; art. 1 , sec. 8 .

"By the Thirteenth Amendment of the Constitution shrery was prohibited. The main object of the moning sentence of the Foms. teenth Amendment was to settle the question, mon which there had been a difference of opinion throughont the comntry and in thiscont,

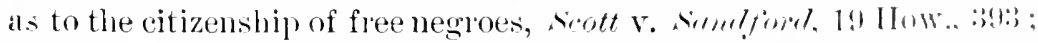
and to put it heyond doubt that all persons, white or blak and whether formerly slares or not, born or naturalizerl in the l'nited States, and owing no allegiance to any alien power, should he ritizens 
nf the Tnited States and of the state in which they resirle. Shomgln-

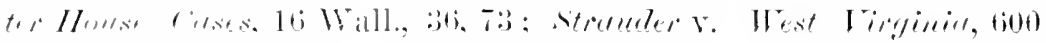

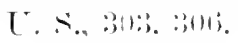

- This sertion antemplites two somers of eitizenship and two

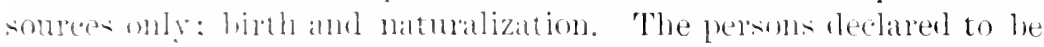

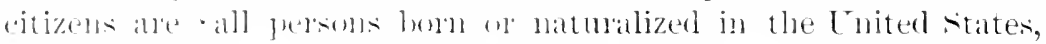
and smbject of thr jumbliction therest.' the evident meaning of these list worrls is not merely suliject in some respeet or degree to the jurisliction of the luited stater. lint completely sulject to their political jurislietion and owing them direct and immeriate allegiance. And the words lolate to the tine of birth in the one case, as they lo to the time of naturalization in the other. Persms not thus subject to the joldisliction of the Lnited states at the time of linth

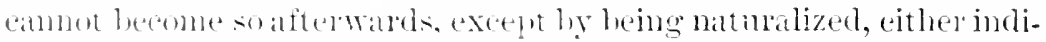

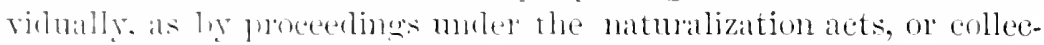
tively. as ly foree of a treaty ly which foreign territory is acenuired.

- Indians bun within the teritorial limits of the Enited states,

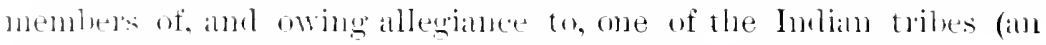

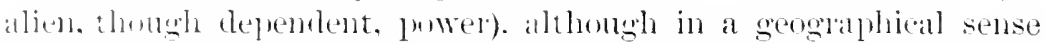
brill in the Cuited states. an no more born in the crited

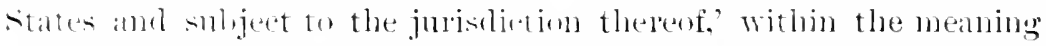
af the finst section of the Fomprenth Amendment, tham the children

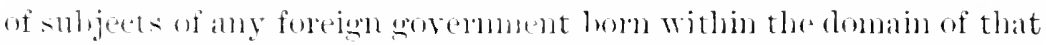
govemment, or the chiblren lom within the Cnited States, of am-

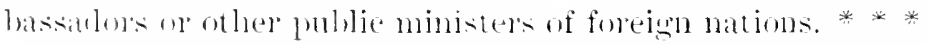

"such Indians, then, not being eitizons by hirth, an only heeome

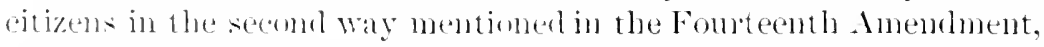
hy being 'natmalizel in the Cnited states, ly or under some

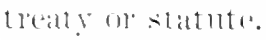

"The act of July 2-, 1sis, ch. 2t!), declaring the right of expatriation to be a natmal and inherent right of all people, and reriting that -in the reoogntion of this primeiple this govermment las frecely

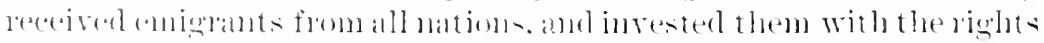

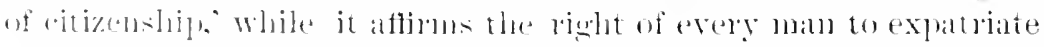

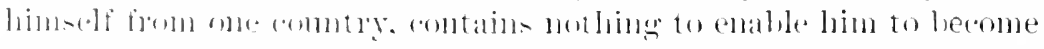

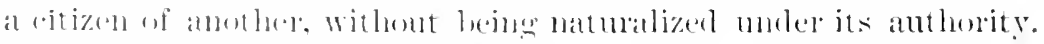

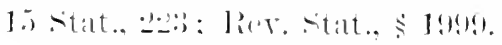

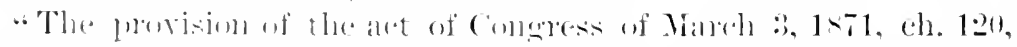

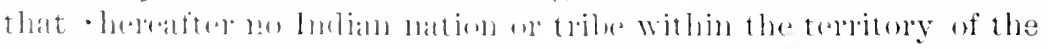

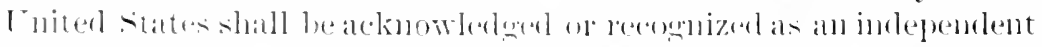

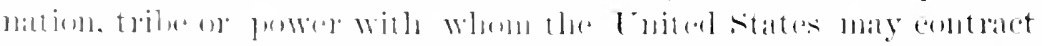

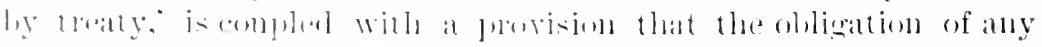

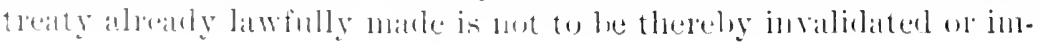


paired, and its utmost possible effeet is to refuire the Imlian tribus

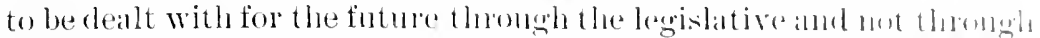

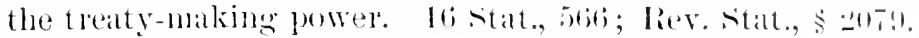

"The plaintifi, not bejug a citizen of the Lnited Statex murler tha"

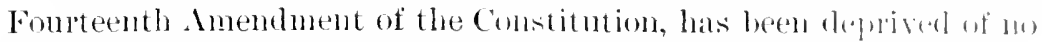
light secured by the Fifteenth Anemdment, and anmot maintan Mhis action.

"Judgenent aflin'ued.",

UNITED STATES Y. K.IG.MM.

Suplene Court of the Lxiten śtates, 1886.

(11s Enited strutes lieports, 375.)

Mr. Instice Muler delivered the opinion of the court.

"The case is brought here by certificate of division of opinion between the Cirenit Judge and the District . Jube hohling the (ilcuit court of the Lnited states for I)istrict of californial.

"The questions certified arise on a demurel to an indirtment against two Indians for mulep commited on the Indian leservation of IIoopa Valley, in the state of California, the preson mordered being also an Indian of sidd reservation. Thongh there are six prestions certified as the subject of difference, the point of them all is well set out in the third and sixth, which are as follows:

"Whether the provisions of said section 9 (of the alet of congress of March 3, 1885), miking it a crime for one Indian to eommit mulder upon another Indian, upon an Indian reservation situated wholly within the limits of a State of the Union, and making such funlian so committing the crime of mulder within and upon sucl Indian reservation 'subjeet to the same laws' and subjeet to be trict in the same eomts, and in the same mammer, and sulject to the same penalties as alle all othel persoms' committing the erime of mululu "within the exclusive julisfliction of the L'nited states, is a consitutional and valid law of the Luited states?"

" 6 . Whether the eourts of the Cnited sitates have jurislietion or anthority to try and punish an butian helonging to an lindian tribe for committing the erime of murler upon another Indian leslonging to the same Inelian tribe, hoth sustaining the usual tribal relations, said crime having heen committed 11 mo an Indian bescovattion marle and set apart for the use of the Indian tribe 10 which sild Indians both belong?' 
"Tise imlictment sets out in two comnts that Kagama, alias Paetah Billy, an Indian. murlered Iyouse, alias Ike, another Indian, at Iìmonbollt comuty, in the state of California, within the limits of the Jonpal Valley lieservation, and it charges Malnawaha aliats Ben, also an molian, with aidiug and abetting in the murler.

.. The haw referedel to in the certificate is the last section of the Inlian apheroulation act of that year, and is as follows:

.. 9. That immediately upon and after the date of the passage of thi- act all hulians commitumg agalust the pelson or property of annther Indian of other person any of the following crimes, mandy, mulle, manslanghter, rape, assantt with intent to kill, arson, burglary and lareny, within any territory of the Enited states, and either within of withont the Indian reservation, shall be subject therefor to the laws of sald Territory relating to said erimes, and shall be tried therefor in the simne eomts and in the same mammer, and shail be s!luject to the same penalties, as are all other persons chatren with the commission of the satd arines, respectiveiy ; and the said courts are luesely given juristiction in all such cases; and all snch Indians committing any of the above crimes agamst the ferson on property of another Indian or other person, within the bmondaries of any state of the Enited states, and wilhin the limits of any Indiun reservation, shall be subject to the same lavs, tried in the sibne comts and in the sime mamer, and subject to the same penalties, as are all other persons committing any of the above rimes withu the exchnive jurisdiction of the Cnited States., 2:3 Stat. ( 'l., :) $+1,: 36,59,885$.

. The almve enactunent is clearly separable into two distinct definitions of the conditions moled which ludians may be punished for the santerimes as defined by the commund haw. The first of these is whero the offence is committed whthin the linjts of a territorial govejument, whether on of off an Indian resorvation. In this class of

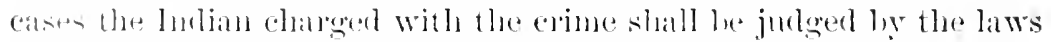

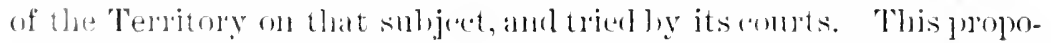
sition itself is new in legislation of compless, which has leectofore

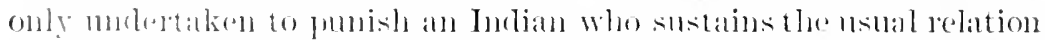

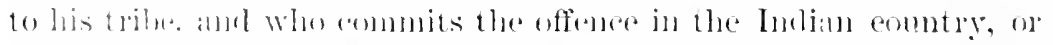
on an lutian reservation, in exceptional ases ; as where the offenee

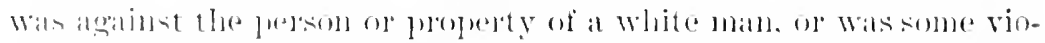

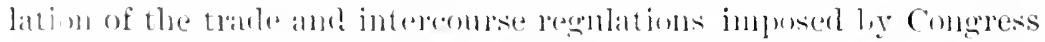

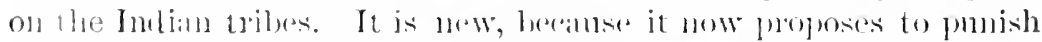
then affemes when they ale committed hy onc Indian on the person

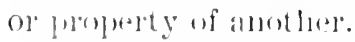

"The seconnl is where the ofifence is committer ly one Indian 
against the person of property of another, within the linits of at statto of the Enion, but on an Indian reservations. In this easte wi which the state and its tribmals womkl have juristied ion it the offenes wats

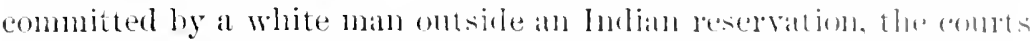

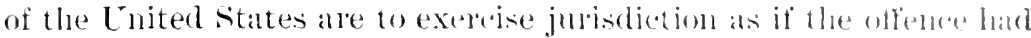
been committed at some place within the exelusive jurisoliretiono of the Enited states. The first elanse suljects all Imlians gulty of these crimes, committed within the limits of a Territory, to the liows of that "lerritory, and to its courts for trial. The second, which alplies solely to offences by Indians which are committed wilhin the limits of a state and the linits of a reservation, sulpjeets the oflender's to the laws of the United states passed for the governument of platees under the exehusive juristiction of those latws, and to trial l,y the eourts of the Lnited States. This is a still furthel advaneer, as ascolting this jurisdiction over the Lndians within the limits of the slates of the Enion.

"Althongh the offence chalged in this indictment was rommitted within a state and not within a Territory, the considerations which are necessary to a solution of the problem in regard to the one must in a large degree affect the other.

"The Constitution of the Tnited States is almost silent in monel to the relations of the government which was establisherl ly it to the numerons tribes of Indians within its borders.

"In declaring the hasis on which repesentation in the buer bunch of the Congress and direet taxation shouhl be apportionel, it was dixed

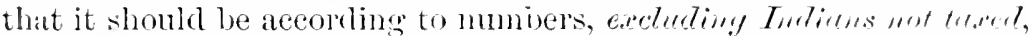
which, of course, exehded nearly all of that race, but which meant that if there were such within at fite as were taxed to smumert the govermment, they should be comnted for representation, am in the conprutation for direct taxes levier by the Enited states. This expression, exeluding Intians not taxed, is fomm in the XIVth amentment. where it deals with the same subject moler the new combitions produced by the emancipation of the slaves. Neithel of these shed much light on the power of Congress over the Indians in their exintenee as tribes, distinet from tire orelinary citizens of a state or "l'r. ritory.

"The mention of Indians in the constitntion which hat ropejerl most attention is that found in the elanse which onves cinderes "power to regulate commeree with foreign nations and anmon the sevelal States, and with the Inclian tribes.'

"This clause is relied on in the argment in the fresent (atsi", the proposition being that the statute moler eonsideration is al roundition of commerce with the Indian tribes. Bnt we think it womkl le a 
very stranerl construction of this clatuse, that a system of eriminal

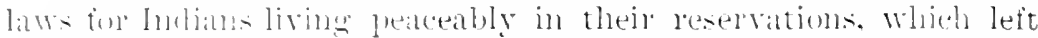

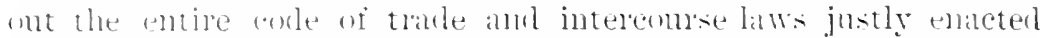

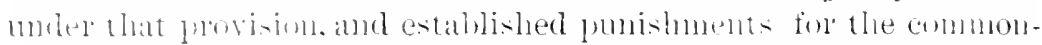

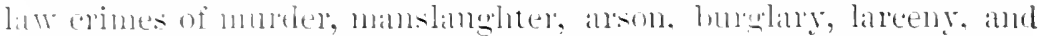
the like, without any leference to their relation to any kind of commeree. Was anthorized hy the grant of puwer to regulate commeree with the molian tribus. While we ale mot ahle to see, in either of these damses of the Constitution and itsantementents any delesation

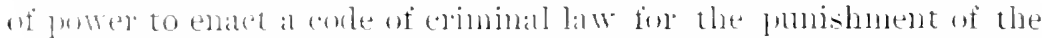

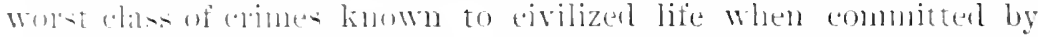

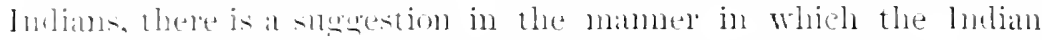

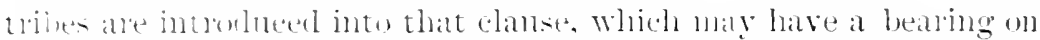

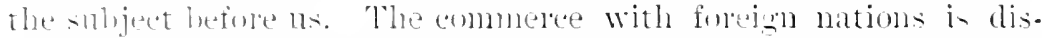
timely staterlas smbitted to the comtrol of Conguess. Were the

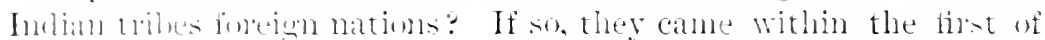
the three classes of commeree mentioned, and dia not need to be repeated as Indian tribes. Were they nations, in the minds of the flatmels of the c'mstitution? If so, the natural phase would have befoll foretgn nations and Indian nations, an, in the terseness of

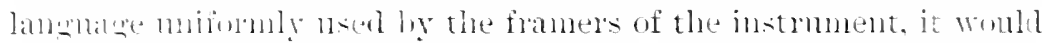

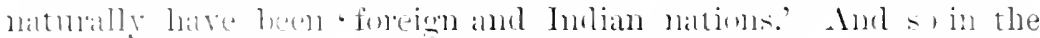

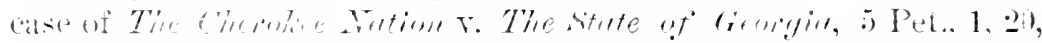

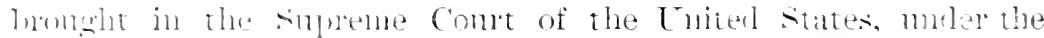

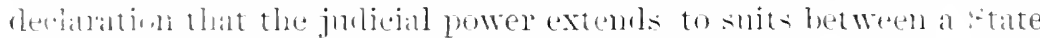

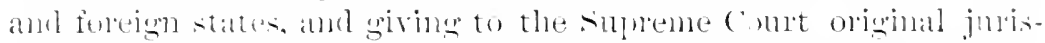

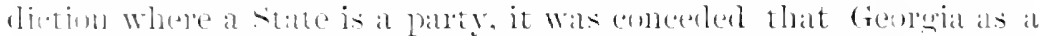
state tanne within the clanne, hat held that the cherokets wele not

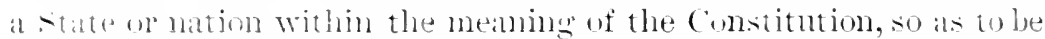
allie to matintain the suit.

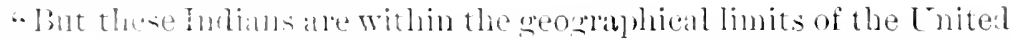

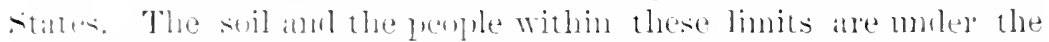

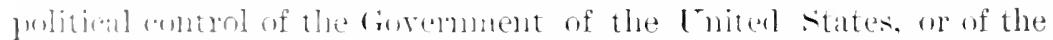

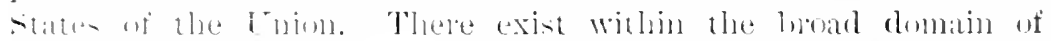

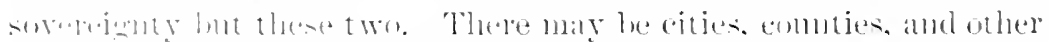

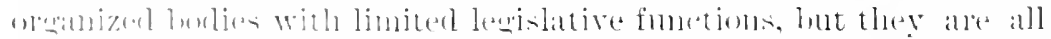

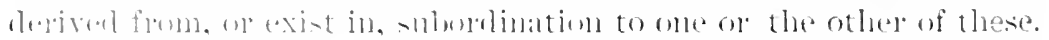

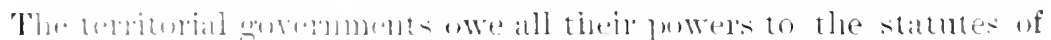

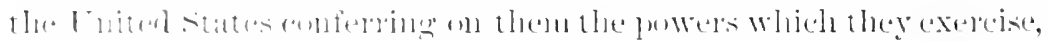

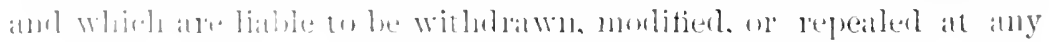

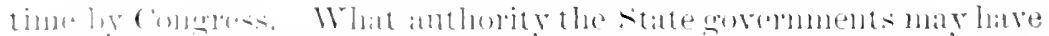

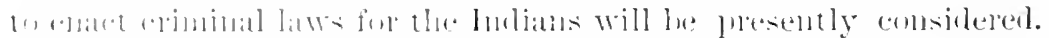

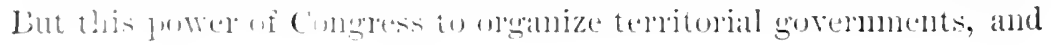


make laws for their inhabitants, arises not so mueh from the "liulse? in the constitution in regand to dispesing of and matking moles and regulations concerning the 'lerritory and othere property of then Initerl states, as from the ownership of the eomntry in whinh lla Territories are, and the right of exehsive sovereignty which must exist in the National Government, and ean be fomm molnere alse.

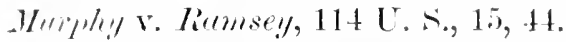

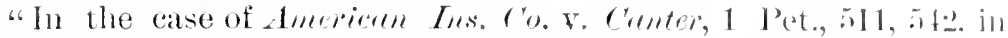

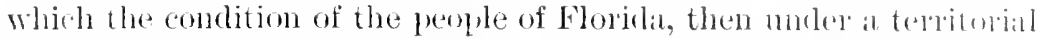

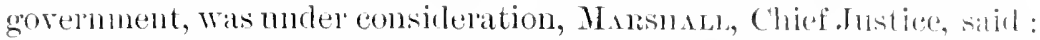
'Perlatps the power of governing a 'Territory belonging tuthe Luitrel States, which has not, by hecoming a state, acpuired the monus of self-gorermment, may result necessarily from the fact that it is mut within the jurisdiction of any particular state, and is within the powel and jurisdiction of the L'nited states. The right to goreln may be the inevitable consequence of the right to aconire Territory. Whicherer may be the source whence the power is derivell. thet possession of it is mquestioned.'

"In the case of the Crited stotes v. Rogfers, 4 How., 587, 57:2, where a white man pleaded in abitement to an indictment for murler committed in the country of the Clorokre Indians, that he harl been adouted hy and become a member of the Cherokee tribe, chief. Instice Thxey said: "The comntry in which the erime is chatred to have been committed is a prot of the territory of the Lnited statrs, and not within the limits of any particular state. It is true it is occuprecl by the ('herokee Indians. But it has been assigned to them by the Enited states as a place of domicil for the tribe and they hold with the assent of the Enited states, and under their authority.' Ifter referring to the policy of the Enropean nations and the Inited states in asserting dominiom orer all the comntry discovered by them, and the justice of this conlse, he ands: "But had it been otherwise, and were the right and the proniety of exercising this power now open to question, yet it $i .3$ a question for the law-making and political dopartments of the government, and not for the judielal. It is ond futy to oxpound and exeente the law as we find it, and we think it too firmly and clearly establisherl to admit of dispute, that the lucian tribes, residing within the territorial limits of the Lnited states, ale subject to their authority, and when the country occupied ly ont of them is not within the limits of one of the States, Congress maly ly law punish any offence committed there, no matter whether the offender be a white man or an Indian.'

"The Indian reservation in the case before us is land bough by the United States from Mexico by the treaty of (inadilonpe Inidalgo, 
and the whole of California, with the allegiance of its inhabitants, many of whom wele lublins, was transferred by that treaty to the Luitul ritules.

" The relation of the Indian tribes living within the borders of the Enited states, both before and since the lievolution, to the penple of the Inited states has always been an anomalous one and of a (o)mplex chamater.

- Following the policy of the European governments in the discovery of America towarls the Indians who were found here, the enlonies hefore the levolution and the states and the Cnited states simer. hatre reconnizer in the Indians a posiessoug right to the soil orer which they roaned and hunted and established oceasional villises. But they atserted an ultimate title in the land itself, by which the Indian tribes were forbidlen to sell or transfer it to other nations or people withont the comsent of this paramount authority. $1 \mathrm{I}_{1+3}$ a tribe wisher to dispose of its land, or any part of it, or the stateor the Cuited states wished to purchase it, a treaty with the tribe Wat the only mode in which this could he done. The Luited states reconized no right in private persons, or in other nations, to make suld a purchase by treaty or otherwise. With the Indians themselves these relations are equally dificult to define. They were, and always have been, regarled as haring a semi-independent position when they preserved their tribal relations; not as states, not its nations, not as possessed of the full attributes of sovereignty, lut ats a separate people with the power of regulating their internal and social lelations, and thus far not brouglat unler the laws of the Cuinu of of the state within whose limits they resided.

- Merhaps the best statement of their position is fom in the tro mpinions of this comt hy Chief Justice Marshall in the case of the

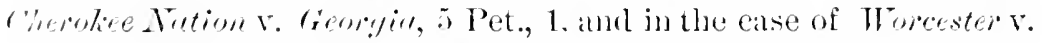

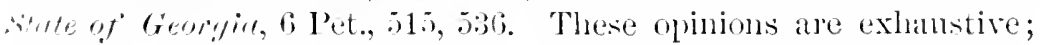
and in the sepanate opinion of Mr. Justice Ibaldwin, in the former, is a very ralualle resmme of the treaties and statutes concerning the Intian tribes previons to and ruring the eonferluation.

- In the first of the above cases it was held that these tribes were neither states une nations, hat only some of the attributes of sor"repinty, and combl not he so far recognized in that capaly as to smstain a snit in the supreme court of the Lnited States. In the second case it was sibl that they were not smbjeet to the jurisdiction atserter over them ly the state of Georgia, which, beeanse they were within its limits where they hat been for ages, har attempted to extend her liws and the jurisiliction of hes comts over them.

. In the opinions in these cases they are spolien of as "wath of 
the nation,' 'pupils,' as local depumlent communities. In lhis spirit the Eniterl states has comblueterl its relations to them hom its organization to this time. But, after an experience of a hmulreal years of the treaty-making system of govermment. (1) meness hats determined upon a new departure-to govern them hy achof of (im-

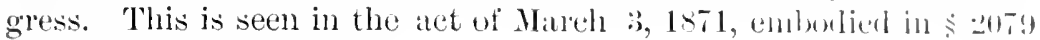
of the Revised statutes:

" No Indian nation or tribe, within the territory of the Tuited States shall be acknowlergexl on resomized as an imlenendent nattion, tribe, or power, with whom the Uniter states maly comblact by treaty; but no obligation of any treaty lawfully made and ratified with any such Indian nation or tribe prior to Manch third, eighteen hundred and seventy-one, shall be herely invalidited or impariced.'

"The case of Crom Tlog, 109 U. S., 556, in which an anderment with the Sioux Indians, ratified by an act of Congress, was smpuserl to extend over them the laws of the Lnited States and the jurindiction of its courts, covering murder and other grave erimes, shms the purpose of Congress in this new departure. The decision in that case admits that if the intention of Congress harl been to punish, by the United States courts, the murder of one Indian by another, the law rould have been valid. But the court could not see, in the agreement with the Indians sanctioned by Congress, a pmrose to repeal $\$ 21+6$ of the Revised Statutes, which expressly exchules from that juriscliction the case of a crime committer by one Indian against another in the Indian conntry. The passage of the act now under consideration was designed to remove that oljection, am to go further by including such erimes on reservations lying within a state.

"Is this latter fact a fatal objection to the law? The statute itself contains no express limitation upon the power's of a state on the jurisdietion of its conrts. If there be any limitation in either of these, it grows ont of the implication arising from the filct llat Congress has defined a crime committer within the state, and made it punishable in the comrts of the Cnited states. But Comgress has done this, and can do it, with regard to all offences relating to matters to which the Federal authority extends. Does that authority extend to this case?

"It will be seen at once that the nature of the offence (muricr) is one which in almost all cases of its commission is pumishable ly the laws of the States, and within the jurisdiction of their courts. 'The distinction is claimed to be that the offence murler the statute is committed by an Indian, that it is committed on a reservatim set 
apant within the state for residence of the tribe of Indians by the

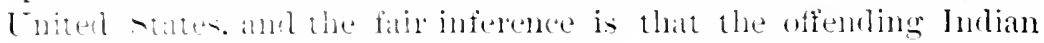
shall helome to that w some ather tribe. It does mot interfere with

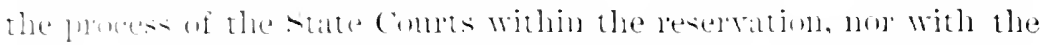

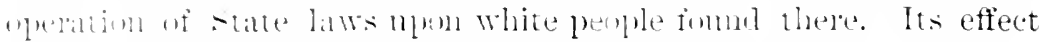

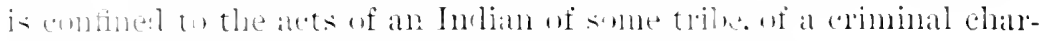

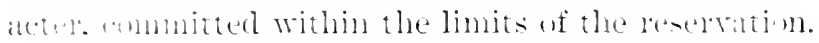

-. It seems to us that this is within the ampletenty of Congress. These Imbian trithes are the warts of the nation. They are com-

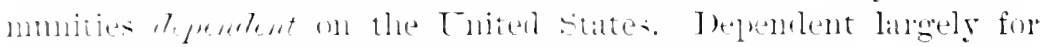
thet daly ford. Imepentent fur their political rights. They owe no allewinde to the stater. and rectre from them no protection. liegmae of the lowal ill-feeling, the penple of the states where they ane tamb are often their deatliest endus. From their rery weaknew and helplessness, so langely due to the comres of dealing of the Ifeleral foremment with them and the treaties in which it has been lmomi-ed, there arises the duty of potection. and with it the power. This has alwars been recognized by the Executive and hy Congress, and hy this Count whenerer the question has arisen.

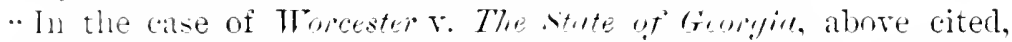
it wa-held that, though the Indians had by treaty sold their land whing that state, and agreed to remre awas. which thes had failen th ho, the state endil not, while they remained on those lumls. cxtend its laws, crininal and eivil, orer the tribes ; that the dulnan pomer to compel their removal was in the Lnited states, ant the tribe was moler thei" protection, and could not be subjected to the latwe of the state and the process of iis courts.

.. The sime thing was decided in the cave of Fenlors v. Blacksmith

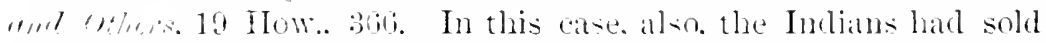

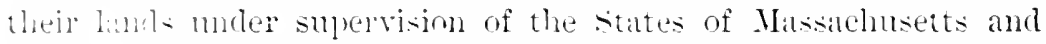

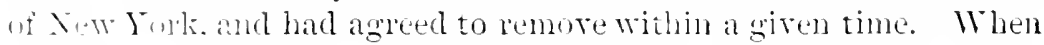
the time came a shit to recover some of the lond was brought in the -npreme cont of New York, which sare judgment for the

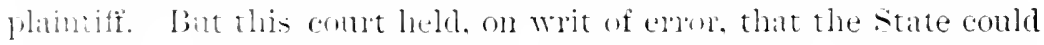
mot enionce this lemoval. lut the duty and the jurer to do so was in

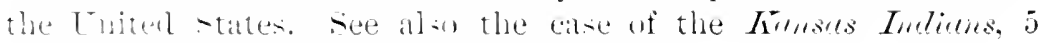

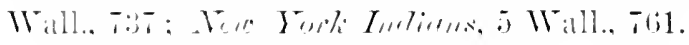

. The purer of the cincral forermment orel these remmants of a race nuce porrertul, now weali and dininished in nmmbers, is necesongly their protection, as well as to the satety of those among whom they dwell. It must exist in that gorermment, because it never has existed anywhere clie. hecamse the theater of its exereise is within the greographical linits of the Lnited states, beciluse it has 
never been denied, and because it alone call enforce its laws on all the tribes.

"We answer the questions propounded to lls, that the bh seetim of the act of March, 1855, is a valid law in both its branciles, and that the Cirenit Court of the C'nited states for the District of ('allifornia has jurisdiction of the offence charged in the indictment in this calse."

16 



\section{PART II.}

\section{INTERNATIONAL RELATIONS AS MODIFIED BY WAR}

\section{CIIAPTER I.}

MEASUIES SHORT OF WAR.

$\S$ ?6.-REPRISALS.

\section{SILESIAN LOAN, 1752.}

\section{(Martens: Causes Cétebres, II., 97.)}

The controversy in this case was as recards the right of a state to confiscate, for any reason, its public debt, held by foreign creditors.

In 1735 the Emperor Charles VI. borrowed of several London merehants the sum of $1,000,000$ écus (3,000,000 francs), and as security for repayment, gave them a mortginge on the revenues of the Province of Silesia. After the death of the Emperor (17fo) Flederick II. of Prussia seized Silesia, which Maria Theresa was constrained to formally cede to him by the treaties of Breslan and berlin. 17.2.'. Frederick agreed, however, to assme the debt of the province and to paly the English creditor's.

In 174t war broke ont hetween England on the one sirle ank France and spain on the other. And luring the next fonr gears the English seized eighteen Prussiaio ressels and thirty-three othel' nentral vessels, freighted in whole or in part by Prnsian suljeets, and laden with merchandise on accomnt of French sulpjects. Theste ships and their cargoes were seized for carrying contrabinu of watr or goods belonging to the enemy.

The government of England having refused to listen to the denamel of the Prussian govermment for an indemnity to the alimants, 
Fretierick II. apponted a commission in 1751 to examine these daims and compensiate the elaimants ont of the silesian loan, the payment of which hat been withlselel for this purpose. The next year the commission gave julgment. transferring the English mortgalge (a) the silesian revenues to the Prussian claimants as indemnity for the seizne of their property.

The contention of the Prussian govermment was that England hat acted illecally in calpturing the property of leer enemies on nentral rescels.-that the rule. supported by the practice of most of the nations of Enrope, was " free ships, free soods:" and further that the treatien of England with the nentral powers. confirmed by the declarations of the English ministry to diplomatic agents of P'ussia. had exempted such goods from capture. According to the law of natme. say the I'rusian eommissioners, the ressel of a nentral is his property wherever it may be fond ( $i$ e. on the high seas), and a belligerent has no more right to enter it to seize the goods of his chems. than he bas to enter a nentral port and seize the vessels of lis ent 11 : therein anchored.

As to eontraband of war, the general rule of international law linited it to muntions of war, the only exception being things of "menifitis "sos destined to a beseiged or blockaded port. It was -hown that England herself had made several treaties in which provisions ancl articles of naval construction were expressly excluded from the list of contraband.

Finally. it was asserted, that the English admiralty court had no right of jurindietion over Prussian vestels or cargoes seized in places not within English territory: and that these unjust confiscations furnished a just eame for reprisals on the part of I'russia.

The matter was referred hy the English government to a commission. compond of Sir R. Lee. julge of the supreme Court. Dr. P'anl, the King - Alvoeate-General in the eivil eourts, sir Dudley Ryder, the diturney-(ieneral, and Mr. William Mrurray, solicitor-Genesal (cetebrater later as Lord Mansfield). The report of this commission

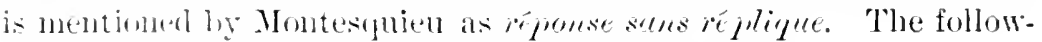
ing buglo-itions were latid down:-

(1) When two powers alde at war, each has the right to seize as prize of war. the ships and merehamblise of the other, hut the property of neatrals should not be calptured so long as they preserved their nentrality. It follows, therefore. (2) That the goods of an enemy on brand at nentral vessed may he seized. (:) That nentral monds. not contrabual, on board the vessel of an enemy, should be

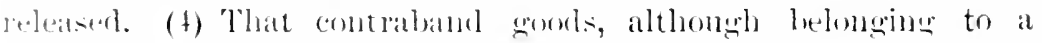
lethtral, may be setized ats prize of war. (j) Defore alphepriation of 
captured goods, there must be eondemmation by a court of anminalty,

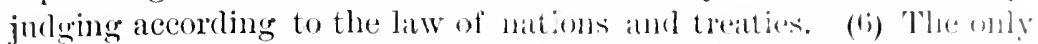
eompetent court for that purpose is the aout of the capur. (7) 111

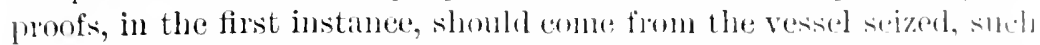
as the ship's papers and the depositions of the matster and principul officers of the ship. (8) Every vesisel must be furnishert with the enstonary papers. (9) If a seizure is made without sutheien eromols, the eaptor is to be eomelemed in damages am expenses. (10) Finally, the law of nations permits reprisils in only two catses First, in the case of a violent wrong directed and suplorted by thes sovereign, or second, of an absolnte renial of justice on the part of all the tribunals, and the sovereign himself, in a matter that admits of no doubt.

The report then takes up the cases of the captured vesscels in detail, and shows that they were julged with the utmost impartiality. It would seem that all the Prussian vessels were restorel, and all the cargoes in both classes of vessels save fifteen were likewise restorerl. The Prussian arguments are then answered seriatim, and shown to be without foundation in law or enston. Perhaps the weakest pint of the report is the answer to the Prussian contention that contratband was limited to munitions of war. 'The question, says Wheaton, was at that time in litigation between England and the states of the north who had an interest in the free exportation of the procucts of their soil, as naval stores and provisions. The commissioner's only said that Prussia could not claim the advantage of molifications of international law which had been the result of mutual coneesions between England and certain neutral states.

As to the Silesian loan, the King of Prussia had pledgerl his royil word to pay the debt dne to private individuals. This debt rass negotiable, and a large part of it may lave been transferred to sub. jects of other states. It would he difficult to find a case where a sovereign had ever seized hy way of reprisal a deht which he owet to private individuals. When indivaluals lend money to a sorerergn, they have to trust to his honor; for a sovereign may not, like other men, be sued, and forced to pay by the mterposituon of comrts of liw. England, France, and spain, it was asserted, had adhered religionsly to the principle of the inviolability of the public faith.

The dispute was finally settleci hy a clause of the treaty of Westminster, January 16, 1756, by which Frederick stipulater to pay the English creditors, and the English govermment agreed to pay 2010.10u pounds sterling to satisfy the Prussian claimant. (Vlueaton: IIintoire du Droit des Gens, I., 260.)

The importance of this case rests, more upon the able exposition of 
the lat of marime caltume ly the English commissioners, than

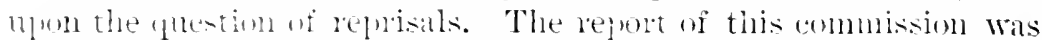
gentrally ateropert as a correct statement of the law of prize as then

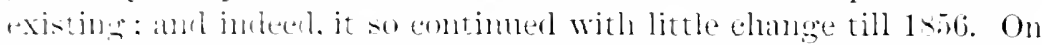
the other hamclo the l'ussian contention wats an attempt to establish the minciple of “ fuee ships," free gonds, which was not lealized till a

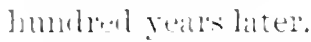

As to the glestion of repisil, England rintually yielded the point

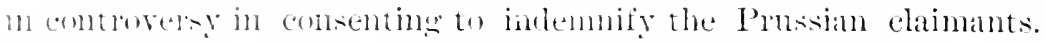

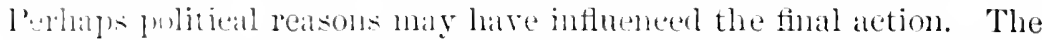
alliane letwers Frante amb Anstriat at this time forced England and Prusia into a comber-alliance, and their minor ditferences were surethenl over lather hastily.

\section{CASE OF DON PACIFICO, 1850.}

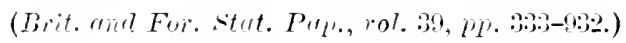

Is a state rerpon-ible for the lawhs actions of its citizens. to foreign states

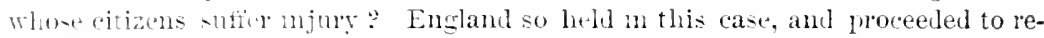
lisals to entore her lution.

David Pacifico was a Jew, born at Gibnaltar, hut in 1847 resident at Athens. By vintue of his linth, he was entitled to the character of a british sulject: he lad repusented himself in that character and laal a britisle jassont.

It was rustomany in Greece for the people to signalize the festival

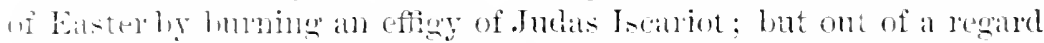

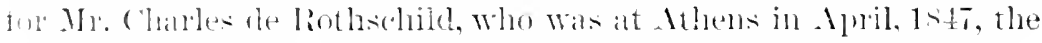

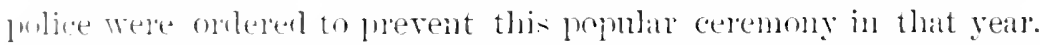
'The mol, attriluting this action of the Atlenian anthorities to the

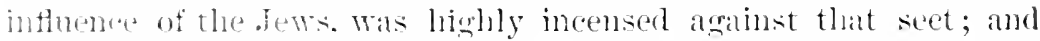

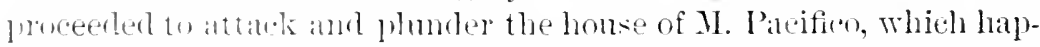
gened to stand near the plate where the effigr was wont to be burned.

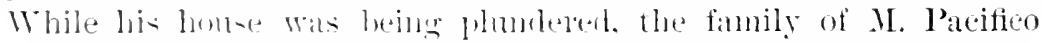
recejvel the crosicest ill-treatment. M. Pareifico lodged a eomplaint with the procurem-enteral of the king. who, on the very day of the ring. helil an implest on the sind, and heard the testimony of the

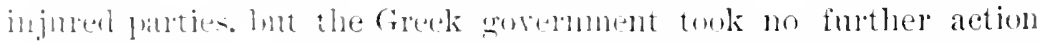
in the matter. II. Pacifico, believine that. ly reason of the ortimm

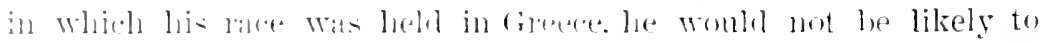

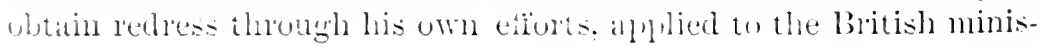


ter at Athens, Sir Edmund Lyons. This gentleman called the attention of the Greek govermment to the fints of the catse: hot his note. wils left manswered for nine months, althomgh he wrote saverat

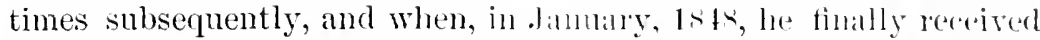
an answer, it was chite msatisfactory. The government of cireece suggested that M. Pacifico should collect his damages, through the ordinary courts, from the persons who took part in the riot.

There were other British claims pulding against Greeres some of which were of long standing, and als no sitisfaction could be obtianed from the Greek government, Mr. Wyse, successol to Sir Ellumud Lyons, was instructed, in December, 1\$49, to deliver an ultimatum to that govermment; and in case it was rejected, Arhmiral Panker, commanding the English fleet in the Mediterranean, was ordererl to lay an embargo upon Greek shipping. The demands of the ultimatum were rejected, and the embargo was immediately enforced, several Greek ships of war and many merchant vessels being seized and detained in the Piræus.

Shortly afterwards, in February, 1850, French mediation was accepted, pending which, active meisures were suspented on the part of the English fleet. Mr. Wyse and Baron Gros, the French mediator, came to an agreement upon all points at issue silve one; namely, a demand of indemnity by Pacifico for the loss of papers which, he alleged, were evilences of a valid clatim by him against the Portuguese govermment for twenty-one thousind pomds. Mr. Wyse proposed that the Greek gorermment should put into his hands a sum of money as security for the payment of this claim, if, after investigation, it should appear to be well-founded. Baron Gros objected to this, because he not only considered the clatim to be worthless, but he contended, further, that this demand was too humiliating for Greece. Failing to agree upon this point, Baron Gros withdrew from the negotiations; thereupon, Mr. Wyse sent a new ultimatum to the Greek govermment, and this time it was accepted, and the indemnity demanded immediately paid.

The total amount of this indemnity was $6,40: 3,10 \mathrm{~s}$, with the addition of a deposit of about $5,000 \mathrm{l}$ as security for the Portugnese claim. The indemnity awarded included the following items: For personal injury, 500l; for loss of household effects, jewelry, etc., $4.26 \bar{l}$, ss. As to his Portnguese claim, a comminsion, having investigaterl the case reported in 1851 , that it could not be substantiated : but in view of the expense he had incurred, and a small amount due him, he was awarded 150 ?

Don Pacifico has usually been represented as an adventurer who had little claim upon the sympathy of his fellow-men; and England 
has generally been severely criticised for supporting his claim. Tet if he was a British subject, he had a right to be protected as such. He was born in British territory, Gibraltar, and his father was born in London. IIis letters relating to this affair are dignified, and show much ability. His chief erime would seem to have been that of being a Jew. The argument that Pacifico ought to have resorted to the ordinary courts of Greece to obtain his indemnity is quite untenable. What clance of success would he have had in a suit against at mob of several hundred persons, to him unknown, and with public opinion against him? Indeed he bronglit the matter to the notice of the judieiary deprartment of the govermment; and it was then the duty of the government to take further proceedings. The fact would seem to be that the whole trouble lay in the weak and vacillating poliey of the Greek government, which conld easily have avoided all tronlule by simply doing justice to M. Pacifico and the other daimants. Whether the British government was justified in resorting to such extreme measures may be questioned; but that some aetion was called for there can be little doult. ${ }^{1}$

1 Other eases of Reprisal. The bombardment of Greytom, 1854.-"Greytown was a port on the Mosquito eoast, in which some United States citizens resitled. These eitizens, and others interested with them in business, were subjected to sross indignities and injuries by the loeal anthorities, who were British, but who professed to aet under authority from the king or ehief of the Mosquito Islants. The parties injured accordingly appealed to the commander of the United States sloop-of-war Cyane, then lying near that port, for proteetion. To punish the anthorities for their aetion, he bombarded the town. For this aet he was denouncel by the British resilents, who elaimed that the British government had a protectorate over that region. II is action was sustained by the govermment of the Cnited States, the gromul being the neeessity of pruishing in this way a great wrong to citizens of the United States, ant preventing its eontinuance." (1 Wharton's Digest, p. 2.2.? and II., p. 5:5.)

A favorite form of reprisal in coercing weaker states has been by what are ealled "parific blorkatks:" thus, in 1\$27" the coasts of Greee were blockaded by the English, French and Russian squadrons, while the three powers professed to be at peace with Turkey."

"The Togus was blockaded by Franee in 1\$31, New Granada by England in 1861, Mexico by France in 1..35, and La Plata from 1838 to 1840 by France, and from 1845 to 1,4 by France and England." (Hall's International Law, Ed. 1890, p. 369.)

In like manner, without a deelaration of war, France blockaded the Island of Formosa. and in 1s:3, the coast of siam. In 1856 Greece was blockaded by the fletets of nearly all the great European powers. 
Section 27.-Mostife Embigan.

TIIE "BOEDTS ILIST."

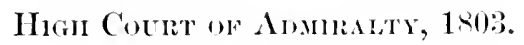

(5) C. Robinsom, 2.45.)

This was the ease of a Dutch ship on a voyage from Demerara to Batavia, embargoed at the Cape of (rood Ilope by an English squallon hefore the artual declaration of war against Holland in $1 \diamond 0 ;$, and afterwards condemmıl as amemy's property.

Sir W. Scotr, J.-Extract:-“'This was the state of the first soizure. It was at first equivoeal ; and if the nutter in dispute harl terminated in reconciliation, the seizure would lave been converted into a mere civil embargo. That would have been the retroactive effect of that course of eircumstances. On the eontrary, if the transatetions end in hostility, the retroactive efreet is directly the other way. It inlpresses the direct hostile character npon the original seizure. It is declared to be no embargo, it is no longer an equivocal act, sulject to two interpretations; there is a declaration of the animes, by which it was done, that it was done hostili animo and is to be considered as an hostile measure ab initio. The property taken is liable to he used as the property of persons, trespassers ab initio, and guilty of injuries, which they have refused to redeem by any amicable alterition of their measures. This is the necessary conrse, if no particular compact intervenes for the restitution of such property tiken before a formal declaration of hostilities. No such convention is set up on either side, and the state, by directing proceedings against this property for condemnation, has signified a eontrary intention. Accordingly the general mass of Dutch property has been condemneal on this retroactive effect; and this property stands upon the same footing. ${ }^{1}$

1 The object of a hostile embargo may be by way of reprisal to obtain satiofaction for an alleged injury: or, it mal he. in the expectation of the outbreak of wall. to get possession of property which will presumably be hostile, for the purpen of confiseating it later-after the aetual outbreak of war. Although the govermment might restore such property at the breaking out of war, it has not been the practice to do so; and henee, as Dana says, embargo "refers itself direstly to lh. 


\section{SeCtiox 2-.-DecliRitiox of War.}

\section{TIE "TELTONIA."}

Piris Cuexcil, 1870.

$$
\text { (t Prixy Conincil Reports, 171.) }
$$

War may exist de incto without a declaration, but in that case there must be actual commenicenent of hostilities.

11.7. that a tate of war did not exist between France and Prussia, in 1570, frior in the 1!th of July, when a formal declaration on the part of France was ronmuniatal to the Prussian Govermment.

The Lorl Chief Justice Melusin:-_This is an appeal in a cause instituted under the bth section of the Admiralty Court Act, 1861,

quistion of the right, on breaking ont of war, to seize ships and cargoes found in jort." (banst : Wheaton. p. 8.:- note.)

In the rase of Linto r. Itudney, Douslas, 615, Lord Mansfield said, "Ships not knowing of lostilities come in by mistake; upon the declaration of war, or hostilitic. all the ships of the enemy are cletained in onr ports, to be confiscated as the property of the enemy, if no reciprocal agreement is male."

The enche writers upon international law do not mention embargo, at least in the serse of hostile embargo. Intil towarts the end of the last centurs, there was really no distinction male between property fomb on lans. and that found atloat. In both cases it wa-liable to capture. At the time of livnkershoek and of latel. private groperty of 1 ly enemy was contisated. thongh sone treaties late "xpmpted it from spizme at the commenfentent of war. (Bynkershow, I.,

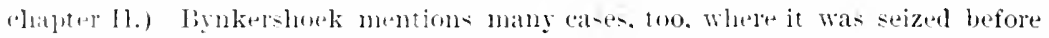
the derlamation of war. It was left to the English admiralty courts to formulate the pratite into fergal maxims ly their decisions. As to the retroactive effeet of

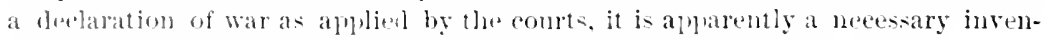
tion of sir William sott to deralize a pratetiee alleady in rogue.

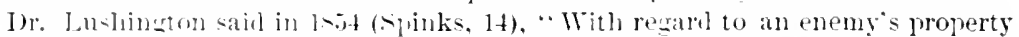

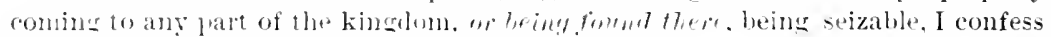
I am atoni-hed that doubt should exist on the subject. I apluthen the law has been this, that it is romperent for any peron to take pusession of such property,

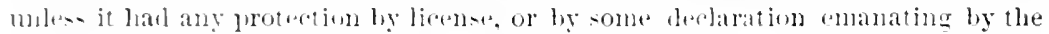
anthority of the crown. and to ani-t the crown to procesd against it to aljudiration."

At the breaking out of the f'rmean War in 1-it, merchant ressels of the enemy were allowed by the belligerents six weels for louling their eargoes and departing. And further. vessels of the same character sailing from foreign ports prior to the promulgation of these orders, wele allowed to enter the ports of the enemy and 
on behalf of Messis. Nmmam, Fox, de ('o, the ennsignous of a hill af

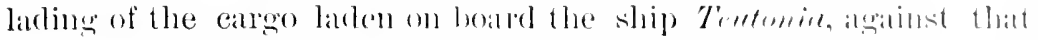
ship and her freight, and acainst the owner of the ressed.

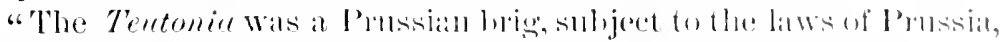

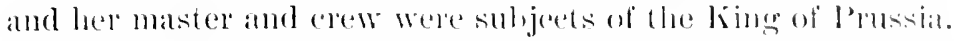

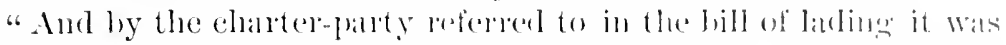

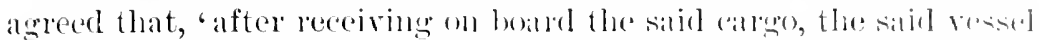

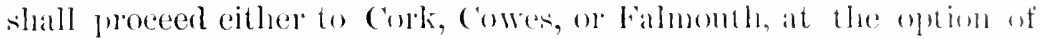

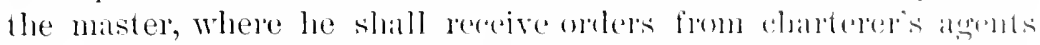

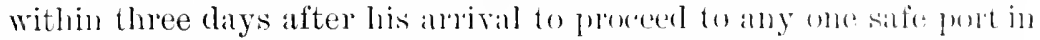
Great Britain or on the Continent between Ifave and I lamburesh, both included, and there, aceording to bills of lading and chaterparty, deliver the argo, "the act of corl, the Queen's enemies, fire, and all and every ofler risk, dallgers, and alecildents of the seas, rivers, and navigation of whatever nature and kiml soever excepted," freight to be paid in mamer herein mentioned on a true and right delivery of the cargo in the port of discharge at and after the rate of $45 \mathrm{~s}$. British sterling jer ton.'

"The ressel arrived at Falmonth on 10th of July; and the master, whilst there, heard rumours that wal was poblahle betwere liance and Prussia. On the 11 th of July, the master receiverl orders from the consignees to diseluare the cargonat Donkirk; and he at ondee set sail for Dunkirk, and arrived at a ristance of abont fomrtern miles off that port, at 120 colock at night of the $16 \mathrm{hl}$, which was a Saturday; and the master says that, after lying to for aboat two

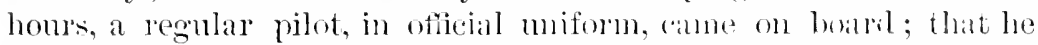
asker the pilot abont the war ; that the pilot told him it had been declared two days ago; that he asked the pilot where he combl bring-to in safety, so that he might aseertain whether war was ate mally leclared or not; that the pilot offered to talie him to fholning, or the Iowns, or wherever he liked. The master elected to son the Downs; and he anchored there on sumbly morning, the 17th. at 10 orlock. He says, that on that day he could ohtain no advice or

discharge their cargoes and to depart. The initiation of this molifiration of the

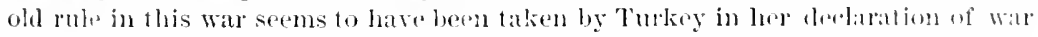

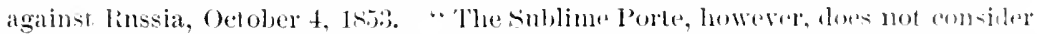
it just that, agreeably to aneient nsaere, an embargo should he latid on liumian mer-

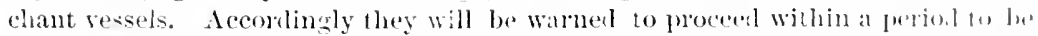
fixed hereafter to the Black fiea or to the Meditorranean, ats they rhoore." (IIallerk. 1. 3tit. Ifertslet, II., IITi.)

The departure from the old rule in this case, eompled with the numprome treaties

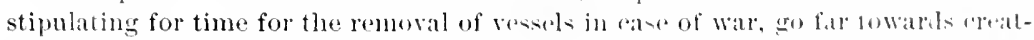
ing that change of practice which ultimately changes the law of nations. (Dana's Wheitom, note No. 150.) 
information: that on the Monday, the 1 -th, he was on shole at Deal, and the Gemman consul told him that war hald broken out. He telegraplied to the owner, who was his father, and received an answel. forlidling him to go to Dunkilk; and on 'Tuesday the 19 th le tork the ship into Dover. as the nearest port.

- On the same 19th of .July, the French decelaration of war wats delivered to the Prussian Goremment at berlin. which was known the silne day by telegraph in Englind. (On the asd of July, an agent of the plaintiffs went to Jover, and reguired the master to lroceel to Domkirk, which he refused to do. Afterwards, on the 1st of August, the plaintitis repuired the master to deliver them the cargo at Dover, which he refused to do mnless he was paid his freight.

- Ender these circmmstances, the plaintiffs allege that the master has committed two hreaches of contrat or duty: first in refusing to proceed to, and deliver the cargo at. Imukink; and secondly they complain that, when the perfomance of the contract becane impossible, and the contract was, as they allege, dissolved by the war, the master was not justified in refusing to deliver the cargo to the plaintiff: at Dover without payment of treight.

". The first question to be consirlered is. whether the master was hound to have entered the port of Dunkirli on the 17th of July : and on that guestion, the leaned Judge (Nir R. Pmumone) in the comt below las fomd that on the 16th of . Inly, the Tentomire could not hatre entered the port of Immkirli with her cargo withont being exposed to the penalties of trading with the enemy of her comntry ; but that, if this was an erroneons application of the law to the faets at that date, the eircumstances justitied the master in pausing and making further inguiries as to the existing relations between his own comntry and France. and that he did not exceed the limits of a reasonable time in makiug the inquiry.

"Their Iondships have great difficulty in agreeing with the learned Jurge that the Tentomie could not have entered I)unkirk withont leing exposed to the penalties of trating with the enemy of its enuntry on the loth of July. There does not appear to their Lorlships to be any satisfactory evidence that a state of war existerl between France and Prussia prior to the 1, th of July.

"Their Lordships do not think that either the dechation made ly the French Minister to the French Chambers on the 16th of July, or the telegram sent ly Count Bismarck to the I'mssian Ambasidor in Londom, in which he states that that dechation appears to be equal to a declaration of war, amomuts to actual declaration of war. And though it is true, as stated by the learned Judge, that a 


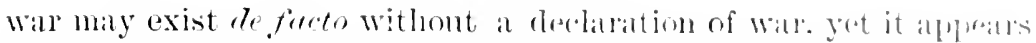

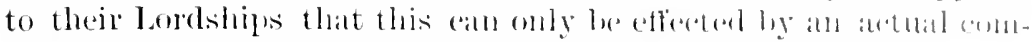

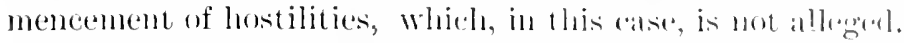

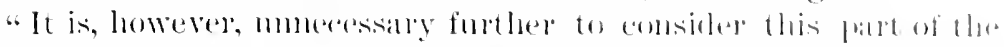

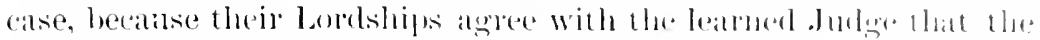

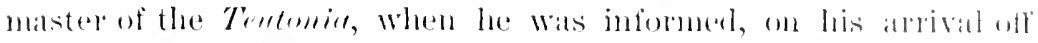
Donkirk, by the pilot, althomgh incorrectly, that wat hat leren actmally declared two dilys hefore, was entithed to panse and to take a reasonable time to make forther implories, and that he did mot excerel the limits of a reasomatble time ju making inguiries.

"If the master had entered l)mkirk, and it had tumed out that wall had been previomsly deebared, he womld have entered it with notice that he was entering an enemy's jolt, and this would have obvionsly exposed his ship to condemmation, and might haverexposerl himself to severe penalties when he retmmed to his own ammty. It seemsobvoms that, il a master recoives corlible infommation that, if he contimmes in the direct comse of his royage, his ship will be exposed to some imminent peril, as, for instance, that theje are

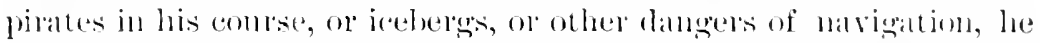
must be justified in pansing and deviating form the direce comser, and taking any step which a probent man womld take for the purpose of aroiding the danger. And their Lomblips ander, if

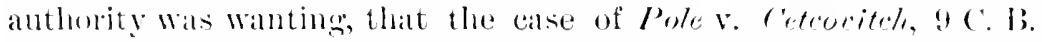
(11. s.), 430, is an anthority in point. It was angued, however, on the fart of the alpullatis, that, to justify this comse, both ship and

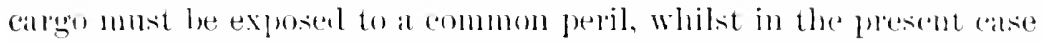
the cargo, being the poperty of a nentral owner, would have been in no langer from being anried into a Fench port, and it was argued that thomgla a masteg might be justified in deviating form

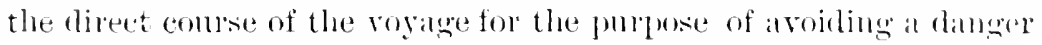
to which both ship ame carso were cxposed, althomed it mieldt afterwards tum ont that the information mpon which the matster aleted was ineorrect, yet that if the reportod damgrel was a danger to the ship alone, the master would commit a breach of contratet by deviating from the direct comrse of the vorage muless the dauger ald tually existed, and the master conld allege that he wats prevented hy one of the perils excepted in the hill of lating fom fmoming his roginges in the direct comse. It apprats to their Jomelships, howerer, that there is no somed gromed for thes distinction; if the callow hath been a I'assian areo it would have been exposed to the sume lamger as the ship from entering the port at Domkirk, and it appears to their Lomblipes that when an English merchant shipe gonels on board a foreign ship. le cammot expeet that the master will alct in any lenpert 


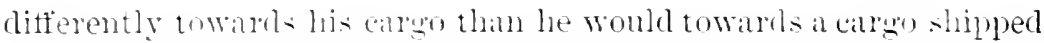
hy one of his own commty. and that it camnot be contended that the mister is tepurivel of the right of taking reasonable and prolent

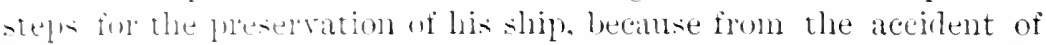
the earno nut belongrig to his own nation, the cargo is not exposed to the silme dimgere as the ship.

- ()n the whole. therefore, their Lordships are of opiniom, on this

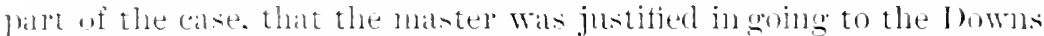
for the purpose of ascetatining whether war hau actually heen

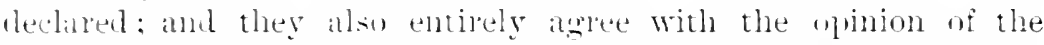

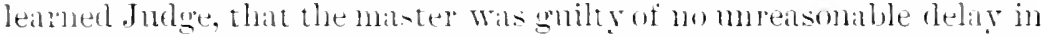
not returning to Dunkirk before watr was atetually declared on the 19 th of .July."

[The Lorks next consider * Whether the master was homnd to deliver the cargo at Dorer withont any payment in respect of freinht: :

The decision is made in accordance with English law, and. in substance. is as follows: While the breaking ont of the war dirl rencer it illestal for the Tentomin to enter a French port, yet the antuatet, moler the particular terms of the charter-party. could be legally gerformed by the delivery of the cilpo at so:ne of the other lunts mentioned in the chatrter-party-that the contrate was not disiolvel hy the inposibility of delivering the cargo at Domkirk, and thit the shipowner harl not lost his chatrtered freight nor his lien for it at the time when the cargo was demanded at Dorer.]

\section{TIIE PRIZE CASES. (1)}

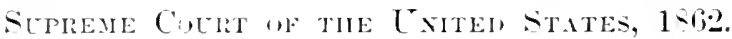

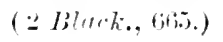

Thr claracter of a ciril war-- 1 ciril war is never solemnly declared-The porers

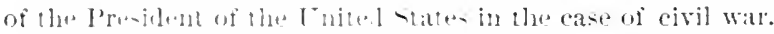

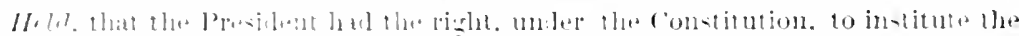

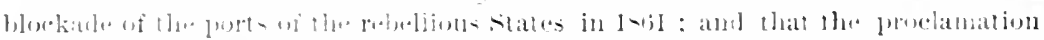

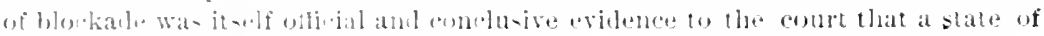
wal +xi-teal.

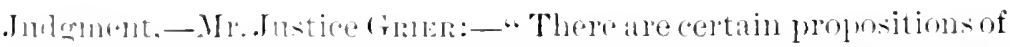

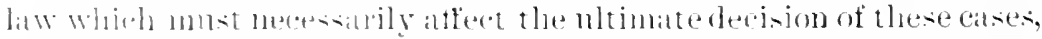
and luthy nhers. which it will he plopele to discuss and decide before we notiete the sleetal filets peculiar to eateh. 
"They are, 1st. IIan the President a right to instinte a liluels.

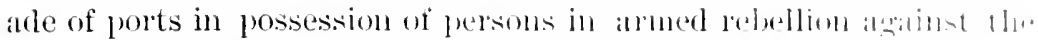
Government, on the principles of international law, as linom and acknowledired amomen civilized states:

"20l. Was the property of persoms domiciled or residin" within those states a proper subject of capture on the seal as 'chemines luperty?"

"I. Nentrals have a right to challenge the existence of a librekade de fiecto, and also the aluhority of the party exereising the rigite to institute it. 'They have a right to enter the ports of a friendly nation for the purposes of trade and eommeree, but ane bomnd to recognize the rights of a belligerent engagerl in actual will, wo nse this mode of cocleion, for the pmrpose of smbduing the enumy.

"That a blockide de fiecto attully existed, and wats fommally declared and notified by the President on the :27th and soth of April, 1861 , is an aldmitted fact in these cases.

"That the Presitent, as the Execntive Chief of the corermment and Commander-in-ehief of the Army and Navy, was the propel person to make such notitication, has not been, and cammot be disputed.

"The right of mize and capture has its origin in the ,jus l, lli, and is governed and aljudged muler the law of mations. To legitimate the eapture of a nentral vessed or property on the high seas, at war must exist de fircte, and the nem ral must have a knowlenge on notice of the intention of one of the parties belligerent to nse this moke of coercion agininst a port, city, or territory, in possession of the other.

"Let us inquire whether, at the time this blockade was instinted, a state of wall existed which would justify a resort to these means of sublining the hostile force.

"War has been well defined to be, "That state in which a nition prosecutes its right by force.'

"The parties belligerent in a public war are independent nations. But it is not necessary to constitute wall, that both partics shombl h. acknowledged as indepentent nations or sovereign states. A wan. may exist where one of the belligerents chims sovereigh rights ats

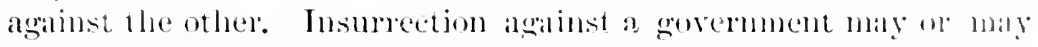

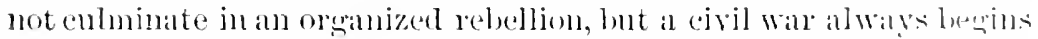
by insurection aganst the lawful anthority of the fovernment. A civil wat is never solemmly declared; it beemess such hy its abei-

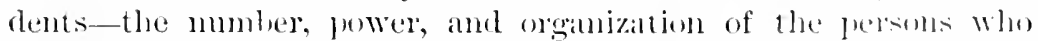
originate and carry it on. When the party in rebellion oxplup and hold in a hustile mamner a certain portion of territury ; hare deadren 
their indelendence; have cast off their allegiance; have organized alnifs: have commenced hostilities agamst their former sovereign, the world acknowledges them as belligerents, and the contest a ura: $T \%$, claim to be in arms to establish their liberty and independence, in order 10 become a sorereign state, while the sovereign party treats then as insurgents and rebels who owe allegiance, and who should le pmished with deatl for their treason.

". The laws of mar, as established among nations, bave their fomdation in reason, and all tend to mitigate the eruelties and misery poduced by the scourge of war. Hence the parties to a civil war lisually concede to each other belligerent rights. They exchange prisoners, and adopt the other courtesies and rules eommon to public ol hational wars.

‘. I eivil war', says Vattel, 'breaks the bands of soeiety and govermment, or at least suspends their force and effect; it produces in the nation two independent parties, who consider each other as enemics, and acknowledge no common judge. Those two parties, therefore, must necessarily be considered as constituting, at least for a tine, two separate hodies, two distinct societies. Having 110 common superior to judge between them, they stand in precisely the same perlicament as two nations who engage in a contest and have reconusse to arms.

" "This being the case, it is rery evident that the common laws of war-those maxims of hmunity, moderation, and honor-ought to be observed by both parties in every civil war. Should the sovereign conceive le has a right to hang up his prisoners as rebels the olposite party will make reprisals, etc, ete, the war will beeome "ruel, horrible, and every day more destructive to the nation.'

"Is a civil war is nerer publicly protaimed, eo nomine agamst insmronts, its actmal existence is a fact in our domestie history which the court is bound to notice and to know. The true test of its existence as found in the wring of the sages of the common law, may be thus summarily stated: "When the regular course of justice is intermented by revolt, rehellion, or insurrection, so that the Comts of Instice cammot be kept open, civil are earsts and hostilities may be proseroterl on the same footing as if those oplosing the Government wore foreign enemies invaling the land.'

" by the Comstitution, Congress alone has the power to declare a national or forejgn war. It camnot declare war against a State, or any $1 m m$ mer of States, by virtue of any clanse in the Constitution.

"The constitution confers on the l'resilent the whole executive power. Ile is bomel to take cale that the laws be faitlofully executed. IJ. is Commander-in-chief of the Army and Nary of the United 


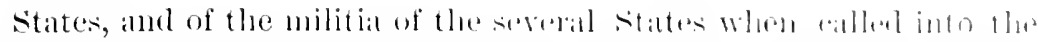

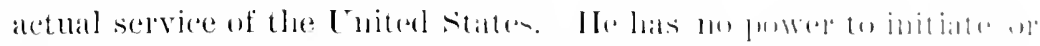

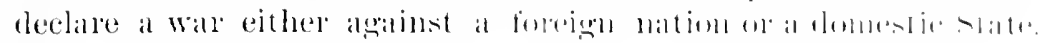

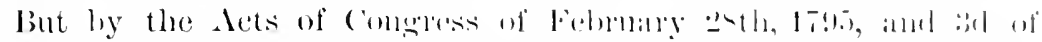

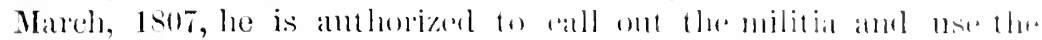

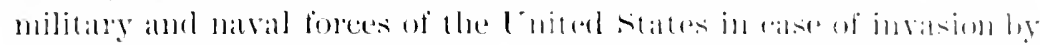

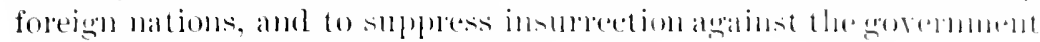
of a state of of the Lruited states.

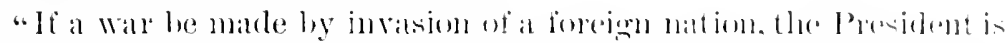

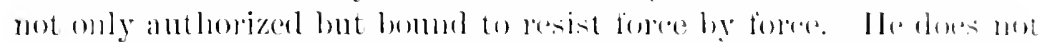

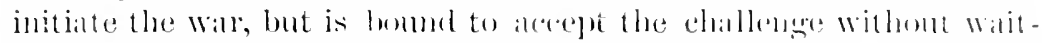
ing for any special legislative anthority. Amb wether thr hostibn farty be a foreign invaler, or states oreanized in rebelliom, it is nome the less a War, althomgh the dedatration of it be - muilateral. Lomel

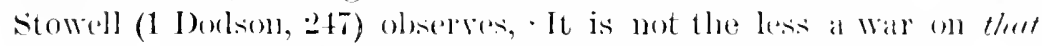
account, for wan maly exist without a teclanation on cither sisle. It is so latid down by the best witers on the law of mations. A reclatration of war by one comtry omly, is not a mere challenge to be acecepterl or refused at pleasme hy the other.'

"The battles of Palo . llto amd liesaca de la Pahma harl been fought before the passigge of the let of Congress of May 1:3th, 1sti, which recognized "stute of' un as existing by the art of the la pullir: at Mexico. This act not only provided for the future proserention of the war, hut was itself a vindication and ratifiation of the let of the President in aceepting the challenge withomt a fllevioms formal declanation of war by Compless. This greatest of rivil wats wats not

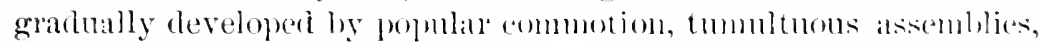

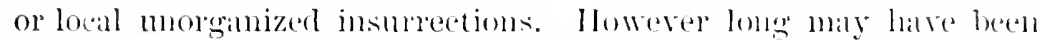
its previons conception, it nevertheless sprmon forth suldemly from the parent hatu, a Minerva in the full panoply of ane. The l'ardent was bound to meet it in the shape it prescuted itself, withont waiting fol Comgless to biptize it with a mane; and no name given to it by him ol them could ehange lle falct.

"It is not the less a civil war, with lelligerent parties in hostile array, beeause it may be called an - insurection by onc sille, and the insurgents be considered ats lebels or trators. It is not necenally that the independence of the revolted povince or state be aldimwledged in order to constitute it a palty belligerent in a war anconling to the law of nations. Foreign nat ions acknowledge it a wall by a declatation of neutality. The comblition of nembality atmol exis

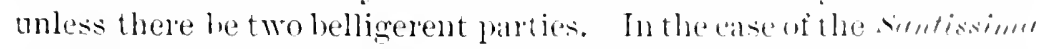
Trinidad (7 Wheaton, 3:35), this Comt saly : The Gorelmment of the Enited states has recognized the existence of at ciril wa letween 
Fpain and her rolonies, and has arowed her determination to remain nentral between the parties. Ealdh party is therefore deened by us a helligerent nation, having, so far as concerns us, the sovereign right

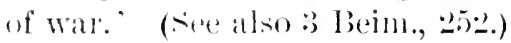

". Is som as the news of the attack on Fort sumter, and the organization of a government ly the seceding states, assuming to ald as lelligerents, conld become known in Enope, to wit, on the 1:3th of May, 1-til, the (Qneen of England issued her proctamation of nentrality, recognizing hostilities as existing between the Government of the Inited states of Antrica and certuin states styling themselves the Conferlerate states of America.' This was immediately followed by similat declarations or silent acquiescence by other nations.

"After such an official recognition by the sovereign, a citizen of a foreign state is estopled to deny the existence of a war with all its conseguences as regarls nentrals. They camot ask a Court to aflect a technical ignorance of the existence of a war, which all the world acknowledges to be the greatest civil war known in the listory of the hmman lace, and thms eripple the arm of the fovermment and paralyze its power by subtle rletinitions and ingenions sophisms.

"The law of nations is also called the law of nature; it is founded on the eommon comsent as woll as the common semse of the world. It contains no such anomalons dortrine as that which this Count are now for the first time desired to promounce, to wit: That insurgents who have risen in rebellion against their sovereign, expelled her Comts, establisher a revolutionary government, organized armies, and commenced hostilities, are not memies, heeanse they are tratom; and a war levied on the Government by trators, in order to dismember and destroy it, is not a rm, because it is an 'insmrection.'

"Whether the President in fultilling his duties as Commanderin-chief, in smpressing an insurreetion, has met with such armed hostile resistance, and a civil war of such alarming proportions as will compel him to aceord to them the character of belligerents, is a question to be rleeirled h!y him, and this Conrt must be governed by the decisions and acts of the political department of the Govermment to which this power was entrusted. IIe must determine what degree of force the crisis demands.' 'The proclamation of blockade is itself official and conchwive evidence to the Conrt that a state of war existed which demanded and anthorized a recourse to such a measure, morler the circmostances peenliar to the case.

"The correspontence of Lord Lyous with the Secretary of State admits the fact and conchules the question.

"If it were necessary to the technical existence of a war, that 
it should have legislative sanction, we find it in ahmot erory act passed at the extratorlinary session of the Legislatme of 1 was wholly employed in enateting laws to enable the coromment to proseente the war with rigor and efliciency. And fintlly. in lail, we find Congress 'ex mojore coretel,' and in anticipation of such astute objections, passing an act 'apploving, legalizing and makind valid all the acts, proclamations and orders of the President, ete. at

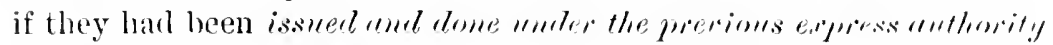
and direction of the Congress of the Truited states.'

"Without admitting that such an act wats necessary moler the? circumstances, it is plain that if the Presirlent had in any manner assumed powers which it was neeessary should have the authority or sanction of Congress, that on the well-known principle of law, 'ommis: ratilubitio retrotrahitur, et mombero equiparofur,' this ratification

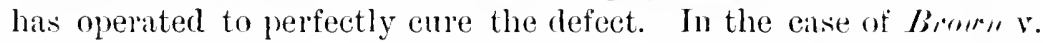
Crited States (8 Cr., 131, 13:2, 1:33), Mr. Justice STory treats of this subject, and cites numerous anthorities to which we may refer to prove this position, and concludes, 'I am perfectly satisfied that no subject can commence hostilities or capture property of an enemy, when the sovereign has prohibited it. But suppose he dirl, I would ask if the sovereign may not ratify his proceedings, and thus by a retroactive operation grive valielity to them?'

"Although Mr. Justice STory dissented from the majority of the Court on the whole case, the doctrine staterl by him on this point is correct and fully substantiated by authority.

"The objection made to this act of ratification, that it is e.r post fucto, and therefore unconstitutional and void, might possibly have some weight on the trial of an indictment in a eriminal court. But precedents from that source cannot be received as authoritative in a tribunal administering public and international law.

"On this first question, therefore, we are of opinion that the President had a right, jure belli, to institute a blockarle of ports in possession of the States in rebellion, which neutrals are bound to regard." (See the remainder of this decision under $\$ 33$. ) 
CHAPTER II.

EFFECTS OF WAR AS BETWEEN EXEMIES.

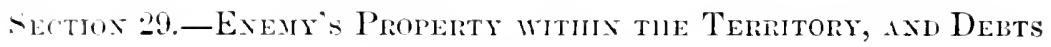
DCE TU THE ENEMY.

W.MRE v. IIYLTON.

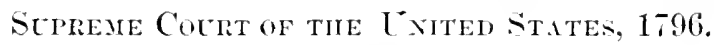

(:; Dillus. 199.)

A1! the justices admitted-some howerer with great reluctance-that, in striat lat. debts dne to an eneng might be confiveated. But this point was not necesatry to the decision: for the aret of contiscation in question (of Virginia) was held 1o in anmulled by the the article of the treaty of 17-; with England.

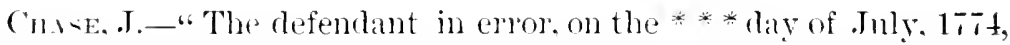
prisel their penal hom to Farrell and . Tomes for the parment of ex.976

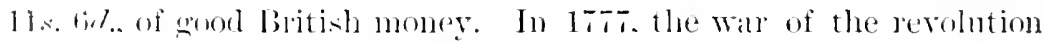
latring buken ont. the legislature of Virginia passed a la wo serpester britinh property : the at section of which was as follows:

.. That it shomld be lawful for any eitizen of Virginia. owing money to a shliject of (ireat britain) to bity the same. or any lat thereof,

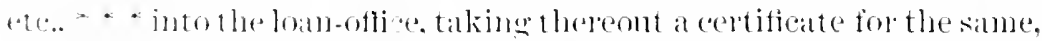
in the name of the creditor, with the emblosement, moler the hand

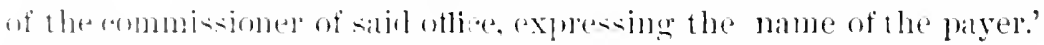
The (iovernor and combeil were to see to the safolieeping of such

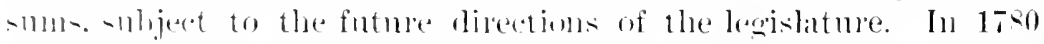

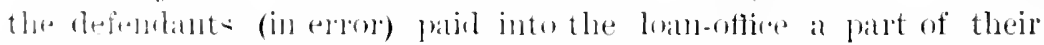
debt. in accoldance with stipmbations of the above baw. After the

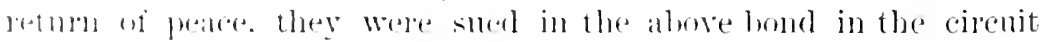
comt of Virginia: and pleaded the sad law of the legislature of 20 il! 
Virginia, and the payment theremeles, in bat of so much of the

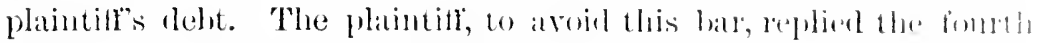

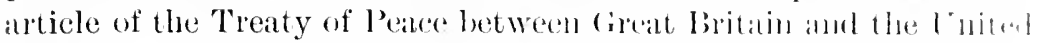

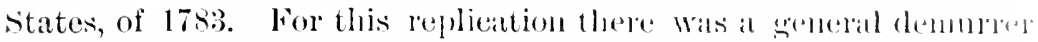

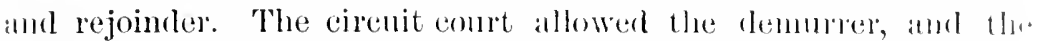
plaintiff bronght the present writ of erren.

"The comsel for the plaintiff denied that the Virginia lecrislatme"

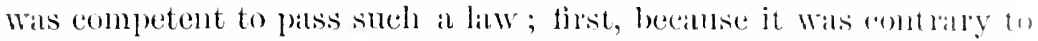
the law of nations, relying on Vattel (lil, :3, e. 5, see. Ti); imt, secondly, that the legislatme was mot eompetent imasmmeh at all such power belonged exchusively to comgress. But it wats held hy the eourt that at the time of passing the law, Virginiat was at fine and independent state, inasmueh as Congress ats well as the serral individual states had decialed their independence; and the artiches of conferleration had not yet been ratitiorl. Situposing a general right to eonfiscate British property is arhitted to be in congress. then the same right belonger to the legislature of Virginia at the time of passing the act. "The legislative powel of every mation can only be restrained by its own constitution; and it is the luly ut its conrts of justice not to fuestion the valielity of any law marle in pursuance of the eonstitution. In this ease the law is obligatmy on the comrts of Virginial, and in my opinion on the eomets of the Lniteil

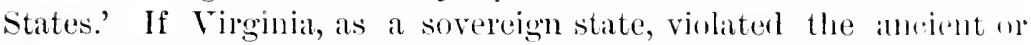
modern law of nations, in making the law of the 20th Oct., 17T, she was answerable in her political capacity to the British nation, whose subjects have been injured in consernence of that law.'

"It appears to me that every nation at war with amother is justjfied, hy the general and strict litw of nations, to seize and contiscate all movable property of its enemy (of any kind or natme whaterer) wherever fomol, whether within its torritory or not." (Bynkershow, Q. J. P'. de rebus belliess, lib. 1, c. 7 , pu. 175, 177; Vattel, l3. t, sece 2.21 ; Sir Thomas Parker’s liep., 267.$)^{1}$

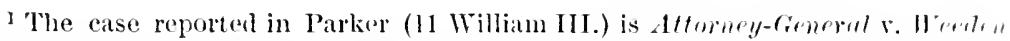

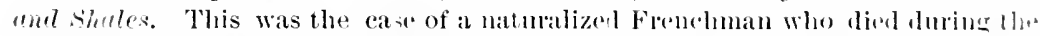
war, leaving in his will several lexaleies to fremelmen living in bondeanx. I rommission wats issued to investigate the matter ; but peace was made nue:mlime lon

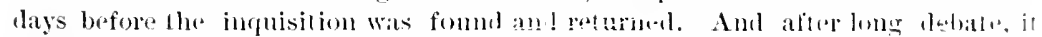
was resolved: "First, that ehose in action whieh belongel to an alien "nemy wer. foricitable to the crown.

"Sereomdly, that this ought to be fomd by incuisition to make a tille 1 , the King: and that this was an inquisition of entitling, and not of inslmelinn. (Pun s Crase, 5) ('o., 52).

"Thirdly, that the peace being concluded before the induisition was taken, disclarged the cause of forfeiture. 
. The right to confiscate the property of enenies luring war is delivel fiom a state of wall and is ealled the rights of war. This right urginates from self-preservation, and is adopted as one of the means to weaken an enemy, and to strengthen ourselves. Justice, al-o. is another pillar on which it maty rest; to wit, a right to reinhlun-e tire expense of an unjust war. (Vattel, lib. 3, c. 8, sec. 13s; and e. 4, sec. 16il.)

. Vittel is the only author relied on (ar that can be fomd to maintain the distinetion between eonfiscating lnivate delsts, and other lnonety of an enemy. Mr. Lee sals, 'By the law of nations, rights and eledits are not less in our power than other goods; why, therefore. should we regard the rights of war in regard to one, and not as to the othel's? And when nothing occurs which gives room for" a proper distintetion, the general law of nations ought to prevail.' IIe nives many eximples of confiscating debts, and concludes (p. 119), - All which prove, that not only actions, but all other things whatevel. are forfeiterl in time of war.' (Lee on Capture, c. 8, p. 118.) ***

. If a lation, during war, conduets herself contrary to the law of nations, and no notice is taken of such conduct in the treaty of leace. it is thereby so far considered lawful, as never afterwards to le revired, or to be a sulject of complaint.

." The validity of such a law (the act of the Virginia legislature) womld not be questioned in the Connt of Chancery of creat Britinin; and the doctrine seemed strange to me in an Anerican comrt of justice." (see Lord Chancellor Thurlow in Wright v. Tutt, 1782, II. Biack. Rep. p. 1:5, 149: : Term. Rep., 7:6.)

['l'he sixth article of the present Constitution of the Lnited States, ". That all treaties made or which shall be made, under the authority of the Cnited states, shall he the supleme law of the land; and the judges in every state shall be homnd thereby, anything in the ensstitution, ol laws, of any state to the contrary notwithstanding." Was held to bave a letroactive effeet, and to be considered in the silne light as if the Constitution hard been established before the maling of the treaty of 17-3; and that Comgress was competent to malie the fomrtharticle of the sad treaty. whieh is to the following effeet : "It

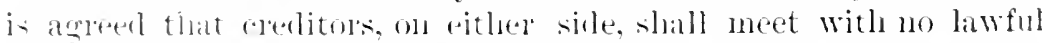
iupredinn ant to the recovery of the full value, in sterling money, of all

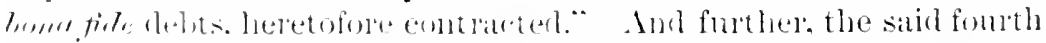

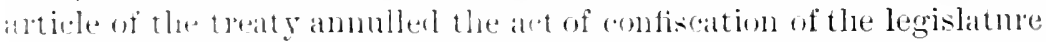

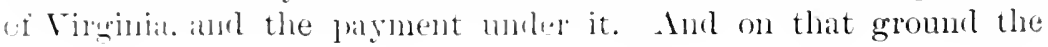

"Fondhly. lhat the inquisition taken aflerward dis not relate to set al this

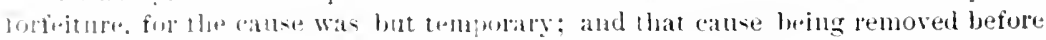
the King', tille was found, the finding afler should not relate." 


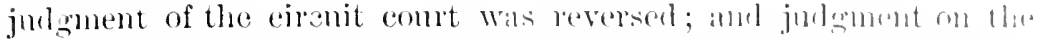
demurer for platintilf in error with costs in the cinenit enmt, and the eosts of the alpreal.

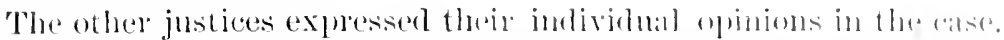

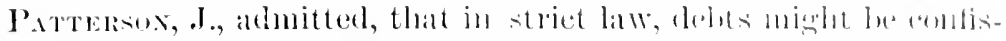
cated, but spolie stromgly against the polixy of thing so.

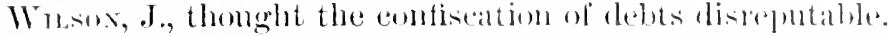

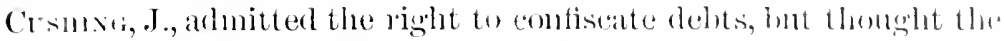
fourth article of the treaty ammled the statute of Viringiat and further that the state omght to be responsible to the debtor for the amount paid inte the loan ofice.-F. S.]

\section{BROIN v. THE I'NITED N'TA'TES.}

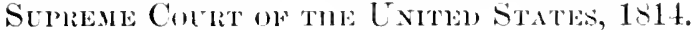

$$
\text { (s cimm 1 10.) }
$$

There is no lifierenee in principte batween the confistation of tebts the to the enemy and the contiseation of the properly of the pueny found in the rountry at the onbreak of war. Ilehl, that by the striet law of war both may be confiscalud; but, ander the constitution of the United states, it can only be done by the authority of Congress.

The Emulous, owned by John Delano and others, citizens of the Enited States, was chartered to a company earying on trate in Great Britain, one of whom was an Ameriean citizen, for the pmopose of earrying a eargo from Siatumab to Plymonth (England). After the cargo was put on board, the vesiel was stopped in port hy the embargo of the the of April, 1812. On the 25th of the same month, it was agreed between the master of the ship and the agent of the shippers, that she should proceed with her calso to New liolford, where her owners resided. While the ship was lying at New Inelford, war was deelared (18th of .Jume); and in Ortoher or Xovermber the eargo, comsisting of pine timber, staves, and laths, was unloaded, the timber being put in a salt-water roek-not navigable, and on the Tth November was sold by the agent of the owners, an Amerion eitizen, to the chimant, Amitz Brom, wlon was also an American citizen. On the 19th April, 1sl:3, a libel was tiled hy the attomey for the Inited states m the district comet of Massalelusetts against the saill eargo, as well on helalf of the Inited states as for

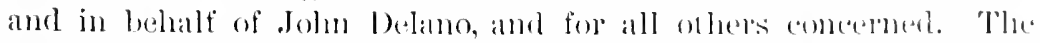
attomey han so instruetions from his superion, the jusident of the Enited states, but acted at the instance of Delano, the ownel of the Eineulous. 
The distriet cont dismisser the libel. The circuit court (Nomer, Ju-tice) lerelsed lhis sentence, and condemmed the pine timber as

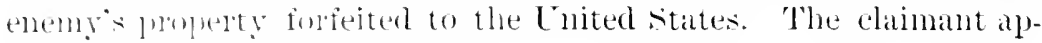
pealeel to the sinpeme court.

\section{Jurlement, ly M.nismolle, C. .J :-}

"The material ynestom made at bar is this: an the pine timber, pron anmiting the popedty not to be changed by the sale in No-

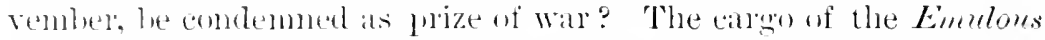
latring heen leswally anduined and put on board the vessel, having been dotained ly all embaran mot intender to atet on foreign property, the vesel having sitiled before the war, from simamah, muler a

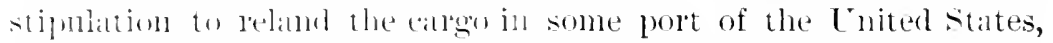
the re-landing having heen marle with respect to the residne of the carro. and the prine timber having been floated into shallow water, where it was seculed and in the custorly of the owner of the ship an Amerann citizen. the Cont cannot perceive any solis distinction, $\therefore$ fiar as lespects confiseation. hetween this jopelty and other IBritisle property foumd on hand at the commencement of hostilities. It will therefore be comsinlered as a question relating to such propelty ancrally, and to be governed ly the same lule.

"Respeting the power of gorelnment no doubt is entertaned. That wal gives to the soreleign full right to take the persons and (onfiscate the property of the enemy, wherever found, is concederl. The mitigations of this rigid rule. which the humane and wise policy of molern times has introduced into practice, will more or less affect the exere of this right, but camot impair the right itself. That remanns molininishet, and when the sovereisn anthority shall chose to bung it into operation. the juclicial department must give eflect to its will. Iint motil that will shall be expressed, no power of comblemmation can exist in the compt.

"The pulestions to be decided by the eomet are:

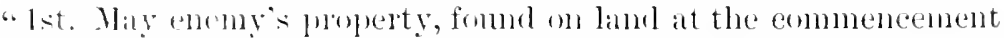
of hostilities. he seized and confemmed as a necessany consequeneo wi llae lecelaration of wall:

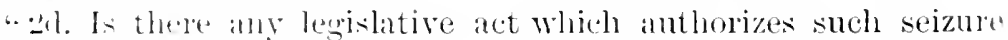
andel comelemmatiman:

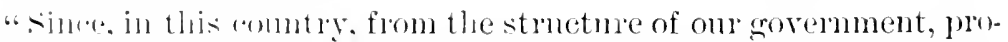

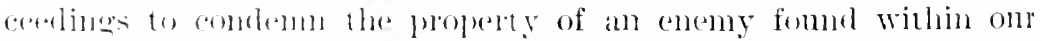
truptory at the declatration of watr, can be sustained only mpon the lumbiple that they are instituter in execution of some existing law we are led to ats :

"Is the declaration of wall such a law? Does that declaration, by 


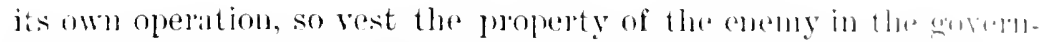

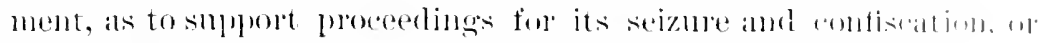
does it rest only a right, the assertion of which depends an the will of the sovereign power?

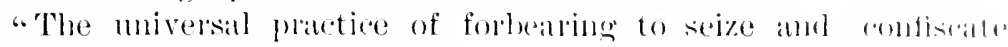
dehts and credits, the prineiple miversally receiverl, that the right to them revives on the restoration of peace, would semento pure that war is not an absolute confisation of this punderty, hut ainlyly confers the right of confiscation.

" between delsts contrated muder the faith of laws, and proferty" acgitided in the combse of trade, on the faith of the sime latws, leasion rlaws no distinction; and, althomgh, in practice, ressels with theid calgoes, foumd in port at the declanation of wal, may have heen seizerl, it is not believed that molern nsage wonld simetion the. seizule of the goods of an enemy on land, which ware anduind in

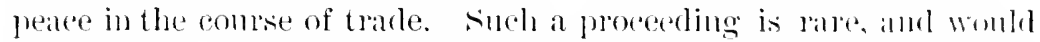
be deened a harsh exereise of the riglt of war. But althomb the practice in this respect maly not he muform, that cirrmmstanes does not essentially affect the question. The inguiry is whether. such property vests in the sovereign ly the more declintalion of

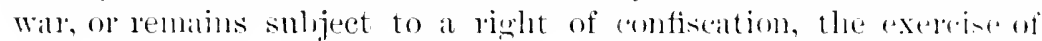
which depends on the national will : and the Jule which applites to one alse so far as resperts the operation of a rechatration of wall on the thing itself, must apply to all others over which wall gives an e(uas) right. The right of a sovereign to confiscate dehts being" precisely the same with the right to confiscate other proporty fomm in the country, the operation of a declastion of was an delits and on other property fomd in the comntry must be the same. What, then, is this operation?

"Fven livnkershoek, who maintains the broad principle, that in war everything done aganst an enemy is lawful that be maly be destroyed. thomgh malmed and defenceless; that frand or even poison, may he employed against him; that a most mulimited right is acpuired to his person and property a aluits that wall does not transfer to the sovereign a labt due to his enemy ; and, therofore. if payment of such debt be not exacted, peace revives the forman right of the ereditor' 'becanse' he says, "the occupation whirh is hat hy wall consists mole jn fact than in law.' Ile arlds to his olservations on this subject, 'let it not, howerer, be supposed that it is only true of actions, that they are not condemmed ifso. jur. for other things also helonging to the enemy, mat be conceded and escape combemmation.'

"Vattel salys, that ' the sovereign can nejther detain the persums 
nor the lunperty of tho:e subjects of the eneng who are within his (onminion- at the time of the declanation.'

.. It in trote that this rule is, in terms, applied by Vattel to the monerty af those only who are persomally within the territory at the (onmmeneenent of hostilities; but it alphlies equally to things in ateinand to things in possession; and if wal diel, of itself, witholl :uy further exereise of the sovereign will, rest the property of the enemy in the sovereign, his fresence wonld not exempt it from this oferation of war. Nol can a leason be pereeped for mantaining that the public fath is more entirely plerlged for the security of puperty trusted in the territory of the nation in time of peace, if it he accomplnied by its owner, than if it be confided to the care of otluers.

"Chity, after stating the general right of seizure, says, 'but, in strict justice, that right can take effect only on those possessions of a helligelent which have come to the hands of his adversary after the declanation of hostilities.' (P.67.)

.. The moder'n rule, then, would seem to be, that tangible property behorging to an enemy and fomd in the comntry at the commencement of war, onght not to be immediately contistated : and in almost erery commereial treaty an article is inserted stipulating for the right to withdraw such property.

. This rule seems to be totally incompatible with the idea that wall dus of itself vest the property in the helligerent govermment. It maly he consirleref as the opinion of all who have witten on the ins lllli, that wal gives the right to contiscate. but does not itself confiscate the property of the enemy; and their rules go to the exel'oise of this right."

Ilaving hous decided that war gives the right. in accordance with intemational law, to eonfiscate enemy's property in the situation of thin carro. lint not of its own force, the compt next proceeded to inquire whether the Comstimtion $\mathrm{m}^{\circ}$ haw of the linited states had andlorized such confiscation. The Comstitution confersupon Congress

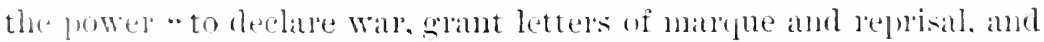
make drules concerning captures on land and water." It is evident

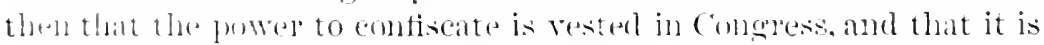

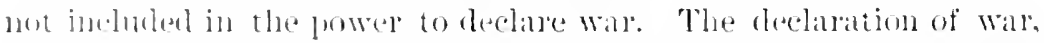

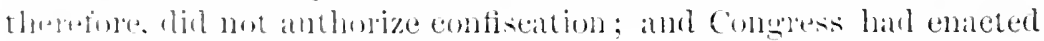
110) wher latw to that effect.

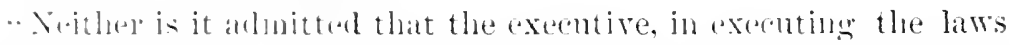

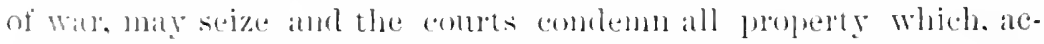

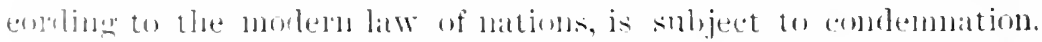
The rule is in its nature flexible. It is subject to infinite modifica- 
tions: it is not an immmtable pule of law, bit depends om pulitioul

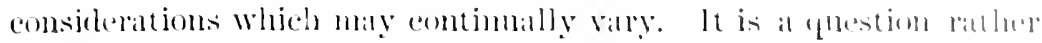
of polisy tham of law ; and like all other foustioms of policy, it is froper for the consideration of a department which and molity it at will; not for the consideration of a department which call purstle only the law as it is written. It is puper for the comsinteration of the legrislature, and not of the excentive or julliciary.

"The eomt is therefore of opinion that there is aros in the sem-

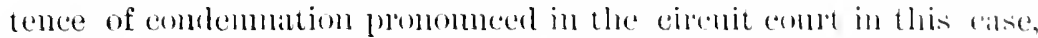
and doth direct that the simne be reversed and ammuled, and that the sentence of the district eomet be affirmed."

Ir. Iustice Srom with a minority of the eomt, held that, the right of confiscation existing, it was within the power of the execoltive to enforee confiscation, in the sime mamel that the executive established bhockades and anthorized the eapture of the enemy's prouerty at sea, and contrabind goods.

\section{ER Prote BOLSSMAKER.}

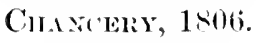

(13) Iresey .Jum., T1.)

ITelit. that property of an enemy, in the form of a dividend arising from a contract made before the war, could not be contiscated.

This was a petition to be arhinted to prove a debt under' a commission of bankluptey; which the commissioners refuscd to admit, upon the ohjection that the ereditor's applying to prove were alicu enemics.

The Lord Chancellor, Erssixe, said: "If this had been a deht arising from a contrat with an alien enemy, it eomld not posibly stand; for the contrat would he void. But, if the twomations ware at peace at the date of the contact, from the time of war taking place the erealitor eonld not sne; hut the contratet being oriminally good, mon the retum of peace the right wombl revive. It wombl be contriry to justice, therefore, to confisente this dividend. Thumbh the right to recover is suspended, that is no reason why the fimd should be divided among the other creditors. The point is of enterat

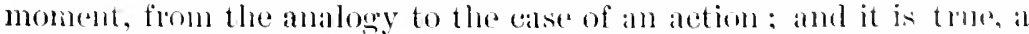
conrt of haw wonk not take notice of the objection withont a jlat. It must appear upon the recorel. * * The policy, aroinling romtracts with an enemy is somel and wise; but when the contur' t 
Was originally wom ant the lemedy is only suspended, the proposition. that therefore the fund should be lost, is very different.

"Let the claim be entered; and the dividend reserved."

\section{WOLFF $\because$ OXIIOLII.}

KIxG's Bexcit, 1817.

(i) Moule and selugn, 92.)

Mfln. that the confiacation of private debts due to an enemy was not in conformily with the usige of nations.

()xhohn, a I inish snbject, was indebted, February 7,1800 , to the

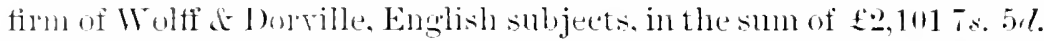
sterling money, for which a suit was instituted in the Danish courts hy Wolti d Dorrille through their proctor, resilent in Denmark. The defendant set up certain eomer-elaims in defense. To atroid this, the platintitts in 1 soij assigned the debt to a Induish subject, whoshomb sue and recover in his own name, thus avoiding some technicality in the Danish laws which affected the tase.

The defendant, in sept., 1806, instituted a erosi-suit. In 1 s whikt these suits wele pending. a war broke ont between freat britain and Tennark; and an ordinance was made by the gorernment of lemmark, Angut 16, 1s07, hy which all ships, goods, momey, and money's worth, of or belonging to English subjects, weredeclared

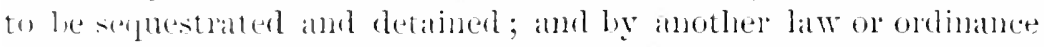

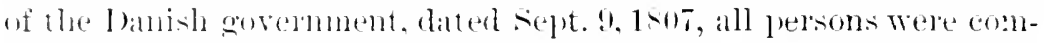
matmet with in three days after the publieation thereof wherever

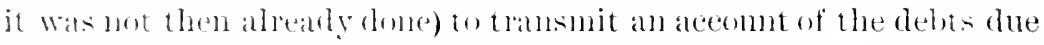

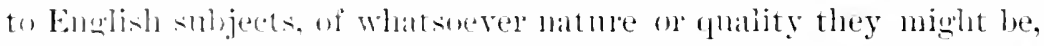
the whole of which were dibereted to be paid into the Danish treasisy, and in eatse of concealnerent the person so offending wats to be poro-

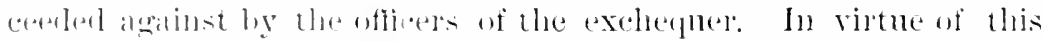

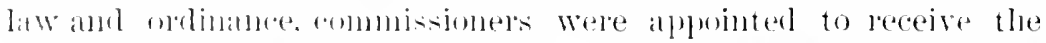

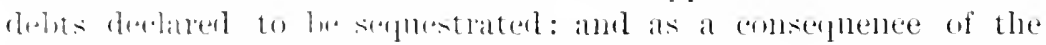

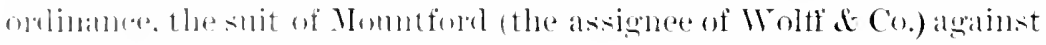

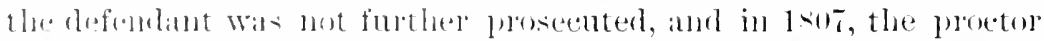

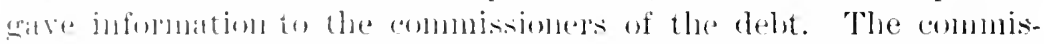
sinuls anthorizel smeh parnents at the then eurrent rate of exchange,

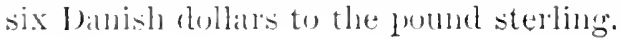




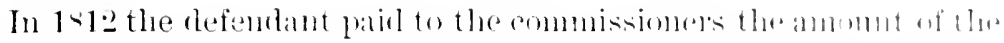

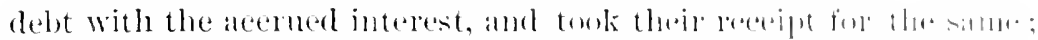

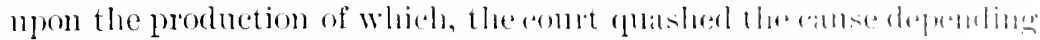
between Mountforl and the defembant. It is silil the mate af ex change at the time of palyment, was forty-five to tifty dollats la the

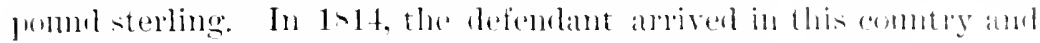

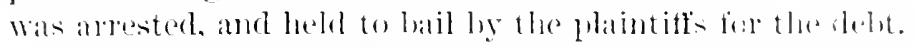

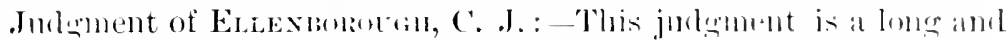

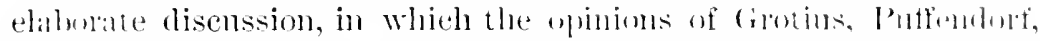
Vattel. and some older anthorities ale analyzed : and the eomelusim

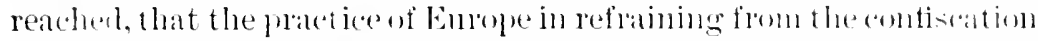
of debts had becomeso soneral that eomtiscation must he comsidered as a violation of the publie fath. It is andmitted that binkershork

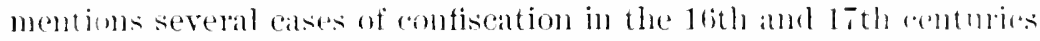

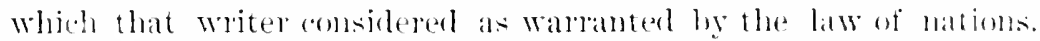
A similar case is cited as deribled by a court at l'aris in the mindle of the lith century. Moneorer, sir Matthew llale is pluted ats saly. ing .. that ly the law of England dehts and gows fomml in the rath belonging to alien enemies belong to the King and may be seized hy him." but, saly the comt, the books referred to do mot fmmish an instance of the seizme of delsts, or a decided case in smpunt of the

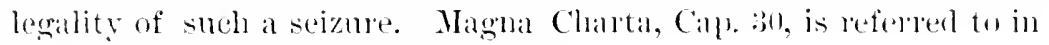
supprut of the position of the comt.

Amd timally, in the mirlst of all the extramelinary violenes of mo orn times, say the eourt, "this ordinance of the compt of lommalk stands single and alone, not supported hy any precedent. war atopted as ar: example in any other state." Sot heins thereforeconfommble to the nsage of nations, the guashing of the suit of the plaintiffs theremuler cond form no bar to the present suit.

"l'osteal to the plaintifls." 1

This lecision is directly at variance wilh the Ameriean cases abore quoted.

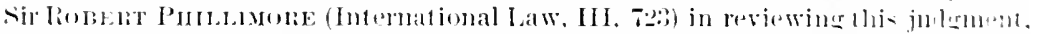
shows that the inferences from the languase of Vattel. Cirotius, and P'uffumbert

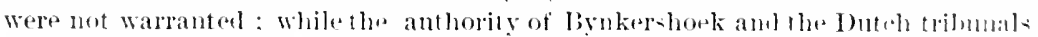

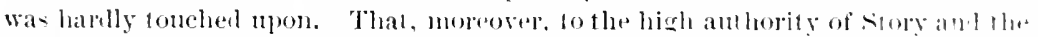

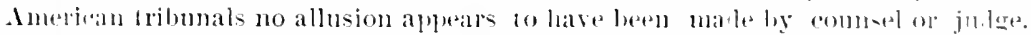

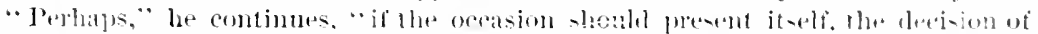

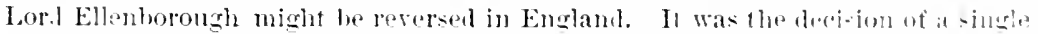
court not much accustomed to deal with guest ions of international law."

The provocation for the act of the loanjoh government was very ereat. An Enelish

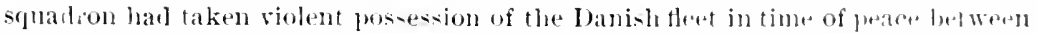

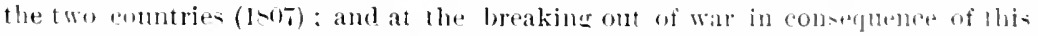
act, the English governuent had confiscated all the Unuish ships found in Englisl, ports as droils of armiralı. 


\title{
Sectiox 30.-Private Contricts.
}

\author{
IIANGER r. ABBOTT. \\ Supreme Colit of the Linted States, 1867. \\ (6) Wriluce, 5i2.)
}

IIfln. that, in the case of contraet debts, as between persons who beeome enenties, the remedy is suspended during the perion of the war, and revives on the return of peace. In such ease, the statute of limitations does not run during the war.

Error to the Circuit Court for the Eastern District of Arkansas.

J. \& E. Abbott, of New IIamphire, sued IJanger, of Arkansas, in assumpit. The latter pleaded the statute of limitations of Arkan-

In the case of the Johemun Emilie, Spinks' Prize Cases, 14 (15.5). Dr. Lr'suxgTos saill. "If the property was on land, aceording to the ancient law, it was also seizable; and certainly during the Ameriean war there were not wanting instances in which such lroperty was seized and condenmel by law,-not by the anthority of this court, lut of another. That rigor was afterwards relaxel. I believe no such instance las occurred from the time of the Ameriean war to the present day-no instance in which property inland was subject to search or seizure. but no dould it wonld be comperent to the anthority of the erown if it thought fit."

During tle eivil war in the [nited states (1861), the ('ongress of the Confederite States conficeated by act of congress all property, movable or immovable, and all rights, cre:lits, ant interests held within the Confederaey by or for any alien enemy, "xrept public stocks and securities. And all persons domiciled within tlue enemy's conntry wepe helel to be subjeet to the provisions of the act. (Aet of Augnst 6th, 1Nil. Irelpherson. IIistory of the Rebellion, 20:3.)

It would sam to be clear that, by the striet law, tangible property and debts are still suloject to contivation by a belliererent. But it is equally clear that the entire drift of muleru opinion and practice is opposed to the exercise of that right.

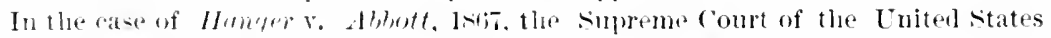
sail "in strictmess it (the riglit of conficeating such lebts) nay still be saisl to exist, but it may well berem-illered as a naked and impolitie right, condenmed by the enlientenenl eonscience of modern times."

On the other liant, property of the enemy fomm afloat in ports at the outbreak of war, as ships with their careoes, has generally in the absence of a contrary acresenent, been confiscatted, following the rules still in practice in respect of private property of the enemy at seat. In Bromen $x$. The Thited states, the supreme Court was eareful to exelude from the rule of the lecision property fouml alloat in ports. ]3ut bere, too, there are strong indications of a milder rule, if indeel it is not already uretty firmly establislied. 
sas, which limits such action to thee years. The formed geplied ilue

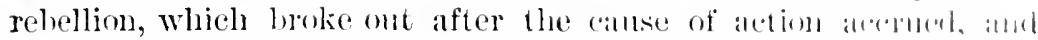
closed for more than three years all law and judgment aganst it, and error to this and, the furstion here was, simply, whether the time during which the entet in Arkinsis were closed on account of the rebellion, was to be exeluderl form the computation of time fixed ly the Arkansas statute of linitatims within which suits on contracts were to he hronght, there being no exception hy the terms of the statute itsolf for any such casce.

Extracts from the opinion of the court, deliveled by Mr. Instice Cinforon:-

"Proclamation of blockade was male by the President on the nineteenth day of April, 1861, and, on the thirteenth dity of . Inly, in the same year, congress passed a law anthorizing the Prosingent to interlict all trade and intercourse hetween the inhabitants of the States in insurrection and the rest of the Cnited States. 12 stat. at Larre.

"War, when duly dechared or recognized as such hy the war-making power, imports a prohibition to the subjects, or titizens, of all commercial intereourse and correspondence with citizens or persons domiciled in the enemy's comtry. Cpon this principle of public law it is the established rule in all commercial nations, that trading with the enemy, except under a government license, subjects the propert $y$ to confiscation, or to capture and condemnation.

"Partnership with a foreigner is dissolved by the same event which makes him an alien enemy, becanse there is in that case an utter jncompatibility created by operation of law between the part. ners as to their respective lights, duties, and obligations, both pullie and private, which necessarily dissolves the relation, independent of the will or acts of the parties. Direct consequence of the rule as established in those eases is, that as soon as war is commenced all trating, negotiation, commmnieation, and intercourse between the citizens of one of the belligerents with those of the other, withont the permission of the government, is muwful. Xo valid contract, therefore, can be made, nor can any promise arise by implication of law, from any transaction with an eneny. Exceptions to the rule are not admitted; and even after the war has terminated, the defendant, in an action fomded upon a contract made in violation of that prohibition, may set $u$, the illegality of the transaction as a defence. ***

"Executory contracts also with an alien enemy, or even with a neutral, if they cammot be performed except in the way of commeredil intercourse with the enemy, are dissolved by the declaration of wall. 
which operates for that pmrpose with a force equivalent to an act of

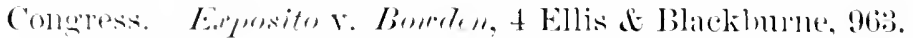

"In former times lhe right to confiscate dehts was anmitted as an ackmowlederel doutline of the law of nations, and in strictness it may still be said to exist. hut it may well be considered as a naked and impolitic right, condemmed by the enlightener conseience and judsurent of modern times. Better oplinion is that exeented contratet. suth as the deht in this calse, althomgh existing mior to the War. ane mot anmulled or extinguished, lut the remerly is only suspenterl, which is a necessaly eonchusiom, on acemut of the inability of an alin enemy to sue of to smstain, in tho langmage of the civil-

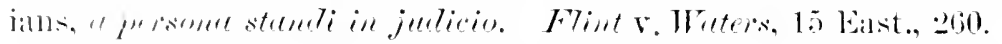

". Trading, which smpuses the maling of contracts, and which also involves the necessity of intereomse and correspondence, is necessarily contradictory to a state of war, lut thers is no exigeney in war which lequires that belligerents should confiseate or anml the helts ane by the citizens of the other contending party. ***

- Enler the thirty-fourth section of the Judiciary let, the statutes of limititions of the several states, where no special provision has been male ly Congress, form the rule of deeision in the courts of the Cnited states, and the same effect is given to them as is given in the courts of the state. ***

"When on ancestors immigrated here, they bronght with them the statute of 21 Jac. 1 , e. 16 , entitled An act for limitation of actims, and for aroiding of suits in law, known as the statute of linitations.

- Pelsons within the age of twenty-one years, femes corert, non "ompus mentis, persons implrisoned ol beyond the seas, wele excepted ont of the oneration of the thind section of the act, and were allowed the sane frerind of time after such disalbility was removed. Just exeeptions indeed are to be fomnd in all such statutes, but when examined it will alpen that they were framed to prevent injustice and never to encomage laches or to promote negligence. Cases where the comls of justice ale chosed in consequence of insurrection or rolden are not within the express terms of any such exeeption, but fle statute of limitations was passed in 162:3, mole than a eentury before it canne to be muderstoon that debts due to alien enemies were nut sulject to confiseation. Down to 1737, says Chancellor KExt, the opinion of jurists was in faror of the right to confiscate, and many maintaned that such dehts were anmlled by the decharation of wall. Regarding such debts as amulled by war, the law-makers of that any lever thonght of making provision for the collection of the sane on the restoration of peace between the belligerents. Com- 


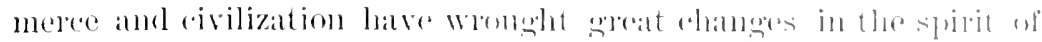

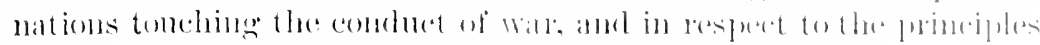
of internationat law alphlicable to l lae subjeret.

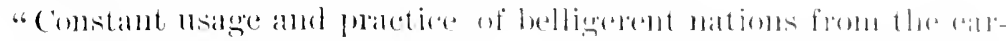

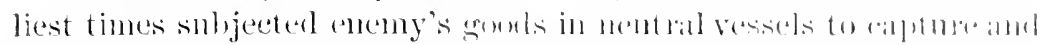

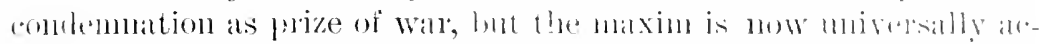

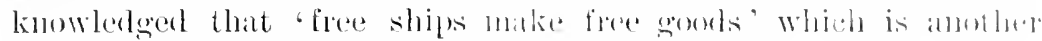

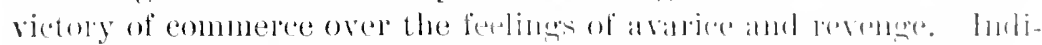

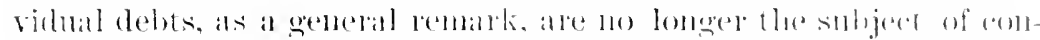

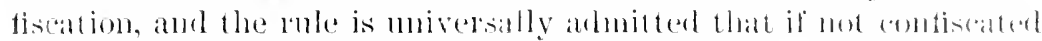
during the wall, the return of pene brings with it hoth the right

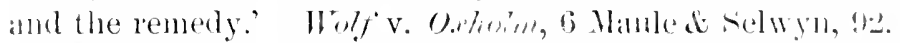

"Old decisions, marle when the lonle of law Was that Wat ammulled all dehts between the subjeets of the belligerents, ane antiterl bo but

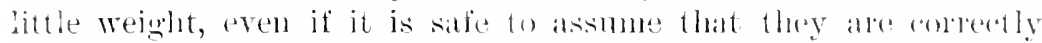

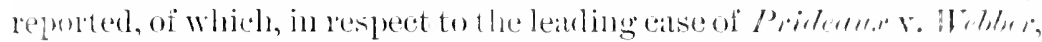

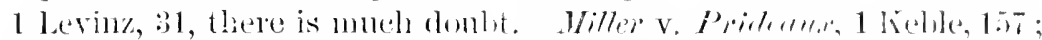

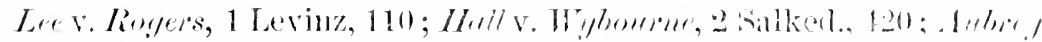
v. Fortescue, 10 Moxlern, 205, ald of the same (lisis, and to the salme effect. All of those decisions wele mathe hetwern baties who mare citizens of the same jurisdirtion, and most of them wele marlementy

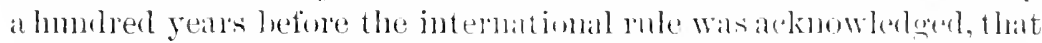

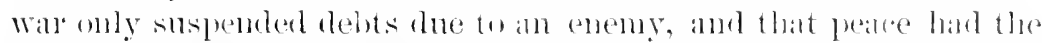
effecet to restore the remerly. The role of the present dily is, that debts existine prior to the will, but which mane no pald of the reasons for undertaking it, romain entire, and the remerlies are revived with the restoration of prace. * * *

"Text writers usually say, on the anthority of the old arses lo-

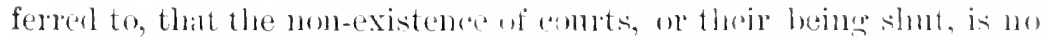
answer to the bar of the statute of linitations, but l'owelon says that things haplening by an infincible necessity, homels they be aganst common law, or an act of l'arliament, shall not be prejurlicial.

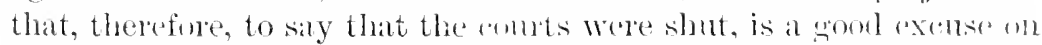
vourler of record. Exeeptions not mentioned in the statutes have sometimes been admitted, and this cont hele that the time whilh elapsed while certain prior procererlings were suspended hy aplearl, shonk be deducted, as it alymand that the injured party in the meantiue har no right to demand his money, or to sue for the leonsery of the sime; and in view of those rircmustances, the const de-

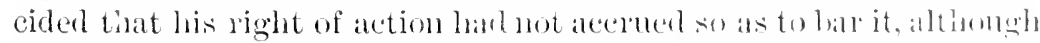

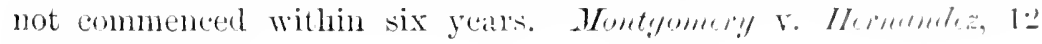
Wheaton, 129.

"Int the exception set up in this ease stands upon much none solid 18 
reasons, as the light to sue was suspented hy the acts of the government, for which all the citizens are responsible. Culess the rule be so, then the eitizens of a state may pay their debts by entering into an insurnection of rebelliom against the govelument of the Enion, if they ale able to close the couts, and to successully resist the laws, mutil the bat of the statute becomes complete, which cammot for a moment be adnitted. Peace restores the risht and the remedy, and

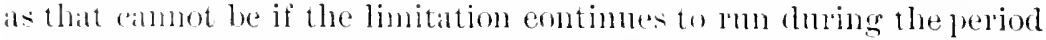
the creditor is rendered incapable to slle, it necessarily follows that the opreration of the statute is also suspended during the same period.

"Judgment aftirmed with costs." I

\section{GRISWOLD V. WADDINGTON.}

\section{Colmt of Appenls of New Yurk, 1818.}

(15) Johnson's Reponts, it.)

II 7 . that commereial partnerships existing between eitizens of two states are disolwel by the breaking ont of war between those states.

Anl, that the decharation of war itself furnishes the necessary legal notice of such dissolution.

Before the breaking out of the war between the Inited states and England, in 141:. Joshma Waddington, an American citizen residing in Jew Jork, and llenry Wadklington, a british sulject residing in Lombon, were patmers in a commercial husiness. I) ming the wan, X. I. atud G. Givisold had tansations with .J. Waddingtom, in the Fuited states. After the close of the wall, the Griswolds sued to Jecover a habanee of accomt arising ont of those transactions; and their ontention was that II. Waddington, the London partner, was liable for the deltet.

Julgment, hy sipexrer, J.:-

"It apprears to me, llat the declaration of war diel, of itself work a dissolution of all commercial partherships existing at the time between british subjects and American citizens.

"by dealing with cither party, no thind person conld acquire a legal right agraist the other, because one alien enemy cammot, in that capacity, make a private contract binding mon the other. This conelnsion wonld seem to be an inevitable result from the new relations

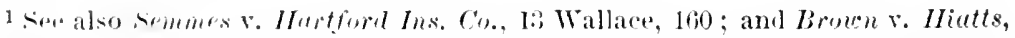
15) Chil., 17\%. That interest does not run during the war, see Broun $v$. Iiatts, 15 Wallace, 17 . 


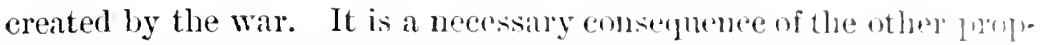
osition, that it is monaful to have commmnication oi tralt: with an enemy. To suppose a commerecial partuership (such as this wats) to be contimed, and recognized hy law as subsisting, when thesumb law had serered the smbjects of the two countries, and declared them enemies to each other, is to sulpose the law chargeable with incomsistency and absurdity. For what nse or pmpose could the law uphold such a comnection, when all further intercomse, (ommmmicattion, negotiation, or dealing between the partners, Wals pohibiterl. ats unlawful? Why preserve the skeleton of the firm, when the sense and spirit of it has fled, and when the execution of any one article of it by either, would be a breach of his allegiance to his conntry: In short, it must be obvious to every one, that a state of wall creates disabilities, imposes restraints, and exacts duties altogether inconsistent with the continuance of that relation. Why does war disolve a charter-party, or a commercial contract for a particular royage? Because, says Valin, (tom. 1 p. 626,) the war imposes an insurmomtable obstacle to the accomplishment of the contract; and this ohstacle arising from a cause beyond the control of the party, it is rery natural, he observes, that the charter-party should be dissolved, as of course. Why should the contract of partnership contime by law when equally invincible olstacles are created by law to defeat it? If one alien enemy can go and hind his hostile partner, by contracts in time of war, when the other can have no agency, consultation, ol' (onntrol concerning them, the law would be as mjust as it would he extravagant. The good sense of the thing as applicable to this sul)ject, is the rule prescribed by the Roman law, that a copintmership in any business ceased when there was an end put to the hminess itself. Item sialicujus rei societus sit, et finis negotio impositus est, flinitur societus. (Inst. 3, 26, 6.)

"The doctrine, tlat war does not interfere with private contracts, is not to be carried to an extent incomsistent with the rights of war.

"Suppose that II. \&.J. W. had entered into a contract before the war, which was to continue until 1814 , by which one of them was to ship, half yearly, to London, consigned to the other, a cargo of purovisions, and the other, in return, to ship to New York a calco of goods. The war which broke out in 1812, would surely have put an end to the further operation of this contract, lawful and innocent as it was when made. No person conld raise a doubt on this point; and what sanctity or magic is there in a contract of copartnership, that it must not yield to the same power?

"If we examine, more particularly, the nature and objects of commercial partnerships, it would seem to be contrary to all the rules 
hy which they ale to be construed and governed, that they should

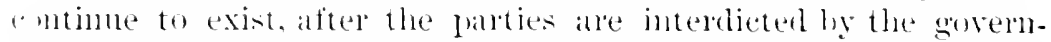
ment, from any ammmmication with eateh ofler, and are platered in at state of alsolnte hostility. It is of the essence of the eomtratet that

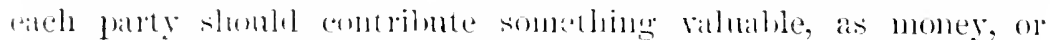

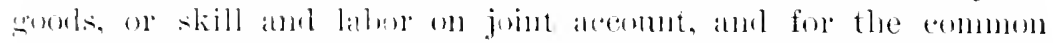

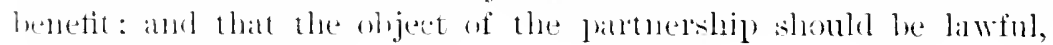
athd lomert husintess.

"Bnt bow cant the fartuers have any unity of interest, or any joint olject that is lawtul. when their pursuts, in comsentuence of

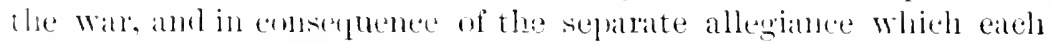
"westo his own govermente most be muthally lostile?

.. The eommeredal business of earle commtry and of all its people, is an object of attack, and of restrmetion to the other. One party

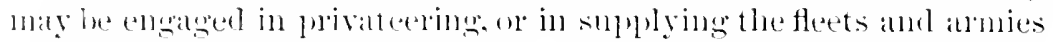

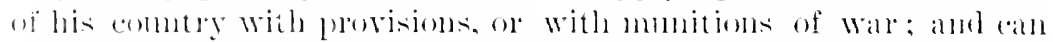

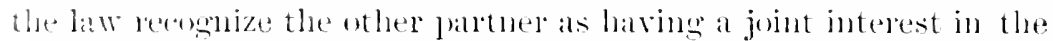
lowits of slleh business: It would he imposible for the one parther

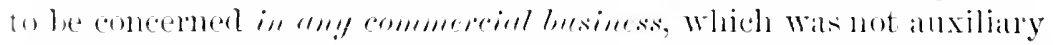
to the resonces and efforts of his commtry in a matime War. Ant

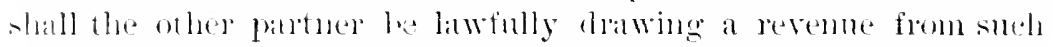

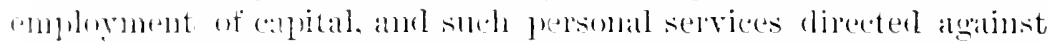
his own comtry: We cambot contemplate such a confusion of obligattim between the law of partuelship and the law of war. ol such at

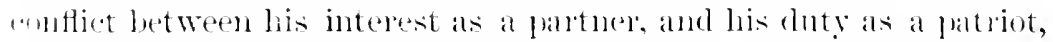
withont a mistme of astomishment and dreat. siall it be silid that

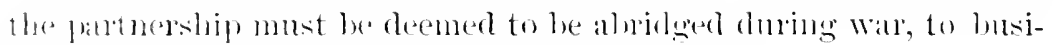
mere that is altogether imoxions and harmless?

- lint I womle ask, how an wo ent down a pastmesship in that

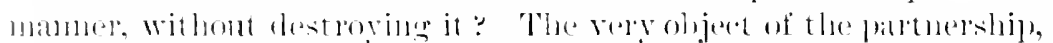

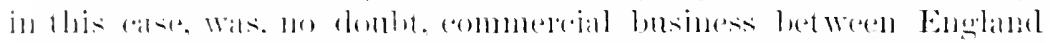
and the laited states and which the how ile state of the two comb

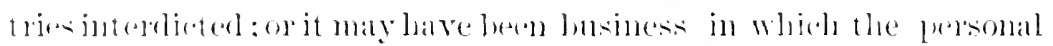

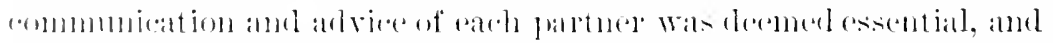

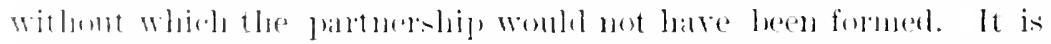

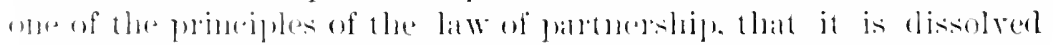

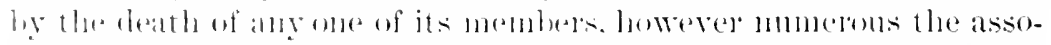

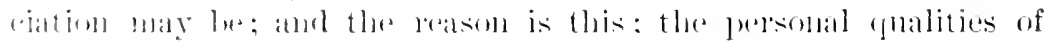

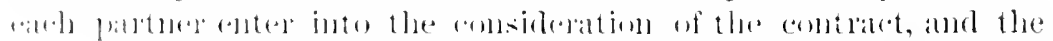

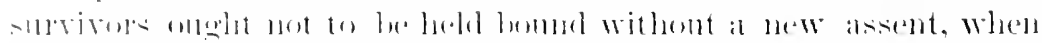

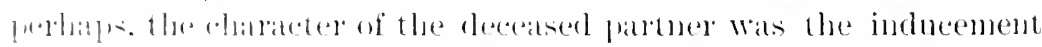
to the andultertions.

". Shall we sal that the puthership entinues during war, in a 


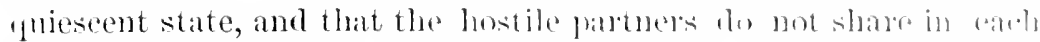

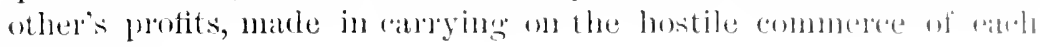
colintry?

"It wombl he then most mujust to make the party who dial not

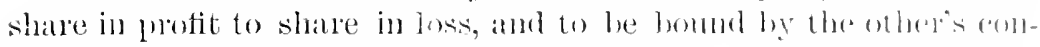
tracts; but if one partuer does not shate in profil, that abone dhe stroys a partnership. It wombl the what the lioman lawyes ablled societas leomim, in allusion to the fable of the liom, who, labing entered into a partnership with the other aninals of the forest in hunting, alpropriated to himself all the prey.

"It is one of the fumbamental principles of every commereial partnership, that each partner has the power to buy and sell and pay and receive, and to contrat and bind the firm. But then, again, ats a necessary check to this power, calch parturer can interfere and stop any contract about to be made ly any one of the rest. This is an elementary rule, deriverl from the civil law. In af prif potionem cunsum esse prohibutis constent. (Pothier, Trait. lu cont. sec. 11.90.$)$

"But if the partnership continues in war betweon hostile associates, this salutary power is withlowwn, and each partner is loft defenceless. If the law contimues the connection, after it has dostroyed the check, the law is then cruel and unjust.

"In speaking of the dissolution of partnerships, the French and civil law writers say, that partnerships are dissolved by a change of the condition of one of the parties which disables him to perform his part of the duty, as by a loss of liberty, or banishment, or haukruptey, or a judicial prohibition to execute his businns, or by contiscation of his gools.

"The English law of partuership is derived from the same somre: and as the cases arise, the same principles are applinl. The principle here is, that when one of the panties becomes disabled to act, or when the business of the association becomes impracticalle. alue law, as well as common reasom, adjudges the partnership to be dissolved.****

"Another objection was rased, from the want of notio" of th" dissolution of the parturship. The answel to this is axmancly eisy, and perfectly conchsive. Notice is requisite when a partnership is dissolved by the act of the parties, hut it is not menesiny when the dissolution takes place, ly the act of the laws. The declatation of war, from the time it was duly made know? to the nations, put an end to all futme dealings between the suligen and citizess of the two comntries, and. comsequently, to the future opelar tion of the copartnership in question. 
"The declaration of witr was, of itself, the most authentic and monitory notice. Any other notiee, in a case like this, between two public enemies, who land each his domicil in his own comtry, would hate bren useless. All mankind were bomd to take notice, of the wall. and of its conseguence. The notice, if griven, conde only be wiven by ach partner in his om combly ; and there it would be useless, as his combrymen eould not hold any lawful intercourse with the enemy. It could not be griven ats a joint act, for the bantuers camot lawfully commune together.

- But, it wals sald, that the peace had a healing influence, and restored the baties to all their rights, and arrested all confiscations, and forfeitures, which had mot previously and duly attached. I do not linow that I ditter from the counsel in any just application of this dectrime.

*. Is far as the war suspended the right of action existing in the adrerse baty luior to the war, that right revired; but if the contract in this ase was unlawful, peace condd not revive it, for it never had any lexal existence. So, too, the conntuership being once dissolved ly the war, it was extinguished forever, except as to matter's existing prior to the war."

\title{
NEW YORK LIFE INS. CO. r. STATIIEM.
}

\section{SAME V. SEYMS.}

\section{MANIIATTAN LIFE INS. CO. v. BLCK, ExECTtor.}

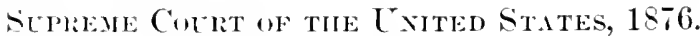

(10) Cnited states lieports, 24.)

Executors contracts between persons who become enemies, where time is material and of the essence of the contlact, are anmollet by the wate.

Life in-urance policies are of this eharacter ; but the assuled is entitled to recorer the equilable value of the policy, at the time of the oubreak of the war.

The first of these atses is here on alpual from, and the second and thind on whits of eron lo, the circuit Comt of the United states for the forthern District of Mississiplit.

The first atse is a bill in repuity, filerl to recover the amount of a

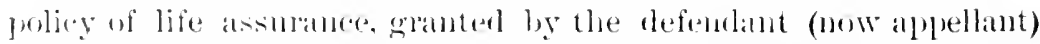
in 1-.il. on the life of J)r. A. I). Stathem, of Mississippi, from the

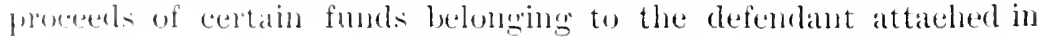


the hands of its agent at Jackson, in that state. It alpleats from the statements of the bill that the ammal premimms aceluing om the [olicy were all regularly paid, until the brealinger ont of the latte eivil war, but that, in enseguence of that erent, the freminn dhe on the Sth of December, 1861, Was not falid the parties assinter being residents of Mississippi, and the defendant a corporation of New York. 1)r. Statlem died in July, 1s62.

The other cases are sintilar.

Eateh poliey container various conditions, mon the breate of which it was to be mull and void ; and amomgst others the following: "That in ealse the sair (assured) shall not pay the sajal preminm on or before the several days hereinbefore mentioned for the payment thereof, then and in erery such ease the said comprany shall not le liable to the payment of the sum insured, or in any liat thereof, and this policy shall cuase and determine."

The Manhattan policy antained the additional provision, that, in every ease where the poliey should cease or become null and void, all previous payments male thereon should be forfeiter to the oompany.

The non-paynent of the premiums in arear was set up in bar of the actions; and the plaintitis respeetively relied on the existence of the war as an exense, offering to dednet the preminms in arrear from the amounts of the polieies.

The deeree and judgments below were against the defendants.

Mr. Justice Bribler, after stating the case, delivered the opinion of the court.

" ire agree with the comrt helow, that the contract is not an assurance for a single year, with a privilege of renewal from year to year by paying the ammal premium, but that it is an entire contract of assurance for life, subject to discontinuance and forfeiture for nom-payment of any of the stipulated preminns. Fueh is the form of the contract, and such is its character. $* * *$

"Each instalment is, in fact, part eonsideration of the entire insurance for life. It is the sime thing, where the ammall preminms are spreal over the whole life.

"The case, therefore, is one in which time is material and of the essence of the contrat. Non-paynent at the day involves absohnt. forfeiture, if such be the terms of the contrat, as is the case luele. Courts cannot with safety vary the stipmlation of the parties by introducing equities for the relief of the insured adainst their own negligence.

"But the eont below bases its decision on the assmmption that, when performance of the condition beeomes illegill in consecplenee of 
the prevalence of gublis war, it is excused. and forteiture does not

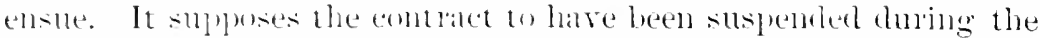
walr, and to hatre revived with all it-force when the wall ended.

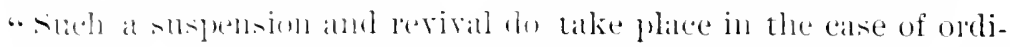

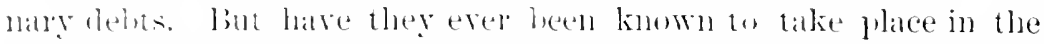
case of exeromery contallets in which time is material? If a Texas

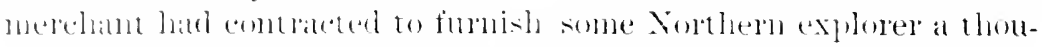

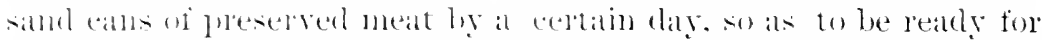

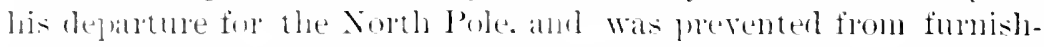
ing it by the oivil watr, would the contract still be woon at the close of the wats five rears afterwards. and after the retum of the experition:

- It the proprietor of a Temuessee fliarry had agleed, in 1860 , to furbish. during the two following reas, tem thomsand cubic feet of marble. for the construction of a Bmilding in Cincinuati, could he have ditimed to gertim the entratet in 1805 , on the ground that the wall prevented an carlier prerformance?

."The treth is. that the doctrine of the revival of contracts suslemeted during the war is one based on consielerations of equity and justice, and canmot be invoked to revive a contratet which it would be mjust on ineruituble to revive.

"In the casce of life insurance. lesicles the materiality of time in the ledolmance of the contract, anomber strong reason exists why the policy shemblet be revived. The garties do not stand on eyllal gremel in reference to such a revival.

"It womb opelate most unjustly aganst the company. The mosiness of insmance is fomeded on the law of averages; that of life insmance eminemly so. The arelage rate of mostality is the batis on which it rests. Dy slueating their risks over a large num-

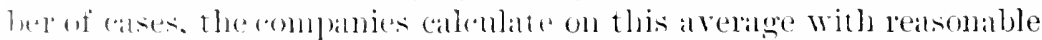
cotatinty and safoty. Anythiug that interferes with it deranges the secolity of the haness. If every policy lapsed ly reasom of the wall shold be pevived, and all the back pemimms shombl be paid, the enmplaties wombl have the bentefit of this avelage amomit of risk.

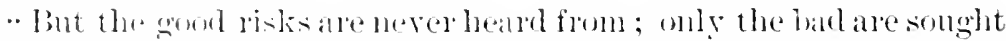
to be revivel, whele the person insuled is eithel dead or dying.

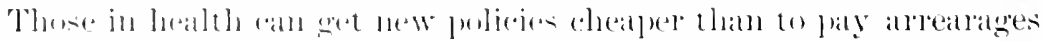

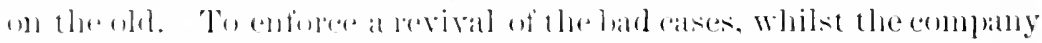

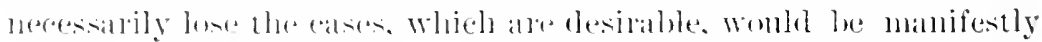

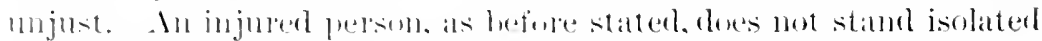

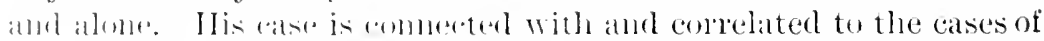

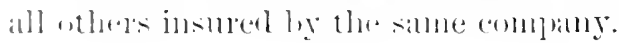


"The nature of the lominess, as a whole, must lue lookerl at w understand the general equities of the parties.

"We are of opiniom, therefore, that an action camot he maintained for the anmont assmed on a policy of hore-insmance forfeited, like those in question, hy mon-payment of the premimn, event thomgh the payment was perented by the existence of the watl.

"The question then andises, Must the insumed lose all the money which has been pair for preminns on theid respertive policies: li they must, they will sustain an equal injustice to that which the companies would snstain by reviving the policies. At the rely first binsh, it seoms manifest that justice repuires that they shombl have some compensation or retmon for the money allealy pated, otherwise the companies would be the ganers from their loss; and that from a cause for which neither party is to blane. The case may bo illustrated thms : Suppose an inhabitant of Georgia hal barmaind for a house, situated in a Northern city, to be latil for hy insialments, and no title to be made mutil all the instalunents wrop pail, with a condition that on the falilure to pay any of the instaments when due, the contract shomld be at an end, and the previoms paymonts forfeited ; and suppose that this comdition was decladed by the parties to be absolute and the time of payment material. Now, if some of the instalnents were paid lefore the war, and of hous atecruing during the war were not paid, the eontract, as an exerntory one, was at an enr. If the necessities of the ventor ohligen him to avail himself of the condition, and to resell the property to amoller party, would it he just for him to retain the money he hat received? Perhajs it might le just if the faihue to pay had been volumaly, or coukl, by pussil,ility, have been aroiled.

"But it was caused by an event beyond the control of either party, -an event which made it mulawful to pay. In such case, whilst it would be mujust, after the wall, to enforce the contract as an executory one aganint the venclor contrary to his will, it wombl be ennally unjust in him, treating it as ended, to insist upon the forfejume of the money alrearly paid on it. An epuitable right to sime compensation or return for previons gayments would clealy lesult from the circumstances of the case. The money paid by the purchaser, sulpject to the value of any possession which he may have

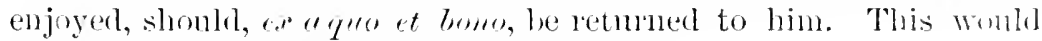
clearly be demanded hy justice and right.

"Inl so, in the present case, whilst the insumee (omplany las a right to insist on the materiality of time in the condition of paynunt of preminus, and to holl the contract ended by reason of mon-palyment, they cannot with any faimess insist upon the andition, as it 
legards the forfeitule of the premiums already pata ; that would be clearly unjust and interuitable. The insured has an equitable right what this amoment restored to him, sulject to a deduction for the value of the assumance enjuged by him whilst the pulicg was in exintence: in other words. he is fairly entitled to ladre the equitable balle uf lis pulicy ***

. We ale of opinion. therefore, first, that as the companies elected to insist num the conditin in these cases, the policies in question

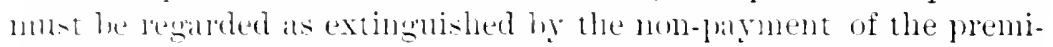
mun. themgl callsed hy the existence of the War, and that an action will uot lie for the amome insmerl thereon.

". -exomolly, that snch failne heing cansed ly a public was, without

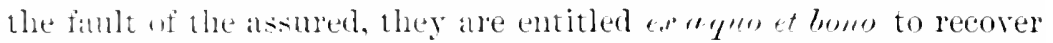
the equitable value of the policies with interest from the close of the will. * * * *

- In estimatins the equitalle value of a poliey, no dednction should be luake form the precise anome which the calculations give, as is sometines done where policies are voluntarily surentered, for the furlose of discouraging such surrenders ; and the ralue sinould be taken ats of the day when the first default occured in the payment of the lurminm hy which the policy hecane forfeited. In each case the lates of mortality and interest used in the tables of the company will form the basis of the calculation.

"The decree in the equity suit and the judgments in the actions at law ane reversed, and the causes respectively remanded to be proceeded with aceording to law and the directions of this opinion.

\section{Currose, .J., (with whom eoncurred IIrxt, J..) dissenting:-}

- Where the parties to an executory money-contrated live in different commtries, and the governments of those comntries become involvol in pmblic war with eath other. the contrat between such

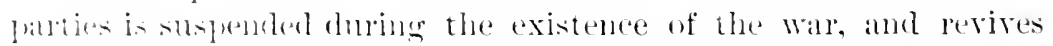

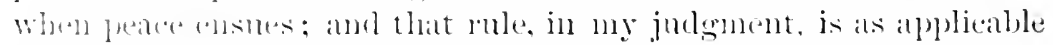
to the contract of life-insurance as to any onlite execontory con$11: i 1 \cdot 1$.

* (amsequenily. I an obliged to dissent from the oprinion and jullgnent of the court in these eases." I

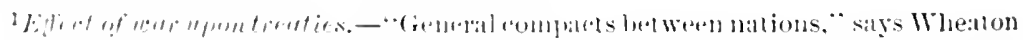

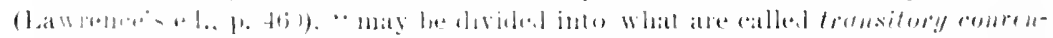

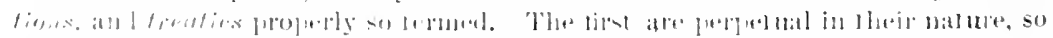

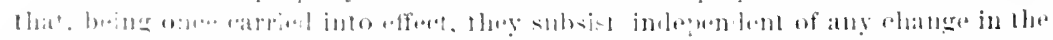

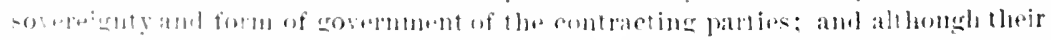

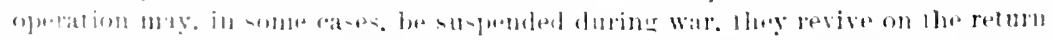

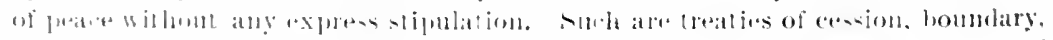

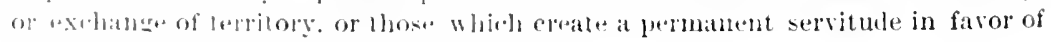
ond Hatom whin the territory of another." 
Section 31.-Trabe with the Exemy.

TIIE "IIOOI"."

High Court of Ammintr, 1799.

(1 C. Rolinsom, 196.)

British merchants are not at liberty to trate with the enemy withont the King s license; all poperty taken in such trade is contiscable as prize to the canter.

Jurlgment.-SIR Wr. Srott._" This is the case of a ship laten with flax, mathler, geneva, and cherse, and bomal from liofterdam ostensibly to bergen; but she was in truth coming to a british port, and took a destination to bergen to deceive the Fench eruiser's ; and, as the (dian discloses (of which I see no reason to doubt the trith), the goods wele to be imported on aecomnt of British merchants, leing most of them articles of considelable nse in the mannfactures and commerce of this comntry, and heing brought under an assmance from the commissioners of eustoms in seotland that they might be lanfully inported withont any license, by virtue of the statute 355 Geo. 3, e. $15, \$ 180.1$

"It is said that these circumstanees compose a case entitled to great indulgence; and I do not deny it. But if there is a role of law on the subject binding the comrt, I must follow where that rule leads me; thomgh it leads to conseguences which I may privately regret, when I look to the particular intentions of the parties.

"In my opinion there exists such a general rule in the maritime jurisprudence of this combry, by which all trating with the pullic enemy, mless with the permission of the sovereign, is interdicted. It is not a principle peculiar to the maritime law of this eomotry ; it is laid down by bynkershoek as an miversal minciple of law.'Ex naturâ belli commercia inter lostes cessare non est dolitanılum. Quanvis nulla specialis sit commerciomm prohibitio, ipso timen

1 The :35 G. :3, c. 15 (March 16, 1795), enacts, "that it shall be litwful to import such goots belonging to sulpjects of the Cuited Provinces, or to any who were subjeets before the 1 !nh of Jantiay, 17\%, or to any subject of his miljesty. 10 be landed and secured in warehouses for the benelit of the proprielor. and for the security of the revenue." Subserguent aets contain further resulations for properly cunsting from llolland, in the ambignous sitnation of the wo count ries at that tinte. 


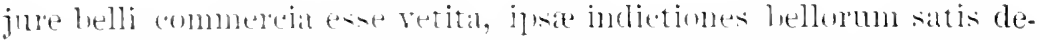

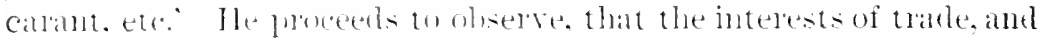

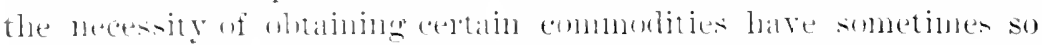

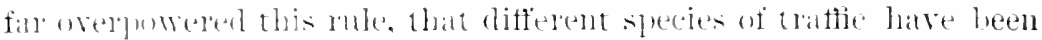

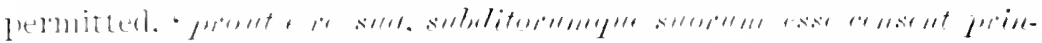

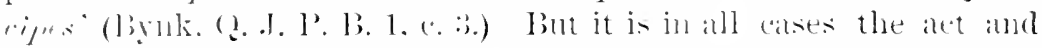

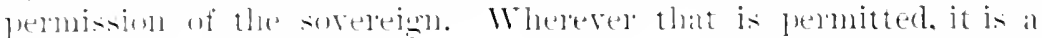

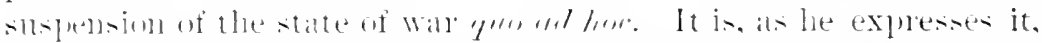

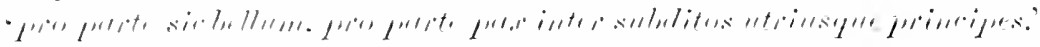

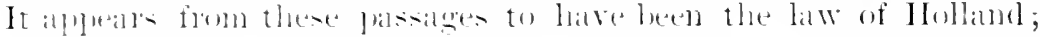

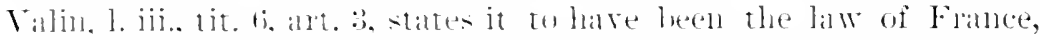
whether the trate wats attempteil to be carried om in national or in nemtarl resels: it will alplear in a case which I shall have occa-

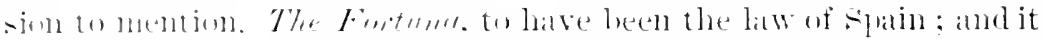

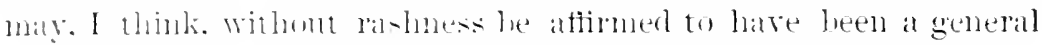

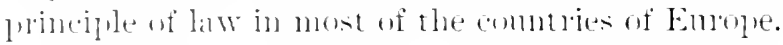

.. hy the haw and eomstitmtion of this comntry. the sovereign alone

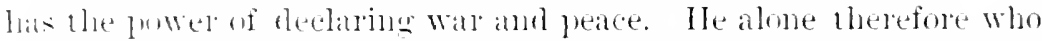
has the powel of entilely lemoring the state of war. has the powel

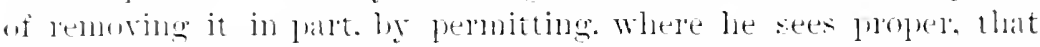
commeleitl intereoulse which is a partial suspension of the watr. Thede maly he ocasions on which such an intercomse maly be highly experlient. IBut it is not for individuals to determine on the experiency of such occasions on their own notions of commelce, and of commeret melely, and posibly on grounds of purvate adrandace not vere recomedalule with the general intelest of the state. It is for the

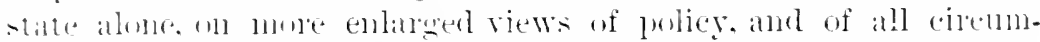

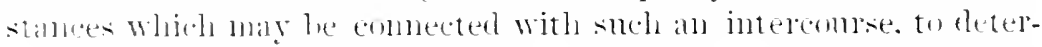
mblue whell it shall he permitlet, and muter what regalations. In

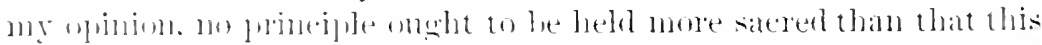

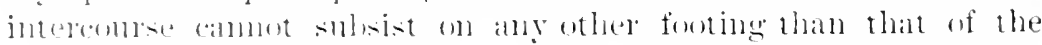

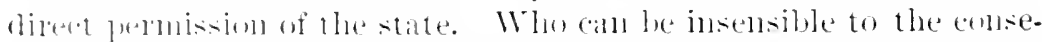

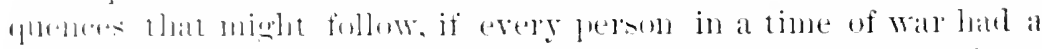

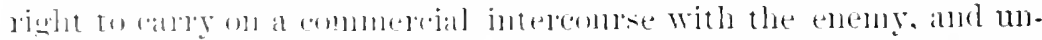

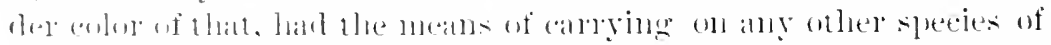

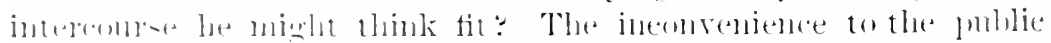

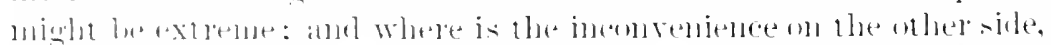

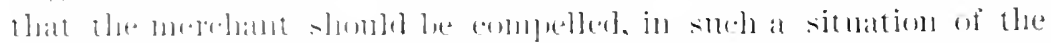

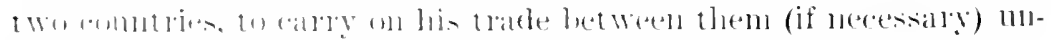

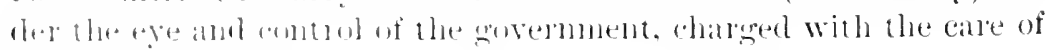
the puldir sitioly?

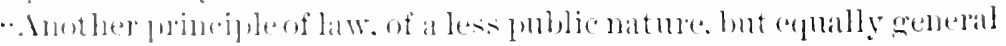

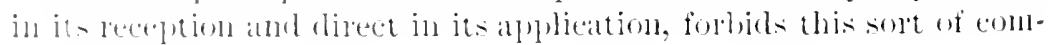




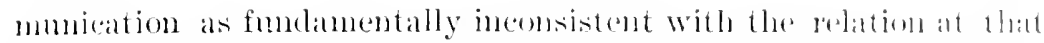
time existing leetween the two comblese and that is, the wat inability to sustain any entract hy an apleal to the tribmats of 1 hes

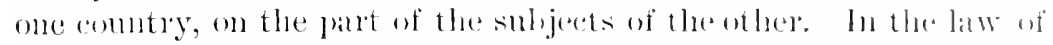

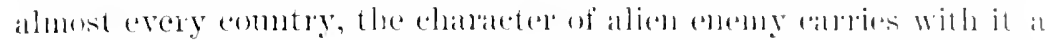

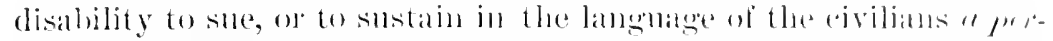

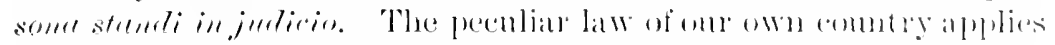
this principle with great rigne. The same principle is recoivel in ond conts of the law of nat ioms; they areso far liritish combts, that

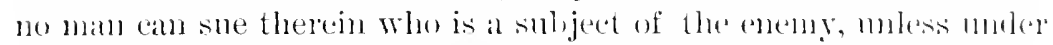

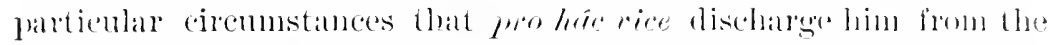

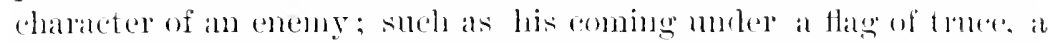
cartel, a pass, or some other act of pullic authority that puts him in the King's peace fro hrie reve. But otherwise he is totally e, le, : even in the case of ransoms which are contrats, hut contlatets allis-

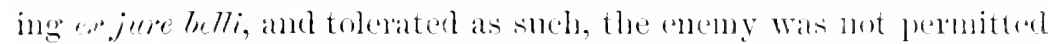
to stle in his own gonele person fon the payment of the lansom bill ; lut the payment was enfonced by an actom hompht by the implisoned lostage in the comts of his own comnty for the reorely af his freedom. I state in which contratets cammot be enforeel, rimmot be a state of legal commeree. If the parties who ale to contratet have no right to eompel the performance of the antract, mor erent lo appear in a comt of justice for that purpuse, an there be a stromger proof that the law imposes a legal inability to comtane? 'To such transactions it gives no sanction: they have 110 lesal existence ; and the whole of snch commeree is attempted without its potedion and against its anthority. Bynkershel expresses himself with areat force upon this argunent in his first honk, dapter 7 , where he lays down that the legality of commerce and the mutual use of comto of justice are inseparable; he says, that cases of commerce are mulistinguishable from cases of any other slectes in this respet. 'si hosti semel permittas actiones exercere, llifficile est distinguere ex [nti causî orimter, nec potui animalrertere illam distinctionem usin fuisse servatam.'

"C pon these and similar gromuls it has been the establisherl rule of law of this comt, confimed by the jumgment of the silpreme Comt, that a trading with the enems, exeept moler a royal license. subjects the property to confiscation;- and the most eminent persons of the law sitting in the Supreme Court have uniformly sustained such jurgments. $* * * 1$

${ }^{1}$ In support of this rule Sir $T$. Scott reviews a large number of cases derethen on appeal by the Lords of Appeal. These cases are the following: The lingeme Jacob, 1750: The Lady Jane, 17t9; Deergaden, 17t7; The Eliz.be 1. 17.1!: The 
"I omit many other eases of the last am the present war merely on this gromed that the rule is so firmly established, that no one ease exists which hats heen permitted to contravene it,-for I talke upon me to arer, that all cases of this kind which have come lefore that tribunal have receired an miform determisation. The cases which I have produced, porve that the rule has been rigitly enforced:where acts of parliament have on different oceasions been made to rebax the navigation-law and other revenneacts; where the government has anthorized, moler the sanction of an alet of parlianent, a homeward thate from the enemy's jossession, but has not especially potected an outward tade to the same, though intimately connected with that homeward trale, and almost necessaly to its exist. ence; that it has been enforced where strong claim not merely of convenience, but almost of necessity, excused it, on behalf of the individual ; that it bas been enforeel where carriages have been haden before the war, hut where the parties have not nsed all possible diligence to comntermand the royage after the first notice of hostilities; and that it has been enforced not only against the subjects of the erom, hut likewise against those of its allies in the war, upon the smposition that the rule was fomnded on a strong and miversal principle, which allied states in war had a right to notice and apply, mutully, to each other's subjects. Indeen it is the less necessary to produce these cases, because it is expressly laid down by Lord Manstielel, as I molerstand him, that such is the maritime law of England." (Grist v. Muson, 1 T. R., 85.)

[In conchusion. sir IV. Seott held that the acts of Parliament in question were not intended to legalize the trade withont special licenses; and that the law adviser's of the commissioners were wrong in theis conchusions to that effect. The property was therefore condemuned according to the strict rule of law.]

Juffrow Lonica Margaretha, 1781; The St. Lonis, 1781: The Victoria, 1781; The Conzts de Wohrougoff, 1781; The Gnidita, 1755: The Eenigheid. 1795; The Fortuna, 1745: The Freeten, 1795; The William, 1795.

These were all eases in which the property in fuestion was condemned. thongh some of them, like the case of the Hool, were cases of great hardship upon Britisl merehants. 
PO'TTS $v$. BELL.

King's bisch, 1800.

(STerm lieports, DA.)

Trading with the eneny withont the King's licenes is illegal.

This was the case of a neutral ship captured by a French cluiser on a voyage from Rotterdam to IIull, for having on board enemy propert y (English). These goods were bought in Rotterdam by the agent of an English house, after the hreaking ont of hustilities between France and England, and insured in an English company. In action was brought on the insurance policy.

The defendant insisted that the plaintiff was not entitled to recover; because the policy was void, inasmuch as it was not lawful to trade with the enemy. The Common Pleas found for the plaintiffs. But on appeal, this judgment was reversed:

Judgment,-Lord Kexrox, Ch., J.:- "The court hat very fully considered the case immediately after the very learned agment which had been made by the King's adrocate, sir J. Nicholl, in the last term. That the reasons which he had urged and the anthorities lee had cited were so many, so miform, and so concinsive to show that a British subject's trading with an enemy was illegal, that the cuestion might be considered as finally at rest. That those authorities, it was true, were mostly drawn from the decisions of the admiralty courts; and that though all diligence had been used, there was only one direct authority on the sulject to be found in the common-law books, and that one was to the sime effect. But that the circumstances of there being that single case only was strong to show that the point had not been since disputed, and that it might now be taken for granted that it was a principle of the common law that trading with an enemy without the King's license was illegal in British subjects. That it was therefore needless in this case to delay giving judgment for the salke of pronouneing the opinion of the court in more formal terms; more especially as they combl to little more than recapitulate the judgment with the lomg train of authorities, already to be found in the clearest terms in the principal report of the case of the Hoop published by Dr. Pobinson. That the consequence was that the judgment of the cumt of Common Pleas must be reversed." 


\section{TIIE "R.APII)."}

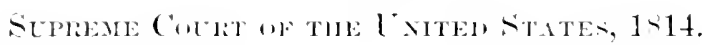

$$
(-r i n+1,12 \pi)
$$

After a derlaralom of war, an American citizen cannot lewally send a ressel to

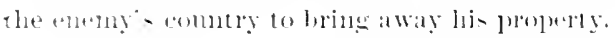

This wals an appeal from the sentence of the circuit court, for the distriet of Massalduscets.

The material filcts in the case were these.

Jabez llarrison, a mative American citizen, the elamant and alppellant in this ease. had purelatsed a quantily of English goofs in

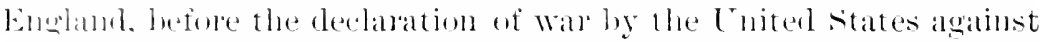
that anmtry and deposited them on a small iskand, leelonging to the Einglinh, called Indian Island, and situated near the line between Nona seotia and the Enited states. E Pen the breaking out of the

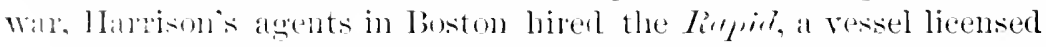

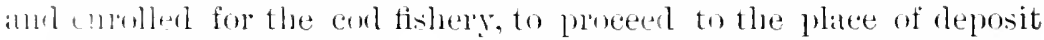

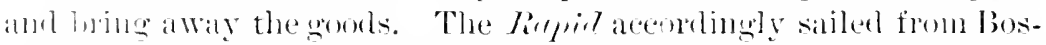

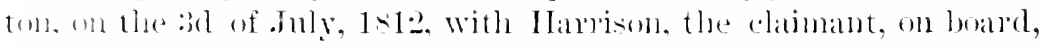

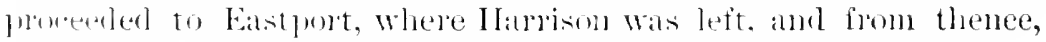

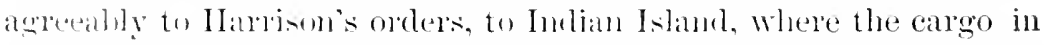

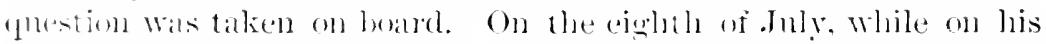

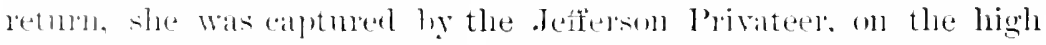
seas, and bromelst into sialem. The gools, being libeled as prize,

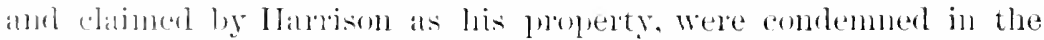

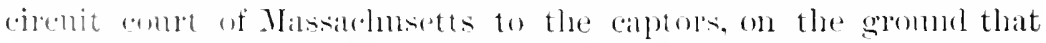
hy. trating with the enemy, they had atchuired the chander of enemiese jumelty.

A diand Was also interposed by the Lniterl states, on the sromel

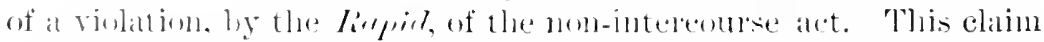

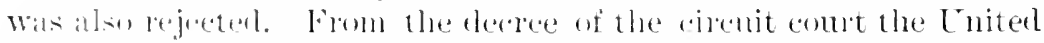
stales and llarrison alpealed a the trial before the supreme Cont

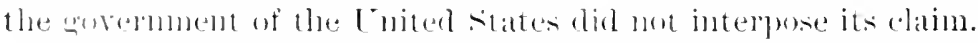

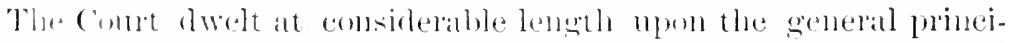
ples of the role which prohihited trabling between enemies; and as the re was no guestion of the observance of this rule in international lats, this part of the opinion is omitted. The claimant contended, lowerer, that there was not a trating with the enemy in tisis case; 
that on the breaking ont of war, crery ritizen lual a right to with-

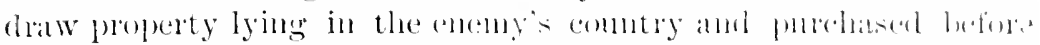

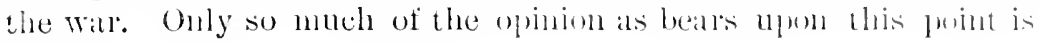
givell.

.Judgment, —.Junsox, .J. :-

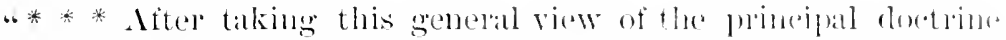
on this subject, we will ensider the prints matle in belablf of the

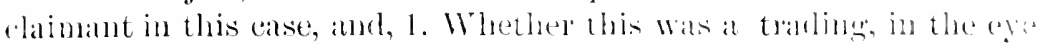

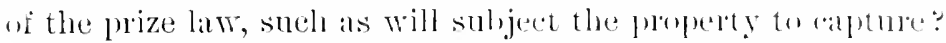

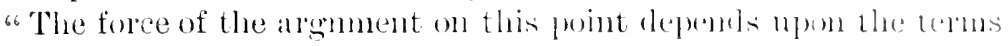
made use of. If by tomling, in prize law, wats neant that signifiation of the term which consists in negoliation of contratet this

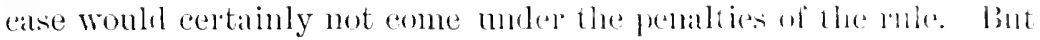
the object, policy, amol spirit of the rule is to cut ofl all commumication or actual locomotive intereomse lutween individnals of the belligerent states. Negotiation or contrated has, therefore, no neeessary comeetion with the offence. Intereourse inemsistent with actual hostility, is the offenee atrallst which the opreation of lise rule is disected; and by sabstituting this defintion for that of tratmg with an enemy, an answer is given to this alsmment.

"2. Whether, on the hreaking ont of a war, the citizen has a right to remove to his own enmtry with his pnoperty, is a guestion which we conceive does not arise in this ease. This rammint artainly had not a right to leave the Cnited states, for the pmone of hinging home his property from an enemy's comntry ; mmch less ankl he claim it as a right to hring into this country, gools, the importattion of which was expressly prohilited. As to the claim for the ressel, it is foumded on no pretext whatever ; for the mulertaking, besides being in violation of two laws of the Cnited States, was altogether voluntary and inexeusable. With regart to the importattions from Great Britain about this time, it is well kmomn that the forfeiture was released on gromels of poliey and a suphoser obligation indnced by the assmances which had been held ont by lhe American charge d'afraires in England. But this clamant comlel allege no such exuse.

"3. On the third point, we are of opinion that the foregoing olservations furnish a sufficient answer.

"If the right to capture property thus oftending, grows ont of at state of war, it is enough to support the conclemmatim in this atas. that the act of Congress should plorlace a state of wall, and that the commission of the privateer should atuthorize the alpture of any property that shall assume the belligerent character.

"Such a character we are of opinion this ressel and carego took 19 
upon herselt; or at least, she is deprived of the right to luove herselt otherwise.

- We are aware that there may exist considerable hardship in this are; the owners, hoth of vessel and cargo, may lave heen unconseions that they were violating the duties which a state of war imposed now them. It does not appear that they meant a daring violation either of the laws or belligerent rights of their comntry. Bnt it is the menvied province of this comrt to be directed by the hearl and not ly the heart. In deciding upon principles that must define the rights and duties of the citizen and direct the future decisions of justice, no latitude is left for the exercise of feeling."

\section{TIIE "ST. LAWRENCE."}

\section{Sipleye Coyrt of the Lited states, $1814-1815$.}

(o cranch, 434, whe a Crench, 120).)

Without decilling whelher an American citizen may, after the outbreak of war, withlraw with his property from threnemy's country, held, that he camot do so elecen mouthe after the declaration of war.

This was an appeal from the sentence of the Cnited states Circnit Comt for the district of New Itamplise.

The ship st. Lamperce was captured on the zoth of June, 1813, and, whth her argo. hibled as prize, in the Isistrict comrt of New IIampline. (nn the 5th of May, 1813, a license was granted by the privy comeil of Great Britain to 'Jhomas White of London, and others, permiting them to export, direct to the Enited States, an emmerated cargo in the st. Lawence, provided she eleared out before the last lay of that month. On the 30th of May, 1sl3, shesaled from Liverporl for the Inited states with the cargo specified in the license. Mr. Alexamder MrGregor and his family were passengers on brated.

It appeared from the examination of Mr. MGregor, that he was born in sentand. Wor natmalized in the Lnited States in 1795, had lived, the last seven years, in Liverpool, and was returning in the st. Lawrence, with his fanily to the Cnited states.

There were several claimants, but only so much of the case is given as refers to the claims of M'Gregor and Pemuman.

Wesstes, for M'Gregor and Penniman, said :

"We contend that a rlistinction is to be taken between an American citizen, domiciler in England at the breaking out of the war, with- 
drawing his funds, and an Americun eitizen who goes to Fugland after the deelatration of war, for the same purpose. That the former, whether a native or naturalized eitizen, has a right (ambl furlarjs it is his eluty) to return to the Inited states with his etfeets. If he has no sueh right, why should the law of bations have provided it reasonable time for remoring in case of watr?

"This rule of the law of nations las heen fommed upon the necessity of the case, and upon the bardship which would attend the wath of such a rule. A citizen of one comitry may lawfully gon to any othed comtry, in time of peace, and tatke ny) his residene there; and it would be very haud if he must suffer hy the sudden and mexpected breaking ont of a war-an event over whish he had no control. I nentral would be permitted to withllaw his funds in sluh a case ; and if we should allow the privilege to nent sals, why shonkl we deny it to our own citizens? 1 Rob., 1 , The Figilentic 1 ; Bos. and I'nl., 355, Bell v. Gitson.

"The case of Escott, rited in The IImp', 1 Rob., 165, 196, nay perhaps be thought to make against our clatim.

"But the eases are not alike. In that case, Escott sent for his proplerty: here M'Gregor came with his.

"A character gained by residence, is lost by non-resirlence. When Wharegor ceased to reside in England, his character, if lostile hefore, no longer continued hostile. That it was not his intention to continue his residence in England, is eleally evidenced hy his actual return to the United States with his family.

" IVith regard to his half of the ship, we contend that if he ham a right to return, he had a right to use the means necessily for that purpose-he had a right to purchase a ship for the converance of himself and his family. So if it was lawful for him to withllaw his funds, he might lawfully invest those funds in merehandise, if he could not otherwise withlraw them. + Rob., 161, 195, The Hartomme delle Gracie ; 3 Rob., 11, 12, The Imtian Chiet; 5 Rob., 24s, The President ; 5 Rob., 84, 90, The Oceun : 5 Rob., 60, The Dirmu."

Judgment :-

"It is not the intention, to express any opinion as to the right of an American citizen, on the breaking ont of hostilities, to withriaw his property purchased before the war, from an enemy comtry. Admitting such right to exist, it is necessary that it should be exercised with dne diligenee, and within a reasonable time after the knowledge of hostilities. To admit a citizen to withllatw property from an enemy comntry, a long time after the war, muler the pretence of its having been purchased before the war, would leal t." the most injurious consequences, and hold ont strong temptations to every 
species of framblent and illegal traffic with the enemy. To such an molimited extent we are all sitistied that the right camnot exist. The present shipnent was not mate motil inore than eleven months

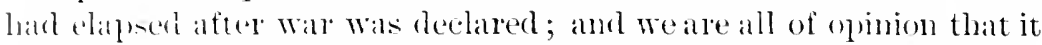
Was then tox late for the pirty to malie b he shipment, so as to exempt him from the penaly attathed to an illegal traftic with the enemy. The conseguence, is that the property of Mr. I'emmiman must be (rimslemmetl.

*. And their decision is fatal, also to the daim of Mr. M'Gregor. Intependent, indeed, of the principle, there are many ciremotances in the case unfaromale to the latter gernleman. In the first place, it is not predented that the goods inchuled in his claim were purchased hefore the war. In the next place, he was the projector of the present rovige, and beame, as to one molety, the charterer or frrchatser of the ship. Nearly all the eargo eonsisted of goods helonginf (as it must now be deemed) exclusively to British merchants. Ile wats, therefore, engaged in an illegal traffic of the most noxions nature: a traflic not only prohilited hy the law of war, but by the municipal resulations of his adopted comtry. His whole property, therefore, embrked in such an enterprise, must alike be inflicted with the taint of forfeiture."

\section{TIE BRIG “JOSEPII"}

\section{U. S. Cincent Colrt foe Missicnusetts, 1813.}

(1 Gulliwon, 545.)

When a ritizen of the Cnited states is residing in the enems's comntry at the chubrak of watr. ly is not permisted to bring his property back in stech a way as 10 involve a trate witl the enemy.

The following is an extract from the opinion of Ml. Justice STory : _- It has heren farther aromerl, that a dechation of war is, in effect, a command to the citizens of the belligerent comntry almoal at the time, of retum lome, and that the law allows a reasomabe time and way to eflicet it.

"I am mot a ware of any principle of public law, which olloliges every

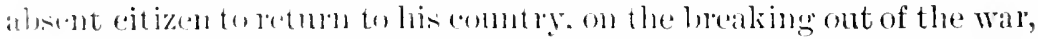

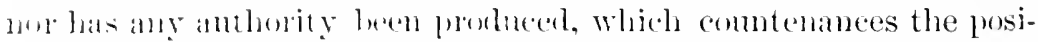
tion. It may be arluitted, that the sorereign power of the combly latis right to reguire the services of all its eitizens, in time of war, and for this punkse may recall them home under penalties for dis- 
obedience. But until the sovereign power has promulgated : ind h command, the eitizens of the conntry have at ferfect right to purstle their ordinary business and tratle in and with all other commtion, except that of the enemy. Lum any other supposition, all forming commerce would, during wat he suspended ; for if it were the dnly of absent eitizens to retmm, it would, mon the sime principle, lu the duty of those at home to lemain there. Is to citizens in the hostile comntry, the declaration of war imports a suspension of all farther commeree with such enuntry, and oblines them to return, mess they would be involved in all the eonserpueness of the hostile character. If they wish to return, they must (lo it in a manner, which does not violate the laws; and their property cannot he lesmoved witl safety from the enemy comntry, mbess under the sant.tion of their own govermment.

"But even if the position were generally true, that is contendul for, the law would never deem that a reasonable mode of eomreyine" property home, which involved it in a noxions trate with the publix: enemy. That can never be held to be a reasonable mole of retmming a ship to the Enited states, which involves her in a traflie for bidden by the laws."

\section{TIIE " WILLIAM B.AGALAY."}

Supreme Contr of the Cxiten states, 1860.

(5) Hralluere, 408.)

As to the duty of an American citizen to retmon home when the United States becomes involved in war whth the conntry of his residence.

Extract from the judgment,-CLifrom, .J. :-

"The duty of a eitizen when wall brealis ont, if it he a foreign war. and he is abroad, is to return withont delay; and if it be at civil war, and he is a resident in the rebellioms seetion, he shmold leave it as soon as practicable and adhere to the regular establisherl goverument. Domicil in the law of prize beemes an important momiderattion, becanse every person is to be consiblered in suh procerlings as belonging to that comntry where he has his domicil, whiteror mat be his native or adopted comntry.

"Personal property, except sinch as is the produrt of lho lostilo soil. follows ss a general rule the rights of the propricont: lnt if suffered to remain in the hostile commtry after wall lopiks ant, it beeomes implessed with the national character of the ledigerent. 
where it is simated. Promptitude is therefore justly required of citizens reident in the enemy comntry, or having personal property there. in changing their domicil, severing those husiness relations, on disposing of theil effects, as matter of duty to their own government, and as leuting to weaken the enemy. Presmmption of the law of nations is aganst one who lingers in the eneny's country, and if he antinues there for mueh length of time, without satisfaetory explanations, he is liable to be considered as remorant, or gunity of colpable delay, and an enemy." 1

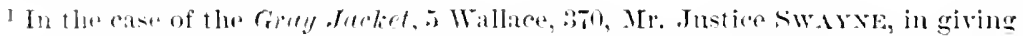
the opinion of the court, said: "The only qualitication of these rules (property coming bon the enemy country to be comlemnell) is that when, upon breaking out of ho-tilities, or as seron after ats po-sible, the owner escapes with such proprerty as lar "an take with him, or in goo:l fath thus early remoses his property, with the riew of putting it byom the dominion of the howtile power. the property in such rater in exempt from the liability which would otherwise attent it."

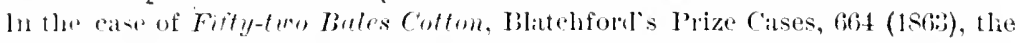
cotton was calptured on a flat-boat fastened to a wharf in Texas, and belonged to a ritizen of Xew York, who went to Texas before the war to collect elebts due to hin. The proceets hat been invested in this cotton, with a view to leare the hostile (w) nutry after the lowaking ont of the war.

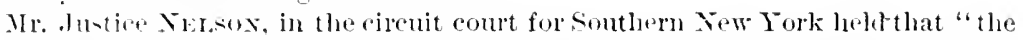

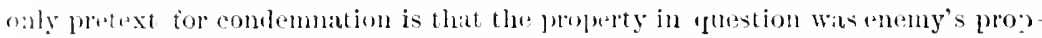
"aty which I think is not sustained. It appen's to me that the claimint used all Miligence to collect his effects, with a view to leave the hostile conntry, after the brealising out of the wat, and is brought fairly within the principle of intermational lat that proterets liam."

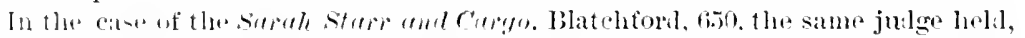
that atter the loreaking ont of war eitizens of the loyal states resilent in the states in pebellion should be accorded a reasonable time to convert their property into funds which conld be conseniently carriel, and to withdrat from their business commertins in the enemy's comntry. To the same affert the case of the follen firl-

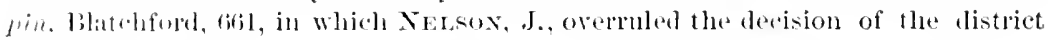
(a)turt.

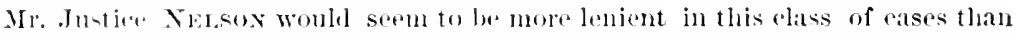
the matjority of his collexgnes on the supreme beneh. In the I'rize Cases, he disstuted brom the ofinion of the majority, and asserted that there coull be no illegal tratine with the eneny prior to the proclamation of the President, on the lith of Aluguat, latil.

Sre further on the removal of property on the outbreak of war, the case of the

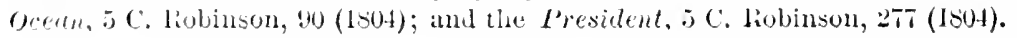


KERSIAW Y. KLLALY.

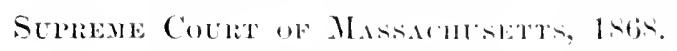

(100 Mussuchusetts lieprorts, stil.)

A citizen of Massachusetts, resilling in Mississippi luring the civil war, latsent a plantation and planted it with crope; bett was driven atwy by soldiel's of the

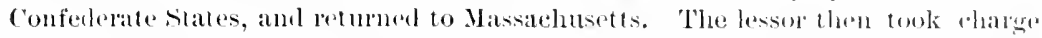
of the plantation, harvested the crops, and delivored to the besseres son, in Min-issippi, cotton of the value of $\$ 10,000$. The cotton wats shiplest to the leseree at Boston by his son. After the close of the wate, the lessol stell to reevere rint, ete.

Ifeld, that, as between lessor and lessee, them was no trading betwern enemies, and that the lessor conld recover on the contract of lease.

Judgment,—Grix, .J.:-

"The defendint, a eitizen of Massachuset ts, in Feluruary, 1stit, in Mississippi, took from the plaintifl, then and ever since a citizen and resident of Mississippi, a lease for one year of a totton plintation in that state, and therein agreed to pay it rent of ten thomsind dollars, half in cash, and half 'out of the first part of the cotton erol, which is to be fitted for market in reasonable time.' The lessor also agreed to deliver, and the lessee to receive and pay the value of the corn then on the plantation. It does not appear whether the defendant went into Mississippi before or after the beginning of the war of the rebellion; and there is no evidence of any intent on the part of either party to violite or evade the laws or oppose or injure the govermment of the Enited states. The defendant paid the first instilment of rent, took possession of the plantation and corn, used the corn on the plinutition, provided it with supplies to the amonnt of ahout five thonsand dollats, and planted and sowed it, lut early in Mareh was driven away by rebel soldiers and never returned to the plantation, extept once in $\Lambda_{\text {pril }}$ following, after whieh he eame hack to Matsiachusetts. The plaintiff contimed to reside on the plantation, raised at crop of eotton there, and delivered it in Mississippi to the defomdint's son, by whom it was forwarded in the autum of the same yeal to the defendint; and he sold it and retained the profits anomnting to nearly ten thonsind ciollars.

"The plaintiff snes for the unpaid instalment of rent and the value of the corn. The elaims mate in the other' connts of the declatration have been negatived by the sporial finding of the jury.

"The defendant, in his answer, denied all the phintifl"s allegations; 
amb at the trial andented hlat the lease, having been made during the eivil war. Was illenal atul roil. as well by the plibeiples of inter-

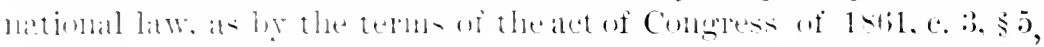

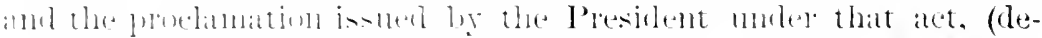

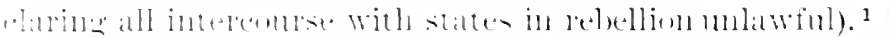

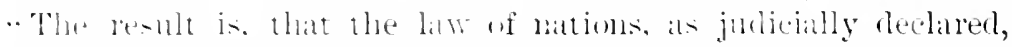

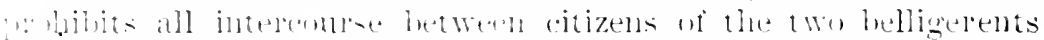

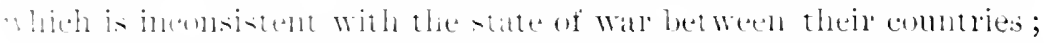

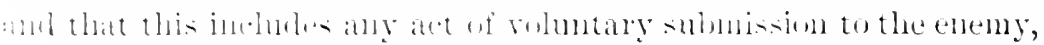

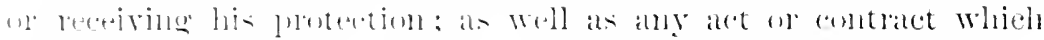

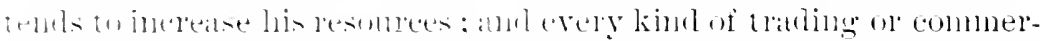

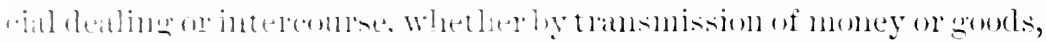
ol hy unders for the delivery of either, between the two combtries,

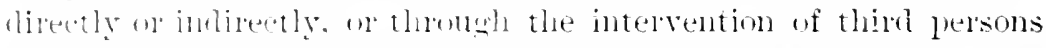

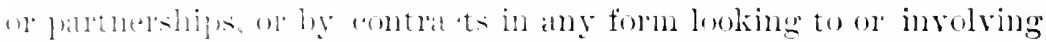

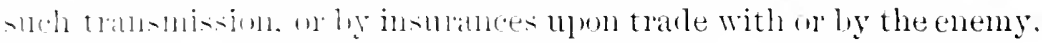

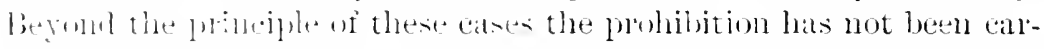
ried hy julicial decision. The more sweeping statements in the text lwakis are taken from the dicta which we hatve alrealy eximnined, and in mone of them is any uther example given than those just mentimsenl. It this ange of the world. when all the tendentes of the law of nations are on exempt indiviluals and private contlatcts from injury or restraint in conseguence of war between their govermments,

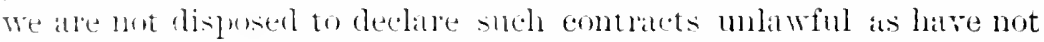
leen ileretofone ad judged to be inconsistent with a statte of war.

." The tratling an tramsulision of property or money which is prohibited hy intemationat law is from or to one of the comntries at war. - In alien enemy reviding in this comtry maly comtatet and sue like a

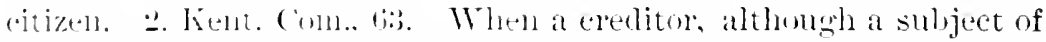
the eneny, rematint in the comtry of the debtor, or has a linown andut there antherizer to lecerive the amount of the debt, throughout

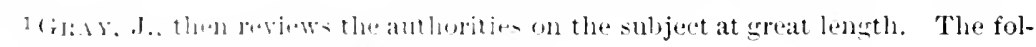

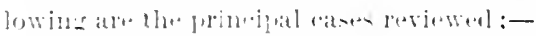

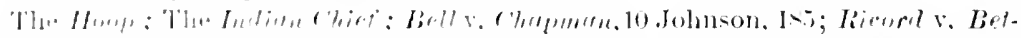

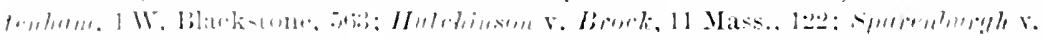

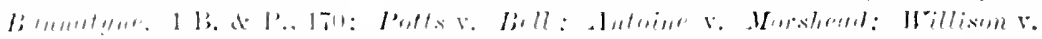

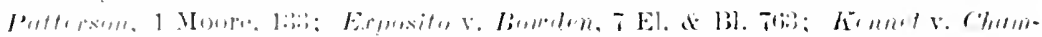

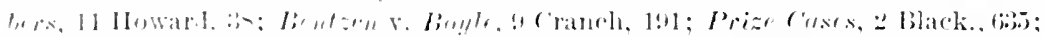

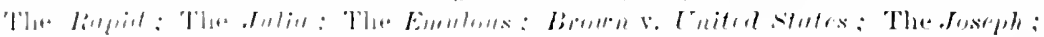

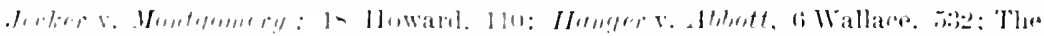

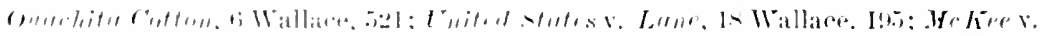

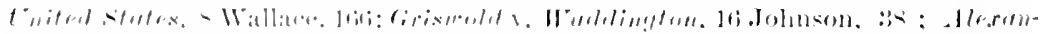

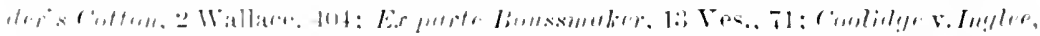

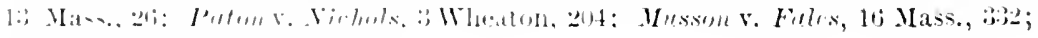

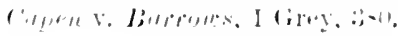


the war, payment then to such creditor or his agent ean in 110 resperet be construed into a riolation of the huties imposed by a stalte if Watl upon the debtor; it is not male to an entemy, in contemplation of

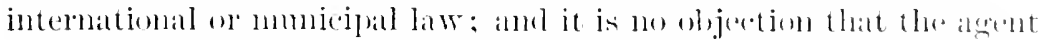
may possibly remit the money to his principal in the enemy's ammtry; if he should do so, the offence would he imputilble to him. and

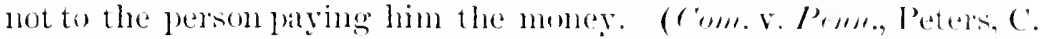

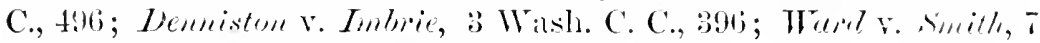
Wall., 4ti; Buclermene v. ('ury, 19. Johms., 137.)

"The same reasous cover an agreement made in the enemy's territory to pay money there, ont of funds accruing there, and not agreed to be transmitted from within our own territory; for, as was sajol by the siupeme Court of New York-the last case eited, "This rule is founded in public policy, which, forlids, during wal, that money or" other resomres shall be transferred so as to aid or strengthen our enemies. The crime consists in exporting the money or property, or placing it in the power of the enemy.

"The lease now in question was made within the rebel territory where both parties were at the time, and would seen to have contemplated the continned residence of the lessee upon the demised premises throughout the term. No agreement appears to have been made as jart of a contract contemporaneously with the lease, ahat the cotton crop shonld be transported, or the rent sent back, across the line between the belligerents, and no contract or communication appears to have been made across that line, relating to the least, the delivery of possession of the premises or of the corn, or the prament of the rent of the one or the vilue of the other. The subsenurint forwarding of the cotton by the defendant's son from Mississiple to Massachnsetts may have been unlawful; but that camnot affert the validity of the agreements contained in the lease. Neither of these agreements involved or contemplated the transmission of money ar property, or other commmication, between the enemy's territory and our own. We are therefore unanimously of opinion that they did not contravene the law of nations or the public acts of the government, even if the plantation was within the enemy's lines: and that the plaintiff, upon the case reported, is entitled to recover the unpaid rent, and the value of the corn." 
LYTTED STATES Y GROSSMLIYER.

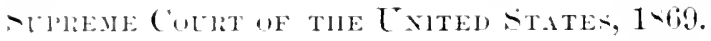

(1) Hollect. 72.)

A merehan rojding in Sew York. conld now legally tran-mit orders by a third

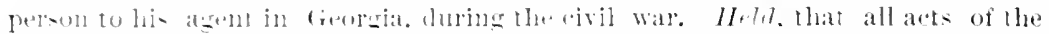
atent, in carrying on -nh orders, in dealine with the propesty or debts of his Irineigral, were null and whl.

This easte Wats an alplethl from the Comt of Claims.

Elias Einstein, at resident of Macon, Georgia, was indebted, when the late rebellion lorke ont. to crossmayer, a resident of New York, for wodr sold ank money lent, and while the war was in progress a cormenmelenee on the subject was maintained through the medium of a thind lessoll, who pasiced lack and forth sereral times between Manon and New York. The communation between the parties resulted in crosinayer requesting Einstein to remit the amomt due him in money or sterling exchange, or, if that were nut possible, to invest the sum in eotton and hold it for him mil the elose of the Wats.

In lumance of this direction-and, as it is smposed, hecanse money o. sterling exchange could not be transmitted-Einstein ynelined cotton for cimsinales, and informed him of it : Grossmayer

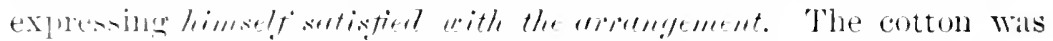

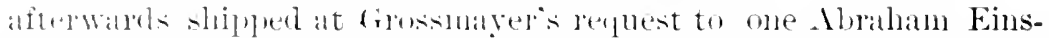
teill, at sarmmah, who stored it these in his own name, in order to furerat its seizure by the rebel anthorities. It remainerl in store in

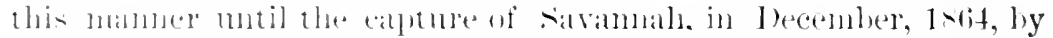
throuldus of the lniterl states, when it was reporterl to our military forma an forsinaler's cotton, and taken by then and sent to New Yurk and sirlil.

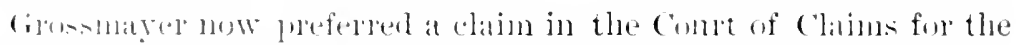

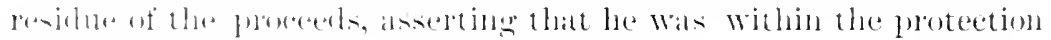

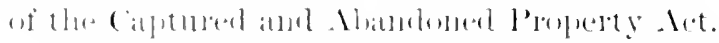

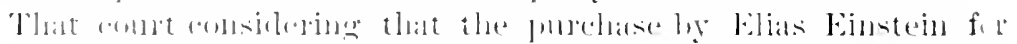

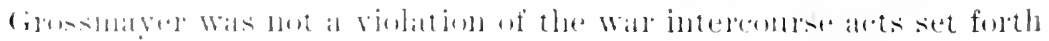

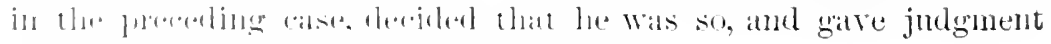

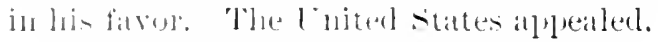

Juclonent,-D.nis. J.:- 
"Glossmayer insists that he is within the protertion of the Captured and Abandoned Property Aet, hat it is hand to see on what gemomel he ean base this chin for protection. It was matmal that firosomalyer shond desire to be pairl, and creditable to binstein to wish to disrlatrge his olligation to him, hut the same thing tall be sald of vely many persoms who were similarly sithated elurimg the wat, ant if all persons in this eondition labl been allowed to do what wats done in this case it is easy to see that it would have produred great mulnarassment and obstrueted very materially the operations of the amy. It has been found necessary, as som as wall is emmmenced, that husiness intercomse shomld eease between the eitizens of the resjeetive parties engaged in it, and this necessity is so mleat that all writers on publie law agree that it is mawful, without any express declaration of the sovereign on the subject.

"lint Congress did not wish to leave any one in ignomance of the effect of wat in this regald, for as early as the 13th of .July, 1stil, it passed a Non-intercomrse Aet, which prohibited all commeroial intereourse between the states in insurrection and the rest of the Criter states. It is true the l'resiclent conld allow a restricter trade, if he thought proper; but, in so far as he cidd allow it, it had to be conducted according to regulations prescribed by the secretary of the Treasury.

"There is no pretence, however, that this particular transaction was anthorized by any ome comected with the Treasury Department, and it was, therefore, not only incomsistent with the duties growing out of a state of war, but in open violation of a statute on the sul, ject.

"A prohibition of all intereomse with an eneny luring the wall affects debtors and creditors on either side, equally with those who do not bear that relation to each other. We are not disposed to deny the doctrine that a resident in the territory of one of the belligerents may have, in time of war, an agent residing in the territory of the other, to whom his debtor comb pay his debt in money, or deliver to him property in discharge of it, hut in such a case the angency must have been created before the war hegan, for there is no power to appoint an agent for any purpose after hostilities have ardually commenced, and to this effect are all the anthorities. The rason why this camot be done is ohvioms, for while the war lasts nothing which depends on commercial intereonrse is permitted.

"In this case, if Einstein is to be comsiclered as the agent of riossmayer to buy the cotton, the act appointing him was illexal, betallse it was done by means of a direct eommmieation through a mosionger who was in some mamer not stated in the record able to pass, during 
the war, hetworll Intom and Xew York. It Wals mon necessatly to

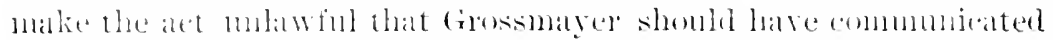

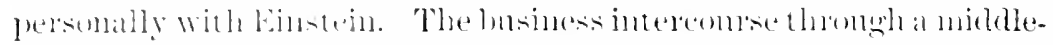

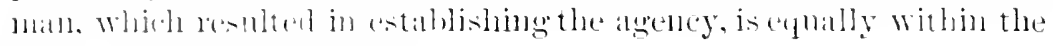

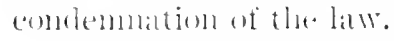

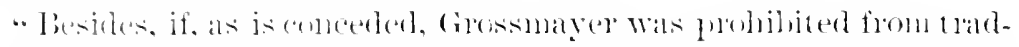

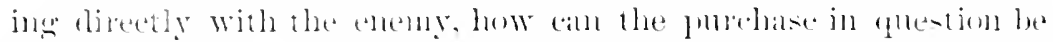

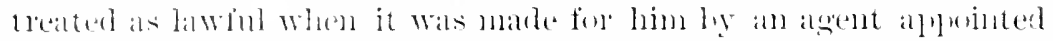

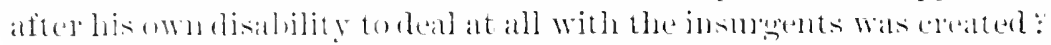

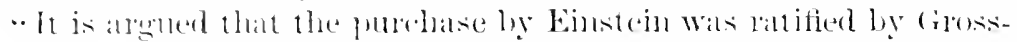

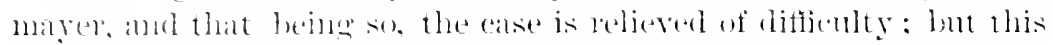
is a mistaken view of the principle of ratifieation, for a transietion

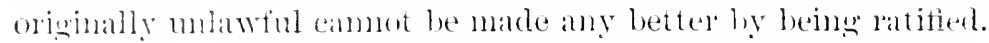

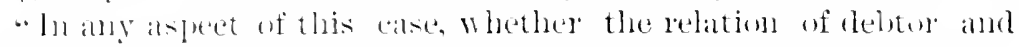
erefitom comtimexl, or wats changed to that of principal and agent,

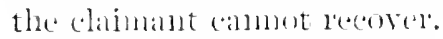

* As he was gubhibited during the wall from having any dealinges with Einstein, it followis that nothing which both or either of them ald in this case cond have the effect to rest in him the title to the antom in question.

" Vot heing the owner of the property he has no claim against the Enited states.

- The funlunent of the Comrt of Clams is reversed, and the cause is remanded to that court with directions to enter an order

"Dismissing the petition."

\section{TIIE "SEA LION."}

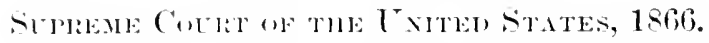

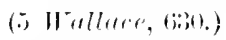

The art of congrese of ouly 1:B, Nit, authorizing the President to license certain

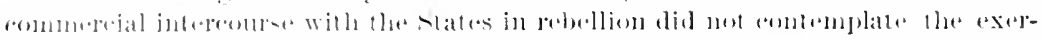

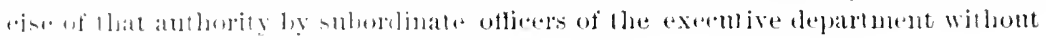

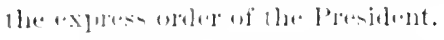

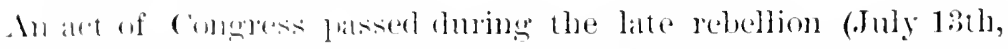

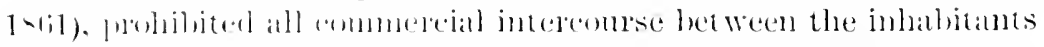
of any siate which the l'resibent might dechare in a state of jusurleretion. and the ritizens of the Jest of the Cnited states; and enated that all meschandise coming from such territory into other 
forts of the Cuited states with the vessel eomveying it shomld bx forfoiterl.

The act provided, however, that "the President" might $\cdots$ in his

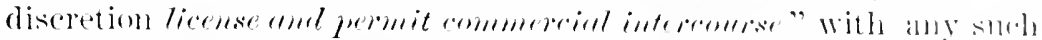
part of a state the inhabitants of which hast berest so derelated in a state of insmeetion, "in such anticles, and for sull time, anm ly, snch persons, as he, in his discretion, mal thimk most andureive to the public interest." And that, "such nutereourse, so far as hy him

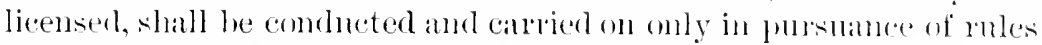
and regulations preseribed by the secretary of the dreasm?."

The l'resillent having soom after declared several fouthern states, and amoug them Alabama, in a state of insurrection, and the sereretary of the Treastry having issued a series of commereial renmla-

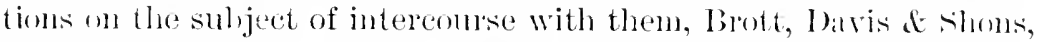
a commercial firm of New Orleans, obtained from Mr. (i. S. Bennison, special agent of the Treasury l)epartment, amd alding (oullectror of Customs at Now Orleans, a payer, ditted Febrlatry 16tl, 1s6:3, as follows:

"The Lnited States military and other authorities at New Grisans promil ("otton to be received here from beyond the Enited states nititary lines, and such aoton

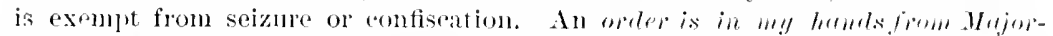

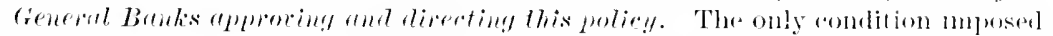
is that cotton or other produce nust not be hought with sperie. All entom or

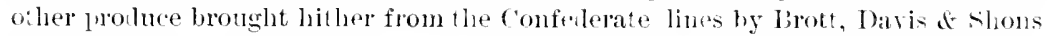
will not be interfered with in any manner, and they can ship it direct to any foreign or domestic port."

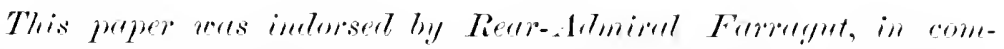

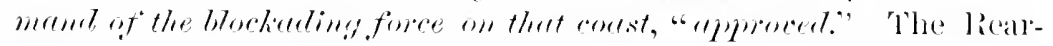
Arminal had given also the following instructions to his commanders of the ILobile blockarle:

"Should any ressel come ont of Mohile and deliver it self up as the propertr of a Enion man desiring to go to Xew Orluans, take possession and send is into Xew Orlean for an investigation of the facts. and if it be shown to be as represented, the ressel will be considered a legal trader, under the general order printting all cotion and other produce to come to New Orleans."

With this paper of the collector of New Orleans in their lamrls, Brott, Davis \& Shoms had, thromgh their agents in Mobile, seventytwo bales of eotton shipped at that port on the ressol sea Lion to be carried to New Orleans.

The vessel was captured hy the blockading fleet off Molile, and taken to key West, and there libeled as prize. The district court 


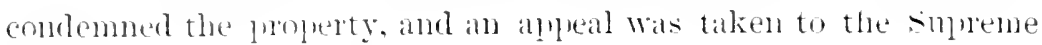
comt.

Mr. Justice swrys, in delivering the opinion of the comt, said as

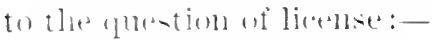

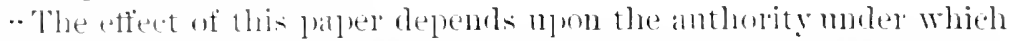

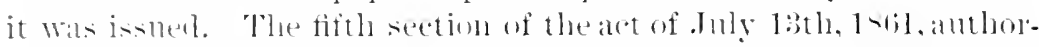

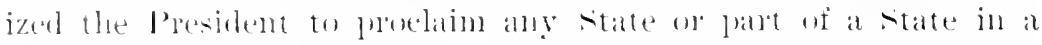

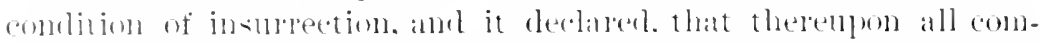

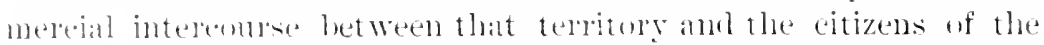
lest of the leniter states, shomle ceatse and he unlawful, so long as the condition of lustility shomblentinne, and that all goods amb

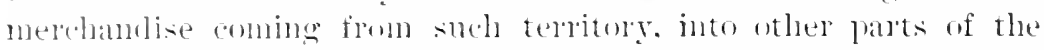
Initerl states, and all poceeding to such territory by land or water,

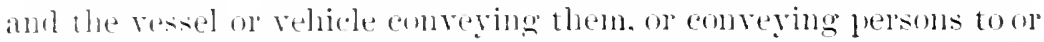

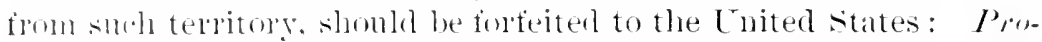
rirlol. lomener. That the President may, in his discretion, license and lermit commereial intereomse with any such part of said state or section, the inhabitants of which are so declared in a state of insurlection in such articles, and for such time, and by snch persons, as lle, in his diseretion, may think most conducive to the punlic interest: and such intercouse, so far as hy him licensed, shall be comflueted and carried on only in pursunce of rules and regulations pescriber by the secretary of the Treasury.'

". There is no other statutory provisiom bearing upon the subject material to lex considered.

- ()n the lith day of August, 1-ti1, the Presirlent issued his proelatmation declaring the inhabitants of the reluel states, including Alabama. to he in a state of insurrection.

". ()n the $2-t h$ of the same montl the secetiry of the Treasury, fursuant to the provisions of the act referred to, issued a series of resulatioms mon the smbject of commercial intereourse with those stattes.

..'These resulations continnel in force mutil the 31st of Mareh, 1-rii, when a new series wele issued ly the same anthority. The former were in foree when the alleged license bears date; the latter when the vessed amb cargo lett Mobile and when they were calptured. It is mmecesstry to amalyze them. It is sufficient to remark that they (o) tain mothing which atfurls the sligltest pretext for issuing snch a paper. It is in conflict with rules and requirements contained in broth of them. It fimls nu warmant in the statute. The statnte lowercilues that the Presilent shall license the trade. The only function of the soeretary was to establish the rules by which it should be regulated, when thus permitted. The order of General 
Banks is not produced. If it were as comprehensive ats the rperobl

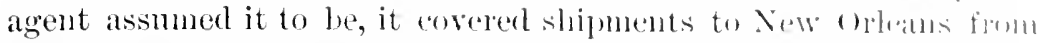

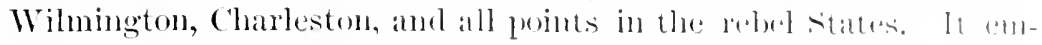
braced merchandise, coming alike from platees within, anul blatue lesyond his military lines. With resperet to the latter it wats wealy void. The l'resident only conld grant snch a licesuse. Mulile Was then in possession of the anemy. The vessel and an'an lum the stamp of the enemy's property. The palere relied npen wats at nullity, and gave them no protertion. They were as muld liable to capture and condeimation as any other vesisel or arewe leaving a blockated port and coming within reach of a blockithing vessel.

"The decree below was rightly rendered, and it is

"Afimecl."

\section{Mr. Justice Grier:--}

"I do not concur in this judgment. The vessel went out of Molile by permission of the commander of the blockate there. To ("ondemn such property would be a violation of goor faith. No English court has ever condemned under such eircumstances."

FLRTADO v. RODGERS.

Comang Pleas, 1802.

(3 Bos. \& Pull. 191.)

An insurance effected in Great Britain on a French ship previous to the commencement of hostilities between Great Britain and France does not cover a loss by British capture.

This was the case of the ship Petronelli, which sailed from Bayomne in France, Oet., 179:2, for Martinique insured in an English company, the policy dating 15th Oet., 179\%. The next year, while still at Malltinique the war between France and England broke ont; and the island of Martinique with all the shipping in the harbor's wats (alptured by the English. After the peace of Amiens in 180:2, the owner of the ship brought suit in Common Pleas in England, to recorer the insurance on the ship.

Judgment,-Lord Alraxuer, C. J.:-

"As it is of infinite importance to the parties that this case should be decided as speedily as possible, and as we entertain 110 domlits upon the subject, we think it right to deliver the judgment of the court without any further delay; at the same time consirtering , lue 
masnituke of the gluestion we shall allow the parties to convert this

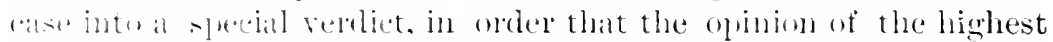
comm in this kinglon maty be talien, if it shomld be thomght nee-

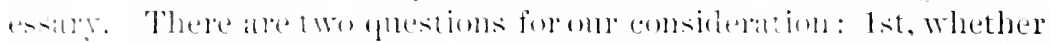

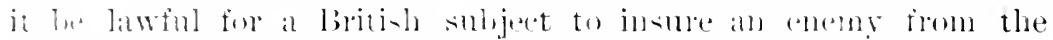

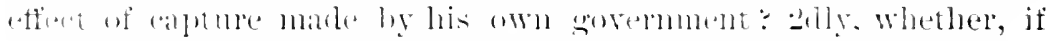

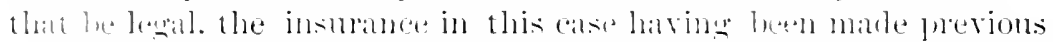
t:s the rommencement of lostilities will make ing alifference? As

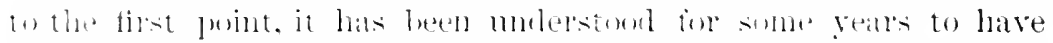

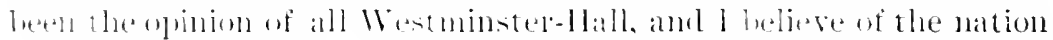

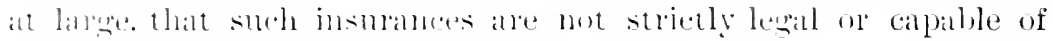

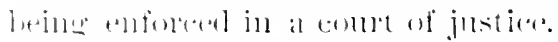

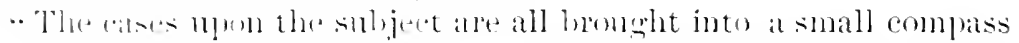
in the two valuatile bonks of Mr. l'ark and my brother Marshall.

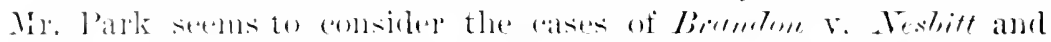

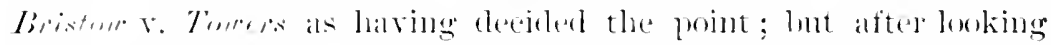
rely arematery into all the cases. I am realdy to arbmit that there is

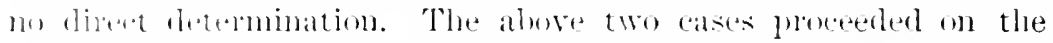
slont gromel of alienage, which was sufficient to support the decision of the Comt withont entering into the other question : and I lo not

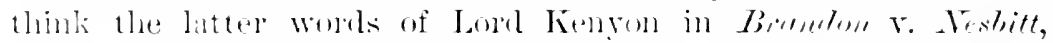

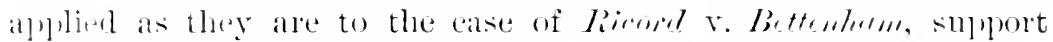
the infelenee which has been drawn by my brother Matrshall, the

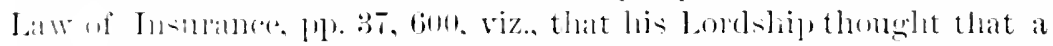

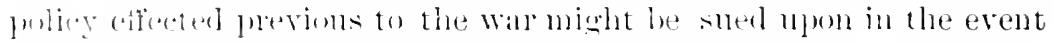
of perace, aren thomgle the loss sllstained hy the assured arose from british anture. It is well known that for a comsiderable time,

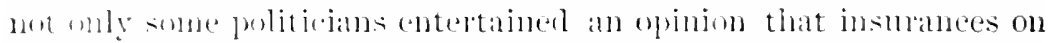

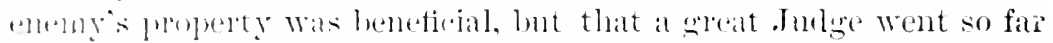

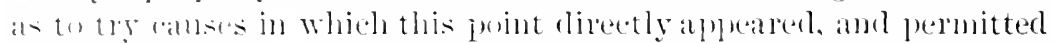

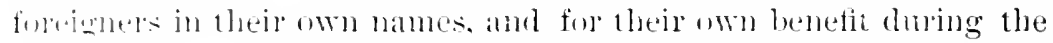

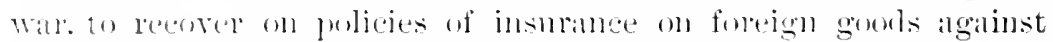

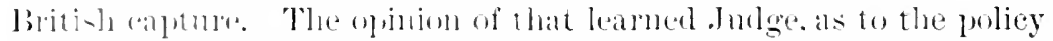
of smell insmonces, is well known, ame it was supluser he would not latve sitnetioned them muless lis opinion in point of law had

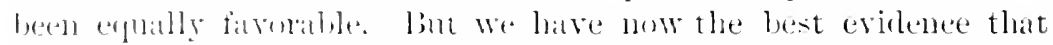
his sentineme in that respert wele different from what thes were

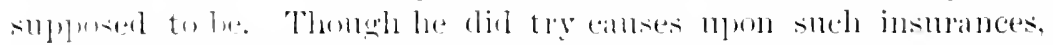

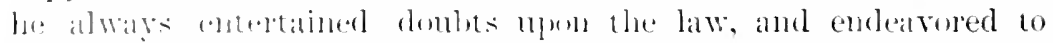
kerle ollt of sight a duestion which might oblige him to decide aganst What he thoment for the henefit of the combly. This takes off matedially flom the effect of those anses which have heen cited to induce it suplosition that the law of England had tolerated such 


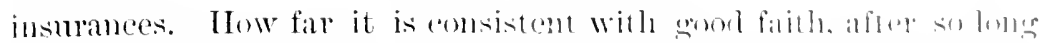

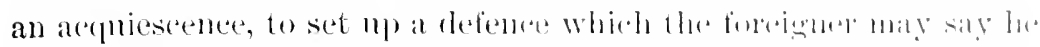

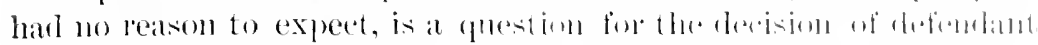

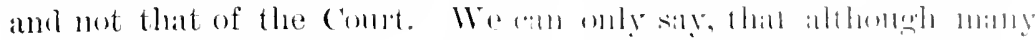

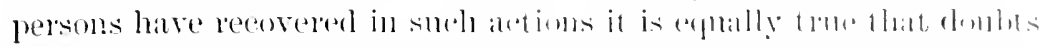

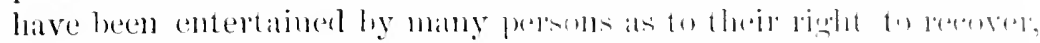

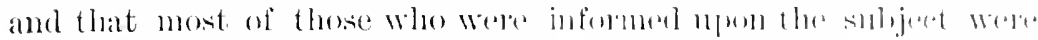

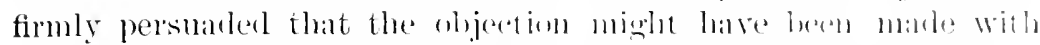

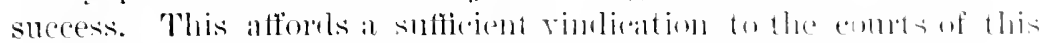

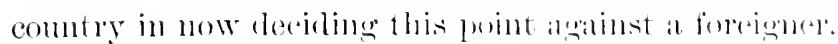

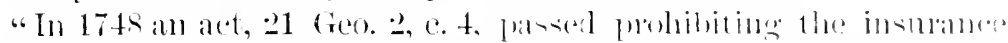

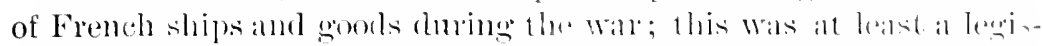
lative declaration of the impolicy of sureh insmances ant fhat time.

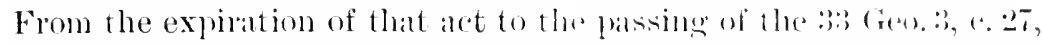
s. t, no legislative interference njwn the suljowt evor tomk plare, and previoms to the last mentiomed alet the policy in glustiom was

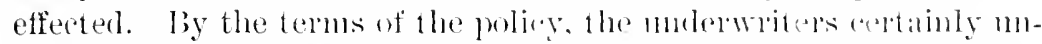

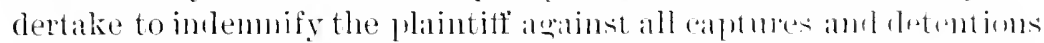
of princes, without any exerption in respect of the acts af the gow-

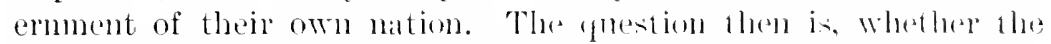
law does not make that exeeption, and whether it he commetent to an

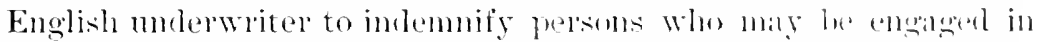

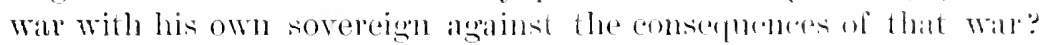
We are all of opinion, that on the primeiples of 1 he English law, it is not competent to any subject to entele into a cont latet lo du amything which may be detrimental to the interests of his own anmtry ame

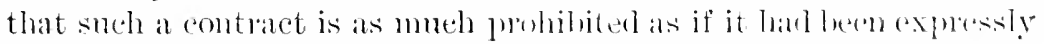
forbililen by an act of parliament. It is almitted that if a man anmtract to do a thing which is afterwards pohibited log act of parlia-

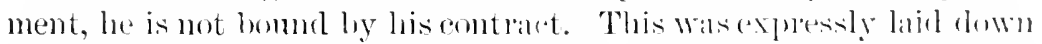

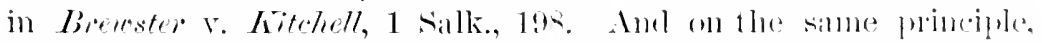

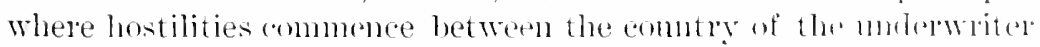

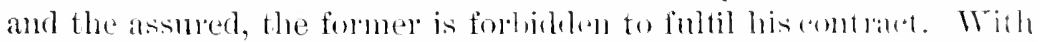
respect to the experliency of these insmances, it serme muly necessily to cite a single line from Bynkershork (Quars. Juris. P’uh. lih. 1, ‘.

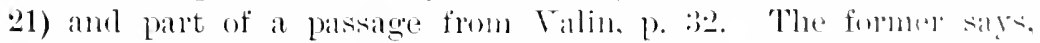
'Hostium periculd in se suscipere y

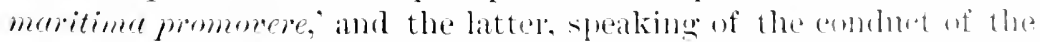
English doring the wal of 17.56 , whe permitted these insmandes, says, "The consequence wis, that one pald of that nation restomed wo us by the effect of insurance, what the other took from us by the

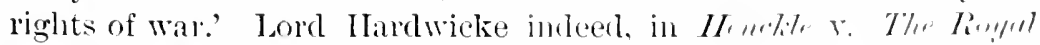

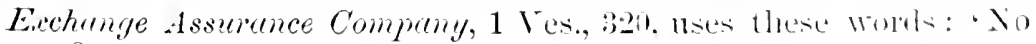


determination has heen that insumance on enenies ships huring the

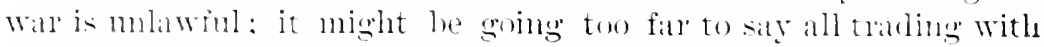
enemies is mblawful, for that peneral doctrine would on a werat way,

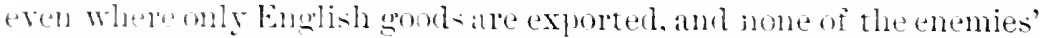
imponted, which mily be very heneficial. I do not go on at forndatim of that kimb, and there have been several iusmances of this solt denines the wall which a determination upon that point might hurt.' This howerer is but a douhtful opinion as t.) the leandity of such in.

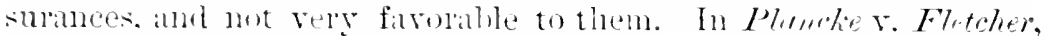

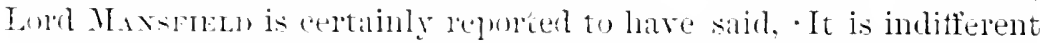
whether the gonds were English or French, the risk insured extends to all captures, which seens at first to go a great way towards giving effect to insurances aganst Blitish eapture. But we must suppose this to have been said beeanse the defendant did not press the objection: and if the party acquiesced, the expression gives no more weight to the calse thim helongs to any of the other cases which have been cited, such as Burnom v. Woombridge. Ertor v. Prirlinson, and Tyson v. Gmm! in which the question was not ratsed at all. On

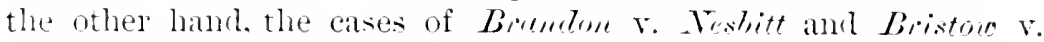
Tomers certainly proced on the gromed of alienalge. These is no express declatation therefore of the Compt of King Bench, either for or against the legality of such insurances, and the question comes now to be deciled for the first time. We are all of opinion that to insure enemies' property was at the common law illegal, for the reatsons given by the two forejon jurists (Bynkershock amd Valin) to whom I have refered. If this be so, a contract of this kind entered into previns to the commencement of hostilities must be equally matraling in a comet of law. since it is equally injurions to the interests of the comntry: for if such a contratet comld be supported, a foreigner might insure previons to the war aganst all the evils incident to wall. But it is sald that the action is suspemeled, and that the indemmity comes so late that it does not strengthen the resources of the enemy during the war. The enemy lowevel is vely little injured hy captures for which he is sure at some period or other to be

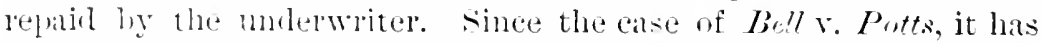
beth universally molerstond that all commercial intercourse with the entemy is to be comsidered as illegral at common law [though l'revious to that casea very learned juclge (Mr. Justice Brules, in Bell r. Fitson, 1 Bos. \& Pull., 345) alpears to have entertained doubts on that smbject]. and that comseruenty all insurances fomded on such intercomrse are also illegil. Wly are they illegal? Because they are in contrarention of his Majcisty's object in making war, which is by the capture of the enemies' property, and by the pronibition of 
any beneficial intercourse botween thom and his own suligets 1 ,

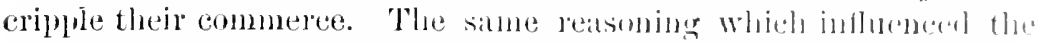

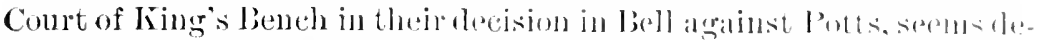
cisive in the presentease. For it heing dotermined that doming war all commercial intercourse with the enenty is illegal at common latw.

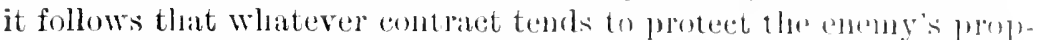
erty from the ealamities of war, thomegh efferted anterestent to the war, is nevertheless illegal. "It hats beon supposell that the doetrine" which has prevaliled respecting ranson bills tends to farol these insurances; but no action wals ever maintalled npon a lallsom bill in

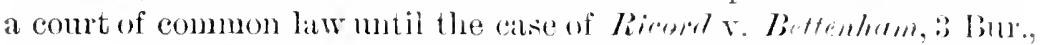

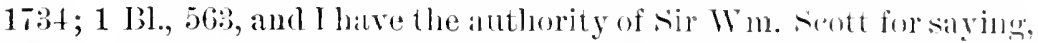
that in the Admiralty Comrt the suit was always instituted by the

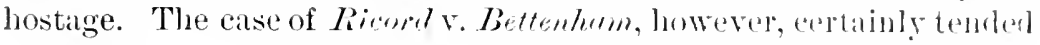
to show that such an action miglit be maintainerl in the compts of common law at the suit of an alien enemy. In consegnence of this,

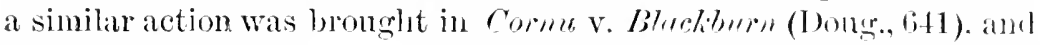
after argument, the Cont of King's Bench held that it might be sustained. But in futhom v. Fisher (Dong., 649, (i,s), in notes), the contrary was expressly determined upon a wit of eror in the $\mathrm{Ex}$ chequer Chamber. I forbear to enter into the argmuents surgesterl at the bar in falvor of the rlefendant, that the law will not cnfores a contract founded on a transaction detrimental to the pullic policy of the state. The gromm upon which we recicle this case is, that when a British subject insures against eaptures, the law infers that the contract contains an exception of captures marle hy the government of his own country ; and that if he had expressly insiued andinst British capture, such a contract would be abrogated hy the law of England. With respect to the argmment insisted mpon hy way of answer to the public inconvenience likely to arise from permittins such contracts to be enforced, viz., that all contracts made witl an enemy enure to the benefit of the King during the war, and that he may enforce payment of any debt due to an alien enemy firm any of his subjects, we think it is not entitled to much weight. Sinch a course of proceeding never has been artopted; nor is it very probuble that it ever will be adopted, as well from the difficulties attenuling it, as the disinclination to put in force such a prerogat ive. The plaintiff, I am sorry to say, is not entitled to a return of preminm, beciuse the contract was legal at the time the risk eommenced, and was a good insurance against all other losses but that arising from calnure by the forces of Great Britain. 


\title{
ANTOINE V. MOLRIIEMT.
}

\author{
('umas Plaks. 1-15.
}

(i) Tountwin, 2:?5.)

\begin{abstract}
A british priconer in Frane drew fire bills of exwhange on his son in England

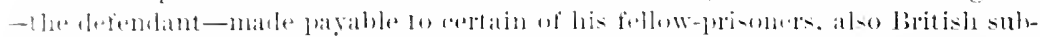

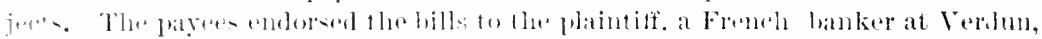

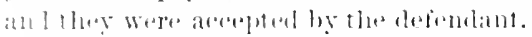

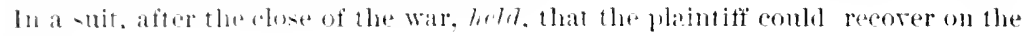
bill.,

This was an aciom mpon five bills of exchange, all drawn by the fillwe of the defendiut, a british smbject, on the 1:2h of september,

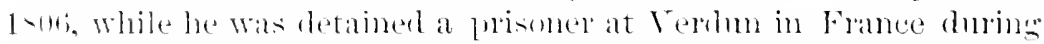
the late war with that comtry paralile. some to Tyndall, some to Estweke loth british subjects in like mamer detained prisoners thele, at one year after date indorsed to the flaintiti, who was a

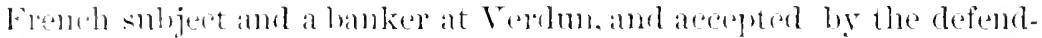
at. The ranse was tried at childhall at the sittings after Easter term, 1-15, before C. . ., when it was contemed on the part of the defindant, that it would he treasm to pay the bills, hy the statute

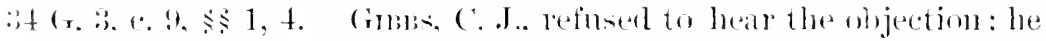

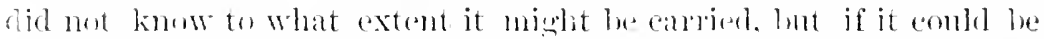
slypunted to jti full extent, mally of om misolalle follow-suljects

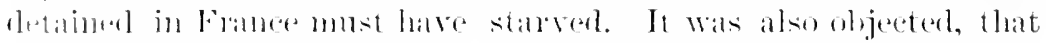

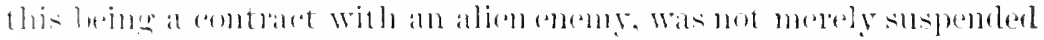

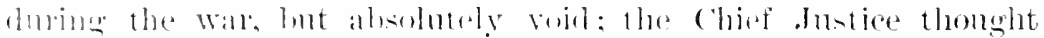

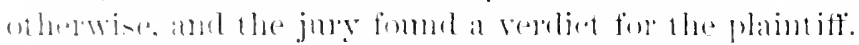

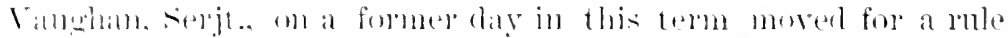

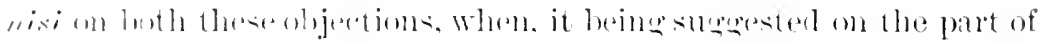

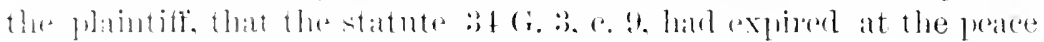

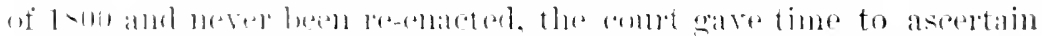

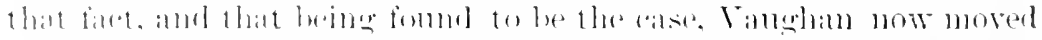

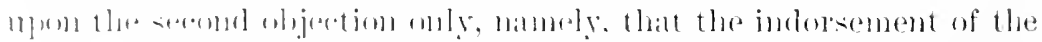

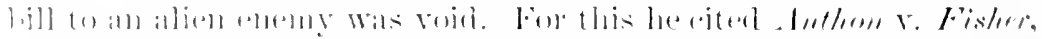

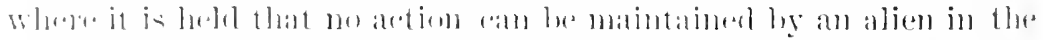

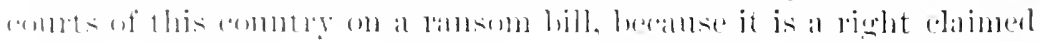

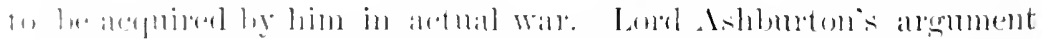

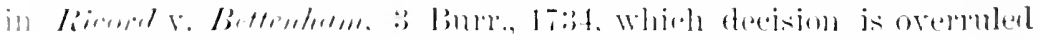

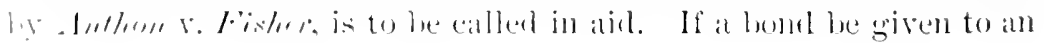


alien enemy, it is good quenel the obligol, that is, it rmmers only fol

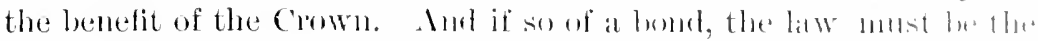
like on a bill of exchangere sis is it of contratets of instrantere mante.

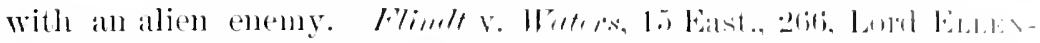

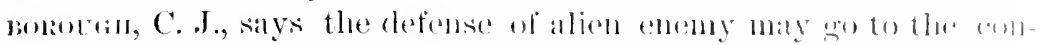

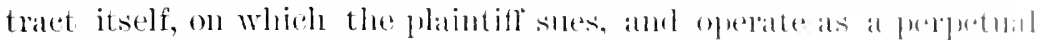

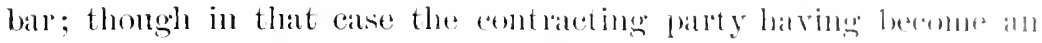

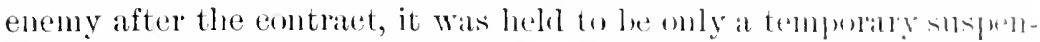
sion of the right to sue, but he showed a disposition to entirm the.

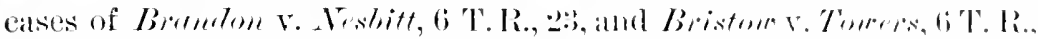
35. No eatse has deejed that a contrat made with an alion enemy in

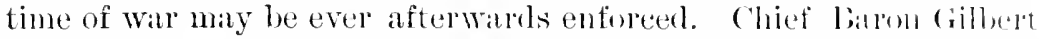
lays it down, that mon the plea of alien eneny the right of the plaintiff is forfeited to the crown, as a speeies of reprisal mou the state committing hostility.

Grms, C. J.:-"It will not be useless to consider what legal popositions can be dedured from the eases cited on behalf of the dofendant, and to try how far they are applieable to the present adse. This is no bill of exelange drawn in favom of an alien enemy, lmt ly ame. subject in favour of another subjeet, "1pon a subjett re-iklent here. 1 he two first being both detaned prisomers in France; the law mo migh legally draw sueh a bill for his subsistence. After the hill is so drawn, the payee indorses it to the plaintiff, then an alien ememy. How was he to avail himself of the hill, exeept by negotiating it, and to whom condd he negotiate it, except to the inhalsitants of that comntry in which he resided? I can recollect hut two prindiples from the eases cited by the connsel for the defendant, and they an: principles on which there never was the slightest donht. First, that a contract made with an alien enemy in time of wal and that of smch a matnie that it endangers the secmity, or is aganst the policy of this colintry, is void. such are polieies of insmrance to pontect an enemy's trade. Another principle is, that howerel valid a contrat originally may be, if the party heome an alien enemy he eamot sme. The Crown, during the war, may lay hands on the deht, and reaster it, but if it do not, then, on the return of pale the rights of the onntracting alien are restored, ant he may himself sue. No other principle is to be deduced. The first may he latid ont of llu case, for this was not in its ereation a contract malle with an alien rumy. 'The seeond question is, whether the hill came to the handsof the phaintift

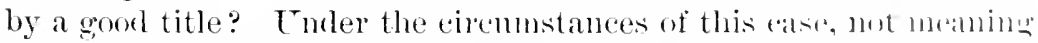
to lay down any general rule beyond this case, I and of ypinjon that the indorsement to the planintiff eomveyed to him a lexal title in this bill, on which the king might have sued in the time of the wal, 
and he not having so done, the plitintiff might sue after peace was proclitimerl."

Il:st1, .J., Was absent.

Cunmals. I._- I am perfeetly of the same oppinion. and it would he at rery mischieroms eonsequente if it were otherwise."

I) Im.......... This is not a contratet letween a smbjeet of this eountry and an alien enemy, nor is it s contratet of that sort to whieh the principle an be applied. That printeinle is, that there shall be no commmnication with the enemy in time of war, but this is a contrat between two subjects in an enemy"s country, which is perfectly legial.

"Ruled refused."

\title{
Section 32.-R.ixson Bills.
}

\section{CORNL v. BLACKBLRAE.}

\author{
Kixg's Bexch, 1781.
}

$$
\text { ( } 2 \text { Douglas, 640.) }
$$

A French captor had ransomed a British vessel, taken a hostage, and was then in tum calutured by British cruisers; but he concealed the ransom bill, and afterward sted unon it. Held, that he conld recover in the action.

This was the case of an English vessel and cargo captured by a French priatter and ransomed and a hostage taken as security; but the privateer was in turn caltumed by two English frigates and taken into an English port. 'The ransom hill was concealed, howerer, ly the first captor, and mot given np: and the present suit is on the lansinn hill. This doemment is as follows:

"Xo, bit. Rivristeres the present ransom bill at the deminalty oflice, Boulogne,

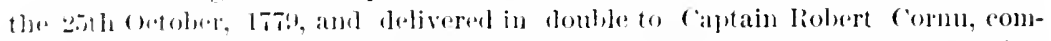

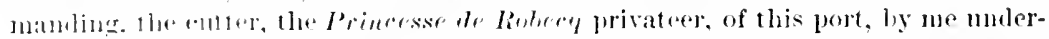

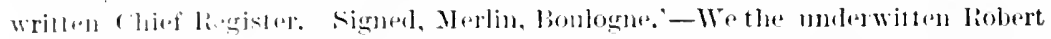

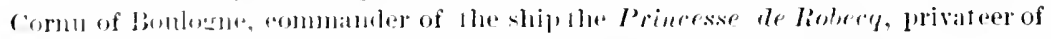

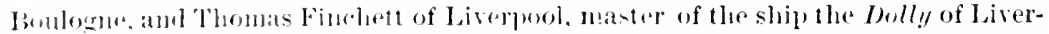

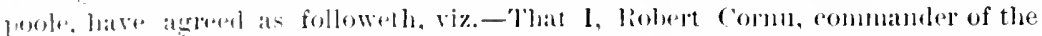

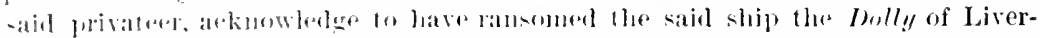

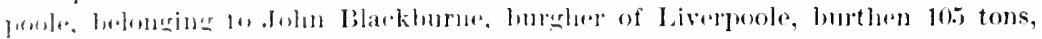

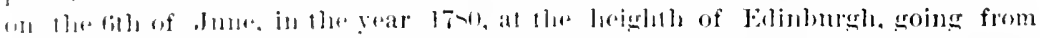

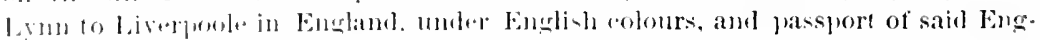
lambl loakl with wheat, for the account of John blackburne, burgher of Liver- 


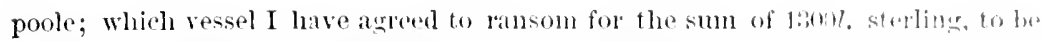

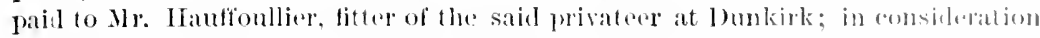

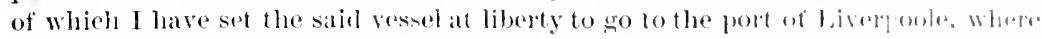
she is to be arrived in the time and spare of three months, ather life cxpiration of which this present agreenent shall not clear her from being taken by any atlune

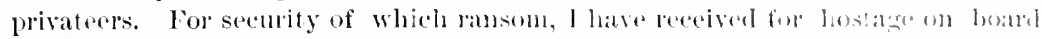

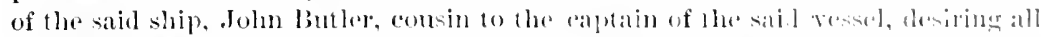

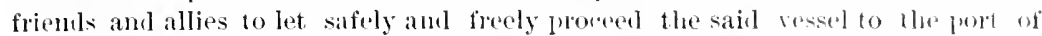
Liverpoole, withont any let or molestation, during the sais hime or coures of hel royage; and 1, Thomas Finchett, owner of the satel ship and merehatulizes, hate roluntarily submitted to the pryment of the sild ransom, viz. 1:3k), sterling; for surety whereof I havedelivered up the said John Butler of Liverporle for hostage, promising not to go agatinst the conditions of this present contrat, wherest earh of us have a copy by us, which we have signet, with the said hostatge. Figned on boad the said ship, the fith of Jume in the year 17s0. And it is mither cxpressly corenanted and agreed, that I the said Thonas Finchett do hind and ohligre myself, and engage my ressel and cargo, to pay or eause to be paid th the owners of the said privateer, the full amomi of the said ransom, should the satil hostage comes to die, or to desert, or that the said privatede should perish, of the taken with the lostage on boasl, withent whish condition the eaptain of the said privateer would not have consented to the alove ransom, which, in all cases whatsorver, shall be well and truly paid.-(Signed) liobert Cornu. Thomas Finchett. Joln buther."

Lord Maxsfeles :- " It is sound policy, as well as gool momality, to keep faith with an enemy in time of wal. This is a contrat which alises out of a state of hostility, and is to be governed loy the law of nations, and the eternal rules of justice. The additional clanse is particularly adapted to this case. There is no pretext to impeach it, on the ground of fraud or extortion. The bill wats registered before the French ship sailed, with this clanse in it. Nor dnes any inference arise, from its insertion, that the general law was molerstonl to be otherwise; for it is, also, stipulater, that the deatl of the lostage shall not vacate the contract, which stipulation the parties must be presimed to have known to he munecessary, becanse the decision in Ricond v. Bettenhum was notorious over all Europe. Leaned lamyer's were written to on that occasion, both in France and IIolland, and Mr. Justice Buachstone slewed me several letter's he had rereived from abroad, on the subject. It is said, that, by the law of nations, the recapture puts an end to the ransom bill; ard the aldoment is, that the court of Admiralty decrees salvage for retaking the ramsom bill.

"But what are the cases brought to plove this position? Nont? of them were litigated but the last, and, there, no ransonn hill was forthcoming. Upon what was salvage given in that ease? They seem to have mistaken the natme of salvage. They serm to (4m surler it as a debt which may be exacted. Int 110 man cam be emmpellad to pay salvage, unless he chooses to have the property batk. They 


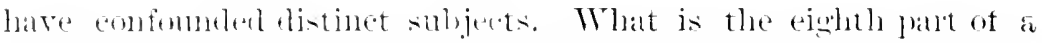

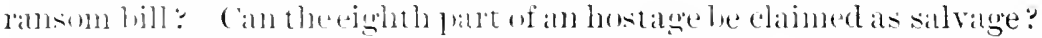
Could the leselpted make nse of the latmsom hill:

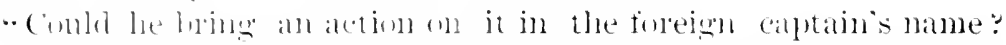

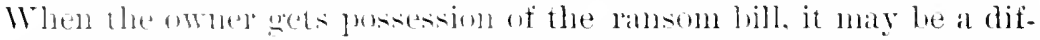

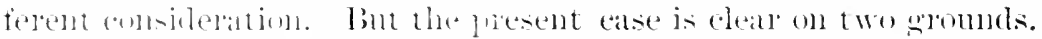
1. Thus

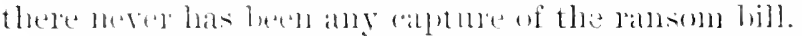

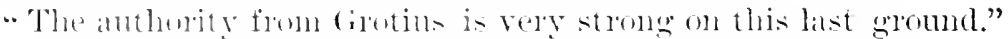

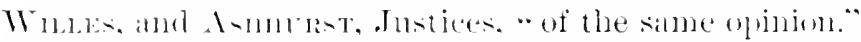

But.ter. .Justice. . of the sinne "pinion.-The last ground goes all the leleth: fou the hill was neree taken.

". The l'steat to be deliveled to the plaintift." 1

\title{
TILE "CIIARMING NANCY."
}

\author{
OpINIAx of G. Hay, 1761.

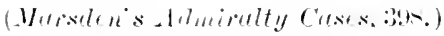

Who may sue on a ranson bill?

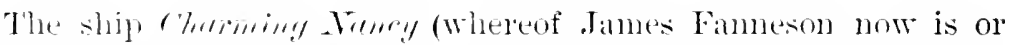
lately wats matede) being laken at prize hy the French, was with her "aren lamsomed by the master for the sum of \pm " Jint and whe of the erew, whose name is muknown, romsented to go at hostarges for the payment of the sald ransons in conseguenee

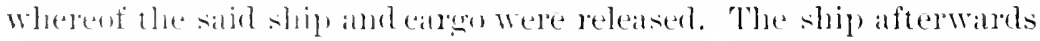

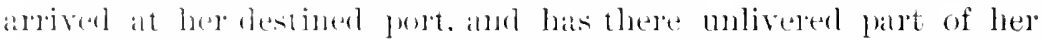

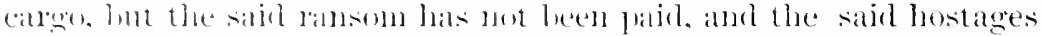

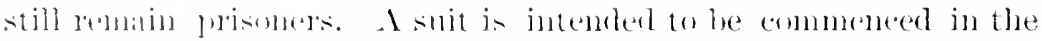

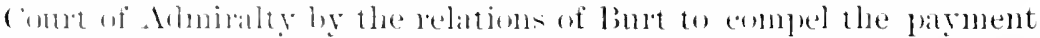

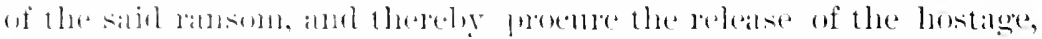

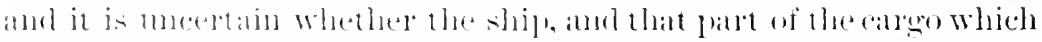

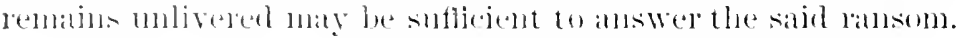

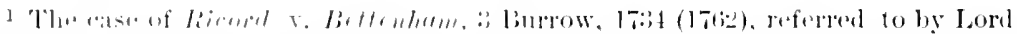

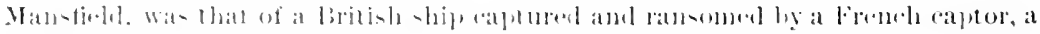

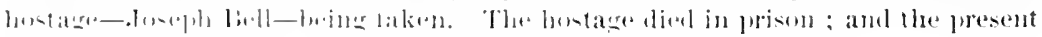

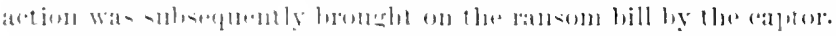

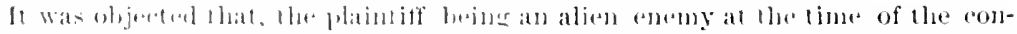

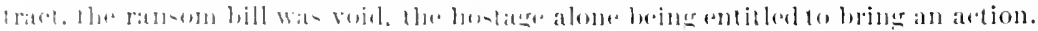

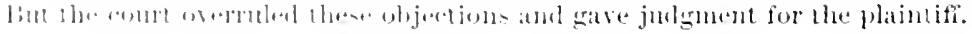




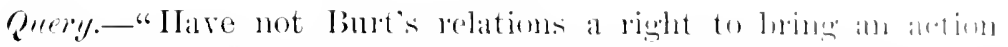
against the master, for the ferformanee of whose antratet the

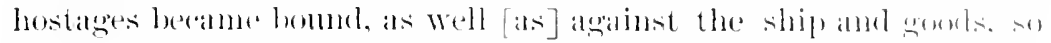

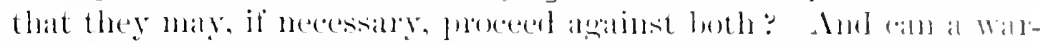

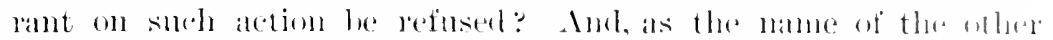
hostage is not at present known, may mot such action be entered in the name of burt and aompany as hostages?"

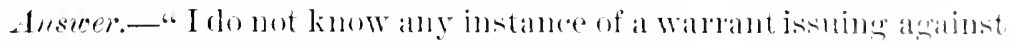
the master in snch a rase. The ship and goods are in the first place answerable for the reclemption of a lostager.

"These may he arresterl, and the suit may be homedh ly limes relations on behalf of hoth the hostages, naming the one and describing the other of nane at present muknown."

$$
\text { (i. Har, Januany } 20 \text {, 17il. }
$$

"In the first instance I think you eamont proceed andinst the master. If the ship and goods will not produce the smo stipulated for the ranson, and you can show that the master trandulently ransomed, I think he may then be prosecuted on behalf of the hustages."

\title{
'TIIE "I'ATIIXENT."
}

\author{
Oprios of Wy. Wryxe, 1781.

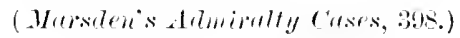

A British ship was ransoned by an American captor, and a hostale taken. The bill was sent to Holland to be forwarded to England for enllection. The orinion was that a suit on the ransom bill coukl be maintained against the natele and owners of the ransomed ressel, but, it must first be shown that the husate was cletained or dear.

The ship P'otivent, Inmmibal Lush, master, was takin hy an Anerican privateer, and was ransomed for t5,500 sterling, and an hostage delivered, who was carried to America. For the alowe sma the captain of the ransoned ship dew a bill mpon Messis. John Glassford \& co., merelunts in Glisgory, a coly of which is mulerwrittell, who are owners of the vessol.

The rausom-bill was sent to Amsterdam, and from themere remitterl to merchants in London, to recover the value of it. When it was first presenter to the gentlemen mon whom it was dram, lluy

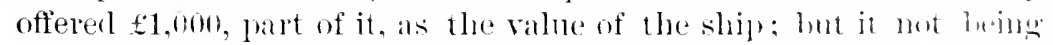
thought proment to receire a part of the money, their ofler was then 
lefusel: sine which the said gentlemen, together with the owners of the caren. hare lefused to pay the bill or any part of it.

Yom opinion is desired whether the holder of this ransom till can mantain a slit in the Almiralty Comt aganst the owners of the

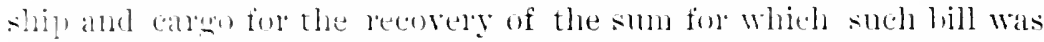
wiven: And whethel such suit must be brought against every indivithal ownel of the ship and cargo.

\section{Coly of THE BILL.}

$6 \pm 5,500$.

On board the schooner Harina.

$$
\text { July } 26,1779 .
$$

". It ninety days' sight my second biil of exchange. first and third of the sane tenor not paid. pay to lichard Jackson on wder the sum of tive dhomsand tive hunded pound sterling, for the lansom of the slipl l'etrient and her cargo.

Haxibal Lish.

\section{"To Mesirs. Jums Glassford \& Co., "Merchants, Glasgow."}

Arses.- I think that the owner of this ransom-bill may maintain a suit in the Comt of Almiralty for the recorery of the sum for which the bill was given ; lut I apprehend they must make it appear that the hustage is not at liberty if he is livins, hefore they can obtain palyent of the money. The proper way of commencing such a suit would be hy anesting the ransomed ship with the eargo on buat. but if that camnot be done, I think it will be sufficient to ming the suit atainst Lush, the master, who drew the bill, and Mans. Glassford \& Co, the owners of the ressel, mpon whom it is drawall."

Wu. Wryxe, Doctors' Commons, July 25th, 1781.1

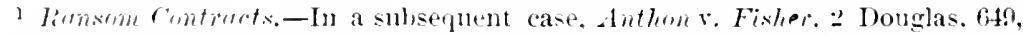
note. It was sotted in English law that an alien enemy "annot sue on a ransom

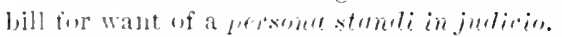

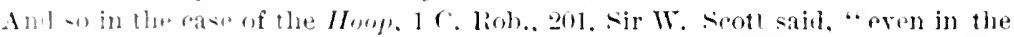

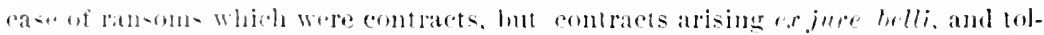

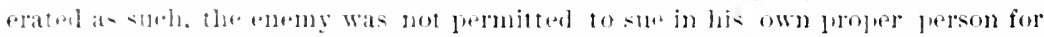

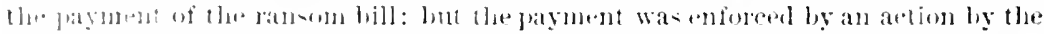

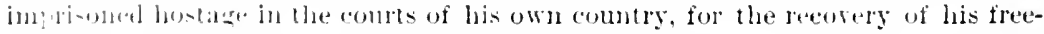
din,

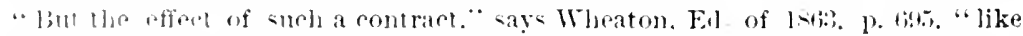

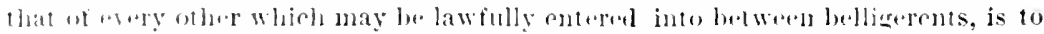

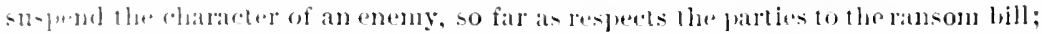
annl, consedplently, lhe technical objection of the want of a personce standi in judi- 


\title{
Sertion 38.-Comanercill Domirm.
}

\section{THE "INDIAN CIIEF".}

\section{High Coert of Amminter, 1801.}

\author{
(3 C. Lohinsm, 12.)
}

This was the case of a ship and cargo seized in the harlor of Cowes, on a royage from Batavia to Hamburg, in which two quentions arove, respeting the nat ional character of the owners of the ship and cargo respectively. both Ammican citizens residing in british territory, and charged with trading with the entemy.

IHeld. That a nentral merehant residing in a betligerent comtry is o be rewardod as a belligerent trader; but that the moment he puts limself in monion bum fide to remm to his native comtry sine animo reverlendi, he loses his belligerent character, and resumes that of a neutral.

\section{Judgment,一sir IV. Srott :-}

"This is the case of a ship seized in the port of Cowes. Where she canc to receive orders respecting the delivery of a callow laken in at Batavia, with a professed original intention of proceriing to IJanbmrog; but on coming into this country for latrtienlan orters, the ship and cargo were seized in port. It does not appear clear to the comt, that it might not be a cargo indencled to be delivered in this comtry, as many such cargoes have been, 111 .

cio cammot. on principle, prevent a suit being brought by the captor, direwly on the ransom bill." And this appears to be the practice in the maritime comt of the European continent. (Valin, Ord. de la Marine, liv. 3. tit. 9, art. 1!): Pintoge et Durorly, I.. 22il et set.)

"If the ransomed ressel," says Wheaton, El. of 186ii. 1. 694, "is lost by the perils of the seat, before her arrival, the obligation to pay the sum stipulated for her ransom is not theroly extinguished. *** Even where it is axpressly agreel that the fos of the vessel by these perils shall diseharge the capturel from the payment of the ramsom, this clanse is restrained to the case of a lotal loss on the himl wats. and is mot extended to shipwreck or stranding, which might affort the master at templition

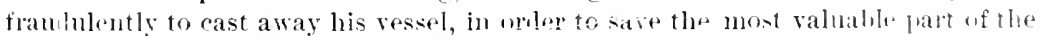
cargo, and aroil the payment of the lansom. *** so. if the raptor, affer hating

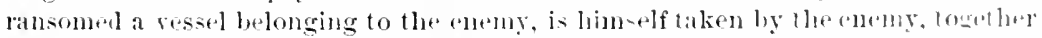
with the ransom bill, of which he is the learer, llis rancom bill herounes at part of the eapture mate by the enemy: and the perous of the hostile nation who were debtors of the ransom are thereby dischatres from their obligat inn."

On the subjert of ranson generally, see Judge Srontrs opinion in Mrcismmune $r$ Teatiny, ․ Gallison, 337 . 
der the Tutele punemy act: I mention this to meet an observation

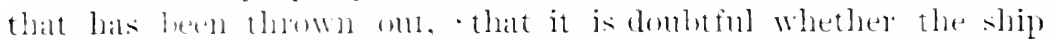

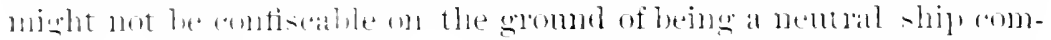

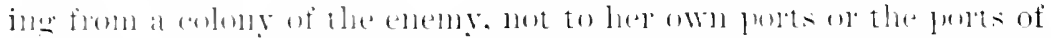

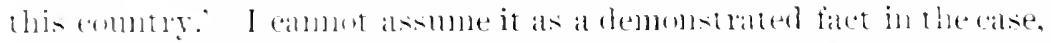

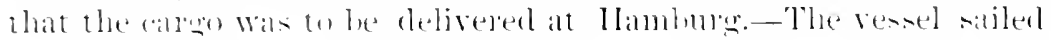

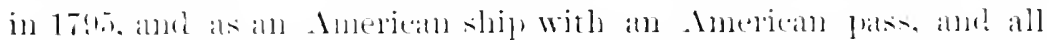

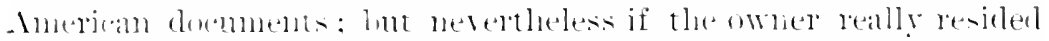

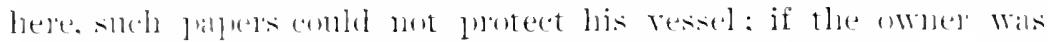

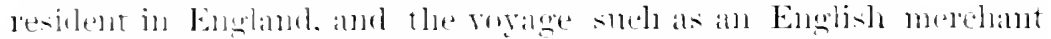

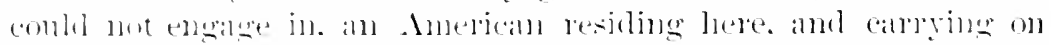

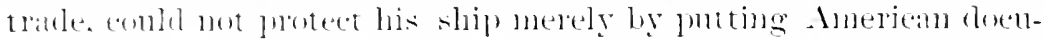
ments on luarel his interest must stand or fall according to the deterninatom which the enurt shall malie on the national chalacter of $\mathrm{s}$ (l) a l pelsm.

. There are two propositions which are not to be controterted; that Mr. Julusom in an Anelican genelally ly birth, which is the cimomstance that first impresses itself on the mind of the comt ; and also hy the fart which he took on the brealing ont of the American war. He came hither when both comblies wele open to lim: hut on the brealing ont of lostilities. he made his election which comtry he wonld athere to, and in consequence theserf went to France. Is to the dombt that las been suswesterl, whether he

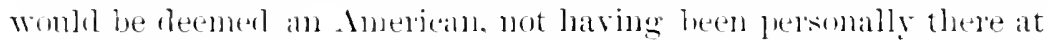
the time of the declanation of the independence of that combry; I think that is sufticiently cleared up, by the cinemustances of his leeing

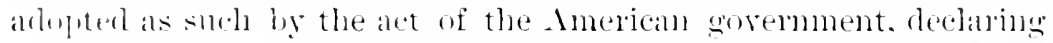
him and his fambly to be smeriean subjects and hy the official chalateter whidh that ensermonent has intrusterl to him: I alla of opingon, therefore, that he has met lost the benefit of his native

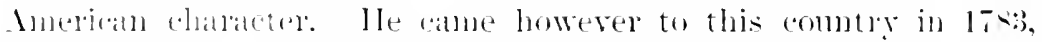

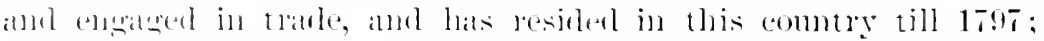

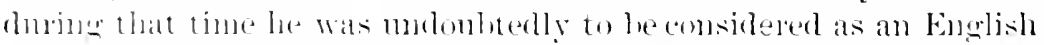

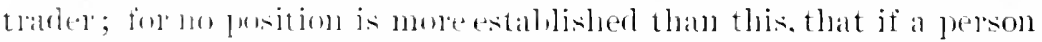

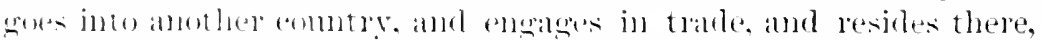
lee is, hy the law of nations. to be comsidered as a merelomt of that

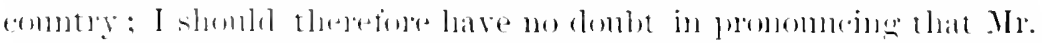

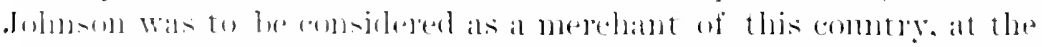

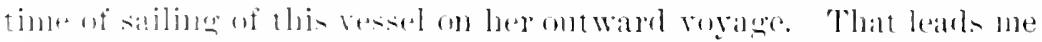

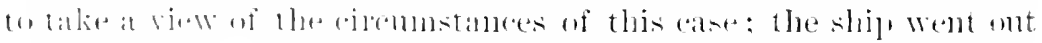

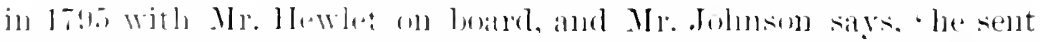

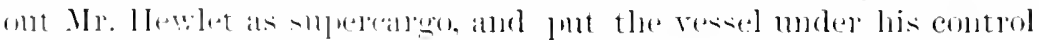
to talie freight for Amerieat, but that his designs vere frustrated by 


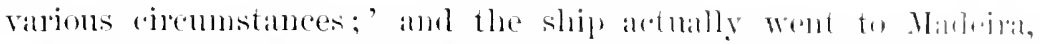

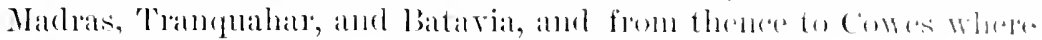
she mas aresested.

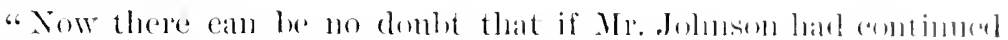
where he was at the time of saling, if he hat rematimed resielent in England, it most be consirlered as a libitish transalion: and themefore a criminal transitetion, on the eommom primeiple that it is illegal in any person owing an allegiance, thmogh tomponary. to trate with the public enemy. bint it is plearled that he hatel quited this combly before the capture, and that he hald dome this in consequence of an intention le had formen of remoring much earlier, lont that he harl heen preventer by obstarles that

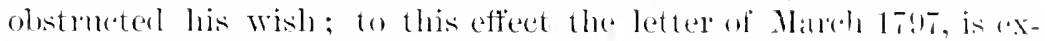

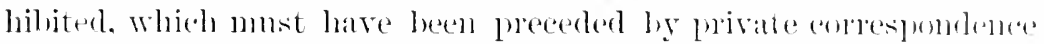
and appliation to some of his creclitors. It doess, I think, heathe strong expessions of intentiom, and of an andent desire to sere orer the restraint that alone detained him ; and it aflonds conclnsive reasom to believe that if le had been a fres man, and at liberty to wo where he pleased. he would have removed lome befole; and that he wats detained here as a hostage, as he deseribes himselt, to his croblitors,

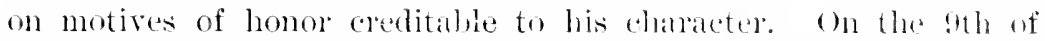
septemler 1797 he did actually retire: of the sincolyty of his puit-

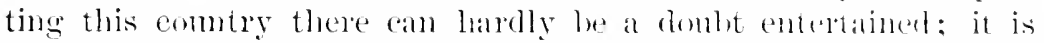
almost imposible to represent stronger ol more malmal momols for such a measure; and I do not think the Comt rums any risk of encountering a fraudulent pertension, put forwarl to meet the circumstances of the moment, without anything of an miginal and bome fide intention at the bottom of it.

The ship was sent out moler the management of the suplerarson, and it is said that Mr. Hewlet exceeded his commissiom. The affistirit does not go so far ; it does not appear from that, that the arent harl not the power to enter into such an engagenent hut this, I think, appears elenly, that it was the molerstanding both of Mr. Johnsom, and of his agent, Mr. IJewlet. who had been his telek, and to whom he refers for a eonfirmation of his avowed design of remoring. that before the completion of such a vovage Mr. Johnson Would be in Ameriea ; therefore if the illegality of the vovalge must be sulpuserl to have presented itself to their minds, as a British transation. om ing to Mr. Jolmson's residence in England, there was reason enomgh for them to eonelude that Mr. Johmson would be remored: and. on that view of the matter, althomgh it is certain that an acent would himb his employer in such a case, there is gromol sufficient to plesmme that the agent acterl farly and bome firls, and under the expectation that Mr. Johnson would be returned to America. 
. The ship arrives a few weeks after his dejurtme: and taking it to be clear. that the national charateter of Mr. Johnsom as a British merehant was fommled in residence only, that it was acronimed by

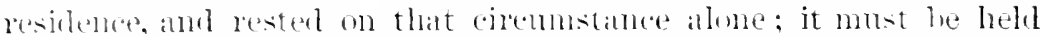
thit from the moment he turns his back on the comntry where he lak residerl, on his way to his own combry, he was in the act of resuming his original chatater, and is to be considered at an Amel-

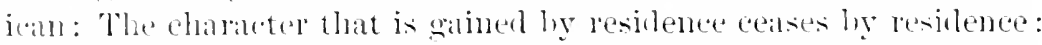
It is an alventitions charater which no longer alleles to him, from the monent that he puts himself in motion, bome file. to quit the

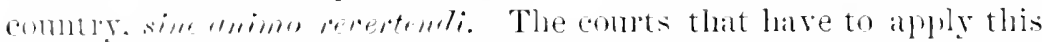
primeiple, have applied it both ways, mufaromaly in some cases, and faromilly in others. This man had actually gnitted the comntry.

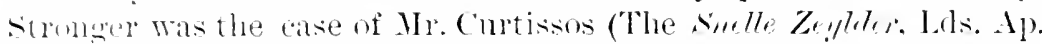
2.. 17-9): he was a British bom-subject, that had been resident in surinam and st. Eustatius, and hall left those settlements with an intention of retmming to this comntry lut he had got no farther thin Holland, the mother eomtry of those settlements, when the war moke ont. It wis determined lig the Lolds of Appeal, that he was in ifirem. that he had put himself in motion, and was in pursuit of his native British eluacter : and as such, he was held to he entitled to the restitution of his property. So here, this gentleman was in alual pursuit of his American character: and, I think, there can be 1un doult that his native character wis strongly and substantially weverl. not oceasionally. nor coloralily. for the mere purpose of the fresent chims and therefore I shall restore the ship."

[The cirno of this ressel belongel to Mr. Millar, resident in Calcutta as Anerican consml. He was held to be a British merchant engager in trale with the enemy, and his gools were therefore condemmed as droits of admiralty, heing seized in a british port. IIis comsulat character made no difierence whatever in protecting his trate.] 
TIIE " VENLS."

Sepreje Colto of the L Mited sitates, 1-14.

(8 (ranch, 2.5:3)

If a citizen of the [nited States establishes his domicil in a torimn cointry between which and the Cnited states hostilities afterwards break unt. any loweerty shippel by such citizen before knowledge of 1 he war, and rathen by an American cruiser after the eleclaration of war, must be condenumed at law ful priz".

Judgment,-W ismingtox, J.:-

"*** The great question involved in this, and many other of the prize eases which have been argued, is, whether the pronerty of these claimants who were settled in Great Britain, and engatged in the commerce of that country, shipped before they had at knowledge of the war, but which was captureel, after the declintition of witr, by an American cruiser, onght to be condemned ats lawful prize. It is contended by the calptor's, that as these chamants harl gilinerl at domicil in Great Britain, and contimned to enjoy it 11 to the time war was declared, and when these captures were mate, they must be considered as British subjects, in reference to this property, ancl, consequently, that it may legally be seized as pnize of war, in like manner as if it had belonged to real British subjects. But. if not so, it is then insisted that these elaimants, having, after their naturalization in the Lnited states, returned to Great Britain, the comntry of their birth, and there resettled themselves, they becane redintegrated British subjects, and ought to be considered by this court in the sitne light as if they never had emigrated. On the other side it is argned, that American citizens settled in the country of the eneny, as these persons were, at the time war was declared, were ent it led to a reatsonable time to elect, after they knew of the war, to remin there. or to return to the Cnited states; and that until such election wiss, brom fidl. made, the courts of this country are bound to consider them ats American citizens, and their property shipped before they had in opportmnity to make this election, as being protected against Lnerican capture.

"There being no dispute as to the facts upon which the dimieil of these claimants is asserted, the questions of law alone remain to be considered. They are two._First, by what means and to what extent, a national character may be impressed upon a person slifferent from that which permanent allegiance gives him? and. secondly, 
What are the lewal conseruences to which this adpuiped character mas expose him. in the erent of a war talking nlate between the (e)mery of his gesidenee and that of his birth. or in which he had

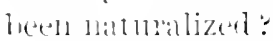

- 1. The witers mpon the law of nations distinguish hetween a

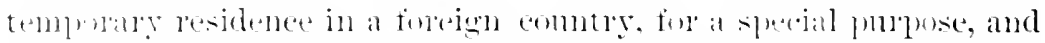

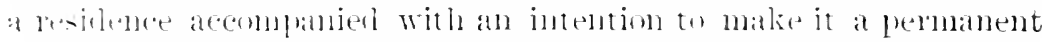

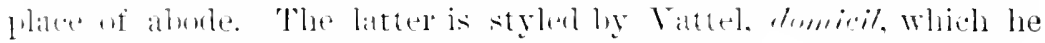
defines to he. a hathitation fixed in any plate with an intention of alway-s saying theme: * *

" The pluestion whether the person to be atfected hy the right of demiveil had snticiently made known his intention of fixing himself felmanenty in the foregon comoly, must depend upon all the circmm-tandes of the case. If he har malle no expess declaration on the snhject. and his secret intention is to be discovered, his acts

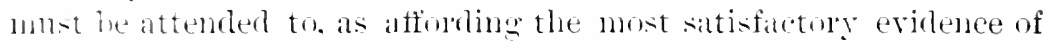
his intention. On this gromed it is, that the comets of England have

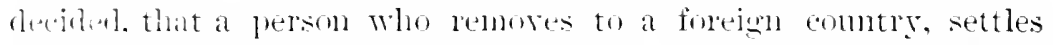
himself there. and engages in the trate of the combry. furnishes by there atcs steh evidence of an intention permanenty to resite there, as to stamp him with the national chatratel of the state where he

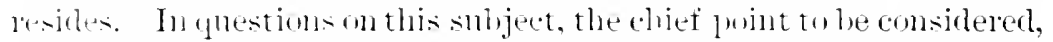
is the mimms mememt : and connts ane to devise suel reasonable mules uf evilence as may estahlish the fact of intention. If it sufficiently alpear that the intention of removing was to make a permanent settlement. or for an indefinite time the right of domicil is acpuired lis a resilence even of a few days. This is me of the rules

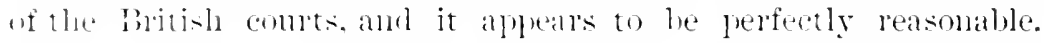
Auntuer is. that a nentral or subjet, fomml residing in a foreign

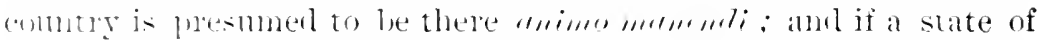

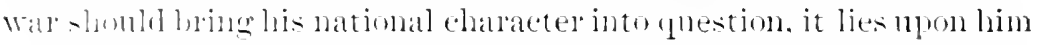
lo explain the ciremnstance of his residence-(the Bronon, 1 C. Rob., - $6.111-2)$.

.... The next question is. what are the anseguences to which this atepluided domieil may legally expose the person entitled to it, in the event of a war taking plate hetween the govermment under which le reables and that to which he owes a permanent allegiance? A nelubal in his situation. if he shomld enerage in open hostilities with the other helligerent would be ensidered and treated as an menyy. A citizen of the other bellinerent eould not be so considered, becantio. he conld not hy an! act of hostility reuder himself, strietly spealines an enemy. ermtrary to his permanent allegiance. But altinngh lue camnot be eonsidered an enemy, in the strict sense of 


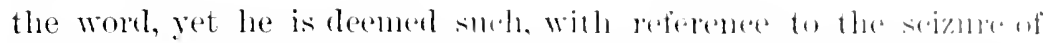

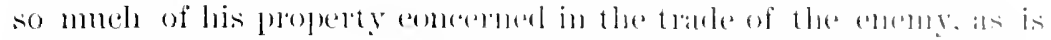

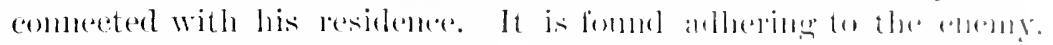

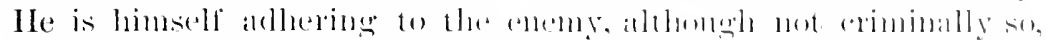

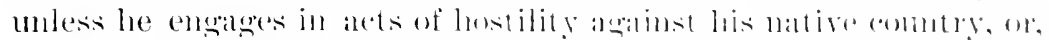

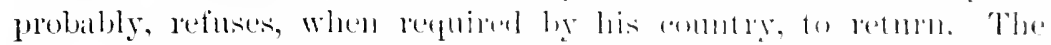

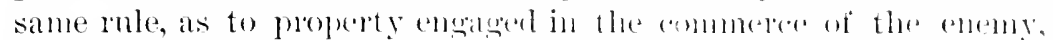
applies to nentrals; and for the simm reasom. The comporse of

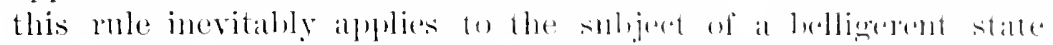
domiciled in a neutral comnterg he is dermed a mental by loth belligerents, with reference to the trable which he atlolies on with the alverse belligerent, and with all the rest of the wolld.

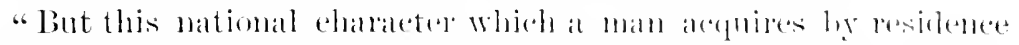

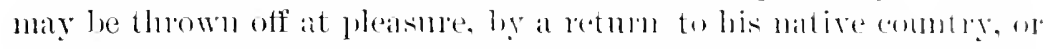
even by tmming his bark on the commly in which lo has pesirled,

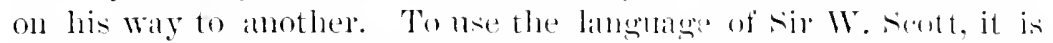

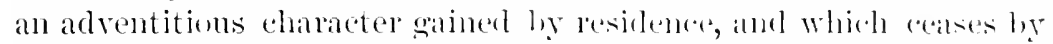
non-resillenee. It no longer allores to the barty from the moment he puts himself in motion, bome fide, to quit the commly sime amimen

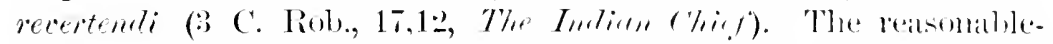

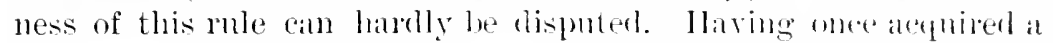
national chancter hy residence in a foreign combly, le onght to be bound by all the consegnemees of it, motil he has thrown it off, eithel by an actual retum to his mative combly, of lo that where he was naturalizer, or by commencing his removal bmen, firle, and without an intention of retulning. If anylhing short of alctual removal be almitted to work a change in the national chatracter acquired by residence, it seems perfeetly reasonable that the evidence of a bome firle intention to remove shouhl be such as to leare no doubt of its sincerity. Mere decharation of snch an intention onght never to be relied unon, where contradicted, or at least remblerert doulfful, by a continuance of that residence which impresied the character. They may have been macle to deceive; or, if sinerery made, they may never be executerl. Even the party himself omght not to be bound by them, beause he may afterwards find reason to change his determination, and ought to be permitted to do so. But when he aceompanies those declatations with acts which speak a language not to be mistaken, and can hardy fail to be comsmmmated by aetual removal, the strongest evidence is aftorded which the nature of such a case can furnish. And is it not proper that the courts of a belligerent nation shonld deng to any lersun the right to use a character so efuirocal, as to put it in his foller to riim whichever may best suit his pmpose, when it is called in guestion? 
If his ponerty he taken traling with the enemy, shall he he allowed to slitede it fom contisation, hy alleging that he had intended to remove from the conntry of the enemy to his own, then nentral, and, therefore, that, as a nemtral, the trade was lawinl: If war exists hetwenthe comntry of his residence and his native comtry, and his proferty be seized by the former, or by the latter, shall he be head to say in the former case, that he was a domiciled subject of the comnty of the captor. and in the latter. that he was a native suligeret of the comntry of that captor also, because he had declared an intention to resmice his native character : and thus to parry the belligerent lights of both? It is to guad against such inconsistencies, and aganst the frands which such pretensions, if tolemated, would sanction, that the rule above mentioned has been adopted. Cpon what sound principle can a distinction he framed between the case of a nentral. and the smbject of one belligerent domiciled in the comutry of the other at the brealing out of the war: The propelty of each, fomd engaged in the commerce of their adopted country, helonging to them, hefore the war, in their character of subjects of that country, so long as they continued to retain their domicil: and a state of war takes place between that comtry and any other, hy which the two nations and all their subjects lecome enemies to each otler, it follows that all the property, which was once the property of a friend, belongs now in reference to that property, to an enemy. This doetrine of the common-law and prize comrts of England is founded. like that mentioned moler the first head. upon national law : and it is believed to be strongly suphorted we leasm and justice. It is laid down ly Grotins, 1. 563, that all the smhjects of the enemy who are such from a permanent cause, that is to say, settled in the comtry, are liable to the law of reprisals, whether they be natives or foreigners: but not so if they are only trading on sojomming for a little time. And why, it may be confillently askerl, should not the property of such subjects be exposed to the law of reprisals and of war. so long as the owner retains his acquired domicil, or. in the words of Grotius, continnes a permanent residence in the comntry of the enemy: They were before, and continne after the war. bound, by such residence, to the society of which they are member's, sibject to the laws of the state, and owing a qualified allerginnce thereto: they are obliged to defend it (with an exception in filvor of such a subject, in relation to his native (omntry). in return for the protection it affords them, and the privileges which the laws bestow mon them as subjects. The property of such persons, equally with that of the native subjects in their tutality, is to be considered as the goods of the nation, in regard to 
other states. It belongs, in some sort, to the state, from the right

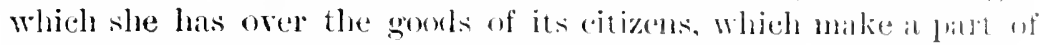
the sum total of its riches, and amsment its power. Valt., 17 , amul also B., 1, c. 14., \$ 1s.2. In reprisals, contimus the same anthur. We seize on the property of the sulject, just ats we would that wif the sovereign; everything that belongs to the nation is suljeret in reprisils, wherever it can he seizerl, with the cxeeption of a drumit

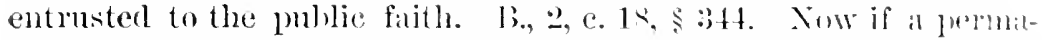
nent residence constitntes the person a sulject of the comntry where he is settled, so long as he continnes to reside there, am subjects his property to the law of reprisals, as a part of the property of the nation, it would seem difficult to maintain that the same comsepnences wonld not follow in the ease of an open and public wats, whether between the adopted and native commures of persons so domiciled, or between the former and any other nation. If, thenn, nothing but an actual removal, or bons firle beginning to remove, am change a mational eharacter acquired by domicil, amb if, at the time of the inception of the voyage, as well as at the time of eapture, the property belonged to such domiciled person in his character of a suliject, what is there that does, or onght to exempt it from eapture ly the privateers of his native comtry, if, at the time of capture, he (onntinnes to reside in the country of the adverse belligerent? It is contended that a native or naturalized subject of one comtry. Who is surprised, in the comntry where he was domiciled, by a declaration of war, ought to have time to make his election to continue there, or to remove to the comntry to which he owes a permanent allegiance, and that, until such election is made, his property onght to be protected from capture by the cruiser's of the latter. This doctrine is believed to be as unfounded in reason and justice, as it clearly is in law. In the first place, it is founded rpon a presumption that the person will certainly remove, before it ean possibly be known whether he may elect to do so or not. It is saich that this presumption omght to be made, because, on receiving information of the war, it will be his duty to return home. This position is denied. It is his duty to commit no acts of hostility against his native country, and to return to her assistance when required to do so; nor will any just. nation, regarding the mild principles of the law of nations, require him to take arms against his native comntry, or refuse her permision to him to withdraw whenerer he wishes to do so, mulesi muler peculiar circumstances, which, by such removal at a critical perion, might endanger the public safety. The conventional law of mations is in conformity with these principles. It is not uncommon to stipulate in treaties that the subjects of each shall be allowed to remove 
with their proforty. on to remain mmolested. Sucle a simmlation

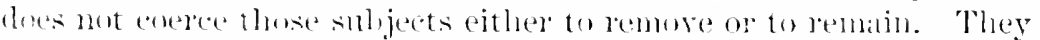
alle lat fore in rhome fon themselves: and when they have made their election, they raim the right of enjoying it moter the treaty. lint motil the election is mate, their former chatreter continnes mebanged.

" Lutil this elertion is malle, if his property fommel npom the high sals angagerl in the commere of his arlophed commtry, shomld be

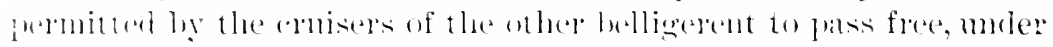

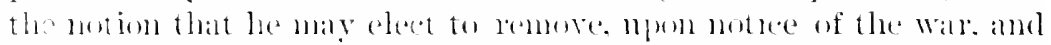
shomblarrive safe. What is to lu dome in case the owner of it shomel afterwatis teret to remain whele he is? or if captumed and honght

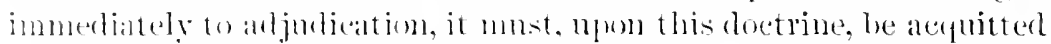
motil the elextion to remain is male known. In short, the point comtemled for womlil apply the doctrine of relation to cases where the party elaiming the leenefit of it maly gain all, and eam lose nothing. If he, after the apture, slontel find it his morest to remain: where he is domiciled, his poperty embalked hefore his election was marle, is safe: and if he finds it best to return, it is salfe of comse. I1 is safe whether he goes or stays. This doctrine, probucing snch

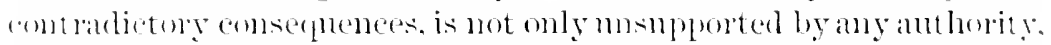
lut it womld vinlate principles long and well establisherl in the prize romts of Englane, and which omeht not, withont strong reasone which may remler them inapplicalle to this eomntry to be dis. residuled hy this comt. The rule there is, that the character of the

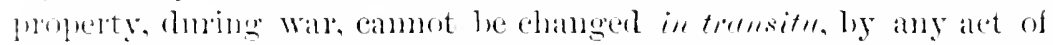

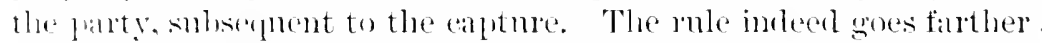
as to the rorrectuess of which in its greatest extension, no opinion neel now lo wren; but it may safely be affirmed that this chasege

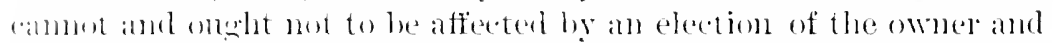

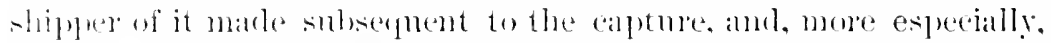

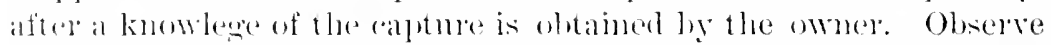
the conserforeces which womld result from it. The eapture is made and known. The omner is allowed to deliberate whother it is his interest to remain a sulject of his aldepted, of of his native comntry.

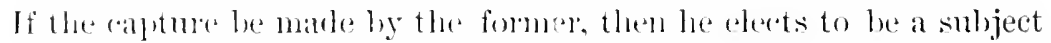
of that comotry: if hy the latter, them a subject of that. Can such

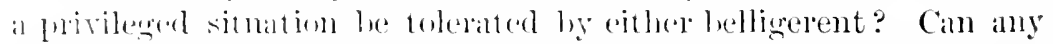
sistem of law becorrect, which plates an individual who adheres

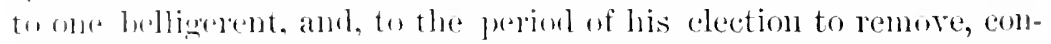

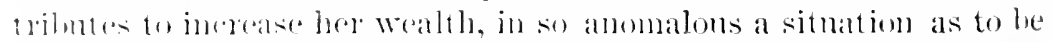

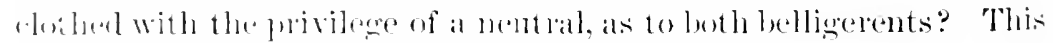
notion about a tempolaty stale of nentrality imporsed nuon a sub- 
ject of ofe of the belligerents, and the eonsofuent exemption of his property from eapture ly eithes, moth he has hat motioe of the wall

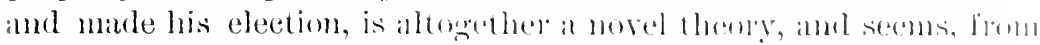

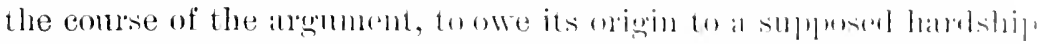

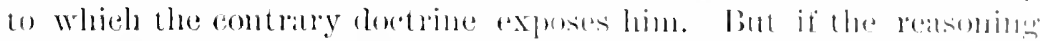

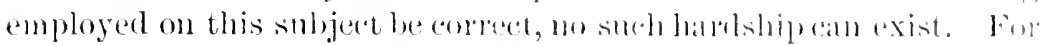

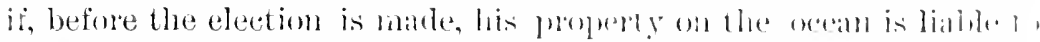

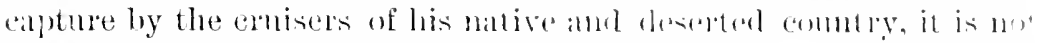

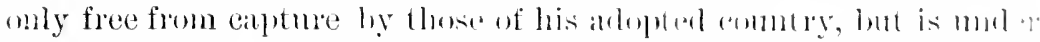

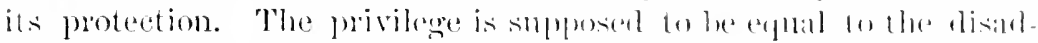
vintage, and is therefore just. The domble privilege elaimed seems too moreatsonable to be granterl. ***

"Condemnation was pomounced in all the tasess." 1

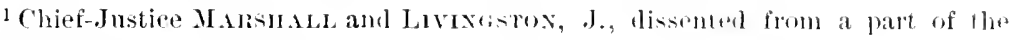
julgment.

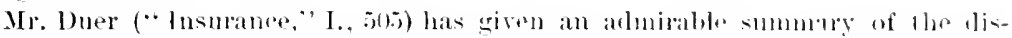

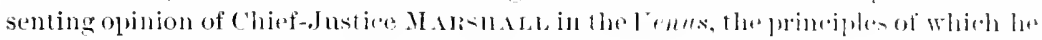
seems inclined to think are more in areordance with reatson than the one hath down by the majority of the bench.

Mr. Dner says: "From this opinion of the majority of the court rhiof-andtan

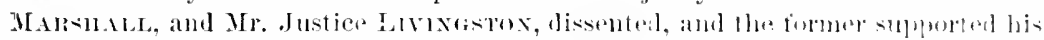
dissent in an elaborate argument, which, as it bears, in an eminem derren. 1 he inpress of his vigorous and comprehensive mind, claims, and will amply reward. the diligent perusal of the stulent. The hasis of his argment was the pusilion. hath. a mere commereal domicil. wholly aeprired in time of peare, neressarily reas at

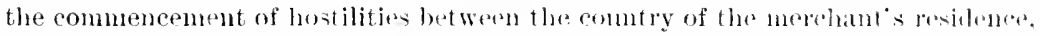
and that of his allegiance; and this position he expands and illustranes by at wat variety of arguments, from varions someres. It is only a resy comblusel riew of his reasoning that I shall attempt to exhibit. Where a merchant remores to a foreign couniry, for commercial prupeses, in time of peace it is lratimathle to believe, that he intends to remain only solong as he ean eary on hi- trade, lawfully and alvantageously, without a violation of duly to the country of his alffections and his allegiance; but the interention of a war betwen the country of

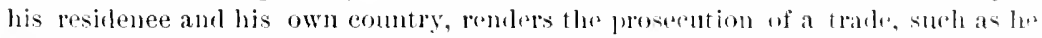

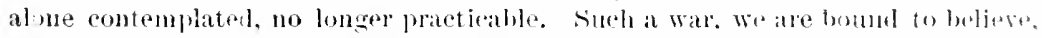

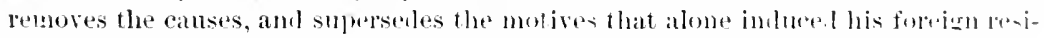

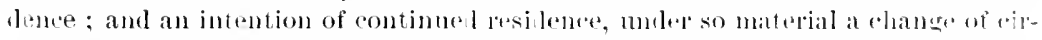
cumstances, onglit no longer to be imputel to him. On the contraly, when we consiler that the right of the merehant to remain an l prosente the trake in which

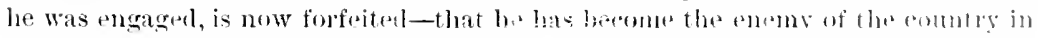
which he resides-that his continnanee in it will, pobthly, expme him to maty and serions inconveniences-that his interests and his duly and mont probubly. his inclinations, eall him home-it seems. not only a fatr. hut almos al mosentry inference, that the ehange in his situation has frolued a change of his infm-

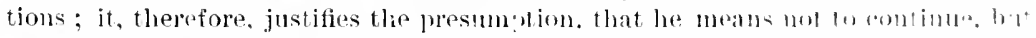
as soon as practicable, to terminate his resitenes. It is alike inmolitiv anl un just, to huili any argument mpon his tirst pesilence, of his intention to throw of permanently his original character and allegiance. 


\title{
TIIE "IIARIIONY."
}

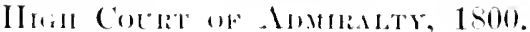

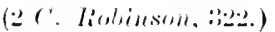

In entsidering the evidence which shall constitute domicil, time is the most int. fortant inamedinnt.

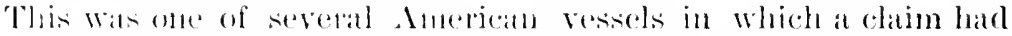

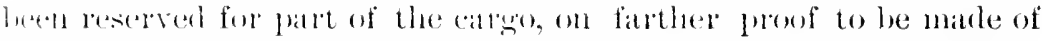

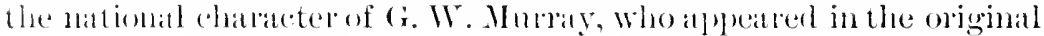

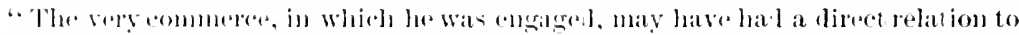

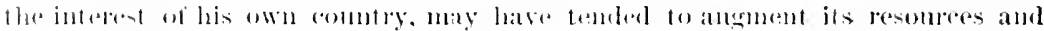
wallh. Xir nation that takes an interest in the prosprety of its own commeree,

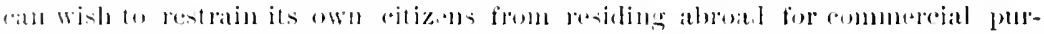

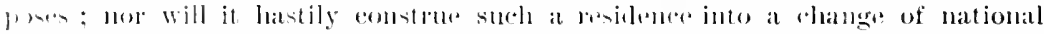
rhatarter, to the artain injury of the individual, and probahly to its own. Sor is blis all. It is the doctrine of the most alpuswerl writers on the law of nations, t!at a e ditzell of one comutry, who is resiling, but not natluralize l, in another, is

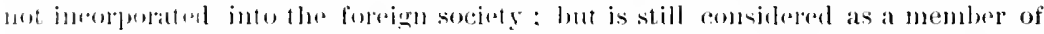
that to whieh he originaly belongerl. If a war braks out between the two nations

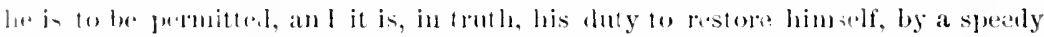

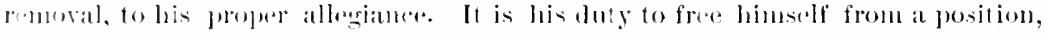

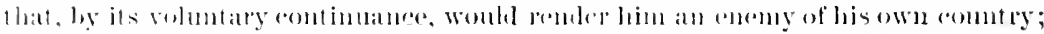

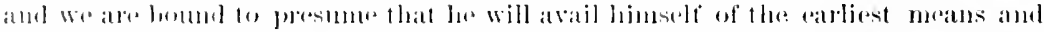

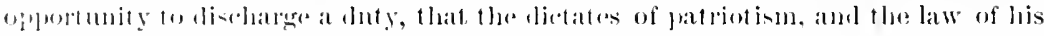

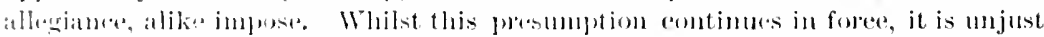

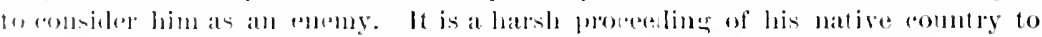

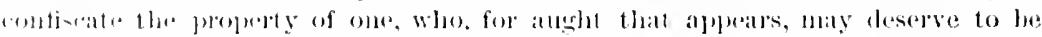

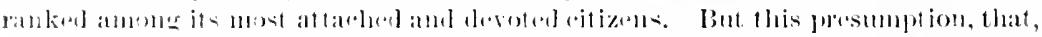

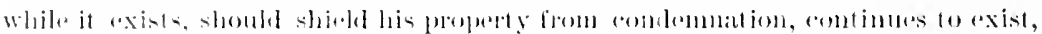

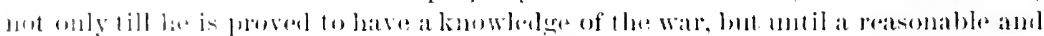

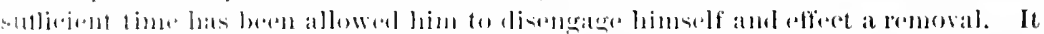

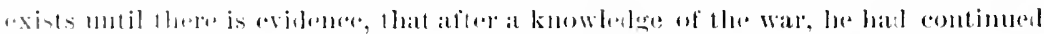

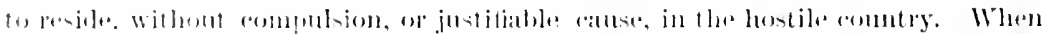

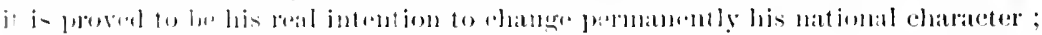

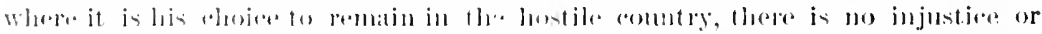

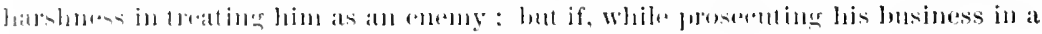

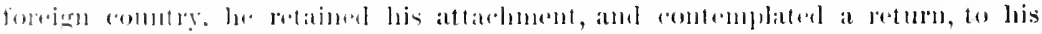

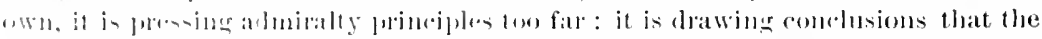

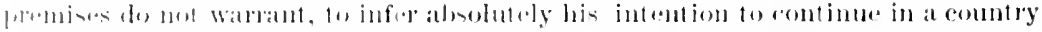

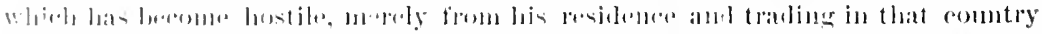

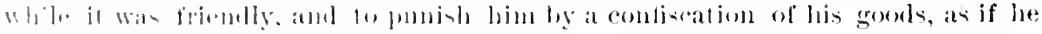

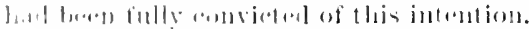

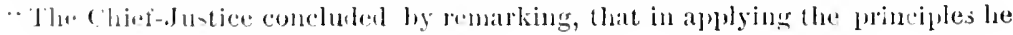




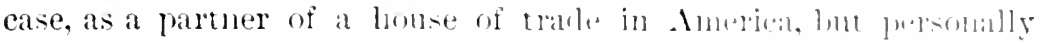

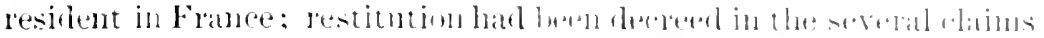

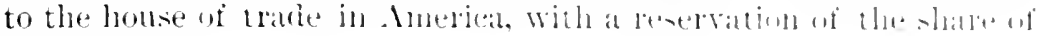
this prartnets.

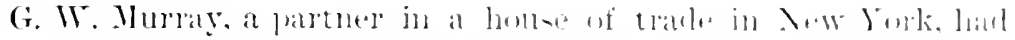

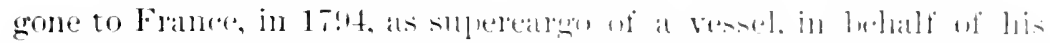

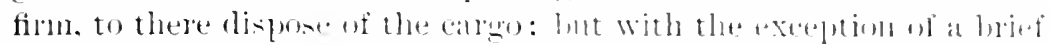

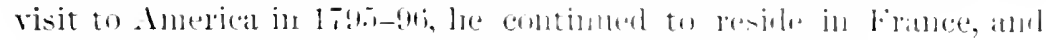

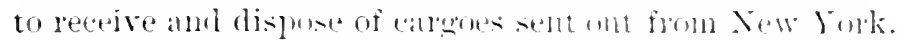

At the time of the tirst trial. Mr. 1;. Wr. Murray hanl net leen in

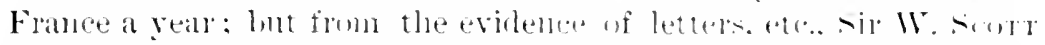

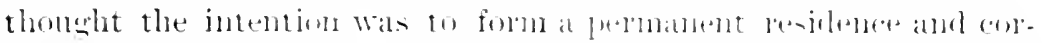
respondence in France. This belief was stremethemel heg the faret

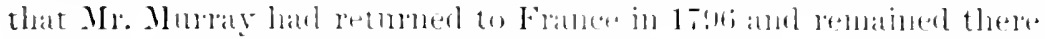

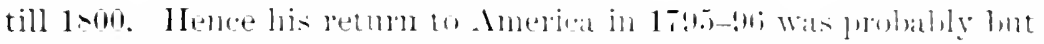

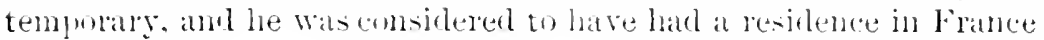
for six years.

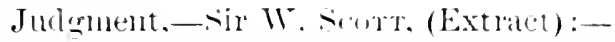

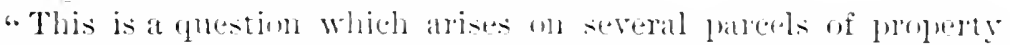
claimed on behali of 6 . M. Murmay ; and it is in all of them at que-

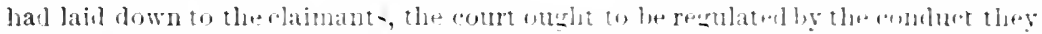

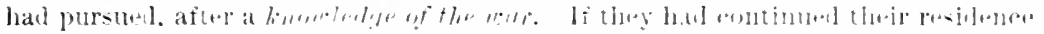

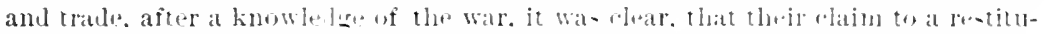

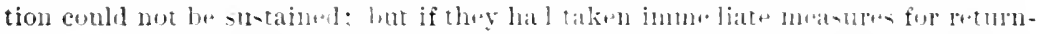

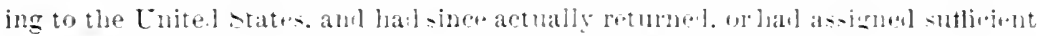

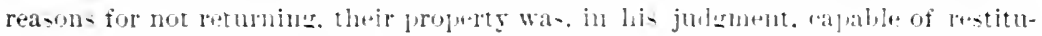
tion, and that by this diserimination some of the claimants. although not all. were entitlent to the restoration of theil anests.

"In the cours" of this opinion. which I lave ruluctantly abriluel. the ('hief-

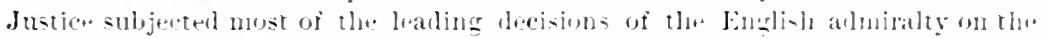
question of domicil. to a -trict and searchine analy-is, and he arrivel at the eron-

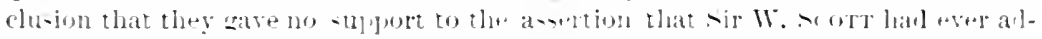

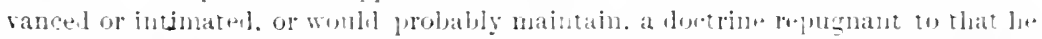

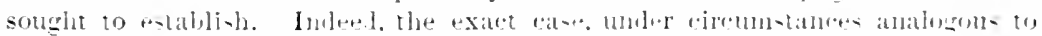

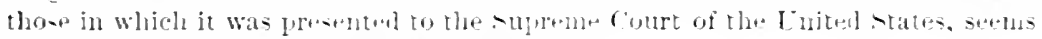
never to have arisen in the courts of Enclanl.

"It is necessary. in conelu-ion. to rwark that the raimant in the rase which

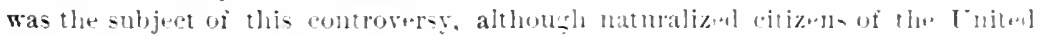

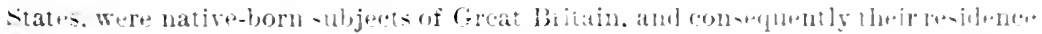

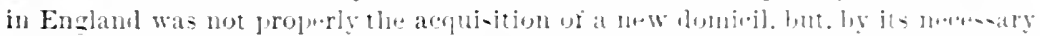

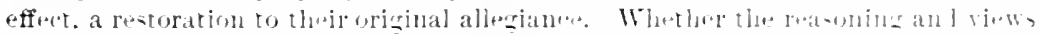

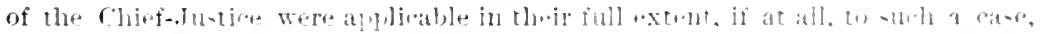

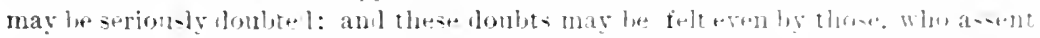

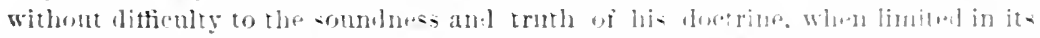
applieation to native suljuets or citizens, resiling merely, and not natualized, in a foreign country." 
tion of resilemee of dombil, which I have often had oecasion to ob-

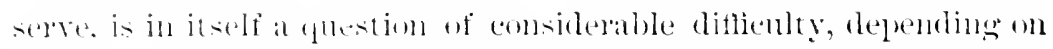

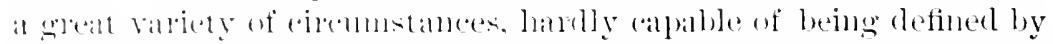

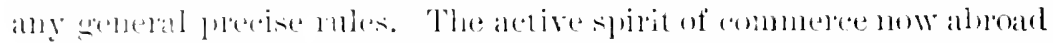

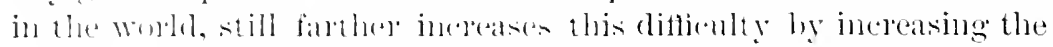
valdety of lowal situations, in which the same individual is to be

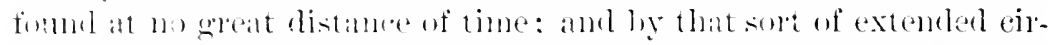

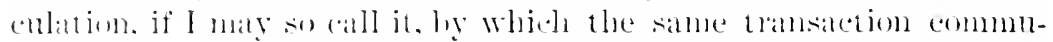

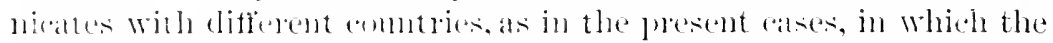

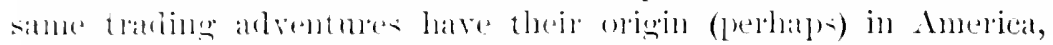

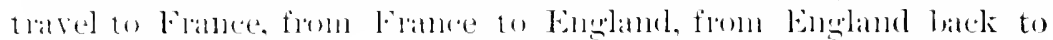

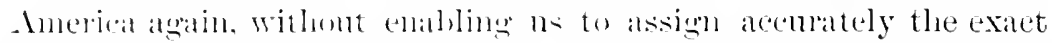

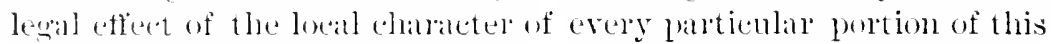
divieled transactions.

- In deciding smeh cases. the necessary freedom of commerce inpoes liliewise the duty of a particular attention and delicaey: and striet prineiple of law must not le pressed too eagerly arainst it; and I have before had oceasion to remark, that the garticular situation or Anerica, in respect to distance. seems still nore particnarly fo entitle the merehants of that eomuly to some faromable distinetions. They live at a pleat distalle from Eumpe they have not thes sume open and realy and comstant correspondenee with individllals of the sereral nations of Emope, that these persons have with each ofles: they are on that rerg acomut mone likely to have theis

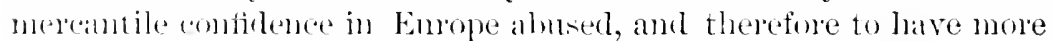
frepount ealls for a persomal attendamee to their own comcerns : aud

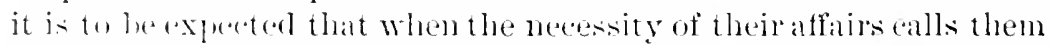
arese the Alantic they should make rather a lomer stay in the anmotry where they ane allerl, than foreign nereluats who step

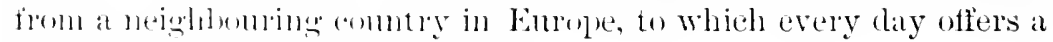

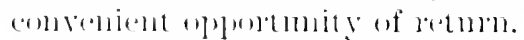

- In comsilering this particular case, it may mot he improper to

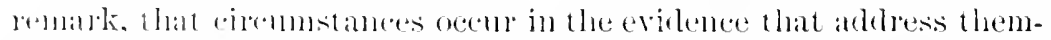

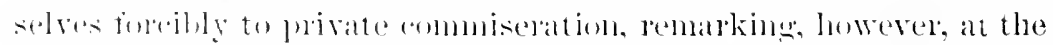

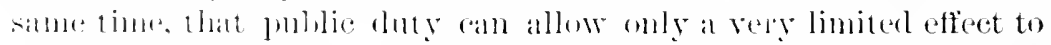

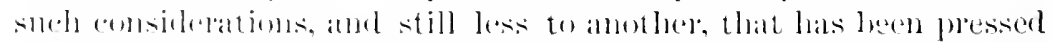

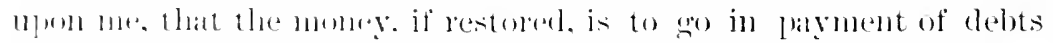

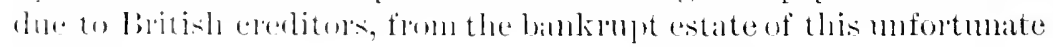
jersint.

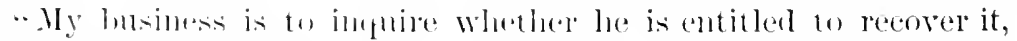

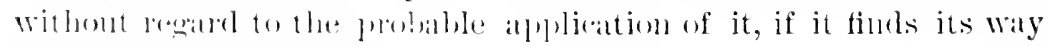

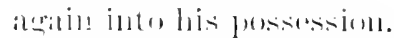

.. () f the few principhes that cam be latel down generally, I may 


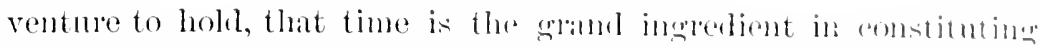

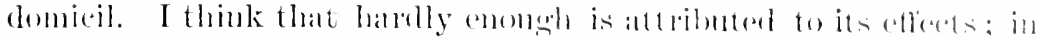

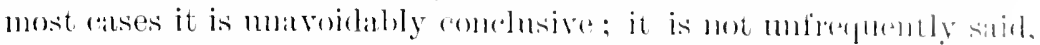

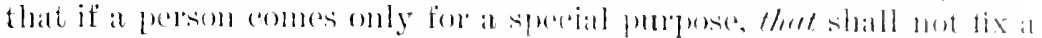

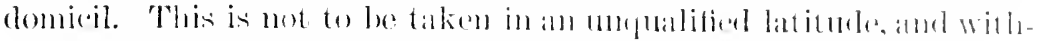

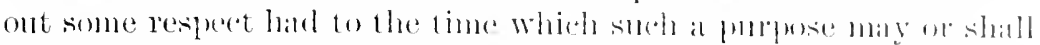

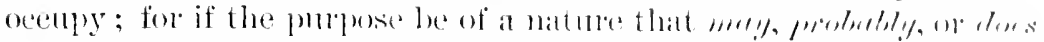

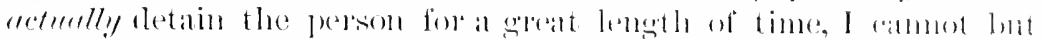

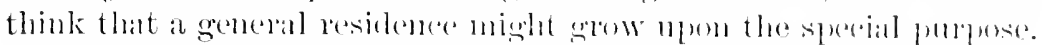

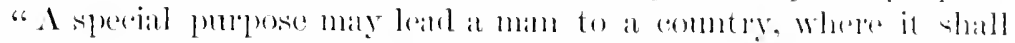

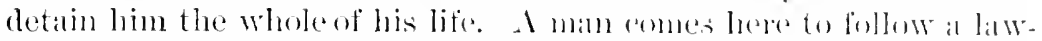

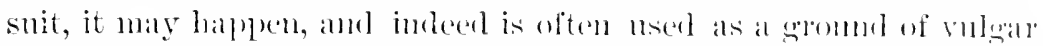
and unfomeded reproateh (mofommed as matter of just rependell thomgh the faret may he true, on the laws of this commly, that it

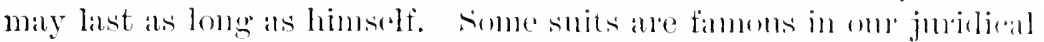
history for having even ontliverl senclations of suitols. I cammot

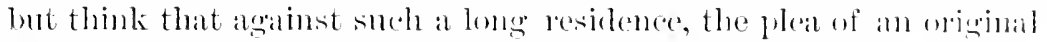

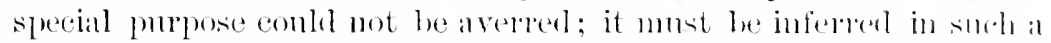
case, that other pmproses foreed themselves nym him and mixed themselves with his original design, and impressed mpm him the clatareter of the combly where he lesided.

"silppose a man eomes into a belligerent combly at or before the beginning of a war ; it is certainly reasomalse not to hind hin too soon to an acpuired charactere, and fo allow him a fatr time to

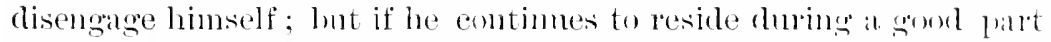
of the war, eontributiug, ly payment of taxes, amd other means, to the strength of that eomutry, I am of opminim, that he eomil not plearl his special purpose with any effect asiust the rights of hostility. If be conle, there would be no sufficient gnall against tho framl and abuses of maslied, pretemberl, original, amb sole purposes of a lomscontinned residence. There is a time which will estopstrell a plat:; no rule cin fix the time "promi, but stleh a time there mmst he.

"In proof of the efficary of more time, it is not impretiment to remark, that the same quantity of business, whirh womld mot fix at domicil in a certain spatce of time, wombl nevertheless have that effect, if distribnted over a large spalce of time. Fupposi an . Imeriean romes to Europe, with six contemporary carrenes of whidh he

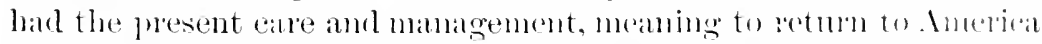
immediately: they wonld form a difterent case from thatl. of the simme American, eoming to any particular comntry of Enrope, with onde

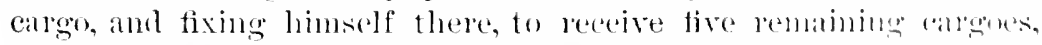

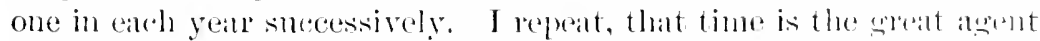
in this matter; it is to be taken in a compoumd ratio, of the time and 
the oecupation. with a sreat preponderance on the article of time: be the ocolphation what it may, it camnot happen. but with fow exceptions. that mere length of time shall not constitute a domicil."

\section{BEXTZEN . BOYLE.}

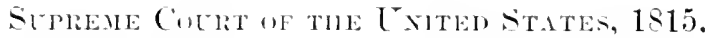

$(1)(1 \% 26 \%, 191$.

The produre of enemy soil while msohl is hostile, whaterer be the domicil of the owner of the soil.

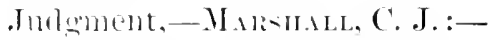

" The lstand of simta Cruz, belonging to the kinglom of Denmakk, was smblued during the late watr, by the alms of his britamic Majesty. Mrrien benjanin Bentzen, an onticer of the banish soremment, and a froprietor of land therein, withdrew from the iskund on its smrender, and has since resident in Denmark. The lonpery of the inhabitants heing seemed to them, he still retained lis estate in the island muler the mimagement of an agent, who shiphed thirty hogsheals of sugar, the purbet of that estate, on boald a british shiph, to a commereial hollse in Lomdon, on ateeome amel risk of the said A. B. Bentzen. On her plssige she wats tapmored be the American privateer. the romet, and hrombit into bal-

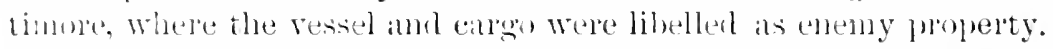
I rain for these sherars wats put in by bentzen; but they were en-

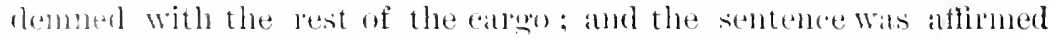
ly the cirruit comet. The claimant then appealed to this comet.

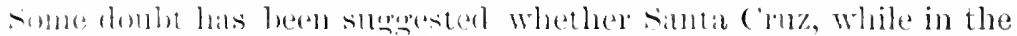

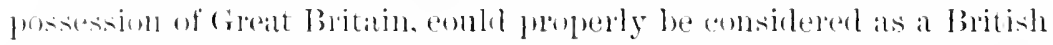
islant. Sint, for this dombt there can be no fommlation. Mlthomgh

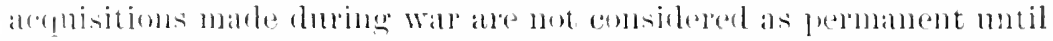

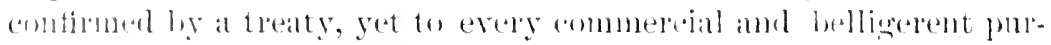

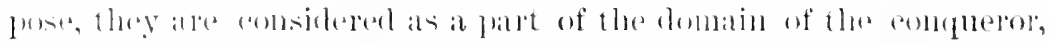

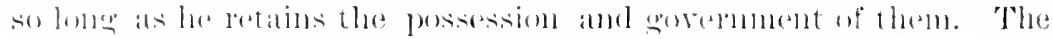

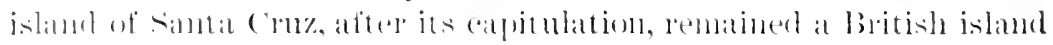

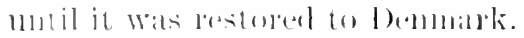

* llus the prombet of a plantation in that island, shipperl by the

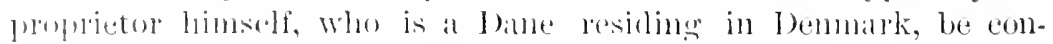

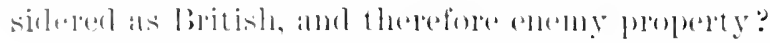

"In arening this question, the eomusel for the chamant has made 
two points. 1. That this ease does mot come within the rul. alphliable to shipments fiom an enemy eomutry, even as latid down in the

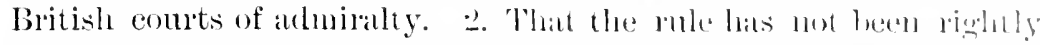

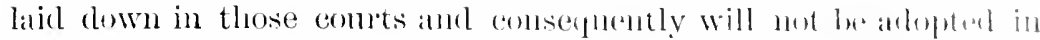
this. 1. boes the rule laid down in the British combts of abmirahy embrace this case?

"It appear's to the comet that the case of the IMr. mi, 1 is procisely" in point. In that case a vessel was captured on a veralge flom suri-

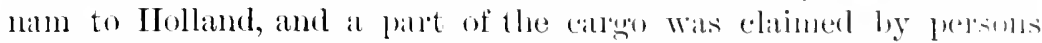
resiling in Germany, then a nentral comntry, as the porluce of their estates in Surinam.

"The comnsel for the captors eomsidered the law of the rase ats entirely settled. The commsel for the claimant dicl not eomtrovent

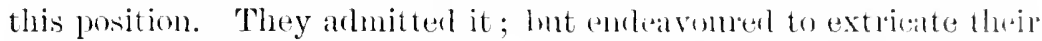
arse from the general principle by giving it the protection af the

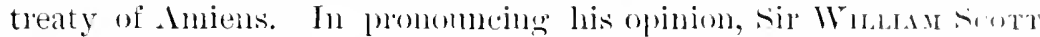
lays down the rulo thos: "Certainly nothing can be more decilent and fixed, as the principles of this comt and the simpene Comet 11 m very solem arguments, than that the possession of the soil does inlpresis mpon the owner the chanater of the comntry, whatevel the local lesirlence of the owner may be. This has been so lepeatledly decided, both in this and the superior Compt, that it is molomerer open to discussion. No question ean be male on the point of law, at this day.'

"Afterwards, in the case of the Trom" Amme ('atherime, 5 ('. Riob),

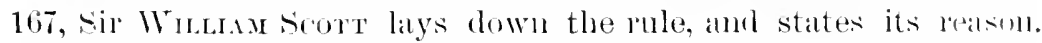
'It camot be doubted,' he says, 'that there are tramsantions so radically and fumbanentally national as to impress the nationat character, independent of peace or war, and the lowal resiclence of the part ies. The pronluce of a person's own plantation in the colong of the enemy, though shipped in time of peace, is liable to be comsidered at the property of the enemy, by reason that the propulietor has incorporated himself with the permanent interests of the nation as a holder of the soil, and is to be taken as a part of that combtry, in that particular transaction, independent of his own personal residence and occupation.'

"This rule latid down with so much precisiom, does not, it is antenderl, embrace Mr. Bentzen's alaim, becallse he has not 'incorpunated himself with the permanent interests of the nation.' I le acplibed the property while Santa Crou was a Danish colony, and he with. drew from the island when it became british. 
"This distinction boes not alpreall to the comt to be a somm one. The identiti allon of the mathomal chatalete of the owner with that of the solle in the particular transation, is not plated on the disposi-

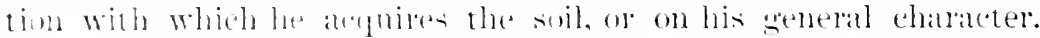

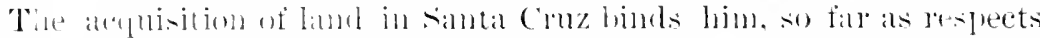
that laml. to the fatc of sinta c'ruz, whaterer its desting may be.

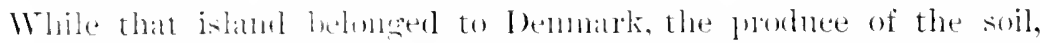

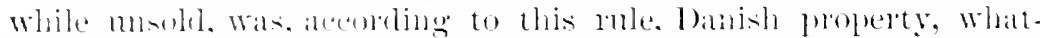

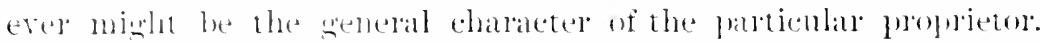
When the istand hatane british, the soil and its produce, white that

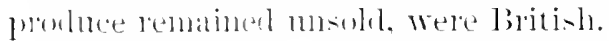

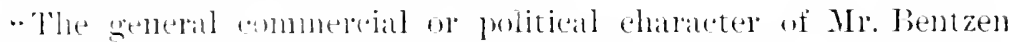
combl not, aceording to this rule, atfect this gaticular thansalction.

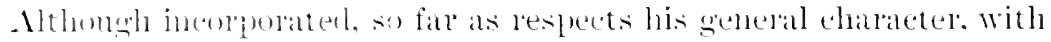
the pemanent interests of lemmark, he was incolpolated so far as gespents his plintation in santa cruz, with the permunent interests of -antal Croz, which was at that time British; and though as a bane, he was at wal with freat blitain, and an enemy, yet, as a groprietor of land in sinta Cruz, he was no enemy; he could ship his gloduce to (ireat Britain in perfect safety.

" The ase is certainly within the rule as lair down in the British comets. The next inquiry is: how far that rule will be adouted in this comotry:

." The law of nations is the great source whence we derive those rules. lespeting neutral and lelligerent rights, which are recognized

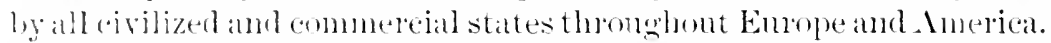
This law is in part mwritten, and in pat conventional. To ascertain that which is mwritten, we resort to the great principles of

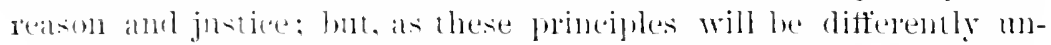

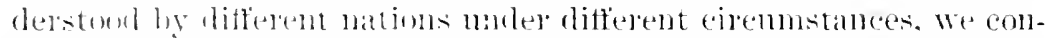
sider them as bejog in some legree, fixed and rendered stable by a series of jullebal derisions. The decisions of the comts of erery anmtry, sil far as they are fommled on a law common to every

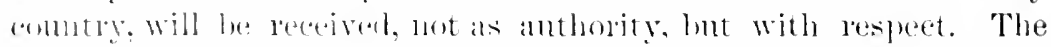

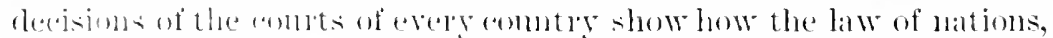
in the siven ease, is molerstome in that eomntry and will be con-

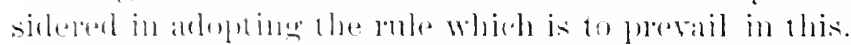

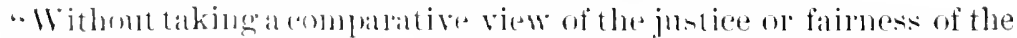

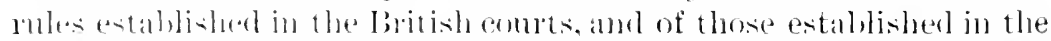

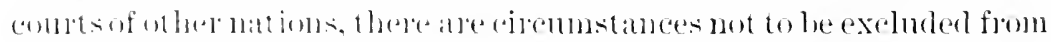
consinleration, whirls give to those lules a claim to our at tention, that

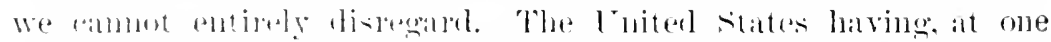
time, forme it component part of the british Empire, the ir prize law 


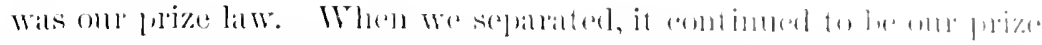

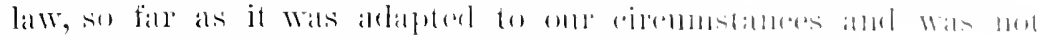

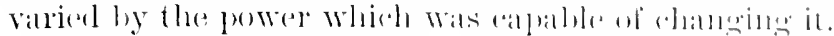

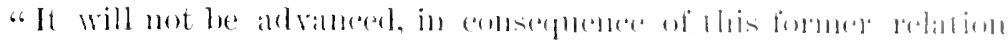

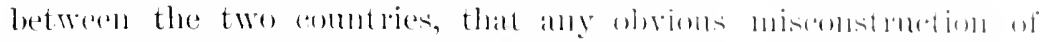

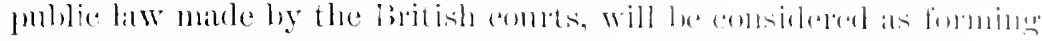

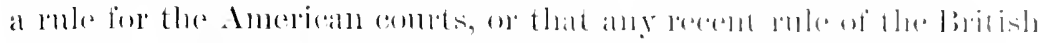

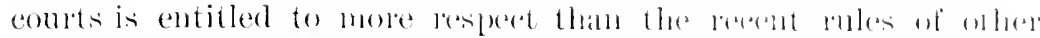

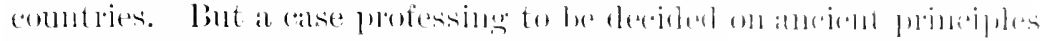

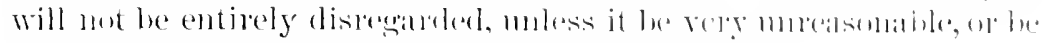

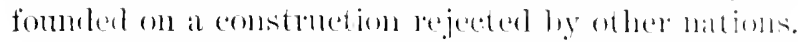

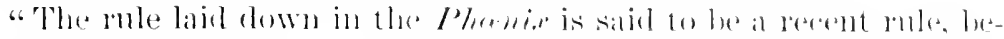

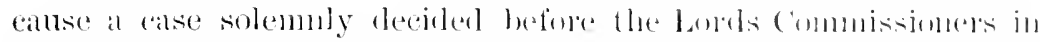

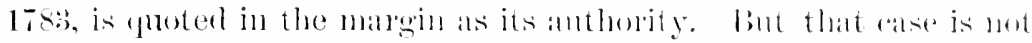

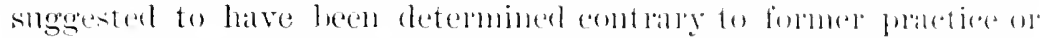

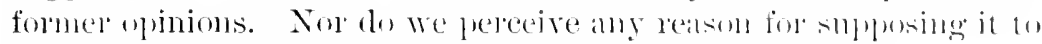
be contrary to the rule of other mations in a similar case.

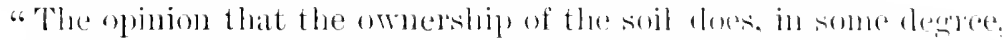
commeret the owner with the property, so far at resperes that soil, i:

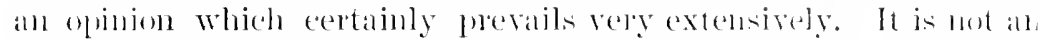

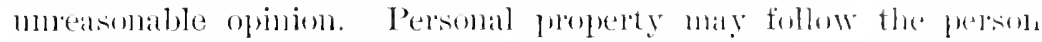

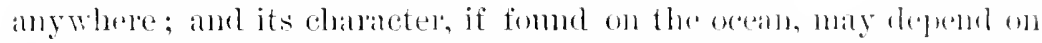
the domicil of the owner. But land is tixed. Whelerel the onmer

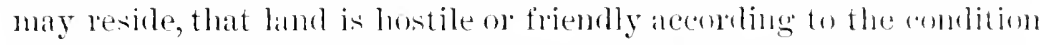
of the eomenty in which it is placed. It is no extrat ragat perversion of principle, nor is it a violent offemse to the enmse of lmman npinion to say that the proprietor, so far as respects his interest in this hand,

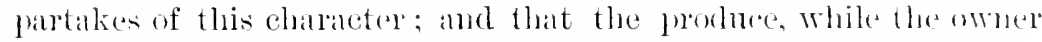
remains mohonged, is smbject to the same disabilities. In comblemning the sugars of Mr. Bentzen as enemy property, this comt is of opinion that there was no error, and the sentence is affirned with costs." 
TIIE " PII\%E C.ISE.',

Siplene (inclit of the liten states, 1862.

( 2 Blarli.. $17 i 1$.

The property of all pereons pesident withinthe territery of the states in rebellion, dnrine 1 he will war in the [nitel states, and engaged in commerce upon the sea, is anemy propredty and subject to contemuation as prize.

II. "We come now to the consideration of the second question. What is included in the term 'entmies' property?'

- Is the fluperty of all persons residing within the territory of the states now in rebellion, capturerl on the high seas, to be treated as 'meny's property' whether the owner be in arms against the goremment ar not?

" The right of one belligerent not only to coerce the other by direct force, hut also to cripple his resomes by the seizure or destruction of his property, is a necessary result of a state of war. Money and wealth, the products of agriculture and commerce, are said to be the sinews of war, and ats necessary in its conduct as numbers and physical force. Itence it is, that the laws of war recognize the right of a belligerent to ent these sinews of the porrer of the eneny, hy eapturing his property on the high seas.

"The aplellants contend that the term 'enemy' is properly applicable to those only who are subjects or citizens of a foreign state at war whith omn. They quote from the pages of the common law, which sily, that persons who wage war against the king may he of two kinds, subjects or citizens. The former are not proper enemies, but rebels and traton's; the latter are those that come properly muled the name of enemies."

"They insist, moleorer, that the l'resident himself, in his proclandition, andmits that great numbers of the persons resirling within the territories in the possesion of the insmrgent government, are logal in their feelings, and foreed by compulsion and the violence of the rebellioms and revolut ionary larty and its ' le fiecto government, to submit to their laws and assist in their seluene of revolution; that the acts of the nsmping goremment cammot legally serer the lond of their allegiance; they have, therefore, a co-relative right to ching the protection of the govermment for thein persons ant property, and to be treated as loyal eitizens, till legally convicted of 


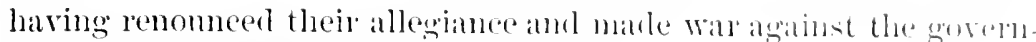
ment by treasomably resisting jts laws.

"They eontend, also, that insmuertion is the an of individuals,

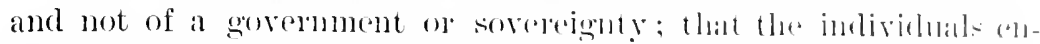

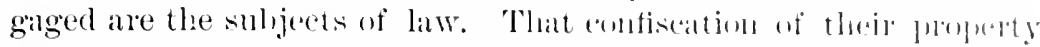
can be effected only moder a munieipal law. That ly the latw af th. land such confiseation cammot talie place withont the censivetion of the owner of some offence, and finally that tho seresion ondinallets

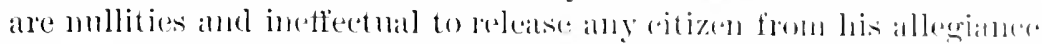
to the mational government, and comserpently that the oomstimbion and laws of the Enited states are still operative orer pelsons in all the states for pumishment as well as portretion.

"This argunent rests on the assmuption of two poppositions. ealch of which is withont fommation on the established law of lations.

"It assumes that where a civil wal exists, the billy hellinglent claiming to be sovereign, cammot for some mblomm leason, exereise the rights of belligerents, although the revolutionaly latly may. Being sovereign, he can exercise only sorereign rights orer the ather party.

"The insmrgents may be killed on the battle-field or by the executioner; his property on land may be contiscated moler the mumicipal law; but the commerce on the ocean, whicls supplies the ledels with means to support the war, cammot be made the subject of capture under the laws of war, beeanse it is 'meonstitutional ?:! Now, it is a proposition never donbted, that the belligerent pary who elaims to be sovereign, may exercise both belligerent and sorereign rights; (see $4 \mathrm{Cr}, 2-2 \cdot 2)$. Treating the other party as a belligerent and using only the milder modes of coereion which the law of nations hats introduced to mitigate the rigors of war, camot be a subject of complaint by the party to whom it is accorded as a gralee or granted as a necessity. We have shown that a civil wal such as that now waged between the Northern and sonthern states, is properly comdueted aecording to the humane regulations of public law as regards capture on the ocean.

"Under the very peculiar constitution of this govermment, althongh the eitizens owe supreme allegiance to the Feteral government, they owe also a qualified allegiance to the state in which they are domiciled.

"Their persons and property are subject to its laws.

"Hence, in organizing this rebellion, they have acterl as stutes claining to be sovereign over all persons and property within their respective limits, and asserting a right to absolve thejr citizens from their allegiance to the Federal govermment. Several of these states 
have combined to fomm a new conferleracy, claming to be acknowlalered hy the world as a sovereign state. Their right to do so is now leing deeided hy watere of hattle.

.. 'lhe ports and territory of each of these states are hell in hostility

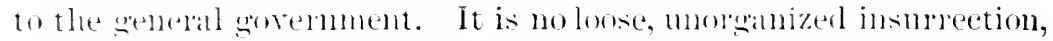

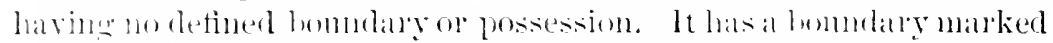
he lines of hayomets.and which ean be rosect only by foree,-south of this line is enemies territory, becanse it is talimed and held in possesion ly an oreanized, hostile and bedligerent power.

* All persons resiling within this teritory whose poperty may le 1 side to increase the revemes of the hostile power are, in this contest, liable to he treated as enemines. thongh not foreigner's. They have cast off their allegince and mate war on their govermment, and are none the less enemies beamse they are trators.

. Iint in refining the meaning of the term 'enemies' property' we shatl he led into error if we refer to Fleta and Lord Cuke for their definition of the wold e emeny'. It is a technical phrase peculiar to prize comrts and dejends upon principles of public policy as distinandished from the eommon law.

- Whether property be liable to capture as 'enemies' property' does not in any mamer depend on the personal allegiance of the ownel. "It is the illegal traftic that stamps it as " enemies' propexty." It is of no consequence whether it belongs to an ally or a ditizen. s Cr., 3st. The omer, jor hecere, is an enemy.' 3 Wash. C. C. li., 1-3.

." The produce of the soil of the hostile territory, as well as other property engaged in the commerce of the hostile power, as the somree of its wealth and strength, are always regarded as legitimate prize, without resurd to the domicil of the owner, and much more so if he resinc and trade within their territory." I

For the first part of this case see 528 . supre.

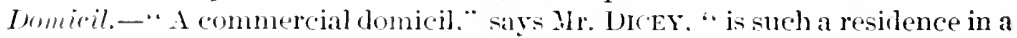
country for the purpose of trading there as niakes a persons trade or business contribute to or form fart of the resonrces of such country, and renders it. therefore, leationable that his hostile friendly or neutral character should be determined lig reference to the character of such country. When a persons civil romicil is in cuestion, the matter to be hetermined is whether he has or has not so setthel in a given countly as to have marle it his home. When a person's commercial domicil is in question, the matter to be determined is whether he is or is not residing in a griven country with the intention of continuing to trade there." (Dicey on Domicil. 345.)

In the cant of the turomia Jchanna. 1 Wheaton. 159. the Supreme Court of the Lniterl States held, that the share of a partner in a neutral house is, jure belli, sub- 


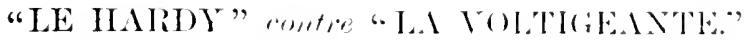

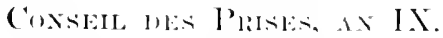 \\ (Pistone et Dureroly. I., :3:1.)
}

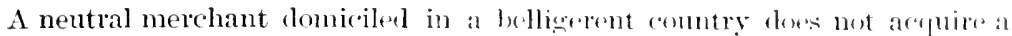

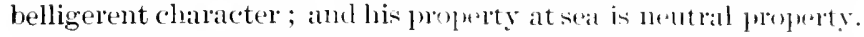

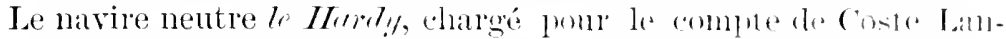

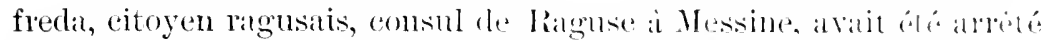

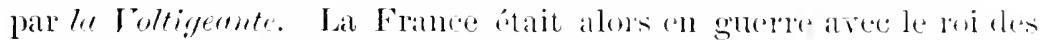
Deux-sieiles; il s'agissait de saroir si coste Lanforla, rituren et consul d'une nation nentre, devait etre considine comme ennemi on comme nentre.

Le Coxslat,-Oni le rapport du citogen Jacoste, membre du Conseil ;

Au moyen de ce qu'il résulte principalement des plicces qu’il n’a

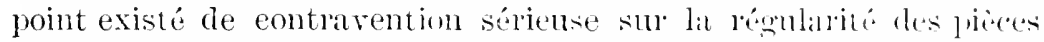

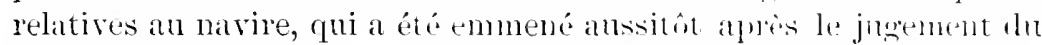

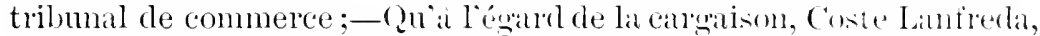
qui en est propriétaire, exergant it Messine les fonctions de consul rle

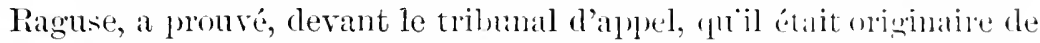
Raguse, ce qui ne permet pas de s'arrêter a l'assertion vilgue dur calphtaine, portant qüil le croyalt sujet de Xaples;-(gưl ny a point en de double destination constatée, et que, lors même quelle l'eint écé, les deux ports indiqués étant également l'm nentre, l'autre allić, il

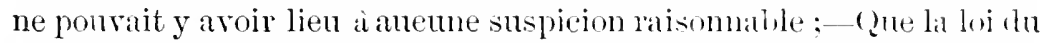
29 nivôse an VI, ne eoneernant que les marehandises du eru anglatis,

ject to confiscation where his own domicil is in a hostile comtry. (3 Wharton's Digest, 343.)

In the case of the Friendschuft. $t$ Wheaton. 10.5, the court held. that the property of a house of trade establisher in the enemy's combtry is comblemnithe als prize, whatever may be the personal domicil of the partners. (:) Whartenis Digest. 343.)

Other cases on Commereial Domicil are: Bell v. Reril. 1 Maul. \&.Selw. Fol

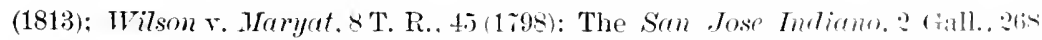

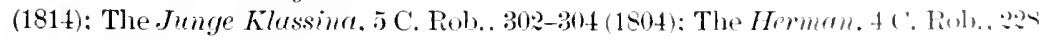
(1802): Sparenburg v. Bamatyme. 1 Bos. \& Pul., 169) (179r): The Alu. 1 Sipink.

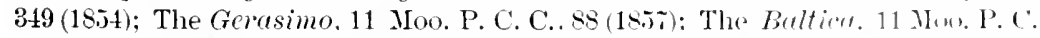
C., 141 (185i): Hrs, Alexander's Cotton, 2 Wall., 404 (1864): The Flying semel, 6 Wall.. $263(186 \tau)$. 


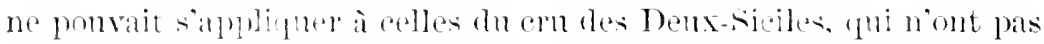

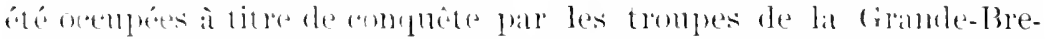

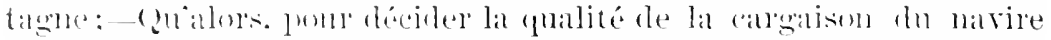

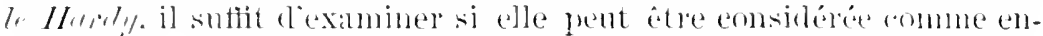

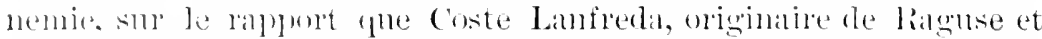

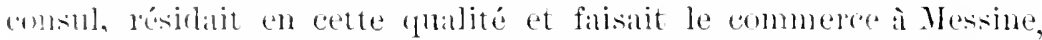

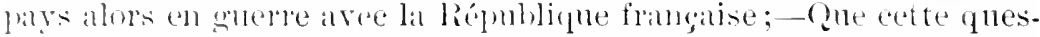

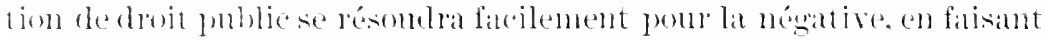

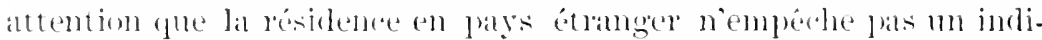

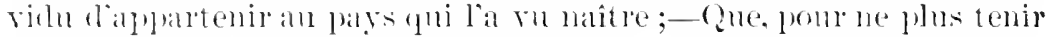

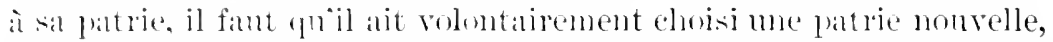

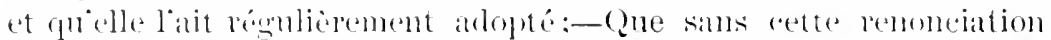

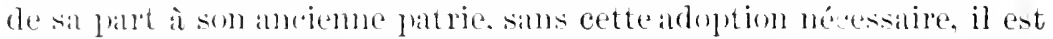
tomjums ce qu’il etait orignarement, ami des amis, ememi des enmemis de sil matrie native: que, lorsque cette patrje est nentre, il

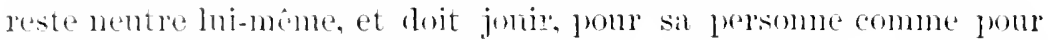
res biens, de toms les avantages de la nentralité, paree que les hiens nont pas far ens-memes de carative nentre ou hostile, mais prenant tomjons celui dont se tronve revên lemr propictaire;-Clue

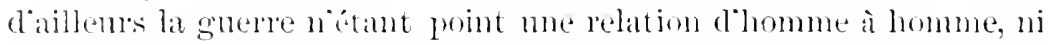
des sociétés anx indivilns, mais lien des Etats entre enx. on ne peut forcer à y pendre part celui yni nat pas manifesté la volonté expresse

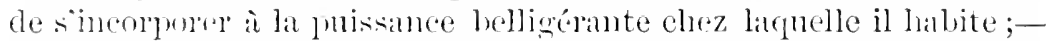
Que les inconvénients, les alus que pent entraner le systime con-

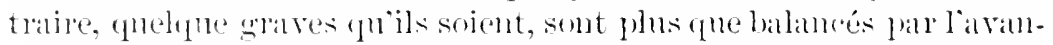

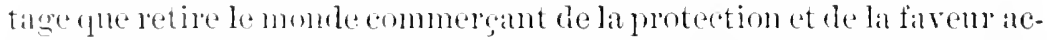

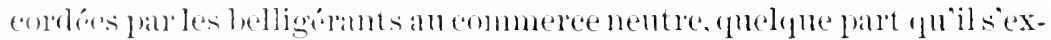

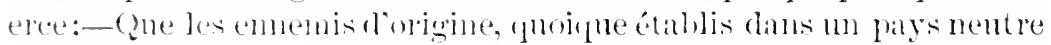
et y farisont le enmmere soms la protection et le pavillon neutre, ne

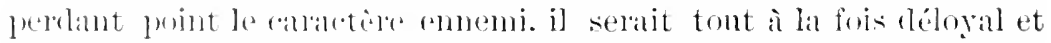

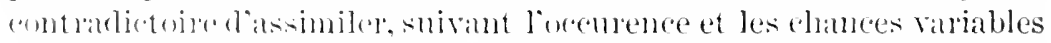

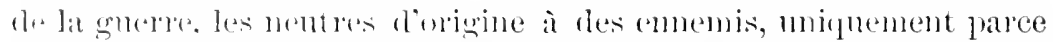

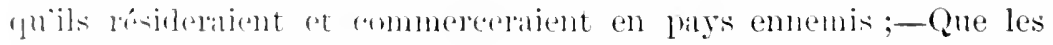

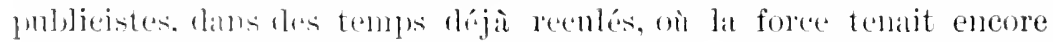

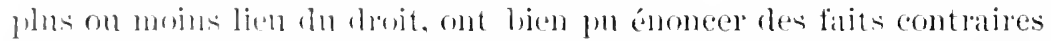

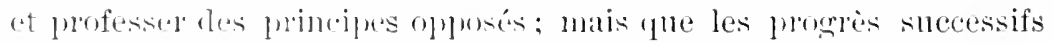
hre la civilisation, le habin, miversellement senti, de lateroissement ot de la biherte hes redations commerciales entre les pemples, ch ame-

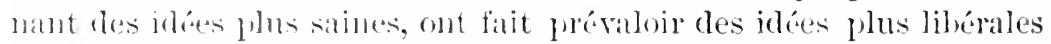

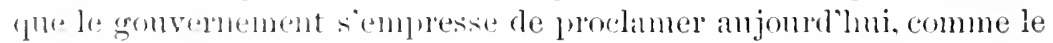

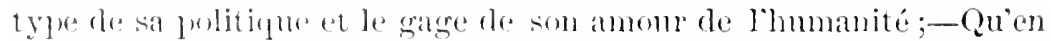

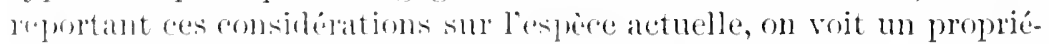

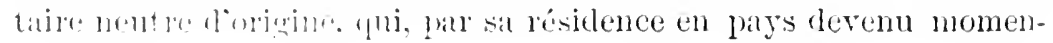




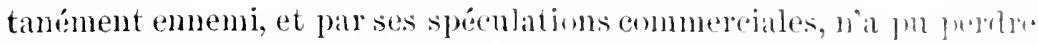

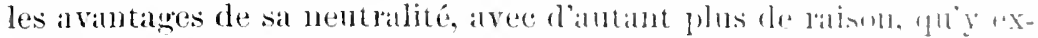

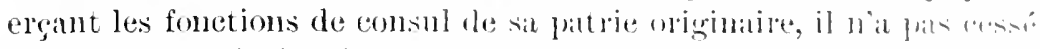

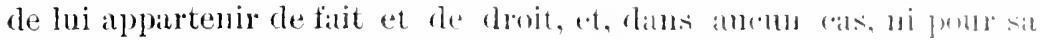

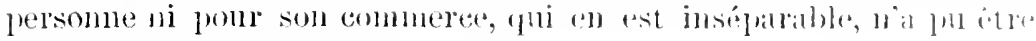
consicléré comme ennemi ;

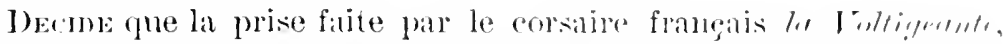

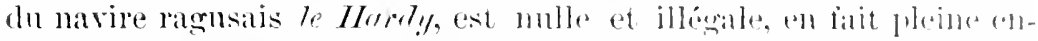

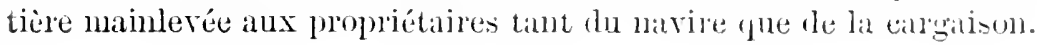

Section 34.-Owxersinp of Goolds in Trassit.

\section{THE PACIE'T “ JUE BIIIBO.।."}

Hign Colrt of Anminenty, 1799.

\section{(2C. Robinson, 133.)}

In time of war, or in contemplation of war, gools in tromsitu on the ocean are hell to belong to the consignee.

This was a case of a claim of an English house for goorls shipperl on the oreler of a Spanish merchant. before hostilities with spain. ant capturer] lecermber. 1796. on a royage from London to Corunna. Held, that the contract wats valid and the goods were restored.

\section{Judgment, - sir Wr. Scotr:-}

"This is a claim of a peculiar nature for goods sent by British subjects to Spain, shipped before hostilities, during the tine of that situation of the two comntries, of which it was unlinown, eren w our government, what would be the issue between them. There appears to be no ground to say that this eontract was influenced by speculations on the prospeet of a war, or that anything has heen specially done to aroid the risks of war. It is shown in the athirilvit of the claimant 'that this is the constant halbit and prictice of this trade;' whether it is the practice of the spanish trade gesuerally, or only the particular moke of these individuals in earrying on commerce together is not material, as the latter womld $\mathrm{w}^{\circ}$ quite sufficient to raise the subject of this claim. The question is. in whom is the legal title? Secanse, if I should find that the interest was in the Spanish consinnee, I must then conclemm, ambl leave the British party to apply to the Crown for that wake am favor which it is always reaty to shew; the property being eondemable to the Crown as taken before hostilities. 


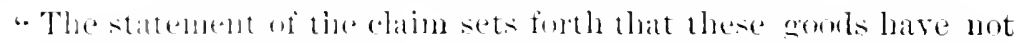

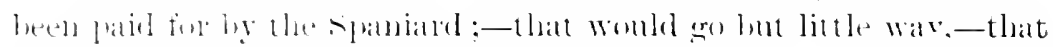

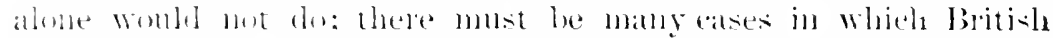

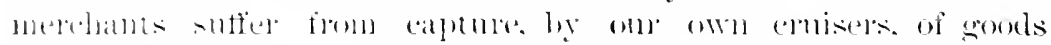

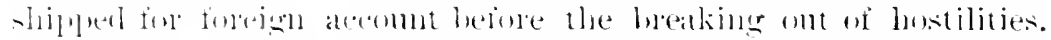

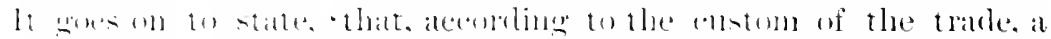

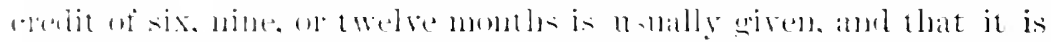

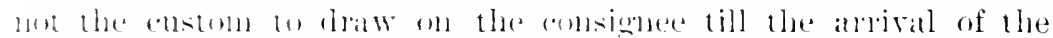

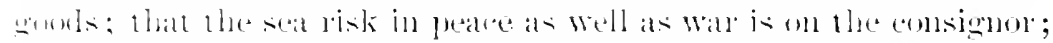
that le insmes. and has mo lemely aramst the emsighee for any

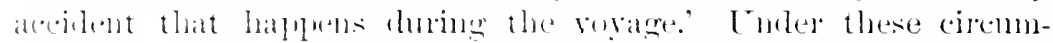

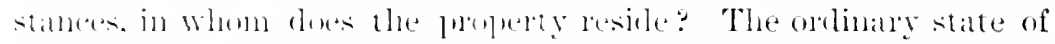

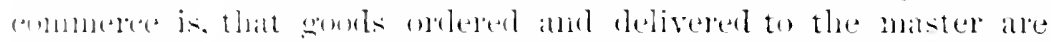

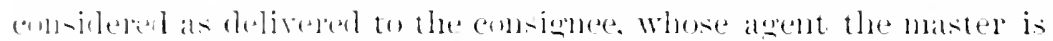

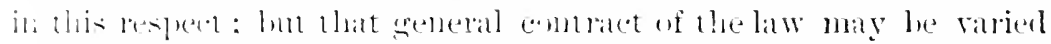

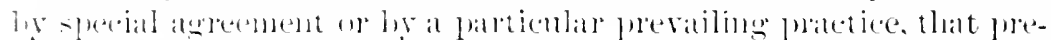

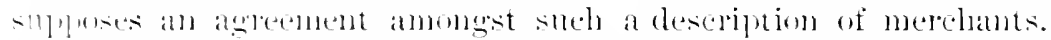

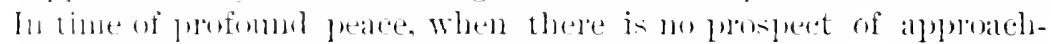
ing war, there womld munestionalnly be mothing illegal in contracting. that the whole risk shomld fall on the comsignom, till the goots

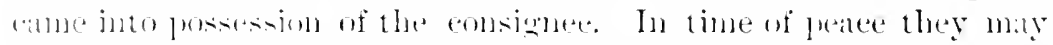

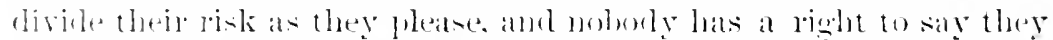

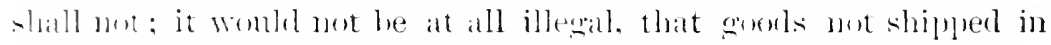
imse of War. or in contemplation of war, shomble be the risk of the-hiller. In time of wall this eamot le permitted. for it wombl

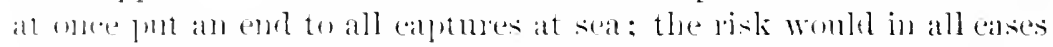

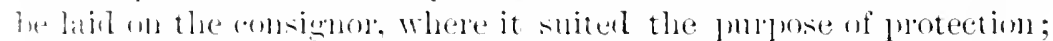

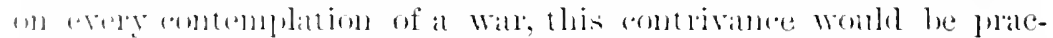

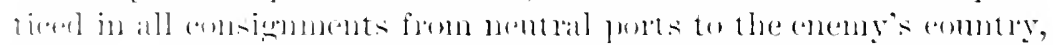

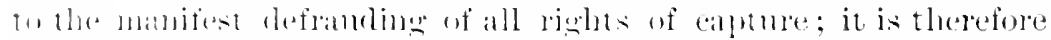

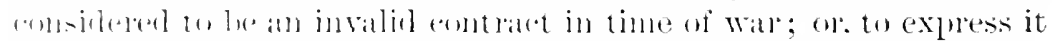

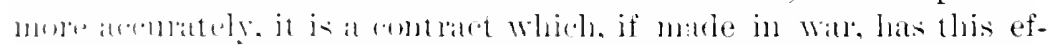

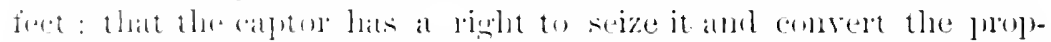

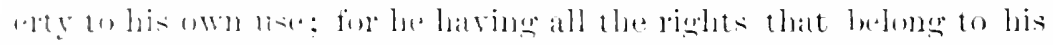

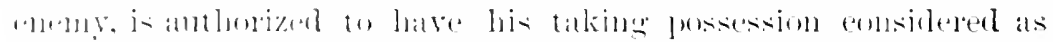

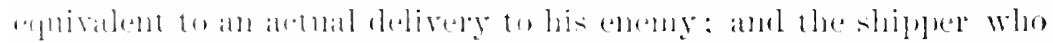

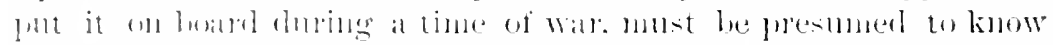

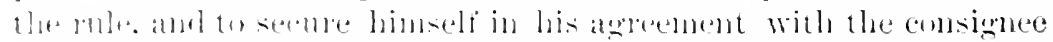

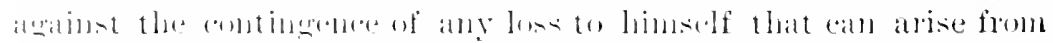

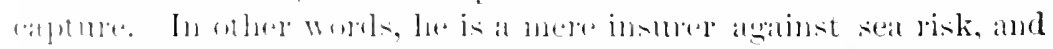

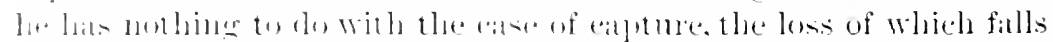

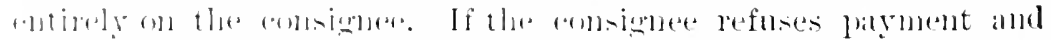

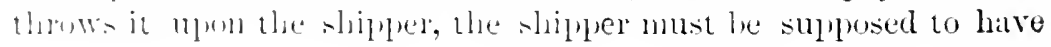


guarled his own interests against that hazard, or lo hats acter im. providently and withont eantion.

"The present contrace is not of this sort; it stambs as a lawfol

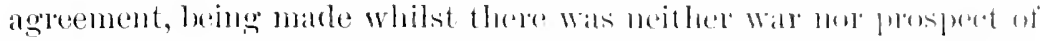
war. The gools are sent at the risti of the shipenele if they law

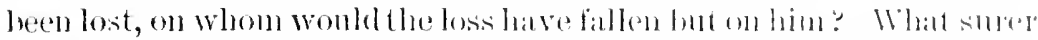
test of property cam there be that this: It is the true ariteriem of property that, if you ale the persom on whom the hos will fall, you

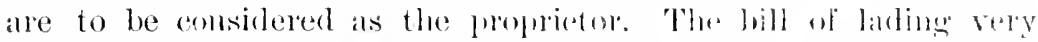
much favors this acomot. Tho master binds limmelf to dhe shipper, 'to deliver for' your and in yomr name' by which it is to be molerstood that the delivery hat not been made to the matster forl the eomsignee, but that he was to make the delivery in the llane of the shipper to the comsinnee, till which time the inforence is that they were to remain the property of the shipper: as to the payment

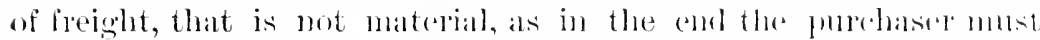
mecessirily pay the earriage. The other consideration-who bears the loss? mueh ontweighs that, - meither ders the alse put shew the contrary. The case put is-smpposing spain and kngland loth nentral and that these gooks had heen taken by the Foroheh and sold to great profit, to whose arvantage wonld it have losu? 'The' answer is, if the goods were to contime the property of the shiplere till delivery, it must have enumerl to his benefit, and not that of the consignee. To make the loss fall ujon the shipher in the caste of the present shipment woukd be harsh in the extreme. Il ships his goods in the ordinary eourse of traftic, by an aglesement mumally understoot between the parties, and in no wise injurions to the rights of any thind party; an event subseguently halpens which les conld in no clegree provide aganst. If he is to be the sutperer he is a sufferer withont notice and withont the means of seroring himself; he was not caller upon to know that the injustine of the of her party would produce a wal hefore the delivery of his goods. The consignee may refuse payment, referring to the terms of the ondtratet which was made when it was perfectly lawful; and muder what circmostanees and on what prineiples the shiplel oomld aro enforce palyment against the comsignes is not easy to discoveds. The

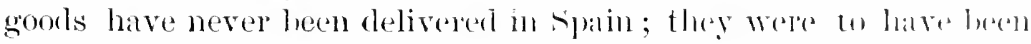
at the risk of the shipler until alelivery, and this muler a bertertly fair contrat. I must comsirler the property to reside still in llue English merchant. It is a case altosether olifferent from other

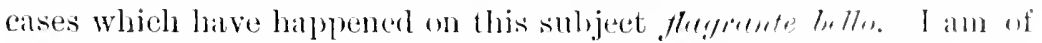
opinion that, on all just eonsiderations of ownewhip, the lowill plofrerty is in the British nerchant; that the loss must hase fallen on 
the shipler. and the delivery was not to bave been made till the

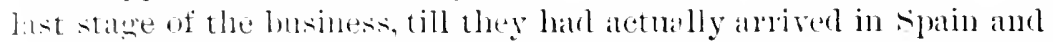
ham been put into the hands of the comsignee; and therefore I shall serere restitution of the goods to the shipler."

on liager that the captors expenses might be paid, it was answerest that they had already had the bencfit of the condemmation of the ship.

r.mit.- - I think there has heen a great service performed to the shipher. If the gromblat not been eaptured they womld have gone into the posiseion of the eneny. The eaptor did right in bringing the preation letore the eomt, and he onght hy no means to be a losel. I shall not give salvage, hut shall direct the expenses of the eaptor to be paid out of the proceeds."

\section{TIIE "S.IN .JOSE INDLANO."}

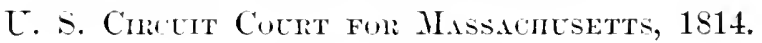

( 2 Gallison, 268.)

Title to goods in transitu-stoppage in transitu.

Extract from the opinion of STory, .J. :-

"The next is the clatin of Mr. J. Lizam, of — in Brazil.

"The shipment was made hy Messis. Dyson Brothers \& Co., and by the hill of lading the goods are consigned to Messis. Dyson Brothers and Fimney, Rio de .Janeiro.

"The acommpanying involces express the shipment to be made by

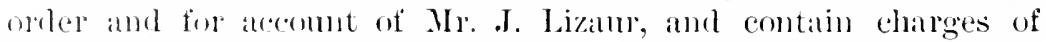
freight, commoission and insumee and an atcknowledgment of giving crertit for thereand six months. In a letter of the thh of May, 181t, adbhessed by the shippers to the consignees, they sily, "for Mr.

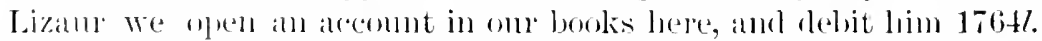
11 . 7. for 1 li cases of ambries, ete., at three months erelit; we rammot yet asertatin proceeds of his hides, etc., bist find his older

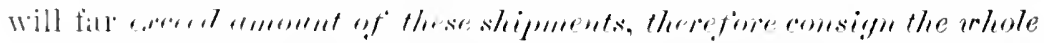

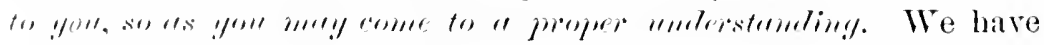

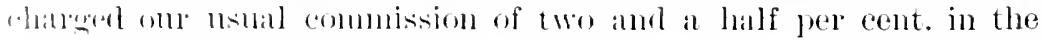

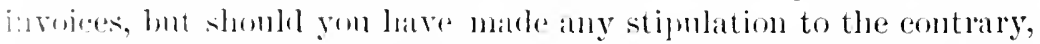

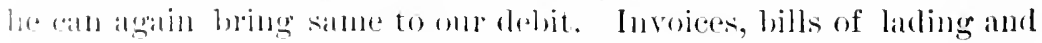

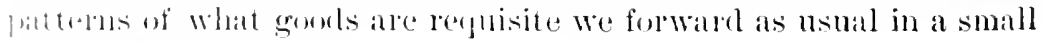

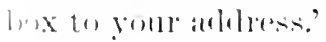

"The single question presented in this claim is, in whom the prop- 
erty vested during its transit; if in Mr. Lizand, then it is to be lo. stored; if in the shippers. then it is to be comblemmerl. It is amo-

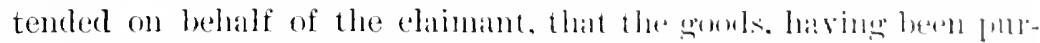
chased by order of Mr. Lizand, the proferty vesterl in him immoliately by the purchase, and the ontmet being extented by the sille,

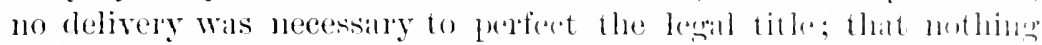
was reserved to the shipler's, hut a mere right of stoplatge in formsitu, and that if they had been bunt before the shipment, or lost during the voyage, the loss mist have fallen on Mr. Lizantr.

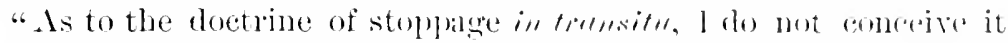
can apply to this case. That right exists in the single ascof insolyency, and presupposes, not only that the property in the goosh has passed to the consignee, but that the possession is in a thipl person in their tramsit to the consignee. It eamot, therefore, forch a case, where the actual or constructive possession still remains in the shipler or his exclusive agents.

"I agree also to the position, that in general the rules of the prize comrt, as to the vesting of property, ale the same as those of the common law, by which the thing sold, after the completion of the contrat, is properly at the risk of the purchaser. but the puestion still leeurs, when is the contract executed? It is certainly competent for an agent abroad, who purchases in puswance of orders. to vest the property, immerliately on the purchase, in his principan. This is the case, when he furchases on the eredit of his principal, or makes an absolute appropriation and designation of the property for his principal. But where a merehant aboad, in jursmance of orelers, sells either his own goods, or purchases goods on his own credit (and thereby in reality becomes the owner), no property in the goods vests in his correspondent, until he has done some notorioms act to divest himself of his title, or has parter with the possession by an actual and uneonditional delivery for the use of such correspondent. Until that time he has in legal contemplation tho exclusive property, as well as possession; and it is not a wongful act for him to convert them to any nse, which he pleases. IIe is at liberty to contract upon any new engagements, or substitute any new conditions in relation to the shipment. And this, I understand, not only as the general law, hat as the prize law pronomeer ly that high tribunal, whose decisions I am bound to obey.

"In the Temus, 1814, on the claim of Masee and .Jomes, in deliver-

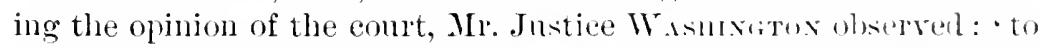
effect a change of property, as between seller and buyer, it is issential, that there should be a contract of sale agreed to by both parties, and if the thing agreed to be purchased is to be sent ly the 
vendor to the vendee it is necesiary to the perfection of the contract, that it shomb be delivered to the purelister or to his agent, which

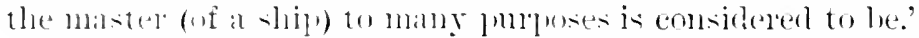

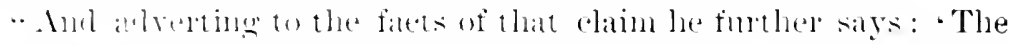
delively of the ands to the mastel of the vessel was not for the use of Yatere and Jomes, any nume than it wis for the shipler solely, and comseputanty it amometed to mothing. se as to divest the property ont of the shiplele until Magee should elect to take them on joint alecount, or to alet as the agent of Jones."

\section{TIIE -.S.ILLY"}

Loris, 179.$)$

\section{(3C. Robinson. 300. note.)}

Yerehandise shipped to become the property of the enemy on arrival. if taken in tromitu. is tobe condemmed as enemy's property. Supposing it was to become the linnerty of the enemy on delivery. capture is considered as delivery.

The silly was a cate of a caroo of com shipped Mareh, 1798, by stewarl and Plunket, of Baltimore. ostensibly for the aromut and

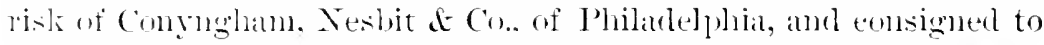

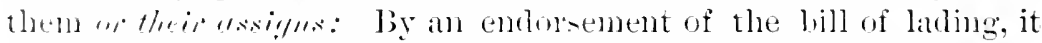
Wats forther agreed that the ship should proceed to Iarre de Grace, and thele wait such time as might he necessary, the orders of the

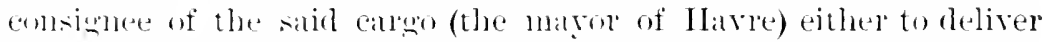
the same at the port of Iarre, or preeed therewith to any one port

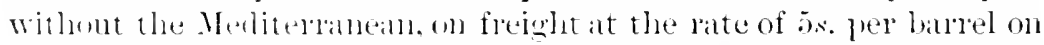
delively at Harre, and $5 x$. $(j, 7$. at a secomel port, the fireiglat to be

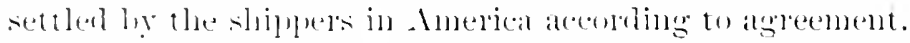

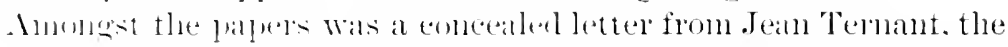

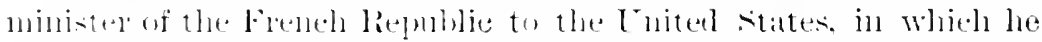

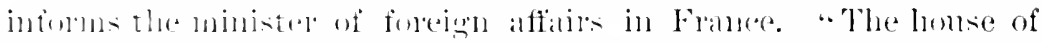

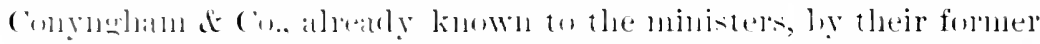

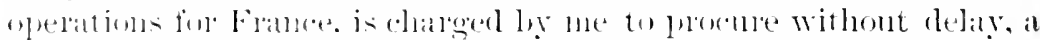

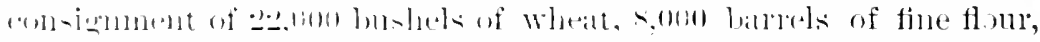

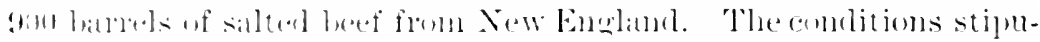

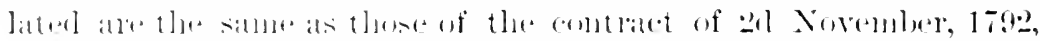

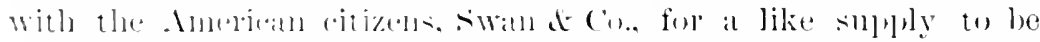

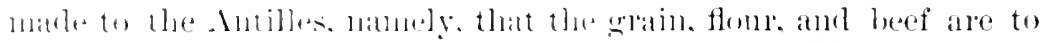

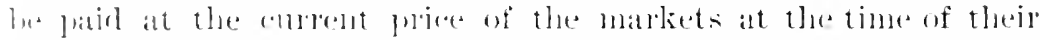
being shipled ; that the foeghts shall he at the lowest course in the 
ports; that an insurance shonk be on the whole; and that at forne mission of five ger cent. shall be allowed for all the melehtatutse

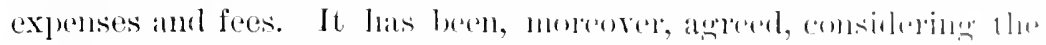
actual reports of war, that the whole shall he sent ats Amerion

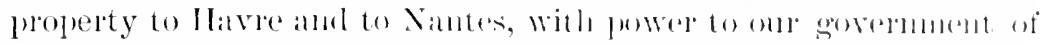

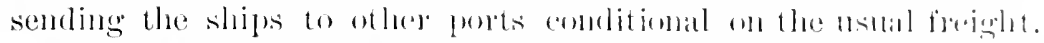

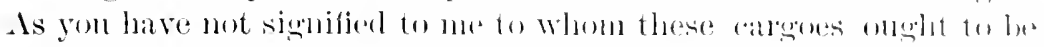
delivered in onr parts, I shall provide eateh alptain with at letter to the mayor of the plate."

There was also a better from Joan Termant to the mayed of the munieipality of IIave. "()m govormment having ondered me to send supplies of provisions to yom port, I infom gom that the beares of this, eommanding tho Ameriean ship, the solly, is buten with a eargo of wheat, of which he will deliver you the bill of lating."

To the 12th and Eoth interosatories the master deposed, " that he believes the flom was the property of the Freneh erovermont, and,

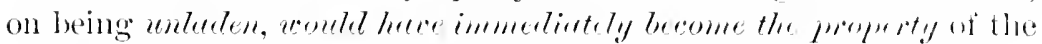
French government."

In the argument it was insisted, one the prest of the cheiments, that the cango was to be comsintered as the property of the Ambrican merchants; that it hat been orderes by them, to bo supplied and

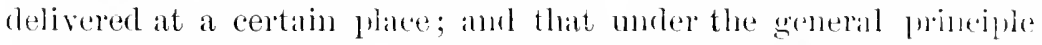
of law, property was not considered to be divesterl between the ventor and vendee till andual delivery.

It was contended, that the contuat remained enecontom till the comptetion by delivery in burope; that the payment was contingent on the completion of the contratet in this form, amb that mo monty han passed, nor any compensation or agreement hall intervented to froduce an absolute comversion of the property ; and it was pared that the court would admit firther proof to ascertain that eilemmstance.

(In the port of the coptom it was replied, that the general rule of law subsisting between vemblor and vembe in a commeredal llansaetion, referring only to the eontrating parties, and mot affecting the rights of third persons, eould not aplyly to contrats marle in time of war, or in contemplation of war, where the rights of a belligerent nation interveneal; that the effeet of such a fontlated at the present womb be to protect the trable of the eontateting belliserent from his enemy ; and that if it conld be allowerl, it womll pmt an and to all captme. It was sald to be a known principle of the mi\%e

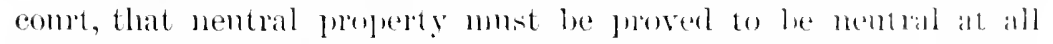
perioels from the time of shipment, withont intermision, to the 


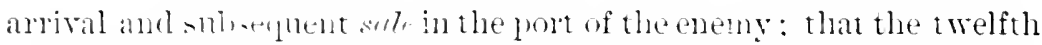
and twentieth inteluratories were framed with this view to inguire, "whether on it arrival, etr.. it slatl and will helomg to the same

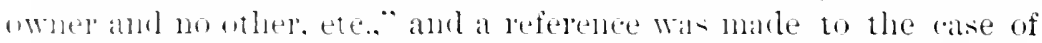
llo Charles llavereswerth in $17+1$, in which the form of attestation Wat divected to be prepared ly the whole bar, and was established in the puresent form to asertain the property at the several periods

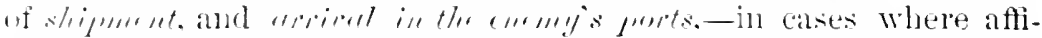
dirvits were to le received to sllply the detects of the original

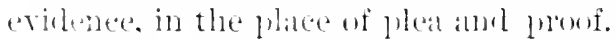

The Comt :-.. It has alway leen the rule oi the prize conts, that

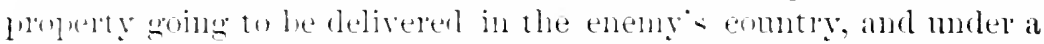
contaret to become the proprerty of the enemy immediately on arrival, if talien in tomsitu. is to le comsidered as entenies property. Where the rontract is made in time of peace or withont any contemplation of a war. no sueh rule exists:- but in a case like the present, where the form of the contract was framed directly for the prupose of obviating the danger alprehended from apluaching hostilities, it is a rule which mavoidably must talie place. The hill of lading expresses acomnt and risk of the American merehants; but papers alone make no proof, mless supported ly the depositions of the master. Instead of smburting the contents of his papers, the master deposes, "that on anrival the goods would hecome the property of the French govemment, and all the concealed papers strongly support him in this testimony: The ecidentie oi is ton strong to almit farther junf. Suplosing that it was to become the property of the enemy

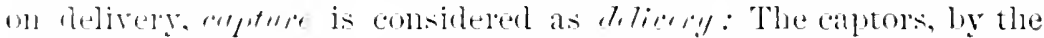
rights of wall. stand in the plice of the enemy, and are entitled to a

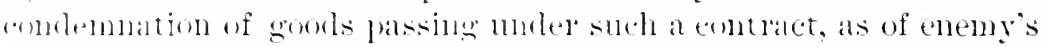

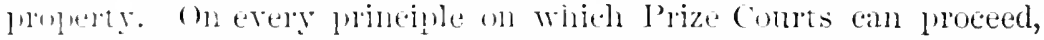
this anco must be considered as enemy"s property.

"Condemned,"

\section{TIIE " INX.I C.ATIIALIX.L."}

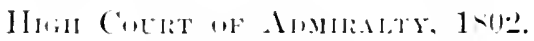
(4) Ioblinson, 10i.)

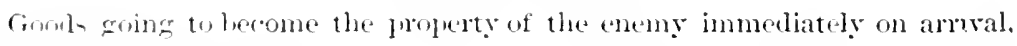
(a) lelemmenl.

This wats a case of a cargo of dry goods, otc., taken Oetober, 1s01, un at rogatge from IIamburgh to Lal (inaylal, and described in the 
ostensible patpers and depositions, "as going to take the chander of

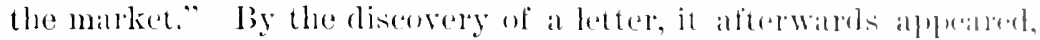

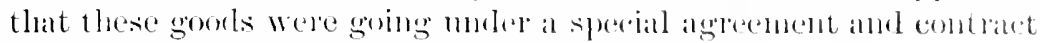
with the Fianish governmont of the Catalcats.

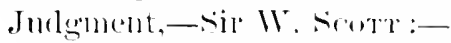

* * Taking the shiplexes to he neutral nerehants " how does the

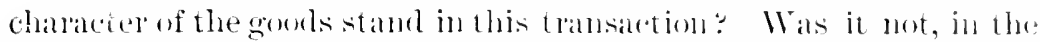
first place, a cangogoing to become the propert y of the sibuish government inmediately on arrival? Was mot the Fianish government entitled to possession? It was only on the viobation of the contract, on the part of the Spanish govermment, that these gours were to talie the chance of the market. Theshiplers comsidered themselves as lomml to deliver them to the use of the spanish govermment, under the agreement; as entitled to the benefit, and subject to the oblingtions of that contract. Were there any intermediate acts to be done after the arrival of the vessel: Or were the acts such, as would have the eflect of substantially distinguishing this ease from the sirll!, and other cases? Is there any act of ownership which the chamant was at liberty to exercise, so as to prevent the delivery? If not the goods must be considered as having substantially become, in itinede, the punperty of the enemy. ***

"It is sald * * * that these goods do not exactly collespond with the cmumelation in the agreement, that they are mot anforect fonels; and conseguently, that withont any violation of public faith, the aceeptance of them was merely optional and eontingent. Lat, I cannot think, that it is now open to the parties to make this aremont; when it is evident, on the face of their own letter's, that they harl relied on the clear and absolute obligation of the spanish government to talie them as such. ****

"These distinctions are, in my juclement, totally insufficient to take the ease ont of the authority of the precerlents alluded to. Where the grods are sent under a contract by the party, it surely eanmot be permitted to the elamant himself to aver, that the gomis so sent are not contract goods. *** Under these ciremustances, I an strongly disposed to hold, that this eargo was going in time of war to the port of a belligerent, there to lecome the property of the belligerent, inmediately on alrival, and that the legal consengeme of condemnation would on that gromed alone attach upon it."

\footnotetext{
1 Only somuch of this case is given as refers to the shipment of govels under contract to a belligerent port.
} 


\author{
I.E "TROA FRERER." \\ CoUITÉ HE SILIT PYHLH, AN III. \\ (Pistonge et Inecordy. 1.. 3.5.)
}

Semble that by the French rule. the neutral shipher may assume tire risk of gands in transit lo an enemy country.

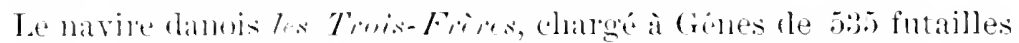

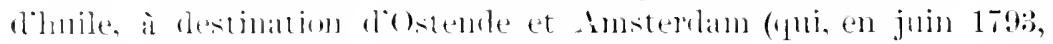

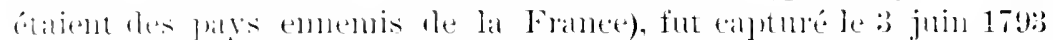

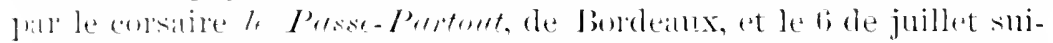

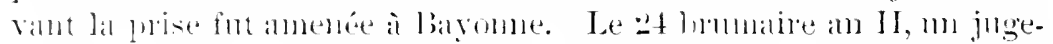

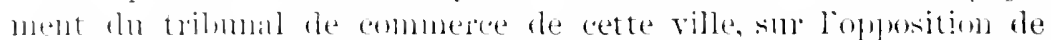

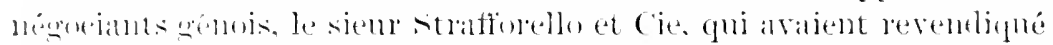

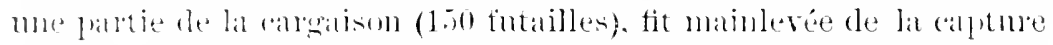

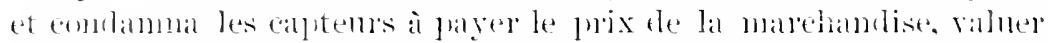

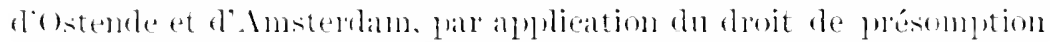

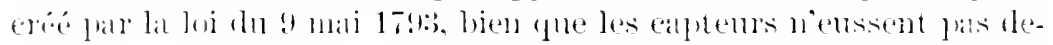

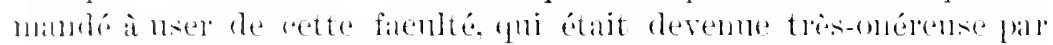

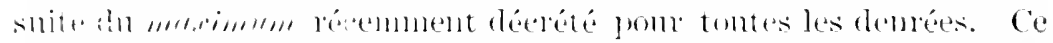

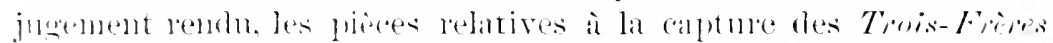

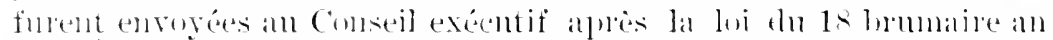
I1. et le comité te salut public, quise substitua a ee comseil exérltif,

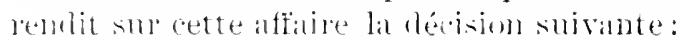

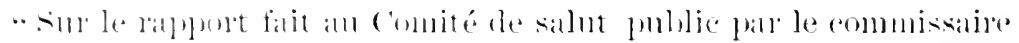

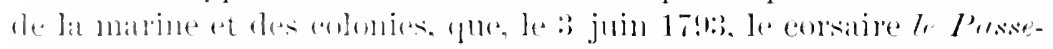

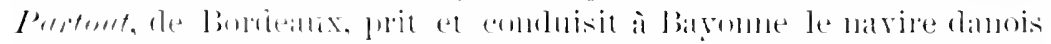

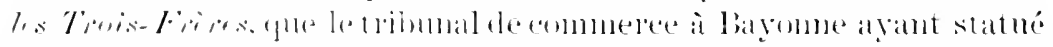

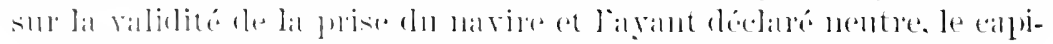

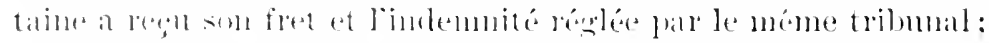

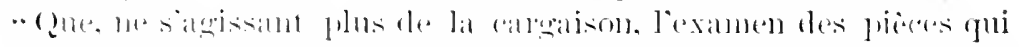

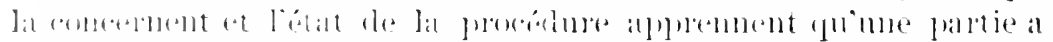

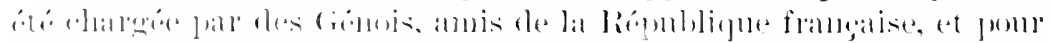

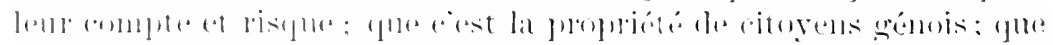

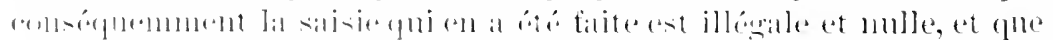

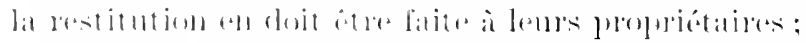

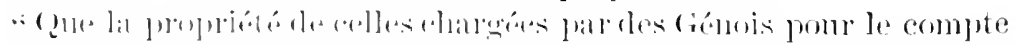

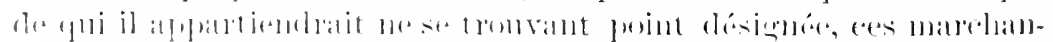

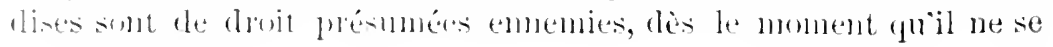




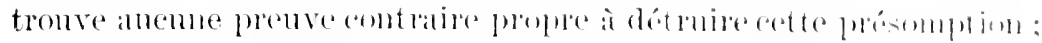

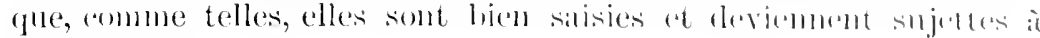
eonfiscation;

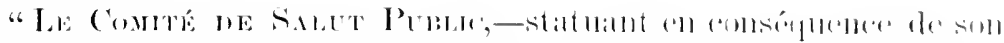

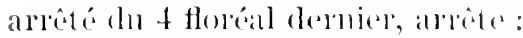

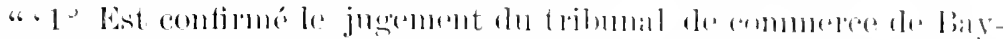

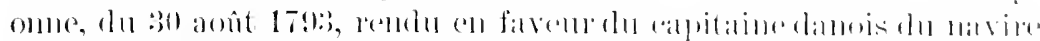

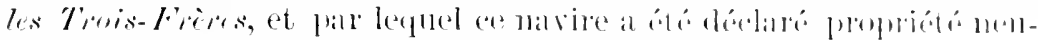

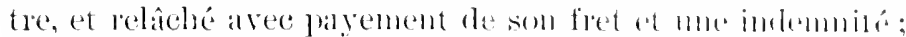

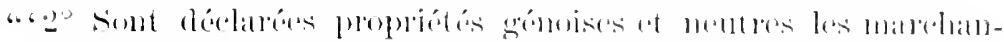

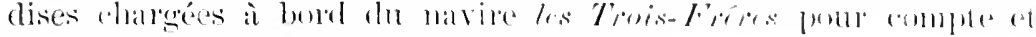

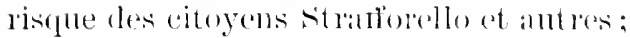

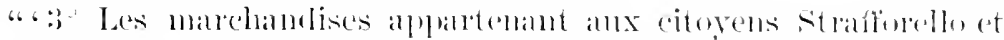

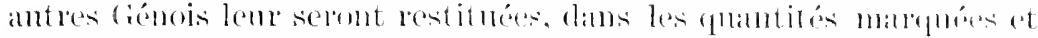

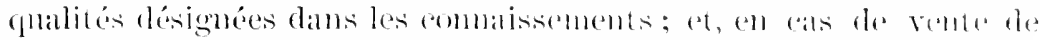

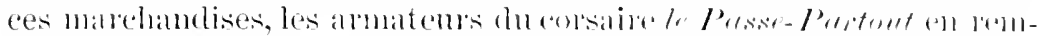

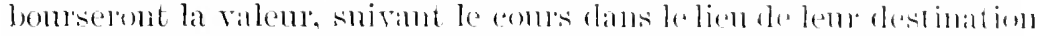

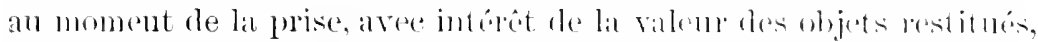

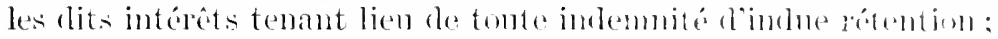

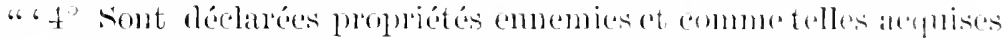

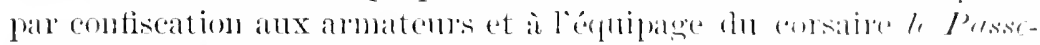

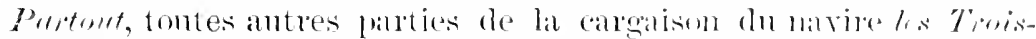

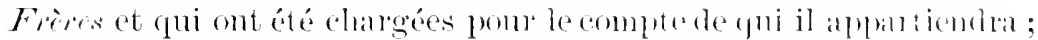

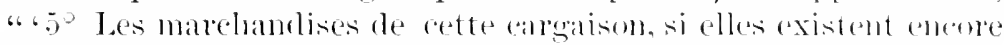

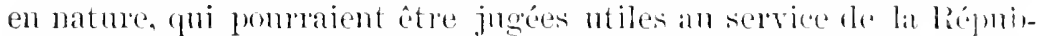

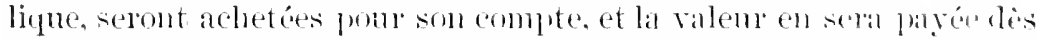

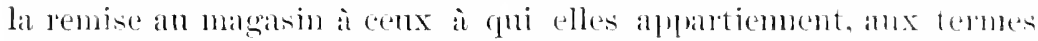
chl present arrête." (Cette canse était usuelle an temps do comile

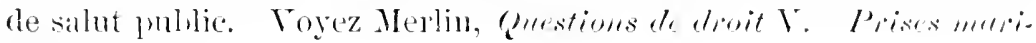
times, SII.) ${ }^{1}$

1 Observations.--" Aujourd bui, que le principe que le parillon couve la "argaison est admis sans conteste, cette decision pent paraitre an premior almor

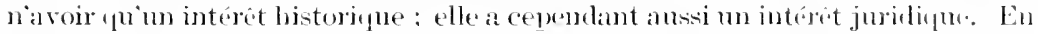

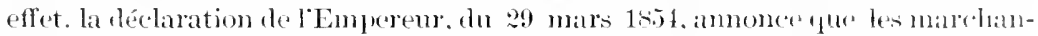

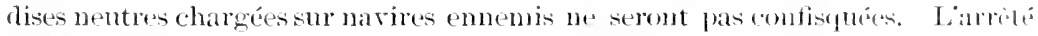

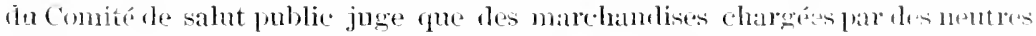

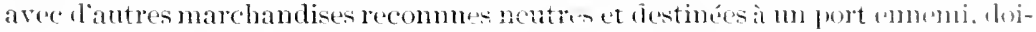

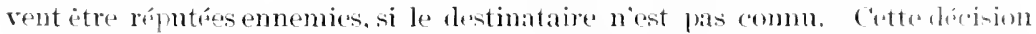

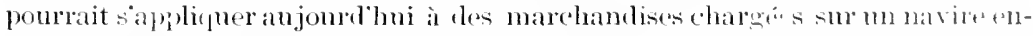

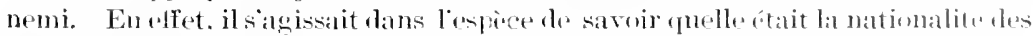
marchandises. et cettequestion était tout a fait indépendante de la nationalite du navire recteur." 


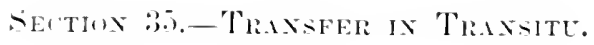

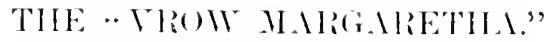

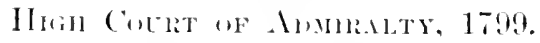

(1 C. Rolinsorm, 336.)

This was the case of a carco of hrandies shipped by Spanish merchant s in Spain in Mar. Figt. betore spanish ho-tilities and transferred to Mr. Berkermyer at Hamburgh, dhring their vovage to Holland. Hed, to be a bona fide transaction, and the rule against transfer in trousitu was not applied.

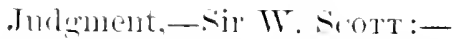

." This is a diam of Mr. Th. Berkeymyer, of IIamburgh, for some pareels of wine which were sejzed on boand three Dutch ressels detained ly oreler of govemment in 179. The ships have heen since condemued: the cargoes were described in the ship's papers, as far as the property was expessed, as helonging to spanish merchants. It is material, in this ease, to consider the relative sitnation of the conntries form which, and to which these cargoes wers goiner. Frain and llolland were then in alliance with this comntry and at was with Frunce: it might, theretore, be an inducement witl a spanish merclunt to coneeal the property of his gooks, although it

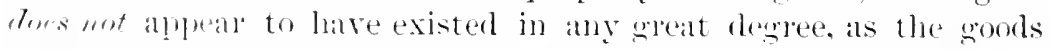

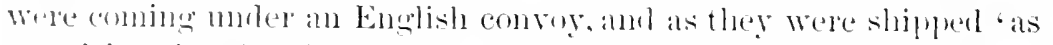

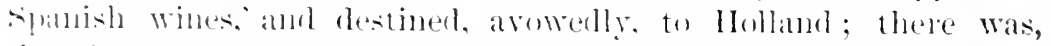
therefore nothing in this part of the case to mislead om crusers. Mr. Borkegurese is allowed to be an inhalitant of llamburgh,

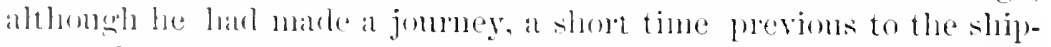
nellt of these callowes to shain (whele he had resided some years

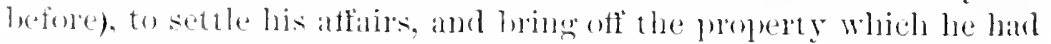
left behind hin. Ile had quitted syan. however, previous to the heraking out of spanish hostilities, and had resumed his original

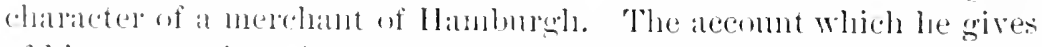
of his transaldioms in shaju, as far as they regard this case, is, that lue entered into a contract with two spanish homses for some wines,

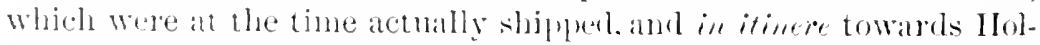
land. The first whjertion that has been taken is. that such a transfer is invalid, and camnot be set nu in a Prize Comt, where the property 
is always considered to remain in the same elat motol in which it wats

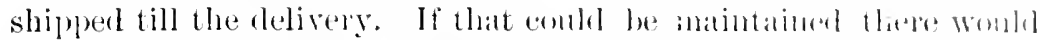
be an end of the fluestion, heranse it hats been anduitterl that threse

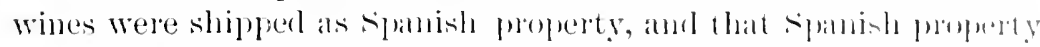

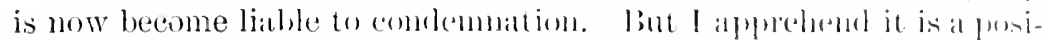
tion which cammot be maintained in that extent. In the ordinaly comrse of things in time of peatee-for it is mot denienl that smbh it

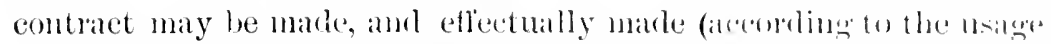

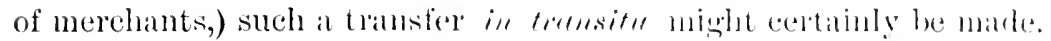
It has even been eontented that a mere delivering of the hill of lading is a transfer of the property. But it might be more condectly explessed, perhaps, if said that it transfers only the right of delivory; but that a transfer of the bill of lading, with a contract of sale accompanying it, maty transer the property in the ordinary comses of things, so as effectnally to hind the parties, and all other's, cammot well be doubted. When war intervenes, another rule is set up hy Courts of Aclmiralty, which interferes with the orlinary practioe. In a state of war, existing or imminent, it is hell that the property shall be deemed to continue as it was at the time of shipment till the actual delivery; this arises out of the state of war, whill gives a belligerent a right to stop the goods of his enemy. If wuch a rule did not exist all goods shipped in the eneny's comntry would be protected by transfers which it wond be impossible to detect. It is on that prineiple held, I believe, as a general rule, that property ('annot be converted in trorsitn; and in that sense I recognize it as the rule of this Court. But this arises, as I have said, out of a state of war, which creates new rights in other parties, and camnot he alplicel to transactions originating, like this, in a time of peace. The trans. fer, therefore, must be consiclered as not invalid in point of law, at the time of the contract; and being marle before the war it must be judged according to the ordinary rules of commerce.

"It has been farther oljecterl to the validity of this contract, that a part of the wines did actually reach Inmbmrgh, where they were sold, and the money was detained by the consignees in payment of the advances which they had nade. It is said that this ammuls the contract--to the extent of that part it may lo so, and the deficiency must be made up to the purciaser by other means; but it appears that it has been actually supplied by bills of exchange. and au assigmment of other wines sent to Petersburgh. It is not for me to set aside the whole contract on that partial gromal. or to comstrme the defect in the execution of the contract so rigorously as to extend it to those wimes which never went to IIolland, and which never beeame de facto subject to be detained by the consignees. They are 
free for the contratet to act upon: and if the parties are desirous of ablering 10 lheir antrat in its whole extent, it does not become

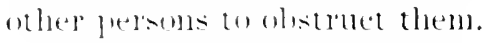

-. It emes then to a ghestion of falct, whether it was a bond firle trinsfer on not: I lhink the time is a strome ciremustance to prove the falmess of the transaletion. Ilat it happenter three months

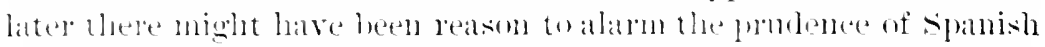
merehants. and induce them lo resont to the experlent of covering theje punerty. but at the time of the contract there seems to have heen 110 leasion for anprehension, and therefore there is nothing to

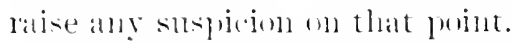

". The instruments of sile have heen produed. and no olsservation

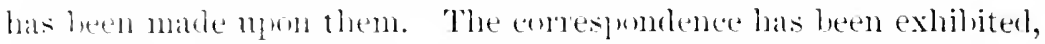
and there is certanly some confusion in the dates. Explanations have been given. which are probable enongh: still they are hut conjectural. If the comsel for the captors reguire it I will order the original documents in proof of these explanations to be produced; althomgh I must say, at the same time, that the impression upon my mincl is. that it is a firir transaction.

"The originals decreed to be produced.

"Janmaly 15th, 1no0. The captors being satisfice with the farther proof produced, Mr. Berkeymyer"s clains were restored without oppusition."

\section{TIIE “JAN FREDERICK."}

\section{IIGH Colle wF Anymatr, 1804.}

\section{(5) C. Robrinson. 125.)}

A contrace in contemplation of war. for the transfer of colonial produce in treusit". lsthl illewal.

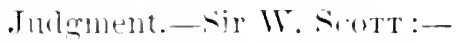

"This gllestion alises on parts of several cargoes put on board

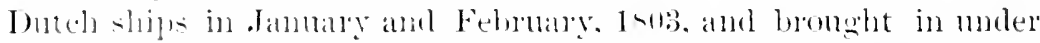
the enenolal embargo on Inteh property puevious to hostilities, in

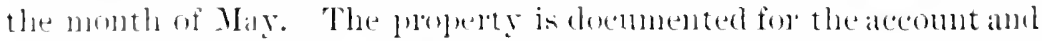
risk of certain estates in Surinam : and certainly if it was not allowalle mulel any consinlelations to arer against the evilence of the slific docmments. it must be sulject to condemmation as Dutch forperty. But the comet lats opened a dour to sueh chams, in opposirion (1) the averment of the ship's papers; and it has done this, on 


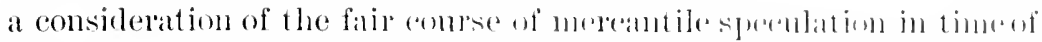

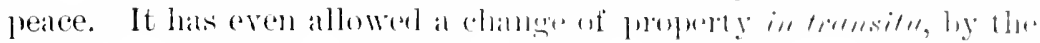

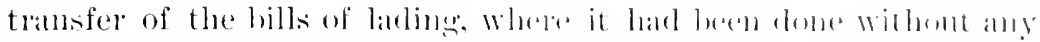

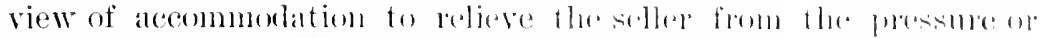

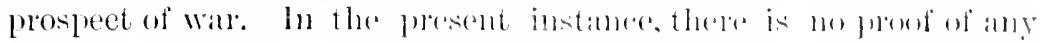

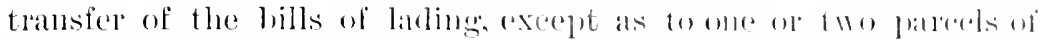

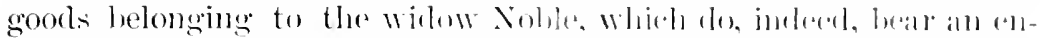

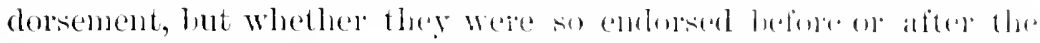

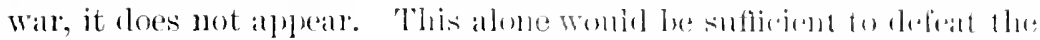

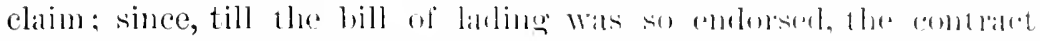

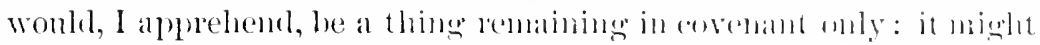

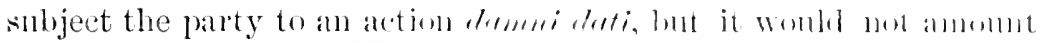

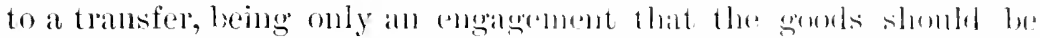
transfered when they arrivel. That a tramsfor maly talie platee in

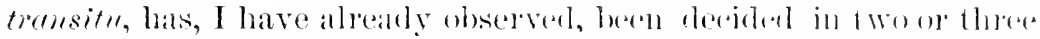

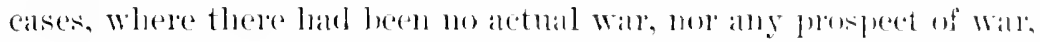
mixing itself with the transatem of the parties. Ban in time of

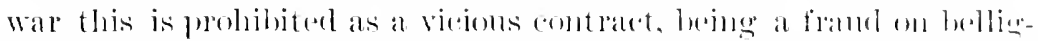

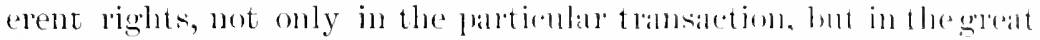

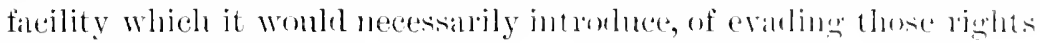
heyomb the possibility of detection. It is at roal thal, in timent 11 all:

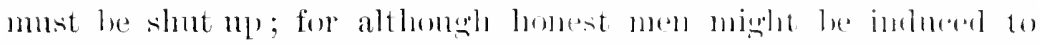

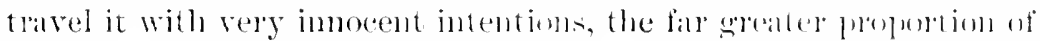
those who passed womld nse it only for sinister julluwes, and with views of fraud on the rights of the belligerent.

"This, howerer, is not a contract makle in time of wall ; and there-

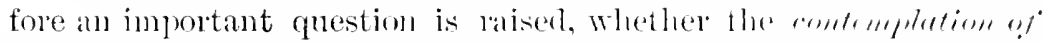
arre would have the same effect in vitiating these comtlateds as atet-

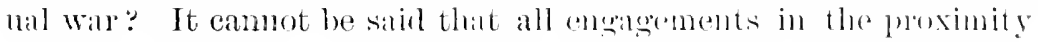
of war, into which the speculation of wall minth enter, as for instance, with regard to the price, wombl therefore he invalio. The contemplation of war is molomberly to betaken in a mome restrived sense. Shat if the contemplation of war leals immoriately to the transfer, and becones the fommbtiom of a comtuat, that womlel mot otherwise be entered into on the part of the seller ; and this is kmom

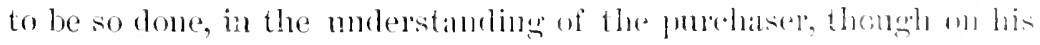
part there may be other concurrent motives, as in the asise af a the

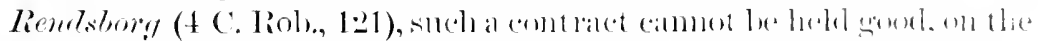
same principle that applies to invaliojale at tamsfor in formsiln in

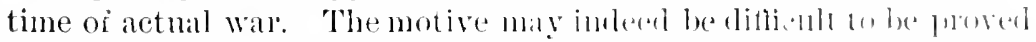
-but that will be the difficulty of particular eases. Supposing the

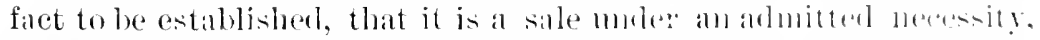
arising from a certain expectation of war ; that it is a sale of gunds 23 
not in the posiession of the selles, and in a state where they could mot. husing war, he lewally transferred, on aceont of the framb on helligerent lights. I cammot but think that the same frathl is committerlatainst the helligerent, not, indered as an atetual belligerent, but as one who was, in the cleall expectation of both the contrating parties, likely to heeome a belligerent before the arrival of the property, which is marle the suhjeet of their anderment. The mature of both contrats is irlentically the same, being equally to protect the property from apture of wall-not indeed in either case from capture at the present moment when the contrat is made, but from the dangere of capture, when it was likely to ocenr. The object is the sane in both instances, to athord a guanutee against the same erisis. In other worls, both are done for the purpose of eluding a belligerent right, either present or expected. Both contracts are framed witl: the same anime firdudendi, and are, in my opinion, justly subject to the same rule.

"I am of opinion, therefore, that if the papers and letter's which have been produced, do suthiciently establish the purpose attributed to the contract, if it is pored to have been built immediately and fundamentally on the contemplation of war, on the part of the seller, and that it would not otherwise have fallen into the hands of the furchasel, it is an illenal contrat, and must be held on every gremul. on which similar contracts in time of was have been held to le invalicl. ***

"lint taking it to be a bom firte contract, yet leing formed in tomsitu, for the purpose of witholawing the pupesty from capture,

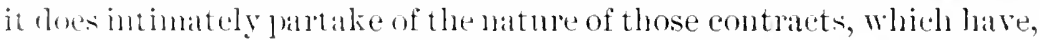
in the bejeated decisions of this, and of the supreme compt, been pronomeed mull and invalid ; and I pronounce this property subject (1) conclemuation."

\section{TIIE SIIIP" AXX GREEN."}

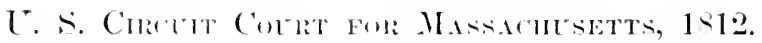

(1 Cirllisom. 254.)

Property unt permittul to rhamgen hamater in transit ; nor shall property con-

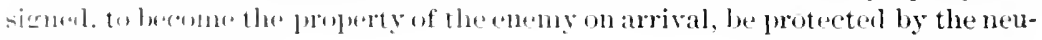
trality of the shiplent.

Extrace form the ophinim of strur. J. :-

"It labs been further arghed, that this eapture, being made while 
the property was in tomsitn, and wat intervening, it is to be comsid-

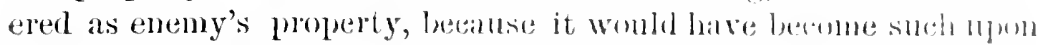
arrival at the port of destination: and at all covents it womld hatrolnem liable to seizme and confiseation. Isto the fact that the property

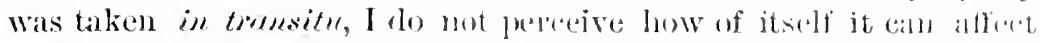
the rights of the parties either way nor do l perecive how this poperty was to have become enemy's ploperty on ils arrival. 'Phe

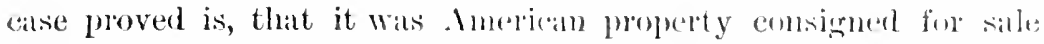
only, and not a consigmment where the ploperty was, at the 1 ime of slipment or of arrival, to belong to the comsignee. 'The cases are, at I think, settled upon just pinciples, that deciele that in time of war, poperty shall not be permitted to change character in its transit; nor shall property consigned, to hecome the property of the enemy on arrival, be protected by the nentrality of the shipper. Fuel contracts, however valid in time of peace, are considered. if made in war or in contemplation of war, as infringements of belligerent rights, and calculated to introduce the grossest frambs. In fact, if they combl prevail, not a single bale of enemy's goods wonld ever be fomol upon the ocean." ( Trono Merguretha, 1 C. Rob., s36; Corl Walte, 4 C. Rob., 207; Jom Frederick, 5 C. lioh., 12s; 'The comstomtia, 6 C. Rob., 821; The smue Cuthurina, + C. Rob., 107; Packet He bilbon, 2 C. liob., 133.) ${ }^{1}$

'In the case of the ship Francis and Cargo, 1 Gallison, 44,, approved by the Supreme Court, 8 Cranch, 35 t (1813), a shipment made by an enemy shipler to his correspondent in America, to belong to the latter at his election. in twentyfour hours after the arrival thereof, was held liable to condemnation as hostile property.

In war property cannot change its character in transitu; and in this case, an election during the transit would not merge the hostile character of the property.

On the subject of the sale in transitu by a belligerent to a neutral, see an article by T. S. M. Browne, in the Law Magazine and Review, 1870, vol. 29, 1. 233. 


\section{SETTHA Bti.-FlieIGIT.

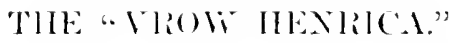

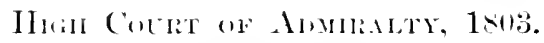

(4 C. Rolinistm. 343.)

Where a neutral resel carrying enemy's goods is captured, the neutral master in. an a general rule, entilled to his freight, which is a lien on the cargo. On acmum if the preculiar ciremustances of this case. the freight was postponed to the "atpors

This was a case of a Danish ressel taken on a voyage from Valencia to Londom. Fhe ship had heen restored with freight to be a charece on the cargo, which was condemned, hint the proceeds not heing sultielent to pay the freight am the expenses of the captor, it Was payed on the part of the neutral ship, that the priority of payment might he eriven to freight, on the authority of the Bremen Floifle, + C. Robl), 90.

Jukloment,_.ir W. Scott:-

-I liave considered the cases which I directal to be looked np, and I see no reason to alter the opinion which I before (xplesterl, that frejpht is, in all ordinary cases, a lien which is to take place of all others. The captol takes cum onere: It is the allowerl privilege of neutral trade to carry the property of ther alemy, sub ject to its capture and to the temporary detention of his versel: and if the party does not prevalieate, or eonduct himself in any lesect with ill-fathe he is entithel to his freight. This

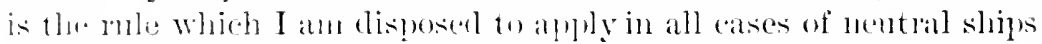

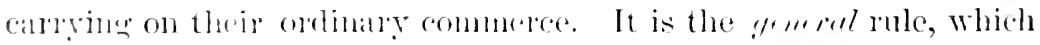

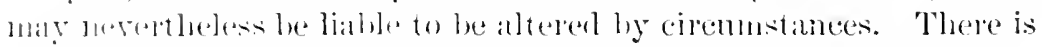

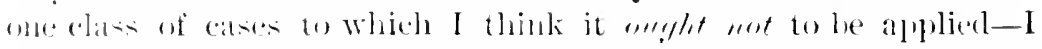

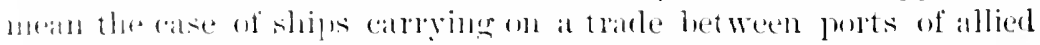

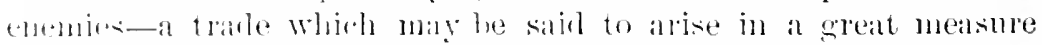
ont of the ciremmstaness of war, thomeh not alteresther: I say not

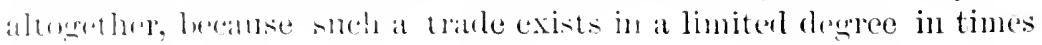

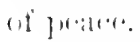

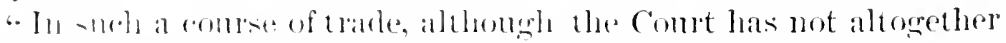
refited froight to the neutral ship, get it may not think it unreason- 
able that the captor should, in preference, be entithel to his exponses, inasmuch as the nature of such a trate cammot but very mulh influence the judgment which he must unaroblably form of his duty to bring in the eargo for atjulication. In the prosent eatse, the voyages is not between the ports of allierl enemies, hut between the ports of two belligerents, from Valencia to London; that comstitutes, I think, a solt of midalle case, with respect to the ohligation hy whids the eaptor might conceive himself bomel to bring the cango to arljudication. There might be a presumption, molouhtedly, that tho. property beloiged to the enemy exporter; but there is a fonmdation also for presmming that it might helong to the consignee, and that it mould not have been sent on a destination to this country, but muler the protection of a license.

"It is, therefore, a cise of a mixed nature, to which I shall apply a sont of a middle julgment. I will allow the captor his law expenses, and firect the other expenses to be postponed to the palyment of fleight."

\section{THE "FORTLNA."}

\section{High Colrt of Amarilty, 1802.}

\section{(4C. Robinson, 278.)}

Freight is due to the captor, in virtue of the ship. which harl been condemmed, wher the cargo (neutral) is carried by them to the place of its destination.

This was case on petition of the captors, praying to be allowel freight for a cargo, whieh had been restored as neutral property. The demand for freight was fomeded on a suggestion, that the ship, which had been eondemmed, harl actially performed the contratet of the original affreightment, by earying the eargo to the place of its destination.

\section{Julgment,_sij IV. ScotT:-}

"This is the case of a ship which had carried a eargo of eorn to Lisbon, the original port of destination. In surh a ease I apprehend the rule to be, that the captor is entitled to freight, and on the same principle, on which he would be held not to be entitlerl. where he does not proceet, and perform the original voyage. The slereitir contract is performet in the one case, and not performed in the other. It is the rule of practice laid down in the case of the Irayheirl, Lords, 17st, a case perfeetly within my reeollection as a ase very deliberately considered at the Cockpit. It is conformale to 
the text law, and the opinion of eminent jurists. "Qnod additur de veetura pretios solvendis (says hynkershoek), ejus juris rationem nom adsefuor. Satis intelligo, qui navem hostilem oecupant, etian oceulatise omme jus quod navi, sive navarcho debebatur, ob merces trinslatas in portum destinatmm. Proponitur alutem, navem in ipso itinere fuisse caltim. Eccur igitur capienti solvam mercedes? si yni cepit navem, eam cum mereibus in locmm destinatmm perducere faratus sit, ejus juris dationem intelligerem, ceteroquin non intelligo.

"In the catse of the Treglesel, all the considerations that conld be alprliet to this question were fully canvassed, and it was then recog-

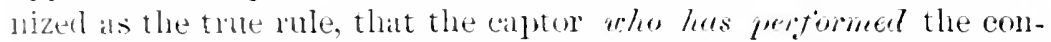
tratet of the ventel is. as a matter of right, and de corsen, entitled to fleight; although, if lie has done anything to the injury of the propaty w has been guilty of any misconduct, he may remain answerable for the effect of such misconduct, or injury, in the way of a setoff atainst hims.

. The ane then is reduced to a question. whether the eaptor, in this instance, las done anything to forfeit the right, which, under the seneral rule. he had acpuired.

- Tuler the circumstances of this case, I am of opinion, that the captor has not forfeited the interest which he had acquired.

"Freight decreed to the captor."

Section 37.-RechptrRe-Rescee.

TIE "SANTA CRLZ."

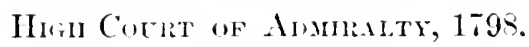

(1 C. Robinson, 49.)

Cieneral rules of recapture and salsage.

The law of England. on recapture of property of allies, is the law of reciIrecity.

This was the case of a I'ortuguese vessicel taken by the French, Inerust 1, 17!mi, and retaken ly Euglish cruisers, on the zsth, after beine a month in the posiession of the encmy.

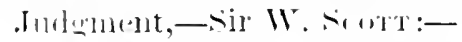

.. * * In the arrmments of the comnsel, I have heard moch of lie rules which the litw of nations preseribes on reeapture, respect. 
ing the time when property vests in the eaptor ; and it certainly is a question of much curiosity to inpuire what is the true rule on this sulject; when I say the true mer, I nean only the rule to which civilized nations, attending to just principles, ought to alhere: for the monent you admit, as admitted it must be, that the pratice of nations is various, $y$ on adnit there is 110 rule olerating with the proper force and anthority of a general rule.

"It may be fit there shoukl be some lule, and it might be either" the rule of immediate possession or the rule of pernoetation and twenty-four hours' possession; or it might be the rule of bringing infire presidia ; or it might be a rule requiring an atetnal sentence of condemmation; either of these rules might be sufficient for general practical convenience, although in theory perlans one might appear more just than another; but the filct is, there is no such rule of practice; nations concur in principle, indeed, so fir as require firm and secure possession; but their rules of evidence re. specting the possession are so discoldant and lead to such opposite conclusions that the mere mity of principle forms no miform rule to regulate the general prietice. But were the public opinion of European States more distinetly agreed on any principle as fit to form the rule of the law of nations on this sulject, it by no means follows that any one nation would lie under an obligation to observe it.

"That obligation could arise only from a reciprocity of practice in other nations; for from the very circumstance of the prevalence of a different rule among other nations, it wonld become not only lawful, but necessary to that one nation to pursue a different conduct: for instance, were there a rule prevailing among other nations that the immediate possession and the very act of capture should divest the property from the first owner, it would be absurd in Great Britain to act towards them on a more extended principle; and to lay it down as a general rule, that a bringing infia prosirlin, though probably the true rule should in all cases of recapture he deemed necessary to divest the original proprictor of his rights ; for the effect of adhering to such a rule would be gross injustice to British subjects. * * *

"If I am asked, under the known diversity of practice on this sulject, what is the proper rule for a state to apply to the recaptured property of its allies, I should answer that the liberal and rational proceeding would be, to apply in the first instance the rule of that comntry to which the recaptured property helongs.

"If there should exist a country in which no rule prevails. the recapturing country must then of necessity apply its ow lule and 
rest on the mesumption that that rule will be atopted and athminstered in the futme fratctice of its allies.

"I mulemetand [the law of England] to be clearly this: That the maritime baw of Englam, haviug atopted a most liberal rule of res-

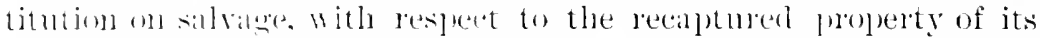

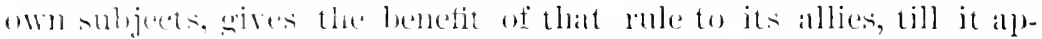

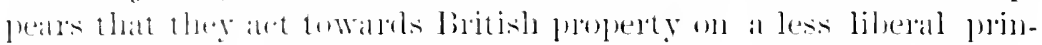

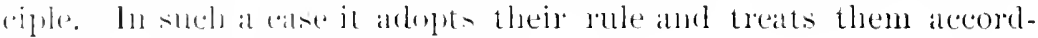
inge to their own meatsme of justice.

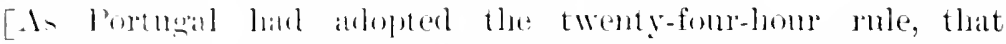

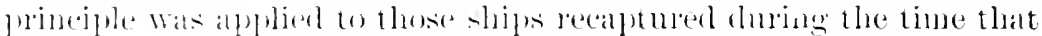
rale prevated in lontual, and the rate of salvage decreed was the loutughese late. one-cighth to ships of war and one-fifth to privateers. The English rule allowed one-sixtlo to privateers.]

\section{TIIE "CARLOTT.A."}

\section{Higil Collit of Amminaty, 1808.}

(.) C. Robinson, it.)

Salvage on neutral property. retaken out of the hands of the enemr, not given-muless it can be shown by references to the ordinances or to the practice of the prize conts of the enemy, that the first seizme was made under stch circunstances ats would have exposed the goods to condemnation in the hanch of the enemy.

This was a quation of salvage, on the recapture of a spanish shipe and callon fom a french cruiser.

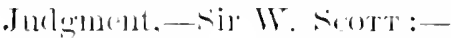

"The question mow to be decided is, whether salvage is due on

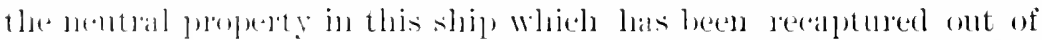

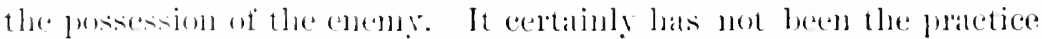

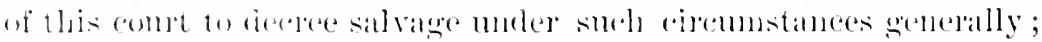

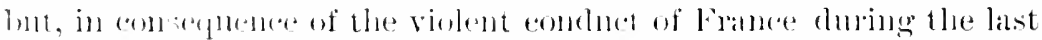

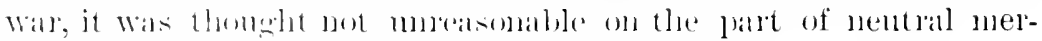

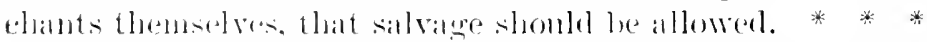

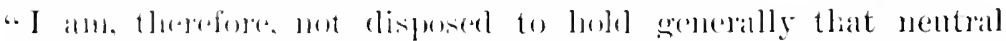

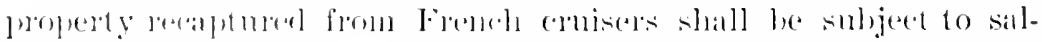

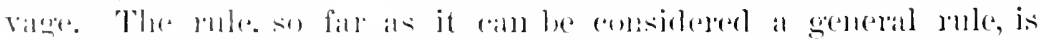

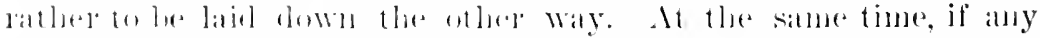

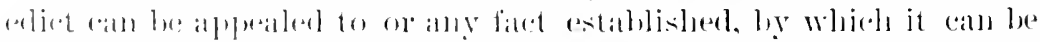
shewn that the froperty would have been exposed to condemmation 
in the eomets of France, I shall hold that to be suffic iont groment to induce we to pronomee for salvige in that particular catse. With

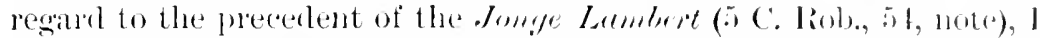
think I am warlanted to consiller the anthority of that case as in at great measure done away hy the subsefuent decision of the Iands in the late wan, in which they have repeatedly pomomored for salvage on the reeapture of nentral property. In departing from the old rule they lave in some degree dischined the principle; and, 1 think, with great poplety, as fal as it could be eomsidered as an universal punciple, governing the practice of our prize comts in all possible cascs, withont any possible exception. In the present instance there does not appear to me to be any gromuls on which it can be supposed that this monerty would have becu combemmed, merely hecause it came out of the hamds of a British priviteer, al becanse the original voyage had been the colony of sipain (1) London. No edict has been produced from the French code to shew that this property would have bees subject to any such penalty on either of those aceomits, in the prize conts of France. The cxpenses of the recaptors must be fully paid; but I slall not pronounce salvage to be due." 1

\section{'THE "EMIIY ST. PIERRE."}

(Lancence's ITheuton, 667, 1021.)

It is not the duty of a neutral government to restore a private vessel of one of its citizens which has been rescued by her crew from a belligerent captor before condemnation.

This wals a British vessel, captmed by the United states hlok. ading stuathom, in the at of breaking the blockade of Clanleston, s. C., and ordered to Philarlelphia for ardjulication in chasere of a prize crew. The original crew, hy frand and force, resalinerl posicssion, and fook the vessel to Liverponl and restored hed to the porisession of her owners. Mr. Arlams applied to Farl linsisell for a restoration of the ressel, on the gromirl that the rescone was a vination of the law of nations, which furnished smfloient eanse for anmlemmattion, and a breach of the duty of a luentral, who is bomm insuhmit io the arjudication of the prize comet of the aptor. Fand linssell refused the demand on two gromuds, - first, that, as tlue mescoue

${ }^{1}$ For an account of the laws of different comntries on the subject of recapture and salvage, see Dana:s Wheaton, Pl. 466-1i2. 
Was not a violation of any municipal law of England, and as the vessel was not in the custody of the british Government, that government lad no lowal right to take her from the hands of her owners, or to prosecute o! proceel against the ressel or the owners for any violation of law; and, semert, that, in addition to the technical objection, the oftense was solely one against the laws of war marle for the henefit of andor's, which the captor's conld assert and rindicate only in their own tribumals. Admitting that rescue was gromm for combemmation, he contended that the decree conld only be malde by the belligerent prize court. No other cont, either of the belligerent or of a neutral country, had jurisliction to condemn or restore propery taken in war. If the private neut ral resenes his vessel by force he takes all risks of the eaptor"s rights of force recognized by nations, but nothing more. The courts and government of the neutral comnty camnot decide that the title to the ressel has passed to the cartor before condemuation by the prize courts of the captor's eomutry. All they can do is to restore to the captor the temporary possessory right, which he has between capture and condemmation. such possessory right he held to be one of force, which the captor's govermment could guard and assert ly condemnation or other penalty on the property, if in its possession, throngh its prize court: but, even by the comts of the captor, the neutral rescuer cond not be personally pmisher, as for a erime. He contended that it was not incumbent on nentral govemments to make laws to enforcesuch belligerent possessory rights against their own citizens, any more than it is in case of crimes committed by their own citizens abroad, whom they do not even deliver up to the offended govemment for trial, except by treaty stipulation; or in case of violations of the revemue or embargo laws of other comntries, which they never even indirectly take active cognizance of ; or in ease of successful breach of hlockidle.

In the comrse of the correspondence Mr. Adams citer a parallel case, in which the position of the two goveruments was reversed, ats

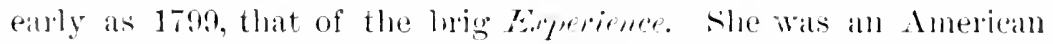
ressel, (aptured (with two other vessels) by a british cruisere resened by lere crew and hronght to Philadelphia. By diredion of Lord

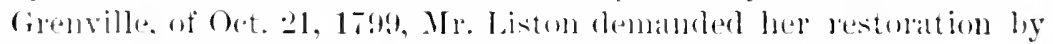

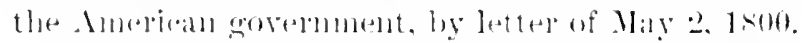

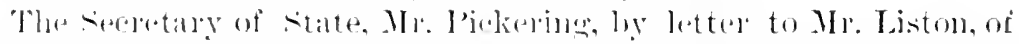

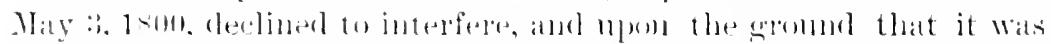

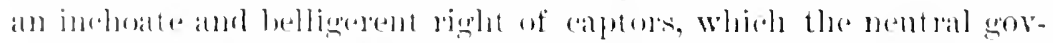

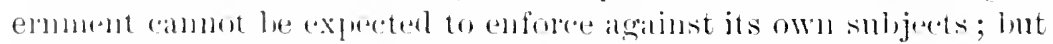
referred the British Minister to the Admiralty Courts of the Cnited 


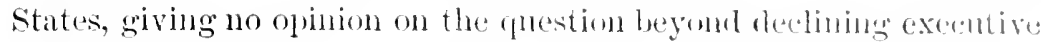
intervention.

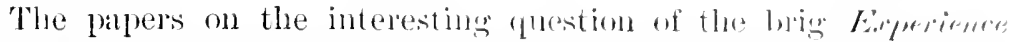

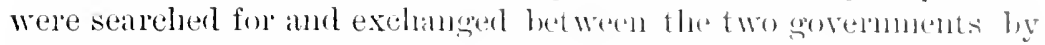
both Earl IRustell and Mr. Minms; and Earl linsiell stated that

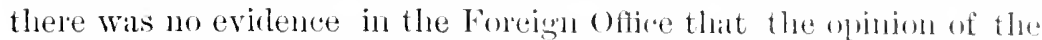
law-officer of the erown had been taken in that asse, or that any further proceedings were hat after the roply of Mr. Pickering. Mr. Alams, on his part, did not press further the case of the Emily ry. P'ieme, nor attempt proceedings in the daniralty Comts of Great Britain.

It may, therefore, he considered as settlel hy thesc two cases, that a nentral govermment is not required, by exentive atetion, to restore a private vessel of one of its eitizens whith has been resched hy her crew from her captors before condemmation, on flemand of the govermment of the captors. The possessory, lelligerent right of the eaptors, is not to be enforced hy neutral powers hy any positive action in the way of penalty or seizure for restitution. Whether the right can be vindieated by a possessory suit by the eaptors in the Armiralty Courts of the nentral, has not been judicially determined; but the conrse of the politieal departments of both governments, and the reasoning on which they proceded, seem to settle the judicial, as well as the political (puestion. (Dana's Wheaton, 475.) ${ }^{1}$

${ }^{1}$ In the case of the Lone, $3 \mathrm{Cp}$. Atty.-Gen., 3\%, this vessel had entered the port of Matamoras while it was blockaded by a French squarlon (14:3), and sailel thence for New Orleans. On the voyage she was capturerl hy a French cruiser: but some days later she was rescued by her captain, who bought her into New Orleans. A demand was made on the President by the French Government for her return to the captors. Attorney-General Grundy arlvised that the Presiclent had no power to grant the demand, the case involving questions to bo settled by the courts, and not by the executive, and that the claimants must go into the courts. He also advised that if a vessel. after escaping from her captors, terminated her voyage in safety, her lialility to condemnation for the escape entirely ceases. (3 Wharton's Digest, 199.) 


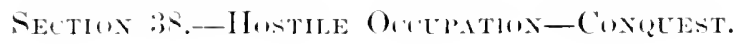

TYTED STATES r. liLE.

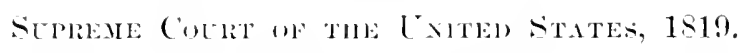

(4 Hhector, 246.)

Hei.7. That. while Castine. in Maine, was in the military possesion of the Briti-h forces. it wats not a port of the United States, within the meaning of the revenue laws. so that, after the evacuation of the place, the United states could collext ruties on gouls imported into it during the occupation.

sirnir, .J., delivered the opinion of the court:-

." The single question arising on the pleadings in this case is, wheller gonds inporterl into Castine, during its oecupation by the enemy, ale liable to the duties imposed by the reveme laws upon goods imponted into the Cnited states. It appears, by the plearings, that on the first day of september, 1st4, Castine wats captured by the entmy, and rentined in his exchsive possession, under dhe command and entrol of his military and naval forces. until after the ratiti altion of the treaty of peatee, in Febratry, $1 \times 15$. Inding this period, the fritish govermment exereised all eivil and military anthorty orea the plater: and established a custom-house, and admitterl goods

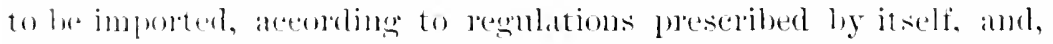

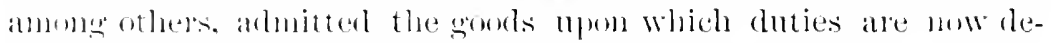

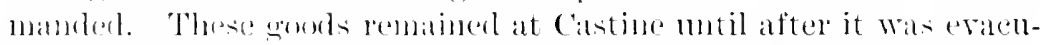
ated hy the enemy, and upon the reastablishment of the American

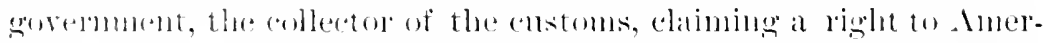

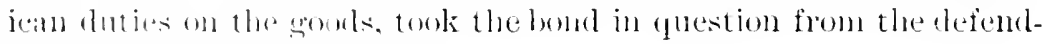
atht, for the serentity of them.

" Pmber these cinementanees, we are of opinion, that the claim

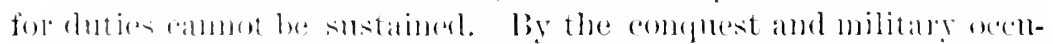

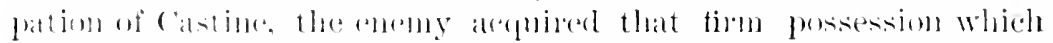

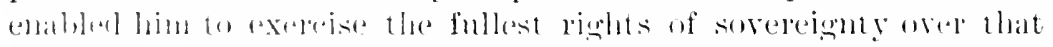

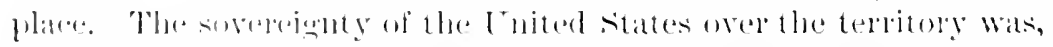

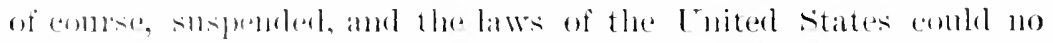
lomere be righthly anfored there, or be obligatory mpon the inlab-

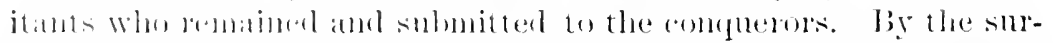
dender the inlialsitants fatssed under a temporary allegiance to the 
British government, and were bomml by such laws, and suthomb ats it chose to recognize and impose. From the matme of the cascan other laws could be obligatory mpon them; for where there is mo

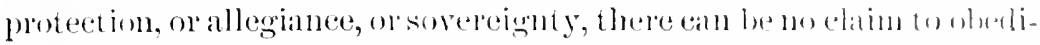

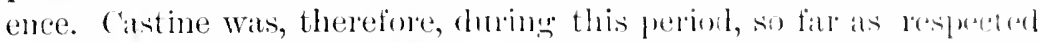

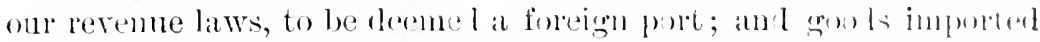
into it ly the inhabitants, were subjeet to such doties only as lhe

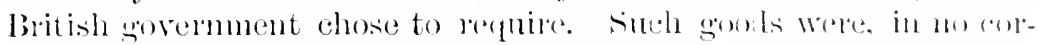

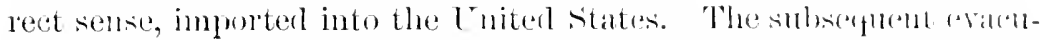
ation ly the enemy, amel resmmption of anthority ly the lonited States, dir not, and eonld not, ehange the ehanater of the previoms transilutions.

"The ductrines respecting the jus postliminii ane wholly indphlinalble to the case. The goods were liable to American dutirs, whon importerl, or not at all. That they were not so liable at the timo of importation, is cleal fom what has been alrealy staldel ; and wholl, upon the return of peace, the juriscliotion of the Tuitol states wath reassumed, they were in the sime predicament as they would have been if Castine had been a foreign territory colder loy traily to the United siates, and the goods had heen previonsly imported there. In the latter case, there wombl he un pretence to saly that . Inerion duties conld be demanded ; and, monn principles of pmblic of municipal law, the eases are not distinguishable.

"The anthorities cited at the har, would, if there were any donlst, be decisise of the question. But we think it too clear to requireany aid from athority." 1

\section{FLEMING r. PAGE.}

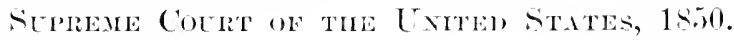

\section{(9) Houtert. 603.)}

Hell. that yoods importerl into the Uniterl States from Tampico. Mrexico.

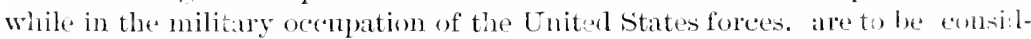
ered as importations from a foreign comntry.

This action is brought by the plaintifts, mepehants, resiling in the city of Philadelphia, against the defendant, the late collenton of the port of Ihiladelphia, to recover the sum of one hlousand tive hum-

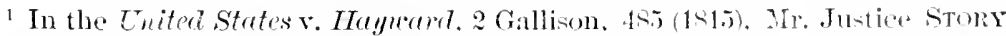
held that Castine was to be considered a " rorsigin port," with reference to the non-importation acts. 
drenl and twenty-nine dollars, duties paid on the 1+th of June, $1 \rightarrow+\pi$, mmer protest, on gools belonging to the plaintiffs, brought from 'Timprico while that plate was in the military ocemation of the forces of the Inited chates.

On the 15th of Noremiler, 1846, Commodore Commer took military possession of 'Jampleo, a seaport of the sitate of T'amamlipas, and from that time until the tranty of peatee it was garrisoned by imerjean forces, and remained in their military oeenpation.

Instice was administered there by conrts alpointed moler the military andhority, and a enstom-house was established there, and a collector appointed, meler the military and naval anthority.

I pon a certificate of division in opinion in the Cireuit Court the case anue up to this comt.

Jurment,-ThNer, C. .J. :-

"The question certitier hy the Circnit Court turns upon the construction of the act of congress of July $30,18 \frac{16}{16}$

"The duties levied mon the eargo of the schooner catharine were dnties imposed ly this law upon conols imported from a foreign eomutry. And if at the time of this shipment 'Tampico was not at forejun port, within the loneaning of the act of Congress, then the duties were illegally charged, and, having been pairl under protest, the phaintiffs would be entitled to recorer in this action the amount exicterl by the eollector.

"The port of Tampien, at which the gands were shipped, and the Irxican state of Tamanlipas, in which it is sitnated, were mondoubteily at the time of the shipment subject to the sorereinty and hominion of the Enited States. The Mexican amborities had been driven ont, or had submitted toom army and navy; and the comtry was in the exclusive and firm possession of the Laited states, and arorered by its military anthorities acting under the orders of the l'resident. But it does not follow that it was a part of the Lnited status, or that it ceased to be a foreign eomutry, in the sense in which these words are used in the atets of comgress.

"The eomuty in question hatd been eompleded in war. Jint the genins and charater of om institntions are peaceful, and the power 10 declare war wits not conferred npon congress for the purposes of aggresion of argrandizenest, lut to enable the general govermment to vindicate by arms, if it shombl become necessiuly, its own rights and the rights of its citizens.

" $1 \mathrm{Wa}$, therefor", declated hy Congress, can never be presmmed to be waged for the furpuse of eomplest or the acquisition of teritory; nor does the law declaring the was imply an anthority to the I'resident t'e enlunge the limits of the Enited states by subjugating 
the enemy's eountry. The Lnited sitates, it is true, may extend its boundaries by conduest or treaty, and maty demand the exsion of territory as the condition of paree, in orrer to inclemmify its citi\%(s) for the injuries they lave suffered, of to lomburse the govermment for the expenses of the war. But this can be done only by the treaty-making power or the legislative anthority, and is not a part of the power conferred upon the President by the dextatration of war. Ilis duty and his power are purely military. Is commander-in-rehict, he is anthorized to direct the movements of the naval and military forces placed by law at his comminrl, and to employ them in the mamer he may deem most effeetual to harass and eonquer and subdue the enemy. IIe may invale the hostile eomntry, and subject it to the sovereignty and authurity of the Enited states. Int his conquests do not enlarge the bonndaries of this Union, nor extend the operation of our institutions and laws beyond the limits before assigned to them by the legislative power.

"It is true, that, when Tampico had been captured, and the state of Tamaulipas subjugated, other nations were bound to regard the country, while our possession continued, as the territory of the Cnited states, and to respect it as such. For, by the laws and usages of nations, eonquest is a valid title, while the victor maintains the exclusive possession of the conquered country. The citizens of no other nation, therefore, had a right to enter it without the permission of the American anthorities, nor to hold intercourse with its inhabitants, nor to trade with them. As regarderl all other nations, it was a part of the Lnited States, and belonged to them as exclusively as the territory inchuded in our established boundaries.

"But yet it was not a part of this Union. For every nation which acquires territory by treaty or conquest holds it aceording to its own institutions and laws. And the relation in which the port of Tampico stood to the Cnited States, while it was occupied by their arms, did not depend upon the laws of nations, but nyon our own Constitution and acts of Congress. The power of the Presiolent, muler which 'Tampico and the state of Tamanlipas were conquered and held in subjection, was simply that of a military commanter prosecuting a war, waged against a public enemy, hy the anthority of his government. And the country from which these gouds were inported was invaded and subdned, and oeeupied as the territory of a foreign hostile nation, as a portion of Mexico, and was held in possession in order to distress and harass the enemy. While it was occupied by our troops they were in an enemy's comntry, and not in their own; the inlabitants were still foreigners and enemies, and owed to the United States nothing more than the smbmission and 
oberlience. sometimes called temporay alleriance, which is the from

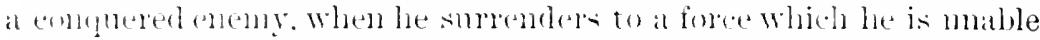
to resist. But the lommlaties of the Luited states as they existed

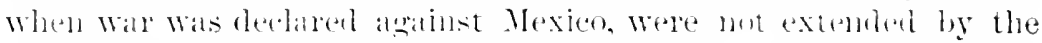

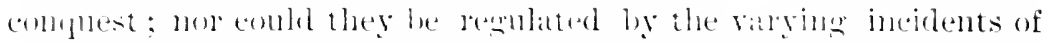

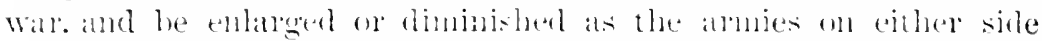

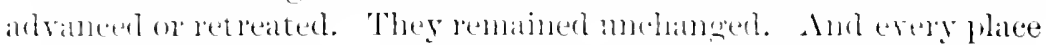
which wats ont of the limits of the fuited states ats luevionsly

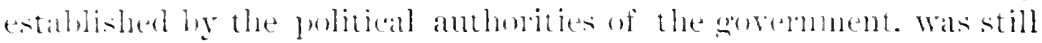

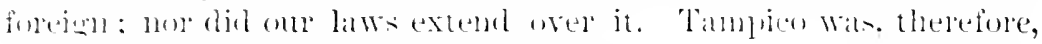
a foreign burt when this shipment was made.

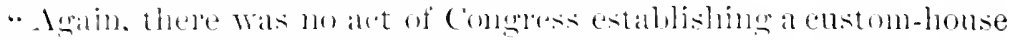

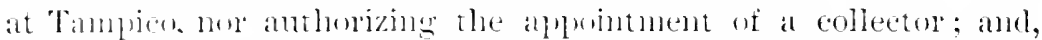
comseguenty, there was no officer of the Luited states anthonized hy law to glamt the clearance and anthentitate the consting manifest withe aras, in the mamer directer hy law. where the rovage is from one gort of the Enited states to another. The ferson who acterl in the tharacter of collector in this instance ateded as sneh mules the authority of the military commander, and in obedience to his orters: and the dnties he exicterl, and the regulations he

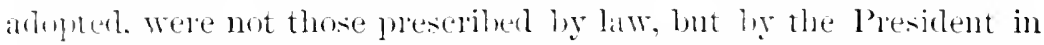
his ehatrater of eommander-in-chief. The enston-house was establisherl in an enemy comnty, as one of the wealmons of war. It was established, nut for the purpose of giving to the people of Tamamligar the lemefits of enmmerce with the Lnited states. or with other comm nes, but as a measure of hostility, and as a lant of the military oferations in Inexico; it was a morte of exacting contributions from the enemy to smlpurt our army, and intended also to ariple the resumeses of Yexien, and malie it feel the evils and bmolens of the

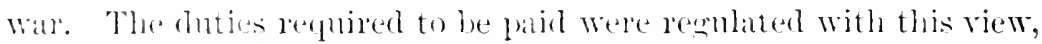
and were nothing more than contributions levied mpon the enemy, which the usiges of war justify when an army is operalting in the

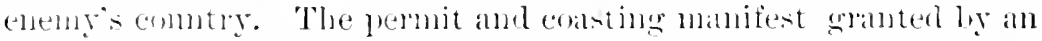

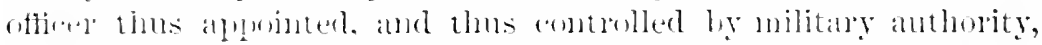

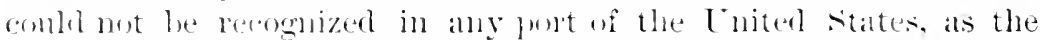

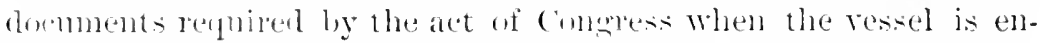
gargerl in the conting trade, nor conld they exempt the cargo from the parnent of huties.

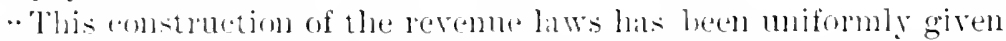
ly the administrative department of the govermment in every case that has come hefore it. Ind it hats, indeed, bexn griven in eases where there alpuears to have been stronger gromm for reanding the place of shipment as a domestic port. For, after Floridat had been 


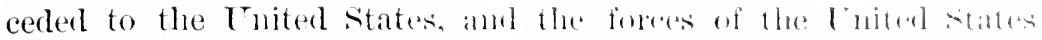

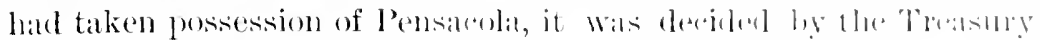

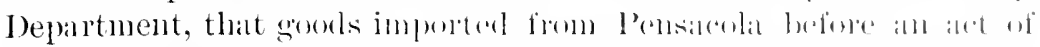

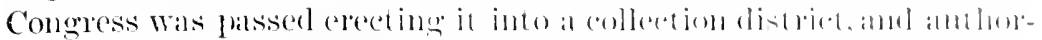

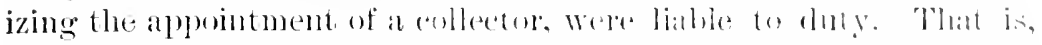

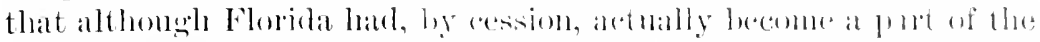

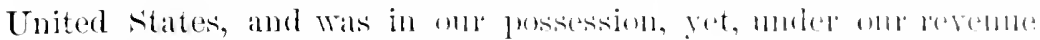

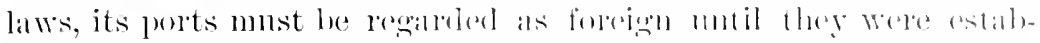
lished as domestic, hy act of (omeress amb it alphand that this decision was sanetioned at the line by the stlormey-firmeral of the United states, the law ofticer of the sovermment. And, althomb

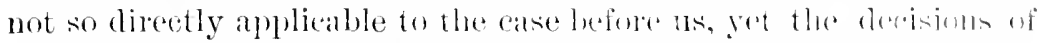

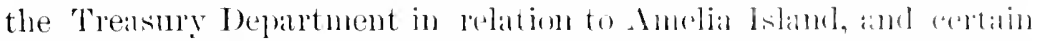

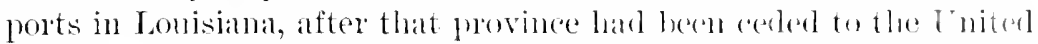
States, were both marle upon the simne grombls. Amb, in the lantro ease, after a eustom-honse had been established hy haw at Xew Orleans, the collector at that platee was justructed to resuld as foreign ports Baton Rouge and of her settlements still in the pusses.ion of span, whether on the Mississiply, Herville, or the seatomit. The Department in no instance that we ale aware of, since the establishment of the government, has ever jecosnized a flare in a

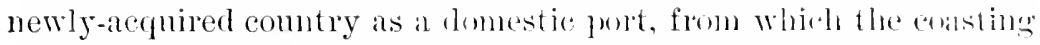
trade might be carried on, miless it had becn previonsly made so by act of Congress.

"The prineiple thus alopted and acted mon hy the excrutive department of the govelnment has been simctiond hy the derisions in this eomt and the circuit comts wherevel the ghestion came before them. We do not puopose to comment mpon the different cases eited in the argument. It is suffirient to say, that there is no discrepaney hetween them. And all of them, so far as they apply, maintain, that under our revenne laws every fort is remaled as a foreign one, unless the costom-lomse from which the rescel rlears is within a eollection district extublished ly act of (ongress, and the officels granting the clearance exercise their fometions number the authority and eontrol of the laws of the frited states.

"In the view we have taken of this questim, it is mmecessary 10 notice partiendarly the pasiages from eminesut writers on the latrs of nations which were brousht forwarl in the aremment. Ther speak altogether of the rights which a sovereign acopions and the powers he may exereise in a conchered combly amb they do not bear upon the question we are comsidering. For in this combly the sovereignty of the Lnited states resides in the penple of the ser. eral states, and they act through their representatives according to 
the relesation and distribntion of powers contained in the constitution. And the constimted amblomities to whom the power of making War and concluding leate is confirled, and of determining whether a complererl combly shall be permanently retained or not, neitles elained morexered any lights or fowers in relation to the tereptory in question hut the lights of war. After it was suldued it Wils miformbly treated as an enemy combry and restored to the

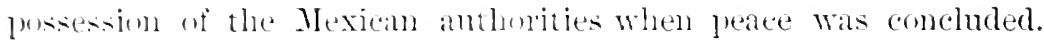
- lur certainly its suljugation did not compel the Enited States, while they hell it, to regirel it as a part of their clominions, nor to give to it any form of eivil govermment, nor to extend to it our laws.

" Veither is it necessary to examine the English decisions which liave been refered to ly comsel. It is true that most of the states hare arbogted the principles of English jurisprudence, so far as it eoncerns luivate and individual rights, and when such rights are in question we habitually refer to the English decisions, not only with respect. Int in many cases as anthoritative. But in the distribution of political power between the great departments of govermment, there is such a wide difference between the power confered on the President of the Enited states and the anthority and sovereignty which belong to the English cowns that it wonld he altogether unsafe to reason from any smplosed resemblance between them, either as regarls conquest in wir or any other sulject where the rights and powers of the executive am of the goremment are bronght into question. Our own constitution and form of government must be om only guide. And we are entirely satisfiel that. moler the constitution and laws of the Enited States, Tampico Was a foreign Int, within the menning of the act of $18+1$, when these gonds were slipled, and that the cargeres were liable to the duty charged upon them, and we shall certify ateordingly to the circuit comt."

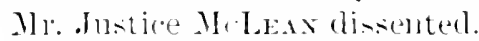

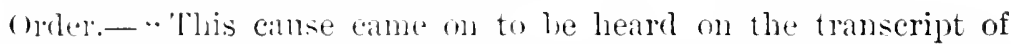
the recorl from the circuit compt of the tniter states for the

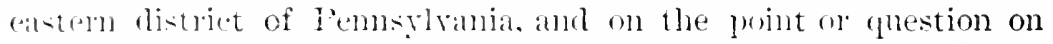
which the jurlges of the sith circuit court were opposed in opinion and which was certified to llis comt for its olminn, agreealbly to the act of congerse in sheh cise made and provided, and was

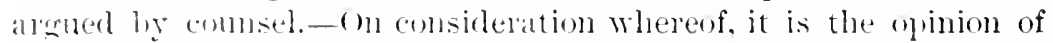
this comt. that Tamplew was a foreign jort within the meaning of the act of cimpress of .July :30, 1-46, contitled an act reducing the ruties on imports, amel fur otluel purposes, and that the goods, wares, and melelundise as set forth and described in the record 
were liable to the duties charerol npon them umder sairl act of comgress. Wherempon it is now laere ordered and aljudgerl ly this court that it be so certitied to the said cireuit court."

\section{CROAS r. MARRISON.}

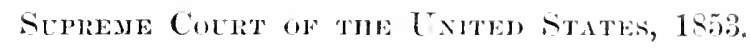

(16) Hourerd, 164.)

Claracter of the military and civil government set up in California under the military occupation of the United States army.

In the war with Mexien the port of Sim Francisco was conquered by the arms of the Enited States, in the year 1sti, and shortly afterwards the United States har military possession of all of Epler California. Early in $18+7$ the President of the Enited sitates, as constitutional commander-in-chief of the army and 1uary, anthorized the military and naval commanders of the Cuited states forces in California to exercise the belligerent rights of a concuneror and to form a civil and military govermment for the conguered territory, with power to impose duties on imports and tomage for the support of such government and of the army which had the armquest in possession.

This was done, and tonnage and import dnties were levied under a war tariff, which had been established by the civil govermment for that purpose until official notice was received by the civil and military governor of California, that a treaty of peace had been marle with Mexico, by which Upper Califormia had been eeder to the United States.

Cpon receiving this intelligence the governor directed that import and tomage duties should thereafter be levied in conformity with such as were to be paid in the other ports of the Enited sitates, hy the acts of Congress; and for such purpose he appointed the defendant in this suit eollector of the port of san Franeisco.

The plaintiffs now seek to recover from him eertain tomage duties and imposts upon foreign merchandise pairl ly them to the defendant as collector between the $3 d$ of Febrully, ists (the date of the treaty of peace), and the 13th of November, 1-49 (When the collector appointed by the President, according to lan, contererl upm the duties of his office), upon the gromnd that they had heen illegilly exacted. The formation of the civil govermment in Califomin, when it was done, was the lawful exercise of a belligerent right over a 
conguered territory. It was the existing govermment when the territory Was ceded to the Enited rtates, as a conghest, and did mot

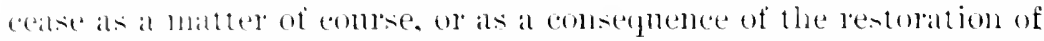

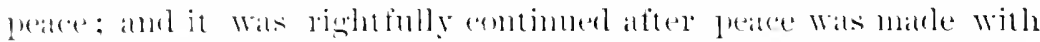

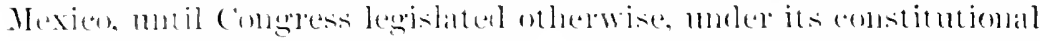

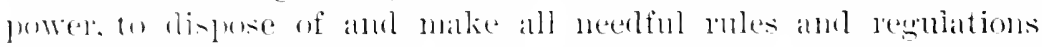

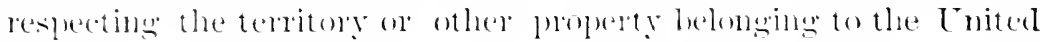
states.

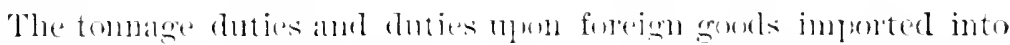

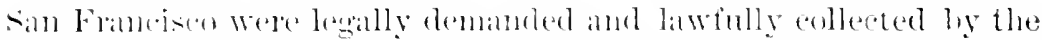

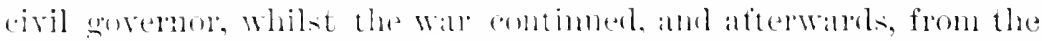
ratitication of the treaty of peare muth the revenme system of the

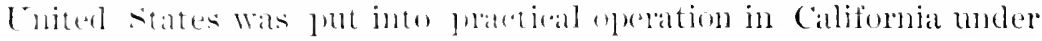
the aces of Coungess passed for that purpose.

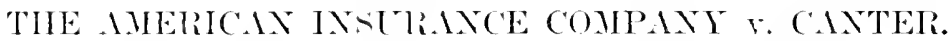

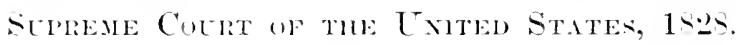

\section{(1 Peters. i11.)}

Status of the people of Florida after the cession of that territory to the United Stittes.

The following is an extract from the julgment:-

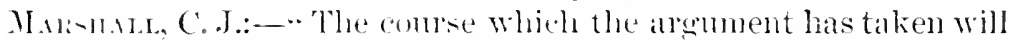
ledpine. that, in decinling this guestion, the comt shomld talse into view the redition in whieh Florida stants to to the Cuited states.

"The comstitution confers absolutely on the goremment of the fuim the jovers of making war and of making toaties: comse-

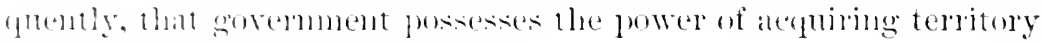

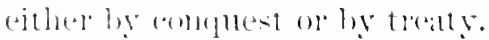

"The usige of the world is, if a mation be not antirely sublued, to

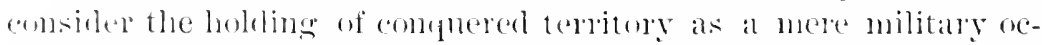
(11) matom, until its fate shall be determined at the treaty of peace. If it le coded hy the treaty. the areduisition is comfimed and the coles territong ixeomes a jout of the nation to which it is an-

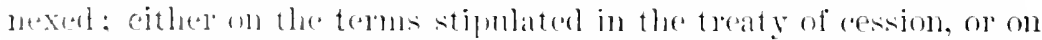

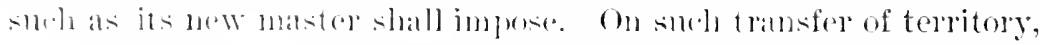

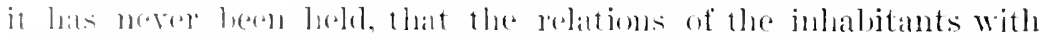

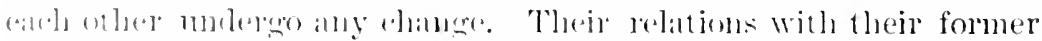

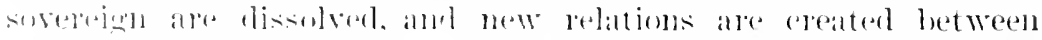

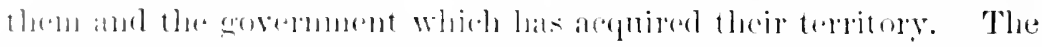
silne act which talusfers blecir country, transfers the allegiance of 
those who remain in it; and the law, which may he lemominated po.

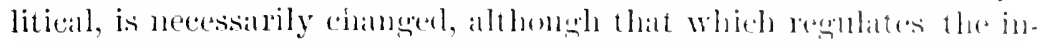
tercourse and general conduct of individuals, lematus in foree mutil altered by the newly-created puwer of the state.

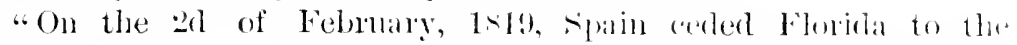
Inited states. The Goth artiele of the traty of cesson comtains the following povision: "The inhalitants of the torritories which his Catholie majesty celes to the Initod states ley this teaty, shall lue incorporated in the Enion of the luited fiates as soon as may le consistent with the principles of the forloral (omstitution: and admitted to the enjoyment of the privileges, rights, and immmities af the eitizens of the C'nited states.'

"This treaty is the law of the land and almits the inhabitamts of Florida to the enjoyment of the privilexes, rinhts, and immmities of the citizens of the Lnited states. It is mmeensing to inguile whether this is not their andition, independent of stipulation. They do not, howerer, participate in political power: they do not share in the govermment, tiil Floricla shall become a state. In the meantine Florirla eontinnes to be a territory of the Luiter Sitates; governed by virtue of that clanse in the Constitution which am. powers Congless to make all nealful rules and rentations respecting the territory or other property belonging to the Enited states."

\section{JECKER V. MONTGOMERY.}

\section{Scpreale Covit of the Lxited States, 1851.}

\section{(13 Houcurel, 498.)}

Teither the President of the United States, nor any inferior executive officer. can establish a court of prize, in territory occupied by American trooss. connpetent to take jurisdiction of a case of capture jure belli.

After California had been ocempied by the Tnited states forres, during the wall with Mexier, a P'ize Comt was set m] at Monterey, at the request of Commodore Biddle, and sanctioned ly the President.

An American vessel-the Admittance-was captured for traldins with the enemy, April 7,1847 , and condemmed by this comrt at Monterey; and the resiel and cargo were sold maler the sintence.

The question finally came before the sinperme cont.

Chief Justice Taxkr, in pronomming the judgrment, sild in respect of the power of establishing courts:- 
"** * In relation to the procectings in the comt at Monterey, which is the suhject of the first demmrer, the recision of the cirenit comrt is enreet.

" 1 ll alptures jube belli ale for the benefit of the sovereign under whose anthority they atre made; and the validity of the seizure and the glestion of plize or no prize ean be determined in his own rommen omls. num which he has conferred jurisoliction to try the ylustion. And under the Constitution of the Luited States the fundial power of the general gorermunt is rested in one supheme (nnlt, and in such inferior compts as Congress shall, fom tine to tine, orlatin and astablish. Every comt of the Eniterl states, therefore. must derive its juristiction and its anthority from the Constitution of the laws of the Lniter states. And neither the President nor any military ofticer can establish a cont in a conquered comutry, and authorize it to deeirle upon the rights of the Enited States, or of inclivinals in prize cases, nor to arlminister the law of nations.

"The conlts established ol" sanetioned in Mexico during the war hy the commanders of the American forces were nothing more tham the anents of the military power, to assist in preserving order in the conquered territory, and to protect the inhabitants in their persons and property while it was ocemped by the Aneriean arms; they wele subject to the military power, and their decisions under its contol, whenever the eommanding officer thonght proper to intertere. Ther were not comrts of the Cnited States, and had no right to arjulicate upon a question of prize or no prize. And the sentence i condemnation in the cont at Monterey is a nullity, and can have no effect upon the rights of any party.

"Th" second demurrer denies the authority of the district cont to adjurlicate, lecallse the property had not been bronght within its jurisliction. but that proposition eannot be maintaned; and a brize comt, when a proper catse is marde for its interposition, will broceed to anjurlate and comberm the captured property or awand restiunion, although it is not actually in the control of the eombt. It may always proced in rem whenever the prize or proceeds of the prize ein be trated to the hatnds of any person whatever." I

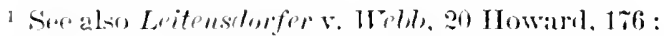

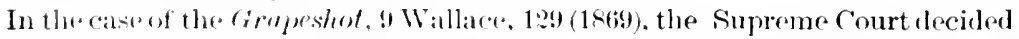
that dhuring the rivil war, when the national forcesocapied parts of the revolted 1.rritory it was within the anthority of the President, as commander-in-chief,

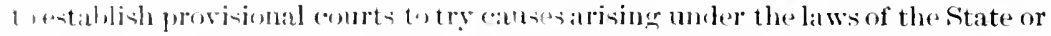

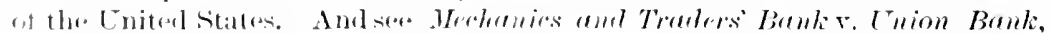

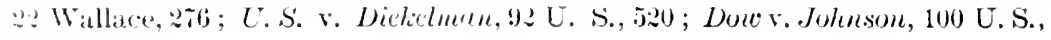
1.5 .5$. 


\section{UNITED STATES r. MORRENO.}

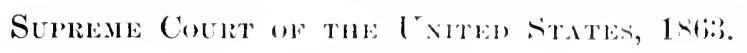

(1 Wallace, foro.)

Conquest or cession of territory works no (hange in private titles to land.

The following is an extrat from the opinion of the eonnt delivered by Mr. Justice Sware: :-

" California belonged to spain by the rights of discovery anr conquest. The govermment of that comntry establisher romalations for transfers of the publie domain to individuals. When the sovereignty of spain was displateed by the revolutionary aetion of Mexico, the new govermment established regulations 11 mon the same subject. These two sovereignties ane the suning hearls of all the land titles in Califomia, existing at the time of the cession of that comntry to the United states by the treaty of Guadalme Ilidalgo. That eesion did not impair the rights of private property. They were consechater by the law of nations, and protected hy the treaty.

"The treaty stipulation was but a formal recognition of the pleexisting sanction in the law of nations. The act of March 30, 1851, was passed to assure to the inhabitants of the ceded teritory the benefit of the rights of property thus secured to then. It recognizes alike legal and equitable rights, and should be administered in is large and liberal spirit. A right of any valiclity before the cussion was equally valid afterwarks, and while it is the duty of the cont in the cases which may come before it to grourd carefully aganst claims originating in fraud, it is equally their duty to see that no rightful elaim is rejected. No nation ean have any higher interest than the right administration of justice."

\section{CASE OF GUERIN.}

\section{Court of Appeal of Naxer, 1872.}

( Dalloz, 18\%, II., P. 18.5.)

The necupation of a department of France by the troops of the anemy does not suspend therein the civil and criminal laws of france; which continum ehligattory upon all Frenchmen, so long at least as they have not been expressly and specifically abrogated by the exigencies of the war. 
Doring the military oreupation of valous depantments of France,

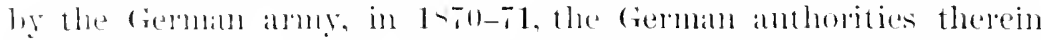

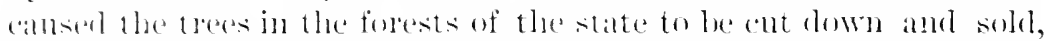

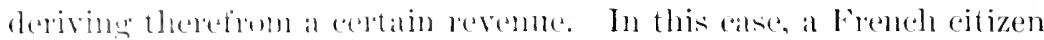

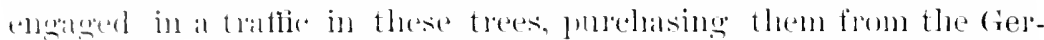
matns. After the wall he was prosecuterl for a beateh of the forestry litws of Friulue.

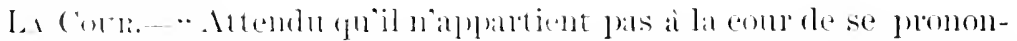

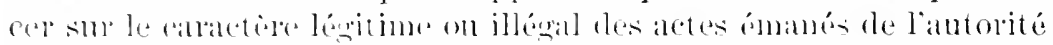

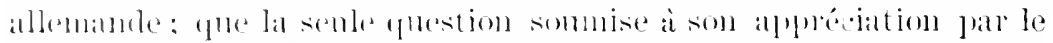

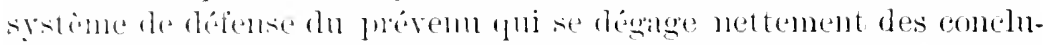

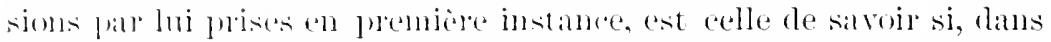

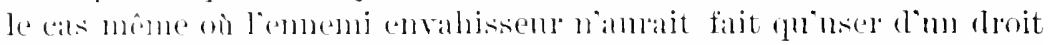

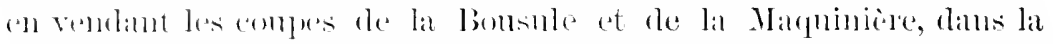

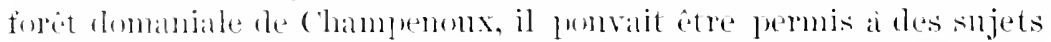

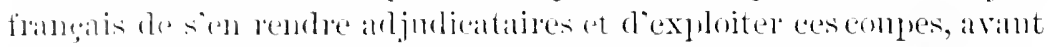

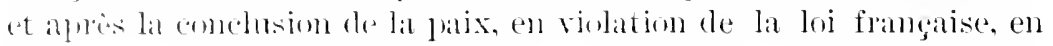

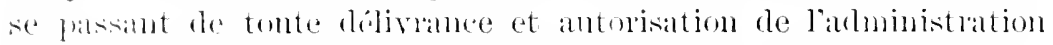
forestiore sims encomir les pémalités élictées par le eode forestier ;-

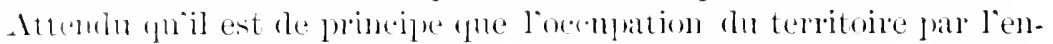
nemi nentrane pas la snspension du droit pelitique on privé du fays ocempe que les lois civiles et penales eonservent an eontraire

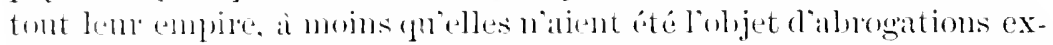

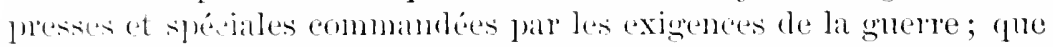

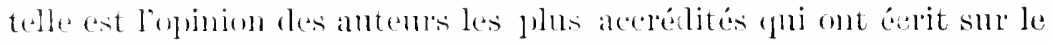
Aroit international; - Ittendu quen anstituant en Losmine monvernement militaire, avec anjometion alm eommissaire eivil, le sou-

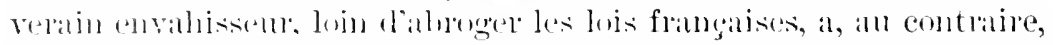

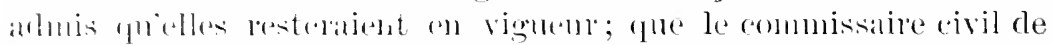

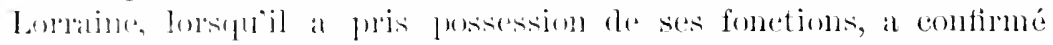

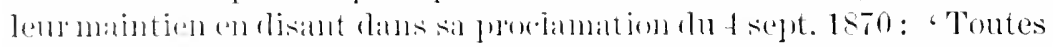

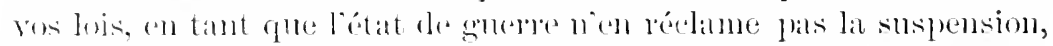

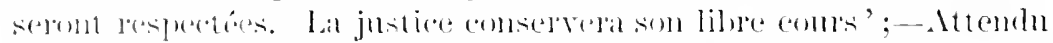

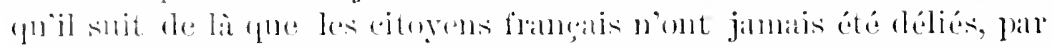

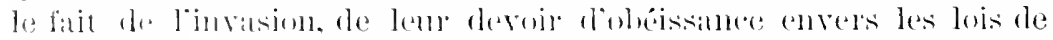

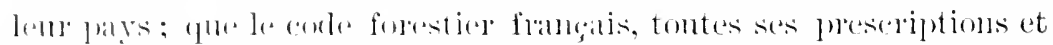

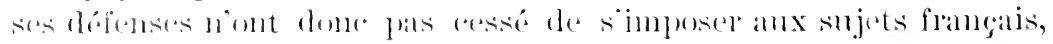

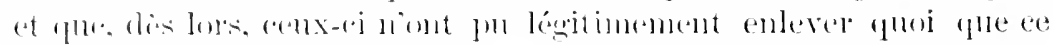

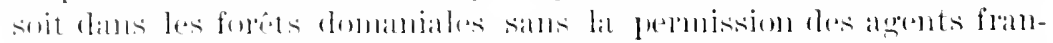

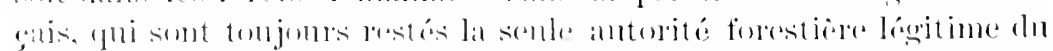

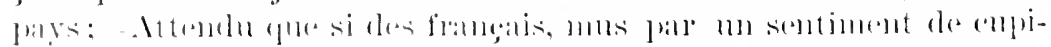

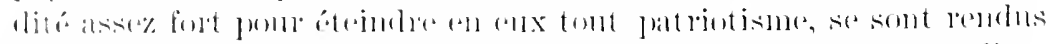

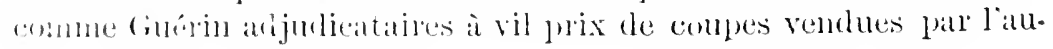




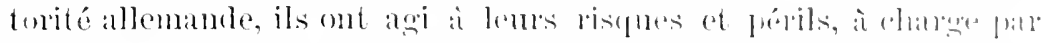

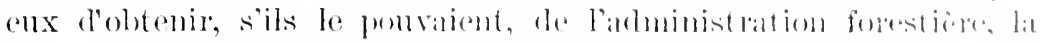

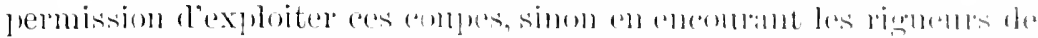

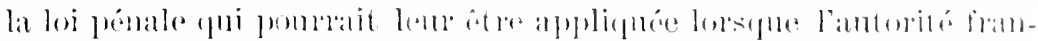

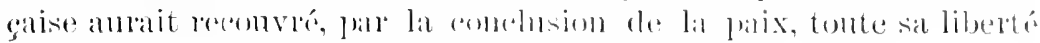
d’atetion et la plénitude de sa pomissance répressise." l

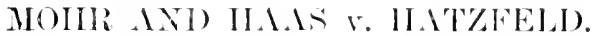

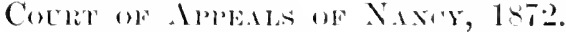

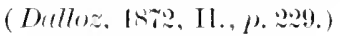

The military occupation of a territory conlers upon the invaler the right to

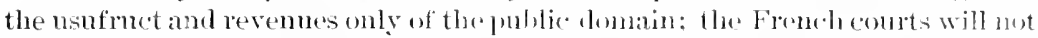

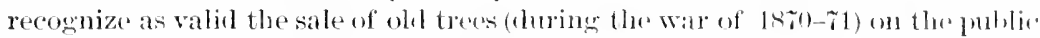
domain, which were reserved at the time of the ammal entting. They are ats inalienable as the soil of the torest itselt.

L.s Cour:- "En ce qui tom he l'appel principal (des siems Wuh"

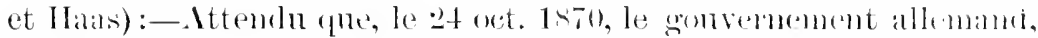

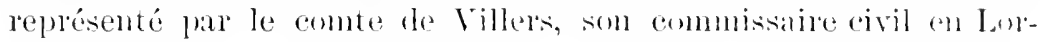

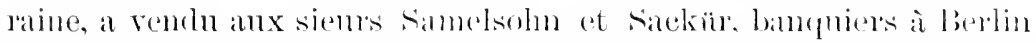

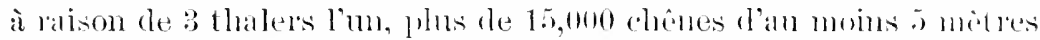

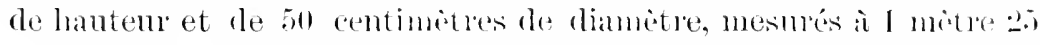
centimetres au-dessus dusol, ì prendre dams les fortsts domamiales

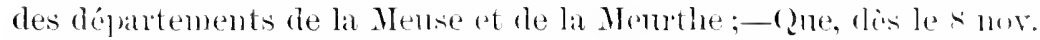
suivant, les acquérems rétrocédabent purement et simplement le bénéfice de leur marché anx siems Mohr et IIals, négoeiants a Man-

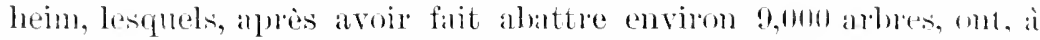
lem tom, transmis toms lemes droits an siem Ihatzfehl, de Nancy,

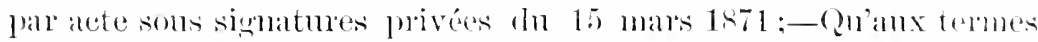

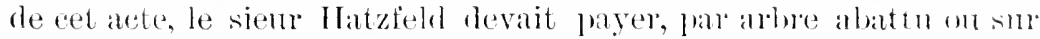
pied dont il prenchait possession, nom plus : thallus, mais fll hr. phus

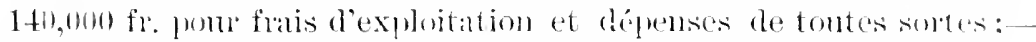
Quil versi 150,000 fr. comptant, et que, jour le smplus, il somsorivit

1 The same mule, says Dalloz, was enforced in respect to the colstoms laws: and even in that part of the ocenpied territory where the Germans collerotinl and appropriated the dinties.

" Les; introductions de marchandises faites en framlo anxiltes lois de domane

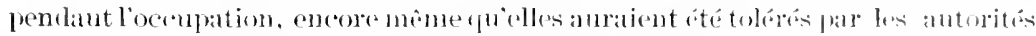
étrangères commamlint dans exs départements, sont poursuivies à bon droit apres le retahhssement du service de la doume framęaise." (Dilloz, 1s.2. II., 1s., notes 3 and 4. ) 


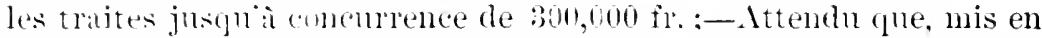
demente lexécuter les conventions par lui solscrites le 15 mars

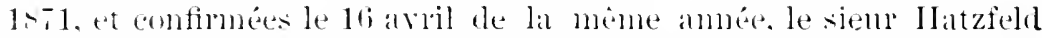
se refuse a cette exedution, en excipant de mulités gut la cour a,

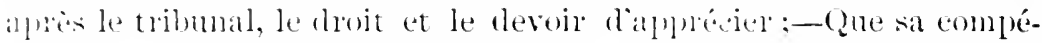

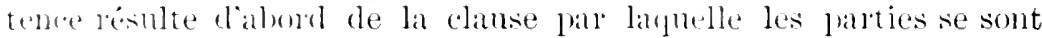

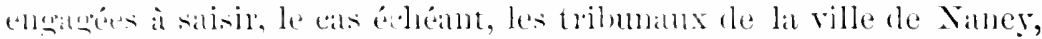

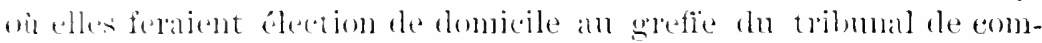

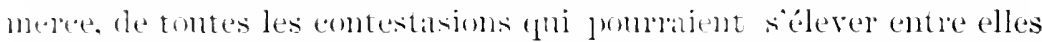

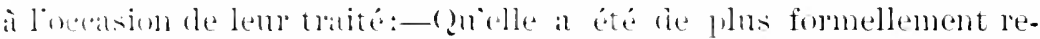

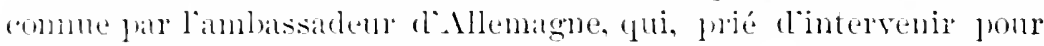

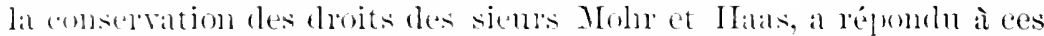
derniers, le sest. 1- 1 , an $130 \mathrm{~m}$ de son gonvernement, que 'l'affiare devait être jugee suivant le droit ejvil fraugais.'

- Attendu que la plemière et la plus délicute des questions a examiner et it lésondle est celle de savoir si le gonvernentent allemand

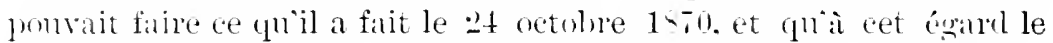
Aroit intemational, bien plus que le doit rivil, pose des regles in-

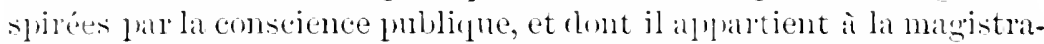

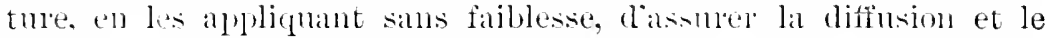

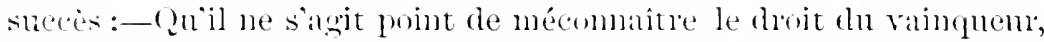
mais de le mainteniz dans les limites que lui assignent les précé-

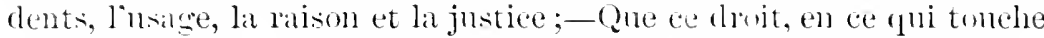
les immenbles, ne emsiste que dims la prise de possession temporalue

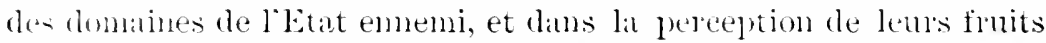

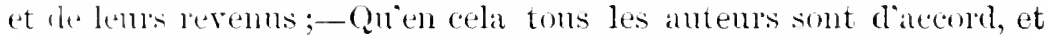
que deax des plus récents et des moins suspects, les célibres professemrs de licole allemande, Blumtselnli (art. 64b), et IIcffer. *** Quil fant donc proclamer que les fruitset les revenus des propriétés domaniales alplatiennent senls an vampuem, et que, lorsque celuici lispose lantre chose, il clispose de ce qui ne lui appartient pas;

- Attoum que, réchuito à ces termes, la question ne présente plus

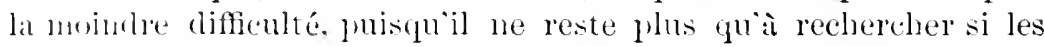

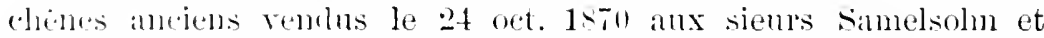
Silckür, fuis revendus le 15 mats 1801 an siem latzfeld, constituent

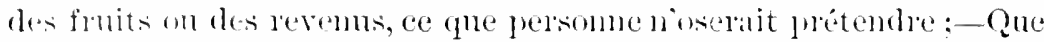

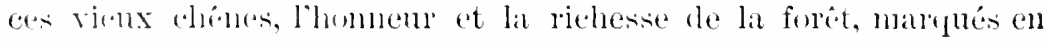

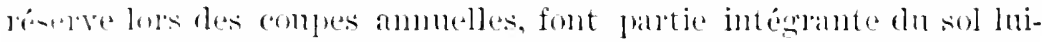

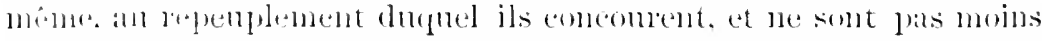

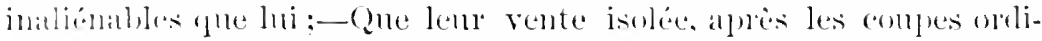

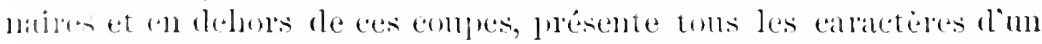
fait anomal, exceptionmel, et ne pellt soperere aux trines de liart.

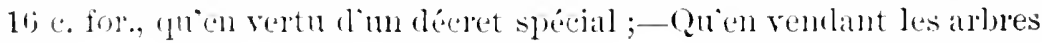




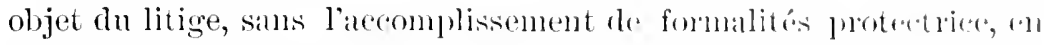
contravention a m aménagement répulior, le ante de Villers, ot

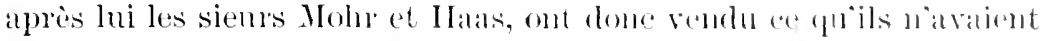

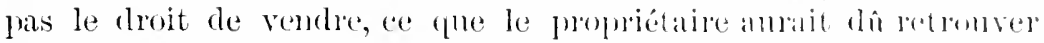

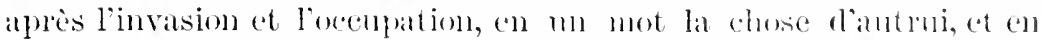
tous cas une chose qui nowat pas dams le commerer.

"Que le Gouvernement allemand lni-mîme a mont ló, pall som atti-

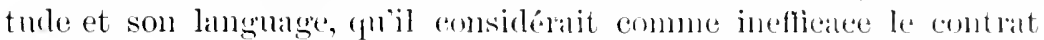

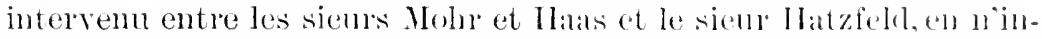
sistant pas pour son insertion dams le traté de faix, en refusint ensuite de prévenir par son intervention le ploces atefun, en laissant enfin sans un mot de léponse la déclaration suivant des plónipotentiaires franģais, eonsigné an protecole de signature de la romvention adudiomnelle au traité de paix (ln 10 mai 1871: ' l)es aliénations de coupes de bois dans les forets de l'Etat ont dé comsenties rumant la guerre, sur le territoire frangais, par les antorites civiles et militaires allemandes. A raison des circonstances an milien despluelles ont écé souserits les contrats passés ì ce sujet, le Gonvernement frangyis ne saurait, en ce qui le eoncerne, recomatre à ces comtunts ni valemr légale ni force obligatoire, et entend reponsser tonte responsalilité pécmiaire on autre que les tiers intéressés pomraient de ce chef vouloir faire peser sur lni ; - Que cette déclantion solemelle du Gouvernement frangais, non eontrerlite par les plónipotont inires allemands, a, an point rle vue du droit international, me inportanee dont les juges du droit civil sont antorisés à s'emparer, pour rendre plus manifeste eneore le bien jugé de la sentence frapréc d’appe];

"En ce qui touche l'alpel incident du siem Iratzfeld:- Ittendu qu'il ne suffisait pas de condamner les siems Mohr et IJals it restituer les $150,000 \mathrm{fl}$. par eux inchument regus; qu`il fillait aussi les comdammer ì payer une somme équivalente an profit que le sienr Inatzfeld aurait tiró de ce cupital, s'il ne s’en était pas dessaisi-gne sans cela les appelants s'enrichiraient an préjuclice d'autri, ce que ne permettent ni l’écinitó ni la justice;

"Par ces motifs, rejette comme mal foncle l'appel principal;-

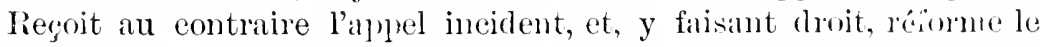
jugement de premiére instance en ce guril a refusé à Inatzfell tomte espèce de dommages-intérêts;-Condamne les appelants a palyer i l'intimé, à titre de dommages-intérêts, la somme de 11,601) fr., arrece intérêts a partir de ce jour, tinnt du caphital que de la somme allouré a titre de dommages-jntérêts;-Condamme les sieurs Mohr et Ilais à l'amende et aux frais, etc." 


\title{
VILLASEEQLES CASE.
}

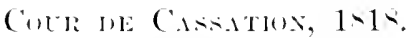

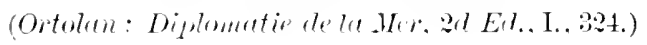

A crine committul hy a French citizen in spanish teritory. occupied and anministered by the French army. ledt. to be committed in a foreign country.

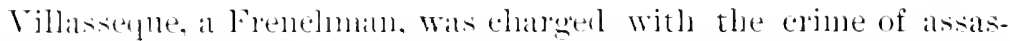

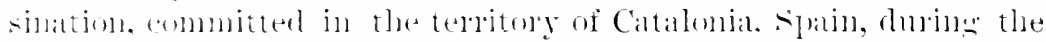
military oremplation hy Flance in the smmmes of 1-11. It was com-

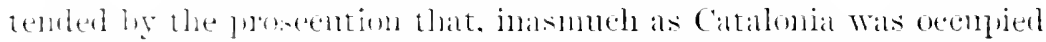

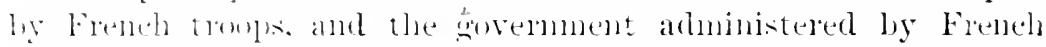
anthorities it must be emsintered as French territory. On alpeal

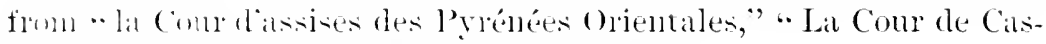
sitjon" jurnouncerl the following judgment:

. Attentu. . . . quen regle généble, le droit de poursuive un arme nappartient ynan magristrat du territoire sur legnel le crime

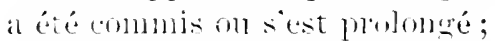

* Qne les semles exceptoms admises à ce principe par le code doinstruction criminelle sont renfermées dans les articles j, $\mathbf{b}$ et $\bar{\tau}$,

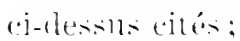

.. (gue la demande de Villasseque, tembante à ce que le crime porté

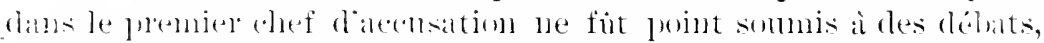

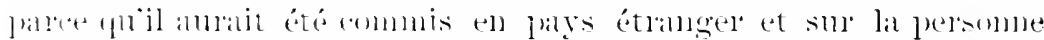

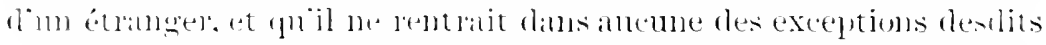

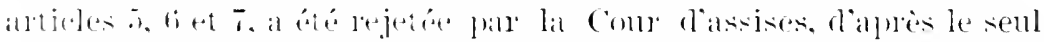

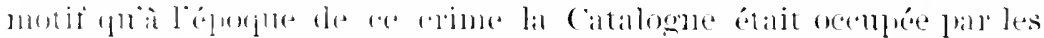

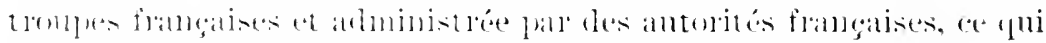

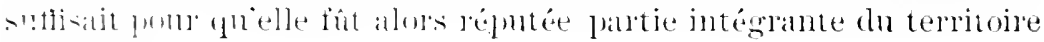
ilatirgatis:

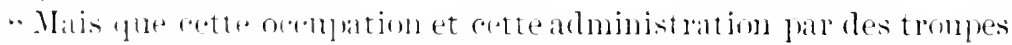

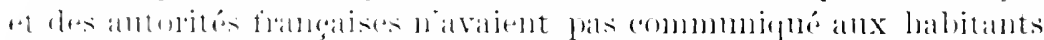

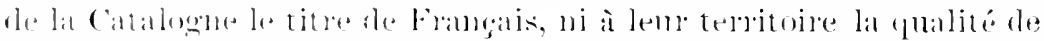

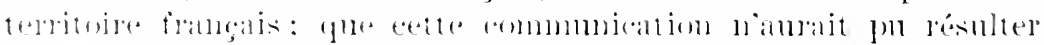

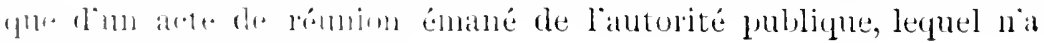
jannais existe; Catsot, etc." 


\section{TIIE ELECTOR OF IIESTE CASSEL.}

(Phillimore's Intermational Lar. III., 811.)

Hesse Cassel was contuered ly the first Nipoleon in 1sof, and remained for about a year under his immerliate control : when it was ammexed to the mew kingdom of Westphalia, and formed a part of that kingrlom till aftor the battle. of Leiprzig, in 1813 .

The question was whether dehts owing to the lilector were valielly discharged by a payment to Napoleon and reeciving from hin a cquittance in full.

The legal title of the Emperor was sot forth as follows:-

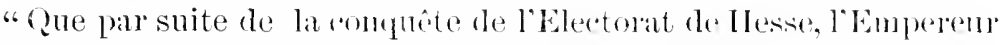

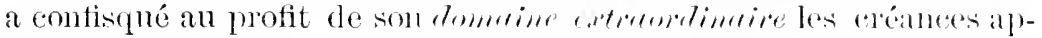
partenantes, soit an ci-rlivant Electem de llesse, soit anx btats ot provinces, dont il avait été pujs possession, et a déclaté, fu'il entendait, 'fu'aucm débiteur ne pût se libérer valablement qu'au tréson' dudit clomaine."

One of the rlebtors of the Elector was Comut von IIalun, a suljeret of Mecklenburg, and having lange estanes in that dnchy. The mortgage of these estates held by the Elector of Ilesse, Was duly rexistered in the proper office in Mecklenburg.

The Duke of Mecklenhmrg, at the instance of Naynoleon, issurel an order (circular Reseript), which, after reciting that Napwleon, leinds possessed of the sovereignty of Hesse Cassel, was possested, as an accessory to the principal, of the debts dne to that sovereign, directerl the Comrt of liegistration to recomed as extinguished thuse munterases in faror of IIesse Cassel, for which a particular discharge or receipt had been given by Napoleon, or by his appointee for that purpose.

The Peseript was dated the 15ith of Jume, 1810. It aplears that it was obeyed, but that a particular mimute of the cimemustanoe of the extinguishment of the mortgage was also recorded, so as in some measure to leave open the question of the lawfulness of the dischande.

The affairs of the Comnt beeme embarrassed, and after lis death creditors elamed his property; among them was the restoled l'rince

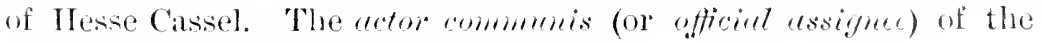
creators bromght the question into eomet.

The Mecklenburg cont of justice at Gïstrow first entertained the question. The Prince denied hoth the valiolity of the discharge and the legality of the Mecklenburg order of 1810 , and assered that Jit 
poleon possessed libuself of the money in the character of a robluer,

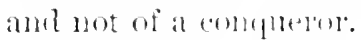

This matter Was then remitted to the Prussian Iniveleity of Bres-

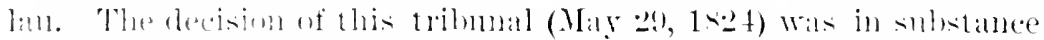

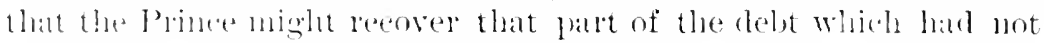

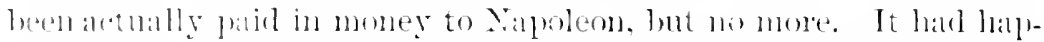

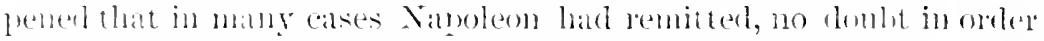

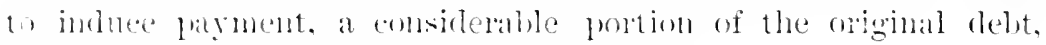
giving, howeres, a discharge from the whole.

butl, parties, heing alisiatistied with this judgment. appealed to

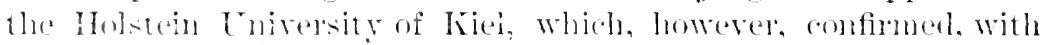
some difference as to the costs, the senteree (March 2t, 1s:31). But

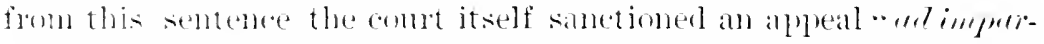

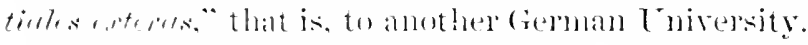

This leamed horly (name not givon) delivered at great length the reasoms of their julgment.

They lighty silul that the real question was, whether Napoleon had. or land not, become the true creditor of the Ilesse Cassel funds. They drew a hroad distinction between the valielity of acts dome hy a mere transient conqueror and acts dome he him after the kinglom had been wholly suluhed, and the smbjects had either expessly, ol by necessiry implication, accepted him as their mor.

In the formor case the conqueror's right was confined to the effects of his private acts, to the oremgention hellien, and reguiled actual scizme and pusession for its valiul exercise.

In the latter case the rights and title of the conqueror hat been ratified by the publie aet of the state. As Napolenn's right and title Was of the latter lind, the fact that these fumds were the juivate luoperty of the I'rince, and not the pablie juoperty of the state, hrams of mo importance. They rejecter the consideration of the justice or injusti of of the war which Sapoleon had waged against the Jrince, wisely holding that the presmotion of law, upon which they were homel to act, was in farom of its justice. Sor did

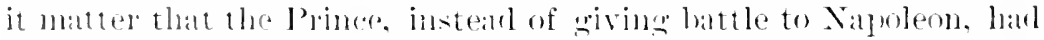

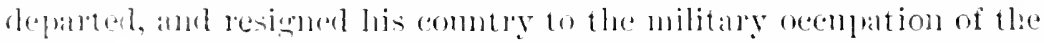
ancmy. They pointer ont that the l'rince hade from the time of his departure or aluliation. heen an active enems of the new government established muler Napoleon and Jerome, and that, ly the latws

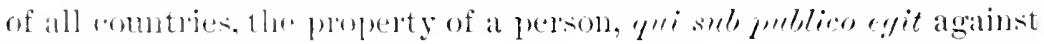
the state, wats comtiscalle.

They dejected the duetrine that, hecamse the Jrince harl retained possession of the instmments containing the witten acknowledgunents of the dehtors, he therefore had comstructive possessiom 
of the dehts, the circmmstances being ansideren moler which the

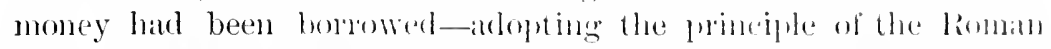

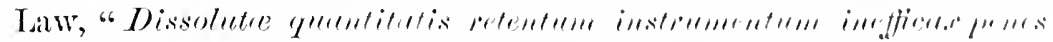
creditorem remanere * * * mon ast nmbigni,juris."

They considered how the guestion was affereled hy the letmrn of the Prince, and hy his rectamation of his former property, and they held that the principle of the decision of the Amphictyons in the case of the Thebans and Thessalians was somed law, and that it hat been so treated by almost all jurists, ancient and molem.

They ensidered the senelal duestion whether, after peace, there did or did not take place a rostitution in integrem with resperet to those who had been dispossessed by war. They held that, even according to the letter of the loman Law, the restored omer must talie the property as he fomd it, and was entitled to no compensation for the damage which it might have suffered in the interval; that what was actually gone he eould not claim to have replaced ; and especially that what the public exchequer (fiscus) had alienated was not to be restored.

That as to such alienations the prineiple of all law, whether private, publie, or international, was expresserl in the words of the

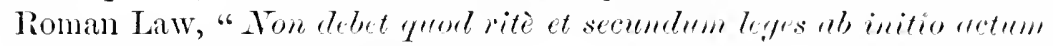
est, ex alio eventu resuscituri."

It was impossible, these jutges observed, to consider the return of the Prince as a continution of his former govermment.

He had not been constantly in arms against Napuleon, and at last successful, by force of arms, in recovering his domains. He hath been treated by the peaces of 'Tilsit and schönlmum as politically extinct, and the King of Westphalia had been recognized by the continental powers as Regent of llesie Cassel.

They remarked that the Prince's own tribmals of IIesse Cassel had pronomeed (Jume 27,1818 .) that those suljeets of the King of Westphalia who had paid to him or his excheguer their debts, and received due dischurges, condd not be legally called upon to pay a second time; and they thought the principle of that decision, as wetl as the anthorities which they had referred to, led them to the jurlicial conclusion that all the debts, whether the whole smm had heen paid or not, for which discharges in full had been given ly Napoleon, were validly and effectmally paid; and they, therefore. so far, reversed the former sentences, leaving, it should seem, both parties to pay their costs. 


\title{
OCCLPATION OF N.MPLES BY CHIRIES VIII., 1495.
}

\author{
(Phillimoris International Lan. III.. :3s.)
}

May citizens lexally discharge the debts which they owe to the sovereign by laying the amount to the temporary conqueror or military occupier of the terrirory of the state:

In the year 1ta.), Charles the Eighth of Fance overuan Italy, and reflacerl for a monent the IJouse of Anjon mon the throne of Naples. During his brief tenule of that lingolom the French king

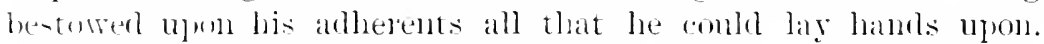
Amonest other devices for empielnime the Angerin party, that of cilling in dehts due to the state from the opposite faction was arlinted. Hany of these debtors gaid homestly the finl anount of their doht. Some tried to drive a haranin to their advantage, payins omly a fortion of their delot, and olutaining a receipt for the whole. Fome comblived to pay nothing. and obtain a witten dischares from everghing. Four months afterwark. when the French king. with the Angevins, was driven ont. and Ferdinand, with the Arlatumese. Wats restored, the question as to the validity of these filyments and receipts was sharply contested. Amomgother jurists

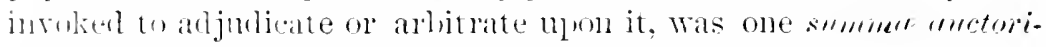

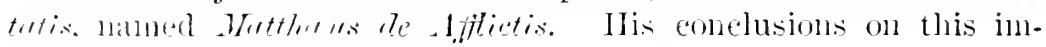
fortallt smijecet are as follows:-

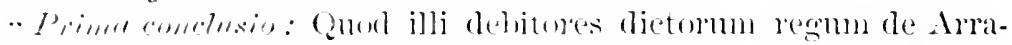

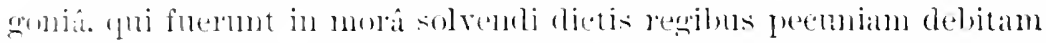

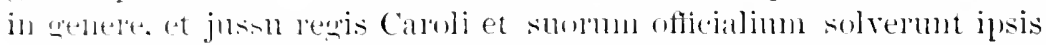
domatarijs, guom mon sont liberoti, et tementur solvere dietis regibus, veris orerlituribus.

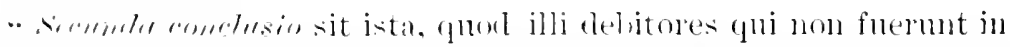

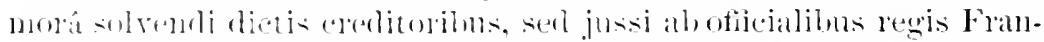

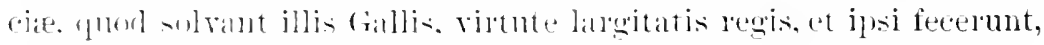

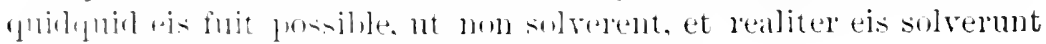

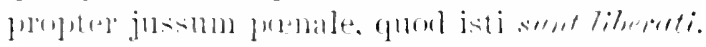

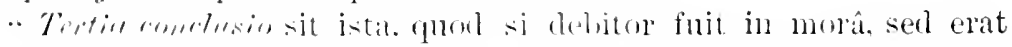

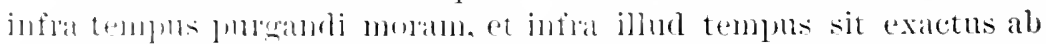

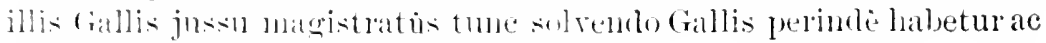

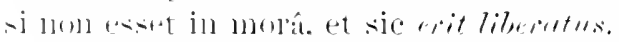

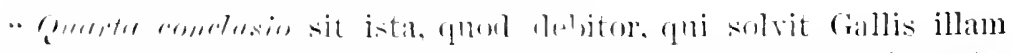
peeunian delitam regibus de Arrageniâ virtute jussub magistratus, 


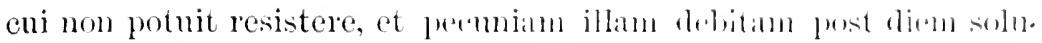

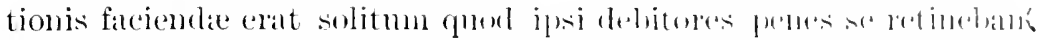

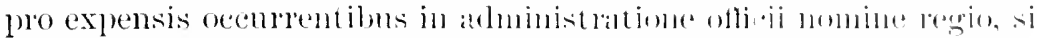

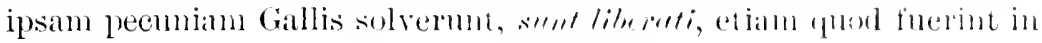
mor'â.

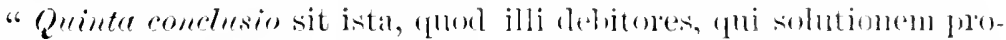
bant per confessionem Gallormm philicam rol privatam, ita, ynow

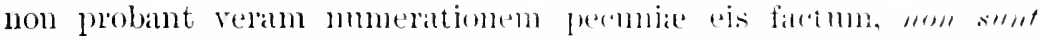

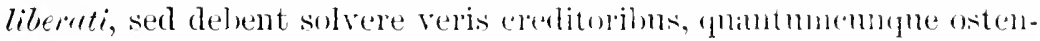
derint dictum jussimn.

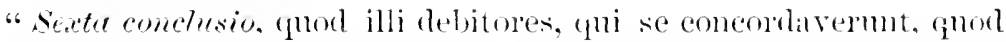
si non ostendunt veran solutionem in totum vel in partem, non sunt liberati.

"Exitus rei approbavit istas conclusiones."

SECTION 39.-Tervixitux of W.M.

TIIE " MENTOI:."

\section{Higil Coent of Ammirhets.}

(1C. Robinson. 179.)

Hostile acts committed after the conclusion of peace are illegal: and the injured party may sustain an action for lamages against the wongrloer. But if an officer conimits such act in ignorance of the ending of the war, his own government should protect him.

The following is an extract from the judgment of sir W. Scorr :-

"The circumstances of the case, as fall as it is necesialy lo state them, are these: The ship being .merican property, was on a royage from Itavamah to Philadelphia, in 1783; off the Indaware she was pursued by ILis Majesty's ships, the Centmion and the Fulture, then cruising off that liver, under the command of the almiral on that station, Admiral Dighy. All parties were in complote ignorance of the cessation of hostilities; not only the persons on board the King's ships, but the Americuns, as well those on the -lowe. as those on board the ressel. In the pursuit, shots were fired on both sides, and, it is alleged on the part of the briti-h, that the ship was set on fire by her own crew, who took to the shore.

" Now, I incline to assent to Dr. Lawrences positin. that if an act of mischief was done by the King's ofticer's, though through ignu. 
rance in a place where no act of hostility onght to have been exer-

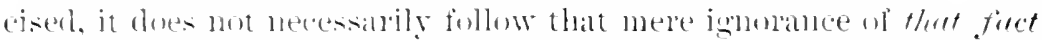

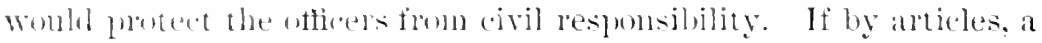

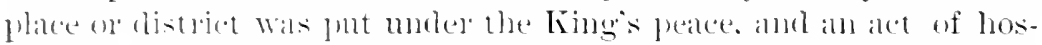

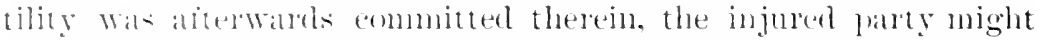
have a right to resort to a comet of prize; to slow that he had been injured hy this breach of the peatee amd wats entitled to combensa-

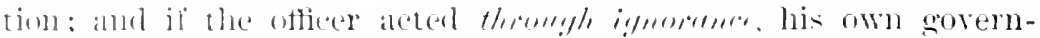
ment must loweret him: for it is the duty of govermment, if they jut a cotain distriet within the Kings peace. to take care that due notice shall be given to those persoms ly whose conduct that peace is to be maintained: and if mo suth notice has been given. nor due dilinence nsed to give it, and a breach of the peace is committed though the ismoramee of those persons, they are to be borne hammless, at the expense of that govermment whose duty it was to have given that nutice." 1

\section{THE "XYIPH."}

Cosseil ines Pisses, 1801.

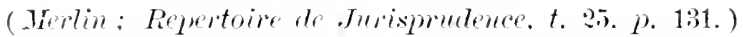

It was stipulated by the Peace of Amiens. between England and France, that twomonths should be allowed for the news of the close of the war to reach their repectivecturers in the West Indies. A British vessel was captured before the two month-hallexpiresh. hut after news of the peace had reached the captors. coning. howerer. through British sources. The ship was restored.

The Nympll, abitish vesel, was captured hy the privateer

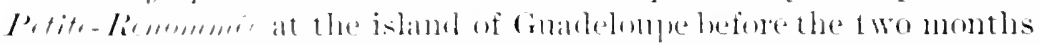

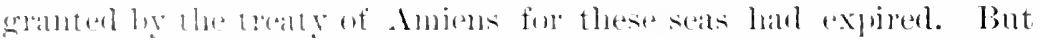

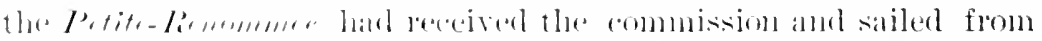

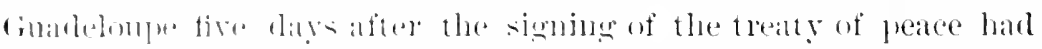

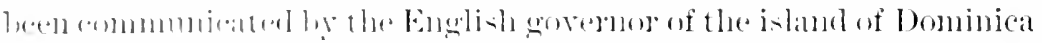

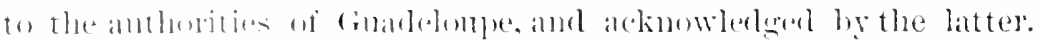

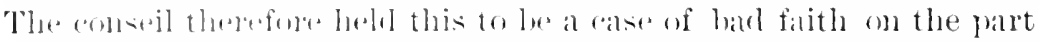
af the captor": and although juformation of peace was enmmunicated

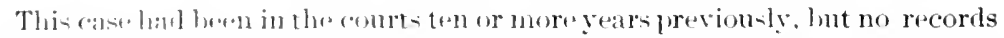

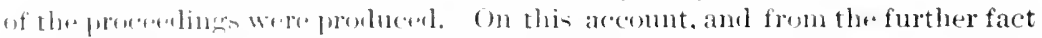

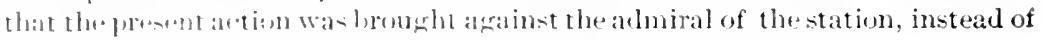
arainst the actual wrongeloer, the court refused to give relief. 
by the enemy, it was suffeient to stop any argesesive acts ol wall

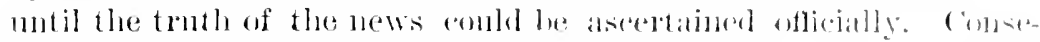
quently the. lymph was destoged with damages.

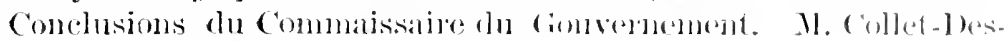
cotils:-

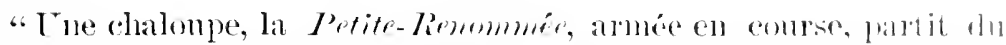

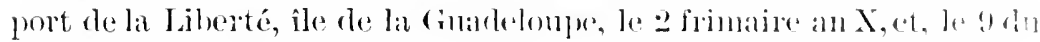

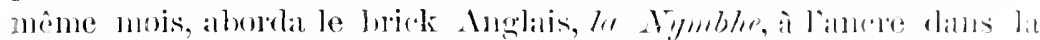
rade de lile de faint-Christophe, compa son cible det lenlevit.

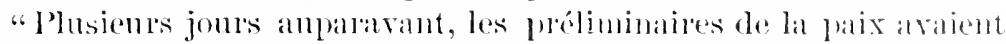
até publiés dans les îles Anglaises de eres parages ; le apitaine de lat flégate Anglaise, le Timer, avait cuvogé um parlianentaire a la Guadelompe pour en domer la nomvelle, qui etait confirmide con meme

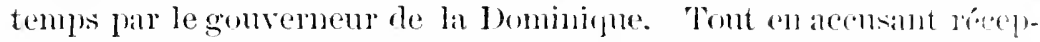
tion de ces denx commmications an gonvernement Inglatis a lat date du 2t hrumaire, le mulitre P'élage qui avait usmpé le gonvernement militaire de la Guadelompe, se hita d'expédier des pomvolis i des corsaires, qui mirent immérliatement à lit mer, dams le dessein de profiter de la sécmité des Anglais. Lne decescommissions, délivrón.

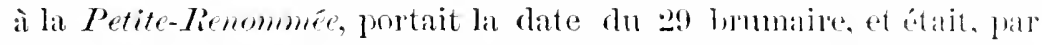
conséquent, postèrieure de cinq jours a la réponse de l'álage. I bus sa protestation contre la capture, le capitaine Inglais derlara que la

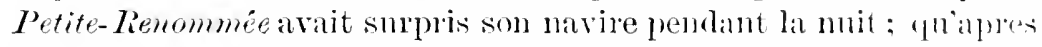
avoir conpé son câble, les corsaires étaient montós a bond wis tont l'equipage dormait, et avaient usé de lems armes, quoiqu ambom des Anglais ne fût armé; qu’ils avaient pillé lóquipage, ainsi que les marchandises de la cargaison.

"Par déeision dn 2t frimaire an $\mathrm{X}$, le commissaile de la marine an port de la Liberté, assisté du enntrîlenr de la marine et do sonscommissaire chargé de linscription maritime, prononģa la confiseation du navire et du chargement, qui furent vendus, et dont le prolnit fint versé à la caisse des invalides de la marine jusqu' à ce qu’il fut statué définitivement.

"sur lappel porté devant les Conseil des prises, le prucurempánéral conclnt á l'annulation de la prise. Les armatenrs a vialent allexpme quion ne devait reconnatre comme nouvelles de la paix que les numvelles officielles, e'est à dire émanent dn gomvermement ; qur. salls cela, on serait exposé à devenir vietime de la luse des emmemis et re la confiance qu'on aurait ene rlans me fansse nomvelle.

"C'est se tromper etrangement, dit M. Collet-Iescotils, commissaire du Gonvernement, que de confondre la perficlie ave la ruse; et ce serait une perfidie dont il n'est point d'exemple dans lihistoire des nations de l'Europe, qu'une fansse nonvelle de paix, dommée 
offirdelement bar des commandmants militaires dime nation arec

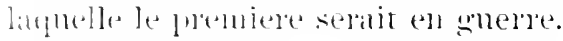

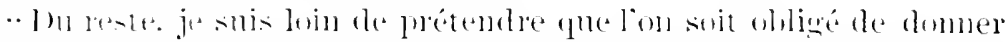

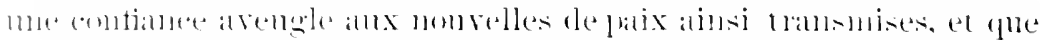

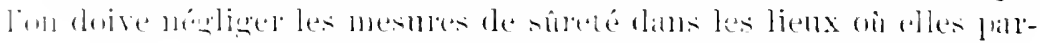

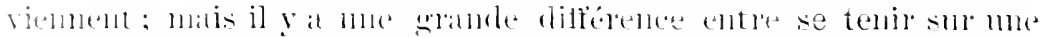

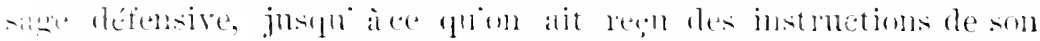

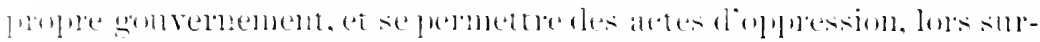

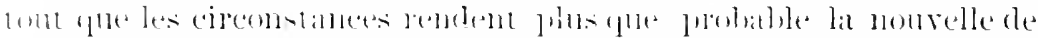

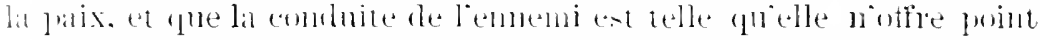

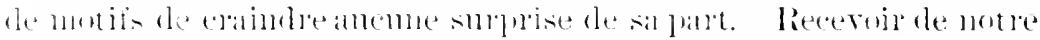

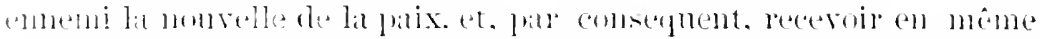

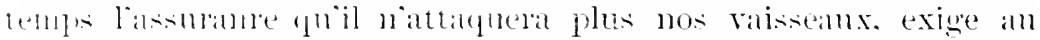

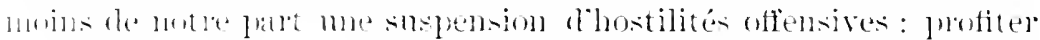

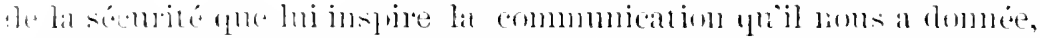

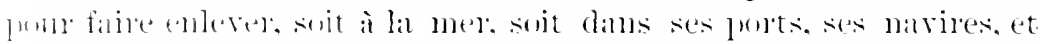

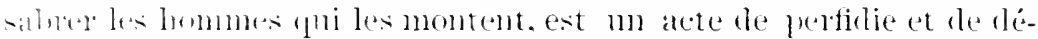

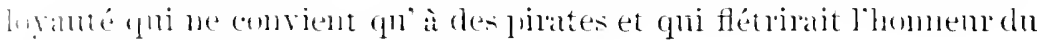

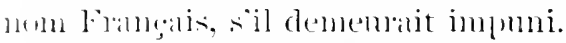

- Les anmatems do corsalire ont encore pretendn que tonte prise

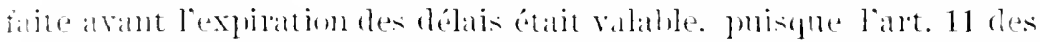

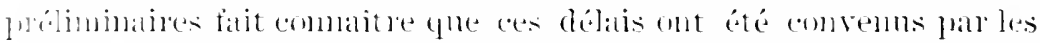

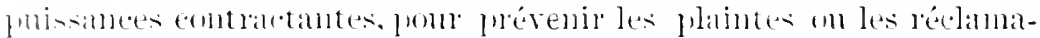

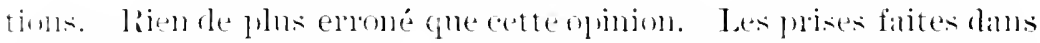

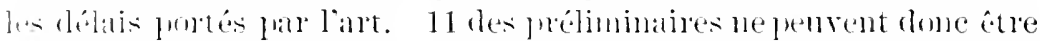

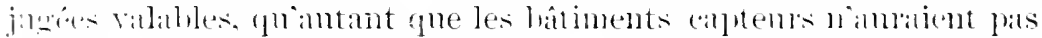

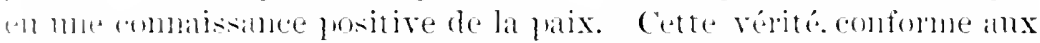

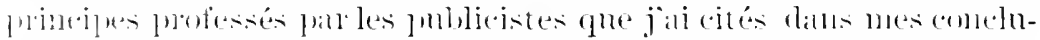

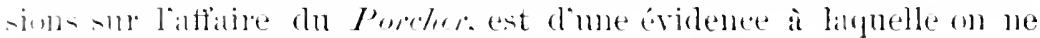

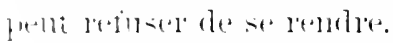

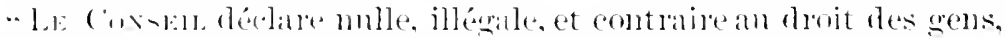

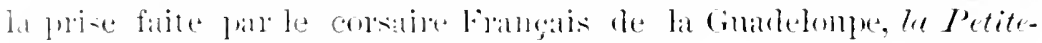

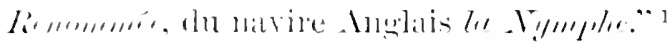

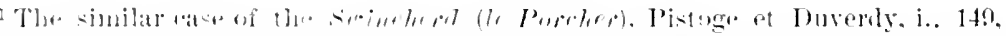

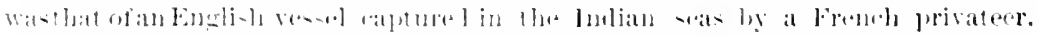

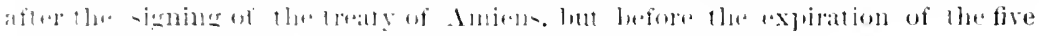

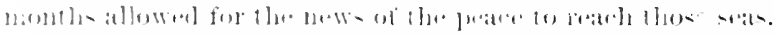

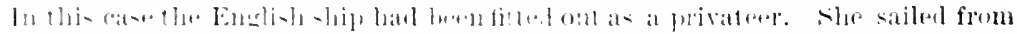

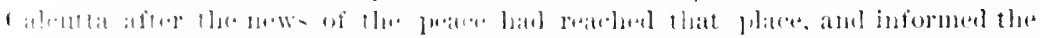

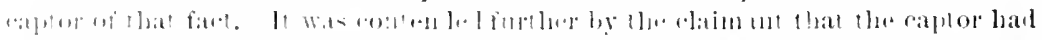

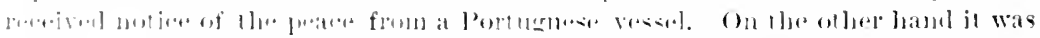

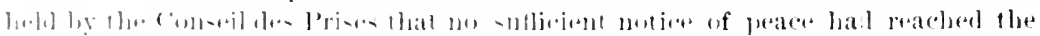

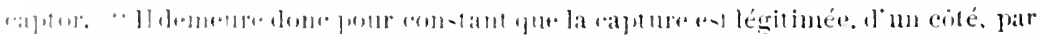

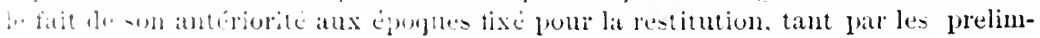




\title{
"THE "TJE'T's."
}

\section{Constu, DES Plases, 1 Sol.}

\author{
(I'ixtoye et burerly, I., 14s.)
}

A ressel captured botwen the dates of the signine of the foreliminary treaty of

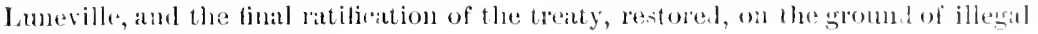
capture in lime of peace.

"Ia capture de lo Thétis avait éte faite le s mans, 1sol, vingtneuf jours apres la signature du traité de Lumeville, qui est hu!

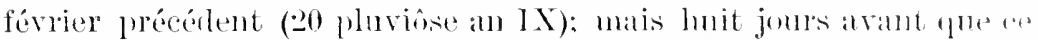
traité fût ratifié, cépni a en lien le 16 mars, 1801 . Qnant à la publiation, elle est do 19 mars, 1801 .

"Le commissaire du gomvermement a conclu de ces fats qu' i lópoque de la capture nous étions en paix avec la phissince sous lo pavillon de latuelle voyageat he Thetis, navire antrichion.

"Dire que le traité de Laméville n'etait pas encore ratití, et pur, par consequent, il ne ponvait pas encole avoir som exention, cest sontenir me proposition vaiment lérisoire. Sams donte, mu trato ne devient définitif entre demx puistances qu'aples la ratification; mais le senl bon sens noms dit que, pom parvenir à eette ratification, ehaque puissince respective est intéressee it exeenter sur-li-champ les clanses de ce traité, sans qu' un alete de cette nature, lien blus

inaires que par le traité de paix ; de l'autre par le défaut de commaissunce sntlis-

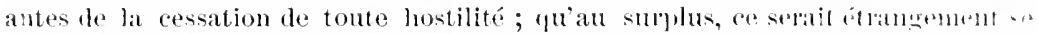

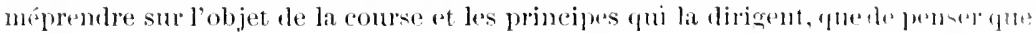

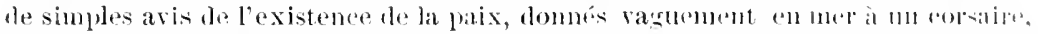

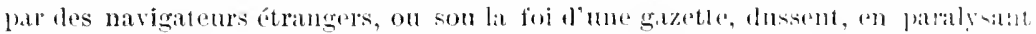

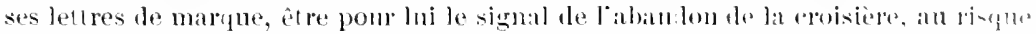

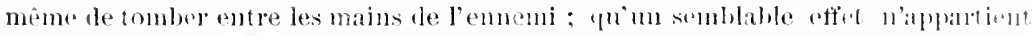

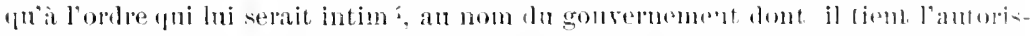
ation formelle de ealuturer; que si cependant la communicalion de lat paix hui

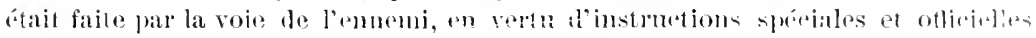

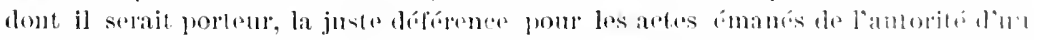

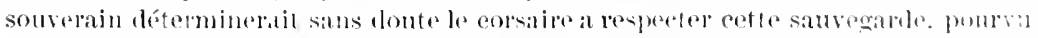

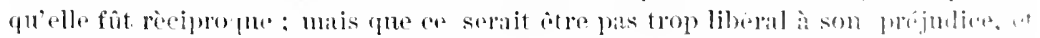

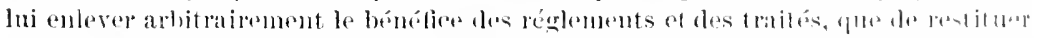

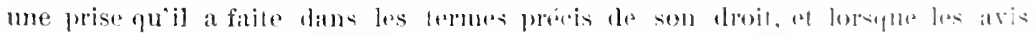

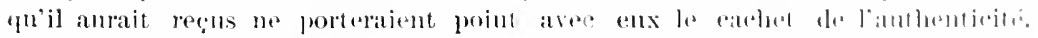
et rnoore le crage de sa sécurité particulière." The ressel wats therelore con ciemneil as latwful prize. 


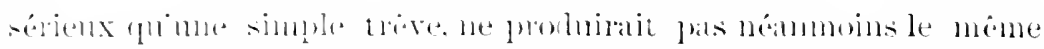

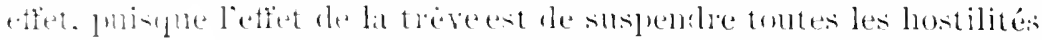

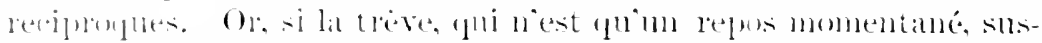

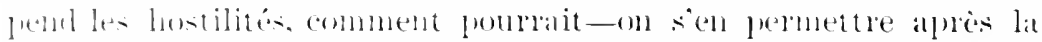

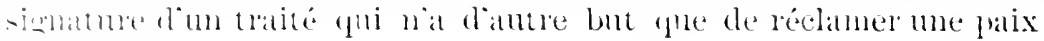
diurible:

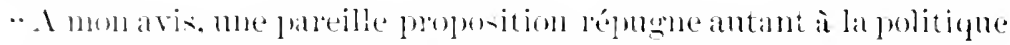

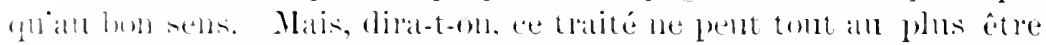

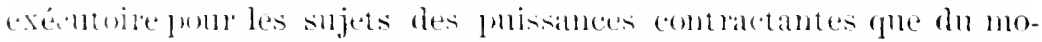

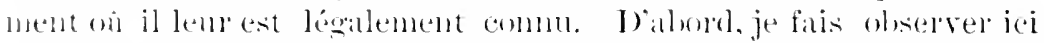
fue le traté dont ast cats ayant mo existence de vingt-nent jonls a

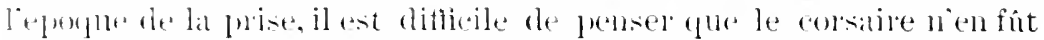

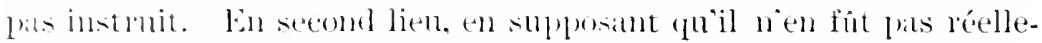
nent instruit quen résulterait-il: Rien. sinon yne sa bonne foi le

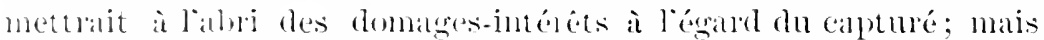

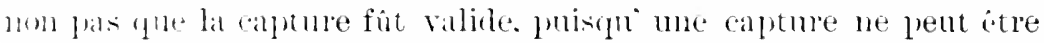

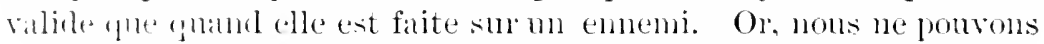
fas qualifier demnemi celni avec lepuel nomsaroms signé mu traté de

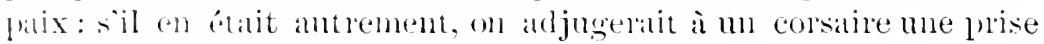
yne le gromremenent serait ollige de restituer.

- Matis, a-t-on dit eneore, la carratison doit an moins eneore être rombe ennemie: $1^{0}$ pare quelle comportatit des objets de eontrelambe; - jorec quelle était destinée pour des emnemis.

- I cela, je crois devoir falire olstrver: $1^{\circ}$ yne prom qu'me carcalison soit réputée de contrelande, il faut que les objets prohibés

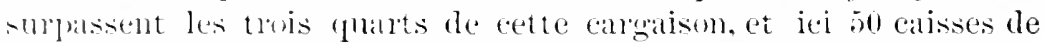
fusils sest tomveres confondues entre 120 caisses de vitriol et me

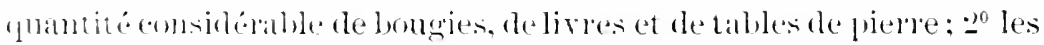

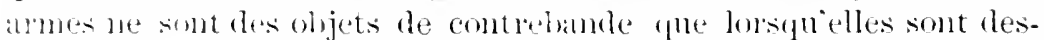

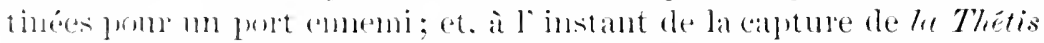

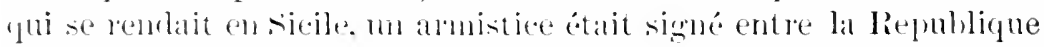

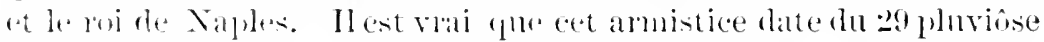

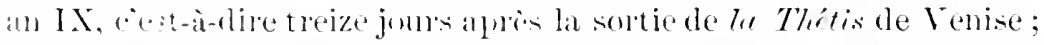

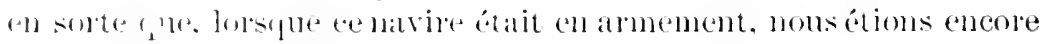

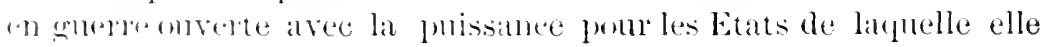
$\therefore$ talit destinios.

- Maris, ombro que reserait vaiment mo question que celle de

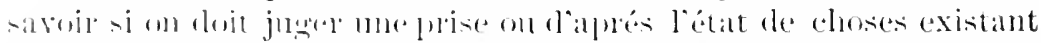

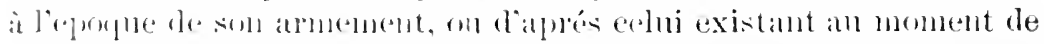

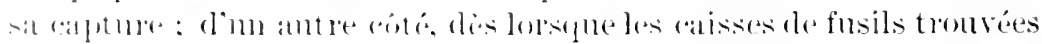

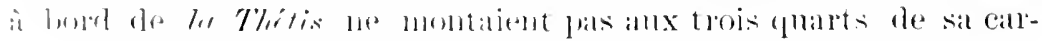

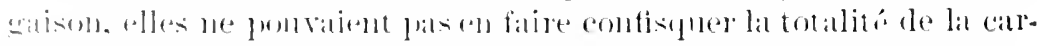

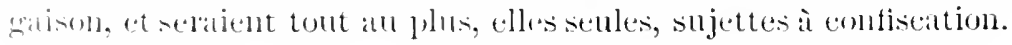




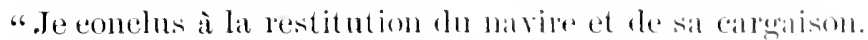

"Dn 7 ventose an IX.-Decision du conseil tes prises, qui invaliele la prise de le Tlétis."

\section{TIIE " Plio'TEC'TOli."}

Supheme Coflet of the liviten Sithtes, 1871.

$$
\text { (12 Hallace', 700.) }
$$

The beginning and termination of the civil war in the Unitod states in reference to statutes of limitation, is to be determined by some public act of the political department.

The war diel not begin or close at the sane tine in all the States.

The question in this ease was whether the suit was barrol by the statute of limitations in Aalsama. As the statute did not run doring the period of the war, it was necessary to determine preeisely the dates of begimning ant end of the war.

Judgment,-CuAsE, C. J.:-

"The question, in the present ease is, when did the rebellion locgin and end? In other words, what space of time must be comsintered as excepted from the operation of the statute of limitations by the war of the rebellion?

"Acts of hostility by the insurgents oecured at periods so varions, and of such different degrees of importince, and in parts of the country so remote from each other, both at the commencement and the close of the late civil war, that it would be difficult, if not impossible, to say on what precise day it began or terminated. It is necessary, therefore, to refer to some public act of the political departments of the govermment to fix the dates; ant, for obvions reasons, those of the executive department, which may be, and, in lact, was, at the commencement of hostilities, obliged to act during the recess of comgress, must be takell.

"The proclamation of intended blockate by the l'lesident may, therefore, be assumed as marking the first of these dates, and the proclamation that the war had elosed, as marking the second. but the war did not begin or elose at the same time in all the states. There were two prockanations of intenderl blockate: the first of the 19th of April, 1 s61 (12 stat. at Large, 12.s), (mmbrating the states of South Carolina, Georsia, Alabama, Fhorial, Mississippi. Jonisiana and Texas; the second, of the 20th of Aplil, litil (1:2 stat. at I.., 1259), embrating the States of Virginia, and North Carolina; and 
there were two pondanations declaning that the wath had closed one

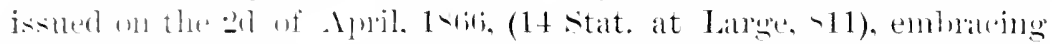

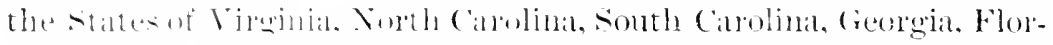

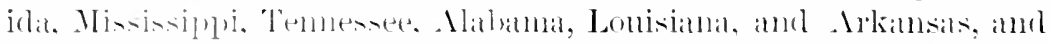

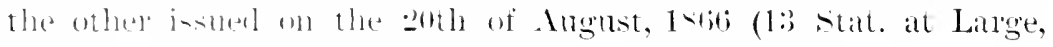
s1.t), embratcing the statte of 'Texas.

"In the absence of none certain criterial, of efually general application. We most take the dates of these froclanmations as ascertaning the combencement and the close of the wat in the states mentioner in them. Alplying this rule to the atse hefore as, we find

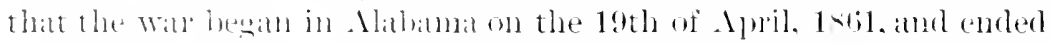

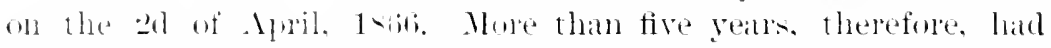
elapsed finn the close of the Will till the 17th of May, 18T1. When this anpeal was bromght. The motion to dismiss, therefore, must be

. Glanted." I

1 See Bromen r. Hiutts. 15 Wallace. 1\%i.

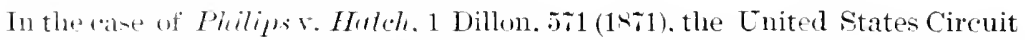
Comet for fowa held that a contract entered into in the spring of 1866 between a resielent of the state of Iowa and a resident of the State of Texas, was void as a contract between enemies. 
CIIAP'TELi III.

RELATIONS BETWEEN BELIIGERENTS MND NELTRALS.

Section 40.-Bellaghext Comple in Neltral Maters.

\author{
TIIE ". INXI." \\ IIgh Colet ois Ammenty, 1805.
}

(5 C. Robinson, 373.)

The capture of the ship of an enemy in neutral waters is illegal : and the ship will be restored by the prize cont of the cal ror.

Territorial waters extend three miles from the shore, or flom inlands near shore.

This was the case of a ship under American colors, with a cargoof

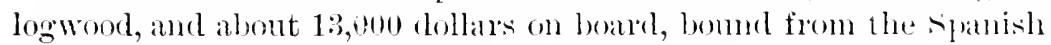
main to New Orleans, and captured by the Miremere privaterlente the month of the river Mississippi. A elain wats given moler the direction of the Anerican Minister for the ship and carow, as taken within the territory of the United States, at the distance of a mile and a half from the western shore of the principal entrance of the Mississippi, and within view of a port protected by a gmu, and where is stationed an officer of the Tnited states.

The following is an extratet fom the jombment of sir W. sorro:-

"When the ship was brotght into this comntry a chaim was wein of a grave nature, alleging a violation of the territory of the Cuited states of America. This great leading faet has very ponply lowen mate a matter of much discossion, and charts hatre been latil hefore the cont to show the place of capture, thongh with ditionent repressentations from the atrerse parties. The capture Mas mathe it seens, at the month of the river Mississippi, and, as it is contendel in the elaim, within the lommlaries of the [nited statter. Wr all

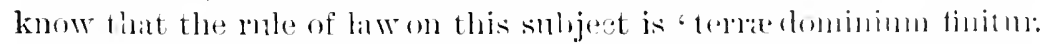
ubi finitm armormm vis, and since the introthetion of fire-inms 
that distanee bas nswally been recongized to be abont three miles form the sluoe. IBut it so happens in this eatse, that a question

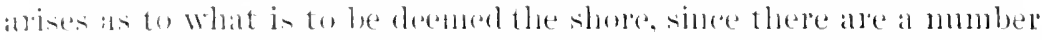

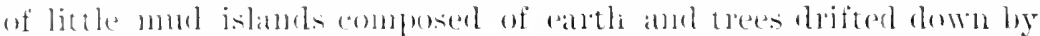

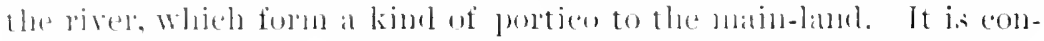
tember that these alle not to be comsidered as amy part of the terri-

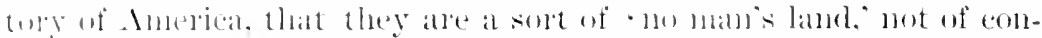

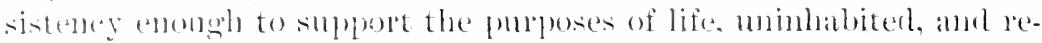

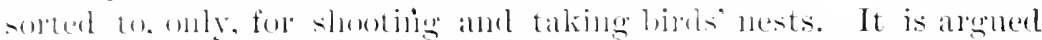
that the line of territury is to be takese only tom the batise, which

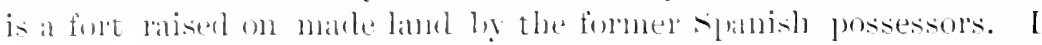

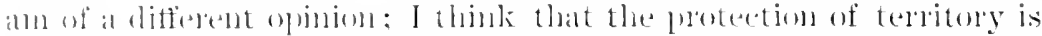

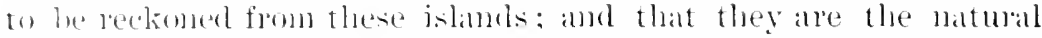

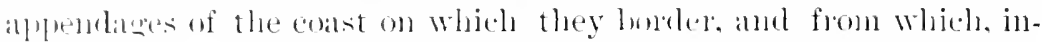
dererl, they are formed. Their elements are derived immerliately

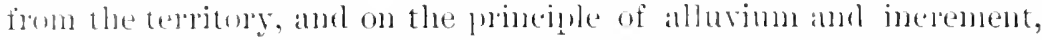

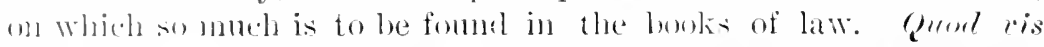

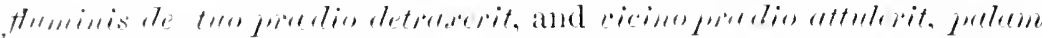

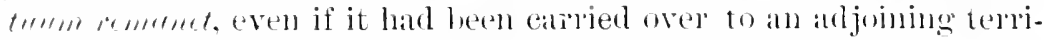
bory. Comsider what the eomsequence would be if lands of this deserintion were not considered as appendant to the main-land, and

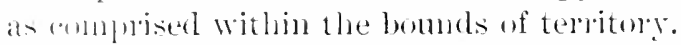

- If they do not belong to the Enited rtates of Americal, any other jower might oeewy them; they might be embanked and fortitied. What a thern womld this be in the side of Anelical It is physi-

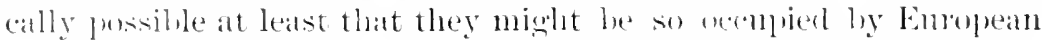
nations, and then the eommand of the river wonld he no lomeser in

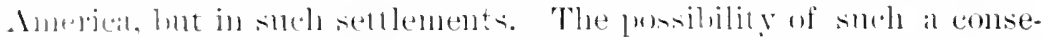

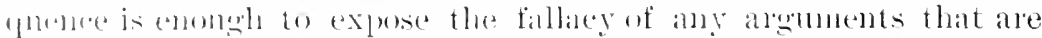

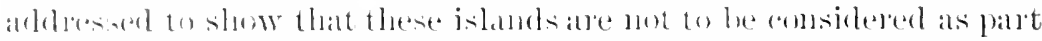

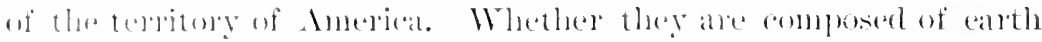

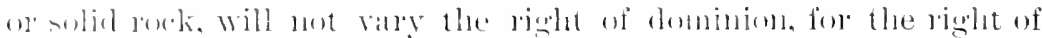

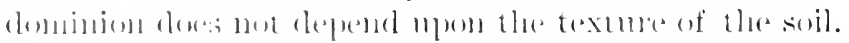

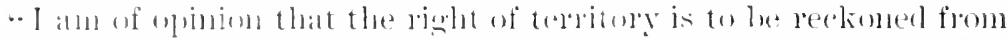
thore istands. 'Phat heing established. it is not denjed that the

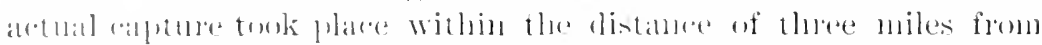

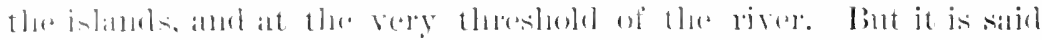

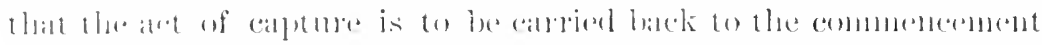

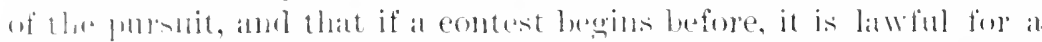

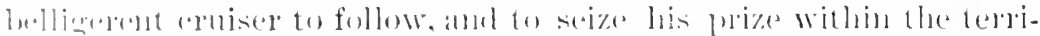

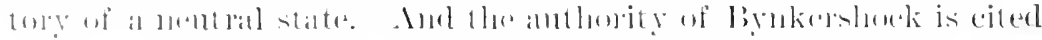

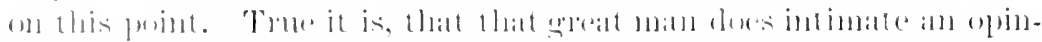

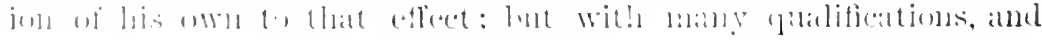




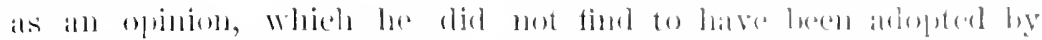

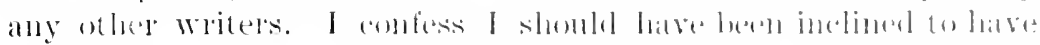

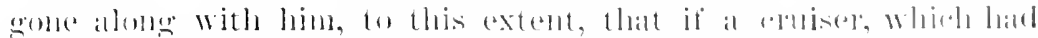

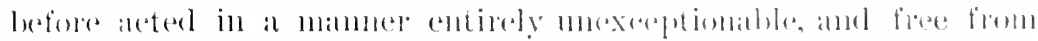

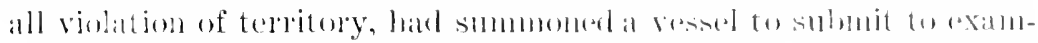

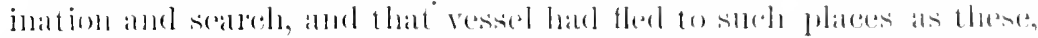

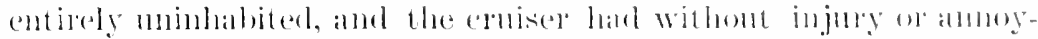

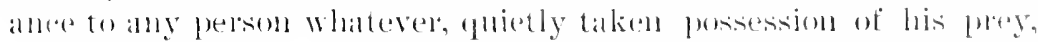

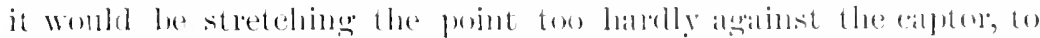

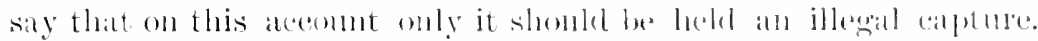

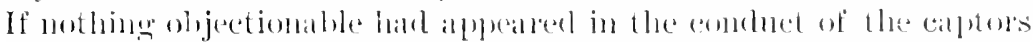
hetore, the mere following to smole a plater as this is, would, I think, not invalielate a seiznre otherwise just and haful.

"lint that hings me to a palt of the case, on which I and of opin-

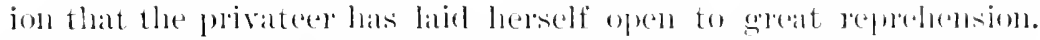
Cantors must mulelstam that they are not to stat ion themselves in

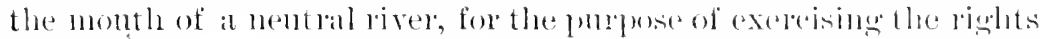
of war from that rivel, mole less in the river itself. It alpleats from the privateer's own log-hook that this vestel hats flome both ; and as to any attempt to sheltel this combluet moler the exampln of ling"s ships, which I do not believe, and whidh, if trur, wombl be no justification to ofhers, eaptors most, I say, be admonished, that the practice is altogether incletensible, and that if Kinges ships slould be guilty of such misconduct, they would be as much subjeet to censure as othel aruisers.

"It is munecessary to go over all the entries in the log. The calp-

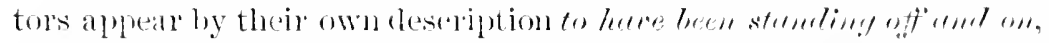
ohtaining information at the Balise, overhatuling vessels in their comse rown the rivel, and malking the liver as mong smbervient to the purposes of war, as if it had been a rivel of their own eomotry. This is an inconvenience which thestates of America are called npm to resist, and which this court is bound on every principle to discourige and correct.

"With respect to one vessel, it appears that the Bilmon. muler

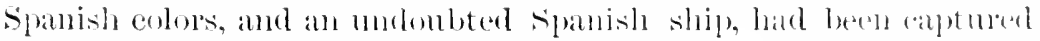
and callied into the river ; and it was stated in an affichrit which Wats exhibited to aceomet for the alsenee of the usmal wilnesses in

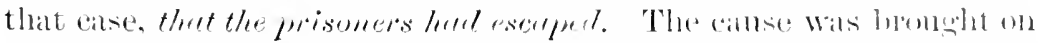

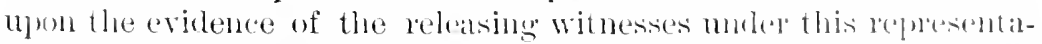
tion. It now appealis by an entry in this loge, thet the furismens

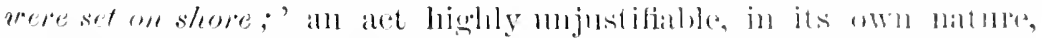

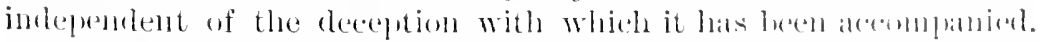

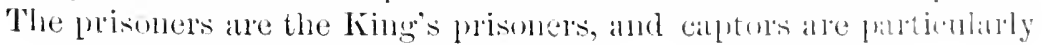


enjoinel hy the instrotions not to release any prisoners belonging

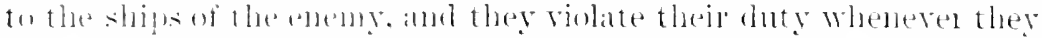

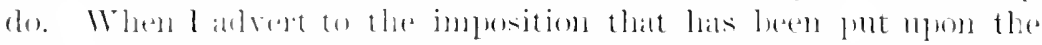

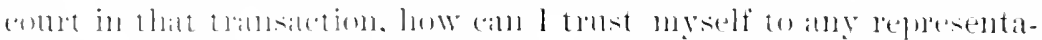

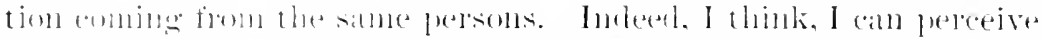

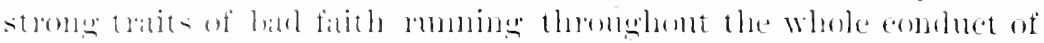

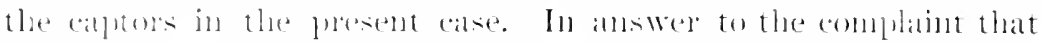

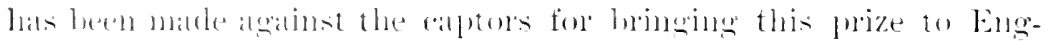

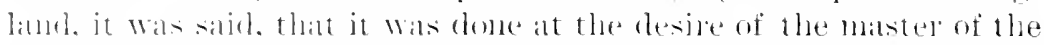

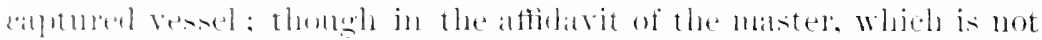

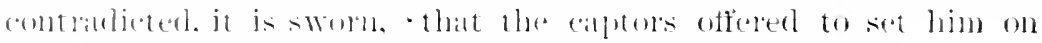

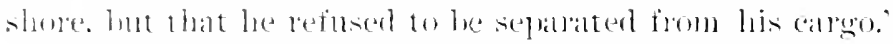

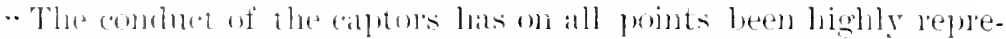

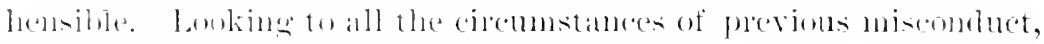

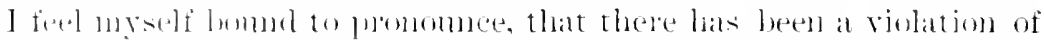

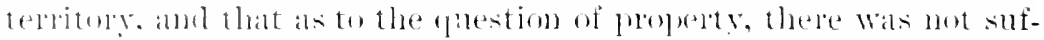

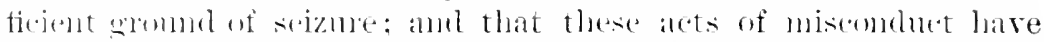

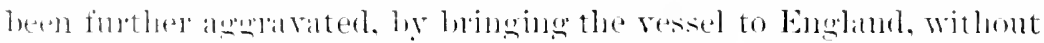
aly neresity that can justify such a measme. In such a calse it womlel he talling short of the justice due to the riolated rights of Anerica. and to the indiviluals who have slstabed injury by such miscomduct. if I did not follow up the restitution which hats palsised wh the former day, with a decee of costs and damages."

\section{TIE "GENERIL ARMSTIRONG."}

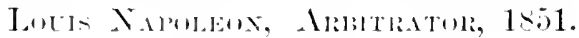

(? Hhertonis Digest. Got.)

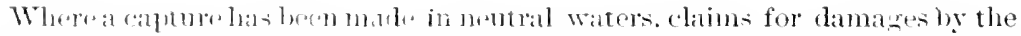

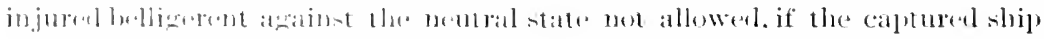

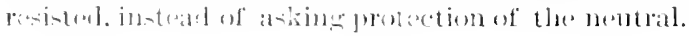

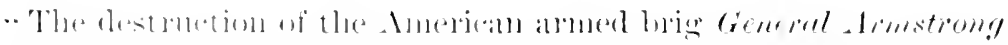

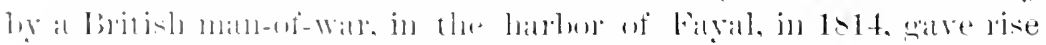

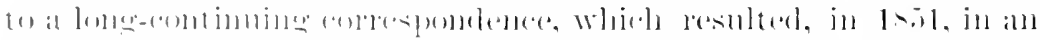

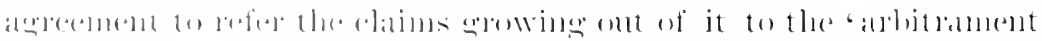

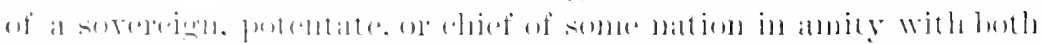

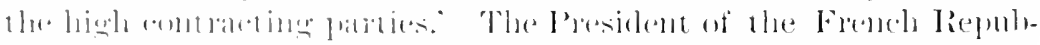

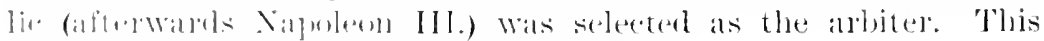

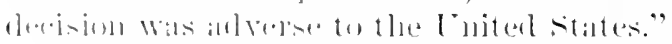

The following is a translation of the material parts of the decision : 


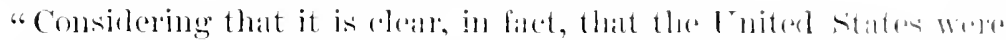

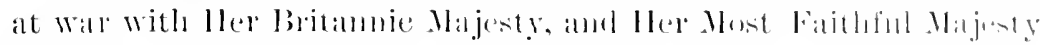

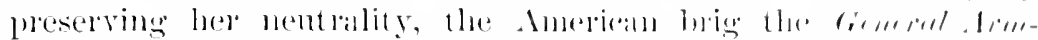

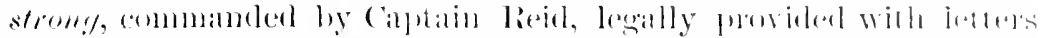

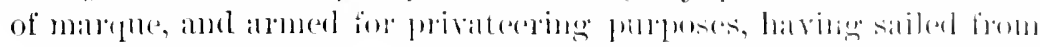

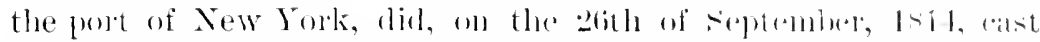

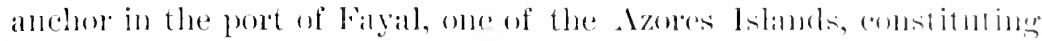

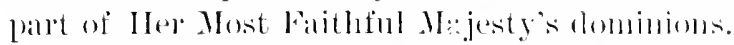

"That it is equally deatr that, on the evenimen of the same day, an

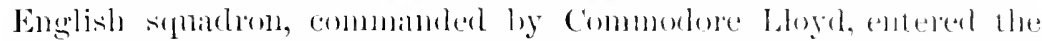
same jort:

"That it is no less certain that, during the following night. regardless of the lights of sosereignty and nentrality of Her Most Faithful Majesty, a blomly encomer took plare bedween the Amerieans and the Enelish; and that on the following day, the 27th of september, one of the vessels belonging the bughtish squadron came to range herself near the Anerian priviteer for lhe purpose of eamonaling laer ; that this demonstration, aleompanded hy the act, detemined captain lieid, followed by his crew, to abandon his vessel and to lestroy her ;

"Comsidering that if it le clear that, on the night of the :-bith of september, some English lomg-boats, commameled hy licutenamt Robert Fausset, of the British nary, apploateher the Anerian brig, the Gereme drmstromg, it is mot eertain that the men who mammed the boats aforesaid were provided with arms amb ammmition :

"That it is evident, in fact, from the doements which lave been exhibiterl, that the aforesaid lomg-boats, having approaldeded the American hrig, the erew of the latter, after having hailen them am summoned them to be off, immediately fired upon them, and that some men were killed on board the English boats, and of hed's wommed - some of whom mortally-withont ally attempt having been males on the part of the erew of the boits to repel at once force hy force;

"Considering that the report of the governor of Fayal proves that the Anerican eaptain dicl not apply to the Portugnese goremment for protection until blood had alrealy been shed, and. when

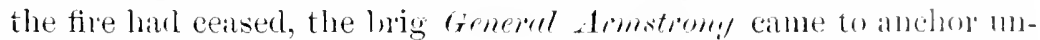
der the castle at a distance of a stones-throw; that the said suremor states that it was only then that he was informed of what wats passing in the port; that he dith, on several occisions. interpose with Commolore Lloyd with a view of obtaming a cessation of hostilities, and to complain of the violation of a nentral territory:

"That he effectively prevented some American salors, who 
were on lanr, from embarking on hoard the Ameriean bris for the

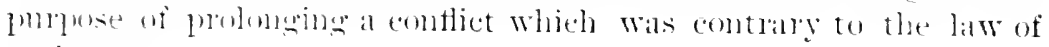
matimis:

"That the weakness of the garrison of the island and the eonstant dismanting of the forts, hy the removal of the sams which

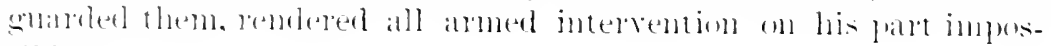
sille:

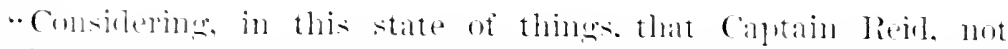

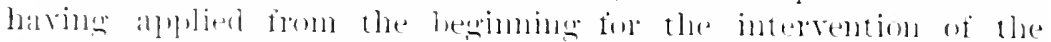

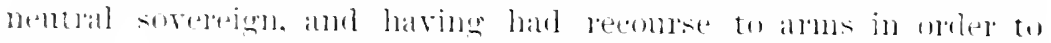

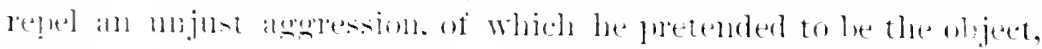

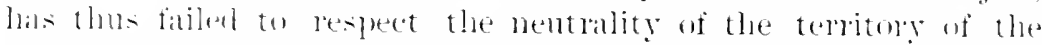
forrisn soredeign. and released that sovereign of the obligation in which he was an afford him protection by atny other means than that uf at latcific: interrestion,

- Fom which it follows that the goremment of Iler Most Fatitulul Majesty cammot be heli responsible for the results of the collision which took plater in contempt of her righles of sovereigny, in violation of the neutrality of her territory. and withont the local officers of lientenants lioving leen required in lroper time. and enabled to grant aid and protection to those having a right to the sime:

"Therefore. we have decided, and we declare, that the chim luresenter by the government of the Enited states against Ier Wost Faithenl Iajesty has no foundation. and that no indennity is due ly lontugal in consequence of the loss of the Aneritan ing the Generel frowtrom, armed for privateering purposes."

\author{
TIE " PFliLE."

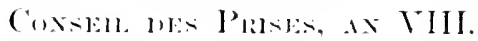 \\ (Pistoge et Duresty. I.. 1mu.)
}

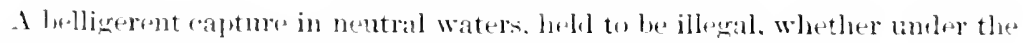

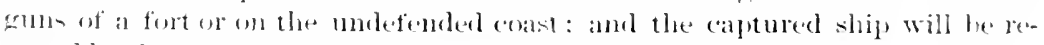

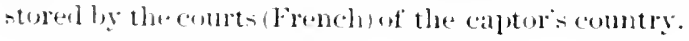

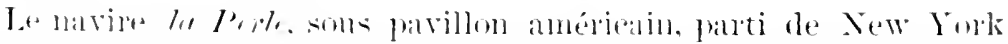

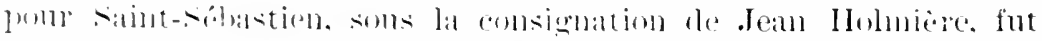

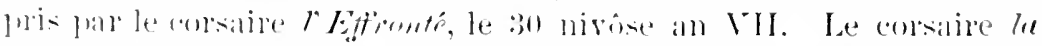

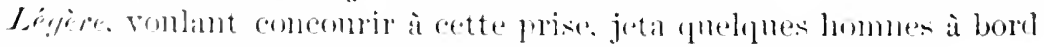

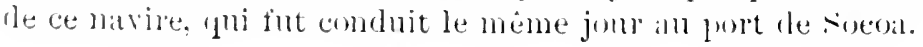




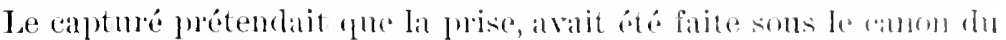

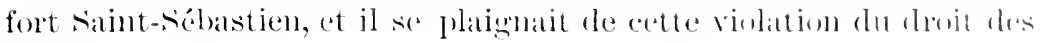
gens.

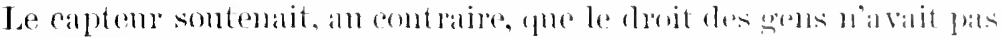
été violé, et que la prise n’avat été faite quà trobs lienes de sarintsébastion.

En fait, le eapture avait paison, la capture avait (n lien daus les eanx espagnoles. M. l'omtalis, commissaire do gonvermentent, déposa les condelusionts suivalltes:

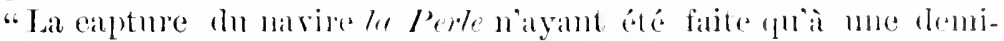

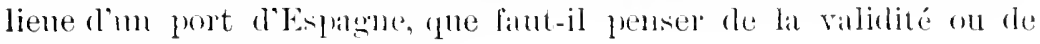
l'invaliclité de cette anture?

"Il serait inmtile de discuter les divers systemes qui ont été publiés relativement anx donts de channe somverains smes mes's qui enviromnent son emprire. Ces systimes noffrent que des questions d'école, abandonnées depuis longtemps ì la dispute et ì la discussion des publicistes.

"Mais, par le droit eonrentionnel des puissances maritimes et par la contume générale, il est recomnu fu'm corsaine ne pent se permettre aucun acte d'hostilité, ni mîme ancme visite, contre 111 navire emnemi on preténdu tel, si ce narire n’est à mo distance convenable du territoire de tonte puissance nentre. Cette distance a ćté fixée ì rlenx lienes.

"Plusiems autems avaient déterminé la ristance que tont amatemr en course doit respecter, par la portée llu eanon; mais on a très-judiciensement ohsel'ré qu’il est plus laisommalbe de déribler que tonte prise faite à moms de deux lienes de distance des côtés dn pays neutre est contre le lroit des gens quoiqu’il n'y ait sur la côte ni forteresse ni canons; car le territoire nentre doit être respecté, indépendamment de la force, et à cause de lni-même.

"Il faut rendre justice à nos temps molernes: on a eherehé i diminuer les maux de la guerre. Ce sont moins les jalousies de juridiction que les prineipes d'une philosophie plus humane qui ont fixé le droit conventionnel des puissances maritimes sur les cogrols respectifs qu'elles se doivent: de hi, elles ont cherché it transformer les prérogatives de leur souverainete en droit d'asile pour les narigatenr's; et, sous ce point de vo, les rivalités même de ponvoir, avonées par l'humanité, ont mérité d'être consacrées comme ntiles au bien dn commerce et an bonlıenr miversel des nations.

"Des dontes sélèvant encore sur la fixation du territoire de chaque souverain, quand il ne sagit que de l'intérét particulier le ses Etats. Ainsi, le voeu des publicistes les plus estimables est de lestreindre le plus que l'on peut les prétentions de territoire, lorsque 
ces putentions ne sout motiveres que fal des idees ambitienses on

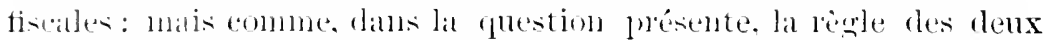

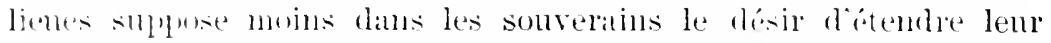

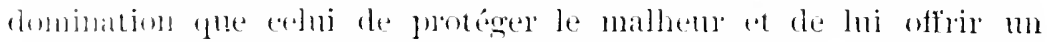

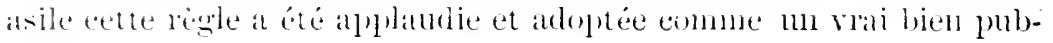
lic:

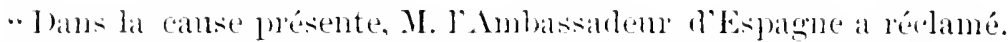

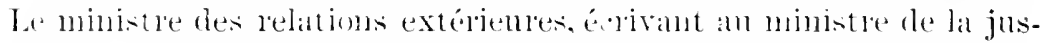

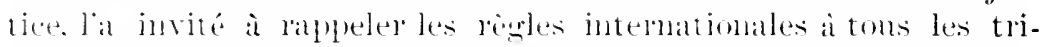

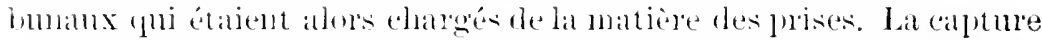
sommise à la décision do Conseil ne pent doncetre antorisée, si elle a cté faite ì mons de denx lientes de distance d' un port on doune cote espanole. Or, il est démontlé, en point de fait, que la eapture du navire lı Perle a éć faite ì demi-liente ln port de saint-Sélatstien ou de celui du Passage. Done, elle offre me violation manifeste du droit lles gens et de la foi mulique; et ce n’est pas vis-a-vis d'un allic firle que loon pent tolérer une pareille violation, aussi condammible anx veux de l'humanité qưà ceux de la politique.

".Je condus à ce que larrestation et la prise du navire la Perle soient déclan rées invalides.

" Le Consen déeide que la prise du navire la Perle et de son cluargement. faite par les corsaires francais la Légère et l'Eftrionté, est nulle et de nul effet."

\section{THE "ANXE."}

\section{Sipleye Colit of the Lyted strates, 1818 .}

(3) Whereton, 435.)

If the cintured ship first commences hostilities in nentral waters. she thereby forfeit-nentral protection.

A capture made in neutral waters is. as between enemies. deemed to all intents and purpors a legal calpture. The neutral sovereign can alone call its validity in question.

This was the case of a british slip captured while lying at anchor near the sianish part of the island of st. Domingo, by the American privateer Itrir.

Extract from the jurgment of Sroms, J. :-

"The raim of the Shanish government for the violation of its nentrai ternitory being thus disposed of, it is next to be considered Whed lee the British elaimant can assert any title founded upon that cireunstance. 


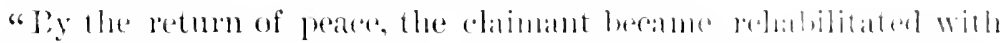

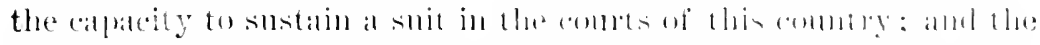

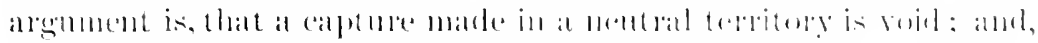

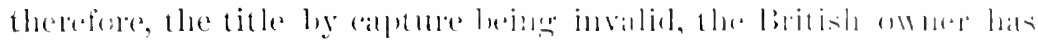

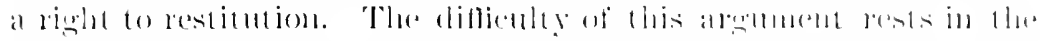

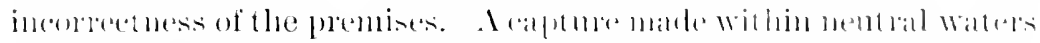

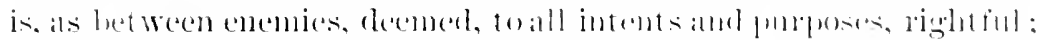

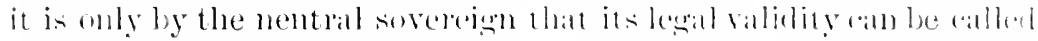

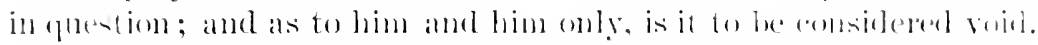

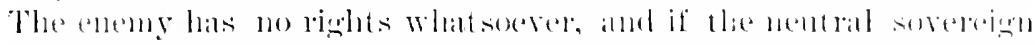

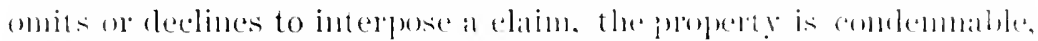
jere lolli, to the eaptors. This is the eleall lesult of the anthorities; ant the doetrine rests on well established plomeiples of public lilw.

"There is one other point in the case which, if all mher hifindules

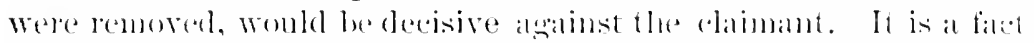
that the catptued ship first commeneed hostilities andinst the priva-

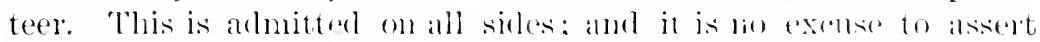

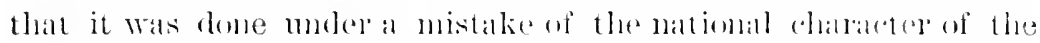
privateer, even if this were entirely maldent in the evidenese. While the ship was lying in nentral waters, she was bomnd lo alstalin fion

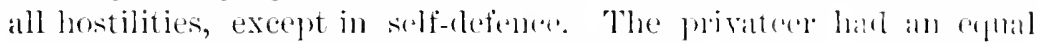
title with herself to the nemtral protection, and was in no drofinlt in

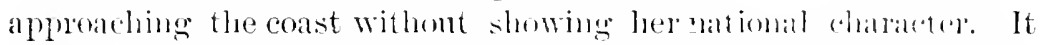
Was a violation of that nent rality which the caldured ship was homm to observe, to eommence hostilities for any porpose in these walters; for no vessel eoming thither was homel to sulmit to stalleh, of 10 aceoment to her for her conduct or character. Wholl, therefore, she commenced hostilities, she forfeited the nemtral pontertiom, and the eapture was no injury for which ally reders comld be rightfully sought from the nentril sovereign.

"The condusion fiom all these views of the casc is, that the ship and carogonght to be condemmed as gom prize of wals." 1

${ }^{1}$ In the case of the Lida. a Spragne, 1ri. it is said that. " it is mulcultedly true that no private person can rest a thim for the restoration of prize in the courts of the captor on the ground that thre caiture was malle in nemt ral wallers. and that the nentral nation whose rights have been infringed alone (an inter-

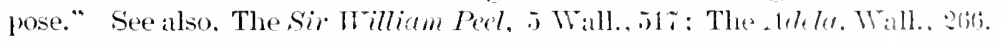

In the case of the British ship, Circenge. (ap)tured in Delaware Bay ly a French

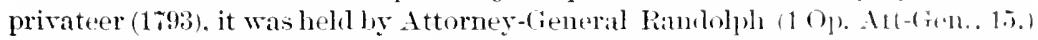
that if the captured ship was bronght within the jurisdiction of the Lnited States, it was their duty as neutrals to restore her to the owner's. To the same effect, see La Estrella, 4 Wheaton, 298. 


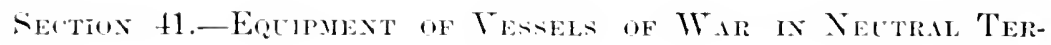
mithis.

\section{LXITED STATES NELTRILITT ACT'S OF 1794 AND 1818.}

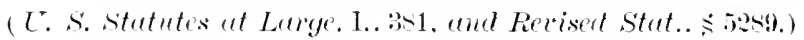

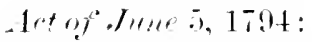

SE Thos: :-_- If any person shall within any of the ports, harbors, hay's, rivers, or other waters of the Cnited Nittes, fit ont and anm, or attempt to fit out and am, or proctue to be fitted ont and armed, or shall knowingly be concersed in the furnishing, fitting ont or arming of any ship or vessel with intent that such ship or vessel shail be employed in the service of any foreign prince or state [or of any colony, district or people], to cruise or commit hostilities upon the subjects, eitizens or property of another foreign prince or state [or of any colong, district or people], with whom the [nited states are at peice, or shall issue or delirer a commission within the teritory or jurisdiction of the Lnited states for any ship or vessed to the intent that she may he employed as aforesiad, every such person so otfemeling shall, wpon eonviction. he adjulged guilty of a high misdemeanon, and shatl be fined and imprisoned at the discretion of the cont in which the eonviction shall be had, so as the fine to be imposet slatl in no case be more than five thomsand [ten thomsand by the act of $181 \mathrm{~s}$. dollars, and the term of imprisomment shall not cxced thee reans, and erey smoh shipor vessel with her tackle, apfarel and fmonime together with all materials, arms, ammmition and stores which may have been procmed for the holdting and equipment thereof shall be forfeiterl. one-half to the use of any person who shall grive information of the oflence, and the other half to the use of the luiterl sitates.

SErtor T.- liy this section the President is authorized to employ the lamb and naval forces or militia to exeente the law.

On arecount of the complaints of Sulain and Portugal (1815-17), of infractions of nenimality on the part of citizens of the Cuited states in the war which those states were then waring with their revolted sonth American colonies, Presirlent Marlison sent a special message on the sulject to Congress, and the result was the more stringent act of April $20,1-1<$. From a suggestion of the spanish Minister, 


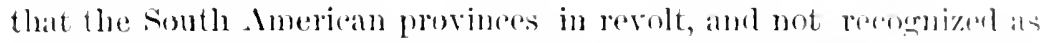
independent, might not be inchuled in the wore "State," thes wonds

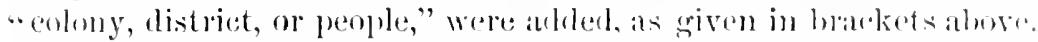

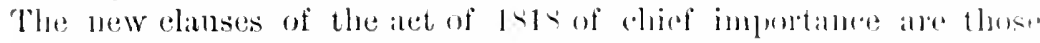
anthorizing the detention of vesiels on suspicion, and rephiring the owners to give bombls on clearance.

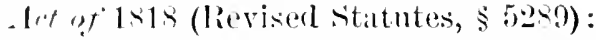

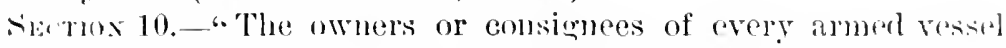
saling ont of the ports of the United siates, bulonging wholly or in part to eitizens thereof, shall, before clearing ont the sims, wive hour to the Inited States, with sufficient sureties, in fomble the amomnt

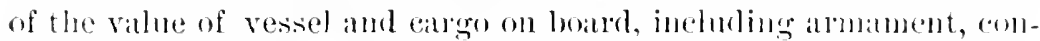
ditioned that the vesiel shall not be employed by such owners to cruise or eommit hostilities anainst the subjects, cit izens, on property of any foreign prince or state, or of any eolony, district, or penple, with whom the Initerl states are at peace."

SECTIOA 11.-"The several eolleetols of customs shall detain auy vessel manifestly huilt for warlike purposes, and abont to depart the United states, the cargo of which principally comsists of arms amb munitions of war, when the mumber of men shipper on bourl, o! other ciremustances, render it probulnle that such vessel is intenderl to be employel by the owners to errise or eommit hostilities upon the subjects, citizens, or property of any foreign prince, ete., with whom the United ritates are at peace, until the locision of the Proident is had thereon, or until the owner grives such boma and sermity as is required of the owners of armed ressels by the precerling section."

BRITISH FOREIGN ENLISTIENT ICT․ OF 1819 AND 1970.

( 59 Geo. III., c. 69, and 33 and 31 Vict., 90.)

\section{Act of .July 3, 1819.-Sectiox 7 .}

"If any person, within any part of the United Kingrom, or in any part of IIis Majesty's dominions heyond the seas, shall, withont the leave and license of IIis Majesty for that purpose first had and (oltained as aforesaid, equip, furmish, fit out, or aru, or attempt or endeavor to equip, furnish, fit ont, or arm, or procure to be equipled, furnished, fitted out, or armed, ol shall knowingly aid, assist, or he concerned in the equipping, furnishing, fitting ont, or arming of any ship or vessel, with intent, or in order that such ship or vesisel shall be employed in the service of any foreign prince, state, or potentate. 
or of any foredon colomy, province or part of any province, or people;

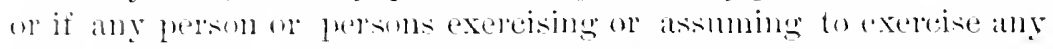

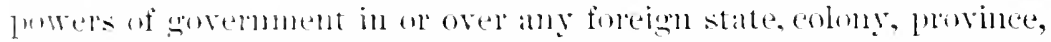

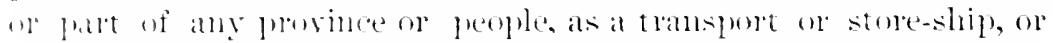

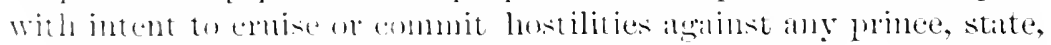

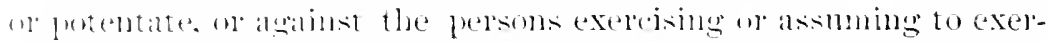

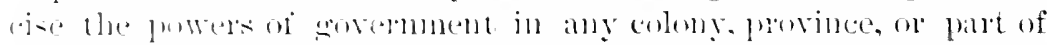

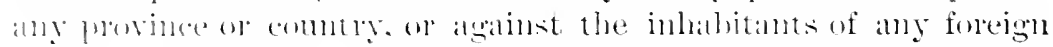

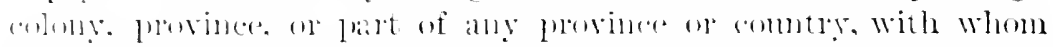
His Vajesy shall mot then be at war: or shall, within the Cnited

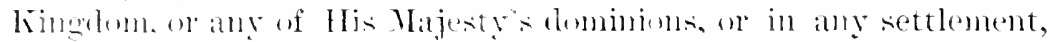

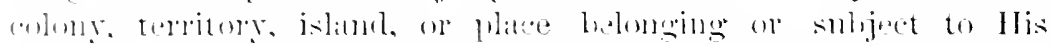

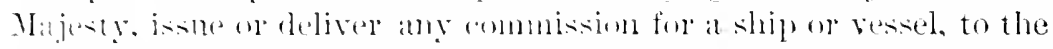

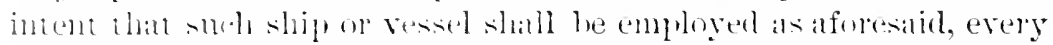

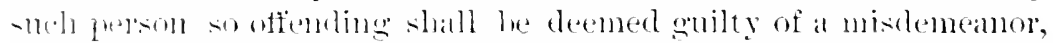

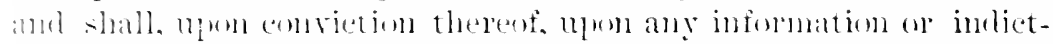

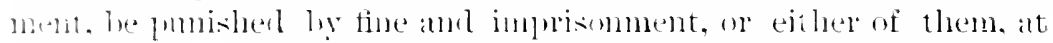
the diseretion of the $m$ me in which smehotfender shall be eomvicted; and erey snch ship or resiel. with the talckle, aplytrel, and fornitme. tosether with all the materials, arms, ammmotion, ant stores, which maty belong to or he on hath of any sheh ship or ressel, - hall the forfeitel, and it shall be lawful for any officer of IIs

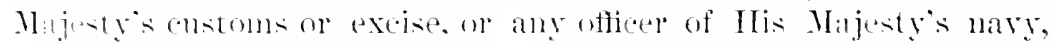

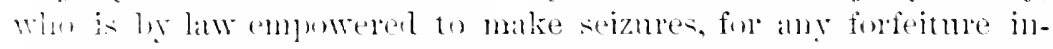

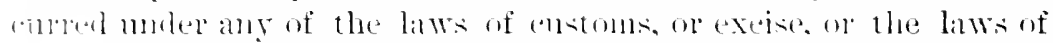

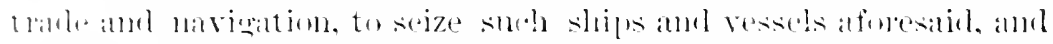

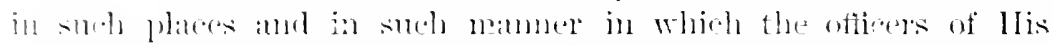

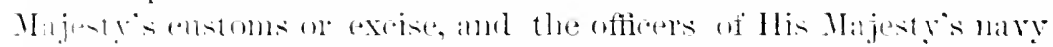

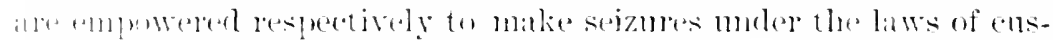

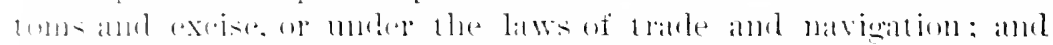

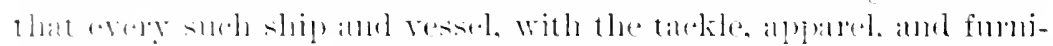

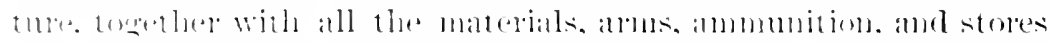

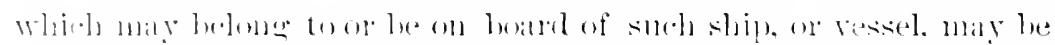

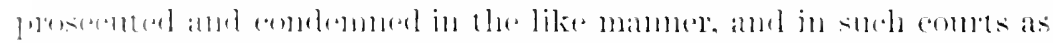

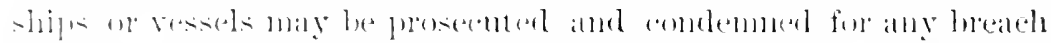

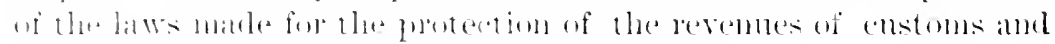

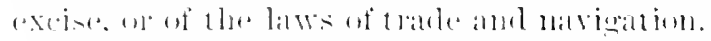

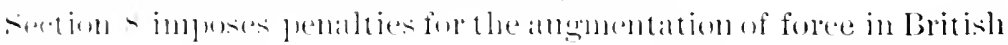

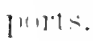

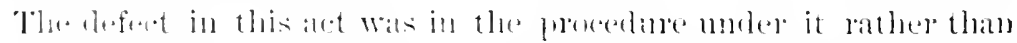

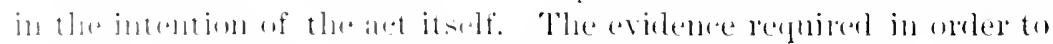

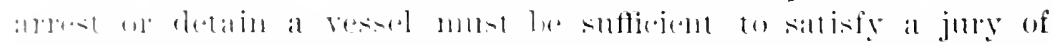

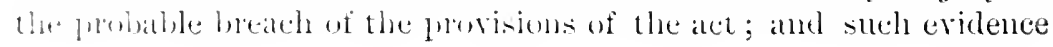




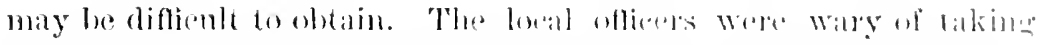

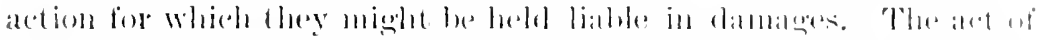

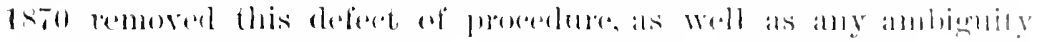

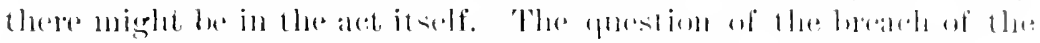

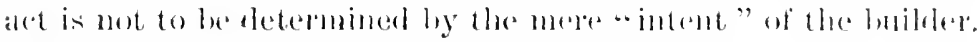

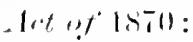

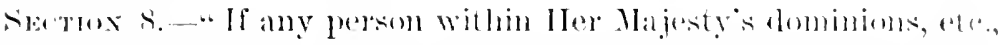

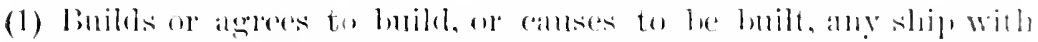

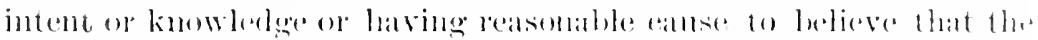

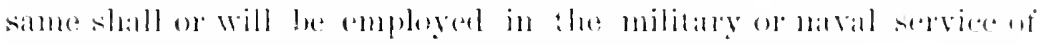

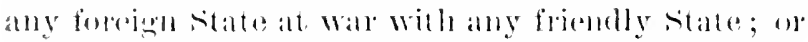

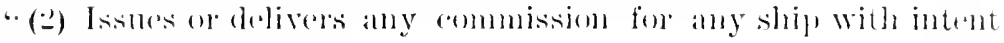

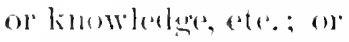

"(i) Equips any ships with intent or knomlerlere, ete. : or

"(t) bespatroles or callses or allows to be despatehed, any ship with intent or kmmledger, etc.

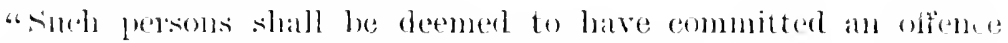
against this let, ete."

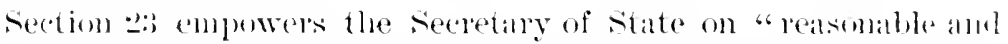

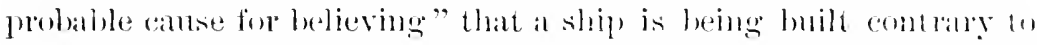

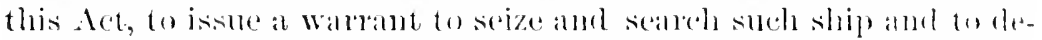
tain the same motil it has been either comblemmef or released hy

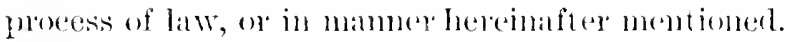

section et provides that "where it is repesented to any local authority" that there is reasonable and probable canse for believiner

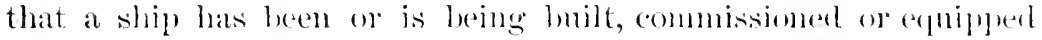
contrary to this Act, it shall be the duty of sileh local anthority lo detain such ship, and forthwith to commmomeate the fart of sorels detention to the secretary of Sitate or ehicf executive anthority, who may then issue a warrant for aletention, or release the vesiel.

\section{TIIE "CASSIIS" OR "ILS JUMEALX."}

$1794-1796$.

(3) Dallas, 121 : H7atertonis State Trials. 93.)

The questions in respect to this vessel are dischised in the cases of Cuited situtes

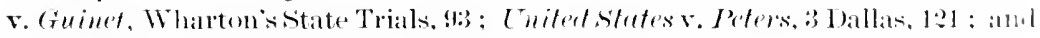

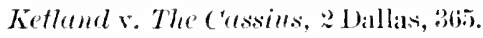

This was the first ease under the mentrality aet of 17!) Originally a British cutter, this vessel canne into the hands of Fenels owners: 


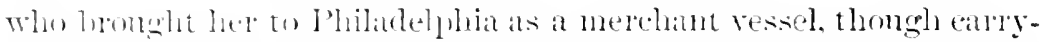

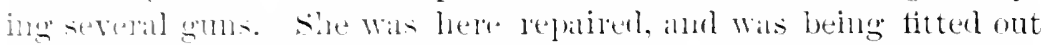

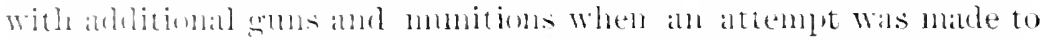

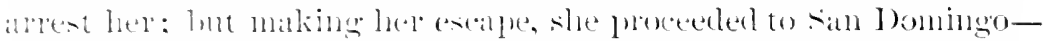

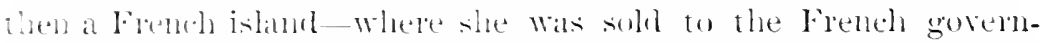

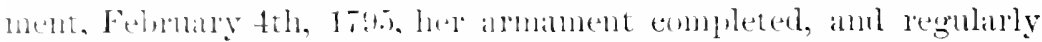

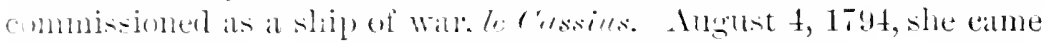

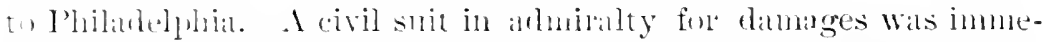

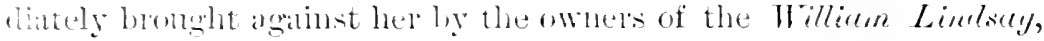

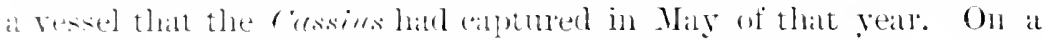

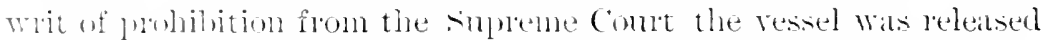
( $I$. . . . I'efor); but a new libel was immetiately filed in the Circint comet by ane of the formel plantitis, on the gromud of illegal chuipment of the vessel the gear hefore. It the October term, 1796, the yluesion anose, whether the circoit Cont entel take original condentee of infomations for forfeiture moler the let of 1794 ; and the enent dismissed the proeedings, on the gromed that sueh proceeding most be instituted in the I)istriet Comrt. No further anction Wastaken in the eompts; and it will thus be seen that the question of international law was left undecided. The French minister, M. Adet, hand dismantled the ship and had formally abandoned her to the government of the Enited states. The practical lesult was that a foreign ship of war was libeled and detained by the comets of the Enited states, and the Federal Executive seemed mable to prevent it.

In the Thited States v. Groinet, the accusenl was tried and condemned to fine and i.mprisonment for aiding in fitting out the C'ussiess in contravention of the det of 1794 .

\section{I.I "AMISTAD DE RLE.."}

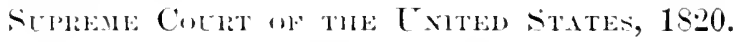

(.) 117heatou. 34.5.)

A civil rourt of a neutral comutry cammot adjurlicate upon the validity of a

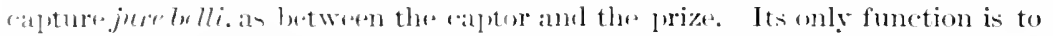
rindicats the offondorl swereignty of its own country, when the capture was mathe in violation of its neutrality.

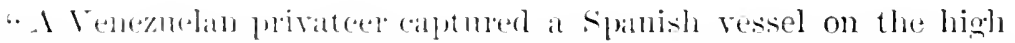

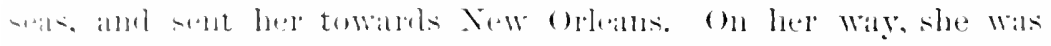
taken lussession of by a Lnited states ship, and terried into that 


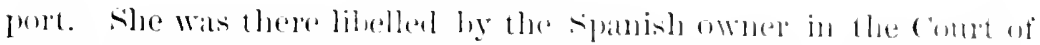

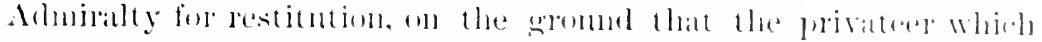

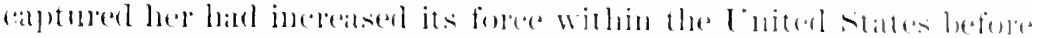

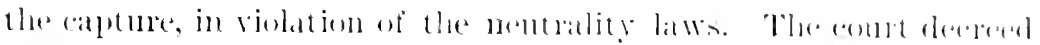

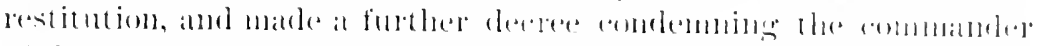

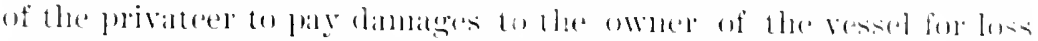

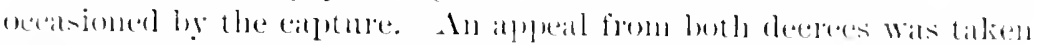
to the suppeme comrt. That eomt, on examination of the porofis, de-

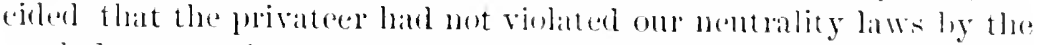
work done mom her, and dismisised the libel. This was, it will heseren, only a decision on a desestion of evidenee; and by that decision the

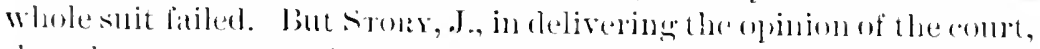
thomght prepere to go beyoud what was necessily for terminatimg the suit, and sithe that, if the privateer had violated omr neutrality laws, so as to have warranted the decree of restitution of the prize, that would not have justified the decee for diumanes. In explanation of this distinction, the learned judge shows that a civil court of at nentral comntry cannot arjudicate npon the validity of at eaturue jube belli, as between the captor and the prize. Its only function is to vindicate the offended sovereignty of its own comntry. If a prize is taken in War, in riolation of the territory or other rights of at neutral, the neutral may molo the act, and jut the parties in stren quo ante, hy releasing tla prize and restoring it to the owner. And the owner of the prize maty demand that. The nentral does this solely to vindicate its own sovereignty, and not with any rogard to the validity or invalidity of the capture as between the parties. Into that, it need sot and cannot inquile. The fact that a capture is made in violation wi the rights of a neutral sovereign, is no legal objection to the captme, as between the parties. Comsequently, the lentral comrt camnot award clamages to the owner of the atjotured vessel, as for a capture male without probable cause, or as otherwise illegal. The nentral nation should faily execute its own laws, and give no asylum to the property mujustly captured. It is momol, therefore, to restore the property, if fomind within its own ports. Beyond this, it is not bound to interpose between the helligerents." (Quoted from Dana's Wheaton, 1. 5.2, mote.) ${ }^{1}$

${ }^{1}$ In the case of The Nereysta. \& Wheaton, 10s (1823). a Spanish ship of war wascaptured by the privateer Irresistitle. which was fittofl out, owned, and commanded by American citizens, cruising under a commision from Artimas, as chief of the Oriental Republic of Rio de la Plata. The prize was talien to Margarita, an island of Veneznela. and there contemmed as prize. Venezheda leeing an ally of the Oriental Republic. She was there comminsiomed as a Ventemelian privateer, and eame to Baltimore. Here she was libelled on behalf w" the King 


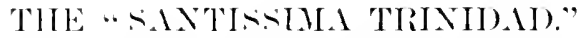

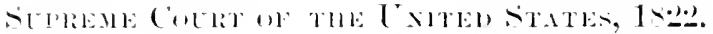

\section{(i Hhertere. 20:3.)}

HWh. that nedutal citizens nay send ammel vesiels to belligerent ports for

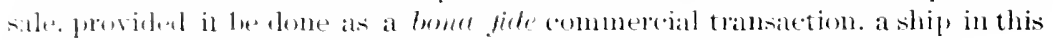
sitnation beingensendered as merely an article of contraband of war.

The alugmentation of tire force of a belligerent cruiser. in mentral territory, is illewal : and will entail the restomation of a prize macle by such vessel, if brought witin the jurislietion of the offended neutral.

This was a liled filed by the consul of spain, in the district comet of Virmial in April, 1-17, aganst eighty-nine bales of eochineal, two bales of jalale and one box of vanillat originally constituting

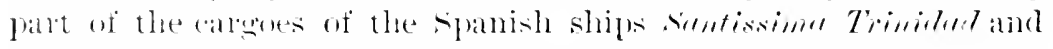

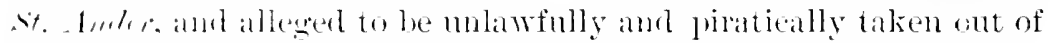
those vessels on the hieh seas ly a seflarlon emsisting of two armed

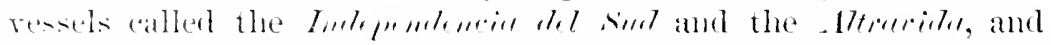
mammed amb commanded ly persoms assmumo themselves to be eitizens of the Tuited Provinees of the libo de la Plata. The libel Was tiled. in behalf of the original spanish owners, hy Dou Pablo Chacen, consul of his catholic Majesty for the gort of Norfolk; and as amended, it insisted upon restitution, principally for three letisisis:

(1) That the commandors of the capturing vessels, the Tulepen-

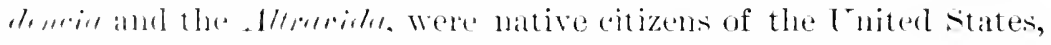

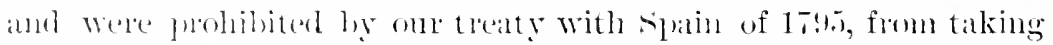

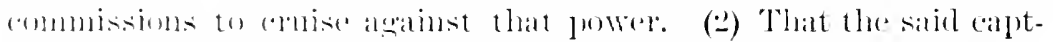
ming restels were omed in the Enited states, and were originally

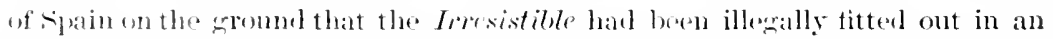

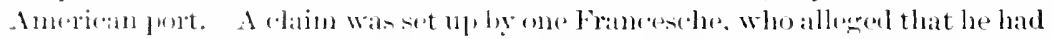

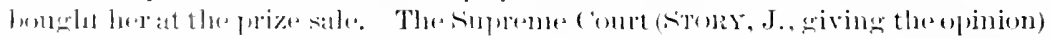

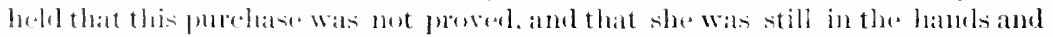

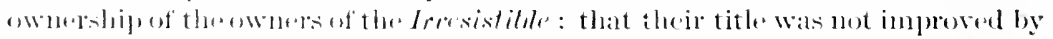

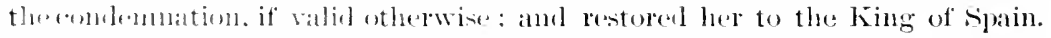

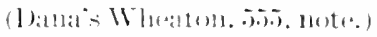

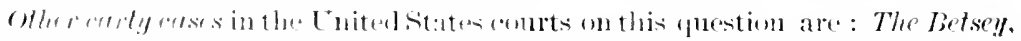

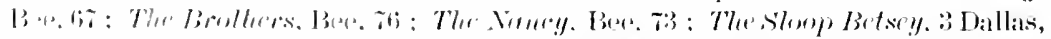

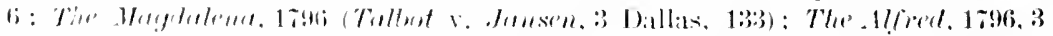

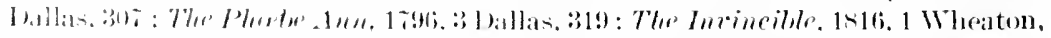

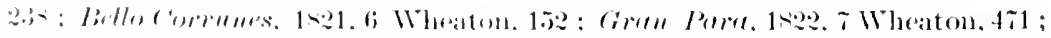

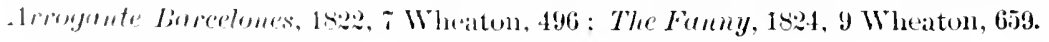




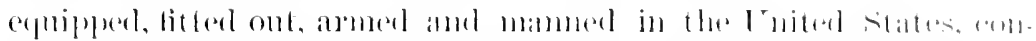

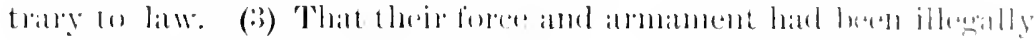
mantmented within the Enitod stattes.

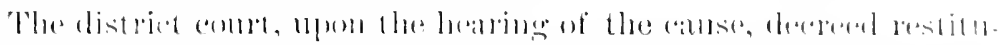

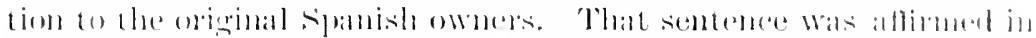

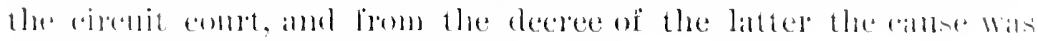

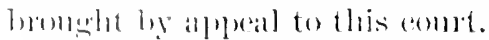

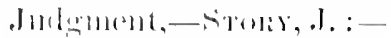

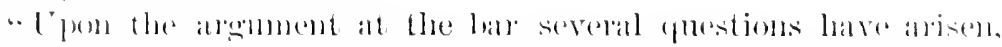

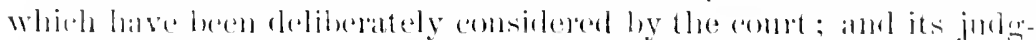

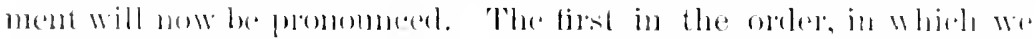

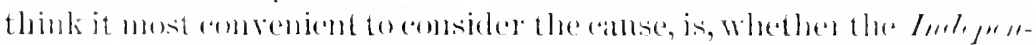

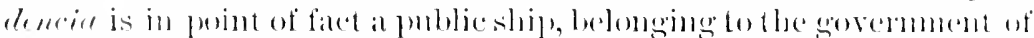

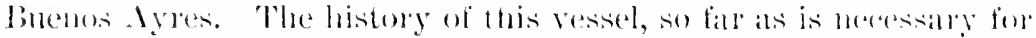

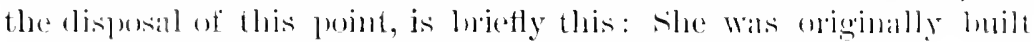

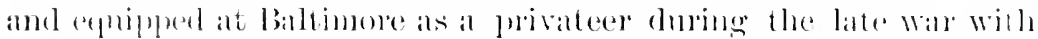

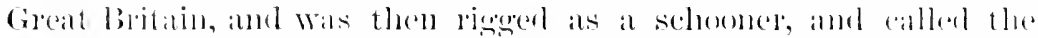

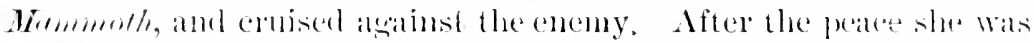

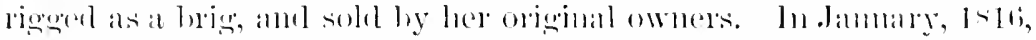

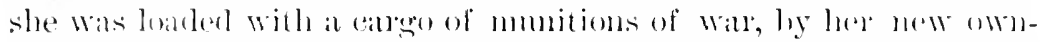

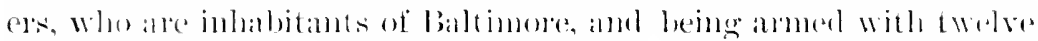
gums, constituting a late of her original anmament, she was de-

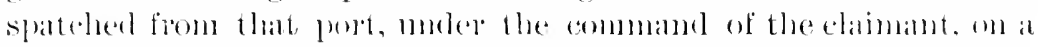
royage, ostensibly to the Northmest coast, but in reality to burmos

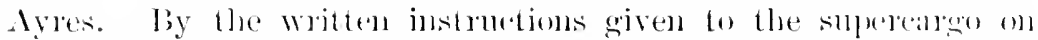
this royage, he was anthorized to sell the vessel to the surmmoment of linenos Ayres, if he comlel olotain a suitable price. She duly arrived at boenos dyes, having exercised no atet of hostilits but salded muler the protection of the Ameriean flag, dowing the roy-

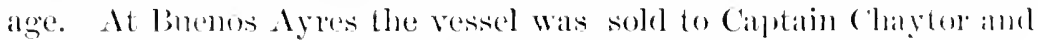

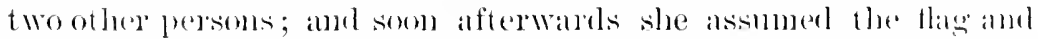

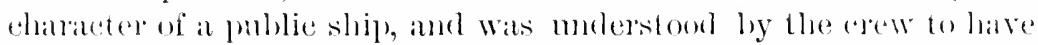

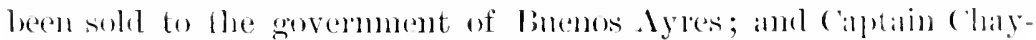
tor made known these facts to the edew, and asserted that he had beeome a citizen of Buenos Ayres; and had received al commission

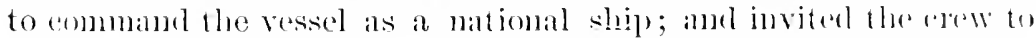
enlist in the service; and the suenter part of them aceorelingly enlisted. From this perion, which was in May, lsti, the publice functionaries of om own and ofher foreign govermments al that purt,

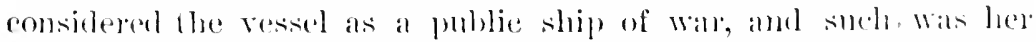
avowed eharateter and repmtation. No bill of sale of the vested fo

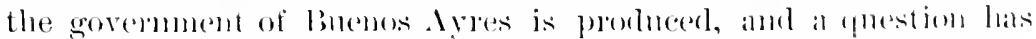
been male princigally from this defeet in the evidence, whether her 
Chametel as a public ship is established. It is not umferstond that any doubt is expuesied ats to the genumeness of Cantain (halgtor"s ommonisions, nor as to the competency of the other proofs in the

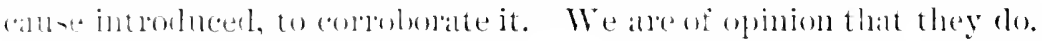
In genteral the comminsion of a pullic ship. sinned by the proper anthomities of the nation to which she behongs, is eomplete proot of

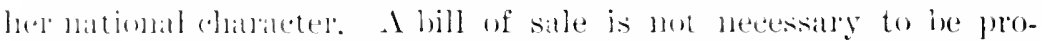

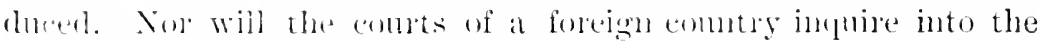
means by which the title w the property has been acpuired. It womld he to exert the right of eximinime into the ralidity of the acts

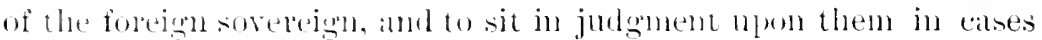
where he lats not conceded the juristiction, and where it wonlel be inconsistent with his own smplenteg. The commission, therefore, of a puhlic ship, when duly authenticated, so fou at leatst as foreign coults are conceraed, imports absolute rerity, and the title is not eximinahle. The property must be taken to be duly actuiled, and cammot he controverted. This has been the sotted practice between nations: and it is a rule fommder in public conrenience and policy, and cammot be lnoken in upon, withont endamgering the patce and repuse, as well of neutral ats of belligerent soverejgus. The eonmision in the present ease is not expresied in the most mequirocal terns; but its fair purport and interpretation must be deened to aprly to a public ship of the government. If we atd to this the cormonative testimony of our own and the British comsul at buenos Aryes, at well as that of private citizens, to the notoriety of her claim of a public charater ; and her armision into om own jouts als a public ship, with the immunities and privileges helonging to surh a ship, with the express apluobation of om own government, it floes not seem too mueh to assert, whatever may be the private

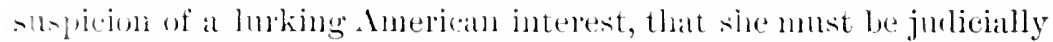
hels to be a public ship of the commtry whose tommission she beill:.

"The next puestion growing ont of this recoul, is whether the papenty in controversy was calptured in viobation of om neutality, so that restitution onght, by the latw of mations, to be decored to the

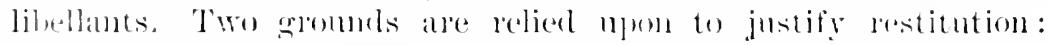

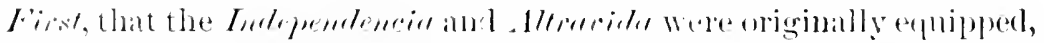

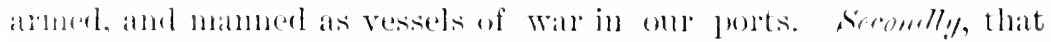

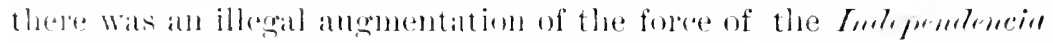
within onr pouts. Are these gromeds, or either of them, sustained by the evidenere:

"The: flustion as to the origninal illegil armament and outfit of the lmeleperdencie maty be dismissed in a few worels. It is appar. 


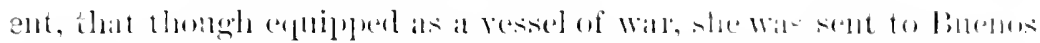

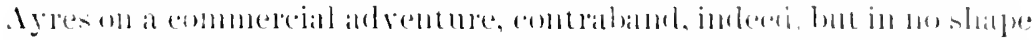

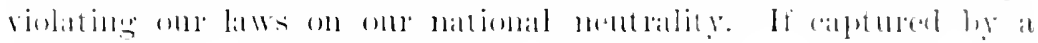

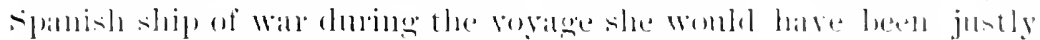

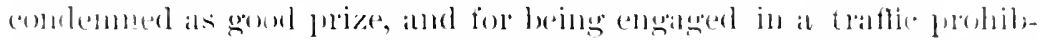
ited ly the lial of nations. But there is mothing in ond litws, on in the lian of mations, that forbids ond citizens from semeling armen lessels, als well ats munitions of war, to foreign perts for sale. It is a

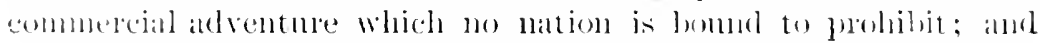
which only exposes the persons enganged in it to the prentilty of contfiscattion. Fupposing, therefore, the vorage to have been for com-

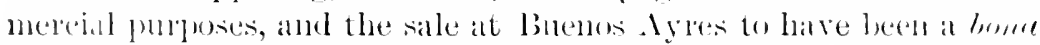
firle salle fand there is nothing in the evidence before ns to contrandiet it), there is 110 pretence to sily, that the original ont fit on the vorage Wits illenal. or that at calpture mate after the sale wats, for that callse allone, invalial.

"The most material consileration is as to the angmentation of her" force in the lnited states, all a sulsecpuent periorl. * * *

"The count is, therefore, driven to the eonelnsion, that there wats

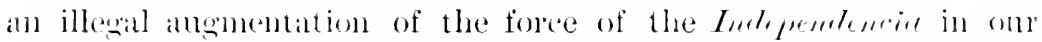
ports ly a subtantial increase of her crew; and this renders it Wholly munecesilly to enter into an investigation of the prestion, whether there wats not also an illegal inereatse of her allmilnemt. * * This view of the question renders it muneressiry to consinler another which has been discussed at the balr respecting what is denominated the right of expatriation. * * *

". And here we are met by an arrmuent on behalf of the clainiant, that the angmentation of the force of the Inteponden-in within our ports, is not an infration of the law of nations, or a violation of our nentrality ; and that so fill as it stands prohibited by om municipal laws the penalties are personal, and do not reach the ease of restitution of captures made in the eruise, dhring which such angmentiltion has taken place. It has never been hede by this comlut that an angmentation of force or illegall ont fit affected any captures mate after the original cruise wils terminated. By analigy to other eases of violations of pullic latw the offence may well be leemed to ledeposited at the termination of the royage, and mot wo afferet finture transactions. But as to eaptures made during the sime aruine, the

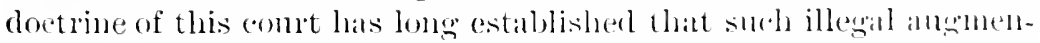
tation is a violation of the latw of mations, als well as of and own

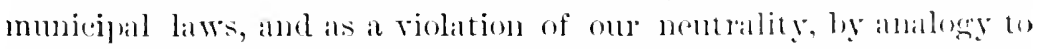

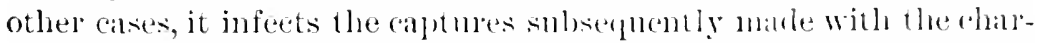
acter of torts, and justifies and recuires in restitution to the frartie: 


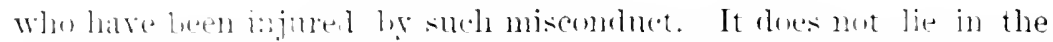

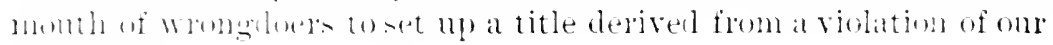
notit ratlia 1 .

" The atses in which this dextrine has been recognized and atplied,

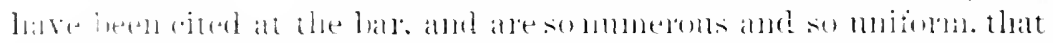

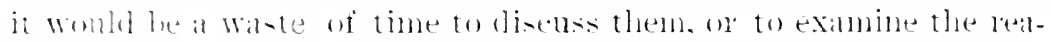

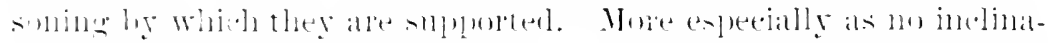

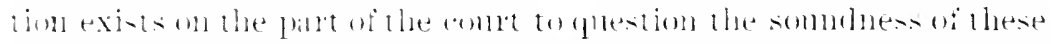

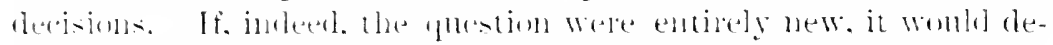

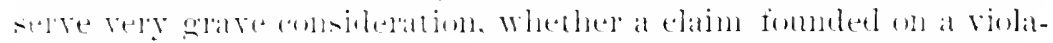

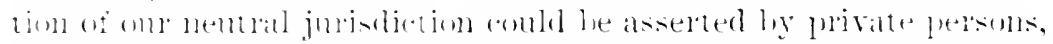

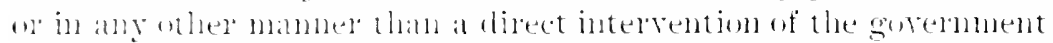
iistef. In the case of a rapture mate within a nentral teritorial

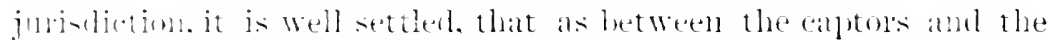

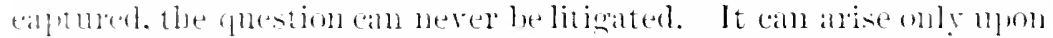

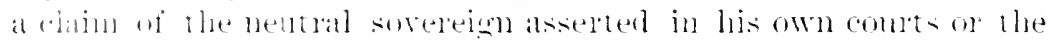

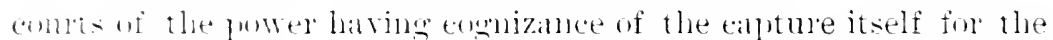

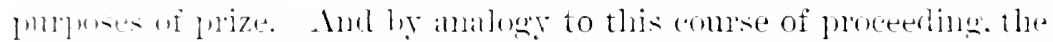

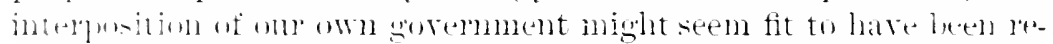

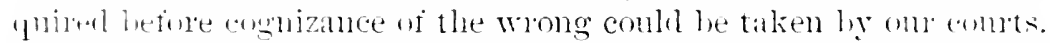
bua the practice from the leginuing in this class of taluses. a perionl of neally :30 years, has heen mifomly the other way: and it is mow tom late to disturb it. If any imonvenience shomld wow on of it. from reasums of state policy or exerotive diseretion, it is comple-

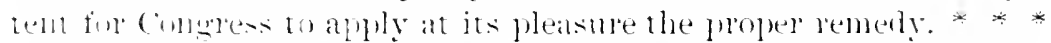

" F pm the whole it is the opinion of the coult that the deeree of the eilevit enent les athined, with corts."

\section{TXITEI STITES r. QTIXCY.}

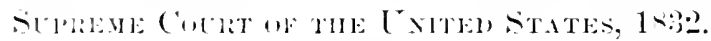

(6) Peters. 44.5.)

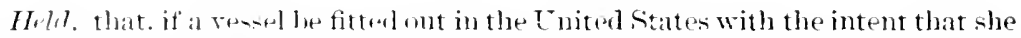

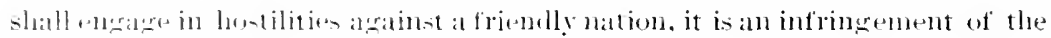
ne-utrality act of ind and subjects the owner to the penalties attached to that ancl

But if the intention was to som the ressel to the West Indies in starch of funds with whirh to amplede her amament, with nopresent intention of preving

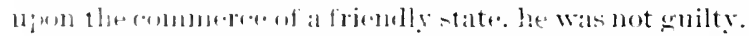

sis. if there Was he fixul intention. lut a mere wish to fit her out. etc.. it would nut betllewal.

Mr. Justien Tumman delivered the opinion of the court :- 


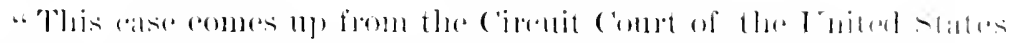

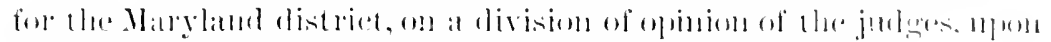

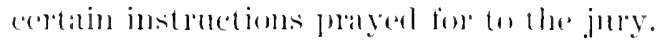

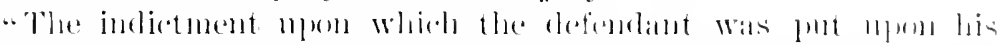

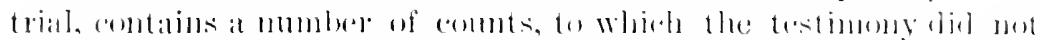

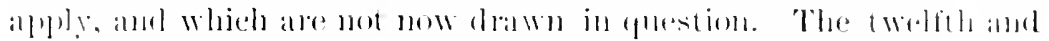

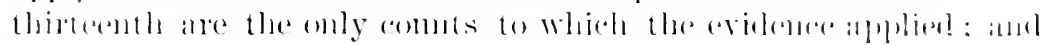

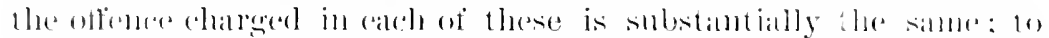

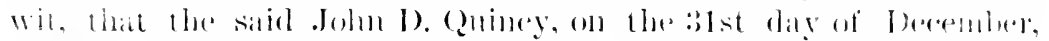

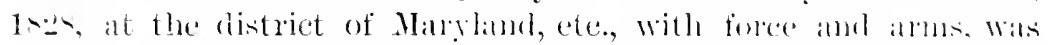

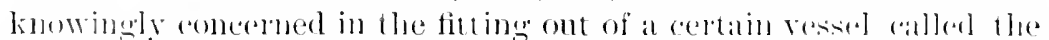

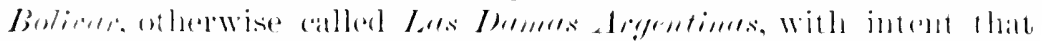

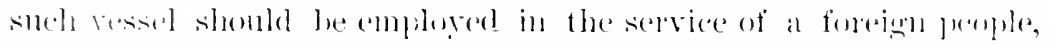

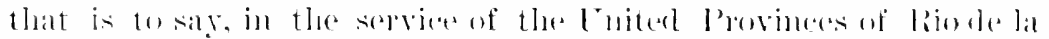

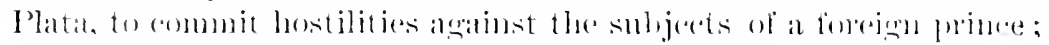

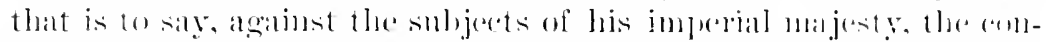

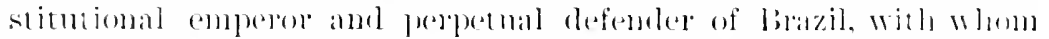

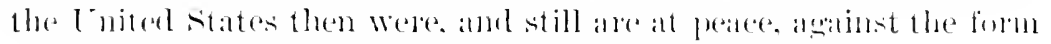
of the alet of Couguess in such case made and jurbided.

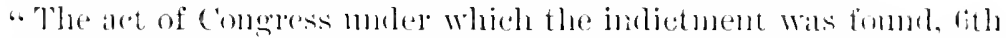
Vol., Laws L. S., 3:21, seot. 3, declates, "1hat if any jersom shall, within the limits of the Enited siates, fit omt and alme on attempt fo tit ant and arm, or procure to be fitted ont and armed. ol stall

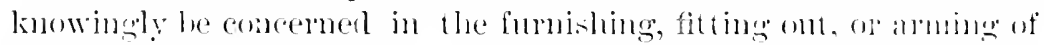
any ship on vessel, with jutent that such ship or vessel shall he and-

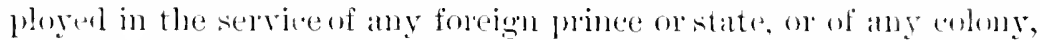
distrut or people, to crotise or enmmit lostilities andust the smb-

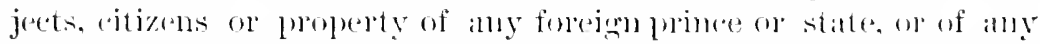
colomy, district or penple with whom the Euiterl states alle at peace,

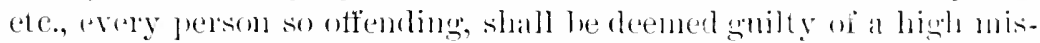
demeanor, and slanll be fined not more than ten thomsand dollats, and imprisoned mot more than thee years, ete.'

"The testimony being closed, several prayers, both on the part of the Enited States and of the dofemdant, were presenter] to the (on)t

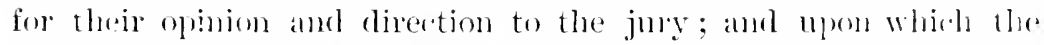
opinions of the jutges were opposed, and which will now he moticed in llee order in which they were marle.

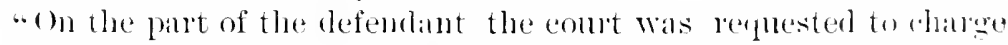

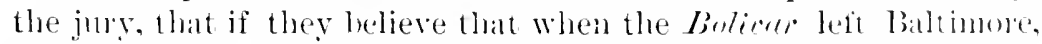
and when she arrived at st. Thomas, and during the rovage flom Baltimore to st. Thomas, she was not armed, or at all prepared for war, of in a condition to commit hostilities, the verdiet must be for the defendant. 
"The prayer on the part of the Enited States upon this part of the arse. Wats, in substance. that if the jury find fom the evidence that the deferdant was, within the distriet of Maryland, linewingly

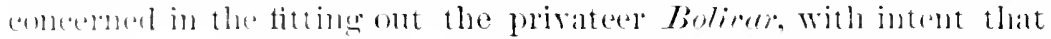
she shomld be emploged in the mamer alleged in the indicenent,

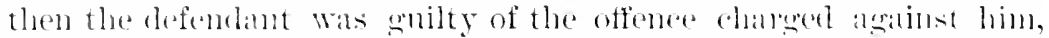
althomgh the jory shembl find that the equipunests of the sald pri-

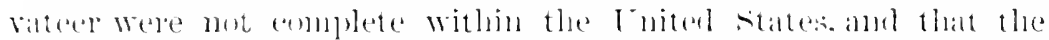

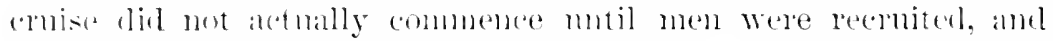
forthere equipments were male at the sisand of st. Thomas in the Went Inties.

"The instruction which ought to be wiven to the jury muler these prayers involves the construction of the act of congresis, tonching the extent to which the preparation of the vesicel for eluising of coumbtting hostilities must be arried hefore she leares the linits of the Cnitel states, in order to bring the case within the act.

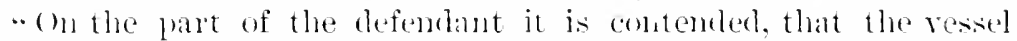
must be fitted out mol amed, if not complete, so fal at leats as to be prepared for war, or in a comblition to commit hostilities.

- We do not think this is the true construetion of the act. It has been argmed that, although the offence created by the atet is a mislemeanor, and there camnot, legally speaking, he principal am a acessory, ret the act evidently contemplates two distinct classes of offeriflers. The principal actors, who are directly engaged in preghring the ressel, and another class, who, though not tine chief actors, ale in some way concerned in the preparation.

"The alct, in this respect, may not be drawn with rery grat perslinenity. but should the view taken of it ly the defendant's commsel he deened conect (which, howerere, we do not adunit). it is not

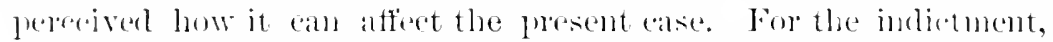
aleending to this enstruction, places the defendant in the second-

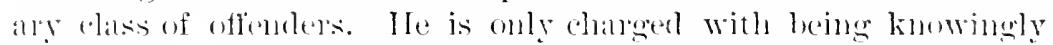
ancernerl in the fitting ont the vesisel, with intent that she shombl be empluloyed, ete.

"To hring him within the words of the act, it is not necessary to (harre him with heing concerned in fitting ont and amming. The worls of the and ale. titting ont or ambing. Either will romstitute the offenee. lint it is said such fitting ont must he of a resicel armer and in a comelition to commit hostilities, oflerwise the minor actor may be multy when the greater wombl not. For, as to the latter, dhere must be a fitting ont amel arming in oreler to bring him within the law. If this eomstruction of the are be well fommede the indictment onght to change, that the defendant was concerned in 


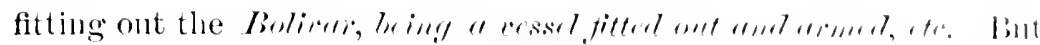

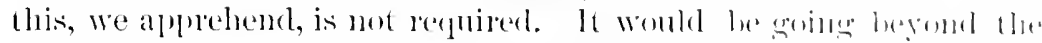

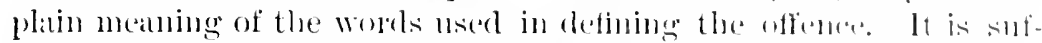

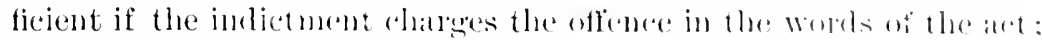

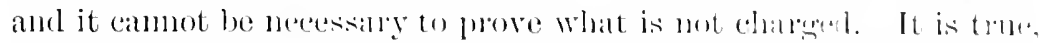
that, with respect to those who have heen demominated at the hall the chief actors, the law wombl seeme to make it meressaly that they

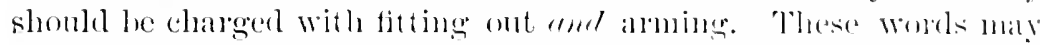

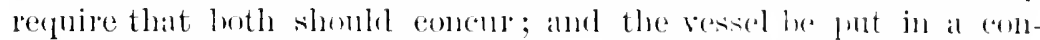
clition to commit hostilities, in oreler to bring her within the law.

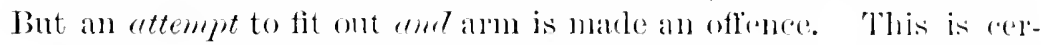
tainly doing something shont of a complete fitting ont and anming. To attempt to do an act cloes not, either in law or in common balllance, imply a completion of the act, or any definite promeses towarls it. Any effort or endeavor to effect it will satisfy the terms of the law.

"This varied phraseology in the law was probably employed with a view to embrace all persons of every description who might he en. gaged, directly or indirectly in preparing ressels witl intent that they should be employed in eommitting hostilities antinst any powers with whom the Enited States were at peace. 1)idiorent de. grees of eriminality will necessarily attach to persoms thus engagerl. IIence the great latitucle given to the conts in affixing the pumish. ment, viz, a fine not more than ten thonsind alollans and imprison. ment not more than three years.

"We are, accordingly, of opinion, that it is not necessiry that the jury should believe or fincl that the Bolirer, when she left bilti. more, and when she arrived at St. Thomas, and during the vorigo from Baltimore to St. Thomas, was armerl, or in a condition to com. mit hostilities, in oreler to find the defendant guilty of the ofience eharged in the indictment.

"The first instruction, therefore, prayed on the part of the de. femlant, must be denied, and that on the pint of the Inited states given.

"The second and third instruetions asked on the part of the defendant, were:

"That if the jury believe that, when the Boliori" was fitter and equipped at Baltimore, the owner and equipper intendal to go to the West Indies in search of funds, with which to arm anm equip) the said ressel and had no present intention of using or empluying the said ressel as a privateer, but intended, when he equiplun her, to go to the West Indies, to endeavor to raise funds to prepare her for a cruise; then the defendant is not guilty. 
$\therefore$ () if the juy helieve that, when the Bulder. was equipred at ballimore, and when she left the Enited states, the equipler hed

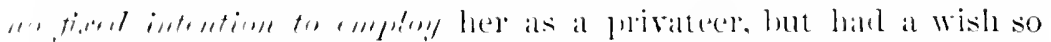

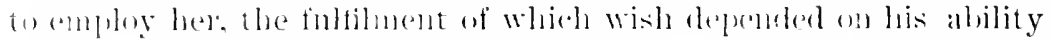

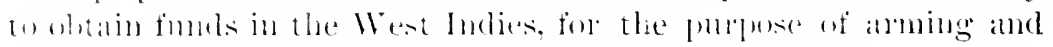

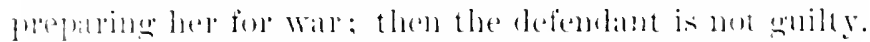

. Wa think these instructions omoht to be wiren. The offence

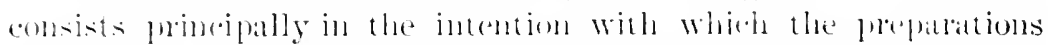

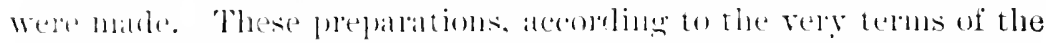
act. must be male within the limits of the Luited states: and it is aplatly necessaly that the inturtion with respect to the employment of the reside should be formed hefore she leares the Grited states. And this must he a tised intention: not combitionalof contindent, depending ons some future arrangements. This intention is at ynetion belomging exclusively to the jury to recide. It is the material print on which the legality or eriminality of the act must mm: and recieles whethel the antrentme is of a commercial or wallike chatrateter.

.. The baw does not mohilit amed vesols belonging to citizens of the lnited states from saling ont of om ponts: it only requires the ommers to rive secmity (ats wats done in the present case) that slleh ressels shall not be employed ly them to enmmit hostilities andinst forejen powers at peace with the Inited states. The colledons alde mot authorized to detain ressels, althomgh manifestly hatile for warlike fmposes, and about to depart form the Enited

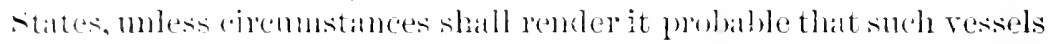
are interred to be emploged by the omners to commit lustilities against some foreign power, at peace with the Juiterl states.

". All the hatume, thesefore, necessary for commereial pumposes, is

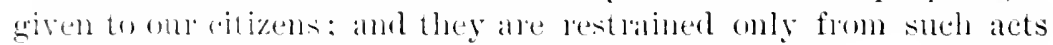
as alle calcolated an involve the remutly in war.

" The secomel and thind instructions, asked on the part of the Eniterl states, onght also to be griven. For, if the jury shall find (a) the instrmetions assmue) that, the defendint was knowingly

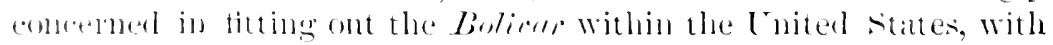
the intert that she shomld be employer as set forth in the indictment, that intantion being defented by what might afterwards take plate in the West Imbies, womld not pure the offence. which was furevinsly ansmmmated. It is not necessaly that the design or intention should be carried into exeention in order to constitnte the offence.

"The last instruction or opinion asked on the prat of the defondant, w:ts: 


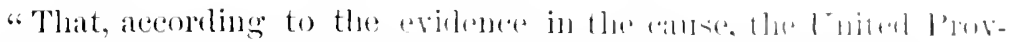

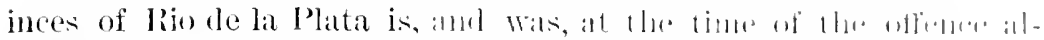

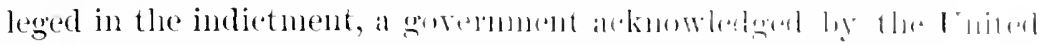

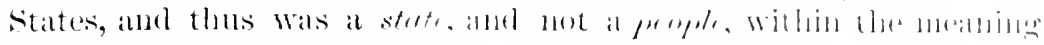

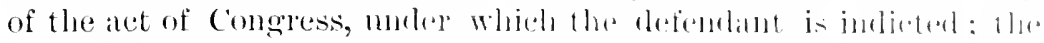

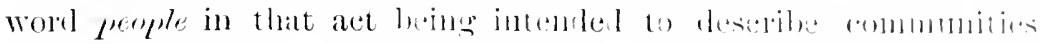

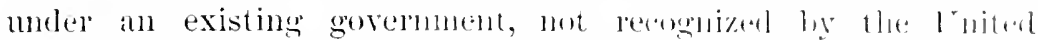
States; and that the indiement cannot be sulpused on this revidence.

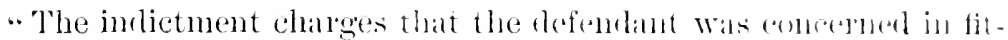

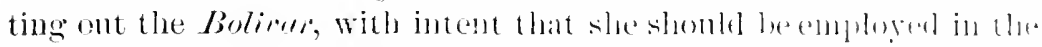
serrice of a foreign perple: that is to say, in the serviee of 1 lat

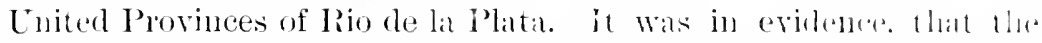

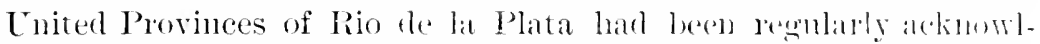
edged as an indepentent nation by the expentive linglument of tho

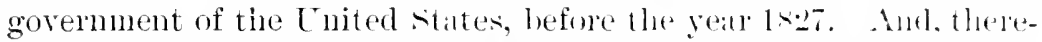
fore, it is argued that the word perple is not properly alprliable to that nation or jower.

"The oljection is one purely technical, and we think not wollfomded. The word proph. as here nsed. is merely descriptive of the power in whose service the vessel was intended to l, employal: and it is one of the denominations aplolied ly the anet of compless to a foreign power. The works are, in the senver of any foreign prince or state; or of any colony, distriet or prople' The alplieattion of the word penple is rembered sufficiently certain ly what follows under the videlicet, "that is to say, the Luiterl P'rovinese of Rio de la Plata.' This particularizes that which hy the word fon, le is left too general. The descriptions are no way repmgnant or inconsistent with each other. and may well stand together. 'l'hat which comes moler the videlicet, only serves to explain what is doubtful and obscure in the word people.

"This instruction must therefore be denied, and the one asked on the part of the Lnited States, viz, that the indictment is suflicient in law, must be given.

"These answer's must accordingly be certified to the circuit comrt." 


\section{TIIE " METEOR., \\ 1. . Cincelt Cuelat for so. New York, 1866.}

\section{(3) II hartonis Digest. it61.)}

A resiel may be fitted out in the Cnited states for war. whether with armament, w without. and sent to a belligerent port in search of a market.

The case of the Moteor, which has been the subject of much riscmsion in this relation is reported in brief in 1 American Law, liev. fol. Aceording to this report, the Meterr was built in the Enited states in 1-6.5, dming the war then pending between Chile mn Frain, and soll to the Chilean govermment, without ammment, anul then, it was alleged, commissioned, when in the Lnited states, as a Chilean privateer. She was libeled in New York and seized Jumlity 2:3, 1s66; and on the hearing before Jndge Bets it was maintained hy the claimant to " be no offense (muter the act of 181-) to issue a commission within the Lnited states for a resisel fitted amd equipperl to cruise or commit hostilities, and intended to ernise and commit hostilities, solong as such ressel was not ammed at the time, and was not intended to be armed within the Luiterl states, althomgh it could be shown that a clear intent existed, on the part of the persul istuing or deliveling the commission, that the vessel should leceive her armanent the moment she should he he gond the jurisdietion of the Lnited stattes." It was sail, howevel, by .Judge Batrs, that " the court camot give any such construction to the statute. such a comstruction was repmelated by the sulpeme comt. * * * 'The lyotor, althomgh not completely fitted ont for military operations. Was a resset-of-war, and not a vessel of commerce. She has in 110 mames been altererl from a vessel-of-war so as to fit her to be omly a merehantman and so als to mufit her to be a vesiselof-war. It neerled only that she shombl reach a point begond the jurisdiction of the Lrital stalles, and there have her armanent and ammmnition I']t on luarel of her, to become an armed cruiser of the chilean govexmment araimst the govermment of sirain. * * * To say that the neutrality latrs of the Eniter states have never prohibited the sale of a rescel-of-war as an article of commerce, is melely to say that thry have not prohibited the fitting ont and arming, or the attempting to fit ont and arm, or the furnishing or fitting out or arming, of a vessel, within the limits of the Lnited states, provided 


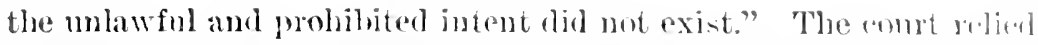
ats authority on Dana's Wheaton, 5tiz, bo:3, note 2215, where it is satil that "an American merehant mal buld and fully alm a ressed and supply her with stores, and offer her for sale in om own markor. If

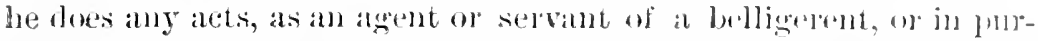
smance of an arrangement or moderstanding with a bolligerent, that she shall be employed in hostilities when sold, les is gully. Ite maly, without violating our law, send out such a vesiel, so expiplund, muler the flag and papers of his own comntry, with no more forece of crew than is suitable for navigation, with no right to resist seared or seizure, and to take the chances of cajpure as contraband morchandise, of blockade, and of a market in at belligerent port. In such case the extent and character of the equipment is as immaterial as in the other class of cases. The intent is all. The act is opren to great suspicions and abuse, and the line may often be seareely traceable; yet the principle is chear enongh. Is the intent one to prepare an article of contraband merchandise, to be sent to the mallict of a belligereis.. - vect to the chances of captrue and of the mar. liet? Or, on the he hand, is it to fit out a ressel which shall loalve our port to cruise, inmerliately or ultimately, against the rommeres of a friendly nation? The latter we are bound to prevent. The former the belligerent mant prevent. Jurge Bexts then procoesled to say: "The evilence in the present case loaves no rational fombt that what was done here in rispeet to the Metegr was done with the intent that she should be employed in hostile operations in faror of Chile against Spain ; and that what was fone by herownerstomads dispateling her from the Enited states was done in pursuance of an arrangement with the anthorized arents of Chile for her sale to that govermment, and for her employment in lostilities against Spain, and that the case is not one of a bonn ficte commercial dealing in contraband of war. With these views, there must he a rlecree condemning and forfeiting the property under seizme, in accordance with the prayer of the libel."

Judge Betrs' decree was reversed in the cirenit court, where the following opinion was delivered by Mr. Justice NELsox :-

"This is an appeal in achiralty from a deeree of eondemmation in a libel of information for the violation of the nentrality laws of the United States. We have examined the pleadings and profs in the case, and have been unable to eoncur in the judgment of the cont below, but from the pressure of other business lave not fomd time to write out at large the gromuls and I sons for the opinion arrivi at. We must, therefore, for the presint, be content in the statement of our conchusions in the matter. 


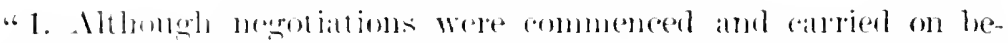

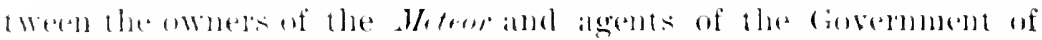
chile, for the sale of her to the batter, with the knowledere that she

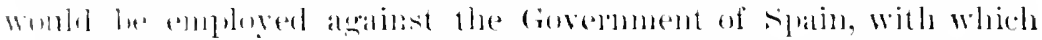

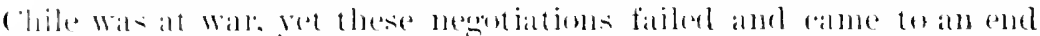

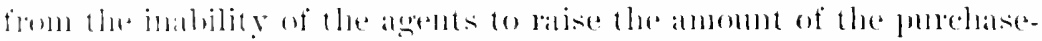

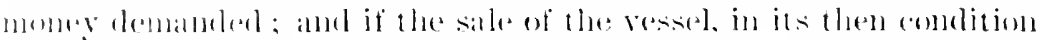

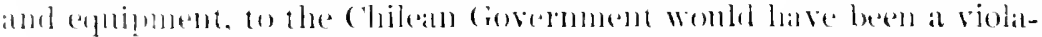

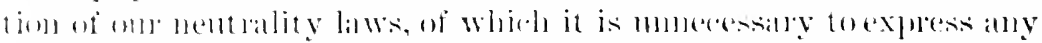

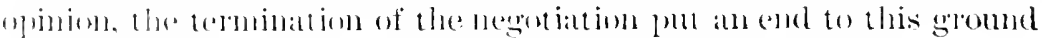
(t)

“. 2. The fonmishing of the vesicel with eoil and provisions for a wratere to Panama, or some other pont of Somth Americat, and the

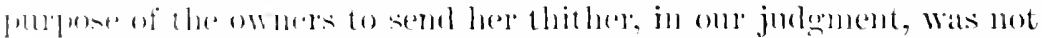

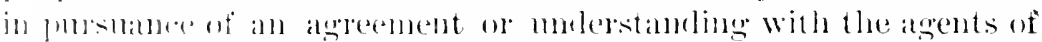

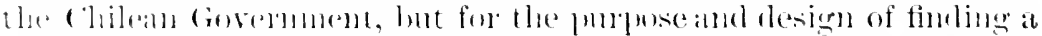
marliot for hers and that the owners were fres to sell heroul her

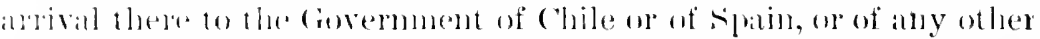
forednment or gerson with whom they might be alle to megotiate il sile.

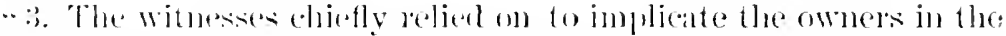

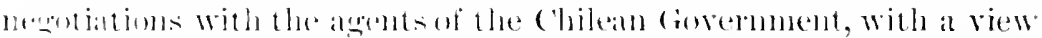

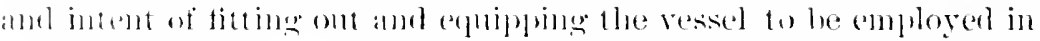

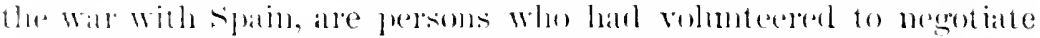

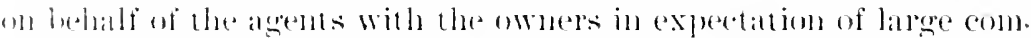
mis-ims in the erent of at sille, or persoms in the experetation of eme

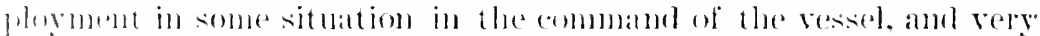

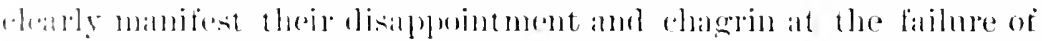
the mentiations, and whose lestimony is to be examined with eon-

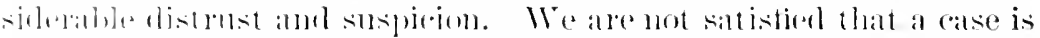

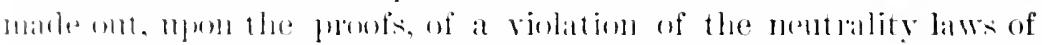

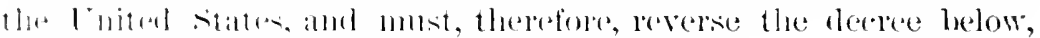

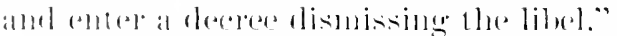

Au alpual Wats taken by the (iovernment from the derision of the

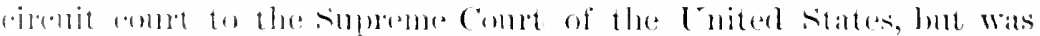

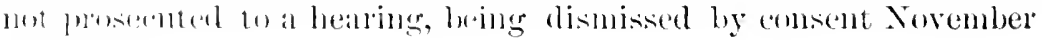
1) I liv.

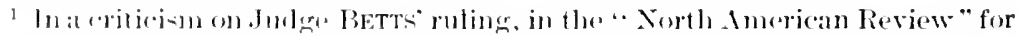

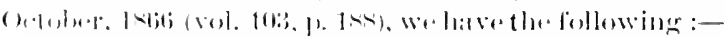

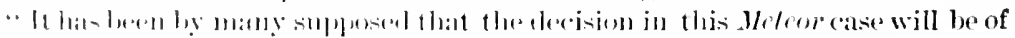

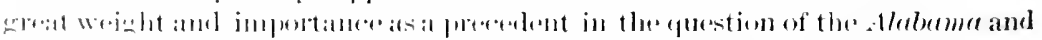

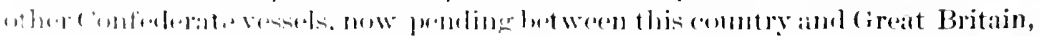

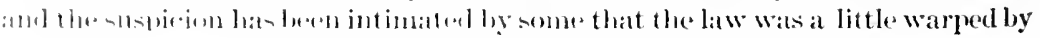




\section{TIIE TELCEIRA AFFAIR, 18:7.}

$$
\text { (Phillimore, Bal Ed,, III., 28\%.) }
$$

An expedition having left Engrish ports toattack the government of Portugal, a British sefuadron was despatehed in pursuit : finding the vessis of the experlition in Portuguese waters, the English eaptain kejtat clese wateh apon them, and linally ordered them ont of the neighorhood.

"In 18:7, Don Pedro, having retained to himself the empire of the Grazils, formally renounced the throme of l'ontugal in faron of his daughter, Domma Maria, having delegated to his bnother, Don Migrel,

the learned judge with the charitable intent of ailling Mr. Seward in the cont loversy. To justify either of these juleas, it is of comre primarily neersisary that the cases should be at least substantially parallel. That they are far from loing so may be briefly shown. The Heteor was built as a purely commereial rnterprise to besent to a foreign land, there to take her chatuce of finding a marlit, subject to the risk of cayture on the way, to be followerl hy conffisention als contraband of war, and to the further risk, should she reach ber destination in salfoty, of finding no market in case the war should be drawing to a close, or terms evuld not be agreed on : liable, also. to be sold to any other bilker whowould pay a better price. She differed nowise from any other contraband meredamolise, except in the wholly insignifieant fact that insteald of being of sheh a nature as to require to becarried she was able to move herself. She wassiumly a merantiles speculation in contraband merchamliwe, which is of all medl amd nations confersedly and avowedly legitimate. The Aleberme presents nome of these waraleteristics. ** * The question then being as Mr. Dana says, of inlent, the vital difference is readily distinguishable. The English hulders hat assmed their trade before they entered upon the untertaking ; the Ameriean merehints only had in view a quite probable purchaser. The former were not free to dispose of their ship to any person who might offer her priee, for she was hespoken: the latter would have been rery glad to have received and chesel with a fair offer from any souree. In short, the action of the formes betrays elearly the intent, the element of illegality, but how the action of the latter (an have been regarderl in the same light we must confess ourselyes malle to see. Where, then, is thes similarity? Or why should it have been concedved necessary to sacritice the" Meteor, to overule old and good law, to create a new necessity repuiring to met by new statutes of untried efficiency, simply for the purpose of "reating a precedent which is after all no precerlent?"

Dana says of the Practice of the United States (note to Wheaton, p. Jfi?) : " Is to the preparing of ressels within our jurisdiction for subseguent hentile operations, the test we have appliel has not been the extent and chalacterol the preparations, but the intent with which the partionlar acts alle done. If aly presson does any act, or attempts to rlo any act, towards such preparation, with the intent that the ressel shall be employed in hostile operations, he is guilty, without refer- 


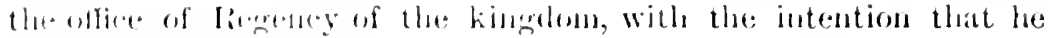

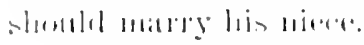

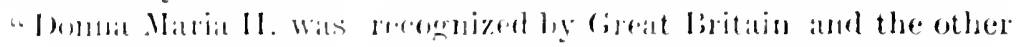

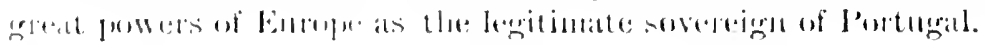

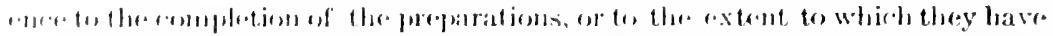

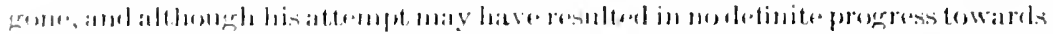

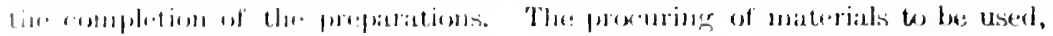

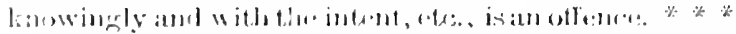

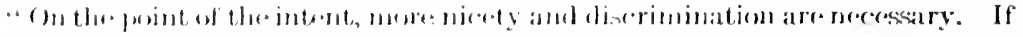

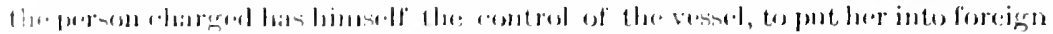

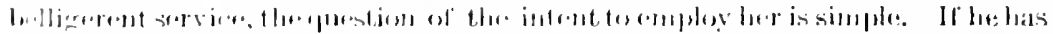

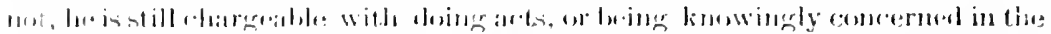

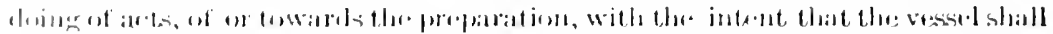

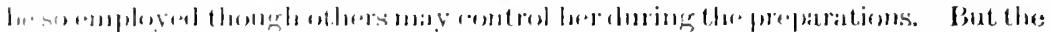

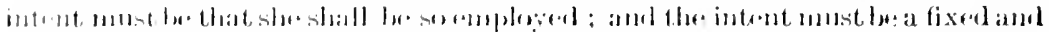
perent intent, and not a wish or desire merely that she may las. If there is a

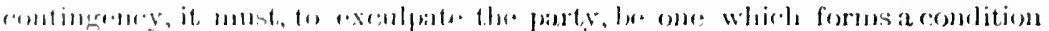

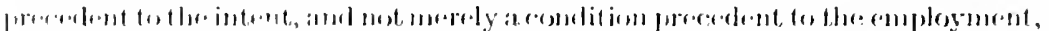

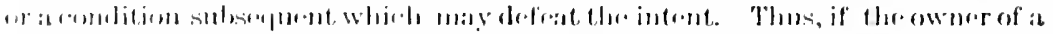

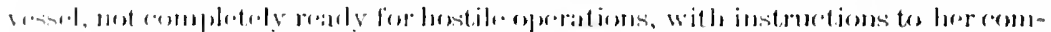

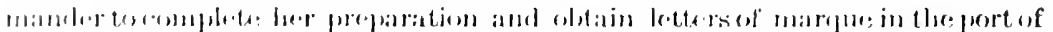

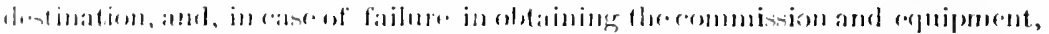

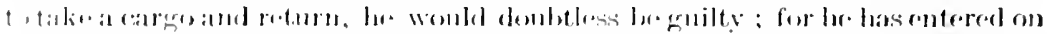

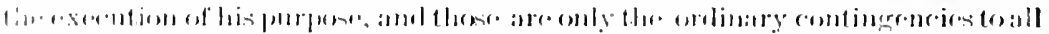

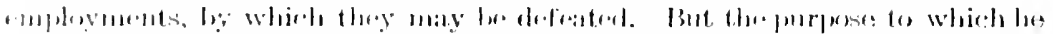

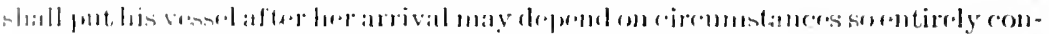

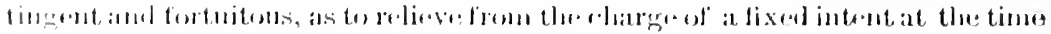

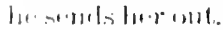

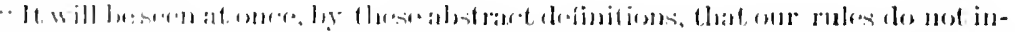

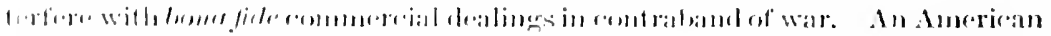

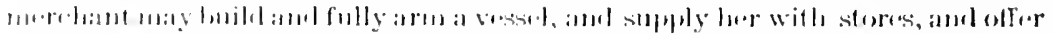

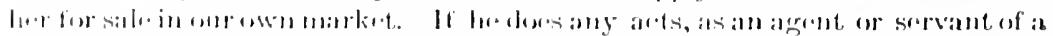

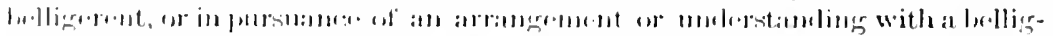

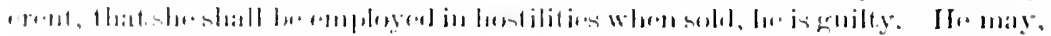

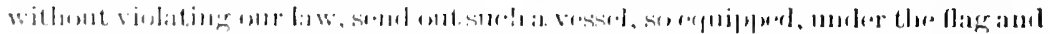

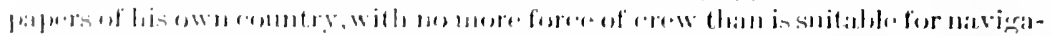

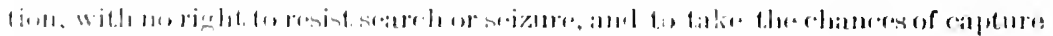

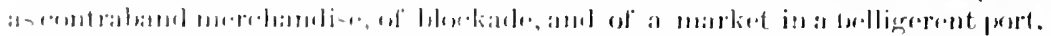

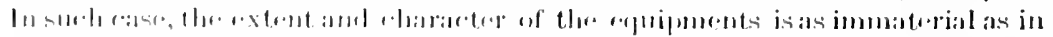

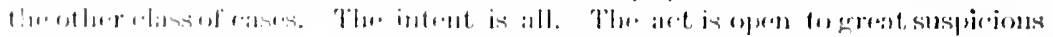

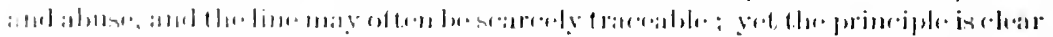

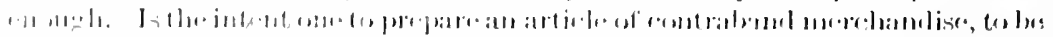

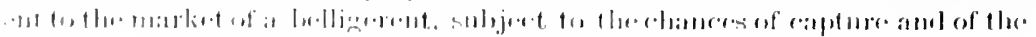

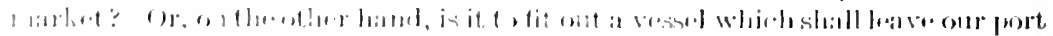

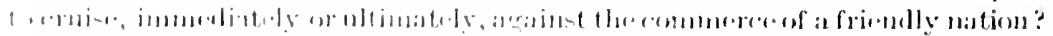

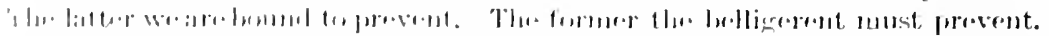

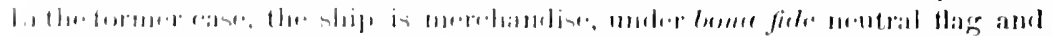

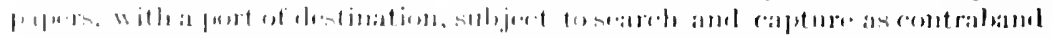

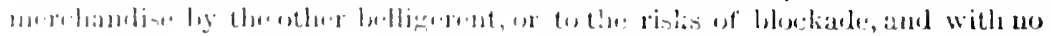




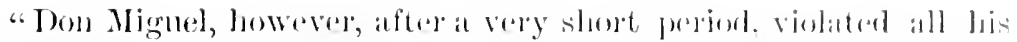

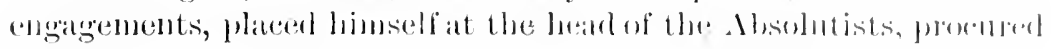

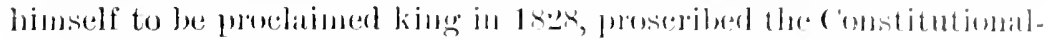
ists, and plungert the comotry into the lonerols af a civil war.

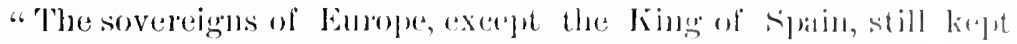
aloof from any commonication with the msmbel-from any and which might be eomsidered a recogntition of his title. The l'ontu-

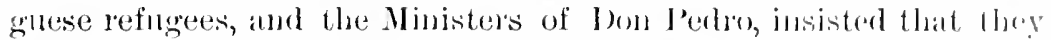
omble to do more, and drive him from his throne ly positive interference. These applications were abluessed particulaty to the Juitislı Ministry.

"The British Government relused, howerer, to interlere in this domestie quarrel; and, holdiug that it was not contitled lo malse any

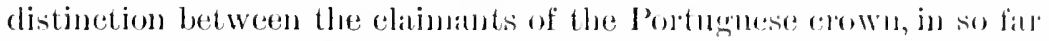
as their respective puetensions were supporter moly ly domestir; force, eomsidered itself bomml to observe, in regard to all military operations, a striet nentrality. $A$ great momber of lontugnese lefugees, most of them military men, had arriverl in England, taking n]' their residence principally in lortsmonth, falmonth, and the noighborhood. As it was halieved that they were meditating to fit ont some experition from these ports anginst Ion Mignel, the british government, holding that to permit this wombl be at breateh of mentrality, informed the barkilian minister that it womld uot allow such designs to be earried on in British harbors, and that, for seondity's salke, the refugees most remove farther from the coatst. The binvoy then stated that those troops were abent to be conveyed to liaril; and aceordingly fomr vessels, having on board fio oflicers and men,

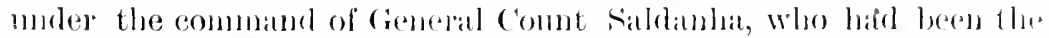
constitutional Vinster of War, sailer lrom Plymonth. The liritish government suspecterl that the troe design wats to band these troms at Tereeira, althongh the ostensible destination was Baril. Notia" was given to them before they sitilerl, that any snch attempt wombl be resisted, and a small foree of armed vesisels, moles tho communam of Captain Walpole, of the Ramgre, was despateherl leforehamel to Tereeira, to enfore the probibition. Ilis instructions were to cruise

right to resist seareh and seizure, and liable to be treatrol ats a pirate by any nation, if she does any act of lostiity to the poperty of a lenlligerent, as much ats if she rlid it to that of a wentral. Such a trade in contraband, a belligerente may

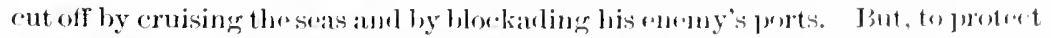
limself against vessels sailingrout of a neutral jort to commin hostilities. it wenlal be necessary for him to hover off the ports of the nelut ral : and tode that effectnally, le must maintain a kind of blockade of the noutral coust; which, as neutrals will not permit, they ought not to give occasion for." 
oft' llue island, to inform the l'ortuguese if they afpeared that he had

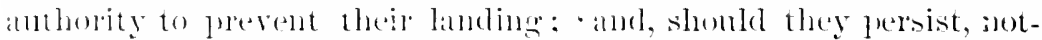
withstanding such walluing, in hovering abont, or in making any

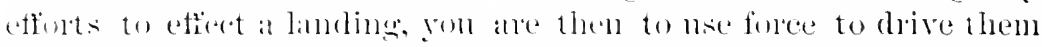

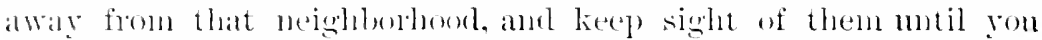
shall be convinced. he the contse they may steer, and the distance they may have grocerederl. that they hal re no intention of returning

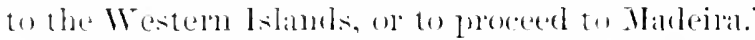

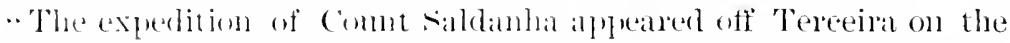

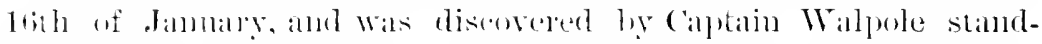
ing risht in for Pont l'ayal. The fiverl two shots to bring them to,

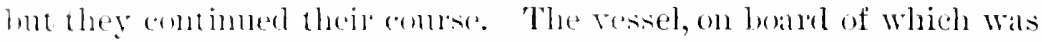
salkanha, althomgh now within print-blank range of the Romefers

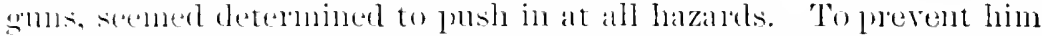
form rflecting his ofject Captain Walpule was under the necessity of firme a shot at the vessel, which killed one man and womnded anoher. The vessels theell lay to, and to a note from Calptain Walfule inguring what was their object in coming thither, salelanhat answerer, My object in apperimglese is to fulfil the orders of Iler

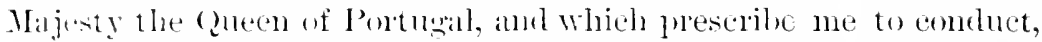
malnued, without any hostile apeneirance, to the isle of Terceira. the ment that are on boild the fom vessels in sight, which island has never crased to obey and acknowledge as its legitimate sovereign, Iler Faiahful Majesty Domma Maria Il. As a faithful subject and soldier, I think it mmecessary to assmeren that I am determined to fultil nuy duty at all peril.' C'aptain Walpole replied, that he tooluad

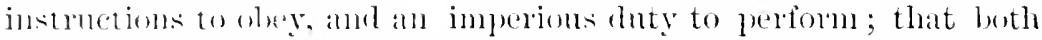
of them preventerl him fom allowing the Comnt, or any patt of his

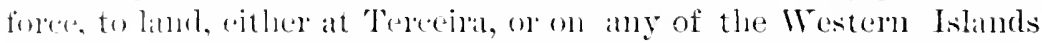

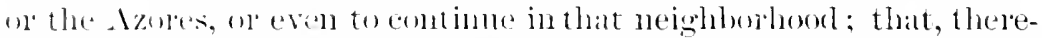

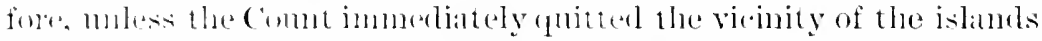
les sholld he olsligerl, and was determined, to nse foree to compel him to do st). Faldanha then tlectared that heconsidered himself and his

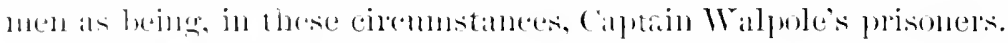

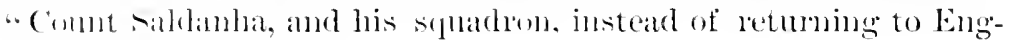
Jamel provecerled to Brest.

"The act of the bitish forremment produced a great excitement in England, and rely andmated clebates in l'allianent, in which the

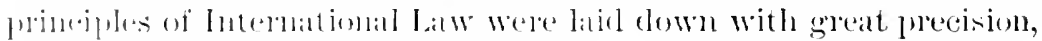

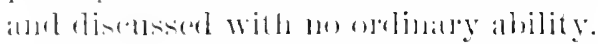

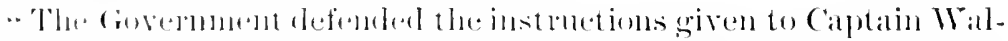

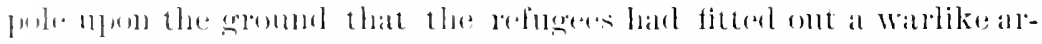

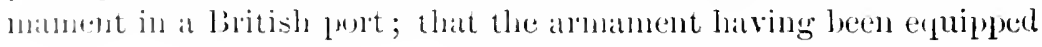




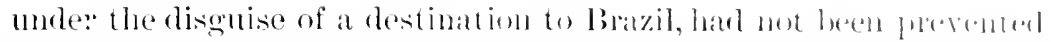

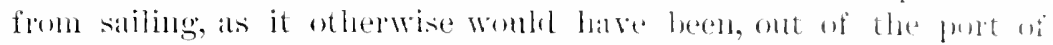
Plymonth; and that they weres, therefore, bonml, hy the dutien of

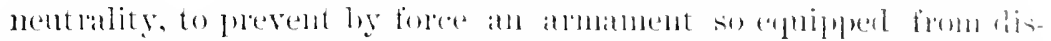

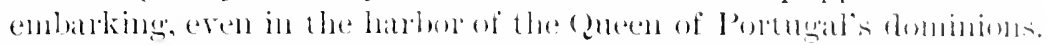

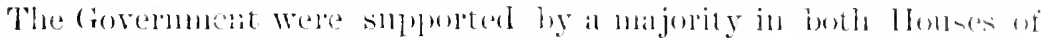

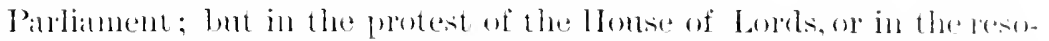
lutions of the Ilonseof Commons, the true princifles of International Latw atle to be fommet.

"The protest of the IIonse of Lords is an follows:-

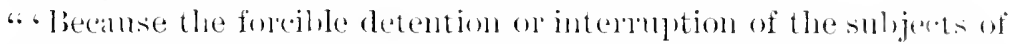
a belligerent state, mon the high seas, or within the legitimate jumisdiction of either of the belligerents. by a nentral, eomstitutes a dipect breach of Nentrality, and is an ohroms violation of the Law of Sations. And such an act of anglession, illegall and mujust at all times against a people with whom the interfering power is not artvally at wall, assmmet in this instamee a yet mole olioms and mogeneroms aspect, inasmmeh ans it wats esereised agdinst the mammed subjeots of a defenseless am friendly sovereigll, whose elovation and

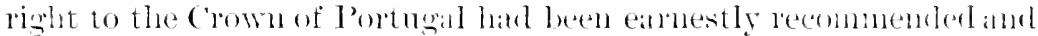
openly recognized hy llis Majesty, ant whose alothal lesidenere in Creat Britain, bespeaking enfirlence in the friendship and protertion of the king, entitled both her and lex subjects to especial farom and

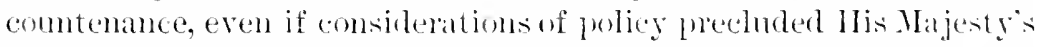
gorermment from enforeing her just pretensions hy arms."

Resolutions moved in the IJomse of Commons suggested, * That the use of force in intereepting these unamed resiels, and preventing them from anchoring and lambing their passengers in the futrbul. of Polto Platia, Was a volation of the sovereignty of the stalle to which the island of 'lerceira belonged; and that the further interference to compel those mercluant ships or transports to quit the neighlorhood of the Azores was an assmmption of juristiction upen the high seas, neither justified hy the necessity of the calse, nom sinnetioned by the general Law of Xations." (cuoted from (inblutt: "Calses," 1. 2(6t.)

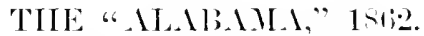

(Papers Reluting to the Treaty of Howhington.)

The Alabama, known in the shipyard as the -..egn," was hult at

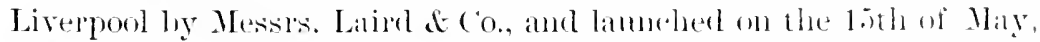
186\%. Mr. Dudley, Enited states consul at Live]pol, having (1)- 
tained evidence that the ".290" was eonstructed as a ressel of war and was being built for the confededate gorermment, tramsmitted this information to Mr. Adams, the Lujted stattes minister in Iondom. On the 2:3 of . June, 1962. Mr. Alans wote to Earl linssell,

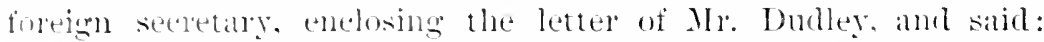
"This vessol has been huilt and launched from the flockyard of persoms, one of whom is now sitting as a member of the House of coms moms, and is fitting ont for the expecial and manifest ohjeet of carrying on hostilities ly sea. It is alumt to be commanded by one of the

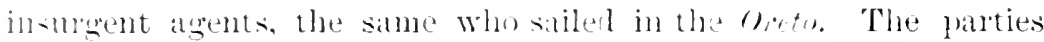
engated in the enterprise are persons well known at Livenpol to be agents and officers of the insments in the Eniterl states, the nature and extent of whose labors are well explained in the copy of an intercented letter of one of them, which l received from my govamment some days ago, and which I lad tise homor to plate in your lorkhipis hame on Thumsiay last."

(In the lst of July, 1862, the commisioners of customs. to whom harl been referred Mr. Adams" letter to Einl liussell, and itsinclosme reported to the Lords Commissioners of the Treasmy, that the vessel was undombtedly intended for a ship of war, but as yet there

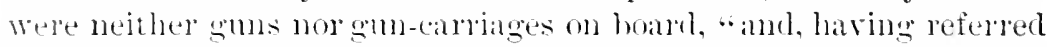
the mattel to our solicinur, he has reported his opinion that at present these is not sufficient gromed to warrant the detention of the vest or any interference on the part of this lepartment, in which lepurt we lewg to express our concurrence." The commisioners fmrther susposted that the American consul shomld smbmit any evidenee he might procure to the collector of enstoms at Liverpool, - who would therempon take smed measures as the provisions of the

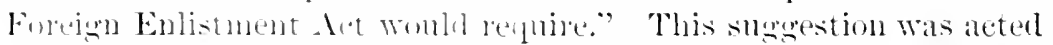
ufmo by Mr. Dnultey, and a mass of evirlence, including six affidavits showing the true state of allatrs, were laid befone Mr. Edwards, the

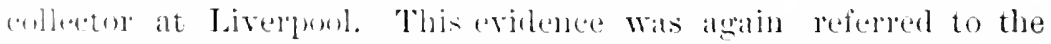

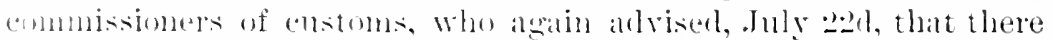
Wils not sufficient evilence to dutain the vessel. The same evidence baving been smbmitted to Mr. la. I'. Colliel, barrister, he gare tho

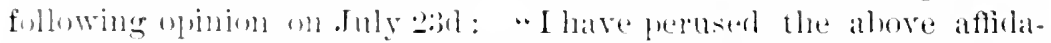
vit and an of ophim that the collector of customs wombl he justi-

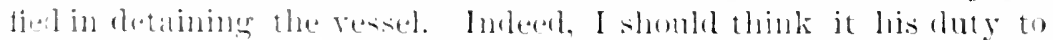
ketain, and that if. after the applieation which hats been marke to

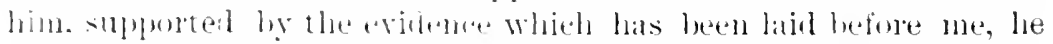

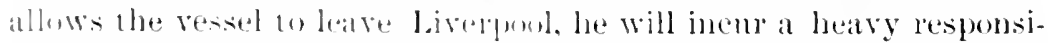
bility, of which the boum of enstoms, under whose direction he apjeats to le acting, must take their slare. 
"It appears diffient to make ont a stronger case of infringennent of the Foreign Enlistment Let, which, if not enforred on this accilsion, is little better than a dearl letter.

"It well deserves consideration whether, if the vessel lw allowod to eseape, the Federal govermment would not have serious grommos of remonstrance."

Finally, on July 2tth, Mr. Arams sent to Earl Russell mopies of two additional afficlavits, and of Mr. Collier's opinion, and on thes same daty the commissioners of customs referred the matter to the law officers of the Crown, as did Eall linssell on the ghth.

On Tuesday, the 29 th, the law officers, before whom all the evidence had been latil, reported to the recretary of state for Forejgn Affiars their opinion that the vessel shonld be detained.

But on the morning of the 29th of July the "2090" went to sea, without a clearance, ostensibly on a trial trip, carrying with her a party of ladies and gentlemen, who were, however, sent bark by a tug from the mouth of the river. She proceeded to Woelfia Bary, on the coist of Anglesea, where she remained at anchor mith the morning of July 31 st, and took on board alont to men, who had heen sent after her from Liverpool in a tug. And althongh it was known to the eustoms officers at Liverpool on .July 30 th that the tm. was to take men to the "290," no steps were taken to follow or seize: her.

On July 31 st the " $290 "$ sailed for 'Terceira, in the Azores, where: she was met by two vessels, the dyrippim, from London, and the Buhemr, from Liverponl, which hrought ont her armament and ad ditional supplies and seamen. Here the transshipment of the arma. ment was effected, and the " $290, "$ now the dlolmmon, under the com. manl of Captain Semmes, and a crew nealy all British seamen, juo. ceeded on her cruise to destroy the commerce of the Lnited states.

From this time until her destruction by the firmesrofe, on the 19 th of June, 186t, the Alobumen was receiverl in british ports ats a forteign belligerent ship of war, heing allowerl the privilege of refitting and of proeuring eoal and provisions.

The Alabuma captured 60 Luited states vessels, of which 9 were

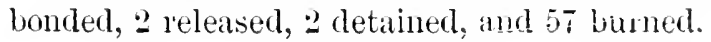




\section{TIIE "FLORII) A," 1 S(6..}

\section{(Papers Refutiong to the Treaty of Waskington.)}

The Florite. orighally known as the Orete, was an inon serew

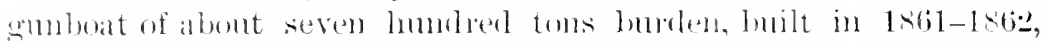

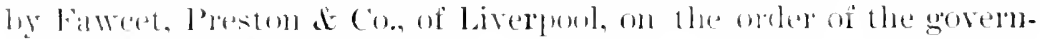
ment of the conferleate states. To arobl suspicin, it was given ont that she was to be hililt for the lablian governuest, but the Ital-

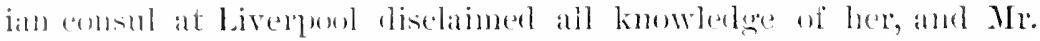

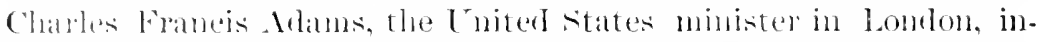

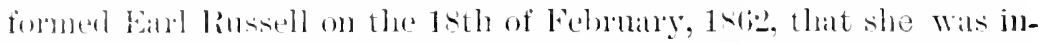
temberl for the comferlerate fovermment. As the result of inquiries set on fout hy the lintish govermment, the commissioners of enstoms

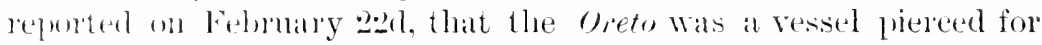

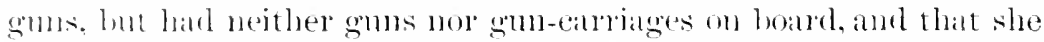
Was intemled for the mse of Thomas bothers. of Palelmo. Ir. Arams astin on the 2oth of March, ealled the attention of Earl I?ussell to the pubbule destimation of this vessel; but on Maleh 2od she had salderl with a general cargo and a clew of 52 men for Palermo and Jimalial. Next aplearing at Nassam, in New Providence. she almsed the suspledons of the American consul and of British naval othi er's, who strongly recommended ler arrest. Other ressels had arriver fom Englane with equipment and gums. The arrest was

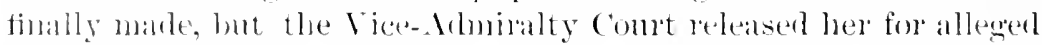

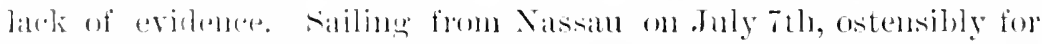
st. Jolms, X. li., she Was followrel hy vossels bearing her ammament,

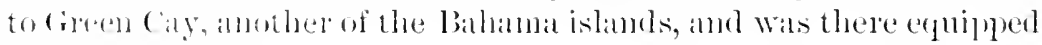
ats a rosicul of wall.

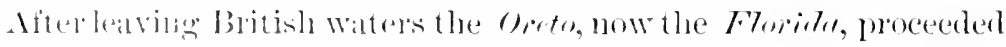

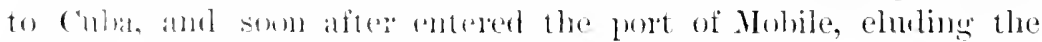

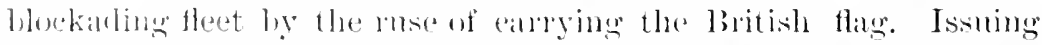

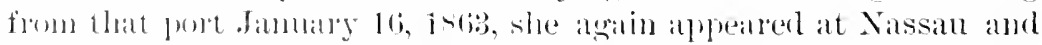
was permitted to take in a smplyly of coill. Jiter that she was rereiver at valums gortsof the liritish West Indies, and in some cases

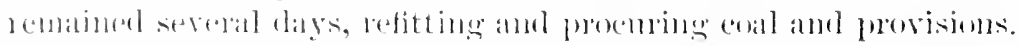

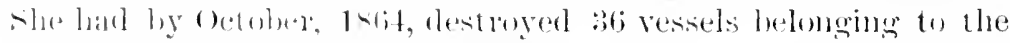
merellant manines of the lonitel states.

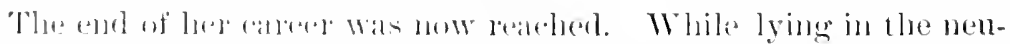

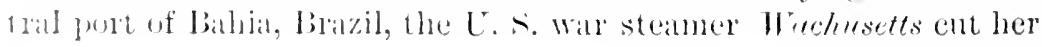




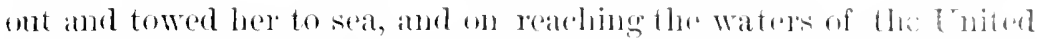

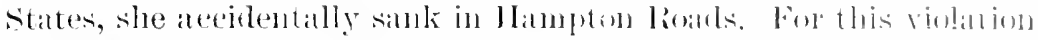

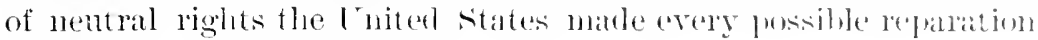
to the govermment of blaril.

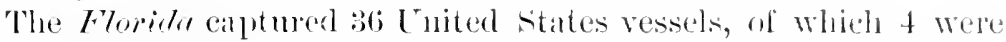
bonded and 320 destroyed.

\section{TIIE “SIIENANTOOAH," 1 Sfit.}

\section{(Pupers Releting to the Treaty of Heshingtou.)}

The Shenemdom was originally a Bitish merehant vessel kuown

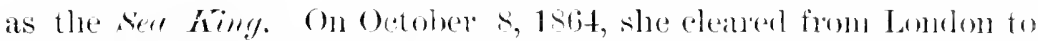
Bombaly with a large smpply of coal and a erew of forty-seven ment The Lened having silled the same day from liverpon with wms, equipment and men, the two vessels mot off the island of Marleira, and as in the case of the Alebreme and Floride, the Soll Fing Was transformed into a Confeterate erniser, muler the name of the shemedom, ant proceeded to prey upon the eommerese of the [nited states. She crossed the Athutic, romeled Cape IIorn, and arriven at Melboume on the 25th of . Jumary, 1865. Notwithstamling the remonstrance of the Enited States comsul at Mellomme, she wis allowed to make extensive repairs, to take in smplies and coal and to enlist more than forty seamen. Proceeding on her cronise, slle destroyed many Lnited states Whaling vessels in the Northern Pacific, and a considerable number after the war had ended. Finally, having made her way hack to Liverpool, she was surendered to the Euglish government, hy whom she was transferred to the Enited

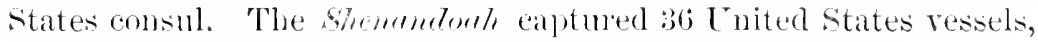
31 of which were destroyed, 3 bonded, and 2 ransomed.

$$
\text { TIIE "GEORGIA," } 186 \% .
$$

\section{(Papers Retating to the Treaty of Washington.)}

The Georgin, previonsly known as the fogmen, and the Firginion, was milt at Dumbarton, on the Clyde, and was equipred by a Lirerpmol firm. Her crew were shipped by the same liverpond tim for Shanghai, and sent romol to freenoek by stemer. Slue was entered on the 31st of Marel, 1s63, as for P'oint de Galle and Itong 
Kong. with a crew of forty-eight men. She cleared on the 1 st of April, and left her ancholage on the 2d, ostensibly to try her engines, but did not retum. Slue had no armanent on leaving Greenwhe lut a few days after her drpartme a small steaner named the

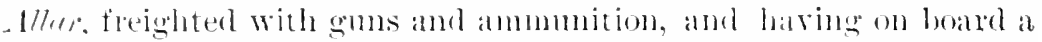
batner of the Liverpool firm who had equiplext hes. left Newhaven and met the Ciengyin off the coast of Fiance, Hear Eshant. The

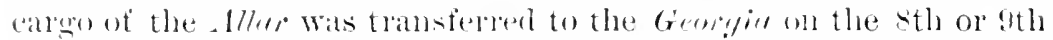
of April, and the Allor put into Plymonth on the 11th. bringing the Liverpool merehant who had directed the proceerlings throughout, and hringing also fifteen seamen who had refused to proeed in the fontro, on leaning her real charater. The rest of the crew, British subjects, remained.

The (itorgin was received in varions British ports as a Confederate man-of-war; but not being rery snceessful in capturing ships she returned to Liverponl on May 2, 1sif, and at Birkenhead was dismantled, her stores sold, and the ressel disposed of to an English merehant. The United states did not, however, recognize the validity of this transfer, and she was subsequently captured of Lisbon by an American cruiser, and eondemned as prize. The (rentyin capturer 9 vessels, 2 of which were bonded.

'Two members of the Liverpool firm, who had engaged in enlisting men for the fromgir, were indieted under the Foreign Enlistment set, and, on conviction, sentenced to fines of $£ 50$.

\title{
CASES OF THE "SLMPTER" AND OTHER VESSELA,
}

\author{
$18(; 1-1565$.
}

\section{(Papers Relating to the Treaty of Washington.)}

The Sumpter, previously the merehant steamer Hocom, was fitted out at New Orleans as a vessel of war, and sailed the Buth of June, 1sil, moler the commund of Ciptain semmes. On the 30th of .July she entered the harbor of 'Trinidad, and was the first of the Conterlabate comisers to receive the reeognition of Enghand as a legitimate ship of war of a reeognized belligent. Flue remained six days, and was allowed to supply herself with eoal and other neecsiary artieles. The simmpter having entered the jort of Gibmaltar, she wats there

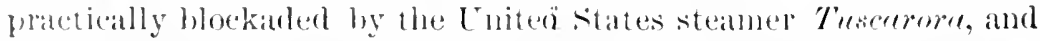
in consegnence, wastismantled and solel to an asent of Frazer, Trenholin o Co., of Liverpool, at which port she arrived on the 17th of 
Felmany, 1803. She was subsepuntly weekerl in attempting to

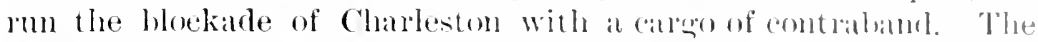
sumpter captured 18 vessels, s of which wele peleatserl, 1 recentutured. 2 bonted, the rest destroyed.

The Fashrille ran out of Charleston thromgh the blockinte: in November, 1861. Her Confederate commission wats reosnizurl in the ports of Bermuda and somthamptom, where she was permithed to repair ship and take in coal aml provisions. She afterwards loturned to Charleston, and was mot heard of again as a ruister. The Nushcille destroyed 2 vessels.

The Tallalussee appeared oft the coast of New York in July, I wit. She was probably built in an English port; little, however, is known of her construction and ontfit, the chief complaint in her ease heing that she was received in British ports. She destroyed ag Cnited States vessels.

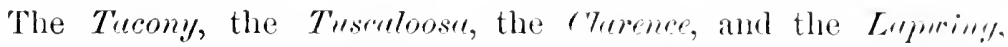
were tenders to the Almblmat and the Floridn. These were vessels captured by the Alabmer and Floridu, and converted into gumboats, at sea, and which acted as tenders to those two ressels. These tenders destroyed or bonded $2+$ United states vessels.

GENEVA AWARD, 18:2.

(3) Wharton's Digest, 630.)

Article VI. of the Treaty of Washington of 1871 , providing, among other things, for an arbitration to determine British liability for the depredations on the commerce of the Lnited states by the Alubrom, and other Confederate cruisers which left British water's, is as follows :

"In deciding the matters submitted to the arbitrators they shall be governed by the following three rules, which are agreed npon by the high contrating parties, as rules to be taken as applicable to the ease, and by such prineiples of international law, not inconsistent therewith, as the arbitrators shall determine to have been applieable to the case:-

\section{"RULES.}

"A neutral Government is bound-

"First. To use due diligence to prevent the fitting out, arming, or equipping, within its jurisdiction, of any vessel which it has reasonable ground to believe is intended to cruise or to carry on war against a power with which it is at peace; and also to use like diligence to prevent tire departure from it: jurisdiction of any vessel intended to cruise or carry on war as above, such 
ress having ben sperially adapted, in whole or in part. within such jurisdietion, w warlike use.

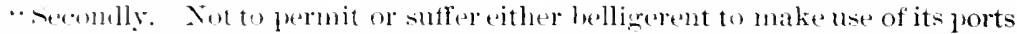

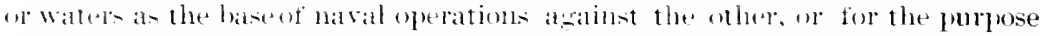

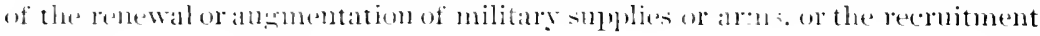
of $31 \mathrm{ten}$.

.Thi, lly. Toesereige due dilizenes in itsown ports and waters and as to all peroms within its juislictions, to prevent any violation of the foregoing ohlizallons and duties.

" Iter britamic Majesty has ommanded her high commissioners and plenipotentiandes an derbare that Her Majesty"s (rovernment can-

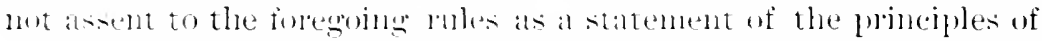
international law which were in inde at the time when the claims mentined in Anicle I. anse, lmt that IIer Inajesty's Govermment, in moln to evince its desine of strensthening the friendly relations

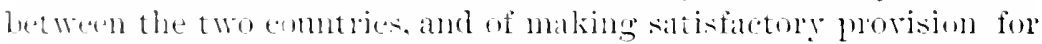
the futme. angees that in deciling the questions between the two comntries arising ont of those chams, the arbitrators should assume that Iter Majesty's Govemment ham molertaken to act mon the funciples set fouth in these mles.

* And the high tontrating partics aclee to olserve these mules as betwen thenselyes in futme. and to hring them to the knowledge of other maritime pors, and to moite them to accede to them."

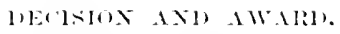

.. The trimmal having since fully taken into their consideration the treaty and also the cases, commereatses, docmments, evirlence, and arduments and likewise all othel communitations made to them

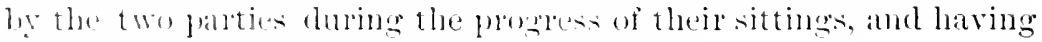
impantaliy and carefuly examined the sime.

.. Ints amperl at the derision embolied in the present amard:

- Whereas, having reand to the sixth and soventh antieles of the

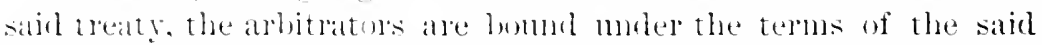

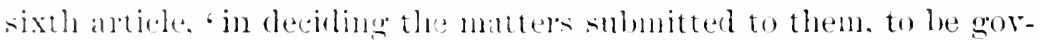

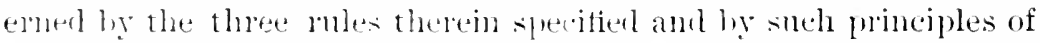
international law, not inemsistent themewith as the arbitrators shall determine to have been aphliablele to the case:"

- Anr whereats the dhe rlilinence, refered to in the first and

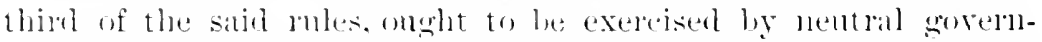
ment: in axact ponoution to the risks to whieh ejther of the belligerent: maty he exposed, from a fallue to fulfill the obligations of nentrality on their part ;

" Aurl whereats the circumstances ont of whieh the facts constituting the -uhject-matter of the present controversy arose were of a 


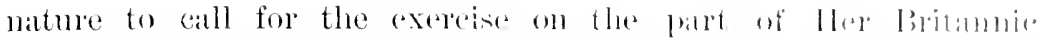

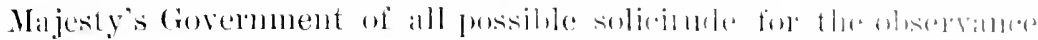

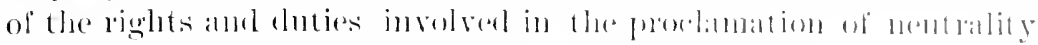
issmed hy IIer Majesty on the lish day of Way, Int.

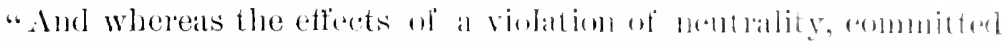

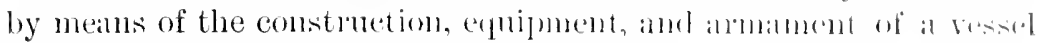

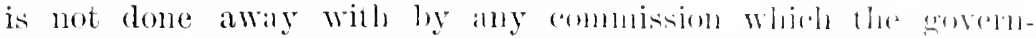
ment of the belligerent power, benetital by the violation of nentrality, may afterwalls labve glanted to that vasid; amb the nltimate step), hy which the olfurse is completed, anmon be admissible as a gromud for the atsolition of the offenter, nor the comsummation of his framb heeome the meams of establishinge his innocence.

"And whereas the mivilege of extraterrituriality, aceorlexl to ressels of war, has heen admitted into the law of nations, mot as an absolute light, but solely as a proceeding fommler on the prindiple of combesy and mutual deference between ditrorent mations, and, therefore, can never he appealed to for the protertion of acts done in violation of neutrality;

"And whereas the alsence of a previons notice eamot be lugarded as a fathure in any consideration reduired by the law of rations, in those eases in which a vessed cambes with it its own condemmation;

And whereas, in order to impart to any suplies of eall a rhara:ter inconsistent with the seeond rule, hohibiting the use of nentral ports or waters, as a base of naval operations for a belligelent, it is necessany that the said smpplies shomld be comeded with sporial circumstances, of time, of persoms, or of plare, which mag eombine to give them suth character;

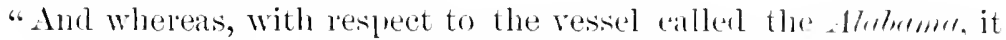
clearly results from all the facts relitive to the construction of llae ship, at first designated by the number "agn, in the port of Iiverpool, and its equipment and armament in the vicinity of 'lorrobia. thromgh the agency of the vessels called the dopippime am the Babema, dispatehed from Great Britain to that and, that the bitish Govermment failed to use due diligene in the ferformande of its neutral obligations, and especially that it onitted, notwithstanding" the warnings and official representations male loy the diplomatic agents of the Enited States during the construction of the said number '290,' to take in due time any effective meanlues of prevention, and that those orders which it did give at last, for the detention of the vessel, were issued so late that thein execution was not practicable; 
"And whereas, after the escape of that ressel, the measmres taken for its pursuit and anest were so imperfect as to lead to no resmt, and therefore cammot be considered sutlicient to release fireat Britain from the responsibility allealy incurred;

". And whereas, in despite of the violations of the nentrality of Great britain, committed by the 'zgo,' this same resicel, later

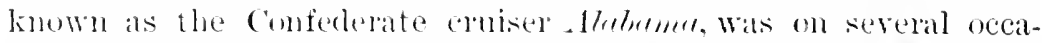
sioms frecly ardmited into the ports of the colonies of cileat Britain,

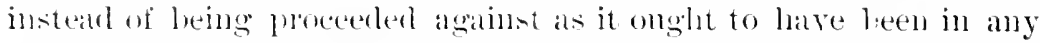
and erery gort within british jurishiction in whith it might have been fomml ;

“ Ant whereas the Govermment of IIer Britamic Majesty camnot justify itself for a failure in due diligence on the plea of insufliciency of the legal means of action which it possessed :

- Fom of the arbitrators for the reasoms above assigned, and the fifth, for reasoms separately assigned by him, are of opinion that Grealt britain lats in this tase fatled. hy omission, to fulfill the duties prescribed in the first and the thimd of the rules, established by the sixth article of the treaty of Washington.

"And whereas, with respeet to the vessel called the Florida, it results from all the facts relative to the eonstrnetion of the oreto in the port of Liverpool, and to its isme therefrom, which fate fatiled to induce the authorities in Great Britain to resort to measures adequate to prevent the violation of the nentrality of that nation, notwithstanding the wamings and repeated representations of the agents of the Tnited States; that IJer Majesty's govermment has failed to use due diligence to fulfill the duties of nentrality;

"And whereas it likewise results from all the fatets relative to the stay of the Oreto at Nassall. to her issue from that port, to her enlistment of men, to lee smpplies, and to her anmanent, with the eo-

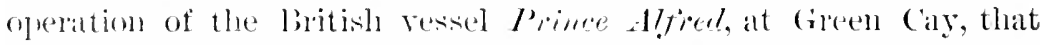
there was negligence on the part of the british eolonial authorities ;

"And whereas, notwithstanding the violation of the nentrality of Great Britain, committed ly the oreto, this sime ressel, later known as the Conferlerate emiser Floridr, was, nevertheless, on several ocatsions freely arlmitted inte the ports of british colonies;

"And whereats the judicial arcquital of the Oreto at Nassau cannot relieve Great Britain from the responsibility incured by ler muler the principles of intermational law; nor ean the fact of the

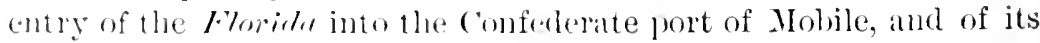
stay there during fom months, extinguish the responsibility previously to that tine ineured by Gleat Britain; 
"For these reasons the trilumal, ly a majority of fomr voipes to one, is of opinion, that Great Britain las in this casts failool, by onission, to fultill the duties peseribed in the lirst, in the surne, and in the thide, of the rules established ly drtiele VI., of the 'Treaty of Washington.

"And whereas, with respect to the vessel called the shemmomol, it results from all the facts relative to the departure from lamblom of the merchant vessel, the sea fring, and to the tramstormation of that ship into a Coufederate cruiser under the name of the shemondoah, near the island of Madeira, that the Government of IIer Britamie Majesty is not ehargeable with any failure, rown to that date, in the use of due diligence to fulfill the duties of neutrulity ;

"But whereas it lesults from all the facts comected with the stay of the shenamdouh at Melbomme, and especially with the angmentation which the British Goverument itself admits to have been clandestimely effected of her force, by the enlistment of men within that port, that there was negligence on the part of the anthorities at that place;

"For these reasons the tribunal is unanimously of opinion, that Great britain has not failed, ly any act ol omission, to fultill auy of the duties preseribed by the three rules of Irticle VI. in the Treaty of Washington, or by the prineiples of international law not inconsistent therewith,' in respect to the vessel called the viommaloch, during the period of time anterior to her entry into the port of Melbourne;

"And, by a majority of three to two voices, the tribmal decirles that Great Britain has failed, by omission, to fulfill the duties prescribed by the second and third of the rules aforesian, in the case of this same vessel, from and after her entry into llobson's IBay, and is, therefore, responsible for all acts committed by that vessel after her departure from Melbourne, on the 18th day of February, 1865.

"And so far" as relates to the vessels called the Tuscrilonsil (ten(ler to the Alabuma), the Clarence, the Tacony, and the Archor, (tenders to the Floride), the tribunal is unanimously of opinion, that such tenders or auxiliary ressels, being properly regarded as accessories, must necessarily follow the lot of their principals, and he suhmitted to the same decision which applies to them respectively.

"And so far as relates to the vessel caller Rotributim, the tribunal, by a majority of three to two voices, is of opinion, that creat Britain has not failed, by any aet or omission, to fulfill any of the duties prescribed by the three rules of Article VI., in the Treaty of Waslington, or by the principles of international law not inconsistent therewith. 
"And so far as relates to the vessels called the Georgin, the

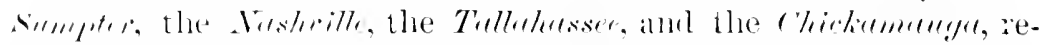
spertively, the trimmal is manimomsly of opinion, that Great britaim has mot fitiled, hy any alet or omission, to tulfill any of the

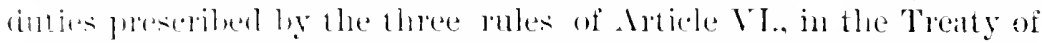
Washington. of hy the prineiples of inteluational law not inconsistent therewith.

". Aull so far as relites to the vessels called the sollie, the fegfer-

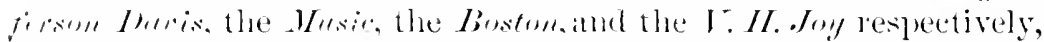
the tribmal is mamimomsly of opinion that they omght to be excholed form comsicleration for want of evidence.

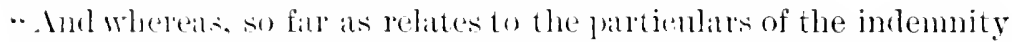
daimed by the Lnited sitates, the eosts of pursuit of the Conferlerate

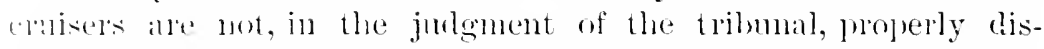
tiundishble from the general expenses of the war earried on by the Eniterl states:

"The tribmul is, therefore, of opmion, hy a majority of three to

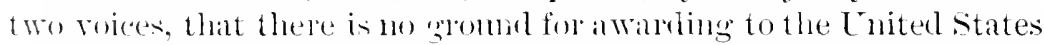
any smm ly way of indemnity moler this hearl.

- And, whereas, pospective andung enmot properly be made the smlject of compensation, inasmuch as they depend in their nature ujom futme and uncertain contingencies:

". The tribmal is momimomsly of opinion that there is no gromul for awarling to the Eniter states any sum by way of inremuity muler lais hearl.

". Aml, whereas, in onder to arrive at an equitalule compensation for the damages which have been smstained, it is neessiary to set aside all demble dalims fol the same losses, and all chaims for "gross

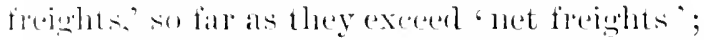

- Aml. whreats, it is just ambl reasomalble to allow interest at a loasmalbl. l:ate;

"Ancl. Whereas, in aceostance with the spirit and letter of the Treaty of Watsingtom, it is preferable to arbogt the form of arljuli-

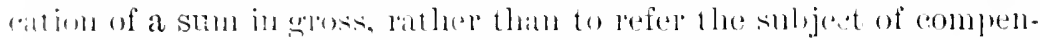

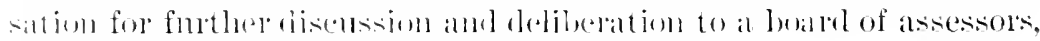

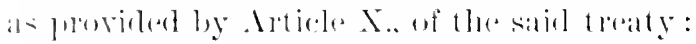

"The tribmal, making use of the anthority conferred mon it hy

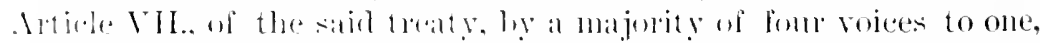

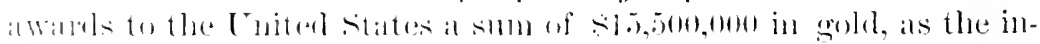

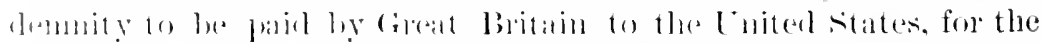

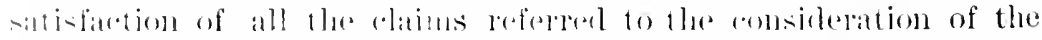

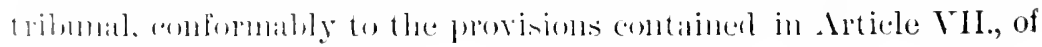
the aforesaicl treaty. 
"And, in alcendance with the terms of Artide XI. of the sald

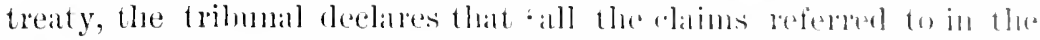
treaty ats sulmited to the tribmal ane herely tolly, pellectly, and tinally settied.'

"Furthermore, it dechares that anch and rvery ome of the silil chams, whether the sime may of may not halve leen foresented to the notice of, or mate, prefermed, on labl bofole the tribmal. shatl henceforth be considered anm lreated as finally sottled, hamed, am inadmissible.'

"In testimony whereof this pursent decision and awadr has been made in duplicate, and signed by the anbitrators who have griven their assent theroto, the whole being in exact conformity with the provisions of Artiele VII., of the said Treaty of Wasleingtoll.

" Made and conchuded at the Hotel de Ville of Genevil, in sivitzerland, the 1tth day of the month of september, in the year of oun Lord one thousand eight hundred and serenty-two. ${ }^{1}$

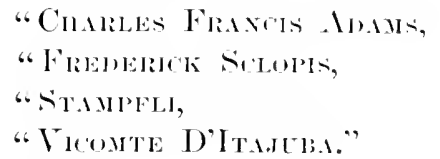

1 The Three Rules of the Treaty of Washington.-These mles have been the subject of widespread interest and eliscussion. The question was immediately raised. whether they formed, at the time of the American civil war, or indered since that time, a true expression of the accepted principles of International Law. The English government, at the timse of the arbitration, amnomerel that it alil not accept them "as a statement of principles of International Law which were in force at the tinse when the claims arose:" and the view generally heid in England was that they were ex post fucto rules.

On the other hant, continental jurists are inclined to regard these ronles ans al fais statement of modern International Law upen the subject to whieh they apply. (See an article by Calvo in the Revue de Droit Intemational, vol. VI., pp. $453-532$.

In consiflering this question, it should he remembered that. by the introhnetion of steam as the motive power of ships and of iron and strel als the matrial of their construction, the conditions of maritime warfare have bern very rati-

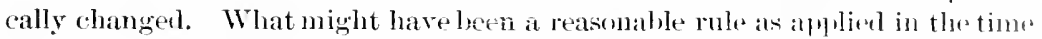
of sailing ships, might now, in the age of swift ironclarls. lee intolemahly up-

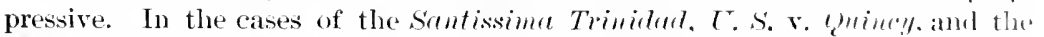
Meteor, the courts were dealing with small sailing vessels, which hard been ronverted into privateers, the possession of which by one or the other helligerent made very little difference in the general result of the strugerle: whereas. the possession of an ironclad ship might rery well turn the scale one way or the other, as indeed it diel in the war between Chili and Porn. in 1 trot-1 great power of inflicting injury upon one of the belligerents, it is firir to say, 


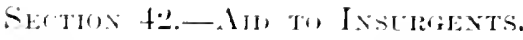

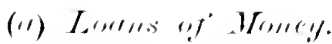

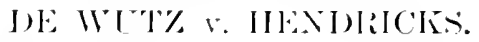 \\ Cinums l's:is, $1 \times 24$. \\ (9) Howne. jos.)}

The frution of the legality of a contract to negotiate a loan in aid of insurerent:

This was an action of trover fol certain papers, and which were fleseriberl in lde declatration to be a power of attorney, and sumdry englowings.

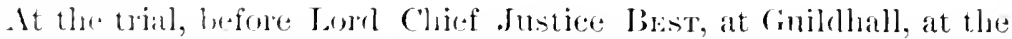
sittins after the last Term, it alpearerl that the phantiff lad puopesed to raise money by way of hom, to esprouse the cause of the

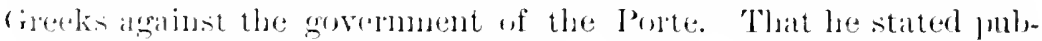

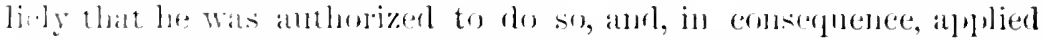
to the refendant, a stockbroker, to nesotiate the loam, who required certain secomites to be leit with him for that pmoses that the jatiutifi aceodelingly lorged with him a power of attorney, which, lee staterl, Was signerl and exeented abroud by the Exaldeh of liavenna, anthorizins hisu, the plaintiff, to raise money for the creek cause;

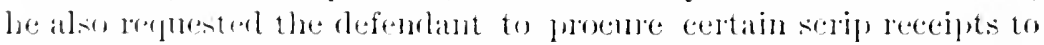

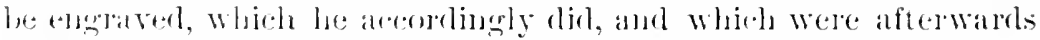

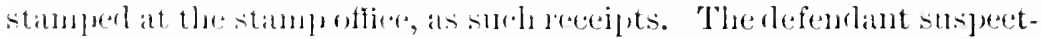

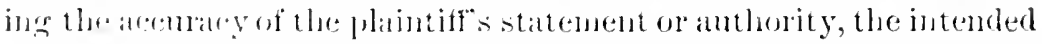

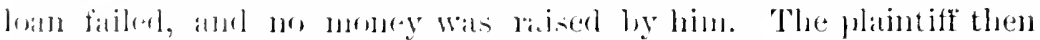

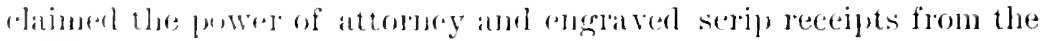

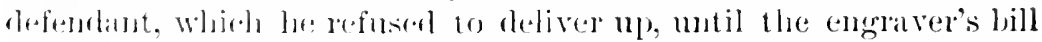

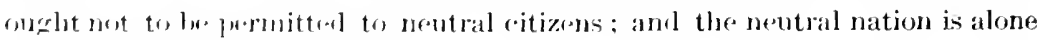
in a [meition to rentrain them.

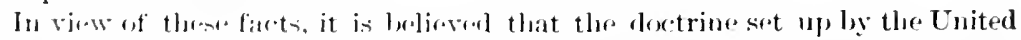

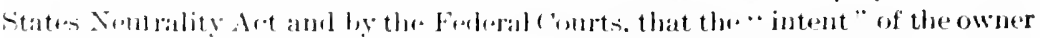

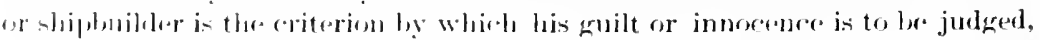

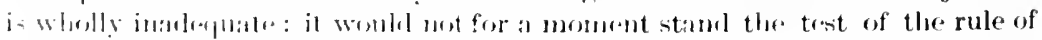

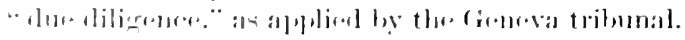

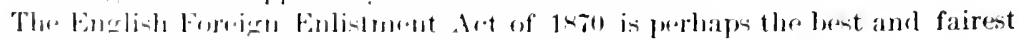
expression of the morkern rule anywhere to be fomm in public laws. 
and other expenses had been pail. On their amount being temdered, the defendiunt elained a commission for serip on part of the lom, which the plaintiff also offered to pity, powided the defendant wond transfer the serjp to him, on which he elajmed stleh commission; but none was in fact ever raised, as the projected loan fell to the gromd in the first instance. The platintiff having again formally demanded the above documents from the defendiut, who refused to deliver them up, he commenced the present action.

For the defendant, it was submitted, that the whole of the trinsaction was a fraud on the part of the plajutiff, as he harl no authority to negotiate the loan in question. And his Jordship leeing of opinion, that a resilent in this country could not enter into an engagenent to raise money by way of loan, to assist subjects of a foreign state, so as to enable them to prosecute a war against a govemment in alliance with our own, without the license of the Crown; the Jury accondingly found a verdict for the defendant.

Iord Chief Justice Best.- "I an of opinion, that the whole of the transaction on which the plaintiff rested his claim to recover the articles in question from the defendant, was hottomed in fraud; the Jury so found at the trial; and I an perfectly sitisfied with their verdict.

"I then thought that it was contrary to the law of mations, for persons residing in this comutry, to enter into engagements to raise money, hy way of loan, for the purpose of supporting subjects of a foreign state in arms aganist a government in allimee with onr own; and that $n$ right of action eould arise ont of snch a transaction; and I consequently sugerested a nomsuit; but as it was not insisted on by the defendants' comsel, I allowed the canse to proceed. A case in circumstances precisely similar to the present, except that a different loan was proposed to be raised. was lately decided in the Court of Chancery in which the Lord Chancellor entertained the same opinion as myselt, and in which he is stated to have said, tiat English Courts of Justice will not take notice of, or afford any assistance to persons who set abont raising loans for subjects of the King of spain, to enable them to prosecute a war aginst that sovereign; or, at all events that such luans could not he raiserl without the license of the Crown. I left the question to the Jury on the merits, and they fomd that the power of attorney was an abrogated filbrication. It appeared on the face of it to have hesp executed in Greece, it was drawn up in the morlern Greek linguage, and was pretended to have been sent from that comntry. The planintiff. how. ever, ardnced no evidence to show that it was a renuine instrument: but, on the contrary, it was proved to have been executed in London, 
but ly whom did mot alleatr. The other articles songht to be re-

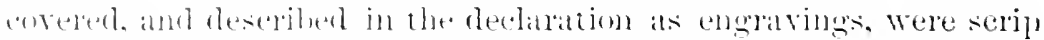

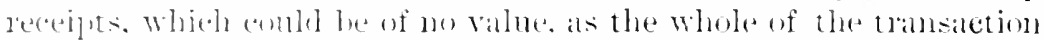
to whide they were intermed to be alphlied tell to the gromed as it

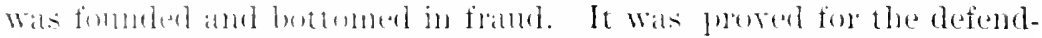

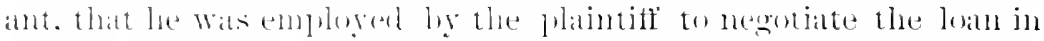
flustion: that many anteles late been written on the sulject, and

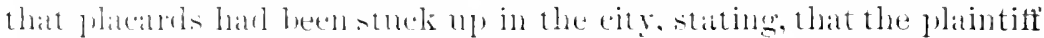

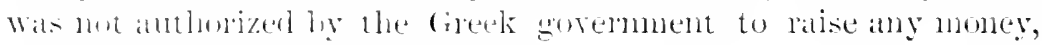
and that it wats altogetlete at trand.

- I told the Inry. that, with lespect to the power of attorney, the

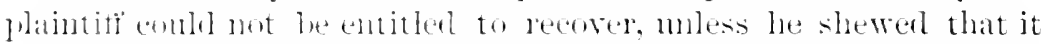
Was a gennine instrument. at it was so deseribed in the declatration;

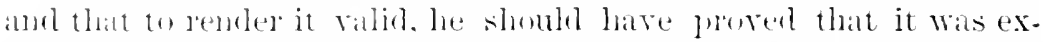

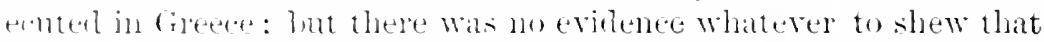
fisct :-m the contlany, it was proved to have been eoneocted and exeented in Jind ins Lame. I also tokl the Jury, that if the plaintift

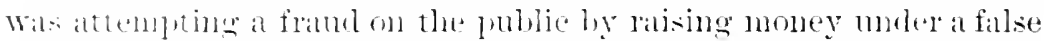

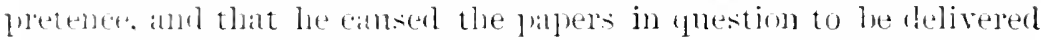
to the defendant in inmberance of such attermet. he combl mot be entitled to decover them hatk in this action. The Jury. under these circmmstances, were fully warranted in comsilering the transaction as framblent; and I an not only satisfied with their vereliet, but am deeidedly of opinion that there is no ground whatever to disturb it.

"The rest of the Count concurring, liule refused."

TIIUMPSON

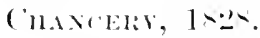

( 2 Simm. 194.)

Loms to unreconnizul communities.

The cont ratet in this (atse was for the purehatse of Guatemala bonds,

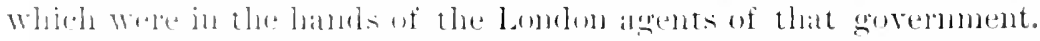

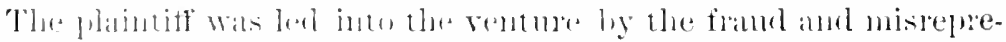

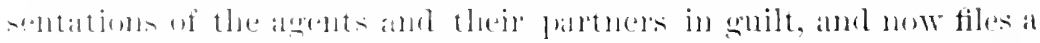
lill in chancery for the renorely of his montey, the Gilltemalim

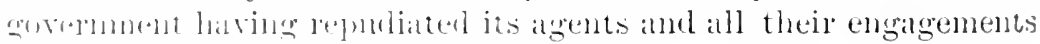
lectalloc wi these firatuls. 
The following is an extl: et irom the jur!gment of the Vim-than cellor:-

"But there is this further consilleration; that this is represonert to have been a contract, hy the plantiti, to purethase the obligations of persoms who were stated to be the Govermunent of the fienteral liepulbic of central Americal.

"I confess that, after all I have heard fall from the momth of homel Elan, on the subject of persons representing themselves to be Governments of Foreign Conntries, which this Comtry had not aneknowledged to be Govermment: and which the comts cammot ackmonedge then to be, till the Govermunt of the comntry has reengnizent them to be so, it does appeas 10 me that this is a combated anteresl into by the plaintifi for the purpose of purehasing that which ly the law of the lambl, he conld not pumelatise. I think that the eomtract, being to purchase securities from these persoms, who, at the plaintiff says, were the Goremment of Guatemala, camnt le (omsidered as leing a contract which this eourt onglit wa sanction. 'The whole case being fomded on that, I do not think that I conld give relief to the party, who builds his case for relief entirely on at transaetion originating in such a mamer: and it appeans to me that, on that gromul, I must allow this demurrer."

\section{KENNETT $\checkmark$. CHLMBERS.}

\section{Sepreme Colmt of the Cxited states, 185\%.}

(14 Hourerd, 38.)

Held, that a contract to raise money to aid the Texans in their war with Mexico. Texan independence not then being recognized by the United states. was invalicl.

The following is an extract from the opinion of the ennt, delivered by Mr. Chief Justice Thxey:-

"To this lill the respondent (Chimbers) demmreet, and the mincipal question which arises on the demmorer is, whether the contratet wats a legal and a valiel one, and such ats eam be enforered hy either party in a comrt of the Cuited States. It appeass on the fiace of it, and by the averments of the appellants in their hill, that it wats marle in Cineinnati, with a general in the Texan army, who was thom en-

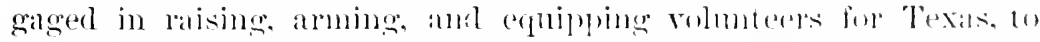
carry on hostilities with Hexico; and that one of the inducements of 
lise apjellants, in entering into this contrat and advaneing the numey, Wak to asist him in accomplishing these oljects.

.. The District Comet decited that the contrate was illegal and voikl and sustained the demurele and dismissed the bill; and we think that the deeision was right.

.. The vatidity of this contract depends upon the relation in which this enmtry then stome to Mexion and Texas; and the duties which these relations imposed mom the governunent and citizens of the Enited states.

.. Texas hat dechared itself independent a few months previons to this asmeement. But it late not been acknowledged by the Cnited states: and the constituted anthorities charged with om foreign relations, resalded the treaties we had mate with Mexieo as still in full force, and ohlientory upon loth nations.

. Br the treaty of limits, Texas hat heen admitted hy our government to he a part of the Mexican territory: and by the first article of the treaty of anity, commerce, and narigation, it was declared, - that there shomd be a firm, inviolable, and muversal peace, and a true and sineere friendship between the Enited States of America anrl the Enited Mexican states, in all the extent of their possessions and territories, and hetween their people and citizens respectirely, withont distinction of persons or place."

"These treaties, while they remaines in force, were, by the Constitminu of the L'nited states, the smpleme law, and binding not only upon the gurermment, but upon every ditizen. So contract conld lawtully he made in riolation of their provisions.

. Tumblitally. when Texas had achiever her independence, no

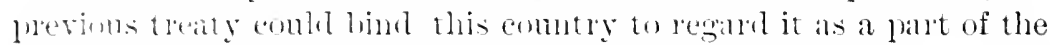
Mexian terditory. Bnt it bedonged to the goremment, and not to individual citizens, to decide when that erent had taken place. And that derison, aeconding lo the laws of nations, depended upon the

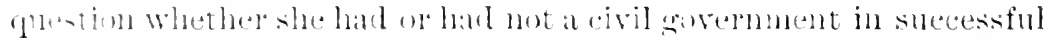

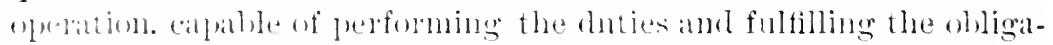

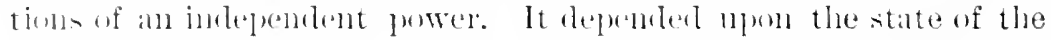
faret. and not upm the right which was in eontest between the latitien.

". Dum the J'mesident, in his messige to the Senate, of Jecember

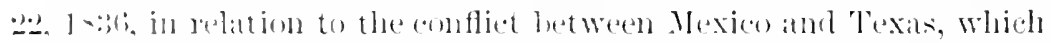

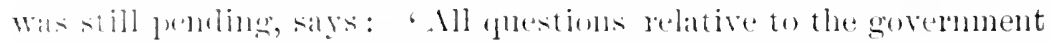

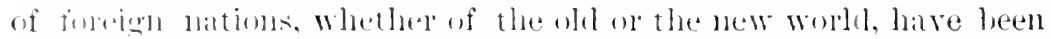

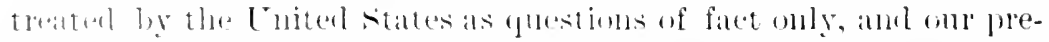

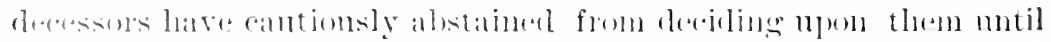
the elearent evidence was in their posiession, to enable them not only 


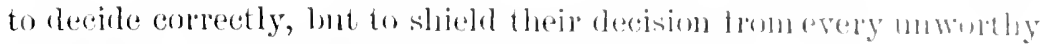
imputation.' Sienate Jomlual of $1 \times 331$, :37, 1). it.

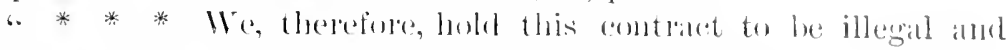

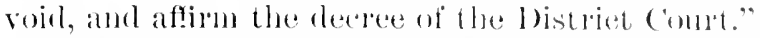

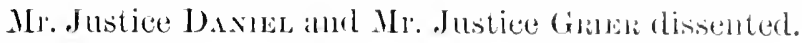

(b) Ships, Munitions, and other simplies.

UNITED STITES $v$ TIRTMBLLL.

U. S. Distmot Cocrot Fon Colnfomin, 1891.

(48 Federal Reporter, 99.)

Ireld, that it is not in conl ravention of the neutrality lews of the Tnited states, to deliver to a vessel belonging to chilean insurgents, in onr walers, anns and ammunitions,

Indictment of 'Trumbull and liut for violation of neutality laws. The opinion was delivered hy lins, .J.:-

"The indictment in this case contains 11 comnts, the first 4 of which, in effect, charge that on the gth day of May, 1 xal, at a coltain designated place in this julicial district, moll the island of sin Clemente, the defendauts mulawfully attempterl to fit ont and arm, fitted ont and amed, pocmed to be fitter ont and amed, and ware knowingly concerned in furnishing, fitting ont, and ambing, a rertain steamship called the Itrotr, which was then and there in the possession and under the conter of eertain citizens of the republic of chile, known as the 'Congresisional Panty' and who were then and there, in said repmblic, organized and banded together in great mombers in anmed rebellion and attemphed revolution, and callying on woull against the republic of Chile, and the govermment therest, with whish the Enited States, then and at the time of the finding of the indictment were at peace, with intent that said ship shomld bo amploged

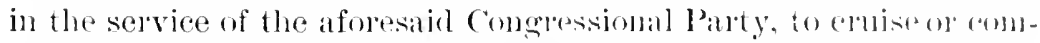

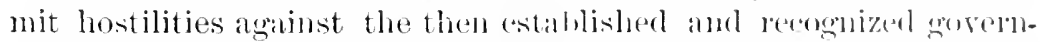
ment of Chile, with which this govermment then was at frame, romtrary to the provisions of soetion ses: of the lievised statutes of the United States, which section is as follows:-

". 'Every person who, within the limits of the Unitul Statrs, fits out and amms. or attempts to fit out and arm, or procures to be fitted ont and ammed. or knowingly is concerned in the furnishing, fitting ont, or arming ol', any ressed, with 
intent thac such ressel shall be employed in the service of any foreign prince or state, or of any rolony. dintrict or people. to cruise or commit hostilities against thes sub,jects. citizen : ar poperty of any foreign frinces or state. or of any col-

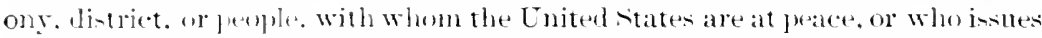
and delivers a commision within the teritory or juriadiction of the Conted stitues for any vescel. to the intent that she shall be so employed. Shall be

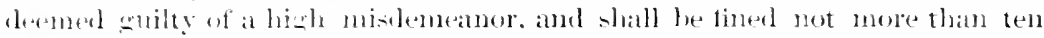

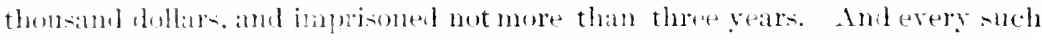
vered. ber tackle, applarel, and furniture, together with all materials. arms, ammunition, atul stores. which may have leeen procured for the building or

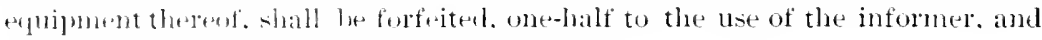
the ollur half to the use of the Lnited States.

.. The next there comnts of the indietment, in effect, change that the defendiants, at the same time and place increaset, molatully flowered to he increatsed, and were knowingly conterned in increatsing. the force of a celtain ship of war and almed steamship called Ifofo. Which alliverl at the port of san l)iego in this judicial distriet om the -ed laty of May, 1<91, and wats at the time of hel satid allrival. and to and inchuling the gth day of May, 1-91 (during which time sle remained within the jurisdiction of the Lnited states, and of this conte, a ship of war in the service of a certain foreign people called the - Compresional Party' then eitizens of and residing in the republic of chile, amb who were then and there banded together in latrot numbers, in open-inmed rebelliom, and attempted forcible revolution, and nulking war against, and being at war with a eertain forejon state, namely, the republic of Chile, and the lawiol government thereot, with which the Cnited states then, and at the finding of the indietment. Wereat peace by adding to the force of said ammeri

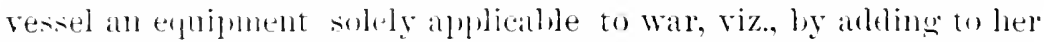

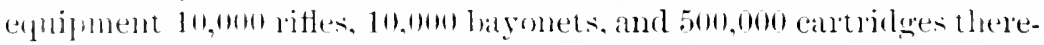
fore entrary to the porisions of section 525 of the lievised statutes of the liniterl states, which is as follows:-

". Every person who. within the territory or jurisdiction of the United States.

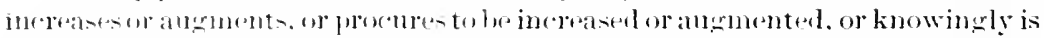

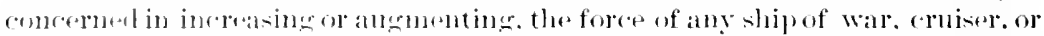
other armenl venetl. which, at the time of her arrival within the Cnitedstates.

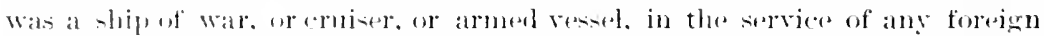

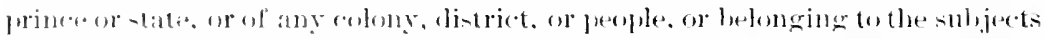

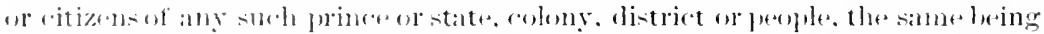
at war wirh any formign prince or state. or of any colony district. or jeople.

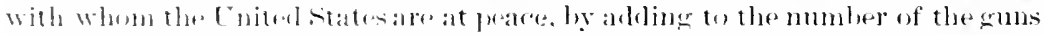

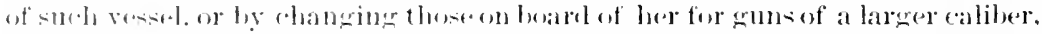

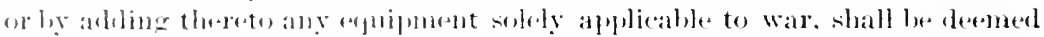
grilty of a hizh mistemeamor. and shall be finesl not more than one thousand chollatr, and imprimeled not more than one year." 
"The last four comnts of the indietment, in efferet, chillewe thit the

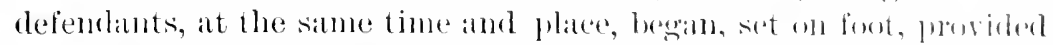
the means for, and prepared the means for, a cortain military apes dition on be earried on fom thenee andinst the territory and domin-

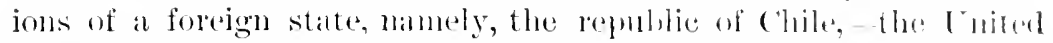
states, then and there, and at the time of the findime of the imbiret

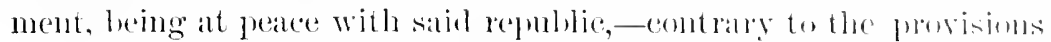
of section 5os6 of the lievised statutes of the luited sitaten, which is als follows:

" Every person who, within the territory of the Unitrd States, lexgins ar sets on foot. or provides or prepares the means for, any military expedition or anterprise. to be carried on from thence against the territory or dominions of any foreign prince or state, or of any colony, district, or parple, with whom the Uniterl states are at peace, shall he deemed guilty of a high misiomeand, am shall be fined not exceeding three thousand dollars, and inumisoned not more than three years.'

"The evidence introduced hy the Enited states in support of the indiennent being conchuded, the compt is asked hy the defombunts to divect the jury to return a verdict of not givily, on the sumb that the evidenes introduced on the part of the porserut ion is insutionent to sustain any comnt of the indictment. For the purposes of the motion, every fact that the evidence tends to establish must, of course, be comsidered as proven.

"Briefly stated, these facts ane as follows: In . Janumy of this real" the steamship Itoto was an whinary merehant vesiel. Eanly in that month she was eaptured in the harbor of Valparaiso, (hile, hy the people designated in this indictment as the compresiomal l'arty, and who wele then engarged in an effort to overthrow the then establisher and recognized government of Chile, of which balmaldeda was the liead. The Itorn was by the Congressional larty put in command of one of its officers, and was nsed in theig mmlertaking as a transport to convey troops, plovisions, and muntions of Wall, and also as an hospital ship, and one in which to comfine prisoness. Fom small cannon were also put mon her decks and she carried a jack and pemant. Some time prios to the following In sil the defendant Trumbull came to the Lnited States as an agent of the comgressional Party, and about the month of April went to the eity of New York, and there bought from one of the linge mercantile firms of that eity, dealing in such matters, 5,000 rifles and $2.000,000$ calltridges therefor, with the intention and for the purpose of sending them to the Congressional Party in Chile for nse in their effonts to overthrow the Balmacedan govermment. The sale and purchase of 
the arms and ammmnition were made in the usmal comse of trade. Trumbull cansed them to he shipled by rail to san Franciseo, and enengerl the defombant burt to atecomplany them, which he did. Ar-

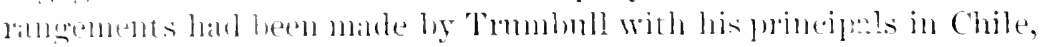

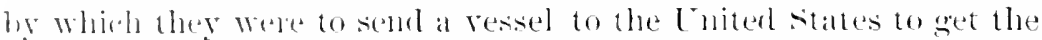
alms and ammonition, and conver them to chile for the nse of the

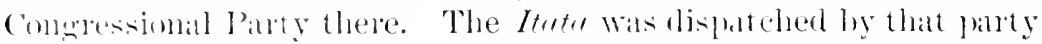

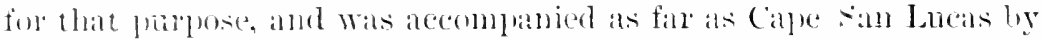
the Exmerdlth. al Wall ship then in the service of the Congressional Party. At one of the Chilean ports the Itote trok on board some solliers, whth their arms, hy one witness stated to be about 1.in, and by another to he about 12 , in number.

" It sin Lucas the eaptain of the Esmepeldue took command of the 1toto, and the captain of the latter was left there in command of the

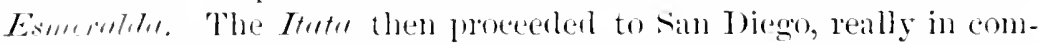
mand of the Exmerelde's captain, hut ostensibly in eommand of another, who repesented to the astoms officer's at that port that she Was an orelinary merchantman, and was bomnd to some pout on the nollherul coast. Before coming into the port of som Diego, or into the waters of the Enited states, the Itro hanled down her jack amb pemant. the canmon theretofore carrind on her decks were remored and stowed in her hold, as were also the arms of the soldiers she carried: and their mifoms, as well as those of the officels, were removed, and all appeared in eivilian's dress. At that port she haid in stores of coal and provisions, all of which were lomght in the open market, and some of which were marked ' Esmeralka.'

- Meamwhile Trumbull had chartered a schoones, alled the Robert "red Minnie, in Sin Francisco to take the arms and ammunition from there to a juint in this judicial distriet, then expeeted to be now the island of Catalina, where she conld meet the Itota, and deliver them on buard of her to be comreyed to chite for the pmposes alvealy

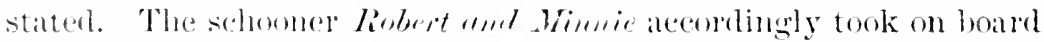
the arms and ammmition at the port of sim Franciseo, and, in eharge of the defendint limt, proceeded to the neighborlood of Catalinat Island, where she rrpected to meet the Itrot. In the mantime the sms pirion of some of tho officers of the Inited states that the nen-

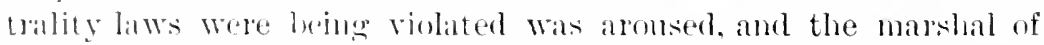
this district Was direeted hy the attomey-general to detain the Itrete,

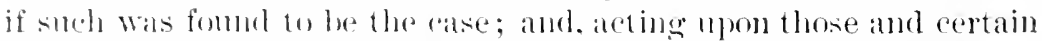
instrutions from the district attorney of the jullicial distret, he Went on bourd the ship at Sian Diego, and put a keeper in charge of hes, and then went in search of the Robret amd. Mimie, which he did not find in the waters of the Cnited states. Commmication was, 
however, had hetween the Itren and the sehooner and a point mar

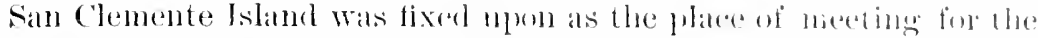
purpose of transferring the arms and ammmitirm fom the schomme

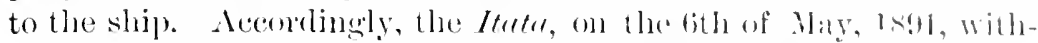

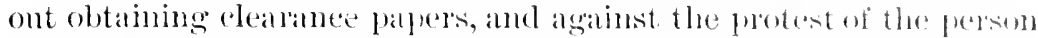
left on bourd and in clarge of her by the mastal, weighed andmen, and stemed out of the harbor of san Jiego, with him on boanl, to

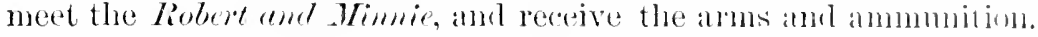
The marshal's keeper was, however, put ashore at Point biallast, before leaving the harbor. While steaming ont of it, one on more of the Itutris camnon were bronght on deck, and some of the soldiers on board of her appeared in miform. On the sth of May, the Tinter and liobert and Mimmie came together about a mile and a half sontherly of San Clenente Island, and there the arms and ammmnition in question were taken from the schooner, and put on board the ship in original packages, and the latter at once left with them for chile.

"No evidence was introduced tending to show that the congrossional Party ever received any recognition of any clataleter from the government of the Cniter states mint september 4 th, whon it was recognized as the established and only govermment of (hile.

"But since the argument and submission of the motion, the comsel for the United States have called the attention of the comet to the following facts fornished by the respective departments, to-wit : ()n Mareh 4 th, the secretary of the navy cabled Admiral Mecamm to proceed to Valparaiso, and observe strict neutrality, and take no part in troubles between parties further than to protect Anterian interests.' On March 20 th, the secretary of the navy cabled Mrmiral Brown, who had smperseded Admiral MeCann, to albstain from proceedings in nature of assistance to either, that is, the Balnatceda or Congressional Party: that the ships of the latter were not to be treated as piratieal, so lomg as they waged war only arginst the balmacela govermment.' On April 25th, Secretary of State Blane cabled the Ameriean minister, "Tou can act as merliator" with Jira-

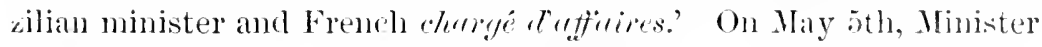
Eagan eabled this government, "Govermment of Chile amd revolutionists have accepted mediation of the T'nited States, lirazil, and France most cordially; those of England and Germany declined.' On May Tth, Acting secretary of State Wharton acknowledger the dispateh of Minister Eigan, and 'expressed hope that throngh commbined efforts of the governments in question, the strife which bas been going on in Chile may be speedily and happily terminaterl.' ()n May 14th Acting Secretary of State Wharton cabled Ninister Eirgan that 'French minister reports threats to shoot the insmatent enroys 
ly Palmarela, and directed that they should have ordinary treat. ment muler hitas of truce.

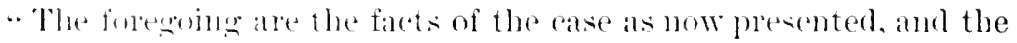

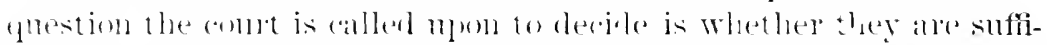

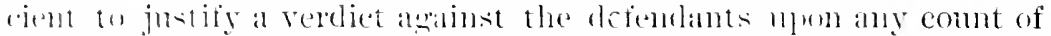

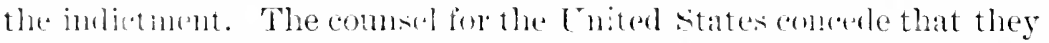
are insuficient to justify a verbict andust the defendants under

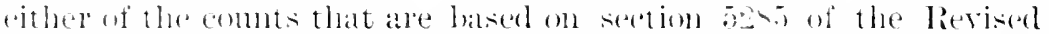

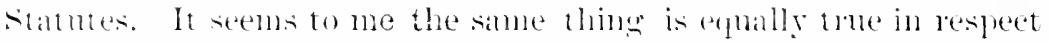

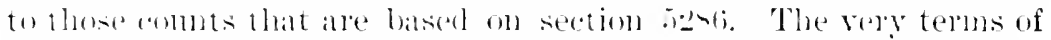
that statue imply that the military expertitims ol enterplises there$1 y$ mohihited are sulh as originate within the lumits of the I'nited states and are to be carried on fom this combtry. "Every person Whe, within the limits or jurisdiction of the Tuited states. hegins or sots un fout, or proviles or prepares the means for any militaly experlition or enterprises, to be carried on from thence, - hat is to say, fron the lnited states,-is the languige of the statute.

"If the evidence shows that in this case there ever was any military expedition hegun or set on font, or provided or prepared for, within the sense of this statute, it wis becom, set on foot. provided

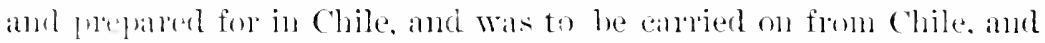
not fom the Enited states. But I think it perfectly com that the semilus of a ship from Chile to the Luited states, to take on board ands and ammunition purehased in this connty, and any them batek to chile, is not the lesinning, seting on foot, proviling or preparing the means for any military expedition on enterprise, within the matnin of section $52-4$ of the Revised statutes.

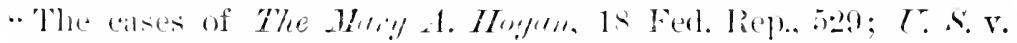

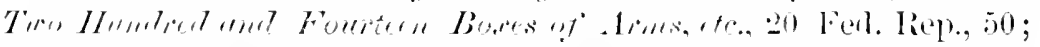

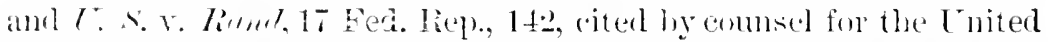
states in suppert of their position in respect to this point do not at all support it. In cach of those eatses there was a militaly experlition, and it was ormanized within, started from, and wats to be carrien on from the Lnited states. The fatets of those cases are wholly ditionerefrom the facts of the present case.

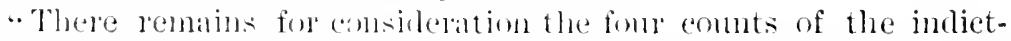
ment that are based on section ins of the lievised statutes. The firnt of there ats has been seen. (dameres that the defentamts, on the sth of Maly latst. at a certain designated plate within this judieial

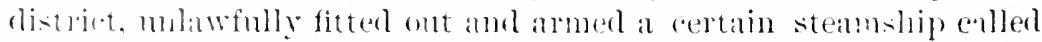
thr. Itutu. which was then and there in the posisesion and moler the ontur of cortain eitizens of the repmblic of Chile. known as the 'Congressional l'aty; and whu were then and there, in salid repub- 


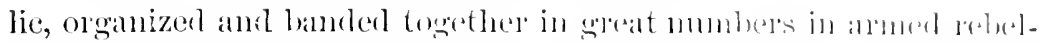

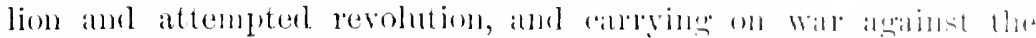

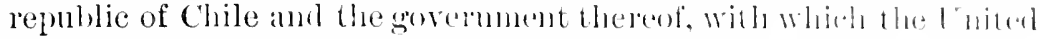
States then, and at the time of the fincling of he indindment, were at

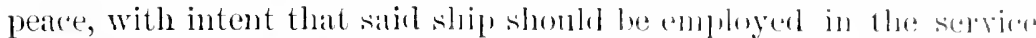

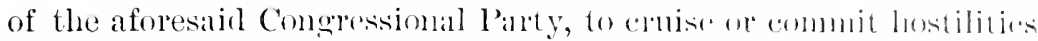

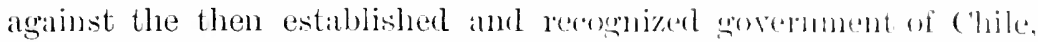
with which this govermment then was at pealee. The seconel enmul

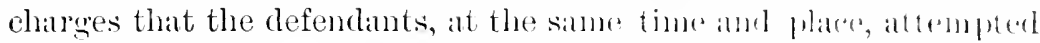
to do the same thing; the third connt elanges that, al the same time

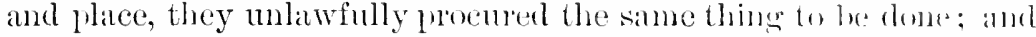
the fourth, that, at the same time and place, defomelants ware 1 mlawfully and knowingly eoncened in the funishing, finting ont, and arming of the Ttatu, with intent, ote.

"It is contended on behalf of the refendants that seretion 5:20:3 has no applieation to this case, for the reason that the perple designated in the indictment as the 'Congressional l'arty' llo not comstitute a people, within the meaning of that section. It is heyond pulestion that the stutus of the people composing the Comgressional l'arty at the time of the commission of the allegerl offense, is to be reanderl by the comrt as it was then regarderl by the political or excrutive department of the Lnitel states. This doctrine is firmly estab-

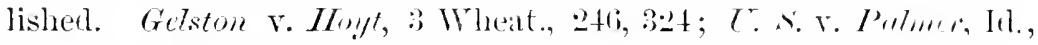

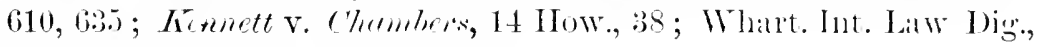
pp. 5.51, 55:, and cases there citer.

"If the dispatehes from the secretary of the nayy, the secretary of state, and aeting secretary of state, alleady refored to, ale to be considered as indicating the light in which the perple composing the Congressional Party of Chile were regarled hy the execntive do malt ment of this govermment prior to their recognition, an the th of Septembar, the position of the United States towarls them seems to have been similar to that taken by the United siates towards the insurgents against IIayti in 1s69. That position Was thus staterl ly Mr. Fish, then secretary of state, in a letter dater september 1 t. 1869 :-

" (1) That we do not dispute the right of the govermment of Hayti to treat the officers and crew of the Qunlier City and Flovide (vessels in the service of the insurgents against ilayti) ats primates for all intents and purposes. How they are to be regarled by their own legitimate govemment is a question of muni.jul law, into which we have no oceasion, if we had the right, to enter.

"،(2) That this govermment is not awate of any leason which would require or justify it in looking upon the ressel named in a 
difforent light from any other ressel employed in the service of the insulgents.

“.(:3) That, regarding them simply as amed emisers of the in-

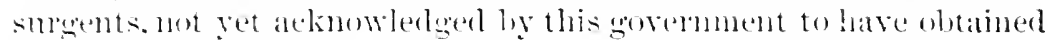
belligerent rights, it is competent to the Enited states to deny and resist the exereises hy those vessels, or any other agents of the relullion, of the privileges which attend matritine war, in respect to our atizens or thoir property entithel to their protection. We may of maly mot, alt ontion, as justice of policy maly lepuire. treat them as fibales in the absolute and muntalifiol sense. or we may, as the cilammstances of any actual case shall suggest. Waive the extreme light, and recognize. Where facts warmant it, an actual intent, on the lint of the indivinlual offenders. not to depredate in a criminal sense and for grivate gain. but to eapture and destroy jure bulli. It is suthieint for the present purpose, that the Cuited states will not atmit any commission or authority proceeling from rebels as a justifitation or excuse for injury to persons or property entitled to the funtextion of this government. They will not tolerate the search or stolphing. ly cruisers in the reled service, of vessels of the Cuited states. nor any other act which is only privileged ly reeggnized hellinerenog.

-..(4) While asserting the right to capture and flestroy the ressels in question, and others of similar chancter, if any aggression num persons or property entitled to the protection of this governe ment slatl recommend smeln action, we camnot atmit the existence of any obligation to hoso in the interest of Ilayti or of the general security of comuneree.' B Mhant. Int. Law Dig., Pr. $46.5,466$.

"Jhes section 5.20:3 of the lievised statuies apply to any people whom it is optional with the [niterl stattes to treat as pirates? That

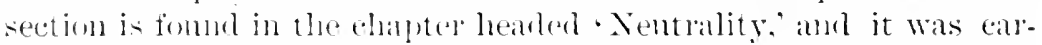
: ied into the lievised statutes. and was originally enacted in furtherante of the ohligations of the nation as a nelltal. The very irlea of mentrality impurts that the mentral will treat wah contending party alike: that it will aterolel no right or privilege to one that it withlolels form the othere, and will withlosh none from one that it

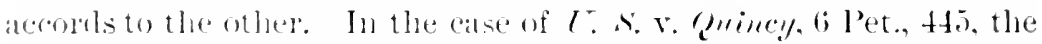
supreme compt of the Inited siates sabl that the worel people in

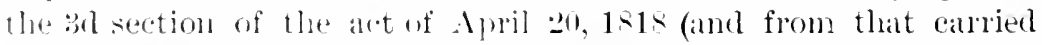
inn the linviserl statutes as seetion 5283), "is one of the denominations applied by the act of compless to a foreign porrer.' 'This can latrlly mean an association of puople in no way recognized by the fuited states, or by the envermunt arainst which they are rehellingr, whose rebellion has nut attained the dignity of war, and who 
may, at the option of the Cuited states, be troated hy throm as

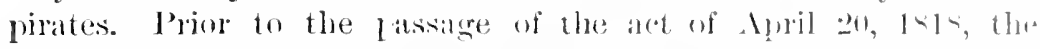

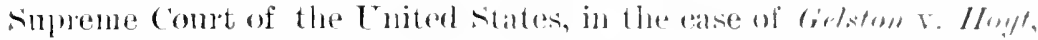

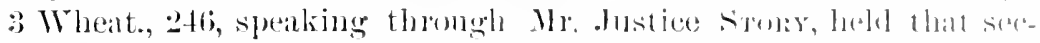
tion :3 of the alet of 1794 , prohiliting the fitting out any ship, atr., for the service of any foreign prince or state, to cruse arganst the sulijects, ete., of any foreign prince or state, with which the l'nitur states were at peace, diul not apply to any new govomment, muss it had been recognized hy the United states or hy the goremmmut of the comntry to which such new comntry belonered; and that a pleat which set up a forfeiture under that act, in fitting ont a slip to cruise against such new state, must arer such recognition, or it is bad.

"Congress, in passing the sulsequent act of Ipril 20,181 , hy which the provision referred to of the act of 1794 was, in sulstance, reenacted, must lie presmmed to have known the construction that hald been theretofore put by the supreme Court upon the works " prince or' state' in the act of 1794 , and with that knowledge, in passing the act of 1818 , inserted in the same clause the words' colony, district, or people.'

"This was done, according to Dana's Wheat. Int. Law, $4: 9$, note 215, and Wharton's Int. Law I)ig., p. 561, unm the suggestion of the Spanish minister that the South American provinces, then in revolt, and not recognized as independent, might not be included in the word 'state.' But in every one of those instances the Cnited sitates had acknowledged the existence of a state of war, and, as a consequence, the belligerent rights of the provinces. The Lubrose Liglit, 25 Fed. Rep., 414, and referenees there mate.

"It will be observer that the Supreme Court, in the case of Gelston v. Moyt did not say that the independence of the new wovernment must have leen recognized hy the Cnited states to milie the statute of which it was speaking applicable. There are difterent kinds or degrees of recognition, but can it be properly said that, in passing an act in furtheranee of the obligations of the mation as at neutral, Congress was legislating with reference to a people not in any way recognized by the government of the [niterl states, anc] whom it might, at its option, treat as pirates? 'To fall within the statute, said Judge Browx, in the case of The Coromblet.: Fed. Rep., 800, "the ressel mmst be intended to be employed in the serrive of one foreign prince, state, colony, district, or people, to cruise al commit hostilities against the subjects, eitizens, or proprerty of another, with whom the United states are at peace. The Tnitedstates can hardly be said to be at peree, in the sense of the statute, with a 


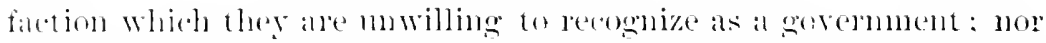

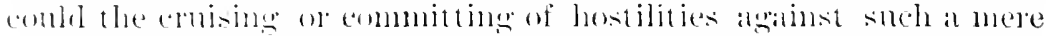
faletion well he said to be eommitting hestities astamst the sub-

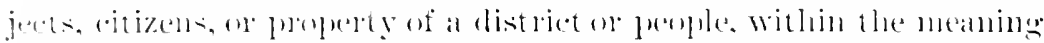

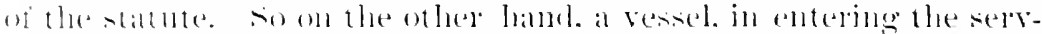

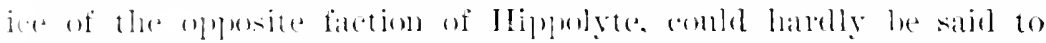

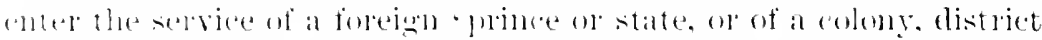

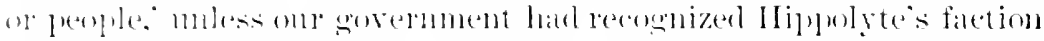
an alt least comstituting a belligerent, which it floes mot aplear to

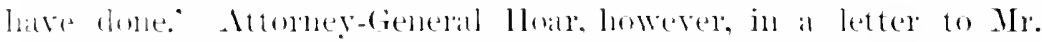

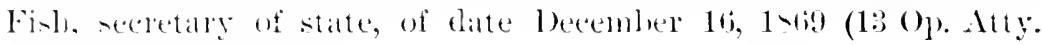
(iol1. (2. - .. 17\%) silil :-

... Pmbmbedly the omdinaly application of the statute [in ques-

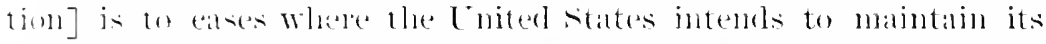
nentrality in wass between two other mations, or where botle parties

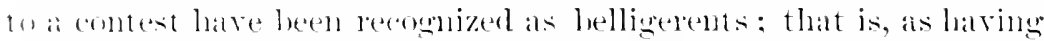

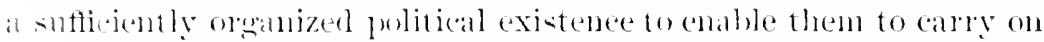

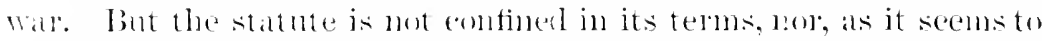

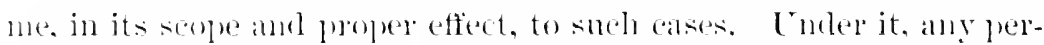
sms who are insmorents, or engaged in what womld he regarded

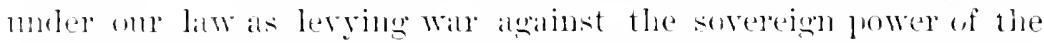
nation, thomgh fow in number and ocempling howeres small a

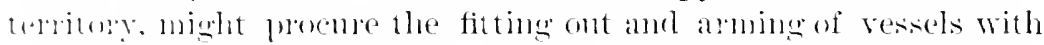
intent to commit hostilities against a nation with which we were at

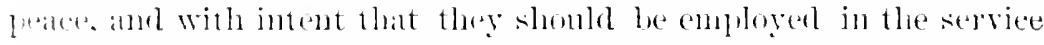

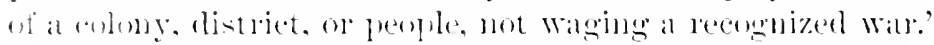

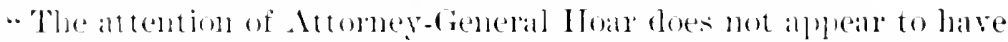

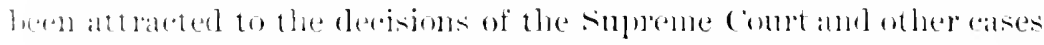

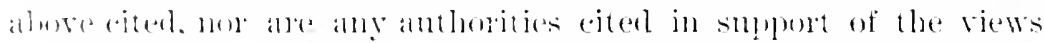

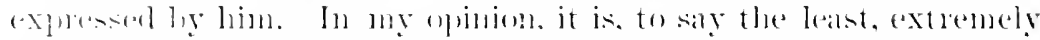

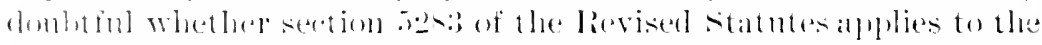

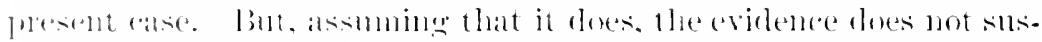

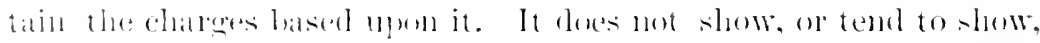

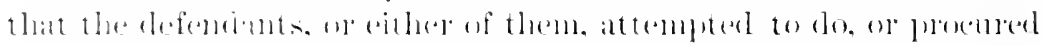

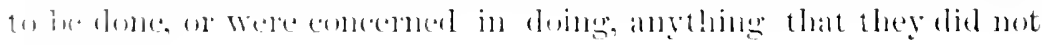
in tial (l).

" What the revidemes slows that they did do has alledrly been

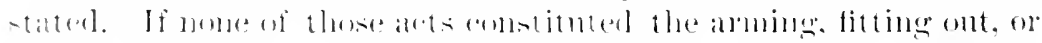

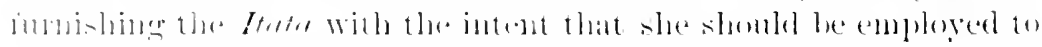

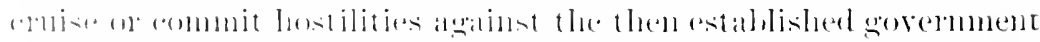

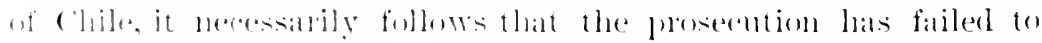

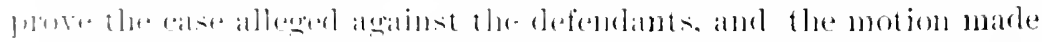

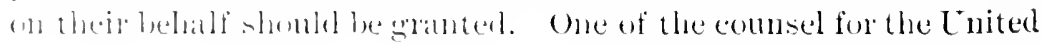




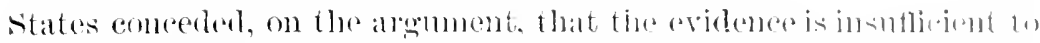

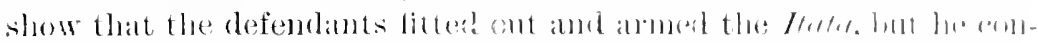

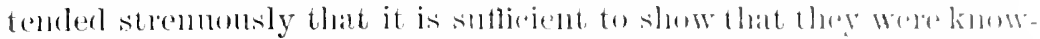

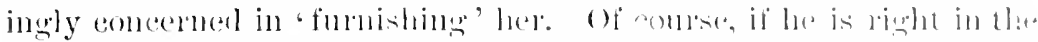

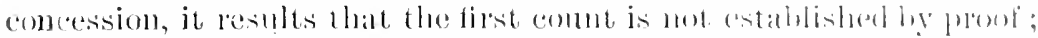

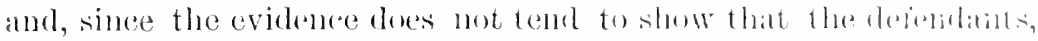

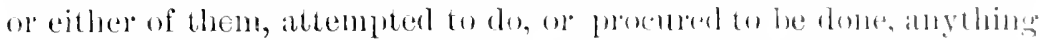
they did not in fact do, the second and thind amots womblatso tall.

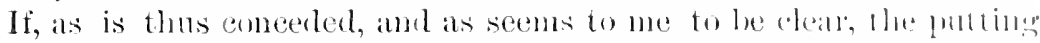

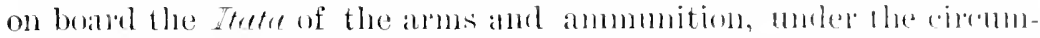
stances and for the pmposes stated, dirl not eomstitute the fit ing ont and arming of that vessel, it is diffenlt to molerstand how l ha same acts, eommitter under the same circumstances and for the same pmeposes, constitnted the 'fumishing' of her. There is mothins in the evilence temling to show that any of the arms of ammmention wores intended for use by the Itutn. On the contraly, the whole arse shows that the defendiunts cansed them to be put on borme of her with the intention that she should transport them to Chile, for the use of the insurecting party there.

"This does not eonstitute the fitting ont, arming, or fumishing of the Itrea, with intent that she shomld be employed to trui-s: or oom-

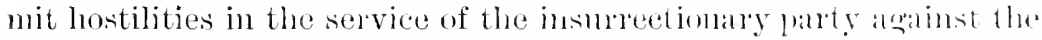
then government of Chile. In principle, the case is, I think, mom

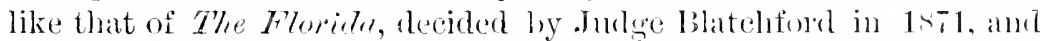

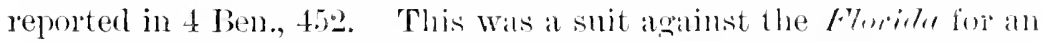
alleged forfeitme incmred under the third section of the act of Alpril 20, 1818, $110 \mathrm{w}$, in sulstance, section 528:3 of the Revised statutes.

"The conte said:

" A Amitting that persons acting as agents of the insmrectionary party in Cuba were the real owners of the vesiel and her carson of arms and munitions of war, and that the transaction of the lomrowing, by Darr from Castillo, of the money wherewith the vesisel am.l her cargo were pmethaserl, was a sham, amr that the vessol was to

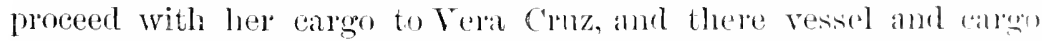
were to be transfered by I)arr, their mominal owner, to fersons ac:-

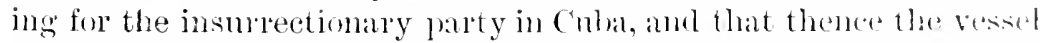
was to take the cargo to some point off the coast of cuba, and hamb it on the shore by the use of rafts made ont of the humber om huard, towed by the steam-lanmeh om board, thomgh shallow watre, to llue shore, and that lowre and sneh real owners of the vessel amd arow harl an intent to do all this in fitting ont the vessel, and punting hel cargo on board, still a violation of the thind section wi lue act $1<1<$ is not thereby made out. I ressel fitted ont with intent to 
do this, in wat fitter ont with intent to cluine or commit hostilitie. within the semse of that section. If so then erery ressel

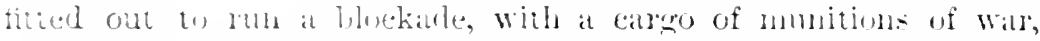
is Hecessarily fitted m, within tle semse of that stetim, to commit

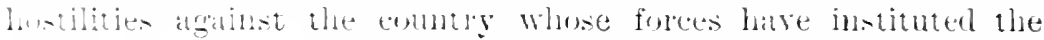

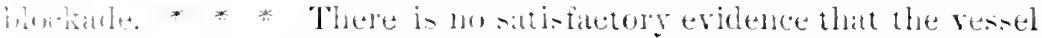

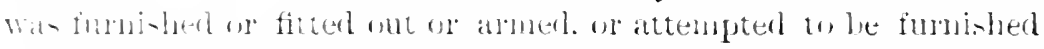
(1) tittal ont as armed, with intent that she should be enologed

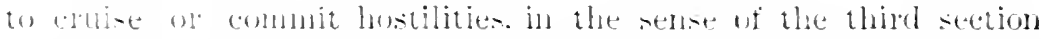

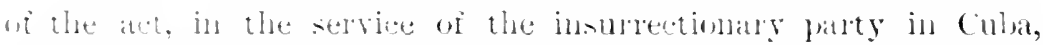

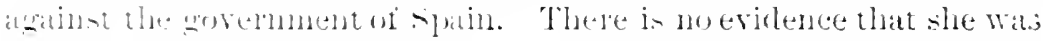

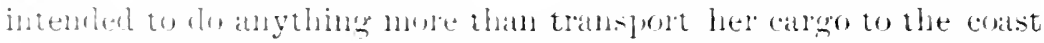
of Cobre and catue it to he lamber there on rafts. ly the aid of the latmele on burret. Tordo this was no violation of the thind section of

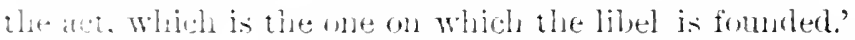

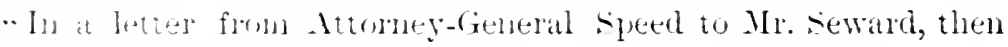

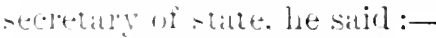

‥ I kims of no law or regnlation which forlids any person or grovermant. Whether the phlitical desisnation be real or assuned,

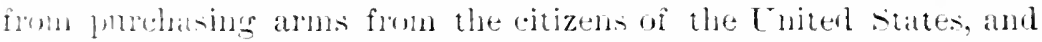

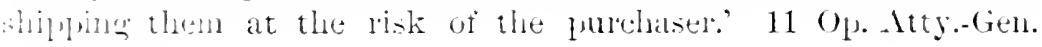
i. . t.i.l.

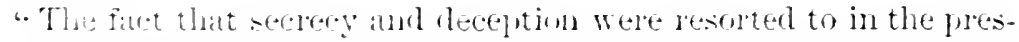

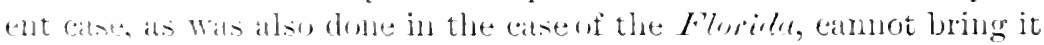
within the lnuvew of the statute, if not otherwise within it; nor

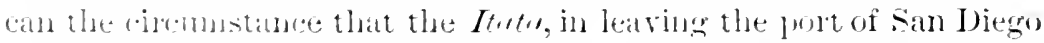
in the nammer diselnsed by the evidence, vinlated other provisions of

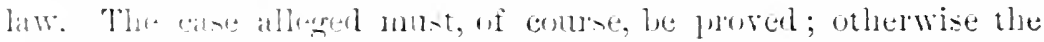

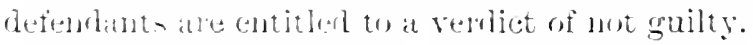

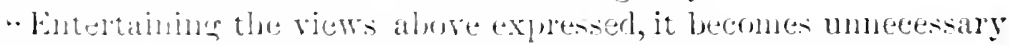

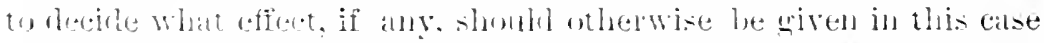

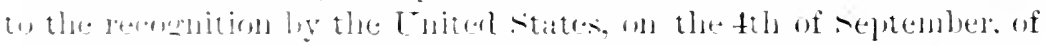

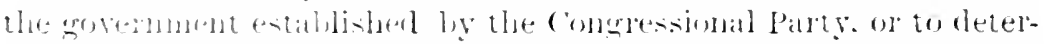

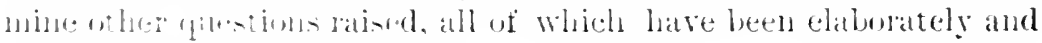

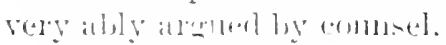

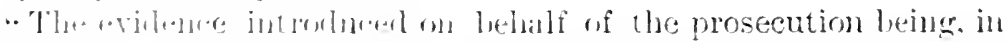

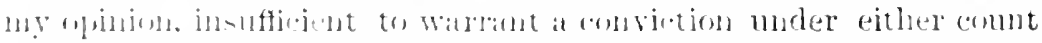

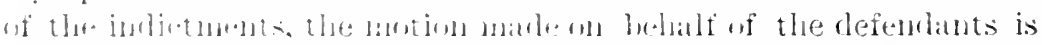

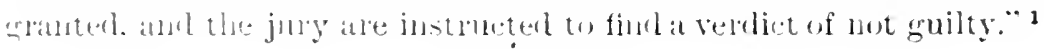

1 This deci-ion has sinew be a trirmed by the Circuit Court for California. 
TIIE "N.1IV.IHOR."

Pisity Cunale, 1870.

(3 Privg Conncil Rep., 21s.)

Held, that a British vessel fitted out in aid of insurgents in the island of Cuha. was liable to forfeiture under the ith section of the Foreign Enlistment Aet of 1819 .

The Proclamation of the 24 th of March, 1s69, stated that an insurection against the Govermment of suan was reported to have taken place, and to be then existing in the fsland of culn, and 1 mon the fact of that report being well-founded, and a state of insmlecetion actually existing in Cuba, the Proclamation against Iler Majesty's suljects in the Bahanas enlisting or engaging in a Foreign service in aid of such insurection was legally and properly issmed.

All the witnesses show, and the leaned Jugge of the Vice-somilalty Court below himself almits, that there wals a very serions insurreetion or revolt in the lsland of cuba against the simuish Government. But the learned Judge, though aprarently satistierl that there was at state of insurrection in Cuba, hesitates to ally)y the penal section of the "Foreign Enlistment lct, becanse lut eammot find that such insurrection is in farol of any persons assmming the powers of Govelmment, or pretended Govermment, in the Istand of Cuba ; though the nature and object of the experlition for which the sulvador was equiphed and fitted-out is from the evidenee proved to have been in aid of this insurrection, and she, being a british ressel, was engaged in and for a military expedition, for the purpose of attacking the dominions of a friendly Power, yet the Judge of the Vice-Admiralty Court refused to declare the vessel liable to forfeiture within the meaning of the 7 th section of the Act.

Their Lordships' judgment was delivered by Lond Camss:-

"This is an appeal from the decision of the Vice-Almilalty Comt of the bahamas, upon an information filed on bethalf of the cmm before that Court moler the Foreign Enlistment Act, witlo regart to the ship saledelor, and seeking ler eomfiscation.

"The section in the Foreign Enlistment set which has to be consideren is the seventh. It has frepuently leen remalkerl, that the interpretation of that section is attrucled with some diftinulty mainly owing to the great quintity of wolds which are used in the 


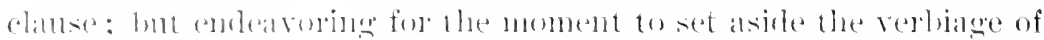

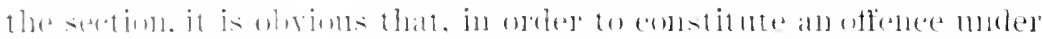

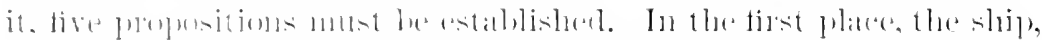

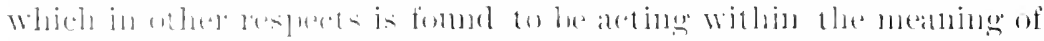

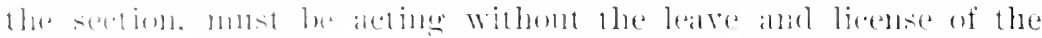

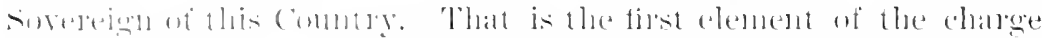

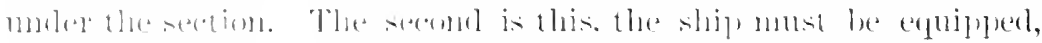

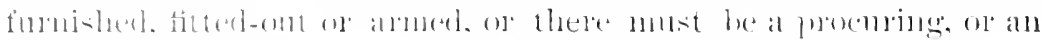

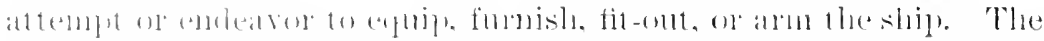

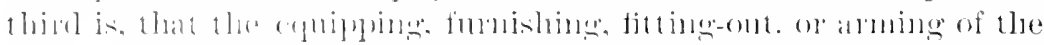

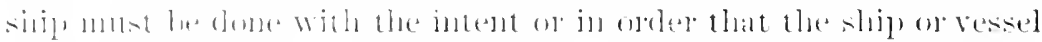

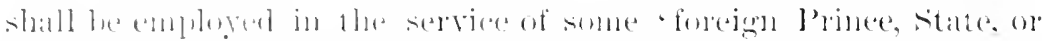

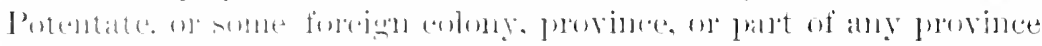

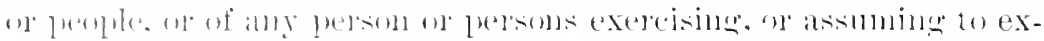

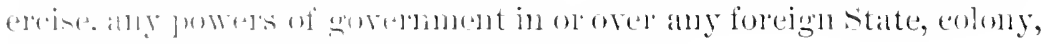

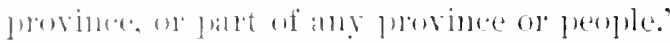

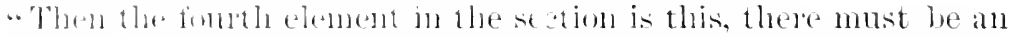

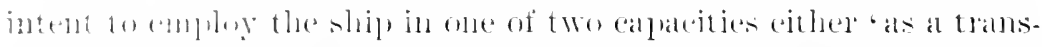

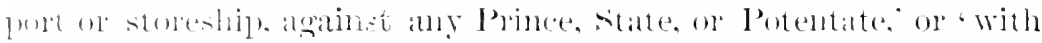

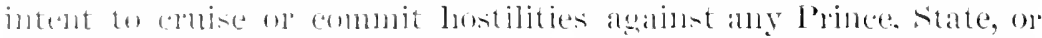

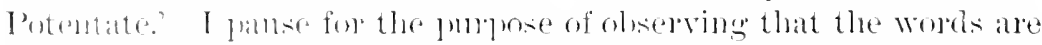

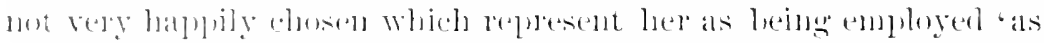

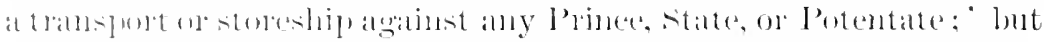

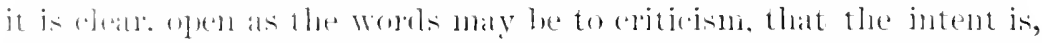

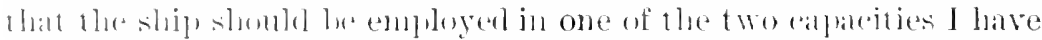

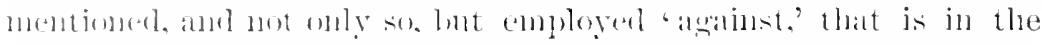

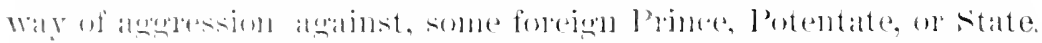

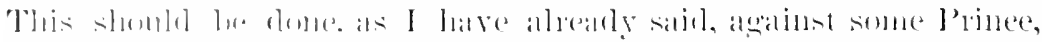

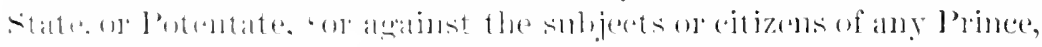

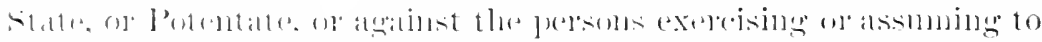

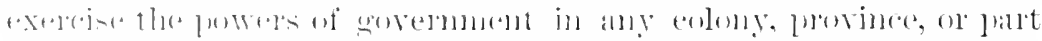

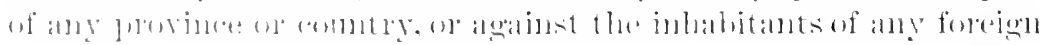

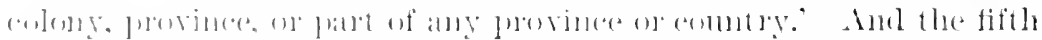

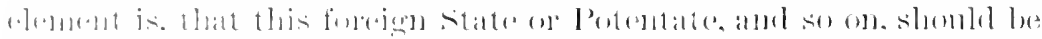

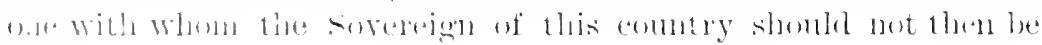
at wall.

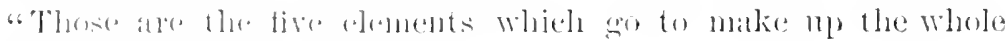

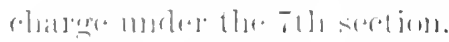

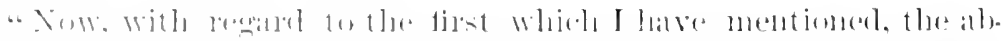

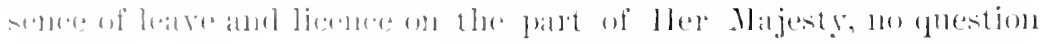
allisis.

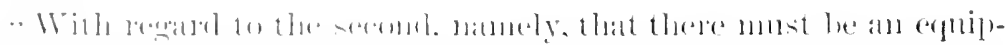

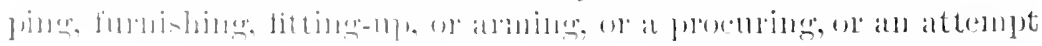




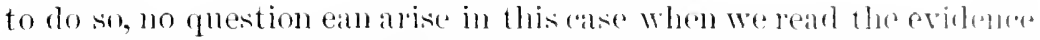

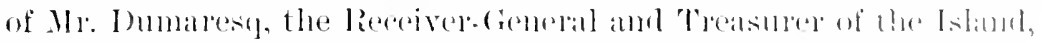
whostates the condition in which he fomm the shipe and the prept

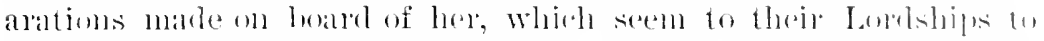
amomet to a fitting-out or alming, or an attempt to do so. withis the.

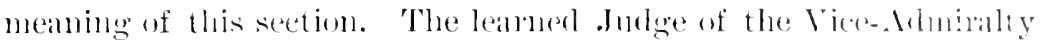
Comt seems to have entertained no doubt himself upon this gart of the case.

"I pass over the thind element which I mentioned, for the moment, in order to say that upon the fourth and fifth heads to which I have referred there can also be no doubt entertained, as it seens tor their Lordships; and bere, again, no donbt was entertained by the leanderl Judge of the compt below. It is quite clear, that the ship was intended to be used as a transport or storeship against a l'rince, state, or Potentate with whom Iles Majesty was not at war. She wats to be used obviously as a transport or storeship for the purpene of comveying to Calsa men and materials; and in that way to do the duty of a transport ship, and so to inflict injury upon the spanish seremment, who, at that time were, and are now, the lawful anthority having the dominion over Cuba. Itere, again, no doubt was entertained ly the leamed. Judge in the Comt behw, and no combt conbl be cutertained by any one who looks at the evidence of Mr. Immalesp, to whom I have alrearly adverted, and also the evidence of In. butler, the collector of levenue, both of whom state what the report was which was made to themselves by Carlin, the master of this vessel, as to her conduet when she went to the coast of cuba-how she landed all the men she had on board, plainly for the mupose of taking part in the insurrection which was going on in cuba-how they abandomed the ship when they saw a Spanisb ship of war in sight-how they were prepared to set fire to their ship it the spanish ship approached them-and how afterwards, when they fomm that they were mmoticed, they took possession of the sulemlor agam, and brought her back to Nassant.

"That leaves moovered only the thind element of change in this section, and it is upon that alone that the learned Judge of the ViceAdmiralty Comrt entertained any donht.

"The thimelement is, that the ship most be employed in this way in the service of some 'foresgn Prince, State, or I'otentate, of of any foreign colony, province, or part of any province or people, or of

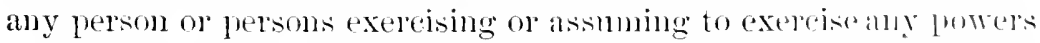
of Gorernment in or over any foreign state, colony, porince or part of any province or people.' It is to he olserved that this pat of the section is in the altemative. The ship may be employed in the 
service of a foreign Prince, State, or Potentate, or foreign State, colong, province, or part of any province or people ; that is to say, if rou find any consolidated body in the foreign sitate, whether it be the lofentate, who hats the absolnte dominion, or the Government, or at part of the province or of the preople, or the whole of the provinter or the people areting for themselves, that is sufficient.

" int by waty of alternative, it is suggested that there may be a alse where, althomgh gom eammot saly that the province, or the people, or a part of the porinee on people ane emploging the ship, there yet may he some person or ferrolis who may le exereising, or assuning to exereise, powers of Government in the foreign colony or state, drawing the whole of the material for the hostile proceedings from abroarl amr, therefore, by way of alternative, it is stated to be sufficient, if you fint the ship prepatred or acting in the service of "any fersin or lersons extereising, or assmming to exereise, any powers of covermment in or over any foreign state, colony, province, or part of any porince or people;' but that alternative need not he resorted to, if you tind the ship is fitted-ont and armed for the purpose of heing ' employed in the service of any foreign state or people, or part of any province or people.'

- Enom that the observation of the learned Judge was this:- "We have no evidence of the olject of the insurrection, whoare the leaders, what portion of Cuba they have possession of, in what manner this insurretion is controlled or supported, or in what mamner they govern themselves. IIow, therefore, com I say that they are assmming the powers of Govermment in or over any part of the Island of ('illa:-'

.. Xiw, it appears to their Lordships, that the error into which the leannel Judge below fell, was in confining his attention to what I hate termed the second alternative of this pat of the section, and in lisienarding the first part of the alternative. It maly le (it is not noesisity to decide whether it is so or not) that you could not state who were the person or persoms, or that there were any person or persoms exereising, or assmming to exereise, powers of Govermment in Cons, in oplosition to the Finish anthorities.

"That may be so: theip Lordships apress no opinion woon that sul,jel, but they will assume that there might be a diflienlly in brighing the case within that second altomative of the seetion; but thril Lordshipe are clearly of ophing, that there is no difliculty in buinging the catse moter the timt altermative of the section, becanse

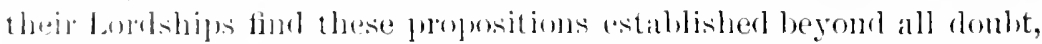

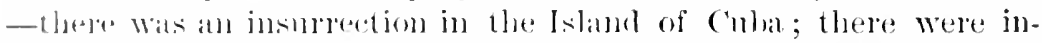
smrents who had formed themselves into a body of people aeting 
together, undertaking and condueting hostilities; these insmrenter,

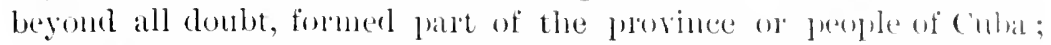
and heyond all doubt the ship in qlestion was to be emplogerl, and was employed, in connection with and in the servine of this bony of insurgents.

"Those propositions being established, as their lomlships think they clearly are established, both by the evidence of J mumesid and butler, to which 1 have alleady referred, and further, hy the evidence of the three witnesses, Loinaz, Wells, and Mann, theip Lomdships think that the requisitions of the seventh section in this respect are entirely fulfilled, and that the ease is made ont muler this heanl, as it is upon all other heads of the section.

"Their Lordships, therefore, will humbly recommend to ller Majesty that the decision of the Vice-Admiralty comrt shomb be reversed, and that julgment should be pronomiced for the crown, according to the prayer of the information.

"It has been intimaterl to their Lordships, that on the Tth of February last, there was a decree by their Lorkhlips for the apratisement and sale of the vesisel. She has been soln, and the net proceeds, $£ 168,4 s$. \&d., pairl into IJer Majesty's Commissumiat Clust in the Ballamas. The Colonial Goremment, it apears, bave incmod expenses to the amount of $£ 145,5 s$. 11, l. in keeping the ressel while she was under arrest, and they claim to be reimbursol those expenses ont of the proceeds of the sale. That, of comre, will he proper', and if it is necessalry to make that part of this Order, it will be done."

Section 43.-Tie Sile of Mevitioxs of War by a Nettral State.

THE SALE OF ARMS, ETC., TO FlidNCE, 1870.

Repont of Sexite Comntee, 1870.

(3 Wharton's Digest, 512.)

During the Franco-Prussian war, the govermment of the United States proceeded to sell a quantity of arms and munitions which it harl accumulaterl during the civil war, but with no intention that these articles shoukl go into the hands of either belligerent. The committee reporterl that the sale was lawtul and proper, and would have been so, if the sale had been made directly to one of the belligerents.

Early in 187: complaints were made to the Fonate of the Lnited States that certain "sales of ordinance stores" had been " made by 
the foremment of the Finted states during the fiscal veate ending lae :yth of . June, 1sil. to parties who were agents of the French

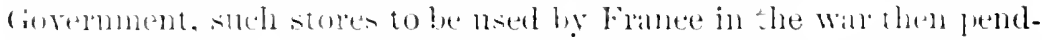

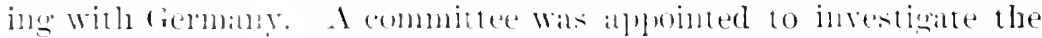

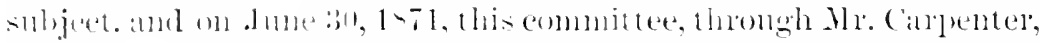

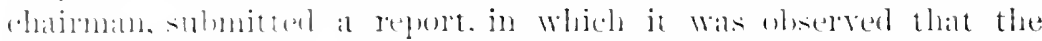

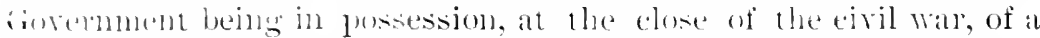

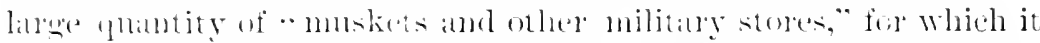

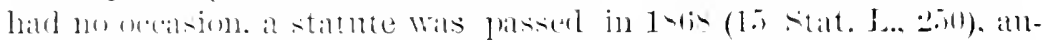

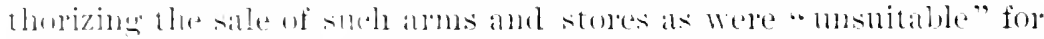

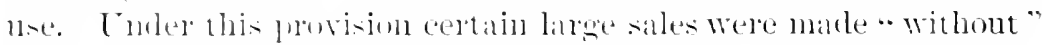

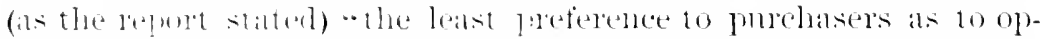

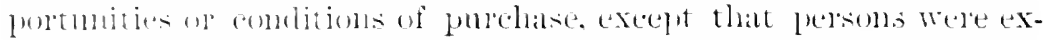

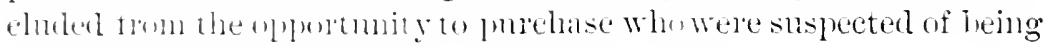
agents of Fiance. then at war with remany."

(1) the gnution whother the sales were "made moler such eir-

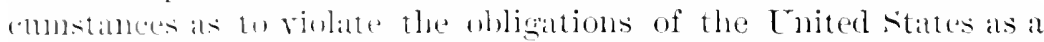
nentral mower pending the watr between France and Germany" the

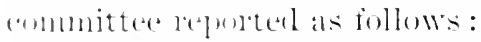

"This sulgect involves two pluestions-one in regard to the law

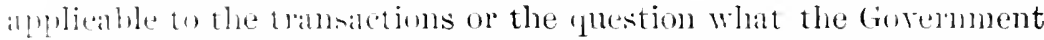
miglit do mule? the cinclumstances, and the other a question of filet,

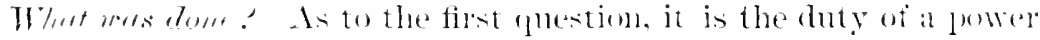

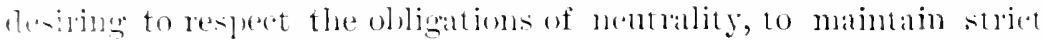
implatiality in reared to the belligerent powers. This, howerer. $j$ :

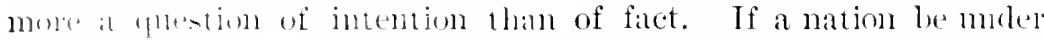

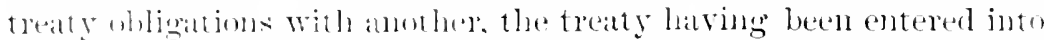

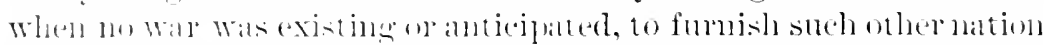

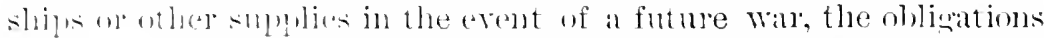

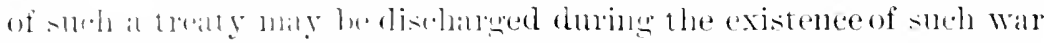

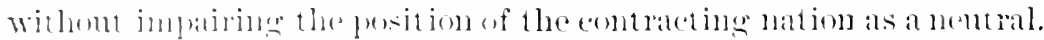

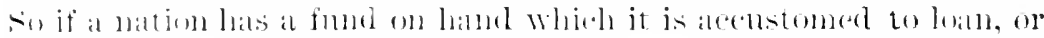

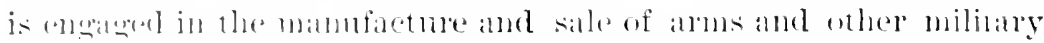

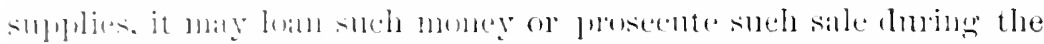

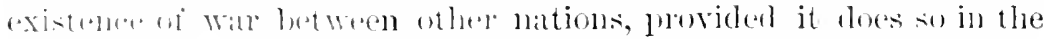
forle fursut of its own interest, ant withont any intention of in-

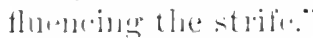

Aftel pheting Vilted to sustain this position, the committee went (1) 11 sily :

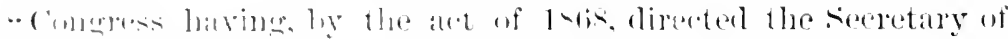

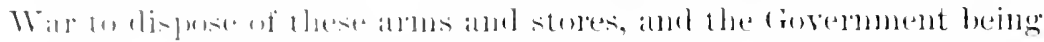

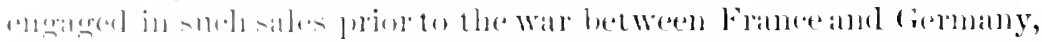

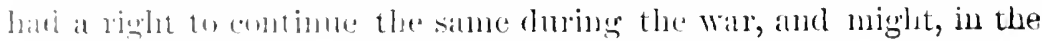


eity of Washington, have sold and delivered any amome of such stores to Frefleriek William or Lomis Napolem in fersom, withmit violating the obligations of nentality, poviling such sales wore

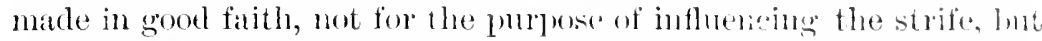
in execution of the lawful purpose of the (iovermment to sell its surplus arms and stores."

It was then stated that efter certain sales to Remington \& sons had been agreed on, but before delivery, the seeretary of War received a telegram, which led him " tosuspert that liemiugtom et soms might he prrchasing as agents of the French Govelmment," and he then gave orders that no further sales shombl be made to them. The sale alleady made, however, was not repuliated, and the articles mere thelivered subserpent to the reception of the telegram.

The committee, after an exammation of the facts, reported ats follows:

"Tour committee, withont hesitation, report that the sales of arms and military stores during the fiscal year enting June 30, 1871, were not mate under such ciremmstanees as to violate the obligations of ou Government as a nentral power: and this, to reeapitulate, for three reasons: (1) The Remingtons were not, in fact, agents of France chring the time when sales were made to them; $(\because)$ if they were sich agents, such fact was neither known nor suspected hy our Govermment at the time the sales were mate; ant (3) it they had been such agents, and if that fact had been known to our Gorernment, or if, instead of senting agents, Louis Napoleon or Frederick William had personally appeared at the War bepartment to purchase arms it roukd have been lawful for us to sell to either of them, in pursuance of a national policy adopted by us prior to the eommencement of hostilities." 1

1 See the Senate Report, 42d Cong. 2 2 sess., Rep. 183. And see Honse Report, 46,421 Cong., $2 \mathrm{~d}$ sess.

Perels, Int. Seerecht, :51, says that the Govemment of the Lnited States solul in October, 1870, at public auction, 500,000 muskets, 163 (arbines, 3.5.100 rexolrers, 40,000 sabers, 20,000 horse-trappings, and 50 batteries with ammunition ; and that the export from New York to France from September to the mirdle of December of that year included 388.000 muskets, $45,000,000$ putroncu, 5.5 cannon, and 2,060 pistols. (2Warton's Digest. p. 513.)

It is to be hoped that the report of the Senate committee does not express ti:e settlerl law of the United States upon this subject. It confound the rights and duties of a neutral state with those of the private citizens of a neutral state. which is a very different matter. Such a transaction, however innecent the intention, can hardly fail to raise the suspicion of bad faith on the part of the newril goremment. For it is undoubtedly true that a war between foreign states provides just the opportunity for the sale of such articles to the best adrantage. 


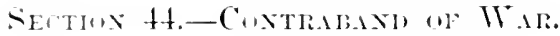

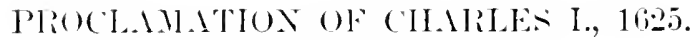

\section{(collectunen Buritimu. it.)}

- Fousmuch as the many injuries and indignities obtruded upon the linges most exodlent Majesty and his most deare and onlie sisele and her childere and his josal Father, of ever blessed menory,

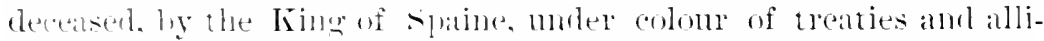

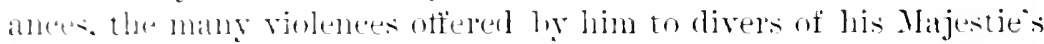
sulfeets in taking. shayng and ramsoming divers of them, in a lostile manner. whilest they intemed onely thejr merehandize at sea. The King of sianes restlesse ambition to asplire to an muiversall mon-

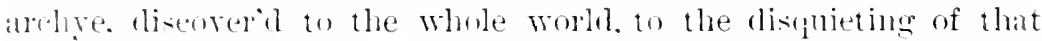
jeace whirls other Princes and states, his neighboms, wonld ghatly lest in and enjoy, have, out of an mavoirlable necessity, draw his most excellent Iajestie to take up aumes agrimst the said King, for defence of himselfe his dominions, and sul,jects and of other l'rinces ond rittes. his comfedorates and allies. there heing nome other safe meanes for the oldegning of an assmerl leace to himself and his smbjeets, and to hisconferlorates and allyes, which liks highness sladl

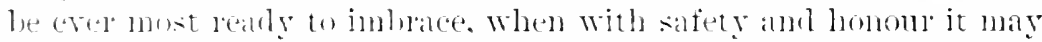

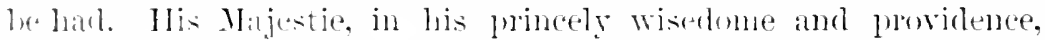
foresering that whilst the said King of suatue ant ynneth in these

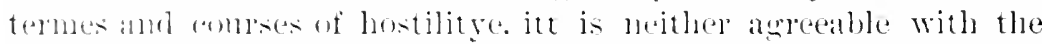
rules of puliole or litw of nations, to permitt the sald King, or his

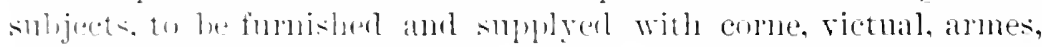

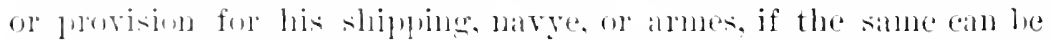

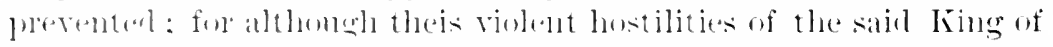

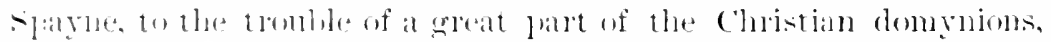
ate mightily magntegned by thealnomblase of his treasme from the lutges. wherein be thuteth, and with the opinion whereof he is futferl ule. Yott itt is mandfest. that to mayntegne his anmes, and

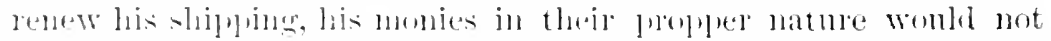

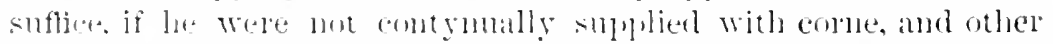
victutlls, amd fornished with mmition, and naterialls for armes and shinging from forcigne combries, whereof neither his Indies, nor

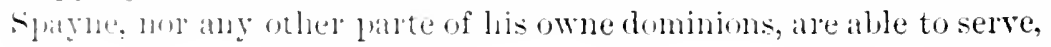


but the same are knowne to he bunght into spayne. Pontugall,

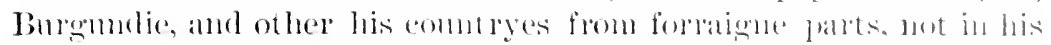
owne subjection, and that expecially from the llans Towns, and Marehamts of the Northeast combries, whe for the desire of galyne are contented to furnish the silid King, thomgh to theil amme axtreame hazarel and prejuclice of their neighbours, with all things requisite to matymane his mujust warrs.

"For this eanse his Majestye,

"Being amongst other l'rinces and States herein principally interested, for the defence of hymselfe, his comntries and subjerts, andinst the said King of spayne's great preparations of his maryes and anmies by sea and ly land; and lis Majesty bemg persumled, that if stuch his provisions for lostilitie to be brought unto him by sea fom forrayne parts might he stayed, or intermpterl, mitil the sair King might he disposed to live in peace, his Majestie might the somer. forbeare to contimue his charge in maintainemg his forces hoth hy sea and land. which he is now constrained yearlie to lenewe only for the just defence of himselfe and his dominioms, and of his (omfederates and allies.

"Doth by these presents, ly the advice of his Privy Comeell, notifye to all mamner of persons of all conditions, that shall sent of carric into spayne, Portugall, Burgundy, or any other the said King of Spaine's comtries, or dominions, any mamer of graine, or other victualls, or any mamer of provisions to serve to build, furnish, or arme any shipps of warl, or any kind of munition for the warr, or materialls for the same, being not of the nature of meere merchandize; that as it is lawful for his Majesty, being a Monareh and Prince Sorereigne, and as other Kings, in like eases, have alwayes used to doe, he will not only anthorize his owne admimalls, and captaines of his owne shipps of warr, serving on the seas, hut will also allow and approve all other his suljects, to arme their shipps at their will, and with them to impeach and arrest all shipps that shall sayle, either out of the East parts, or out of the Lowe Countries, or from any other parts, with intention to passe to spaine, Portugall, Burgumly, or any other the King of Spain's countries or dominions, or to any the King of Spain's shipps, being on the seas, haveing on board any such graine, victuals, or provisions of warre, or furniture for ship)ping, or materialls for the same: and the same to bring in to the next good port, there to be ordered as goods duely forfeited for the benefitt of his Majesty, where his Majestie's shipps shall arrest the same, and to the benefitt of such others as being not in his Majestie:s wages, shall, by their travell and adventure, have stay"ll aus arrested such shipps and goods prohibited, provided that all others. besicies 
the raptatines of his Majesties owne shipps, that shall be disposed to

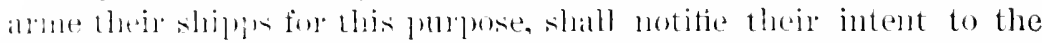

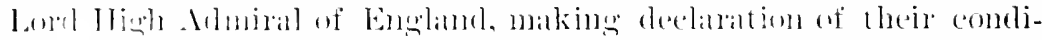

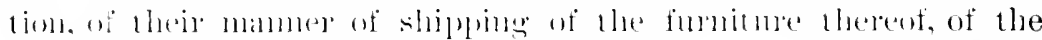

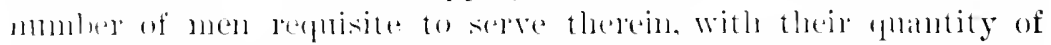

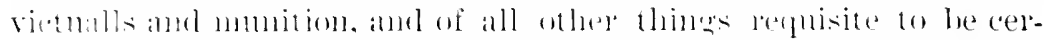

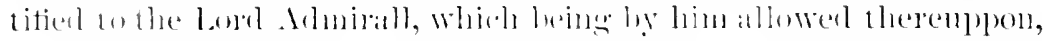

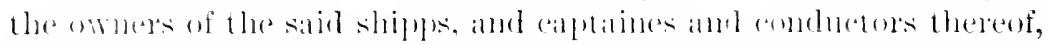

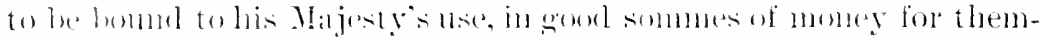

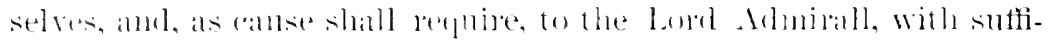

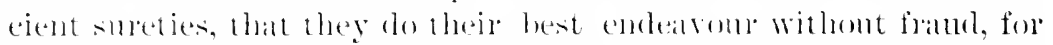

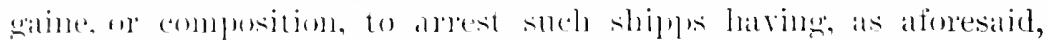

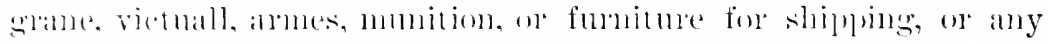
materiall for the same, intemderl to be raryed to any of the King of

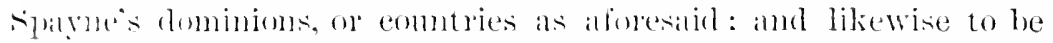
lmoml, as is aforesild, that with the sald shipls noe hame shatl be witlingly done to any person on the seas being in friculship with lis. Majestie, and that shall not be privy to the candiage of any such

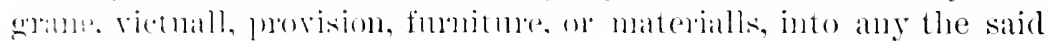

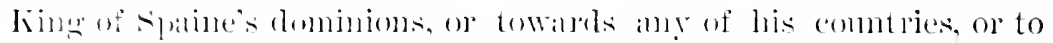

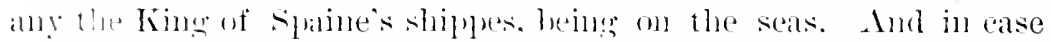
any shall be lonnd to have committed any such offence, whereby

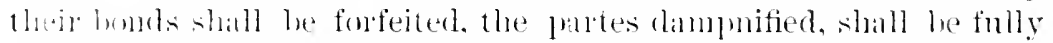
recormunced for all their Josses amd dimages, with the sommes of munte forfeitchl, and otherwise as there sllall be canse, and the offemblus alsoesererely punished aceoribig to their offences, by due comise of hille.

" Given at omr Honor of IIamptom Comrt, the one and thirtieth day of $\mathrm{Decembl}$.

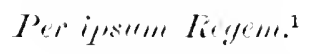

${ }^{2}$ In a sulphenentary prockmation of the next year. to make more definite the

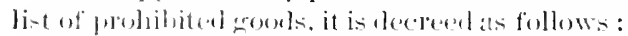

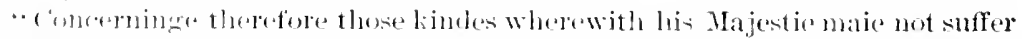

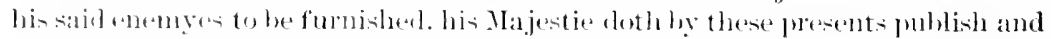

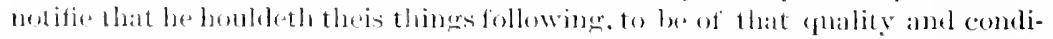

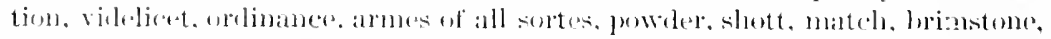

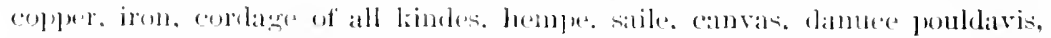

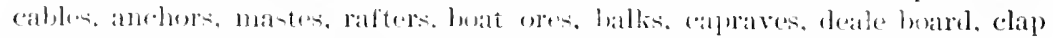

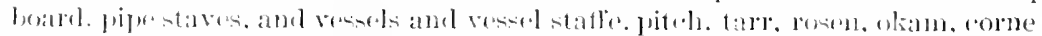

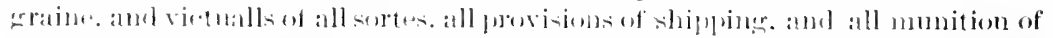

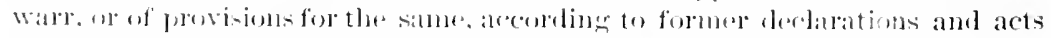

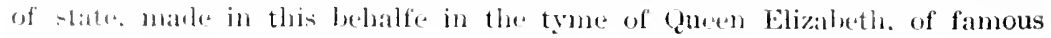
1r: (n)

"Ald therefore if any person whatsoever, after three moneths from the pub- 


\section{TIE "PETERIIIFE"}

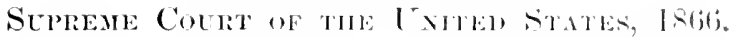

(5 Hillarer, 24, 亦)

Classification of contraband ; non-contrabinel gools belemging to the onwere of contraband on board the same ship are subject to contiscation.

The following is an extract from the opinion of the comth, dur ered hy Mr. Chief-Justice C'ms: :--

"The classifieation of gools as cont maband or not cont labaurl has much perplexed text-writers and jurists. I stridly acemate and satisfactory classifieation is perhals impracticalle; hut that which is best supported by American and Englislo decisions mal be sado to divikle all merchandise into three dasses. (of these classes, lle filst consists of articles mannfactured and primarily amd ordimaly used for military purposes in time of war: the secomb, of artieles which may be and are used for purposes of war or leace, aceorling to cilcumstances; and the third, of articles exchsively used for leaceful purposes.

"Nerchandise of the first class, destined to a helligerent comtry or places ocenpied by the army or navy of a belligerent. is always contraband; merchandise of the second elass is contratiand only when actually destined to the military or naval nse of a helligerent: while merchandise of the thide dass is not contraband at all, thomgh liable to seizure and eondemmation for violation of blockarle or siege.

lication of theis presentes, shall, by anie of his Majesties owne shippes, or of the shippes of anie his subjects authorized to that effect, he taken sayling towards the places aforesaid, or retwring thene in the seme colgege. having renterl or disposed of the said prohiliterl goonls, his Majustie will bonkl both the shiphs and goods soe taken for law ful prize. and cause t!em to be ordered as duely torfeited. whereby as his Majestie doth futt in practice noe innovation, sincos the wame comse hath been held, and the same penalties have heen heretofore inflicted ly other States and Princes, upon the like oceasions, and arowod aml maintayned by public wrytings and apologies, so nowe his Majestie is in a manner inturmel theremto, by proclamations set forth by the King of sipaine ant the Arehe duchesse, in which the same and greater sererity is profeswel aganst these lhat shall carry or have carried without limitation the like commolities into theis his Majesties domynions.

"Given ait our Court att Newmarket, the fowerth diy" of March. 
"A consideralibe portion of the cargo of the Peterhoti" was of the thind class, and need not be further deterred to.

" I lane portion. prephaps, was of the second class, lunt is not poved, as we think, to have been artally destined to belligedent use, and ramed therefore be treated as comtaband. Another portom was, in onr julgment of the first class, or, if of the second, destined directly to the rebel militiry service. This portion of the arron comsistorl of the eases of artillery latmess, and of articles described in the involece as - men's army hluchers, 'antillery boots.'

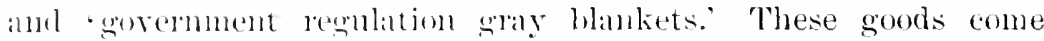

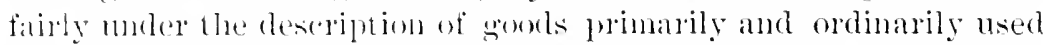
for military pmosese in time of war. They malie part of the necessiry equipment of all ammy.

$\therefore$ It is true that even these goods, if really intended for sale in the malket of Matamoras, womkl be free of liability; for contraband may be transportel ly nentrals to a nentral port, if intended to make part of its general stack in trade. But there is nothing in the case whible tenls to convince us that such was their real destination, while all the circumstances inflicate that these articles, at lant, were dostinerd for the nse of the rebel forces then ocenying bromeville, and other places in the vicinity.

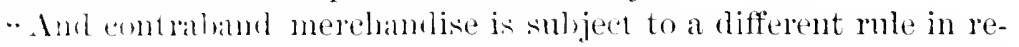
spert to ulterion destination than that which applies to merchandise not contriband. The latter is liable to capture only when a violattinn of blockate is intended : the former when destined to the hostile commtry or to the actual military or naral nse of the enemy, whether blockinder or mot.

"The trate of nentrals with helligerents in articles not contra-

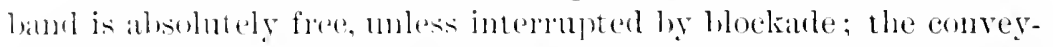

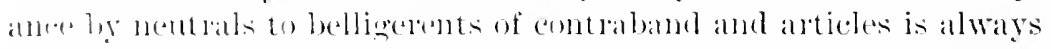
mulawful, and such arteles may alwas be soized during transit by seat. Henee, while articles, not contrabuml. might be sent to Mata-

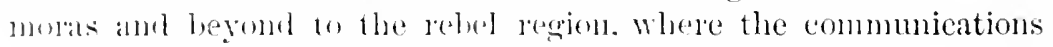
were not interpupted by bloksule, articles of a contraband char. artere destined in faret to a state in rubllion, or for the use of the lulul military forces, were liable to rapture, though primarily destiment to Malamolnas.

- Wre are obliged to conchule that the portion of the eargo which we hater rallaterized as contraband most be condemned.

" Inl it is an established rule that the part of the cargo belonging

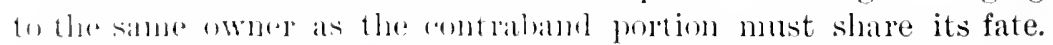
This rule is well staterl ly chancellor Kexr, thus: "Contraband articles are infectious, as it is called, and contaminate the whole 
cargo belonging to the same owners and the invoios of any latle ticular article is not usually admitled, to exempt it from sombarl confiscation.'

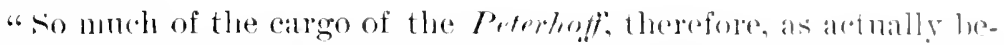
longerl to the owner of the artillery latruess, and the other antratbaud goods, must be also condemmed."

\section{THE “JONGE MARGARETIIA."}

\section{Ihan Colrt of Ammintr, 1799.}

\section{(1C. Robinson, 189.)}

Provisions going to a port of naval eyuipment of the enemy may be treated as contraband of war. And if the ship belongs to the owner of the contraband, it is also condemned.

This was a case of a Papenberg ship, taken on a voyage from Amsterdam to Brest with a cargo of cheese, $\Lambda_{p}$ ril, 1797 .

Judgment,—Sir Wr. ScorT:-

"There is little reason to doubt the property in this care, and therefore passing over the observations which have been mate on that part of the subject, I shall confine myself to the singrte question: Is this a legal transaction in a neutral, being the transiction of a Papenberg ship carrying Dutch cheese from Amsterdan to Brest, or Morlaix (it is said), but certainly to brest; or, as it may be otherwise described, the transaction of a nentral carrying a caroo of provisions, not the product and manufacture of his own comntry, but of the enemy's ally in the war-of provisions which are a callital ship's store-and to the great port of naval equipment of the enemy.

"If I adverted to the state of Brest at this time, it might be no unfair addition to the terms of the description, if I noticerl. whit was notorions to all Europe at this time, that there was in that port a considerable French fleet in a state of preparation for sallying fortin on a hostile expedition; its motions at that time were waltelent with great anxiety by a British fleet which lay off the larhor for the purpose of defeating its designs. Is the carriage of such a sulpply to such a place, and on such an occasion, a traffic so purely neutral as to sulject the neutral trader to no inconvenience?

"If it conld be laid down as a general position, in the mamner in which it has been argued, that cheese being a provision is miversally contraband, the question would be readily answered: but 


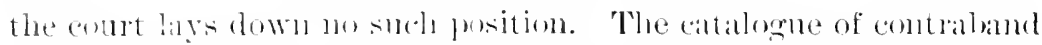

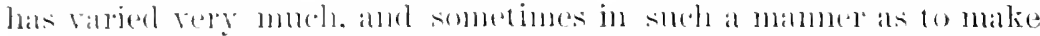

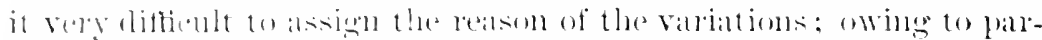

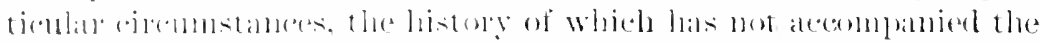

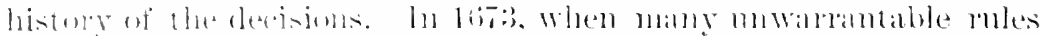

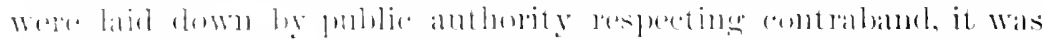

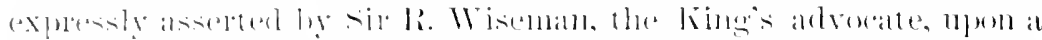

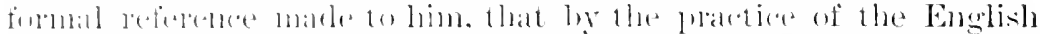

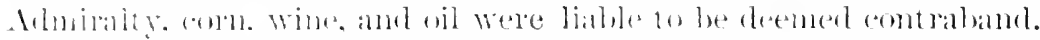

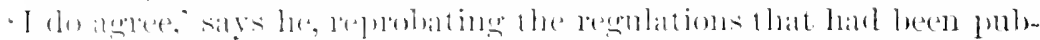

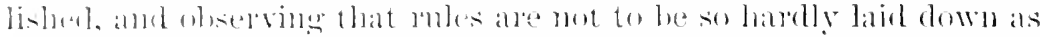

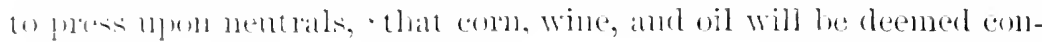
[1;it\};11,1."

" Phese atrticles of movisions them were at that time confiscable,

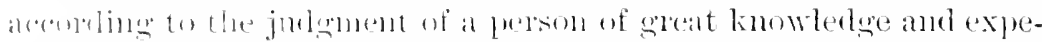

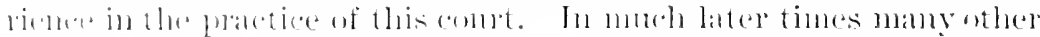

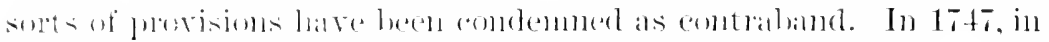

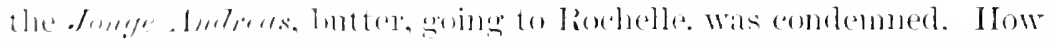

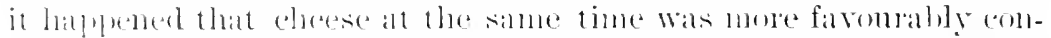

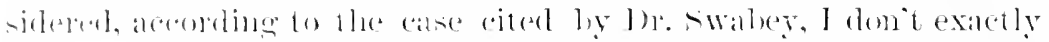

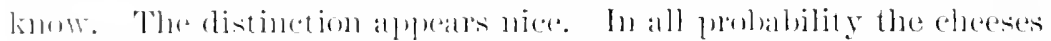

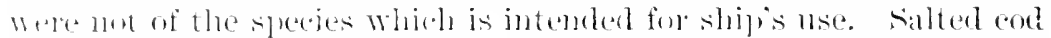

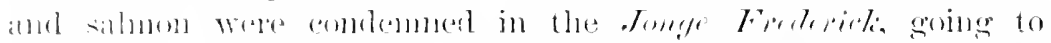

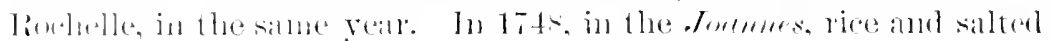

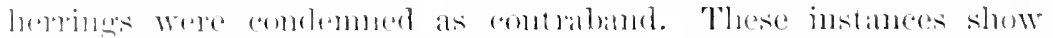

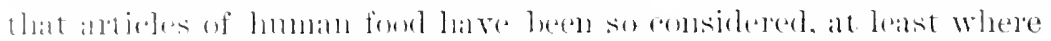

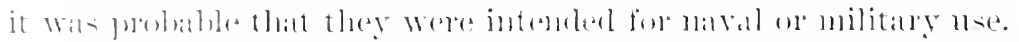

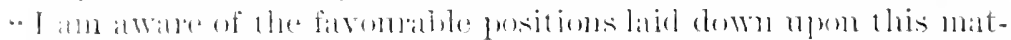

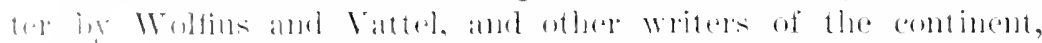

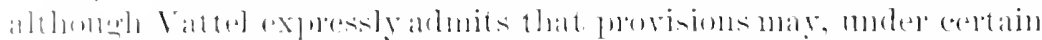

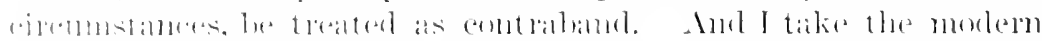

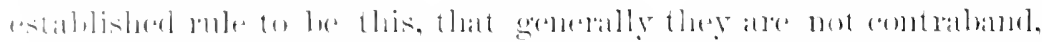

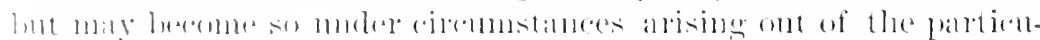

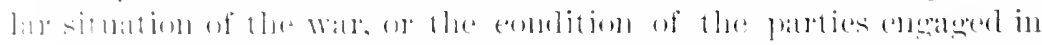

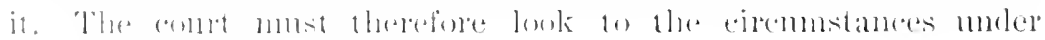
Whind his shlphly was sellt.

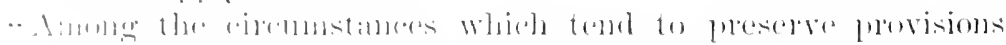

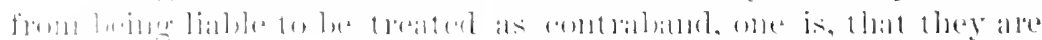

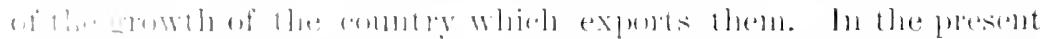

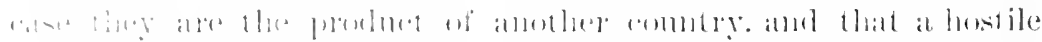

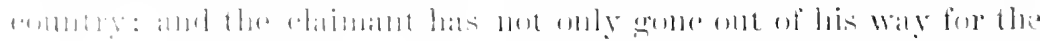

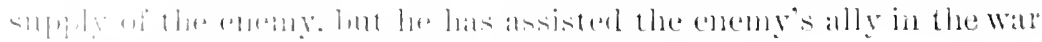

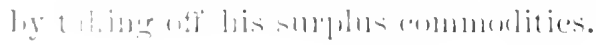




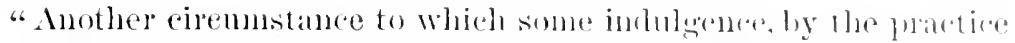

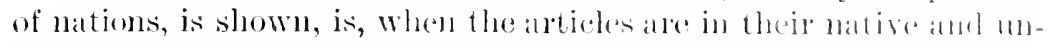

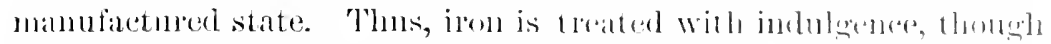

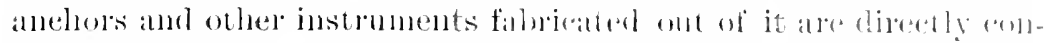

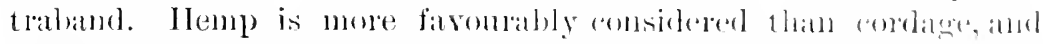
wheat is not comsidered as so moxions a commorlity as any of the.

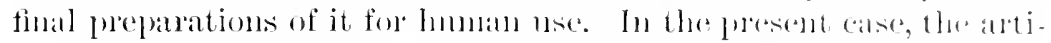
ele falls moler this mufivomable comsideration, lecing a mamufactume prepared for immediate use.

"Int the most important distinetion is, whether the articles were intenter for the ordinary use of life, or aren for mereantile slipis use; or whether they were going with a highly probahlo destination to military use? Of the matter of fact on which the distinetion is to be applied, the nature and giality of the port to which the alt icles were going is not an inational test; if the pont is a moremal commercial port it slatl be mulerstood that the articles wore womer for civil use, although oecasionally a frigate of other shijs of War may be constructed in that port. Comtro, if the great prodominant character of a port be that of a port of naval militaly equipument, it shall be intended that the anticles were soing for military nse, although merchant ships resort to the same place, and althomgh it is possible that the articles might lave been applied to civil coms-mmption; for it being impossible to ascertain the final nse of an antirle ancipitis usus, it is not an injurons rule which deduces both ways the final use from the immeriate destination; and the presmmpiom of a hostile use, foumded on its destination to a military port, is rery much inflamed if at the time when the articles were going, a comsirl. erable armament was notoriomsly preprang, to which a supply of those articles wonld be eminently useful.

"In the case of the Eemdrught, cited for the claimant, the destination was to Bourdeanx; and though smaller vessels of wall maly be oceasionally built and fitter out there, it is by no means a port of naval military equipment in its principal oceupation, in the sante mamer as Brest is miversally known to be.

"The court, however, was mulling in the present case to (o) clude the claimant on the one point of destination, it being allened that the cheeses were not fit for naval use, hut were merely luxming for the use of domestie tables. It therefore permiterl buth partios to exhibit affidavits as to their matme and quality. The daimant

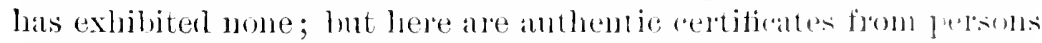
of integrity and knowledge that they are exildly sheh rhenes as are used in British ships when foreign cheoses alle llsed at all, and that they are exclusively used in Frenel ships of wall. 
" Ittending to all these cincomstances, I think myself waranted to promonce these aheeses to be contrahand, and condemn them as

As such, lomerere the gatty has acted without dissimulation in the case. and may have leen mislef by an inattention to eiremmstalles. te which in strichess he ought to have advelted, as well as ly somethimg like an irregula indulgence on which he has relied ; I siall antent myself with fromonmoing the cargo to be contraband withont enforeing the nsmal penalty of the confiscation of the ship belonging to the sime poprietor."

\section{THE "COMMERCEN."}

\section{Simene Court ah the Uxitei) States.}

(1 117 heutom, 35\%.)

By the molem law of nations, provisions are not in general deemed contraband, but they may becone so on account of the particular situation of the war, or on account of their destination to the military use of the enemy.

This wats the case of a Swedish ressel captured on the 16th of April. 1-14, hy the private armed schomer Lamence, on a voyige

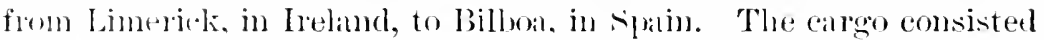
of harley and rats, the property of British subjects, the exportation of which is generally prohibited hy the British government; and, as well by the otticial papers of the enstom-homse as by the private letters of the shipher's, it alprears to have been shipped moler the sperial permision of the government for the sole use of his Britammic

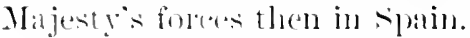

The following is an extract from the opinion of the court, delivererl hiy strul: .l :-

"The single punt mow in rontroversy in this canse is, whether the ship is entilferl w the freight for the voyge. The general rule that the mentrall andior of enemy's polperty is entitled to his freight, is now ton firmly establisherl to alduit of disenssion. But to this rule there ane mally exerptions. If the neutral be genilty of framdnlent or mmental comblut, of has intelposol himself to assist the emeny in "arrying on the ware he is justly deemed to latre forfeited his title

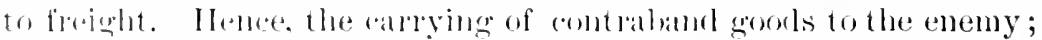
the engaging in the coasting or colonial tarle of the enemy; the

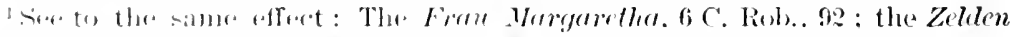

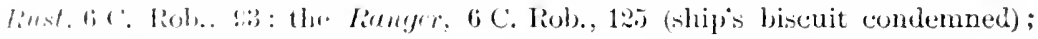
1.16 Ellowel, 1 C. Rob., Gs. 
spoliation of papers, and the fandulent smpluession of enemy intrerests have been held to affect the mentral with the forfeiture of freight, and in cases of a more flagrant character, smeh as calrying despatches or hostile military passengers, an engagenent in the transport service of the enemy, and a lneach of blockarle, the penalty of confiscation of the ressel has also been inflicterl. By the modern law of nations provisions are not, in general, feemerl contraband, but they may become so, althomgly the property of a nentral, on account of the particular situation of the war, of on aceoment of their destination. If destined for the ordinary use of life in the enemy's comtry they are not, in general, contralnand; but it is ot herwise if destined for military use. Itence, if destined for the army or navy of the enemy, or for his ports of naval or military equipment, they are deemed contraband." 1

${ }^{1}$ Provisions. - In the case of Maissonnaire $\mathrm{r}$. Kcating, 2 Gallison, the question was as to the validity of a Russian document, in which the legality of the (at)ture had to be passed upon. It was the case of a cargo of provisions; amd the court held that provisions going to a port of naval equipment of the enemy, and a fortiori, if destined for the suply of his army, became contraband, and subjected the ressel (probably belonging to owner of cargo) and cargo to confiscation by the other belligerent.

Res ancipitis usus. - As to the question: what articles shall be regarderl as contraband of war? there has been, and still is, a wirle difference of opinion. The English prize couts, as shown by the eases given, have treated provisions ats contraband in certain circumstances: and the American courts followed this practice. The French decrees and decisions, on the other hamd, have taken the opposite view, that provisions are in $n 0$ case to be treated as contrabant. And yet, in 1885, the French government amounced that it proposed to treat rice bound for open Chinese ports as contraband of war.

As to other articles ancipitis usus, tlose most in controversy have been naval stores, including in that term every thing used in the enstruction of ships of war. The cases in which these articles have been confiscated by the English prize courts are very numerous. A few of the leading cases are as follows:-

The Staat Embalcn, 1 C. Rob., 26 (masts); the Endranglet, 1 C. Rob., 22 (timber); the Jonge Tobias, 1 C. Rob., 329 (tar) ; the Sarah Christina. 1 C. Rols., 23: 241 (tar and pitch); the Ringende Jacob, 1 C. Rob., 89 (hemp, iron bars); the Neptumus, 3 C. Rob., 108 (sail toth).

The greater number of these articles were trated by Sir William ScoTT as goods absolutely contraband, if going to an enemy's port, without comsidering the nature of the port. The govermment of the United States. in 1r9r, held the same view: "Ship timber and naval stores," said the Secretary of state, "are by the law of nations contraband of war." It will be seen ly the Fronch eases la Ninere and others, that the French prate ice is the reverse of that of England and the United States.

The recent changes in naval warfare, brought ahout ly the introchetion of steam power and steel ships, have introduced a large number of new articles into the list of contraband or "occasional contraband "goods. This may be 


\section{"II. VOL. WYTE"}

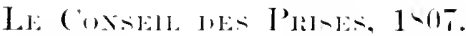

(Pistryge t Heteroly. I.. 409.)

France loes not regarl timber for the construction of thips as contraband of W:11.

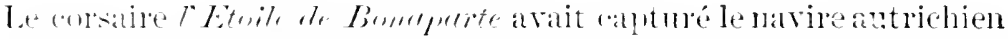

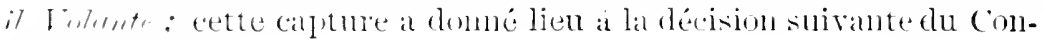
seil deritistis.

- Le Cix-lan:- Attemhn qül est constant, pir les pieces de bord,

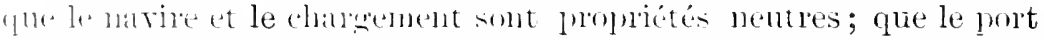

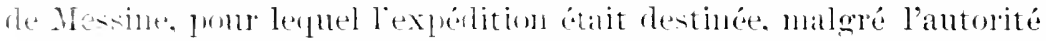

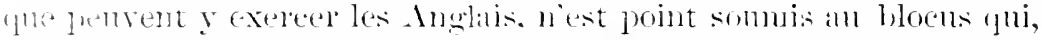
anx tromes dn décret dn 21 norembre 1en6, a lieu forr les ports et les Iles liritanniques : et que les smores. suivant le manifeste et le connabsement, forviemnent de Lisbonne, et ont été raffinés palr la

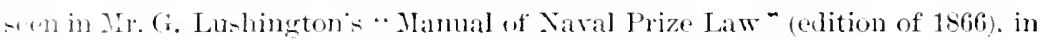
which gends alsolutely contraband alde enmmeratted as follows:-

". Jmon of all linels and machinely for mannfacturing arms. Ammmition and matrerials for anmmitim. incheling lead. sulphate of potasle muriate of

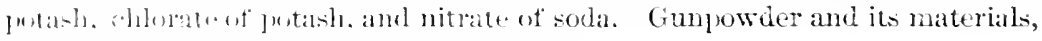

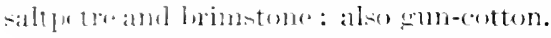

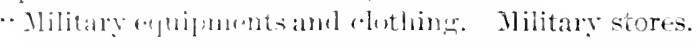

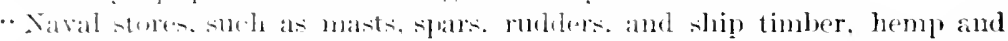

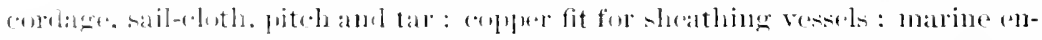

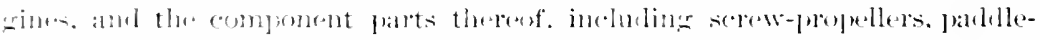

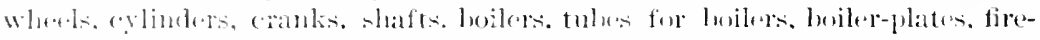
hars: marine cement and the materials in the manufactmo thereof. as blue-lias and lentanel enent. Tron in any of the following forms: Anchers, rivel-

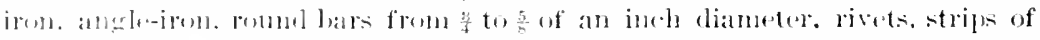

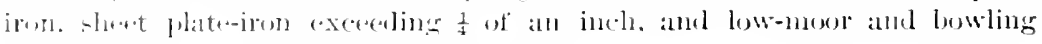
Hiale...

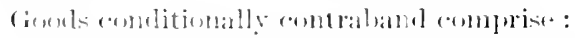

- l'rovi-ions and li

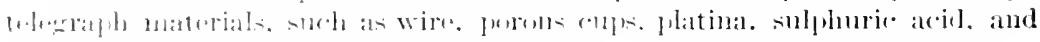

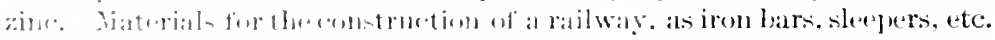

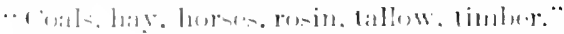

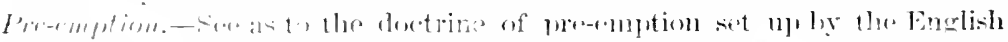

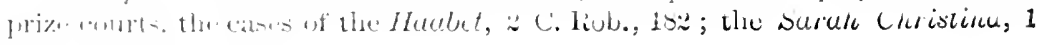

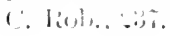




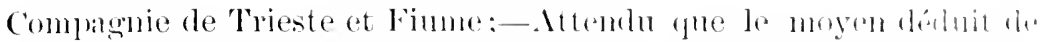

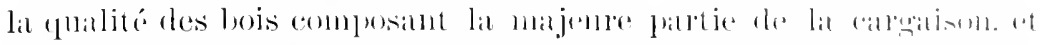

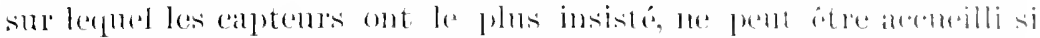

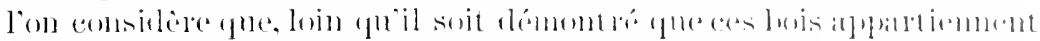

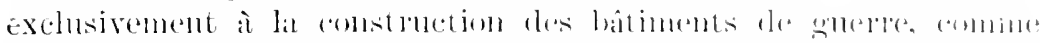

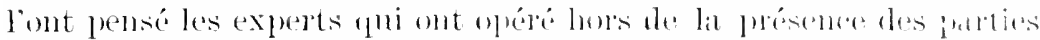

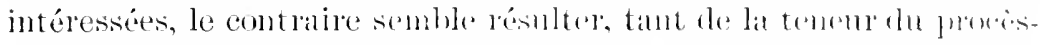

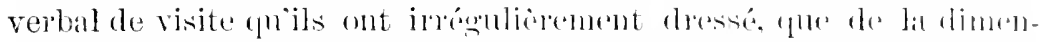
sion fles planches et de lemp mombre complatre aree lat calpatcité dh

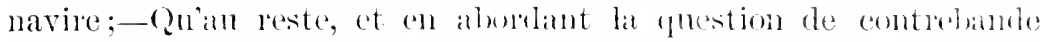
élevée par le corsabe, il est facile de se comvalucle que la solution lui en est contraire. En effet, les hois de construction me som de-

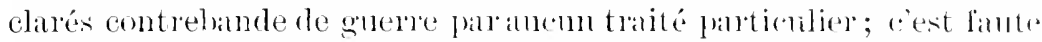

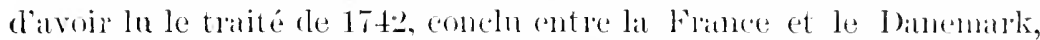
quon a dit qu'il comprenat soms rette dénomination les losis de

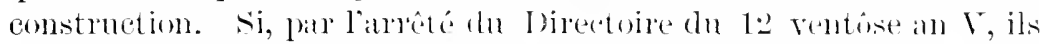

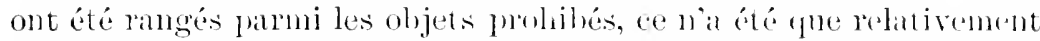

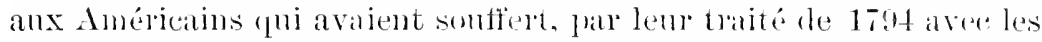

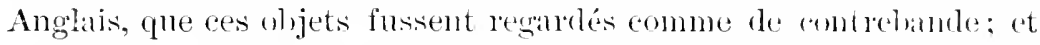

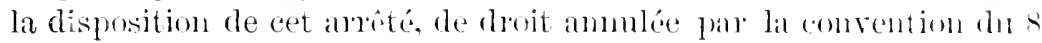

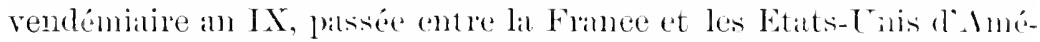
rique, qui, en spécitiant tous les antieles de contrelande, n’y a proint compus les bois de construction. Lors mone que lon annait pu sontenir avec quelyne fondement que la prohibition contenne dims

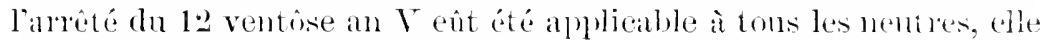
se tronverait implicitement rapportée par l'arrete du 2y frimalre an VIII, qui, à l'énard de la navigntion des neutres, a létabli les dispositions du restement dn og juillet 17Ts, dont l'art. 15 ordomene l'exécution de lonkomnance te la marine de 16-1, laquelle, dans l'anmmélation des objets de comtrebaude de guerre, ne place point les lowis de constuction: d'oì il fant conclume que la destination ponr un

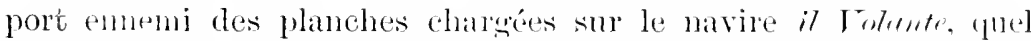
qu'en dit etre l'emploi, ne les a print rendues confisables, et que tout an plus elle serait susceptible, avee les antres ciromstanues do

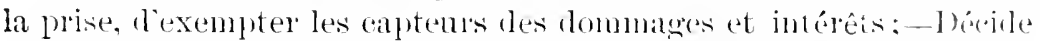

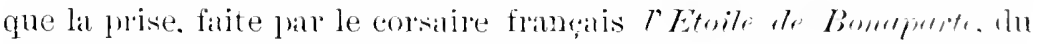
navire antrichien il Volonte, est invalide; en fait pleine et cntione maind are an profit des proprictatires." 1

1 And see, La Minere, Pistoye tet Durerdy, I., 410. 


\title{
TIIE " NELTRAIITET."
}

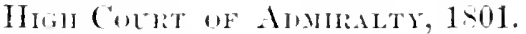

(:) ('. Rolinsom, :295.)

Penaltr for carrving contrabaml. It does not as a rule involve the confisca. tion of thes ship.

This was a case of a Manish ship taken with a cargo on a voyage from Archangel to bordrecht. The ship had been a Dutch vessel, aml Wats asserted to have been purchased hy Mr. Schultz, of Altona. sler then went from Folland to Altoma. and was from lhence sent on tu Irehausel. to carry a cargo to Dordrecht, under a charter party marle by the asserted owner.

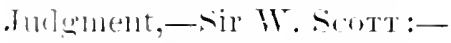

.. The modern rule of the law of nations is, certainly, that the ship shall not be subject to condemnation for carrying contraband articles.

.- The ancient practice was otherwise, and it camot be denied, that it was perfectly defensible on every principle of justice. If to sumbly lle enemy with such articles is a moxions act with respect to the owner of the calro, the vehicle which is instrumental in effecting that illegal purpuse camot be innocent. The policy of modern times has howerer introdnced a relaxation on this point: and the acheral rule now is, that the vessel does not become confiscable for that ar. Fut this rule is liable to exreptions: Where a ship belonges to the ownel of the (arene or where the ship is going on such

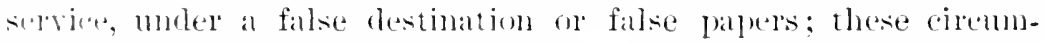

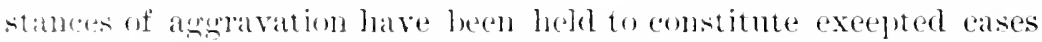
ont of the modem rule, and to contimn them moler the ancient one. The eirrumstances of the present rase compose a case of excrption

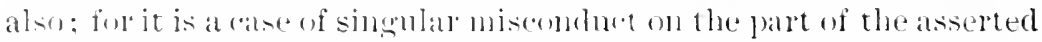

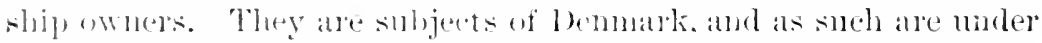

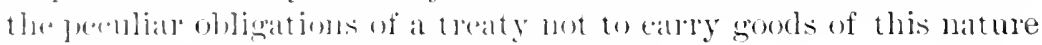

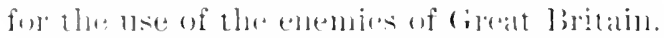

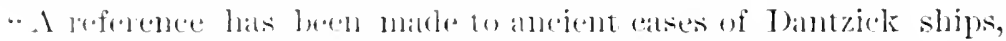

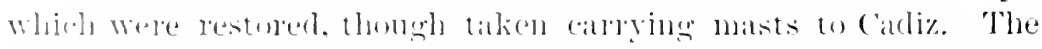

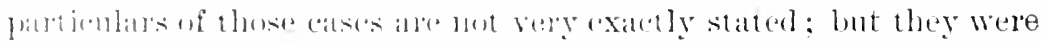
clearly the catses of groprietors expolting the produce of their own 


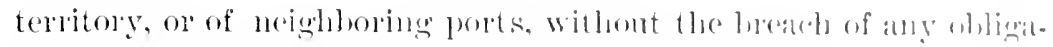

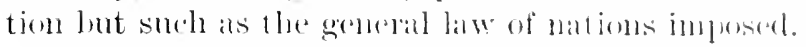

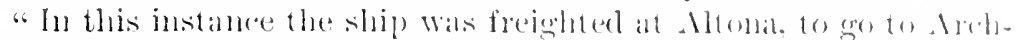

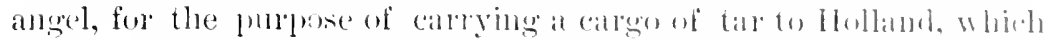

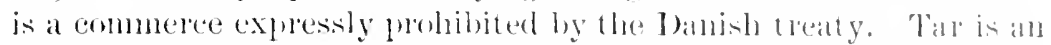

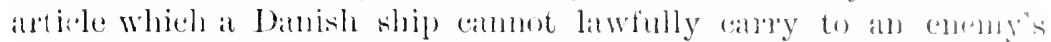
port, even when it is the probluce am mannfactme of bermatk. 'This ship goes to a forejgn port, to cofect fhat which she is fore hilsited from doing, even for the junluce of her own comntry: in this respect, throwing off the chanatel of a Thuish ship by rjolating the treaties of her comntry; and all this is done with the full privity of the asserted owner, who is the person entering juto the charter party. In such a case as the present, the known gromul on which the relaxation was introlncer, the supposition that frejohts of noxions or doubtful articles might be taken, without the personal knowledge of the owner, entirely fails; and the active guilt of the parties is aggravater by the circmustuces, of its being a criminal traffic in forejgn eommorlities, and in breach of explicit and silerial ohligations. The confiseation of a ship so engaged will leare the general rule still mntonched, that the carriage of eontrabund works a forfeiture of freight and expenses, but not of the ship.

"ship condemned."

\section{SETON $\checkmark$ I,OIT. \\ Suprean Cocre af New Yurk, 1799.}

\section{(1 Johnson, 1.)}

A trade by a neutral in articles of contraband is a lawful trade. And a contract of insurance on such goods is valid.

This was an action on a policy of insurance, which inchuler " anl kinrls of lawful goods and merelaundises" on board the Mnement, etc.

The slip having been captured and a part of the goofs contemned as contraband, the defendints lefused to gay the insminne., on the ground that the plaintiffs had not informed them of the nature of the cargo.

The following is an extract from the juclgment:

Kent, J.-"Two questions were ratised on the argument in this case.

"1. Whether the contriband goods were lawful, within the mean. ing of the policy. 
.. 2. If lawful. Whether the assmerl were homm to disclose to the

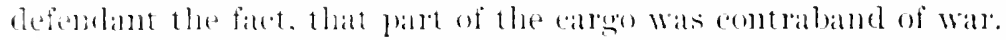

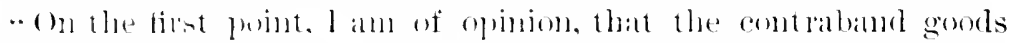

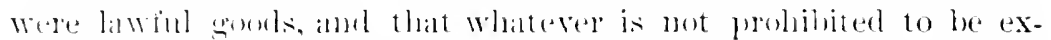

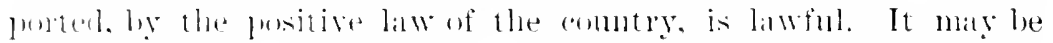

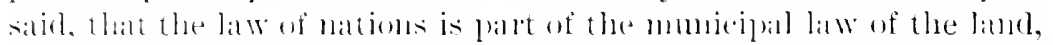
amel that hy that law (and which, so fat as it comedms the present

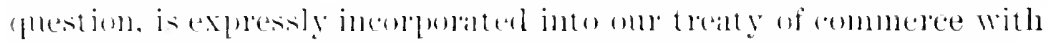

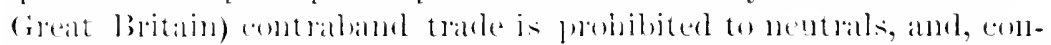

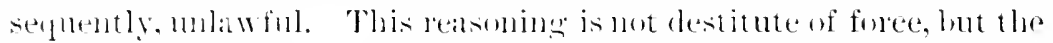

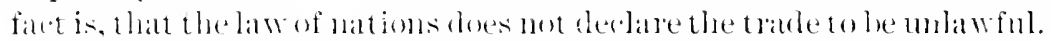
It anly anthorizes the sizure of the andraband antieles ly the let-

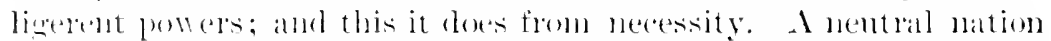

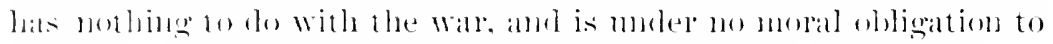

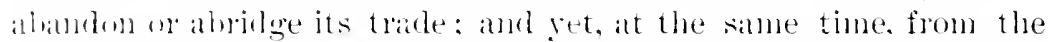
Jall of neesity as Vattel olserves, the powers at war have a right

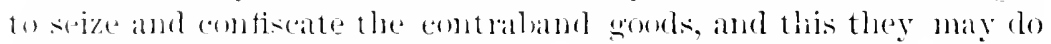
flom the principle of self-defence. The right of the hostile power to sejze, this some very moral and correct writer continues to ob-

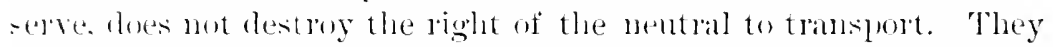
ile rights which may, at times, reciporally chash amd injure each wher. But this collision is the efrect of ineritable necessity and

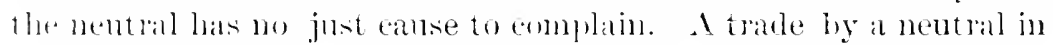
anteles contraband of war is, therefore, a lawfol trade, though a rarle, from necessity, subject to inconvenience and loss."

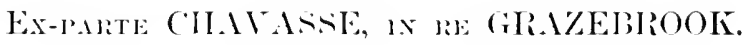

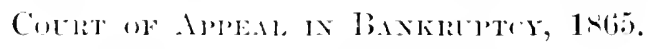

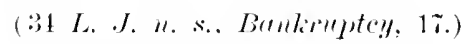

Tracle in contraband articles ly a neutral is lawful.

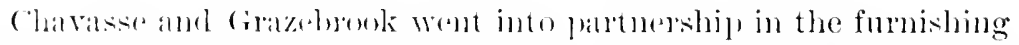

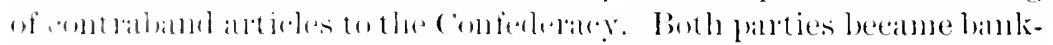

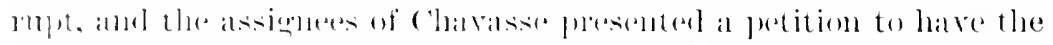

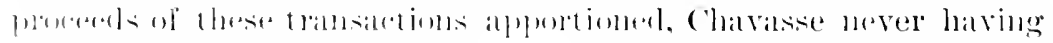

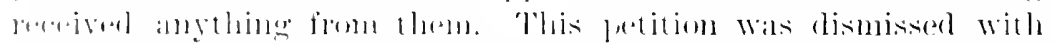

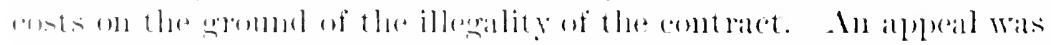

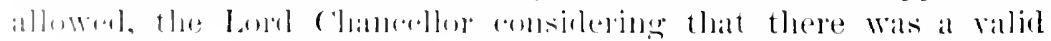

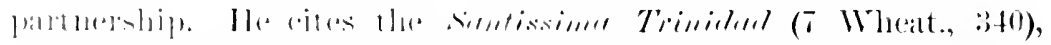
and powtes the following passige to be a verg eorrect representa- 
tion of the present state of the law of bingland also: - "Thume is moth-

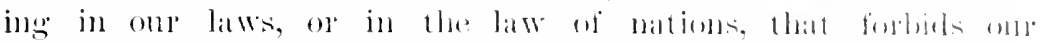
citizens from sending andued resisels as well als momitoms of Wall

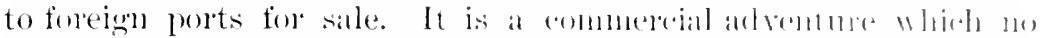

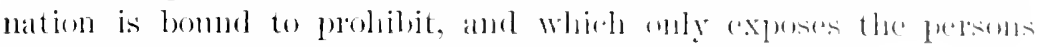
engarged in it to the penalty of comfiscattion."

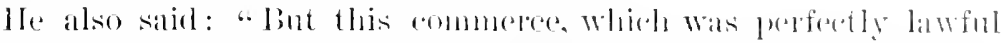
for the neutral with ather helligerent eomery lefore the wats, is not made by the war unlawful or capable of being loohibited by botlo ar either of the helligerents; and all that international law does is to subjeet the nentral merchant who transports the cont raband of wall to the risk of having his ship and ango captured and comblemuned hy the belligerent power for whose enemy the contraband is destined."

\title{
Section 45.-Despatches and Persons an Contraband.
}

\author{
TIIE "AT.IT.ANTA."

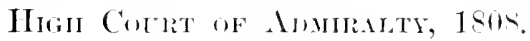 \\ ( 6 C. Robinson. 440.)
}

Carrying dispatches from the Gorernor of the Isle of France to the Minister of Marine, at Paris, is cause of comincation of the ship.

This was a case of a Premen ship and eargo, captumed on at royage from Batavia to Bremen, on the 1 th of .July, 1797. having come last from the Isle of Franee; where a parket contaning dis. patches from the Gorelmment of the Isle of France to the Minister of Harine, at Paris, Was taken on bourd by the master and one of the supercargoes, and was afterwards fomd concealed in the possession of the second supercargo, under ciremnstanees detailed in the judgment.

Extract from judgment,-_ir IV. sort:--

"The question then is, what are the lemal comsepuences attahlong on such a eriminal aet?--for that it is criminal and most moxims is scarcely denied. What might be lhe comsequences of a simple lablsmission of dispatches, I an not called npon by the necessities of alse present ease to decirle, hecanse I have aldearly promommerl this to be a finmdulent ease. That the simple carrying of dispatches. letween

1 The only penalty by the modern law of nations for carrying contraband is the loss of freight and expenses. The Ringende Jacol, 1 C. Rub.. 90 ; tie Saral Christina, Ib.. 24:. and other's. 
the colonies and the mother comtry of the enemy, is a service limbly injurious to the other belligerent, is mest obvions. In the furent state of the workl, in the hostilities of Emorpmen powers, it is an ohjert of great inpontance to preserve the conneretion hetween

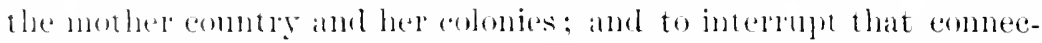
tion. on the pant of the other Betligerent, is one of the most energetic "perations of war. The importance of keeping up that connection. for the eoncentration of troopse and for rarims nuilitary pur-

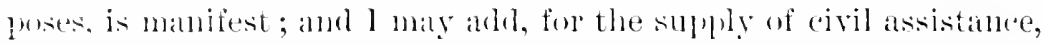
also, and supent, because the intliction of civil clistress, for the purpose of compelling a surrenter, forms no inconsirlunble part of the operations of war. It is not to he argued, therefore, that the imfurtance of these dispatehes might relate only to the civil wants of the olmy, and that it is necessiry to shew a military tendeney; becamse the object of compelling a surrembler being a measure of war, whatever is conducive to that event must also be considered in the contemulation of law, as an ohjeet of hostility, although not produced iy operations strictly military. IIow is this intereourse with the mother country kept up, in time of peace? ly ships of war or by packets in the service of the state. If a war intervenes and the other belligerent prevails to interrupt that communication, any person stepping in to lend himself to effect the sime purpose, under the privilege of an ostemsible nentral charaeter, does, in fict, place himself in the service of the enemy-state, and is justly to be considered in that charater. Nor let it be sulposed, that it is an act of light and rastal importance. The comsequence of such a service is indetinite. infinitely beyom the effect of any contralnand that ean be oonvererl. The earrying of two or three eargoes of stores is necessarily an assistance of a linited nature; but in the transmission of dispatches mal be eronvered the entire plan of a campaign, that may defrat all the projects of the other Belligerent in that dplater of the workl. It is true, as it has been saici, that me luell might take off a 'Turles the XIIth, and might produre the most disastmos effects in "1 "anulaign; but that is a consequence so remote and accidental, that in the contemplition of human events it is a solt of evaneseent fluantity of which no aecount is taken; and the practice has been

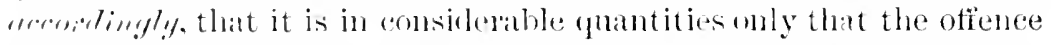
of contraband is contenplater. The case of dispatches is very difforent : it is imposible to limit a letter to so surall a size, as not to lee cilpable of prodncing the most important consecquences in the ngerations of the enemy. It is a service, therefore, which, in what. reer dingee it exists, ean only be considered in one chanacter, as an aet of the most noxions and loestile nature. 


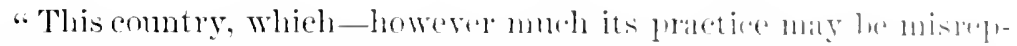

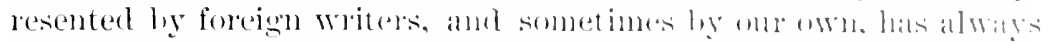

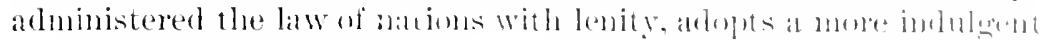
lule, inflicting on the sliponly at forteiture of freight in ordinaly

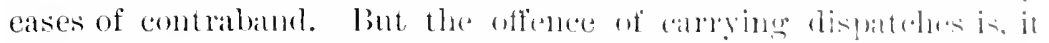

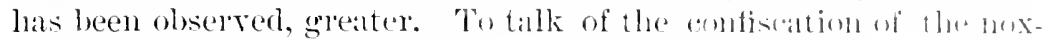

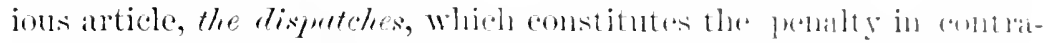

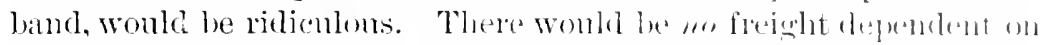
it, and therefore the sime precine penalty ammot, in the nature of things, be applied. It becomes absolutely necessury, as well als j:1st, to resort to some other measure of confiseation. which ean lw no other than that of the rehicle.

"Then comes the other question, whether the penalty is not atsu to be extended further, to the argo, heing the property of the same proprietors-not merely ot antinentien delicti, but likewise becallse the representatives of the owners of the ango, are directly involved in the knowlerge and conduct of this guilty transandion? On the eircumstances of the present ease l have to olserve, than the offence is as much the act of those who are the comstituterlaguts of the cargo, as of the master, who is the agent of the ship. The general rule of law is, that, where a party has heen guilty of an $\mathrm{in}$. terposition in the war, and is taken in delicon, he is not entitled to the aid of the court, to obtain the restitution of any part of his: property involved in the same tr.msaction. It is sair, that the trin. 'interposition in the war' is a very general term and not to be loosely applied. I am of opinion, that this is an aggratrater case of active interposition in the service of the enemy, concerter and (and. tinued in fraud, and marked with every species of malignant (onn. luct. In such a case I feel myself bound, not only hy the general rule, ob continentium delicti, but by the direet participation of wnil in the agents of the cargo. Their own immediate conduct not only exclules all favourable distinetion, hut makes them pre-eminently the object of just punishment. The conchsion therefore is, that I must. pronounce the ship and cargo sulject to eondemmation.

" The court observed afterwards:-I will mention, though it is a cir. cumstance of no great consequence. that I have seen the dispatches in this case, and that they are of a noxious nature, stating the strength of the different regiments, Ec., and other particulars en. tirely military." 


\title{
TIIE " R.APID."
}

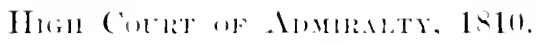

\author{
(Ederards. ․․․)
}

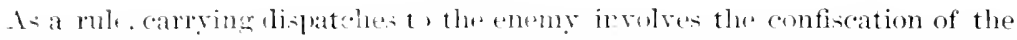

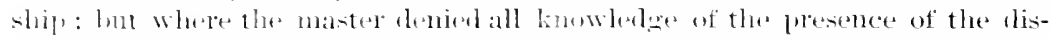

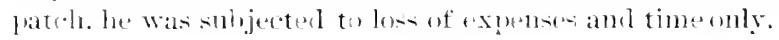

This was the case of an American ship which was captured on her

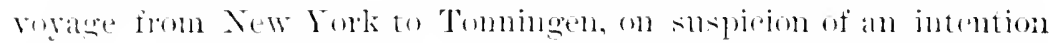
to push ind the Ther. Jut the question of destination being

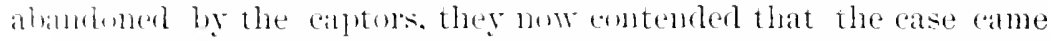
willin the princinle laik down by the cont in the case of the derlenter as it hath been discovered, that among the palpers given up by the mastel at the time of enpture, there was a dispatch ardersid to

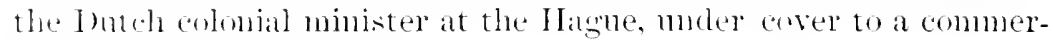
cial homse at Tomingen.

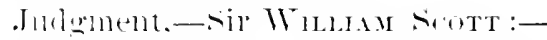

. The question of destination heing disposed of. I have now only (1) amsinke what will be the leand effert of carring these dis-

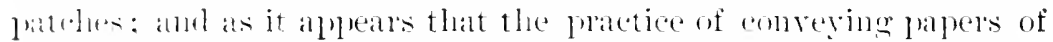
this description, for the enemy previls to a comsiderable extent, I

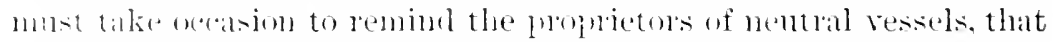

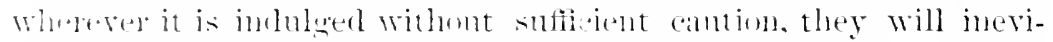

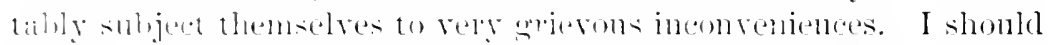

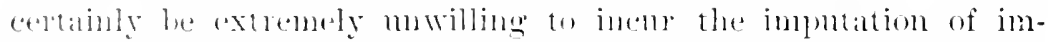

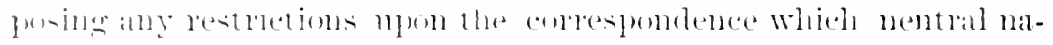
tions ane enteled to mantain with the enemy, or, als it was sug-

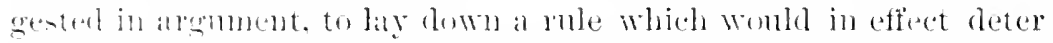

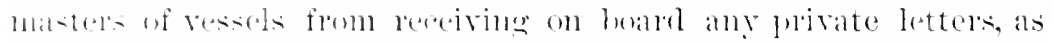
thry cannut know what they nuy comtain. But it must be under-

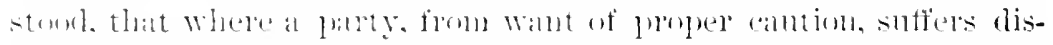

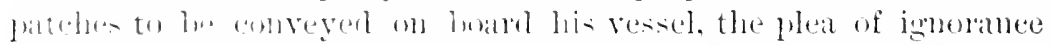

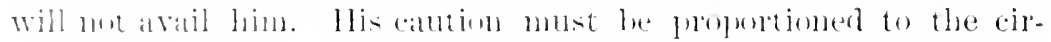

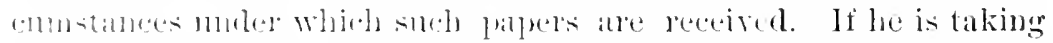

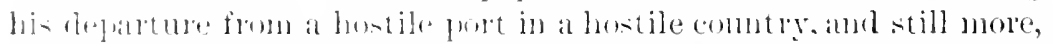

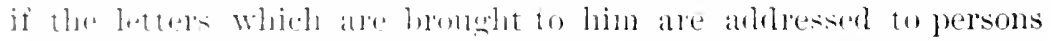
re-ilfolt in an huste wmutry he is called upon to exereise the ntmosi jeatsusy with regard to what propers he takes on board. On 


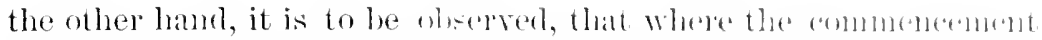

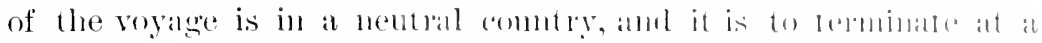

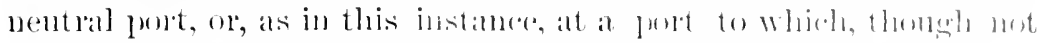

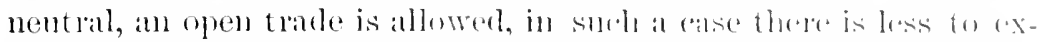

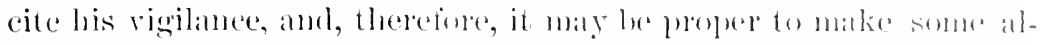

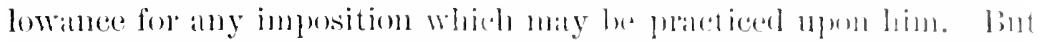

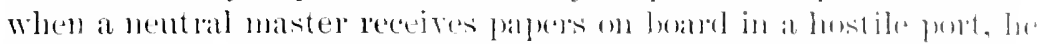
reecives them at his own hazald am tammot he hearl to arel his ignoranee of a fact which, by the enguiry, he might hate mald himself acquanted with. The batty in the present ease has the lededit of the favourable distinction: these palers, with some oflues, wate put on board in an envelope, arldressed to a person at 'lomminges. who was instrueted to forward them to IJolbme, hut of this the master swears he knew nothing. They turn out to lu of a pullic. nature, conveying intelligence of impertance to the sosermuent of the enemy at the IIague, and they hexin, I observe, with an atsertion which I hope is not trie. The witer silys: "The letter and accompanying inclosmes which I this day dispatch to Ilis Ixicellency, the minister of the colomies, rie Tomingen, will, I expert, les communimated to you. I trust my combinet will be apporoved of ly IIis Excellency, and that he will please explain himself, both with regard thereto, as also respeeting the contents of my latter to the Marshal Dammlels. The smest mole of correspondence, is ly way of England or Paris, through the clamnel of the Inteh minister, as

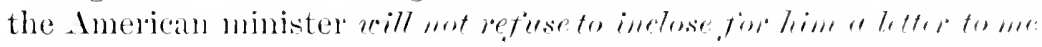

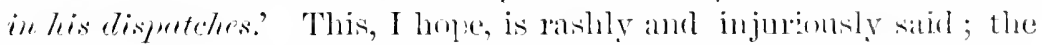
enut camot hring itself to believe, that the accredited ministor of a comtry in anity with this would so far lend himself to the purposes of the enemy as to be the private instruncent of convering the dispatches of the enemy's govermment to their agent. The pulpers in question eome from a ferson who seems to be invested with something of a public chameter, thougl of a jecnlian kiml, and they are upon public business, hat I do not know whether they reme stristly within the definition of dispatches. The writes of them hakl been sent to America from batavia by the governor, to beat up for volunteers among the American merchants, in the hope of incluring them to embark themselves in the trarle of that settlement. How far he late been acknowledged by the Ameriean govermment does not appear ; from the contents of the papers themselves he seems to have been stationed in America, not by the govermment of llollam, but by the Duteh governor of Batavia, rather as a commerefial andent to drive a bargain with indivieluals, and to induce them to join in these speculations for the relief of the Batavian trake, than for ang 31 
pumposes of a mole diphomatic natme. Ilis eommision was such that it minht exist withont his heime ackmoledget as a pmblic aceledited ministor by the Ameriean gorermment, and thesefore the alimant is perhats, entitlerl to the hemetit of the distinction which has heen talken, that these pripers, thomgh mistheroms in their own

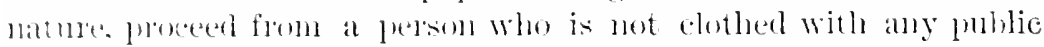
officiall rhandeter. They eante to the hatmols of this American master

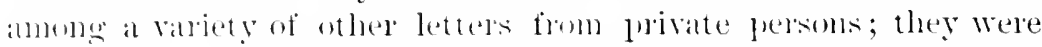

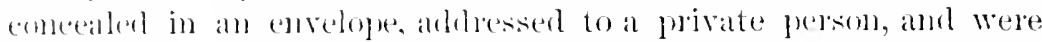

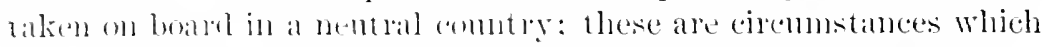

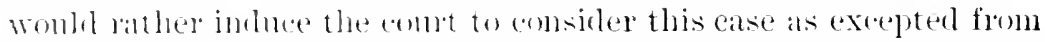
the general me which does not fermit a nentral master, arrying dispatches for the enemy, to shelter himself moler the plea of $\mathrm{jg}$ norance. In the present instance the American master denjes all knomledge of the comtents of these papers, and the benefit of that denial will extend to the cargo: it is not, therefore, a case in which the property is to be confiscater, although in this, as in every other instance in which the enemy's dispatches are found on board a ressel, he has justly subjected limself to all the inconveniences of seizure and detention and to all the expenses of those judicial ingniries which they have occisioned."

\title{
TIIE "M IDISON."
}

\section{IIgn Coltit of Amminter, 1810.}

\author{
(Eteards. 2.24.)
}

Carrying dispatches from an eneny's gorrmment to its oficials in a neutral comtry in lawtul: and no penalty attaches to the ship therefor.

The following ase extrats form the julgment, sir Wr. Soot :-

. Xom I am of ophingu, that a commumication fom the Danish

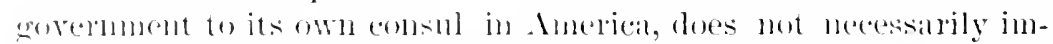
by anything that is of a batme lustile or injurions to the interests uf this eomutly. It is not to he so plesmmed; stleh eommmoicafirms mont be smpusent to halre reference to the business of the eom-nl-eneral's ofliere, which is to maintain the commerebal redations of

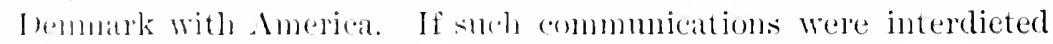
the fmotions of the offiedal persoms womld cease altogether.

". I banish romsul-eneneral in Americal is not stationed there morety for the purpose of Inui-h trade, but of Danish-American 
trade; his funetions relate to the joint commenee in whish the two commtries are engarged, and the caste, therefore, falls within the puin-

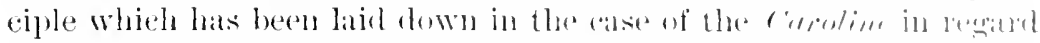
to dispatelues from the enemy to his ambassadiom resident in a luentral countly."

\section{TIIE "OROZEIIBO."}

IIGH Coelit of Amments, 1807.

(6 C. Robinsom, 430.)

A neutral ressel chartered by the enemy to convey military persons is subject to confiscation as engaged in an unlawful commerce.

This was a case of an American vessel that hat been ostensibly chartered by a merchant at Lisbon "to proceed in ballast to Wasa, and there to take a cargo to Imerica," but which had heen afterwards, by his directions, fitted up for the reception of three military officers of distinction and two persons in civil departments in the government of Batavia, who had come from Inolland to take theiv passage to Batavia, uncler the alpointment of the Govermment of Hollind.

There were also on board a lady, and some persons in the cajacit $y$ of servants, making in the whole seventeen passenger's.

Judgment, —,ir Wr. Sortr :--

"This is the case of an admitted American ressel: but the title to restitution is impugned, on the sround of its having heen rmployerl, at the time of the eapture, in the service of the enemy. in transumting military persons first to Nacao and ultimately to Batavia. That a vessel hired by the enemy for the conveyance of military lersoms is to be considered as a transport sulject to condemnation, has berm in a recent case held by this comrt, and on other occasions.

"What is the number of military persons that shall constitute such a case, it may be difficult to define. In the former case there were many, in the present there are much fewer in number: but I accede to what has been observed in argment, that mumber alome is an insignifieant circumstance in the considerations, on which the principle of law on this subject is huilt, since fewer lersoms of hish quality and character may be of more importance, tham a much greater number of persons of lower condition. To semel ont one veteran general of France to take the command of the forces at bataria, might be a much more noxious aet than the conveyance of a whole 
regiment. The comserpuenexs of such assistance are greater: and the lefore it is what the belligerent has a stronger right to plevent and fonish. In this instane the militaly jersoms ale there and

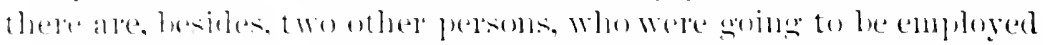

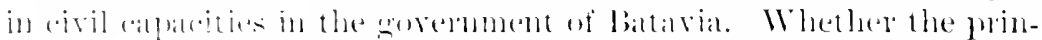

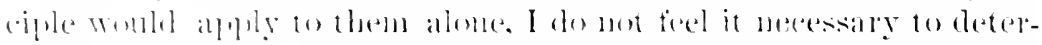

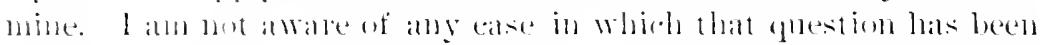

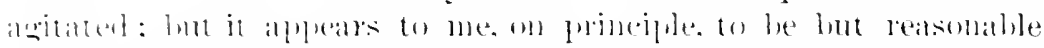

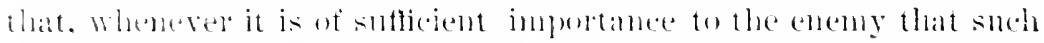

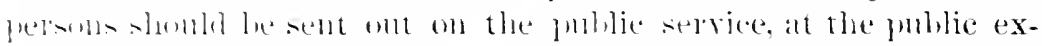

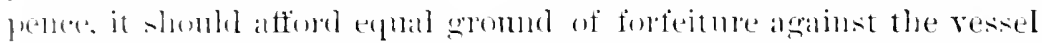
that ma!y he bet ant for at publone so intimately eommected with the Instile: ofereations.

- It has heen arenerl, that the master was ignoment of the charac-

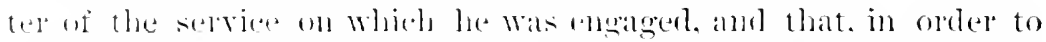
smport the perlalty, it womld he necessily that there shombl he some

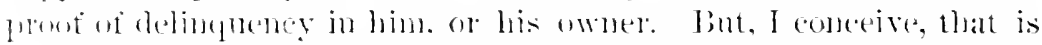

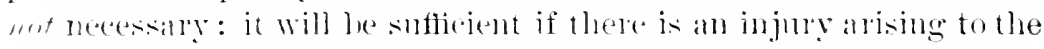
helligenent fom the employment in which the vested is fombl. In

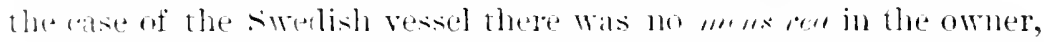

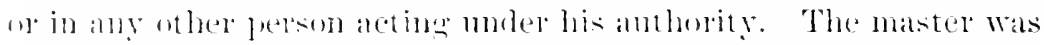

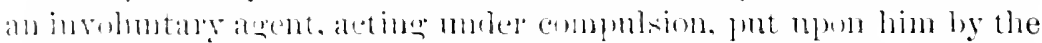

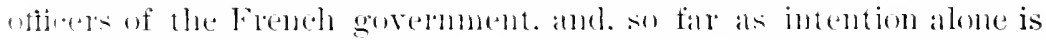

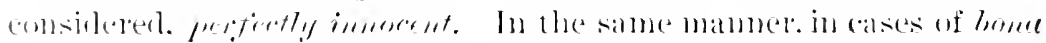

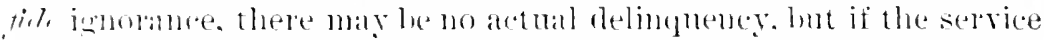
is injurioms. that will be sufficient to grive the belligement a light to

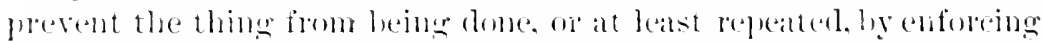

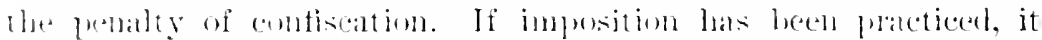

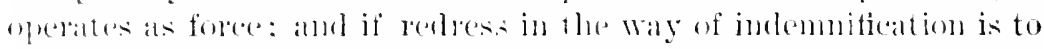

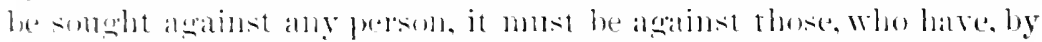

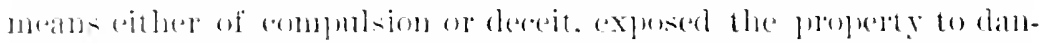

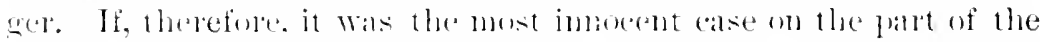
master, if there wats mothise whaterere to atfert him with privity, the

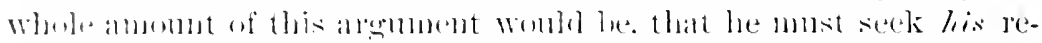

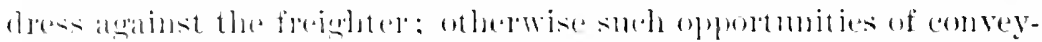

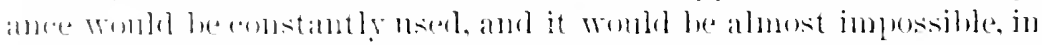

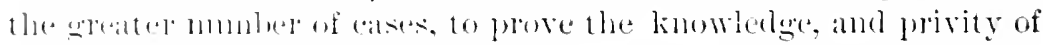

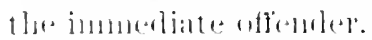

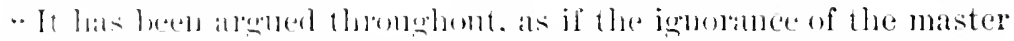

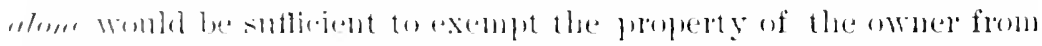

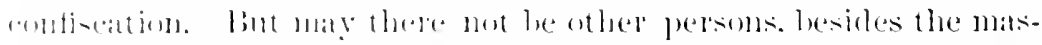
10l. Whose knowledge and privity would carry with it the same conseptences: 


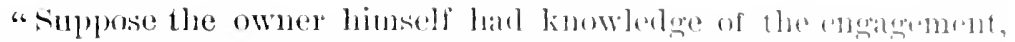

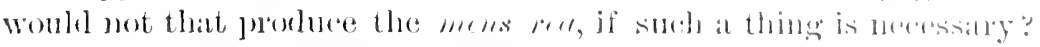

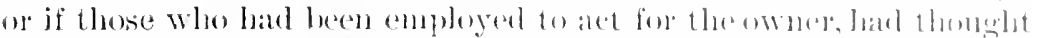

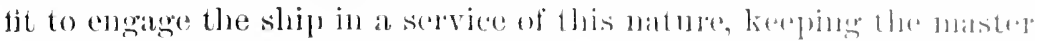

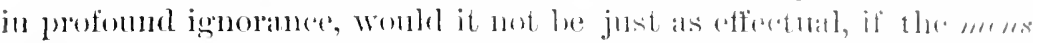
pen js neeessary, that it shomel resile in those fersoms, as in the owner?

"The observations which I shatl have ocension to make on the lamaining parts of this case will, perhats, alprear to justify smelt at supposition, either that the owner himself, or those wholetel for him in Lisbon or in IIoland, were cominsant of the nature of the whole transaction. Jut I will first state distinctly, that the principle on which I determine this case is, that the carlying military persons to the colony of an eneny, who are there to take un them the exercise of their military functions, will lead to comlenmantion, and that the court is not to sean with mimete arjhmetic the nmmber of persons that are so carried. If it has apleared to be of suficient importance to the government of the eneny to send them, it must be enough to put the alverse government on the exedeise of their right of puevention; and the ignomance of the master caln atford 110 ground of exulpation in farour of the owner, who must serk his remerly in cases of deception, as well as of force, agadist those who have imposed upon him." 1

'See the cases of the Friendship, 6 C. Rob., 420; and the Caroline. 4 C. Rob.. 256.

In all these cases the offense is rather the engagement of the vesiel ats an enemy transport than the mere carrying of lostile persoms as pascengers.

In a note to the case of the Friewdship. Br. Robinson silys: " The aut of "arlrying the soleliers of the enemy has heen in former wars asimilated to contraband. by public proclamation and instmetions, and has been dereldred to remerer the ship liable to condemmation. The declaration of war, 2ith March. 1it4, concludes with the following clause :

". And we do hereby command our own suljects, and adroltise all ot heer persons of whatever nation soever, not to transport or arry any soldicrs. arms. powder, ammunition, or other contraband goods, to any of their territen ies. lands, plantations, or countries of the sair French ling. declaring. that what soever ship or vessel shall be met withal transporting or tamying any wol-

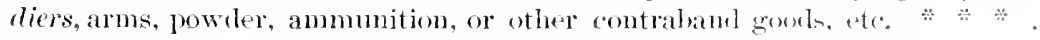
the same being taken, shall be condemned as good and lawful prize"

"The same declaration is also inserter in the secome article ef" the instruction to cruisers, of the same late: also in the second article of the instructions in the war with Spain, 20th Dec., 176s." 


\title{
TIIE "TRENT," 1ヘ61.
}

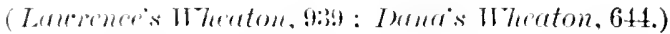

The Trent was carryine, als passengers. Messis. Mason and slidell, agents of the Confederale (ropermment. between the nentral ports of Havana and St. Themal : when these fassengers were forribly removed by Captain ivilkes of the Cnited statessteaner Som Jecinto. Mr. Seward atmitted that these persons conld not be law fully taken from the Trent at sea, but contended that she might have leten brought in as prize.

It an early stage of the eivil war in the Fnited states, in October: 1-til. the Confederate foremment appointed Mr. Mason to England amel Mr. Flidell to France, each with a secretary, to act as commissioner's or ambarsalor's to those comntres. The govermment hat not berell recognized ly any nation, and cond not maintain diplomatic relations; but it lad heen recognized as a lawful belligerent. The object of the mission of Masom and slidell was to aid the insurgent forerment hy all neans in their power: to urge its recomition hy the Eurpean states: to effect treaties of commerce or alliance; to procure, if desined ly their govermment, the intervention of European povers.

It maly be sidd to have been essential that these agents should make the passige muler nentral flass. They suceeded in ruming

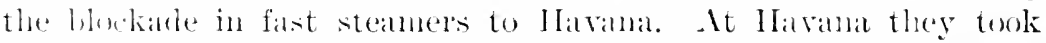
passage, on their way to Europe, in a british steaner, the Tient,

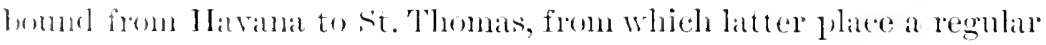
line of -teanels. eomneting with the Tient, ran to England. The

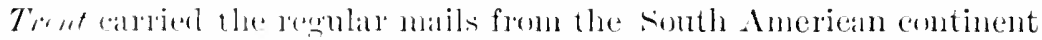
and Cuba to Englant, to transfor them at St. Thomas to the next

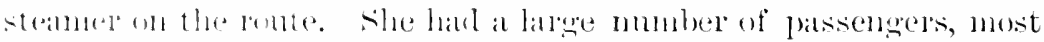

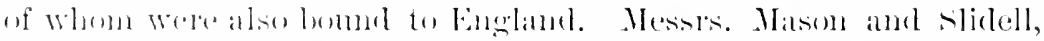

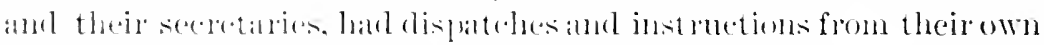

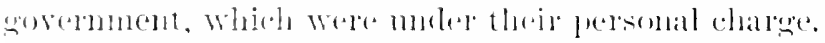

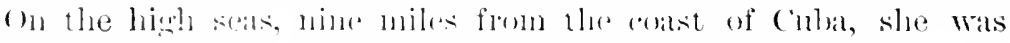

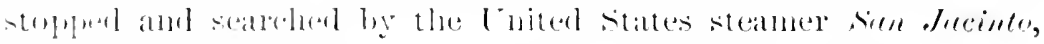
(i)

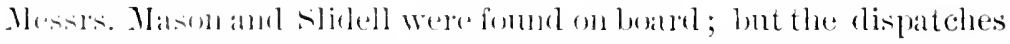

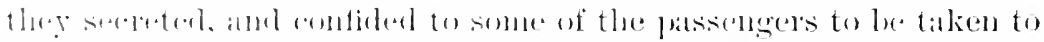

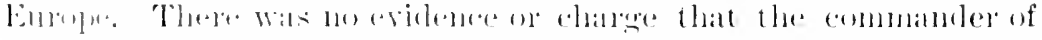

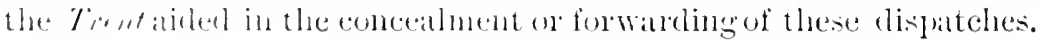


He dirl, howerer, deny the right of somele, refusor all facilitios for

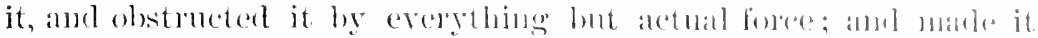

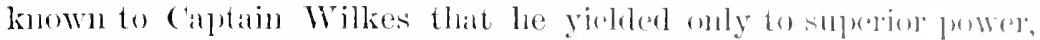

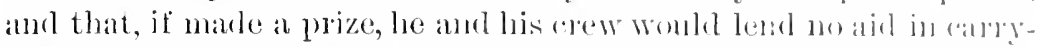
ing the Tient into port. Captatin Wilkes took Messts. Masoneant

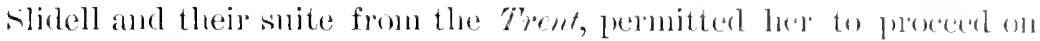

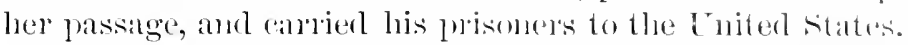

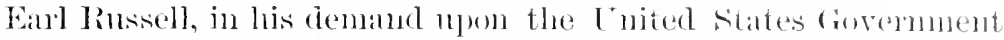
(letter to Lord Lyous, Nov. 30, 1s(i1), stated the pureediug as simply a case of a forcible taking of four passengers form an inmoremt British vessel at sea hy an American ship of war, malings no leference to their official character, on even to their mationality. Mr. Seward's reply (letter to Lord Lyous of Dec. :29, 18li1) goes at length into the subject. Ile comsiders, first, whether these persons were, as lie terms it, contraband of war. IIe cites Vattel as sirying, "War allows us to cut off from om enemy all his lesomees, and to hinder. him from sending ministers to solicit assistance," and Fir William Seott, as saying, "You may stop the ambassalor of your enemy om his passage," and applies the test, in the works of Sir William frott, "If it is of sufficient importance to the enemy that such persoms should be sent ont on the priblic service at the public expense, it should afford equal promed of forfeitme of the vessel that may le let out for a pupose so intimately comerted with the hostile oprations:" and he comes to the comchusom, that these persoms ware, from the nature of their office and destination, eontraband.

Assuming, then, which was not denied, that Captain Wilkes had a right to visit and search the $T \cdot 4$, ats an act of maritime belligerency, and showing that he exerejsed the light of seareh in a proper manner, he examines the last question, whether the talsing of thue persons out of the slip, by Captain Wilkes, Wals justitiable, muler the aceepted law of nations.

He at once diselaims, what Lord Russell assmmed to be the sromm of the act, a light to take rebels or other criminals or emenices, as such, from a neutral vessel, as an exereise of ocean police. I Ie staltes that the whole comse of Captain Wilkes Was in the exercise of a belligerent right of seareh ant caluture. In this commertion, he alludes to the clam lomg made and enforeed by Grout linitain, amb resisted by us, of a right to talie her own seamen from American

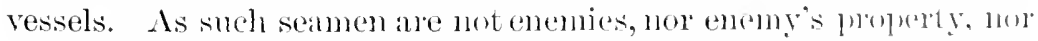
contraband, the exercise of that power wats simply an "xile ise of

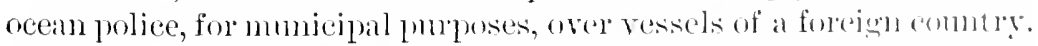

He treats this reclamation of Lond liusidell as a remmeinliom of such a claim in the future by Great britain; and agrees, that, if such 


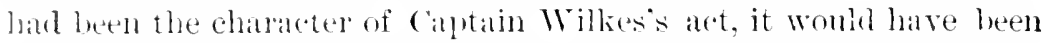
indefensible. Ilaving resolved the question of eontrabane in faror

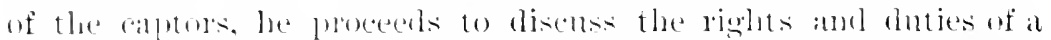

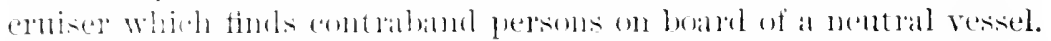

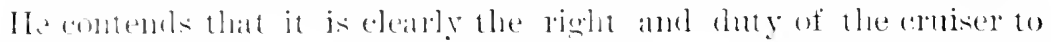

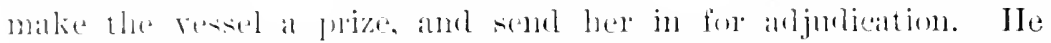

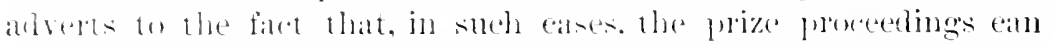

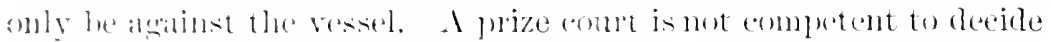

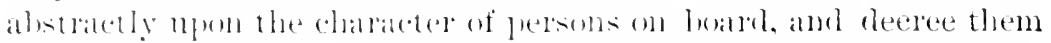
in be either prize or prisoners of war. Itsomly function is to pro-

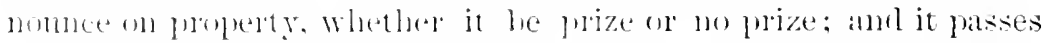

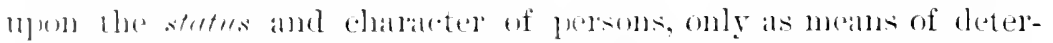

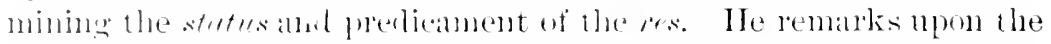

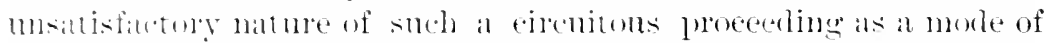
determining the chatrater and fate of persons, wwing to the lialiblity

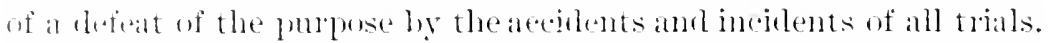
The vesise maty le restored or eombemmed on gromes independent of the rhatuleter of the persons in question. The prize comt has no purer directly to eontrol the persons fomm on board, after their

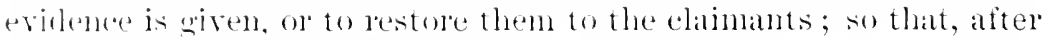
all, the question must be left an diplomiley.

still, lopemsideres that this frocess thongh mustisfactory, is all

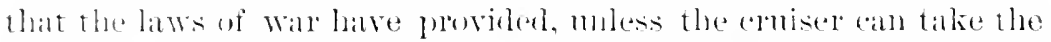

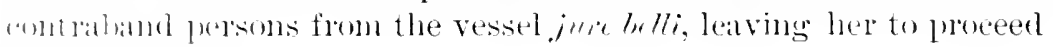
(i) her hereste.

As to subly a right, he says that the Enited states have always

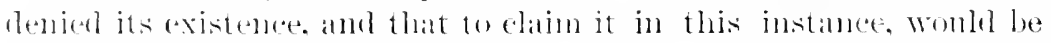

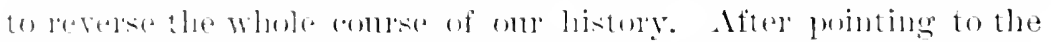
wils that might follow the exereise of the right, he sigs, "I think

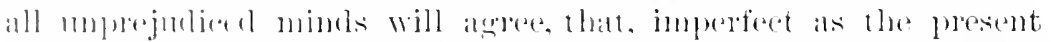

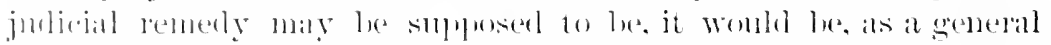

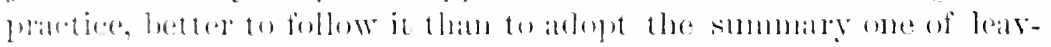

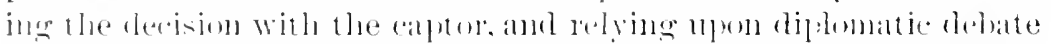

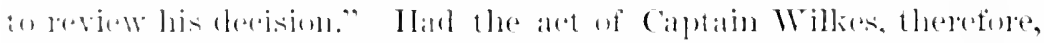

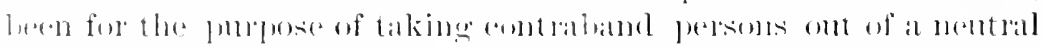

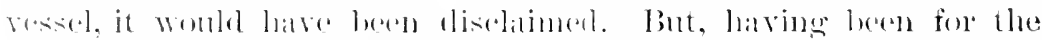

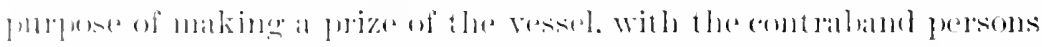

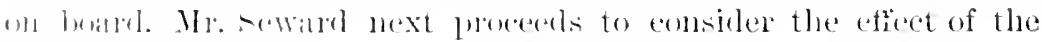

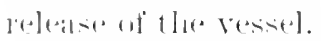

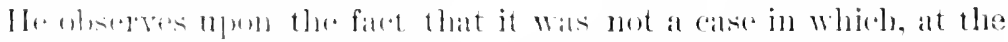

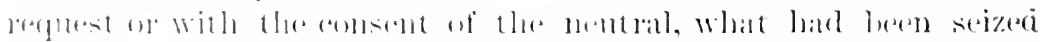

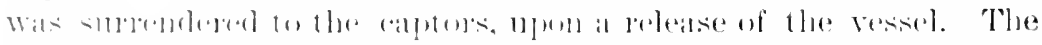

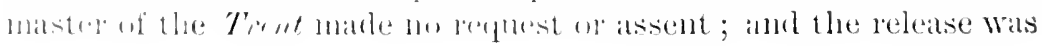


the act of Captain Wilkes solely. Mr. Fewarl then refers to the exceptions to the rule that the capter must send in his lorize fol arljuliention, and finds them all to he eases of substantial nedesity, exensing the performance of what is also a doty. He then examines the statements of Caphain Willes as to the motires which immourd him to release the vessel, and fimls that lue was govomol matuly by a desire to relieve the large number of pastengers, and an murilling-

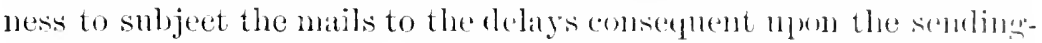
in of the vessel; although it also alperterl that the want of forre to bring in both vessels, conveniently and safely, operated sommolat upon his mind. Mr. Seward comelndes that, while the comity of Captain Wilkes, and his willingness to relinguish for himself and his crew their large possible interest as captors, ale to be alplanded, he did in fact, withont being awate of it, take a step which malde the detention and bringing in of Mason and sliclell mujustifialbe, under those rules of war for which the Lnited states have argued, negotiated, and fought.

Mr. Seward comchnes by declaring that the persons in question, held as prisoners of war, would be liberated.

by an aramgement between Mr. Seward and Lord Lyons, they were placed on board an English war vessel, which took them to st. Thomas, the port of destination of the Trent; thus placing things, as far as possible, in stotu quo rute.

Earl Russell, in his letter to Jord Lyons, of Jan. 23, 186.2, periews the letter of $\mathrm{Mr}$. Seward on the point of the comtraband chatrater of Messrs. Mason and slidell, and comes to a different result. Is the affin was now settled, this letter was for the purpose of prohming an inference, in case of silence, that lie agreed to Mr. Sewarl's jusi. tion. Ile places his argument on two gromels, - first, that the office and character of the persons detained were not sneh as to malke them eontraband; and secomel, that, if contraband in the abstract, they were not, on boand the Trent, contraband in such a sinse as to involve her in any penalties, since her passage was between neutral ports.

On the first point, Earl Russell contends that Messis. Misum and Slidell have the protection which is accorded to diphomatio acents, by the recisions of sir Wilian treott. IIe argues that this protention camot be eonfined to persons who have been alrealy radobral ats diplomatic agents, or persons sent from regularly reeognized sovereignties. The nations of Enrope having reeognizer the conferlerate Govermment as belligerent, and their subjects lorving many indurtant rights of person or property muder the control of that dr fircto govermment, and the recognition of belligerency carrying with it 


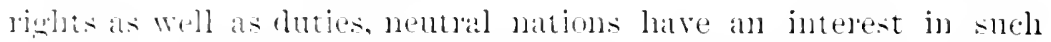
impertect diplomatic lelations as they may matutan with commis-

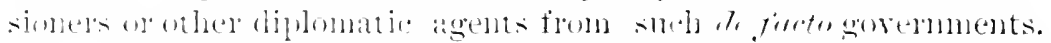

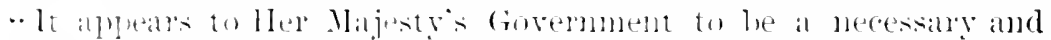
certain derluetion from these principles, that the converance of publie anents of this charatere on their way to direat britain and

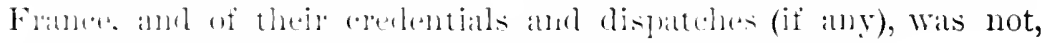
and collel not be: a violation of the duties of neutrality."

PETTHON 41;._BLUkiLE.

\section{TIIE “ NETTEXES."}

IIgh Colnt of Ammintr, 1799.

( 2 C. Fobinson. 110.)

Bhockade by notice. and blockade de focto. When is notice required?

This wats a catse of a ressel sailing on a royage from Dantzick to

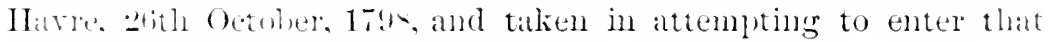
lust on exith November.

Jutrinent._-ije Wr. Sortt:-

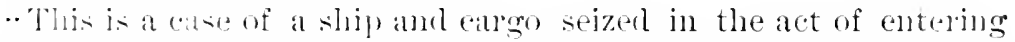
the lunt of latre in fursuance of the orjunal intention males which

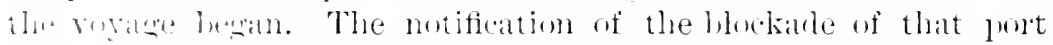

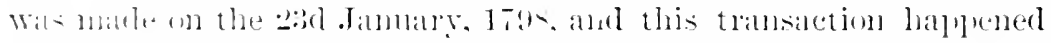

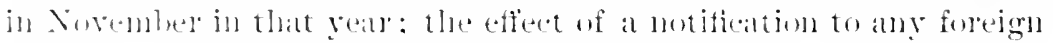

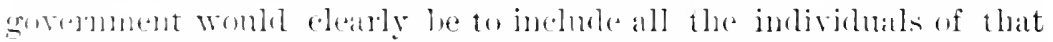
nation: it would be the mow mongtory thing in the world, if indi-

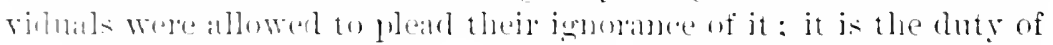

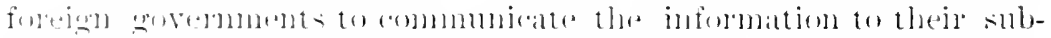

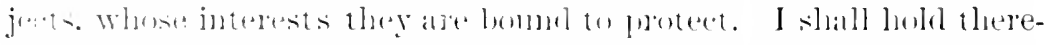

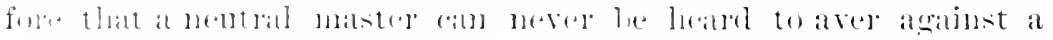

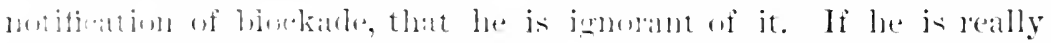

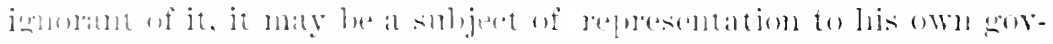

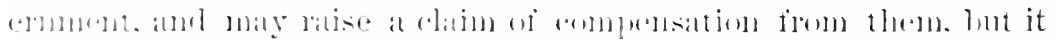

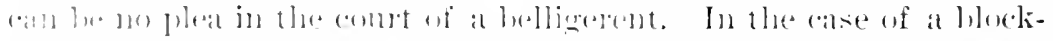

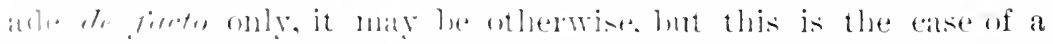

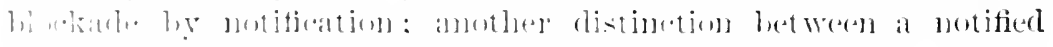

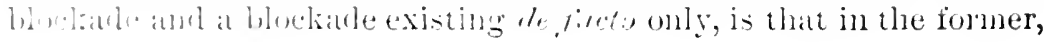




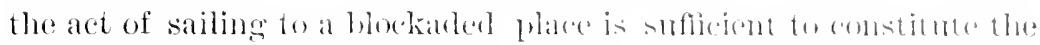
offence. It is to he plestumed that the motitiontion will he formally

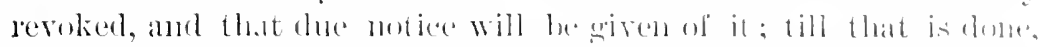

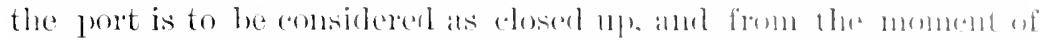
quitting port to sail on such a destination, the oflence of vinhatiun

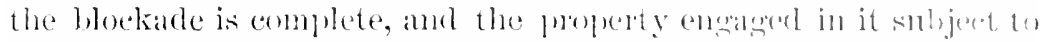

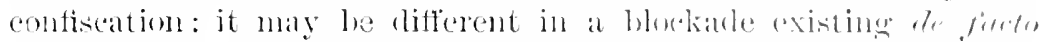
only ; there no posmmption arises as to the emolimblume and the ignorance of the party may be admitted as an (xemse, for salling an a dombtful and provisional destimation. lint this is a casc of a ressel from Dantzick after the notification, and the master anmot be heard to aver his ignorance of it. The sails:-till the monnent of meeting Admiral Inucan's fleet, I should have no hesitation in satying, that, if he had been taken, he would have luen taken in drifin, and have subjected his ressel to confiseation: lut he ments Ambinal Duncin's fleet, and is examined, and liberated by the whtain of am English frigate belonging to that fleet, who told him that he might proceed on his destination, and who, on being askerl, Whother

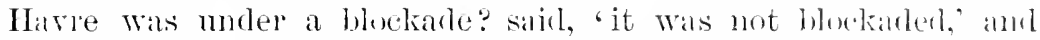
wished him a good voyage. The question is, In what light he is to be considered after receiving this information? 'That it was bome fide given camnot be rombted, as they would otherwise have sizet the vessel ; the fleet must have been ignolant of the fact ; and I lave to lament that they were so: Whrn a blockale is latd on, it ought by some kind of communication to be mante known not only to toreign govermments, hut to the King's sulijects, and particularly to the King's cruisers: not only to hose stationed at the blockaded ports, but to others, and expecially comsiderable fleets, that are stationed in itinere, fo such a port from the difienent tranling comntries that maly be supposed to have an interendse with it.

"Perhaps it wonld have been safer" in the English captain to have answered, that he eomkl not say anything of the simation at IIaver but the fact is (and it has not been contradicterl), that the IBritish

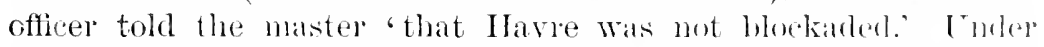
these circumstances, I think that after this informallim ho is ant

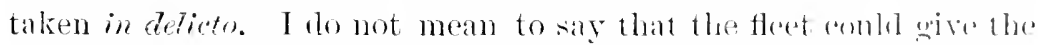
man any authority to go to a blockarlerl port ; it is not sel 110 as an anthority, but as intelligence affording a reasonalle gromme of helief; as it condel not he supposer, that such a fieet as that was, womld be innorant of the fact.

" From that time I consider that a state of immoence commeners: the man was not only in ignomance, but hal reerivel positive information that Harre was not blockaded. Louder these circumstances, 
I think it would be a little too luad to press the former offence

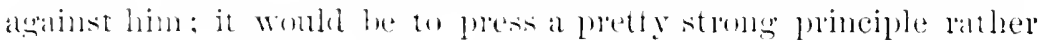

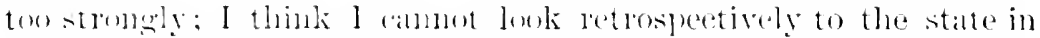

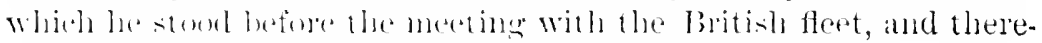
fore I shatl direct this ressel med entyo to be restored."

\section{TIHE "BETST."}

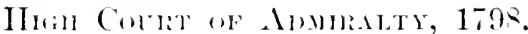

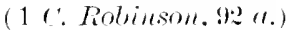

A declaration of hlockade by a commander. without an actual investment, will nul comstitute a bleckatle.

What constitutes a loreach of hockinde:

Extratet from julgument._- ir Wr. Seot :-

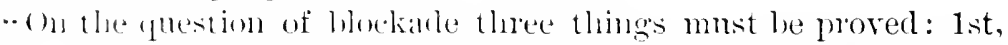
the existence of an actual blockade; 2 llỵ, the knowleche of the fan? : ami, 3lly, some act of violation, either by going in, or by combung ont with a cargo laten after the commenement of hlockide. The time of shipment wonlel on this last peint be very material, for ablumgh it might be lard to refuse a neutral biberty to retire with

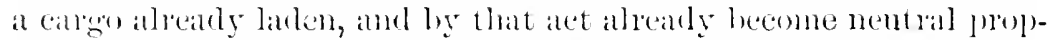

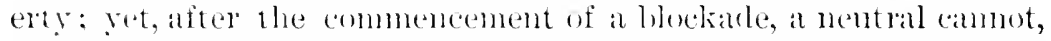

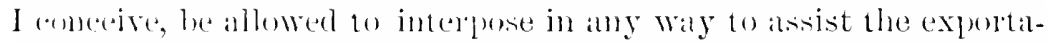

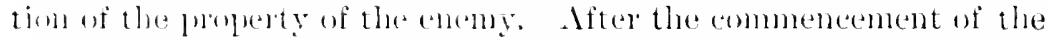
blocliale, a neutral is no longere at liberty to make any porchase in thist purt.

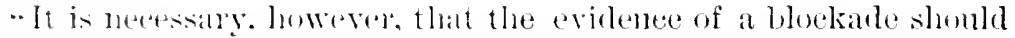

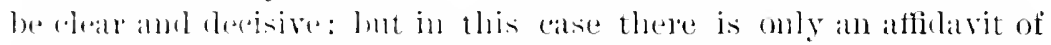
ome of the captoms, and the arenemt which is there griven is, "that on the arrival of the British forese in the West Juclies, a prochanation,

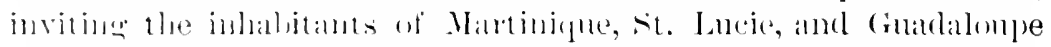

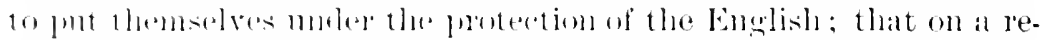

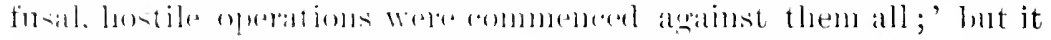

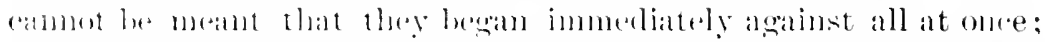

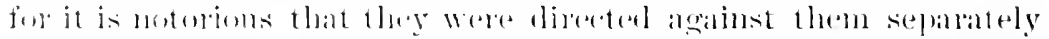

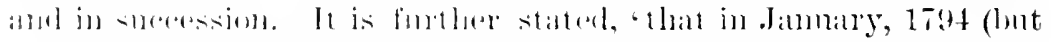

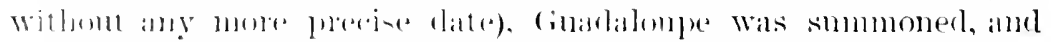

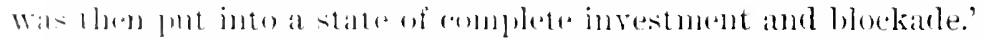

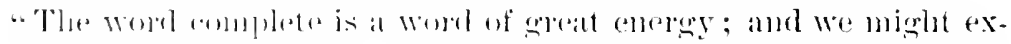
peet from it 10 find, that a momber of vessels were stationed rouml 


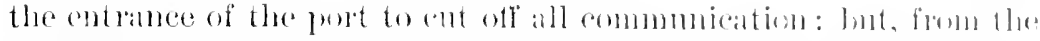

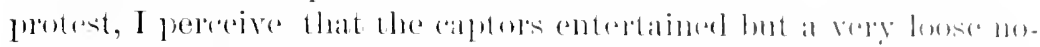

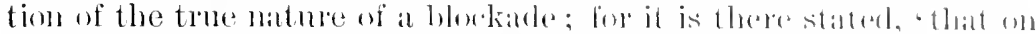

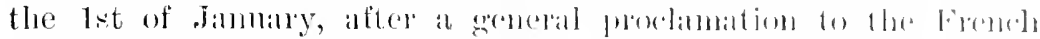

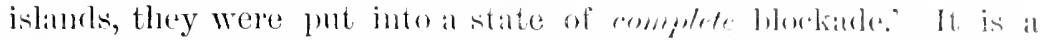
term, therefore, which was applied to all those islands alt the same time, moler the first proclamation.

"The Lolds of Apleal bave detemined Hat such a froclanmation Was not in itself suffeient to eonstitute a logill blockanle: it is aldall, indeerl, that it eould not in reason be sufficient to produce Hore afleet,

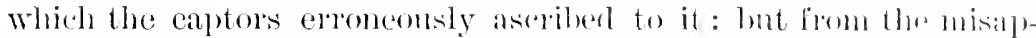
plieation of these phrases in one instance, I learle, that wo must not give too much weight to the nse of them on this oceasion; and, from the generality of these expressions, I think, we must infer, that there was not that actual blockate which the law is now distinctly understood to require.

"But it is attempterl to raise other inferences on this point, from the mammer in which the master speaks of the difhoulty and damger of entering; and from the declanation of the mmicipality of (inatalompe, which states 'the island to have been in a state of sidese.' It is erirlent the American master spealis only of the diffienlty of aroirling the English eruisers generally in those seas; and as to the other phrase, it is a term of the new jargon of France, which is sometimes applied to domestic distubances; and certainly is not so intelligible as to justify me in conchuding, that the island was in a state of investment, from a foreign enemy, which we repuire to comstitute blockade: I camnot, therefore, lay it down, that a blockarle dir rexist, till the operations of the forees were actually directerl against cinadialoupe in April.

"It would be necessary for me, however, to go much farther, and to say that I am satistied also that the parties had knowledge of it: but this is expressly denied by the master. Ile went in withont obstruction. Mr. Incledon's statement of his belief of the notoriety of the blockarle is not such evidence as will alone be sufficient to comvince me of it. With respect to the shipment of the cargo, it dress not appear exactly moler what circumstaness or what time it was taken in: I shall therefore dismiss this part of the oase. * * * 


\title{
TIIE *X.INCY."
}

Privi (insile, 1-19?.

\author{
(1 Acton. is.)
}

It the blockaling flet i= temporarily abetent from the port blockaded. in order to axcomplish ether objects. no penalty attaches to a ship which enters and leates the port during such absence.

This was a calse of seremal appeals from Tiee-Almiralty Courts in Amerien and the West Indies combemming the ships and cargoes for a frealeh ut the blockade of the island of Mantinique, in the gear $1-114$.

A ship. belonging to American citizens, saled from New Tork for st. l'iene. in Maltinique, mbess the simeshomld be blockaded. If

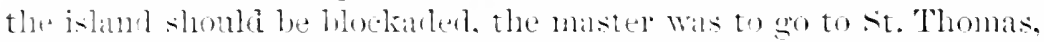
whence he was to return to Sew York with a cargo purchased with the proceeds of the mitward carroo.

Arriring ofi Martinique the 20 h of March, and finding no ship there, and not heing given to molerstand that there existed any bochate at that time, he. in conseguence of the ressel's having slmmog a leak, repaired to the port of Trinity in that island, to retit; fron whence he sabled to st. I'ierre arriving the sil of April.

While in the istand he heard of no hockate, and no ressel of war

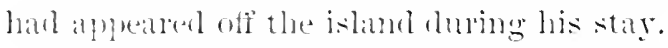

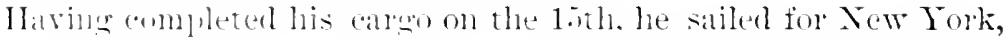
and was calpured and carried into Ilalifax. in Nova scotia, where the vessel and cantor were condenumed as plize.

This statement was supported hy the evilence of a passenger on

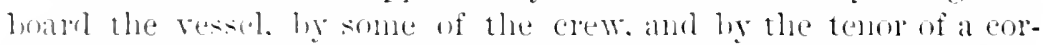

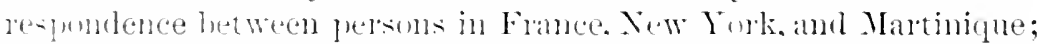
whinh provent that the Huckade was at that lime removed, or left so

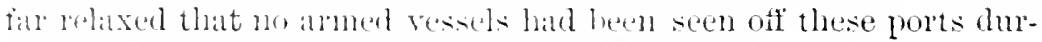
ing the period the vessel remained in the istanci.

Fin the captors it was contended that, although the blockating

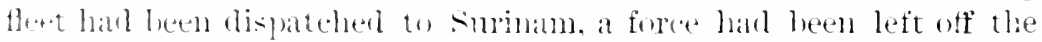
isknd to eontinne the hlorkarle and alphise vessels of its existence. This alpeared, eren by the condespondence exhibited by the claimants, one of the letters alunting that a briti-h fifty-gmu ship contimued off the island, and was now and then seen by the inhabitants. 
Jurginent:-

The comet held that, to constitute a hookade, hlo intention to shot

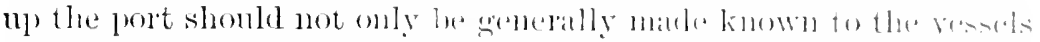

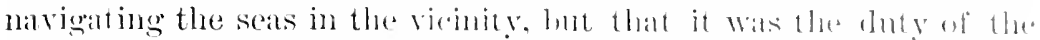

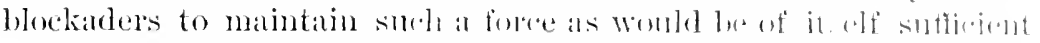

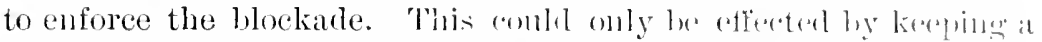
number of vessels on the different stations, so rommmnicatime with each other as to be able to interepet all vesicls attempting to miter. the ports of the island. In the present instance no smoh mestsmes had been resorted to, and this neglect necessarily led nentral vessels to believe these ports might be entered withont any risk. Thr periodical appearance of a vessel of war in the offug eonld not lit supposed a continnation of a blockade, which the eorrespondence mentioned had described to have been previonsly mantained ly a number of vessels; and with such cinparalleled ligor, that mo resiel whatever had been able to enter the island during its continuance. Their Lordships were therefore pleased to order that the ship shom be restored, the proot of property being sufficient, hnt direeter further pronf as to the cargo climimed for the American citizens mentioned.

\section{THE "OCE.IN."}

High Colrt a Mminaty, 1801.

(3) C. Prbinson, 29\%.)

Merchandise going by land or inland navigation from a blockarled port, and shipper from a port not blockaded, is not subject to confiscation for breach of blockarle.

This was a question arising on the blockarle of Amsterkan, respecting a cargo shipped for America at Rotterdam. It appeared that the persons ordering the shipment Larl ordered it of their agents at Ansterdam, as a shipment to be made there, sulseducut to the date of the blockade of that place, but previons to the blockade of the ports of Holland. It was argned that in the intention of the claimants it was to be an exportation actually firom Ansterciam, and that in effect the trade was the same, as the goods were ordered and purchased at Amsterdam, and were to be considered as part of the commerce of that place.

Judgment,-Sir W. ScotT:-

"I am inclined to consider this matter farombuly, as an exportation from Rotterdam only, the place in which the cirrgo hecomes 
first connected will the ship. In what comse it had travelled lefore that time, whether from Amsterelan at all, and if flom Ame

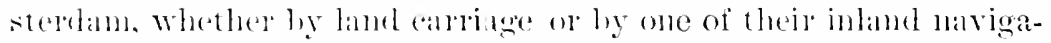

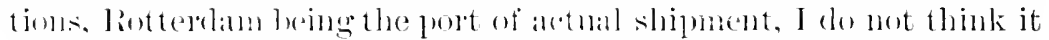

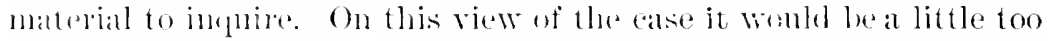
rigorols to saly, that an order for a shipment to be mare at Amster-

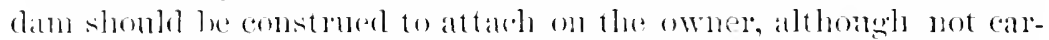

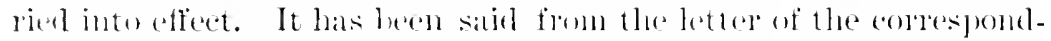
ent all Amstertam, that the anduts there hate informol their

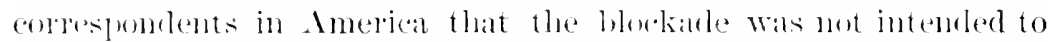
prevent axportion: The representation of the enemy shipper (ould unt lave avaled to exonerate the nentral merchants, if of herwise liable. Were this to be allowerl, it would be in the power of the emony to put an end to the blockate as soon as he pleased. If the general law is, that egross as well as ingress is prohilited by blekide. the nentral merchant is bound to know it; and if he entertains any doult, he must sat isfy himself hy aply lying to the comtry impsing the blockade, and not to the paty who lats an interest in breaking it.

- It haplens in this case, that the intended exportation did not take place. The only criminal act, if any, must lave been the eonreyalde from Amsterdam to liotterdam. It wombl be a litile too much to say, that hy that previous act the gools shiples at liotterdatm atre affecterl. The legal conserpenees of a blockinle must depenel on the means of blockate; ant on the actual or possible appli"at jom of the blockalling force. On the land sirle Amsterdam neither was nom andel be atrected by a blockading naval force. It conlel be

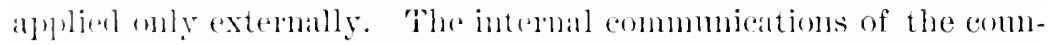
try were ont of its leach, and in no wily sulject to its operation. If the expmetation of goods fom lioteroum was at this time permitterl, it comlel in 10 dengee be vitiated hy a previons inland transmission of them from the city of Amstertam. Restored." 1

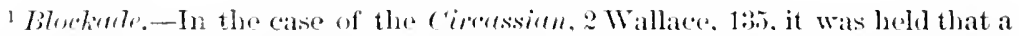

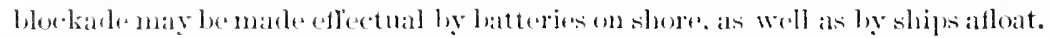

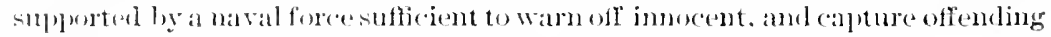

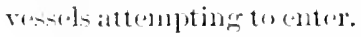

That at blockarle regularly notified to neutral govermments most, in the alsence of rhar prof of a cliscontinuance of $\mathrm{jt}$. be presumed to continue until notification ie given by the blockading govermment of such discontinuance.

That a vesel saling from a neut ral port with intent to violate a blockade is liab. to capture and condennation as prize from the time of sailing. See also the derision of sir WILlasi Scott in the case of the Columbia, $1 \mathrm{C}$. Rols. 15t.

In the Irize rases. 2 Dlack. 635) (sume, 588$)$, it was held, that it in a setted rule that a ressel in a bleckaded port is presumed to have notice of a blockade as 


\section{TIIE "IIELEX."}

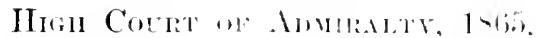

$$
\text { (L. R. 1.11. and I:H. 1.) }
$$

A breach of blockade is not an oritne arainst the laws of the conntry of the neutral owner or master. The only penalty for engaring in such thath is the liability to capture and condemnation by the belligerent.

In this ease, the master sued for wages npon an agroement roltered into between himself and the defendants, the ownels of the H.l.1.

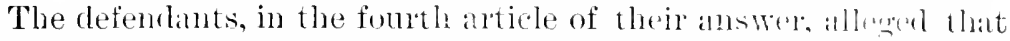
"the agreement was made and entered into for the pmlnes: of lumning the blockide of the somtlern ports of the Thiterl siates of America, or one of them, and was and is contlary to law, and camnot be recognized or enforced by this Honomahle comt."

Judgunent, by Dr. Lusmintitux:-

"This is a motion by the plinintiff to reject the fompth article of the defendant's answer. The parties in this anse ale folnu Andrews Wardell, formerly the master of the Ihe len, platintiff, and the Nlinom Trading Company, the owmers of the ship, defendants. The mastel' sues for wages (with certain preminms adred), alleged to hare been earned between July, 186t, anl Mareh, 1si;. The answer shates that accorling to the agreement as set forth by the defendints, the plaintiff has been paid all that was due to him. This part of the

soon as it commences. See also the rour. Judith. 1 ( . Roh.. 150). In this case a de facto blockade nay be broken withnt notice, by egresis. But persons entering a place under de facto blockate are entitled to waning.

The French rule in respect of a violation of blockade differs essentially from that of the United States and Enchlond. Notwithstanding that a loluckitle has been publicly proclaimed, a ship sailing for a bleckated port is entithel to a warning, entered upon her papers, and is only liable to seizure and combemmition when she subseraently attempts to enter or leave a bleckacled prit. Sies the cases of La Louise, Pistoye et Durerty. I. .382: and the Elise comish. it. . . B. .

As to the blockades established ly the ". orders in conncil." during the witrs with Napoleon I.. see Edwards" Admiralty Reports, 381-116. ant the alpentix: to

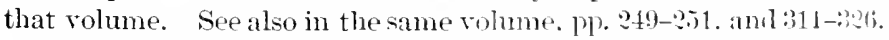

For other cases on the subject of blockade. see the Buigury.? Wall. fit: the

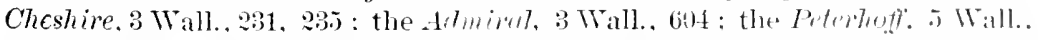

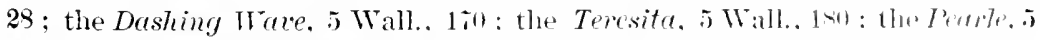
Wall.. 5it ; the Wren, 6 Wall., 58.2: the Franciska, spinks, 111, and 10 Moore. P' C. C., 37 : the Henrich and Maria, 1 C. Rob., 146. 
answer is not oljedeted to. The fourth ane last article is the one

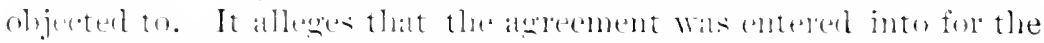

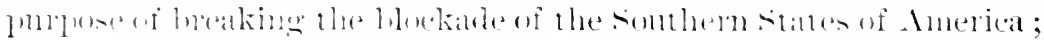

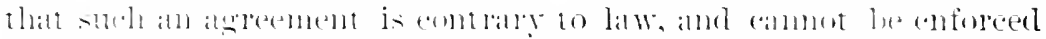

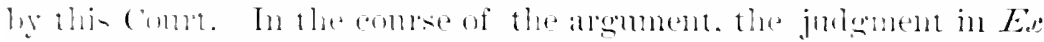

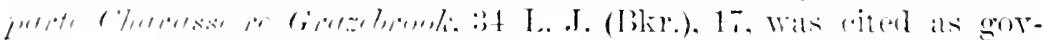

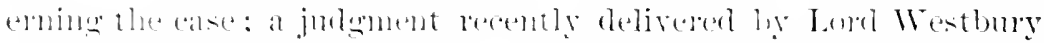

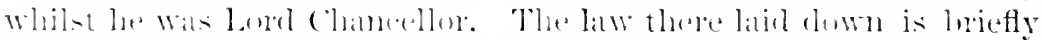

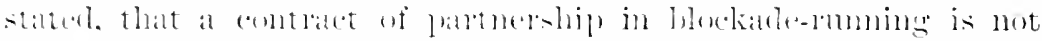

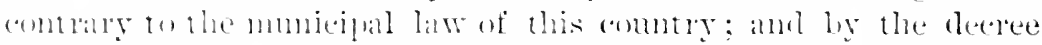

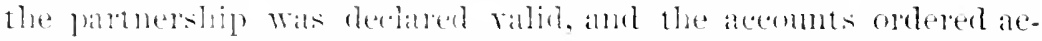

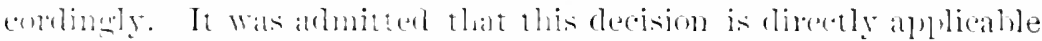

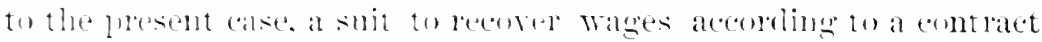

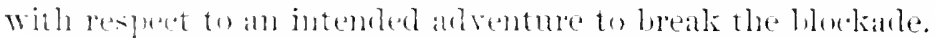

"That a decison of the Lom Chancellor is to be treated hy this comt with the greatest respect there can be no doubt, but is it absolutely limeling:

"There ane thee tribmals whose decisions are ahonlutely binding

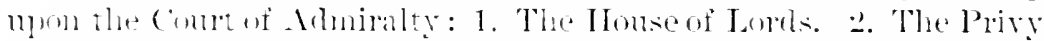
(ommeil. :). 'Tle (inntr of Common Law when deciling upon the anstruction of a statute. If a decisom of any of these tribmals is eited, all that the compt of Ammiraly can do is to impuire if the decising is appliable to the case. If so, then it is the duty of the Come to obey, whatevel may le itsown judgment.

" No other decisions are I heliere, ahsolutely himbing on the Court.

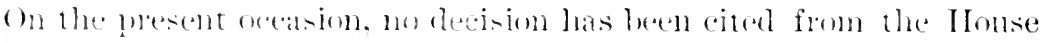

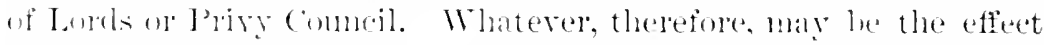
of the deroings of other tribmals, I am not relieved from the duty

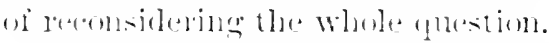

- An intination hats heon given that this ease will be carried to

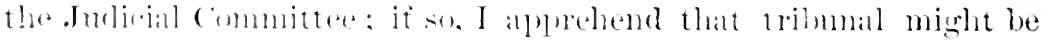
inclimer to remsider me remist in my duty if I land omitted to form

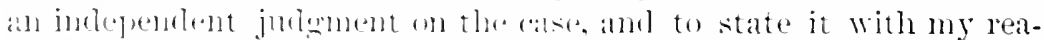

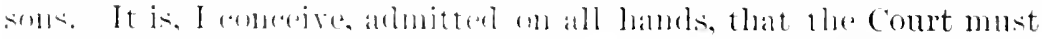

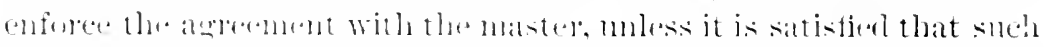

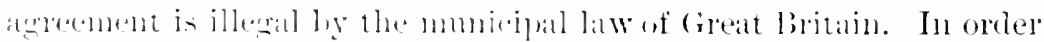

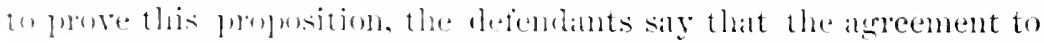

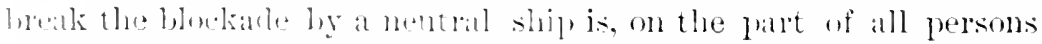

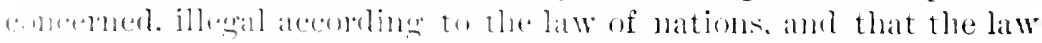
of uations is a lant of the mmicipat law of the land-erge, this contratet wats illegral hy mmikipal latm.

"Now at gomb deal may houmen on the sense in which the word 'illegill' is used. I an strongly inclined to think that the defend. 


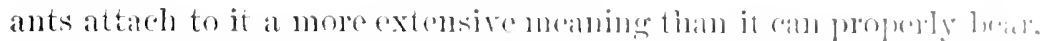

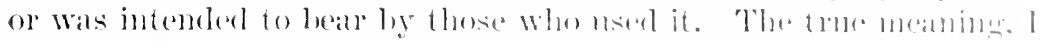

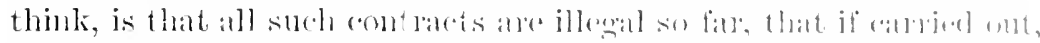

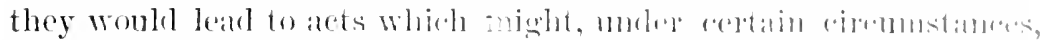

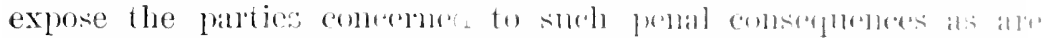

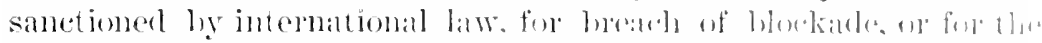

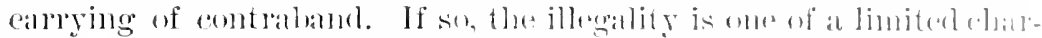

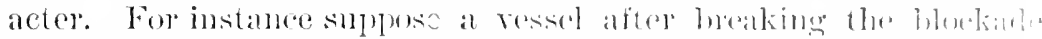

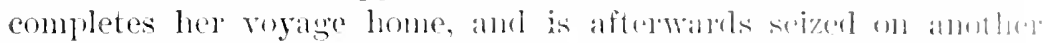
voyage, the original taint of illewality-whatever it may hate lxest -

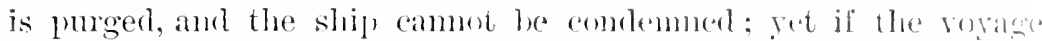
was, ab intio, wholly and absoluteiy illexal, both ly the latw of nations and the municipal haw, why shomld its sncopsinl truminat tion pulge the offence? Let me comsider the relatire simation of the parties. A neutral eomntry has a right to tracle with all other countries in time of peace. One of these comntries lecomes a bellinerent, and is hockarled. Why shomle the right of the nentral he affected by the acts of the other belligerent: The answor of tho blockadiug power is: "Mine is a just and neressilly wall, al mallup which, in ordinary eases, the nentral cannot question, "I must soize contraband, I must enforce hlockarle, to an'ly on the war". In this state of things there has been a longand arbutter wage on the fart of all civilized states-a concession ly loth partios, the bellisenent and the nentral-a miversal nsage which constitntes the lat or nations. It is only with reference to this nsage that the bellierenent can interfere with the nentral. Snppose no guestion of borkide of

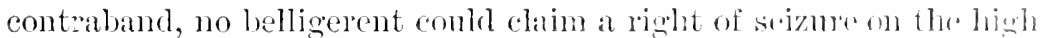
seas of a nentral resiol going to the pult of another luelligerent, however essential to his interest it might le so to rlo.

"What is the usage as to bluckarle? There are several comdition to be observed in order to justify the seizme of a ship for hreath of blockade. The blockade must he effectual and (save aroildutal interruption by weather) eonstantly enforecl. The neutral resicu must be taken in delicto. The hlorkarle must be enforrerl acminct all nations alike, including the belligerent one. When all the neres. sary conditions are satisfied, then, hy the nsige of nations. the 1,$]_{-}$ ligerent is allowed to capture aud comblemu noutral ressh withm:

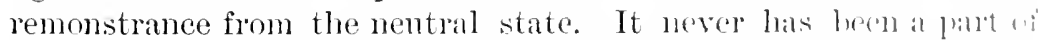
admitted common usage that such voyages should be deemorl illewish by the neutral state, still less that the nentral state slomll le lommi to prevent them; the belligerent has not a shadow of right to roduire more than universal usage has given lim, and has no pretence to say to the neutral: "You shall help me to enforce my belligerant 
right hy coutaling your own freefom of commeree, and making that

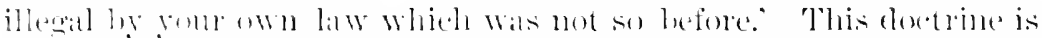

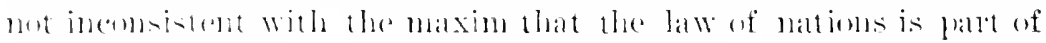
the law of the lamb. The fate is, the law of mations has never

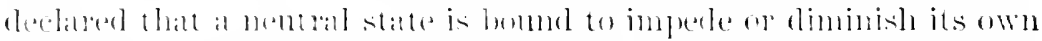

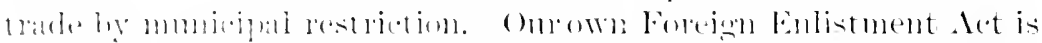

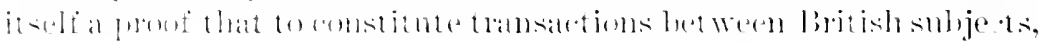

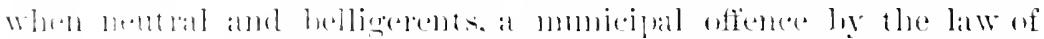

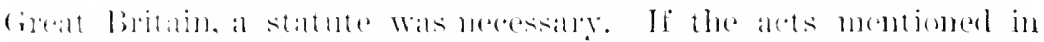

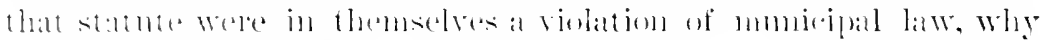

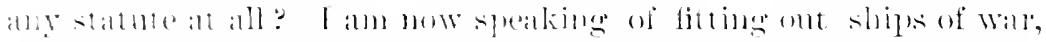

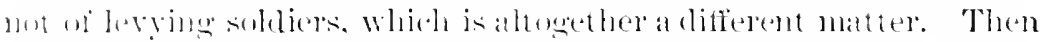

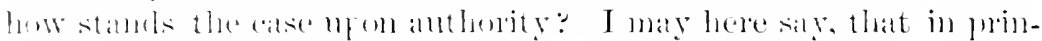

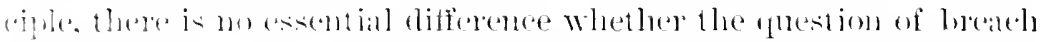

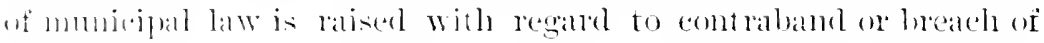
borkarke.

.. Yr. Jner. 'Marine Insmance.' vol. I., lect. VII., is the only textwhter who maintains an minion contraly to what I have stated to

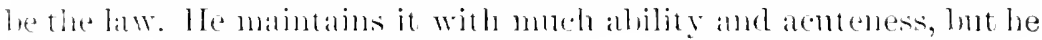

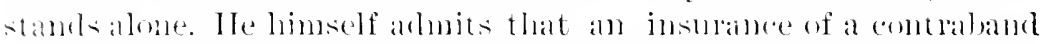

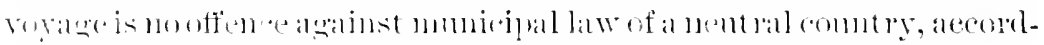

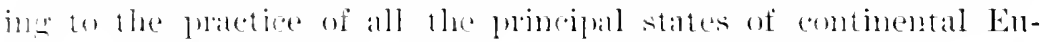

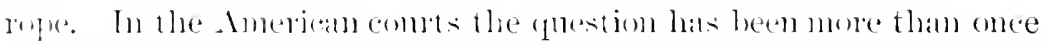

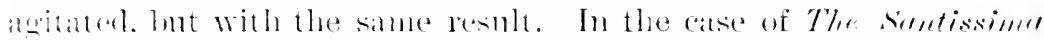

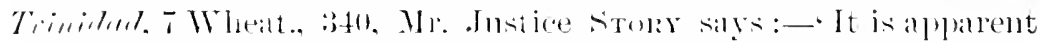

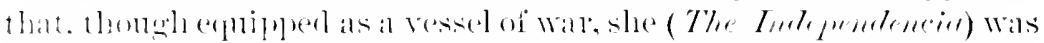

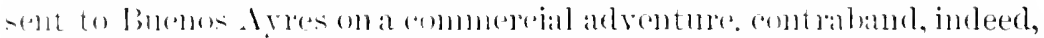

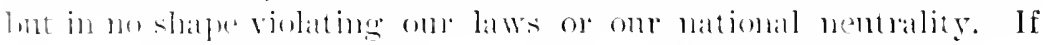

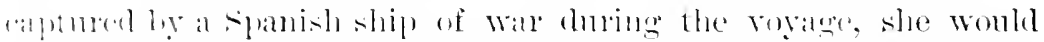

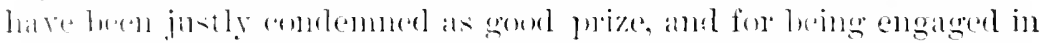

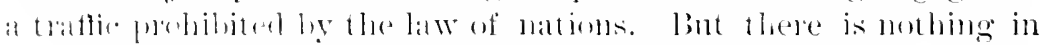

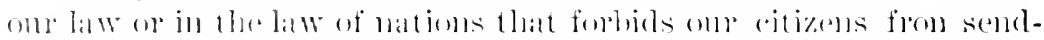

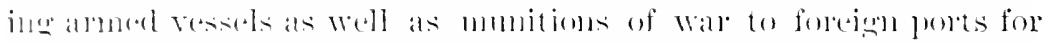

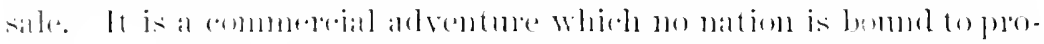

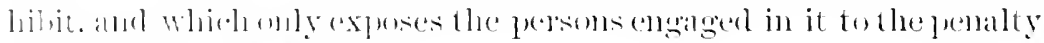
(1)

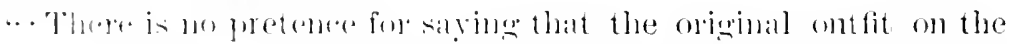

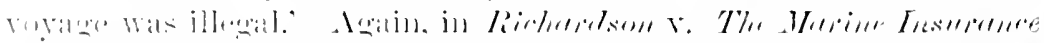

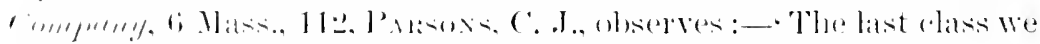

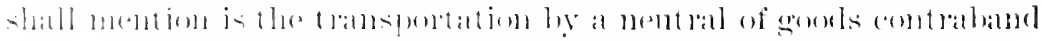

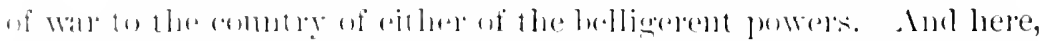

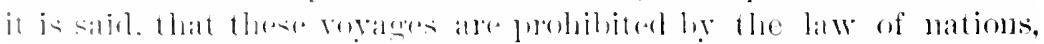

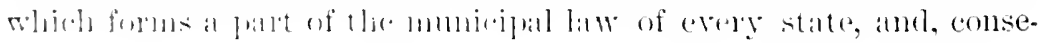




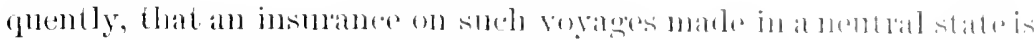

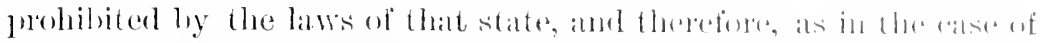

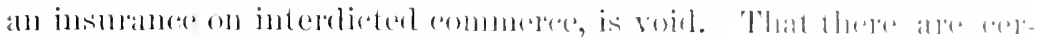

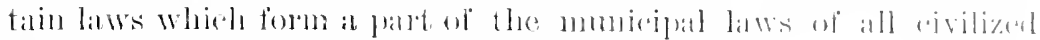

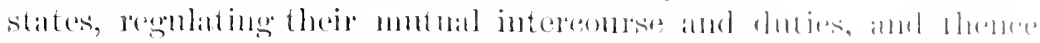

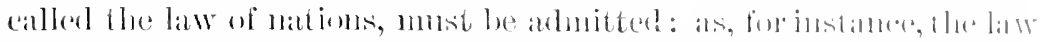

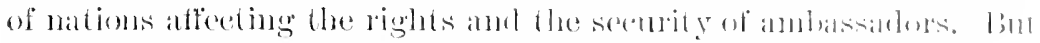

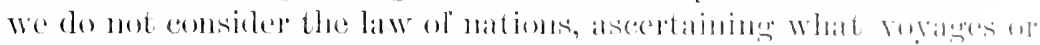

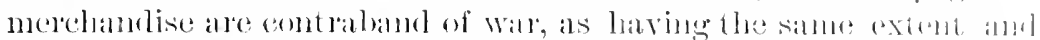
effect. It is arreed by erery civilized state that, if the suldeget of a nental power shall atempt to fumish either of the betligerent sovereigns with goods contraband of war, the other may rightinlly seize and endem them as prize. but wo do not know of any lale established by the law of nations that the nemtal shipper of gands

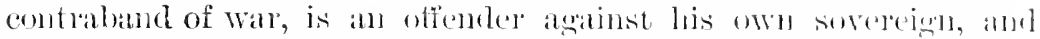

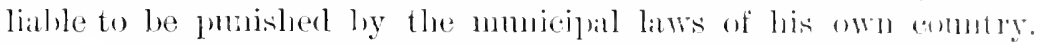
When a nentral sovereign is motified of a derelatation of war, he maly,

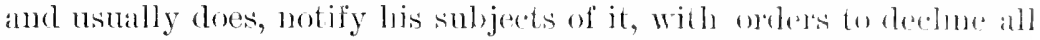
contraband trate with the nations at war, deelaring that, if they and

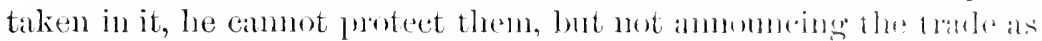

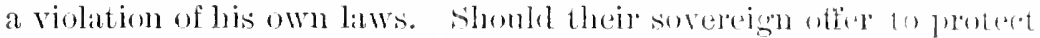
them, his conduet wonld be incompatihle with his mentality. Amb as, on the one hand, le eamot complan of the confiscation of his subjects' goods, so, on the other, the fower at Wall dow mot impmle to hime these practices of his smbjects. A mentral morehom is mot obliged to regard the state of war betwen other nations, hat if he ships goods pohilited jure bolli, they may be rightfully soized and condemned. It is one of the eases where two conflimtim linhtsexist, which either party maty exereise withont eharging the wher with doing wrong. As the transportation is not probibited ly a low lates of the nentral sovereign, his snlijects may lawfully becomermed in it; and, as the right of war lawtully anthorizes a belligerent powed to seize and condem the goods, he maly lawfully do it.' Lastly, in

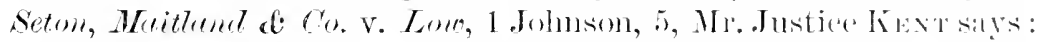

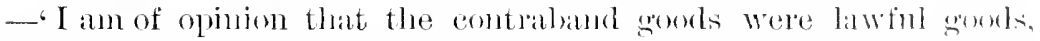
and that whatever is not pohbiter to be exported hy the positive law of the combry is lawful. It may he said that the latw of mations

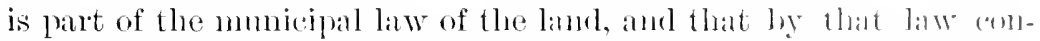
traband trade is prohibited to nentrals, and, conseduently mulanful. This reasoning is not restitnte of forec lont the faret is that the law of nations does not declare-the trate to he malinful. It only anthorizes the seizure of the contraband antiches by the hed ligerent powers.' * * * 
"In the Fugli-h compts the only case in which the momt has been

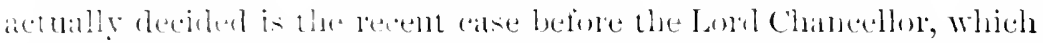

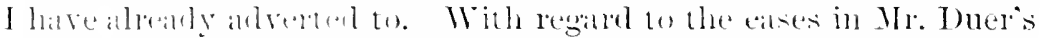

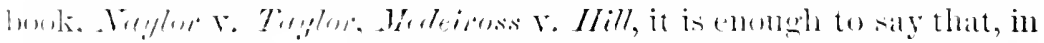
the view which the comt eventully touk of the fitcts, the guestion

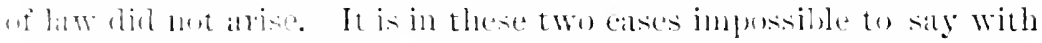

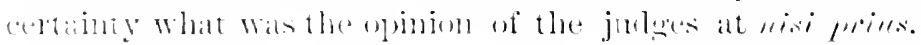

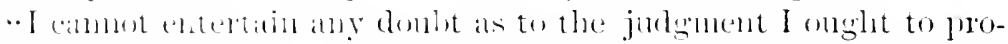

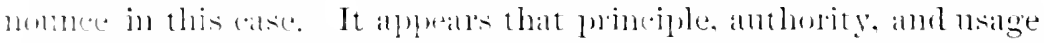

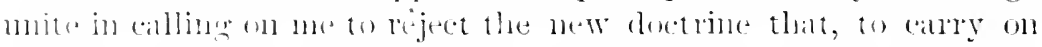

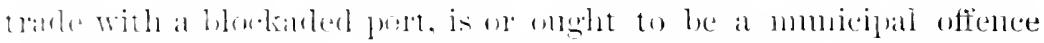
by the law of nations. I must direct the the ant iele of the answel

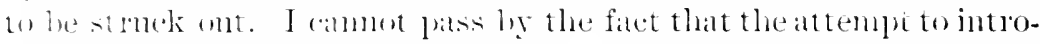

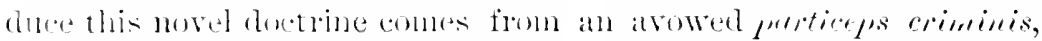
who seeks to benctit himself by it. As he has failed on every aroum, he must pay the cost of his experiment."

SETTUN 47.-Ricle of TIE IVAR of 1756.

\section{TIIE “IMMANLEL."}

\section{Ilom Colst of Ammintr, 1799.}

\section{( $\because$ C. Robinsom, 1s6.)}

Xintrals will not he permitterl to engare in a trade. during a war. from which they were excluded in time of pare. This applies especially to tire colonial trarle.

This was the calse of an asserted IImulurg ship, taken 1 th August, 1799, on a voyage from Hambmrg to st. Iomingo, having in lere vogage tomehed at bourdeatux, where she sold part of the goods

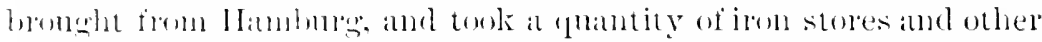

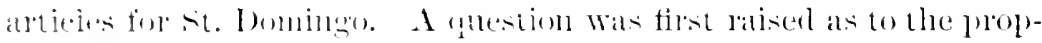

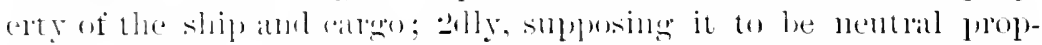

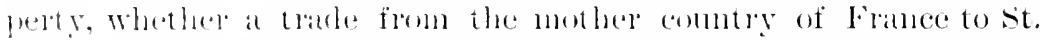

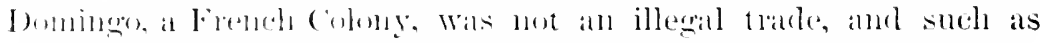

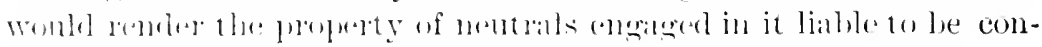
selereel

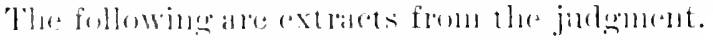

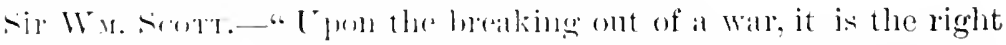

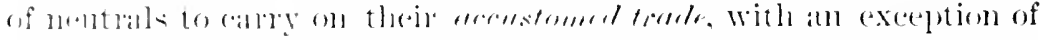

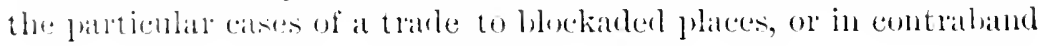


articles (in both which cases theil property is liable to he ommenued),

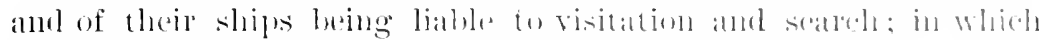

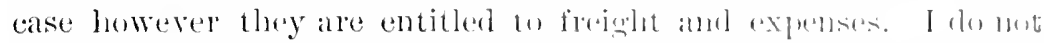

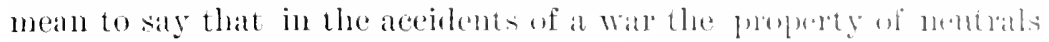

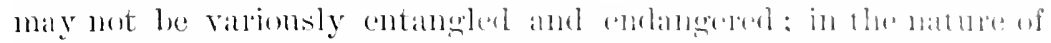

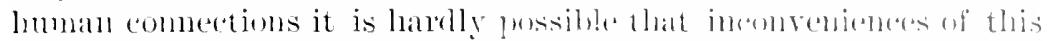

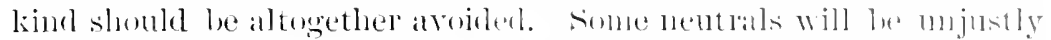
engaged in eovering the gools of the enemy, and uthers will he mu-

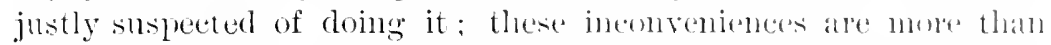
fully balanced by the enlargement of their commores the trate of the belligerents is usmally interrupted in a great degree, and falls in the same degree into the laty of nembals. But withome leference to accidents of the one kind or other, the general rule is, that the neutral has a right to carry on, in time of war, his acenstomed trade to the utmost extent of which that accustomed trade is eapable.

"Very different is the case of a trate which the nentral has never" posisessed, which he holds by no title of nse and halit in tinnes of peace, and which, in fact, ean olntain in war hy no other title, than by the success of the one belligerent andinst the other, and at the expense of that very belligerent moler whose success he sets up his title; and such I take tolse the eolonial trate, generally spealing.

"What is the colonial trade serevolly sperding? It is a trate generally shut up to the exchnive nse of the mother combtry, to which the colony belongs, and this to a clouble use;-that, of silpplying a market for the consmmption of native eommodities, and the other of furnishing to the mother comntry the peculiar commomities of the colonial regions; to these two puposes of the mother enmtry, the general policy respecting colonies belonging to the states of Europe, has restricted them. With respect to other connties, nemerally spealing, the colony has no existence; it is possible that indirectly and remotely such colonies nay atfect the commerce of other countries. ***

"Cpon the interruption of a war, what are the riglits of belligerents and nentrals respectively regarding sule platex? It is an indubitable right of the belligerent to pussess himself of such phare, as of any other possession of his eneny. 'This is his common right,

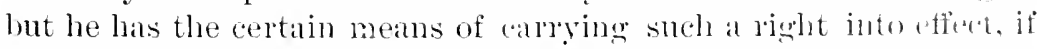
he has a decided superiority at sea: Fuch eolonies arederemblent fur their existence, as colonies, on foreign supplies; if they rammot he supplied and defended they must fiall to the belligerent of anmseand if the belligerent chooses to alply his means to such an oligect, what right has a third party, perfectly nent lal, to step in and provent the execution? No existing interest of his is affected ly it; he can 
have 30 right to apply to his own nse the beneficial comsequences of the mere are of the helligenent ; amb say, "True it is, gom have, by

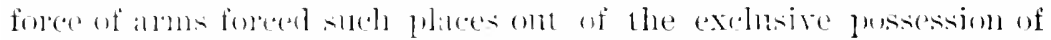

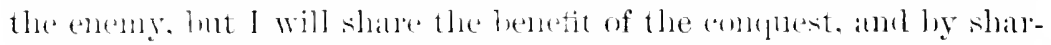

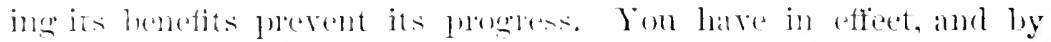
liaful means tomed the enemy ont of the posisesism whith he had

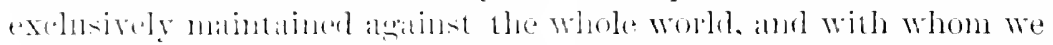

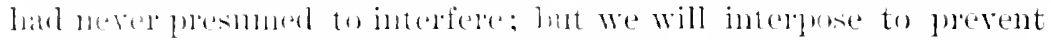

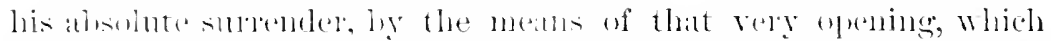

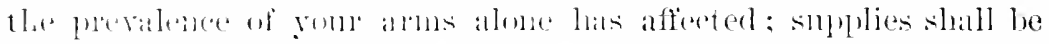

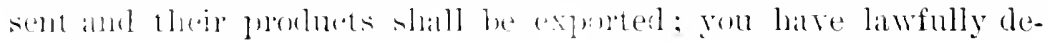

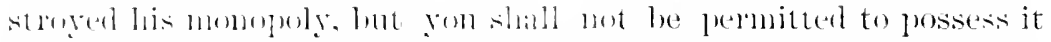
venuself: we insist to slane the fintis of yom victories, and your boul and tratsme have been expended, not for yome om interest, holt for the common benetit of onhers.

- L jon these grmunds, it cammot he contended to be a right of neulabls, do intrule into a commere which had been uniformly shut andint them, and which is mow forcent open merely by the possme of wal : for when the enemy, meler an entire inalility to supply his

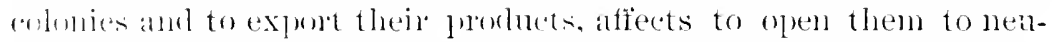
talk. it is not his will lunt his necessity that changes his system ; that

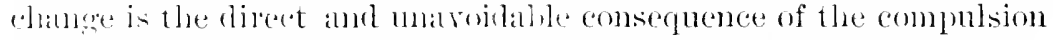
of war. it is a measme not of french comncils, hat of british foree.

- T jon these and other somels, which I shall not at present emumelate, an instruction issuel at an eally period for the purpose

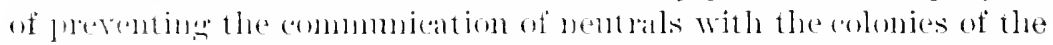

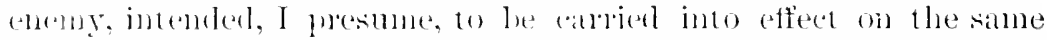

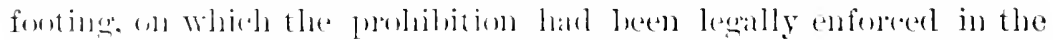

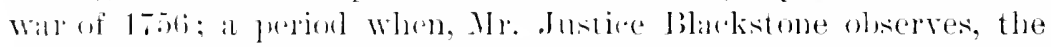

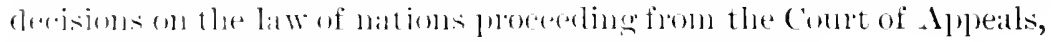
were kisuma and revered by erery state in Europe.

\section{" Condemned."}

\section{THE: "ENINIEL.."}

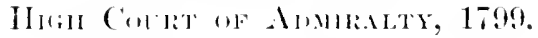

\section{(1 ( Roblinsm, 2!n6.)}

Nontrab not allowral to carry an a trate during war, forbidden to them in tine

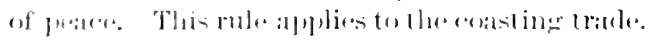

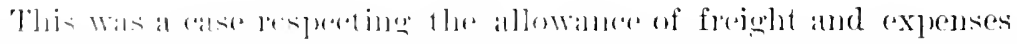

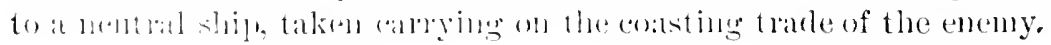




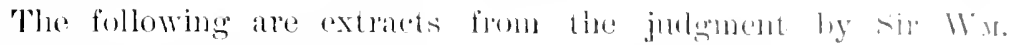
Scome: :-

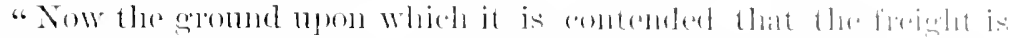

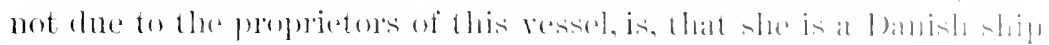

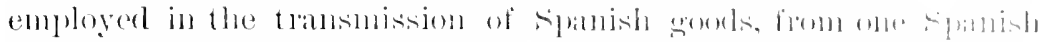

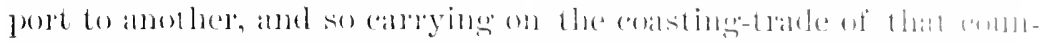

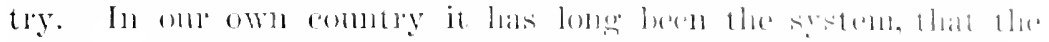

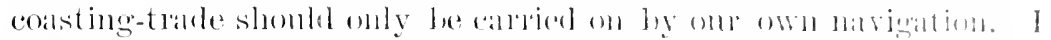
observe, that in all the rage of morel experiment that has distated

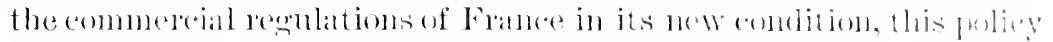

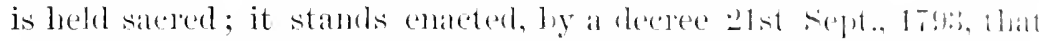

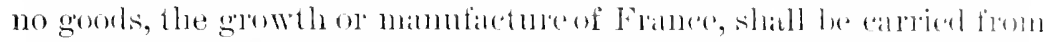

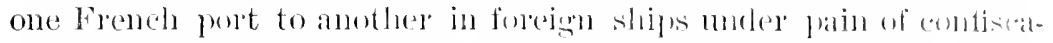
tion.-The same policy has directed the commeredal system of ot luel

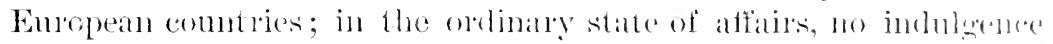
is generally permitted to the ships of most othere cemblries to rally

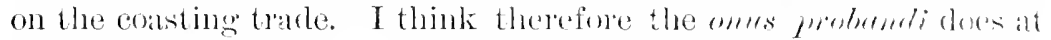
least lie on that side; and always makes it necostaly to he shom

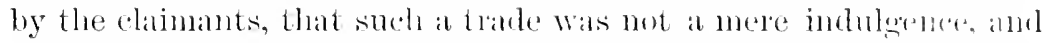
a temporary relaxation of the coasting system of the state in yesetion; lut that it was a eommon and ordinaly trate, open to dhe silips of any comntry whatever. ***

"As to the coasting trarke (supposing it to lo a trade not nsually epened to foreign vessels), can there be deseribed a more whertive accommodation that can be griven to an meny during a wall than he undertake it for him during his own disability?"

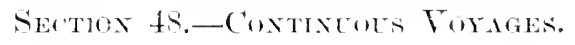

\section{TIIE " WILILA.M."}

Lomds of Apreal ax Prize Cases, 1 kolg.

(5 C., Rolliwsm, 385.)

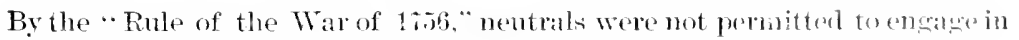
the direct trate between the comemy and his colonies. And the mere toncling at a nentral port to aroid this rule. will not make the vorage laweful.

This was a question on the continuity of a voyage in the cohoubial trate of the enemy, bronght by appreal fom the Vice-Amminally 


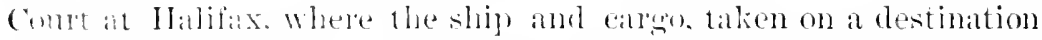

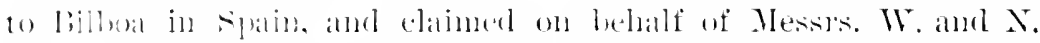

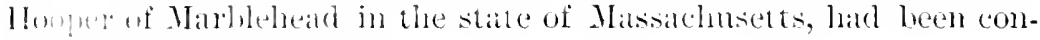
1]+minel 17th July, 1400).

Amomer the palpers was a certificate from the collertor of the cusanm, - that this vesicel had entered and landed a cango of eocoa ledenging to Messis. W. and $\mathrm{X}$. Ilomele and that the duties had

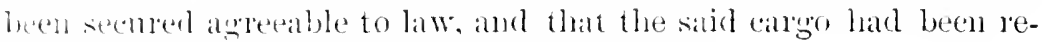
shipgenl on board this vessel bomnd for billoas.

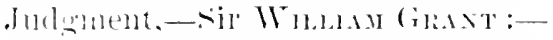

."The prestion in this eatse is, whether that part of the cargo which

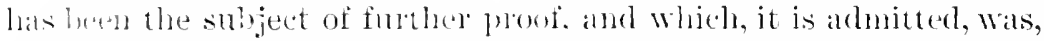
at the tinse of the capture gomg to sprin, is to be comsidered as monime directly from Lagnira within the neaning of his Majesty's insimetions. Aceording to our molerstanding of the law, it is only trun thase instructions that neutrals derive any right of carrying wh With the colonies of our enemies, in time of war, a trade from whin the were excluded in time of peace. The instructions had wh bermited the direct trade between the hostile colony and its mothel country, but had, on the contrary orelered all vessels engaged in it an be brought in for lawful aljudication; and what the present claimants accordingly maintain, is not blat they eould earry the gunluee of Laguiar directly to sian; but that they were not so (anying the callog in question, inasmuch as the voyage in which it War talien was a voyage from Nortl America, and not direetly ibom a alous of silain.

- Wlat then, with reference to this sulject, is to be consiciered as a hibere royage from one place to another? Soborly has ever supposed that a mede deviation from the sibagintest and shortest comrse, in which the voyage could be berformed, womb thange its denomination, and make it cease to be a direct one within the intembnent wi the instructions.

. Xothing ean repend on the degree or the deviation-whether it be of mole or fewer leagnes, whether towarls the coast of Africa, ol tomands that of America. Seither will it be contender that the

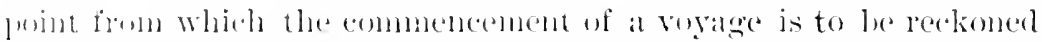

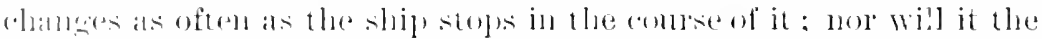

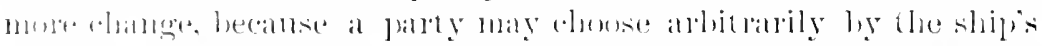

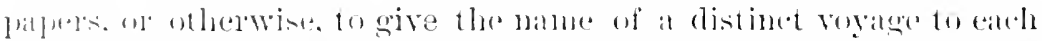

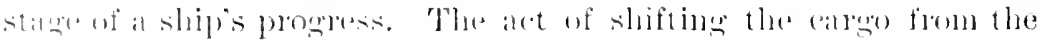

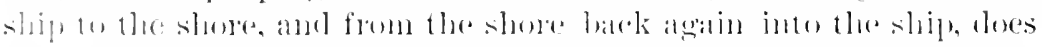

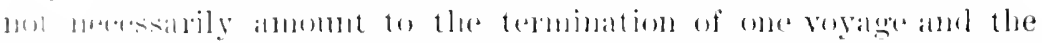

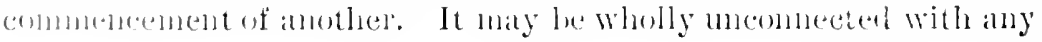




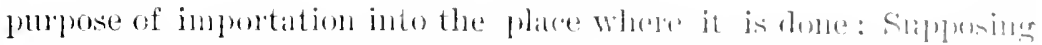

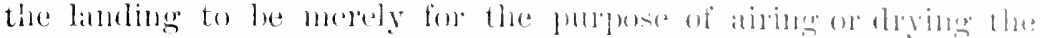

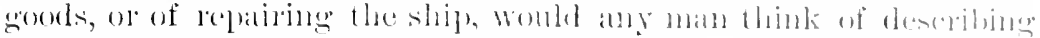

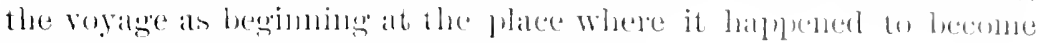
necessary to go thrombly silch a process?

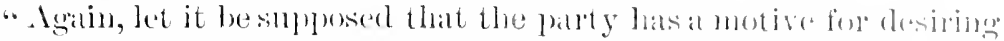
to malie the voyage alpeatr to bogin alt some othere platec thath that

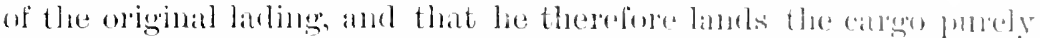
and solely for the purpose of emabling himedi to aflirm, that it Wats

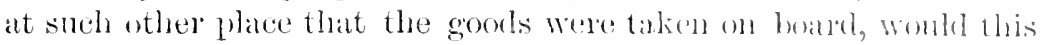
contrivance at all alter the truth of the faret? Wrule] not the real voyage still be from the place of the original shipment, mothith-

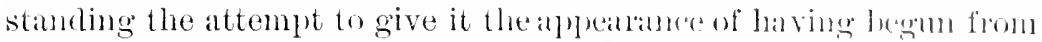
a different place? The truth may not always he discernihle, lut when it is discovered, it is acomeling to the truth and wot anconding to the fiction, that we ane togive to the transaction its chandeter and demomination. If the royage from the plate of lading lee loot leably ended, it matters not hy what acts the party maly have evinced his desire of making it apjear to have been coled. That those als have been attended with trouble and expence cannot alter their quality or their effect. The tromble and rxpence may weigh as cincumstances of evidence, to shew the purlose for which the acts were done; but if the evasive pmrpose be arhitter ar proverl, we an never be found to acept as a sulstitute for the olservance of the law, the means, however operose, which have been employed to onver a lreach of it. Between the actual importation by which a royage is really enderl, and the colomalsle importation which is to grive it the appeanance of being ended, there mont necessanily he a great resemblance. The acts to be done mont he alumost ent irely lle sime; but there is this difference between them. - The landing of the catron, the cutry at the enstom-house, and the payment of such duties as the law of the place requires, are recessory ingredirms in a gemune importation; the true porpose of the omore cambot be eficecter without them. But in a fietitions importation they are meres enlentering ceremonies, which have no natmal emmection whatevor with the purpese of sending on the cargo to another manket, and which, therefore, would never be resorted to hy a person entertaining that purpose, except with a view of giviug to the voyage which loe has resol sul to continue, the appearance of being broken by an importation, whind he has resolved not really to make.

"Now, what is the case immediately lefore us? The carwo in question was taken on loand at hagura. It wats at the time of the capture proeeding to spain; but the ship harl touched at an Ameri. 


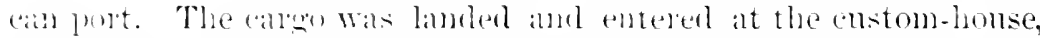

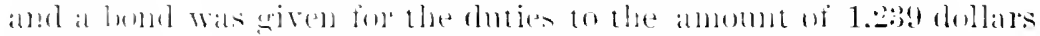

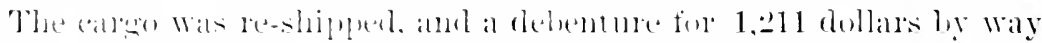

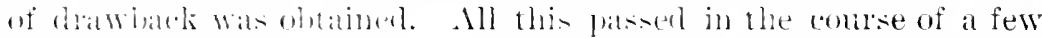

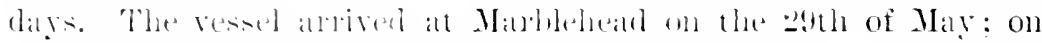

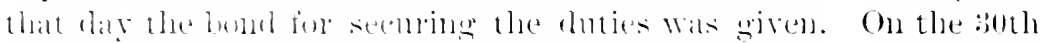

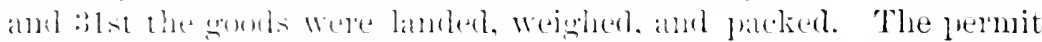

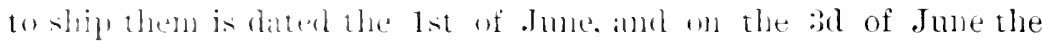

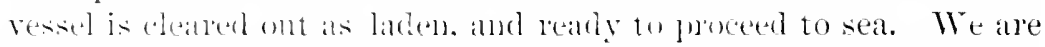

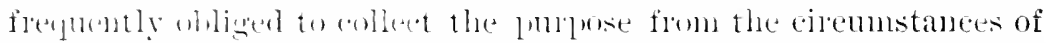
the transabton. 'The lambing thus almost instantaneously followed

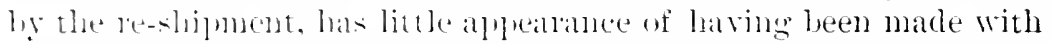
a $v$ in to allual importation: but it is not mpon inference that the andelsion in this atse is loit to lest. The claimants, justead of

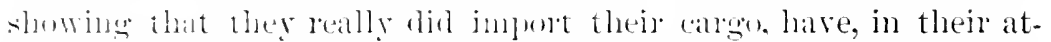
testation. stater the reasons which deterunined them not to import it. They say, indect. that wholl they ordered it to be purchased, -it was with the single vell of hinging is to the Enited States, and that they hard no intention or expectation of exporting it in the

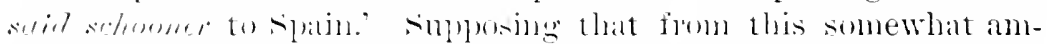
bigums statement we are to collect that their original intention was

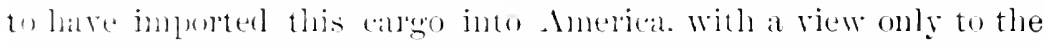

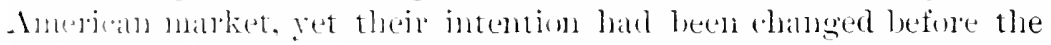

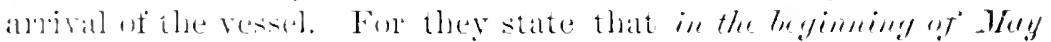

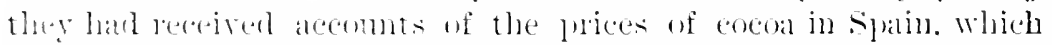
satistien tlem that it womld sell monch bettel there than in America,

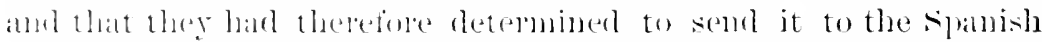

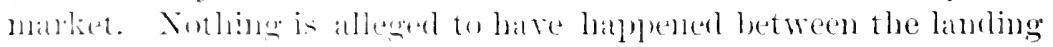

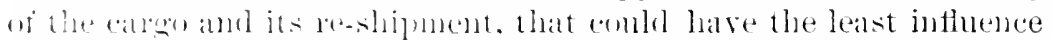
on lheir doternination. It was not in that shont interval that

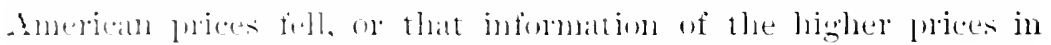

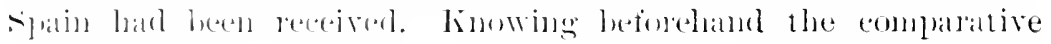

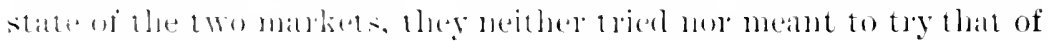

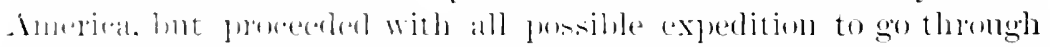

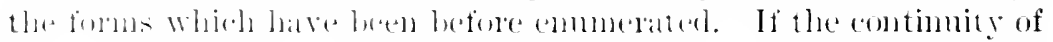

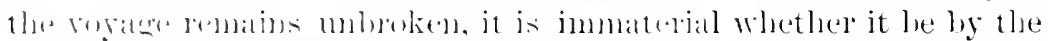

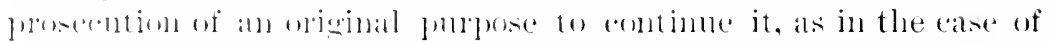

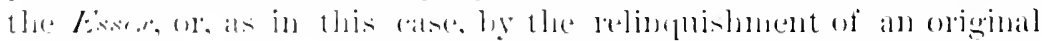

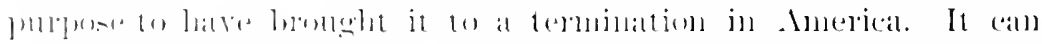

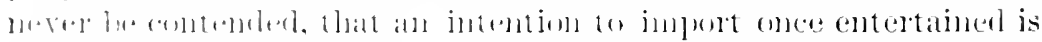

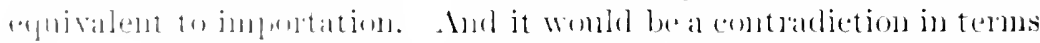

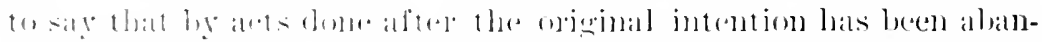

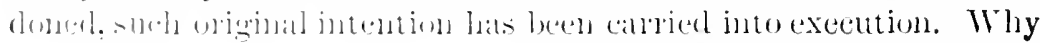




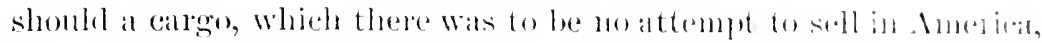

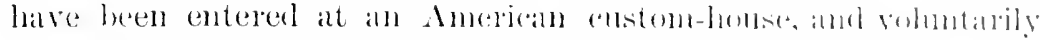

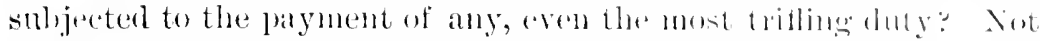

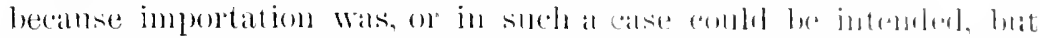

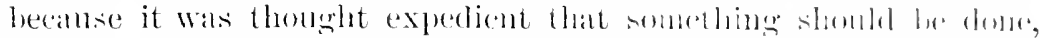
which in a British Prize come might patso for impontation. Inderel,

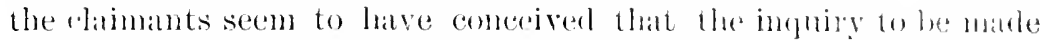
here was, mot, whether the importation was real or protender!. hut whether the pletence had assmmed a pantenlat form, and was atecompranied with eertain eiremstances which by some poritive rule were, in all cases, to stand for importation, or to be conchusive evidence of it. * * *

"Bnt supposing that we had miformly held that payment of the import duties fumished conclusive evirlence of importation, would there have been any incomsistency or contradiction in holking that the mere act of giving a bond for an amomt of duties, of which only a rery insignificant part was ever to be paid, conld not hare the same effect as the actual payment of such amome? The further proof in the Essex first bronght distinctly before us the real state of the fact in this particular. It has been alrealy mentioner that wo hat called for an accomit of the drawbacks, if any, that had hecen received. This produced the infomation that althomgh the duties secmed amomted to 0,278 dollars, yet a debenture was immediatraly afterwards given for no less than 5,080 dollars; so that on that valuable cargo no more than 198 dollars would be nltinately patyable, which sum is said to be more than compensated for the arlvintage arising from the negotiability of the debenture.

"The conseqnence is, that the voyage was illegal, and that the sentence of condemnation must be affirmed."

\section{TIIE "STEPIIEN H.\RT."}

\section{U. S. District Court ror So. New Tork, 1863.}

(Blatchorits Prize Cases, 88\%.)

The mere touching at a neutral port, or even a trans-shipment in such port, will not he considered as breaking the royage, if the intention was. on sailing. (w) carry contraband goods to Confederate ports, or to break the blockade instituted against them.

The schooner Steplien IInt was captured, as lawful puize of War. by the United States vessel of Wat Suphly, on the 2yth of January: 
14i2, off the sombern coast of Florida, about 25 miles from liey West, and alomt s.z miles from Point de Yeacos, in Cuba, homml ostensibly from Lomblom to Cardenas, in Cuba, with a cargo of muntions of wall and army sulpllies.

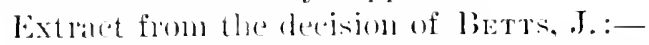

"Nany of the principle questims involver in the present ease, and

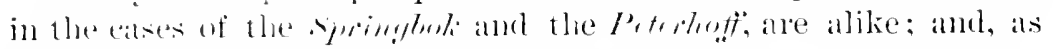
the eonefusion at which the emot has arrived in all of those cases is to combemm the vessels and their cargoes, I shall amomnee, in this catse. the leading principles of public law which lead to a condemnation in all 1 he cases.

"()n luhalf of the libellants, it is megel in this case, 1 st. That the

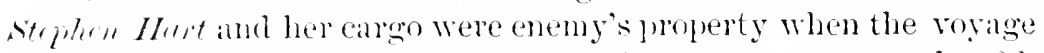
in question was nudertalien, and when the eapture was made; $2 d$. 'That the shooner was laden with articles contraband of war, destined for the aid and use of the enemy, and on tramsportation hy sea to the enemy's comntry at the time of capture; 3 d. That, with a full bnowledge, on the part of the owner of the ressel and of the owners of her cargo, that the ports of the enemy were moler blockade, the ressel and her cargo were despatched from a neutral port with an intention, on the part of the owners of each, that in viola. tion of the blocliade, both the resiel and her cargo should enter at port of the enemy.

"On the part of the claimants, it is maintained, 1st. That the transpontation of all articles, including arms and munitions of war, between montral ports in a neutral vessel, is lawful in time of war; gl. That if a nentral veswel, with a cargo belonging to nentrals, be in filct on a rovage from onc nentral jort to another, she eamot be

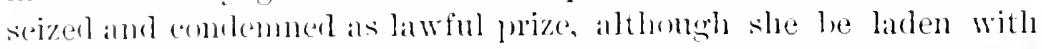

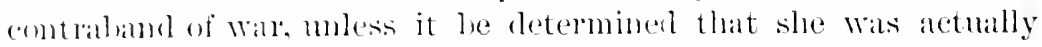

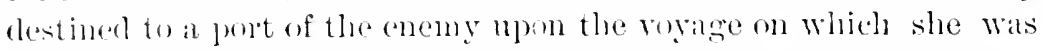
seizerl, of muless she is taken in the act of violating a blockate.

"It is insisted, on the part of the clammants, that the stephen IIort

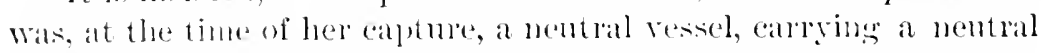
cargo from Lomblon to Cardenas-loth of them being nentral portsin the regular eomse of trate amb eommeree. On the other side it is rentember that the cargo was composed exchusively of artinles contraband of war, destined, when they left Iondon, to be delivered to the anemy. aither directly, by being carried into a port of the encoly in the stephen Mont or by heing trans-shipled at Cardenas to another vosiel; that Carlenas was to be used melely as a port of call for the stoplen Mort, or as a jort of trans-shipment for her carogo; that the ressed and her cargo are equally involved in the forbiden 
transaction; and that the pajers of the vested Wore simmlaten am

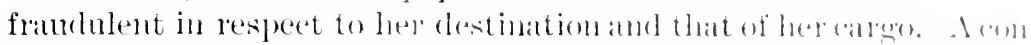

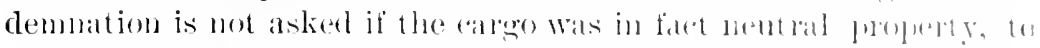

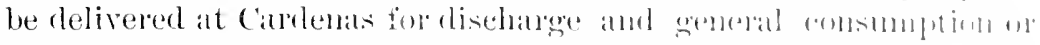

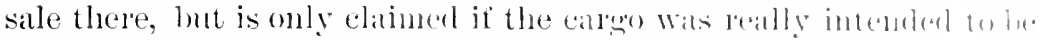
delivered to the enemy at some other fuace than (arrlemas, afture using that port as a port of call or of tams-shipment, so as to thus renter the representations contained in the balders of the ves el false

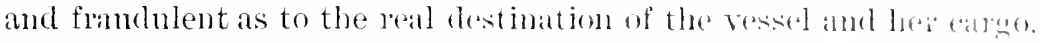

"It would scarcely seem posible that there combl be any serims debate as to the true principles of public law applicable to the solution of the questions thus presented; and, incleed, the law is so woll settled as to make it only necessary to see whether the farets in this case bring the vessel and her cargo within the rules which have been laid down by the most eminent authorities in Englind and in this country.

"The prineiples upon which the government of the Enited states, and the public ressels acting moler its commission, have procectid, during the present war, in cirresting vessels and cargoes as law ful prize upon the high seas, are very succinetly embotied in the instruetions issued by the Navy l)epartment on the 1sthof Angust, 1862 , to the naval commanders of the Cuited States, and which instructions are therein dechared to be a recapitulation of those theretofore from time to time given. The substance of those instructions, so far so they are apllicable to the present cast. is, that a vessel is not to be seizerl "without a search carefully matle, so farl as to render it reasonable to believe that she is engaged in carrying contrabud of war for or to the insurgents, and to their lorts directly or indirectly by trans-shipment, or otherwise violating the blockiarle.'

"The main feature of these instructions, so far as they hear npon the questions involved in this case, is but an application of the doetrine in regard to captures laid down by the government of the United States at a very early day. In an ordinance of the concress of the Confederation, which went into effect on the 1st of Feluning, 178:, 5 Wheaton, Appentix, p. 120, it was declared to be lawful to capture and to obtain eondemnation of all ' eontrabancl goends, watres, and merchandises, to whatever nations belonging, although found in a neutral bottom, if destined for the use of an enemy.'

"The soundness of these principles, and the fact that the law of nations, as applicable to cases of prize, has been olserverl and aplulied by the govermment of the Luited states and its comrts dming the present war, was fully recognized by Earl Russell, her Britunni. 
Majesty principal secretary of state for foregign affitis, in his remarks mate in the Ilonse of Lords on the 1sth of Maty last. Earl linsell there stated that the jumbments of the Lnited States

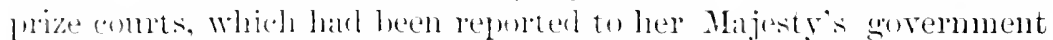
during the present ware did not evine any discegarl of the establishenl prineiples of international baw: that the litw ofliner's of the comms after an attentive emsideration of the derisions which harl beral bilit before them, were of opinion that there was no rational

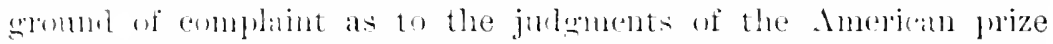
courts: and that the law of nations in reenath to the seareh and seiz.

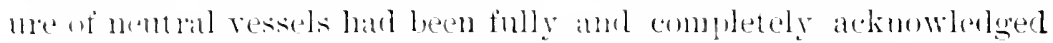
hy the enorimment of the Cuiterl states. On the same aceasion Eirl linsiell remarked: 'It hats been a mont profitable business to send swift ressels to break or rin the hockade of the southem ports. and carry their cargoes into those ports. There is no munieipal litw in this or any eomery to pmish snch an act as an offence. I mulerstand that every eargo which rums the blockade and enters (harleston is worth a million of dollars, and that the profit on these transations is inmense. It is well known that the trade las attracted asteat deal of attention in this country from those who have a keen eye to such gains, and that ressels lave been sent to Xassian in orter to lreak the blockinde at Charleston. Wilmington, and other flaces ami carry contraband of war into some of the ports of the sombern states.' IIe added: 'I certainly am not preprared to declane, nor is there any ground for declaring, that the conts of the Enited states do not faithfully administer the law; that they will nut allow evidence making against the calptors; or that they are bikn to give decisions fombled, not upon the law, but mpon their own pastons and national partialities.' He also sath that in a ease of simulater destination-that is, a vessel pretending that she is goinu wasim, when she is in reallity bonnt to a port of the enemy-the right of seizure exists.

". The then solicitor-general of Englant (Sir Roundell Palmes)

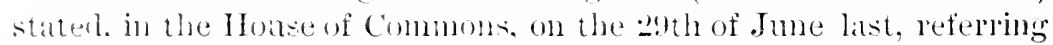

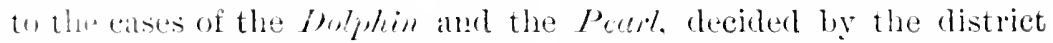
conm for the sonthern district of Florida (those ressels having been ealnumed white ostensibly on voyages from Liverpool to Nassan, and it latring been held by the eourt that the intention of the owners of

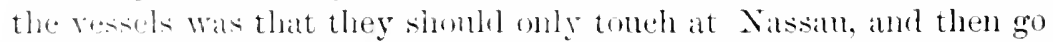
and break the bockarle at Charlestom), that - if the owners imagined that the mere faret of the vessel tonehing at Nitsatu when on such an experition exonerated her, they were very much mistaken;' that the princinles of the judgunent in the case of the Dolphin "were to 
be fomml in every volnme of lomel stomell's derejoms : that it wats

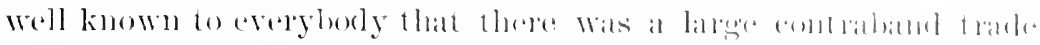

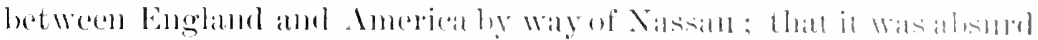

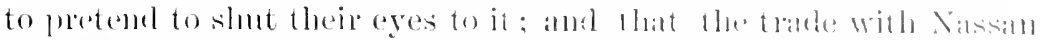

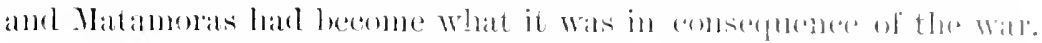

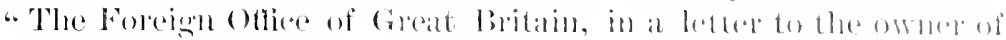

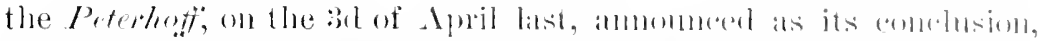

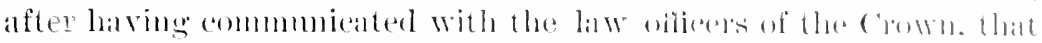

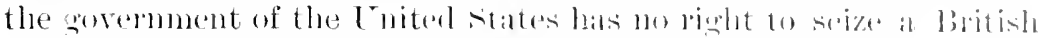

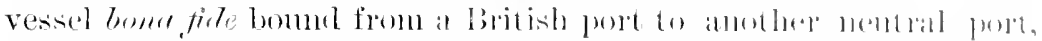
umbes such vessel attempts to tomels at, or has an intermentiate or contingent destination to, some blockaded pont of phate, of is a callrier of eontrabind of war destined for the andemy of the linted

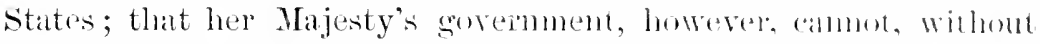
violating the pules of intemational law, claim for lintish restels navigating between Great Britain and sule nentral ports any general exemption fom the belligerent right of visitation by the anisers of the Lnited States, or proced upon any eroneral assmmption that such ressels may not so act as to remeler their apture law ful and justifiable; that nothing is more common than for those who anttemplate a breach of blockade or the carriage of enmtalmant, to disguise their purpose by a simmated destination and by deceptive papers; and that it has already happened, in many cases, that liritish ressels have been seized white engaged in royages apparenty lat ful, and have been afterwards proved in the prize combts to have been really gulty of endeavoring to break the blokkale, or of carlying entraband to the enemy of the Lnited states.

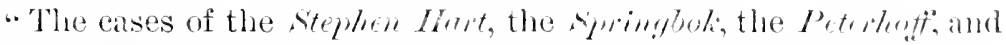
the Gevtrude illustrate a comse of trade which has splung mp ohring the present war, and of which this cont will take julledal cognizance, as it appears from its own records and those of other eonrts of the Enited states as well as from puhlic reputation. Those mentral ports have sudelenly been raised from perts of compandively insignificant trade to mats of the first magnitule. Nasisan and (allcienas are in the ricinity of the blockated ports of the andms, while Matamoras is in Mexien, upon the right lank of the lijo timmle. directly opposite the town of Brownsille, in Thasts. The comperse of

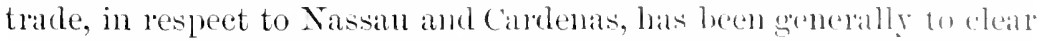

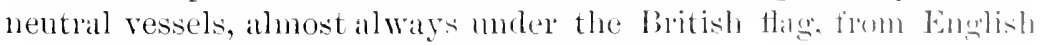
ports for those places, and, using them merely as ports cither of all or of trans-shipment, to eithel resume new royages fom them in the same vessels, or to trans-ship their cargoes to fleet stermer-s, with which to lum the blockade, the eargoes being comprosed, in alnost 33 
all cases, more ol less, of anticles contraband of war. The character and combe of this trate, and its sudden rise, ale very puperly commented 11 on in a despateh from the secretary of state of the C'nited

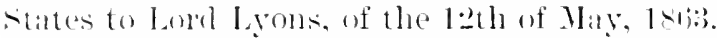

"The horat issule mom the merits in this case is, whether the adventure of the stoflen Mort was the honest voyage of a nentral vesed form ome nentral port to amother mentral, compring nentral goods between those two purts only. of wats a simmlated rovage, the

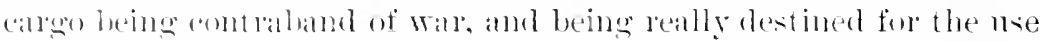

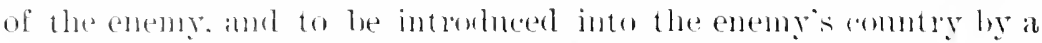

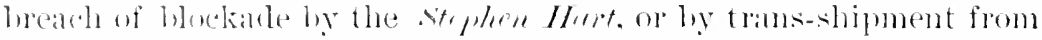

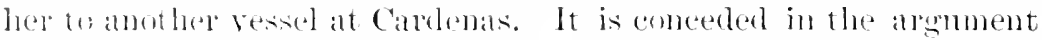
of the leading commel for the elaimants that if the property was owned hy the enemy, and was fraludulently on its way to the enemy as nentral puperty it was enemy's property, and was liable to (a) fure, no matter whence it came or whither it was bomel: and that, if the ressel were really intending and endearomg to rum the bockade, the fornerty was liable to capture, no matter to whom it belomed or what was its character: lut that if it was nentral property. in longlul enmmere, it was safe form seiznre.

"The guestion whether on not the puperty laden on board of the

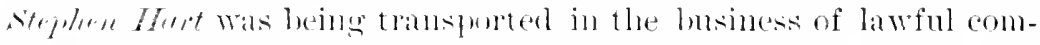
meree is mot to be decirlet by merely deciling the question as to whether the ressel was docmmented for, and saling mom, a voyage from lombon to Cambens. The commeree is in the destination and intenderl use of the property limen on board of the vescel, and not in the incilental, ancillary. and temporary royage of the ressel, which may he but one of many erriers through which the property is to rearh its true and oriminal destination. If this were not the role of the prize liw a very wille loor would be opened for frand

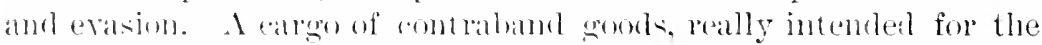

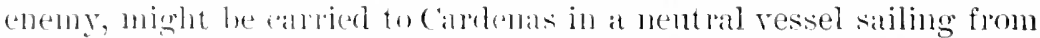

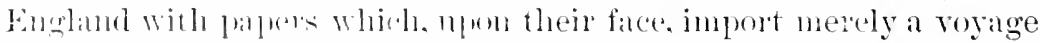

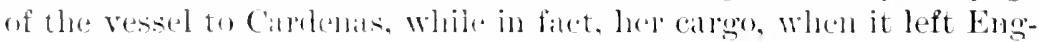
latur, wats destincel by its ommers to le delivered to the enemy by

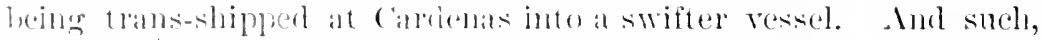

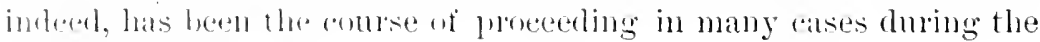
luesint war.

"The law seeks ont the truth, and never, in any of its branches, tolerates any such fiction at that moler which it is sought to

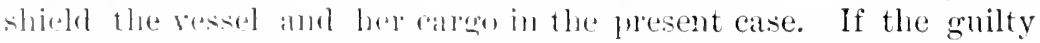
intention. that the eontrabum somds should reach a port of the enemy, existed when such gomls left their English port, that guilty 


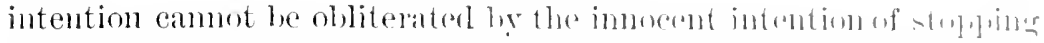

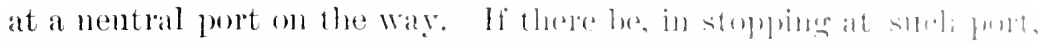

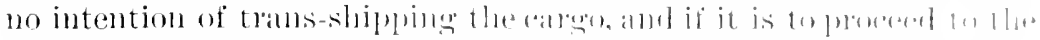

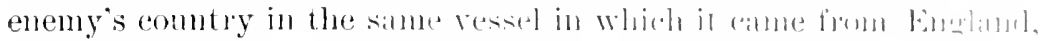

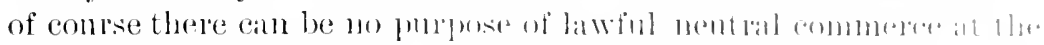

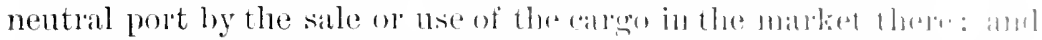

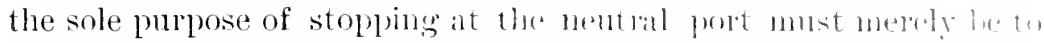
have upon the papers of the vessal an ostensible noutral terminims for the voyage.

"If, on the other hand, the olject of stoppiner at the nembal purt

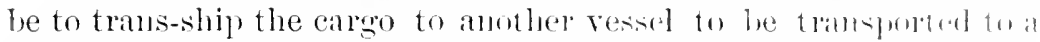
port of the enemy, while the ressel in which it Was Hompln form England does not proeed to the port of the enemy, there is mplally an absence of all liwful nentral comnerce at the nentril purt : and the only commerce carried on in the case is that of the trals lumbattion of the contraband cargo from the English pout to the lunt of the enemy, as was intencled when it left the English gort. This court holks that, in all such eases, the transportation ol voyare of the contraband gools is to be considered as a mit, from the port of lading to the port of delivery in the enemy's comntry; that if any part of such voyage or trinspoptation he mulaful, it is mulatin throughout; and that the resiel and her cargo are subject to arlune: as well before arriving at the first nentral port at which she tonches after her departure from England, as on the royage or transumtittion by sea from such nentral port to the port of the eneny.

"There must, therefore, be a decree condemming both resid and cargo." 1

\section{Section 49. - Visit axd SEARCh.}

\section{TIIE "MIARIA."}

A ressel sailing under convoy of an armed ship for the purpose of arriding risitation and search is liable to condemnation.

This was the leading case of a fleet of swedish merchantmen. alrying pitch, tar, hemp, deals, and iron, to several ports of Fiance,

'Cases involving the same principles, are the Springboli, is Walliare, 1 : Ther Peterhoff, 5 Wallace, 28, and others. The juigment of BETTS. J.. in the sto phen Hart was subsequently briefly affirmed by the Supreme (omrt. and it (Bi:rTs' judgment) is on the whole the clearest and most forcible statement of the principles and the circumstances involved in these cases, to be found in th+ r'purts. 


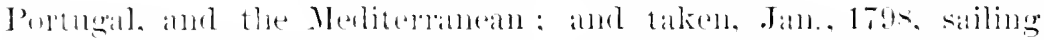

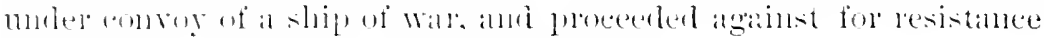

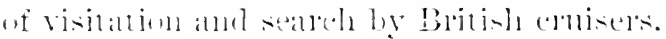

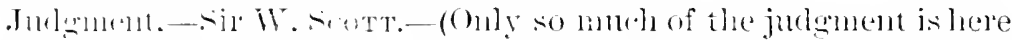

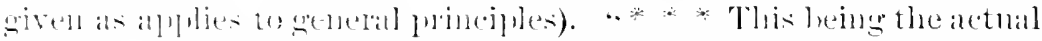

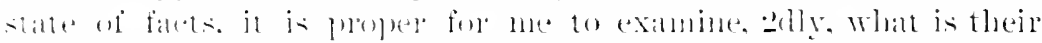

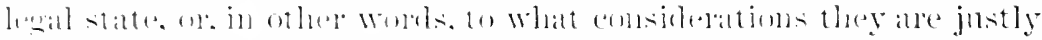

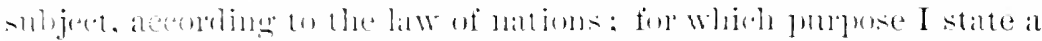

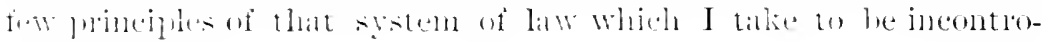
reltible.

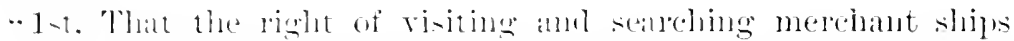

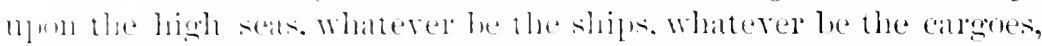
whateral he the destinations, is an incontestible right of the law-

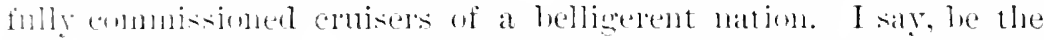

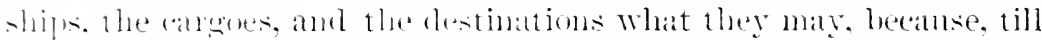

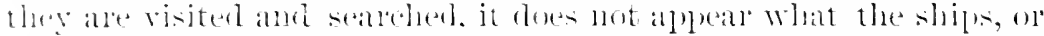

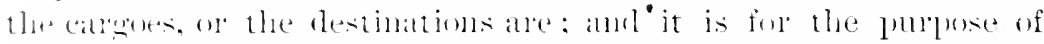

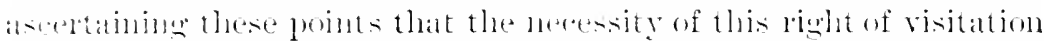
and seatel exists. This right is so eleatr in principle, that no man

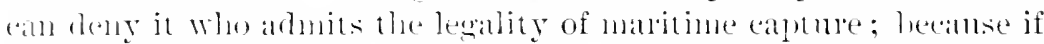

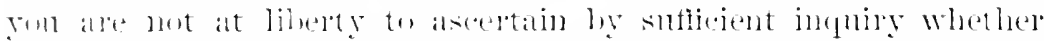

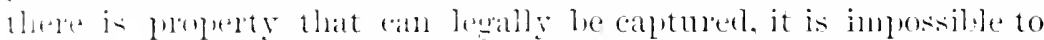

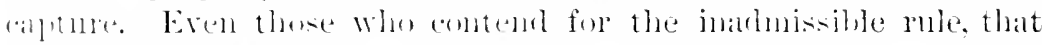

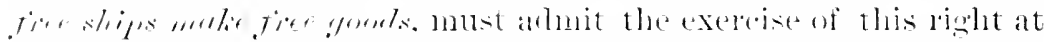

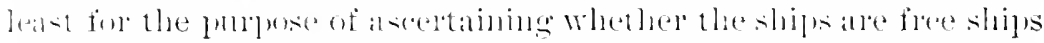

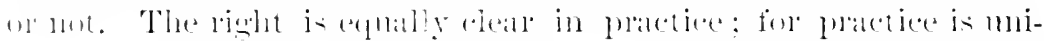

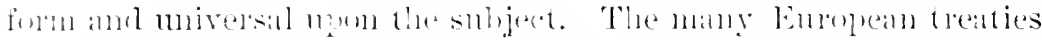

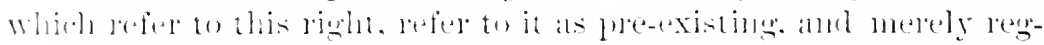

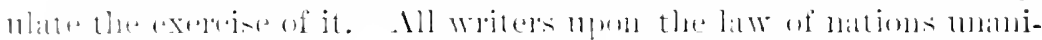

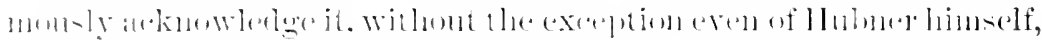

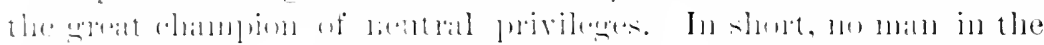

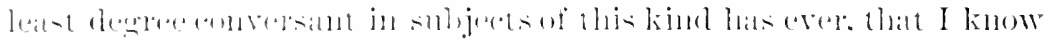

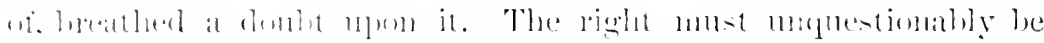

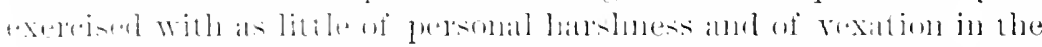

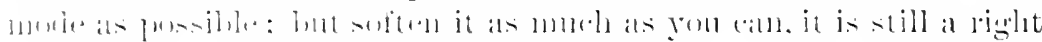

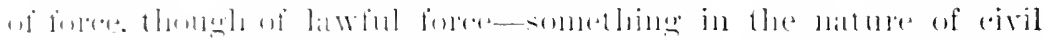

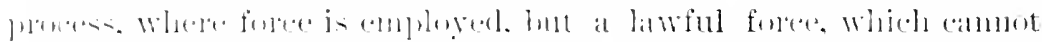

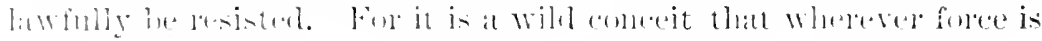

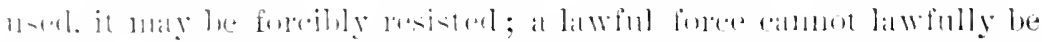

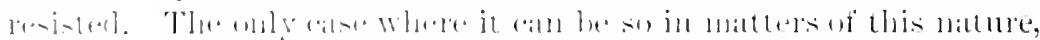

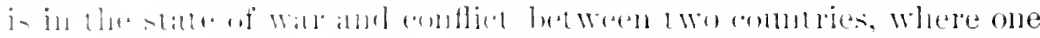

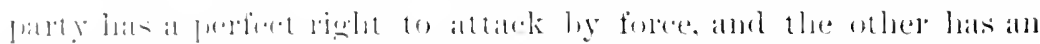

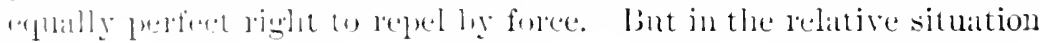




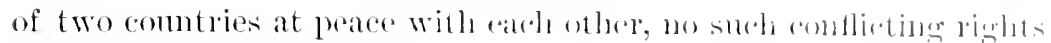
can possilsly roexist.

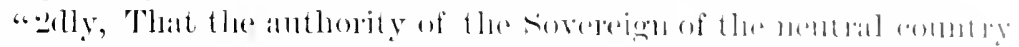

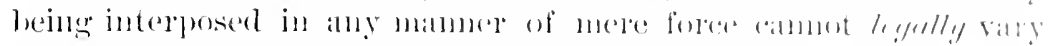

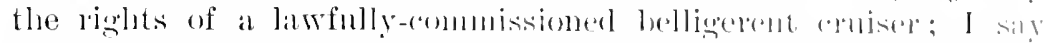
legolly, becanse what maly be siren, ol be fit to bo given, in the al

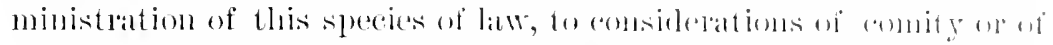
national policy, are views of the mattel which, sitting in this (imbt, I have no riglit to entertain. All that I asseret is, thall / //rlly it rall-

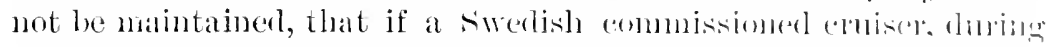

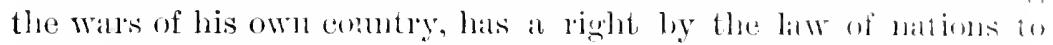
visit and examine nent lat ships, the King of Eugland, heing nentral to sweden, is anthorized hy that haw to obstruct the exereise of that light with respect to the merehant-ships of his commly. I and this, that I camot hut think that if lo obsureted it ly foree, it momb very much lesemble (with all due leverence be it sluken) an oplosition of jllegal violence to legal right. Two soreredgons mat muglestionably agree, if they think fit, (as in some late instances they have agreed,) by special covelumt, that the presence of one of theip almerl ships along with their merehant-ships shall le mutnally understoud to imply that nothing is to he fomm in that consoy of merchamt-shijs inconsintent with andy or nentrality ; and if they consent to anerent this pledge no thipd party has a right to quarel with it any mone than with any other pledge which they may agree mutnally to areepte. But surely no sovereign can leginlly compel the acceptance of surh at security by mere foree. The only security known to the law of nattions upon this subject, independent of all special covenant, is the right of personal visitation and search, to be exercised hy those who have the interest in making it. I am not ignorant, that amonnst the loose doctrines which modern fancy, mulde the vinims demominations of philosophy and phibunthropy, and I kunw not what, have thrown upon the world, it has heen within these few yeas arl raluded, or rather insinuated, that it might posibly he well if surh a somity were accepted. Epon such matuthorizer speculations it is not nox:essary for me to descant: the law and pratetice of natjoms (I indurle particularly the practice of Sweden when it halplens to he helligerent)

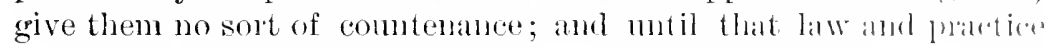

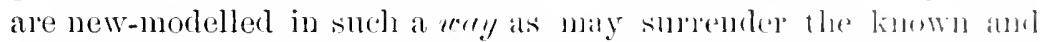
ancient rights of some mations to the present aonventence of other

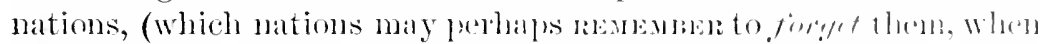

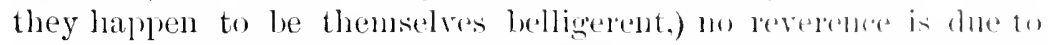
them; they are the elements of that system which. if it in monsistent. has for its real pupose an entire abolition of capture ju wall-that 
is. in other wolds, to rlatnge the natme of hostibity as it lats ever

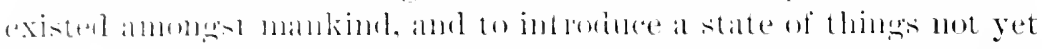

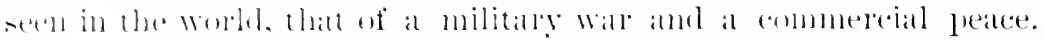

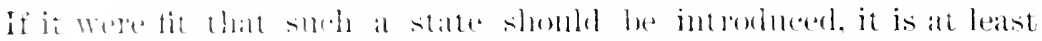

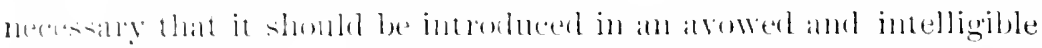

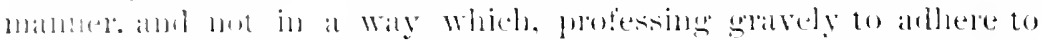

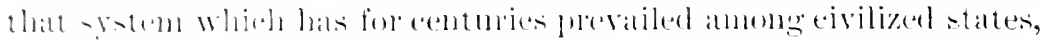

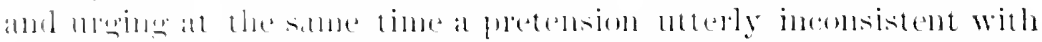

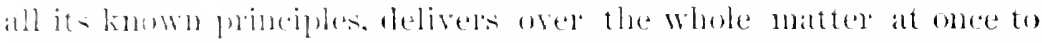
etemal enmtrosel'sy and conflict, at the expence of the eomstame hazard

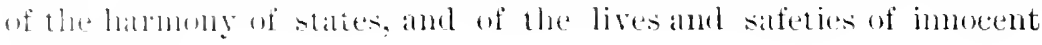
intivimals.

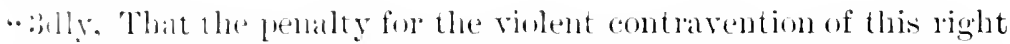
is the confisaltion of the property so withheld from visitation and statrel. For the pront of this I need only refer to Vattel, one of the moni anrect and eertainly not the least induigent of modern profesn) w fublic law." I See Book III., e. vii., seet. 114.

\section{SECTION 50.-Pinze Colits.}

\section{DECINIONA OF TRIZE COLRTS.}

\section{(Larrence's ITheaton, 960.)}

The lecision of a prize court is conclusive in respect of the title to the property.

"The constitution of prize comts is an amomaly ju jurispruclence.

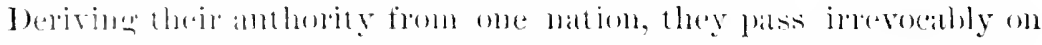

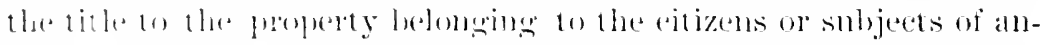

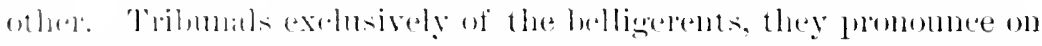

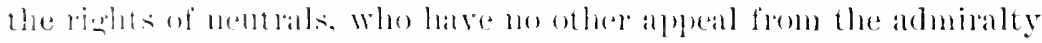

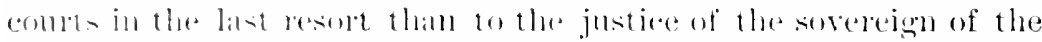

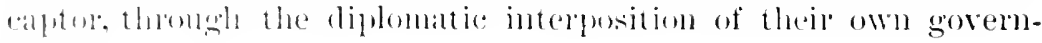
131011.

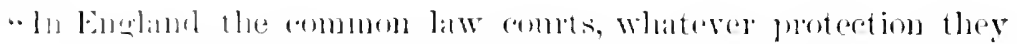

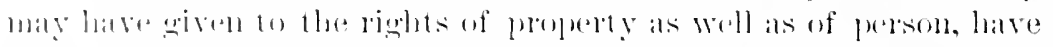

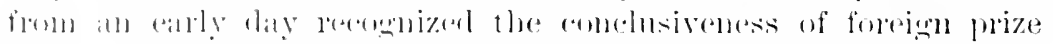

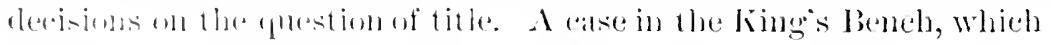

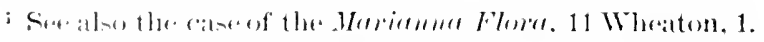

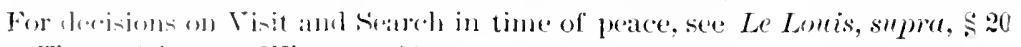
(r) : The bufreme. 10 Wheaton. 119 . 


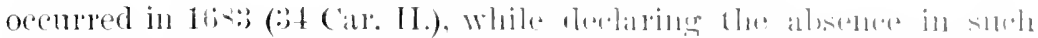

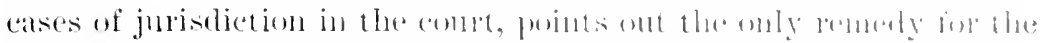

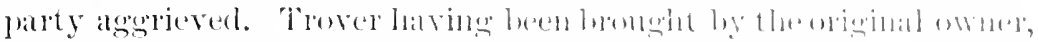

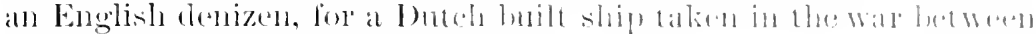

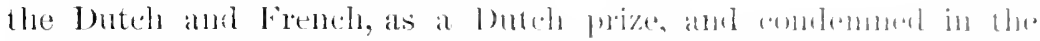

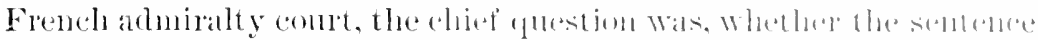

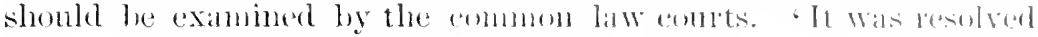

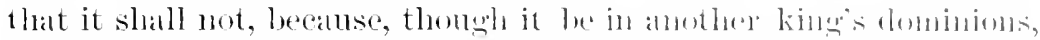
we onght to give ereclit to it, or else the will not wive erenit to dhe

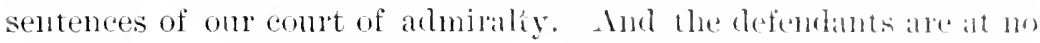
prejudice. The way is, if they find themselves andreverl, to petition the king, who will eximine the case, and, if he finds canse of ammplaint, will send to his ambassador residing with the prine or state where the sentence was given, and upon failure of redress, will grant letter's of marque and reprisal." "

\section{PRIZE COLRT'S ON BOARD SIIIS.}

\section{(Captain Semmes: "Cruise of the Alabama." I., 3t6.)}

Does International Law sanction the establislment of prize courts by commanders of belligerent cruisers, on board their ships:

Captain Semmes, of the Confederate steamer smmptr, and latel commander of the flabume, would seens to have turnerl his calsin into a prize court on the oceasion of erery capture made hy lim. It lias generally been held that the commander of a belligerent cruiser has no right to decile controverted fluestions arising in cases of prize. Ile seizes a vessel on the helief or smspicion that she is antmy"s property, or that she is engaged in a forbiden enmmerese it is left to the prize comrt of the captor"s country to determine whether these suspicions are warranted or not.

During his eruises in the sompter ant the flolmome, captain Semmes had occasion to adjudicate in more than serenty abses of prize; in fifty-nine of these cases, ship, and cargo were condenmed as enemy's property, and burnerl: in nine cases the ships wele lesleased on ranson bonds, the cargoes being plainly nemiral. lint in a large number of the eases of those comblemmed and lumbat. there were claims for the cargoes as nentral poperty. Caphatin sommes seems to have condemned the cargo, muless the we wa pustive prouf

${ }^{1}$ For the constitution and functions of prize courts, sere Lawrences Wheaton, 960 ; Baker's Halleck, II., 411 ; Phillimore, III. . 61と-679. 


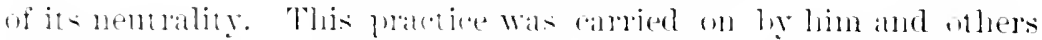

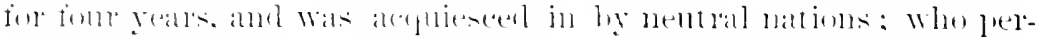

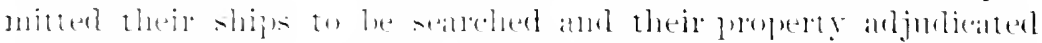

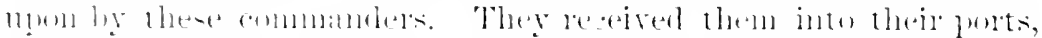

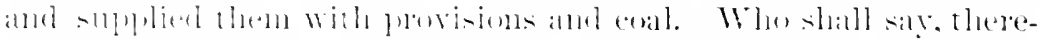

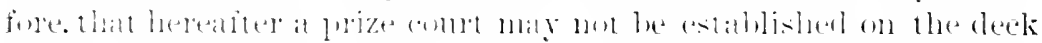

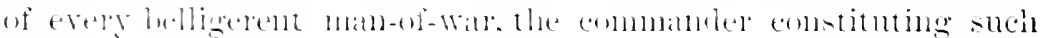
(1) 1111 :

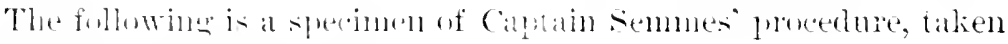

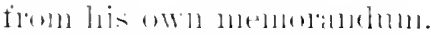

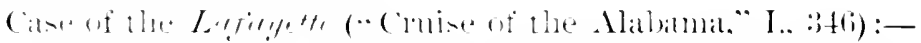

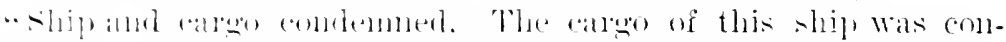

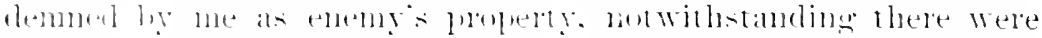

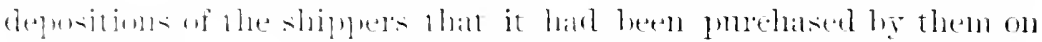

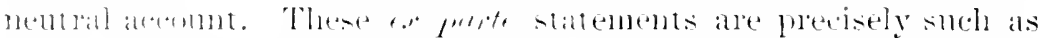

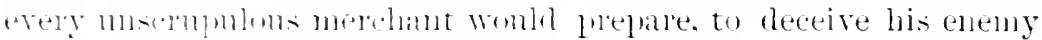

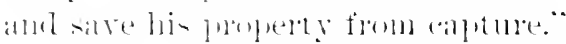

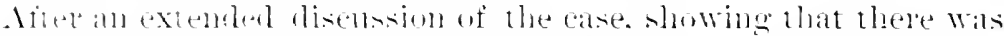
flaml. amb that the atemtality of the eargo was mot established,

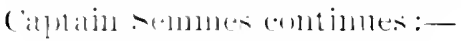

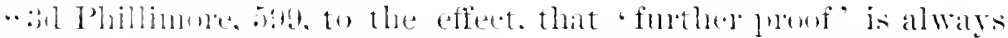

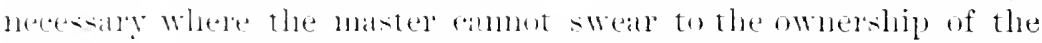

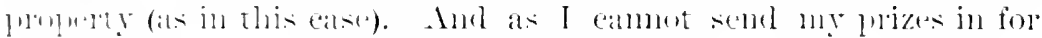

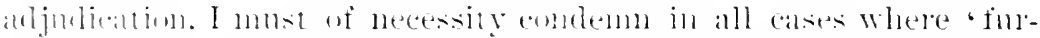

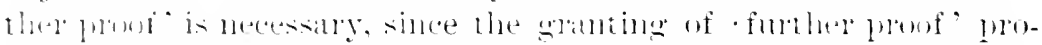

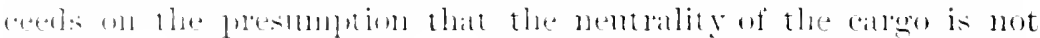

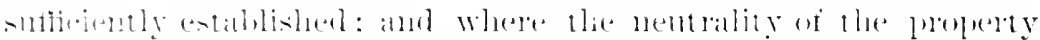

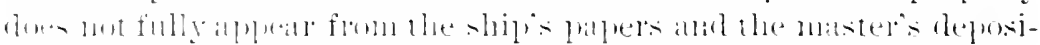

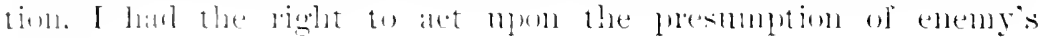
$1+1+1)+1, \cdots$

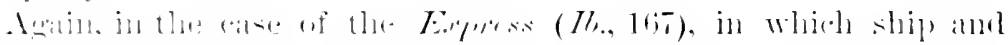

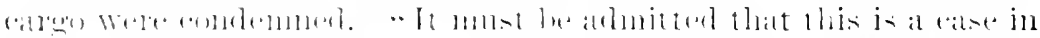

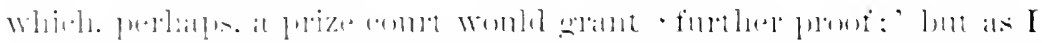

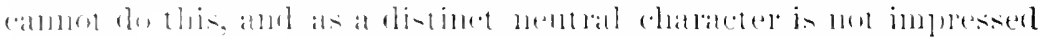

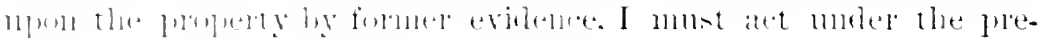

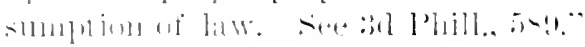

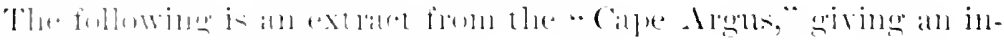

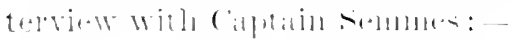

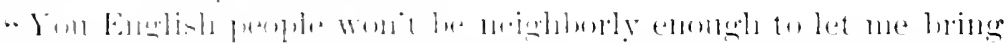

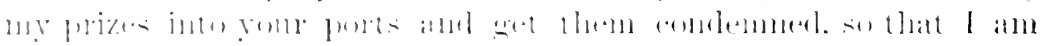

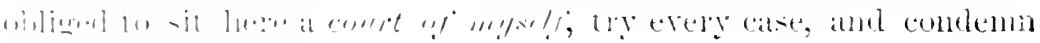
the sliph I tilie: 


\section{APPENDTX.}

A.

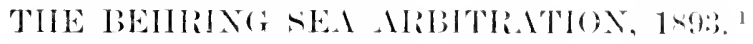

May a State exercise jurisdiction on the high soats for the purpese of poteret ing fur-seals, which, for sereral nonths in each gear, remain on land in its territory.

The controversy in this case siew ont of the seizure ly l luited

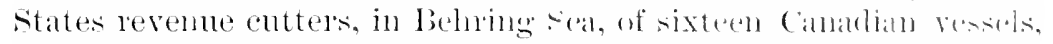

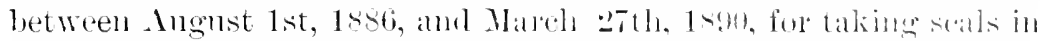
that sea. These seizures were all marle beyombl the thares-mile linit, at distances valying from tifteren to one hombled and fifteren miles from land. It was smpposed that the linited states atederl npon the assumption that behring sea wats mere romsum. That wals lhe

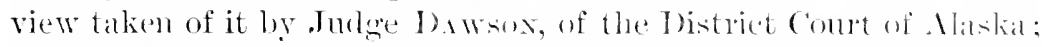
who, in eharging the jury in the case of one of these rescels fthe Thorntom), said: "All the waters within the bonmblat set forth 10 the western end of the Mlentian Irehipelago and chain of islambane to be considered as comprised within the waters of Mlaklia.

"If the jury beliere the defencant killed any otter, mink, matem. sable, or fur-seal, or other fur-learime animals on the shores of Alaska. or in the Behring sean, alst of the 19:3- of west hominule, they slatl fiml him wnilty. * * *."

so, Chief Justice Fuller, in lelivering the opinion of the whe in the salyand case, assmmed that the seizme was make lyg right of mare clatesum.

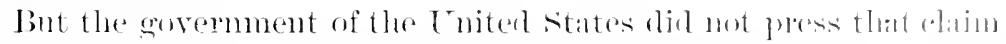

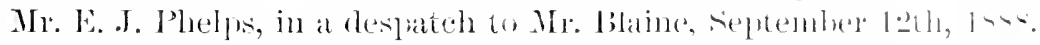
said :-

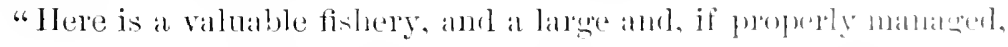

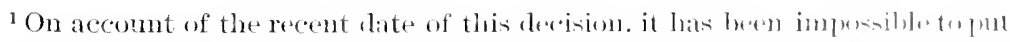

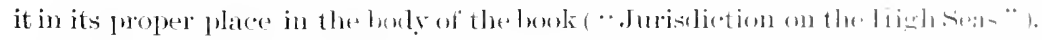

The arguments of the English eomsel have not cande to hand alle therefore are not represented in this report. 
permanent industry, the property of the nation on whose shores it

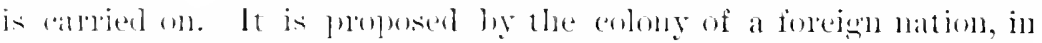
detionere of the joint remonstrance of all the commtries interesterl, to

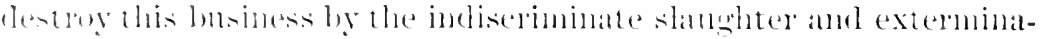

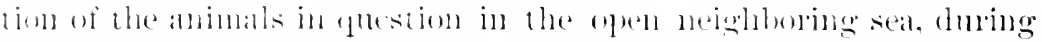
the gerion of getation, when the commons dietates of hmmanty

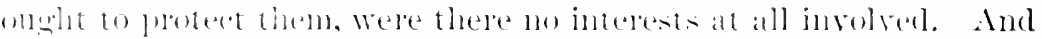

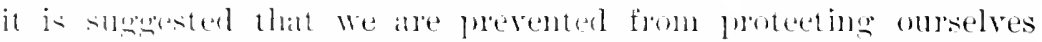

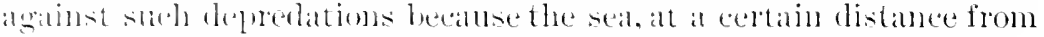

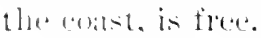

." The same line of alsmusent woml take muler its protection

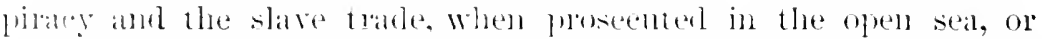
womlit justify one nation in destroying the commeree of another by

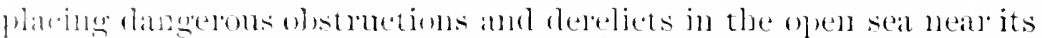
robsts. There are many things that cammot be allowed to be done on the opell sea with impunity, amb aganst wheh every sea is mere . lentm. And the right of self-defense as to person and property ] terals there as fully as elsewhere. If the fish upon camalian ratsts ould he destroyed hy seattering poison in the open sea aldatcent, with some small profit to those engaged in it, wonld Camalda, mon the just principles of intermational law, be held defenseless in suld a case: Tet that process wond be no more destructive, inlumuan, and wantwn than this.

- If precedents are wanting for a defense so necessary and so porper. it is becanse precedests for such a comse of comelnet are likewise minnwn. The best intemational law has arisen from precerlents that have been established when the just oceatson for them

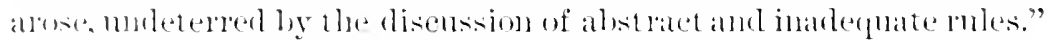

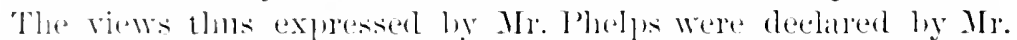
Blaine, to be the views adopted by the covermment of the Lnited stities.

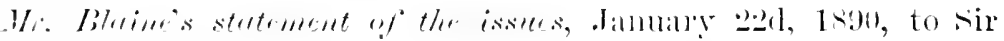
Dulian l'anmedote:-

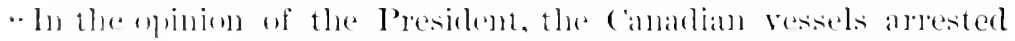

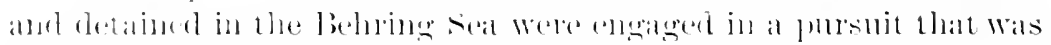

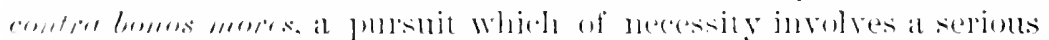

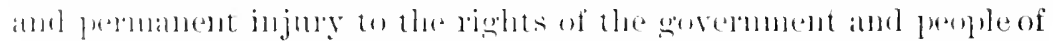

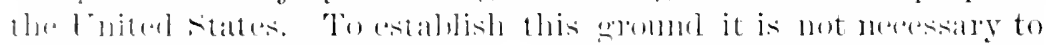

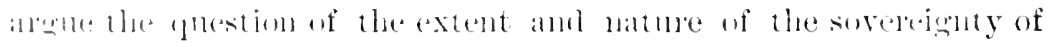

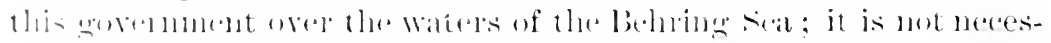

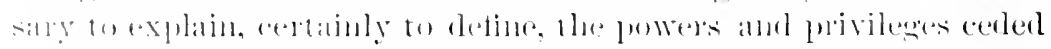

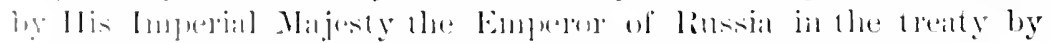

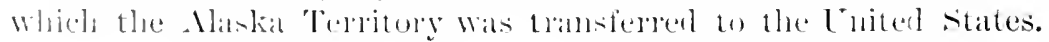




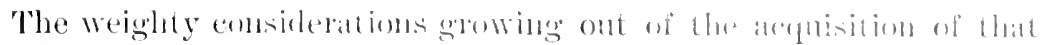

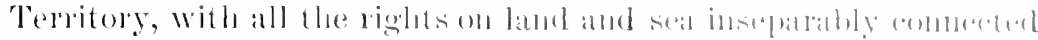

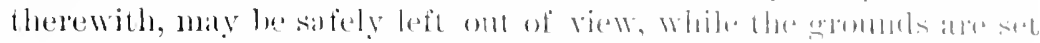

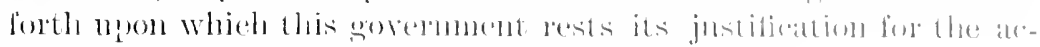

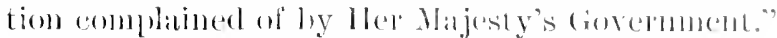

'The somols set forth are these: -

(1) The value of the somberies amb the atsence of any interforences with them down to lisit.

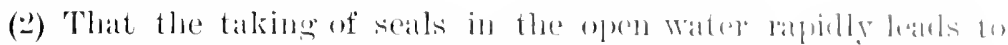

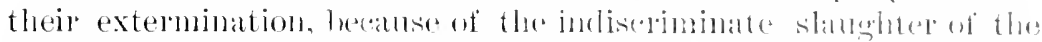
animal, especially of the female; with which slanghter Mr. lialim contrasts the careful methods pursued by the Luited fiates coremment in killing sealis mom the Islaukls.

(:3) That the right of defence ly the Lnited states andust suld extermination is not confined to the three-mile limit, and Mr. Linine remalks as follows: "does llep Majesty's Government sormoly maintain that the law of nations is powerless to prevent smeh vio. lation of the common rights of man? Are the smplomers of justion of all nations to be deelared incompetent to mevent womss so obvioms and so destructive.

"In the judgment of this crovermment, the law of the scal is mot lavlessmess. Nor can the law of the sea, and the liberly whinh it confers, and which it potects, be perverted to justify arets which are immoral in themselves, which inevitably temb to rosults against the interests and anainst the welfare of mankind."

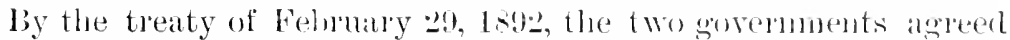
to refer the questions in dispute to a tribmal of alloitration, to be comprosed of seven arlitrators, two to be mamed hy ald of the and-

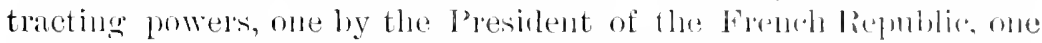
by the King of Italy, and one by the King of Fivelen and Norway.

Article ll. of the treaty contans the fire points of disponte to be passerl upon by the trihmual, as follows: Art. VT. "In alcoilime the mattel's submitted to the Irbitrators, it is asered that the following five points shall be submitter to them, in orebre that their awat

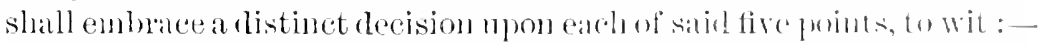

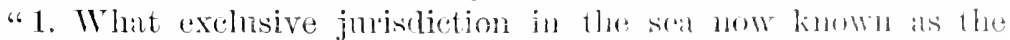
Behring's sea, and what exchuse rights in tho seal fishorice therein, did linssia assert and exercise purom and up to the tine of the eession of Alaska to the Thiterl States"

"2. IIow far were these elaims of juriscliction as to the seal fisheries recognized and conceded hy (troit Britain!"

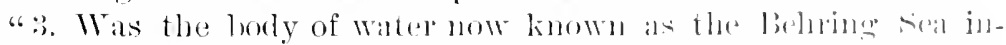
cluded in the phrase 'Pacific Ocean,' as used in the treally of lay 
betwep Great Britain and linsiat and what rights, if any, in the Jiehring rat wele held and exelusively exereised by hussia after silid 'levally:

*4. l)id not all the rights of libsitia as to jumbelietion, and as to the seal ti-beries in belning sea east of the water bommlary, in

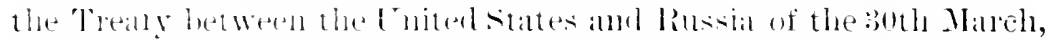

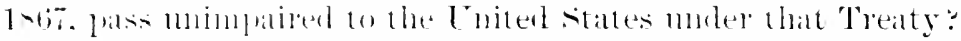

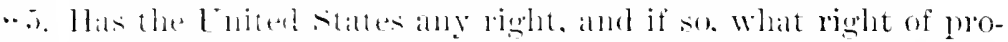

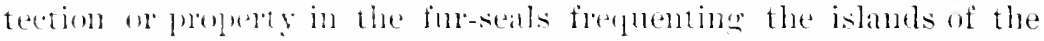
tuibel shates in behring sea when such seals are found ontside the ontimaty thetemile linit:"

In the crent of a decision against the Enited states on these

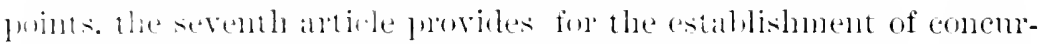

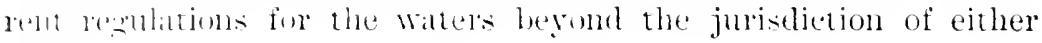
pint?

Tumbe the porisions of this treaty, the tribmal met in Paris in

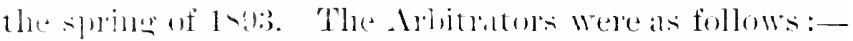

litrm de (courcel, Fance (P'resident): Marquis Emilio Viseonti-

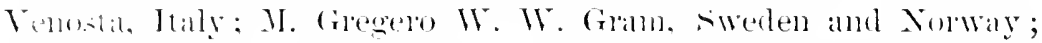

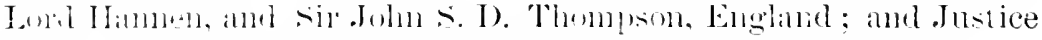

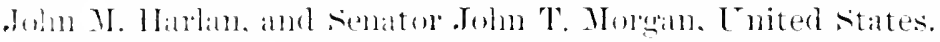

The e:mustel on the part of lhe Luited states were Mesiss. Edwall .I. Phelpr. James C. Carter, Fredelick li. Comdelt, and Ilenry

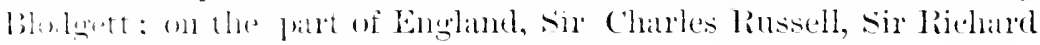

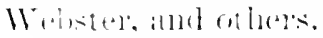

When lhe evilence mas before the Tribmal. it appeared that the

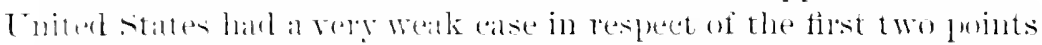

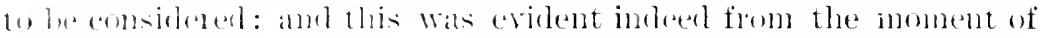

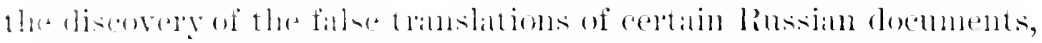

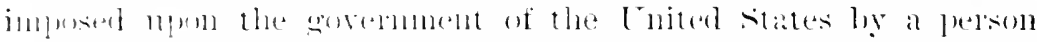

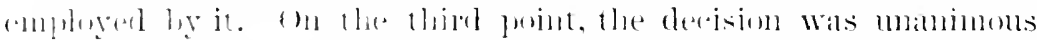
in fatra of the English ambution. That hering the state of the

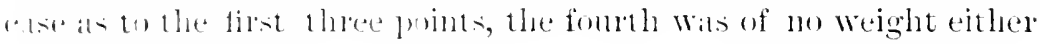
Wi! $?$.

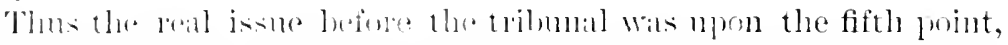

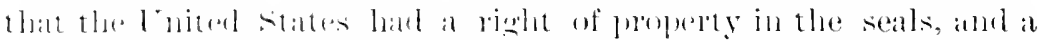

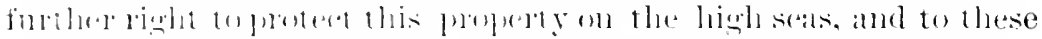

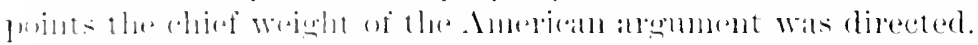

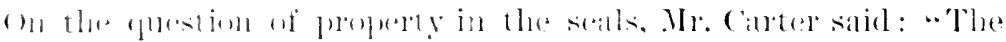

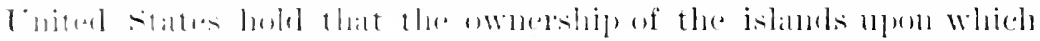

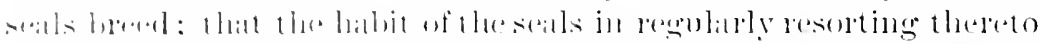

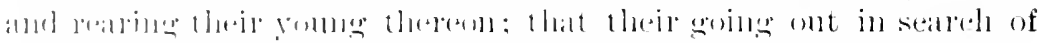

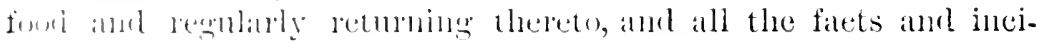




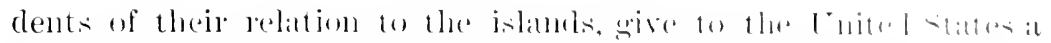

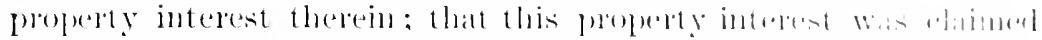

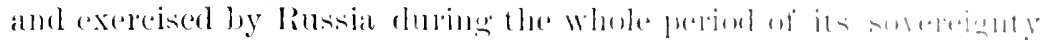

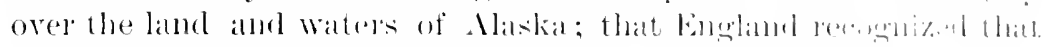

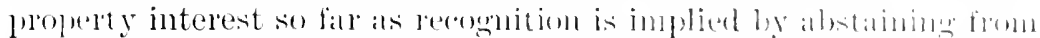

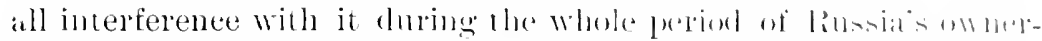

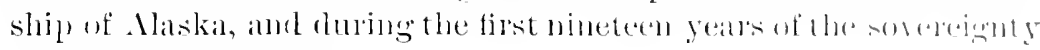
of the laited states.

Ml. Carter arones at great length to pore, from the civil iam anm the Common Jaw, the right of poperty in aninals fin momen.

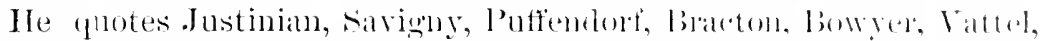

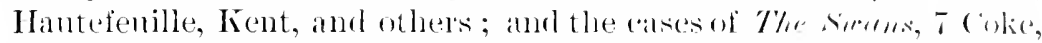

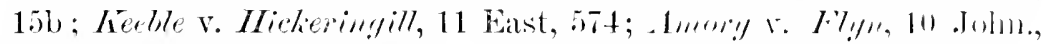

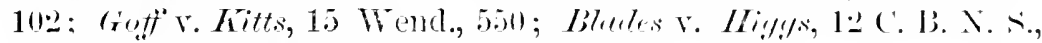
51:); Mrris r. Pouell, Willes, 17:37.

On the question of the right to protect the seals om the high seats, Mr. Ihelps said, the ase of the Govermment of the Cuited statles was:

"1st. That in view of the facts and cirromstances estalndished ly

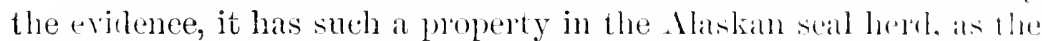
matual product of its soil, made chiefly arailable by its portertion anc expenditure, highly valuable to its people, and a comsindouble sonree of public revenue, as entitles it to preserve the hrol from aldestruction in the manner eomplained of, by an employment of such reasomalne force as mily be neeessilly.

"2d. That irrespective of the distinet right of property, in tho seal herd, the Enited states Govermment has for itself and for its lenple, an interest, an imlustry, and a commere derived fom the lurianate and poper use of the produce of the seal hered on its territor?, whin it is entatled, upon all principles applieable to the case, to protect and an t Wanton destruction by individuals, for the sake of the smatl and casiai! profits in that way to he gained and that no pat of tie high sea is or onght to be onen to inclividuals, for the pmopose of anomplishing the destruction of national interests of such a chancerend and importance.

"Thinel That the Enited States, possessing as they alome possess. the power of preserving and eherishing this valuable interest. and in a most just sense the trustee thereot for the lemefit of mankiml. and shonde be pernitted to diseharge thedr trust withont hindrance."

In support of this view, Mr. Phelps quotes, (imotius. Kent. Twiss.

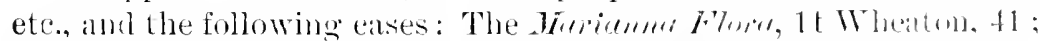

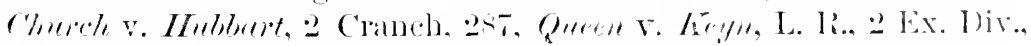
63; Lime v. Himely, 4 Cranel, 2s.; The silecess, 1 Dod, 13:3 The Fox, Ed., $31+$; The sripe, Ed., 382. 
IHETSION.

Ifter a preamble stating the case submitted for decision, the full text of the awarl lums as follows: (New York /ledeld, August 16, $1-(19):$.

- We decide and determine as to the five points mentioned in altiele ti, as an whels on" lewald is to emblace a distinct decision uproll each of them :-

- As to the first of sald five points, we. Batron de comreel, John M.

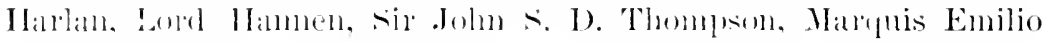

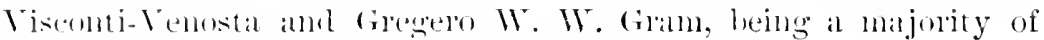
sald arbituaters. do decole ats follows:-

- by the ukase of 1521 Russia chamed juriscliction in the sea now known as behring sea to the extent of one lmmbed Italian miles from the coasts and ishands belonging to her. lont in the conse of the nexotiations which led to the conchuson of the treaty of 1s.-t with the Inited States and the treaty of 150.5 with Great Britain, liusiat armitted that her jurisdiction in sild sea should be restricted so as to reach a cannom shot from shore. It appears, that from that time up to the time of the cession of Maskil to the Cnited states, lausia aever asserted in fact or exercised any exchuse jurisdiction in Belring sea or any exchuse rights to the seal fisheries therem beyomel the ordinary limit of territorial waters.

-. Is to the second of the fire points, we, Banom de Courcel, John .II. Iarlan, Lord Itamen, Sir John s. D. Thomptom, Marquis Emilo Visconti-Venosia and fregero W. W. Gram, heing a majority of said arbit ratons, decirle and determine that creat Britain did not reengnize or concede any cham upon the part of Rossia to exchusive juriscliction as to the seal fisheries in Buring sea ontsile the orminary territorial Wilter's.

- Is to the third print, as to so much thereof as requires us to decirle whether the buly of water now known as behring sea was in-

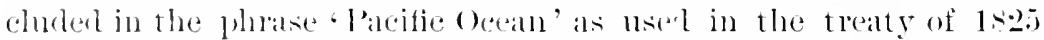
hetween fireat Britain and labssia, we mantmonsly decide and detormine that the horly of water now known als behring tea was iu-

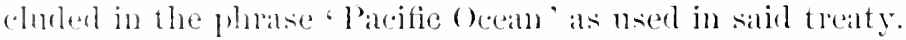

"On the fourth point we decine and determinc that all the rights of lanssia to juriseliotion and to the seal fisheries passed to the Inited states, limited by the cession."

On ahe finh print the decision of the tribmal, Justice Ilarlan and senatur Molgan dissenting, was as follows:-

"On the fifth pint, we, bann de Cumeel, Lord IImmen, sir John $\therefore$ I). Thumpson, Malunis Emilio Visconti-Venosta and Gregero IV. 


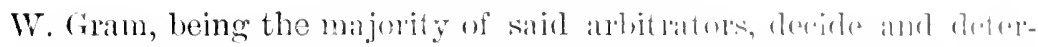

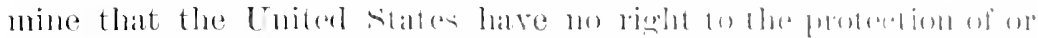

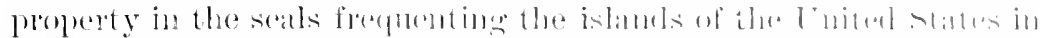

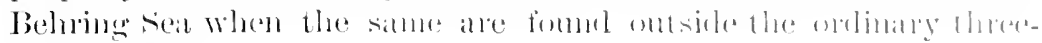
mile limit.

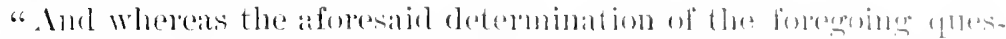

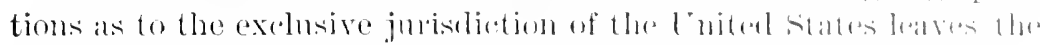

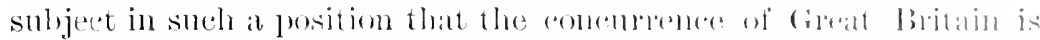

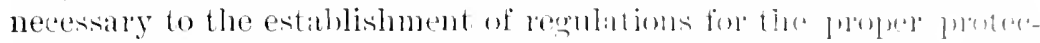

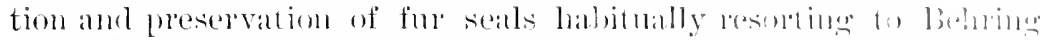

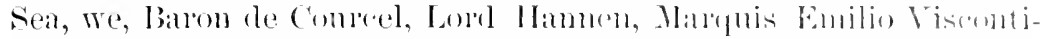

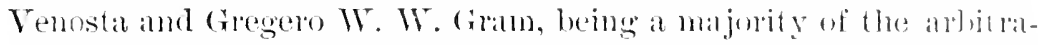
tors, asient to the whole of the nine articles of the following resulattions as necessary entside of the jumistiotion linits of the respertive goverments, and that they should extend over the waters herrinafter mentioned:-

"Art. 1.--The Tuited States and Great britain shall forbil their citizens and suljects respectively to kill, eapture or pmism at any time or in any manmer whatever the animals (ommmonly called fur seals within a zone of sixty miles around the Pribyloti Istanks, inclusive of the territorial water, the miles being geographical miles, sixty to a degree of latitule.

"Art. 2.-The two govermments shall forbiu their atizens or sul,jects to kill, capture or pursue in any manter whatevel during a season extending in each year from May 1 to July 31 inclusive for

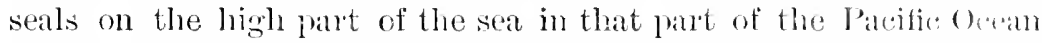
inclusive of Behring tea, situated north of the thirty-fifth rlegres of north latitude, or eastward of the 1soth degree of lomerturle lyom Greenwich until it strikes the water bomdary leseriberl in article 1 of the treaty of 1807 letween the United States and linssia, following that line up to behring straits.

"Art. 3.-During the period of time in the waters in which fursealing is allowed only sailing vessels shall be permitted to (arry omol" take part in fur-sealing operations. They will, however, he at liberly to avail themselves of the use of such cunoes or molecked boats, propelled by paddles, oars or sails, as are in common use as fishing hats.

"Art. 4.-Each sailing vessel authorized to carry on fur-sealing" must be provided with a special license issued for the purpose ly its govemment. Each vessel so employed shall be required to carly a distinguishing flag prescribed hy its goverument.

"Art. 5.-The masters of vessels engaged in fur-scaling shall antel" accurately in an official log-book the date and prace of each operation, the number and the sex of the seals capturerl daily. Therie entries 
shall be communimated ly eale of the two govermments to each

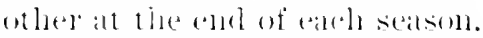

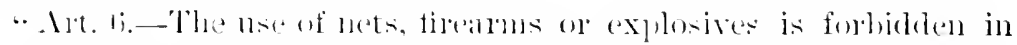

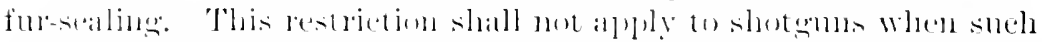

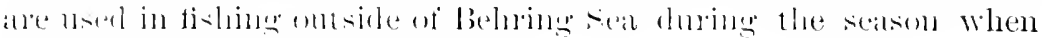

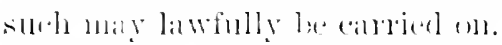

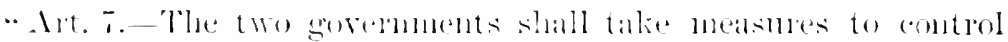

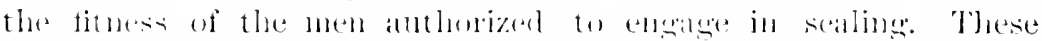

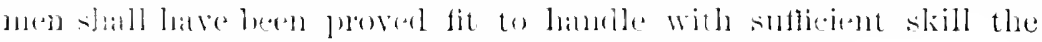

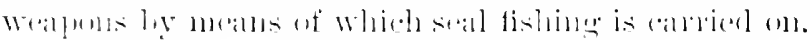

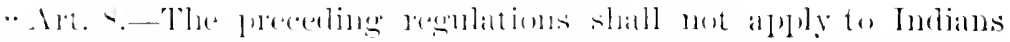

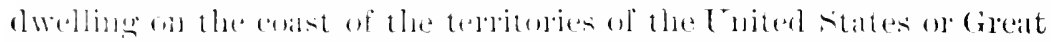

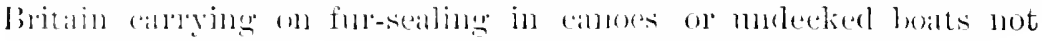

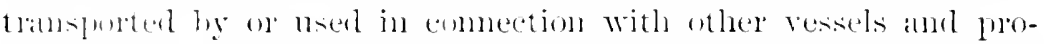
pelled wholly hy pald!les, ans or sals, and mamed ly mot more than five getsms, in the way hitherto patedised by the Indians, purbed that such Indiass are not emploged hy other persons, and powided that when so bunting in comose ol molecked boits the

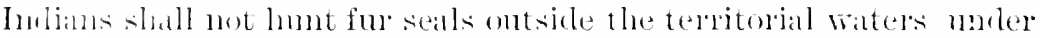
cout ratet to deliver skjus to anglongly. This exemption is not to be

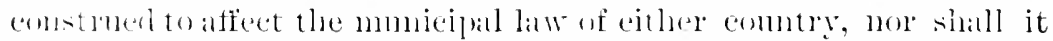

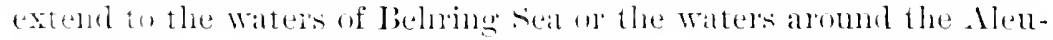
tian lskumis. Xothing herein eomatined is intended to interfere whin the anployment of Indians as lomters on othemise in commection wili saling ressels as lueretofore.

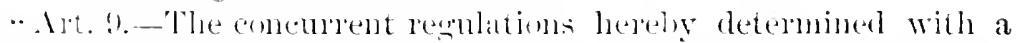

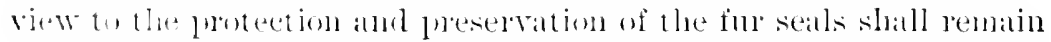

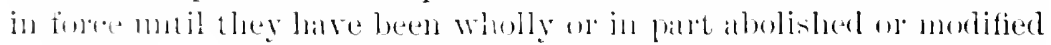

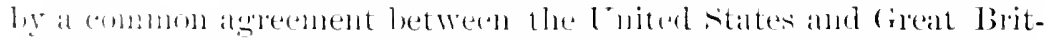

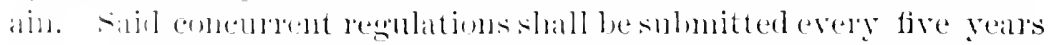
to a mew examination in oreler to enable both govermments to com-

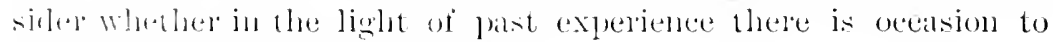
mati: an! mulitication thereol."

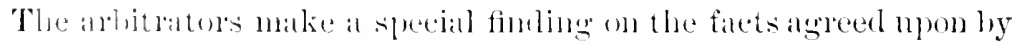

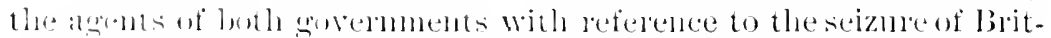

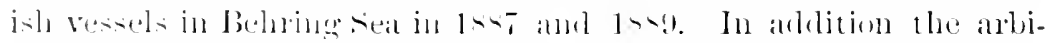

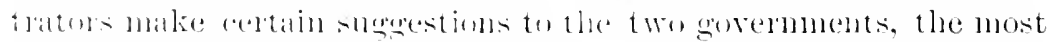

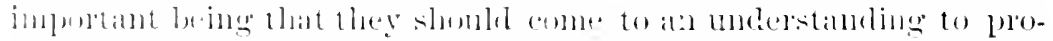

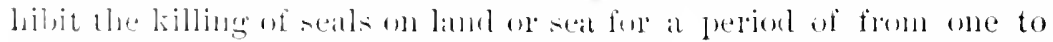
there yeats and should enact legulations to carry out the dindings of lle allitlattus.d

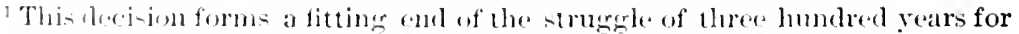
the free 1,sen the seds: it is to be hoped that it will not again be questioned. 
P.

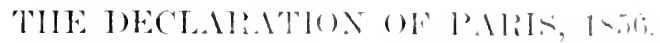

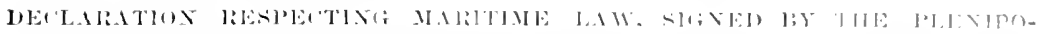

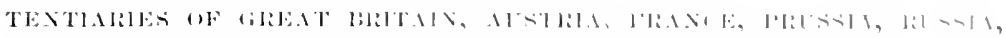

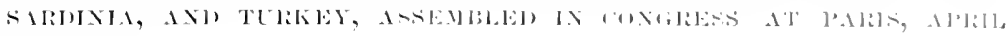
16,1806 .

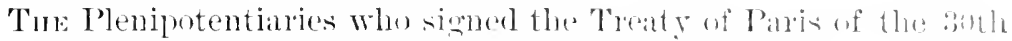

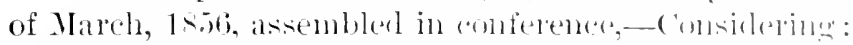

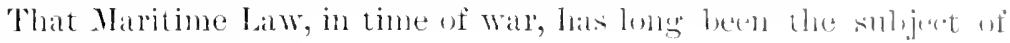
deplorable rlisputes;

That the uncertainty of the law, and of the dution in sinch at matter, gives rise to diffurences of opruion between montrals and belligerents which may occasion serious difficulties, and सcur moflicts;

That it is eonsequently arbantageons to establish a mifom doxtrine on so important a point:

That the Plenipotentiaries assembled in Conmess at Paris anmot better respond to the intentions hy which their goremments alde animated than hy seeking to introduce into international redations fixed principles in this respect:

The above-mentioned Plenipotentiaries, being duly anthorizel. rasolved to concert among themselves as to the means of attainines this object; and, having come to an agreenent, have adopted the following solemn declaration:

1. Privateering is, and remains abolished.

2. The neutral flag cover's enemy's goods, with the exception of contraband of war.

3. Nentral goods, with the exception of contraband of war, alle not liable to capture under the nemy's flag.

t. Blockades, in order to he himing, must be efiectire, that is to say. maintained by a force suticient really to prevent aceess to the coast of the enemy.

The Goremments of the untersioned Pleniputentianies enginge to bring the present Declaration to the knowledse of the states which have not taken part in the Congress of Paris, and to invite then to accerle to it.

Convineed that the maxims which they mow prodain camont but be received with gratitude by the whole work, the molurigned Plenipotentiaries doubt not that the efforts of thein gurements to obtain the general adoption thereof will be trowned with full suc. cess. 
The present Declaration is not and shall not be linding. except

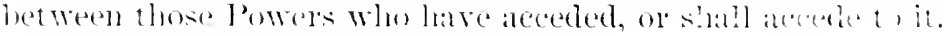

Done at l'aris, Iplil lli, 15 ini.

C.

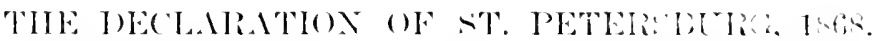

Comsiderine that the puogeres of civilizations should have the efleet of alleviating ats molleh as possible, the callamities of wall ;

That the only legitimate object which states shomld embearon to acemplish during war is a wealien the military force of the enems:

That for this purpose, it is suflicient to disable the greatest possible number of men;

That this object wombl be exceeded by the employment of arms which meelesily agralvate the sufferings of disabled men, or render their death inevitable:

That the employment of such arms would, therefore, be contrary to the laws of lummanity ;

The contracting parties engage, mutually, to renomec, in ease of war among themselves, the emplogment, by their military or natral forces, of any projectile of less weight than fom hmmlex grammes, which is explosive, or is charger with fuminating or inflammable substances.

They aglee to invite all the states which have not talien part in the deliberations of the International Military Commission, assemherl at sit. Petershum, hy semding delegates thereto, to acede to the plesent engargenent.

This colgagenent is olligatory only upon the contracting or accetime parties thereto, in ease of war between two or more of themselves; it is not applicalle with resurel to non-contracting powers, or powers that shall not have aceeded to it.

It will also cease 10 lo oldigatery from the moment when, in a

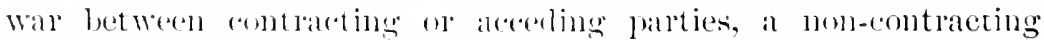
farty, ol a non-alecoling party, shall join one of the belligerents.

The antracting or acceding paties reserve to themselves the right to come to an muderstanding. hereafter, whenever a precise proposition shall be drawn ul. in view of fatme implorements Whirh may he effecter in the armament of troops, in oreler to maintain the principles which they lave established, and to reconcile the necessities of war with the laws of humanity. 
D.

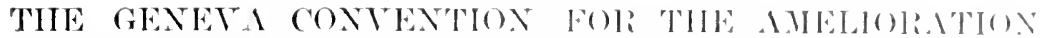

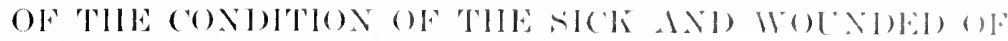
ARMIES IN THE FlEJI).

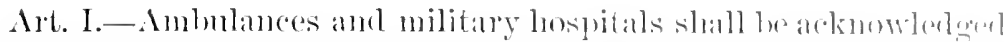

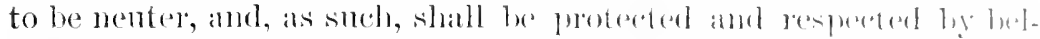

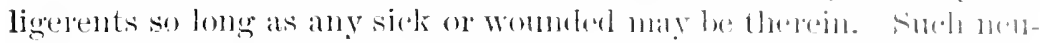
trality shall cease if the ambulances or hosplitals shonld be held l,y a military force.

Art. II.-Persons employed in hospitals and ambulances, onmprising the staff for superintentence, molical service, andmintration, transport of wounded, as well as chaplains, shall participate in the benefit of nentrality, while so employerl, and so long as there remain any wombled to bring in or to snecor.

Art. II.-The persons designated in the preceding article may. even after oceupation by the enemy, continue to fulfill theije dutius in the hospital or ambulance which they serve, or may witharaw in order to rejoin the corps to which they helong.

Under such ciremustances, when these persons shall canse from their functions, they shall be delivered by the occupying army to the ontposts of the enemy.

Art. IV.-As the equipment of military hospitals memains suljoet to the laws of war, persoms attached to such hospitals ("amont, in withdrawing, carry away any articles but such as ale their grivate property.

Under the same circumstances an ambulance shall, on the eontrary, retain its equipment.

Art. V.-Inhabitants of the country who may bing lolp to the womded shall be respected, and shall remain fres. The gemerals of the belligerent powers shall make it thejr care to inform the inhahitants of the appeal addressed to their humanty, and the nentrality which will be the consequence of it.

Any wounled man entertained and taken care of in a homse shall be considered a protection thereto. Any inhabitant who shall havo entertained womder men in his house shall be exempted from the quartering of troops, as well as from a part of the contribntions of war which may be imposed.

Art. VI.-Wounded or sick soldiers shall be entertained and talien care of, to whatever nation they may belong.

Commanders-in-chief shall have the power to deliver immediately, to the outposts of the enemy, soldiers who have been wounded in an 
engigement, when circmmstanees germit this to be done, and with the collsent of both parties.

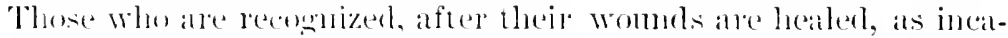

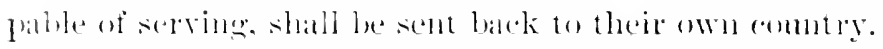

The others mat also be seme latek, on condition of not bearing

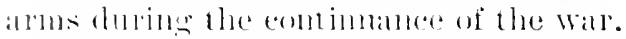

Evandations, together with the pronos moler whose direction

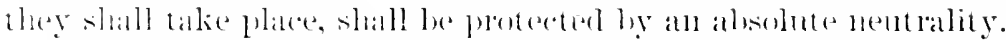

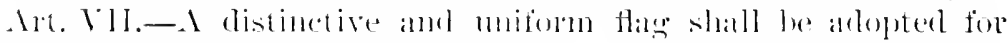
hosiptals. ambulantes. and evachations. It must on erery oceasion

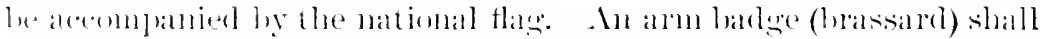
alow be allowed for individnals neutralized, but the delivery thereof shatl be left to military anthority.

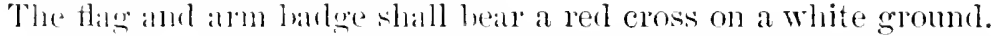

Art. VII.-The details of execution of the puesent envention

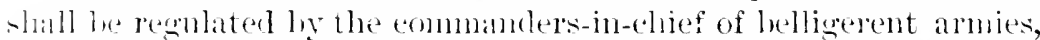
arenrling to the instructions of theil respective governments, and in conturmity with the general principles la id down in this convention.

Art. IX.-The high contracting powers have agreed to commmirate the present anvention to those governments which have not fommel it convenient to send plenipotentiaries to the Intruational (invention at Geneva, with an invitation to acede thereto; the fortocol is for that purpose left open.

Irt. X.-The present convention shall be ratified, and the ratifications exchanged at berne, in four months, or sooner if possible. ${ }^{1}$

E.

\section{INTTIRTCTIOAS}

FOR TIIL:

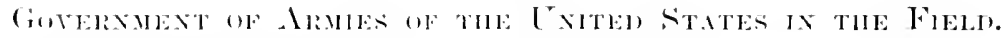

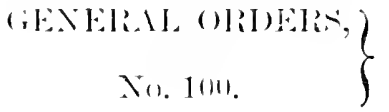

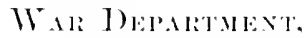

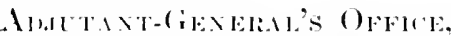

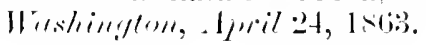

The following "Instructions for the cirvermment of Armies of the

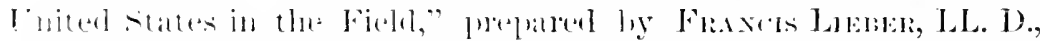

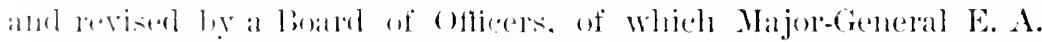

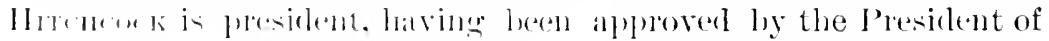

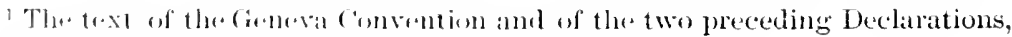
i- laken from the Apendix of Davis" International Law. 
the Enited states, he commands that they le fmblished fin the information of all coneerned.

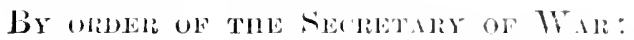
E. 1). T(O) N-ixis,

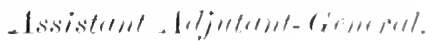

\section{SECTION 1 .}

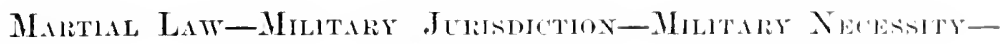 Rethattox.}

1. A place, district, or comntry ocempied by an enemy stamk, in eonsequence of the ocemation, muler the Martial Law of the invin-

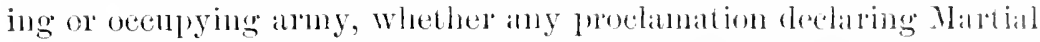

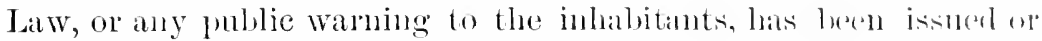
not. Martial Law is the innediate and direet effect and consennence of ocenpation or conquest.

The presence of a lostile army proclaims its Martial Law.

2. Martial Law does not ceatse doring the lostile ocemplation. except by special proclamation, orlered by the commanter-im-chief ; or by special mention in the treaty of peace conchuling the was, when the occulation of a place or territory continum beyomb lun conchusion of peace as one of the conditions of the same.

3. Martial law in a hostile eomotry consists in the suspension, by the ocempying military antlority, of the elininal and civil lat and of the domestic administration and govermment in the ocenpied plates or territory, and in the substitution of military rule and forere for the same, as well as in the dictation of general latws, as far als military necessity requires this suspension, sulstitution, or rlictation.

The commander of the forces may proelaim that the anministrattion of all civil and penal law slabl continne, either wholly al in part, as in times of peace, muless otherwise ordered hy the militiry authority.

4. Martial Law is simply military authority exereised in acoorelance with the laws and nisages of War. Military ofperessiont is ant Martial Latw; it is the aluse of the power which that law comfers.

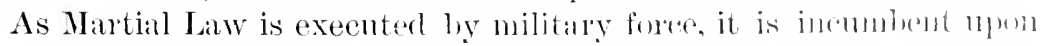

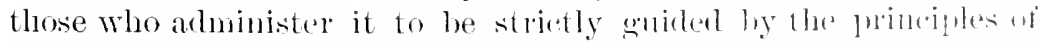

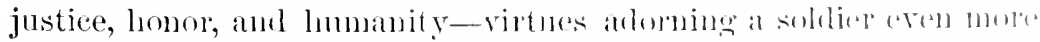
than other men, for the very reason that he possesses the pomer of his arms against the unarmed. 
5. Martial law shonld be less stringent in places and combries

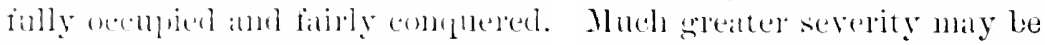

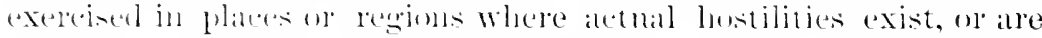

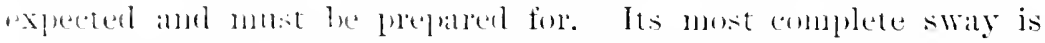
allower - even in the commanders own comntry-when falce to falce

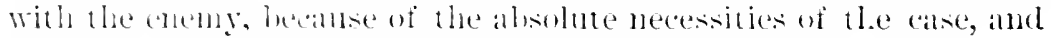

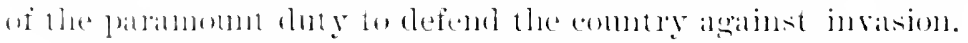

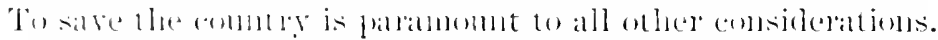

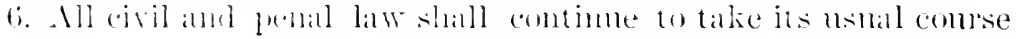

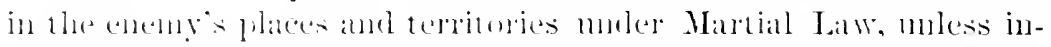

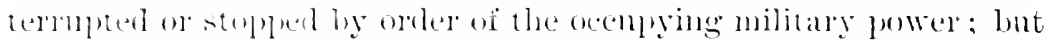
all the fomoloms of the hosile gorermuent-legislative, execontive,

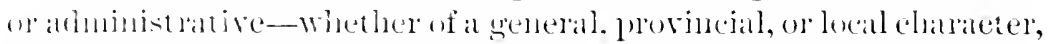
carac under Mantial Lalw, or continne mly with the sanction, of if deeined necessing, the participation of the ecenpier or invader.

7. Mandial Law extemols to property, and to persons, whether they are sulijects of lhe enemy or aliens to that govermment.

\&. Cimsuls, anomg American and Emogean nations, are not diplomatic agents. Nevertheless, their offices and persons will be subjeeted to Martial Law in calses of urgent necessity only : their propeng and businesin ane next exempted. Any delindineney they commit atrinst the established military role may be funjshed as in the case of any other inhabitant, and such pmishment funishes no reasonable gremel for international complatint.

9. The functions of Ambaksalor's, Ministers, or other diphomatic agents, aceredited ly nentral powers to the lostile govermment,

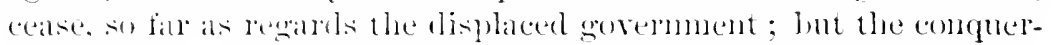
ing or ox"mping power ustally recognizes them as temporarily accoeditcel to itacelt.

11. Martial Law affects chiefly the police and collection of pmblic

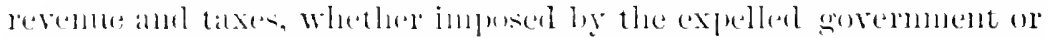

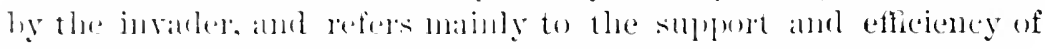
the aluy its satery, and the safely of its operations.

11. The latw of war dees not only disclaim all crobely and bad

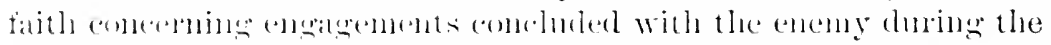
war. lut also the bualimas of stipmlations solemmly comtrated by

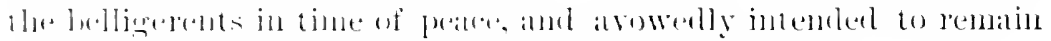

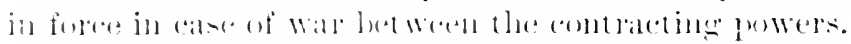

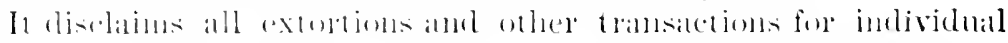

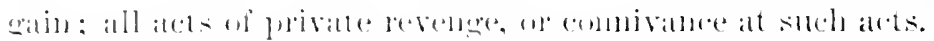

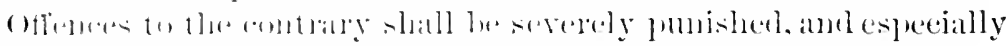

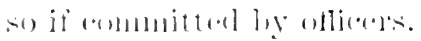

12. Whenever feasible, Martial Latw is carried ont in cases of in- 


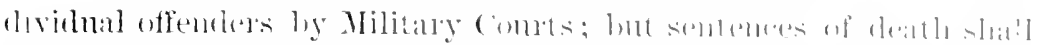

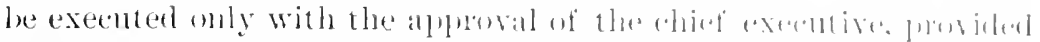

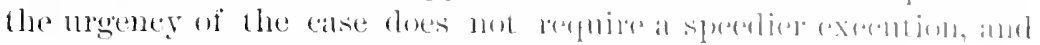

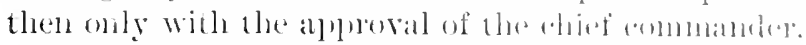

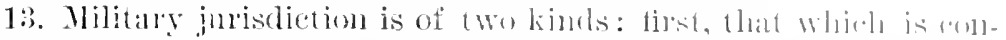

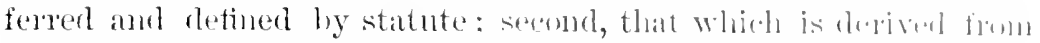

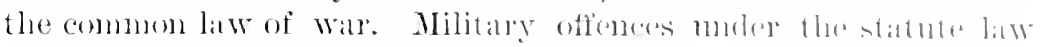
must be tried in the mamer themein direeterl : Mn military oflomes which do not come within the slatute must be tridelant punisher

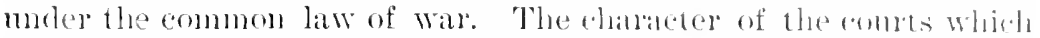
axereise these jurisdietions depends upon the local lats of atch particular eountry.

In the ammies of the Cnited states the first is exereised ly yourtsmatrtial ; while canes whieh do not come within the "linles anm Articles of War," or the jurisdiction eonfereded by statute on entrtsmartial, are trier by military commissions.

14. Military necessity, as morterstood by modem ejvilized nations. consists in the necessity of those measmes which are indispussible for seemring the enrls of the war, and whieh ante lawful atemoling to the molem law and usages of witr.

1.) Military necessity anduts of all direct destruction of life ar limb of armed enemies, and of other persoms whose destrotetion is incidentally ameroridele ju the armed contests of the war ; it allows of the capturing of every armed enemy, and every enemy of immoltance to the hostile government, or of peenlian danger to tle andur : it allows of all destruction of property, and obstruetion of cle ways and chamnels of traffic, travel, or communieation, and of all withholding of sustenance or means of life from the eneny ; of the apr-

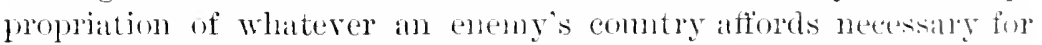

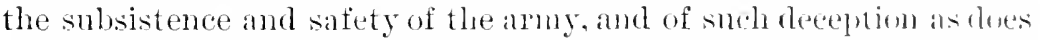
not involve the breaking of goxt faith either positively pledperl, regarding agreements entered into rluring the war, or sllphesed ly the molern law of war to exist. Men who take nl arms against one another in public war do not gease om llis acenut (o) he molnal beings, responsible to one another, and to cont.

16. Military necessity does mot adunt of cruelty, that is, the infliction of suffering for the sake of suffering or for levence, ma of maiming or womkling except in fight, nor of tontme to cxtort andfessions. It does not admit of the nse of poison in any way mo of

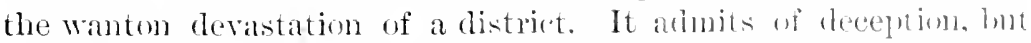

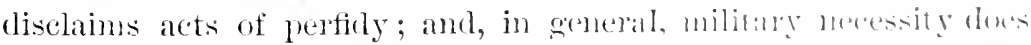
not inelurle any act of hostility which malies the return bo beater unnecessarily difficult. 
17. War is not carped on hy atms alome. It is lawful to stare the hostile belligerent. anmel or murmed, so that it leats to the

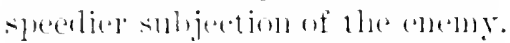

15. Whan the ammander of a besieged platere expels the non-

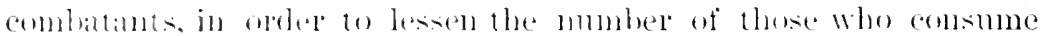

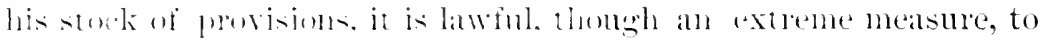

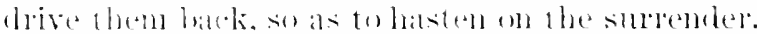

19. Commanders, whenered ahmin-ible, inform the enemy of their intention to lemband a plateresothan the mon-combatints, and eslectally the women and chilelen. may be lemosed befole the lom-

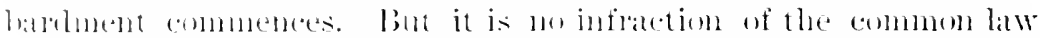
of wall lo omit thus to inform the enemy. Simprise maly be a netersity.

29. Poblic wal is a state of amed hostility between sovereign mations or gurelmments. It is a law and leyuisite of eivilized existence that men live in politieal. onntinums societies, forming

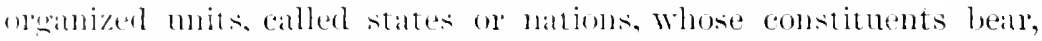
(njuy, and sutfer, advance and retrograde together, in peace and in wat:

21. The citizen ol mative or a hostile comntry is thus an enemy. ats one of the eomstitments of the hostile state or nation, and as stleh is subjecterl to the hatrdships of the wall.

o.2. Xevertheless as civilization has arbanced during the last cemturies, so has likewise steatily atramoel, especially in war on

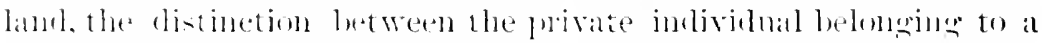

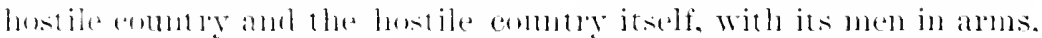

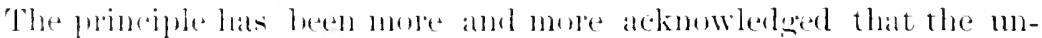

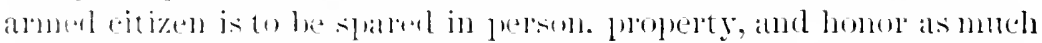
as the exienele of wat will almit.

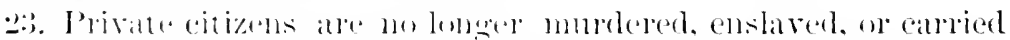

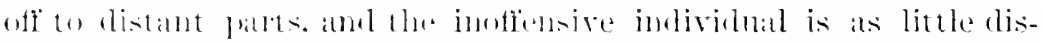

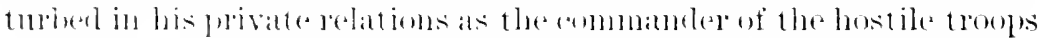

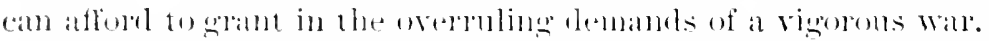

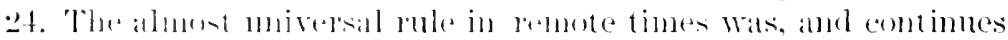

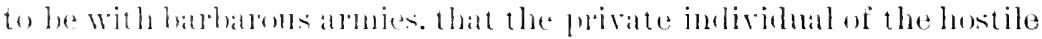

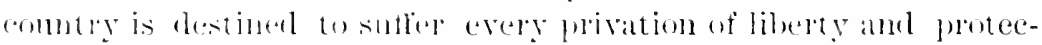

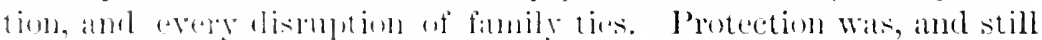

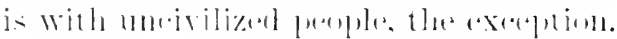

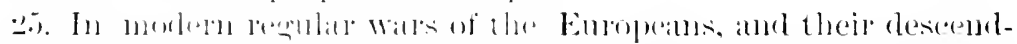

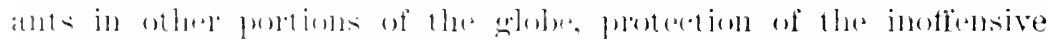

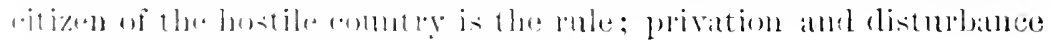

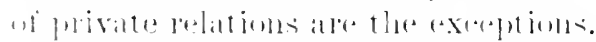

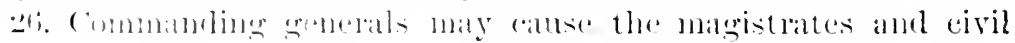




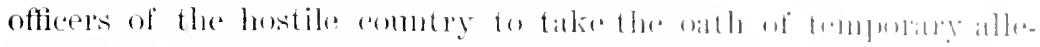

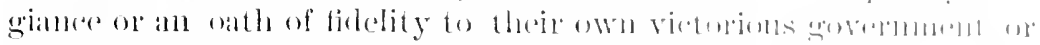

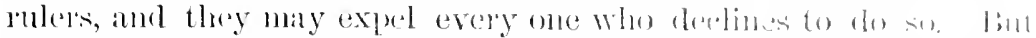

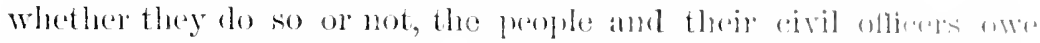

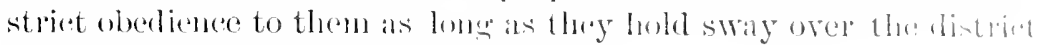
or comntry, at the peril of their lives.

27. The law of war (am no mole wholly dispense with retaliation

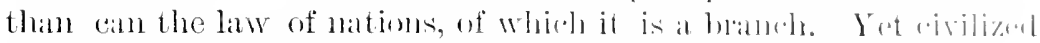
nations acknowledge retaliation as the stronest toathle of wall. A

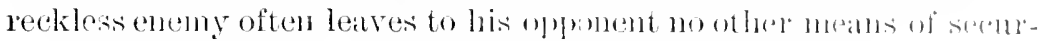
ing himself against the repetition of harbatrus ont later.

2R. Retaliation will, therefore, nerer be lesorted to as a measmon al mere revenge, hat only as a means of plotedive retribution, and, moleover, cantionsly and mavoldahly; that is to saly, rolaliation shall only be resortel to after calrefol induiry into ble leal anellrence, and the charater of the misteeds that may hemand remibntion.

Cujust or inconsiclerate retaliation removes the belligerents farther

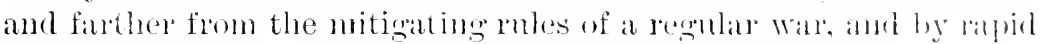
steps leads them nearer to the internecine wars of salvans.

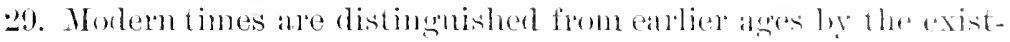

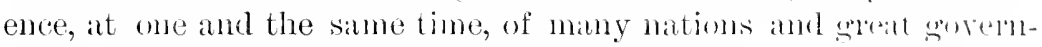
ments related to one another in elose intercomrse.

Peace is their nomal eondition; war is the exeeption. The nhtimate object of all mortern war is a renewer state of puree.

The more vigoromsly wars are pursued, the better it is for hmmanity. Sharp war's are brief.

30. Ever since the formation and eo-existence of 1nolem nations? and ever since wars have become great mational wars, wal has come to be acknowledged not to be its own end, hut tho means a ohatio great ends of state, or to comsist in defence asamst wromp : and no, eonventional restriction of the modes antopted to injum the anum is any longer admitted but the lat of war imposes many limitations and restrictions on principles of justice, fath, and homent.

\section{SF,TION II.}

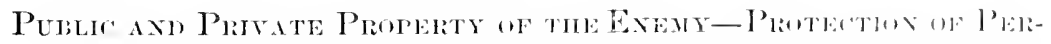

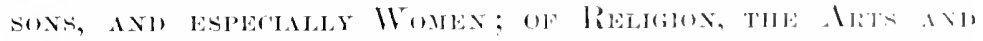

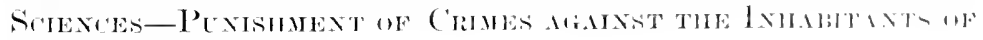
IJostile Colexties.

31. A victorious army alpropriates all public money, seizes all public movable property until further direction by its gorernurent, 


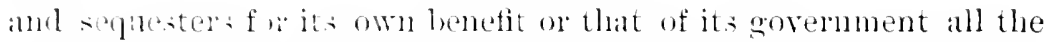
levenum of real property belomging to the hostile sovermment or

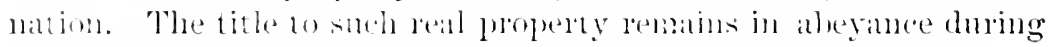
military oecountion, and mut the eompuest is mate complete.

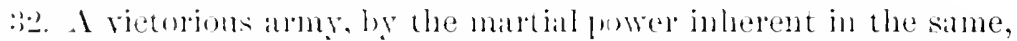
maly smend, change, or abolish, ats far at the martial gower extends,

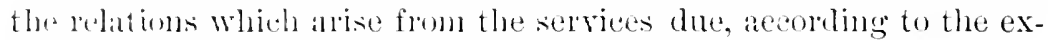
isting laws of the invaled comntry, from one eitizen, subjeet, or natlive of the same to anothere.

The commancle of the army most leave it to the ultimate treaty of peace to sertle the permaneney of this chatrge.

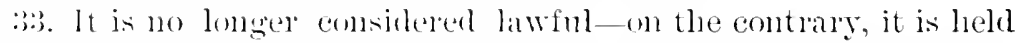

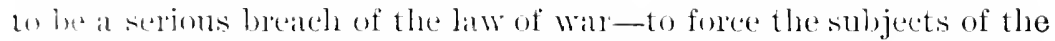
emomy into the servee of the victorions soremment, excest the lat-

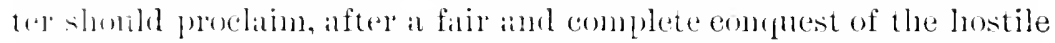
commtry on district, that it is resolved to keep the commery, distriet, ar phace permanently as its own, and make it a portion of its own comint?

:3. As a gencral mule, the property belonging to churches, to hospitals. of of here establishments of an exehusively charitahle chamater, to estallishments of education, of foumbations for the promotion of knmwelge. whelher public sehools, miversities, academies of leannind, or observatories, museums of the fine arts, of of a scientifie (binlater-such property is not to be considered public property in Ihe semse of paraglatph :31; l)ut it may be tixed or used when the jullite servire maly repulire it.

3i- classical works of art, libraries, seientific collections, or prefonts instruments, such as astromemical teleseones, as well as lompitals, must be secomed against all aroblalule injury, even when they ane contaned in fortitied platees whilit lexienged or bombatred.

3it. If such works of art, librarjes, collecoloms, or instruments be-

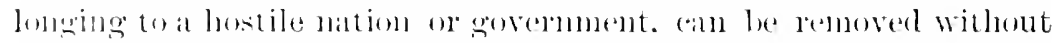
injury, the ruler of the enmuering state or natiom may onder them

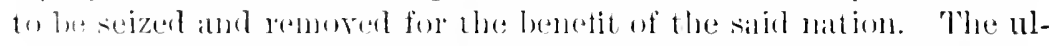

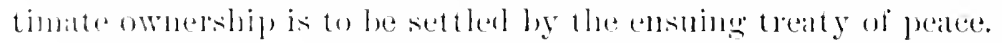

In me rase shall they be sold or siven awaly if eaptured ly the

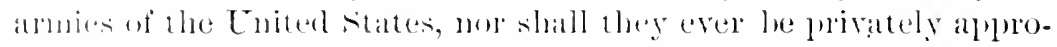
priaterl, ar wantonly (lestroyed or injureal.

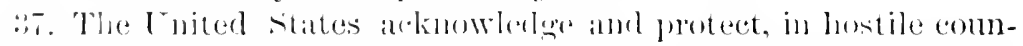

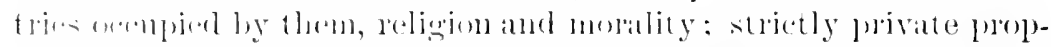

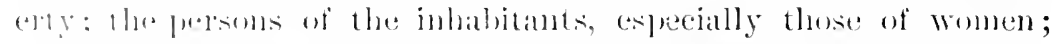

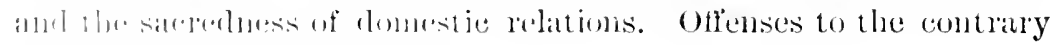
shatl tre rigumem punished. 


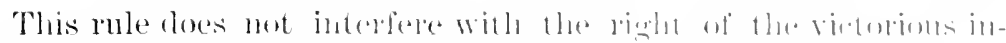

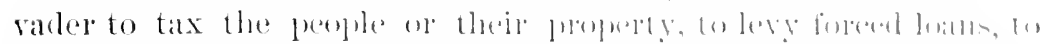

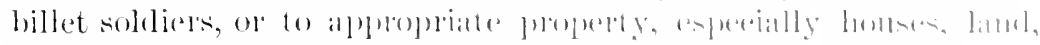

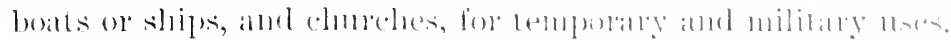

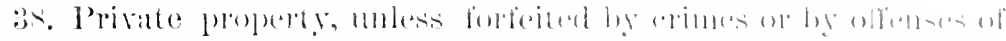

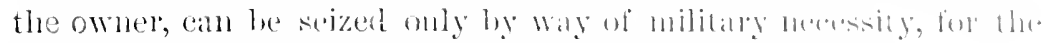
sulport or other benefit of the army of the finter statis.

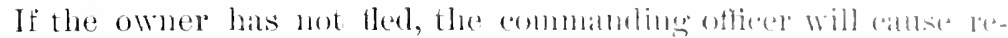
ceipts to be given, which may serve lle spoliated omner to whitin indemnity.

39. The saluries of eivil officess of the hostile goremmont who remain in the invaler territory, and amtinne the work of thoil

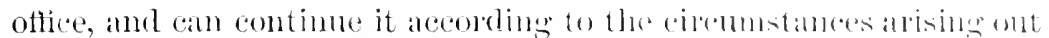

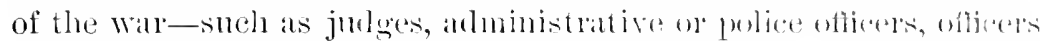
of eity or communal govermments-are paid foum the public reverme of the invaled territory, mntil the military gorermment has reasom wholly or partially to discontinne it. Saluries or incomes combected with purely homorary titles are always stoplerl.

40. There exists no law or borly of anthoutative rules of andion between hostile anmies, except that branch of the law of mature and nations which is ealled the law and usages of war om land.

41. All municipal bar of the gromml on whide the ambies stambl, or of the comntries to which they ledomg, is silent amm of no coflect between armies in the field.

42. Slavery, complicating and confomming the ideas of propurty (that is of a thing), anel of personality (that is of hemenily), exists according to municigal law or lecal law only. The law of mature and nations has never ackunderlged it. The digest of the limman law enacts the early dictum of the pagan jurist, that "so far an the

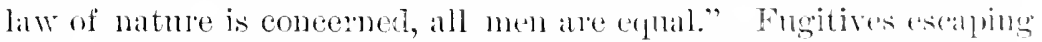
from a combly in which they were slaves. villains, or serfis, into an-

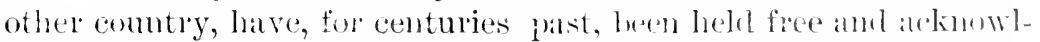

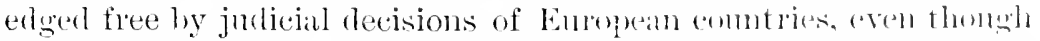
the municipal law of the enontry in which the slave had talien refouge acknowlerged slavery within its own dominions.

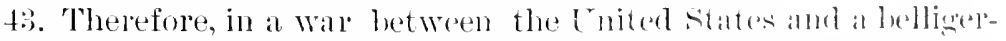
ent which admits of stavery, if a person held in homdage ly that

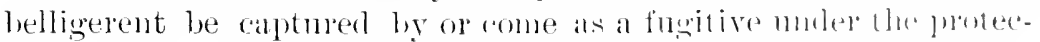

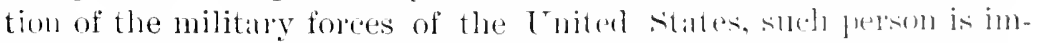
merliately entitled to the rights and privilexwes of a firesman. To

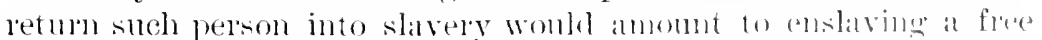

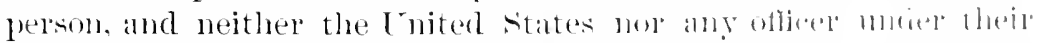
authority can enslave any human being. Moreorel, al lestion sol 
male free hy the law of war is moler the shjeld of the law of mations, and the formere ommer or state can have, ly the law of post.

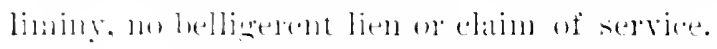

4t. All wantom violende committed agamst persons in the in-

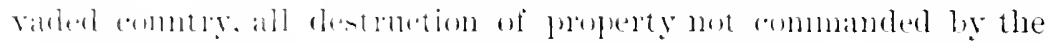

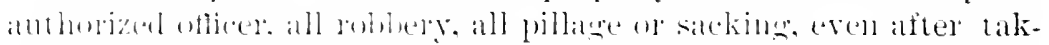

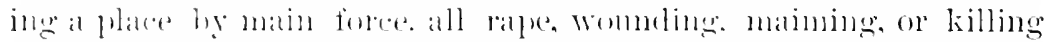

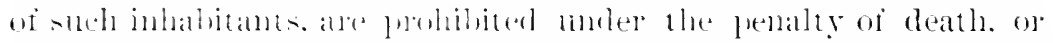

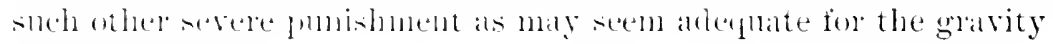
of the ollicuse.

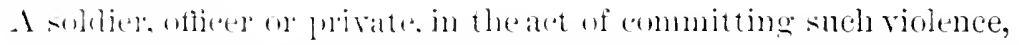

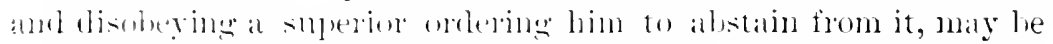

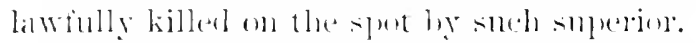

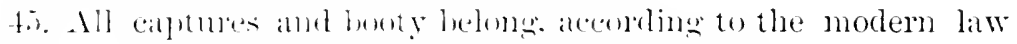

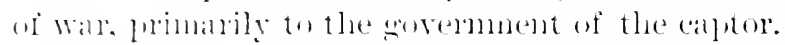

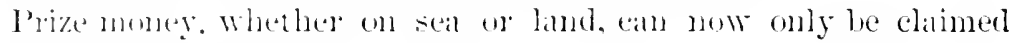

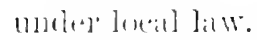

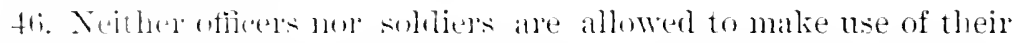

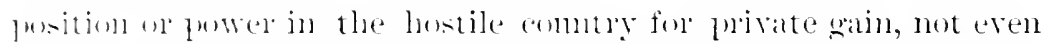
for eommerejal transalelions otherwise legitimate. Otfenses to the

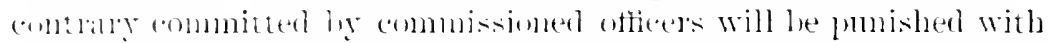

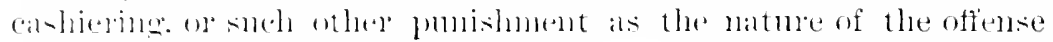
may leguire: if hy solides's, they shall le punished according to the matture of the offense.

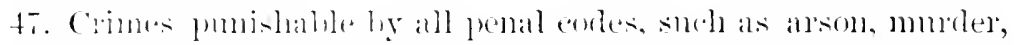
matming. as

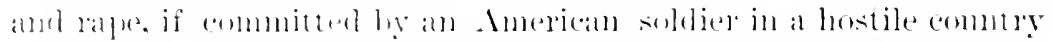

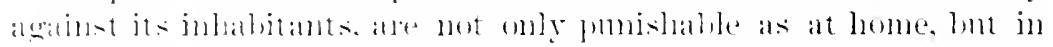
all ascos in which llath is now inflicted, the severer punishment slath be luefurerle

SITTION III.

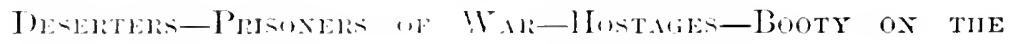
IBITTLE-FILII,

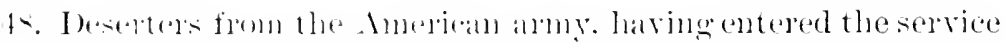

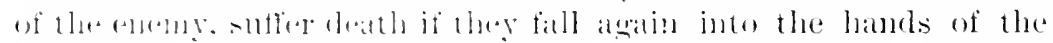

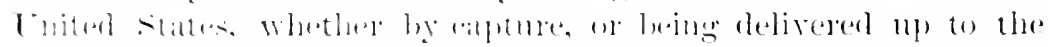

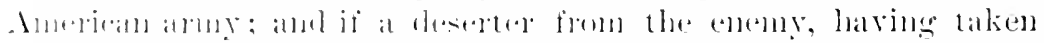

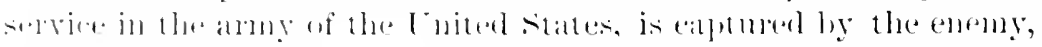

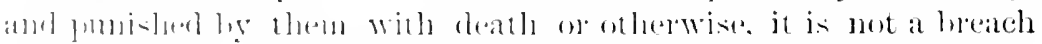

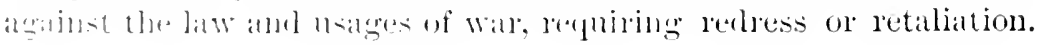




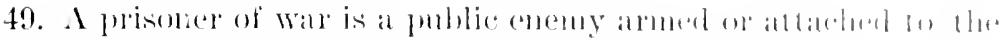

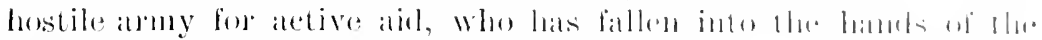

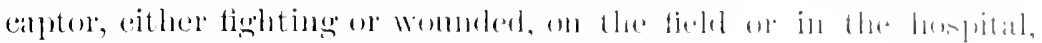
by imlividual smrender or loy atpitulation.

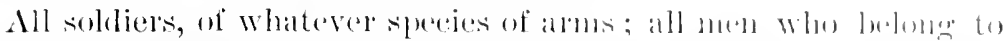
the rising en meese of the hostile commtry ; all those whe alle allatelled to the army for its eflicieney ame promote direetly the ol,ject of thes

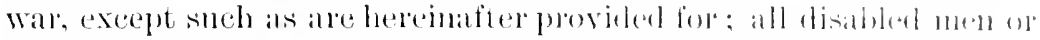

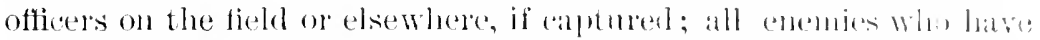
thrown away their arms and ask for puater, are prisonestis of war,

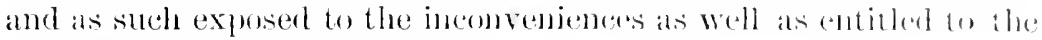
privileges of a prisoner of war.

50. Moreover, eitizens who accompany an andny for whateror lm1-

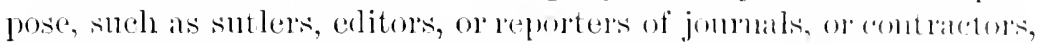
if eaptured, may be made prisomers of wal, and he detained ats smoh.

The momarch and members of the hostile reigning family, mald or female, the ehief, and chief officers of the hostile grovermment, its diplomatic agents, and all persoms who are of particular am simplat use and benefit to the hostile army or its govermment, arr, if alptured on belligerent gromed, and if momovided with a safe conduet granted by the captor's government, prisoners of war.

51. If the people of that portion of an invaled enmtry whinls is not yet ocempied by the enemy, or of the whole eomntry, at the arrproateh of a hostile army, rise moler a duly authorized levy, , messe to resist the invaler, they are now treated as public enemies, and if eaptured, are prisoners of war.

5:2. No belligerent has the right to deche that he will tratt ereng eaptured man in arms of a levy en mose as a hrigand or handit.

If, however, the penple of a eomtry, or any portion of llus salue, already ocempied hy an army, rise aldanst it, they are violatons of the laws of war, and are not entitled to their potedion.

58. The eneny's chaphans, oflicers of the medical stafí, apulue. calles, hosplital momses and servants, if they fall into the hamble of the American ammy, are not prisoners of wan' moless the commanmler has reasons to retain them. In this latter case, on if, at their omm desire, they are allowed to remain with their atpmed complumbus, they are treated as prisoners of wan, and mat be exchanged if the eommander sees fit.

54. A hostage is a person ancepted as a pledge for the fullihment of an agreement concluded between belligerents during the war, an in eonseguence of a war. Instages are rare in the present ande.

55. If a hostage is accepted, lue is trated like a prisomer of wat; according to rank and condition, as cireumstances maly adnit. 
5.8. I prisoner of war is sulject to 110 pmishment for being a pullic nemy, nor is any levenge wealied upon him hy the inten-

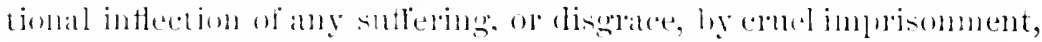

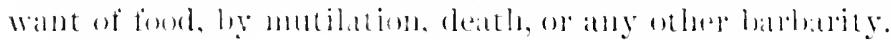

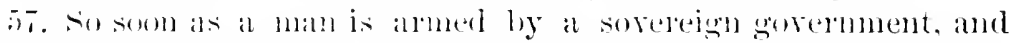

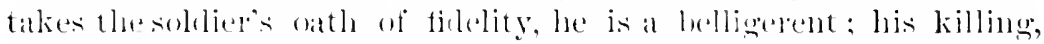

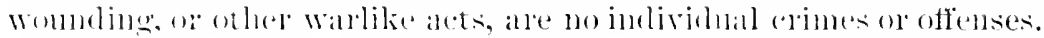

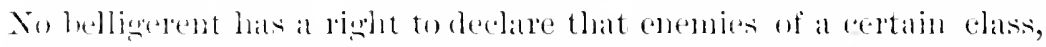

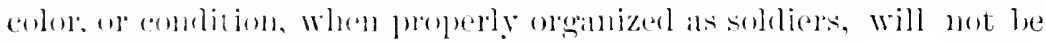

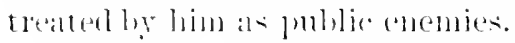

is. Fhe latw of natimus knows of no distinction of color, and if an ememy of the fuitel states shomld enslave and sell any captured gersons of their army, it womk he a case for the severest retaliation,

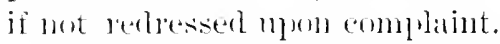

The Luited states camot retaliate ly enslavement; therefore death must be the retaliation for this crime against the lat of nations.

59. A prisoner of war remains answerable for his crimes committerlaninst the captor"s army or people, committed before he was alptured. and for which he has not been punished ly his own anthorities.

All prisoners of war are liable to the infliction of retaliatory measures.

(11). It is against the nage of modern war to resolve, in hatred and revenge, to give no guarter. So body of troops has the right to dieelane that it will not give, and therefore will not expect, quarter;

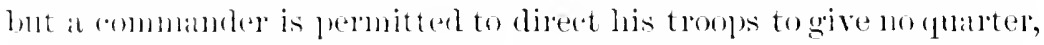
in great straits, when his own salvation makes it impossible to cumbber himself with prisulers.

(il. Thops that gire no guarter lave no right to kill enemies aldarly disiblerl on the gromul, of prisoners expuned by other tinoss.

6iz. All tropps of the eneng known or diseovered to give no quarter in enenelal, or to any protion of the army, receive nome.

(ii). Trows who fight in the nuiform of their enemies, without any platin. striking, anel miform matr of distinetion of their own, can

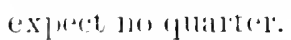

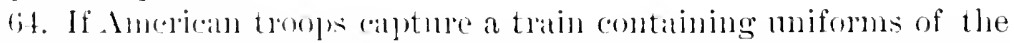

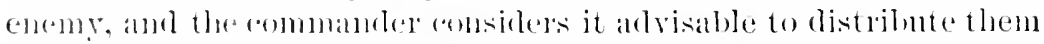
for 11 : andmen his men, some striking mark ol sign must be adopted torlistingmish the Imeriean soldier firom the enemy.

(ji). The nse of the enemy's national stancharl, flag, or other emblem of mationality, for the purpose of deceiving the enemy in battle, 


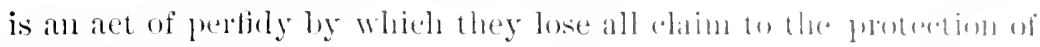
the laws of watr.

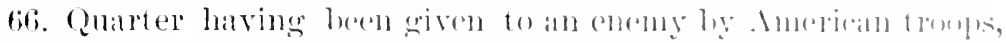

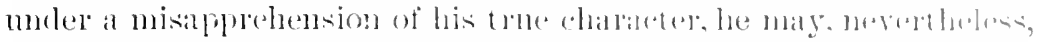

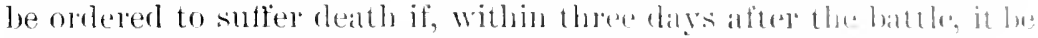

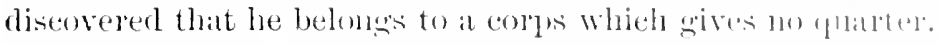

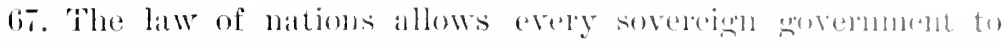

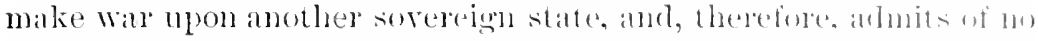

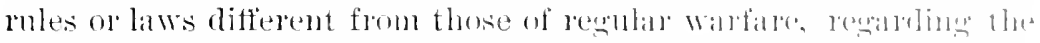

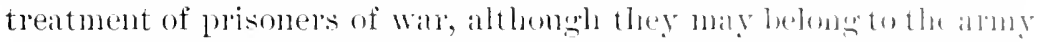
of a govermment which the captor may eomsider as at wanton amb unjust assailant.

6. Morlern wars are not internecine wars, in which the killing of the enemy is the object. The destrution of the enemy in molern war, and, indeed, modern war itself, are means to obtain that object of the belligerent which lies beyond the war.

Ennecessary or revengeful destruction of life is not lawful.

69. Ont posts, sentinels, or pickets are not to be fired mpon, rxerpt to drive them in, or when a positive order, special or general, hats been issiled to that effeet.

70. The use of poison in any mamer, be it to poison wells, or foom, or arms, is wholly exelurled from modern wartare. Ite that nses it puts himself out of the gale of the law and usines of war.

71. Whoever intentionally inflicts additional womolson an enemy already wholly disabled, or kills such an eneny, or whorders of encomages soldiers to do so, shall suffer death, if duly convided, whether he belongs to the army of the Luited states, or is an enemy captured after having committed his misdeed.

72 . Doney and other vabubles on the person of a prisoner, sum as watches or jewelry. as well as extra clothing. are reginded by the American army as the private property of the prisoner, and the appropriation of such valuables or money is considered dishomoralite, and is probilited.

Nevertheless, if lurge sums are found upon the persons of prisoner's, or in their possession, they shall be taken from them, and the sulplus, after providing for their own sipport, appropriated for the use of the army, under the direetion of the commander, mless ot herwise ordered by the government. Nor can prisoners claim, as privite property. large sums found and eaptured in their train, althomgh they had been placed in the private luggage of the prisoners.

73. All officers, when captured, must surescler their side-ilms to the eaptor. They may be restored to the prisoner in marked cases, by the commander, to signalize admiration of his distingushed 
bravery or approbation of his humane treatment of prisoners hefore his alume. The eaptured officer to whom they maly be restored cammot weal them doring ealptivity.

7t. I misoner of war heing a public enemy, is the puisoner of the

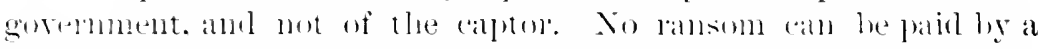

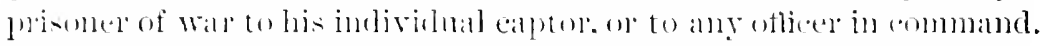
The weremnent alone relenses captives, andonding to rules preseribed hy itsilt.

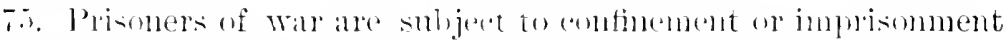

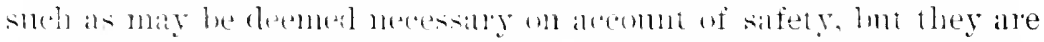
to be subjected to no other intentional sutrering on indignity. The

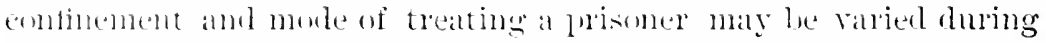
his calp tivity aceording to the demands of safety.

7i. l'vismers of war shatl be feel upon plain and wholesome food whenerer pacticable, and treated with hmonity.

Theer mily be required to work for the bencit of the captor's gorernment, aceording to their rank and condition.

7. I prisoner of war who escapes may be shot. or otherwise killed in his flight; but neither death nor any other pmishment shall be inilieted nom him simply for his attempt to escape, which the law of war does not eonsider a crime. Stricter means of security shall he n-ed after an mosucessful attempt at escape.

It. however. a conspiracy is discovered, the purpose of which is a miterl or general escape, the conspirators may be rigoronsly punished, eron with death: and capital punishment may also be inflicted upon mismers of war discovered to have plotted rebellion agalinst the anthorites of the captors, whether in union with fellow-prisoners or other pereons.

‥ If guinoners of war. having given no pledge nor made any promise on their honor, forcibly or otherwise escalpe, and are calptured atwin in battle. aiter laring rejoined their own army, they shall not be pmished for their eseale, but shall be treated ats simple prisoner's of War. althougl they will he suljected to stricter confinement.

7!. Every eaptured womned enemy shall be medically treated, accombling to the ability of the medical statf.

-11. Ifmonalue men, when calpturet, wiil abstain from giving to the enemy information concerning their own army, and the modern law of will permits no longer the nse of any violence against prisoners in orres to extort the desired information, or to punish them for harving given false information. 


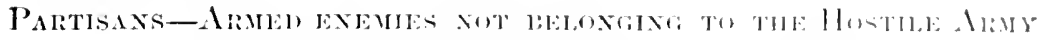

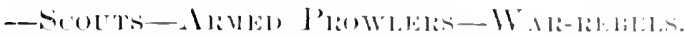

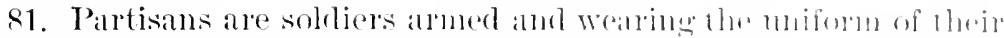

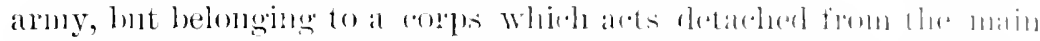

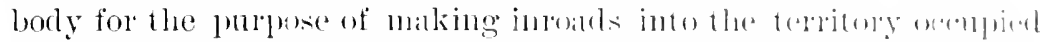
by the enemy. If antureal, they are entited to all the priviluen of the prisoner of war.

8.. Men, or squads of men, who ammit hostilities. whether ly fighting, or inroads for destruction of plumber, of ly ralis af ally kind, withont commission, without heing late and jomtion of the organized hostile army, and withont sharime continuonsly in the wal, but who do so with intermitimg retums to their lumes and arome

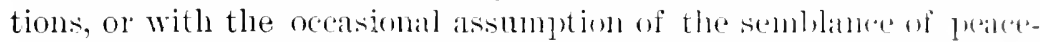

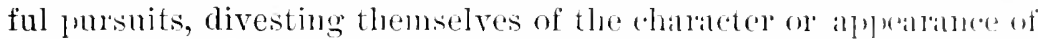
soldiers-such men, or syluds of men, are uot pmble ratantes, and therefore, if captured, are not entitled to the privilenes of prisollers of war, hut shall be treated smmmarily as highway roblers or pirates.

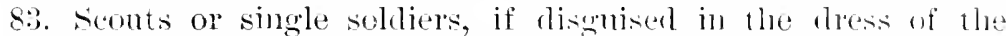
country, or in the uniform of the army lostile to their own, (2m] loyerl in ohtaining information, if fouml within or lneling abont the lines of the captor, are treated as spies, and suffer death.

8t. Armed prowlers, by whatever mames they may le alled, or persons of the eneny's territory, who steal within the lines of the hostile army, for the purpose of roblung, killing, or of destroying bridges, roals, or canals, or of roblying or lestroying the mail. or of cutting the telegraph wires, are not entitled to the privileges of the prisoner of war.

85. War-rebels are persons within an ocenpied territory who rise in arms against the occupging or conquering army, or against the authorities established by the same. If capturer, lhey may sulfel death, whether they rise singly, in small or large hands, and whether called upon to do so by their own, but expelled, govermuent or mot. They are not prisoners of war; nor are they, if discovered and securert before their conspiracy has matured to an actual rising, or to arrued violence.

SECTIOS Y.

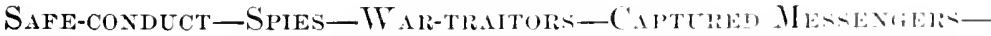
Abuse of THe Flari of Ther E.

86. All intercourse between the territories oceupied by belligerent 35 
armies, whether l,y traffic, ly letter, ly travel, or in any other way, ceases. This is the reneral rule, to be observed without special proclantition.

Exeeptions to this rule, whether hy safe-conduct, or permistion to trade on a small or large scale, or hy exchanging mails, or by travel from one territory into the other, ean take place only aceorling to anreement approved by the govermment, or by the highest military authority.

Contraventions of this rule are highly punishable.

8. Ambassulor's, amd all other diplomatic agents of neutral power's, ancoredited to the ensemy, may receive safe-eomduets through the territories oeconierl by the bedligerents, muless there are military reasons to the contrary, and unless they may reach the plate of their destination conveniently ly another route. It implies no international aff'ront if the safe-conduct is declined. Snch passes are nisually given ly the supreme anthority of the state, and not ly subordinate officers.

x. 1 spy is a person who secretly, in disguise or under false pretense, seeks information with the intention of communieating it to the enemy.

The sly is punishalle with death by hanging by the neck, whether or not he suceed in obtaining the information or in conveging it to the enemy.

a. If a citizen of the Inited states obtains information in a legitinnte mamer, and betrays it to the enemy, be he a military or civil officere, or a luivate eitizen, he shall sutfer death.

96. A trator muter the law of war, or a war-trator, is a person in a place or distriet under mirtial liaw who, manthorized hy the military commanter, gives information of any kind to the enemy, or holds intercourse with him.

91. The wall-taitor is always severely pmished. If lis offense consists in betraying to the enemy anything concerning the conditim, safety, operations or plans of the troops holding or occupying the place or district, his pmishment is death.

6.2. If the eitizen or sulpject of a comntry or place invarled or congueled gives information an his own government, from which he is separated loy the hostile army, or to the army of his gorermment, he is at war-tratitor, and death is the peralty of his offense.

9.3. All armies in the field stand in need of guides, and impress them if they cammot obtain them otherwise.

14. No prefon having been fored by the enemy to serve as guide

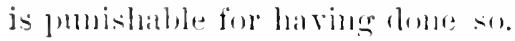

45. If at eitizen of a hostile and invaded district roluntarily serves 


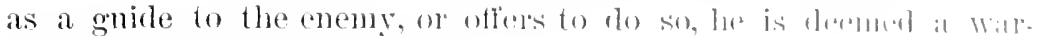
traitor, alle shalls stfer death.

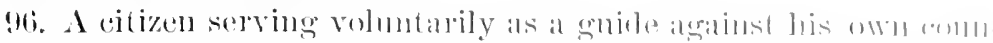

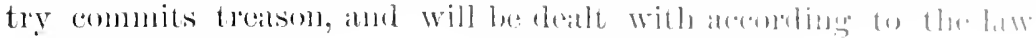
of his commitry.

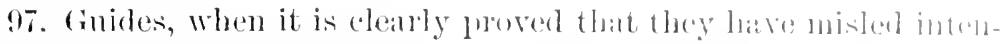
tionally, may be put to death.

98. All manthorized or seceret commmmination with the andenty is considered treasonable by the law of war.

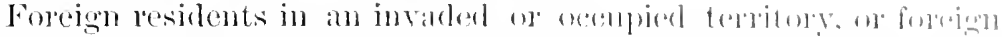

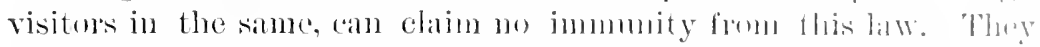

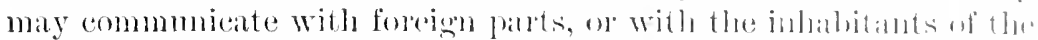
lostile comntry, so fir as the military anthority pormils, but mo further. Instant expulsion fun the ocenpiod forvitory womlat be the very least pmishment for the infraction of this rule.

99. A messenger carrying written dispatches or velpal mescates from one portion of the army, or from a besieger place, formother portion of the same army, or its govermment, if armed, and in the uniform of his army, and if eaptured while doing so, in the torritory ocempied by the enemy, is treated hy the aptor ats a prisomen of war.

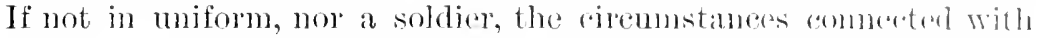
his capture must determine the disposition that shall be madrof him.

100. A messenger or agent who attempts to steal thomaly the forritory occupied by the cnemy, to further, in any mamer, 1 ho inferests of the enemy, if captured, is not entithed to the privileges of lhe prisoner of war, and may be dealt with according to the cinemmstances of the case.

101. While deception in war is amitted as a just and neersingy means of hostility, and is consistent with homolable warfare. 1lur common lav of war allows even capital pmishment for chamblesine or treacherous attempts to injure an enemy, becanse they alre sos dangerous, and it is so difficult to gmard agninst them.

102. The law of war, like the criminal law rexarding othereffomses, makes no difference on acconnt of the difference of sexes, concentuind the spy, the war-traitor, or the war-rebel.

103. Spies, war-traitors, and war-pebels are not exehanged acouril-

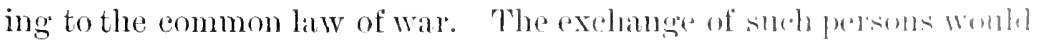
require a special curtel, anthorized by the sovermmont, ar, at al and distance from it, by the chief commander of the andy in the tivil.

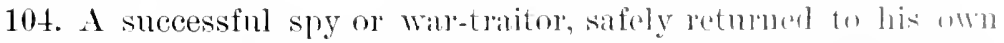
army, and afterwards captured as an enemy, is not subjoct lo punishment for his acts as a spy or wartaitor, but he maly be held in closer custody as a person individually dangerous. 


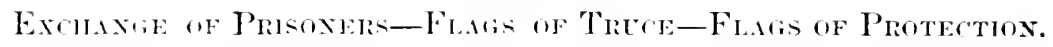

10.i. Exobunges of prisoners take place-number for mumberlank for lank-wombled for wommlerl-with arterl condition for alded comblition-such, for instance as mot to serve for a certain lerisul.

10i. In exchanging prisoners of war. smell mumbers of persons of inferol lank may be substuterl as an equivalent for one of superior

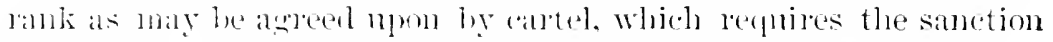
of the wremment. or of the ommander of the army in the field.

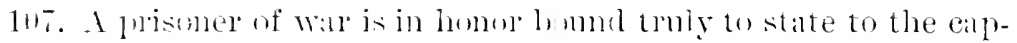
ton litis rank : ancl he is not to asimme a lower lank than belongs to him. in orter to anse a mole alvantarons exchange; nor a higher rink. for the prupose of ohtaining better treatment.

Othenses to the combary have been justly punished by the enmmanders of releaced prisoners, and may be good comse for refusing (1) retease such pitisolners.

112. The surplus nmmber of prisoners of war remaining after an exchange has taken place is sometimes releasel either for the payment of a stipulatel sim of momer, or, in mugent eases of provision, chothins, on other necessintis.

suld armenent, howerel, reprires the sanetion of the highest anthority.

111!. The exchange of prisones of war is an at of convenience to

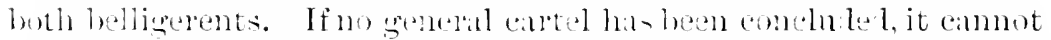
be demanterl by either of then. No belligerent is obliged to exclanger pllismers of watr.

A antul is voluable so som as either party has violatid it.

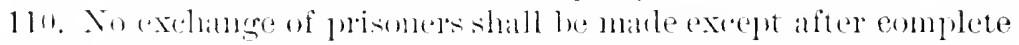

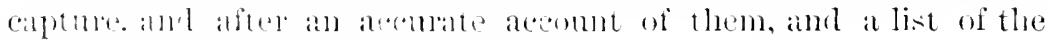

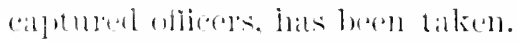

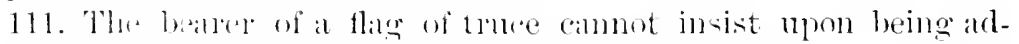

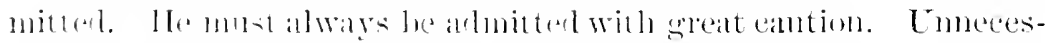

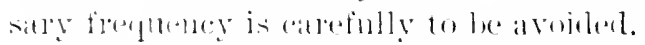

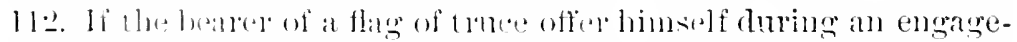
ment. 1he ran be atmited as a vely lalle execplom only. It is no

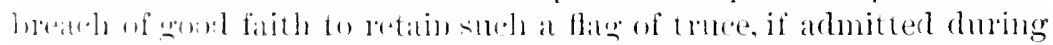

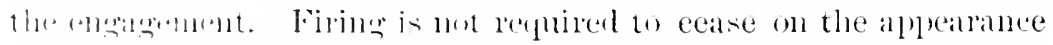
of a flite of 11 llte in bittle.

11:3. li the hearrer of a flag of truce, presenting himself doring an

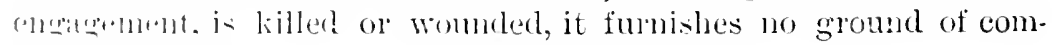
!nitint whitlever. 


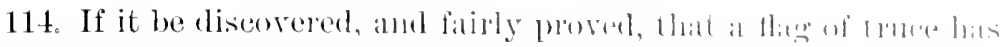

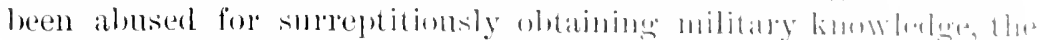

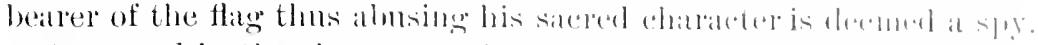

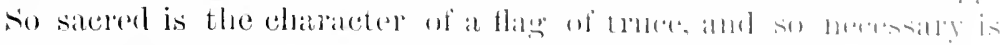

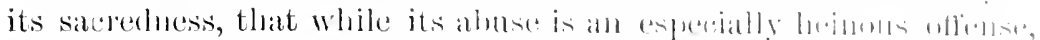

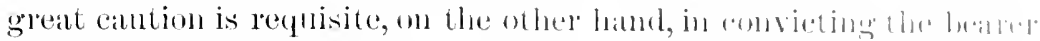
of a than of truce as a spy.

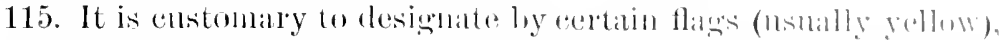

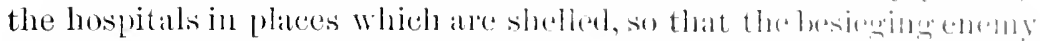
may avoid firing on them. The same las been dome in bilther, whell lospitals are situated within the fickl of the elogigentent.

116. Ionomable belligerents often refuest that the hospitals within the territory of the eneny may be designated, so that they may be sparled.

An honorable belligerent allows himself to be gavical by flags of signals of potection as much as the contingencies and the necesities of the fight will permit.

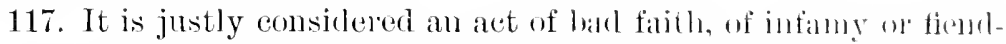
ishness, to deceive the enemy by flatgs of potection. Find an all of bat faith may be good camse for refusing to reyped such flasts.

118. The berieging belligerent has sometimes rafuestad the lusieged to designate the buildings containing collections of works of art, scientific musemms, astronomical olservatories, ol precions libraries, so that their destruction may be avoided as much as fossible.

SECTIUN VII.

The Phiole.

119. Prisoners of war may be released from captivity ly cxilange, and, under certain ciremustances, also by pallole.

120. The term parole designates the pledge of indirilual wom faith and honor to do, or to onit doing, certalin allets after he who gives his parole shall have been dismissed, wholly on fallially, firm the power of the eiptor.

121. The pledge of the parole is always an indivinual hut 1 mot at private act.

12.2. The parole applies chiefly to prisoners of war whom the call-

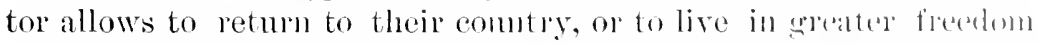
within the captor's comtry or territury, on conditions stater in the parole.

12:3. Release of prisoners of wat by exchange is the genteral rute; release by parole is the excention. 
1.2. Brealing the parole is punisherl with death when the person

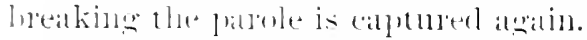

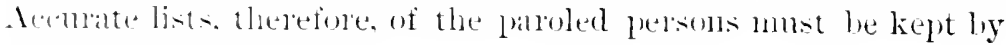
the lielligenents.

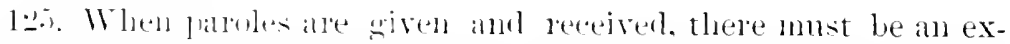

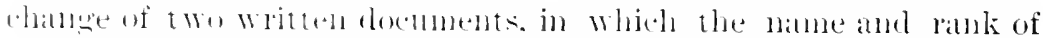

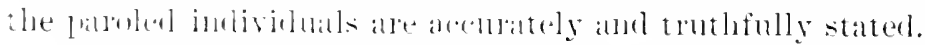

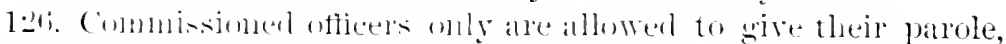
and they eatn wive it moly with the germission of their superior, as

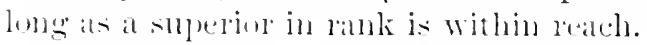

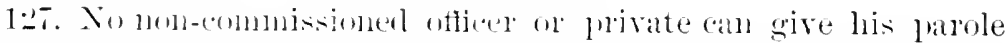

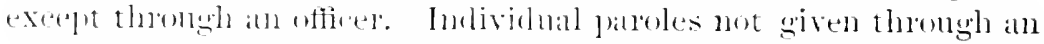

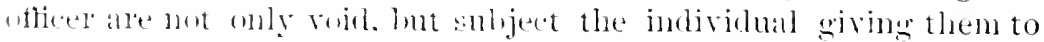
the puni-holedet of death as deserters. The only admissible exception is whede individuals, properly sepanated from their eommands, have sutfeled loms confinement without the possibility of being paroled threngh an officers.

1ㄴ. No parting on the battle-fieln. no paroling of entire bodies of trons after a battle and no dismissil of large mumbers of prisonels, with al selueral declaration that they are paroled, is permitted, (1) of ally villue.

129. In captulations for the smrenter of strong places or fortified

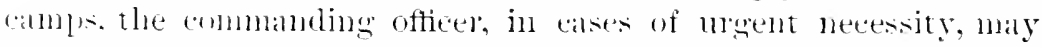
agrete that the trops ounder his command shall not fight again during the watr. muless exchiluged.

1:30. The nstal pledge given in the parole is not to serve during the existing wark muless extlatued.

This pledge refers only to the atetive service in the field, aganst the loboling belligrent or his allies actively engaged in the same

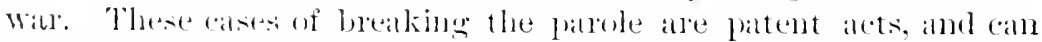

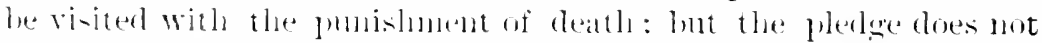

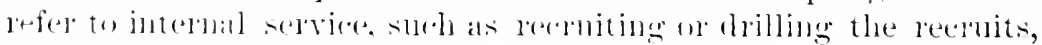

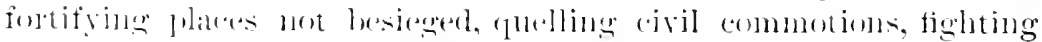

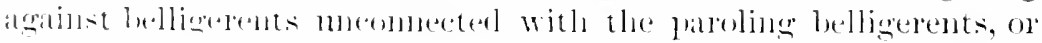
to divil or diplomatic serviee for which the patroled oflicer mat be +mplimegel.

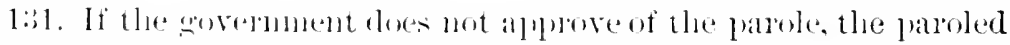

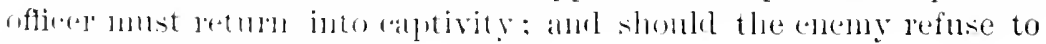

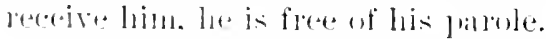

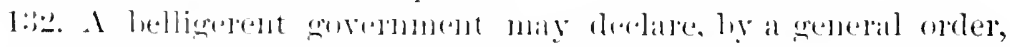
whellel it will allow palmoling. and an what conditions it will allow

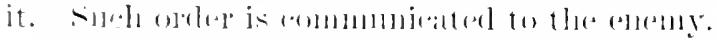

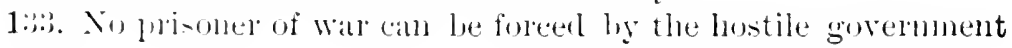




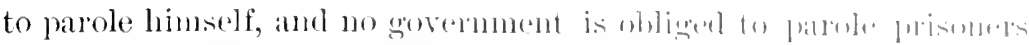

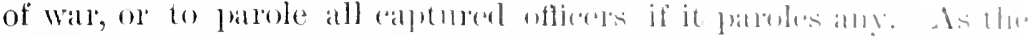

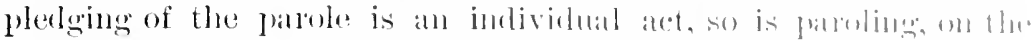

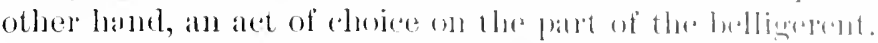

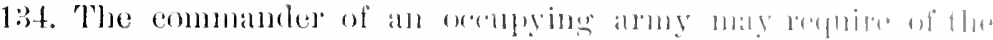

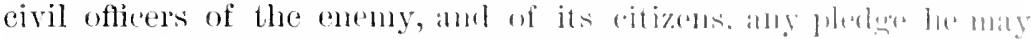

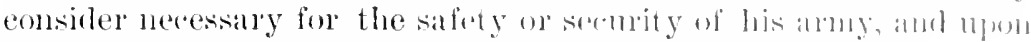
their failure to give it, he may arrest, confine, or detain them.

SECTIUN VIII.

\section{Armistice-Chpitelation.}

185. An armistice is the cessation of active hostilities for a perior agreed mon between belligerents. It mmst be agreerl mpon in writing, and duly ratified by the highest anthorities of the contending parties.

136. If an armistice be declared, withont conditions, it extends no further than to repuire a total cessation of hostilities along the fond of both belligerents.

If contitions be agreed mpon, they shomld be elearly axpessed,

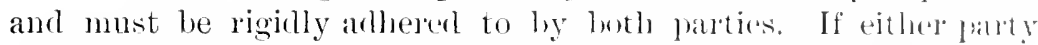
violates any express condition, the armistice may be declared muil and roid by the other.

137. An armistice may be general, and valid for all points and lines of the belligerents; or special-that is, roforing to cortain troops or certain loealities only.

An armistice may be conchuled for a rofinite time; or for an indefinite time, during which either belligerent may lesume hostilitios on giving the notice agreed 11 mon to the other.

13. The motives which induce the one or the of her belligerent to conclude an armistice, whether it he expected to he preliminary to at treaty of peace, or to prepare during the armistice for a more rign'ous prosecution of the war, do in 110 waly affect the chanater of the armistice itself.

139. An armistice is binding mpm the belligerents from tho laty of the agreed commencement; but the oflierrs of the armins are lesponsible from the day only when they receive official intornation of its existence.

140. Commanding officers have the right to comolucle ambintions binding on the district over which their rommand extents: lmt smbll

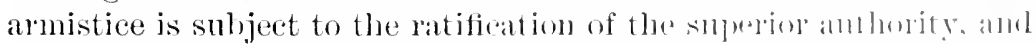
ceases so soon as it is made known to the enemy that the armistice 
is not ratified. even if a certain time for the elapsing between giving notice of eesiation and the resumption of hostilities should have been stipulated for.

141. It is incmubent unon the contrating parties of an armistice to stipulate what intereourse of persons or tratic between the inhabitants of the territories orecupied ly the hostile armies shall be allowenl, if ally.

If unthing is stipulated, the intereourse remains suspended, as duringe anthal bostilities.

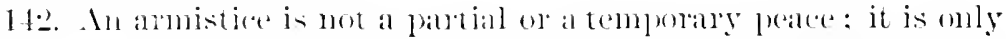
the suspunsin of military operations to the extent agreed upon by the batsties.

14:3. When an armistice is (4) the army hesioging it, it is agreed by all the authorities on this smbject that the hesiener must cease all extensom, perfection, ol advance of his attarking work, as much so ats frem attacks by main force.

but as the is a ditierence of opinion amomg martial jurists, whether the hesienged have the right to repair breaches or to erect new wons of defense within the place during an andistice, this print should be determined by express agreement between the pitrties.

14t. So som as a capitulation is signed, the capitulator has no right to demolish, destroy, or injure the works, arms, stores, or ammmition, in his josession, during the tince whieh elapses between the signing and the execution of the catpitulation, muless otherwise stipulaterl in the same.

14.). When an amistice is tearly boken by one of the parties, the other party is releasen from all obligition to observe it.

14ti. P'risoners, taken in the anet of hreaking an armistice, must

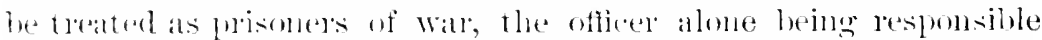
who grives the order for surh a violation of an anmistice. The highest anthority of thr helligerent agrovered may demand redress for the infrartion of an amistire.

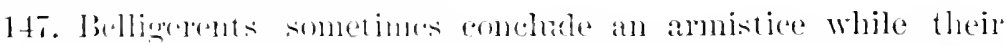

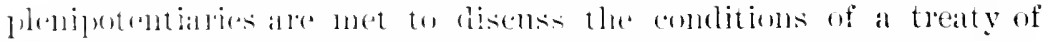

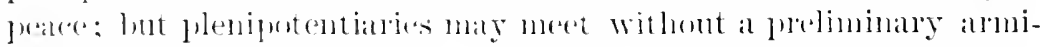
stire: in the latter ealst, the war is carried on without any abatencist.

SITTHE IX.

Asinamisims.

14. The law of watr thes not allow proelaining either an indi- 


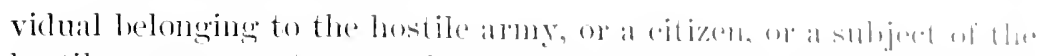

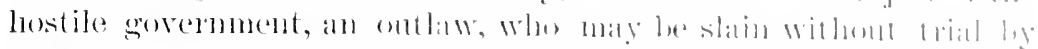

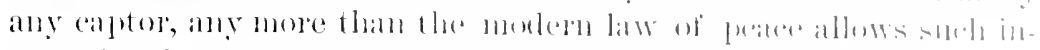

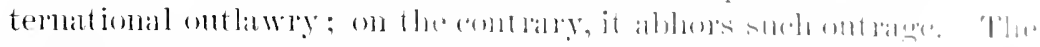

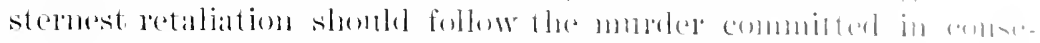

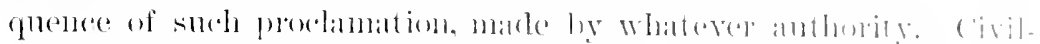

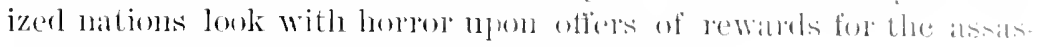
sination of enemies, as relapses into barbarism.

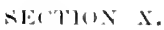

\section{InSURRCTION-CHM, Wh-RERELhON.}

149. Insurretion is the rising of people in arms andinst theil government, or a portion of it, or aganimst one or more of its lams. (1) against an offices or officers of the govermont. It may le contined to mere andmed resistanee, or it maly have preater ends in viem.

150. Civil war is wa between two or more pertions of a connt!y op state, each contenting for the mastery of the whole, and anch chiming to be the legitimate government. The term is also sometines applien to war of rebellion, when the rebellions porinecs on portions of the state are contiguous to those containing the seat of gorelnnent.

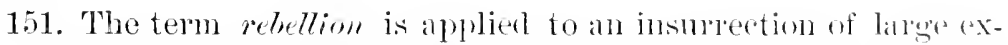
tent, and is usually a war hetween the legitimate goremment of a comntry and portions or provinces of the sime who seck to throw off their allegiance to it, and set 11 , a government of their own.

152. When lumanity incluess the arkption of the rules of reonlar war toward rebels, whether the aboption is partial of culdue it does in no way whatever imply a partial or complete aldimmledgment of their govermment, if they have set np) once or of theme, a an inclependent or sovereisn power. Nentrab have no right to malke

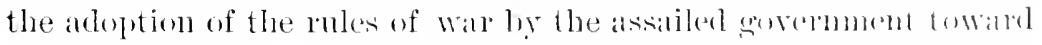
rebels the gromme of their omm acknowlergment of the revolted pertple as an independent power.

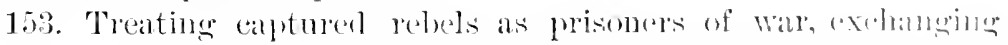

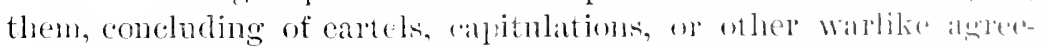
ments with then; addersing officers of a robel army ly the rank they may have in the same; aceepting flags of truce; or an the

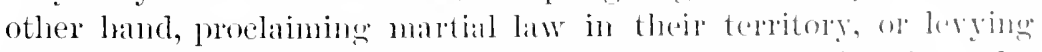

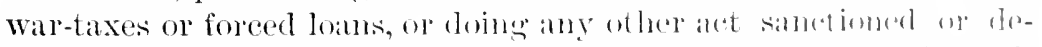

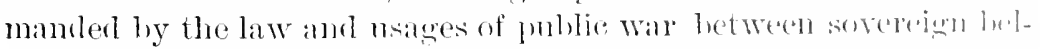
ligerents, neither proves nor establishes an acknowlingment of the 
rebellions peoples or of the govermment which they may have erected, ats al pullic ar sorereign power. Sor does the adoption of the rules

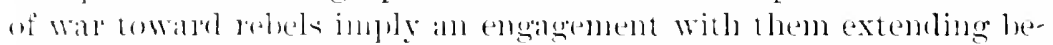
yome the limits of these lules. It is virengy in the field that ends the strife, and sottes the future relations between the contending pillties.

1.it. Treatting, in the fietel, the rebellions conemy according to the law and usiges of war, hats never prevented the legilimate government from tring the leatler's of the rebellion or chief rebels for high treatson, and from treating them aceordingly, muless they are inderrled in al general anmesty.

1.i. All enemies in rewular war are divided into two general

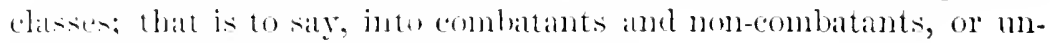
arnerl citizens of the hostile govermment.

The military commanter of the legitimate govermment, in a war of rebellion, distinguishes between the loyal eitizen in the revolted portisn of the comntry and the disloyal citizen. The disloyal citizens maly further be clissified into those citizens linown to sympathize with the reberlion, without positively alding it, and those who, withont taking up arms, give positive aid and comfort to the rebellions enemy, without being borlily forced thereto.

1.ib. Common justice and plitin experliency require that the militilly commander potect the manifestly loyal citizens, in revoled territures, agatinst the hardships of the war, as much as the common misfortme of all witr admits.

The commancler will throw the burken of the war, as mneh as lies within his power, on the disloyal citizens of the revolted portion or

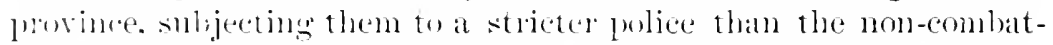

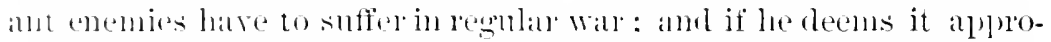
priate, on if his govermment demants of him, that every citizen shall, ly an oith of alleriance, or by some other mimifest act, declare his fidelity to the lexitimatte gorermment, he maly expel, tramsfer, impris. (m). ar fine the revolted atizens who refine to plethe themselves ancow as citizens oberlient to the law, and loyal to the govermment.

Whather it is experlient to do so, and whether reliance ram be plated nuon sinch oath, the eommander or his govermment have the right to rleciche.

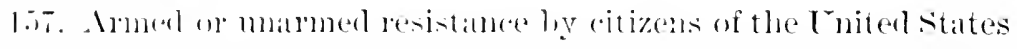

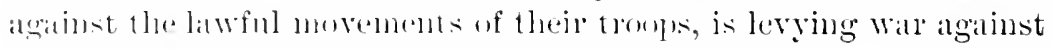
the lnited states, and is therefore treason. 


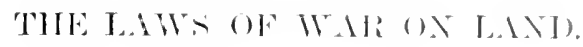

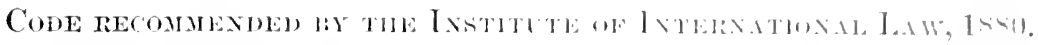

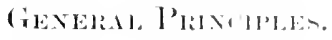

1. The state of war does not atmit of acts of violenee, salve hestween the armed forces of belligerent states. Inelividuals who form

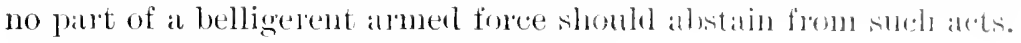

2. The armed force of a state inclumles:

1st. The army projer, or permanent military entalishment, incholing the militia and reserve forces.

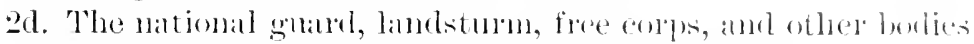
which fulfill the three following conditions; $i$. ..

(a.) They must he moler the direction of respomsible dhicfis.

(7).) They must lave a muform, or distingmishing mank, or batge, reeognizable at a distance, and wom by inlividuals composing steh eorps.

(c.) They must carry arms openly.

3d. The crews of public armed ships, and other vesidels nised for warlike purposes.

4th. The inhabitants of non-oceupied territory, who, at the alpproach of the enemy, take arms opendy and spomtanemsly to resist an invaler, even if they have mol hat tine to oreandze.

3. Every belligerent armed force must cury on its military operattions in aceordance with the laws of war.

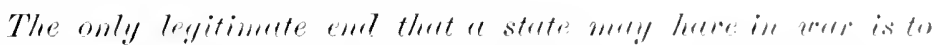
meaken the militur!l strength of the anrm!l.

4. The laws of war do not recognize in helligerents an unlinitud liberty as to the means of injuring the enemy. They and to abstain from all necolless severity, as well as from all prerfilious, mujust, ol tyramical acts.

5. Agreements made between belligerents thring the antinnames of war, such as armistices, capitulations, ant the like, ale wo be sertlpulously observed and respected.

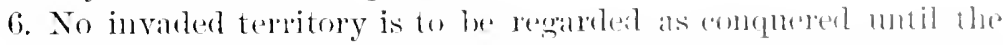

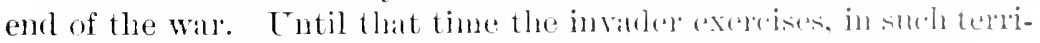
tory, only a de fecto power, essentially provisional in chatraterer. 


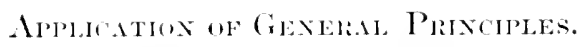

\section{Husthutes.}

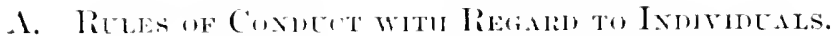

7. It is forbirlen to deal harshly with inoffensire populations.

S. It is forbiglele,

(1.) To make use of poisom, in amy form whaterer.

(b.) Tomake treateheroms altempts mon the life of an enemy; as, for example, hy kexping assalstins in paly, or by feigning (1) struremeler.

(c) 'Tuattack an enemy l)y concealing the distinctive signs of an andured forree.

(\%) To nse impoperly the mational flag, miform, or other distintive signs of the chemies: the flag of truce, or the dislinetive signs of the Geneval convention.

9. It is forliblelen,

(") Tu (mophy arms, projectiles, or materials of any hind. ealrulated to eanse needless suffering, or to agrarate woundsmotahly pojectiles of less weight than four humbled grammes

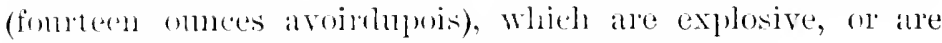
chatred with fuhninating on explosive sulstances.

(lo) Tokill or injure an enemy who hats suremdered, or who is

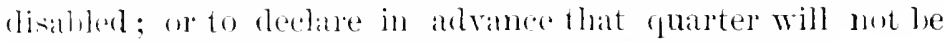
given, eren by those who do mot ask it for themselves.

10. Womder or sick soldiers shall be collected together and caned for, to whateres mation they maty belomes.

11. Commanteds-in-ehief shall have power to deliver, immedi-

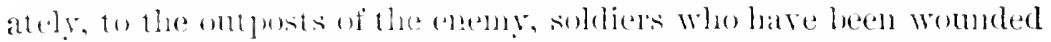

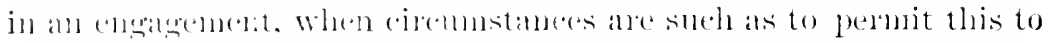

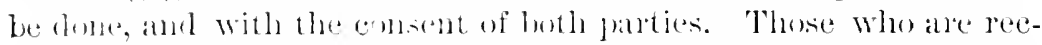
ormizal, able theje womels ane healed, as incalpable of serving, shall be sont bate to their own combly. The others may also be

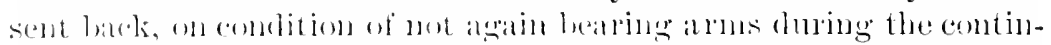

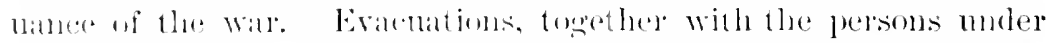
whose direction they take place, shall le purotected ly all absolute 31011 rallity.

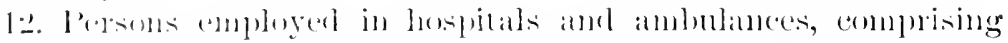

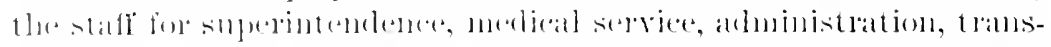

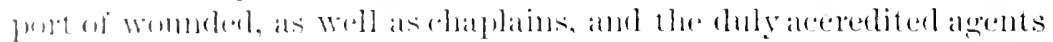

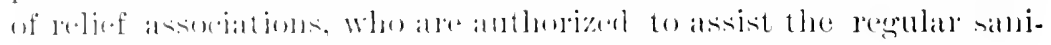
tary stadl, shall participate in the benefie of mentrality while so eme 


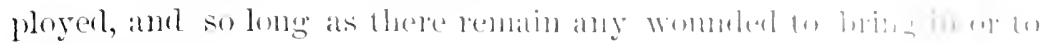
sueers.

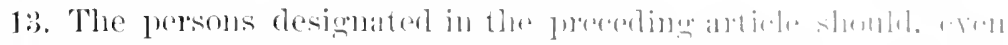

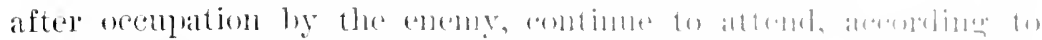

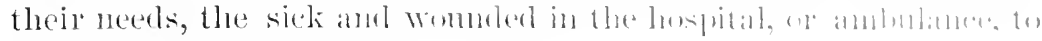
which they are attateber.

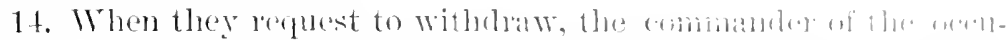

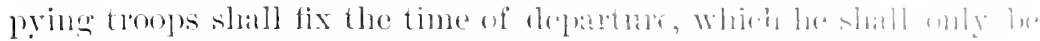

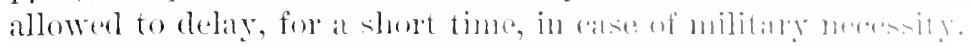

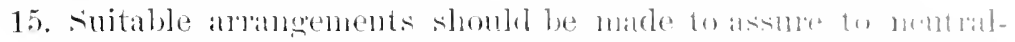

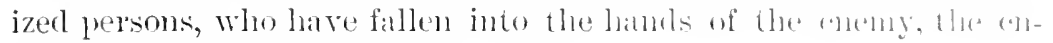
joyment of suitalle salaries.

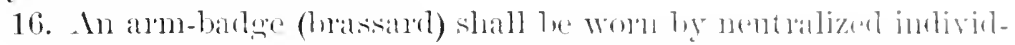
mals, lut the delivery thereof shall he regulated hy military anthroity.

17. The commanting generals of the hellineront pown's shmbl appeal to the lumbanity of the inhalitants, and shombl ambatrol to induce them to assist the wombled, ly pointing ont to them the antrantages that will result from so domg. They shomlel lesald ats invioblible those who respond to this appeal.

15. It is forbidden to rol, or mutilate, the borlies of the dratl lying on the field of lattle.

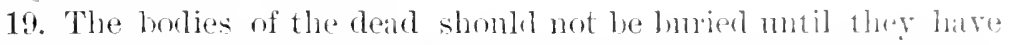
been carefully examined, and all anteles which mal sure wo tix their identity, such as names, medals, numbers, podet-boks, ato. shall have been secured. The articles thus collecterl, from the boties of the eneny's deat should he transmitted to their atrmy at grovermment.

20. Inclividuals who form a part of the belligerent armed foree of a state, if they fall into the hambls of the enemy, are to be tratted ats prisomers of war, in conformity with anticles li1-i sof these instruce

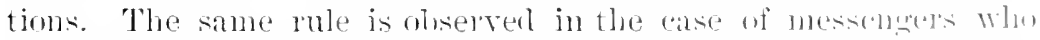

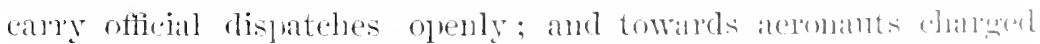
with olserving the operations of an memy, or with the maindenande

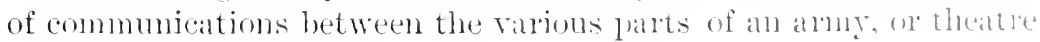
of militasy operations.

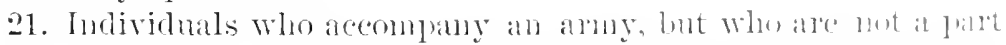
of the regular armed force of the state, sum as colmestumbents, traders, sutlers, ete, and who fill into the hands of the comeng, maty be retrined for such length of time only as is warlanded ly strict military necessity.

2.2. Spies, captured in the act, eammot demand to be treated ats prisoners of war. 
2:?. In individual may not be regarded as a spr, however, who, belomging to the ander foree of either helliserent, genetrates, with-

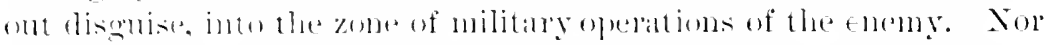

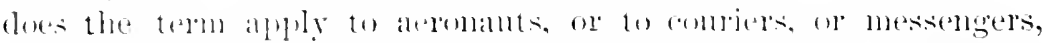

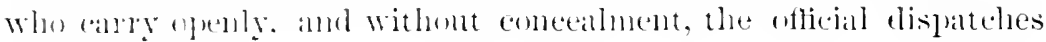
of the entemy.

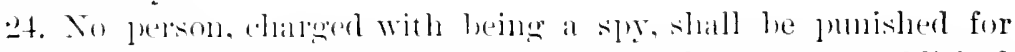
that offenere, motil the fatet of his anilt shall have been established

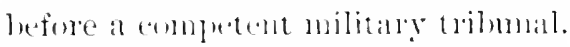

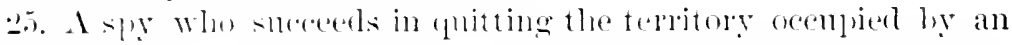
enomy, inems no penalty for his porions offence, should he at any futme time fall into the hands of that enemy.

26. The bearel of a thas of turee. who, with propere authority from one lulliwerent. presents himself to the other, for the purpose of commminating with him, is entitled to complete intiolability of jersill.

-7. He may be acompanied by a chmmmer or trumpeter, by a

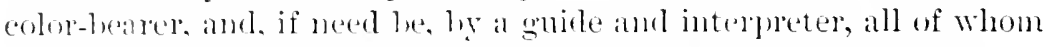
shall be entitled to a similar inviolahility of persont.

2゙. The commanter to whom a flag is sent, is not obliged to reeeive the flis moler all circmonstances.

2!). The commander who recejes a flag has a right to take such grecantionarymeasmes as will prevent his canse fom bejug injured hy the presence of an eneny within his lines.

:31. It the beallor of a flas of truce almse the trust reposed in him, le may le temporarily detajed, and, if it be proven that he has takin anvantage of his position to abet a treasonable ast, he forfeits his charateter of inviolability.

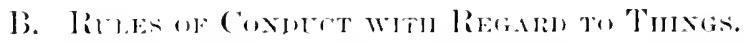

81. It is forliglilur,

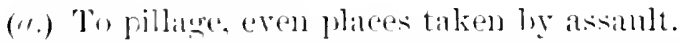

(b.) 'lo destong pullic on private property, mbess such destruction le enmmanded by mont military necessity.

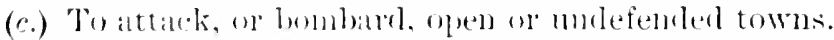

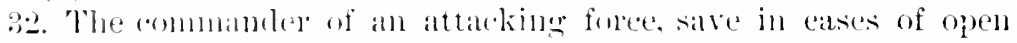
ascanle. slabll, lwhore molertaking a lombandment, make due effort

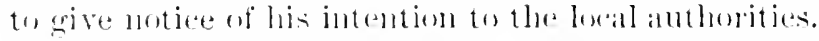

3:). In case of bombarrbment all meerlful measures shall be taken to slare, if it he posible to do so, bullings deroted to religion and charity. to the ants and suences, hospitals, and lepots of sick and wromeled. This on andition, howerer, that such places be not marle use of, directly or indirectly, for purposes of defence. 


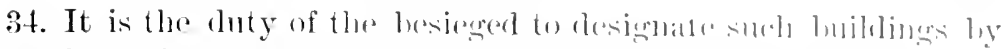

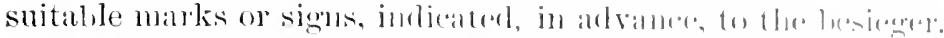

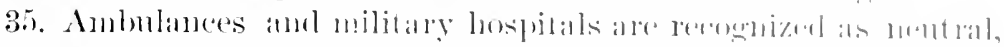

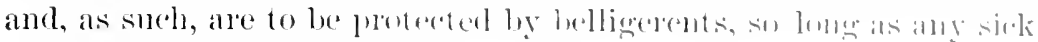
or wommled remain therein.

36. The same rule applies to buldings, or batts of lmblobus, in

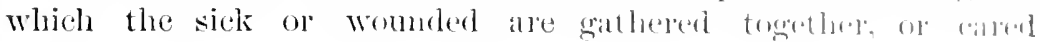
for.

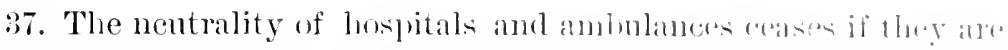

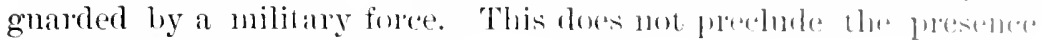
of an adequate police forre.

:8. As the equipment of military hospitats remains subject to the laws of war, persons attached to such hospitals (ammot, in witholatw-

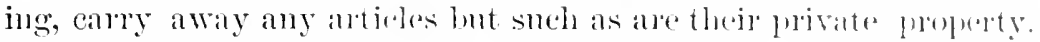
Ender the same ciremstances, an ambulance slabll, on the contrare, retain its equipment.

39. Ender the circumstances foreseen in the abowe batagrajus the term ambulmee is applied to field hospitals, amb ofler temporary estallishments, which follow the troops on the field of battle to receive the sick and womded.

40. A distinctive and uniform flag is adopted for ambulances, hospitals, and evacuations. It hears a red cross on a white sround. It must, on all occasions, be accompanied by the national flag.

\section{OAclpien Teriatory.}

\section{A. Definition.}

41. Territory is regarled as occupied when, as the consemunee of its invasion by the enemy's forees, the state from which is has heen taken has ceased, in fact, to exercise there its resular anthorily. and the invading state, alone, finds itself able to maintain onder therein. The limits within which this state of affairs exists determine the extent and duration of the oecupation.

\section{B. Rules of Condet with Respert to Persis:}

42. It is the duty of the occupying military atuthority un inform the inhabitants, at the earliest practicalle moment, of the pums that he exercises, as well as to define the limits of the occupied territory.

43. The occupying anthority should take all dite ambl needful measures to assure order and public tranquillity. 
44. To that cud the invaler should maintain the laws in force in the territory in lime of peace, and shomle not molify, smspend, or replate them, muless it hecomes absolutely neecessing to do so.

4.). The alministrative officials and rivil employess, of every

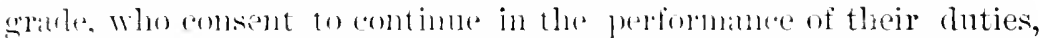

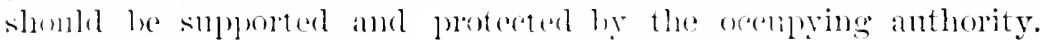
Their appointments ale always revomille, and the have the right

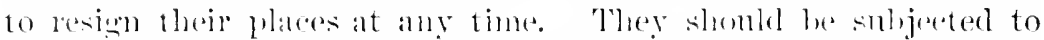
penalties only when they fail to perform duties frecly acerpted by them. and should be given oren to justice only when they lave bellivial thenen.

46. In rase of morener, the invaled may demand the co-oporation of the inhathituts, to amalole him to provirle for the necessities of focal athuinistrations.

47. The population of an invaded district cannot be compelled to

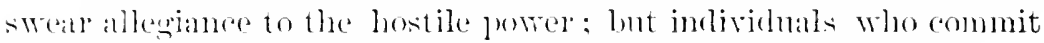
acts of lostility andinst the ocemying authority are pumishable.

4. The inhabitants of an ocempied territory, who sho not sulmit to the orders of the occupying anthority, may be compelled to do so. The invalel, lowever, canmot eompel the inhabitants to assist him in his works of at taek or defence, or to take part in military operations atainst their own combry.

49. Family honor and rights, the lives of individuals, as well as their religions convictions, and the right of religious worship should le respeted.

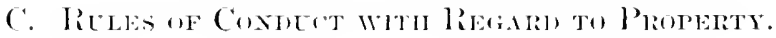

51). The orenpering anthority may seize omly the cash, public

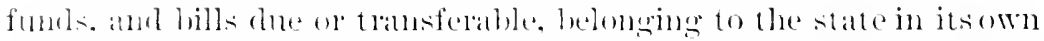
riphe depots of arms and smpllies, and, in gencral, the movable formeley of the state of such chatateder as to be useful in military

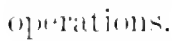

51. Yeans of trans oortation (railways, boats, ete.), as well as tele-

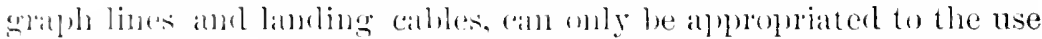
of the invaler. "Their destruetion is forbilden, muless it be eommambled hy militarg necessity. They ale lo be restored, at the peace, in the enentition in which they are at that time.

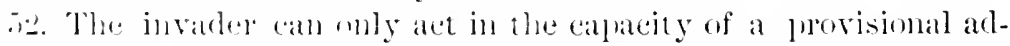

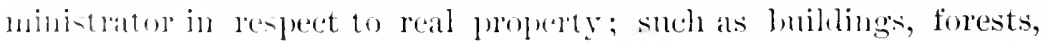
agrionltural establisinment, oto, belonging to the enemys state. He shrmbl pursect these properties and see to their maintenance.

5:3. The property of communes, and that of establishments de- 


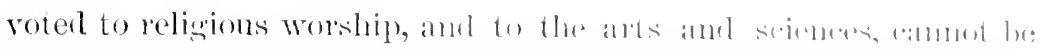

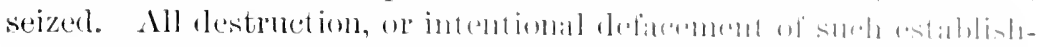

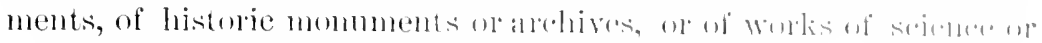

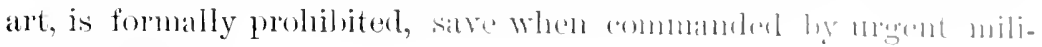
tary necessity.

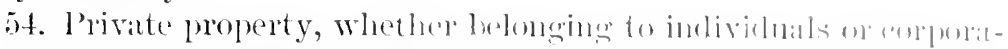

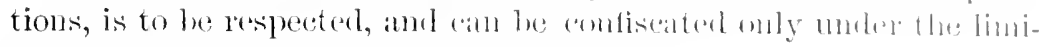
tations contained in the following articles.

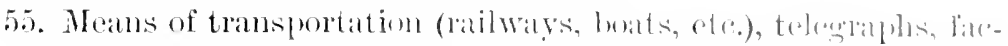

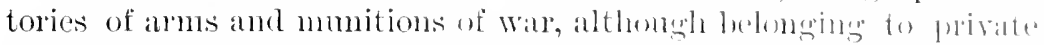
individuals or corporations, may leserzer by an invaler, hut must be restored at peace; if posible, with suitable indemulties.

56. Impositions in kind (repuisitions), levier! nyon enmmmms, $11^{\circ}$ the residents of invaded districts, should beat direet lebltion to the

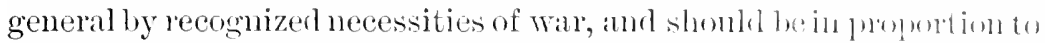
the resomrees of the ristrict. Recuisitions an only he marle, of levied, with the authority of the commanding offecer of the ocenpiert district.

57. The invader may levy, in the way of dues and imposts, only such as are already established for the lumefit of the state reromus. IIe employs them to defray the expenses of administration of the oecupied territory, contribnting in the same proportion in which the legal govermment was bound.

58. The invader camot lery extraordinary eontributions of money, save as an equivalent for fines, or imposts not pair, of tor paymonts not made in kind. Contributions in money cin omly be impored by the order, and upon the respmusibility, of the general-in-chict, or that of the superior civil authority establisher in the oeduberl territory; and then, as nearly as possible, in aceordance with the rule of apportionment and assessment of existing imposts.

59. In the apportionment of hurlens relating to the quatering of troops, and in the levying of requisitions and contributions of watr, account is to be made of the charitable zeal displa yed ly the inhalitants in behilf of the wounded.

60. Impositions in kind, when they are not paid for in calsh, and contributions of war, are authenticated by receipts. Mfatsures should be taken to assure the regularity and bone fide charateter of these receipts.

\section{Prisoners of Mir.}

61. Prisoners of war are the prisoners of the eaptor"s goverunent, and not of the individuals or corps who eaptured them. 
62. They are sulject to the laws and regulations in force in the army of the enemy.

(i:). They must be treated with hmmanity.

6.t. 11 articles in their personal possession, anms excepted, remain their private property.

6.5. Every prisoner of war is obliged to disclose, when duly interrogated upon the subject, his true name and grade. should he fail to do so, he may be deprived of all, or a part, of the privileges aceorded to prisoner's of his dank and station.

tif. lrisoners of war may be confined in towns, fortresses, camps, or other places, with an obligation not to go beyond certain specific limits; lut they may only be imprisoned as an indispensable measme of security.

67. Every act of insuborination, on the part of a prisoner of war, anthorizes the resolt to suitable measures of severity on the part of the government in whose hands he is.

15. Prisoners of war attempting to escape ma, after having been strmmoned to halt or surrender, be fired upon. If an escaped prisoncr be recaptured, before being ahte to rejoin his own army or to ruit the territory of his eaptor, he is only liable to disciplinary penalties: or he may be subjected to a more rigorons confinement. If, after having snccessfully effecter his escape, he is again made a prisoner, hr incurs no penalty for his previons escape. If, however, the prisoner so reviptured, or retaken, has given his parole not to attempt to escape, he may be deprived of his rights as a prisoner of war.

(69. The government having prisoners of war in its hands, is obliged to support them. If there he no arreement between the belligerents 11 km this point, prisoners of war are placed, in all matters resaluing fork and rothing, upon the peace footing of the troops of the state which holls them in eaptivity.

71. l'risoncrs cannot be compelled to take any part whatsoever in operations of war. Neither can they be compelled to give information concernins their army on conntry.

71. They may be (m) ployed upon puble works that have no direct comnection with the captrin military operations; purided, however, that such labor is not detrimental to health, nol humiliating to their military rank, if they besoms to the army; or to their official or social fmition, if they are eivilians, not comected with any branch of the militaty service.

i-. In the event of their being anthorized to engage in private imhistries, their bay for such services may be collected by the anthrolity in chalrge of them. The sums so received may be employed 


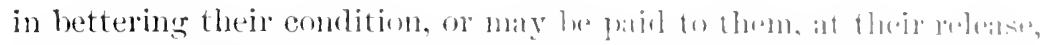

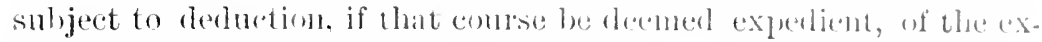
pense of their maincnimce.

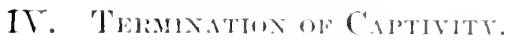

73. The captivity of prisoners of wal rases, at a matter uf rithit. at the conclusion of peree; lut their literation is then romblated hy agreement between the bolligerents.

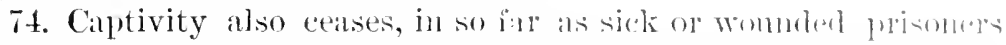
are concerned, so soon as they ale fonml to he mufit fom milifiry s.r. ice. It is the duty of the eaptor, muder such eircumstances, to ar mol them back to their conntry.

75. During the continnance of hostilities, prisoners of war mat he released in accordance with cartels of exchange, agreed mon by the belligerents.

76. Without formal exchange, prisoners may he liherated on latrole, provided they are not forbidden. by their own govermmont, to give paroles. In such a case they are olligerl, as a matter of mili. tary honor, to perform, with sermpuloms exactness, the engigement which they lave freely molertaken, and which shonk be edouly specified. On its part, their own government shond not demimu, or accept from them, any servite contrary to, or inconsistent with, their plighted word.

7T. A prisoner of war camot be constrained to accept a releate on parole. For a similar reason, the enemy's govermment is ant obliged to accede to the demand of a prisoner of wall to lu releasul on parole.

78. Every prisoner of war, liberated on parole, who is recaptnued in arms against the government to which he has given such pande, may be deprived of his rights and privileges as a lrisoner of war" mless, since his liberation, he has been included in an unconditional exchange of prisoner's.

\section{Troops Interied in Neetral Termitory.}

79. It is the duty of a neutral state, within whose teritory commands, or individuals, have taken refuge, to intern them at point: as far removed as possible from the theatre of war. It shomle pmusue a similar course toward those who make nse of its territory tin warlike operations, or to render military aict to eitlel hellimerent.

80. Interned troops may be guarded in camps, or fortifich places. The neutral state decides whether officer's ale to be released, on 
parole, ny taking an engagement not to quit neutral territory without anthinity.

-1. In the event of there being no agreement with the lelligerents con eming the maintenance of interned trons, the neutual state shath smlyly then with ford and chothing and the inmediate aid

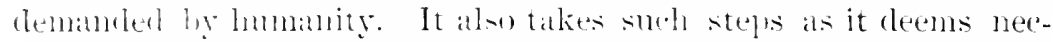

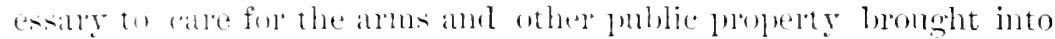

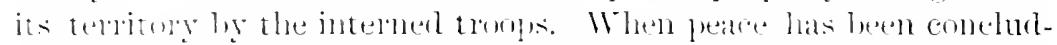

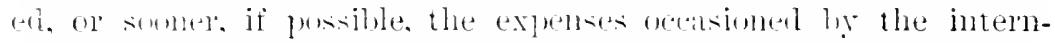
ment are reimbursed to the nentral state, by the helligerent state to whom the interned trons belong.

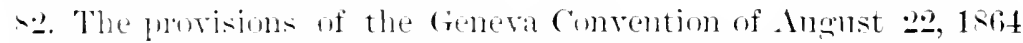

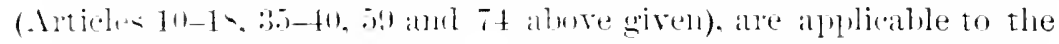
sinnituly statti. as well ats to the siek and wounded, whotalie refuge in, or are conteyes to nentral territory.

-:3. Exaldiations of sick and wombled, not prisoners of war, may

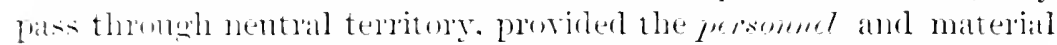
accompluying them are exchsively sanitary. It is the duty of the nentril sate, throngh whose territory the evicuation is made, to take sulh mealsures of safety and necessally control as it may deem necessury to the rigorous performance of its neutral duty.

\section{PART TIIIRD.}

\section{PExh Fixctor.}

At. Offenders against the laws of wal are liable to the punishment sperified in the pemal, or eriminal. law.

$\therefore$ liegrisits ale tomally prolibited in all cases in which the injury complainet of has been redaired.

si. In all eatses of serims impritinter, in which reprisals alppear to

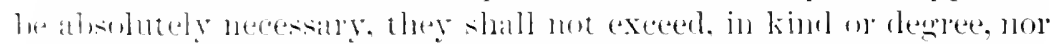
in their me the of application, the exact violation of the law of war anmmittent by the enemy. They can only be resolded to with the

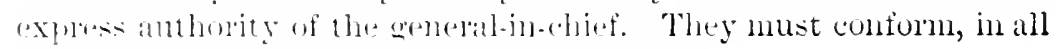
cabes, tu the latis of huminity and norality. 


\title{
INSTRLOTIONS
}

\author{
A1RIASiles
}

PAR S. EXC. LAMIRAL MINISTLE SECTETAIRE D'ETAT

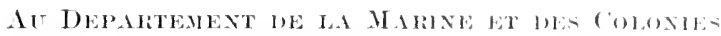

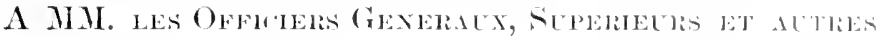

(OMUAYINAT

Les eseadres et les batiments de sa llajesté impriale.

Paris, le 20 juillet $190 \%$.

Messiecris,

Tous trouverez ci-après reprodnite la déclaration faite, le out de ve

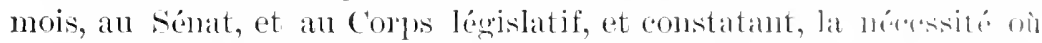

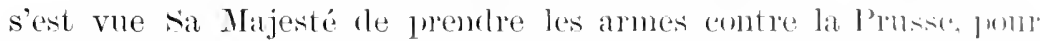

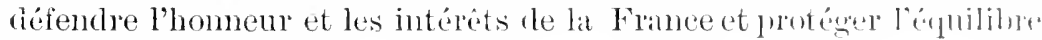
général de l'Europe.

Cette déelaration nons met en état d'hostilité, nom-senlement aree

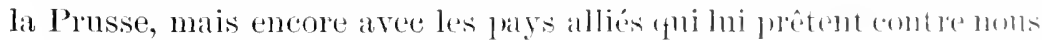
le eoncours de leurs armes. Cenx de cest Etats qui sont situés sme

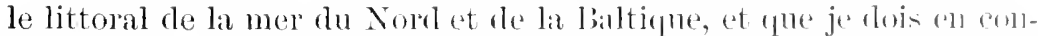

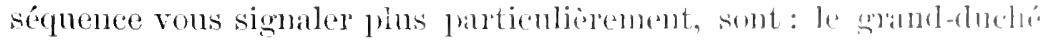

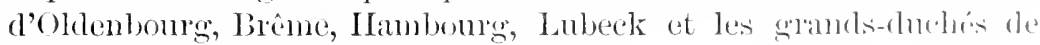
Necklembourg.

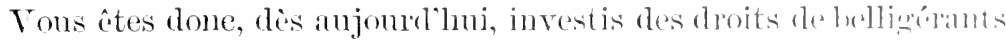

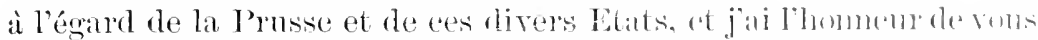

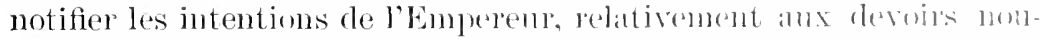

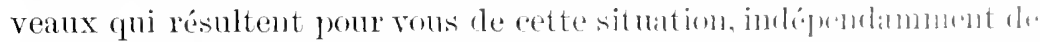

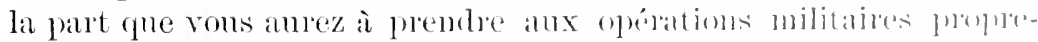

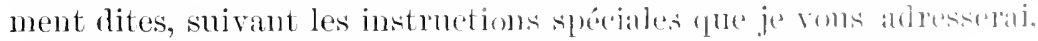

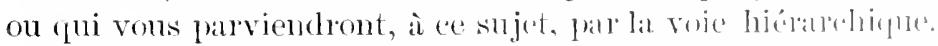

Voici la ligne de conduite que vous devez tenir, cul cxécution des ordres de sa Majesté: 


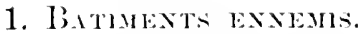

Des ce moment, vous êtes requis de andir sus ì tous les hâtiments

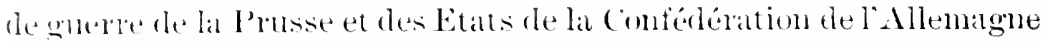

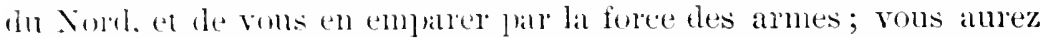
cunlement i combir sus a toms les batiments de commerce emmemis

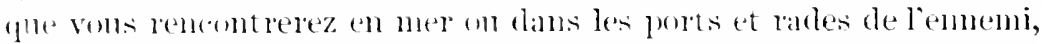
et i les calturer ansi que lenrs angalisons, sous les exceptions suivalutes:

Lu clétil de trente jours a été accordé anx hâtiments de commerce

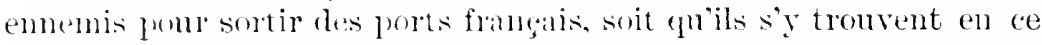
moment ou quïs y entrent nlériemement dans lignorance de l'état de gurre; et ces batiment seront purvus de sauf-conduits, ainsi que lexplique l'ambexe n०3.

En ontre. les batiments de commeree ennemis qui auront pris des carmaisons à destination de France et pour compte frangais antériemement à la déclaration de guerre, ne seront pas sujets ì capture, fommont librement debarquer lemrs chargements dans les ports franc;is et recevront des saufs-conduits pour retourner dans leurs jorts diattache.

\section{Perneries.}

Vous n’apporterez aucun obstacle à la pêche côtière, même sur les cotes de l'ennemi; mais vous veillerez ì ee que cette farem, dictée par un intrièt dhmmanité, n'entraîne aucun abus préjueliciable aux opérations militaires ou maritimes.

\section{Silfs-conintes.}

Vous n`arriterez pas non plus les bâtiments ennemis pourrus d'm sauf-combluit du (ionvernement impérial.

Voms trouverez ei-joint un molicle de la forme adoptée pour ces simfis-eombluits.

Voms voms assurerez que les actes qui voms seront présentés sont

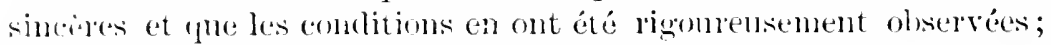

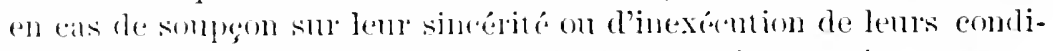
tions, vous ates antorisés a salisir le bâtiment qui en serait portenr.

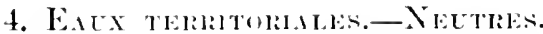

Vons vons abstiendrez dexererer ancm acte d'lustilité dans les forts on dans les canx territoriales des pmissances nentres, et vons

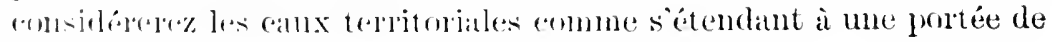
canom all-rledia de lat litisse de basse mer. 


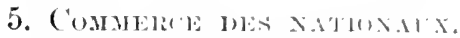

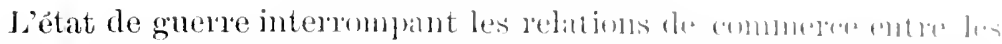

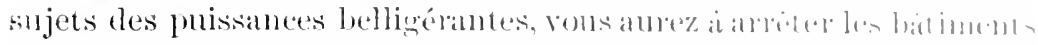

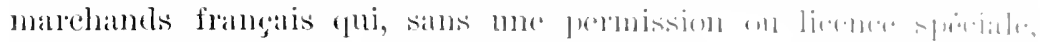

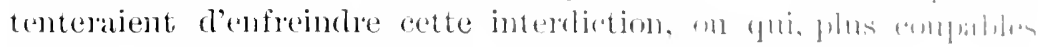

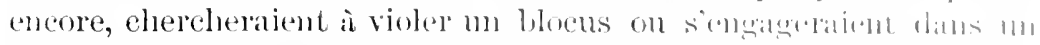

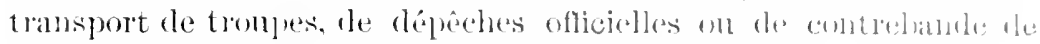
guerre pour le compte on it destination de l'enneni.

\section{Commere hen vertalis.}

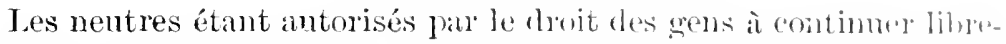
ment leur commerce avee les puissances belligéantes, rous lialliterez les bâtiments neutres que dans les cass snivants:

1. Sils tentaient de violer m blocus;

2. S'ils transportaient, pour le compledn a destination le lemmeni,

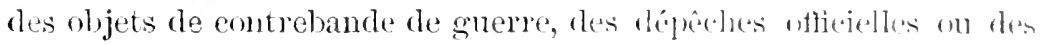
troupes de terre on de mer. Dans ces diver's ars, le batiment et la calgaison sont confiscables, sauf lorique la contrebande drenere me forme pas les trois quarts du chargement, anquel cas les objets de contrebande sont seuls sujets à la confiscation.

\section{Bloots.}

Conformément au paragraphe muméroté 4 de la rléclaration du Congrès de Paris du 16 avil 15.56, tout blocus, pon êtrobligatoire, doit etre effectif, e'est-it-dire maintenu par une force suffisinte form interdire réellement l'accès du littoral de l'emnemi.

L'établissement de tout blocus devra faire lobjet d'une notification formelle aux autorités des points bloqués. Cetle notificaion, dunt vous trouverez ci-joint le modibe seral envoyét ì res antorités en même temps qu'au consul de l'me des puistances nentres an muen doun parlementaire. Il ennviendra de remplir la mome formalite. i le blocus vient à être étemlu à quelques nonveaux points te lat côte. Les limites du blocus seront expresinément désignées par leur lat itule et leur longitude.

La violation d'um blocus ainsi étalli resulte aussi bien de lat tentative de pénétrer dans le lieu blequé que de la tantative dim smir

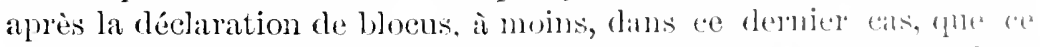

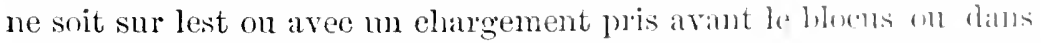
le délai fixé par le commandant des forees navales, délil qui derral toujours être suffisant pour protéger la navigation et le emmmerese de bomne foi. Ce délai devra, d'ailieurs, être mentionné dins lia décla. ration de blocus. 
Les batinents qui se dirigent ver's un port bloqué ne sont censès

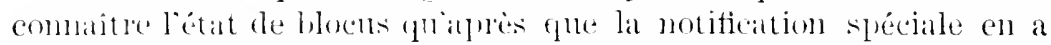

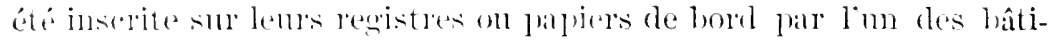

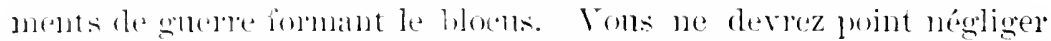
lle faire remplit cette formalité toutes les fois que rous serez engagés alans une onélation de blocus.

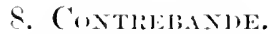

La contrebande de where à moins de stipulations spéciales des

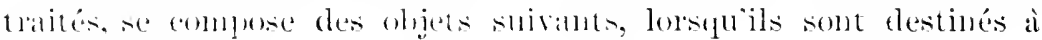
l'mllemill, silsoil" :

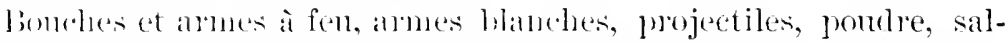

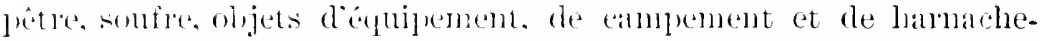
inent militirie, et tous instrunents quelconques fabriqués à l'usage de lia gaverie.

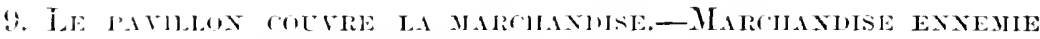

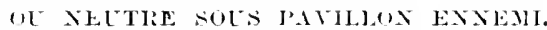

Sillf la vérification relative an commerce illicite dont je vous ai

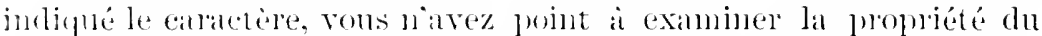
chandenent des mavires nentres, conformément anx principes de la

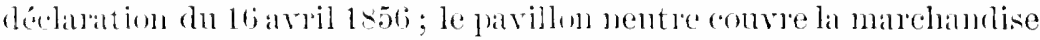

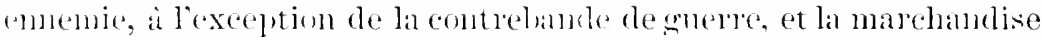

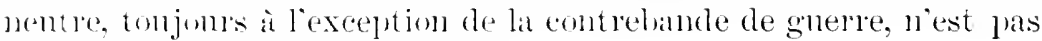
salisissille soms pavillon cmentul.

Ces principes seront applimales a l'Espane et anx Etats-Cnis,

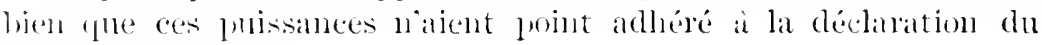
(inlgres de Paris.

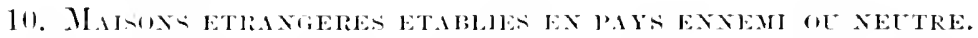

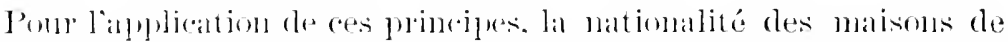

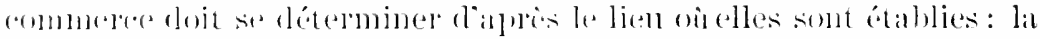

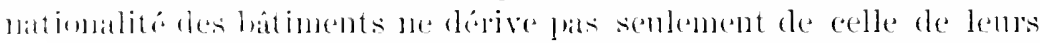
monntitaires, mais encore de leur droit légitime au pavillon qui les (c)110.

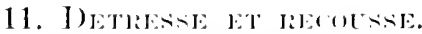

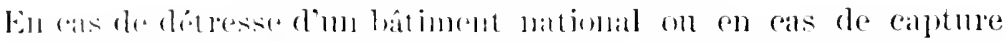

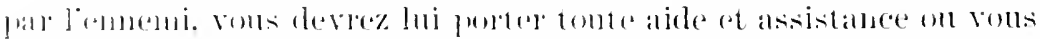

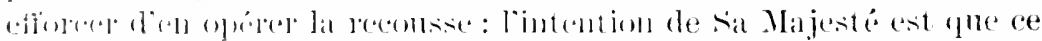

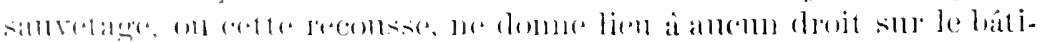

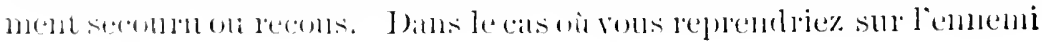




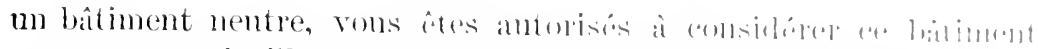

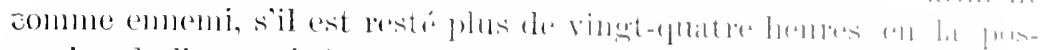

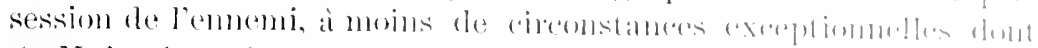

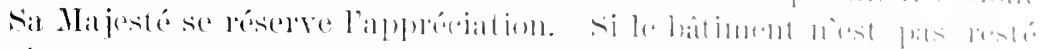

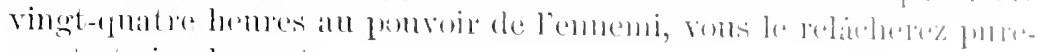
ment et simplement.

\section{Costiniss.}

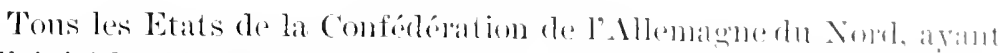

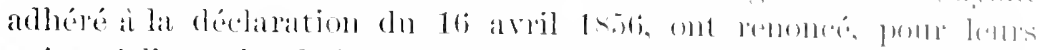

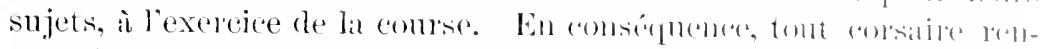

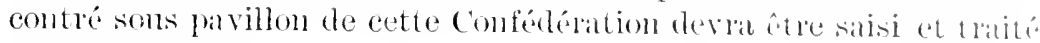
comme pirate.

\section{VINITE.}

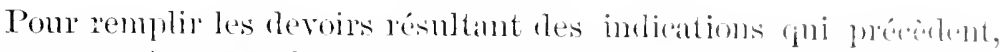

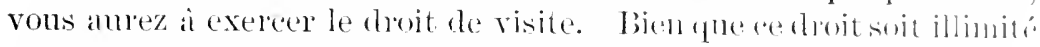

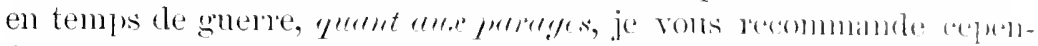

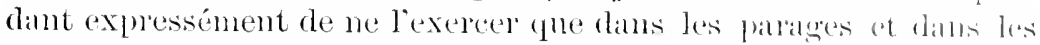
circonstances où vous ampiez des motifs fondés de sulprestre quil peut anener la saisic dn bôtinent visité

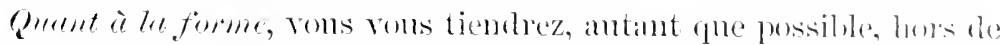

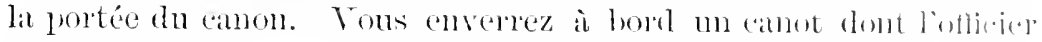

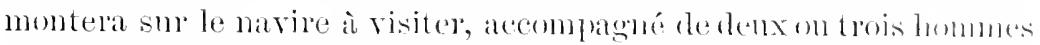

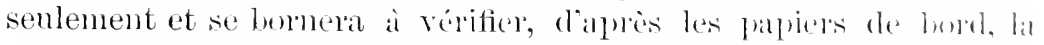
nationalité anosi que la nature du batiment et du chaldement, et ì recomaître si le bâtiment est engagi dans mu commerece illicite.

Lexamen des papiers de bold est d'antant plus important qur, d'aples notre législation, ces palpiers penvent senls servin au jugrabent ultérieur sur la validité on l'invalidité de la prise.

\section{Cinvols.}

Tous ne visiterez point les hatiments yni se tromvelont soms lo ande

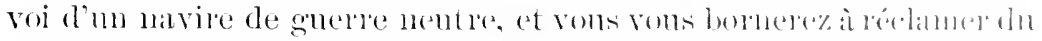

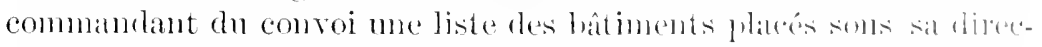

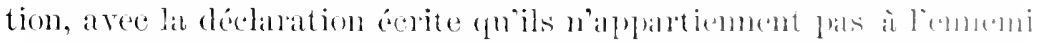

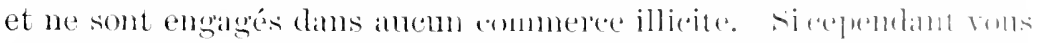

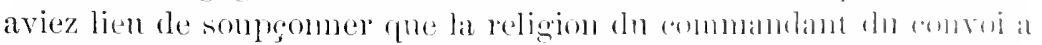

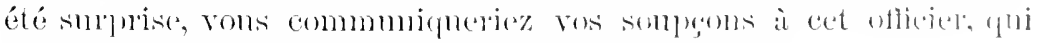
pocéderat seul ì la visite des hatiments smspectós.

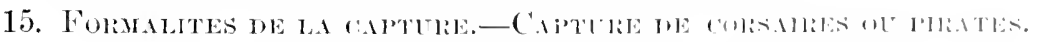

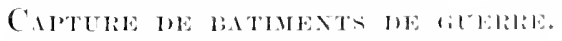

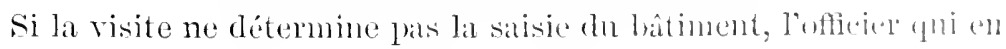


anma été chargé devra senlement la eonstater sur les papiers de bord; si, all contraire, elle déermine la saisie, il clevra être procédé ainsi 411"il suit:

1. S゙emparer de tons les papiers de bord, et les mettre sons scellés alués en alvoir dresisé mu inventaire;

$\therefore$ Dresser un prese-verbal ale capture, anssi gu'm inventaire du bâtiment :

3. Comstater l'état du chargement, puis faire fermer les écontilles de la cale, les cotfres et les sontes, et y apposer les seellés;

4. Mettre i hord un épriprige pour la condnite de la prise.

En cas de prise d'un eorsiare on d'm pirate, rons procéderez de la meme maniere: mais, dius le eas de calpture d'm hatiment de guerre, rous roms bonerez à la constater sur rotre jommal, et vous pourroirez il lit eonduite de la manière la plus conforme ì la sécurité des Equipages auxquels vons la contierez. ${ }^{1}$

1 Décret du is août 15:1, sur le service ì bold des bâtiments de la flotte, articles

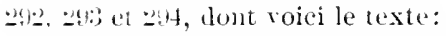

Anamige diene prise.

Ar1. 292. 1. Lorwue le capitaine a fait une prise, il ordonne a l'oficier chargé den prendre possession de faire transporter immédiatenent a son bord les ofheriers

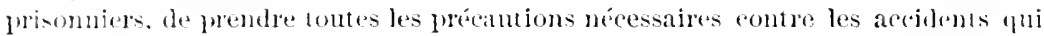

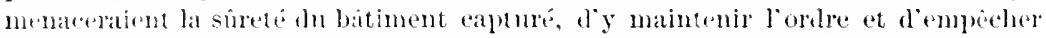

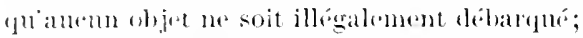

2. 11 ordonné également ì cet ofliejor de so saisir des signaux, joumanx, ordres,

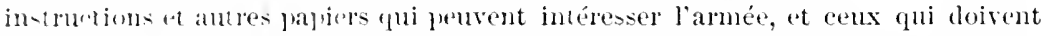
smerir à constater la valislité de la prise.

:3. Il fait arther sur-le-chanp et joursuive tout indivilu coupable d'aroir délourné des objets appartenant alu batiment ou il l'équipage capturé.

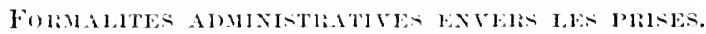

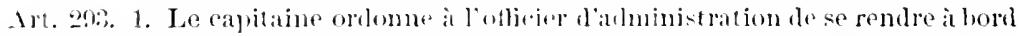

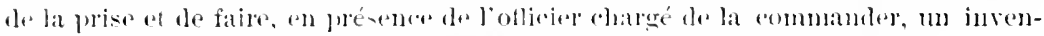

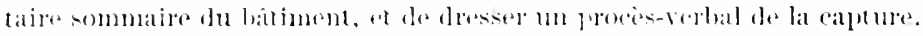

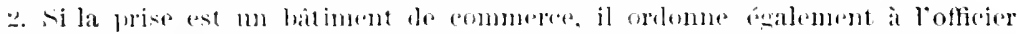

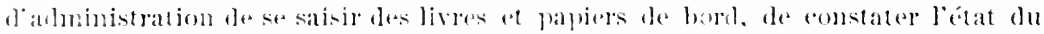

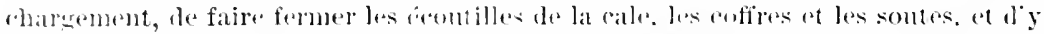

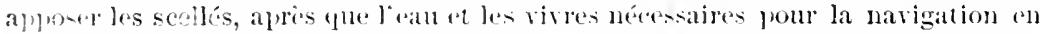
ont atis extraits;

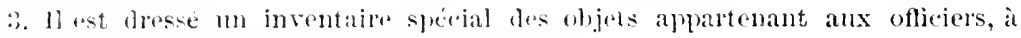

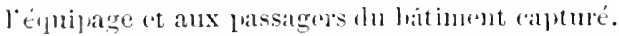

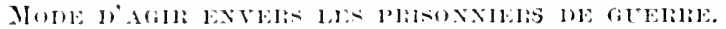

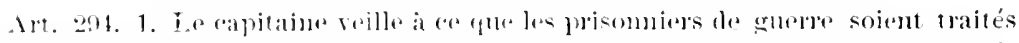

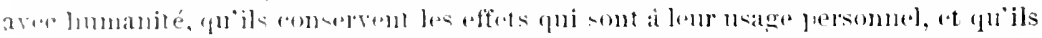

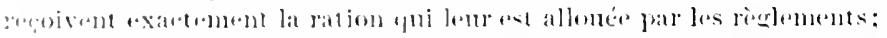

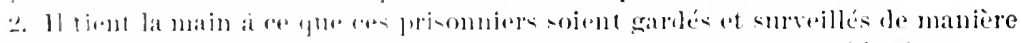

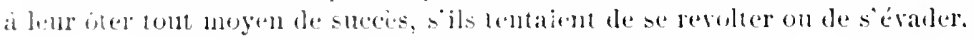


11 .

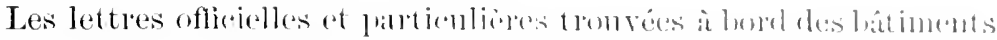

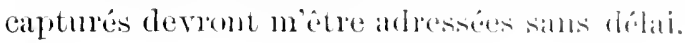

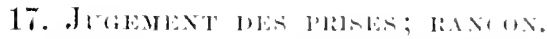

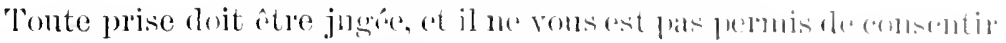

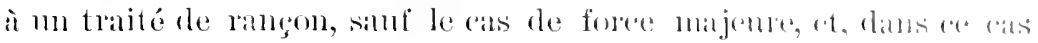

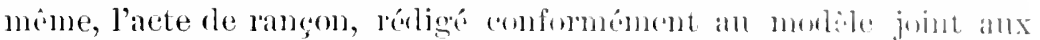
présentes instructions derrar che sommis ì la juridietion pui ast eluargée, en Franee, du jugennent des prises.

\section{REMISE WE IRISES.}

Tous condurez la prise dans le port de France le plus raplporohé, le plus acuessible et le plus sûr, on dans le port de la possession fornçaise la plus voisine; mais, si des circonstances de fored majembe ne vous permettaient pas de conduine la prise en France on dans ume

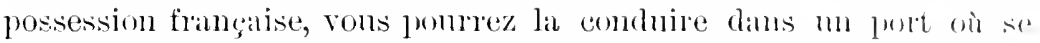
tronverait nu consul de Sa Majesté Impériale, avec lequel vous vous concerterez sur la destination ultérieure de la prise.

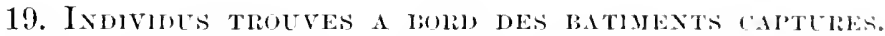

Tous ne devez, à moins de eas de force majeule, distraire du hord aneun des individus qui montent le bâtiment captur'é, s’il s'anit d"m bâtiment marehand ; mais les femmes, les enfants et iontes les persomnes étrangères au métier des armes on ì la majine ne derrom, an aucun cas, être traités comme prisomiers de gurre, ot seront libres de débarquer dans le premier port ou le bâtiment aborderia s’il s'agit d'un bâtiment de gonerre, et sauf la mône exceptiom, rons pourez, si vous le jugez ntile, transhorder me partie de l'ápluipare, et voms tonduirez les prisomiers soit dams mu port militare de France, soit dans tont antre port qui pomrat itre ulterienement désigné eomme lien de dépôt ponr les prisonniers de gnerre.

\section{Rearmenent ext enplot des batmexts raptolles.}

Si l'intérêt public l'exige, vous jourez reanmer les hâtinntuts

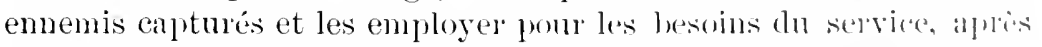
en avoir fait faire l'estimation par nue commission composion, antant que possible, de trois offieiers supérienrs compétents, dont mu nembre du commissarjat.

Vons ponvez également, dans des cas exreptiomels, probuenter, ponr le service de la flotte, les eargaisoms des navines emmemis, anmos 
en aroir fajt dressel un inventaire détaille et un procis-rerbal destimsitions.

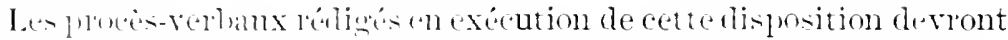

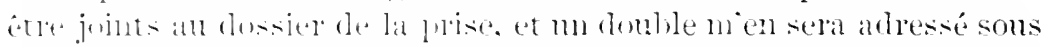

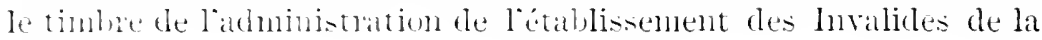
marine.

21 .

The convention a fó conche ì (ienteve, an mojs d'aout 186t. entre

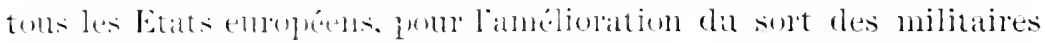

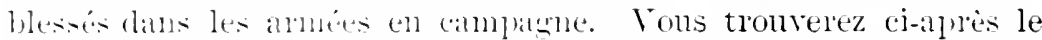

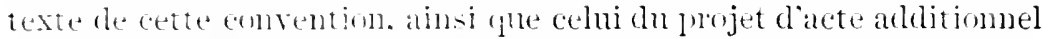

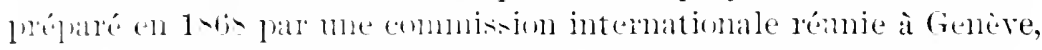

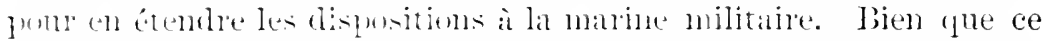
bernien ate nait pas encore re;n la sanetion diplonatique, le Gou-

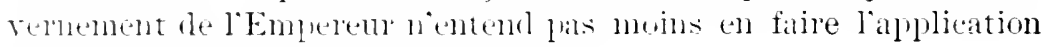

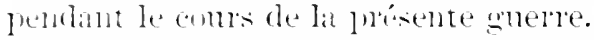

Voms vombez done liten vons confonner, le cas échéant, aux regles trabers lar les denx actes dont il sagrit.

lievere, Mesiens, lassmance de ma consideration tris-distingue.

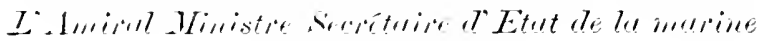

$$
\begin{aligned}
& \text { et ales colomids, }
\end{aligned}
$$

IL. RIG ITIT DE GEXOLILLY.

\section{INSTHCOTIONS COMPLEMENTAIRES.}

\section{VITE.}

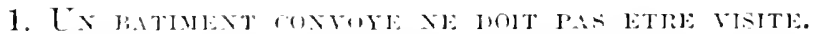

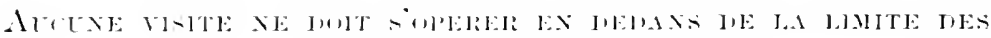

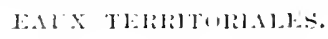

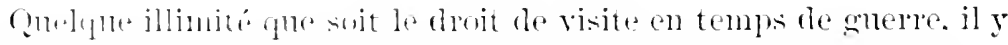

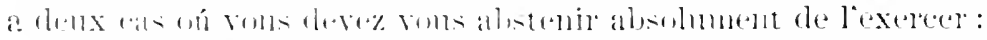

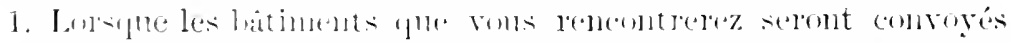

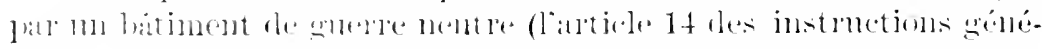

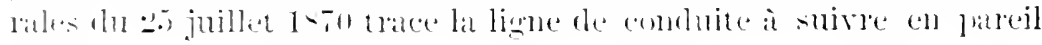
(:il-1:

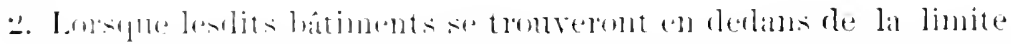

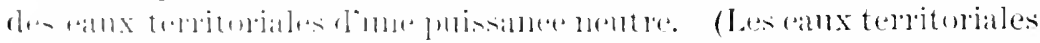

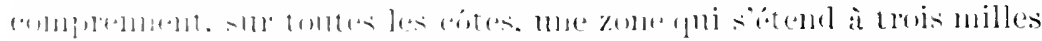

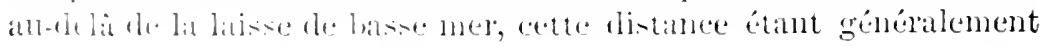




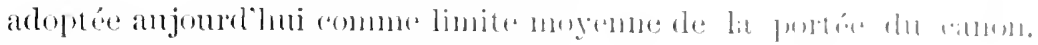
(Art. t des instruetions généralcs.)

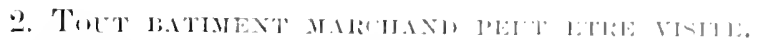

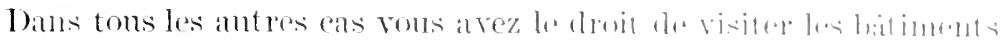

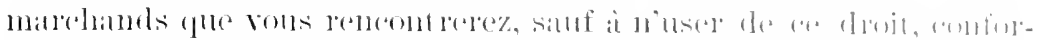

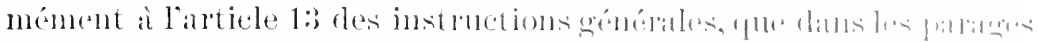

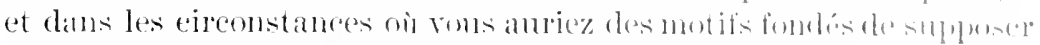
que la visite pent anemer la saisie du bitiment visits.

\section{Ninterel.}

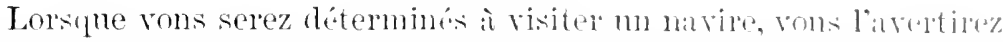

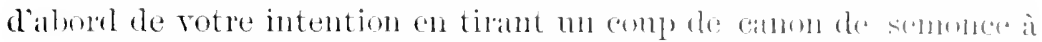

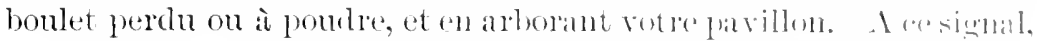

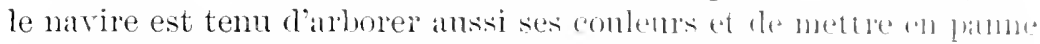

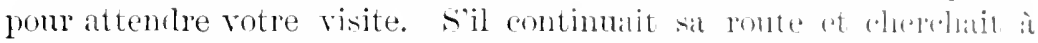

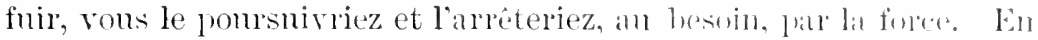
cas de résistance armée de sa lart, vous auriez it le capturer sims autre examen.

\section{Conmext ox procene a LA Vistit:}

Si le navire semoncé s’arrête, vous voms arréterez ansit, on vons temant, antant que les cireonstances de mer le permettent, lons de portée du canon, et vous hi envoyez une embarcation postant le

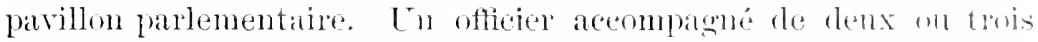
hommes au plus monte ì borl du navire ì visiter. Il procide arint tout i l'examen des papier's rle bord.

\section{PAPIERS JETES I LA MER.}

S'il est constaté que des papiers ont été jetí it lit mer, nu antrement supprimés ou distraits, i bord du navire visité, re natime loit

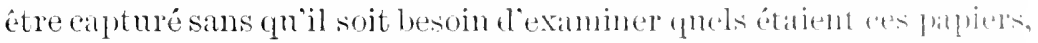

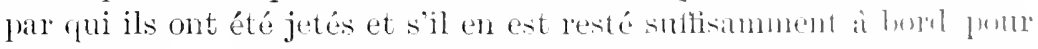
justifier que le narire et son chargement appartiennent i des nentres. (. Irt. : du reglement du 20 juillet 175 .)

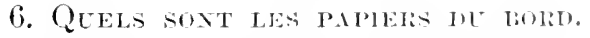

Les principaux papiers de bond d'un natrive somt:

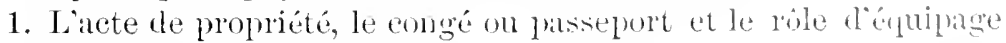
qui établissent sa nationalité;

2. Les comaissements, chartes-parties et factures, qui fiablinent la nature et la nationalité du changement. Il suflit quime de ces 
pieces établisse dimne manière certaine lia neutralité du navire four

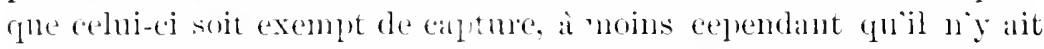
contradietion antre lanlite piece et quelque antre dowment trouvé à

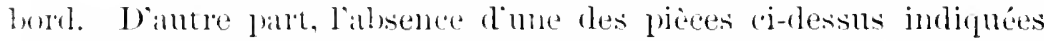
ne justifierait pas pall elle senle lo copture, si d'aillenrs l'ensemble des antres pieces pronvait lisen anthentiqnement la nentralité du narvire et la régularité de lexpédition. Inis il y aurait lien de eapturer le navire smr lequel on tronverait des expélitions doubles, qui laisselaient des doutes sur sa nationalité on sa destination.

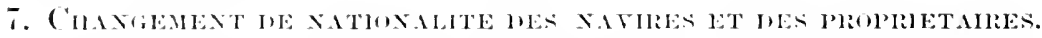

Lorsqu il résulte de lexamen des pivees de bord que depuis la déclaration de gnerre la nationalité du navire antérieurement enneni at été changée prir une vente faite à des neutres, que celle des propriétaires a été modifiée par naturalisation, on que l'équipage d'un batiment neutre comprend une proportion notable de sujets ennemis, il y a lieu de procéder avee lit plus grande attention et de s'issurer que toutes ces opérations ont été exécut ées de bomme foi et non dans le senl but de dissinuler une propriété réellement ennemie.

\section{Visite he changenext.}

Lorsque le navire visité a prouvé sa neutralité, vons n'avez pas à vons péocenere de la nationalité de son chargement, puisque le palvillon neutre convre la marchandise, même ennemie. Quant ì la nature dndit chargement, il convient, en rèogle générale, de ne la vérifier que par l'examen des papiers de hord. Si eependant vous avez des molifs sérienx de soupgomner que le navire renferme de la contrelande de gurre pour le eompte on i destination de l'emnemi,

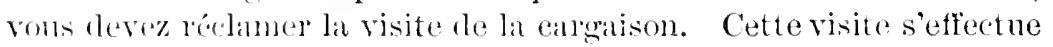
jau Jes soins du capitaine et do réquipage du navire visité, sons les

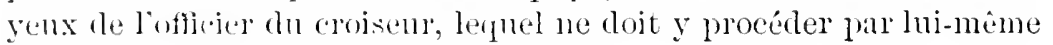
quiten eas de refus de ces demiers.

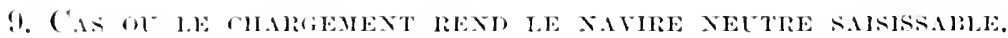

Est passible de alpture tout navire qui transporte des troupes, des déprohes officicles su de la contrebande de gnerre pour le compte on in destination de l'omemi. Tontefois, si la contrebande de gurre ne se trouve a bord que dans une puroportion inférienre anx trois gliarts de lat cargaison, vons ponvez, snivant les cireonstances, soit retenir le navire hi-méme, soit te relâther, si le eanitaine consent à

${ }^{1}$ I f traneport des dépherhes d’un agent diplomatique de l'ennemi, résielant dans un fays neutre, newaraine pas la prise du bitiment neutre. 


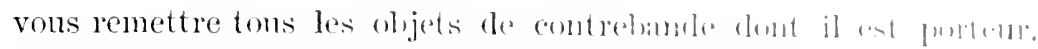

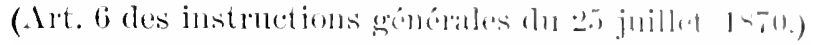

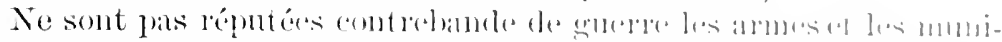

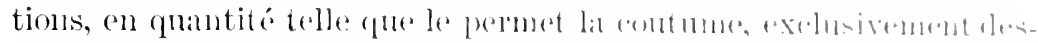

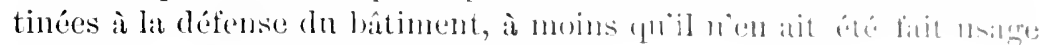
pour résister ì la visite.

10. P.igterith.

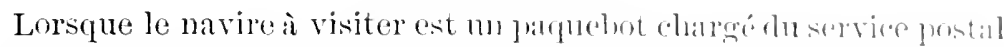

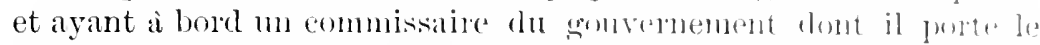

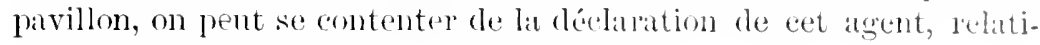
vement à la nature des dépềches.

\section{BLOCES.}

11.

L'article 7 des instructions géuérales définit explicitement les conditions de l'etablissenent d'un blocus, la formalités à observer pon le régulariser et les consérquences qui en déeonlent pour la naviguation neutre.

\section{INTERRLPTION DU BLOCLS.}

Le blocus n'existant qu'à la condition d'être effectif, si les forces navales franģaises étaient forcées, par une circonstance queleongue, de s'éloigner du point bloqué, les navires neutres reconvreraient le: droit de se rendre sur ce print. Dans ce cas, ancun croisenu frandgitis ne serait foncé i les entraver, sous prétexte de l'existence anterrinre du blocus, s'il a d'ailleurs la commaissance certaine de la cessation on de linterruption de ce blocus. Tout blocus lev' on interrompu doit être rétabli et notifié de nouveau daus les formes prescrites.

\section{Par qui il dolt et commext xutifle. Fonilites.}

La notification du blocus ne peut être inscrite sur les plyjers de bord d'un navire neutre que par l'un des bâtiments de gnerre formant le blocus. En conséquence, un eroiseur, non engagé dins cutte opération et se trouvant loin des linites qui y ont été assignées, we peut faire valablement cette notification, ni arreter le navire neut re qui se dirigerait vers le point bloqué, siuf ì exelcer sur ce narire une surveillance spéciale, si les cilconstances l'exigent.

La notification du blocus inscrite sur les registres d'un navire huit toujours mentionner le jour et la position géengraphique du lieu vù cette notification a été faite. 
13.

Ia conduite a tenir envers les batiments pris on saisis est tracée

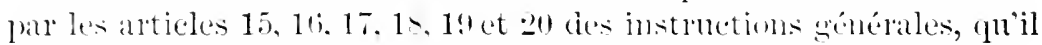
est utile de compliter par les indications suramtes:

\section{PAVILLON IOES P'IISES.}

Les prises mavignent aree te pribllon et la flamme, insignes des bâtiments de l'Etat.

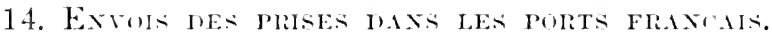

Les prises sont exchusement dirigés sur les ports de France on

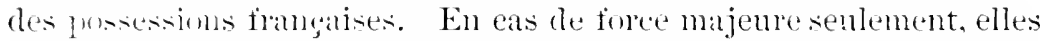
penvent cutrer dins les ports nentres pour réparation davalies on ravitaillement. Elles n'y séjournent que le temps strietement nécessaine à ces operations.

\section{Pieres a menettre par las contectelits hes prises.}

Si le canteur n’escorte pas sa prise, parce qül juge pouroir l'expédier directement, le conducteur de lia prise doit, it son arrivée au port le destination ou de relâche, remettre ì lautorité maritime ou consulatire:

1. Sim rapport de traversée;

․ Le procis-verbal de eapture et dapposition des scellés;

3. Linventalire de lal cargaison ;

4. Les pieces et papiers du bord de tonte nature.

16. Expenthos inhecte hes freres et ines persoxyes.

Lorsprime prise est dirigie sur un port de France, le eapteur peut. dins des circonstances exceptionnelles. expedier directement et par une autre roie les pieces de procédure et les personnes dont lat prérence est nécessaire i lonstruetion, it la condition que leur arrivée en France précédera celle de la prise elle-mème.

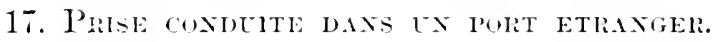

Ioreritune prise est eonduite dans mu port étranger où elle pent étre admise, le conducteur de lia prise représente les eapteurs dians l'instruction consulaire.

\section{Refl's Didinission.}

Prescrue tontes les puissances assimilent les prises aux bâtiments de guerre des belligérants et ne les almettent pats dans leurs ports, 


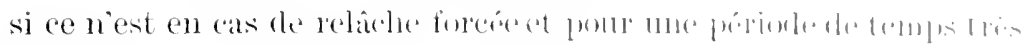
rourte.

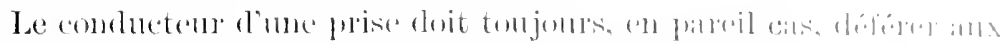

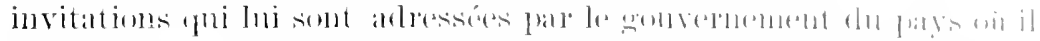

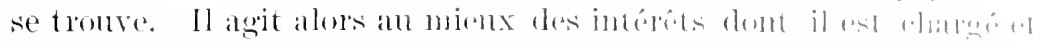

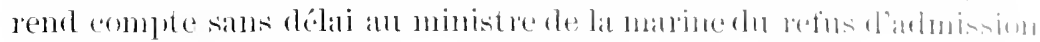
(glilil a csillyé.

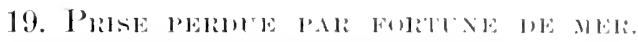

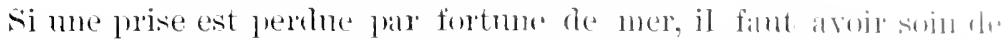

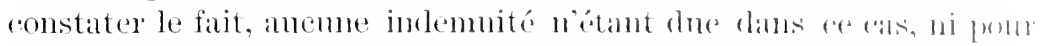
le navine, ni pour le chargentent, mîme si alphes jugennent la prise eût été inmulée.

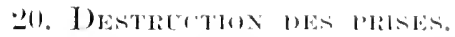

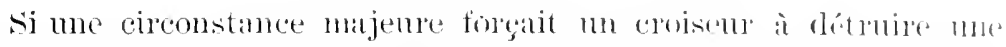

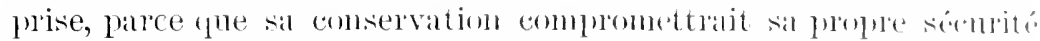

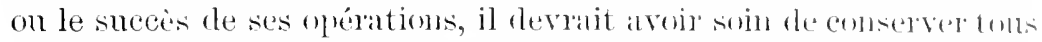

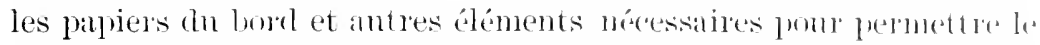
jugement de la prise et l'étahlissement des inclemités a atribner.

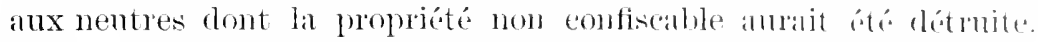
On ne doit user de ce droit de destrutetion quavec la plus grambe réserve. 



\section{TXIEX.}

ABerneEs, on right of asylum of me $r-$ chant vestisels. 14s.

Accretion, xviii., 3:33.

Aecunisition of teritory, xrit.

Adams. J. Q.. on recengnition of indlepremdence, 13.

Aertsen $x$. Slip Aurna, 183.

Agents, right to emplus in the contry of the eneny, xxxii., sess : international agents of a state. vii. : see diplomatic asents.

Alabama, case of the, 425.

Alibert, Lucien, case of, 218.

Aliens, as to exemption from military duty, xxi. : see foreigners.

Allegiance. imdelible, xxiv.

Ally, recapture of property of, see rescapture.

Ambassators of Peter The Creat, 89.

Ambassadors, see diplomatic agents.

Amicalile settlement of disputes, xxvii.

Amistad de Rues, La, case of. 406.

American Ins. Co. $v$. Canter, :3:

Anderson, John, case of, 18 . .

Anemone, $L$, case of, xx.. 124 .

Anna, case of the-capture in nentral waters, xxxrii, 393.

Anna Catharina, ease of the, 346.

Amme, case of the-apture in nentral waters, xxxrii., 400.

Ann Green, case of the, 354 .

Antelope, case of the, xxiii., 21:.

Authon $r$. Fishler-ransom contracts, xxxii.. 314.

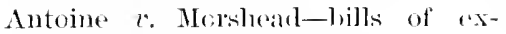
change. xxxii., 3018.

Antonia Johanna, are of the, 320 .
Arhitration amel mediation, v voli.

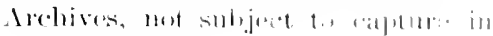
walr, xxxir.

Armod foreses. xx.

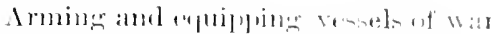
in nentral territery. x.x. ii.

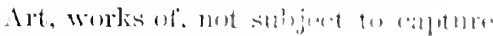
in war, xxxis.

Asylum, riglat of in lowations, xx.

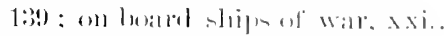

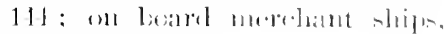
xxi.. $1 \%$.

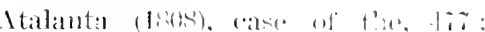
$(14,5), 144$.

Ittorney-General $e$. Wreders.

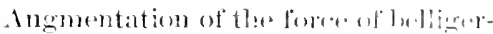
ent resisels in inteltral perte. ser expinment of vemetels. xxxyii.

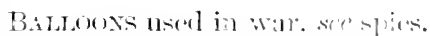

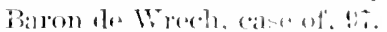

Barrmulials ratere lint.

Bayald. Themats F. riglats of imlivirluals not afreeted ly ehanger of sovereignty. ․․․․

Bays, xix.

behring seat drlitration. ist.

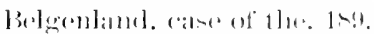

Bolligerent (anmmuntios, what aro.

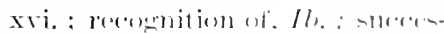
sion torights of . Ih, : right - of an

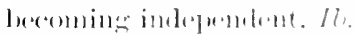

Belligerents. right of to interfere with

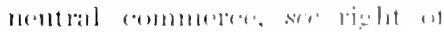
visit and sealleld, xxxix, ה15.

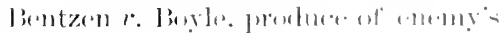

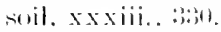

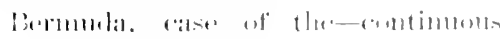
voyages, stix. 


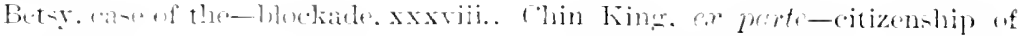
$4 !: ?$.

('Jintere. xxiy.. :1!!.

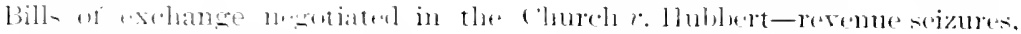

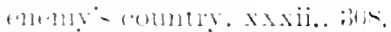

Hlockinte. Axxriit. i!n?

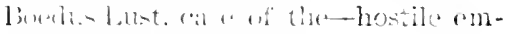

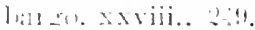

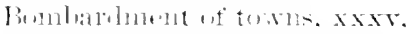

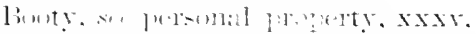

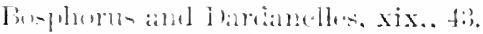

[Bumblatie- Aviii.

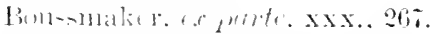

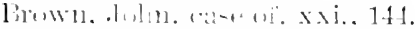

xxii. 19:?.

("itizanship anıl naturalization, xxiv. $21 !$ : ser mationality.

tovil war. serefefintion of war. xxis. Coal als comtraband. we contrabame, xxxvii.

cinsting and colonial tarles xxix., ins.

Cocklum. Air 1.. on natimality, $21 \%$. (imbatants. who are. xxis.

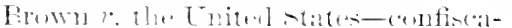

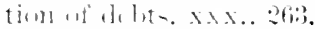

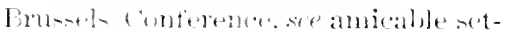

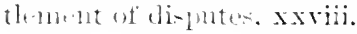

carals. interoconic, Suez Canal, xix.

commenter letli. pacific interesurse of thelligenents. xxxii.

Commercial demicil xxxiii., 315.

commeren, case of the-provisions as (omtralknt. tio).

conferteration, see classification of states. xr.

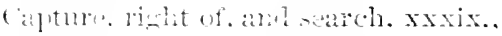
i1).

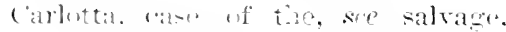
x....... $: 1,11$.

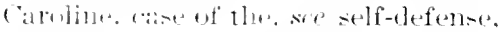
13.

cartek. - at lacife intereourse of lesligterent-. xxyii.

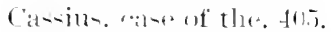

Ca-tioni. in m-phlitioloffenses xxi. $11 ; i ;$.

Comgo state. how recomized, st.

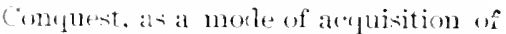
territory. xriii.: temination of war. xxxyi., S\&1.

Constitution, case of the-immunity of shipe of war. xx.. 114.

Constals, orimin functions. otc., xxri.; (1) not pestess inmminities froin local jurisliction, g9: judicial functions of in Eastorn lands, xxri.

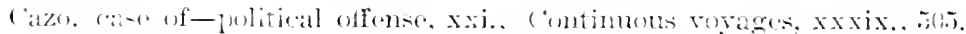
$10,1$.

\{ Hlamalu. Prince. (ats of -immmi-

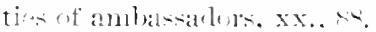

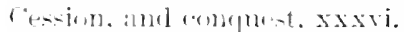

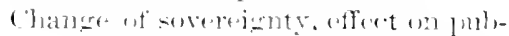
lir rights. xr.. 1s: on private rienth- xvi., 21.

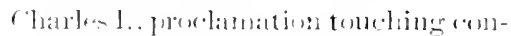
trablatul of war. A6s.

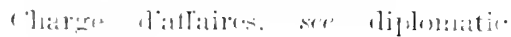
ancint?

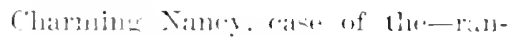

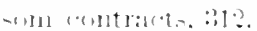

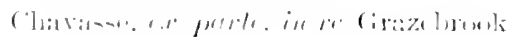

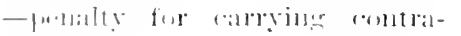
bitull. Aisi.

cintrabland of walr. erencral law of,

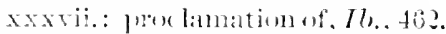

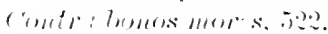

contrarti. ammuled ly war. xxxi. $\therefore i t$.

(ombributions and requisitions, xxxy.

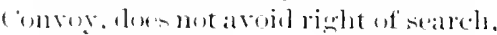
xxxix

(imalentials. sore rights of diplomatic andat- xxy

(in)m r. Iblakklum-ransmn bills. xxxii.. :311.

(rewle. ation of the-merchant ship in foreigne pent $1: 36$.

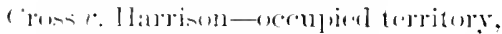
xхxา. :31.

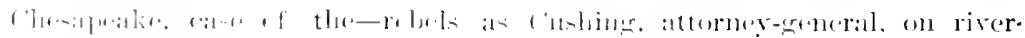
firall-. xxiii.

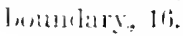




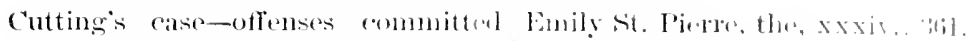

abroal, xxi., 1\%:

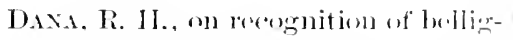
(renle. 24.

Deits, effoct of war on, xxx., ghil: pairl to a militiry oceripurer, xxxi., 34.

Decert, low far allomalse in wall, xxx.

Declaration of Paris, 5*9.

Declaration of Sit. Totershure.s.30.

De facto states, xvi.

De Haber $r$ Quenn of l'ortural-inmunities of sorereigns. 7 ;

Dolagoa Bay, 11.

Despatehes, as contrabamel. xxxviii., ti\%.

Derastation in war, sxx.

Dillon's case-consuls not entitled to diplomatic inmonutites. (9).

Diplomatic agents, classification of. xxv.: refusal to receive. /7.; must be persona grotu. Il..: termination of mission, $I b$., xxyi.: ambassadors rights in third states, $I l$.: immunities of, from criminal jurisdiction, six. 89, from civil jurisdiction, $\mathrm{x} . .89$.

Direct U. S. Calsle Co. v. Anglo-Ans. Telegraph Co.-as to what bays are territorial waters, xix.. 4.).

Discovery, as a mode of accpuijing property, xrii., 6.

Domain, srii.

Domicil, commercial, xxxiii.. 315.

Don Pacifico, reprisals, xxvii., 216.

Du Bois, case of-immunity of diplomatic agents, 98 .

Elector of Hesse Cassel-effect of conquest, xxxvi. 841.

Elk $\imath$ TVilkins-status of Indiais, xxч., 230.

Ellis $\imath$. Mitchell-merchant ressels in foreign ports, xx., 139.

Emanuel, case of the-rule of the war of 17.56. xxxviii., jol4.

Emden, case of-citizenship, xxiv., 223.

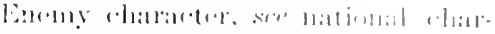

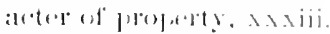

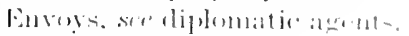

Erfuality of statem, xi.

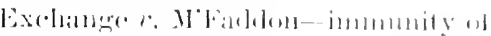
slipis of watr, xx., lo:?.

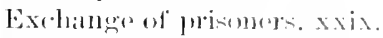

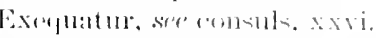

Expatriation-mationality. xxis.

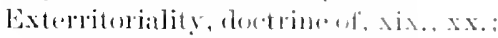
of merelatel rescels. xxii.

Extradition, xxi.

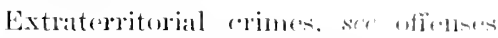
committor] log formingers. Axi.

Fisn, Itanilton, on right of a-ylim, $\mathrm{xx}, \mathrm{14}:$.

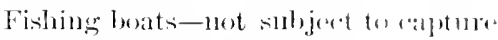
in war, xxxis.

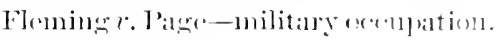
xxxy., :ifis.

Flomilit, case of tho-cefuipment of

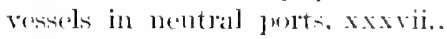
$42 \mathrm{~s}$.

Forrign enlistment an't (Briti-]). xxxvii.. 4(1)?.

Foreign sorereigns--immunities of xix.

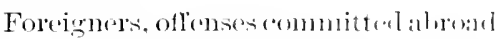
by. xxi. : "xomption foum nulitary iuts. 17 .

Fortuma (1809), casc of the-froight. $3 \%$.

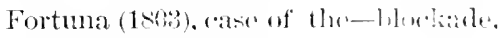
$1: 34$.

Fostor $x$ Neilom-bommlarion. xriii. 14.

Franconia, case of the, sef thenene. Keyn.

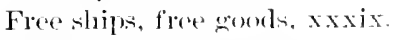

Freiglit, 3\%).

Freinrtschaft, atse of the-luouse of trade, xxxiii.. :3:

Fugitives from justice. serestralition. xxi.

Furtarlo $v$ Roderes-insinamer wn enomies slips, xxxii.. :3::?.

GExishe Arustrose, ease of the- 
capthe in nentral waters, xxxii, Intelihle alleriance, xxir.

:3:11.

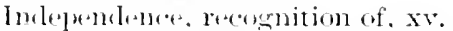

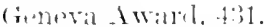

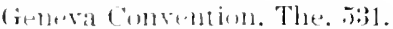

Inclion chiet. case of the-commer. (cial clomiteil. xxxiii., :31,.

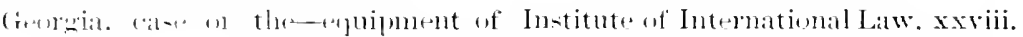
reside in nentral territory. Instructions for the French Xary. xxxrii.. L:24.

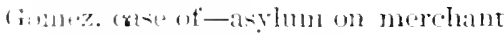
vestels. xxi.. 1tis.

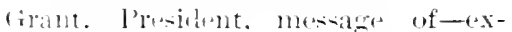
patriation, xxir., :16.

Instructions fin Cniteilstates Armies. ii:?.

Insuranes on ships of the enemy illemal. xxxii.

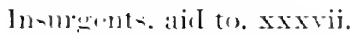

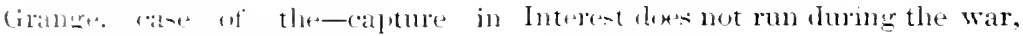

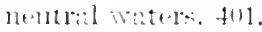

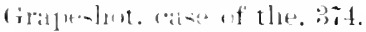

(imat Jalcket. ("at-1) of the. 994.

lirytawn. lumbardusent of. P4s.

Griswelle $\because$ Wallineton-contract: betwen

(illarintere treattien. xxyii.

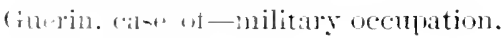
xxxy.. :

Ginitean Trial. The. 108 .

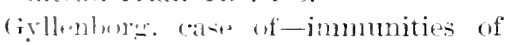
liphometic agents. xxix.. xxxi.

Interention, xxiii.

Jax Frederick, case of the-transfer in trousitu, xxxiii.. 35:.

Jectser $r$. Ilonteromery-military oc(11)ation. xxxy., 373.

Jenkin-, sir Leoline, on piracy, xxiii., $15 \%$.

Johama Enilie.

Johmsm $\quad r$ Iackintosh-discovery. xvii.. 6.

Jange Marperetha case of the.

11ALETK. GExERL-definition of at - tatte. $\therefore$.

Hanger $r$. Ahbott-rontract between (-1)+mitr. xxxi.. ?ill.

Inareourt e. (raillari-lwmularies. 15.

IIardy. Le 2 L Lal Voltireante-com-

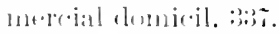

Joneph. ane of the-trarle with the entiny. xxxii. 29 ?.

Juriciction. teritorial, xix.: on the high aras, xxii.; over nerchant vensels, Il,

KExete $x$. Chambers-airl to in:ur(retsts. xxxii. $+1+1$.

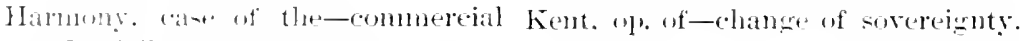

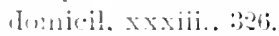
xพ... $: 1$.

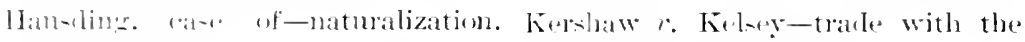
xxir...

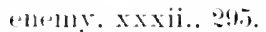

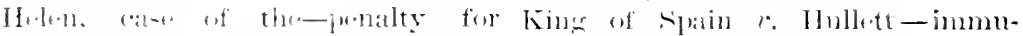

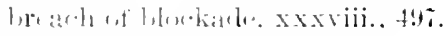

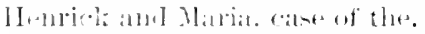

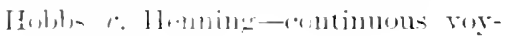
ay- xxis.

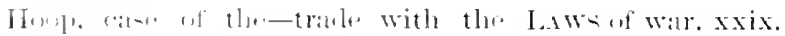

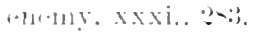

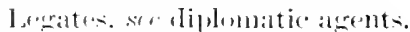

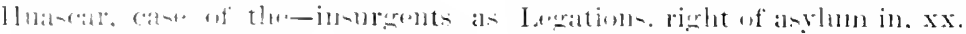

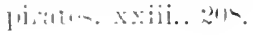

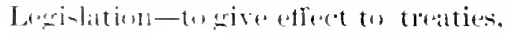
xxrii.

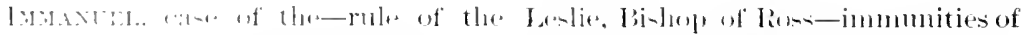

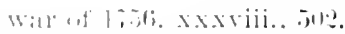

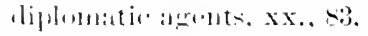

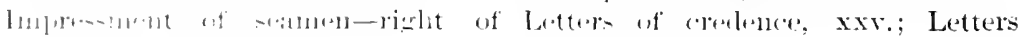
-arth saii. xxix.

jutent. Id. 
Letters of maregue and reprisal, sxix, Naturalization, xxiv.

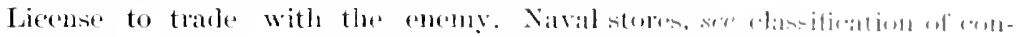
xxxi.

tlalbiml, $x \times x$ viii.

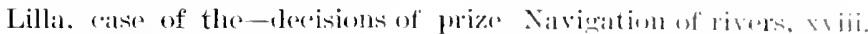
(a)ints. $2 \pi$.

Lindo $\imath$. Rodney-hostil, (mubaren. S.).

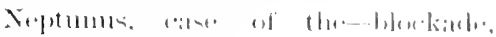
xxxriii. lim.

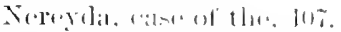

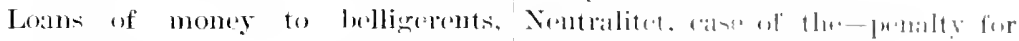
xxirii.

Lonis, case of Le-slave trarle as lilacy, xxiii., 209).

M('LEOD, case of, $1 \%$.

MacDonale, case of-matiomalits, xxix., 214.

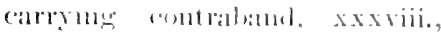
4.1.

Nentral duties, sxxii.

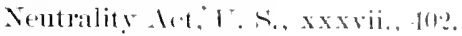

Nent ralizel stalles, xy.

Madison, case of the-dispateleses as contraband, xxxriii., f*s.

Magdalina Steam Navigation (r) $r$. Martin-immmnities of dipkmatic agents, 102.

Magellan Pirates. case of the. xxiii., $20 . \overline{5}$.

Manchester $v$. Massachusett-teritorial waters of a state, xix., 47.

Iare Clatusum, xix.

Maria, case of the-right of search. xxix., 515.

Marianna Flora, case of the.

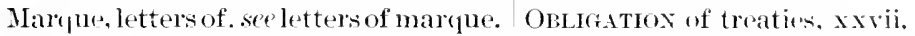

Mendoza. case of-immunities of dip- Oer'upation as a monle of actuiring lomatic agents, $x_{\text {. }}$. s.i.

Mentor, case of the-termination of war, xxxvi., 38.5.

Meteor, case of the-equipment of resiels of war, xxarii. 418.

Minister's, sec diplomatic agents.

Mississippi, navigation of the, 39.

Molir \& Haas $v$. Hatzfeld,-public poperty of the enemy, xxxiv. 33 .

Montezmma, case of the-insurgents as pirates, xxiii., 206.

Iunicipal seizures, sxii. territory. xrii.: military. xxxr.: of Taples (1495), xxxri., :j-1.

Ocean, case of the-hlorkale. xxxriii., $49 . \overline{5}$

Oregon Territory, the, xvii.. 9.

Orozembo. case of the-military pere soms as contrabanıl. xxxriii.. An:?.

PACIfIC hlockade. xxriji.

Pacifico, Don, case of-reprisals, xxxiii.

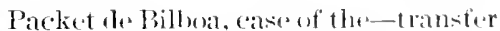
in tromstll, xxsiii. :3:3!.

Munitions of war-sile of. fry a neutral state. xxxrii.

NAscr. ease of the-blockitle. Partnelships. see centrats lutwerll xxrviii.. 49.

Nashrille. case of the, 431.

Nationality. xxir. enemies.

Patrixent, ease of the-ransom con tracts. xxxii.. $31 ;$. 
Peace. efract of treation of xxxyi.

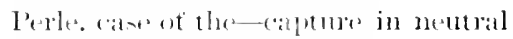

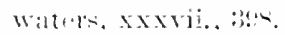

Peterhetr. (atse of the xxxriii., xxxix. t(i.).

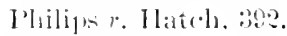

Piracy. xxiii.

Pertiminimm. xxxy.

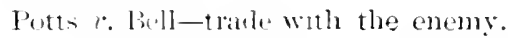
xxxi.. :-

Promption, 4t:2.

l'uerceription, xwi.

Prims Ferlorik, (ake of the-jmmnnitien of pullir shiph. 115.

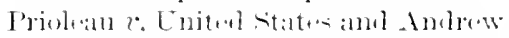
Jolmente-immunities of sorere aing xix.

Prianleme of wall xxix.

Privataers. ser derelatration of Paris.

Private International Law. xis.

l'rize atates. the (1)- lecelaration of

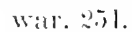

Prize (alsw. the, (3)-commereial remiril. $: 39$ t.

l'rize "unts. xl., j1s.

Prize comets on boarel ships, 519.

Proteder, cand of the-termination of war. xхxเi.. :391.

Provioings ats (ontrabmul. sere oreasisnal (ontentanel. xxxviti.

Prum-ian subjuct. rant of-naturalizaltim. xxir.. 2.24 .

GeEx r. Kryll-juri-aliction arer marrinal stats. xix.. j.j.

Rexwen remtracts, xxxii.

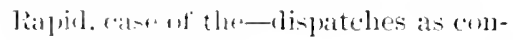

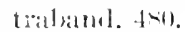

Iircateture, xxxil.

Reromention of ledlizerency xri.

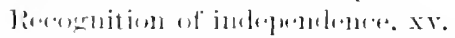

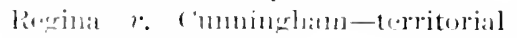
witris. 14.

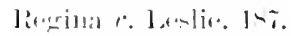

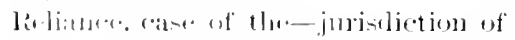

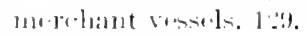

Jin-pi-al一, xxviii.

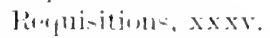

loss ancipitis mosts. til.
Recpulblirat r. De Longchamps-im. munitios of diplomatic agents. 104.

Reterion, xxviii.

licord $r$ Bettenham-ransom lolls. $81:$.

liiplecelat. Inke of-right of asylum, xx.. 1:39.

lavers. Eurenean, navigation of xviii.. 11.

liosere Himely 195.

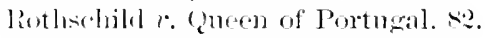

linle of the war of 15itj. xxxviit.

$\therefore \wedge$, Pantalum, case of-immunities of diplunatic atents, xx., Nib.

Sile of arme to France. fist.

Silly a case of the-ownership of groods in tranit. xxxiii.. 344.

salvader, case of the-aid to insurgnents. xxxvii., 4.5.).

Sim Juse Inuliano, case of the-roods in tromsitu. :3 is.

Sinta crum. case of the-recaliture, xxxiv. 3.5.

Sianta Luc.jil. 1:.

Santisinna Trinidad, case of the(xplipusent of ressels of war. xxxvii. 408.

Scotial calse of the, 1.

sea Lim, (ato of the-license to trade, xxxi.. :310.

Self-clefentere, acts of a State in, xxii.

Sirvitulla. xivii.

Seton e. low-penalty for carrying contrabaml. xxxviji. tis.

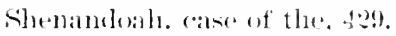

shiple, pullic. immmities of, xx.; rimht of asylum on, xxi.: meschant ships. juristiction over, $\mathrm{xx}$ : r right of atylum on, xxi.

Silesian Lam, The-reprisals, xxriii, 243.

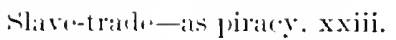

sirl. preduce of in enemy comtry: xxxiii.

Sittelln. rase of - right of asylum, xxi. 14 .

Sommel Dates. The. 41.

Siverengns, inmunities of, xix.

Sijus, xxx. 
State, dofinition of, xir.

Statutes of Limitations. xxxi.

Stephen lfart, catse of the-continm(ls voyages, sxxix., in?.

Sitolvane in tromsitu, xxxiii.

Sit. Mllatus Ratid, The', 16:2.

st. Lawrence, navigation of the. ij.i.

Sit. Lawmence, case of tht -tratle with the enemy. s!n).

St. Marks, seizure of, 1 is.

Straiti, xix.

Sumpler, case of the. $4: 30$.

Swinthere, case of the, :3s.

TACONY, case of the, 4:31.

Tallalassee, case of the. 4:31.

Taylor $r$. Best-immmotics of aplomatic agents, xx.. 90.

Tempest, case of the-merchant vessels, xx., 12\%.

Terceira Affair, The-neutral duties. xxxrii., 121 .

Terra dominium finitur ubj finitur amortin ris, xix.

Territorial waters, xviii.; property. xri.

Territoriality of merchant ressels. xxii.

Tentonia, case of the-derlaration of irar, xxviii.. 250.

Texan Bonds-effect of a rhange of sovereignty upon public rinlit. xr., 18.

Thetis, case of the-termination of war, xxxri., 34 ?

Thompson $v$. Powles-loans to insurgents, xxxvii. 440.

Three-mile zone, xix.

Tousig, Simon, case of, 228.

Trade with the enemy, xxi.

Transfer in transitu, xxxii.

Treaties, xxri.

Trent, case of the-persons as contraband, xxxvi., 486.

Trimhle, case of-extradition. smromder of citizens. xxi., 15s.

Trois Freres, case of. 2ts.

Twenty-fom-hour rule, see recapture. War, definition of, xxriii. : leviaraxxiv.

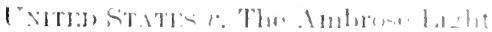

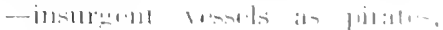
Xxiii., : $: 111$.

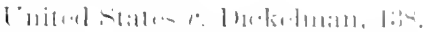

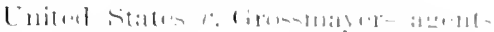

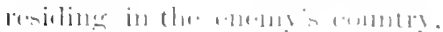
xxxii.. 23!s.

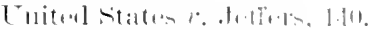

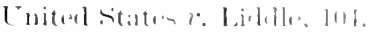

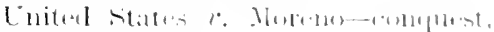
xxiri., :

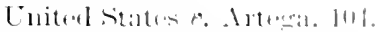

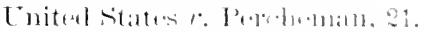

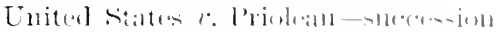

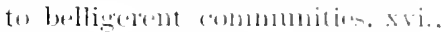
2

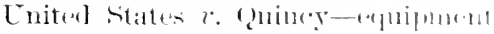

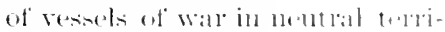
tory, xxxil. 11?.

[nited sitales r. lialuler-extralitim. xxi., 1it.

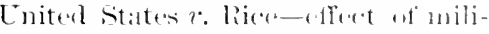
tary ocellpation. xxx

United States $x$. Sunth-piracy. xxiii. 196 .

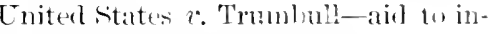
sulpents. xxxy., +13.

[nited States 4 . Wagner. 89.

tri poswlitis, xxxii.

Varasere $\tau$. Kruplp-immunities of foreign sorelejuls. xix. je.

Telnts, case of thr-commercial domicil. xxxiii.. \$19.

Tessels, see ships.

Villassefue, case of-military occenpation, 380 .

Tirginius, case of the. 179.

Visit and seareh, xxxix.

Volante, casc of the-contraband.

Vrow Henrica, aste of the-freinht.

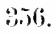

Vrow Marganetha, case of the-tralus-

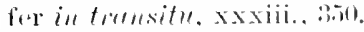

Wagrer, rase of-maturalizanion. xxiv. 9.5.

tion of, 16 . : allects af, xxix. xxxyiii, 472. 
Ware $r$. Ifrlton-effect of war upen Willendson $x$. the Förouket, 13 ?

debts die to enemies. xxx., 260 . William, case of the-continuous roy-

Whetatom. H. catse of -immunitiess of agest xxxix., j05.

Alphmatic agents. xx. 94: on the Williams, J., catse of, 215.

narigation of rivers. 3:. Welff $x$ Oxholm-confiscation of

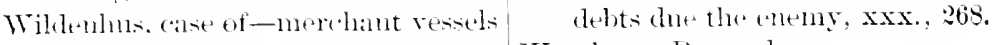

in foreingl ports, xx. 1:6. Wrech, see Barun de. 








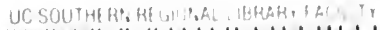

AA 000996224 
\%

\%

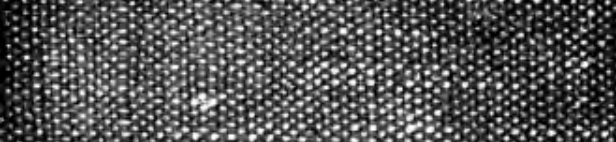

\%

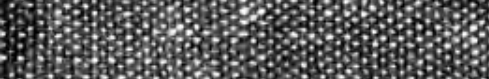

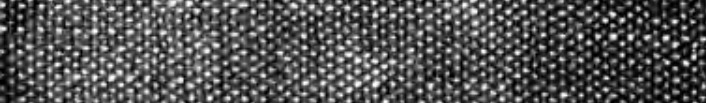

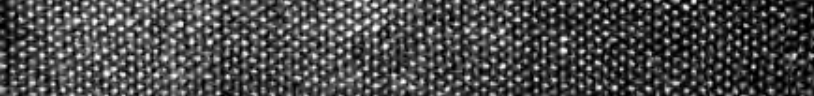

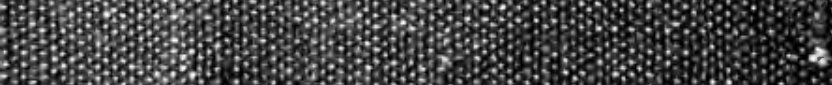

20



Hajom

20\%

(1)

20

70

(7)

(3)

6

10

Ha

P.

(7)

(3)

3.

(1)

H.

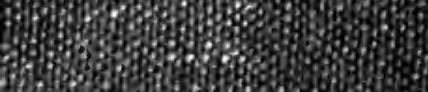

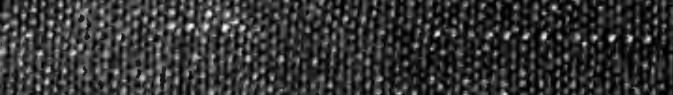

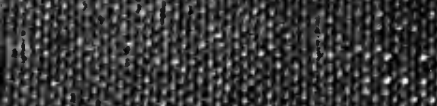

S

Hom

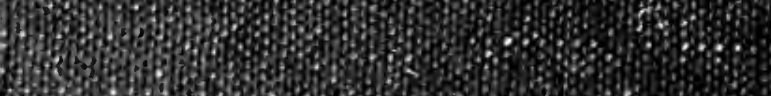

47.5.

(5)

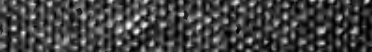

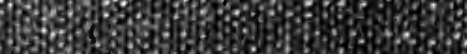

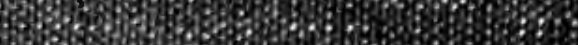

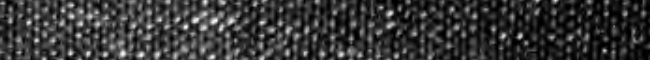

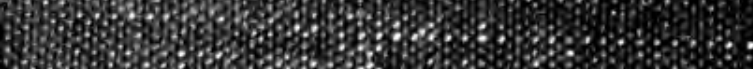

(3)

78 \%

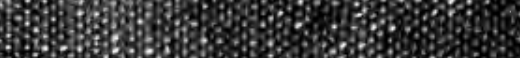

sis

\%

83\%

\% 